Corvinus University of Budapest

Faculty of Economics and Management

Slovak University of Agriculture in Nitra

Visegrad University Association

Association of Agricultural Economists in Slovakia

Hungarian Association of Agricultural Economists

EUNIS Slovakia

International Scientific Days 2020

"Innovative Approaches for Sustainable Agriculture and Food Systems Development"

Conference proceedings

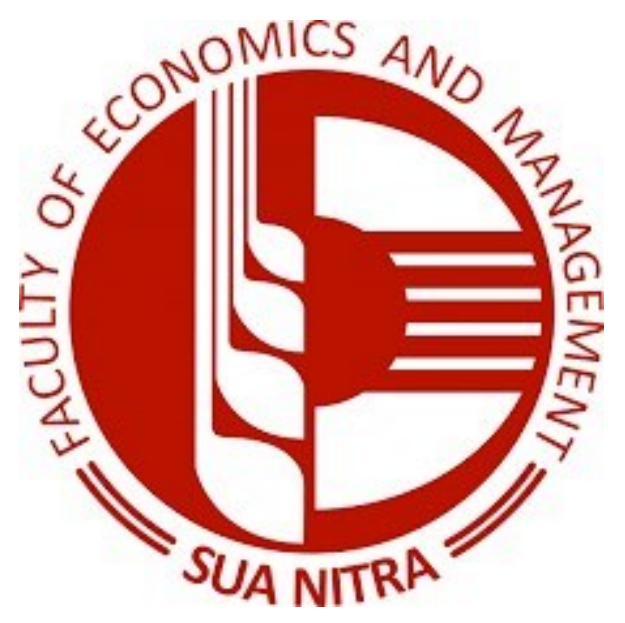

May 14, 2020 Nitra, Slovak Republic 
Title

Editors

Technical Editor:
International Scientific Days 2020. "Innovative Approaches for Sustainable Agriculture and Food Systems Development". Conference proceedings

Elena Horská, Zuzana Kapsdorferová, Marcela Hallová

Marcela Hallová

ISBN: 978-963-269-918-9

DOI: 10.18515/dBEM.ISD.P01.2020 


\section{Scientific Committee}

\section{Chair}

- Elena Horská, Slovak University of Agriculture in Nitra, Slovak Republic

\section{Members}

- $\quad$ Peter Bielik, Slovak University of Agriculture in Nitra, Slovak Republic

- Zuzana Kapsdorferová, Slovak University of Agriculture in Nitra, Slovak Republic

- Vladimír Gozora, SAPV, Slovak Republic

- József Káposzta, Szent István University in Godollo, Hungary

- Martin Pelikán, Czech University of Life Sciences, Prague, Czech Republic

- Pavel Žufan, Mendel University, Brno, Czech Republic

- Jánusz Zmija, Agricultural University of Cracow, Poland

- Andrzej Krasnodebski, Agricultural University of Cracow, Poland

- Jarosław Golębiewski, Warszaw University of Life Sciences, Poland

- Anatolij Dibrova, National University of Environment and Life Sciences, Kiev, Ukraine

- Savino Santovito, Universita degli Studi di Bari Aldo Moro, Italy

- Ángel Carbonell Barrachina, Miguel Hernández University, Alicante, Spain

- Vadym Tkachuk, National University of Life and Environmental Sciences of Ukraine

- Shinkaruk Vasyl, National University of Life and Environmental Sciences of Ukraine

- Elena Kovtun, National University of Life and Environmental Sciences of Ukraine

- John Russin, Luisiana State University, USA

- Bartosz Mickiewicz, West Pomeranian University of Technology, Szczecin, Poland

- István Bíró, University of Szeged, Hungary

- $\quad$ Azeta Tartaraj, Universiteti Aleksander Moisiu, Durres, Albania

- Wim Heijman, Wageningen University, Netherlands

- Astride Miceikiene, Vytautas Magnus University in Kaunas, Lithuania

- Luboš Smutka, Czech University of Life Sciences Prague, Czech Republic

- Dagmar Škodová Parmová, University of South Bohemia in České Budejovice, Czech Republic

- Jámbor Attila, Corvinus University of Budapest, Hungary

- Áron Török, Corvinus University of Budapest, Hungary 


\section{SPONSORS}

Partners of the conference International Scientific Days 2020 " Innovative Approaches for Sustainable Agriculture and Food Systems Development ", May 14, 2020,

Nitra, the Slovak Republic

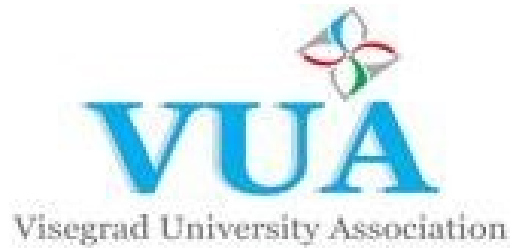

Visegrad University Association
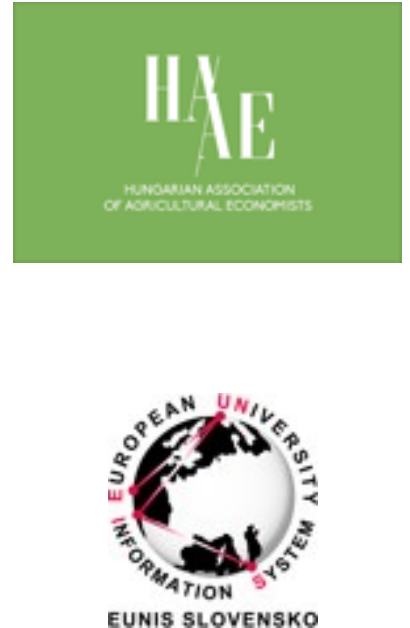

\section{AAES}

Association of Agricultural

Economists in Slovakia

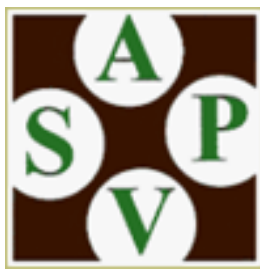

Corporate Social Responsibility and Innovation Activities Focused on Decreasing Food Losses with Regards of Environmental Issues VEGA 1/0802/18

Slovak Research and Development Agency on the basis of Contract no. APVV-16-0244 "Qualitative factors affecting the production and consumption of milk and cheese". Corporate social responsibility and innovation activities focused on decreasing food losses with regards of environmental issues VEGA 1/0802/

APVV-17-0564 "The Use of Consumer Neuroscience and Innovative Research Solutions in Aromachology and its Application in Production, Business and Services" (NEUROSMELL)

Erasmus+ KA2 Strategic Partnerships for Higher Education, no. 2018-1-SK01KA203-046324 "Implementation of Consumer Neuroscience and Smart Research Solutions in Aromachology"(NEUROSMARTOLOGY)

Many thanks to all partners which have contributed to this event. 


\section{Foreword}

\section{Dear colleagues and friends,}

I am pleased to introduce to you a collection of scientific papers presented during the international scientific conference "International Scientific Days 2020 (ISD 2020)," organized by the Faculty of Economics and Management of the Slovak University of Agriculture in Nitra on May, 14, 2020.

This year's conference was very specific. Nobody would have thought what a terrible crisis we will be going through at national and global level at the beginning of 2020. In 2019, we thought about the best partnership and location for our conference offering attractive official and also informal environment. International scientific conference ISD 2020 was to be organized for the first time in its history abroad, in neighboring Hungary, but due to the pandemic situation related to the Coronavirus disease COVID-19 it won a different priority. For the first time in its history, it was organized online and moved to a virtual environment.

The main topic of the 16th year of the conference was "Innovative Approaches for Sustainable Agriculture and Food Systems Development." Making agriculture sustainable is a global challenge. Also the 'European Green Deal', published by the European Commission in December 2019, presents a new framework for EU policy including a Farm to Fork Strategy on sustainable food, intention to maintain biodiversity and to implement measures addressing the environmental challenges.

Conference papers cover several current topics and important areas such as sustainable food systems, food marketing, bioeconomy, agricultural policy and agri-food value chain issues, trade, finance, resource management and innovative approaches to modern business, education and communication technologies. Many of them present latest results of national and international project.

Dear readers,

I hope that research papers in proceedings will bring you a new perspective, information, knowledge, thoughts, ideas for comparative studies or new academic or research contacts as well.

\section{Dr. h. c. prof. Dr. Ing. Elena Horská}

Dean

Faculty of Economics and Management Slovak University of Agriculture in Nitra Slovak Republic 


\section{LIST OF REVIEWERS}

doc. Ing. Alena Andrejovská, PhD. doc. Ing. Dagmar Babčanová, PhD. Ing. Tatiana Bencová, PhD. doc. Ing. Mgr. Ondrej Beňuš, PhD. Ing. Markéta Beranová, PhD. Ing. Eva Bieleková, PhD. Ing. Andrea Boháčiková, PhD. doc. RNDr. Monika Božiková, PhD. doc.Borusiak Barbara, PhD. Mgr. Karol Čarnogurský, PhD. Ing. Anna Diačiková, PhD. Ing. Ludmila Dobošová, PhD. Ing. Alexandra Filová, PhD. Ing. Marcela Hallová, PhD. Ing. Martina Hanová, PhD. doc. Ing. Klára Hennyeyová, PhD. doc. Ing. Ivan Holúbek, PhD. Ing. Veronika Hrdá, PhD. doc. Ing. Monika Hudáková, PhD., MBA doc. Ing. Daniela Hupková, PhD. Ing. Bc. Zuzana Juríčková, PhD. Ing. Zdenka Kádeková, PhD. doc. Ing. Zuzana Kapsdorferová, PhD. Ing. Jozef Koricina Ing. Ingrida Košičiarová, PhD. Ing. Jana Kozáková, PhD. Ing. Jana Ladvenicová, PhD. doc. Ing. Drahoslav Lančarič, PhD. Ing. Zuzana Lušňáková, PhD. doc. Mgr. Peter Madzík, PhD. doc. Ing. Serhiy Moroz, CSc. Mgr. Ing. Vladimír Očenášek, Ph.D. doc. RNDr. Dana Országhová, CSc. Ing. Jozef Palkovič, PhD. Dr. Lukasz Paluch doc. Ing. Viera Papcunová, PhD. Ing. Jan Pavlík Ing. Renata Matysik Pejas, $\mathrm{PhD}$. Ing. Katarína Petrovčíková, PhD. Dr. hab. Bartolomiej Pieranski dr inż. Aleksandra Płonka PaedDr. Peter Polakovič, PhD. doc. Ing. Artan Qineti, PhD. Ing. Renáta Benda Prokeinová, PhD. Ing. Tomáš Rábek, PhD. doc. Ing. Patrik Rovný, PhD. PaedDr. Lucia Rumanová, PhD. Mgr.et Mgr Jana Rybanská, PhD. doc. Ing. Radovan Savov, PhD. doc. Ing. Peter Serenčéš, PhD. prof. Ing. Jana Stávková, CSc. Ing. Śárka Stojarová, PhD. Ing. Zuzana Strápeková, PhD. Dr. Monika Szafranska doc. Ing. Mária Šajbidorová, PhD. Ing. Petra Šánová, PhD. Ing. Peter Šedík, PhD. doc. Ing. Edita Šilerová, Ph.D. doc. Ing. Milan Šujanský, CSc. Ing. Petronela Švikruhová, PhD. doc. Ing. Juraj Tej, PhD. prof. RNDr. Anna Tirpáková, CSc. Ing. Marián Tóth, PhD. RNDr. Darina Tóthová, PhD. prof. Oksana Tulai, D.SC. doc. Ing. Jana Turčínková, PhD. Ing. Mária Urbánová, PhD. Ing. Alexandra Ferenczi Vaňová, PhD. Ing. Ivana Váryová, PhD. 


\section{LIST OF SESSIONS}

SESSION 1: Food Losses and Waste in the Context of Sustainable Food Systems Corporate Social Responsibility and Innovation Activities Focused on Decreasing Food Losses with Regards of Environmental Issues VEGA 1/0802/18

SESSION 2: Food Marketing and Consumer Studies Slovak Research and Development Agency on the basis of Contract no. APVV-16-0244 "Qualitative factors affecting the production and consumption of milk and cheese". Corporate social responsibility and innovation activities focused on decreasing food losses with regards of environmental issues VEGA 1/0802/

APVV-17-0564 "The Use of Consumer Neuroscience and Innovative Research Solutions in Aromachology and its Application in Production, Business and Services" (NEUROSMELL)

Erasmus+ KA2 Strategic Partnerships for Higher Education, no. 2018-1-SK01KA203-046324 "Implementation of Consumer Neuroscience and Smart Research Solutions in Aromachology"(NEUROSMARTOLOGY)

SESSION 3: The Agricultural Policy and Agri-Food Value Chain Analysis: Economics, Management and Logistics

SESSION 4: Bioeconomy, Resource Management and Sustainable Development

SESSION 5: Innovation Systems, Entrepreneurship and Modern business prospects

SESSION 6: Trade, Foreign Investment and Industrial Policies in the EU

SESSION 7: Information and Communication Technologies

SESSION 8: Agricultural University Education, Quality Assurance and Humanity Studies

SESSION 9: Agricultural Markets and Institutions - Organised Session by the Association of Agricultural Economists in Slovakia - AAES

SESSION 10: Finance and Current Issues 


\section{REGISTER}

SESSION 1

Evaluation of Social Responsibility in the Selected Food Chain in the Area of Environmental Protection 15

Pavol Grman ${ }^{1}$, Radka Kataniková ${ }^{2}$, Petronela Švikruhová ${ }^{3}$........................................ 15

Optimization of the Amount of the Company's Insurance Stock...................................... 23

Veronika Hrdál, Zuzana Juričková ${ }^{2}$, Alexandra Filová ${ }^{3}$............................................ 23

Biodegradable Municipal Waste and Possibilities of its Utilization - Theoretical Study

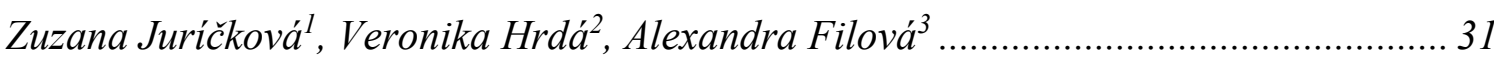

Corporate Social Responsibility and Innovation Activities to Reduce Food Waste in

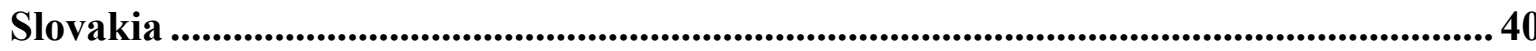

Zuzana Kapsdorferovál, Petronela Švikruhová ${ }^{2}$ Radka Kataniková ${ }^{3}$ Mária

Kadlečíková ${ }^{4}$, Pavol Grman ${ }^{5}$, Mária Medved'ova ${ }^{6}$....................................................... 40

Consumer Behavior and Food Waste .................................................................................. 47

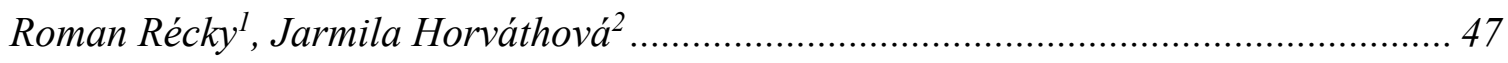

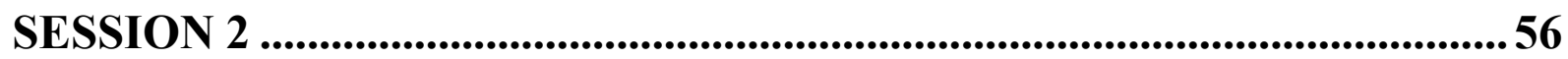

Aromatization and Air Quality as an Important Aspect of Grocery Shopping Environment ....................................................................................................................................... 57

Jakub Berčik $k^{1}$, Johana Paluchová ${ }^{2}$, Jana Gálová ${ }^{3}$, Katarína Neomániová ${ }^{4}$.................... 57

Comparison of Selected Indicators of Production and Sales of Vegetables in the

Conditions of the Slovak Republic and the Czech Republic .............................................. 68

Rebecca Brodňanová ${ }^{1}$, Jozef Šumichrast ${ }^{2}$, Tatiana Evteeva ${ }^{3}$........................................6 68

Innovative Research Solutions in Aromachology and Aromatherapy ......................... 78

Karol Čarnogurský ${ }^{1}$, Anna Diačiková ${ }^{2}$, Peter Madzik ${ }^{3}$.............................................. 78

What prevails at the Slovak Food Market: Similarities or Differences? ........................ 86

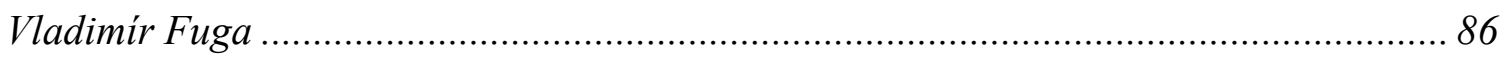

Overview of Corporate Social Responsibility Strategies of the Selected Food Businesses

During the COVID-19 Pandemic ....................................................................................... 93

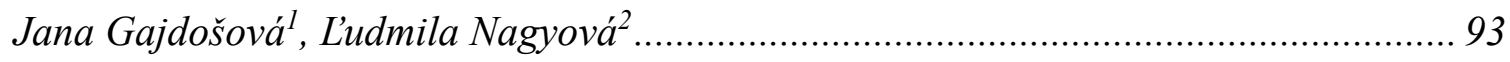

Environmental Corporate Social Responsibility of the Visegrad Group Countries, with

a Focus on Circular Economy and Waste Management ............................................... 101

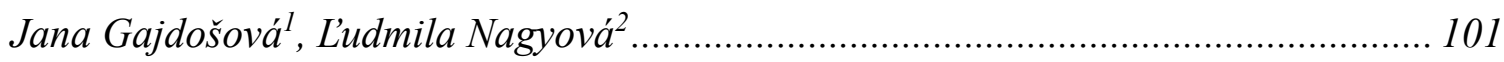

Importance of New Marketing Trends and their Application by Slovak Wine Companies................................................................................................................ 109

Erik Janšto ${ }^{1}$, Klara Hennyeyová ${ }^{2}$, Peter Polakovič̉ ${ }^{3}$, Edita Šilerová ${ }^{4}$ Galina

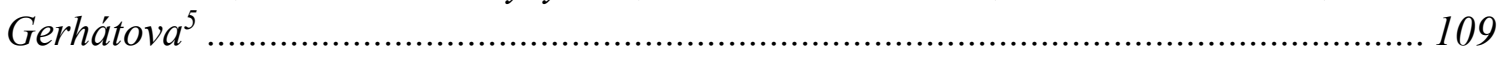

Aromachology and its Role in Influencing Consumer Behaviour .............................. 119 
of Millennials

Zdenka Kádeková ${ }^{1}$, Ingrida Košičiarová ${ }^{2}$, Mária Holotová ${ }^{3}$ L’ubica Kubicová ${ }^{4}$, Kristína Predanocyová ${ }^{5}$

Characteristics of Producers Capable of Development, and Selling in Marketplaces -

Results of Hungarian Primary Research 130

Konrád Kiss ${ }^{l}$...... 130

The Consumption of Milk from the Slovak Consumer's Point of View 139

Lubica Kubicová ${ }^{1}$, Kristína Predanocyová ${ }^{2}$, Zdenka Kádeková ${ }^{3}$, Ingrida Košičiarová 139

Factors Affecting Purchasing and Consumption Behaviour: A Case Study of Slovak Milk Market 148

Ludmila Nagyová ${ }^{1}$, Peter Šedik $k^{2}, J a k u b$ Berčík ${ }^{3}$, Marek Petril'ák $k^{4}$, Csaba Bálint Illés 5148 Placing of Smell in Restaurant and Aromatization' Impact on Customers and Profit 155

Johana Paluchovál, Jakub Berčík ${ }^{2}$, Katarína Neomániová ${ }^{3}$, Patrícia Janičová ${ }^{4}$........... 155

Consumer Preferences on the Wine Market ............................................................................ 165

Tomáš Rebičc $\check{c}^{1}$ Elena Horská ${ }^{2}$, Anna Dunay ${ }^{3}$............................................................ 165

Consumer Behaviour towards Traditional Slovak Cheese "Parenica"........................ 174

Peter Šedik ${ }^{1}$, Jakub Berčík ${ }^{2}$, Ludmila Nagyová ${ }^{3}$,Elena Horská ${ }^{4}$, Emese Tatar ${ }^{5}$........... 174

The Current Situation and Needs of Milk Producers in the Slovak Republic ............ 181

Petronela Švikruhová ${ }^{1}$, Zuzana Kapsdorferová ${ }^{2}$, Radka Kataniková ${ }^{3}$......................... 181

Review of Aroma Marketing Application in Electronics Stores ................................... 189

Adam Vakošl, Michaela Šugrová ${ }^{2}$, Johana Paluchová ${ }^{3}$, Jakub Berčík ${ }^{4}$....................... 189

Development of Raw Cow Milk Prices in the Conditions of the Slovak Republic and

Hungary and its Comparison .................................................................................................... 197

Ivana Váryovál, Zuzana Poláková ${ }^{2}$, Peter Obtulovič³ , Iveta Košovská ${ }^{4}$....................... 197

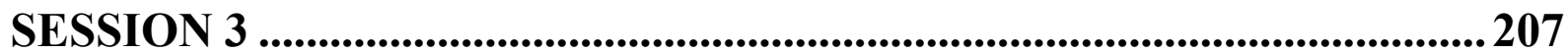

Cultivation of Medicinal Plants in Slovakia and Czech Republic .............................. 208

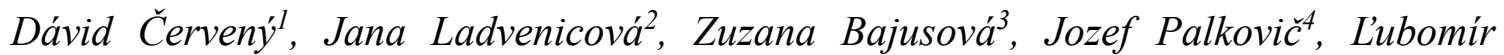
Gurčík ${ }^{5}$

Strategic Imperatives for the Development of the Grain Market in Ukraine ............ 216

Anatolii Dibroval, Larysa Dibrova ${ }^{2}$, Maksym Dibrova ${ }^{3}$............................................... 216

Providing of Export Potential for Agricultural Organization ................................... 226

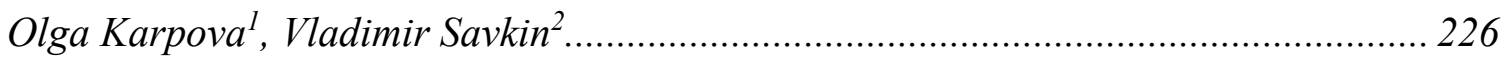

Application of Forms and Types of Agricultural Advisory in Public and Private

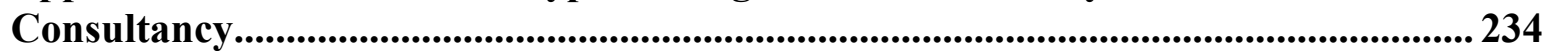

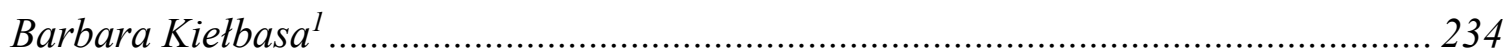

Comparative Analysis of the Milk Market in the V4 Member Countries .................. 243 
Veronika Mihálovál, Daniela Hupková ${ }^{2}$ Ludmila Dobošová ${ }^{3}$, Ondrej Beňuš $\check{4}^{4}$ Yelyzaveta

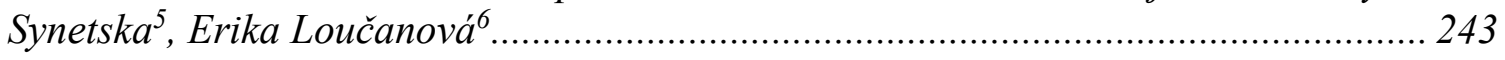

Investment Analysis of Apple Production in Isparta Province, Turkey ....................... 254

Kubilay Ucar ${ }^{1}$, Jozef Repisky ${ }^{2}$, Martina Zaujecová ${ }^{3}$.................................................. 254

SESSION 4

Linear Programming for Land Allocation - Example of Selected Crops in Slovakia263 Tatiana Bullovál, Peter Bielik², Izabela Adamičková3, Mária Urbánová4, Dominika Čeryová ${ }^{5}$......

Evaluation of Development of Selected Renewable Energy Indicators and their Interdependence in the V4 Countries.

Dominika Čeryová ${ }^{1}$, Filip Valentíni ${ }^{2}$, Natália Turčekováa , Izabela Adamičková ${ }^{4}$, Tatiana Bullová ${ }^{5}$

Environmental Awareness of Young People and its Importance for the Green Jobs

Development 279

Anna Mravcovál, Danka Moravčíková . $^{\text {. }}$ 279

Restructuring of Economy in a New Global Environment to a Sustainable - one of the Tasks for a Global Citizen 291 Eva Pechočiaková Svitačovál, Anna Mravcová ${ }^{2}$.. 291

EU Member States Competitiveness and Competitive Potential. 300 Eva Richterová ${ }^{1}$, Martin Richter ${ }^{2}$, Eva Matejková ${ }^{3}$, Zlata Sojková ${ }^{.}$ 300

SESSION 5 311

Connection Between Ethics and Diversity - Theoretical Study. 312 Jana Kozákovál

New Approaches to the Education and Personal Development of Food Business Employees

Silvia Lenčéšová ${ }^{1}$, Mária Šajbidorován, Zuzana Lušňákováa 319

Air Quality and Other Factors Influencing Suitability of Food Businesses Work Environment 328 Zuzana Lušňákovál, Mária Šajbidorová ${ }^{2}$, Silvia Lenčéšováa ${ }^{3}$,Boris Rumanko ${ }^{4}$ 328

Agricultural University Students and their Attitudes Towards Entrepreneurship: Selected Aspects. 337

Danka Moravčikovál, Martina Hanová ${ }^{2}$.

CSR Awareness among Foodservice Companies (Study in Ukraine within the Environmental Pillar) ................................................................................................ 344

Oksana Sokil ${ }^{1}$, Drahoslav Lančarič ${ }^{2}$, Iveta Ubrežiová ${ }^{3}$................................................. 344

Use of Management Information Systems in Corporate Management ....................... 352

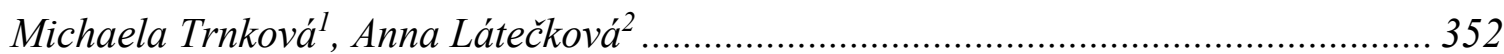

The Code of Conduct in Slovak Companies...............................................................360

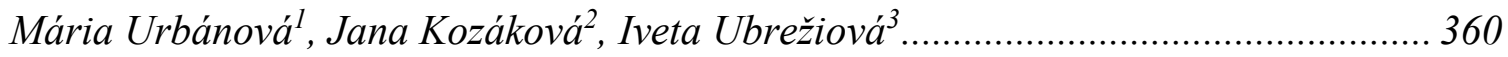


The Role of Government in the Investment Activity of the Regions

Irina Belinskaia ${ }^{1}$, Natalia Frolova ${ }^{2}$.

Competitiveness of the Meat Industry in Hungary and the Slovak Republic Fourteen

Years after Joining the EU

Ondrej Beňuš ${ }^{1}$, Ludmila Dobošová ${ }^{2}$, Daniela Hupková ${ }^{3}$,Veronika Mihálová ${ }^{\text {. }}$

Public Procurement as an Innovative Tool of EU Policies (Case Study) 391 Radomíra Hornyák Gregáňovál, Viera Papcunová ${ }^{2}$. 391

Assessing of Businesses Environment's Essential Indicators in Indonesia 402 Renáta Krajčirová ${ }^{1}$, Martina Krajčirová ${ }^{2}$, Alexandra Ferenczi Vaňová ${ }^{3}$, Jozef Bojňanský ${ }^{4}$ 402

Uzbek Agrarian Foreign Trade and its Competitiveness ......................................... 410 Akhmadjon Ortikov ${ }^{1}$, Luboš Smutka ${ }^{2}$, Michal Steininger ${ }^{3}$ 410

SESSION 7 417

Modelling and Simulation of the Bulk Service Queueing Systems ............................... 418 Veronika Achimská ${ }^{1}$, Katarína Kramárová ${ }^{2}$........................................................... 418

Remote Laboratory Management System for Teaching and Experimentation ......... 425

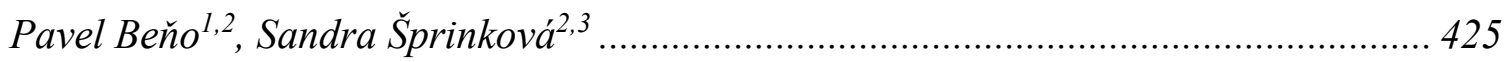

Transformation of Indexes between Relational and No-relational Databases for

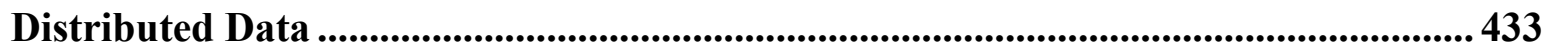
Roman Čerešňák $k^{1}$, Michal Kvet ${ }^{2}$, and Karol Matiaško ${ }^{3}$............................................ 433

Precision Agriculture and its Tools in Environment of Slovak Farms.......................... 442 Marcela Hallová ${ }^{1}$, Martina Hanová ${ }^{2}$, Roderik Virágh ${ }^{3}$.............................................. 442

Virtual Reality Perspectives in Implementation into Serious Game Application ...... 448

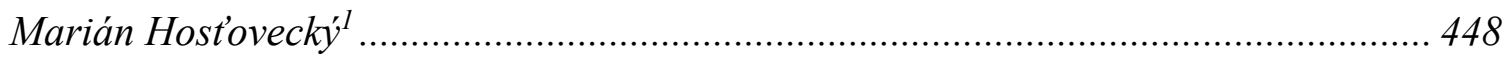

The Digital Age and Its Pros and Cons for Society ................................................. 456

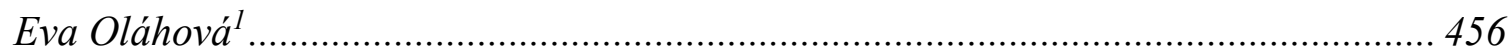

Analysis of Very Large Database Indexing................................................................... 465

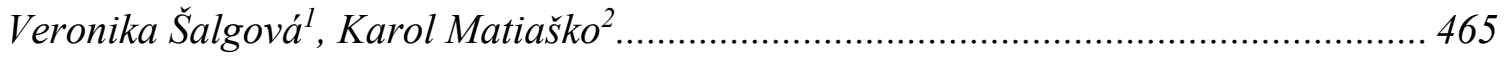

Optimization of Web Enviroment by Analyzing Website Traffic .................................. 473 Darina Tóthová ${ }^{1}$, Jakub Lacina ${ }^{2}$, Marcela Foltánová ${ }^{3}$............................................... 473

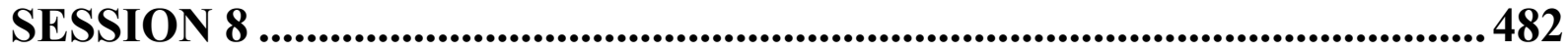

Foreign Languages - a Relevant Condition of Employers for Graduates of the Slovak Universities in the Central European Region ............................................................483 L'ubomíra Moravcová ${ }^{1}$, L'udmila Mad'arová ${ }^{2}$, Serhiy Moroz ${ }^{3}$, Ivan Imrich ${ }^{4}$.................. 483

Evaluation of University Students' Mathematics Knowledge in Linear Algebra ...... 497 
Dana Országhová ${ }^{1}$, Mária Farkašováa, Norbert Kecskés ${ }^{3}$, Radomíra Hornyák

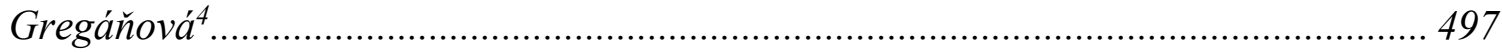

Trends of Number Newly Admitted University Students in the Slovak Republic ..... 506

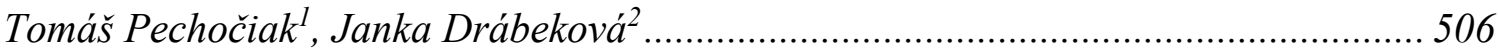

Preventing Food Waste and the Psychological Phenomenon of the "Best-Before

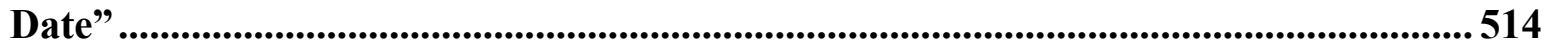

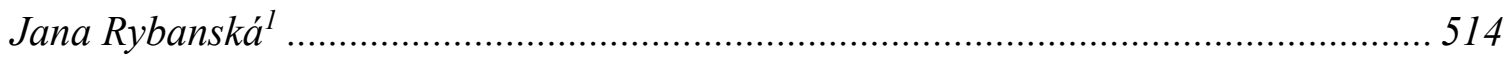

The Modern Ukrainian Model of Quality Assurance in the Agricultural University

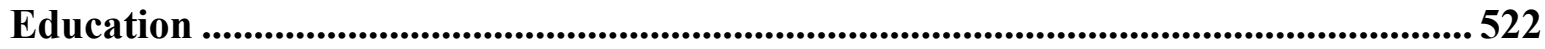

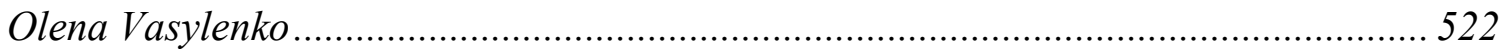

Creation of Partial Individual Study Plans by Students as a Possibility to Increase the Attractiveness of Higher Education at FEM SUA in Nitra ......................................... 530

Roderik Virágh ${ }^{1}$, Marcela Hallová ${ }^{2}$, Peter Stuchlý ${ }^{3}$, Erik Janšto ${ }^{4}$, Silvia Virághová ${ }^{5}$.. 530

Education for Sustainable Development and the Possibilities for Its' Implementation into the Teachers Preparation ............................................................................................... 538

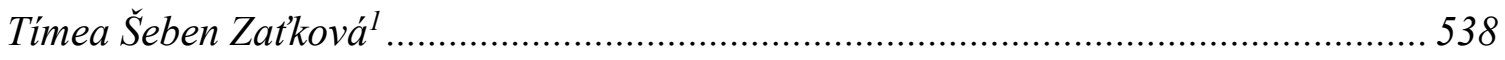

SESSION 9 ................................................................................................ 552

Determinants of ECOWAS Cocoa Export. The Gravity Model Approach............... 553

Emmanuel Bangmarigu ${ }^{1}$, Eva Bieleková ${ }^{2}$, Artan Qineti ${ }^{3}$.............................................. 553

Who Participated in the Block Farm Scheme in Ghana? ...........................................562

Emmanuel Bangmarigu ${ }^{1}$, Ema Lazorčáková ${ }^{2}$, Artan Qineti ${ }^{3}$......................................... 562

Horizontal price Transmission in Ghana. An Asymmetric Error Correction Model (AECM) ...................................................................................................................... 571

Emmanuel Bangmarigu ${ }^{1}$, Miroslava Rajčániová ${ }^{2}$, Artan Qineti $^{3}$................................. 571

Unfair Trading Practices in the Slovak Fruit Sector ....................................................... 585

Katarína Baráthová ${ }^{1}$, Ján Pokrivčák ${ }^{2}$, Miroslava Rajčániová ${ }^{3}$, Artan Qineti ${ }^{4}$............... 585

Economic Loss of Small-Middle Enterprises from Unfair Dealing in the European Food Distribution System ..............................................................................................55

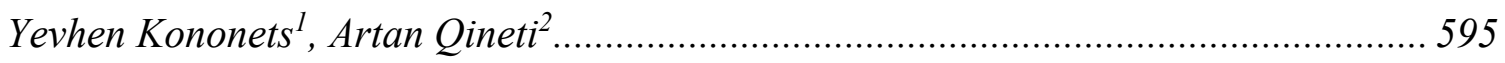

Conditions for Improving the Position of Small-Scale Food Producers in Food Supply

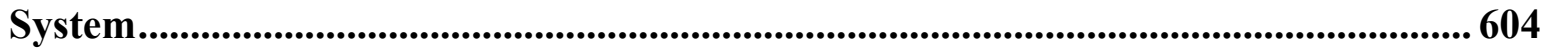

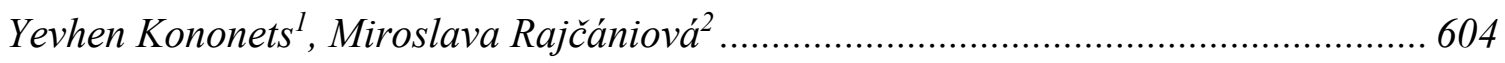

SESSION 10 ........................................................................................613

DEA in Performance Measurement of Dynamic Processes: Comparative Overview of

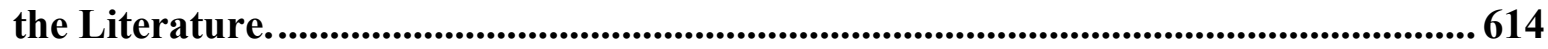

An Illustration of Dynamic Network DEA in Agricultural Enterprises ....................... 614

Tatiana Bencová ${ }^{1}$, Ivan Holúbek ${ }^{2}$, Marián Tóth ${ }^{3}$, Andrea Boháčiková ${ }^{4}$........................ 614

Risk Assessment of Agricultural Companies Using Accounting Beta......................... 628 
Andrea Boháčikovál, Tatiana Bencováa ${ }^{2}$ Zuzana Kapustová ${ }^{3}$, Ivan Holúbek ${ }^{4}$ 628

Influence of Direct Payments on the Economy of Chosen Agricultural Commodities in the Slovak Republic 636

Patrik Rovnýl, Dušan Dobák ${ }^{2}$, Zuzana Strápeková ${ }^{3}$, Lenka Števonková Lavriková ${ }^{4}$..... 636 Profitability of Enterprises in the Agricultural Sector in Terms of the Legal Form of Business ......................................................................................................................... 643

Ivana Kravčáková Vozárovál ${ }^{1}$ Rastislav Kotulič², Peter Adamišin ${ }^{3}$.............................. 643 


\section{SESSION 1}

FOOD LOSSES AND WASTE IN THE CONTEXT

OF SUSTAINABLE FOOD SYSTEMS

(Supported by project: Corporate Social Responsibility and Innovation Activities

Focused on Decreasing Food Losses with Regards of Environmental Issues

VEGA 1/0802/18) 


\title{
Evaluation of Social Responsibility in the Selected Food Chain in the Area of Environmental Protection
}

\author{
Pavol Grman ${ }^{1}$, Radka Kataniková ${ }^{2}$, Petronela Švikruhová ${ }^{3}$ \\ Slovak university of agriculture in $\mathrm{Nitra}^{1,2,3}$ \\ Faculty of economy and management, Department of management ${ }^{1,2,3}$ \\ Address: Tr. A. Hlinku 2, \\ 94976 Nitra, Slovakia \\ e-mail: pavol.steven.grman@gmail.com ${ }^{1}$,radka.katanikova@gmail.com², \\ petronela.svikruhova@uniag.sk ${ }^{3}$
}

doi: 10.18515/dBEM.ISD.P01.2020.p001

\begin{abstract}
Corporate Social Responsibility (CSR) initiatives often help businesses in the form of competitive advantage. Because of these initiatives it is difficult to realize the full value of strategic CSR. CSR can be divided into many areas of business, but the most well-known triple bottom line theory divides CSR into 3 basic areas: environmental, social and economic. In this article we reviewed CSR of the wellknown food chain - Lidl in the context of corporate social responsibility. We focused mainly on the environment part of Lidl's CSR. We described the CSR policy of the retail chain and suggested the necessary improvements. Our aim was to focus specifically on Lidl's actions and to point out the perception of their programs to deal with food waste, as this is currently a serious problem. The question of food waste is very important nowadays, because we have problems with hunger in some countries and on the other hand we have food waste problems because of the surplus offood. Distribution should be more even. Large food chains such as Lidl have an important role to play in wasting food. The problem of the food waste affects similar food chains much more, as food demand is steadily increasing. Food losses and food waste are responsible for 3.3 trillion tons of greenhouse gases. Improving the situation of food losses and food waste is considered to be a significant factor in reducing emissions.
\end{abstract}

Keywords: food losses, corporate social responsibility, environmental protection, food chain

JEL Classification: Q5O, Q56, O29

\section{Introduction}

In recent years, social responsibility has attracted the interest of many enterprises around the globe. Over time, more and more companies are using a strategy called corporate social responsibility for their business activities. This is due to the increased interest of consumers, but also of the general public, in a business initiative for responsible behaviour with regard to economic, social and environmental sustainability (Dhanesh, 2014).

One of the verified approaches to CSR and its communication with the public is, in addition to a critical and interpretative clarification, a functionalist approach where organizations are actively involved and communicate about their social, environmental, ethical and economic activities, because they are motivated to have positive public relations. It brings the results of stronger relationships and capital to support legitimacy and reputation.

However, most of the work done in this area focused on external stakeholders, although employees and customers were identified as an important stakeholder group on CSR.

A necessary first step in engaging the public in CSR activities is through awareness of the opportunities to participate in such activities. Information about CSR activities usually comes from enterprises. Companies design CSR programs through a variety of channels through which they communicate their CSR reports to engage the public in activities such as the most 
commonly used mass media, corporate offline channels, corporate online channels, interpersonal communication and CSR reports. (Bhattacharya et al., 2011).

In the economic area, it pursues business and the process of improvement in the area, which will help to support the development of the economic environment and minimize the possible negative effects of the activities of companies in this field. This may include, for example, the code of business ethics, relations with shareholders, suppliers, consumers, advertising and the protection of intellectual property. In an area that is responsible for the human factor and the social perspective, corporate responsibility is manifested by controlling and minimizing the negative impact of businesses on society and the system in which they work. Examples include health and safety of employees, work-life balance, rules of lobbying, the fight against corruption or improving the quality of life. In the environmental field, corporate responsibility is reflected in increasing environmental protection and reducing the organisation's negative environmental impact (Bussard et al., 2005).

The desire to create a positive social change in the business world is not necessarily a new phenomenon, although the current social, political, economic and ideological conditions today specifically identify it so (May et al., 2007).

Using CSR cynically as a smoke screen to avoid taking serious steps to improve the social and environmental outcomes of a company's operations or masking your lobbying activities has nothing to do with real CSR. Corporate social responsibility is not a policy for all (Martin, 2008).

Business for social responsibility defines CSR as a way of doing business above a framework of ethical, legal, business and social expectations (Pavlík et al., 2010).

Socially responsible businesses strive to behave in a way that promotes sustainable development and a general improvement in the state of society (Čierna, 2008).

\subsection{Corporate social responsibility in environmental protection}

Corporate social responsibility is a concept whereby companies integrate social and environmental concerns in their business operations and in their interaction with the stakeholders on a voluntary basis. (Patil, 2014).

Irrespective of whether a company is polluting or non-polluting, protection of environment should be the concern of every socially responsible organisation. Each company must take steps to make sustainable use of resources, establish a healthy and safe working environment, maintain ecological balance, take proactive steps to minimise waste generation and preserve environment (Sharma, 2014).

In the above-mentioned environmental field, it is clear that enterprises are seeking to minimize the negative impact of their activities on the environment because they can therefore take advantage of new business opportunities.

In small and medium-sized enterprises, a company, which is active in environmental protection has likely a better opportunities to succeed in tenders conducted by large companies and the public sector, and is more likely to attract new customers, especially among environmentally conscious consumers.

The following list contains examples of CSR activities related to environmental categories:

$>$ organic production, products and services

$>$ environmentally friendly packaging, 
$>$ ecological transport and distribution procedures,

$>$ recycling and use of recycled materials,

$>$ energy and water saving procedures,

$>$ waste reduction,

$>$ protection of natural resources; and

$>$ provide accurate environmental information on products, services and activities (Steinerová, 2008).

The society is developing dynamically and within the view of environmental protection. Enterprises that focus on environmental protection can benefit from this approach in terms of socially and environmentally responsible CSR behaviour, such as:

$>$ new business opportunities (such as acquiring new environmentally friendly customers)

$>$ resource protection,

$>$ reduce energy and waste,

$>$ reduce costs by increasing energy efficiency and resource use;

$>$ more efficient action (Steinerová, 2008).

The main aim should be gadget progressively the implementation of proposals to protect the environment and improve the environment protection in general. Environmental problems have recently started to be tackled very seriously at several levels. It is also desirable that each business start by itself and its behaviour towards the environment. All of this is a prerequisite for quality and sustainable implementation of CSR. One important objective is to reduce food waste, which accounts for a large part of the greenhouse gas volume.

Businesses seeking to develop and build a reputation by focusing their CSR policy on environmental protection. In this case, the company's image is a strategic aspect of competition. At present, businesses are required to contribute to environmental issues. The enterprise, which operates in this area, uses environmentally oriented marketing. The main purpose of environmental marketing can be considered to reduce the environmental burden in the market activities of the company through customer satisfaction and use the competitive advantages of the company to achieve its goals (Kramer, 2005).

In 2015, the UN accepted 17 key objectives for the sustainable development of the 2030 Global Agenda. The seventeen sustainable development goals, which include, for example, "ending poverty" and "ensuring a healthy life", systematically translate the key to the major challenges facing humanity. These are objectives that can only be achieved through cooperation and joint efforts by governments, businesses and civil society. Progress in the organization and research of food waste management would contribute to the achievement of several sustainable development objectives (Jurgilevich, 2016).

Food losses invoke to the decrease in succulent food mass throughout the section of the supply chain that precisely drives to edible food for human consumption. Food losses occur at production, postharvest and processing phases in the food supply chain. Food losses appearing at the end of the food chain (retail and final consumption) are rather called food waste, which refers to retailers' and consumers' attitude (Parfitt, 2010).

Food waste is each and every food, and uneatable parts of food, detached from the food supply chain to be regained or disposed, as well as the following destinations: composting, crops ploughed in/not harvested, co-generation, anaerobic digestion, bio-energy production, 
incineration, disposal to sewer, depot or forsaken to sea but not including food or uneatable parts of food detached from the food supply chain to be sent to animal feed or bio-based material/chemistry processing (Tostivint et al., 2016).

In relation to the food industry, CSR is defined in terms of food security, food safety, and quality, as well as environmental and social sustainability (Fuchs et al., 2009).

More specifically, social responsibilities can include ethical and/or sustainable practices in the areas of animal welfare, biotechnology, environment, fair trade, food waste, health and safety, labor and human rights, procurement and community (Maloni \& Brown, 2006).

\section{Data and Methods}

Spread out the globe, there are growing discussions about the food losses and food waste. This is current problem, as in every year, worldwide is dissipate about one third of food, which is originally prepared for human consumption - approx. 1,3 bill. tons, or it is ending in the food waste (Kapsdorferová et al., 2019).

The research is aimed at evaluating Lidl's CSR concept in the environmental field about food waste approaches. For this purpose, the international company Lidl was selected. We achieved this goal with the questionnaire survey.

The information and data mentioned in this paper have been obtained from domestic and foreign literature dealing with the subject, as well as from scientific articles. We also derive from the company's official website, where the published information is freely available. Finally, we used information from an anonymous questionnaire survey aimed at obtaining information about the perception of CSR activities of the enterprise.

Questionnaire survey method - the frequency of use of this method has been increased mainly by the spread of information technologies. The success of this method is conditioned by correct questions, willingness of respondents as well as truthful answers. This method is mainly used for the identification of data of a qualitative nature, but occasionally for the collection of factual data of a quantitative nature. The collected data were processed in Microsoft Excel. We also expressed data graphically in the form of graphs with relative expressions of values.

A total of 301 respondents participated in our survey. The survey was conducted during February 2020. The questionnaire form was distributed online via social networks. The target group consisted of primarily adult Lidl customers.

The $72 \%$ of women and $28 \%$ of men participated in the survey. The largest group of respondents consisted of respondents in the age group from 26 to 35 years, in the range of $47 \%$. The second largest group was respondents aged 18 to 25 , who accounted for $43 \%$ of the total number of respondents. Respondents in the 36-45 age group conducted a survey of 5\%. To a small extent (3\%), people aged 46-55 also participated in the survey. To the smallest extent (2\%), people over 55 were involved in the survey.

The questionnaire survey contained a total of seven questions. The first three questions were identification questions. The remaining four questions focused on identifying customers' perception of CSR activities by Lidl. We asked the respondents the following questions: 1.) Do you know the project to not waste-consume? 2.) Did you know that food just before the expiration date in Lidl is separated from other products and is offered for sale corners with a $30 \%$ discount? If you are buying these foods? 3.) Modern retail chains increasingly use innovative packaging to reduce the risk of food degradation. Have you met in Lidl with such packaging? 4.) Mark the option that you think is the best solution to reduce food waste in the supermarket. For the purpose of writing this scientific article, we decided to publish only the 
results of the first two questions, because these results of the answers sufficiently reflect the perception of customers. We plan to analyze the results of the other two questions in the next paper.

\section{Results and Discussion}

Lidl follows the motto: " On the way to a better tomorrow ", which only emphasizes that Lidl is aware of the importance and importance of CSR and believes that it can help to create a better future through its actions. The company did not just keep up with the words and carries out a number of socially responsible activities that ensure responsible access to all stakeholders and the environment.

\section{Effective ordering processes and high sales}

The main goal of Lidl within this goal is to order very accurately. Therefore, it may happen that the evening before closing the baker's ware is already sold out. This is because the behaviour of customers is often unpredictable and cannot be $100 \%$ determined by the most accurate planning and forecasts. As a result, Lidl minimizes the amount of food waste.

\section{Discounts on food before the expiry date}

The systems for the registration goods in stock and in the supermarket provide every day an overview of whether food is in the period just before its expiry date. This control is also reinforced by the work of Lidl employees who are reviewing and preventing food waste. If there is a product in the store just before the expiration date, it is separated from the other products and is offered in sale corners with a $30 \%$ discount. The discounted goods are sold at Lidl up to 1 day before the expiry date.

\section{Customer education}

Although, according to statistics, food chain accounts for only about 5\% of food waste (households $42 \%$, production $39 \%$, food $14 \%$ ), this is a not insignificant amount in terms of total food waste. Aware of its social responsibility, Lidl decided to engage in a long-term information and education project DO NOT WASTE - CONSUME, which aim is to monitor the situation in the area of food waste, both globally and in Slovakia. It also aims to publish relevant information and thus raise awareness.

\section{Food donation}

By reciprocal agreement, part of unsold food in Lidl is transported to Food bank of Slovakia (FBS). FBS is a civic association with a humanitarian focus. FBS is non-governmental, apolitical and is not bound by any religious movement. It is managed by a presidency elected by the general assembly, in which are represented social and charitable organizations operating in the Slovak Republic. The association collects food free of charge, stores it and assigns it to humanitarian or charity organizations that provide food aid to people in need. The vision is to build warehouses in all critical regions of Slovakia. In short, the activity of FBS consists of donation and distribution, and its activity is based on voluntary free assistance and donation. In doing so, FBS only accepts foods that meet all safety and hygiene criteria.

\section{Biogas stations}

The company has also found a solution for food that is no longer suitable for consumption. Fruits, vegetables, animal by-products and pastries are returned to the logistics centres, where they are concentrated in large-capacity containers and then transported to biogas stations, where electricity is supplied to the grid. In 2018, approximately 4558 tonnes of fruit and vegetables, 1414 tonnes of animal by-products and 1594 tonnes of pastry ended at these stations. 
The first asked question in the questionnaire was request in order to find out the dimension of the knowledge of customers, DO NOT WASTE - CONSUME. This project is the cornerstone on which Lidl is building its customer education policy to reduce the generation of food waste.

Figure 1: Do you know the project DO NOT WASTE-CONSUME?

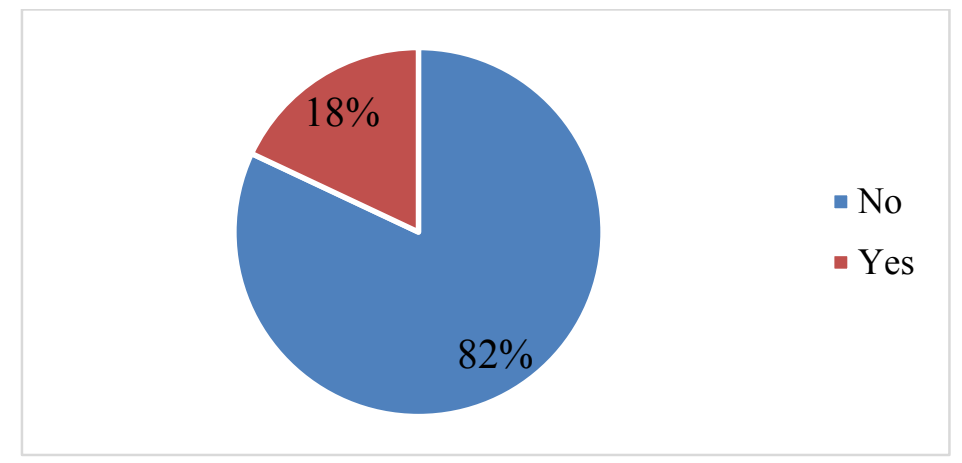

Source: Own processed based on the questionnaire survey conducted in February 2020

Based on the respondents' answers, we found out that up to $82 \%$ of respondents do not know the project DO NOT WASTE-CONSUME. Only $18 \%$ of respondents stated that they know this project, which means that Lidl should increase the promotion and enlightenment of this project, because only by monitoring the food waste reduction situation makes sense. The recommendation remains to collect, advertise and disseminate information of this and educate the general public, which will provide appropriate background for a society-wide discussion and appropriate measures with a vision of more efficient food handling as well as a positive change in consumer behaviour.

The second question was asked in order to ascertain whether customers were aware of Lidl's further precaution in preventing food waste. As mentioned above, the company offers the opportunity to purchase products just before their expiry date. These products are separate from the others and are offered in sale corners with a 30\% discount. Customers can sell this discounted product up to one day before the expiration date.

Based on the survey, we found that $20 \%$ of respondents do not even know about this possibility, which suggests that customers would be reminded of this possibility via online flyers or in-store signboards.

Figure 2: Did you know that food just before the expiration date in Lidl is separated from other products and is offered in sale corners with a $30 \%$ discount? If so, are you buying these foods?
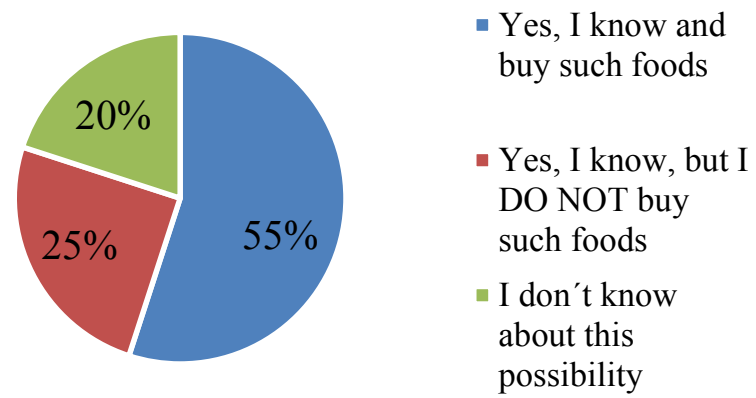

Source: Own processed based on the questionnaire survey conducted in February 2020

Another $25 \%$ of respondents admit that although they know about this possibility, they do not buy such foods. Here, we recommend introducing customer education techniques to draw 
attention to the fact that although food is just before the expiry date, it does not change their quality. The truth is that such foods are intended for immediate consumption, especially when it comes to meat, dairy products or fish. More than half of the surveyed customers $(55 \%) \mathrm{know}$ about the possibility to buy food just before the expiry date and also uses this chance. Such consumer behaviour is welcome as the retail chain does not lose its profits and does not have to deal with food waste and, on the other hand, the consumer purchases food at a discounted price.

\section{Conclusion}

In the theoretical part of this paper we identify the theoretical background of the problem. We pointed out the current market situation and presented the main benefits for which modern enterprises are currently trying to implement CSR policies and measures. We have outlined and described effective methods and activities that fall within this concept.

The importance of the underlined topic is also the fact that food waste is a global problem. According to UN statistics, up to one third of the world's food production ends up as waste, while one of the nine people in the world is going to sleep hungry. So it is not right to waste food in a world where more than 800 million people are starving.

Based on our research, we can conclude that Lidl is fully aware of its responsibility in this fight against food waste and should therefore start measuring food waste in its operations, and subsequently transparently disclose this data and conduct awareness.

As the first retailer in Slovakia, Tesco - a competitor of Lidl, published its food waste data as early as 2017. Since it has regularly measured the amount of food waste in its operations since then, the company is proud to say that it has already achieved the UN sustainable development goal - reduce food waste in half. And only in two years. During this short period, Tesco in Slovakia reduced food waste in its operations by an amazing $52 \%$.

Reducing food waste has a great importance not only for business or charities, but also in a global context. From an environmental point of view, food losses and food waste create about $8 \%$ of greenhouse gas emissions. If food losses were a country, they would be the third largest source of emissions after China and the US. Therefore, one of the goals of the UN's sustainable development is to halve the amount of food waste by 2030 .

Based on our research, we found that despite $18 \%$ of Lidl's efforts to educate on food waste issues, their basic initial project, DO NOT WASTE - CONSUME, only $18 \%$ of respondents knew this project.

We also found that $55 \%$ of respondents are buying food just before the expiration date offered by Lidl with a $30 \%$ discount, $20 \%$ of respondents did not even know about this option, and $25 \%$ of people did not buy discounted food despite such an offer.

Lidl should try to help to reduce food waste for both customers and suppliers. For example, following model of competition such as Tesco. In 2017, Tesco introduced a new range of fruits and vegetables under the name "Perfectly Imperfect". The aim was to help suppliers sell nonstandard shaped fruits and vegetables that would otherwise end up in the waste already at the farmer. Another inspiration-worthy activity of Tesco is the possibility for their partners in the supply chain to call the Hotline for Food Waste, where they can report its potential emergence and the company will help them solve the situation. In this way, Tesco helps its suppliers while ensuring efficient distribution of products at an unusually rich harvest. To conclude, Lidl is a retail chain that is constantly striving to improve. Lidl did not just keep with words, but within the framework of CSR, it is taking a huge step forward, towards predefined goals that benefit 
the welfare of the general society and the environment. Lidl also expresses this endeavour with his motto: "On the way to a better tomorrow".

\section{Acknowledgement}

This article was realized based on research grant: VEGA 1/0802/18, Corporate social responsibility and innovation activities focused on decreasing food losses with regards of environmental issues

\section{References}

[1] Bhattacharya, C. B., Sen, S., \& Korschun, D. (2011). Leveraging corporate responsibility: The stakeholder route to maximizing business and social value. Cambridge University Press.

[2] Bussard, A., Marček, E., Markuš, M., Bunčák, M., \& Mazurkiewicz, P. (2005). Spoločensky zodpovedné podnikanie: Prehlad základných princípov a príkladov. Nadácia Integra.

[3] Čierna, H. (2008). Spoločensky zodpovedné podnikanie a model výnimočnosti. Banská Bystrica: Studia oeconomica, $35,104$.

[4] Dhanesh, G. S. (2014). CSR as organization-employee relationship management strategy: A case study of socially responsible information technology companies in India. Management Communication Quarterly, 28(1), 130-149.

[5] Fuchs, D., Kalfagianni, A., \& Arentsen, M. (2009). Retail power, private standards, and sustainability in the global food system. Corporate power in global agrifood governance, 29-59.

[6] Jurgilevich, A., Birge, T., Kentala-Lehtonen, J., Korhonen-Kurki, K., Pietikäinen, J., Saikku, L., \& Schösler, H. (2016). Transition towards circular economy in the food system. Sustainability, 8(1), 69.

[7] Kapsdorferová, Z.; Švikruhová, P.; Kadlečíková, M.; Grman, P. (2019). The social responsibility and innovation activities at the decreasing of food losses with special focus on the sustainable use of the natural resources. In 9th international scientific conference of business faculty "economic policy and EU integration”. Economic policy and EU integration. Durrës: Universiteti Aleksandër Moisiu,, p. 471 -482

[8] Kramer, M., Urbaniec, M., \& Obršálová, I. (2005). Mezinárodní management životního prostředí: Interdisciplinární rámcové podmínky environmentálně orientovaného řizení podniku. Svazek I. CH Beck.

[9] Maloni, M. J., \& Brown, M. E. (2006). Corporate social responsibility in the supply chain: an application in the food industry. Journal of business ethics, 68(1), 35-52.

[10] Martin, K. (2008). CSR is not one-size-fits-all. Retrieved April 22, 2008, from http://www.edie.net/news/news_story.asp?id=14526

[11] May, S. K., Cheney, G., \& Roper, J. (Eds.). (2007). The debate over corporate social responsibility. Oxford University Press.

[12] Parfitt, J., Barthel, M., \& Macnaughton, S. (2010). Food waste within food supply chains: quantification and.

[13] Patil, D., \& Dilip, Y. (2014). Corporate social responsibility towards environmental management. Available at SSRN 2403680.

[14] Pavlík, M. (2010). Společenská odpovědnost organizace. Grada.

[15] Sharma, R. (2014). Corporate Social Responsibility and Environmental Protection: A Study of Judicial Role. From http://www.legalservicesindia.com/article/1920/Corporate-Social-Responsibility-and-EnvironmentalProtection.html

[16] Steinerová, M. (2008). Společenská odpovědnost firem (Doctoral dissertation, Vysoká škola ekonomická v Praze).

[17] Tostivint, C., Östergren, K., Quested, T., Soethoudt, J. M., Stenmarck, A., Svanes, E., \& O’Connor, C. (2016). Food waste quantification manual to monitor food waste amounts and progression. BIO by Deloitte. 


\title{
Optimization of the Amount of the Company's Insurance Stock
}

\author{
Veronika Hrdá1, Zuzana Juríčková ${ }^{2}$, Alexandra Filová ${ }^{3}$ \\ Slovak University of Agriculture of Nitra ${ }^{1,2,3}$ \\ Faculty of Economics and Management, Department of Management ${ }^{1,2,3}$ \\ Address: Tr. A. Hlinku 2, \\ 94901 Nitra, Slovakia \\ e-mail: veronika.hrda@uniag.sk¹, zuzana.jurickova@uniag.sk², alexandra.filova@uniag.sk ${ }^{3}$
}

doi: 10.18515/dBEM.ISD.P01.2020.p002

\begin{abstract}
The objective of the paper is optimization in the area of supply management of the specific micro company operating on the market since 2004. It is a company doing business in the area of sale of teas and equipment as well as area of catering services. Individual supply items of the given company were divided according to the ABC analysis into specific three categories providing us with the possibility to monitor eight most important types of supplies in 2018. By data about year consumption of these supplies we set their optimum level of turnover stock, insurance stock and expected overall costs connected with supplies. We also evaluated numeric impacts of this analysis on economic indicators of the company like expected overall year costs, revenues and gross margin of supply items of the category A.
\end{abstract}

Keywords: insurance stock, ABC analysis, optimum amount of stocks, costs, revenues

JEL Classification: C02, G31

\section{Introduction}

The issue of creating optimum amount of stocks of various character belongs to the most solved areas of business nowadays. „A supply chain is a network between a company and its suppliers to produce and distribute a specific product to the final buyer. This network includes different activities, people, entities, information, and resources. The supply chain also represents the steps it takes to get the product or service from its original state to the customer" (Kenton, 2019). A wider expression is so called Supplier Relationship Management (SRM), which can be defined as follows: SRM is a comprehensive approach to procurement managing and capturing the post contract value from key business relationships. SRM enables procurement to operate at a strategic level and by adopting a more collaborative approach and developing a closer relationship; this generates more value from the relationship in terms of innovation and efficiency. However, this does involve more time therefore assessment should be carried out as to whether the potential value is greater than the cost of the time required. Another expression in this area is Supply Chain Management. According to (Meredith and Shafer, 2019) "supply chain management is the development of strong relationships with supply chain partners through increased collaboration. It is now widely accepted that all supply chain partners can benefit through greater collaboration." (Gopalakrishnan, 2001) explains "In a typical supply chain, raw materials are procured, items are produced at one or more factories, shipped to warehouses for intermediate storage, and then shipped to retailers or customers. Supply chain management is a set of approaches utilized to efficiently integrate suppliers, manufacturers, warehouses, and stores, so that merchandize is produced and distributed at the right quantities, to the right locations, and at the right time, in order to minimize system wide costs while satisfying service level requirements."

Same like in other areas of entrepreneurial practice, even in the area of logistics and supplier chain management, we monitor huge changes and development. (Dittmann, 2010) states "What 
are the "basics" for supply chain managers today? Ten years ago, the supply chain leader in most companies held a title such as vice president of logistics. It was a largely functional role that relied on technical proficiency in discrete areas: knowledge of shipping routes, familiarity with warehousing equipment and DC locations, and a solid grasp of freight rates and fuel costs. He or she reported to the chief operating officer or chief financial officer, had few prospects of advancing further, and had no exposure to the executive committee." (Burnson, 2019) adds "The data explosion is at its peak and becoming more mainstream across all industries - the supply chain is no exception. Artificial Intelligence (AI) and Machine Learning (ML) will move beyond its current "hype cycle" next year to offer more tangible use cases that deliver real business value."

Emmett (2008) states that „Supply management is a method on how to manage product flow in a supplier chain and reach the expected level of service for adequate price. Development and flow of products is key concept in supply management (as well as in the whole supplier chain)." The author next summarized reasons of creating supplies and ,elimination of relation between supply and demand, safety and security, expected demand and providing services to customers."

As for supplying, it is important to mention Social Value Supply Chain Charter. This issue is discussed by (Patchett, 2019), who states that „Speaking at the Social Value Supply Chain Charter launch, experts discussed how companies might benefit from working with the rising social enterprise sector. They concluded that strong relationships between procurement teams and social enterprises ensured open communication which can help smaller companies overcome accessibility barriers."

\section{Data and Methods}

In the paper we deal with stocking strategy of micro company, employing three employees and has been operating on the market since 2004. It is a company doing business in the area of tea sale and equipment (e.g. sale of tea services, various tea cups, literature and so on), as well as in the area of catering services. Loose tea of all kinds, quality, content, country of origin and so on are sold in the shop in the centre of Michalovce town and online as well. For a long time, they record the highest sales in the shop. The intention of the company was to lower the costs connected with stocks and inventories of loose tea.

\subsection{ABC analysis and classification}

Before computing optimum stock order, whether they are turnover of insurance stocks, it was inevitable to analyse and classify individual supply items into clear categories. For this purpose, $\mathrm{ABC}$ analysis was used, of which the basic principle is the fact that comes from the so-called Pareto rule. This rule says, that $80 \%$ of all the impacts are created by only $20 \%$ of causes. It turned out that that even in stock strategy of companies, Pareto rule is useful, and it significantly reflects way, intensity, size of stock items consumption. As stated by (Wengler, 2007) ,The $\mathrm{ABC}$ analysis is one of the best known and most frequently used controlling tools in key account management. "(Khan \&Jain, 2007) adds „The first step in the inventory control process is classification of different types of inventories to determine the type and degree of control required for each. The $\mathrm{ABC}$ system is a widely-used classification technique to identify various items of inventory for purposes of inventory control. "“

- A category - it includes supply items with the highest share on turnover $(10 \%$ products, $80 \%$ turnover). As for reduction of stocks, it represents the biggest potential of possible level of stocks reduction. 
- B category - it includes supply items with medium share on turnover ( $15 \%$ of products, $15 \%$ turnover). Within these components it is possible to create specific stocks following production plan of a company. These are items with average amount of stock and average potential for level of stocks reduction.

- C category - it includes stock items with the lowest share (within some items even with a zero share) on turnover ( $75 \%$ products, $5 \%$ turnover). This group includes items with low stocks on available. Within these items, usually potential of their possible reduction is either zero of very small and therefore from stock reduction point of view they are insignificant.

\section{Results and Discussion}

$\mathrm{ABC}$ analysis of the monitored company in 2018 is given in the table 1, and 8 supply items create the most important part of stock consumption, 16 items are placed into B category, i.e. medium important items and the least important supply items are at the amount of 78 . In the $\mathrm{C}$ category, there are items which in 2018 had zero consumption.

Table 1: ABC analysis in 2018 of the monitored company

\begin{tabular}{ccccc}
\hline Supply category & $\begin{array}{c}\text { Cumulated } \\
\text { share on the } \\
\text { year } \\
\text { consumption } \\
(\%)\end{array}$ & $\begin{array}{c}\text { Number of } \\
\text { items } \\
\text { (in pieces) }\end{array}$ & $\begin{array}{c}\text { Cumulated } \\
\text { share of } \\
\text { assortment } \\
\mathbf{( \% )}\end{array}$ & $\begin{array}{c}\text { Financial value } \\
\text { of consumption } \\
\text { (in euros) }\end{array}$ \\
\hline A & 80 & 8 & 7,84 & 10937,83 \\
B & 15 & 16 & 15,69 & 2476,01 \\
C & 5 & 78 & 76,47 & 1243,17 \\
\hline Total & 100 & 102 & 100 & 14657,01 \\
\hline
\end{tabular}

Source: own elaboration based on internal data of the company

Figure 1: Lorenz curve of $\mathrm{ABC}$ analysis of the company in 2018

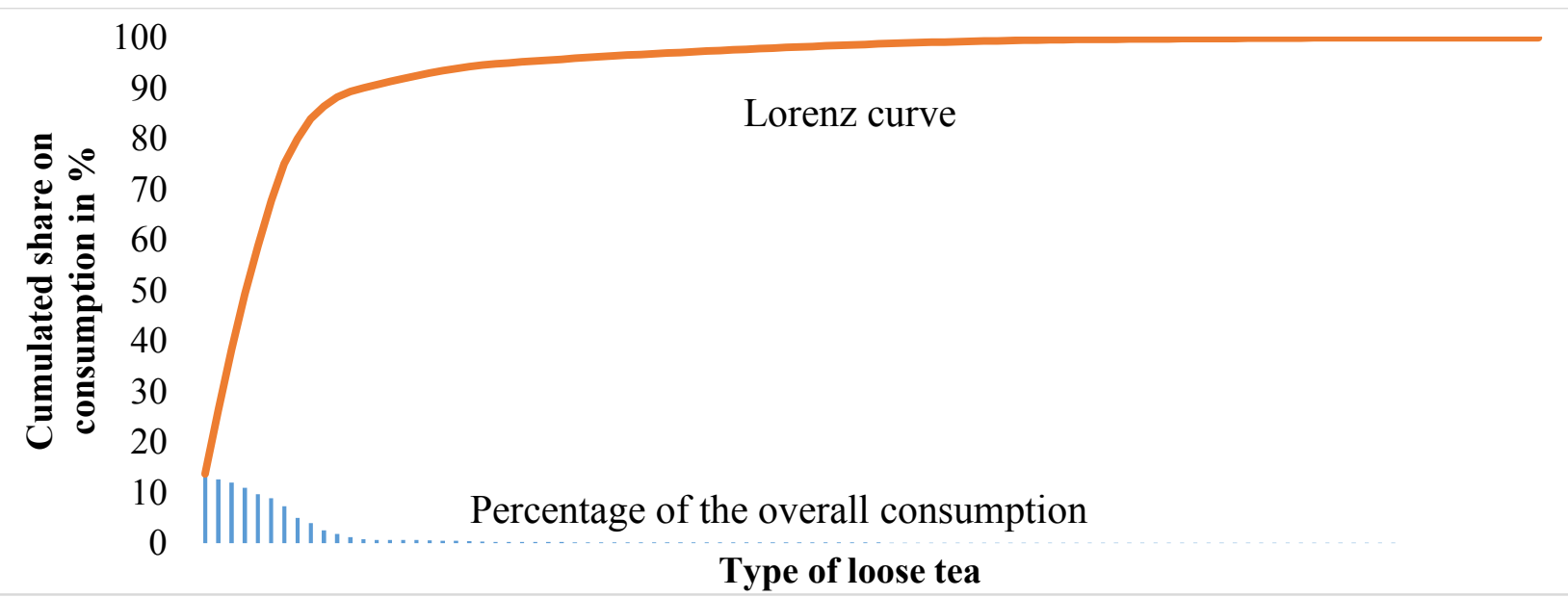

Source: own elaboration based on internal data of the company

Figure 1 shows Lorenz curve of $\mathrm{ABC}$ analysis and individual categories of supply items of the company in 2018 . We can see, that 12 supply items in 2018 had zero consumption, 76 supply items had a consumption under $1 \mathrm{~kg}, 14$ items in 2018 had consumption lower than $5 \mathrm{~kg}$ and only 5 supply items had consumption higher than $50 \mathrm{~kg}$. 
Table 2: Consumption of the most important supply items placed to A category in 2018

\begin{tabular}{llcc}
\hline No & Name of the product & $\begin{array}{c}\text { Size of supply drawing } \\
\text { (kg) }\end{array}$ & $\begin{array}{c}\text { Overall stocks on } \\
\text { inventories } \\
\text { (in euros) }\end{array}$ \\
\hline 1 & Green tea China - China Young Hyson & 74,12 & 1079,19 \\
2 & Whiote tea - China Shou Mee & 68,23 & 2287,75 \\
3 & Herbal tea - Breza - List & 64,89 & 1068,74 \\
4 & Jasmine tea - China White King Jasmin & 59,23 & 2364,46 \\
5 & Fruit tea - Lilly Vanilli & 52,10 & 820,05 \\
6 & Fruit tea - Tatra's fruit & 48,03 & 1337,16 \\
7 & Amazonian tea - Flor Blanca & 39,22 & 1563,51 \\
8 & Rooibos - Blue Star & 26,98 & 416,98 \\
\hline & Total & 432,80 & 10937,83 \\
\hline
\end{tabular}

Source: own elaboration based on internal data of the company

The following table 2 shows products which are placed into A category within ABC analysis. In the whole in 2018 there were $432.80 \mathrm{~kg}$ of the most important supply category consumed, out of which $74.12 \mathrm{~kg}$ was a consumption of green tea item - China Young Hyson. It was the most consumed item of the company in 2018.

As already mentioned above, the company was interested in analysis of their supply management and in optimization of the amount of the company's insurance stocks of the most important supply items. In the previous chapter (table 2) the items were stated.

Figure 2: Monthly consumption in kg, of the most important supply item in 2018

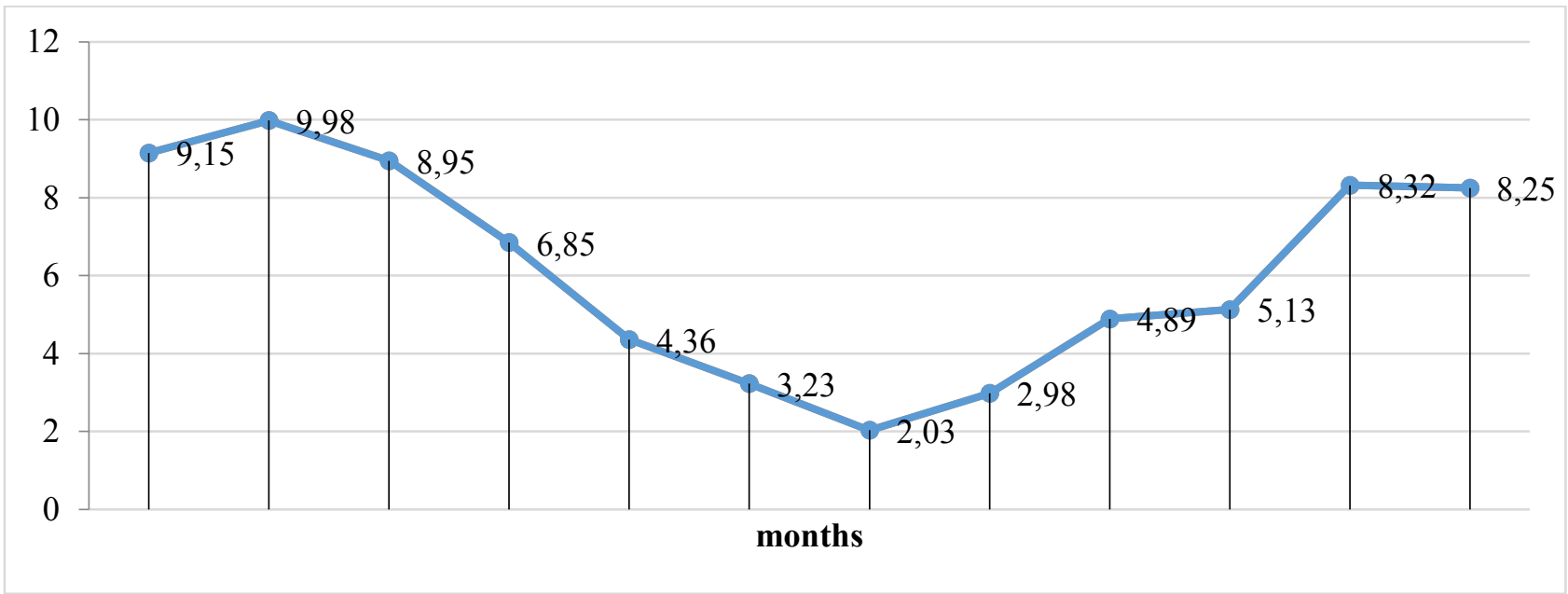

Source: own elaboration based on internal data of the company

Figure 2 and 3 show monthly and daily consumption of the most important supply item according to $\mathrm{ABC}$ analysis. We can see, that consumption has a season fluctuation and in summer, sale of loose tea, offered by the company, is lower than in winter times, or in autumn and spring. Next, we can see that in February they sold most of loose tea and in July the sale was the lowest. This kind of season fluctuation of sales in understandable and predictable. Even though, from the figure 3 the company replenished stocks of the mostly sold supply item four times a year (specifically at the amount of $25 \mathrm{~kg}, 28 \mathrm{~kg}, 3 \mathrm{~kg}$ and $8 \mathrm{~kg}$ ) and this supply strategy did not reflect needs of the company. Figure 3 shows that twice in 2018 there was a deficit of the analysed supply item. This deficit represents lost profit. On the other hand, approximately in the middle of 2018, they replenished the stocks not effectively. The average daily 
consumption of this supply was approximately at the amount of $0.25 \mathrm{~kg}$.

\section{Figure 3: Amount of stocks in kg of the most important supply item in 2018}

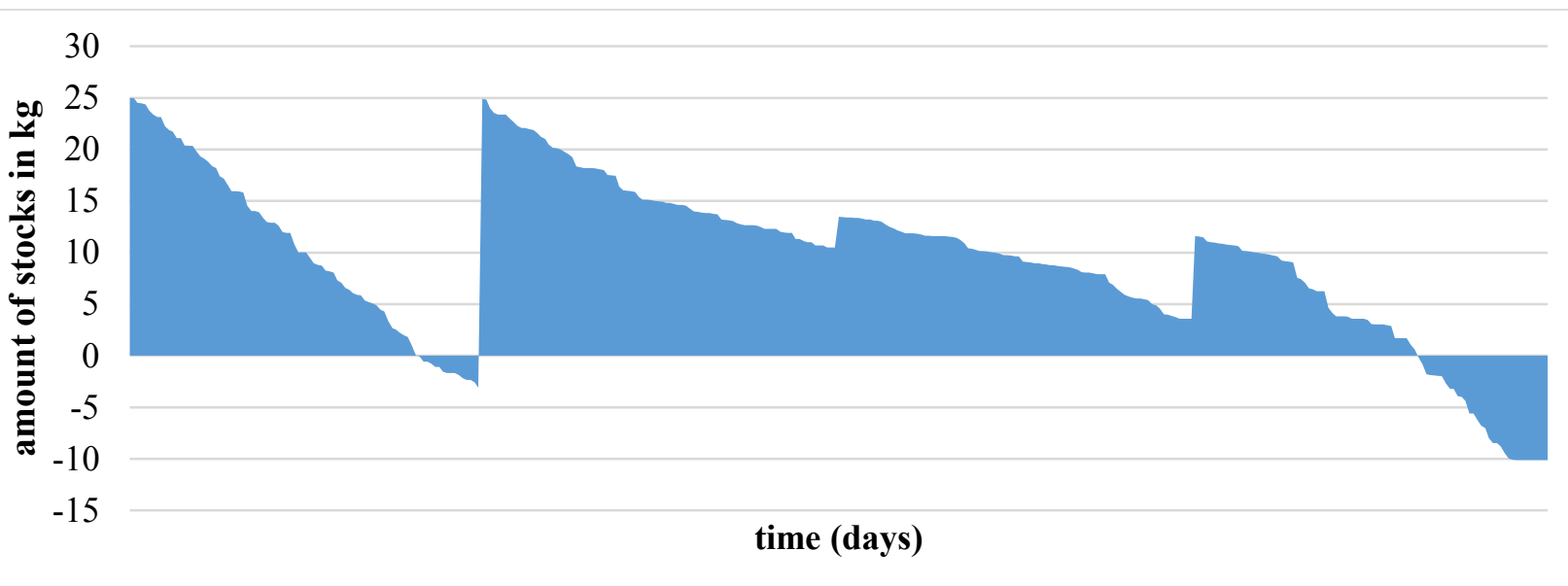

Source: own elaboration based on internal data of the company

To compute optimum amount of overall stocks, insurance stocks and turnover stocks as well as overall expected costs connected with supplying and storage, it is necessary to determine various types of costs.

Table 3: Cost items of individual supplies of A category and their price in 2018

\begin{tabular}{lcccccccc}
\hline Number of supply item & 1 & 2 & 3 & 4 & 5 & 6 & 7 & 8 \\
\hline Price 1 kg (in euros) & 29,1 & 67,0 & 32,9 & 79,8 & 31,4 & 37,1 & 79,7 & 30,9 \\
& 2 & 6 & 4 & 4 & 8 & 2 & 3 & 1 \\
Deficit costs 1 kg (in euros) & 12,0 & 31,0 & 13,9 & 37,4 & 13,2 & 6,79 & 37,3 & 12,9 \\
& 7 & 4 & 8 & 3 & 5 & 8 & 7
\end{tabular}

Source: own elaboration based on internal data of the company

The company has outlined necessary types of costs as follows (others are in table 3):

- Storage costs ${ }^{1} 1 \mathrm{~kg}$ of tea were 2.11 euros.

- Acquisition $\operatorname{costs}^{2}$ in form of fixed costs in 2018 were 1.24 euros.

\footnotetext{
${ }^{1}$ Storage costs include only the costs that change according to their amount or volume of stored item. It includes especially: costs for financing supplies, e.g. if supplies are financed by operating loan, we can use the relevant interest rate, insurance, if the amount of insurance is dependent on the stock amount, any storage costs, which directly depend on the volume, or amount of stocks, for example part of energy necessary for cooling and frosting of stocks in food industry, rental of external storage space, if rent is dependent on the volume, or amount and so on, costs for computing supplies within physical inventories, if it is performed many times a year (more inventories, more time spent by their computing), loss of supplies caused by depreciation or theft (e.g. it can be estimated as average \% from supply level). Storage costs do not include costs that are not dependent on the volume of supplied stocks, like for example: rental for storage space, which is paid regardless of stock volume, depreciation of warehouse space (CFO, 2013).

2 Acquisition costs are costs which are created within placing, receiving and processing orders. Primary the depend on activities, necessary for processing each order, and not from the amount ordered, i.e. they are dependent on the number of realized orders. Among these costs there mostly are: time (wages) necessary for placing order and order
} 
- Costs connected with packaging of $1 \mathrm{~kg}$ of tea were 38 cents.

The following table 4 shows optimum indicators of supply strategy of supply items belonging to A category, which should be followed by the analysed company. To compute these indicators, we used stochastic supply model, description of which and specific formulas are given in the publication [8].

It was necessary to round the computed values because the company buys these types of tea in $1-\mathrm{kg}$ packaging.

Table 4: Computing of optimum supply strategy for supply items of A category

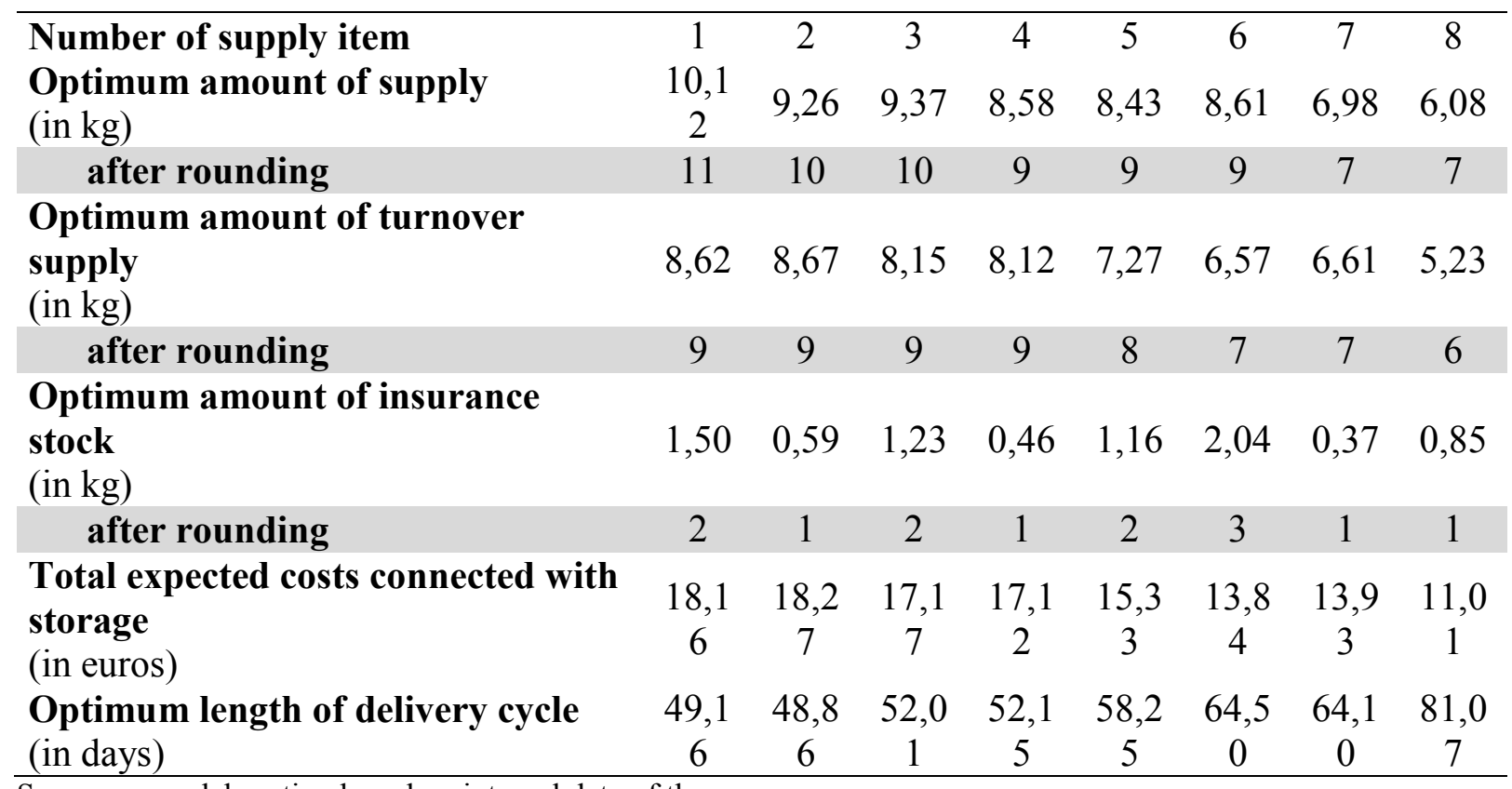

Source: own elaboration based on internal data of the company

Table 5 shows expected economic indicators in form of overall revenues, costs and gross margin for individual supply items of A category. Total expected gross margin for all the items of A category should be 9747.95 euro per year.

Table 5: Total expected year costs, revenues and gross margin of individual supply items of A category

\begin{tabular}{cccc}
\hline No. & $\begin{array}{c}\text { Total costs (in euros) } \\
\text { for the monitored period }\end{array}$ & $\begin{array}{c}\text { Total revenues (in euros) } \\
\text { for the monitored period }\end{array}$ & $\begin{array}{c}\text { Gross margin (in euros) } \\
\text { for the monitored period }\end{array}$ \\
\hline 1 & 1125,51 & 2158,37 & 1032,86 \\
2 & 2331,84 & 4575,50 & 2243,66 \\
\hline
\end{tabular}

approval, costs on selection process / tender, if they are a part of each order.(e.g. if purchasing department buys commodities and within each order it gains price offers from various suppliers), costs connected with physical acceptance of order, its processing and record in the system and control of quality, processing and settlement of supplier invoice. Acquisition costs do not include costs which are not dependent on the number of orders or which are not connected with order such as time (wages) of employees of purchasing department, in connection with other activities such as orders (e.g. by planning, selection process, if suppliers do make the process only once a year, by preparing reports, other administrative and so on) Costs of information system, such as fixed costs in a year (e.g. licence fee) (CFO, 2013). 


\begin{tabular}{lccc}
\hline 3 & 1111,67 & 2137,48 & 1025,81 \\
4 & 2404,14 & 4728,92 & 2324,79 \\
5 & 856,97 & 1640,11 & 783,14 \\
6 & 1370,73 & 1782,87 & 412,14 \\
7 & 1592,25 & 3127,01 & 1534,76 \\
8 & 441,16 & 833,95 & 392,79 \\
\hline
\end{tabular}

Source: own elaboration based on internal data of the company

\section{Conclusion}

As shown in the paper, detailed monitoring of individual supply items is important part of company's management. By this kind of detailed work, the company is able to analyse their supply strategy, which can lead to significant reduction of costs connected with supplying in a company. We found out that for the given company, the most important supplies are eight teas, which are consumed most. For each one of these supply items we computed optimum level of supplies (exactly from $10 \mathrm{~kg}$ to $7 \mathrm{~kg}$ ), optimum level of turnover stock (which was from $9 \mathrm{~kg}$ to $6 \mathrm{~kg}$ ) and optimum level of insurance stock (which was from $3 \mathrm{~kg}$ to $1 \mathrm{~kg}$ ). Moreover, we computed the company's expected costs connected with storage of selected supply item of category A. We also determined optimum length of supply cycle. All this information is important or the company, to be able to create and realize its supply policy and to help more effective business in this field.

\section{Acknowledgements}

This article was realized based on research grant: VEGA 1/0802/18, Corporate social responsibility and innovation activities focused on decreasing food losses with regards of environmental issues.

\section{References}

[1] CFO (2013, november 22). Supply management: optimum size of order (1). Retrieved from: http://www.cfo.sk/articles/riadenie-zasob-optimalna-velkost-objednavky-1\#.WtnwUZrVC70

[2] Kenton, W. (2019, May 20). Supply Chain. Retrieved from: https://www.investopedia.com/terms/s/supplychain.asp

[3] Patchett, L. (2019, October 25). Building strong relationships is key to working with social enterprises. Retrieved from: https://www.cips.org/en/supply-management/news/2019/october/building-strongrelationships-is-key-to-working-with-social-enterprises/

[4] CIPS Chartered Institute of Procurement \& Supply. Supplier Relationship Management. Retrieved from: https://www.cips.org/en/knowledge/procurement-topics-and-skills/srm-and-sc-management/supplierrelationship--management/

[5] Burnson, P. (2019, November 25). Next gen supply chain predictions: Part II. Retrieved from: https://www.scmr.com/article/next_gen_supply_chain_predictions_part_ii/management

[6] Dittmann, P. (2010, October 1). Managing The Basic Supply Chain Functions. Retrieved from: https://www.scmr.com/article/managing_supply_chain_functions

[7] Wengler, S. (2007). Key account management in business-to-business markets: An assessment of its economic value. (1.st ed.). Berlin, Germany: Springer Science \& Business Media.

[8] Palúch, S. \& Peško, Š. (2006). Quantitative Mmethods in Logistics. (1.st ed.). Žilina, SR : EDIS Žilinská univerzita.

[9] Meredith, R. J. \& Shafer, S.R. (2019). Operations and Supply Chain Management for MBAs. (7. Vydanie). New York, USA : John Wiley and son. 
[10] Gopalakrishnan, M. (2001). Electronic issues in Supply Chain Management. Proceeding of the 1st International Conference on Logistics and Supply Chain Management, 6-8 August 2001, PSG College of Technology, Coimbatore, India, pages 3-9, Allied Publishers.

[11] Khan, M.Y. \& Jain, P.K. (2007). Financial Management (fifth edition). New Delhi : India. Tata McGraw-Hill Publishing Company Limited 


\title{
Biodegradable Municipal Waste and Possibilities of its Utilization - Theoretical Study
}

\author{
Zuzana Juríčková ${ }^{1}$, Veronika Hrdá ${ }^{2}$, Alexandra Filová ${ }^{3}$ \\ Slovak University of Agriculture of Nitra ${ }^{1,2,3}$ \\ Faculty of Economics and Management, Department of Management ${ }^{1,2,3}$ \\ Address: Tr. A. Hlinku 2, \\ 94901 Nitra, Slovakia \\ e-mail: zuzana.jurickova@uniag.sk ${ }^{1}$,veronica.hrda@uniag.sk², alexandra.filova@uniag.sk ${ }^{3}$
}

doi: 10.18515/dBEM.ISD.P01.2020.p003

\begin{abstract}
Municipal waste represents one of the biggest threats for environment. Most of the waste in Slovakia ends up in dumps. The biggest share of the waste is created by biodegradable decomposable waste which represents big risk because of toxic gases and substances, which decompose within rotting process and get in the air. Harmful gases such as methane pollute air and extracts from dumps pollute underground waters. The risk of virus transmission and illnesses increase in the food chain and ecosystems get polluted as well. Except for the risks, waste is an important and inevitable issue as well. The objective of the paper is analysis of available data and expressions connected with this social, economic as well as ethical issue. It is inevitable to decrease waste creation, to prevent landfills and therefore eliminate safety risks. Effective action is based on education and changing people's behaviour.
\end{abstract}

Key words: bio waste, municipal waste, waste recovery

JEL Classification: O3, $Q 1, Q 2, Q 4, R 1, R 5$

\section{Introduction}

In 2008, the European Parliament adopted directive 2008/98/ES on waste (hereinafter referred to as "the Directive"), known as waste framework directive. The most important change brought by the new Directive is a change of attitude to waste. Waste is no longer just a thing the holder wants or must discard but it is especially a valuable raw material saving primary sources and at the same time it might be a significant source of energy (Vandák, 2010). According to the Directive, biodegradable waste is waste, which can be anaerobically or aerobically decomposed like for example food waste, vegetable waste, paper and cardboard. The given definition was transported by the notice of the Ministry of Environment of the Slovak Republic no. 283/2001 L. 1. on implementation of certain provisions of the Waste Act, as amended The Directive of the European Parliament and the Council (2008). According to the study "Bio-waste management in the European Union" biologically decomposable waste includes bio waste from gardens and parks, food and kitchen waste from households, restaurants and retailers (sector of catering) as well as similar waste from plants, where foodstuffs are processed. According to this definition, thus, biological waste does not include residues of agricultural and forestry activities, manure, waste sludge and other biologically decomposable waste such as natural textile, paper or processed wood. Biologically decomposable waste creates individual group of waste and represent the most significant part of municipal waste (Orbanová, 2013).

- Biologically decomposable municipal waste is waste from gardens and parks, food and kitchen waste from households, catering facilities and waste from food processing industries. 
- Biologically decomposable municipal waste are not residues of forestry and agriculture, manure, waste sludge or industrial biologically decomposable waste (Orbanová, 2013).

Waste management seeks to reverse the trend of excessive landfilling. According to principles of the European waste management, valuable waste should not be landfilled. The principle is enshrined in the Landfill Directive 1999/31/ES, which was implemented even into the Slovak law order. Biologically decomposable waste although are still landfilled, which should be the last possible solution. Besides that, the main product is landfill gas and its main part is methane, which contributes to intensification of the greenhouse effect (methane share represents approximately $15 \%$ ) (Orbanová, 2013). This attitude causes leaking of the secondary raw materials which can replace non-renewable sources and they can serve as the source of energy Vandák (2010). According to the Minister of Economy Peter Žiga: "landfilling will have to end in a few years and no new landfill will be open. Thus, the only solution will be the incineration or export of such waste." Rojko (2020) says developed countries try to prevent through regulations and notices, the waste produced by citizens from being landfilled and the amount of waste minimized. One of the possibilities is to gain energy from waste (so called waste-toenergy policy) burned at bio gas stations, output of which is bio gas, stated Odpady Portal (2018). Bio gas is a mixture of gases with the highest share of $\mathrm{CH} 4$ methane and $\mathrm{CO} 2$ carbon dioxide. It is created by microbial decomposition of organic matter without air access (so called anaerobic fermentation or digestion). Energetically usable bio gas is produced in specialized technological facilities, so called bio gas stations. Bio gas is also produced in municipal landfill bodies, where it is stored for further use by a system of collection wells and pumping stations (Doskočilová, 2013). Anaerobic fermentation of bio gases brings environmental and socio economic benefit. During the process of fermentation not only bio gas is produced, but bio waste is transformed into digestate as well, being quality agricultural manure. Anaerobic fermentation provides unique opportunity of emission reduction and generation of energy from renewable sources, as well as return of bio waste back to the biological cycle and conversion of waste to highly quality agricultural manure. Technology of the fermentation process can be dry, wet or a combination of dry and wet fermentation. Dry fermentation is appropriate for processing of agricultural commodities (straw manure, corn, grass and cereal silage). Wet fermentation is appropriate for waste water treatment plants and waste sludge of plant or animal origin. In agriculture it is used to process masses with a high content of slurry. The result of the combination of dry and wet fermentation is more economical and effective bio gas production, low operating costs of bio gas station and high reliability and safety of the facility (Doskočilová , 2013).

Acquired thermal energy can be utilized to heat stables, residential buildings or industrial objects. Generated bio gas is the most frequently used for combined production of electric energy and heat in cogeneration units. The main heating part of bio gas is $\mathrm{CH} 4$. Depending on the origin of bi gas (= type of bio mass from which it was created) it may contain some undesirable compounds. These compounds especially have influence on viability of the selected technological units. As for the air protection legislation it is necessary to pay particular attention to compliance with emission limits of sulphur compounds in bio gas. Therefore, some bio gas stations are equipped by systems of bio gas desulphurisation. Comparison of chemical composition with the calorific value of different types of bio gas is given in the table 1 .

Alternatively, bio gas can be cleaned to quality comparable with natural gas. Bio gas stations can create a significant part of clean and self - sufficient energy production (Conference CE Food Waste, 2019). Even though energetic waste recovery is in the most European countries, especially Nordic ones, common practice, in Slovakia besides incinerators in two biggest towns, there are no such facilities. Rojko (2020) states that gaining energy from suds, manure, waste 
substances and plants with high content of energy is for several agricultural companies, waste disposal companies and communities, advantageous investment, which also has favourable aspects of the environment. Bio gas stations are usable in agriculture for the processing of plant and animal bio mass and for the processing of waste from food and similar production (starch production, distilleries, mills, slaughterhouses, cold stores, canneries, sugar refineries and so on). Bio gas from bio gas stations can be used for heat production, and electricity (cogeneration), as well as cold (three generation) - three generation is used only exceptionally also for drive vehicles (automobiles, buses, agricultural engineering, trains).

Table 1: Comparison of properties of different bio gases

\begin{tabular}{lccc}
\hline Parameter BP & $\begin{array}{c}\text { Waste collection from } \\
\text { landfill }\end{array}$ & $\begin{array}{c}\text { Bio gas } \\
\text { (sewage treatment) }\end{array}$ & $\begin{array}{c}\text { Bio gas } \\
\text { (pig slurry) }\end{array}$ \\
\hline $\begin{array}{l}\text { Calorification } \\
\text { (MJ/m3) }\end{array}$ & 16,9 & 21,1 & 24,0 \\
H2 $(\%)$ & 1 & & \\
CO $(\%)$ & 1 & 1 & \\
O2 $(\%)$ & 3 & & \\
N2 $(\%)$ & & & \\
Cl-, F-(mg/m3) & & & 40 \\
NH3 (mg/m3) & 46 & 38 & 31 \\
CO2 $(\%)$ & 49 & 61 & 69 \\
CH4 (\%) & 350 & 1000 & 2300 \\
H2S (mg/m3) & & & \\
\hline
\end{tabular}

Note: The calorific value applies to $15^{\circ} \mathrm{C}, 101325 \mathrm{kPa}$

Source: Conference CE Food Waste (2019). Food waste creates $8 \%$ of emissions of greenhouse gases. Retrieved from: https://corporate.tesco.sk/novinky/2019/konferencia-ce-food-waste-2019-potravinový-odpad-tvorí-8emisií-skleníkových-plynov/

\section{Data and Methods}

The issue of biodegradable waste is crucial, although is being publicly discussed, gaining information about bio waste is complicated because data is gained especially through questionnaires and the answers can be distorted due to people, who do not realize the seriousness of impacts connected with the biodegradable waste management, claimed Sipos (2019). The outputs of the research are not exact because there are no exact criteria to determine what waste is and unified methods of computing are not used. Another problem is processing of waste. The policy focuses on solution and the plans are computed together with development of bio gas stations, on the other hand there are still obstacles like regulation of energy distribution, costs connected with it, unsolved possibilities of environmental risk elimination and insufficient separation of communal waste. The paper is therefore just a theoretical study. The introduction of the study is a compilation of professional expressions and standpoints to the given issue. To process the results of the study we used classical methods like accumulation of information about realized research, its studying, abstraction, comparison and consequent summarization and induction to generalize the gained knowledge. 


\section{Results and Discussion}

Biodegradable municipal waste creates, according to the Waste prevention program of the Slovak Republic for 2019 - 2025, 43 to $46 \%$ of mixed (unsorted) municipal waste. Food waste creates share from 4 to $7 \%$. Program objective is to decrease the amount of biodegradable waste in mixed municipal waste by $60 \%$ until 2025 in comparison with 2016 . Special objective in the area of food waste is to support decrease of its creation at retailers, consumers, and to decrease food losses in the production chain and food distribution. Within the UN goals for sustainable development, Slovakia promised to reduce the amount of food waste until 2030 by a half within 15 years (Szalai, 2018). Municipal waste provides possibilities for separation. Within fulfilment of framework directive goals (50\% of reuse and household waste recycling) share of the municipal waste in the Slovak Republic dropped to $59 \%$. The Slovak Republic landfills more than $70 \%$ of produced municipal waste. With optimum separate collection settings (i.e. at $70 \%$ level of separation) and the consequent landfill rate would fall to $40.5 \%$ in Slovakia, which is the level of the European average. At the maximum level of separation $(100 \%)$ only $503000 \mathrm{t}$ of non-separable waste would remain, out of which it is possible to use $10 \%$ for energetics and landfill rate could theoretically decrease up to $25.5 \%$ (Vandák, 2010).

According to the data of the Statistical Office of the Slovak Republic, bio waste recycling rate after the introduction of compulsory bio waste management improved. While in 2017170 thousand tons of bio waste were recycled, in 2018 it was 202 thousand. The growth, however, can be explained by making data on bio waste accessible. Waste which is processed by households in their own composters, does not count in statistics and was not count in statistics (Kazdová, 2019). According to research of the European Union, up to $53 \%$ of bio waste is produced in households. The numbers do not have to be necessarily exact, as the methodology of bio waste data collection is not uniform. Data is collected especially by questionnaires and answers can be distorted (Sipos, 2019). Statistics cannot be exact because there are no exact criteria to determine what is and what is not waste (Sipos, 2019).

Slovakia has adopted a strategy of prevention to food waste creation. One of the tasks of the commitment, was to try to measure the amount of food waste. National agriculture and food centre was commissioned by the Ministry of Agriculture and Rural development to implement and realize the methodology. The centre repeatedly realized research with the number of employees 530, within the Slovak Republic, who weighed their waste during one month. The average weight was $35 \mathrm{~kg}$ of food waste per person in one year. Research was realized twice, in summer and in autumn. The surveyors assumed that in autumn the biggest share would be created by pastry and fruit and vegetable waste would reduce, which was not confirmed. Food ratios did not change, the highest share of waste, approximately $60 \%$, was represented by fruits and vegetable. Afterwards, finished meals, up to $8 \%$, meat around $6-7 \%$, pastry $5-6 \%$, milk and dairy products up to $5 \%$ (Sipos, 2019).

In the Czech Republic research was realized within 900 households by analysing municipal waste in three different residential zones. The assumption was that different lifestyle in individual localities means different content of waste. The first category was a rural housing estate with prevailing share of local heating with solid fuels and the possibility of burning waste in the stove, composting bio waste in the garden or using food waste to feed the animals. The second category consisted of households in villa development, heating predominantly with gas or electricity, with the possibility of garden composting. In case of the third category, households in the settlement development, there were no possibilities to use waste in the place of its creation. Bio waste represented approximately $40 \%$. 
As for the municipal waste, in the settlement development there were $39 \%$ of biological waste, out of which $28 \%$ of plant waste and $4 \%$ of animal waste. In the villa development the share of bio waste on the overall volume of waste, was $39 \%$, however the proportion of waste of kitchen origin differed plant waste accounted for $14 \%$ and animal waste for $5 \%$.

In case of rural houses, surveyors identified up to $43 \%$ of bio waste in municipal waste. As for the kitchen waste, plant waste accounted for $16 \%$ and animal waste accounted for $4 \%$ of the overall volume of all the waste. Most foodstuffs end up in collecting containers in housing estates, there are about $33 \mathrm{~kg}$ of food per capita per year. Obviously, the fact that there is no possibility of composting or feeding the animals plays a huge role. This type of locality provides the most valid review of how much food waste the households produce. In case of villa development houses, the surveyors assumed the volume of produced food waste per capita per year to approximately $20 \mathrm{~kg}$. The average inhabitant of a rural house according to the assumption, throws away approximately $21 \mathrm{~kg}$ of food waste (Szalai, 2018).

Besides the above mentioned research, a survey was conducted by a team from Mendel University in the form of a questionnaire among 1.569 respondents from the Czech Republic. From the research it is clear that the average amount of food waste according to individual assumption of the respondents after computing accounts for only $4.2 \mathrm{~kg}$ per capita per year. According to the statistics of the EU, however, in the Czech Republic, up to $81 \mathrm{~kg}$ of food per capita per year are depreciated annually (together 830000 tons).

The experts of the Mendel University in Brno looked into the households' containers. They found out that the inhabitants of housing estates and family houses produce several times more food waste than they proclaim. The inhabitants of Brno's housing estates throw away $33 \mathrm{~kg}$ of foodstuffs on the average per year, households in villa development produce $20 \mathrm{~kg}$ of food waste on the average and rural houses approximately $21 \mathrm{~kg}$. It results from the first assumptions of researchers of the Mendel University in Brno who have been researching for several years whether it is possible to influence consumers to reduce the amount of food waste produced. The whole EU generates approximately 88 million tons of food waste at the amount of approximately 143 billion Euros. People do not realize wasting nor they have idea about how much foodstuffs they waste and how much money they spend. We assume, that if people had this information they would change their behaviour. It is therefore necessary to show reality of wasting together with all the economic and environmental impacts, "as stressed out by Szalai (2018).

The experts agree that if Slovakia wants to reach the European recycling goals, it must fight against biological waste. The waste, according to their assumptions, represents $40-50 \%$ of municipal waste. Recently, there were several researches realized about food waste. The most relevant one were those, in which the state office took part, and the third one was a research of the TESCO retail chain. Although results differ slightly, out of all the three researches it is clear that the Slovak households mostly throw away bread, pastry, fruits and vegetables. A significant part is represented by finished meals, claims Ministry of Environment SR (2018).

Table 2: Retail chain has edited a report on food waste per financial year 2018/19

\begin{tabular}{lcccc}
\hline Research & $\begin{array}{c}\text { Food Research Institute/ } \\
\text { National agriculture and } \\
\text { food centre 2017 }\end{array}$ & $\begin{array}{c}\text { National } \\
\text { agriculture and } \\
\text { food centre }\end{array}$ & $\begin{array}{c}\text { TESCO } \\
\mathbf{2 0 1 8}\end{array}$ & $\begin{array}{c}\text { Tesco } \\
\mathbf{2 0 1 8} / \mathbf{1 9}\end{array}$ \\
\hline Bread, pastry & $53 \%$ & $5,5 \%$ & $40 \%$ & $19 \%$ \\
Vegetables, fruits & $57 \%$ & $60 \%$ & $35 \%$ & $41 \%$ \\
Dairy products & $17 \%$ & $5 \%$ & $14,7 \%$ & $7 \%$ \\
$\begin{array}{l}\text { Finished meals } \\
\text { (leftovers) }\end{array}$ & $24 \%$ & $8 \%$ & $25 \%$ & $12 \%$ \\
\hline
\end{tabular}




\begin{tabular}{|c|c|c|c|}
\hline $\begin{array}{l}\text { Meat, fish and eggs } \\
\text { Foodstuffs }\end{array}$ & $\begin{array}{c}6,5 \% \\
35 \mathrm{~kg} / \text { person.,year }\end{array}$ & $9,7 \%$ & $\begin{array}{c}5 \% \\
4779 t\end{array}$ \\
\hline
\end{tabular}

Source: Szalai, P. (2018). Eurostat published new waste statistics, Slovakia rose. PROPERTY \&

ENVIRONMENT s. r. o. Retrieved from: https://euractiv.sk/section/obehova-ekonomika/news/eurostat-

zverejnil-nove-odpadove-statistiky-slovensko-poskocilo/

In 2016, according to Eurostat Slovakia produced 1.890 million tons of municipal waste. That is by 106 thousand tons more than in 2015 . Per capita, it is $348 \mathrm{~kg}$, which is one the lowest levels in the Union. Less waste per capita is produced only in the Czech Republic (339), Poland (307) and Romania (208). Hungary produced, within Visegrad Group, most waste per capita (379). All the countries of the V4 are however under the average of the Union in 2016, which is $482 \mathrm{~kg}$ / per capita. For a comparison, in 2015, one European produced $481 \mathrm{~kg}$ of waste on the average. Between 2015 and 2016 the overall amount of municipal waste rose in the Union - from 244.8 to 246.3 million tons. According to the data from Eurostat (2016) about the amount of municipal waste, in Slovakia approximately $180 \mathrm{~kg}$ of food waste per capita per year is wasted (Detersová, 2019).

Table 3: Amount of municipal waste

\begin{tabular}{lc}
\hline Waste & \\
From households & $53 \%$ \\
Food processing & $19 \%$ \\
Eating together & $12 \%$ \\
Primary production & $11 \%$ \\
Wholesale, retailer and foodstuffs distribution & $5 \%$ \\
\hline
\end{tabular}

Source: Detersová (2019). Bio waste is still an issue for municipalities, many break the rules. EURACTIV

Retrieved from: https://euractiv.sk/section/obehova-ekonomika/news/bioodpad-je-pre-samospravy-aj-nadalej-

problem-viacere-porusuju-zakon/

Other Visegrad countries, on the contrary, recycled more municipal waste: Czech Republic 33,6, Hungary 34,7 and Poland 44,0 \%. That almost reaches the average of the Union which is $45,8 \%$ of recycled municipal waste. The statistics of Eurostat however do not have to be completely comparable, the countries use different methods of computing (Detersová, 2019). Most food waste according to the European study comes from households (53\%), followed by area of food processing (19\%), eating together $(12 \%)$ and primary production $(11 \%)$. Wholesale, retail and foodstuffs distribution have the lowest share (5\%), says Kazdová (2019). $23 \%$ of municipal waste in Slovakia was recycled, $65 \%$ landfilled and more than $10 \%$ of municipal waste was burnt. Between 2015 and 2016 Slovakia improved its position in comparison with other countries of the EU. In 2015 Slovakia was, with almost $15 \%$ of recycled waste the second last. In 2016 it had sixth place from the end. It overtook Croatia $(21,0$ $\%)$, Cyprus $(17,2)$, Greece $(17,0)$, Romania $(13,3)$ as well as Malta $(7,1)$. In Slovakia, food waste is still the topic. In 2018/2019 Slovakia produced approximately 4.700 tons of foodstuffs. The most of it, up to $41 \%$, is represented by fruits and vegetables, followed by pastry (Prostredníková, 2016). Except for households, food waste is created in retails, wholesales and production as well as in restaurants.

\subsection{Attitudes of selected retail chains to solution of the given issue}

- Tesco company, as the first one, published data about waste in 2017. Due to this fact, it was possible to effectively identify problems of waste in the given company. In case 
that some surplus is produced, foodstuffs appropriate for consumption are donated to the Food Bank of Slovakia and its local partners. Actually, the chain helps people in need by donating foodstuffs on daily basis from 143 of its branches. The company in Slovakia committed that until 2020 they would donate foodstuffs from all the branches in Slovakia, of which there are 150. Besides, the company donated 2.043 tons of foodstuffs as animal feed. Company's management cares about sustainable future and therefore wants to lead positive change within solution of the most severe social and environmental challenges. Their strategy of social responsibility named Small help plan is focused on goals of sustainable development of the UN. Amongst them there are goals like no famine, health and life quality, responsible consumption and production and climate protection.

- Kaufland monitors development of depreciation in individual product groups and regularly trains their employees in the area of acquisition and optimization of stocks. It started a nationwide project to donate foodstuffs after expiry date.

- Lidl in engaged in the project „don't waste - consume“. It cooperates with the Food Bank, which it occasionally provides with dry products. Some foodstuffs are used by the company as a bio waste, from which electricity is made at bio gas stations. In 2017, 4.347 tons of fruits and vegetables ended up in these stations, 389 tons of side animal products and 1.107 tons of pastry, to produce bio gas (Prostredníková, 2016).

The document of the Economy resort sees bio gas as a part of renewable sources strengthening decarbonization and energetic safety. The objective of the government is to support effective systems of central heat supply from the supply from renewable sources of energy, waste heat from industrial processes on economically costly utilization of renewable sources of energy, especially locally available biomass/biomethane and waste. Although government plans count on bio gas station development, hurdles are stop-state in distribution of electricity, costs of injection into the gas system or environmental risks but especially insufficient separation of municipal waste. Public and financial support will be provided especially to bio gas stations which will take and consequently process selected bio waste, Ministry of Environment SR (2019). According to analysis realized, in Slovakia, low share of waste separation prevails. Two legal possibilities how to handle bio waste and stop landfill is to provide collection containers for bio waste and consequent security of bio waste utilization, or the second possibility is having households with composters, in which families can utilize bio waste in the form of useful compost. Elimination of biodegradable waste is the first step reducing landfill waste, explains Potočár (2019).

The British research proved that if a town or a village has separate collection of bio waste, households tend to waste food less. According to the report, published within the British action plan for Waste Management and Sources, leads to ensuring that separate collection of bio waste from households reduces the amount of food waste, the households produce. Researchers compared the amount of food waste, produced in villages and towns, disposable of waste collection, with those not separating. They took into account data from 101 local offices in England, Scotland and Wales, sheltering period from 2012 to 2017. The report emphasizes, that in the introduction of separate collection of bio waste there is the potential to reduce the volume of food waste from households. The analysis of the situation in the UK it is clear that in towns and villages, where the offices provide separated collection of bio waste, yearly produced by $16,1 \mathrm{~kg}$ less of food waste per household on the average than where they do not separate waste. The reason could be the fact that food waste separation in households more significantly draws its members' attention to the volume of food, they throw away, which probably motivates them to prevent creation of this kind of waste. It can, of course, be only short-term change in 
behaviour which manifests for example right after implementation of bio waste separation system, but in many cases prevention of food waste creation becomes mind setting, says Sipos (2019).

\subsection{Recommendations}

To improve knowledge of consumers about waste creation, its economic, social and ecological impacts and ways of waste management and possibilities of its positive utilization to improve information within consumers about expiry dates and minimum shelf life of food and support food sale directly from the producer/farm or market or small stores in the surroundings as each big group of respondents does not realize wasting, it is important to increase level of education for more effective stock management and food consumption, Ministry of Environment SR (2019).

\section{Conclusion}

Within landfills there are several intensive chemical processes present, during which gases of different chemical substances get in the air. Landfill gases spread across distances due to air flow. Soil is polluted by seepage waters and leaking gaseous impurities from the landfill. Solid waste plays an important role in soil degradation, not only by direct action, but also by supplying toxic and harmful substances into the soil, which destroy soil organisms and damage plants growing in such soil. Due to these effects soil has the lowest fertility possible, even in some cases such areas with degraded soil cannot be used agriculturally. Gases, for example methane and carbon dioxide, which are created especially within rotting process of bio waste, significantly contribute to the greenhouse effect creation and to changes in climate. The biggest amount of bio waste is created in households. According to the studies of the UN, annually and nationwide, approximately 1.3 billion tons of foods are thrown away. The UN for nutrition and agriculture (FAO) states that approximately one third of all the foodstuffs produced in the world is wasted or is thrown away. Food that is harvested but eventually discarded consumes approximately a quarter of all water used in agriculture and requires arable land the size of China. Food waste annually generates approximately $8 \%$ of nationwide emissions of greenhouse gases. In the conditions of the EU, the assumptions about the creation of food waste, range around 83 million tons per year (Szalai, 2018). Despite publish discussion about negative impacts of excessive creation of waste and food waste, existence of several directives, regulating waste management, knowledge of people about creation and effects of biodegradable municipal waste on environment, area of separated collection, area of material utilization of biodegradable municipal waste and area of energetic utilization of biodegradable municipal waste is insufficient and responsibility for minimizing waste creation is lagging behind.

\section{Acknowledgements}

This article was realized based on research grant: VEGA 1/0802/18, Corporate social responsibility and innovation activities focused on decreasing food losses with regards of environmental issues.

\section{References}

[1] Conference CE Food Waste (2019). Food waste creates 8\% of emissions of greenhouse gases. Retrieved from: https:/corporate.tesco.sk/novinky/2019/konferencia-ce-food-waste-2019-potravinový-odpad-tvorí-8emisií-skleníkových-plynov/ 
[2] Detersová, K. (2019). Bio waste is still an issue for municipalities, many break the rules. EURACTIV Retrieved from: https://euractiv.sk/section/obehova-ekonomika/news/bioodpad-je-pre-samospravy-ajnadalej-problem-viacere-porusuju-zakon/

[3] Doskočilová, A. (2013). Dostálová, H; Chládek, M.; Svitavský, M.; Šimíček, V. Biomass for energy [online]. Tábor: Secondary Industrial School of Machinery and Construction, Tábor, Komenského 1670, 2013 [cit. 2019-05-14]. Chapter Biogas, p. 61. Available online. Retrieved from: http://zelenymost.cz/files/biomasa_pro_energii.pdf

[4] Kazdová, T (2019). Households waste the food most, according to the survey of the EU. PROPERTY \& ENVIRONMENT s. r. o. Retrieved from: https://www.odpady-portal.sk/Dokument/104818/potravinaminajviac-plytvaju-domacnosti-vyplyva-z-prieskumu-eu.aspx

[5] Ministry of Environment SR (2018). Program of waste prevention. Retrieved from: https://www.minzp.sk/odpady/program-predchadzania-vzniku-odpadu/

[6] Ministry of Environment SR. Greener Slovakia. (2018, May 5). In: Strategy of environmental policy of the Slovak Republic up to 2030.2 Retrieved from: https://www.minzp.sk/files/iep/03_vlastny_material_envirostrategia2030_def.pdf

[7] OdpadyPortal (2018). Incineration of waste. PROPERTY \& ENVIRONMENT s. r. o. Retrieved from: https://www.odpady-portal.sk/Dokument/100872/spalovne-odpadov.aspx

[8] Orbanová, A. (2013). Management of biodegradable municipal waste. The fifth seminar Bioscrap Know How to manage in Austrian Mistelbachu Bioscrap Know - How. Retrieved from: http://bioscrap.eu/sk/bioodpad/co-je-bioodpad

[9] Potočár, R. (2019). Most foodstuffs are thrown by people in housing estates, as survey showed. PROPERTY \& ENVIRONMENT s. r. o. Retrieved from: https://www.odpady-portal.sk/Dokument/104994/najviacpotravin-vyhadzuju-ludia-na-sidliskach-ukazal-vyskum.aspx

[10] Prostredníková, Z. (2016). Bio waste ending in dumps is a huge issue. What is the practice? JRK Waste management. Retrieved from: https://www.menejodpadu.sk/bioodpad-konciaci-na-skladke-je-velkymproblemom-aka-je-prax/

[11] Rojko, M. (2020). Energetic evaluation is perceived by politicians as real management of waste processing. PROPERTY \& ENVIRONMENT s. r. o. Retrieved from: https://www.odpadyportal.sk/Dokument/105147/energeticke-zhodnocovanie-vnimaju-politici-ako-realne-riesenie-spracovaniaodpadov.aspx

[12] Sipos, A. (2019). We throw away foodstuffs at the amount of 400 billion. This is how retail chains manage food waste. StartitUp. Retrieved from: https://www.startitup.sk/vyhadzujeme-potraviny-v-hodnote-400miliard-takto-riesia-plytvanie-potravin-retazce-u-nas/

[13] Szalai, P. (2018). Eurostat published new waste statistics, Slovakia rose. PROPERTY \& ENVIRONMENT s. r. o. Retrieved from: https://euractiv.sk/section/obehova-ekonomika/news/eurostat-zverejnil-noveodpadove-statistiky-slovensko-poskocilo/

[14] Szalai, P. (2018). Many people do not realize food waste. PROPERTY \& ENVIRONMENT s. r. o. Retrieved from: https://euractiv.sk/section/ekonomika-a-euro/news/mnoho-ludi-si-plytvanie-potravinami-anineuvedomuje/

[15] The Directive of the European Parliament and the Council 2008/98/ES from November 19th 2008 on waste and repeal of certain directives. Retrieved from: https://eur-lex.europa.eu/legalcontent/SK/TXT/PDF/?uri=CELEX:32008L0098

[16] Vandák, R. (2010). Influence of the framework directive 2008/98/ES for waste disposal in the Slovak Republic. PROPERTY \& ENVIRONMENT s. r. o. Retrieved from: https://www.odpadyportal.sk/Dokument/100575/vplyv-ramcovej-smernice-200898es-na-nakladanie-s-odpadmi-v-sr.aspx 


\title{
Corporate Social Responsibility and Innovation Activities to Reduce Food Waste in Slovakia
}

\author{
Zuzana Kapsdorferová ${ }^{1}$, Petronela Švikruhová 2 , Radka Kataniková ${ }^{3}$, Mária \\ Kadlečíková ${ }^{4}$, Pavol Grman ${ }^{5}$, Mária Medved'ova ${ }^{6}$ \\ Slovak University of Agriculture in Nitra, \\ Faculty of Economics and Management, Department of Management ${ }^{1,2,3,4,5,6}$, \\ Address: Tr. A. Hlinku 2, \\ 94976 Nitra, Slovakia \\ e-mail: zuzana.kapsdorferova@uniag.sk¹, petronela.svikruhova@uniag.sk², xkatanikova@uniag.sk³ \\ maria.kadlecikova@uniag.sk',xgrman@uniag.sk ${ }^{5}$, xmedvedova@uniag.sk $^{6}$
}

doi: 10.18515/dBEM.ISD.P01.2020.p004

\begin{abstract}
Food waste is problem of all the planet. On one side we are fighting against hunger and on the other side we waste a lot of food. The problem with hunger will even grow in importance because of rising population in the world and the need to feed the population. Ongoing discussions about food waste and food losses shows how big problem it is, and the reality shows how little work we have done in this issue. But food waste contributes also to economic disparities, social inequalities and environmental pollution. Forecasted recent calculations in a long time period vision shows that halving the food waste and food losses will occurs that instead of increasing agricultural production to $60 \%$ we will need increase the production only to 25\% to enhance nutrition for 9,1 bills. people in 2050. According to FAO (2019) approximately one third of the food produced at a global level (1,3 billion tons yeas) is wasted every year and individuals in developed countries waste as much food (222 mil. tons) as entire food production in sub-Saharan African (203 mil. tons). However, the causes of food waste differ in each country depending on the level of economic development" in underdeveloped countries almost $40 \%$ of the food waste is a result of inadequate processing and storage of raw materials, whereas in developed countries more than $40 \%$ of foo waste is a result of market inefficiencies. There is need to pay high attention on responsibility for sustainability of natural resources. The main objective of the submitted paper is to assign the situation with food losses and waste in Slovak Republic and to propose activities and innovative approaches to minimization the food losses and food waste to reduce food waste and food losses.
\end{abstract}

Key words: food waste, poverty, household awareness, responsibility, sustainable food, innovation activities

JEL classification: $M 10$, M31

\section{Introduction}

\subsection{Outline of Current Research in Food Waste and Food Losses}

Nowadays the problem of food waste has moved up a public more intensive then in a past. This problem will even grow in importance because of rising population in the world and the need to feed the population. Food waste is an urgent problem because about one-third of food for people's nutrition loses ends in food waste. Food losses occur throughout the food chain starting from harvesting, continuing through the processing and ending with the consumption of household food. In more developed countries, food losses at the end of the food chain dominate. The fact that food waste has an enormous impact on the economy as well as on environment, makes a problem of social and economic range. 
Food losses refer to the decrease in edible food mass throughout the part of the supply chain that specifically leads to edible food for human consumption. Food losses take place at production, postharvest and processing stages in the food supply chain. Food losses occurring at the end of the food chain (retail and final consumption) are rather called food waste, which relates to retailers' and consumers' behaviour (Parfitt et al., 2010). Food waste is any food, and inedible parts of food, removed from the food supply chain to be recovered or disposed, including the following destinations: composting, crops ploughed in/not harvested, anaerobic digestion, bio-energy production, co-generation, incineration, disposal to sewer, landfill or discarded to sea but not including food or inedible parts of food removed from the food supply chain to be sent to animal feed or bio-based material/chemistry processing (Tostivint et al., 2016). The European Commission defines food waste as: fractions of 'food and inedible parts of food removed from the food supply chain' to be recovered or disposed (including: composted, crops ploughed in/not harvested, anaerobic digestion, bioenergy production, cogeneration, incineration, disposal to sewer, landfill or discarded to sea) (Stenmarck et al., 2014). However, the EU definition of food waste does not include losses at stages of the food supply chain where certain products have not yet become food as defined in Article 2 of Regulation (EC) No 178/2002, such as edible plants, which have not been harvested, excluding crops ploughed in/not harvested. The figures show up that one third of all world food produced for human consumption is lost or is wasted. The lost are provided mainly by developed countries and irresponsible consumer behaviour. According to World Bank data (2019) 1520 calories are wasted daily by final consumer. Due to these growing environmental but also social and economic concerns, food waste is increasingly acknowledged as an urgent issue among governments, businesses, NGOs, academics, and the general public. In response, there is a mounting evidence base on the quantities of food wasted and the related emissions along the food production-consumption chain (Beretta et al., 2013, Edjabou et al., 2016). For this reason, the European Parliament's Agriculture Committee has adopted a resolution committing members of the Commission to take radical steps to reduce food and food waste from a farm to fork by up to $50 \%$ by 2025 . Upon this initial step there must be developed a strategy and action plan to combat food waste in Slovak republic.

\section{Data and Methods}

The main objective of the submitted paper is to assign the situation with food losses and waste in Slovak Republic and to propose to propose activities and innovative approaches to minimization the food losses and food waste to reduce food waste and food losses. Stemming from the above mentioned, the main objective of submitted paper is to find out the data about the food waste in our circumstances and to identify main problems of food waste in Slovakia. Into the research had been involved 250 households who responded on 22 questions related to food waste. The survey was undertaken in May - December 2019 and for its delivery had been utilized hardcopies of questionnaire, as well as its electronic form distributed through social media and personal asking.

\section{Results and Discussion}

\subsection{Structure of Waste Generated by the Household}

Wasting food means wasting of resources. It is estimated that $111 \mathrm{~kg}$ of food is discarded by average Slovak annually. In the EU, 88 million tons per year are discarded, which represents $173 \mathrm{~kg}$ per person per year. Among EU countries Netherlands waste the food the most and Slovenia the least (Eurostat, 2019). Food is losses or wasted throughout the entire supply chain. 
Food losses or waste are occurring practically in each segment of the food chain, starting from agricultural primary production, continuing through food processing and ending with food consumption in households. In the more developed states, the food losses are dominating at the end of the food chain. According to EU data the estimation for 2012 for food losses or waste are households responsible for 53\%, food processing for $19 \%$, food service and catering for $12 \%$, primary productions is responsible for $11 \%$ and retail wholesale for $5 \%$, food is lost along the whole supply chain from farms to processing and manufacturing in shops, restaurants, and home (Figure 1). However, in EU most of the food is wasted by households.

Figure 1 Food Losses and Waste in EU in 2012 (\%)

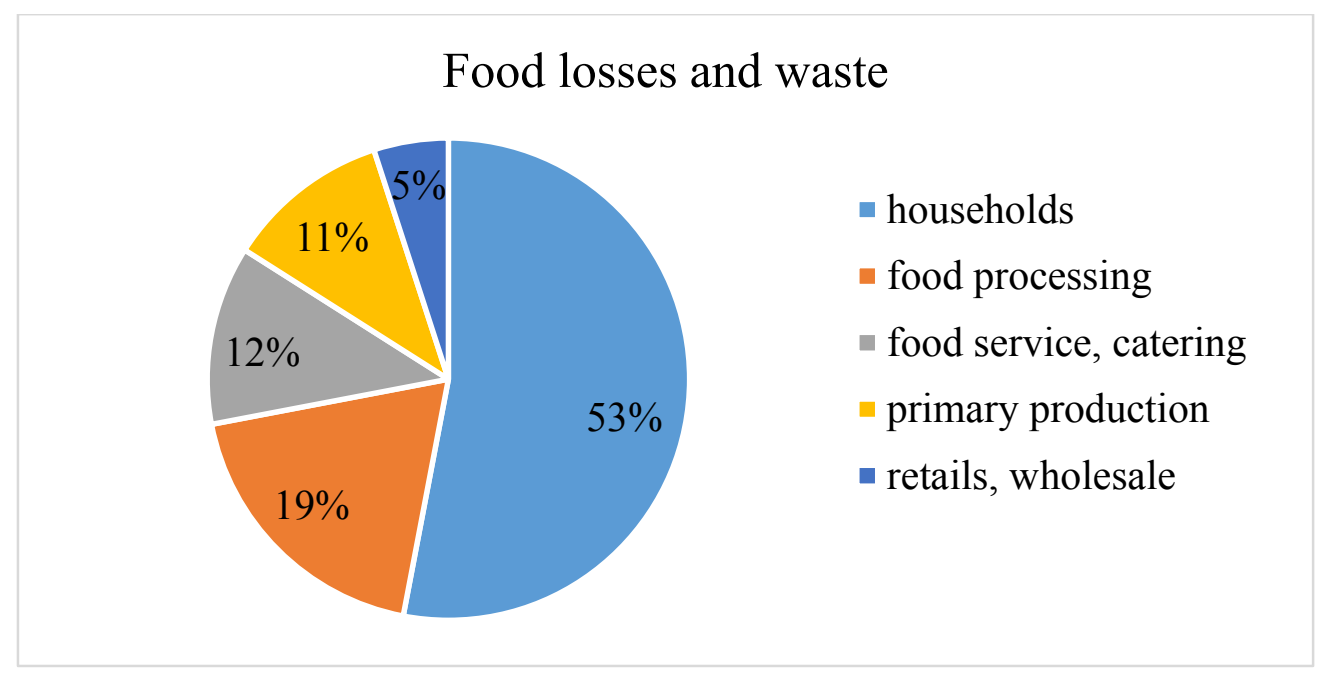

Source: European Parliament, 2019

Very similar results of the research were conducted by research team at FEM SUA in Nitra. It showed up the following results. In Slovakia the households are responsible for $50 \%$ of food waste, but they are often unaware of the fact. Slovakian families thrown away $22 \%$ of weekly shop (Figure 2). In Slovakia is food most wasted by young and middle generation. The problem with food waste also has showed that at the school canteen every 8 child does not take up every day.

Figure 2 Food Losses and Waste in SR in $2018(\%)$

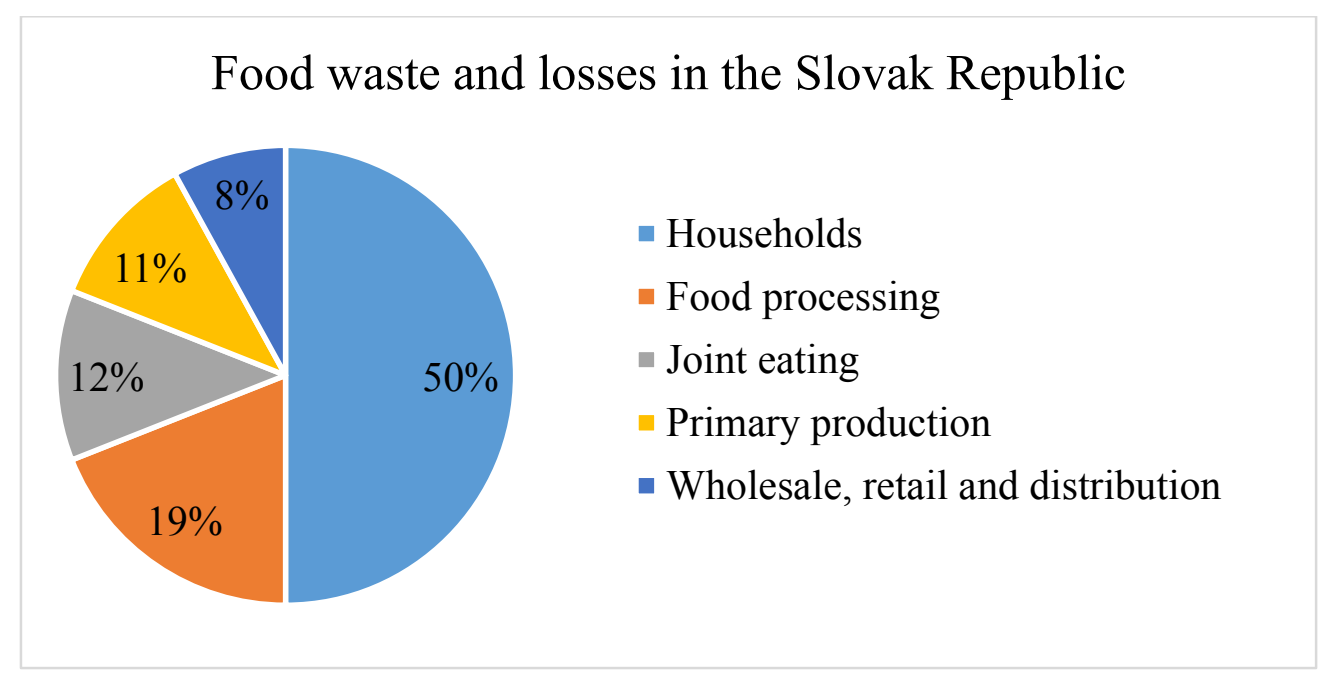

Source: Own research

As far as we know there are five main problems of food losses and food waste in Slovakia that we must pay attention at: 
1. Measuring food losses and food waste - the scarcity of data or no data at all is a big problem. The problem is that there is no defined method of data collection: surveys, administrative data, statistical estimations as well as their combination. There is also needed to clear define food waste, distinction in edible and non-edible required and clear operationalization of food and non-food. Currently, EU member states are now obliged to monitor the generation of food waste along the food supply chain and to take measures to limit it. To contribute to the harmonization of food waste quantification in the EU, the European Commission has published a delegated act establishing a common methodology and minimum quality requirements for the uniform measurement of food waste generated in Member States. The amendment to Directive 2008/98/EC on Waste (European Commission, 2018) obliges European Union (EU) Member States (MSs) to monitor the generation of food waste along the food supply chain (FSC) and to take measures to limit its generation.

2. Need of change legislation. If we want to reduce the production of food waste, we must change a law, which is more liberalized in the EU countries. Example can be removing of durable food from food waste category, unconsumed food offered for feeding animals or deducted of taxes for food donations. There are also talks going on about the possibility to sell food after the date of minimum durability. The option is also to change legislation and not to use term "date of minimum durability". In some EU countries it is forbidden by law to through food to supermarket, which also helps to reduce food waste.

3. More responsible approach. The number of people at risk of poverty living in Slovakia has decreased over the last decade. According to Statistical Office it has dropped from 704000 to 670000 in 2016 (Figure 3). Every sixth person, in fact, is at risk of poverty or social exclusion in the country. There were 109.2 million Europeans living at the risk of poverty or social exclusion in 2018 (Eurostat, 2019). It has decreased from almost 25 percent, between 2009 and 2012, to 21.7 percent in 2018.Despite this, the EU is lagging one of its Europe 2020 strategy targets - lifting 20 million people out of the risk of poverty and social exclusion. In fact, only 8.2 million have received enough help in not facing poverty from 2008 onwards. According to EU's statistics in Slovakia lived 872,000 people at the risk of poverty in 2018. Moreover, Slovakia has the third lowest share of people threatened by poverty in the European Union.

Figure 3 The Number of People at Risk of Poverty in Slovakia in 2011-2017

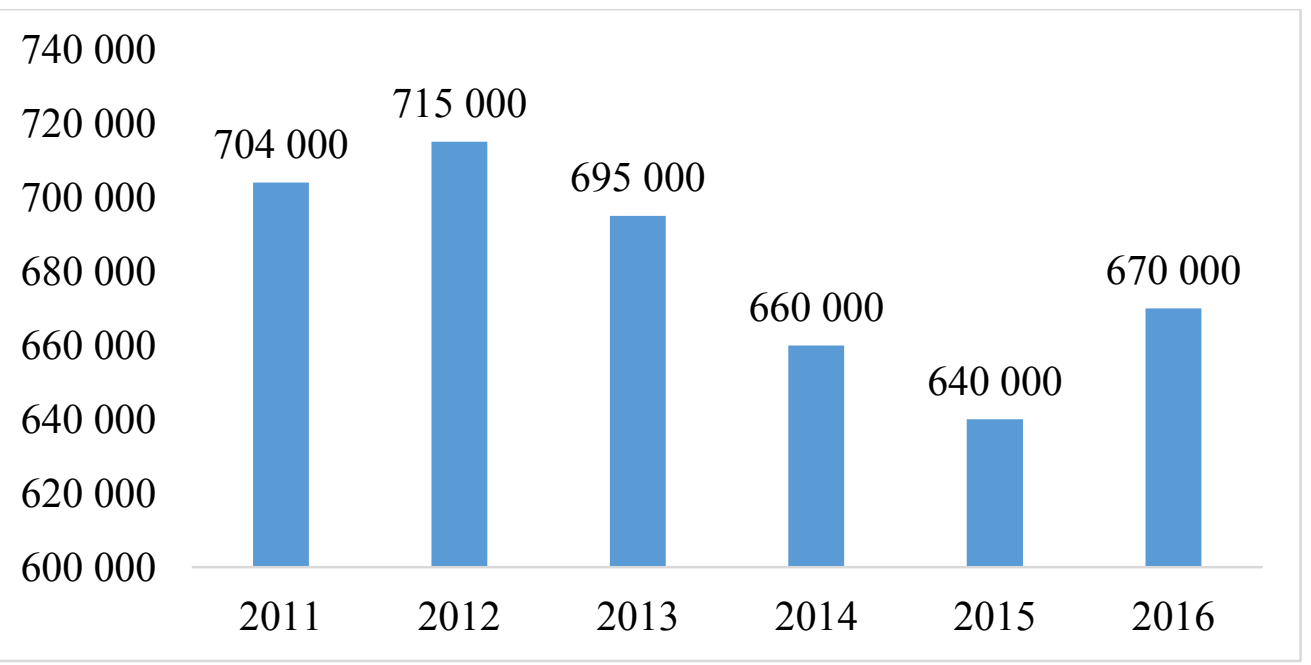

Source: ŠU SR, 2019

The risk of poverty is calculated for single member households with a monthly amount of almost 348 EUR, which is 4171 per year. The poverty goes in hand with hunger. Hunger is not 
happening somewhere else, hunger is there, and we must be aware of it. Therefore, it is required to have more responsible approach to reduce food for everyone. The biggest waster of food are households and we highly recommend to consumers to be more responsible, to buy less and more often and they will have fresher food and Slovak families will waste less. The research finds out how Slovakian families decrease the food waste? Most often they freeze the food, fruit and vegetable surpluses dry, offer food surpluses to pets or they compost the food. Households did not mention the opportunities to donate the food. There is a big gap in a system a lack of knowledge of consumers in an issue of food donation.

4. Donation of food - there must be strict hierarchy what to do with a food waste. The most important is to reduce food waste and offer food to most vulnerable people to reduce hunger and poverty in the country. Then the food waste can be offered to feed animals and afterwards for industrial use such as production of energy and composting. The last and the easiest is to landfill (Figure 4).

Figure 4 Hierarchy of Food Donation

\section{Reduce Food Waste}

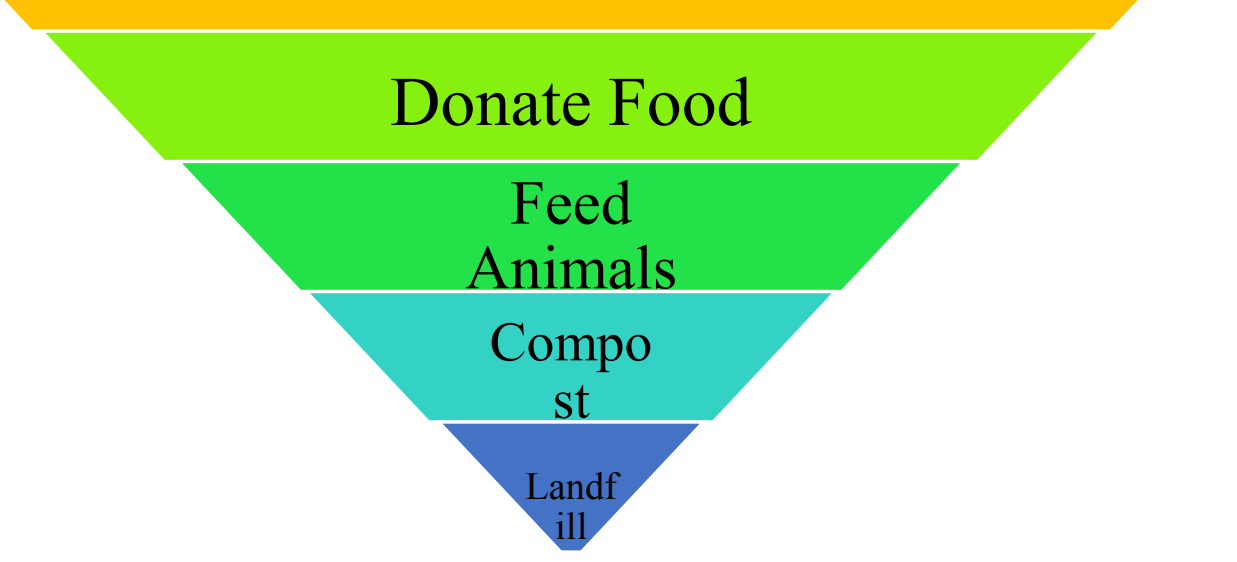

Source: Own processing

\section{Possibilities to donate food in Slovakia}

\section{Food Bank in Slovakia}

A food bank is a non-profit organization that distributes food those who need it the most. The idea came from United States. The first food bank started to operate in Slovakia in 2005. The food banks collect food from retail chains and food producers which they were unable to sell, but which is still of merchantable quality. The main idea is to provide or distribute food to those who have difficulty to purchase it and to avoid hunger. Since January 2017, stores may donate food after the expiry date of the minimum durability to charitable organizations. Many of the food markets have thus significantly reduced food waste and have contributed to improving the lives of socially weaker groups. In Czech Republic it is forbidden for supermarkets to throw away food since 2019. Therefore, the food banks in Czech Republic has 3 times higher food supply from supermarkets than in Slovakia.

\section{Community Fridges in Slovakia}

The first Community fridges were set up in Germany in 2012 and later in Spain. Unfortunately, in Slovakia, the project of Community fridges has not been very well accepted. The main obstacle is a strict legislation. The operator must ensure that the fridge is kept clean and food is safe. At the same time, the operator must demonstrate at any moment the origin of the food. 
There must be also a guarantee that nobody abuses the food from fridge for making profit. On the other hand, the question is, what would the Slovaks have taken from a publicly shared food from fridge? Survey showed, that idea of community fridge would very much be accepted, but not everyone would have picked up the food from such a fridge. For the future it would be very important for this project the location of the fridges.

5. Environmental problem - uneaten food accounts $25 \%$ of all fresh water, land, labour, energy, manufacturing, packaging. Food waste and organics in landfills create large amounts of methane, a powerful greenhouse gas. The amount of a waste produced by households in Slovakia is enormous, no matter whether we live in a house, flat or at a dormitory. Approximately $300 \mathrm{~kg}$ of a waste is produced by each citizen of the Slovak Republic. The waste that's being generated is mostly mixed garbage which means that everything is thrown into one bin (Kročková - Lieskovská, 2016).

Figure 5 Structure of waste generated by the household, 2016

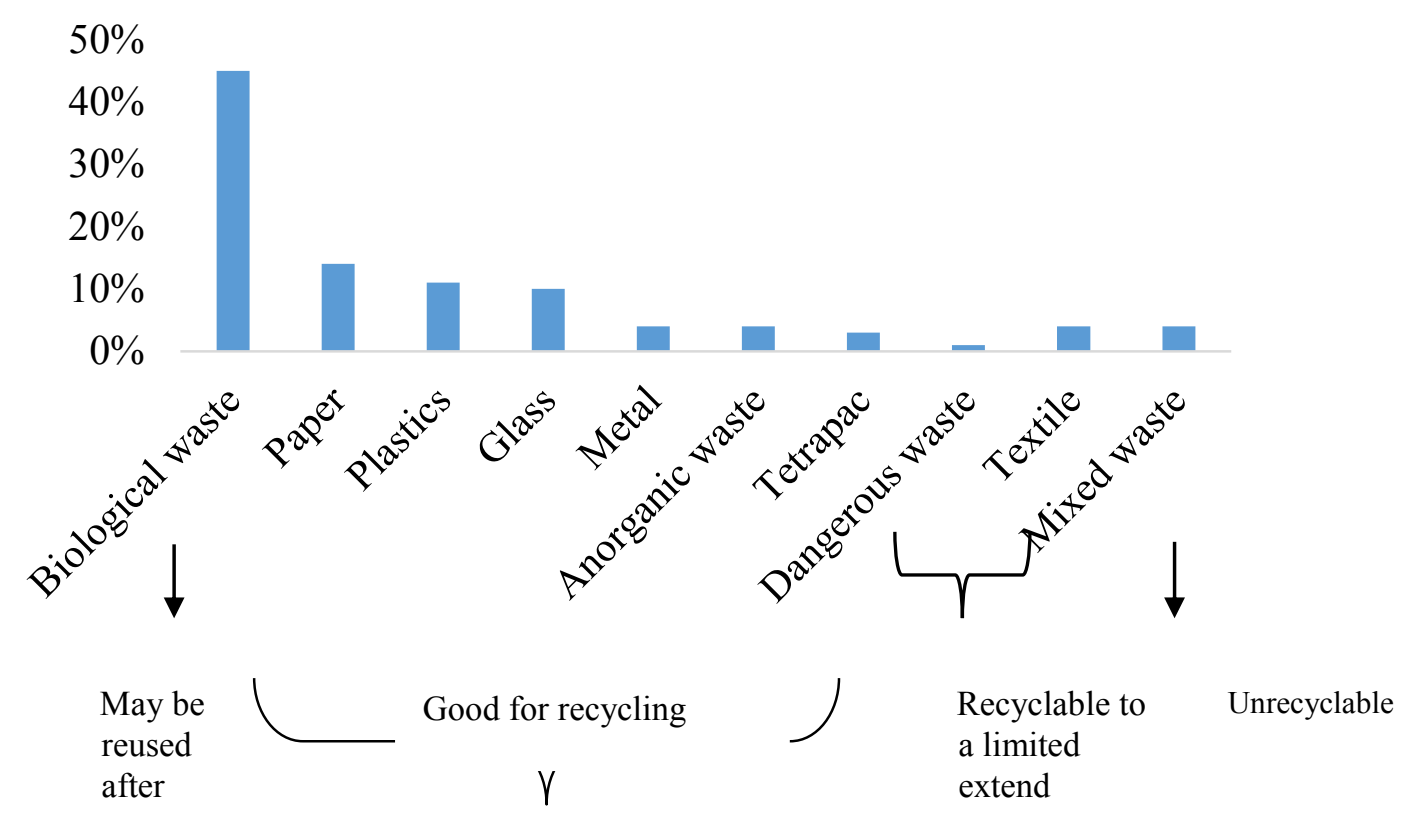

Source: Kročková - Lieskovská, 2016, own processing

We consider the biological waste - compost - as a valuable natural resource that may be used for the soil fertility enhancement. This agro-ecological approach will obviously boost soil productivity and reduce the need for use of chemical fertilizers which to the end will prevent the undersurface water from the contamination. The analysis of a municipal waste in the region of Nitra from 2016 says that only $8.8 \%$ of a waste is used for composting, or for energetic purposes, but $91.20 \%$ of garbage is defused. Most of the defused part creates the mixed municipal waste generated by a household (more than $70 \%$ ). If Slovakia wants to achieve European recycling targets, it must combat with bio-waste, which currently creates $50 \%$ of all waste. Cities must build a composting plant and ensure collecting of the food waste, which up to $2 / 3$ of the cities in Slovakia is not doing.

\section{Conclusion}

The survey pointed out how serious problem is a food waste in Slovakia and what must be changed. It is our responsibility to solve it and reduce food waste. It is estimated that $111 \mathrm{~kg}$ of food is discarded by average Slovak annually. At the same time, according to EU's statistics, in Slovakia lived 872,000 people at the risk of poverty in 2018. In Slovakia the households are 
responsible for $50 \%$ of food waste, but they are often unaware of the fact. Slovakian families thrown away $22 \%$ of weekly shop. In Slovakia is food most wasted by young and middle generation. The problem with food waste also has showed that at the school canteen every 8 child does not take up every day. Consumers do not behave responsible. There is need to educate consumers how much they waste and how unecological it is to waste the food. There is also placed to work more effective for municipalities. If Slovakia wants to achieve European recycling targets, it must combat with bio-waste, which currently creates $50 \%$ of all waste. Cities must build a composting plant and ensure collecting of the food waste, which up to $2 / 3$ of the cities in Slovakia is not doing. Mankind is half of the problem.... but also, half of the solution!

\section{Acknowledgement}

This article was realized based on research grant: VEGA 1/0802/18, Corporate social responsibility and innovation activities focused on decreasing food losses with regards of environmental issues.

\section{References}

[1] B. Å. Stenmarck, C.Jensen, T.Quested, G.Moates. 2014. Estimates of European food waste levels. ISBN 978-91-88319-01-2doi.org/10.1098/rstb.2010.0126. ISSN 0962-8436

[2] B. Kročková - Z. Lieskovská.(2016). Zelená domácnost’ alebo konajme 3E - ekonomicky, environmentálne a eticky - hospodárenie v domácnosti, 2.čast', Bratislava: Ministerstvo životného prostredia SR, ISBN: 97880-89503-49-0

[3] C. Beretta, F. Stoessel, U. Baier, S. Hellweg. (2013), Quantifying food losses and the potential for reduction in Switzerland. Waste Manag.., 33 (2013), pp. 764-773

[4] C. Tostivint et.al., (2016). Food waste quantification manual to monitor food waste amounts and progression. Fusions project, c.n. $311972 \quad$ [online] available at http://www.eufusions.org/phocadownload/Publications/Food $\% 20$ waste $\% 20$ quantification $\% 20$ manual $\% 20$ to $\% 20$ monitor $\% 20$ food $\% 20$ waste $\% 20$ amounts\%20and\%20progression.pdf

[5] Directive 2008/98/EC on Waste (European Commission, 2018)

[6] European Parliament [2019]. https:/www.europarl.europa.eu/news/en/ deadlines/society/ 20170505STO73528/ food-waste-the-problem-in-the-eu-in-numbers-infographic

[7] FAO (2019), „Key facts on food loss and waste you shold know!“, Retreved from www.fa.org/savefood/resources/keyindings/en. Accessed 17 July, 2019

[8] FAO UN (2014): The Food Losses and Food Waste in Europe and in Central Asia, FAO Regional Conference for Europe and Central Asia, 2014, Bucurest, Romania, 2.- 4. Apríl, 2014

[9] J.Parfitt - M.Barthel - S. Macnaughton (2010). Food waste within food supply chains: quantification and potential for change to 2050. Philosophical transactions of the royal Society

[10] M.E. Edjabou, C. Petersen, C. Scheutz, T.F. Astrup. (2016). Food waste from Danish households: generation and composition. Waste Manag., 52 pp. 256-268 Fusion 2014

[11] Regulation (EC) No 178/2002, European Parliament and Council, 2002. available at http://www.legislation.gov.uk/eur/2002/178/contents

[12] ŠU SR (2019) .https://slovak.statistics.sk/wps/portal/ext/aboutus/office.activites/officeNews/archivaktualit

[13] World bank 2019. https://www.worldbank.org/en/news/feature/2014/02/27/infographic-food-loss-waste https://ec.europa.eu/eurostat/news/themes-in-the-spotlight/poverty-day-2018 


\title{
Consumer Behavior and Food Waste
}

\author{
Roman Récky ${ }^{1}$, Jarmila Horváthová ${ }^{2}$ \\ Slovak University of Agriculture in Nitra \\ Faculty of Economics and Management, Department of Marketing and Trade ${ }^{1}$, \\ Department of Foreign Languages ${ }^{2}$ \\ Address: Tr. A. Hlinku 2, \\ 94976 Nitra, Slovakia \\ e-mail: roman.recky@uniag.sk ${ }^{1}$, jarmila.horvathova@uniag.sk ${ }^{2}$
}

doi: 10.18515/dBEM.ISD.P01.2020.p005

\begin{abstract}
Agriculture and foodstuff production is being increasingly influenced by the climatic changes. Along with the rising human population it will be interesting to observe how many people our planet is able to sustain. Food waste is predominantly related to the developed countries; however, it is becoming the global problem. On the other hand, about one milliard of people is facing the risk of malnutrition. Food waste begins already at the field during harvesting the farm crops and continues during transportation, storage and processing. The biggest quantities of food are being wasted in the households, public or restaurant facilities. The unused foodstuff means not only the direct loss but also the additional costs needed for its disposal. In our paper we analyse the marketing survey which was targeted at the food waste in the Slovak Republic. Almost $69 \%$ of respondents consider the food waste to be a serious global problem, but only $34 \%$ of them plan their food purchase. $70 \%$ of respondents are not familiar with the organizations such as the food bank, $60 \%$ answered that the food is being spoilt and therefore it is thrown away. The food waste can be decreased by a better unforcedness of the consumers about these problems, the improvement of infrastructure and communication within the supply chain and introduction of stricter regulations.
\end{abstract}

Keywords: agriculture, foodstuff, food waste, waste.

JEL Classification: $Q 15, Q 18, Q 19$.

\section{Introduction}

Food and water waste ranks among the key themes of the global food and nutritional policy. It is the issue dealt with by media, politicians, specialists, businesspersons and many others, and they try to solve this problem in several ways. However, the solution is too complex and requires great endeavour, mutual coordination, understanding, as well as searching for the new approaches and elimination of the different barriers. The studies of the Food and Agriculture Organization (FAO) claim that about one third of foodstuff produced for the human consumption is globally unused, i.e. on average 1.3 milliard ton of food. These numbers and many other facts are the evidence that this is the vital problem which refers to any individual on our planet. There is no doubt about the necessity to solve this issue immediately.

According to FAO food loss and waste has indeed become an issue of great public concern. FAO is partnering with governments, international organizations, the private sector and civil society to raise awareness on the issues and to implement actions to address the root of the problem. The FAO 2030 Agenda for Sustainable Development calls for halving per capita global food waste at retail and consumer levels by 2030, as well as reducing food losses along the production and supply chains (UN Food and Agricultural Organisation, 2020).

The food waste is present in the whole food and supplying network, from the agricultural basic industry to the final consumption in households, catering establishments, public and restaurant 
facilities. Unfortunately, there exist the serious drawbacks in the knowledge related to the global food losses and food waste, therefore it is necessary to increase continuously the awareness of people about this problem. It is needed to search for and also accept not only legally non-obligatory measures, but predominantly the legal measures how to avoid food waste, how to decrease and eliminate it. The legislation itself will never be sufficient if we do not campaign consistently at all levels of the food network and consumers for respect of food and water, so that all involved subjects are able to purchase, store, prepare and consume properly. This approach requires a considerable effort, educational training, responsible attitude, but also the interference into the freedom of trade, profit increase, competitiveness and many others.

Food waste has also the negative environmental impact. When food winds up in landfills it produces methane, a greenhouse gas and carbon dioxide.

In the high-income countries the food is wasted because $20-30 \%$ of fruit and vegetables in shops do not have the enough rich colour, accurate calibre - size, or they are slightly damaged and inacceptable aesthetically for a consumer. For example, in the USA every year the average family of four tosses roughly $\$ 2,000$ in food; 30 to 40 percent of food produced in this country ends up discarded. The Food Waste Reduction Alliance in the USA - a collaborative effort of the Grocery Manufacturers Association, the Food Marketing Institute and the National Restaurant Association - is working to standardize the confusing panoply of labels that consumers use as cues to determine if food is still safe to eat. Some governments are taking more aggressive actions to stem food waste. France, for example, bans grocery stores from tossing edible food. South Korea prohibits food waste from landfills and requires people to separate food waste from their regular trash. (Foundation, Outrider, 2020).

The agreed goal of the European Union (EU) calls for a 30 percent reduction of food waste per capita by 2025 and a 50 percent reduction by 2030. This vote has been welcomed as a huge victory by members of the European Parliament, as the result of a very long and disputed negotiation process between the different EU Member States (https://foodtank.com/news/2018/).

The countries of V 4 (Vysegrad group) also pursue their programs of the food waste reduction. The Waste Management Plan of the Czech Republic for the period 2015-2024 defines waste prevention and reduction of specific waste production as a major strategic goal. The principles for achieving this objective include the implementation of "waste prevention programmes" and the implementation of the waste management hierarchy (http://www.reducefoodwaste.eu/situation-on-food-waste-in-czech-republic.html).

Poland's waste management plan includes procedures to reduce waste, to prepare them for reuse, recycling, other recovery operations and for waste disposal. The National Waste Management Plan for 2022 is in line with the strategic documents adopted at EU and national level (http://www.reducefoodwaste.eu/situation-on-food-waste-in-poland.html).

In Hungary some related strategic documents addressing food and waste in food industry exist. The two important national strategies on this matter are the "Food Chain Safety Strategy 2013 - 2022". This plan is not directly aimed at the reduction of food waste but has implications on food waste generating activities (http://www.reducefoodwaste.eu/situation-on-food-waste-inhungary.html).

In the developed countries another problem consists in the incorrect food storage, i.e. improperly adjusted temperature regime, when either too high cooling or, on the contrary, too high temperature during storage of fruit and vegetables cause their waste up to $55 \%$. Unlike the developing countries, in the industrial countries there exists a closer integration of 
producers, suppliers, processors and distribution systems, which prevents the losses. The supermarkets are the dominant intermediary between the farmers and consumers. Even in the poorer countries the supermarkets mean the principal tool for the distribution of the different foodstuff.

Food waste does not have an official definition therefore the project EU FUSION suggested the definition which will be common for the food rubbish. Food waste is the foodstuff or inedible part removed from the food chain which should be devalued, including the ungathered anaerobic decomposition, burning, bioenergy production, sowing, composting, liquidation into sewer, throwing away into sea or dumping place.

FAO distinguishes the definitions of food loss and food waste as follows: "Food loss is the decrease in the quantity or quality of food resulting from decisions and actions by food suppliers in the chain, excluding retailers, food service providers and consumers. Food waste refers to the decrease in the quantity or quality of food resulting from decisions and actions by retailers, food service providers and consumers" (UN Food and Agricultural Organisation, 2020).

The problem of food waste refers to Slovakia as well. In 2016 the Slovak Modern Trade Alliance (SAMO) initiated the discussion about the unreasonable wastage of groceries. This organization initiated the possibility to donate these products, which resulted in the new form of the Food Law enforceable since 1 January 2017. In 2016 six members of SAMO - Billa, DM Drogerie Markt, Kaufland, Lidl, Metro and Tesco - provided to the Food Bank and several charitable organizations the food before its expiration in the sum of 647,000 euros. In the previous four years the value of the donated food achieved altogether more than 3 million euros, exactly 3,177,000 euros. In the multiples stores of the SAMO members also fruit and vegetables, which are sorted several times a day, at the end of the day are donated as suitable for the human consumption or given to zoo, or the breeding associations of non-farming animals.

\section{Data and Methods}

The objective of the paper was to study the consumer behaviour when purchasing food and food waste in the Slovak households. The primary data were collected from the respondents via the questionnaire. The survey was conducted in April 2019 in the form of the written questionnaire and the received data were consequently coded into the electronic form in the program Microsoft Excel.

The acquired information was analysed through the selected factors of the consumer behaviour when purchasing food and the food waste in the respondents' households.

The primary survey was pursued by the questionnaire administered to 519 respondents.

At the beginning of the paper there is the brief overview of the selected authors dealing with the issue of food waste. The main part of the paper constitutes the evaluation of the questionnaire survey. The answers were processed into the graphs by the program Microsoft Excel. We have used the methods of analysis, synthesis and comparison. The evaluation of the responses utilized the absolute and relative frequency. We also depicted the answers in the graphs. In the end the whole issue is being summarized and the conclusion is suggested related to the food waste. 


\section{Results and Discussion}

In this part of the paper we evaluate the questionnaire survey referred to the opinions of the Slovak consumers about food waste. The questions were targeted predominantly at food waste in households, the restaurant facilities and also the separation of biowaste.

Out of the total number 519 respondents, 296 (57\%) were represented by women and 223 (43 $\%$ ) by men. From the age aspect, the highest percentage was achieved by the age group $31-59$ years old $227(44 \%)$, followed by the age group $20-30$ years of $211(41 \%)$ respondents, 60 and more years constituted $54(10 \%)$ and $27(5 \%)$ were aged $10-19$ participants. According to the number of household members, the most numerous were the households of three members - 286 (55\%), followed by $1-2$ members 125 (24\%) households, and more than four members represented $108(21 \%)$ households. From the aspect of the employee rating, 281 (54 $\%)$ were the employed, $136(26 \%)$ students, 51 (10\%) retired people, $5 \%$ were the unemployed and $5 \%$ of respondents were in the maternity leave. When we take into account the completed education then the biggest group are the people of the completed secondary education with the secondary school leaving exam 230 (44\%), followed by the university graduates $202(39 \%)$, next group is the one of the secondary education without the school leaving exam 64 (12\%) and $5 \%$ of the respondents achieved only the primary education. The majority of survey participants live in flats $208(40 \%)$, the following group has a house with a garden $205(39 \%)$ and $106(21 \%)$ respondents have a house without a garden. The last identification question was the number of populations in their towns or villages. The highest percentage was represented by places of residence of 10,000 - 49,999 inhabitants $138(27 \%)$, followed by the places of less than 1,500 people $126(24 \%), 3,000-9,999$ residents $111(21 \%), 1,500-2,999$ people $74(11 \%), 50,000-100,000$ inhabitants $9 \%$ and more than $100,000-5 \%$.

The main part of the questionnaire survey were the relevant questions aimed at the principal objective - food purchase and food waste. The first question was: "How often do you buy food?" The answers are indicated in the Figure 1. The most frequent reply was 2-3 times a week. This answer was marked by $268(51.6 \%)$ respondents. 123 ones $(23.7 \%)$ go shopping for food every day. 106 buyers $(20.4 \%)$ puchase food once a week.

Figure 1 How often do you buy food?

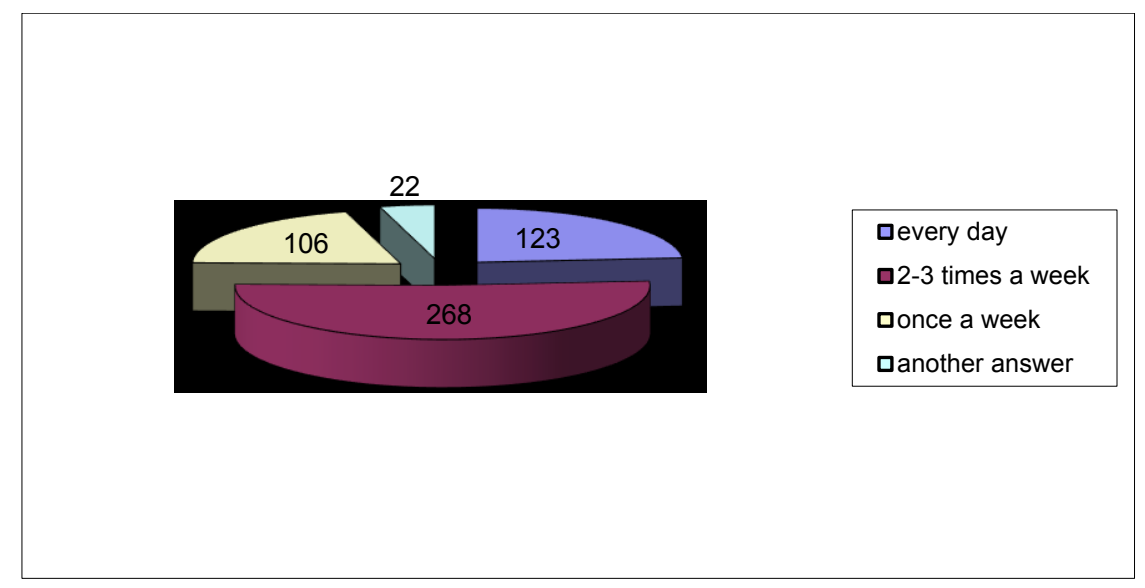

Source: own processing

The second question:" Estimate your monthly expenses on food" and the reactions are given in the Figure 2. The most frequent answer was the scale $201-300 €$. This option was marked by 197 (38.0\%) respondents. The following one was the answer $100-200 €$, chosen by 179 (34.5 $\%)$ and finally the expense $301-400 €(14.5 \%)$. 
Figure 2 Estimate of monthly expenses on food

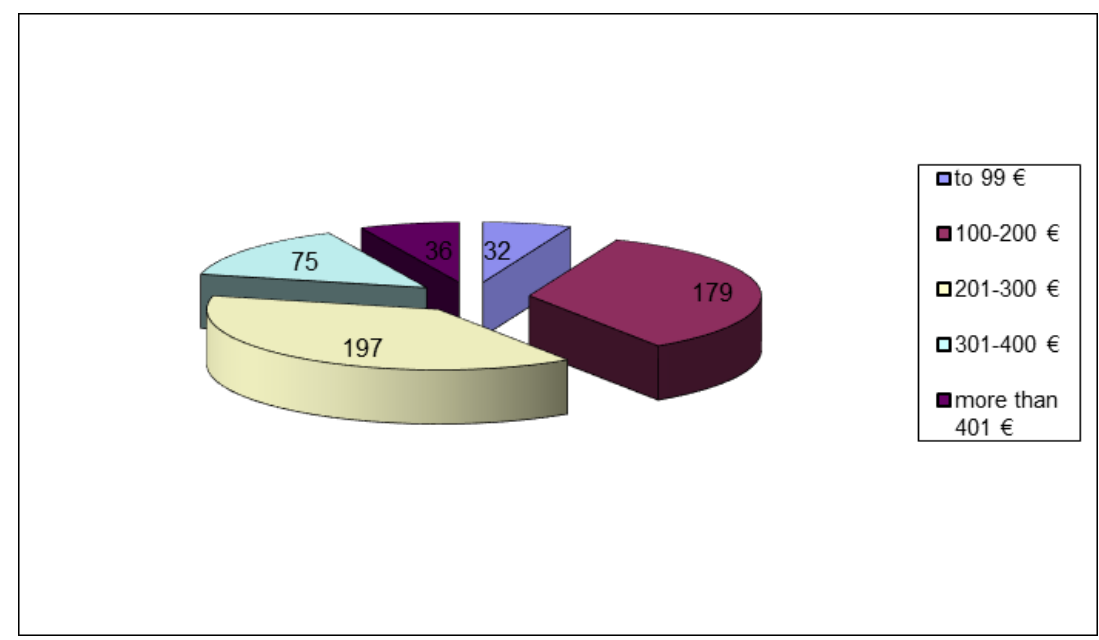

Source: own processing

The third question was related to the checking the expiration date, or minimal durability. The answers are indicated in the Figure 3.220 respondents $(42.4 \%)$ usually check these important dates. Nearly the same number of the shoppers (228 or $43.9 \%)$ stated they control the expiration "sometimes". Only 71 respondents do not check these dates when they go shopping.

Figure 3 Do you check the expiration date and minimal durability?

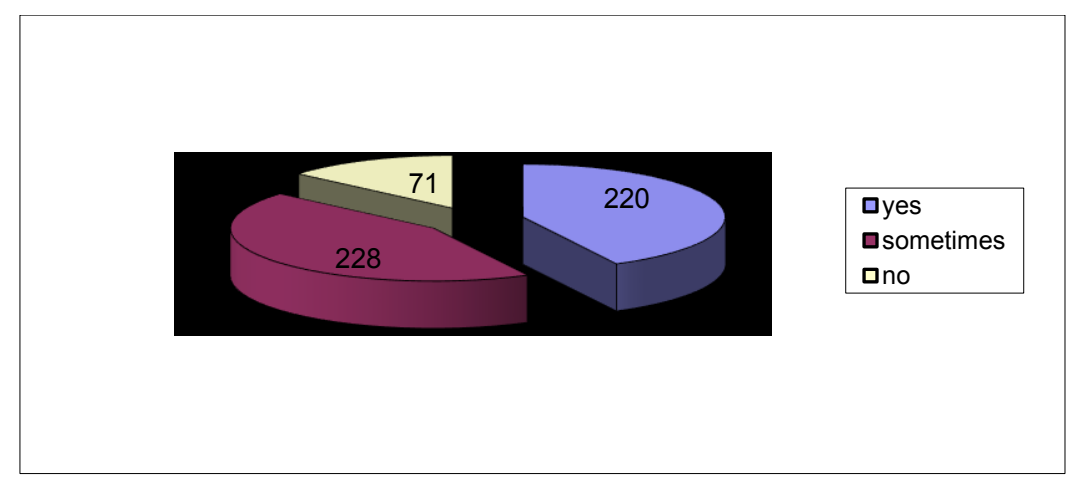

Source: own processing

The next question was related to the estimation of food waste per week (Figure 4). 143 respondents (27.6\%) answered that they throw away 50 -199 g of food. The following option was - 200 - $499 \mathrm{~g}$ marked by 123 people $(23.7 \%) .113(21.8 \%)$ respondents claimed from 49 g. The foodstuff is not thrown away by $87(16.7 \%)$ of households.

Figure 4 Estimation of food waste weight per week

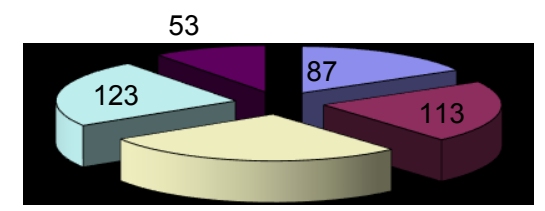


The following question asked about three most frequent reasons for wasting food (Figure 5). People stated as the most often reason the spoilt food (312 respondents), the food after expiration -273 answers and the uneaten leftovers was marked by 272 respondents.

Figure 5 The most frequent reasons for wasting food
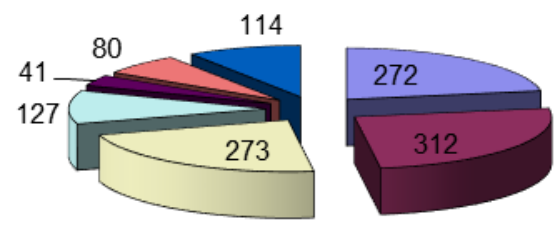

口leftovers on plate

口spoilt foodstuff

口after expiration date

口bad taste

口excessive shopping

口unconzumed meals

口inappropriate storage

Source: own processing

This question referred to the problem of usage of food waste in households (Figure 6). The respondents could indicate the optional number of replies. 299 respondents claimed that they use the food waste for feeding animals and 257 people for breadcrumbs. 90 respondents compost the waste and 89 respondents do not use it at all.

Figure 6 Usage of food waste

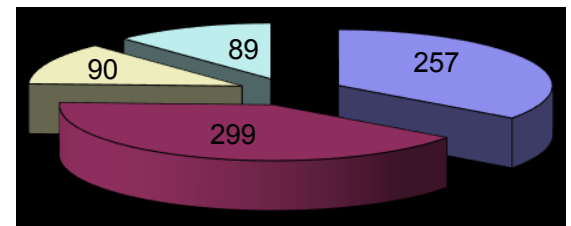

口bakery products for

breadcrumbs

fodder for animals

口composting

口do not use

Source: own processing

This question was targeted at the costumer behaviour in the restaurants. The reactions are indicated in the Figure 7. Most respondents (170) ask to prepare the take-away, 96 of them leave the food on the plate and 75 respondents ask the partners at the table to finish the food. 


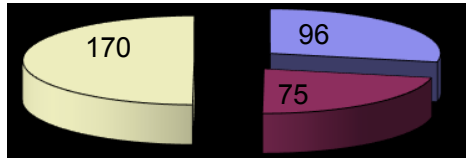

口l leave rest on plate

口। ask the ohers

ㅁ ask for takeaway

Source: own processing

Most respondents $356(68.6 \%)$ consider the food waste to be a serious global problem. Only 27 people $(5.2 \%)$ do not think that this issue is global. The answers are given in the Figure 8 . The figure 9 depicts the assessment of the respondents, which refers to the devalued food within the whole food production network that starts from farmers, and is followed by processing and distribution, and finally ends with a consumer. The most respondents (146 or $28.1 \%)$ think that one third of the produced food is wasted. 121 people estimate it is about one quarter. 115 respondents could not assess.

Foundation, Outrider (2020) claim "So many people work on food waste issues in their own spheres, but it's time to change the culture and adopt a holistic approach to get everyone working together and sharing ideas. If we could take these solutions and scale them, the food we'd save could feed millions of hungry people, conserve resources, and make a big dent in one of the biggest sources of climate change."

Figure 8 Food waste - global problem

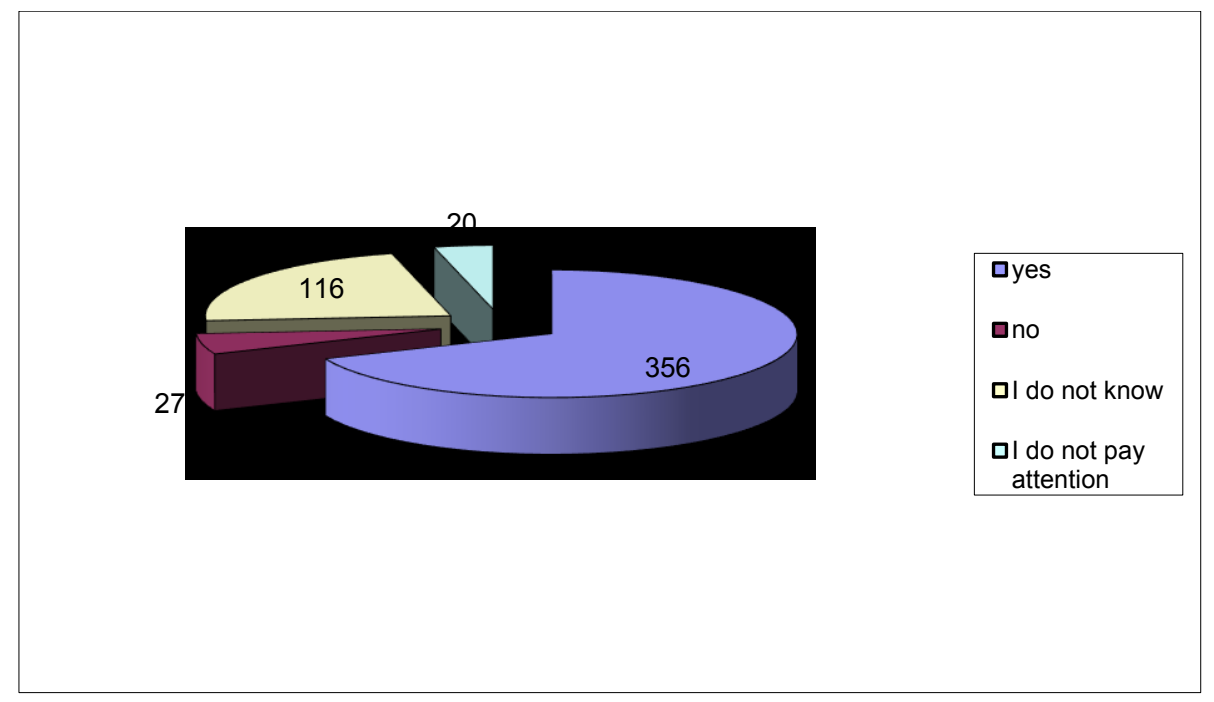

Source: own processing 


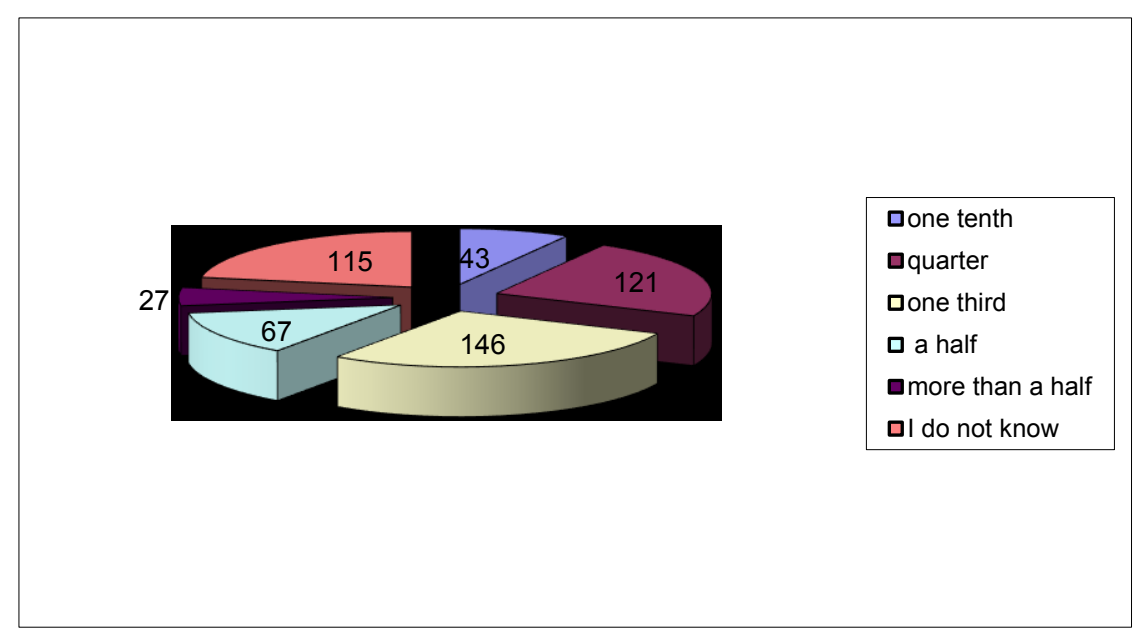

Source: own processing

\section{Conclusion}

The food waste is created in the whole foodstuff vertical - in the agricultural basic industry, processing, storage and manipulation, distribution, trade and final consumption. Almost $69 \%$ respondents consider the food waste to be the global problem. One third of the survey participants $(28 \%)$ suppose that approximately one third of the produced food is wasted. The most frequent reasons for food throwing away is the spoilt food, the expiration date and uneaten leftovers on a plate. The respondents use the food waste mostly for feeding animals, the production of breadcrumbs and composting. $17 \%$ of respondents do not waste food. People buy food most frequently 2-3 times a week. The participants (38\%) spend mostly $201-300 €$ on food per month, followed by the option (35\%) $100-200 €$.

The food waste is the principal problem of the foodstuff policy in the global aspect. It has a broader aspect - ethical, social as well as environmental. From the ethical viewpoint we can consider it to be a kind of barbarism when we consider that nowadays one milliard of population is endangered by starvation and malnutrition - according to the data of FAO. The developed countries waste the tons of food, which is safe and of high quality, and it could be consumed in the poor countries. The big part of inhabitants can afford to buy food, there it even food surplus, however, the socially deprived groups of people cannot buy a high-quality food or suffer from the food shortage. This global problem should be solved at all levels of the foodstuff vertical, predominantly by education and better informedness of all concerned subjects.

\section{References}

[1] Foundation, Outrider (2020) "Opinion | Food Waste is the World's Dumbest Environmental Problem". [online]. [cit. 2020-01-22]. Retrieved from

[2] FUSIONS Definitional Framework for Food Waste. [online]. [cit. 2020-01-22]. Retrieved from

[3] Golian Jozef, Fašiangová Katarína. (2016). Plytvanie potravinami - etický, ekonomický, sociálny a environmentálny problém Food waste - ethic, economics, social and environmental problems [elektronický zdroj] In: Bezpečnost' a kontrola potravín / Bezpečnost' a kontrola potravín [1 DVD-ROM (219 s.)]. Nitra: Slovenská pol'nohospodárska univerzita, s. 23-28. ISBN 978-80-552-1481-8.

[4] Golian, Jozef. (2017). Potraviny a spotrebitel'. Prvé vydanie, Slovenská pol'nohospodárska univerzita v Nitre. 104 s. ISBN 978-80-552-1767-3.

[5] http.//www.eufusions.org/phocadownload/Publications/FUSIONS\%20Definitional\%20Framework\%20for $\% 20$ food $\% 20$ Waste $\% 202014$.pdf. 
[6] http:/www.modernyobchod.sk/aktuality/samo-o-plytvani-potravinami-aj-na-intraco-special-2017/.

[7] https:/www.google.com/search?q=\%22Global+Food+Loss+and+Food+Waste\%22.+UN+Food+and+Agric ultural+Organisation.

[8] https://www.google.com/search?q=Foundation $\% 2 \mathrm{C}+$ Outride $+\% 22$ Opinion $+\% 7 \mathrm{C}+$ Food + Waste + is + the $+\mathrm{W}$ orld $\% 27 \mathrm{~s}+$ Dumbest + Environmental + Problem $\% 22 .+$ The + Rising $+\%$ E2 $\% 80 \% 94+$ Covering + how + changes $+\mathrm{i}$ $\mathrm{n}+$ the+environment + impact + business $\% 2 \mathrm{C}+$ technology $\% 2 \mathrm{C}+$ and + politics

[9] Ku, G. (2008). Learning to de-escalate: The effects of regret in escalation of commitment. Organizational Behavior and Human Decision Processes, 105(2), 221-232. doi:10.1016/j.obhdp.2007.08.002.

[10] SAMO o plytvaní potravinami aj na INTRACO SPECIAL 2017. [online]. [cit. 2020-01-22]. Retrieved from

[11] Situation on Food Waste in Hungary. [online]. [cit. 2020-03-05]. Retrieved from http://www.reducefoodwaste.eu/situation-on-food-waste-in-hungary.html.

[12] Situation on food waste in Poland. [online]. [cit. 2020-03-05]. Retrieved from http://www.reducefoodwaste.eu/situation-on-food-waste-in-poland.html.

[13] Situation on Food Waste in the Czech Republic. [online]. [cit. 2020-03-05]. Retrieved from http://www.reducefoodwaste.eu/situation-on-food-waste-in-czech-republic.html.

[14] The European Union aims to halve food waste by 2030. [online]. [cit. 2020-03-05]. Retrieved from https://foodtank.com/news/2018/06/european-unione-food-waste-reductiontarget/?gclid=CjwKCAiA44LzBRB-EiwA-jJipD0n3xjcpRIxienCJRrE7cCOSMH1U6FueHCvIinZoov3oFr_41h1xoCDc4QAvD_BwE.

[15] UN Food and Agricultural Organisation. (2020). "Global Food Loss and Food Waste". [online]. [cit. 202001-22]. Retrieved from 


\section{SESSION 2}

FOOD MARKETING AND CONSUMER STUDIES

Supported by projects: Slovak Research and Development Agency on the basis of

Contract no. APVV-16-0244 "Qualitative factors affecting the production and consumption of milk and cheese". Corporate social responsibility and innovation activities focused on decreasing food losses with regards of environmental issues VEGA

1/0802/

APVV-17-0564 "The Use of Consumer Neuroscience and Innovative Research Solutions in Aromachology and its Application in Production, Business and Services" (NEUROSMELL)

Erasmus+ KA2 Strategic Partnerships for Higher Education, no. 2018-1-SK01KA203-046324 "Implementation of Consumer Neuroscience and Smart Research Solutions in Aromachology"(NEUROSMARTOLOGY) 


\title{
Aromatization and Air Quality as an Important Aspect of Grocery Shopping Environment
}

\author{
Jakub Berčík ${ }^{\mathbf{1}}$, Johana Paluchová ${ }^{2}$, Jana Gálová ${ }^{3}$, Katarína Neomániová ${ }^{4}$ \\ Slovak University of Agriculture in Nitra \\ Faculty of Economics and Management, Department of Marketing and Trade $1,2,3,4$ \\ Address: Tr. A. Hlinku 2, \\ 94976 Nitra, Slovakia \\ e-mail: bercik.jakubxx@gmail.com¹, johana.paluchova@gmail.com², jana.galova@uniag.sk³, \\ katarina.neomaniova@gmail.com ${ }^{4}$
}

doi: 10.18515/dBEM.ISD.P01.2020.p006

\begin{abstract}
Today, the use of multiple senses is without a doubt an essential part of every successful business which is trying to direct customer choices, create a pleasant environment and boost its sales. One of the options when it comes to creating a pleasant environment is the use of aromatization and also the air quality factors. Nowadays, it is very common to use air conditioning and necessary change of air even in retail, but there are still many shops and stores that do not have or do not use it. The reason is often that the managers do not have the necessary knowledge of the required air quality at the point of sale and the technological options, which cannot take into account the real situation in the store. Thus, it is important to get the feedback about the air quality and scent compounds directly at the point of sale. This article deals with the study of the knowledge of managerial employees, measuring air quality and subjective evaluation of aromas in retail stores.
\end{abstract}

Keywords: aromachology, air quality, emotions, environmental factors, retail

JEL Classification: M31, M39, M81

\section{Introduction}

There are many aspects that have to be taken into account when it comes to creating a good environment inside a grocery store, such as good lighting. Based on the research of Jin et al. (2017) in China, where customers of eight big shopping malls were asked whether lighting plays an important role in their perception of the store, the results showed that daylight and its existence in the malls played a big role in their satisfaction. Another important aspect of the shopping environment is the air quality and its effect on customers. When the air quality is bad and the $\mathrm{CO}_{2}$ levels rise, the air automatically gets worse. Chen et al. (2017) found out that less tourists come to the Sun Moon Lake in Taiwan when the air quality is bad. Shang et al. (2016) studied three air quality factors (customer density, ventilation and the emission characteristic of merchandise). The customer density had a positive impact on the levels of $\mathrm{CO}_{2}$, which were higher during the weekends, compared to the weekdays, so the daily $\mathrm{CO}_{2}$ levels were positively correlated with customer flow rate. Authors also recommend to increase the ventilation in the malls during the rush hours to decrease $\mathrm{CO}_{2}$ concentrations.

US Environmental Protection Agency (EPA) (2019) warns that short term or immediate effects of poor air quality result in irritation of the eyes, nose, throat and overall fatigue, none of which is a good sign for the business itself. According to Soreanu (2016), the well-being, comfort and health of indoor occupants is directly connected to indoor air quality (IAQ). 
There are several ways how a particular business can improve the air inside. One of the solutions can be the use of artificial aromatization. The so called ,aroma marketing“ is an invisible, but a very powerful tool when used correctly, because not only it can improve the overall quality of the air, but it can also play an important role in convincing the customers to buy. Aromatization of the store is also trying to improve the customer's satisfaction with the overall environment and tries to make them stay longer and enjoy the shopping more.

Michon et al. (2004) state that aromatization and ambient scents can have a positive impact on the evaluation of the store mostly in the medium retail density levels, although they also found out that scents can have a positive impact even in low-density levels, mainly in the morning. This is because older people usually shop in these lower-density levels and they are more likely to pay more attention to their environment, including the air. According to Mattila et al. (2001), when the scent and in-store music are congruent in terms of their arousal, the customers rate the shopping environment a lot more positively.

Guillet et al. (2017) say that of all the senses we have, the smell is the one most connected to emotions, and fragrances are most likely to increase the probability of creating an emotional response from customers. But aromatization is not that simple. There are many important factors that have to be considered before, like the right choice of a scent, the intensity and timing. According to Minsky et al. (2018), the business should work with aroma professionals to fully develop a signature scent and test it before its use. An essential thing is also to choose the diffusion points, where exactly the scent will be diffused an its intensity, how much of it should be diffused at what time.

Leenders et al. (2019) found out that the scent intensity greatly affects how much time customers spend in the store, their mood and whether they do (self-reported) unplanned shopping. In their research, they used melon scents of three stages of intensity. The conclusion was that the strongest intensity was the one that worked the best. It had a positive effect on customers, their mood and time spent at the store, which they tended to underestimate, compared to low intensity scent, when they tended to overestimate. Researchers say that the pleasant scent seemed to improve the mood of hurrying customers and relax them, so they became more positive and calmer.

The main goal of this research is to see the knowledge of managerial employees about air quality, the effect of air quality on the overall atmosphere of the shopping environment and measurement of selected air quality factors in chosen parts of retail stores.

\section{Data and Methods}

The paper is based on research that has been done in the following fields:

- The effect of air quality on human perception

- Aromachology

- The shopping environment in retail stores

This research was conducted with the purpose of finding out the air quality, the knowledge of managerial employees and subjective aroma evaluation in selected retail stores. PAPI (paperand-pencil interviewing) and TAPI (tablet-assisted personal interviewing) were used in October and November 2019. The research included three stages:

- Interviews with the managers of retails stores,

- Measuring the air quality $\left(\mathrm{CO}_{2}\right.$, humidity, temperature) in chosen parts of the retail store

- Subjective evaluation of air quality at the point of sale 
Parts of the store in which the air quality was evaluated:

1. The entrance to the store is the place, in which the air is changed most often, but also the temperature between the outside and inside is being balanced.

2. The centre of the store is the place that mirrors the air quality of the whole store the best.

3. The place near the cash registers has the biggest concentration of people, who wait in the queues, so we can estimate higher $\mathrm{CO}_{2}$ levels.

4. The cooling shelves can, despite the ecological measures that were taken, degrade the air near them because of leaks of cool air. There are still many stores that leave these cooling shelves open.

The total number of small grocery stores in Slovakia is more than 3000, this research was conducted on the sample of 110 grocery stores, mainly in Nitra and Trnava region. Later, data from 100 stores were processed in the research (due to faulty data recordings in some cases). The percentage of foreign stores was $33 \%$ and the percentage of Slovak stores was $67 \%$, which we can consider as representative. There were 30 store managers, 50 assistants of store managers, 14 assistants of department managers and 6 owners participating in the research. Except individual interviewing, the respondents also answered 12 questionnaire questions in electronic forms through tablets.

The measurement of basic air quality factors (temperature, humidity, $\mathrm{CO}_{2}$ ) in visited stores was conducted with the help of Extech Instruments C0250 in four parts of the store (entrance, the centre, cash registers and cooling shelves). Simultaneously, the subjective evaluation of the air quality took place by pollsters, the answers were recorded through tablets as well.

For the purpose of primary data analysis, descriptive and inductive statistics were used in the MS Excel software.

Descriptive statistics:

The arithmetic mean $(\dot{x})$ is defined as a division of a sum of $x$ and the range of statistical set $n$ (Sodomová, 2010). For the purpose of calculating the arithmetic mean, we use this relation:

$$
\bar{x}=\frac{1}{n} \sum_{i=1}^{n} x_{i},
$$

where $\bar{x}$ arithmetic mean, ${ }^{x_{i}}$ values of statistical set $(i=1,2, \ldots, n), n$ the sum of values of statistical set.

Inductive statistics:

Chi-square test is an extension of Chi-square test of independence (Rimarčík, 2010). It is based on a contingency table (Table 1) and is used to find out the dependence between non-numerical statistical values (variables). This test confirms if the differences between real and expected values are random (the variables are non-dependent) or they are too big to be random (there is no relation between the variables).

The hypotheses for this test are as follows:

$H_{0}$ : The values are non-dependent

$H_{1}$ : The values are dependent

Table 1: Contingency Table

\begin{tabular}{|l|c|c|c|c|}
\hline & Sign 1 - 1. group & Sign 1 - 2. group & $\ldots$ & Total \\
\hline Symbol 2 - 1. group & Real values & Real values & $\ldots$ & $n_{1}$ \\
\hline
\end{tabular}




\begin{tabular}{|l|c|c|c|c|}
\hline Symbol 2 - 2. group & Real values & Real values & $\ldots$ & $n_{2 .}$ \\
\hline$\ldots$ & $\ldots$ & $\ldots$ & $\ldots$ & $n_{j .}$ \\
\hline Total & $n_{.1}$ & $n_{.2}$ & $n_{. j}$ & $n$ \\
\hline \multicolumn{5}{|c}{$n_{i .}=\sum_{j=1}^{s} n_{i j} n_{. j}=\sum_{i=1}^{r} n_{i j}$} \\
\hline
\end{tabular}

Source: Paralič, 2003

This research is a pilot study in how to define practical and theoretical relations between the change of environmental factors and the shopping behaviour and decision-making.

\section{Results and Discussion}

Balancing the aromatization of a space and the air quality in order to make the customers feel comfortable and stay longer at the point of sale is not an easy task. Today, air conditioning and necessary change of air is common even in retail, however, there are still many stores that do not use this option or they simply do not have it. In the end, the customer is likely to avoid the store.

Figure 1 shows that mostly supermarkets $(48 \%)$ and small grocery stores of up to $400 \mathrm{~m}^{2}$ (42\%) participated in the research, but there were some discount stores, hypermarkets, specialty stores and also cafés selling goods involved. From the total number of visited stores, only $7 \%$ had some aromatization.

Figure 1: Stores Participating in the Research

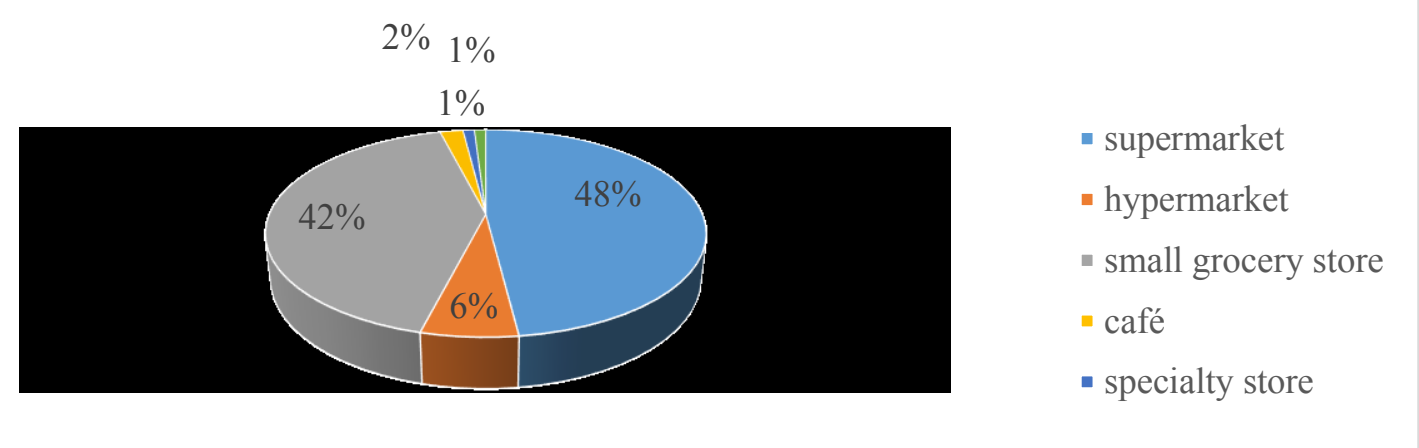

Source: Own processing 2019

An important finding is that $81,67 \%$ of managerial employees think that the use of a specific aroma in the store is an important marketing tool. When evaluating the importance of air quality and its impact in a scale from 1 to 6 ( 1 meaning big effect and 6 for no effect), most employees chose 4 and 5 (Figure 2). This shows a relatively low level of knowledge of this field, since air quality can significantly affect the whole perception. 
Figure 2: The Evaluation of Air Quality by Managerial Employees from the Viewpoint of Affecting Customers

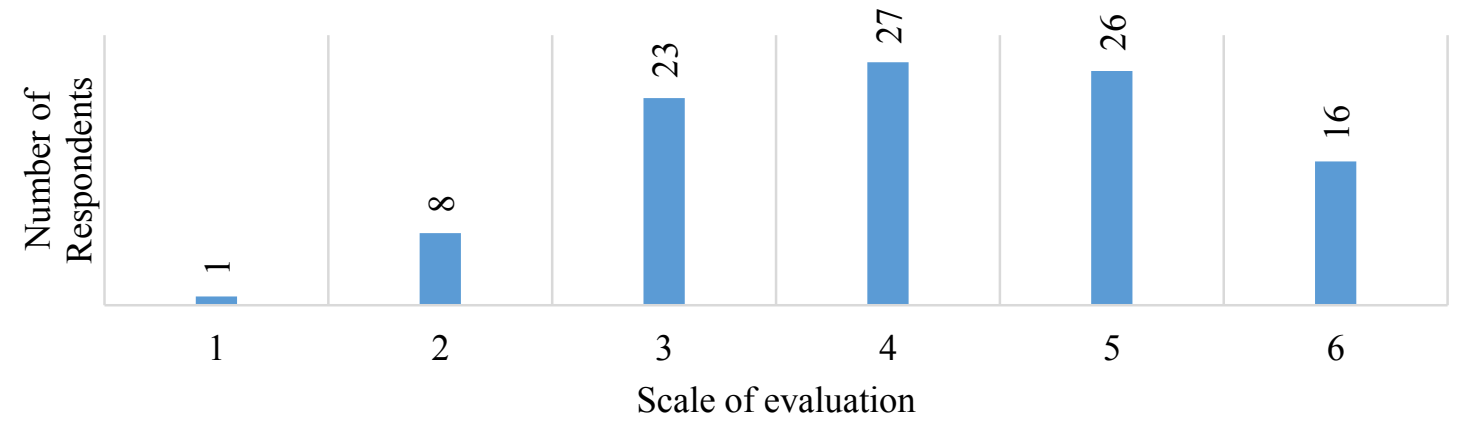

Source: Own processing 2019

We evaluated the assumption of a relation between the store type and the perception of air quality as an important marketing tool using the Chi-square test on the significance level 0.05 and the hypothesis of a relation was confirmed. Cramer's contingent coefficient has a value of 0.36 , which is a relatively strong correlation.

Figure 3: The evaluation of air quality as an important marketing tool divided by type of store

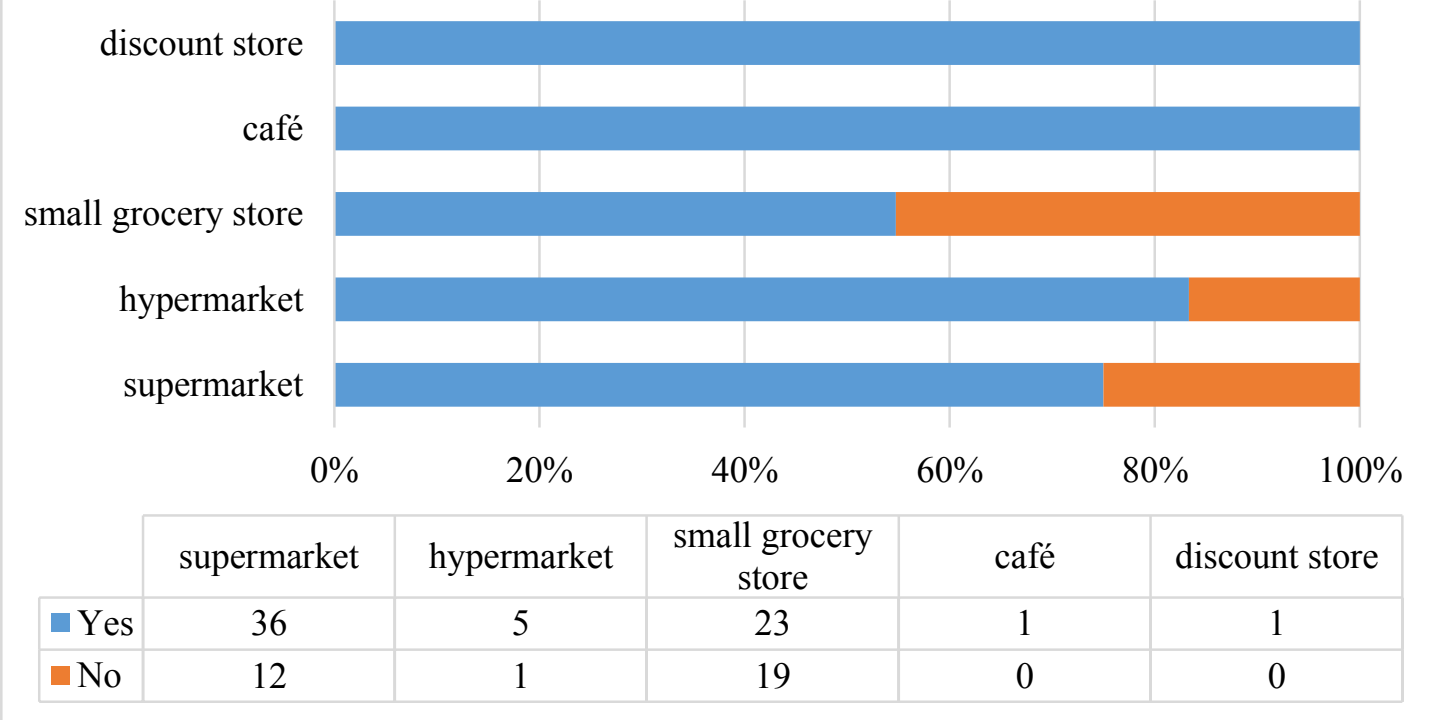

Source: Own processing 2019

We then evaluated and measured the temperature, humidity, and $\mathrm{CO}_{2}$ particles in the air upon entering the store, the cash registers place, in the centre of the store and near the cooling shelves. All of these places were chosen on purpose, so they can be compared between different types of stores. It is clear that not only the right lightning and sound are important factors, but it is also important to maintain the temperature, humidity and also a breathable, clean air. If there is a big $\mathrm{CO}_{2}$ concentration inside, the effect for the customers is that they will get fatigued and sleepy, which has a negative effect on the time they spend inside.

Table 2: Average recorded amount of $\mathrm{CO}_{2}$ concentration in the store types

\begin{tabular}{|l|l|c|c|c|c|}
\hline \multirow{2}{*}{ Store type } & $\begin{array}{l}\mathrm{CO}_{2} \mathrm{ppm} \\
\text { Concentration }\end{array}$ & $\begin{array}{l}\mathrm{CO}_{2}- \\
\text { store entrance }\end{array}$ & $\begin{array}{l}\mathrm{CO}_{2}- \\
\text { cash registers }\end{array}$ & $\begin{array}{l}\mathrm{CO}_{2}- \\
\text { centre of the store }\end{array}$ & $\begin{array}{l}\mathrm{CO}_{2}- \\
\text { cooling shelves }\end{array}$ \\
\hline \multirow{3}{*}{ Hypermarket } & average & 1115 & 1103 & 1168 & 1134 \\
\cline { 2 - 6 } & $\max$ & 1298 & 1289 & 1285 & 1293 \\
\cline { 2 - 6 } & $\min$ & 892 & 880 & 875 & 890 \\
\hline
\end{tabular}




\begin{tabular}{|c|l|c|c|c|c|}
\multirow{4}{*}{ Supermarket } & average & 1199 & 1315 & 1318 & 1293 \\
\cline { 2 - 6 } & $\max$ & 2183 & 2102 & 2152 & 2215 \\
\cline { 2 - 6 } & $\min$ & 579 & 584 & 624 & 542 \\
\hline \multirow{3}{*}{$\begin{array}{c}\text { Small grocery } \\
\text { store }\end{array}$} & average & 1340 & 1315 & 1318 & 1293 \\
\cline { 2 - 6 } & $\max$ & 2753 & 2102 & 2152 & 2215 \\
\cline { 2 - 6 } & $\min$ & 582 & 584 & 613 & 512 \\
\hline \multirow{3}{*}{ Café } & average & 951 & 950 & 945 & 950 \\
\cline { 2 - 6 } & $\max$ & 981 & 990 & 981 & 981 \\
\cline { 2 - 6 } & $\min$ & 892 & 880 & 875 & 890 \\
\hline
\end{tabular}

Source: Own processing 2019

Fresh air is made out of approximately $400 \mathrm{ppm} \mathrm{CO}_{2}$ and in an average room, this number can double in 1 hour. This applies to one human in a calm state. If there are more people in the room and they also do some kind of physical work (shopping), it is necessary to change the air a few times in an hour. Getting the right amount of fresh air increases the costs of heating and $\mathrm{A} / \mathrm{C}$, for which we assume different attitudes for different store types. Table 2 shows all the $\mathrm{CO}_{2}$ measurements, where in almost every type of store, the $\mathrm{CO}_{2}$ level is between 950 to $1340 \mathrm{ppm}$, which suggests worse air, because for fresh air, we need not to exceed the value of $700 \mathrm{ppm}$. From the viewpoint of the store types, the highest values were recorded in the small grocery stores up to $400 \mathrm{~m}^{2}$, and in one of them, the value was $2753 \mathrm{ppm}$, which is against hygiene standards. On average, the best amount of ppm (around $900 \mathrm{ppm}$ ) were recorded in cafes. Surprising is the limit amount in bigger types of stores, like hypermarkets or supermarkets.

Similarly, important factor of the air quality is its temperature. The customers can be discouraged by a too low or too hot temperature of an environment, which, in combination with high $\mathrm{CO}_{2}$ concentration creates the worst scenario possible. Table 3 shows the average temperatures recorded in different store types and in their different parts. The highest average temperature was recorded in the cafés $\left(22,3{ }^{\circ} \mathrm{C}\right)$. On the other hand, the lowest temperature $\left(18,3^{\circ} \mathrm{C}\right)$ was in the supermarkets. The temperature is different in different types of stores, the $4^{\circ} \mathrm{C}$ difference between the highest and lowest temperature is a proof. The optimal temperature is somewhere between $18-24^{\circ} \mathrm{C}$, and there needs to be a compromise between a good temperature for the customers, so they can feel comfortable and having a good temperature for all the merchandise in the store. In this case, in all of the stores that can be seen the most often in Slovakia, there was above the limit temperature $26^{\circ} \mathrm{C}$, which is not a good sign for a pleasant environment. In some stores, there were also under the limit temperatures $\left(15^{\circ} \mathrm{C}\right)$, but this was probably caused by old cooling shelves with too much of cool air leaking out.

Table 3: Average air temperature in the store types

\begin{tabular}{|c|c|c|c|c|c|}
\hline Store type & Temperature & $\begin{array}{l}\text { Temperature - } \\
\text { store entrance }\end{array}$ & $\begin{array}{l}\text { Temperature - } \\
\text { cash registers }\end{array}$ & $\begin{array}{l}\text { Temperature - } \\
\text { centre of the store }\end{array}$ & $\begin{array}{l}\text { Temperature-- } \\
\text { cooling shelves }\end{array}$ \\
\hline \multirow{3}{*}{ Hypermarket } & average & 20 & 21 & 20 & 16 \\
\hline & $\max$ & 26 & 26 & 23 & 24 \\
\hline & $\min$ & 19 & 20 & 18 & 17 \\
\hline \multirow{3}{*}{ Supermarket } & average & 19 & 20 & 18 & 16 \\
\hline & $\max$ & 26 & 26 & 24 & 22 \\
\hline & $\min$ & 10 & 17 & 17 & 16 \\
\hline \multirow{3}{*}{$\begin{array}{l}\text { Small } \\
\text { grocery store }\end{array}$} & average & 19 & 20 & 19 & 16 \\
\hline & $\max$ & 26 & 26 & 25 & 24 \\
\hline & $\min$ & 10 & 17 & 16 & 15 \\
\hline \multirow{2}{*}{ Café } & average & 22 & 22 & 23 & 22 \\
\hline & $\max$ & 24 & 24 & 24 & 24 \\
\hline
\end{tabular}


Source: Own processing 2019

Because retail stores use $\mathrm{A} / \mathrm{C}$ to maintain the optimal temperature and $\mathrm{CO}_{2}$ concentration, there is also another important factor, and that is humidity. The air at the point of sale cannot be too dry nor too wet. The optimal humidity is around $30-70 \%$. Based on Table 4, we can say that the highest humidity (almost $70 \%$ ) was recorded in the smallest grocery stores of up to $400 \mathrm{~m} 2$. The lowest humidity (around $20 \%$ ) was recorded in the case of small grocery stores but supermarkets as well. Except these under the limit values mainly in the centre of the store and near the cooling shelves, all the stores had, at the time of measurement, relatively optimal air humidity.

Table 4: Average humidity in the store types

\begin{tabular}{|c|c|c|c|c|c|}
\hline Store type & Humidity & $\begin{array}{l}\text { Humidity - } \\
\text { store entrance }\end{array}$ & $\begin{array}{l}\text { Humidity - } \\
\text { cash registers }\end{array}$ & $\begin{array}{l}\text { Humidity - } \\
\text { centre of the store }\end{array}$ & $\begin{array}{l}\text { Humidity - } \\
\text { cooling shelves }\end{array}$ \\
\hline \multirow{3}{*}{ Hypermarket } & average & 34 & 41 & 37 & 38 \\
\hline & $\max$ & 43 & 43 & 44 & 46 \\
\hline & $\min$ & 37 & 38 & 20 & 22 \\
\hline \multirow{3}{*}{ Supermarket } & average & 45 & 43 & 38 & 39 \\
\hline & $\max$ & 61 & 63 & 54 & 57 \\
\hline & $\min$ & 25 & 29 & 31 & 31 \\
\hline \multirow{3}{*}{$\begin{array}{l}\text { Small grocery } \\
\text { store }\end{array}$} & average & 46 & 46 & 46 & 45 \\
\hline & $\max$ & 63 & 62 & 66 & 66 \\
\hline & $\min$ & 33 & 32 & 20 & 20 \\
\hline \multirow{3}{*}{ Café } & average & 41 & 41 & 41 & 36 \\
\hline & $\max$ & 44 & 45 & 44 & 43 \\
\hline & $\min$ & 38 & 38 & 39 & 24 \\
\hline
\end{tabular}

Source: Own processing 2019

Simultaneously, as the measurement of air quality (temperature, humidity and $\mathrm{CO}_{2} \mathrm{ppm}$ ) took place, pollers also subjectively evaluated their impressions of the air quality.

Figure 4: The evaluation of air quality by people responsible for the polls

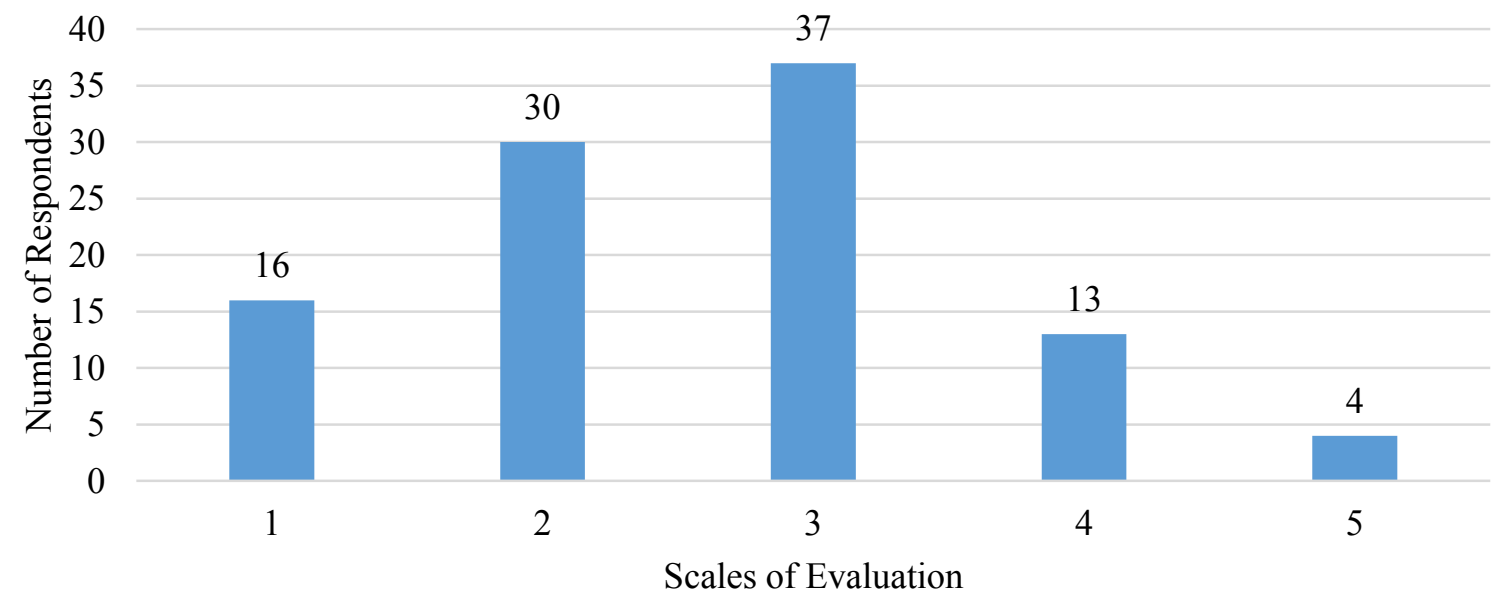

Source: Own processing 2019

When evaluating the subjective impression of the air quality and its effect on the customers on the scale from 1 to 6 ( 1 meaning the most positive impression and 6 for the worst), most people 
chose either 2 or 3, as seen in Figure 4. This means relatively good environment based on the subjective viewpoint.

Except the air quality, there are also other factors that create a pleasant environment and affect customers, like some compounds, which are diffused into the air automatically, for example in the case of fresh merchandise, but also from artificial aroma. The problems arise when these aromas start to mix one with another and the aromatization is not set right with the properties of the air. The most important are the intensity of aroma, so the employees are not negatively affected and also how to choose the right kind of aroma based on the merchandise sold.

\subsection{Discussion}

The current legislation for the protection of public health does not specifically regulate the requirements for the air temperature in retail stores, parts of those stores or shopping centres. The requirements for the air temperature and air humidity are regulated in the legislation for the protection of public health of the Ministry of Health of the SR (MZ SR) n. 259/2007 Z. Z. for the details and requirements for indoor environment of buildings and minimal requirements for flats of lower standard and accommodation facilities. In the warmer parts of the year, mainly in the summer, the optimal temperature for the activity such as shopping is $22-25^{\circ} \mathrm{C}$. Acceptable temperature is between $19-27^{\circ} \mathrm{C}$. In the colder parts of the year, the optimal temperature is 18 $21^{\circ} \mathrm{C}$, acceptable temperature is $15-24^{\circ} \mathrm{C}$. According to the legislation, the humidity inside a building should be between 30 to $70 \%$. These standards are set by EU and are individually adapted on the local scale by the countries. Similar studies with the focus on dust particles was already conducted in 6 other reports (Grimsrud et al., 1999; et al., 2001; Rea et al., 2001; Maskey et al., 2011; Chan et al., 2012; Brown et al., 2012; Dong et al., 2013). Five of these studies state PM10, eight studies state PM2,5, one of them states PM1 and another one study states the weight concentration of polycyclic aroma hydrocarbon (PPAH) caught. Even though in this study, we focused only on the basic parameters of air quality, which are affected by the $\mathrm{A} / \mathrm{C}$ and ventilation, in some cases we found above-the-limit numbers, which do not meet the legislation standards. Similar results were found in the research of dust particles (Zaatari M. et al., 2014), in which half of the stores either met or exceeded ASHRAE Standard 62.1-2010 (ASHRAE, 2010a) or California law, head 24-2010. Other studies (Bridges, et al. 2013) focused on the air quality and ventilation of three small retail stores, which were under the management of the same company, and which are in three different climate areas in the United States of America. The study was made so it can use the approach IAQ (section 6.3) norm ASHRAE 62.1-2007.

Human perception of aroma can trigger strong emotional reaction, because the aroma stimuli are sent right into the limbic system of the brain. These stimuli affect the behaviour of customers differently, because every human have their own subjective view of the scents. This is the reason why it is important to teach employees to check the air quality and get a feedback about the effect of air quality right at the point of sale.

\section{Conclusion}

This research shows that the managerial employees do not have enough knowledge about what affects the air quality and in what way it can impact the shopping environment, and in the end, how it can affect the employees as well, because they are in this type of environment for longer periods of time. The managerial employees of bigger stores are those, who should know about 
the air quality and its effects the most, because the bigger stores have all the necessary tools to affect the air quality, from air conditioning to ventilation. If set up correctly, the air quality can be influenced in the right way. The problem is that most of the time, their setup is general and does not take into account the specific situation inside the store. The factors that were subject of the measurements in this research can negatively affect the customers and employees mainly at the psychological level. The main focus of this research was not to study the microbiological contamination, which was studied by others that we mentioned in the discussion.

Employees of smaller store types of up to $400 \mathrm{~m}^{2}$ had lower level of knowledge about the air quality. It is quite a surprise, because $72 \%$ of managerial employees said that they have the ability to affect the air quality at the point of sale. Today, it is quite common that the $\mathrm{A} / \mathrm{C}$ cannot negatively affect the microbial quality of the air. Every ventilation needs to be kept in the best condition possible. In order for the $\mathrm{A} / \mathrm{C}$ to function properly, it needs to be maintained often, and its filters need to be checked and changed often. Despite the information about the measured temperature, humidity and $\mathrm{CO}_{2}$, it is quite clear that there are still stores, in which there are still above and below the limit values, which not only negatively affect the customers and their whole perception, but also are against the legislative standards.

The main source for the comparison of each factor was the aforementioned legislation for the protection of public health of the Ministry of Health of the SR (MZ SR) n. 259/2007 Z. Z. According to this legislation, the humidity allowed inside buildings is in between 30 to $70 \%$. In this case, we focused on testing the typical grocery stores of many formats, no matter whether with or without $\mathrm{A} / \mathrm{C}$ or ventilation, because we focused on the factors (humidity, temperature and $\mathrm{CO}_{2}$ ), which affect the comfort and psychological health of people. In this study, we did not focus on the biological processes that are present in some of the parts of the shops, for example fruit or vegetable corner.

We need to remember that the environment of the store is one of the most important aspects of sale, because more than $70 \%$ of customer choices are made right at the point of sale. The final decision of the customer is not based only on the price and quality, but also on the visual communication of the store and its air quality. This is the reason why it is important to educate the managerial employees on how to check the air quality in the store and how to get the feedback needed to better understand the customers and their needs. The results of the pilot study say that many of the managerial employees do not have enough knowledge about how to secure the optimal environment from the viewpoint of air quality. The finding that worse air quality (higher $\mathrm{CO}_{2}$, lower temperature and dry air) can affect and increase the frustration, creates space for more research. We plan to carry out similar research with the added value of real emotional feedback from respondents using neuromarketing tools. In the end, we can say that the air quality is an important aspect, which it is important to focus our attention on, because it can seriously affect the comfort of the shopping, loyalty of customers and in the end, the profits.

\section{Acknowledgements}

The paper and planned activities on the topic of air quality and aromachology are supported by the research project $A P V V-17-0564$ "The Use of Consumer Neuroscience and Innovative Research Solutions in Aromachology and Its Application in Production, Business and Services", and VEGA 1/0580/18 "The Use of Consumer Neuroscience in the Implementation of Aromachology in Selected Sectors of the Economy" solved at the Department of Marketing and Trade at the FEM SPU in Nitra. 


\section{References}

[1] Bridges, B., Carlson, N., Grimsrud, D., Springman, T., \& Williams, S. (2013). Application of the Standard 62.1-2007 Indoor Air Quality Procedure to Retail Stores. ASHRAE Transactions. 2013, 119(2), 265-273.

[2] Brown, K.W., J.A. Sarnat, \& P. Koutrakis. (2012). Concentrations ofPM2.5mass and components in residential and non-residential in-door microenvironments: The sources and composition of particu-late exposures study. Journal of Exposure Science and Environmental Epidemiology, 22, 161-172. doi: $10.1038 /$ jes.2011.41

[3] Chan, W., M. Sidheswaran, D. Sullivan, S. Cohn, \& W. Fisk. (2012). Contaminant Levels and Source Strengths in US Retail Stores-A Pilot Study. No. LBNL 5547E. Berkeley, California: Lawrence Berkeley National Laboratory. doi: 10.1111/ina.12152

[4] Chen, C-M., Lin, Y-L., \& Hsu, C-H. (2017). Does air pollution drive away tourists? A case study of the Sun Moon Lake National Scenic Area, Taiwan. Transportation Research Part D: Transport and Environment, 53, 398-402. doi: https://doi.org/10.1016/j.trd.2017.04.028

[5] Dong, C., L. Yang, C. Yan, Q. Yuan, Y. Yu, \& W. Wang. (2013). Particle size distributions, PM2.5concentrations and water-soluble in-organic ions in different public indoor environments: a case study in Jinan, China. Frontiers of Environmental Science and Engineering, 7(1), 55-65. doi: https://doi.org/10.1007/s11783-012-0411-1

[6] Grimsrud, D.T., B.B. Bridges, N.G. Carlson, and D.E. Hadlich. (1999). Ventilation requirements in a retail store. Proceedings of the 20thAIVC Conference Ventilation and indoor air quality in buildings, the8th International Conference on Indoor Air Quality and Climate, Edinburgh, Scotland, August 9-13

[7] Guillet, B.d., Kozak, M., \& Kucukusta, D. (2015). It's in the air: Aroma marketing and affective response in the hotel world. International Journal of Hospitality \& Tourism Administration, 20(1), 1-14. doi: https://doi.org/10.1080/15256480.2017.1359727

[8] Jin, H., Li, X., Kang, J., \& Kong, Z. (2017). An evaluation of the lighting environment in the public space of shopping centers. Building and Environment, 115, 228-235. doi: https://doi.org/10.1016/j.buildenv.2017.01.008

[9] Leenders, M.A.A.M., Smidts, A., \& Haji, A.E. (2016). Ambient scent as a mood inducer in supermarkets: The role of scent intensity and time-pressure of shoppers. Journal of Retailing and Consumer Services, 48, 270-280. doi: https://doi.org/10.1016/j.jretconser.2016.05.007

[10] Li, W.M., S.C. Lee, \& L.Y. Chan. (2001). Indoor air quality at nine shopping malls in Hong Kong. Science of the Total Environment, 273, 27-40. doi: 10.1016/s0048-9697(00)00833-0

[11] Maskey, S., T.H. Kang, H.J. Jung, \& C.U. Ro. (2011). Single-particle characterization of indoor aerosol particles collected at an under-ground shopping area in Seoul, Korea. Indoor air, 21(1), 12-24. doi: 10.1111/j.1600-0668.2010.00677.x

[12] Mattila, A.S., Wirtz, J. (2001). Congruency of scent and music as a driver of in-store evaluations and behavior. Journal of Retailing, 77(2), 273-289. doi: https://doi.org/10.1016/S0022-4359(01)00042-2

[13] Michon, R., Chebat, J. CH., \& Turley, L.W. (2004). Mall atmospherics: the interaction effects of the mall environment on shopping behavior. Journal of Business Research, 58, 576-583. doi: https://doi.org/10.1016/j.jbusres.2003.07.004

[14] Minsky, L., Fahey, C., \& Fabrigas, C. (2018, April 11). Inside the Invisible but Influential World of Scent Branding. Harvard Business Review. Retrieved from https://hbr.org

[15] Rea, A.W., M.J. Zufall, R.W. Williams, L. Sheldon, \& C. Howard-Reed. (2001). The influence of human activity patterns on personalpm exposure: A comparative analysis of filter-based and continuous particle measurements. Journal of the Air and Waste Management Association, 51(9), 1271-1279. doi: 10.1080/10473289.2001.10464351

[16] Shang, Y., Li, B., Baldwin, A.N., Ding, Y., Yu, W., \& Cheng, L. (2016). Investigation of indoor air quality in shopping malls during summer in Wester China using subjective survey and field measurement. Building and Environment, 108, 1-11. doi: https://doi.org/10.1016/j.buildenv.2016.08.012 
[17] Soreanu, G. 2016. 12 - Biotechnologies for improving indoor air quality. Torgal, F.P., Rasmussen, E., Granqvist, C-G., Ivanov, V., Kaklauskas, A., Makonin, S. Start-Up Creation. 301-328. Woodhead Publishing

[18] U.S. Environmental protection agency (EPA). (2019). Introduction to Indoor Air Quality. Washington, DC: Author. Retrieved from: https://www.epa.gov/indoor-air-quality-iaq/introduction-indoor-air-quality\#sources

[19] Zaatari, M., Nirlo, E., Jareemit, D., Crain, N., Srebric, J., \& Siegel, J. (2014). Ventilation and indoor air quality in retail stores: A critical review (RP-1596). HVAC\&R Research, 20(2), 276-294. doi:10.1080/10789669.2013.869126 


\title{
Comparison of Selected Indicators of Production and Sales of Vegetables in the Conditions of the Slovak Republic and the Czech Republic
}

\author{
Rebecca Brodňanová ${ }^{1}$, Jozef Šumichrast ${ }^{2}$, Tatiana Evteeva ${ }^{3}$ \\ Slovak university of agriculture in Nitra \\ Faculty of economy and management, Department of marketing and trade $\mathrm{e}^{1,2,3}$ \\ Address: Tr. A. Hlinku 2, \\ 94976 Nitra, Slovakia \\ e-mail: rebecca.brodnanova@gmail.com¹, jozef.sumichrast@gmail.com², taniaevt1992@gmail.com³
}

doi: 10.18515/dBEM.ISD.P01.2020.p007

\begin{abstract}
Vegetables form the basis of rational nutrition of man. Recently, consumers have become increasingly interested in their origin and quality. They prefer fruits and vegetables from domestic production to foreign ones. The aim of the paper was to evaluate the situation in the vegetable sector and its prospects based on the analysis in Czech Republic and Slovak Republic. The paper is divided into theoretical and practical part. The content of the theoretical part is the definition of basic concepts related to the topic of the thesis. The practical part is devoted to the analysis of the situation in the vegetable sector to compare chosen country. The conclusion is a summary of the paper and an evaluation of the findings of the practical part.
\end{abstract}

Keywords: vegetables, production, import

JEL Classification: G13, E23, Q110

\section{Introduction}

Vegetables has an irreplaceable role in the nutrition of people of all ages. A wide range of vegetable products allows consumers to meet their requirements. Agricultural production and especially special vegetable production in Slovakia after accession to the EU overcomes the imbalances in the Slovak agrarian market. The accession to the EU, which was proclaimed in the negotiation approaches, has had a significant impact on the restructuring of agricultural production plans. After joining the EU, the Slovak market became part of the EU agrarian market, which has significant differences in the subsidy policy towards the conditions of Slovak farmers. This has had a serious impact on our farmers, and the aforementioned land-based subsidies policy put special crops at a disadvantage and favour densely sown oilseeds and cereals.

\subsection{Agriculture in EU}

EU Council President Roderick Galdes (2017) for Agriculture and Fisheries (AGRIFISH) said: "The EU agriculture sector is facing major challenges. As politicians, we have the opportunity to set a vision for the future. So we should continually improve our policies so that European agriculture generates growth, jobs and prosperity." (Galdes, 2017)

Bujňáková draws attention to rapidly changing conditions and requirements on the European market. It therefore stresses that agriculture must be flexible and ready for possible changes. The European market has rapidly changing conditions, so it is advantageous for farmers to be prepared. (Bujňáková 2009) 
In 2017, arable land with an area of 6,240 hectares achieved the production of vegetables in the volume of 96,181 $\mathrm{t}$ with an average harvest of $15.30 \mathrm{t} / \mathrm{ha}$. Areas of supported vegetables through Integrated Production are: in 2016 it was 4026,03 ha, in 2017 we registered 5244,36 ha. The pumpkin occupied $33 \%$ of the supported areas over the last three years. Thus, the pumpkin was supported over the three years by $2001542.40 €$. (Šumichrast 2019)

Rovný notes that the agri-food sector will decline. This is the cause of inefficient but also poor quality production of domestic producers. The different economic focus causes them a disadvantage compared to their competitors. He also says that the market and trade are more capital-intensive than the nature of primary production and processors of the food industry. (Rovný P. 2007)

Šimkovič states on euractiv.sk that European agriculture ministers discussed the main topic, namely the future of the CAP after 2020. All ministers were in favor of simplifying the correct distribution of funds under the two pillars, as there is a lack of agreement. (Šimkovič 2017)

Through staged changes, the EU's Common Agricultural Policy (CAP) has been adapted to the new requirements that are essential for European agriculture. The necessary requirements include:

- Rational use of natural resources

- Climate change

- Increased competition in global markets

- Preservation of rural areas across the EU. (Consilium.europa.sk 2020)

A little over half $(55.5 \%)$ of apple production was concentrated in Poland, Italy and France. Similarly, a little over half $(52.7 \%)$ of onion production was concentrated in Spain, the Netherlands and Poland. Of the main fruit and vegetable, the production of carrots was more evenly distributed, with seven Member States accounting for $9 \%$ or more of the EU-27's harvested production in 2006. (Martinez - Palou and Rohner - Thielen 2008)

\subsection{Marketing in agriculture}

Baco (2010) says that even when developing marketing concepts, it is important to take into account the important peculiarities of the agrarian market in relation to land management. The most noticeable peculiarities of breeding and cultivation processes include the biological nature of business, seasonality, coherence and urgency of production, the impact of natural factors on production processes, the shelf life of products and others.

Distribution channels that they are created by the quantity of diverse marketing organizations and their relationships to promote product distribution. This distribution is directed from manufacturers to consumers or businesses. (Nagyová 2018)

As Horská et al. (2011) notes that food quality and safety belong to the most important factors of building the image of the brand, product, or country of origin at the local, global or regional markets. The research results point at the food hygiene as the most important qualitative factor for the respondents. On the other hand, the packing as a factor is considered as of either a less importance or an irrelevant one in terms of the product quality perception. (Horská E. et al., 2011) 


\subsection{Subsidies in agriculture}

Government subsidies are important policy instruments to stimulate enterprise innovation. Given the spill over property of technological innovation, enterprise innovation will inevitably experience market failure and fund shortage, thereby making direct financial subsidies of the governments for technological innovation become effective means of compensating innovation externality. In strategic emerging industries (technological innovation intensive industries), in particular, government subsidies make up the funding shortfall arising from high investment in innovation, reduce technological innovation risks and improve innovation output of enterprises. Therefore, government subsidies are necessary and effective in promoting enterprise innovation. It has been widely recognized by scholars that government subsidies have a positive impact on enterprise innovation input and output. Czarnitzke and Licht research the influence of German government $R \& D$ subsidies on $R \& D$ investment of enterprises and argue that government subsidies improve the overall innovation output of German enterprises. (Claessens S, Feijen E, Laeven L.2008)

State that from an agricultural point of view direct sales contributes to better realization of production, provides immediate direct money flow to the company and deepens the useful relationship between the consumer and the producer. Motives that encourage consumers to buy food in direct sales are their freshness and quality as well as reasonably lower price. (Kretter and Paluchová 2013)

Before the transformation process in the agricultural sector Slovakia was one of those areas that were financed from state subsidies. After joining the EU, the transition to a new model of economic relations was government incentives minimized. This resulted in a significant decrease in total agrarian production and mainly in vegetable production. (Némethová and Hudáková, 2019)

\subsubsection{Situation in Slovak republic}

Kročková on the enviroportal.sk website pointed to a downward trend in the area of agricultural land has persisted since 1990. Between 2000 and 2015, it decreased the area of agricultural land by $2.1 \%$ which is $(-51051 \mathrm{ha})$. From the environmental aspect it is a negative phenomenon that between 2000 and 2015 the area of all types of agricultural land were reduced. The largest part of the area was arable land $59.1 \%$ and permanent grassland $35.9 \%$. On the other hand, the lowest proportion was in hop gardens $0.02 \%$, fruit orchards $0.7 \%$, vineyards $1.1 \%$ and gardens $3.2 \%$. Thus, the total area of agricultural land in 2015 was 2389616 ha in the whole of Slovakia. (Kročková 2017)

\subsubsection{Situation in Czech Republic}

In terms of growing, 2017 was quite favourable for the production of vegetables, which is particularly true for those growers who had the opportunity to irrigate. Due to favourable weather, it increased year-on-year total harvest by $4 \%$ and reached 311.3 thous. t. The increase was observed in most of the monitored vegetable species, except tomatoes, parsley, onions, cabbage and cucumbers. Total vegetable harvest area in 2017 they decreased by 203 ha compared to the previous year to 14.2 thous. ha. Significant reduction of areas occurred in cabbage, cucumber gherkins, tomatoes and parsley, on the contrary increased mainly in peas marrow, onion, garlic and salads. (Buchtová, 2018) 


\section{Data and Methods}

The main aim of the article is to focus on specific types of vegetables that we evaluate in terms of average consumption of the population, production in Slovakia and the Czech Republic and imports of our commodities. The aim of the study is to research the marketing of production and sales of evaluated commodities. In the paper we analyse the development of the current state of production of selected commodities in Slovakia and the Czech Republic. Furthermore, we evaluate the consumption of assessed commodities per capita and calculate the difference between production and consumption in Slovakia and the Czech Republic. We evaluate in $€$ per capita how much we consume from domestic consumption and imported consumption. In the article, we further discuss what area our farmers should deploy selected commodities to be self-sufficient in the production of traditional specialty commodities.

In order to achieve the stated objectives, the documents for the elaboration of the article in question were vuepp.sk, statistics.sk. The information obtained from secondary sources helped us to work out the theoretical part. Using the literature of Slovak and foreign authors dealing with the mentioned areas. In addition to book publications, we used information from Internet publications, proceedings, scientific journals or laws. We were assisted in the compilation of information by various working methods, namely analysis, synthesis, data collection, induction and deduction. In order to meet the set goals and assess the current state of the evaluated issue in the conditions of the Slovak Republic and the Czech Republic, analytical approaches to the examination of physical (production) and value (consumption import exports) objectives were used. To meet the supportive goals of obtaining information and evidence on consumer behaviour in the demand for evaluated vegetables, we compared the differences between production and consumption per capita in natural and currency form.

\section{Time series}

A time series consists of values that are collected, recorded, or observed sequentially over time. We will use this method to examine and evaluate the current situation on the Slovak market for vegetables. Obtaining up-to-date information from available situation and prospective reports of the Research Institute of Agriculture and Food Economics. We summarized their production, yield per hectare, consumption, commodity prices, necessary imports resulting from consumption in 2004 and 2017.

\section{Search}

We first compiled a bibliographic review of documents important authors, statistics, focusing on the state of the art by grouping information. It helped us to understand the subject matter and find different perspectives. Using this method, we were able to evaluate individual developments in selected commodities and in the comparison of the Czech Republic and the Slovak Republic.

\section{Comparison}

With the help of several authors who deal with agrarian marketing, sales, food distribution or retail, we were able to compare different perspectives on the mentioned areas of the problem. We compared two selected countries - the Czech Republic and the Slovak Republic. We compared their production, yield per hectare, consumption, commodity prices, necessary imports resulting from consumption. 


\section{Analysis}

Process that helped us to gather several terms in the theoretical part, namely in definitions, goals or divisions. We analysed two selected countries - the Czech Republic and the Slovak Republic. We analysed their production, yield per hectare, consumption, commodity prices, necessary imports resulting from consumption.

\section{Synthesis}

Method by which we could combine information into a whole. Using it, we were able to divide the thesis into chapters and subchapters so that they build on each other. Through the synthesis, we were able to reconcile individual production, yields per hectare, per capita consumption or women of selected commodities.

\section{Linear prediction}

The trend as a deterministic function of time linear trend the simplest form of dependence directly proportional relationship between the trend value of the Czech Republic and the value of the time variable.

$\mathrm{y}_{\mathrm{t}}=\mathrm{b}_{0}+\mathrm{b}_{1} \mathrm{t}$

$\mathrm{t}$ - is a formal time variable that gives the order of the value of the indicator being examined

$y$ - let us denote the values of the surveyed indicator

$\mathrm{b}$ - allows the shift function to better accommodate data

\section{Results and Discussion}

We analysed production, yield per hectare, consumption of individual types of vegetables in countries, total need of these types, resulting import, prices, and subsequently the need of hectares for individual commodities. We chose carrots, parsley and kohlrabi as commodities. In the article we analyse the production in individual countries for individual commodities from 2004 to 2017 and its linear prediction for the next two years. We also analysed the resulting import for individual countries and individual commodities also from 2004 to 2017, and its linear prediction for the next two years.

Table 1: Production of total vegetable in tons

\begin{tabular}{|l|r|r|r|r|r|r|r|r|r|r|r|r|r|r|}
\hline $\begin{array}{l}\text { production } \\
(t)\end{array}$ & 2004 & 2005 & 2006 & 2007 & 2008 & 2009 & 2010 & 2011 & 2012 & 2013 & 2014 & 2015 & 2016 & 2017 \\
\hline $\begin{array}{l}\text { total } \\
\text { vegetable } \\
\text { in CR }\end{array}$ & 322333 & 273357 & 291552 & 282027 & 274324 & 253840 & 218623 & 277602 & 232873 & 239693 & 294240 & 247155 & 298624 & 311280 \\
\hline $\begin{array}{l}\text { total } \\
\text { vegetable } \\
\text { in SR }\end{array}$ & 203449 & 164846 & 139851 & 99393 & 117786 & 97343 & 77721 & 143286 & 7672,64 & 81656 & 108494 & 92869 & 114858 & 110413 \\
\hline
\end{tabular}

Source: vuepp.sk and eagri.cz and own research

Whole production of vegetable in both country is in Table 1. As we can see there are big differences between Czech Republic and Slovak Republic. In first year of reference Czech Republic had 322333 tons of total vegetable production. Slovak Republic had 203449 tons of total vegetable production which is 118884 tons less of total vegetable production than Czech Republic. In last year of reference Czech Republic ha 311280 tons of total vegetable 
production. Slovak republic ha 110413 tons of total vegetable production which is 200867 tons less production of total vegetable production than Czech Republic.

When we compare this two years 2004 and 2017 we can see huge different especially in Slovak Republic. We can see a decrease of up to 93036 tons. On the other hand, in Czech Republic is different too but not as striking as in Slovak Republic. In Czech Republic is decrease just 11053 tons.

\section{Figure 1: Production of parsley in $\mathrm{kg}$}

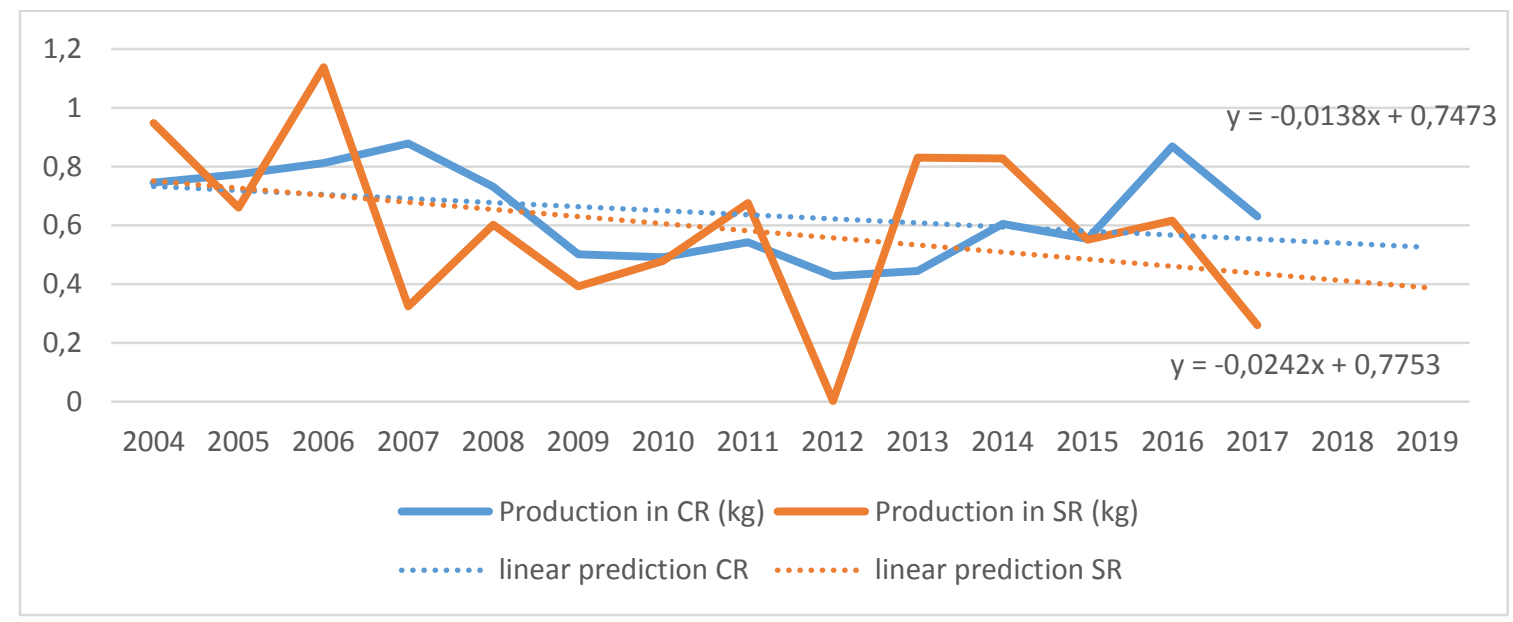

Source: vuepp.sk and eagri.cz and own research

Figure 1 shows a comparison of parsley production in the Czech Republic and the Slovak Republic. In the Czech Republic, production reached its maximum in 2007, which represented $97 \%$ coverage of consumption per capita, resulting in the lowest import required in the period under review. In 2012, the Czech Republic reached approximately $61 \%$ coverage of consumption per capita in this country which was the lowest in the years

The Slovak Republic reached its maximum in 2006, which represented $47 \%$ coverage of consumption per capita. On the contrary, the minimum reached in 2012, which represented only about $0.11 \%$ market coverage, which in turn implies the highest import, up to $99 \%$.

\section{Figure 2: Import of parsley in kg}

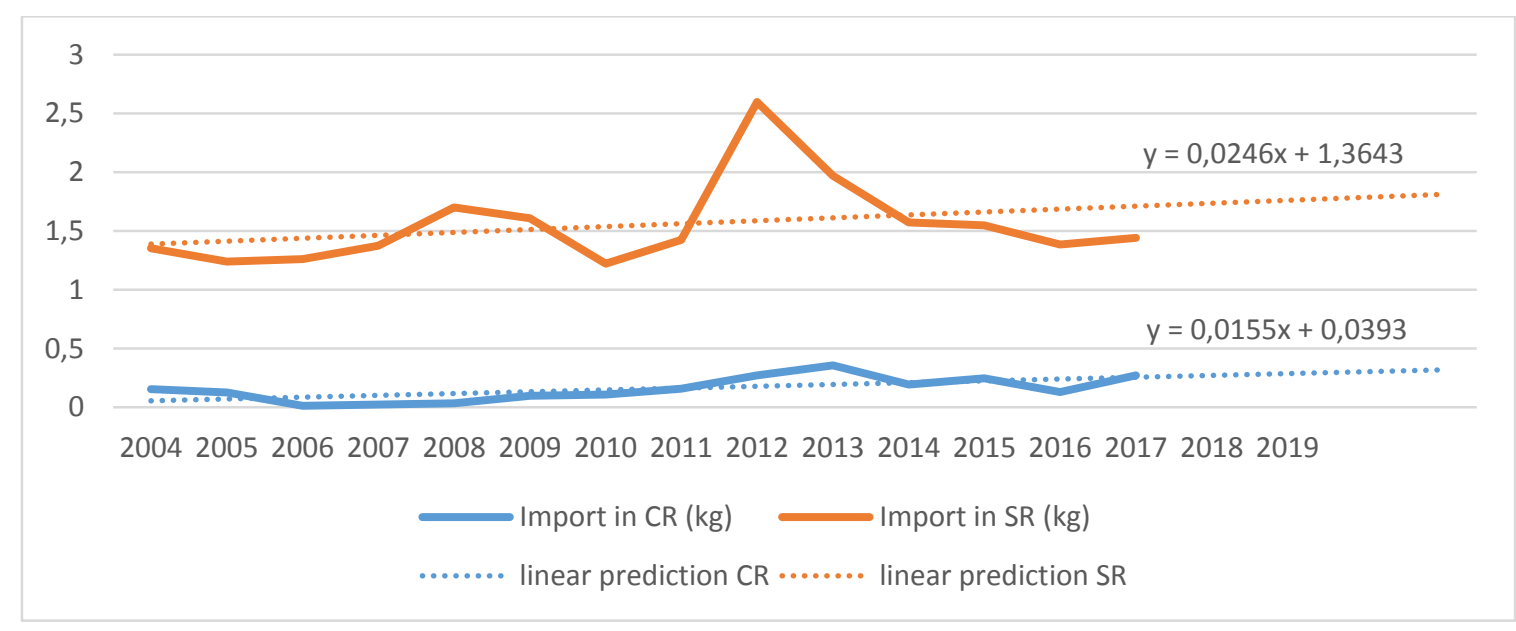

Source: vuepp.sk and eagri.cz and own research 
Linear forecasting suggests that imports will increase in both countries under review. However, its value will be substantially higher in the Slovak Republic than in the Czech Republic.

\section{Figure 3: Production of kohlrabi in kg}

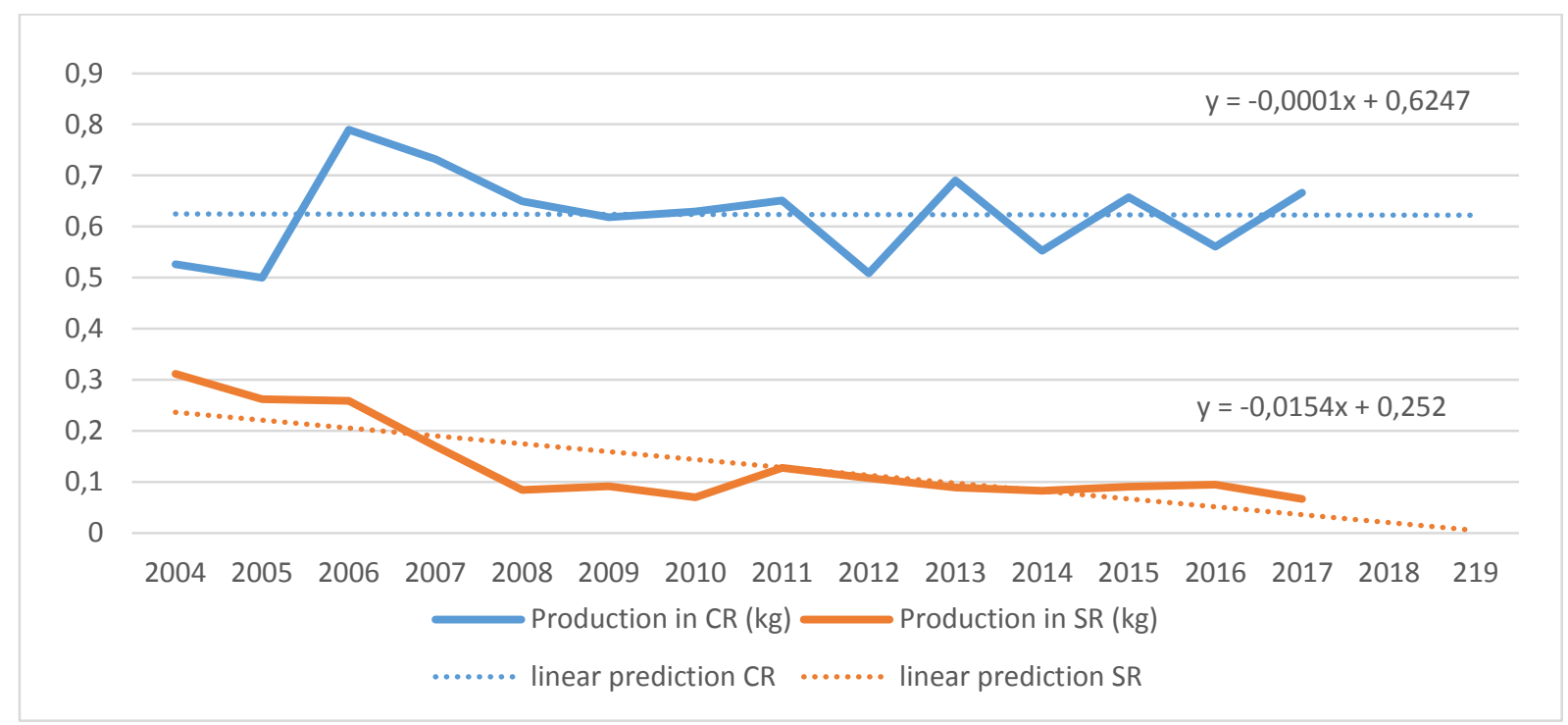

Source: vuepp.sk and eagri.cz and own research

Figure 3 show us shows a comparison of kohlrabi production in the Czech Republic and the Slovak Republic. As we can see production of kohlrabi in Slovak Republic is constantly lower every year. The Slovak Republic reached its maximum in 2004 which represented about 11\% coverage of consumption per capita. On the contrary, the minimum reached in 2017, which represented only about $1,58 \%$ market coverage, which in turn implies the highest import, up to 98\% as we can see in Figure 4. In the Czech Republic, production reached its maximum in 2006 , which represented about $32 \%$ coverage of consumption per capita. In 2005, the Czech Republic reached approximately $25 \%$ coverage of consumption per capita in this country what was the lowest in over the reporting period.

\section{Figure 4: Import of kohlrabi in kg}

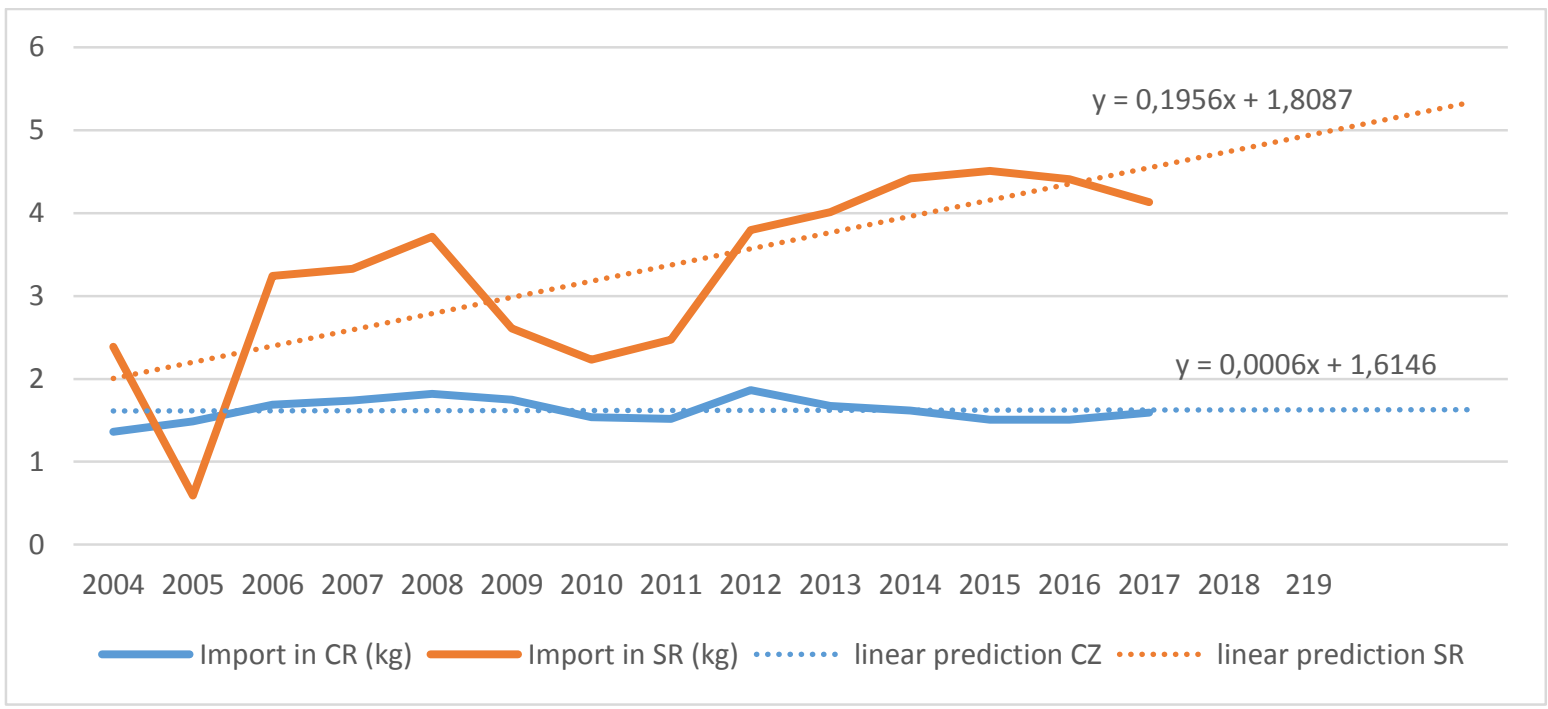

Source: vuepp.sk and eagri.cz and own research 
Linear forecasting suggests that imports will increase just in Slovak Republic. For Czech Republic it seems that import of kohlrabi will be same next two years as other years in the past.

\section{Figure 5: Production of carrot in $\mathrm{kg}$}

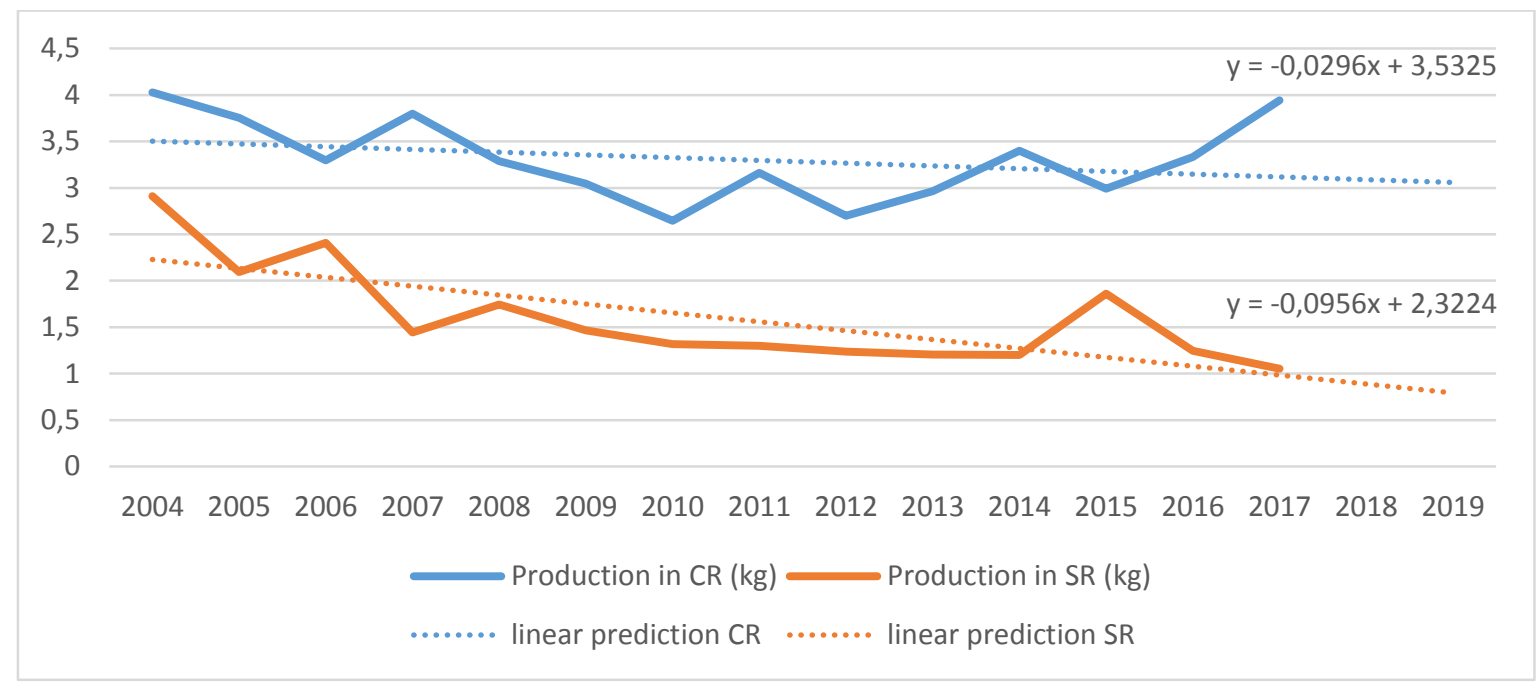

Source: vuepp.sk and eagri.cz and own research

Comparison of carrot production in the Czech Republic and the Slovak Republic show us a Figure 5. As we can see production of carrot in Slovak Republic is constantly lower every year. The Slovak Republic reached its maximum in 2004 which represented about 30\% coverage of consumption per capita. On the contrary, the minimum reached in 2017, which represented only about $8,99 \%$ market coverage, which in turn implies the highest import, up to $91 \%$ as we can see in Figure 6. In the Czech Republic, production reached its maximum in 2004, which represented about $61 \%$ coverage of consumption per capita. In 2010, the Czech Republic reached approximately $40 \%$ coverage of consumption per capita in this country what was the lowest in over the reporting period. This implies the highest import needed in 2010 and up to $59 \%$ to cover consumption per capita.

\section{Figure 6: Import of carrot in kg}

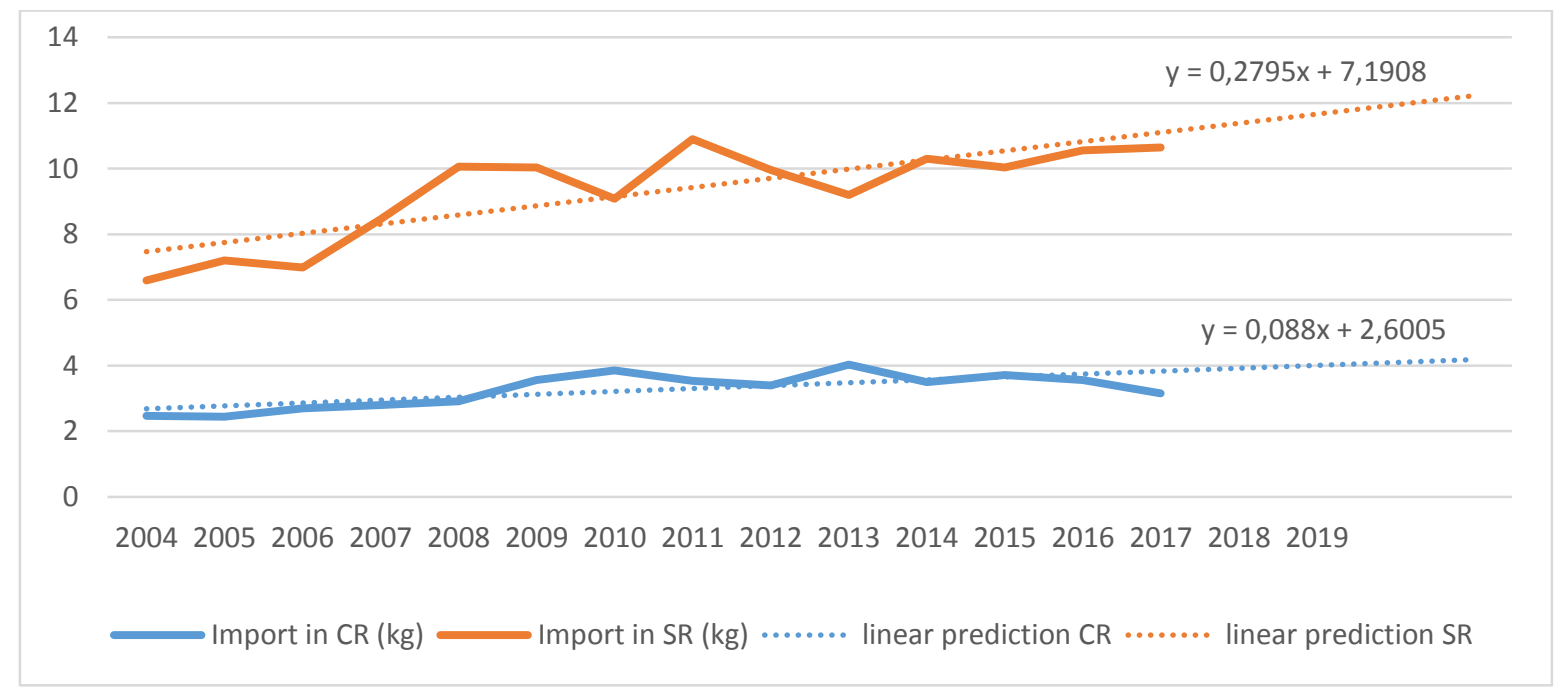

Source: vuepp.sk and eagri.cz and own research 
Linear forecasting suggests that imports will increase in both countries under review. However, its value will be substantially higher in the Slovak Republic than in the Czech Republic. As we can see in Figure 4 and 2 import will substantially higher in Slovak Republic than in the Czech Republic.

\section{Conclusion}

In every single picture we can see comparing the Slovak Republic and the Czech Republic. As we can see The Slovak Republic is much worse in production every year than the Czech Republic in every single commodity observed: carrots, parsley and kohlrabi. For example, in 2017, the Slovak Republic needed to import up to 98\% of kohlrabi while the Czech Republic needed 69\%. The production of carrot in Slovak Republic is constantly lower every year. The Slovak Republic reached its maximum in 2004 which represented about $30 \%$ coverage of consumption per capita. In the Czech Republic, production reached its maximum in 2004 same like in Slovak Republic, which represented about $61 \%$ coverage of consumption per capita. Linear forecasts suggest that parsley imports will increase in both countries under review. However, its value in the Slovak Republic will be substantially higher than in the Czech Republic.

Consumption of fresh vegetables decreases. In the Slovak Republic it decreased by $6.9 \mathrm{~kg}$. In 2016 the consumption per capita was $78.9 \mathrm{~kg}$ and in 2017 it was $72.00 \mathrm{~kg}$. This implies that total consumption of fresh vegetables decreased by $66555 \mathrm{t}(-15.5 \%)$ to $361618 \mathrm{t}$ from the original 428172 t. However

The Slovak vegetable industry will be able to compete if it chooses the right varietal and species composition, starts communicating the benefits of domestic vegetables and builds its brand. At the same time, greengrocers need to associate sufficiently and establish equal partnerships with traders. The state should encourage the cultivation of vegetables that make sense here. At the same time, it should encourage the cultivation and processing of better vegetables. State support should also be directed at innovations and producer associations. At the same time, the state needs to help the vegetable growers to cope with climate change, in particular by supporting the building of drought irrigation and frost protection. Overall, Slovakia is in the last places in the co-financing of subsidies for special crops within the European Union. Vegetables must therefore be made more attractive to attract young professionals.

\section{References}

[1] Baco, P. 2010. Podnikanie v pol'nohospodárstve. In.: Zborník z celosvetovej odbornej konferencie. Nitra : Agroinštitút, 2010, p.7. ISBN 978-80-7139-163-4.

[2] Buchtová I. (2018), Situační a výhledová zpráva zelenina, Print: Ústav zěmědelské ekonomiky a informácií, p.3, ISBN 978-80-7434-474-9

[3] Bujňáková, M. 2009. Postavenie pol’nohospodárstva v ekonomike SR. In Zborník vedeckých prác z riešenia projektu VEGA, roč.09, n.1,p.14. ISBN 978-80-555-0103-1

[4] Claessens S, Feijen E, Laeven L. (2008) "Political connections and preferential access to finance: The role of campaign contributions. Journal of financial economics, 88(3), pp.554-580

[5] Horská E., Ürgeová J., Prokeinová R. (2011) Consumers food choice and quality perception: Comparative analysis of selected Central European countries, In: Agric. Econ.-Czech, p.:493-499 
[6] Kretter A. and Paluchová J., : Activiation of the agricultural products sale to the final consumer. Business management - practice and theory in the 21 st century. Nitra: Slovak University of Agriculture, 2013,p. 307312. ISBN 978-80-552-1026-1.

[7] Kročková, B.: Štruktúra využívania pol’nohospodárskej pôdy (2017). Retrieved January 15,2020, from: https://enviroportal.sk/indicator/detail?id=601

[8] Martinez-Palou A. and Rohner-Thielen E. (2008) Fruit and vegetables: fresh and healthy on European tables, In Eurostat statistics in focus 60/2008, ISSN 1977-0316

[9] Ministry of agriculture and food of bulgaria. 2010. Direct payments. 2020. January 18,2020, from: http://www.mzh.government.bg/MZH/ShortLinks/SelskaPolitika/DirectPayments.asp x

[10] Nagyová, L' at al., (2018) Marketing II. Nitra: Print: Slovenská pol’nohospodárska univerzita v Nitre, 2018 p. 234-237 ISBN 978-80-552-1943-1

[11] Némethová J. and Hudáková M. (2019) Dynamics of livestock production developement in the slovak republic between the years 2004 and 2017 potential impact of the changes on the agricultural sector and landscape, In Budapest 2019, s. 7649-7666, ISSN 17850037 (online)

[12] Reforma spoločnej pol'nohospodárskej politiky po roku 2013 (2020). Retrieved January 20, 2020, from: http://www.consilium.europa.eu/sk/policies/cap-reform/

[13] Rovný P. (2007): Vývoj teritoriálnej štruktúry agrárneho zahraničného obchodu Slovenska po vstupe do Európskej únie. In: Zborník z medzinárodnej vedeckej konferencie: marketing v teórií, výskume a praxi. 2007. SPU Nitra. 211p. ISBN 978-808069-957-4

[14] Šimkovič, J. Spoločná pol'nohospodárska politika sa má opät’ zjednodušit' (2017), Retrieved January 19,2020, from: https://euractiv.sk/clanky/potravinarstvo/spolocnapolnohospodarska-politika-sa-ma-opatzjednodusit/

[15] Šumichrast, J. and Brodňanová, R. (2019) Realita slovenského zeleninárstva in Rol'nícke noviny 49/2019, ISSN: 0231-6617 


\title{
Innovative Research Solutions in Aromachology and Aromatherapy
}

\author{
Karol Čarnogurský1, Anna Diačiková ${ }^{2}$, Peter Madzík ${ }^{3}$ \\ Catholic University in Ruzomberok, \\ Faculty of Education, Department of Management ${ }^{1,2,3}$ \\ Nábrežie Jána Pavla II, č. 15 \\ 058 01, Poprad, Slovakia \\ e-mail: karol.carnogursky@ku.sk¹, anna.diacikova@ku.sk², peter.madzik@ku.sk³
}

doi: 10.18515/dBEM.ISD.P01.2020.p008

\begin{abstract}
Recent research on neuromarketing provides a wide range of problem solving opportunities not only for businesses, non-profit organizations, advertising and research agencies, but also for manufacturers to create their own products, services and brands. Neuromarketing is based on a sensible perception of man, and scent or smell belong among five fundamental perceptions. In the paper, this important human perception is analysed through the scientific disciplines of aromachology and aromatherapy for further use in the field of neuromarketing and the study of its impact on human performance in the work process. At present, there is a wide range of possibilities for neuromarketing research, and the term aroma marketing or aromachology is mentioned quite often. At the same time, we are very much confronted with the term aromatherapy. The presented paper is aimed at the theoretical approach of the two concepts, which are closely related to each other.
\end{abstract}

Keywords: aromachology, aromatherapy, neuromarketing, marketing, customer behaviour, employees' performance

JEL Classification: M30, O30

\section{Introduction}

Marketing always had and still has scope for the realization and development of its activities where market changes exist. The economy cannot grow endlessly in the conventional way, as we understand it today, and new ideas can appear anywhere. It is therefore short-sighted to watch only traditional competitors and traditional marketing tools (Petersen et. al, 2015). Marketing is primarily driven by technology to develop and offer solutions for unsatisfied needs and customer demands, often relying on shortcomings in previous marketing concepts (Lemke et. al, 2010). The starting point for these activities is not only its potential, but mainly the market and the requirements of individual market segments. The development and contemporary perception of marketing is influenced by the facts that characterize the current shift in social relationships and structures (Batra et. al, 2016), (Križo et. al, 2018). Individual cultures constantly overlap, the impact of social and sociographic changes is manifested, in particular by changing purchasing power, which reflects the differentiation of customer requirements. The individual marketing strategies are aimed at balancing the tension between focusing on individual needs, increasing business performance, developing new jobs and, last but not least, changing the hierarchy of living values (Križo et. al, 2018). At the same time, social structures are overlapping, creating preconditions for companies to operate on the global market, which ultimately reflects on the global strategic decisions of investors (Killian et. al, 2015). As for the homogenization of demand, it is caused mainly by globalized products and services, but with local aspects. In doing so, it is important to keep customer loyalty so much that the business can rely heavily on their loyalty and the creation of long-term relationships. 
Thus, it is still possible to characterize the current concept of marketing as holistic (Dessart et. al, 2015), (Petersen et. al, 2015).

In business, and especially in today's boom of information technology and the transfer of marketing activities to the digital environment, it is necessary to walk ahead and this is reflected in marketing activities. Continuous innovation and progress has become a natural phenomenon, and the failure to use the latest trends can often become a problem of liquidation for businesses (Killian et. al, 2015). The primary goal of marketing is to define and understand customer needs as precisely as possible and to design such products and services to satisfy them perfectly. Understanding consumer behavior represents a challenge for marketing since the beginning of its existence (Godey et. al, 2016). Consumers often do not even know what product they want and what features it should meet. On the other hand, businesses often fail to choose the right way to communicate to reach target audience groups in an appropriate marketing campaign (Killian et. al, 2015). For their exact determination, classical methods of marketing research are often not enough and new possibilities for their realization are being opened.

It results from the above mentioned facts that intensive cooperation between the business and the scientific sphere is increasingly needed in marketing activities. Each of the two sides promotes their interests, which complement each other and create a synergistic effect. The flexible scheme at present now shows the financial participation of businesses in research, which can speed up scientific work (Križo et. al, 2018). The results of many of the current research suggest that today's consumer in shopping is not rational, but emotional in particular (Ariely et. al, 2010), (Boksem et. al, 2015). Marketing experts agree that linking a particular product or service with a gripping story and quality content that includes emotions will help increase its memorability. Humor, love, fear, anger, or sadness can get deep into the subconscious. Research is currently intensively trying to exploit a deeper look at buying behavior, testing emerging situations, or improving future marketing communications (Batra et. al, 2016). This area is being monitored by a fairly new, scientific discipline called neuromarketing. Neuro-marketing tracks the human brain's response to various sensory-marketing stimuli, as well as emotions relevant to human decision-making. It monitors and combines knowledge from neuroscience, psychology, neuro-economy, informatics and information technology, and last but not least from marketing (Ariely et. al, 2010). In connection with neuromarketing, the term neuro-science is often used because neuro-marketing is based on it (Boksem et. al, 2015). This is a scientific discipline that aims to understand how the brain and mind of customers/consumers work, that is to understand the brain processes involved in perception, learning and decision making (Lee et. al, 2007). Neuro-science as such studies the human nervous system along with its properties and architecture. Its specialty part, called "cognitive neuroscience", is the science about information processes going on in the brain. It examines how information is acquired from basic human senses, how processes of perceptions and recognition are realized, how thinking and consciousness arises, what learning is, how memory works and individual decision processes (Ariely et. al, 2010). The result is effective marketing communication following real brain reactions and optimization of the product itself in relation to the customer.

\section{Data and Methods}

For the collection and processing of data, we used the analysis of the available information sources and the results of studies in international scientific databases.

\section{Sensible and Sensorial marketing}


Everything that consumers or customers have experienced is preserved in the human brain, no matter by what senses it was received. Information and suggestions received and captured by means of the sense of smell, taste and touch are kept in memory for the longest period (Lee et. al, 2007). By means of vision and hearing, a huge number of conscious and unconscious external stimuli are processed. The task of the basic sensory systems is to obtain a certain type of information from the external environment and convert it into a form of nerve representation in the brain (Boksem et. al, 2015). The human body, through its senses, perceives information from the outside world that, in the form of electrical impulses, gets to the brain. Brain then interprets this information and produces chemical and physical responses that are the source of reactive behavior. (Krishna, 2012). The entire process is shown in Figure 1.

\section{Figure 1. Running Sensors Marketing}

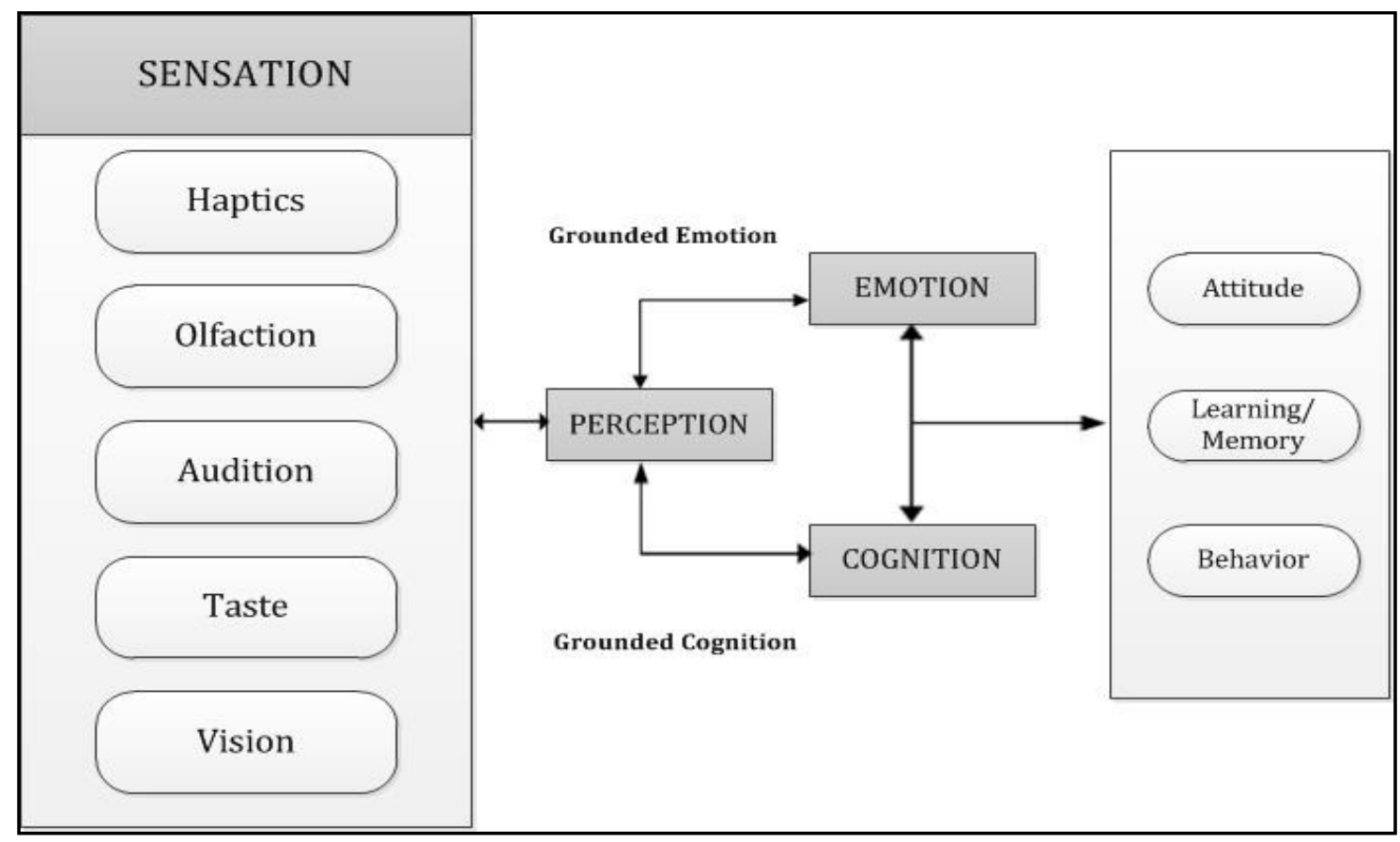

Source: Krishna, 2012

When marketing communication focuses concurrently on all senses, it can give the business a great competitive advantage in a view of their impact on consumer choice. This can be essential, for example, for communication when selling in traditional stone shops, because the use of all five senses can be an advantage over e-shops, since it is quite difficult to be different with price, range of offer or convenience to do the shopping (Killian et. al, 2015). Linking sensory perception with a certain event also greatly enhances the chance of remembering it, especially if the situation is positive. The more senses are attracted by the product or the service and the more positive reactions it raises, the higher is the chance to be remembered by customers (Lee et. al, 2007). In connection with the subject of this paper, its authors focused on summarizing the knowledge about olfactory perception, where the effect of specific fragrances on the individual behaviour and emotion of the individual is monitored and studied, which is in the centre of aromatherapy attention. On the other hand, aromachology is increasingly used for monitoring employee performance and consumer behaviour not only in shopping centres. Since 
both areas are very closely related to the issue of neuro-marketing, the present paper is aimed at the theoretical approach of these concepts from professional foreign sources and research.

\section{Results and Discussion}

Sense of smell is the most powerful human sense because it has a direct connection with those parts of the brain that control emotions, behaviour, and certain types of memory. The article is focused on mainly differences between aromatherapy and aromachology.

\section{Sense of Smell - Aromatherapy and Aromachology}

The fragrance can cause an immediate emotional reaction in humans (Lwin et. al, 2015). Everyone is capable of answering immediately whether he likes the scent or not. Aromas carry the message and they affect people in such a way that they often do not even know that they feel or smell something. This is a very important function from the marketing point of view. There is a basic process of sensing and perceiving the fragrances of the human brain. When sensing the smell, at the first place the person perceives its pleasantness. It follows that the aroma is not perceived analytically but hedonistically (Herz, 2009). Consequently, there is a judgment of awareness, i.e. whether or not the specific smell has been perceived and reminds a person of something. In the last step, one perceives its intensity (Lwin et. al, 2015). Research has shown that positive emotions resulting from the perception of pleasant smell increase to a certain degree of intensity. On the other hand, however, there is a certain break where the too strong smell becomes unpleasant. Similarly, the reverse procedure works. After evaluating the three characteristics of the fragrance perceived, one begins to think about what the smell is and where it comes from (Gulas et. al, 1995). This affects the emotions before we can be orientated in it. The above procedure can be observed in the Figure 2 .

\section{Figure 2. Purpose and Progress of Aroma Perception}

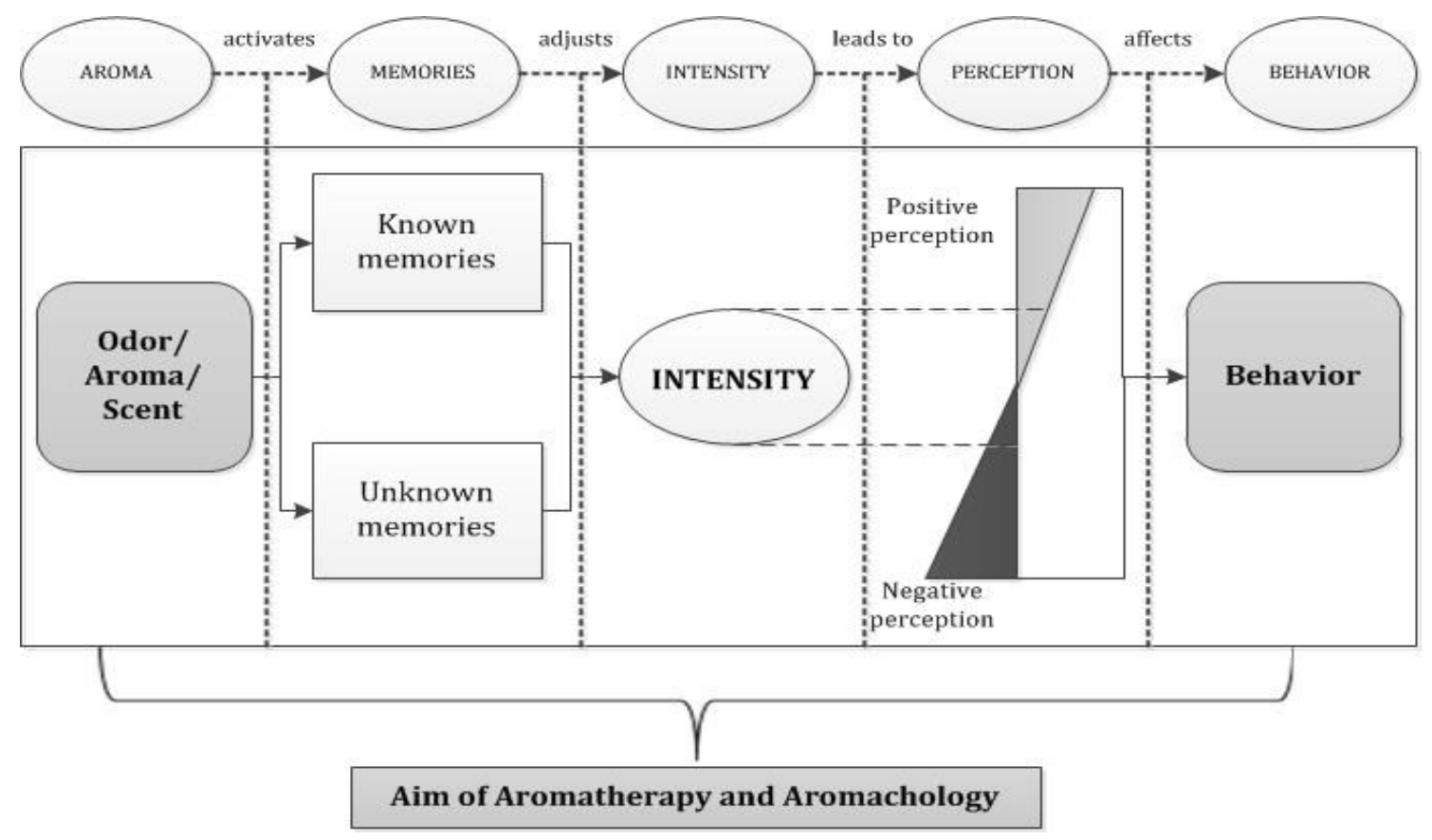

Source: Authors' own processing. 
An interesting finding has been the paper (Small et. al, 2005), in which the aroma is perceived by man in both ways - nose and mouth. Aromatic molecules contact the olfactory epithelium by a nose (orthonasal olfaction), this is an outside world aroma or by a mouth (retronasal olfaction), where the aroma comes from the mouth and connects with a taste like sweet, acidic, salty, spicy and hot. The authors examined the difference in the perception of reference aromas: chocolate, lavender, farnesol (typical floral scent) and butanol (alcohol). The difference in sensitivity and pleasantness of these reference fragrances was found when passing through the nose or, respectively, mouth. Smell stimulation is different whether it is the smell of food or non-food (Small et. al, 2005). It has been proved by the experiment that the perception of the scent of the brain is different, whether it is perceived through the nose, mouth.

The main finding of the realized researches was that the same smell or the odor can cause different responses in the human brain depending on whether it is orthostatically sensed, that is, it passes through the nose or is sensed by the retronasal pathway, i.e. from the back of the mouth. This result is supports hypothesis that ortonasal and retronasal olfaction represent qualitatively different sensory experiences. This hypothesis is consistent with a particular pattern of differential activity that has been observed as a response to orthostatic and retronasal application of odour. In contrast to this, it can be assumed that the odour responses to orthonasal vs. retronasal olfactory stimulation are observed. Since the study tested only one food (chocolate), further experiments are needed to determine whether other aromas produce the same differential brain activation (Rozin, 1982). With regard to the topic of the submitted paper, aroma perceived by a man through the nose will be developed theoretically.

There are two basic views on the perception and evaluation of aromas by humans, namely, aromatherapy and aromachology. Although these terms may look very similar, they differ in their content, i.e. quality of flavor, priority purpose and utilization. However, both support positive effects on the mood and emotion of the person, the first (aromatherapy) is the therapeutic use of natural fragrances, while the second (aromachology) is based on scientific studies and is closely intertwined with psychology (Herz, 2009), (Tomi et. al, 2011).

Aromachology is based exclusively on scientific research that examines the psychological effects of natural and synthetic scent on man. Aromatherapy is much older and has been an integral part of folk medicine in the past. Unlike the aromachology - in aromatic essential oils, their healing properties are mainly observed (Wang et. al, 2005).

Table 1. Differences Between Aromatherapy and Aromachology

\begin{tabular}{|c|c|c|c|c|}
\hline & $\begin{array}{c}\text { Fragrance } \\
\text { quality }\end{array}$ & $\begin{array}{c}\text { Solves } \\
\text { preferentially }\end{array}$ & Main purpose & Utilization \\
\hline AROMATHERAPY & Natural & $\begin{array}{l}\text { Launching and } \\
\text { causing a specific } \\
\text { physiological } \\
\text { reaction in } \\
\text { humans }\end{array}$ & $\begin{array}{l}\text { Health status of } \\
\text { individuals }\end{array}$ & In medicine \\
\hline AROMACHOLOGY & $\begin{array}{l}\text { Natural } \\
\text { Synthetic }\end{array}$ & $\begin{array}{l}\text { Launching and } \\
\text { causing a } \\
\text { psychological } \\
\text { reaction in } \\
\text { humans }\end{array}$ & $\begin{array}{l}\text { Affecting the } \\
\text { mood and } \\
\text { behaviour of } \\
\text { people }\end{array}$ & $\begin{array}{l}\text { For commercial } \\
\text { purposes - retail, } \\
\text { work } \\
\text { environment }\end{array}$ \\
\hline
\end{tabular}

Source: Authors' own processing. 
Based on the differences, it can be said that both disciplines complement each other, although they are often perceived differently. A detailed view of aromatherapy and aromachology based on scientific articles is presented in the following part of the paper.

\section{Conclusion}

Current trends in advertising and marketing are most often targeted at sight and hearing, but the most important and yet underestimated sense is just the smell. At present, the audiovisual space is overwhelmed, making such an advertisement harassing and neglecting. Scientists and practitioners agree that the future of marketing lies in the synergy of senses - scent, eyesight, hearing, touch and taste that create complex marketing communication. Perfuming or scenting spaces can influence man, motivate, improve mood, remind beautiful memories or even change behavior. A man's subconscious has the energy and capabilities that lead him to achieve the goals. Science proved that a scent has a strong long term connection to memory and sensory ties to certain things or experiences. This is the base of marketing of fragrances or aroma marketing. Invoking positive emotions, whether directly or indirectly, is a vital way to achieve business success.

Fragrances create lasting memories, which the man preserves subconsciously, and the senses of smell he remembers for several years. Scent or olfaction is the only sense that is directly connected to the part of the brain that drives our behaviour, certain kinds of memory and emotions. In addition, scent cannot be turned off. Therefore, the feeling the scent causes immediate, direct and subconscious emotional responses, and it was only a matter of time when fragrance starts to be used for marketing purposes. Aroma marketing can be used in areas such as:

- business - the first impression is very important. Especially in institutions where a pleasant smell at the entrance creates a higher level of trust in clients in the institution and its services. In addition to client premises, it is advisable to use selected fragrances to increase employee productivity, which is currently being investigated;

- automotive - one of the most controversial secrets of aroma marketing is the smell of a new car. This scent was developed decades ago.

- gastronomy - smells of favourite food (chocolate, cake, coffee, fresh pastries or pizza) spread throughout the gastronomic premises increase customers' taste for shopping and intensify their experience;

- shops - a proper aromatization affects what a person buys, in what quantity, or even can encourage to buy premium products;

- relax - e.g. adjusting the hotel aroma in which style it is tuned;

- entertainment - casinos, thanks to pleasant smell, record longer time which their customers spend in the premises. Also known is the campaign of the Nivea sunscreen maker in the cinema when a very typical scent of the cream was introduced to the cinema through the air conditioning distribution during the commercial spot. At the end of the spot, the slogan appeared: "NIVEA - Fragrance of Summer." The result was a 515\% increased interest in the company's products compared to the same spot, but without the use of smell;

- health - waiting for a doctor or visiting a pharmacy is associated with unpleasant emotions. Aromatization and a suitably chosen scent can, in addition to unpleasant odors, eliminate the feeling of anxiety, create a soothing and positive environment, remove odorous smells, induce a sense of hygienic and clean environment, soothe 
patients, relieve feeling, insecurity, fear and nervousness, because nice aroma helps feel pleasant;

- services - scents can create permanent memories of people to remember service vendors;

- production facilities - the impact of aromachology on productivity, or safety has not yet been scientifically proven, or published.

The influence of aroma on man in medical thought, such as aromatherapy, has long been known and sufficiently described. However, the influence of aroma on man as a new scientific discipline (aromachology), first described in the 80s of the last century, has not published enough independent research papers and unambiguous studies in the literature. Despite the fact that there is already a significant amount of information in the sphere of scent research, the effects of the aroma on consumers' behaviour and the work performance of staff are not verifiably clarified, and therefore this area has been the subject of many scientific institutions and scientific projects.

\section{Acknowledgment}

Research has been supported by the research grant APVV 17-0564 "The Use of Consumer Neuroscience and Innovative Research Solutions in Aromachology and Its Application in Production, Business and Services". This research was supported by grant VEGA 0663/18 "Requirements non-linearity and its integration into quality management process".

\section{References}

[1] Ariely, D., \& Berns, G. S. (2010). Neuromarketing: the hope and hype of neuroimaging in business. Nature Reviews Neuroscience, 11(4), 284-292. doi:10.1038/nrn2795

[2] Batra, R., \& Keller, K. L. (2016). Integrating Marketing Communications: New Findings, New Lessons, and New Ideas. Journal of Marketing, 80(6), 122-145. doi:10.1509/jm.15.0419

[3] Dessart, L., Veloutsou, C., \& Morgan-Thomas, A. (2015). Consumer engagement in online brand communities: a social media perspective. Journal of Product \& Brand Management, 24(1), $28-42$. doi:10.1108/jpbm-06-2014-0635

[4] Godey, B., Manthiou, A., Pederzoli, D., Rokka, J., Aiello, G., Donvito, R., \& Singh, R. (2016). Social media marketing efforts of luxury brands: Influence on brand equity and consumer behavior. Journal of Business Research, 69(12), 5833-5841. doi:10.1016/j.jbusres.2016.04.181

[5] Gulas, C. S., \& Bloch, P. H. (1995). Right under our noses: Ambient scent and consumer responses. Journal of Business and Psychology, 10(1), 87-98. doi:10.1007/bf02249272

[6] Herz, R. S. (2009). Aromatherapy Facts and Fictions: A Scientific Analysis of Olfactory Effects on Mood, Physiology and Behavior. International Journal of Neuroscience, 119(2), 263-290. doi: $10.1080 / 00207450802333953$

[7] Killian, G., \& McManus, K. (2015). A marketing communications approach for the digital era: Managerial guidelines for social media integration. Business Horizons, 58(5), 539-549. doi:10.1016/j.bushor.2015.05.006

[8] Krishna, A. (2012). An integrative review of sensory marketing: Engaging the senses to affect perception, judgment and behavior. Journal of Consumer Psychology, 22(3), 332-351. doi:10.1016/j.jcps.2011.08.003

[9] Križo, P., Chocholáková, A., \& Sirotiaková, M. (2018). Using Knowledge Management in Scientific Work - Time Analysis. Knowledge Management in Organizations, 15-25. doi:10.1007/978-3-319-95204-8_2

[10] Lee, M. S., Choi, J., Posadzki, P., \& Ernst, E. (2012). Aromatherapy for health care: An overview of systematic reviews. Maturitas, 71(3), 257-260. doi:10.1016/j.maturitas.2011.12.018 
[11] Lemke, F., Clark, M., \& Wilson, H. (2010). Customer experience quality: an exploration in business and consumer contexts using repertory grid technique. Journal of the Academy of Marketing Science, 39(6), 846869. doi:10.1007/s11747-010-0219-0

[12] Lwin, M. O., Morrin, M., Chong, C. S. T., \& Goh, S. X. (2015). Odor Semantics and Visual Cues: What We Smell Impacts Where We Look, What We Remember, and What We Want to Buy. Journal of Behavioral Decision Making, 29(2-3), 336-350. doi:10.1002/bdm.1905

[13] Petersen, J. A., Kushwaha, T., \& Kumar, V. (2015). Marketing Communication Strategies and Consumer Financial Decision Making: The Role of National Culture. Journal of Marketing, 79(1), 44-63. doi:10.1509/jm.13.0479

[14] Small, M. D., Gerber C. J., Erica Mak, Y., Hummel, T. (2005). Differential Neural Responses Evoked by Orthonasal versus Retronasal Odorant Perception in Humans. Neuron, 47, 593-605, August 18, 2005. ISSN: 0896-6273.

[15] Tomi, K., Fushiki, T., Murakami, H., Matsumura, Y., Hayashi, T. and Yazawa, S. (2011). RELATIONSHIPS BETWEEN LAVENDER AROMA COMPONENT AND AROMACHOLOGY EFFECT. Acta Hortic. 925, 299-306 DOI: 10.17660/ActaHortic.2011.925.44

[16] Wang, C.X., Chen, Sh.L. Aromachology and its application in the textile field (2005) Fibres and Textiles in Eastern Europe, 13(6), pp. 41-44. 


\title{
What prevails at the Slovak Food Market: Similarities or Differences?
}

\author{
Vladimír Fuga \\ Slovak University of Agriculture in Nitra \\ Faculty of Economics and Management, Department of Marketing and Trade \\ Tr. Andreja Hlinku 2, \\ 94976 Nitra, Slovakia \\ e-mail: vladimirfuga@yahoo.com
}

doi: 10.18515/dBEM.ISD.P01.2020.p009

\begin{abstract}
The purpose of this work is to verify the claim that basic shopping habits do not differ in individual Regions within Slovakia and thus Slovakia can be considered a single market. We conducted the research with an electronic questionnaire, which was filled in by 1981 respondents from all over Slovakia. The Shapiro-Wilk test showed a normal distribution of the questionnaire responses. By a paired t-test of the proportion of respondents and the proportion of inhabitants in the Regions we confirmed that the response rates and the population proportions are suitable for analysing preferences throughout the country. We analysed purchasing behaviour from two perspectives. $20 \%$ of respondents make the main weekly purchase of food in one store. 67\% buy in two to three stores. Only $13 \%$ buy in another way, for example in specialised stores. $77 \%$ of respondents said they would spend on a weekly purchase between EUR 40 and EUR 80. The distribution of the share of expenditure is similar in all Regions. Other responses, such as I do not go shopping, I am not watching expenses, or I spend more than EUR 100 or less than EUR 30, were distributed very differently.
\end{abstract}

Keywords: regional product, local product, regional differences, consumer research, purchasing behaviour

\section{JEL Classification: M31}

\section{Introduction}

Public interest in local and regional products has increased enormously in recent years. In line with this interest, governments also support the production and sale of local products. However, what is a region or a local product is not defined.

Pirog (2003) claims that the most commonly used understanding of regions is based on the principle of territorial (government) classification. A region is understood to be a state or a smaller, clearly defined unit within the state. For example, some studies define products from any farm in the United States as local. Other studies, Porjes (2007), try to define the region by defining the exact distance. For example, a range of 50 to 150 kilometres or even 300 kilometres. Even looser definition states it is the "distance of a day trip by car."

Some surveys, such as Berry (1977), indicate that consumers perceive as local those products that are linked to their community. This, however, merely moves the definition of a local product to a community product, thus leaving the same task, i.e., defining what the community is. It is also unclear whether a community is to be understood as a geographical area or a group of people with the same characteristics or activities. 
Noll, S. and Werkheiser, I., (2017) analysed the current marketing communication and sales support used by large chains or directly by large producers. These chains use the term local producers to attract customers to their shops.

In general, the region is seen as a guarantee of something better, of higher quality or exceptional. It is assumed that there are fundamental differences between regions, which make it possible to gain an advantage in the production and sale of a product. In this work, we will analyse whether the idea that there are fundamental differences between regions in terms of customer purchasing preferences can be accepted. If there is no difference between the purchase preferences in the regions, then a particular competitive advantage can be applied throughout Slovakia.

The area of Slovakia is $49035 \mathrm{~km}^{2}$, representing only $1.2 \%$ of the area of the European Union. 5,4 million inhabitants of Slovakia account for $1.1 \%$ of the total population of the European Union. Slovakia is currently divided into 8 Regions. For statistical and decision-making purposes, these Regions are often informally connected into three larger units: Western Slovakia, Central Slovakia and Eastern Slovakia. The Statistical Office of the Slovak Republic also uses this connection in its surveys. However, it is an informal presentation that is not used in officially binding communication.

Bratislava, as the capital of the Slovak Republic, is not a separate Region, nor does it have a formal special or independent status. The proportion of inhabitants of the city of Bratislava in the total population of the Bratislava Region is $67 \%$. Outside the capital city, only three districts are part of the Bratislava Region: Malacky, Pezinok and Senec. In our work, however, we will examine the values for the capital city of Bratislava separately.

The following table provides basic information on the territorial and administrative organisation of the Slovak Republic, population and area of the Regions.

Figure 1: Slovak demography by regions

\begin{tabular}{|c|c|c|c|c|c|c|c|}
\hline region & ISO 3166-2 & population & $\begin{array}{r}\text { area } \\
{\left[\mathbf{k m}^{2}\right]} \\
\end{array}$ & $\begin{array}{c}\text { population } \\
\text { density } \\
{[\text { pop./km²] }}\end{array}$ & $\begin{array}{c}\text { number of towns } \\
\text { and villages }\end{array}$ & $\begin{array}{c}\text { number of } \\
\text { towns }\end{array}$ & $\begin{array}{l}\text { number of } \\
\text { districts }\end{array}$ \\
\hline 1 Bratislava & SK-BL & 669592 & 2053 & 326 & 73 & 7 & 8 \\
\hline 2 Trnava & SK-TA & 564917 & 4147 & 136 & 251 & 17 & 7 \\
\hline 3 Trenčín & SK-TC & 584569 & 4502 & 130 & 276 & 18 & 9 \\
\hline 4 Nitra & SK-NI & 674306 & 6344 & 106 & 354 & 16 & 7 \\
\hline 5 Žilina & SK-ZI & 691509 & 6809 & 102 & 315 & 19 & 11 \\
\hline 6 Banská Bystrica & SK-BC & 645276 & 9454 & 68 & 516 & 24 & 13 \\
\hline 7 Prešov & SK-PV & 826244 & 8974 & 92 & 665 & 23 & 13 \\
\hline 8 Košice & SK-KI & 801460 & 6755 & 119 & 440 & 17 & 11 \\
\hline Total: & & 5457873 & 49036 & 111 & 2890 & 141 & 79 \\
\hline
\end{tabular}

Source: Statistical Office of the Slovak Republic

The population in the two Regions of the eastern part of the country (Prešov and Košice) is obviously larger than in the other six regions. The Banská Bystrica Region is more than four times larger than the Bratislava Region, but with almost comparable population. The Prešov and Košice Regions are traditionally understood as regions with a large share of the rural population. However, the Prešov Region has only 3 \% more inhabitants than the Košice Region, while these inhabitants live in an area that is $33 \%$ larger and the Prešov Region has $51 \%$ more towns and villages. More such examples can be found in the table below. Slovakia is therefore often perceived as an extremely non-homogeneous country with huge regional differences in the economy and consumer preferences. 
The aim of this work is to verify the hypothesis that Slovakia can be seen as a single market in planning the marketing of basic food items. We assume that the way of shopping - the number of shops visited and food expenditure do not differ in individual Regions of Slovakia.

\section{Data and Methods}

We used a questionnaire online survey to obtain data for the study. The possibility to answer the questionnaire was offered to respondents during the search for goods through one of the most visited Slovak price comparison websites.

For the purposes of our questionnaire, it is important to know the following information: gender, place of residence, Region, age, employment and financial income. Specific research issues can be divided into two groups:

- Questions related to preferences and views on local and regional products.

- Questions related to higher costs associated with the production, storage and transport of local and regional products.

The questions were concise and closed. Based on previous studies, demographic questions were placed at the end of the questionnaire.

In the course of one week, 1982 respondents from all over Slovakia answered the questions. This number of respondents significantly exceeds the current response rate for similar surveys. For further analysis, we work with the assumption that the topic of food and especially local products is of interest to the consumer.

In the question "I live in the Region" we offer 9 options - the city of Bratislava is excluded, as shopping preferences may differ in the capital and at the same time, shoppers in Bratislava have objectively different shopping options.

The normality of the measured data (frequencies) has been verified by Shapiro-Wilk test. The significance level is selected to a value of $5 \%(\alpha=0.05)$. The percentage of respondents to the questionnaire are compared with the percentage of population in each Region by a paired t-test.

Statistical data evaluation was performed using GraphPad Prism 7.02 software (GraphPad Software, Inc., USA).

\section{Results and Discussion}

To verify the hypothesis that Slovakia can be considered one market in terms of consumer shopping habits, we use two basic assumptions:

- The number of stores in which the buyer makes the main weekly purchase

- The amount of expenses that the buyer spends on the main weekly purchase

For the question "I make a weekly purchase of food:", respondents had the possibility to choose from the following answers:

- I make the whole purchase in one store.

- I buy everything in 2-3 stores.

- I buy groceries in several specialised stores.

- I do not buy. The question does not apply to me. 
Figure 2: Preferences for the number of purchases

\begin{tabular}{|c|c|c|c|c|c|c|}
\hline Regions: & $\begin{array}{l}\text { I do not buy. The } \\
\text { question does not } \\
\text { apply to me. }\end{array}$ & $\begin{array}{c}\text { I buy groceries in } \\
\text { several specialised } \\
\text { stores. }\end{array}$ & $\begin{array}{l}\text { I make the whole } \\
\text { purchase in one } \\
\text { store. }\end{array}$ & $\begin{array}{c}\text { I buy everything in } \\
2-3 \text { stores. }\end{array}$ & Grand total & \\
\hline Banská Bystrica Regi & 2 & 26 & 45 & 161 & 234 & \\
\hline Bratislava Region & 2 & 4 & 19 & 54 & 79 & \\
\hline Košice Region & 5 & 26 & 65 & 172 & 268 & \\
\hline City of Bratislava & 2 & 21 & 48 & 151 & 222 & \\
\hline Nitra Region & 5 & 31 & 39 & 163 & 238 & \\
\hline Prešov Region & 6 & 38 & 64 & 191 & 299 & I make the whole \\
\hline Trenčín Region & 6 & 26 & 37 & 161 & 230 & purchase in one store. \\
\hline Trnava Region & 2 & 25 & 28 & 116 & 171 & \\
\hline Žilina Region & 7 & 22 & 54 & 158 & 241 & I buy everything in 2-3 \\
\hline Grand total & 37 & 219 & 399 & 1327 & 1982 & stores. \\
\hline Banská Bystrica Regi & $0,85 \%$ & $11,11 \%$ & $19,23 \%$ & $68,80 \%$ & $100,00 \%$ & $88,03 \%$ \\
\hline Bratislava Region & $2,53 \%$ & $5,06 \%$ & $24,05 \%$ & $68,35 \%$ & $100,00 \%$ & $92,41 \%$ \\
\hline Košice Region & $1,87 \%$ & $9,70 \%$ & $24,25 \%$ & $64,18 \%$ & $100,00 \%$ & $88,43 \%$ \\
\hline City of Bratislava & $0,90 \%$ & $9,46 \%$ & $21,62 \%$ & $68,02 \%$ & $100,00 \%$ & $89,64 \%$ \\
\hline Nitra Region & $2,10 \%$ & $13,03 \%$ & $16,39 \%$ & $68,49 \%$ & $100,00 \%$ & $84,87 \%$ \\
\hline Prešov Region & $2,01 \%$ & $12,71 \%$ & $21,40 \%$ & $63,88 \%$ & $100,00 \%$ & $85,28 \%$ \\
\hline Trenčín Region & $2,61 \%$ & $11,30 \%$ & $16,09 \%$ & $70,00 \%$ & $100,00 \%$ & $86,09 \%$ \\
\hline Trnava Region & $1,17 \%$ & $14,62 \%$ & $16,37 \%$ & $67,84 \%$ & $100,00 \%$ & $84,21 \%$ \\
\hline Žilina Region & $2,90 \%$ & $9,13 \%$ & $22,41 \%$ & $65,56 \%$ & $100,00 \%$ & $87,97 \%$ \\
\hline Grand total & $1,87 \%$ & $11,05 \%$ & $20,13 \%$ & $66,95 \%$ & $100,00 \%$ & $87,08 \%$ \\
\hline
\end{tabular}

Source: own calculation

Respondents chose the most the 'I buy everything in 2-3 stores' response. Of the total, $66.95 \%$ of respondents in the whole of Slovakia chose this answer. In individual Regions, this selection was represented from $63.88 \%$ in the Prešov Region to $70.00 \%$ in the Trenčín Region. We consider a difference of approximately $3 \%$ from the average to be insignificant. It can therefore be assumed that the average customer in Slovakia prefers to buy in 2 to 3 stores. Or, this is how $67 \%$ of consumers behave.

The second most frequent answer was "I make the whole purchase in one store." This option was selected by $20.13 \%$. The lowest proportion of respondents $(16.09 \%)$ chose this option in the Trenčín Region and the highest in the Košice Region (24.25\%). The difference of $4 \%$ can be considered significant in terms of the frequency of this response, as it accounts for a quarter of the respondents to this question. However, this difference is not significant in terms of the overall number of responses.

To assess whether the preferences of the shoppers in relation to the number of stores are the same in individual Regions in Slovakia, we analysed the sum of respondents who selected the two most numerous options. Thus, a total of $87.08 \%$ of respondents make their purchase in one to three stores. The lowest value was in the Nitra Region $(84.87 \%)$ and the highest in the Bratislava Region (92.41\%). The number of these responses in the Bratislava Region was $3 \%$ higher than the average of the responses in other Regions.

Only $1.87 \%$ of respondents said they did not buy at all and $11.05 \%$ said they preferred specialised stores. The total proportion of $12.92 \%$ of respondents is not a number that would significantly define purchasing preferences in Slovakia and in individual Regions. The main differences in responses were in the choice of specialised stores. The smallest interest in specialised stores is $5.06 \%$ in Bratislava. On the contrary, the biggest interest in specialised stores is $14.64 \%$ in the Trnava Region. These results cannot be properly interpreted without more precise research. 
Traditionally, public opinion assumes that the main difference between the Regions or smaller areas is in the purchasing power of the population. However, to verify our single market hypothesis, we will not examine the purchasing power in the Regions or the amount of expenditure reported by respondents. In the question of "For a major family (such as a weekly) food purchase, I usually pay:" respondents could choose from the following options:

- Less than EUR 30

- Approximately EUR 40

- Approximately EUR 60

- Approximately EUR 80

- Approximately EUR 100

- I do not monitor how much I pay.

The weighted average of the purchase amount according to the respondents to our questionnaire is EUR 58. This is slightly less than the value reported by the Statistical Office at EUR 67. The difference is due to the proportion of buyers who do not monitor their expenditure. It can reasonably be assumed that the expenses of customers who do not monitor the amount of purchase are higher. Perhaps their financial situation allows them not to monitor the amount of food expenditure. A total of $6.31 \%$ of respondents do not monitor their expenses. The largest proportion of these responses was in Bratislava and the Bratislava Region. This corresponds to the expected higher purchasing power.

The highest amount of EUR 100 and above and the lowest amount of less than EUR 30 chose approximately the same number of respondents. A total of $16.80 \%$ does not constitute such a market share that this could be considered as a definition of customer behaviour. $76.89 \%$ of customers indicated their expenses in the amount of approximately EUR 40 to 80 .

The frequency of individual responses was subjected to the Grubbs' test for outliers. There were no outliers for any of the Regions or options. There are small differences between the frequency of individual responses. However, these differences cannot be explained by a simple regional explanation, for example, in population or average income levels. 
Figure 3: Share of shoppers by amount of expenditure by Region

\begin{tabular}{|c|c|c|c|c|c|c|c|c|}
\hline Row Labels & $\begin{array}{l}\text { Less than } \\
\text { EUR } 30\end{array}$ & $\begin{array}{c}\text { I do not } \\
\text { monitor how } \\
\text { much I pay. }\end{array}$ & $\begin{array}{c}\text { Approximately } \\
\text { EUR } 100\end{array}$ & $\begin{array}{c}\text { Approximately } \\
\text { EUR } 40\end{array}$ & $\begin{array}{c}\text { Approximately } \\
\text { EUR } 60\end{array}$ & $\begin{array}{c}\text { Approximately } \\
\text { EUR } 80\end{array}$ & Grand total & \\
\hline Banská Bystrica Region & 20 & 8 & 20 & 69 & 78 & 39 & 234 & \\
\hline Bratislava Region & 4 & 8 & 10 & 21 & 23 & 13 & 79 & \\
\hline Košice Region & 27 & 18 & 16 & 75 & 98 & 34 & 268 & \\
\hline City of Bratislava & 20 & 22 & 12 & 64 & 74 & 30 & 222 & \\
\hline Nitra Region & 26 & 9 & 19 & 71 & 69 & 44 & 238 & \\
\hline Prešov Region & 23 & 16 & 27 & 93 & 95 & 45 & 299 & Approximately \\
\hline Trenčín Region & 17 & 15 & 17 & 64 & 84 & 33 & 230 & EUR 40 \\
\hline Trnava Region & 11 & 8 & 23 & 41 & 59 & 29 & 171 & to \\
\hline Žilina Region & 21 & 21 & 20 & 69 & 70 & 40 & 241 & Approximately \\
\hline Grand total & 169 & 125 & 164 & 567 & 650 & 307 & 1982 & EUR 80 \\
\hline Banská Bystrica Region & $8,55 \%$ & $3,42 \%$ & $8,55 \%$ & $29,49 \%$ & $33,33 \%$ & $16,67 \%$ & $100,00 \%$ & $79,49 \%$ \\
\hline Bratislava Region & $5,06 \%$ & $10,13 \%$ & $12,66 \%$ & $26,58 \%$ & $29,11 \%$ & $16,46 \%$ & $100,00 \%$ & $72,15 \%$ \\
\hline Košice Region & $10,07 \%$ & $6,72 \%$ & $5,97 \%$ & $27,99 \%$ & $36,57 \%$ & $12,69 \%$ & $100,00 \%$ & $77,24 \%$ \\
\hline City of Bratislava & $9,01 \%$ & $9,91 \%$ & $5,41 \%$ & $28,83 \%$ & $33,33 \%$ & $13,51 \%$ & $100,00 \%$ & $75,68 \%$ \\
\hline Nitra Region & $10,92 \%$ & $3,78 \%$ & $7,98 \%$ & $29,83 \%$ & $28,99 \%$ & $18,49 \%$ & $100,00 \%$ & $77,31 \%$ \\
\hline Prešov Region & $7,69 \%$ & $5,35 \%$ & $9,03 \%$ & $31,10 \%$ & $31,77 \%$ & $15,05 \%$ & $100,00 \%$ & $77,93 \%$ \\
\hline Trenčín Region & $7,39 \%$ & $6,52 \%$ & $7,39 \%$ & $27,83 \%$ & $36,52 \%$ & $14,35 \%$ & $100,00 \%$ & $78,70 \%$ \\
\hline Trnava Region & $6,43 \%$ & $4,68 \%$ & $13,45 \%$ & $23,98 \%$ & $34,50 \%$ & $16,96 \%$ & $100,00 \%$ & $75,44 \%$ \\
\hline Žilina Region & $8,71 \%$ & $8,71 \%$ & $8,30 \%$ & $28,63 \%$ & $29,05 \%$ & $16,60 \%$ & $100,00 \%$ & $74,27 \%$ \\
\hline Grand total & $8,53 \%$ & $6,31 \%$ & $8,27 \%$ & $28,61 \%$ & $32,80 \%$ & $15,49 \%$ & $100,00 \%$ & $76,89 \%$ \\
\hline
\end{tabular}

Source: own calculation

We compared customer behaviour when buying food from two perspectives: the number of stores in which the customer buys and the amount the customer spends per purchase. We compared the individual response rates between individual Regions of Slovakia. From $77 \%$ to $87 \%$ of the responses were identical. It can therefore be reasonably said that customers in the different Regions of Slovakia behave in a similar way when buying food, despite the differences in geographical values and economic possibilities.

This finding may be contrary to the general public opinion on large regional disparities, for example in the area of income. However, this study has shown that such generalisations are incorrect in the case of food purchases. We can assume that buyers from higher income groups will sometimes buy more expensive food. However, there is no reason to assume that buyers from lower income groups will buy significantly less. The purchase of food is one of the basic purchases, which are subject to needs rather than wishes.

It may be interesting to analyse the difference in purchasing habits between urban and rural customers in a future study. It is generally assumed that rural buyers have lower food expenditures due to their own production. However, this may not be true for several reasons. For example, personal links between the urban and rural population are still strong.

\section{Conclusion}

We compared customer behaviour when buying food from two perspectives: the number of stores in which the customer buys and the amount the customer spends per purchase. Then we compared the individual response rates between individual Regions of Slovakia. Between 77 $\%$ and $87 \%$ of respondents have the same shopping habits. These habits are not determined by place of residence. In all Regions, there is approximately the same proportion of $67 \%$ of shoppers who prefer to buy in 2-3 stores. $33 \%$ of buyers spend approximately EUR 60 . The proportion of buyers who spend about EUR 40 or EUR 80 is also identical. Between 13 and 23 $\%$ of respondents have fundamentally different preferences, while the numbers of these 
respondents were not distributed similarly in the Regions. The numbers of individual responses had variance from 5 to $13 \%$. It can therefore be concluded that customers throughout Slovakia in a similar way.

\section{References}

[1] Albert, J. ed., 2014. Innovations in food labelling. Elsevier.

[2] Balázs, B., 2012. Local Food System Development in Hungary. International Journal of Sociology of Agriculture \& Food, 19(3).

[3] Barham, E., Lind, D. and Jett, L., 2005. The Missouri regional cuisines project: Connecting to place in the restaurant. Urban Place: Reconnections with the Natural World. MIT Press, Cambridge MA, pp.141-72.

[4] Berry, Wendell (1988) The Work of Local Culture [online]. The E. F. Schumacher Society Annual Lectures - Iowa Humanities Lecture. Available at http://www.schumachersociety.org/publications/essay_work_of_local.html

[5] Canavari, M., Miniucchi, D., Nocella, G. and Viaggi, D., 2003, July. Electronic commerce in agriculture and agribusiness: The case of Emilia-Romagna (Italy). In EFITA 2003 conference (pp. 5-9).

[6] Cronin Jr, J.J., Brady, M.K. and Hult, G.T.M., 2000. Assessing the effects of quality, value, and customer satisfaction on consumer behavioral intentions in service environments. Journal of retailing, 76(2), pp.193218.

[7] Darby, K., Batte, M.T., Ernst, S. and Roe, B., 2008. Decomposing local: A conjoint analysis of locally produced foods. American Journal of Agricultural Economics, 90(2), pp.476-486.

[8] DeCarlo, T.E., Franck, V.J. and Pirog, R.S., 2005. Consumer perceptions of place-based foods, food chain profit distribution and family farms.

[9] Ellis, K. and Keane, J., 2008. A review of Ethical Standards and labels: is there a gap in the market for a new 'Good for Development' label?. Overseas Development Institute.

[10] Evans, T.L. and Miewald, C., 2010. Assessing the pocket market model for growing the local food movement: A case study of metropolitan Vancouver. Journal of Agriculture, Food Systems, and Community Development, 1(2), pp.129-144.

[11] Giovannucci, D., Barham, E. and Pirog, R., 2010. Defining and marketing "local" foods: Geographical indications for US products. The journal of world intellectual property, 13(2), pp.94-120.

[12] Kim, D.J., Ferrin, D.L. and Rao, H.R., 2008. A trust-based consumer decision-making model in electronic commerce: The role of trust, perceived risk, and their antecedents. Decision support systems, 44(2), pp.544564.

[13] Meidinger, E., 2007. Beyond Westphalia: Competitive legalization in emerging transnational regulatory systems. In Law and legalization in transnational relations (pp. 133-155). Routledge.

[14] Noll, S. and Werkheiser, I., (2017) Local food movements: Differing conceptions of food, people, and change.

[15] Pirog, R.S., Van Pelt, T., Enshayan, K. and Cook, E., 2001. Food, fuel, and freeways: An Iowa perspective on how far food travels, fuel usage, and greenhouse gas emissions.

[16] Pirog, Richard, and A. Benjamin (2003) Checking the Food Odometer: Comparing food miles for local versus conventional produce sales to Iowa instiutions. Leopold Center for Sustainable Agriculture: Ames, IA

[17] Porjes, Susan (2007) Fresh and Local Food in the U.S. Packaged Facts: Rockville, MD.

[18] Riedel, B., Bokelmann, W. and Canavari, M., 2009. Combining cluster and value chain approaches to analyze the competitiveness of fresh vegetables producers: case studies in Germany, Italy and Spain (No. 698-201647815). 


\title{
Overview of Corporate Social Responsibility Strategies of the Selected Food Businesses During the COVID-19 Pandemic
}

\author{
Jana Gajdošová ${ }^{1}$, Ludmila Nagyová ${ }^{2}$ \\ Slovak University of Agriculture in Nitra \\ Faculty of Economics and Management, Department of Marketing and Trade ${ }^{1,2}$ \\ Trieda Andreja Hlinku 2, \\ 94976 Nitra, Slovak Republic \\ e-mail: xgajdosovaj@uniag.sk¹,nagyoval26@gmail.com²
}

doi: 10.18515/dBEM.ISD.P01.2020.p010

\begin{abstract}
The aim of this document is to create an overview and qualitative analysis of the participation of food companies in addressing the social impact of the crisis caused by the COVID-19 pandemic, through the development of socially responsible business strategies. Using an analysis of the strategies of selected larger food companies, we identified the 5 largest areas of support during the COVID-19 pandemic: health and safety, mental health, cooperation, communities, and the environment. The involvement of companies in addressing the effects of the crisis is demonstrable. Supporting the solution of the situation through CSR activities of companies points to the increased need to develop sufficiently strong strategies of social responsibility, which will closely cooperate and follow the goals of national governments and international organizations covering the world trade and humanitarian aid.
\end{abstract}

Key words: Corporate Social Responsibility, Food Business, COVID-19, Pandemic

JEL Classification: M30, M31, M39

\section{Introduction}

Over the past years, the need for a sustainable business approach and ethical treatment of employees, suppliers, and business partners became a fundamental pillar of business functions. Corporate social responsibility has created an opportunity to share business values, and communicate strategies of sustainable business with customers, considering positive effects of using CSR strategy for higher market share, competitive advantage, and employee satisfaction.

When employees see that their organisation is involved in CSR activities enhancing its reputation, employees would have positive perceived CSR and make organizational affiliation worthwhile. (John, Qadeer, Shahzadi, Jia, 2019). Nowadays, CSR should be deeply embedded in corporate governance of an organisation and the company's long-term goals would go hand in hand with the strategy, as the concept of the CSR affects all the company's functions. Probably the more relevant and pressing question is not about whether to invest in CSR or not, but more about how to invest in CSR to achieve the mutually beneficial and interdependent social/environmental and economic goals. (He, Harris, 2020). But the process goes on and further develops: in order to evaluate and communicate responsible behaviour and results, CSR strategy must be given its due consideration in sub-themes that come together to compose a more detailed and specific CSR portrait of the enterprise as a whole (Perrini, 2005). CSR usually touches on ethical and environmental issues, thanks to which it connects business with the long-term goals of national governments and global organizations. In the past, these topics were taken exclusively as the responsibility of countries and state policies. Initially, CSR was understood as a concept irrelevant to the business (Kim, Rhou, Uysal, Kwon, 2016). 
Environmental CSR can help firms to acquire green-related information and resources that can help firms to invest in green technologies and improve their products accordingly ( $\mathrm{Ji}$, Miao, 2020). On the other hand, when a company is perceived as socially responsible, it creates a more positive context than if it is not (Janssen, Sen, Bhattacharya, 2014). Need of businesses to create corporate social responsibility strategy is shown especially in times when worlds trade struggle during different types of crisis.

When on March 11, 2020, World Health Organisation announced a pandemic of new Coronavirus known as COVID-19, businesses could start to test their CSR strategies in circumstances, in which sharing and having the right approach was required by their customers, employees and stakeholders. People must have isolated themselves at home and decline physical contact to prevent infection, thus, firms must pay more attention to developing and strengthening their online business by rapidly marketing innovations. (Wang, Hong, Li, Gao, 2020). The firm's response to crisis is highly dependent on the current state of the digital transformation (Cortez, Johnston, 2020). During a COVID-19 pandemic, several companies have started to use CSR as a communication strategy. By this way, companies could deal with social responsibility, they could obtain long term trust of employees, clients, and inhabitants, which will create sustainable business models (Antošková, Csikósová, 2014) for them in the future.

By their approach to corporate responsible business, companies during pandemic of COVID19 must show interest in sustainable, profitable activities in Health and Safety, Environment, Communities, Cooperation, and activities, which will help people to stay focused and not be pressured by different psychological consequences of the crisis. When anxiety affects a larger population, it may result in panic buying, leading to exhaustion of resources. Because of anxiety, people adopt various unwanted lifestyle and dietary modification under the influence of rumours. These may affect mental health adversely (Roy, Tripathy, Kar, Sharma, Verma, Kaushal, 2020). The support of rational shopping behaviour during the pandemic was transformed into a socially acceptable concept of CSR. Also, the pandemic has uncovered the need to address the mental health of society on a more intensive scale than has been the case so far, which may serve companies in the future in developing a less discussed part of social responsibility in their CSR strategies. COVID-19 has pointed out the interdependence between the government, the business, and the local community. It has demonstrated that environmental sustainability is directly related to business activities (Sheth, 2020). Corporate environmental performance is the area that is most likely to provide evidence of socially responsible investing (Abeysekera, Fernando, 2018). The corporate responsibility-driven self-regulatory measures can minimize the environmental impact of the economic sector (Kudlak, 2018). Environmental impact of the pandemic is mostly a secondary effect. According to iea.org, global $\mathrm{CO} 2$ emissions are expected to decline by $8 \%$, or almost 2.6 gigatonnes $(\mathrm{Gt})$, to levels of 10 years ago. The achieved reduction of $\mathrm{CO} 2$ emissions into the atmosphere and other positive ecological effects of the pandemic on the ecosystem should be considered by companies when developing CSR strategies for the coming years. It should be borne in mind that the concept of socially responsible business was created mainly because of the long-term neglect of environmental impacts on large-scale production in today's consumer society, which means that if the current situation has improved the environment, producers and consumers should keeping this in positive change.

The fundamental needs for the vulnerable ultra-poor group can undeniably cause the socioeconomic crisis and mental stress due to the COVID-19 lockdown. It has further created unemployment, deprivation, hunger, and social conflicts. (Shammi, Bodrud-Doza, Islam, 
Rahman, 2020). Central banks, government agencies, and multilateral organisations have engaged in an ongoing series of interventions in the financial market to stimulate economies. The International Monetary Fund (IMF) estimated that government stimulus packages adopted during the COVID-19 pandemic amounted to USD 3.3 trillion, and that additional loans, equity injections and guarantees amounted to USD 4.5 trillion (Akhtaruzzaman, Boubaker, Sensoy, 2020). Economic aid to maintain the competitiveness of economies imposes an obligation to appeal to firms with sufficient economic strength to provide sufficient support to low-income areas of the world in times of crisis, thus avoiding the secondary impact of possible neglect of support for developing areas in the future.

The priority area of CSR in times of crisis COVID-19 is the creation of sufficient Health and Safety policies that will protect workers who, due to their position, cannot perform their work from home during the crisis, or any other way. Companies must ensure that employees benefit from higher standards of occupational health and safety than required by the law, and also taking into account external implications, like the application in the workplace of health, safety and welfare criteria in the recruitment of subcontractors or in the process of commercialising goods and services (Montero, Araque, Rey, 2009).

\section{Data and Methods}

As corporate social responsibility is a qualitative part of society, for the article we use qualitative analysis of data from selected food companies and retail chains. We focused on food companies, which rank among the top 25 largest companies (based on turnover 2019) and their CSR strategies, during the COVID-19 pandemic, which were published on companies' websites. We then sorted the data collected from the companies' websites according to areas and selected the most striking data, which we then used for comparison and reporting. Environmental impact data come from the National Aeronautics and Space Administration and their observations.

Research areas needed to be defined: environment, communities, health and safety, cooperation, and mental health - the 5 most applied areas of CSR during a pandemic. Subsequently, we created an analysis of the existence of reports on the strategy of socially responsible business in the period of the COVID-19 pandemic and their qualitative evaluation.

\section{Results and discussion}

\subsection{Evaluation of Health and Safety standards during Coronavirus spread}

Regardless of the spread of the virus during a pandemic, health and safety are crucial in all around the world. Occupational health protection is one of the basic pillars of socially responsible business towards the company's employees. During the pandemic, in addition to the restrictive measures imposed by national governments, companies decided to promote the health and safety of their employees and people in the community by including education on safety information to prevent the spread of coronavirus. Coca-Cola company shared COVID19 prevention tips with Brazilians (Brazil was the country with the second-highest number of infected people in the world in early June- wordmeters.info). Labels included basic safety information and a QR code linking to full safety guidelines on the Ministry of Health website. The program was targeted to reach $40+$ million Brazilian homes (coca-colacompany.com1). In Southern and East Africa, they shared WHO- endorsed public health and safety messages on 
Coca-Cola labels, truck backs, billboards, TV and radio ads and retail signage (cocacolacompany.com2). Promoting social responsibility in developing countries through highimpact businesses can lead to higher levels of compliance by the population than when this information is delivered through standard communication channels. Company Jbs s. a. has adopted enhanced safety measures, health protocols and worker benefits to keep workplaces and staff safe, including free Live Health Online services that allow for virtual doctor visits at no cost, health screenings and $100 \%$ temperature testing of all team members and other different benefits (jbssa.com1). Access to healthcare, which is fully funded by business, is not only a manifestation of society's goodwill in the field of health and safety but also affects the mental health of employees who are not under increased pressure due to possible neglect of their health during coronavirus infection. Company MARS offered insurance coverage for medicallynecessary testing and treatment for COVID-19 (mars.com1).

\subsection{Mental health as a part of the corporate social responsibility strategy}

Adherence to health and safety rules is a priority in food and farm businesses. However, we must not forget the mental health of workers who are exposed to extreme stress, as the food industry is one of the few that people cannot do without and must, therefore, continue to produce continuously during any crisis. One of the most effective tools for the mental well-being of workers is, in a period of pandemic spread, to enable staff to work from home as much as possible. PepsiCo cancelled all participation in face-to-face meetings both internally and externally for the foreseeable future and instituted a flexible working policy for roles that can be done remotely, encouraging as many associates who could work from home to do so (pepsico.com1). Most profitable food company Nestlé offered different types of tools to support not only the mental health and wellbeing of their employees, but also areas of life that could cause agitation, fear, depression, and anxiety. Nestlé decided to provide cash loans or advances for those in financial distress, asking employees worldwide not to travel internationally for business purposes, paying all hourly and salaried staff affected by temporary stoppages in full for a minimum of twelve weeks, distributing meals and transport for staff to help reduce the risk of them falling ill, and provided parents with the flexibility to manage their family responsibilities and their role (nestle.com1). MARS launched virtual training for their employees (mars.com2). Cargill helped U.S. restaurant workers through the fund, where impacted workers could apply for a one-time $\$ 500$ grant to assist with living expenses such as food, transportation, and medical bills. (Cargill.com1)

\subsection{Financial and non-financial support during COVID-19}

Community support is possible through direct financial support from the community, by allocating resources to the less developed parts of the world that are most affected by the effects of the pandemic. In crises such as the global spread of COVID-19, it is important to consider the importance of existing organizations, creating an ethical and financially viable environment for workers in developing countries and closely linked to the concepts of sustainable business. They are organizations such as RSPO- round table on sustainable palm oil, RTRS- round table on sustainable soy, sustainable rice, and others. Promoting a sustainable business concept for small and rural farmers must be a primary concern of CSR strategies of companies from developed countries that have sufficient economic strength to support such functioning suppliers. In many parts of Asia and the Pacific, farming is an indispensable part of the rural economy, accounting for $29 \%$ of GDP and $65 \%$ of all employment (unenvironment.org1). This data confirms the importance of support for farmers and organizations in developed countries of the world. If a farmer must face any crisis and fluctuation, such as the existence of 
a coronavirus today, he can secure basic health care, protective equipment, etc. thanks to ethical and sufficiently high income from the work created. Globally, PepsiCo has committed \$7 million to the UN Foundation, of these funds, \$2 million is going to the World Health Organization COVID-19 Solidarity Response Fund and a total of $\$ 5$ million is being distributed to the 15 charitable organizations responding to COVID-19 (pepsico.com2). Allocation of financial resources can be realized by a direct subsidy of the selected subject, or the use of the subsidy can take place through the established network of support of interested companies. Company Danone allocated financial support of $€ 300$ million, financed by Danone's cash flow, to the 15,000 small businesses in their global ecosystem (farmers, suppliers, service providers), to the entrepreneurs of Danone Manifesto Ventures' portfolio, and the communities of Danone Ecosystem. (danone.com1). The Coca-Cola system and The Coca-Cola Foundation are pledged more than $\$ 100$ million to support COVID-19 relief efforts around the world, channelling funds to organizations that are best positioned to mobilize quickly and provide aid to healthcare workers and vulnerable communities. (coca-colacompany.com3). Company Nestlé donated ventilators, hospital beds, gowns, and masks to assist critical COVID-19 patients, in Germany, they provided 9,000 care packages worth over 1.8 million to frontline workers and more than 900 hospitals across the country, not forgetting about animal shelters and pet welfare organizations they donated more than 2 million meals for dogs and cats, supporting at-risk homebound seniors with the delivery of 40,000 meals directly to them and other kinds of help (nestle.com2). Unilever contributed $€ 100$ million through donations of soap, sanitiser, bleach, and food, and making available $€ 500$ million of cash flow relief for small and medium-sized suppliers and customers (unilever.com). Cargill donated an ambulance and Rapid Test Kits to support local government in Indonesia in handling COVID-19 pandemic, company donated more than $€ 1$ million contributions to distribute food via food banks across the U.S., in Brazil was Cargill converted part of the sugar mill in Sao Paulo to produce disinfecting alcohol for donation to hospitals and other organizations, they donated 3,300 litres of glycerine to the University of Nebraska-Lincoln to produce more than 330,000 litres of hand sanitizer for health care workers throughout the state (Cargill.com1). The temporary change of production focus represents, in a period of insufficient supply coverage of basic products and necessary materials/devices, a unique help from the area of socially responsible business entrepreneurship. Through the implementation of the necessary changes in production and willingness to help, the definition of socially responsible business as the responsibility of economically strong entities is fulfilled. Of course, the willingness to implement changes related to the production process is not only based on a pure need to help but also represents the company's key decisions that will provide it with better public opinion and a higher market share in the future.

\subsection{Cooperation with organisations responsible for allocation resources}

Activities in the field of socially responsible business not only support organizations providing an allocation of emergency aid (for example, the International Federation of Red Cross and Red Crescent Societies - IFRC, Foodbanks) but also subsidies to funds of companies actively involved in the charitable side of CSR. Addressing financial assistance to humanitarian professionals, whether internal company departments or international organizations, is an effective way to leave management and logistics to dedicated staff with experience in the field, making the assistance more effective and usable. At a time of pandemic caused by the spread of COVID-19, active cooperation with professionals in various sectors is a key factor in stopping the spread of the virus as effectively and as quickly as possible. Companies as PepsiCo (pepsico.com3), Nestlé (nestle.com3), Cargill (Cargill.com2), and the others supported The 
International Federation of Red Cross and Red Crescent Societies. To increase life-saving services and support to address the immediate impacts of the pandemic and its long-lasting social and economic repercussions, internationally functioning organization IFRC, that has a sufficiently developed logistics network and cooperates with professionals in its field, made a collective appeal for 3.1 billion Swiss francs (3.19 billion US dollars), (icrc.org). The public appeal for aid only highlights the need to develop socially responsible business strategies that are ready, willing and able to create and allocate resources for the functioning and cooperation of humanitarian aid, both in times of global crisis and beyond.

\subsection{The need to maintain an increased appeal to the environmental side of CSR}

A negative situation, such as a coronavirus pandemic, has also brought positive aspects, especially in the field of the environment. Thanks to the restriction of the movement of the population and the cessation of international transport, the environmental burden on the planet have become less, as evidenced by studies by experts and organizations. Ongoing observations of air quality and of the Earth at night have helped provide immediate examples of how Earth's systems are responding to these changes in human behaviour. From space, NASA's Ozone Monitoring Instrument (OMI) aboard the Aura satellite and the European Space Agency's TROPOspheric Monitoring Instrument (TROPOMI) aboard the Sentinel-5P satellite has provided the data behind the images of rapidly falling nitrogen dioxide (NO2) levels around the world due to people staying at home (nasa.gov). The question arises, in terms of business and socially responsible business behaviour, what steps are needed to maintain this positive impact as long as possible? It is the responsibility of companies to systematically work on the environmental side of the CSR strategy after the lifting of the restrictive measures. Thanks to NASA's observations, we can hypothesize the existence of a causal link between international trade and the quality of the environmental goals achieved by CSR strategies of companies. National and community policies should help to reduce the environmental impact of business and world trade. Restricting over-transport for a world agricultural and food trade may be influenced by sufficient support for countries' self-sufficiency, which could at least lead to a reduction in emissions from the transport of products and crops that the country can ultimately grow and procure from its resources. It faces the impacts of climate change on biodiversity, soil and water quality, and the demands of the global marketplace. EU farm policy has changed considerably in recent decades to help farmers face these challenges and respond to peoples' changing attitudes and expectations. EU agricultural policy covers a wide range of areas, including food quality, traceability, trade, and promotion of EU farm products. The EU financially supports its farmers and encourages sustainable and eco-friendly practices, while also investing in the development of rural areas (Europa.eu). Multinational retail companies should focus their CSR strategy on the use and support of local farmers and producers, thus ensuring a reduction in traffic between countries in the future and the goal of reducing $\mathrm{CO} 2$ emissions year-on-year could become reality.

\section{Conclusion}

The aim of this paper was to create a qualitative analysis and evaluation of the involvement of larger global food companies in the field of socially responsible business in the period of the pandemic caused by the spread of the COVID-19 virus.

The main findings show a sufficient involvement of companies and CSR strategies in a period of pandemic spread. Based on selected examples of the application of CSR during the crisis, multinational companies have supported key parts of the fight against the effects of the 
pandemic through their own involvement. They applied increased care and health and mental well-being of their employees, developed higher standards of health and safety. The companies supported humanitarian organizations, higher subsidies to corporate solidarity funds and nonfinancial support. The variable nature of the application of socially responsible business implies that it is not possible to establish clear correct and incorrect procedures for fulfilling the strategy. However, the absolute basis should be to engage in the challenges posed by global crises, such as the spread of COVID-19.

The crisis caused by the pandemic highlighted the need to develop socially responsible business strategies, which should be preventing the devastating effects of any crisis in the future. There is a need to promote sustainable agriculture, the ethical and economically viable treatment of farmers and growers in developing countries, who, based on a long-term favourable assessment of their work, can achieve economic strength that can maintain living standards and provide basic health care in the event of a crisis. Likewise, supporting farmers in these areas will provide a higher level of education, which will help alleviate the crisis, as only through sufficient and proper education can people stop the crisis.

The crisis has also highlighted the need to support local agriculture and trade, by finding significant reductions in $\mathrm{CO} 2$ concentrations. According to several experts, the connection between emission reductions and commercial transport is provable. CSR strategies of companies must be supported by national policies of the states, which will support the highest possible self-sufficiency of countries and the use of local suppliers, thus reducing the transport burden of trade to the lowest possible level.

A summary of the findings in this paper provides an opportunity for future research and analysis of the socially responsible business.

\section{References}

[1] A. Seadler, NASA Monitors Environmental Signals from Global Response to COVID-19, April 2020, https://www.nasa.gov/feature/nasa-monitors-environmental-signals-from-global-response-to-covid-19

[2] Amal P. Abeysekera, Chitru S. Fernando, Corporate social responsibility versus corporate shareholder responsibility: A family firm perspective. The address for the corresponding author was captured as affiliation for all authors. Please check if appropriate. Corfin(2017), doi:10.1016/j.jcorpfin.2018.05.003

[3] Antošová, M., \& Csikósová, A. (2015). Influence of European Union Policy to Corporate Social Responsibility. Procedia Economics and Finance, 23, 733-737. doi:10.1016/s2212-5671(15)00456-6

[4] Cargill, Supporting our communities during the coronavirus pandemic, 2020, https://www.cargill.com/news/supporting-our-communities-during-the-coronavirus-pandemic

[5] Cortez and W.J. Johnston, The Coronavirus crisis in B2B settings: Crisis uniqueness and managerial implications based on social exchange theory, Industrial Marketing Management (2020), https://doi.org/10.1016/j.indmarman.2020.05.004

[6] European Union, Agriculture, Vibrant rural areas and quality agricultural products https://europa.eu/european-union/topics/agriculture_en

[7] F. Perrini, Building a European Portrait of Corporate Social Responsibility Reporting, European Management Journal Vol. 23, No. 6, pp. 611-627, 2005

[8] H. He, L. Harris, The Impact of Covid-19 Pandemic on Corporate Social Responsibility and Marketing Philosophy, Journal of Business Research (2020), doi: https://doi.org/10.1016/j.jbusres.2020.05.030 
[9] H. L. Kim, Y. Rhou, M. Uysal, N. Kwon, An examination of the links between corporate social responsibility (CSR) and its internal consequences, International Journal of Hospitality Management, Vol. 61, pp. 26-34, 2017, http://dx.doi.org/10.1016/j.ijhm.2016.10.011R.M.

[10] International Committee of the Red Cross, COVID-19 appeal: None of us are safe until we're all safe, 2020, https://www.icrc.org/en/document/covid-19-movement-appeal

[11] International Energy Agency, Flashing Report, Global Energy Review, The impacts of the Covid-19 crisis on global energy demand and CO2 emissions, April 2020, https://www.iea.org/reports/global-energy-review2020

[12] J. Sheth, Business of business is more than business: Managing during the Covid crisis, Industrial Marketing Management (2019), https://doi.org/10.1016/j.indmarman.2020.05.028

[13] Janssen, C., Sen, S., \& Bhattacharya, C. (2015). Corporate crises in the age of corporate social responsibility. Business Horizons, 58(2), 183-192. doi: 10.1016/j.bushor.2014.11.002

[14] JBS, S. A., We are proud to provide food for our families, our communities and our nation as we face this challenge together. 2020, https://jbssa.com/about/news/2020/coronavirus

[15] Ji, H., Miao, Z., \& Zhou, Y. (2020). Corporate Social Responsibility and Collaborative Innovation: The Role of Government Support. Journal of Cleaner Production, 121028. doi: 10.1016/j.jclepro.2020.121028

[16] John, A., Qadeer, F., Shahzadi, G., \& Jia, F. (2019). Getting paid to be good: How and when employees respond to corporate social responsibility? Journal of Cleaner Production. doi: 10.1016/j.jclepro.2019.01.074

[17] Kudłak, R. (2019). The role of corporate social responsibility in predicting CO2 emission: An institutional approach. Ecological Economics, 163, 169-176. doi: 10.1016/j.ecolecon.2019.04.027

[18] Mars, Incorporated, Expanding Health and Wellbeing Benefits Amid COVID-19 Pandemic, 2020, https://www.mars.com/news-and-stories/articles/health-wellness-priority

[19] Md Akhtaruzzaman, Sabri Boubaker, Ahmet Sensoy, Financial contagion during COVID-19 crisis, Finance Research Letters (2020), doi: https://doi.org/10.1016/j.frl.2020.101604

[20] Montero, M. J., Araque, R. A., \& Rey, J. M. (2009). Occupational health and safety in the framework of corporate social responsibility. Safety Science, 47(10), 1440-1445. doi: 10.1016/j.ssci.2009.03.002

[21] Nestlé, Our response to COVID-19, 2020, https://nestle.com/aboutus/our-response-covid-19-coronavirus

[22] PepsiCo, Inc., COVID-19, 2020, https://pepsico.com/news/stories/covid-19

[23] Roy, D., Tripathy, S., Kar, S. K., Sharma, N., Verma, S. K., \& Kaushal, V. (2020). Study of knowledge, attitude, anxiety \& perceived mental healthcare need in Indian population during COVID-19 pandemic. Asian Journal of Psychiatry, 102083. doi: 10.1016/j.ajp.2020.102083

[24] Shammi, M., Bodrud-Doza, M., Towfiqul Islam, A.R.M., Rahman, M.M., COVID-19 pandemic, socioeconomic crisis and human stress in resource-limited settings: A case from Bangladesh, HELIYON, https://doi.org/10.1016/j.heliyon.2020.e04063.

[25] The Coca-Cola Company, The Coca-Cola Foundation Supports Red Cross and Red Crescent Teams In 60Plus Countries Impacted by COVID-19, 2020, https://www.coca-colacompany.com/news/the-coca-colafoundation-supports-red-cross-and-red-crescent-societies-in-90-plus-countries-impacted-by-covid-19

[26] The Coca-Cola Company, Coronavirus Local Actions, 2020, https://www.cocacolacompany.com/news/coronavirus-local-actions

[27] Unilever, Covid Response, 2020, https://www.unilever.com/news/covid-response/

[28] United Nations, Sustainable Food Production, 2020, https://www.unenvironment.org/regions/asia-andpacific/regional-initiatives/supporting-resource-efficiency/sustainable-food

[29] Worldmeters, COVID-19 coronavirus pandemic $\quad$ statistics, June, 2020 https://www.worldometers.info/coronavirus/

[30] Y. Wang, A. Hong, X. Li, J. Gao, Marketing innovations during a global crisis: A study of China firms' response to COVID-19, Journal of Business Research (2020), doi: https://doi.org/10.1016/j.jbusres.2020.05.029 


\title{
Environmental Corporate Social Responsibility of the Visegrad Group Countries, with a Focus on Circular Economy and Waste Management
}

\author{
Jana Gajdošová ${ }^{1}$, L'udmila Nagyová ${ }^{2}$ \\ Slovak University of Agriculture in Nitra \\ Faculty of Economics and Management, Department of Marketing ${ }^{1,2}$ \\ Address: Trieda Andreja Hlinku 2, \\ 94976 Nitra, Slovak Republic \\ e-mail:xgajdosovaj@uniag.sk¹,nagyoval26@gmail.com²
}

doi: 10.18515/dBEM.ISD.P01.2020.p011

\begin{abstract}
This paper aims to create a comparison of environmental policies of the Visegrad Group countries: Slovakia, the Czech Republic, Poland, and Hungary. Government support for CSR is key to developing companies' environmental strategies, which in turn can encourage consumers to adopt more environmentally friendly habits and comply with legal rules, triggering a cyclical response. On the environmental side of CSR, we focus mainly on goals in the circular economy and waste management. The support of the partners of the Visegrad Group is important, as these are countries with historical connections and populations with common features and habits. The adaptation of environmental policies in individual countries could be interconnected within the V4 countries, which would bring a greater scope of the researched area and experts with innovative solutions.
\end{abstract}

Key words: Corporate Social Responsibility, Environment, Visegrad Group

JEL Classification: M30, M31, M39

\section{Introduction}

In general, one of the most important parts of a company's socially responsible business strategy is its environmental performance. The environmental impacts of business are affected by global sustainability goals, they are part of UNSG 2030 and national policies. Environmental CSR may be particularly relevant to customers who care about the environmental issue and hence, green value in CSR programs can be better embedded in message directed to them (Chuan, ElManstrly, Tseng, Ramayah, 2020). CSR provides an opportunity for all the stakeholders to stand on the same platform that might help the organizations to achieve their desired sustainable objectives (Shahzad, Qu, Javed, Zafar, Rehman, 2019). The effects of CSR investment is social sustainability and reusing the returned items as the environmental sustainability (HosseiniMotlagh, Ebrahimi, Zirakpourdehkordi, 2019) are very possitive. CSR initiatives can influence consumer behaviors that are critical to its survival in the market (Castro-González, Bande, Fernández-Ferrín, Kimura, 2019). Firms that display higher level of strength and lower level of concerns with regard to corporate social responsibility, such as environmental concerns, are more likely to be supported. (Vu, Lin, Liu, 2016). Responsibility for business sustainability and corporate social responsibility should start with legislation adopted by national governments, continue through the supply chain and end with the consumer. A focus on environmental responsibility in the supply chain leed to new ways of collaboration with suppliers, in terms of developing environmental technologies with critical suppliers, to environmental audits, and training provided for second tier to ultimate suppliers (Kovács, 2008). Considering firms can choose between profit seeking or CSR and their emphasis is to characterize a mixed outcome 
(one profit seeking, the other CSR), which is stable for low impact of pollution and CSR sensitivity (Chao, Hong, 2018). Green practices were found to partially mediate the relationship between CSR and performance. It demonstrates the importance of adopting green practices within the organization as well as implementing CSR initiatives among the stakeholders to improve performance (Suganthi, 2019).

Participation in the environmental objectives of economic or geographical groupings has advantages that may affect the efficiency of the resources used. For the Eastern Bloc area of the European Union, such a grouping is represented by the Visegrad Group. The Visegrad Group (also known as the "Visegrad Four" or simply "V4") reflects the efforts of the countries of the Central European region to work together in a number of fields of common interest within the all-European integration. Czechia, Hungary, Poland, and Slovakia have always been part of a single civilization sharing cultural and intellectual values and common roots in diverse religious traditions, which they wish to preserve and further strengthen (visegradgroup, 2020). Policymakers may leverage CSR mechanism to fix environmetal responsibilities at firm level (Prasad, Mishra, Bapat, 2019). Legislations are enacted for sustainable development and/or environmental protection in other sectors such as agriculture, or different areas of focus such as climate change (Xia, Olanipekun, Chen, Xie, Liu, 2018) The expansion of the green economy in Europe is being accelerated by concerns relating to energy generation, resource use and environment management. Energy policies, addressing the need to tackle climate change by reducing greenhouse gas emissions and, at the same time, achieve greater energy security along with a diversity of generation that has the flexibility to meet variable demand, are driving the development of renewable energy technologies (Pop, Dina, Martin, 2011).

Corporate social responsibility partially mediated the effect of green marketing awareness on consumer purchase intentions of the retail product (Suki, Suki, Azman, 2016). The tool for effective interconnection of customers and the use of environmental strategies remains to involve retailers, as economically strong participants, in discussions with representatives of governments and multinational groups, such as the Visegrad Group. Research has shown that managers and owners of companies do highlight areas for policymakers and government bodies to focus on making improvements. (Dey, Petridis, Petridis, Malesios, Nixon, Ghosh, 2018). As frequently happens, suppliers do not really understand the environmetal or social requirements set by their customers (Cramer, 2007). For all these reasons, it is necessary to link the environmental objectives of CSR along the line of the supply chain, as well as along the line of linking legislation with the practical application of changes to prosperous sustainable business.

\section{Material and Methods}

To evaluate the obtained data, we used a qualitative analysis of the current The Environmental implementation review 2019 of the Visegrad Group countries: Slovakia, the Czech Republic, Poland and Hungary. By comparing the data from the Review and official Eurostat databases, we found differences in the attitude of individual V4 countries in supporting waste management infrastructure and addressing some environmental issues, as we believe that only a wellestablished legislative environment can fully support the environmental CSR strategy of companies in the supply chain. The right setting of legislation, strategies and the subsequent cooperation of the legislature with economically strong key partners can ensure a better understanding of CSR by the consumer and sustainable development supported by customers. 


\section{Qualitative analyse and discussion}

\subsection{Recycling and municipial waste management of V4 countries}

Waste management is an important component of the environmental part of corporate responsible business. Environmental policy and sustainable growth remain a priority in the European Union's 2030 strategy.

Figure 1: Recycling rate of municipal waste 2010-2018

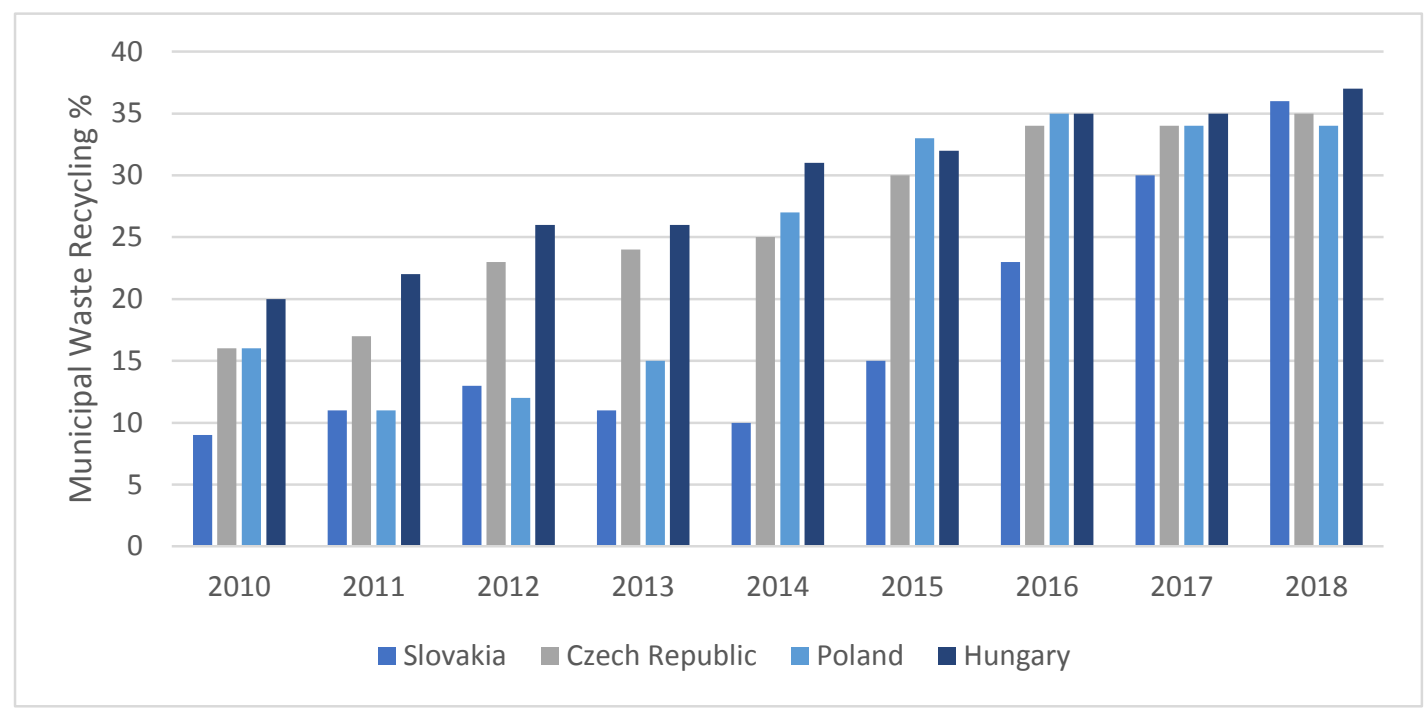

Source:

Developed by the authors according to Eurostat Information

The level of municipal waste recycling rate (Eurostat), at the beginning of the observed period in 2010, represented more than half the difference between the data of Slovakia and Hungary. The Czech Republic and Poland had approximately the same rate of waste recycling. Until 2015, the Slovak Republic had a considerable stagnation in waste recycling behind the other V4 countries, which began to change in 2016. The latest data from 2018 show an approximately balanced rate of waste recycling among the Visegrad Group countries. The European Commission has set a target for member states for 2020, which represents a $50 \%$ share of recycled municipal waste. In the Report on the Implementation of Waste Legislation of the European Commission, the Commission raises concerns about the non-fulfilment of the target by three countries out of 4 members of the Visegrad Group: Slovakia, Hungary, and Poland. Scenario modelling performed for this exercise15 confirmed this and concluded that if no additional policy action is taken, some of the Member States concerned would probably not even meet the $50 \%$ target by 2025 (European Commision, 2018).

The question arises whether it is possible to use the promotional power of retailers and wholesalers to support consumers in recycling waste. International retail group Schwarz Group, owner of Lidl and Kaufland, actively develops policies for the sustainable handling of plastics, including their recycling and reduction of use. For many years, the Schwarz Group has been committed to collecting, sorting, and recycling the reusable materials that are indispensable for transport and packaging in food retail. Three-quarters of the approximately 2.2 million tons of waste generated by the Schwarz Group each year can be reused. To reap the full ecological and economic benefits of these reusable materials, GreenCycle developed uniform collection stations for the group's stores, warehouses, and offices. The project was initiated as part of the Respect Recyclables campaign. (Schwarz Group, 2020). Countries of the Visegrad Group could collaborate on a project to increase the recycling rate of municipal waste, and support initiatives 
of retail and wholesale groups, by creating a functioning logistics system for municipal waste treatment and legislative coverage of the issue.

Figure 2: Comparison of municipal recycling rate \%, V4 to EU, 2010-2018

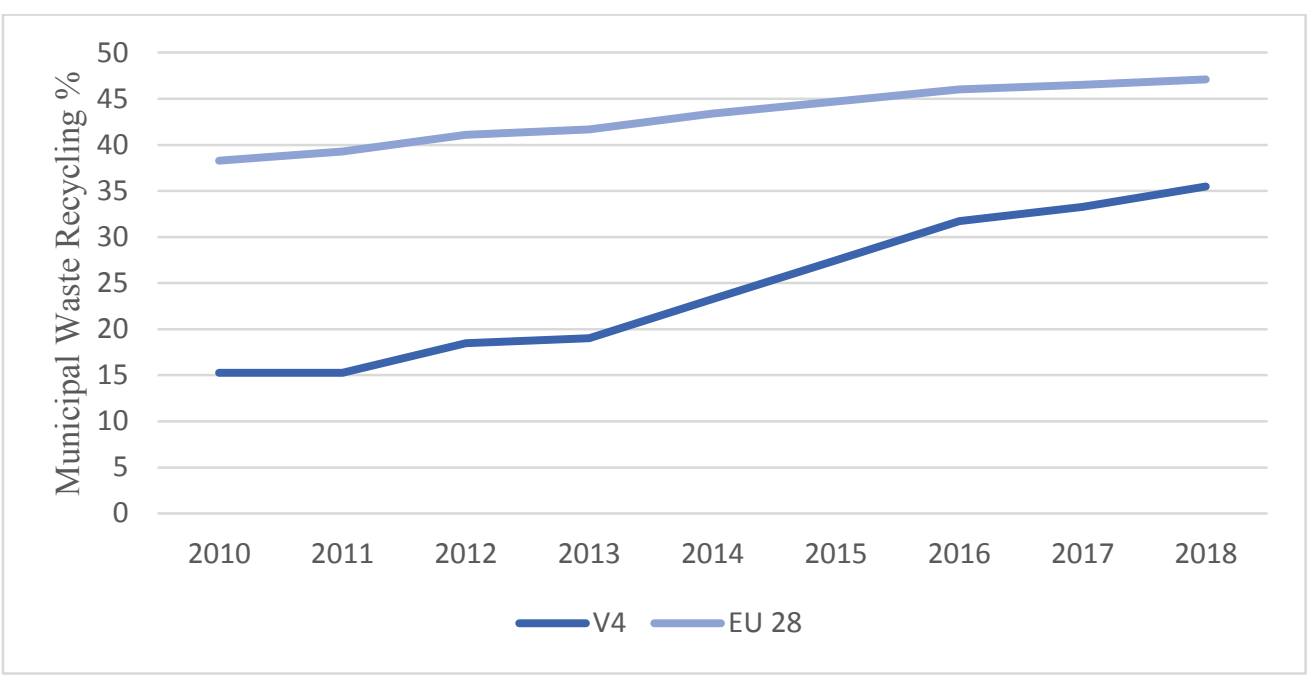

Source: Developed by the authors according to Eurostat Information

Figure 2 shows that the average recycling of municipal waste among the countries of the Visegrad Group is in the long run below the level of the countries of the European Union. To support socially responsible business in the field of recycling and reuse of raw materials of primary producers, consumers and retailers, the role of the state is to sufficiently support the initiative of entrepreneurs with effective tools such as: Improve and expand the separate waste collection, including bio-waste, develop minimum standards for separate waste collection services to ensure a high level of capture of recyclable waste, improve the functioning of extended producer responsibility schemes in line with the general minimum requirements for extended producer responsibility and others. Likewise, economic instruments such as raising the landfill tax would redirect more recyclable waste from landfills to lunch and could be reused. The Visegrad Group countries should streamline the application of tools to improve this situation. By working together to create economic and non-economic instruments to improve the level of municipal waste recycling, national governments could benefit from support for countries with a similar economic situation and history to the V4 countries.

Figure 3: Generation of Municipal Waste, 2018

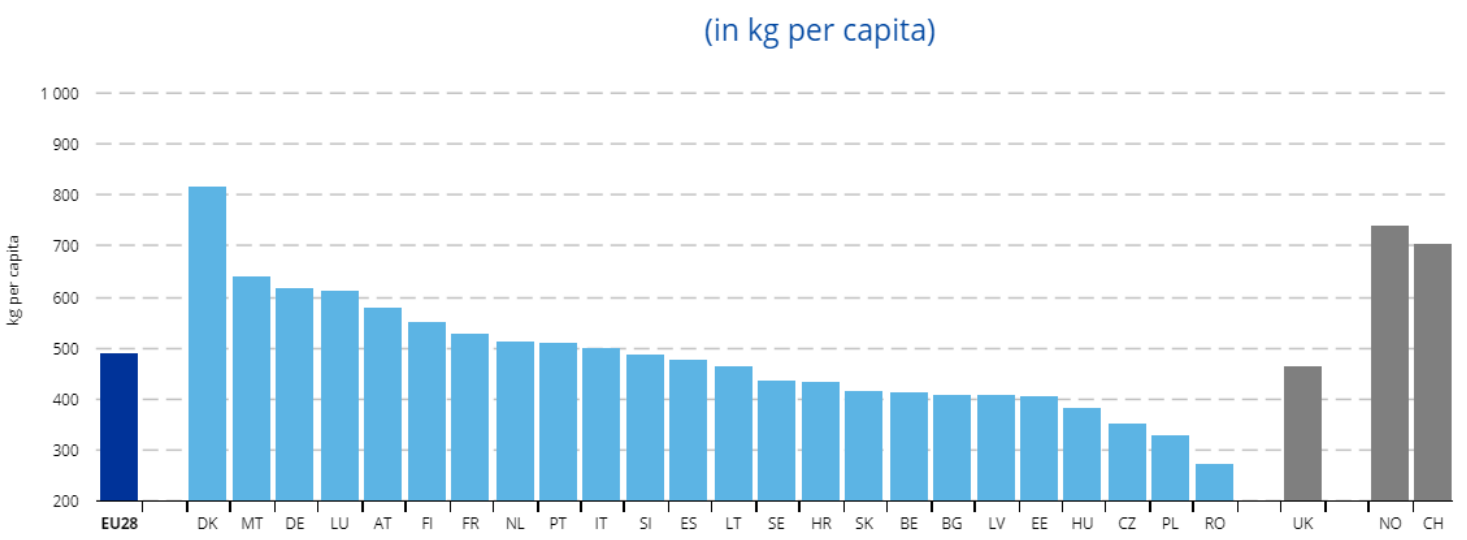

Source: https://ec.europa.eu/eurostat/cache/digpub/keyfigures/\# 
The amount of waste produced per capita is among the lowest among all member states of the European Union. In 2018, generated municipal waste in $\mathrm{kg}$ per capita was $351 \mathrm{~kg}$ in Czechia, $414 \mathrm{~kg}$ in Slovakia, $329 \mathrm{~kg}$ in Poland, and $381 \mathrm{~kg}$ in Hungary. Average in the European Union was about $489 \mathrm{~kg}$ per capita. According to the ec.europa.eu portal., the amount of municipal waste generated by each inhabitant reflects consumption patterns and economic wealth, as does the way waste is collected and managed. According to the living standards of the V4 countries, generated waste might be lower compared to other countries of the European Union. Consumption patterns are important in reflecting the CSR strategies of companies. If from a historical point of view, the population is naturally less interested in the consumerist way of life, CSR strategies of companies must adapt goals, packaging use, recycling and more to the benefit of their customers. In particular, these differences need to be considered in the formulation of targets related to long-term ecological and sustainable sales. The reason for the low quantification of waste per capita can also be contrary to the essence of a socially responsible business. This involves setting up illegal landfills and disposing of waste in ways that destroy the environment, e.g. waste incineration. The European Commission states that there is still a relatively high number of illegal landfills in Slovakia. Important measures that will enable the effective use of the CSR strategy in practice require the highest possible support from the legislation, otherwise the strategies will serve to artificially create support for nonexistent systems.

\subsection{Resource Productivity}

In 2017, last Special Eurobarometer 468 on attitudes of EU citizens towards the environment measured found out, that $86 \%$ of people in Slovakia were concerned about the effects of plastic products on the environment and $88 \%$ said they were worried about the impact of chemicals. In Hungary, 84\% people were concerned about the effect of plastic products on the environment and $89 \%$ about impact of chemicals. $86 \%$ of Polish were concerned about plastic production and $88 \%$ about chemicals. $84 \%$ of Czech people were concerned about plastic pollution and $85 \%$ about impact of chemicals (European Commission, 2019). Average values in EU 28 were: $87 \%$ about plastics and $90 \%$ citizens were worried about chemicals. The data show indicates approximately the same degree of concern for the population in environmental issues in the Visegrad Group. The setting of policies to help address sustainability and environmental issues, as well as environmental CSR strategies, varies from country to country.

To meet the goals of the European Union for 2020, the Slovak Republic has the most inefficient set environmental goals from the V4 countries. The main reason is the high concentration of industrial production in the Slovak Republic, which reduces the possibility of positive ecological indicators. Failing to adopt the circular economy model will only increase the challenge and widen the existing regional disparities. The new 2018-2030 Environment Strategy is expected to put greater focus on the circular economy in Slovakia. Furthermore, the 2030 economic policy will introduce an updated raw materials policy which covers circular economy principles. Agenda 2030 vision for Slovakia is also under the preparation. These documents should assist Slovakia in ensuring policy coherence (ec.europa.eu, 2019). Support for ecological and green solutions in the field of sustainability policy could help Slovak entrepreneurs in creating a sufficiently effective strategy for socially responsible business. A new logistical solution for waste management, together with educational activities in the field of ecology, could provoke a higher degree of initiative on the part of the final consumer and the population, thus meeting the environmental goals set by the European Union. If such a solution exists in the V4 countries, Slovakia could request cooperation in its adaptation. When the Hungarian Ministry of Agriculture hosted a TAIEX-EIR Peer 2 Peer workshop on 17-18 May 
2018, experts from Finland, the Netherlands and Slovenia, which are more advanced in process of developing circular economy policy, shared their experiences with government experts from Hungary, the Czech Republic, Slovakia and Poland. This is an exact example of cooperation needed in creating an environment for effective socially responsible business strategies.

Hungary's fourth (2015-2020) national environmental programme is a strategic six-year plan for environmental and nature protection. It encompasses several different strategies and could therefore be a good starting point for the transition towards a circular economy. This programme identifies resource efficiency as a priority. Hungary set out its national smart specialisation strategy in 2014 with clean and renewable energies and sustainable environment as priority areas. In the 2017, a suggested action for Hungary was to develop an overarching circular economy policy framework. However, there are key challenges in this process, in particular the lack of institutional coordination and the lack of dedicated funding. Initial dialogues and consultation mainly involve the waste management sector (ec.europa.eu, 2019).

In 2015, the Minister for Economic Development of Poland set up a multi-stakeholder group tasked with developing a circular economy roadmap. In January 2018, the roadmap for 'Transformation towards a Circular Economy was opened for public consultation. The roadmap will cover four main strategic areas:

- Sustainable industrial production

- Sustainable consumption

- The bioeconomy

- New business models

However, while Poland may expect improvements in eco innovation investment and activities in the coming years, the overall shift towards a more resource-efficient economy will require long-term systemic innovation (ec.europa.eu, 2019). In Czechia, the country has no specifically dedicated national circular economy strategy or roadmap yet. Preparations for establishing a national strategy called "Circular Czech Republic 2040" are still at an early stage, adoption is expected in 2020 (ec.europa.eu, 2019). Outside the Slovak Republic, the V4 countries have at least defined areas of interest in creating a circular economy necessary to meet the environmental objectives of the whole community.

\section{Conclusion}

This paper aimed to examine the existing similarities in the solution of environmental issues, focusing on the circular economy and waste management of the Visegrad Group countries. The historical interconnection of countries points to the persistent attitude of the population to ecological issues. In a Europe-wide survey, the people of the V4 countries expressed interest in issues related to business sustainability and natural pollution. Legislatively, however, we find differences that complicate companies in building a sufficiently functioning environmental CSR strategy. In the future, the cooperation of the Visegrad Group countries would be welcome. Countries would gain different perspectives on the same issues and experts who can bring innovative ideas and ways to implement them. 


\section{References}

[1] Castro-González, S., Bande, B., Fernández-Ferrín, P., \& Kimura, T. (2019). Corporate social responsibility and consumer advocacy behaviors: The importance of emotions and moral virtues. Journal of Cleaner Production. doi:10.1016/j.jclepro.2019.05.238

[2] Chao AC, Hong L, Corporate Social Responsibility Strategy, Environment and Energy Policy, Structural Change and Economic Dynamics (2018), https://doi.org/10.1016/j.strueco.2018.11.010

[3] Chuah, S. H.-W., El-Manstrly, D., Tseng, M.-L., \& Ramayah, T. (2020). Sustaining customer engagement behavior through corporate social responsibility: The roles of environmental concern and green trust. Journal of Cleaner Production, 262, 121348. doi: 10.1016/j.jclepro.2020.121348

[4] Cramer, J. M. (2008). Organising corporate social responsibility in international product chains. Journal of Cleaner Production, 16(3), 395-400. doi:10.1016/jjclepro.2007.01.007

[5] Dey PK, Petridis NE, Petridis K, Malesios C, Nixon JD, Ghosh SK, Environmental management and corporate social responsibility practices of small and medium-sized enterprises, Journal of Cleaner Production (2018), doi: 10.1016/j.jclepro.2018.05.201

[6] European Commission, Report From The Commission To The European Parliament, The Council, The European Economic And Social Committee And The Committee Of TheRegion,https://ec.europa.eu/environment/waste/pdf/waste_legislation_implementation_report.pdf

[7] European Union Statistics, Key Figures on Europe, https://ec.europa.eu/eurostat/cache/digpub/keyfigures

[8] European Union, The Environmental Implementation Review 2019, Country Report Czech Republic, https://ec.europa.eu/environment/eir/pdf/report_cz_en.pdf

[9] European Union, The Environmental Implementation Review 2019, Country Report Hungary, https://ec.europa.eu/environment/eir/pdf/report_hu_en.pdf

[10] European Union, The Environmental Implementation Review 2019, Country Report Poland, https://ec.europa.eu/environment/eir/pdf/report_pl_en.pdf

[11] European Union, The Environmental Implementation Review 2019, Country Report Slovakia, https://ec.europa.eu/environment/eir/pdf/report_sk_en.pdf

[12] Eurostat,https://ec.europa.eu/eurostat/tgm/refreshTableAction.do?tab=table\&plugin=1\&pcode=t2020_rt120 \&language $=$ en

[13] Kovács, G. (2008). Corporate environmental responsibility in the supply chain. Journal of Cleaner Production, 16(15), 1571-1578. doi:10.1016/j.jclepro.2008.04.013

[14] Pop, O., Dina, G. C., \& Martin, C. (2011). Promoting the corporate social responsibility for a green economy and innovative jobs. Procedia - Social and Behavioral Sciences, 15, 1020-1023. doi:10.1016/j.sbspro.2011.03.232

[15] Mohsin Shahzad, Ying Qu, Saad Ahmed Javed, Abaid Ullah Zafar, Saif Ur Rehman, Relation of Environment Sustainability to CSR and Green Innovation: A Case of Pakistani Manufacturing Industry, Journal of Cleaner Production (2019), https://doi.org/10.1016/jjclepro.2019.119938

[16] Mousami Prasad, Trupti Mishra, Varadraj Bapat, Corporate Social Responsibility and Environmental Sustainability: Evidence from India using Energy Inten-sity as an indicator for Environmental Sustainability, IIMB Management Review (2019), doi: https://doi.org/10.1016/j.iimb.2019.07.014

[17] Seyyed-Mahdi Hosseini-Motlagh, Samira Ebrahimi, Roza Zirakpourdehkordi, Coordination of dual-function acquisition price and corporate social responsibility in a sustainable closed-loop supply chain, Journal of Cleaner Production (2019), https://doi.org/10.1016/j.jclepro.2019.119629

[18] Suganthi, L. (2019). Examining the relationship between corporate social responsibility, performance, employees' pro-environmental behavior at work with green practices as mediator. Journal of Cleaner Production. doi:10.1016/jjclepro.2019.05.295

[19] Suki, N. M., Suki, N. M., \& Azman, N. S. (2016). Impacts of Corporate Social Responsibility on the Links Between Green Marketing Awareness and Consumer Purchase Intentions. Procedia Economics and Finance, 37, 262-268. doi:10.1016/s2212-5671(16)30123-x 
[20] The Schwarz Group, https://reset-plastic.com/en/recycle/

[21] Visegrad Group, History of Visegrad Group, http://www.visegradgroup.eu/about

[22] Xia, B., Olanipekun, A., Chen, Q., Xie, L., \& Liu, Y. (2018). Conceptualising the state of the art of corporate social responsibility (CSR) in the construction industry and its nexus to sustainable development. Journal of Cleaner Production, 195, 340-353. doi: 10.1016/j.jclepro.2018.05.157

[23] Wu, D., Lin, C., \& Liu, S. (2016). Does community environment matter to corporate social responsibility? Finance Research Letters, 18, 127-135. doi:10.1016/j.frl.2016.04.010 


\title{
Importance of New Marketing Trends and their Application by Slovak Wine Companies
}

\author{
Erik Janšto ${ }^{1}$, Klara Hennyeyová ${ }^{2}$, Peter Polakovič ${ }^{3}$, Edita Šilerová ${ }^{4}$, Galina Gerhátova ${ }^{5}$ \\ Slovak University of Agriculture in Nitra \\ Faculty of Economics and Management, Department of Informatics ${ }^{1,2,3,5}$ \\ Address: Tr. A. Hlinku 2 \\ 94976 Nitra, Slovakia \\ Czech University of Life Sciences in Prague \\ Faculty of Economics and Management, Department of Information Technologies ${ }^{4}$ \\ Address: Kamýcká 129 \\ Praha 6 - Suchdol, Czech Republic \\ e-mail: xjansto@is.uniag.sk¹, klara.hennyeyova@uniag.sk², peter.polakovic@uniag.sk³, \\ silerova@pef.czu.cz ${ }^{4}$,galina.gerhatova@uniag.sk ${ }^{5}$ \\ doi: 10.18515/dBEM.ISD.P01.2020.p012
}

\begin{abstract}
Marketing communications trends are gradually becoming an integral part of the development in the marketing world. It is confirmed particularly increasing the use of digital tools in practice, increasing the number of publications in this field and implementing digital strategies in companies. The main aim of our research is to determine the effect of wine producer's propagation and digital activities on marketing success indicators. We will utilise primary data using a Likert scale and analyse data using multiple regression analysis. In conclusion, the study will set out to address the question of human resources capabilities and the main barriers to implementing marketing activities, which will support our analysis.
\end{abstract}

Keywords: propagation, wine, digital marketing,

JEL Classification: L66, M31, M39

\section{Introduction}

Marketing communication and marketing have gone through several innovations. The traditional concept focuses on target groups that are less attractive and replaced by modern approaches. Marketing has a natural development that causes considerable effects on the market and in consumer behaviour. In a commercial environment, marketing is a competitive market. For each European country, including Slovakia, where wine has a historical and social character, the market becomes highly fragmented in terms of both products and competition. The use of digital marketing tools to communicate with customers develops slow pace (unfortunately, sometimes at the elementary level) but is considered a critical competitive advantage. Therefore, the chance to increase to a higher level of wine marketing should significantly increase by using modern marketing trends and tools. The concept of the marketing mix is natural and comprehensive for each sector, with some contextualization (Lauterborn, 1990). For the wine sector, the focus of the marketing mix is gradually shifting from tangible assets to intangible assets - from consumer goods to customer experience (Berkowitz, Kerin and Rudelius, 1989). According to Harrell and Armstrong (2008) wine producers should not underestimate communication with the customer, they cannot expect that good wine at an attractive price and with good access to the customer can be automatically high 
demand. In the wine industry, there is much competition, so it essential that wine producers have to communicate with their customers. Communication is considered to be a strategic marketing process that forms part of customer value creation activities (Trivedi and Morgan, 1996). Therefore, it assumed that the communication strategies adopted by companies lead to customer satisfaction (EL-Ansari, 2006). A growing number of businesses are using measures to meet customer needs to develop, track and evaluate products and services (Yeung, Lee Chew and Ennew, 2002). The company's ability to satisfy customers provides a sustainable competitive advantage that is essential in today's competitive global environment (Smith \& Wright, 2004). It should be noted that information and communication technologies are an increasingly important factor in the promotion and achievement of business objectives (Host'ovecký et al., 2015). The gradual development has shown that information and communication technologies (ICT) help to create value enabling support business processes that generate profit (Hallová et al., 2017). According to Kramer, Jenkins and Katsa (2007), several vital attributes characterize the role of ICT in modern marketing and development. ICT offers instant connectivity, improve efficiency, accuracy and transparency of voice, data and visual information. It is an adequate substitute for other means of communication and transactions. It reduces costs and helps to increase productivity.

Internet boom for companies and people's daily lives has brought a profound transformation of marketing and its tools and strategies. Although companies understand the Internet as a new channel to increase their awareness, soon they began to look for ways to maximize their differences on the platforms and online services. Online marketing communication is an integral part of operational marketing in terms of progress in specific marketing lines known as digital marketing (Krishnamurthy, 2006). Digital marketing is adaptive; technologically supported the process by which companies collaborate with customers and partners to jointly create, communicate, deliver and sustain value for all stakeholders (Kannan and Li, 2017). In uncertain economic times, it is impossible to ignore trends. Companies need to be sure that they bring value to customers for their current needs. According to Tasner (2010), the main changes that have begun to change marketing strategies dramatically have been the way to use the Internet daily. Significant trends in this area occurred in sharing content, creativity, segmentation, social components and the added functionality. The development of marketing has brought new forms of effective communication, which potential customers perceive in different ways. The power of traditional advertising media remains in the new media environment (Nunes and Merrihue, 2007). Research in the field of communication continue to be engaged in many interesting, relevant topics which, for example, show how the informative advertising to create brand awareness and knowledge about new products or new features of existing products (Barros Llobet, 2012; Amaldoss and He, 2010), the role of advertising (Reinartz and Saffert, 2013), comparative advertising effects (Thompson and Hamilton, 2006) competitive advertising (Danaher et. al., 2008), estimated response functions (Vakratsas et al., 2004; Freimer and Horsky 2012; Thaivanich et al., 2000) or re-marketing effects (Malaviya 2007). Event marketing, which is no longer a new concept, still has a broader application. It is considered an overarching tool that uses specific communication tools to stage the experience. Another unique form of business with a value-added technology, sending and saving options for reporting is the mobile marketing that is fast, cheap and reaching to all markets regardless of the limitation of message content. Through the use of applications and personalized information access to rich content and system of the mobile phone is perceived as a useful tool for customer acquisition and development of consumer bases (Baines et. al., 2013). Integrated mobile and social media strategies have become essential success factor for best brands (Butcher, 2011) To use Buzzmarketing through Word of mouth, marketers should provide 
consumers with unique information and encourage them to talk with members of the strong bond as friends and family. Strategies for strong links in WOM campaigns are more effective than campaigns without them. Given the patterns of creation of strong and weak linkages vary considerably within the online and offline platforms (Phua et al., 2017). Strategy can be optimized by identifying the right platform for this purpose. Companies or businesses choose which forms of communication will be most cost-effective in achieving the objectives of sales and brand properties (Risselada et al., 2014; Katona et al., 2011). New trends have always had a smaller and broader impact on changes in marketing strategies. Therefore, businesses at wine industry should understand their opportunities and options and choose the most relevant and useful tools to help them capture the wave of trend and thus develop their business.

\section{Data and Methods}

For the collection and processing of data, we used the following research methods: analysis of the available information sources, Quantitative research: a questionnaire for wine producers in Slovakia.

We targeted 198 wine producers in Slovakia; however, we managed to get 80 completed questionnaires. To find out the primary data, we utilize a Likert type questionnaire in which wine producers had the choice of 5 scales. Set of questions were focused on respondents' companies' methods to the propagation and digital communication on a scale of $1-5$ (strongly disagree, and 5 strongly agree).

The questionnaire was filled in by the staff responsible for marketing, communication or the company executive. To fulfil the stated goal of the article, we have defined the following hypotheses:

H1: There is a statistically significant correlation between promotional practices and brand awareness.

We assume that propagation practices in wine sector affect non-financial indicator.

$\mathrm{H} 2$ : There is a statistically significant correlation between digital practices and new customers.

We assume that digital marketing activities carried influence on acquiring new customers.

Before processing data, all records checked for completeness and consistency and logical answers. Subsequently, the data were processed in Microsoft Excel and partially using the SPSS ${ }^{\circledR}$ for WindowsTM statistical program. Our data we analysed by multiples regression analysis. We tested data for the possibility of multicollinearity using Pearson Correlation and Variance inflation Factors. In all the results, we did not find any problem. Our data passed the test of reliability using Cronbach Alpha. Both scales had variable values above 0.50 , which is considered an acceptable level.

\section{Results and Discussion}

Comparing data consisted of businesses in the wine sector, in particular, 47 micro and 33 small companies. The sizes of the companies were selected according to the number of employees. In the questionnaire, we mainly focused on companies from all wine-producing regions of Slovakia. Regions are represented with Malokarpatska (43 \%), Juznoslovenska (21 \%), Nitrianska (15\%), Východoslovenska (11\%), Stredoslovenska (5\%), Tokaj (5\%). Other 
classification data include legal form, years of operation, vineyard size, location and marketing indicators of success.

\section{Propagation practices}

As we can see in Figure 1, Propagation practices mean values range from 2,38 to 3,45. Wine companies mainly used promotion practices through Word-Of-Mouth $($ PN_P6 $=3.45)$ and organizing wine tours (PN_P2 $=3,45)$. It is interesting to note that use of social media (PN_P9 $=3,24)$ has a higher score than print advertising $\left(\mathrm{PN} \_\mathrm{P} 3=2,78\right)$. Less used practices are online advertising (PN_P4 $=2,94)$, use customer reviews in your ad (PN_P5 $=2,86$ ) and sponsorship events (PN_P8 $=2,75)$. The least interesting for wine producers are active engagement in PR $\left(\mathrm{PN} \_7=2,59\right)$ and participation in fairs and presentations $(\mathrm{PN} \mathrm{P} 1=2,38)$.

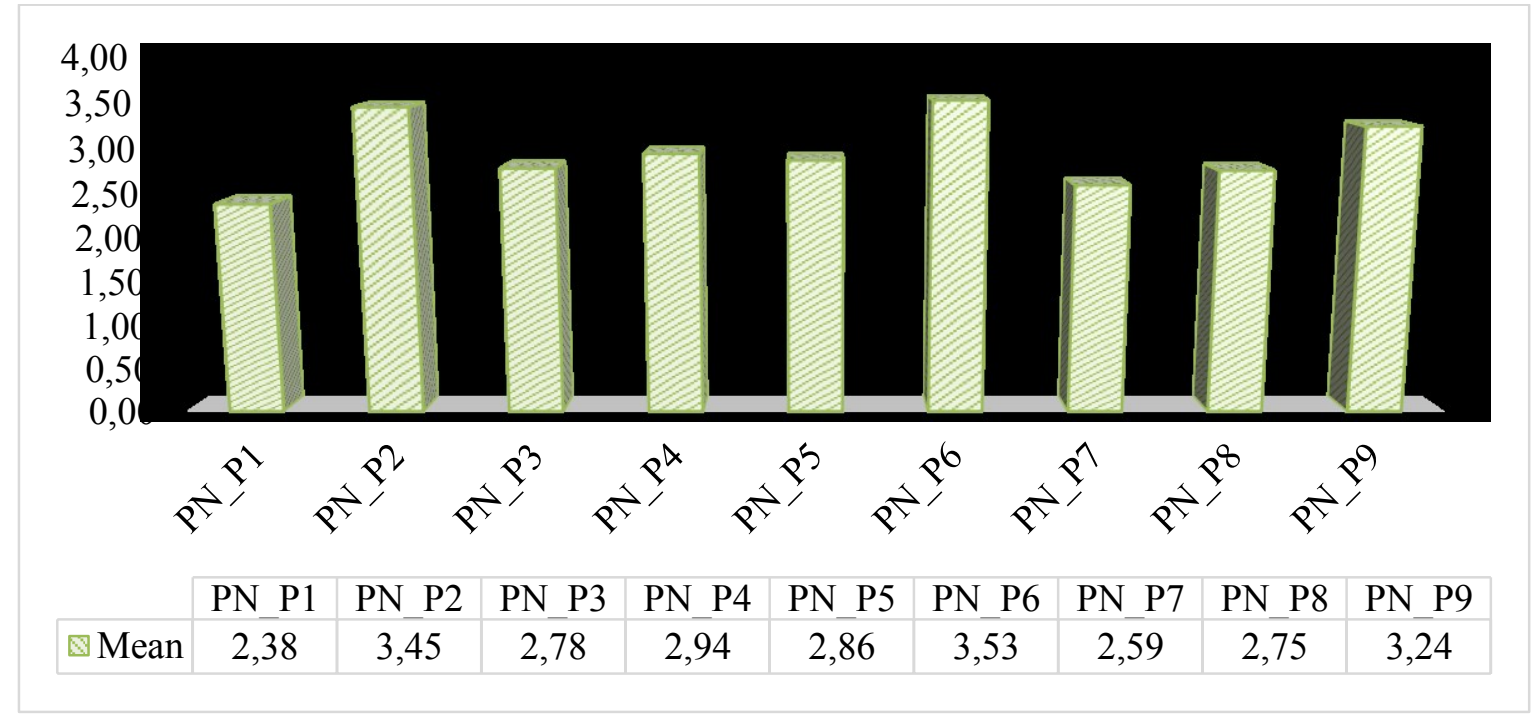

Figure 1: Propagation practices of wine producers

Source: own processing, 2020

The model is significant at the level of alpha 0.01 ; the model variability is $38 \%$. This is a relatively low dependency, so we have verified the dependency through a correlation matrix. We conclude that the model is suitable for describing dependency, but it is not appropriate to describe dependencies between some variables.

Table 1: Model Summary of propagation practices of wine producers

\begin{tabular}{|l|l|l|l|l|l|l|l|l|l|}
\hline Model & $\mathbf{R}$ & $\mathbf{R}$ & $\begin{array}{l}\text { Adjuste } \\
\text { Square }\end{array}$ & $\begin{array}{l}\text { Std. Error of } \\
\text { Square }\end{array}$ & & & \multicolumn{2}{l|}{ Change Statistics } \\
\cline { 5 - 9 } & & & & $\begin{array}{l}\text { R Square } \\
\text { Change }\end{array}$ & $\begin{array}{l}\text { F } \\
\text { Change }\end{array}$ & df1 & df2 & $\begin{array}{l}\text { Sig. F } \\
\text { Change }\end{array}$ \\
\hline $\mathbf{1}$ &, $616^{\mathrm{a}}$ &, 380 &, 279 &, 6159352004 &, 380 & 3,782 & 11 & 68 &, 000 \\
\hline
\end{tabular}

Source, own calculation, 2020

Table 2 presents the coefficients results between the variables. The regression analysis shows that propagation practices had a positive and significant correlation with brand awareness 
(sig. 0,037) and vineyard size (sig. 0,010). However, we did not find any significant correlation on other variables. This indicates an increase in brand awareness significantly contributes to increased promotional activities. The results also indicate that build a relationship with a brand can lead to positive expansion to manage larger areas of vineyards. Regression results supported hypothesis 1 : $(\beta=0,236 ; p<0,01)$.

Table 2: Coefficient results of propagation practices, classification variables and marketing success indicators

\begin{tabular}{|c|c|c|c|c|c|c|c|c|}
\hline \multirow{2}{*}{\multicolumn{2}{|c|}{ Model }} & \multicolumn{2}{|c|}{$\begin{array}{l}\text { Unstandardized } \\
\text { Coefficients }\end{array}$} & \multirow{2}{*}{$\begin{array}{l}\text { Standardized } \\
\text { Coefficients } \\
\text { Beta }\end{array}$} & \multirow{2}{*}{$\mathbf{t}$} & \multirow{2}{*}{ Sig. } & \multicolumn{2}{|c|}{$\begin{array}{l}\text { Collinearity } \\
\text { Statistics }\end{array}$} \\
\hline & & B & $\begin{array}{l}\text { Std. } \\
\text { Error }\end{array}$ & & & & Tolerance & VIF \\
\hline \multirow[t]{12}{*}{1} & (Constant) & 1,719 & ,454 & & 3,791 &, 000 & & \\
\hline & Legal form & ,042 & ,047 & ,098 & ,896 & ,373 & ,759 & 1,317 \\
\hline & Size &,- 009 & ,234 &,- 006 &,- 040 & ,968 & ,357 & 2,801 \\
\hline & $\begin{array}{l}\text { Years of } \\
\text { operation }\end{array}$ & , 154 & ,106 & ,161 & 1,453 & ,151 & ,741 & 1,349 \\
\hline & Location & ,045 & ,048 & ,097 & ,931 & ,355 & ,841 & 1,189 \\
\hline & $\begin{array}{l}\text { Vineyard } \\
\text { size }\end{array}$ & ,245 & ,093 & ,417 & 2,651 & ,010 & ,369 & 2,707 \\
\hline & I_Sales &,- 028 &, 073 &,- 042 &,- 381 & ,704 &, 735 & 1,361 \\
\hline & $\begin{array}{l}\text { I_Market } \\
\text { share }\end{array}$ &,- 078 & ,086 &,- 103 &,- 902 & ,370 & ,703 & 1,423 \\
\hline & $\begin{array}{l}\text { I_New } \\
\text { customers }\end{array}$ & ,142 & ,072 & ,228 & 1,965 & ,053 & ,680 & 1,470 \\
\hline & $\begin{array}{l}\text { I_Brand } \\
\text { awarness }\end{array}$ & , 177 &, 083 & ,236 & 2,130 & ,037 &, 745 & 1,342 \\
\hline & I_Loyalty &,- 152 &, 085 &,- 201 & $-1,790$ & ,078 & ,726 & 1,377 \\
\hline & I_ROI &,- 058 & ,072 &,- 085 &,- 801 & ,426 & ,804 & 1,243 \\
\hline
\end{tabular}

\section{a. Dependent Variable: PN_AVG}

\section{Cronbach alpha: 0,819}

Source: own calculation, 2020

\section{Digital marketing activities}

The results of the research indicate that the companies involved in wine production mainly used email marketing (D_M7 $=3,7)$ to contact potential customers. It is important create a valuable and interesting content (D_M5 $=3,28)$, and build a relationship with people through social media (D_M3 =3,14). Wine producers also cooperate with external vendors, respectively. with affiliate partners (D_M4 $=2,93)$. They use slightly less performance marketing - PPC (D_M2 $=2,85)$, mobile marketing $\left(\mathrm{D} \_\mathrm{M} 9=2,73\right.$ ) and SEO optimization of website or e-shop 
$\left(\mathrm{D} \_\mathrm{M} 1=2,66\right)$. The least attractive for wine producers are viral marketing $\left(\mathrm{D} \_\mathrm{M} 8=2,51\right)$ as well influencer marketing (D_M6 = 2,01).

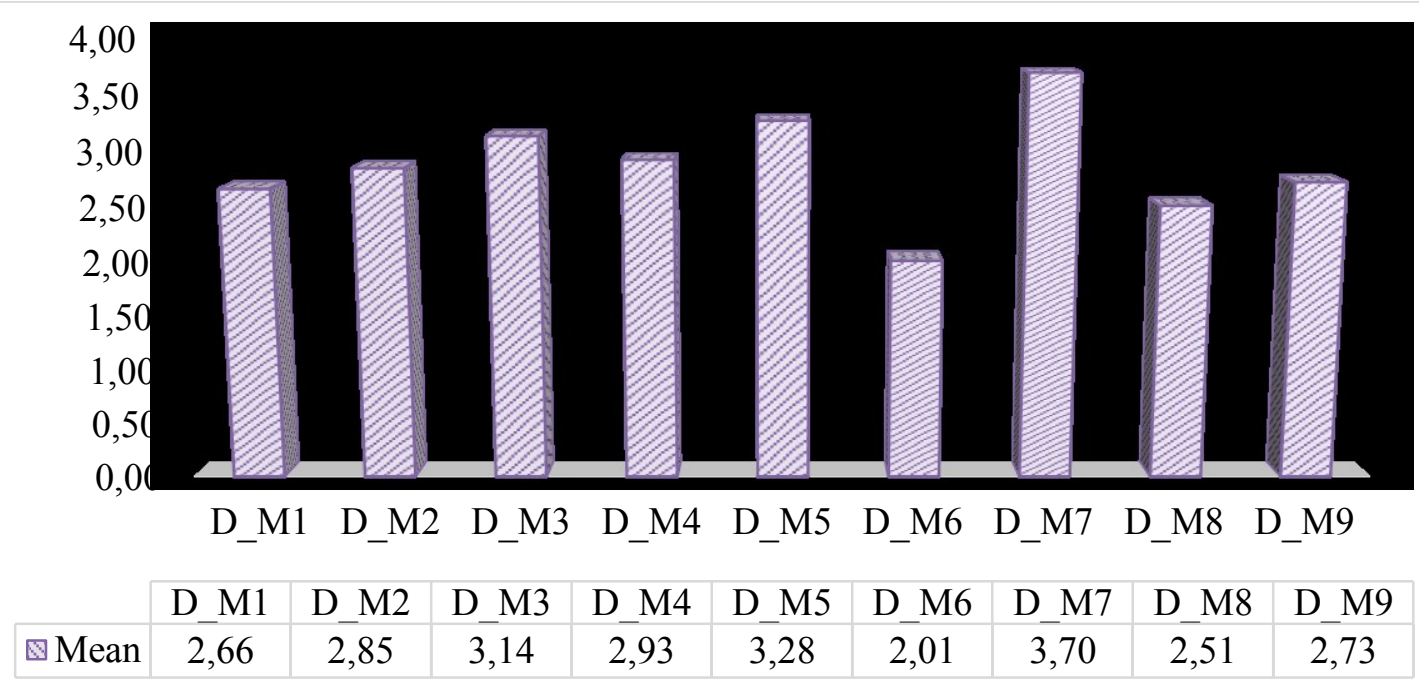

Figure 2: Digital marketing activities of wine producers

Source: own calculation, 2020

Next model is statistically significant at the level of alpha 0.01 ; however, variability level is $35 \%$. This is a relatively low dependency, so we have verified the dependency through a correlation matrix. We conclude that the model is suitable for describing dependency, but it is not appropriate to describe dependencies between some variables.

Table 3: Model Summary of digital marketing activities of wine producers

\begin{tabular}{|l|l|l|l|l|l|l|l|l|l|}
\hline Model & R & $\begin{array}{l}\text { R } \\
\text { Square }\end{array}$ & $\begin{array}{l}\text { Adjusted } \\
\text { R Square }\end{array}$ & $\begin{array}{l}\text { Std. Error of } \\
\text { the Estimate }\end{array}$ & \multicolumn{2}{l|}{ Change Statistics } \\
\cline { 5 - 10 } & & & $\begin{array}{l}\text { R } \\
\text { Square } \\
\text { Change }\end{array}$ & $\begin{array}{l}\text { F } \\
\text { Change }\end{array}$ & df1 & df2 & $\begin{array}{l}\text { Sig. F } \\
\text { Change }\end{array}$ \\
\hline $\mathbf{1}$ &, $593^{\mathrm{a}}$ &, 351 &, 246 &, 6626284982 &, 351 & 3,344 & 11 & 68 &, 001 \\
\hline
\end{tabular}

a. Predictors: (Constant), Legal form, Size, Years of operation, Location, Vineyard size, I_Sales, I_Market share, I_New customers, I_Brand awarness, I_Loyalty, I_ROI

Source: own calculation, 2020

Table 4 reports the regression results. The regression analysis shows that digital marketing had a positive and significant correlation with acquiring new customers (sig. 0,013). On the other hand, the result shows a significant and negative correlation with the return of investment (sig. 0,017). In the other variables, we have not to notice significance. Positive acquiring new customers significantly contributes to increased activities in the digital area. The results also indicate that increase return of investment harms digital marketing. Regression results supported hypothesis 2 : $(\beta=0,301 ; p<0,01)$. 
Table 4: Coefficient results of digital marketing activities, classification variables and marketing success indicators

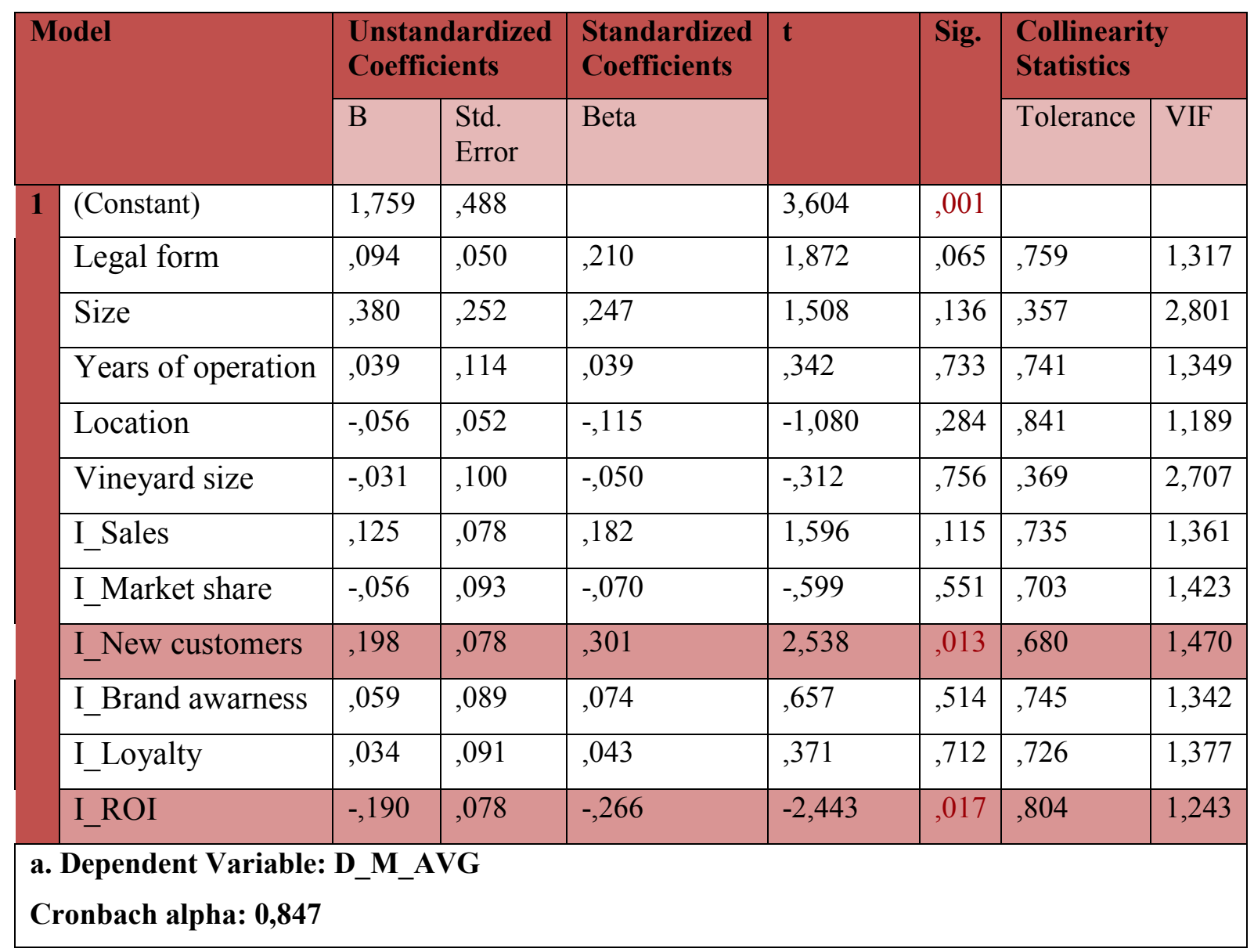

Source: own calculation, 2020

The study focused on the question of whether the promotional and digital activities currently in use affect some marketing success indicators. First of all, with existing literature, brand awareness affects the ability to access business promotions. Secondly, smaller wineries are more dependent on the reputation of their products, that is why most wine producers using Word-Of-Mouth in the region or directly where the products are sold. Thus, solutions have a competitive advantage if selected tools are used to a sufficient extent.

Thirdly, acquiring new customers was found to affect company digital marketing activities. Companies have more access to extended data through internet and analytical tools, which play an important role in current strategies. These information's are an essentials ingredient for a new opportunity to be success on market.

\section{Marketing management}

The next question aimed to find out who carried out (in charge) in companies marketing activities. The questioning included the employees who manage the marketing into a particular group, according to marketing knowledge and actual implementation. To a large extent, there are companies that have no marketing staff. Marketing activities are transferred to business owner $(31 \%)$, sales representative $(20 \%)$ or external company $(3 \%)$. On the other hand, a full 
$46 \%$ have a marketing employee whom they think is a specialist in the field and devotes most of their efforts to marketing and communication.

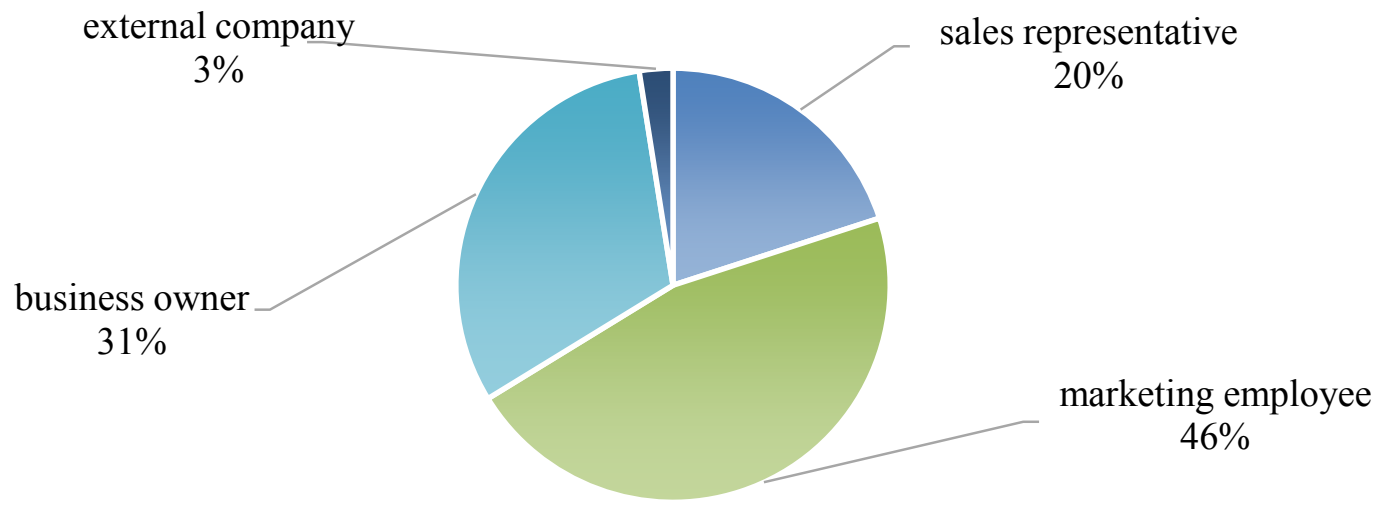

Figure 3: Human resources provide marketing in wine sector

Source: own processing, 2020

The main underlying barriers include lack of human resources $(65,6 \%)$. It can be caused by business owners, which in many cases take responsibility for management of marketing activities. That is also associated with second barrier - low digital literacy $(60,1 \%)$, where many employees have a different duty, job description and have not a lot of time to improve their skills in marketing area. Half of the wine producers agree with the difficult implementation of marketing activities, especially in terms of time. Last but not least respondents see barriers in lack of financial resources $(46,5 \%)$ and too expensive services $(35,2 \%)$. For a few wine producers are not necessarily further marketing activities $(3,5 \%)$ for their operations.

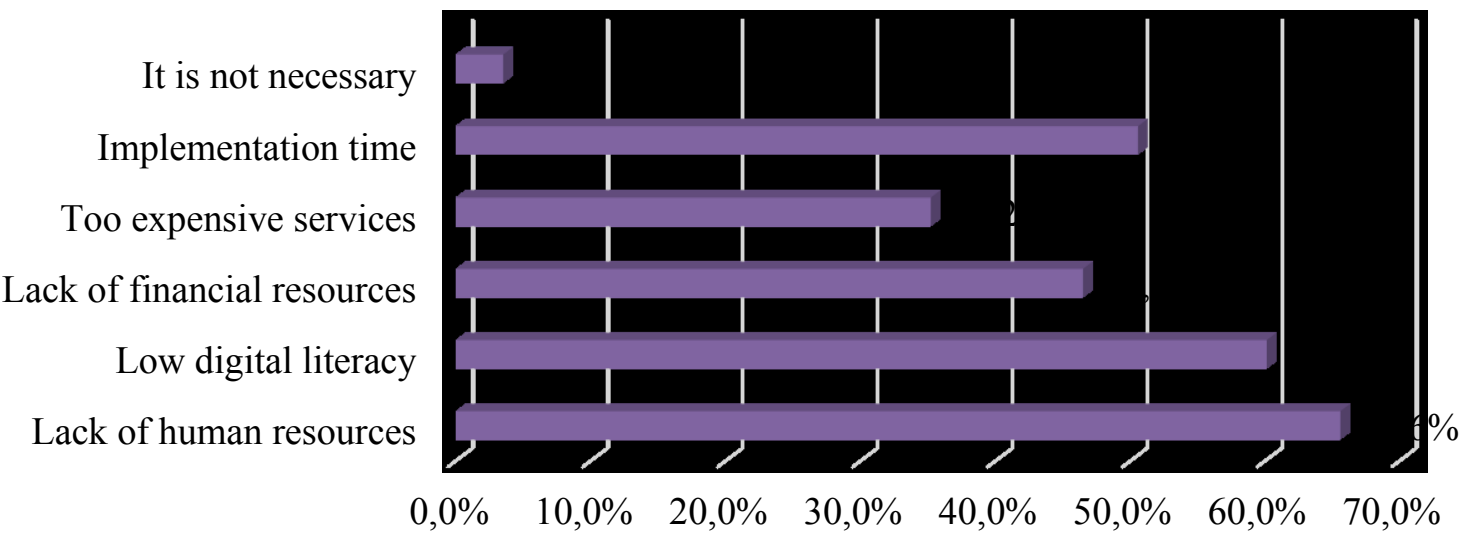

Figure 4: Main barriers to further marketing activities

Source: own processing, 2020

\section{Conclusion}

Marketing and media are undergoing dynamic development. This development is linked to the search for "new ways". For these new ways, we consider digital marketing tools and media. 
Their importance in the commercial world is strengthened continuously and therefore have their place and also used in the wine sector. Digital marketing is gradually becoming an essential part of the communication mix. A suitable combination of classic and digital methods can streamline marketing communications. Digital marketing is something normal and typical for a new generation of young people. Wine producers cannot only adapt to digital time, but also have to determine trends in communication. This article aimed to identify and describe the influence current propagation and digital activities focusing on marketing success indicators. The fulfilment of this objective should contribute to enhancing knowledge about marketing in this sector. Slovak wine sector is undergoing a slow restoration of marketing and digital activities just starting to implement. So, if companies solve main barriers and implementation processes, with the correct distribution of assets, time, resources and people, wine companies will be able to improve the current marketing situation.

\section{References}

[1] Amaldoss, W. And He CH. (2010) Product Variety, Informative Advertising, and Price Competition. Journal of Marketing Research 47 (February), pp. 146-56, DOI: https://doi.org/10.1509/jmkr.47.1.146.

[2] Baines, P., Fill, Ch., Page, K. (2013) Essentials of Marketing. OUP Oxford, 2013. p. 413, ISBN: 9780199646500

[3] Barroso, A. and Llobet, G. (2012) Advertising and Consumer Awareness of New, Differentiated Products. Journal of Marketing Research, 49 (December), pp. 773-792, DOI: http://dx.doi.org/10.1509/jm.15.0419

[4] Berkowitz, E.N., Kerin, R.A. and Rudelius, W. (1989) Marketing Bostom, MA: Irwin. International edition, ISBN: 0-07-116830-3

[5] Butcher, 2011. Mobile most effective medium for initiating dialogue with consumers: Experian, available online: https://www.mobilemarketer.com/ex/mobilemarketer/cms/news/research/9580.html

[6] Danaher, P. J., Bonfrer, A., and Dhar S. (2008) The Effect of Competitive Advertising. Journal of Marketing Research, 45 (April), pp. 211-25

[7] El-Ansary, A. I. (2006). Marketing strategy: taxonomy and frameworks. European Business Review, 18(4), 266-293.

[8] Freimer, M., and Horsky D. (2012) Periodic Advertising Pulsing in a Competitive Market. Marketing Science, 31 (July-August), pp. 637-648

[9] Hallová, M., Polakovič, P., And Slováková, I. (2017) Current Trends in Training of Managers in the Field of Information and Communication Technologies and identifying the barriers to education of managers. AGRIS on-line Papers in Economics and Informatics, Vol. 9, No. 4, pp. 45-52. ISSN 1804-1930, DOI 10.7160/aol.2017.090405.

[10] Harrel G., Amstrong G., (2008) Marketing: connecting with customers. 8th ed. Chicago, IL: Chicago Education Press, 586 p. ISBN 09-798-3040-0.

[11] Host’ovecký, M., Mišút, M. And Pribilová, K. (2015) Web based testing in science education. In "Innovations and advances in computing, informatics, systems sciences, networking and engineering: lecture notes in electrical engineering", CISSE 2013 virtual conference, Springer international publishing, Vol. 313, pp. 247254. ISBN 978-3-319-06772-8.

[12] Kannan, P. K. (2017) Digital marketing: A framework, review and research agenda. International Journal of Research in Marketing, 34(1), 22-45.

[13] Katona, Z., Zubcsek, P. P., and Sarvary M. (2011) Network Effects and Personal Influences: The Diffusion of an Online Social Network. Journal of Marketing Research, 48 (June), pp. 425-443

[14] Kramer, W. J., Jenkins, B., \& Katz, R. S. (2007) The role of the information and communications technology sector in expanding economic opportunity. Cambridge, MA: Kennedy School of Government, Harvard University. 
[15] Krishnamurthy S. (2006) Contemporary research in e-marketing. Hershey: Idea Group Inc (IGI)

[16] Lauterborn, R. (1990) New marketing litany: 4P's passé C-words take over. Advertising Age, 61 (41), 26.

[17] Malaviya, P. (2007) The Moderating Influence of Advertising Context on Ad Repetition Effects: The Role of Amount and Type of Elaboration. Journal of Consumer Research ,34 (June), pp. 32-40.

[18] Nunes, P. F., and Merrihue J. (2007) The Continuing Power of Mass Advertising, Sloan Management Review, Winter, pp. 63-69.

[19] Phua, J., Jin, S. V., \& Kim, J. J. (2017) Gratifications of using Facebook, Twitter, Instagram, or Snapchat to follow brands: The moderating effect of social comparison, trust, tie strength, and network homophily on brand identification, brand engagement, brand commitment, and membership intention. Telematics and Informatics, 34(1), 412-424

[20] Reinartz, W., and Saffert P. (2013) Creativity in Advertising: When It Works and When It Doesn't. Harvard Business Review, June, pp. 107-112.

[21] Risselada, H., and Verhoef, P. C., and Bijmolt T. H.A. (2014) Dynamic Effects of Social Influence and Direct Marketing on the Adoption of High-technology products. Journal of marketing, 78 (march), pp. 52-68

[22] Smith, R. E., and Wright, W. F. (2004) Determinants of Customer Loyalty and Financial Performance. Journal of Management Accounting Research, 16, 183- 205.

[23] Tasner, M. (2010) Marketing in the Moment: The Practical Guide to Using Web 3.0 Marketing to Reach Your Customers First. FT Press. ISBN: 9780132101363

[24] Tellis, R. K. CH., and Thaivanich P. (2000) Which Ad Works, When, Where, and How Often? Modeling the Effects of Direct Television Advertising. Journal of Marketing, Research, 37 (February), pp. 32-46.

[25] Thompson, D. V., and Hamilton R.W. (2006) The Effects of Information Processing Mode on Consumers' Responses to Comparative Advertising. Journal of Consumer Research, 32 (March), pp. 530-40.

[26] Trivedi, M., \& Morgan, M. S. (1996) Brand-specific heterogeneity and market-level brand switching. Journal of Product and Brand Management, 5(1), 29-39.

[27] Vakratsas, D., Feinberg F. M., Bass, F. M. and Kalyanaram G. (2004) The Shape of Advertising Response Functions Revisited: A Model of Dynamic Probabilistic Thresholds. Marketing Science, 23 (Winter), pp. 109-19

[28] Yeung, M. C. H., Chew, L. G., and Ennew, C. T. (2002) Customer satisfaction and profitability: A reappraisal of the nature of the relationship. Journal of Targeting, Measurement \& Analysis for Marketing, 11(1), 24-34. 


\title{
Aromachology and its Role in Influencing Consumer Behaviour of Millennials
}

\author{
Zdenka Kádeková ${ }^{1}$, Ingrida Košičiarová ${ }^{2}$, Mária Holotová ${ }^{3}$, Lubica Kubicová ${ }^{4}$, \\ Kristína Predanocyová 5 \\ Slovak University of Agriculture in Nitra \\ Faculty of Economics and Management, Department of Marketing and Trade $1,2,4,5$ \\ Department of Accountancy ${ }^{3}$ \\ Address: Tr. A. Hlinku 2, \\ 94976 Nitra, Slovak Republic \\ e-mail: zdenka_kadekova@yahoo.com¹, ingrida.kosiciarova@gmail.com², maria.holotova@uniag.sk³, \\ kubicova.lubka@gmail.com ${ }^{4}$, kristina.predanocyova@gmail.com ${ }^{5}$
}

doi: 10.18515/dBEM.ISD.P01.2020.p013

\begin{abstract}
Scent strengthens consumer loyalty and perceptions of quality. The fragrances evoke moods and enhance brand recall, so obvious candidates for scent marketing are hotels, transportation providers, retail stores, that too often ignore the possibilities of olfactory marketing. The relationship between sense of smell and ability to retrieve memories and evoke emotions is a proven fact and an established marketing tool. Paper points at Aromachology and its role in influencing consumer behaviour of Millennials. The aim of the present paper was to find out how the scent affects the shopping behaviour of respondents (in our case of Millennials). We wanted to determine what fragrance and where exactly would this target audience appreciate it, so that potential sellers could better reach them. As the main research method, there was used the method of questionnaire survey. The total number of respondents was 325 Millennials. For a deeper analysis of the research objectives, there have been formulated totally eight hypotheses, which were tested by applying the statistical methods of Contingency table chi-square test, Pearson's chi-square test, Cramer's coefficient, and Mantel-Haenszel Chi-Square test. The results of the research show, that most of our respondents think that they had already encountered with the aromatization of retail space; most of them think that the scent of retail space affects them positively in their purchasing decision as it creates a pleasant atmosphere and encourages them to purchase; more than half of them would even buy goods rather in professionally aromatised spaces; and up to $19.69 \%$ of respondents purchased something based on the fact that the store smelled pleasantly.
\end{abstract}

Keywords: aromachology, millennials, consumer behaviour, purchase, scent marketing.

JEL Classification: M31, M32, M39

\section{Introduction}

Nowadays consumer behaviour has an increasing role in launching products on the market (Džupina et al., 2016). Although brand has a huge impact on the consumer's purchasing decision, it is closely related to the products placement in the stores due to the fact that the final purchase decision by the consumer is made in the store or point of sale. The fact is that the environment is the most powerful influence when making the final purchase decision. The choice of the store depends on the customer's knowledge, experiences, beliefs, expectations, attitudes and similar. The consumer above all expects not to get only the product purchased in the store, but to get a range of different services (Gutic and Barbir, 2009). And here is created a space for scent marketing and aromachology. 
The scent launches emotions in people and therefore differentiates various environments. Companies use a variety of activities in order to standardize the scents in their stores and thus differentiate its products and the impact on consumer spending. Consumers stay longer in stores that have a pleasant scent and scent plays a key role in attracting the consumer's attention to the products and the final decision to buy. Scent marketing has become a whole new branch of the former marketing in which companies pay a lot of attention when placing their products on the market. Nowadays companies give equal attention when creating the distinctive scent of the product as well as the scent of the store through which the product will be placed. Since the choice of the store is not random but depends on various factors such as proximity, store design, product range, services offered and similar, it is necessary to examine what impact has the scent compared to other factors in the perception of the store (Doric et al., 2016).

Humans have five senses: hearing, sight, taste, touch, and smell. The sense of smell is the most powerful and influential one. In fact, humans are 100 times more likely to remember something based on scent than any other sense. Along with scent's prevalent connections to memory, it is also the sense that evokes the most powerful emotional response. Appealing to customers' sense of smell creates sales opportunities by putting them in the buying mood (Abassi, 2016).

Aromachology is the science of understanding scent's role in the human decision-making process. According to major players in the scenting industry, scenting can help increase the perceived quality and value of a produce or brand while also increasing customers' linger time. Scent marketing could drive the brand and sales results because it uses the most powerful sense the human body has (Jordan, 2015).

According to a Rockefeller University study, the reminiscent "power" of each of human senses is as follows (Figure 1): touch (1\%), ear (2\%), sight (5\%), taste (15\%), smell (35\%).

\section{Figure 1: The reminiscent "power" of each of human senses}

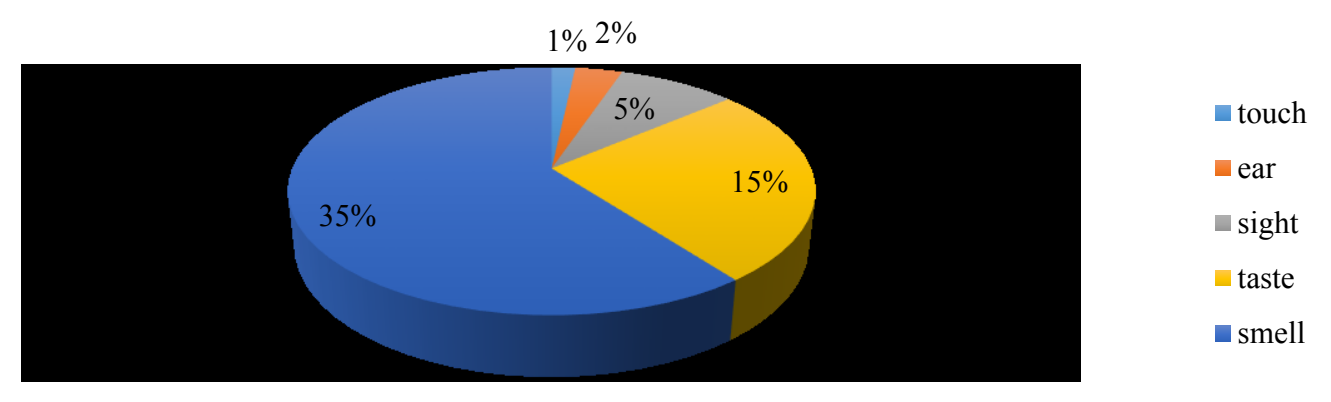

Source: E2 Aroma. (2019). Rockefeller University: How Scent Marketing Could Drive you Results. Available online.

These are the most remembered smells by the costumers as for their great scent by Rockefeller University (2019):

- Baby shampoo,

- The newness of a dealership car,

- Most hospitals cleanliness,

- A bakery's recent bread - has worked great for large supermarkets in-store bakeries.

- The smell of chocolate in a confectionery shop,

- Old books' smell in a library. 
There are several ways to get higher sale involving human senses too. One of the options is a security of stimulating atmosphere of sale, business environment (Berčík et al. 2016). Creating a custom scent or olfactory logo, for a brand is not a one-size-fits-all process. It involves digging deep to discover what the brand represents and who comprises its customer base. It's crucial to pay careful attention to the kind of buying experience the brand is trying to evoke, and what kind of experience it represents. When customers enter an enhanced environment that was created specifically for them, they are likely to feel more comfortable making a purchase. By influencing customers' emotional responses, can be maximized the brand experience, enhanced the selling environment, and ultimately, increased the bottom line (Abassi, 2016).

Knowing consumer's behavior, his preferences and reactions provides company with better chance to establish itself in trade (Géci et al., 2017). The relationship between sense of smell and ability to retrieve memories and evoke emotions is a proven fact and an established marketing tool resulting in increasing sales (E2 Aroma, 2019; Polakevičová, 2015).

\section{Data and Methods}

The aim of the paper was to find out how the scent affects the shopping behavior of respondents (in our case the young generation - Millennials). We wanted to determine what fragrance and where exactly would this target audience appreciate it, so that potential sellers could better reach them.

The total number of respondents was 325 (note - the sample can be considered representative as $n \geq 100$ ), while our attention was focused on the young generation - Millennials, since they represent potential customers who are educable and have the potential to become loyal customers in the future.

As the main research method there was applied the method of anonymous questionnaire survey, which has covered the entire territory of Nitra region. The questionnaire was conducted over the internet and consisted of totally 14 questions divided into two parts - the first part consisted of questions on the subject and the second part consisted of the classification questions. The questionnaire was evaluated using the contingency tables prepared by Microsoft Office Excel, under which they were subsequently created the graphs.

As can be seen from the Table 1, the majority of respondents were women $(75.08 \%)$, respondents under the age of $25(95.38 \%)$, respondents with bachelor's degree $(57.85 \%)$, students $(99.38 \%)$ and respondents from the countryside $(55.08 \%)$.

Table 1: Characteristics of respondents

\begin{tabular}{l|c}
\hline Gender & Number of respondents \\
\hline Men & 81 \\
Women & 244 \\
\hline Age structure & Number of respondents \\
\hline under 25 years & 310 \\
from 26 to 35 years & 15 \\
\hline Educational attainment & Number of respondents \\
\hline Vocational education & 3 \\
Secondary education & 122 \\
University education 1. degree & 188 \\
University education 2.degree & 12 \\
\hline Economic activity & Number of respondents \\
\hline
\end{tabular}




\begin{tabular}{l|c}
\hline Student & 323 \\
Employed & 2 \\
\hline Residence & Number of respondents \\
\hline Town & 146 \\
Village & 179 \\
\hline
\end{tabular}

Source: own research

The collected data were processed out with the use of Microsoft Excel and then evaluated in the statistical program XL Stat and SAS Enterprise Guide 7.1. For a deeper analysis of the research objectives, there have been formulated totally eight hypotheses, which were tested by applying the statistical methods of Contingency table chi-square test, Pearson's chi-square test, Cramer's coefficient and Mantel-Haenszel Chi-Square test.

In hypothesis testing, if the p-value is lower than significant level, in case of XL Stat software, it is 0.05 , the null hypothesis is rejected, and the alternative hypothesis is confirmed (Witek, 2016).

\section{Results and Discussion}

For effective targeting of marketing strategy, it is appropriate to know current internal processes of target groups, as well as their psychological state in the process of purchase (Bulanda et al., 2017) respectively incentives and factors that affect them to a large extent.

Smell is the most powerful and emotional of all the senses. By using scent, brands are able to connect with consumers a deeper emotional level, resulting in a more memorable experience and by that a stronger relationship. Scent cannot just attract new customers, but also increase the sales, heighten value perception and expand brand recognition and customer satisfaction (Air aroma, 2019).

As already mentioned in the section Data and Methods, the aim of our research was to find out how the scent affects the shopping behaviour of the young generation, as well as to determine what fragrance and where exactly would this target audience appreciate it, so that potential sellers could better reach them. For the above reasons, the questions in questionnaire were conceived on respondent's experience with aromatizing of business premises, preferences among a wide range of scents as well as on their opinion which places, they would prefer to be aromatized. Our focus has been on the younger generation, so called Millennials (note - people born after 1996 (Světlík and Bulanda, 2019)), who have common similar characteristics and behaviors, they have been brought up and formed under certain circumstances and they have similar values and reach similar attitudes (Deloitte Millennial Survey, 2016; Deloitte Millennial Survey, 2017), as well as they can become loyal customers, that we can "raise" right now.

The evaluation of our research has revealed several interesting findings, which can serve not just as a basis for similar researches, but also as a guide for sellers who, thanks to the results, can better reach potential customers.

The results of our research show that most respondents stated that they had already encountered with the aromatization of retail space ( $89 \%$ of respondents). The scent of retail space affects them positively in their purchasing decision as it creates a pleasant atmosphere and encourages them to purchase $(78.15 \%$ of respondents) (note - the same result was also confirmed by e.g. Laird, 1935 and Cox, 1969, but we must add that their researches have focused on consumers in general and not just on one segment of them, as it was in our case); more than half of them (51.08\% of respondents) would even buy goods rather in professionally aromatised spaces (also 
confirmed by e.g. Blondeau and Tran, 2009, but again his research was made on consumers in general and not just on one segment of them); and up to $19.69 \%$ of respondents purchased something based on the fact that the store smelled pleasantly. There are also respondents who have never realized that retail spaces can be artificially aromatized and think that the scent cannot affect them in any way in their purchasing decision.

In connection with formulated questions and answers we were interested not only where exactly our respondents experienced the aromatisation, where they would aromatisation appreciate and what kind of scent they would prefer, but also what is the dependence between selected characteristics of respondents and their responses to formulated questions.

For the above reasons, the dependencies between characteristics of respondents and respondents' answers were tested. We tested how the aromatization of the retail unit effects on purchasing behaviour, if the respondents purchased something because the store smelled pleasantly as well as if they would even buy goods rather in professionally aromatised spaces, all in connection to respondents' characteristics.

To verify the given dependencies and their strengths, there were used the statistical methods of Contingency table chi-square test, Pearson's chi-square test, Cramer's coefficient and MantelHaenszel Chi-Square test. As it can be seen from the Tables 2 - 6, interdependencies were confirmed only in the case of dependence between purchase based on pleasantly smelled store and education as well as between preference of professionally aromatised spaces and education. Despite the fact, that the strength of a dependence between variables is considered as low and moderate, we can conclude, that these correlations are still statistically significant.

Table 2: Statistical dependence between the impact of space aromatization on respondents' behaviour and gender.

\begin{tabular}{lrrr}
\hline Statistic & DF & Value & Prob \\
\hline Chi-Square & 2 & 3.0336 & 0.2194 \\
Likelihood Ratio Chi-Square & 2 & 3.9282 & 0.1403 \\
Mantel-Haenszel Chi-Square & 1 & 0.4319 & 0.5111 \\
Phi Coefficient & & 0.0966 & \\
Contingency Coefficient & & 0.0962 & \\
Cramer's V & & 0.0966 & \\
\hline
\end{tabular}

Source: own research, output of SAS Enterprise Guide 7.1

Table 3: Statistical dependence between purchases based on pleasantly smelled store and education

\begin{tabular}{lrrr}
\hline Statistic & DF & Value & Prob \\
\hline Chi-Square & 2 & 0.1371 & 0.9338 \\
Likelihood Ratio Chi-Square & 2 & 0.1361 & 0.9342 \\
Mantel-Haenszel Chi-Square & 1 & 0.0300 & 0.8626 \\
Phi Coefficient & & 0.0205 & \\
Contingency Coefficient & & 0.0205 & \\
Cramer's V & & 0.0205 & \\
\hline
\end{tabular}

Source: own research, output of SAS Enterprise Guide 7.1 
Table 4: Statistical dependence between purchases based on pleasantly smelled store and education

\begin{tabular}{lrrr}
\hline Statistic & DF & Value & Prob \\
\hline Chi-Square & 6 & 23.5394 & 0.0006 \\
Likelihood Ratio Chi-Square & 6 & 24.6021 & 0.0004 \\
Mantel-Haenszel Chi-Square & 1 & 3.8124 & 0.0509 \\
Phi Coefficient & & 0.2691 & \\
Contingency Coefficient & & 0.2599 & \\
Cramer's V & & 0.1903 & \\
\hline
\end{tabular}

Source: own research, output of SAS Enterprise Guide 7.1

Table 5: Statistical dependence between preference of professionally aromatised spaces and gender

\begin{tabular}{lrrr}
\hline Statistic & DF & Value & Prob \\
\hline Chi-Square & 2 & 11.0713 & 0.0039 \\
Likelihood Ratio Chi-Square & 2 & 12.1359 & 0.0023 \\
Mantel-Haenszel Chi-Square & 1 & 5.3126 & 0.0212 \\
Phi Coefficient & & 0.1846 & \\
Contingency Coefficient & & 0.1815 & \\
Cramer's V & & 0.1846 & \\
\hline
\end{tabular}

Source: own research, output of SAS Enterprise Guide 7.1

Table 6: Statistical dependence between preference of professionally aromatised spaces and education

\begin{tabular}{lrrr}
\hline Statistic & DF & Value & Prob \\
\hline Chi-Square & 6 & 23.1364 & 0.0008 \\
Likelihood Ratio Chi-Square & 6 & 24.3657 & 0.0004 \\
Mantel-Haenszel Chi-Square & 1 & 8.3263 & 0.0039 \\
Phi Coefficient & & 0.2668 & \\
Contingency Coefficient & & 0.2578 & \\
Cramer's V & & 0.1887 & \\
\hline
\end{tabular}

Source: own research, output of SAS Enterprise Guide 7.1

As already indicated above, in the questionnaire survey we also focused on the questions related to aromatized spaces - it is widely accepted that aromas show some mental and physiological effects that are often called "aromachology" effects (Tomi et al., 2011). Targeted activities using aromas in a space may be regarded as a tool aimed at influencing the consumer's emotions. Aromatising and neutralising aromas/fragrances is performed not just to refresh the air, but also to create a proper background for presentation of the company offer, to improves its perception, or to create the unique brand image (Tarczydlo, 2014). This is why one of the questions formulated in our questionnaire was related to places where respondents noticed the presence of excessive aroma, they were aware of either in a positive or negative way. On the other hand, we wanted also to know where they would welcome the presence of aromatising units.

As it can be seen from the Figures 2 and 3, basically we can discuss about identical spaces. The most of our respondents is experienced with aromatization mainly in shopping centres, electronics stores, garden centres, car interiors and bakeries (Figure 2); aromatisation would be welcomed in similar premises, but also in places such as the post office, pharmacy and drugstore (Figure 3). As can be seen from these pictures, respondents quite often used the possibility of free answer, where they mentioned e.g. cafés, chocolatiers, pharmacies and perfumeries. 
Figure 2: Places where respondents experienced aromatising of space

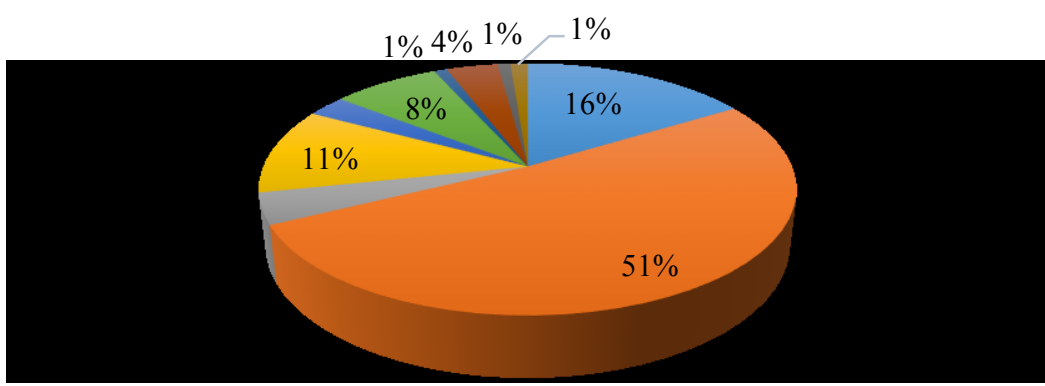

a

combinations of a

combinations of $\mathrm{b}$

combinations of $\mathrm{c}$

d

combinations of $\mathrm{d}$

a

䑤

combinations of $\mathrm{f}$

i

Source: own research

Explanatory notes: $\mathrm{a}$ - shopping center, $\mathrm{b}$ - electronics stores, $\mathrm{c}$ - garden center, $\mathrm{d}$ - car interior and car shop, e showroom, f - bakery, $\mathrm{g}$ - post office, $\mathrm{h}$ - shop, $\mathrm{i}$ - other

Figure 3: Places where respondents would appreciate aromatising of space
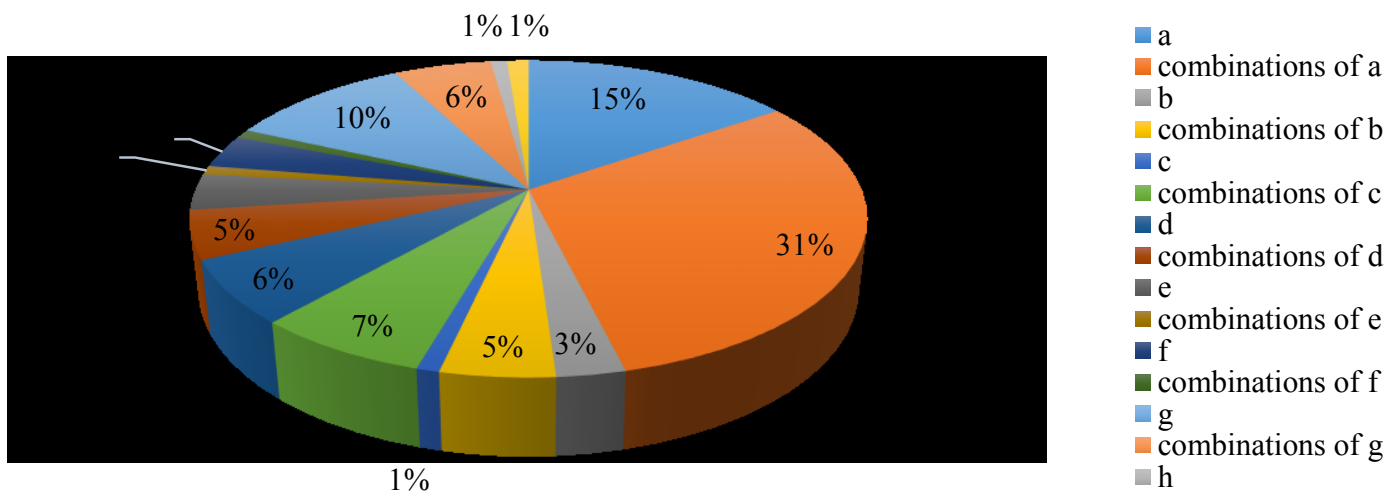

Source: own research

Explanatory notes: $\mathrm{a}$ - shopping centre, $\mathrm{b}$ - electronics stores, $\mathrm{c}$ - garden centre, $\mathrm{d}$ - car interior and car shop, $\mathrm{e}-$ showroom, $\mathrm{f}$ - bakery, $\mathrm{g}$ - post office, $\mathrm{h}$ - shop, $\mathrm{i}$ - other

Following the evaluation of two previous questions, we wanted to find out the interdependence between the choice of respondents' answer to the question and gender. The formulated hypotheses were verified with statistical methods of Contingency table chi-square test, Pearson's chi-square test, Cramer's coefficient and Mantel-Haenszel Chi-Square test, their results showed that both of the observed dependencies show strong statistical dependence.

Table 7: Statistical dependence between places where respondents would appreciate aromatising of space and gender

\begin{tabular}{lrrr}
\hline Statistic & DF & Value & Prob \\
\hline Chi-Square & 49 & 158.5669 & $<.0001$ \\
Likelihood Ratio Chi-Square & 49 & 177.8340 & $<.0001$ \\
Mantel-Haenszel Chi-Square & 1 & 5.1822 & 0.0228 \\
Phi Coefficient & & 0.6985 & \\
Contingency Coefficient & & 0.5726 & \\
Cramer's V & & 0.6985 & \\
\hline
\end{tabular}

Source: own research, output of SAS Enterprise Guide 7.1 
Table 8: Statistical dependence between places where respondents experienced aromatising of space and gender

\begin{tabular}{lrrr}
\hline Statistic & DF & Value & Prob \\
\hline Chi-Square & 40 & 175.2060 & $<.0001$ \\
Likelihood Ratio Chi-Square & 40 & 192.2203 & $<.0001$ \\
Mantel-Haenszel Chi-Square & 1 & 12.4604 & 0.0004 \\
Phi Coefficient & & 0.7342 & \\
Contingency Coefficient & & 0.5918 & \\
Cramer's V & & 0.7342 & \\
\hline
\end{tabular}

Source: own research, output of SAS Enterprise Guide 7.1

In the last block of questions were formulated questions about a specific scent, which our respondents would appreciate in the business units, because the scent encourages them to purchase. As can be seen from the Figure 4, respondents would most welcome the scents typical of the season, e.g. cinnamon, apple-cinnamon during Christmas time ( $45 \%$ of respondents), neutral, respectively less pronounced scents that do not disturb during the purchase $(32 \%$ of respondents) and vanilla scent (13\% of respondents). Reasons why they would choose the scents differed by places. The above mentioned results confirm also the results of the research made by Vlahos (2007), who has realised that one of the mostly used and best received scent is the vanilla, resp. the citrus aroma.

\section{Figure 4: The scents preferred in business units}

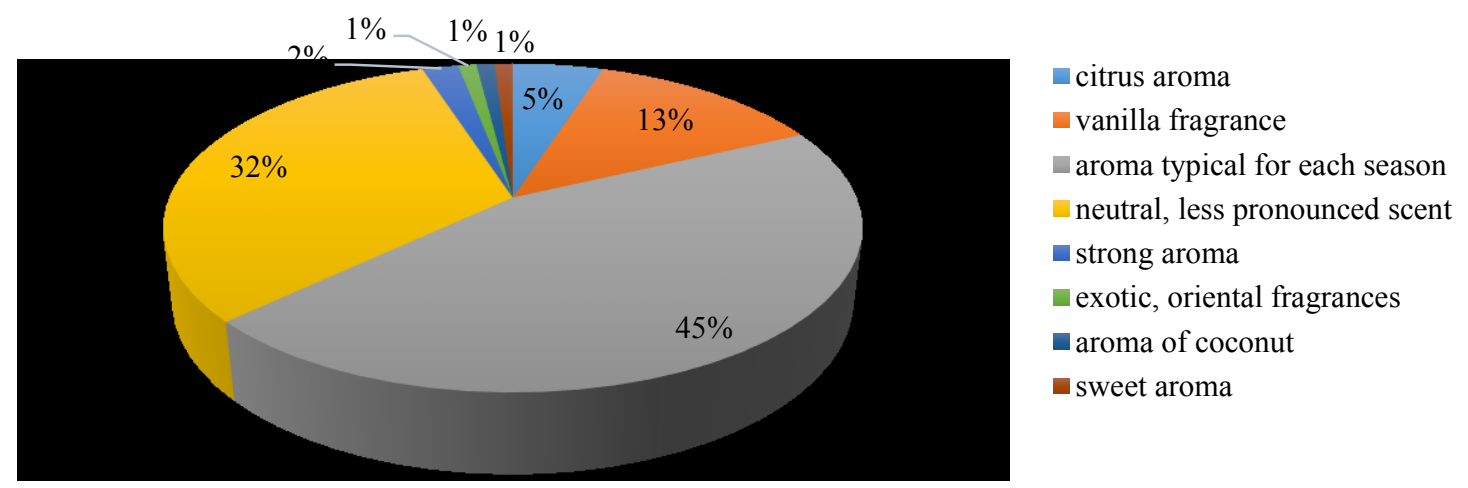

Source: own research

The last tested dependency that we wanted to verify the truth of respondents' claims was the dependence between "how the scent affects the shopping behaviour of respondents" and "if respondents purchased something based on the fact that the store was aromatised".

As can be seen from the Table 9, respondents indicated the truth as there is a statistically significant dependency among tested variables. Respondents who reported that the scent in the store affects them positively and encourages them to purchase, they actually made a purchase in the past based on aromatised space. 
Table 9: Statistical dependence between "how the scent affects the shopping behaviour of respondents" and "if respondents purchased something based on the fact that the store was aromatised"

\begin{tabular}{lrrr}
\hline Statistic & DF & Value & Prob \\
\hline Chi-Square & 4 & 36.0403 & $<.0001$ \\
Likelihood Ratio Chi-Square & 4 & 35.4685 & $<.0001$ \\
Mantel-Haenszel Chi-Square & 1 & 0.5125 & 0.4741 \\
Phi Coefficient & & 0.3330 & \\
Contingency Coefficient & & 0.3159 & \\
Cramer's V & & 0.2355 & \\
\hline
\end{tabular}

Source: own research, output of SAS Enterprise Guide 7.1

\section{Conclusion}

Retail spaces have plenty to consider when creating the right atmosphere to suit the goods and services they're selling. The combination of visual, tactile, and intangible elements including aromatised air in a physical retail space is so important because these factors can actually influence shopper behaviour, including purchase intent.

The aim of the paper was to find out how the scent affects the shopping behaviour of respondents. In our research we focused on young generation - Millennials. From the results of the research carried out by the authors we can conclude that Millennials have a positive attitude towards aromatised spaces, and they are aware of their presence. Most respondents, totally $89 \%$ stated that they had already encountered with the aromatization of retail space; for $78.15 \%$ of respondents the scent affects them positively in their purchasing decision and encourages them to purchase; more than half of respondents $(51.08 \%)$ would even buy goods rather in professionally aromatised spaces and last findings showed that $19.69 \%$ of respondents made unplanned purchase based on the fact that the store smelled pleasantly. In connection with formulated questions, the dependencies between characteristics of respondents and respondents' answers were tested.

To understand how important context is to scent marketing, researchers suggest that labelling a scent good or bad is as important as the scent itself. Fortunately for retailers, the science behind scent marketing isn't just academic - major retailers like Nike found that scent marketing in retail stores "increased intent to purchase by $80 \%$." In another real-world scent marketing experiment, the smell of fresh-brewed coffee at a gas station increased coffee sales by $300 \%$ (Orvis, 2016). Scents have also been shown to persuade customers to stay in retail spaces longer and browse more, improve their sense of quality, and create a warm feeling of familiarity.

\section{Acknowledgements}

The paper is part of the research projects APVV-17-0564 "The Use of Consumer Neuroscience and Innovative Research Solutions in Aromachology and Its Application in Production, Business and Services"

\section{References}

[1] Abassi, F. (2016). Scent Marketing Helps Bring the Sweet Smell of Sales to the Showroom. Dealer Marketing Magazine. Retrieved from: https://www.dealermarketing.com/scent-marketing-helps-bring-the-sweet-smellof-sales-to-the-showroom/ 
[2] Air Aroma. (2019). Scent marketing. Retrieved from: https://www.air-aroma.com/scent-marketing

[3] Berčík, J., Palúchová, J., Vietoris, V. \& Horská, E. (2016). Placing of aroma compounds by food sales promotion in chosen services business. In Potravinárstvo, 10(1), 672-679. doi.org/10.5219/666

[4] Blondeau, M., Tran, A. (2009) Scent Marketing: What is the impact on stores in Umea? Retrieved from: http://www.diva-portal.org/smash/get/diva2:224612/FULLTEXT01.pdf

[5] Bulanda, I., Franková, V., Džupina, M. (2017). Analýza nákupného rozhodovania v segmente žien generácie Y na úrovni ego stavov transakčnej analýzy. In Analýza a výskum v marketingovej komunikácii, Nitra: UKF, 5/2 2017,27-36, ISSN 1339-3715

[6] Cox D.F. (1969) The sorting rule model of the consumer product evaluation process, Risk Taking and Information Handling in Consumer Behavior. Boston, MA, Graduate School of Business Administration, Harvard University, 324-369

[7] Doric,B., Primorac D. \& Kozina G. (2016). Scent impact on the store perception. In 15th International Scientific Conference on Economic and Social Development - Human Resources Development. Varazdin 910 June 2016

[8] Džupina, M., Hodinková, D. \& Kiková, H. (2016). Spoločensky zodpovedné podnikanie ako zdroj hodnôt značky, Nitra, UKF, p. 84. ISBN 978-80-558-0991-5. (In Slovak)

[9] E2 Aroma. (2019). Rockefeller University: How Scent Marketing Could Drive you Results. Retrieved from: http://www.e2aroma.com/en/scent-marketing/scentmarketingresearch/details/rockefeller-university

[10] Géci, A., Nagyová, L., \& Rybanská, J. (2017). Impact of sensory marketing on consumer's buying behaviour. Potravinarstvo, 11(1), 709-717. doi.org/10.5219/835

[11] Gutić, D. \& Barbir, V. (2009). Ponašanje potrošača. Makarska: Fortunagraf.

[12] Jordan,T. (2015). Scentsational Marketing in Business: A Study of Scent Atmospherics. Undergraduate Honors Theses. Paper 270. Retrieved from: http://dc.etsu.edu/honors/270

[13] Ku, G. (2008). Learning to de-escalate: The effects of regret in escalation of commitment. In Organizational Behavior and Human Decision Processes, 105(2), 221-232. doi:10.1016/j.obhdp.2007.08.002

[14] Laird D.A. (1935), What can you do with your nose? in Scientific Monthly, 41, 126-130.

[15] Orvis, G. (2016). The Science of Smell: How Retailers Can Use Scent Marketing to Infuence Shoppers. Shopify blogs. Retrieved from: https:/www.shopify.com/retail/the-science-of-smell-how-retailers-can-usescent-marketing-to-make-more-sales

[16] Polakevičová, I. (2015). Aplikácia transakčnej analýzy do oblasti marketingovej komunikácie. 1. edition. Nitra : UKF. 192 p.

[17] Světlík, J., Bulanda, In. (2019). Adolescents perception of the commercial advertising in Slovakia. In $40^{\text {th }}$ International Scientific Conference on Economic and Social Development - Buenos Aires, 10-11 May 2019, 201-209, ISSN 1849-7535.

[18] Tarczydlo, B. (2014). Scents and Elements of Aroma Marketing in Building of an Appropriate Brand Image. In Knowledge - Economy - Society. Managing organizations : Concepts and their applications. Cracow. 97107. ISBN 978-83-62511-54-9.

[19] The 2016 Deloitte Millennial Survey. (2016). Winning over the next generation of leaders. Retrieved from: https://www2.deloitte.com/content/dam/Deloitte/global/Documents/AboutDeloitte/gxmillenial-survey2016-exec-summary.pdf

[20] The 2017 Deloitte Millenial Survey. (2017). Apprehensive millenials: seeking stability and opportunities in an uncertain world. Retrieved https://www2.deloitte.com/content/dam/Deloitte/global/Documents/AboutDeloitte/gxdeloitte-millennialsurvey-2017-executive-summary.pdf

[21] Tomi, K., Fushiki, T., Murakami, H., Matsumura, Y., Hayashi, T., Yazawa, S. (2011) Relationships Between Lavender Aroma Component And Aromachology Effect. In Acta Hortic, 925, 299-306. DOI: 10.17660/ActaHortic.2011.925.44 https://doi.org/10.17660/ActaHortic.2011.925.44 
[22] Vlahos, J. (2007) Scent and Sensibility. In The New York Times. Retrieved from: http://www.oasis.ua/oasis/files/File/Scent\%20and\%20Sensibility_nytimes.pdf

[23] Witek, L. (2016) Influence of Socio-demographic Characteristics of Consumers on Attitudes Towards Cause Related Marketing. In Acta Universitatis Agriculturae et Silviculturae Mendelianae Brunensis, 64(6), 2173 2182. doi:10.11118/actaun201664062173 


\title{
Characteristics of Producers Capable of Development, and Selling in Marketplaces - Results of Hungarian Primary Research
}

\author{
Konrád Kiss ${ }^{1}$ \\ Szent István University, Doctoral School of Management and Business Administration \\ Address: Páter K. u. 1. \\ Gödöllö, Hungary \\ e-mail:konrad.kiss@phd.uni-szie.hu' ${ }^{1}$
}

doi: 10.18515/dBEM.ISD.P01.2020.p014

\begin{abstract}
Short supply chains (SSCs) are a supported EU priority in the present budgetary period from 2014 till 2020. The purpose of SSC-subsidies is to help the involved (small-sized) agricultural producers' sales. The purpose of the current research is to assess the success factors of small producers selling directly to consumers in marketplaces (too). The research is based on primary research made in Hungary. Two hundred and fourteen producers participated in the survey, from the agglomeration area of Budapest and the area of Gyöngyös town. 40\% of them could be considered to be capable of developing. They are able and willing to produce more in the case of better demand and sales opportunities. Nearly half part of them was originated from the producers' markets of Budapest capital city and its agglomeration area. They occurred in traditional markets and market halls at a lower rate. Age of producers, a higher level of (vocational) education, trade of processed products were in correlation with the producers' developmental ability and willingness. To some extent, these producers were (already) satisfied with the profitability of their farming.
\end{abstract}

Keywords: small-sized producers, direct sale, (producers') markets, rural development.

JEL Classification: $Q 12, Q 13, R 11$

\section{Introduction}

In recent years, increasing demand for alternative supply chains and directly sold products could be observed worldwide (Benedek \& Fertő, 2015). This interest is observable both in the support policy and on the consumers' side.

The beginning of the considerable research of alternate food chains dates back to the late nineties. Since then, various, generally empirical studies have been written about alternative food chains (Maye \& Kirwan, 2010).

In addition to their economic role, researchers also examine the role of short supply chains in rural development. As I experienced, it is very difficult to draw a generalizable conclusion on this topic. According to Benedek and Balázs (2014), quantitative studies (especially, which cover an entire country) that expound short supply chains in an empirical and generalizable way are rare. Short supply chain studies are generally case studies; in this way, their areal comparative examinations meet difficulties.

The current study aims to assess - through the example of marketplace sales - whether direct sales and short supply chains can serve as a "breakthrough" for small-scale producers and (in this way) contribute to rural development. According to my previous research experiences, producers' markets, and organic-sourced markets - functioning with higher consumer prices, providing presumably profitable sales - mainly occur in developed urban areas. 


\subsection{Conceptual approach to short supply chains}

In my article, I consider those supply chains "short" where there is at most one intermediate participant between producers and consumers - in line with the Regulation (EU) No 807/2014 and with the Hungarian Rural Development Program operative between 2014 and 2020. Within short supply chains, direct producers' sales are a narrower category. According to Priefer et al. (2016), the most well-known direct marketing systems are farm shops, farmers' markets, delivery of vegetable boxes by subscription, mail-orders, producer co-operatives, solidarity purchasing groups, and Community Supported Agriculture (CSA).

The categorisation can be read in the Hungarian Rural Development Program (2014-2020) considers conventional marketplaces also short supply chains. It must be noted that in conventional markets, traders also sell, and that situation cannot be considered as a short supply chain (or at most in that case, as defined above, if they are the only intermediaries). In my paper, I did not make a distinction between producers' and conventional markets in this way, but only producers were involved in the survey. Traders were excluded.

\subsection{Economic sustainability of short supply chains}

Supporting short food chains or alternative supply chains is a common practice in more countries (Maye \& Kirwan, 2010). SSCs are a supported EU priority in the current budgetary period (between 2014 and 2020).

Supporting short supply chains in rural development policy is based on better integration of primary producers into the food chains (small producers are included naturally). This aspiration includes the trades of local markets and short supply chains. (De Fazio, 2016)

In agreement with Popp et al. (2019), there are many suggestions in the literature that certain forms of short supply chains play an important role in rural development. On the other hand, these systems hardly exist in the EU Member States that joined in 2004, where relatively low willingness to pay hinders the development potential of short supply chains. This perception is in agreement with the observations of Benedek and Balázs (2015) that Hungarian local food movements are in an early phase. Emergence and success of new-type, neotraditional SSC channels, such as box schemes, webshops, community supported agriculture, buying groups are primarily found in urban and peri-urban areas.

Schupp (2016) examined the location of producers' markets in the United States. According to his findings, producers' markets rarely occur in rural areas. They typically affect the middle and upper classes and rarely can be found in areas with lower than average socio-economic indicators. Similar reports can be read in the American study of Low and Vogel (2011), that local food trade provided opportunity for economic development mostly in urban areas. (Kiss et al., 2019). After analysing an (outdated) register of the Hungarian, Research Institute of Agricultural Economics (Agrárgazdasági Kutatóintézet [AKI], 2012), I found that the location of producers' and organic-sourced markets are also concentrated in Hungary and more concentrated than the location of conventional ones (Kiss \& Nagyné Demeter 2018). Mostly, they occur near larger cities.

Nonetheless, according to Benedek and Balázs (2015), political interest in the relocalisation of food is increased in Hungary. 


\section{Data and Methods}

The main research question is whether short supply chains can provide profitable sales alternatives for producers and whether they fulfill their role in rural development - as a supported EU priority. As the simultaneous and complex examination of short supply chain channels would have been a huge and difficult task, I have narrowed my survey to the examination of markets, producers' markets, organic markets, and market halls.

The sample area meant the marketplaces of various sized cities within the $40 \mathrm{~km}$ radius of Budapest, the capital city, and the town of Gyöngyös in the Mátra region. (The 40-kilometer radius was based on a Hungarian regulation on small-sized producers' trade.) The survey was conducted at conventional markets, market halls, producers' markets, and an organic-sourced market. The fundamental difference between market types is that in conventional marketplaces and market halls, both producers and traders can sell. In larger marketplaces, there was a reserved part only for producers, and they could distinguish themselves with their certificates. In producers' markets, only producers were allowed to sell (and traders were not). There, consumer prices are typically higher than in conventional marketplaces or other (usual) commercial channels. In the organic-sourced marketplaces, only products form legal, officially certified organic farms could be sold. I conducted a paper-based questionnaire with 214 producers between August and December of 2018. I did the survey alone, in 12 settlements and 22 different locations. This meant 24 workdays in the field (Table 1). (Kiss, 2019)

Table 1: Distribution of sample by area and market type

\begin{tabular}{|l|l|l|}
\hline Location of the sampling - market type & Number of locations & Number of responders \\
\hline $\begin{array}{l}\text { Budapest area - conventional markets, } \\
\text { market halls }\end{array}$ & 6 & 74 \\
\hline Budapest area - producers' markets & 9 & 75 \\
\hline Gyöngyös area - conventional markets & 7 & 65 \\
\hline Total & 22 & 214 \\
\hline
\end{tabular}

Source: own survey

The preliminary hypothesis of the survey was that professional, development- and futureoriented small-sized producers were primarily selling in the Budapest area (providing higher demand.)

The next important task was to determine which producers can be considered as ,capable of development" or a ,professional, development- and future-oriented," so who is not doing the work out of compulsion but a profession, and is willing and able to grow or develop.

This can be deduced from the following factors in the case of my survey:

- Age of the responders

- Highest level of education

- Does the producer consider farming and selling as a full-time job?

- Since when have the responder involved in production and sales?

- Type the products: Does the respondent sells processed products alongside or instead of primary or unprocessed products? (These three product categories are defined in the Regulation (EC) No 852/2004.)

- Satisfaction with the profitability of farming 
- Would the producer produce more in the case of better sales opportunities?

- Aims and goals for the future

Based on the factors mentioned above, - beforehand, subjectively - I considered those producers to be "capable of developing" who:

- (with possible exceptions) are not in retirement age, rather

- a (relatively) young producers (having the necessary financial background);

- who have a higher education or vocational qualification;

- to who producing and selling is a full-time job;

- who have professional experience and the necessary enthusiasm;

- who optionally offer added values, and also sells processed foods;

- who are satisfied with their farming (however, it should be noted that dissatisfaction can also be a motivating factor for development);

- in the case of better sales opportunities and higher demand, who have the willingness and capacity to grow;

- who have positive aims for the future.

It should also be noted that there are other aspects that contribute to determining success, for example, the financial background or social capital of the farms as resources and site-specific features. Due to the different economic profiles and land use, it was not possible to determine land sizes or livestock sizes based on the questionnaire. For this reason, farm sizes were not included in the determination of "successfulness." Although plant size is determinant in successfulness, indicators like "standard output (SO)" were not available for me.

I aimed to identify the group of producers who are capable of developing, for which I wanted to do factor analysis and cluster analysis. However, due to the characteristics of the sample, this was not successful. The factors and clusters formed during the calculations could not be interpreted. As an alternative solution, I examined that how many producers said that they had positive, forward-looking goals for the future, or on the contrary, how many producers were stagnant, incapable of development, or wanted to reduce or terminate their farming. This indicator became the new basis for categorizing producers according to their „development potential." I statistically examined the relationship between the above listed „factors of successfulness" and the location of the queries. (Table 2.) As statistical methods, I used the Chisquare test (with a 5\% level of significance) by IBM SPSS Program. In the case of statistically significant relationship, the strength of the relationship was determined by Cramer's V association (see „Statistics How To Website). In the comparion, I mostly found ,very strong,” or ,strong" relationships. It depended on the value Cramer's V associtation: values higher than 0,25 was considered 'very strong, and values between 0,15 and 0,25 were strong relations.

In the research, I assumed that responders could be considered as "permanent members" in the given conventional, producers' marketplaces, market halls, and organic-courced market. The limitation of the research is that I was not aware of whether the interviewed producers were alternately selling in the different market-types of the Gyöngyös or Budapest area.

\section{Results and Discussion}

According to previously published results of this same research (Kiss, 2019), the spatial (urbanrural) location of the marketplaces was important primarily because the examined producers' 
markets were concentrated in the Budapest area. The presence of producers' markets was the cause of the higher producers' satisfaction from the Budapest agglomeration in the sample.

There were 87 producers in the sample whose goals included improvement, whether in terms of quantity or quality. In contrast, 77 producers were either unable or unwilling to develop or for example, due to their older age - wanted to reduce or end the farming. There were further 49 producers in the sample who did not answer this question. I guessed that they did not respond because they did not have specific aims. (For this reason, they may be similar to the groups that plan to keep the farming unchanged or to reduce it. I did not deal with this group anymore in the article. ) (Table 2.)

Table 2: Producers' groups formed according to the future aims

*Legend: Groups formed according to the aims of the producers.

1. group: Reduce production, end farming or pass on the farm $(n=21)$

2. group: To maintain the current state of farming $(n=56)$

3. group: Development, growth, (positive) change $(n=87)$

4. group: No answer / no exact notions $(n=49)$

\begin{tabular}{|c|c|c|c|c|c|c|}
\hline \multirow{2}{*}{\multicolumn{2}{|c|}{ Factors }} & \multicolumn{4}{|c|}{$\begin{array}{l}\text { Groups formed according to } \\
\text { the aims of the producers* }\end{array}$} & \multirow{2}{*}{$\begin{array}{l}\text { Presence of } \\
\text { statistically } \\
\text { significant } \\
\text { relationship and } \\
\text { its strength }\end{array}$} \\
\hline & & $\begin{array}{l}\text { 1. g. } \\
\mathrm{n}=21\end{array}$ & $\begin{array}{l}\text { 2. g. } \\
\mathrm{n}=56\end{array}$ & $\begin{array}{l}\text { 3.g. } \\
n=87\end{array}$ & $\begin{array}{l}\text { 4.g. } \\
n=49\end{array}$ & \\
\hline \multirow[t]{5}{*}{ Age } & 20 years $>$ & - & - & - & - & \multirow{5}{*}{$\begin{array}{l}\text { Yes; strong/very } \\
\text { strong } \\
\text { relationship }\end{array}$} \\
\hline & $20-35$ years & $0 \%$ & $5 \%$ & $24 \%$ & $10 \%$ & \\
\hline & $36-50$ years & $24 \%$ & $27 \%$ & $47 \%$ & $33 \%$ & \\
\hline & $51-65$ years & $62 \%$ & $48 \%$ & $21 \%$ & $31 \%$ & \\
\hline & 65 years + & $14 \%$ & $20 \%$ & $8 \%$ & $27 \%$ & \\
\hline \multirow{4}{*}{$\begin{array}{l}\text { Highest level of } \\
\text { education }\end{array}$} & Primary, secondary or technical school & $67 \%$ & $71 \%$ & $43 \%$ & $74 \%$ & \multirow{4}{*}{$\begin{array}{l}\text { Yes; strong } \\
\text { relationship }\end{array}$} \\
\hline & Agricultural specialised secondary ed. & $10 \%$ & $5 \%$ & $14 \%$ & $10 \%$ & \\
\hline & Higher education & $10 \%$ & $18 \%$ & $22 \%$ & $14 \%$ & \\
\hline & $\begin{array}{lll}\begin{array}{l}\text { Agricultural } \\
\text { education }\end{array} & \text { specialised } & \text { higher } \\
\end{array}$ & $14 \%$ & $5 \%$ & $22 \%$ & $2 \%$ & \\
\hline \multirow{3}{*}{$\begin{array}{l}\text { Is farming and } \\
\text { selling a full- } \\
\text { time job? }\end{array}$} & Yes, full-time job & $52 \%$ & $58 \%$ & $71 \%$ & $51 \%$ & \multirow{3}{*}{$\begin{array}{l}\text { Yes; } \\
\text { strong/medium } \\
\text { relationship. }\end{array}$} \\
\hline & Part-time job, or as employee & $19 \%$ & $22 \%$ & $20 \%$ & $23 \%$ & \\
\hline & Only a pension supplement & $29 \%$ & $20 \%$ & $9 \%$ & $26 \%$ & \\
\hline \multirow{3}{*}{$\begin{array}{l}\text { When did } \\
\text { he/she start it? }\end{array}$} & Less then 6 years & $5 \%$ & $7 \%$ & $32 \%$ & $8 \%$ & \multirow{3}{*}{$\begin{array}{l}\text { Yes; very strong } \\
\text { relationship }\end{array}$} \\
\hline & $6-10$ years & $14 \%$ & $9 \%$ & $24 \%$ & $16 \%$ & \\
\hline & For over 10 years & $81 \%$ & $84 \%$ & $44 \%$ & $76 \%$ & \\
\hline \multirow{2}{*}{$\begin{array}{l}\text { Does he/she sell } \\
\text { processed } \\
\text { products? }\end{array}$} & No & $76 \%$ & $71 \%$ & $24 \%$ & $60 \%$ & \multirow[t]{2}{*}{$\begin{array}{l}\text { Yes; very strong } \\
\text { relationship }\end{array}$} \\
\hline & Yes & $24 \%$ & $29 \%$ & $76 \%$ & $40 \%$ & \\
\hline \multirow{3}{*}{$\begin{array}{l}\text { Would he/she } \\
\text { produce more } \\
\text { in case of better } \\
\text { sales } \\
\text { opportunities? }\end{array}$} & Yes (decidedly) & $10 \%$ & $13 \%$ & $47 \%$ & $30 \%$ & \multirow[t]{3}{*}{$\begin{array}{l}\text { Yes; very strong } \\
\text { relationship }\end{array}$} \\
\hline & Somewhat yes & $24 \%$ & $25 \%$ & $37 \%$ & $22 \%$ & \\
\hline & No & $67 \%$ & $63 \%$ & $16 \%$ & $48 \%$ & \\
\hline $\begin{array}{l}\text { In what measure } \\
\text { he/she satisfied }\end{array}$ & \begin{tabular}{l|lll} 
does & Dissatisfied & or & somewhat \\
with & dissatisfied & &
\end{tabular} & $33 \%$ & $11 \%$ & $11 \%$ & $26 \%$ & $\begin{array}{l}\text { Yes; strong } \\
\text { relationship }\end{array}$ \\
\hline
\end{tabular}




\begin{tabular}{|c|c|c|c|c|c|c|}
\hline \multirow{3}{*}{$\begin{array}{l}\text { the profitability of } \\
\text { farming and selling? }\end{array}$} & Moderately (so-so) & $24 \%$ & $34 \%$ & $19 \%$ & $42 \%$ & \\
\hline & Somewhat satisfied & $29 \%$ & $39 \%$ & $51 \%$ & $24 \%$ & \\
\hline & Satisfied & $14 \%$ & $16 \%$ & $20 \%$ & $8 \%$ & \\
\hline \multirow{3}{*}{$\begin{array}{l}\text { Location of } \begin{array}{r}\text { the } \\
\text { inquiry/used } \\
\text { channels }\end{array} \\
\text { sales }\end{array}$} & $\begin{array}{l}\text { Area of Budapest - conventional } \\
\text { market or market halls }\end{array}$ & $24 \%$ & $36 \%$ & $28 \%$ & $44 \%$ & \multirow[t]{3}{*}{$\begin{array}{l}\text { Yes; strong } \\
\text { relationship }\end{array}$} \\
\hline & $\begin{array}{l}\text { Area of Budapest - producers } \\
\text { markets and eco market }\end{array}$ & $29 \%$ & $25 \%$ & $49 \%$ & $24 \%$ & \\
\hline & $\begin{array}{l}\text { Area of Gyöngyös } \\
\text { conventional markets }\end{array}$ & $48 \%$ & $39 \%$ & $23 \%$ & $32 \%$ & \\
\hline
\end{tabular}

Source: own survey, "Statistics How To"

The sample confirmed all my previous assumptions regarding the producer group "capable of development." The factors affecting the developmental abilities I listed above showed statistically significant differences between the four groups.

In the majority of cases, the age of the 77 producers who wish to reduce or do not want to develop is above 51 years (in $76 \%$ and $68 \%$ of the cases.) Conversely, the age of the 87 producers seeking to grow was mostly between 36 and 50 years (in $47 \%$ of the cases). Furthermore, the proportion of producers younger than 36 years was also the highest in this group (24\%). Although the (aggregated) proportion of primary, secondary or technical education was dominant in each group, it is noteworthy that the proportion of higher-level education (44\%) or agricultural qualification $(36 \%)$ was highest in the case of producers who are capable of development. (Only nine producers had primary education as their highest qualification.)

Three-forth part producers sold processed products too. In the case of the other groups, this ratio was typically inverse. The difference was mainly because (unprocessed) fruit and vegetables were the most dominant sold product category in the other three groups (in 59-76\%). In the case of the third group (able to develop), the following products occurred in relatively significant shares: dairy products (29\% of the group), meat products $(21 \%)$, other specialties (e.g., spices) (22\%), and processed fruit products (syrup, jam, juice, quince cheese) $(13 \%)$.

Related to the development goals, $37 \%$ of the third group were somewhat able, and another $47 \%$ were surely able and willing to produce more in the case of better sales opportunities and higher demand. This represents $84 \%$ of the group. In the case of producers intended to reduce or maintain the farm unchanged, only one-third part of the participants would have been willing (even slightly) to produce more. In this way, especially for the producers able to develop ( $40 \%$ of the sample), there would be a need for better sales opportunities.

$71 \%$ of farmers who wanted to grow and develop, expressed a positive opinion about the profitability of their farming. $20 \%$ of them were definitely satisfied. This suggests that developmental intention already implies that the farm is relatively stable, and adequate or satisfactory profitability can be expected also in the future. In the other groups, the rate of dissatisfaction was higher.

The majority of producers able to develop were the respondents from the producers' markets. In other words, $57 \%$ of the respondents from the producers' markets and eco-market from the Budapest area were considered to be capable of development. In contrast, their rate in conventional markets and market halls of the Budapest area was only $34 \%$ and $29 \%$ in conventional marketplaces from the Gyöngyös area. Thus, there is a statistically significant relationship between the presence of producers able to develop, and the location of the sampling. However, if we exclude the participants of the producers market, there is no 
statistically significant difference between the conventional markets or market halls of the Gyöngyös and Budapest sampling area.

\section{Conclusion}

This survey, on the on hand, confirmed my hypothesis that the producers selling in the Budapest area are more professional, development-oriented, and capable of development on the whole than in the examined rural area. On the other hand, the type of marketplaces - and not solely their geographic location - was (and still is) dominant in this relation. According to my previously published results (Kiss, 2019), these same producers were significantly more satisfied with the producers' markets (located in the area of Budapest). There was no significant difference in the satisfaction of the producers in the traditional markets and market halls in the urban-rural context. The current survey also supports this result. A statistically significant difference found in the fact that most of the surveyed producers capable of development sold in the producers' markets (and the organic-sourced market) located in the area of Budapest. In these producers' markets, I found that $57 \%$ of the respondents were capable of development. By contrast, their rate was only $34 \%$ amongst the participants from conventional markets and market halls from the Budapest area and $29 \%$ in the case of the conventional markets of the Gyöngyös area. These last two values are not significantly different from each other. There was just only a few producers' markets in the Gyöngyös area (with just a few producers), and I was not able to include them in my survey.

Based on examples from the literature (Low \& Vogel, 2011; Schupp, 2016; Kiss \& Nagyné Demeter 2018), I conclude that producers' markets are less typical in underdeveloped rural areas. I do not know about any research examines the consumer demand for producers' markets in rural areas explicitly, but my experience is that weak demand or purchasing power in poorer regions cannot maintain producers' markets of high consumer prices. However, according to my primary research results, producers' markets were considered to be relatively successful in producers' direct selling the sample area.

The producers able to develop ( 87 persons; $40 \%$ of the sample) are in almost all cases $(87 \%)$ able and willing to produce more (up to a certain level) in case of better sale opportunities and more consumers. It is, therefore, appropriate to provide them better sales opportunities, for example, by the infrastructural improvement of (already existing) markets or circumspect establishment of new (producers') markets and other sale opportunities, in case of appropriate demand, even in rural areas.

Producers who were younger (and relatively early in the production), and who were considering farming and producing as a full-time job, and having a higher level of education or specialized agricultural qualification, occurred in grater shares in the group of producers capable of development. Increased sales of processed products were also a success factor. The share of producers selling dairy- or meat-based products or processed fruit products was higher among this group. They were also relatively more satisfied with the profitability of their farming and selling. In my opinion, better exploit or assistance of the above-mentioned success factors (even with governmental aid), would improve the situation of producer sales. For example, supports for vocational training or education, supporting career-starters, improving the opportunities for market-trades (taking the demand of the area into account), developing the infrastructure of (conventional) marketplaces, subsidies for small producers, assisting or encouraging product processing can be mentioned here. These ideas naturally depend on the producers' needs and 
interests also. Some additional potential success factors (such as farm size, startup capital, annual income level) were not included in my study.

\section{References}

[1] Agrárgazdasági Kutatóintézet [AKI] (Reseach Institute of Agriculutral Economics). (2012). Piacokkal kapcsolatos kutatás (2011-2012) (Reseach regarding marketplaces 2011-2012); file: "Piac_Lista_0927 (XLS)"

https://www.aki.gov.hu/publikaciok/publikacio/a:421/Piacokkal+kapcsolatos+kutat\%C3\%A1s+(20112012) retrieved February 6. 2020.

[2] Benedek, Zs., \& Balázs, B. (2015). Efficient support of short food supply chains in Hungary: A spatial analysis (MT-DP-2015/51). Centre for Economic and Regional Studies - Hungarian Academy of Sciences, Budapest. https://www.mtakti.hu/en/publikacio/mtdp-muhelytanulmanyok/efficient-support-of-short-foodsupply-chains-in-hungary-a-spatial-analysis/ retrieved February 2. 2020.

[3] Benedek Zsófia, \& Balázs B. (2014). Az élelmiszertermelés relokalizációjának térbeli-társadalmi különbségei Magyarországon (Socio-spatial differences in the relocalisation of food production in Hungary). Tér és Társadalom, 28(4), 63-76. http://real.mtak.hu/18910/1/2644-7286-1-PB.pdf retrieved February 2. 2020.

[4] Benedek, Zsófia, \& Fertő, I. (2015). Miért választják a termelők a rövid ellátási láncokat? (Why do producers choose short supply chains?) Statisztikai Szemle, 93(6), 580-597.

[5] De Fazio, M. (2016). Agriculture and Sustainability of the Welfare: The Role of the Short Supply Chain. Agriculture and Agricultural Science Procedia, 8, 461-466. https://doi.org/10.1016/j.aaspro.2016.02.044

[6] Hungarian Rural Development Program (2014-2020): 876 p. https://www.palyazat.gov.hu/node/56582 ; retrieved February 2. 2020.

[7] Kiss, K. (2019). The satisfaction of producers, selling in various marketplaces-Results of a primary survey from Hungary. Annals of the Polish Association of Agricultural and Agribusiness Economists, 12(3), 183190. https://doi.org/10.5604/01.3001.0013.3542

[8] Kiss, K., \& Nagyné Demeter D. (2018). Lokalizáció - egy példa: a rövid ellátási láncok szerepe a gyakorlatban (Localisation - an example: role of the short supply chains in practice). 130-139 p. In: CsiszárikKocsir, Á., Garai-Fodor, M. (Ed.): Vállalalkozásfejlesztés a XXI. században 8(2). Budapest, Hungary, Óbuda University.

[9] Kiss, K., Ruszkai, C., \& Takács-György, K. (2019). Examination of Short Supply Chains Based on Circular Economy and Sustainability Aspects. Resources, 8(4), 161. https://doi.org/10.3390/resources8040161

[10] Low, S. A., \& Vogel, S. (2011). Direct and Intermediated Marketing of Local Foods in the United States. ERR-128, U.S. Department of Agriculture, Economic Research Service, November 2011. https://www.ers.usda.gov/webdocs/publications/44924/8276_err128_2_.pdf?v=41056 retrieved: February 6. 2020.

[11] Maye, D., \& Kirwan, J. (2010). Alternative food networks. Sociapedia.isa (Editorial Arrangement of Sociopedia.isa). http://www.sagepub.net/isa/resources/pdf/Alternative\%20Food\%20Networks.pdf retrieved February 2. 2020.

[12] Popp, J., Oláh, J., Kiss, A., Temesi, Á., Fogarassy, C., \& Lakner, Z. (2019). The socio-economic force field of the creation of short food supply chains in Europe. Journal of Food and Nutrition Research, 58(1), 31-41.

[13] Priefer, C., Jörissen, J., \& Bräutigam, K.-R. (2016). Food waste prevention in Europe-A cause-driven approach to identify the most relevant leverage points for action. Resources, Conservation and Recycling, 109, 155-165. https://doi.org/10.1016/j.resconrec.2016.03.004

[14] Regulation (EU) No 807/2014: COMMISSION DELEGATED REGULATION (EU) No 807/2014 of 11 March 2014 supplementing Regulation (EU) No 1305/2013 of the European Parliament and of the Council on support for rural development by the European Agricultural Fund for Rural Development (EAFRD) and introducing transitional provision; https:/eur-lex.europa.eu/legalcontent/EN/TXT/PDF/?uri=CELEX:32014R0807\&from=. retrieved February 2. 2020. 
[15] Regulation (EC) No 852/2004 OF THE EUROPEAN PARLIAMENT AND OF THE COUNCIL of 29 April 2004 on the hygiene of foodstuffs https://eur-lex.europa.eu/legalcontent/EN/TXT/PDF/?uri=CELEX:02004R0852-20090420\&from=HU_retrieved February 2. 2020.

[16] Schupp, J. L. (2016). Just where does local food live? Assessing farmers' markets in the United States. Agriculture and Human Values, 33(4), 827-841. https://doi.org/10.1007/s10460-015-9667-y

[17] Statistics How To - Statistics for the rest of us - Cramer's V Correlation, https://www.statisticshowto.datasciencecentral.com/probability-and-statistics/correlation-coefficientformula/, retrieved: February 7. 2020. 


\title{
The Consumption of Milk from the Slovak Consumer's Point of View
}

\author{
L’ubica Kubicová ${ }^{1}$, Kristína Predanocyová ${ }^{2}$, Zdenka Kádeková ${ }^{3}$, Ingrida Košičiarová ${ }^{4}$ \\ Slovak University of Agriculture in Nitra \\ Department of Marketing and Trade $1,2,3,4$ \\ Address: Trieda A. Hlinku 2, \\ 94976 Nitra, Slovakia \\ e-mail: kubicova.lubka@gmail.com¹, kristina.predanocyova@gmail.com², \\ zdenka_kadekova@yahoo.com ${ }^{3}$, ingrida.kosiciarova@gmail.com ${ }^{4}$
}

doi: 10.18515/dBEM.ISD.P01.2020.p015

\begin{abstract}
Drinking milk contributes the most to the total consumption of milk and dairy products in the Slovak Republic. For this reason, the aim of the paper is to point out the development of consumption of drinking milk in the last 10 years in the Slovak Republic and to identify the main factors determining the consumption of drinking milk. Secondary data obtained from the Statistical Office of the Slovak Republic and primary data obtained from the consumer questionnaire survey were used to fulfil the stated aim. Nowadays, consumption of drinking milk is $45.7 \mathrm{~kg}$ per capita and year. The results of the questionnaire survey showed that the average consumer involved in the research consumes 0.25 litres of drinking milk daily, and more than 50\% of consumers buy drinking milk daily or several times a week. The quality, composition, durability and price of milk are the main factors that most affect consumers in the process of buying and consumption of drinking milk.
\end{abstract}

Keywords: consumption, consumer, drinking milk, factors

JEL Classification: M31, M39, Q13

\section{Introduction}

Current milk consumption in Slovakia has decreased significantly compared to the recent past. Similar situation has developed in other Central European countries and in some economically advanced countries, including the USA. The main cause is the misunderstanding of the importance of milk for nutrition and emphasizing only its negative properties, especially fat. Various myths about the harmfulness of milk have also contributed to despise, such as the fact that milk encompasses the whole organism, causes asthma, diabetes, cancer, and so on.

However, nutritionists consider milk to be one of the most nutritious and complex foods (Keresteš, 2016, Čuboň, Haščík \& Kačániová, 2012; Nicklas, O’Neil \& Fulgoni, 2009). It consists of proteins, fats, minerals, vitamins, enzymes and other nutritional and health-related components. High-quality proteins contain amino acids that the human body cannot synthesize. An essential component of milk is also fat and milk sugar, which are an energy source for the body. Milk supplies the body with mineral nutrition. Milk contains various biologically active ingredients, virtually all vitamins, over 60 different enzymes and other biological factors with anticancer, antimicrobial, antisclerotic, immunostimulatory and other properties (Zeleňáková \& Golian, 2008; Beck \& Coad, 2017; Dror \& Allen, 2014).

Modern science considers milk as a functional food, which means that it is also characterized by several health and vitality-enhancing effects (Koca, Akcam, Serdaroglu \& Dereci, 2017). Milk is the significant food due to its irreplaceable place in the intake of nutrients that are essential for the growth of the human organism and can be considered as a medicine for all age 
categories of consumers with different levels of their health condition (Košičiarová, Nagyová \& Holienčinová, 2017; Herian, 2006). Nouzovská (2007), based on studies by several experts who regard milk as an exceptional food for its ingredients, highlights its need for body building (Geng, Qi \& Huang, 2018). Regular consumption of milk and dairy products has, in the first place, beneficial effects on health of bones and teeth. An inadequate amount of calcium and vitamin D can lead to negative health consequences, in particular can cause osteoporosis and osteopenia, so it is beneficial and necessary for people to include milk and dairy products in their daily diet (Prentice, 2014; International Osteoporosis Foundation, 2015).

Consumption of milk and dairy products as part of a rational, healthy diet also has positive effects on optimal blood pressure. Milk, which is an important source of potassium and contains a low sodium content, is effective in preventing and promoting the elimination of the risk of cardiovascular disease. Milk and dairy products due to its high content of minerals act preventively against the development of colon cancer. Experts also point to a sufficient amount of vitamin D in milk, which has a beneficial effect on hormones associated with mood, appetite and sleep, which can lead to the elimination of depression of consumers. Various studies aimed at examining the positive effects of milk on the human organism also emphasize its importance in brain and nerve tissue development, regulation of body temperature, bowel movement, bile acid reduction, good vision, and resistance to infections of various kinds (Herian, 2006; Ware, 2016).

\section{Data and Methods}

The aim of the paper is to point out the consumption of drinking milk in the conditions of the Slovak Republic and to identify the main determinants affecting the level of consumption. This aim was achieved by using and processing secondary and primary data. The secondary data obtained from the Statistical Office of the Slovak Republic are the basis for the development of consumption of milk and dairy products up to 2020 by using the coefficient of determination $\mathrm{R}^{2}$ and the calculation of the average growth coefficient by using $\bar{k}$.

The primary data were obtained by questionnaire survey which was aimed to find out the consumption of drinking milk and to identify the main factors affecting the purchase and consumption. Questionnaire survey was conducted on a random sample of 516 respondents from April to December 2018 in the Slovak Republic and was implemented in an electronic version. In terms of the number of respondents involved in the questionnaire, this is a representative sample for the Slovak Republic. As the questionnaire survey was conducted by random sampling, representativeness according to individual demographic characteristics was not possible.

Respondents participating in the survey were diversified into 9 categories, for example by gender (women 64.3\%, males 35.7\%), age (up to 25 years $43.1 \%$, 26-35 years $23.2 \%$, 36-50 years $19.1 \%$, more than 51 years $14.7 \%$ ), education (basic $1.9 \%$, secondary school $45.8 \%$, university $52.3 \%$ ), permanent residence (countryside $48.8 \%$, city $51.2 \%$ ), economic status (student $36.3 \%$, employed $48.1 \%$, the self-employed person $4.6 \%$, unemployed $1.2 \%$, maternity leave $2.9 \%$, retired 6.9\%), monthly household income (less than 1,000 Eur 20.1\%, 1,001-2,000 Eur $54.4 \%$, more than 2,001 Eur 25.5\%) and by the number of members of the household (1-2 members $22.3 \%$; 3 members $23.2 \%$; 4 members $37.5 \%$; 5 members and more $17.0 \%$; more than 5 members $5.0 \%$ ). 
Collected data was processed by using Microsoft Excel and then evaluated in the statistical program XL Stat.

For a deeper analysis of the research objectives, the following hypotheses were formulated:

Hypothesis 1: We assume that there is a dependence between the amount of consumption of drinking milk and the age of the respondents.

Hypothesis 2: We assume that there is a dependence between the frequency of purchase of drinking milk and the daily amount of consumption of drinking milk.

Hypothesis 3: We assume that there is a dependence between the frequency of purchase of drinking milk and the preference for choosing drinking milk from the heat treatment aspect.

Hypothesis 4: We assume that consumers evaluate the factors influencing the purchase and subsequent consumption of drinking milk differently.

The formulated hypotheses were tested by applying the following statistical tests:

- Chi-square test for independence of two variables,

- Cramer's coefficient,

- Friedman test,

- Nemeny's method.

In hypothesis testing, if the p-value is lower than significant level 0.05 , the null hypothesis is rejected and the alternative hypothesis is confirmed.

\section{Results and Discussion}

Drinking milk has the largest share of total milk and dairy products consumption. The development of drinking milk consumption in the analyzed period $2009-2018$ has a downward trend with an average annual decline of $0.8 \%$ (Fig. 1). In the first reference year, consumption was $48.9 \mathrm{~kg}$ per capita and in 2018 only $45.7 \mathrm{~kg}$. Of course, the fluctuations in milk intake by Slovak consumers were also recorded. The largest increase was registered in 2010, which was determined by the state's support activities for milk consumption. However, in the context of the above, it is also important to note the elimination of consumption from 2011 to the present. Consumption of drinking milk does not cover the recommended intake and falls by almost $50 \%$, which we consider to be a very significant lack of rational nutrition. In the next two years, we expect an even lower consumption of drinking milk based on the determinant coefficient $\left(\mathrm{R}^{2}\right)$, which should reach an annual level of about $40 \mathrm{~kg}$ per capita in the Slovak Republic. Low milk consumption contributes to increasing milk prices and to constantly expanding supply of other dairy products such as cheese, yoghurt, or other sour-milk products (Kubicová, 2008; Kubicová \& Habánová, 2012; Kubicová, Predanocyová \& Kádeková, 2019). Consumption of milk could be also influenced by the level of retail prices in relation to the average income of the population (Bousbia et al., 2017), the gross domestic product and its distribution among the population, the standard of living, structure of the market, intensity of international trade or the individual consumer behavior (Matošková \& Gálik, 2016; Skořepa, 2009). 
Figure 1: Annual consumption of drinking milk per capita of the Slovak Republic

Source: Statistical Office of the Slovak Republic, 2019

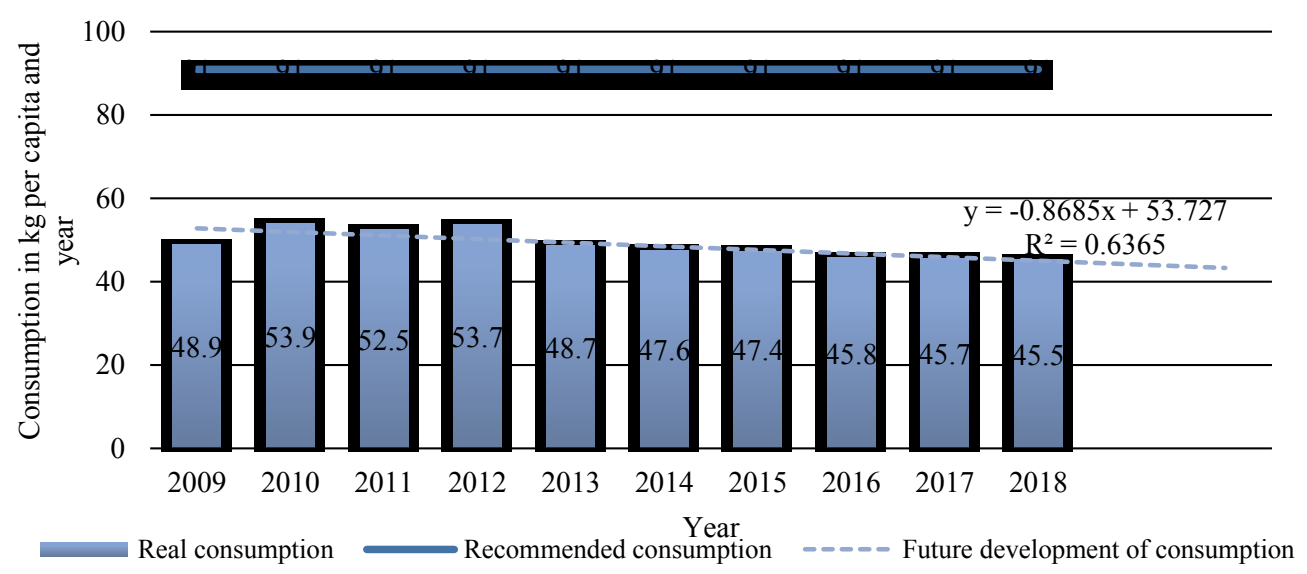

The aim of the consumer survey was to find out the amount of milk consumption, the frequency of milk consumption and to identify factors influencing its consumption. Research results have shown that $10.2 \%$ of consumers do not consume any drinking milk. $52.7 \%$ of respondents consume on average 0.01 to 0.2 liters of drinking milk per day, which is up to 21 grams of milk. The recommended dose of milk is 27 grams per day and only $9.5 \%$ of consumers adhere to this recommended amount. $8.2 \%$ of respondents daily consume milk in the amount of 32 to 51 grams and $9.5 \%$ respondents state that their average daily consumption of milk is more than 52 grams. In the context of the daily amount of milk consumption, the stated hypothesis assumed the dependence between the amount of milk consumption and the age of respondents. Based on the results of the Chi-square test for independence of two variables, it can be concluded that the dependence was not confirmed ( $p$-value $=0.373$ ). However, the following Figure 2 shows the amount of milk consumption in each age category, where slight differences in consumption can be observed between younger and older consumer age groups.

Figure 2: Average daily consumption of drinking milk according to age of respondents

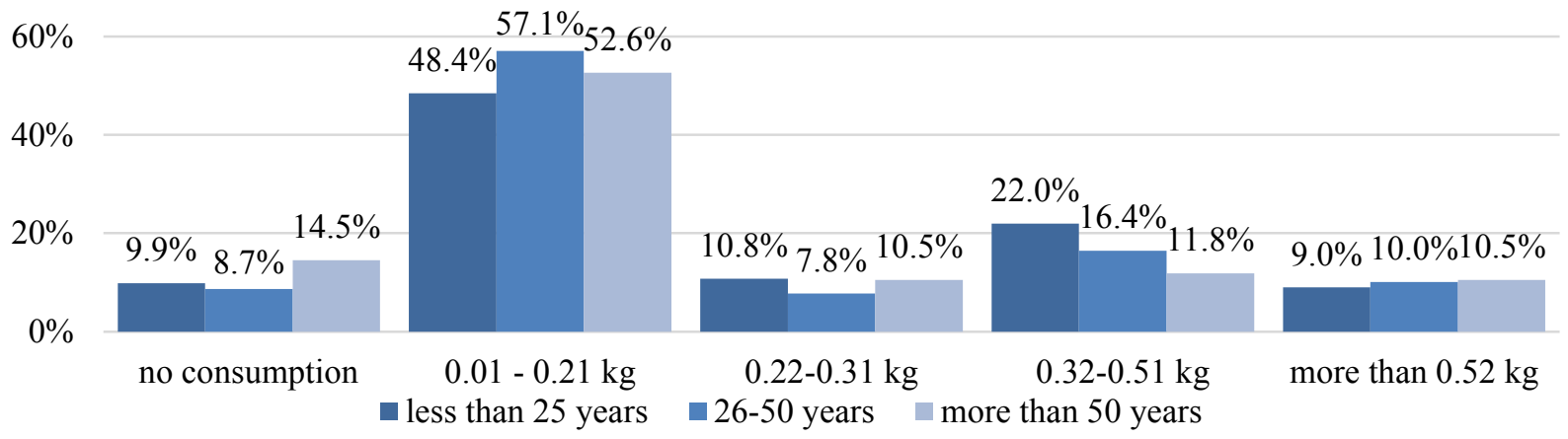

Source: questionnaire survey, 2018

The questionnaire survey was also oriented how often Slovak consumers buy drinking milk. The results show that $24.9 \%$ of consumers who consume drinking milk buy it on a daily basis. $27.7 \%$ of Slovak consumers buy milk for subsequent consumption two to three times a week. $34.1 \%$ of respondents buy milk once a week and $13.3 \%$ of Slovak consumers buy it at irregular intervals. In the context of this question, the stated hypothesis assumed the dependence between the frequency of purchase of drinking milk and the daily consumption of drinking milk. The hypothesis was formulated because not every consumer buying milk has to consume it. Based on the results of the Chi-square test for independence of two variables, it is possible to conclude 
a confirmed dependence ( $p$-value $=0.001$ ). From the aspect of dependence tightness, there is a relatively strong dependence demonstrated by the calculation of the Cramer's coefficient $(0.42)$ (Fig. 3).

\section{Figure 3: Frequency of buying drinking milk according to daily consumption of drinking milk}

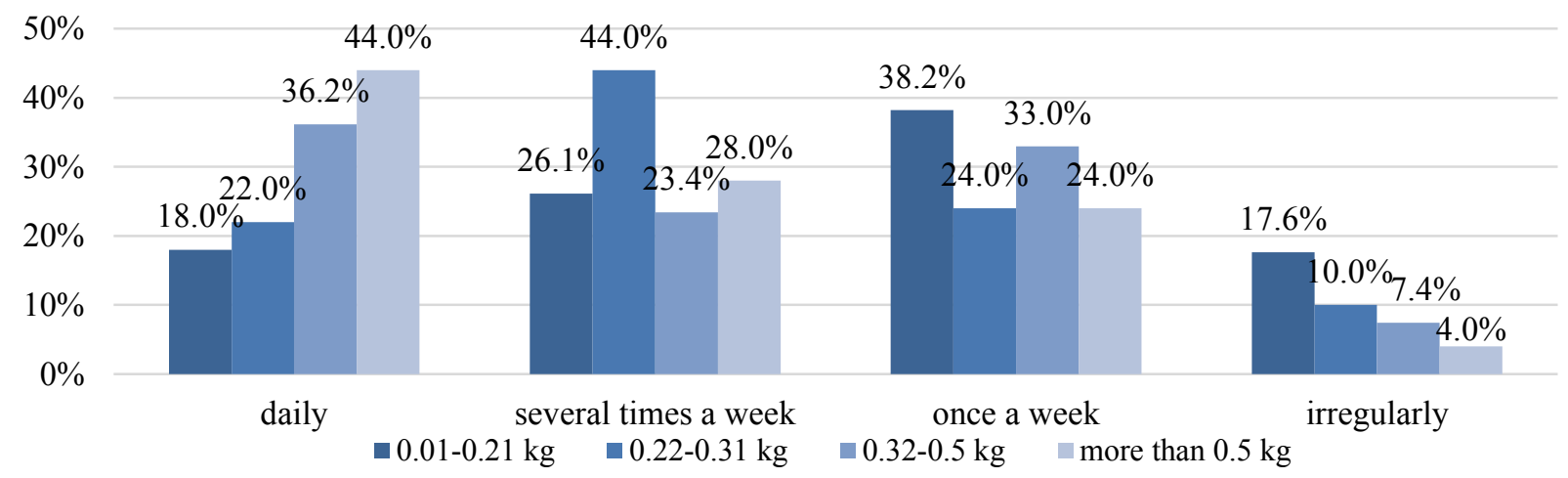

Source: questionnaire survey, 2018

Based on the results of the research we assume that consumers who buy milk daily and several times a week prefer fresh milk, while consumers who buy milk once a week or irregularly prefer UHT-treated milk, mainly because of longer shelf life. We have verified this assumption by Chi-square test for two variables. By calculating this test, we confirmed the dependence between the frequency of purchase of drinking milk and the preference of the type of milk for the treatment ( $p$-value $=0.014)$. From the aspect of dependence tightness, there is a weak dependence demonstrated by the calculation of the Cramer's coefficient (0.15) (Fig.4).

Figure 4: Frequency of buying drinking milk according to the preference for choosing drinking milk from the heat treatment aspect

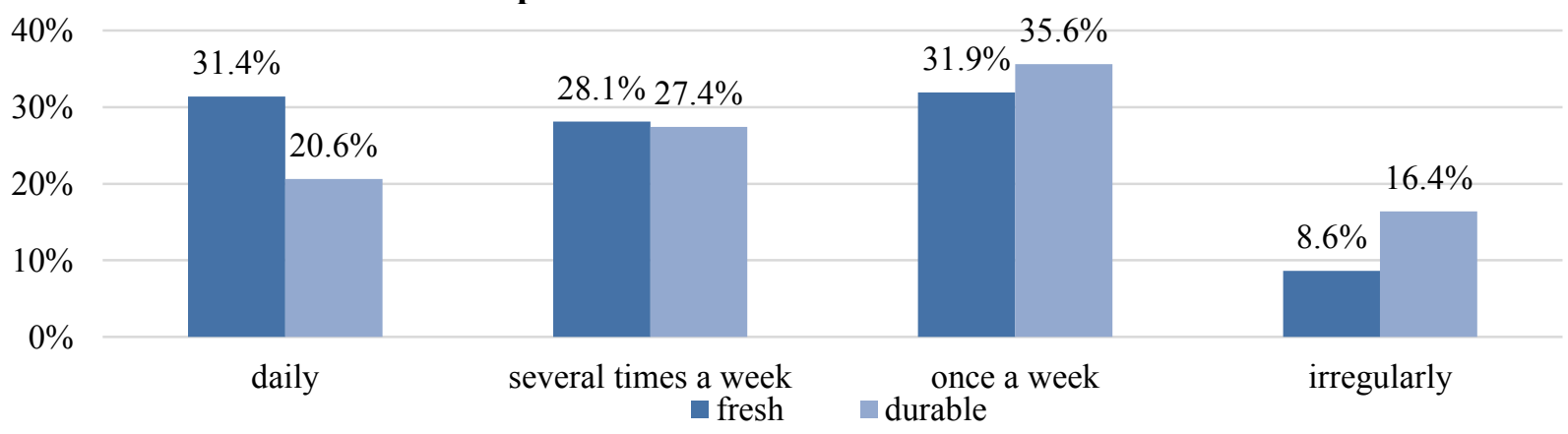

Source: questionnaire survey, 2018

The questionnaire survey was also geared towards the factors that Slovak consumers influence when purchasing the analyzed foods. Consumers determined the importance of each factor on a scale of 1 to 4 ( 1 was the least important factor and 4 was the most important factor). Based on the results of the questionnaire survey and the calculated average value of each factor, it can be concluded that quality (3.78) is the most important factor for the consumers involved in the questionnaire survey. The following is a composition factor with an average value of 3.53 and a price factor with an average value of 3.48 is the third most important aspect that determines consumers in the process of buying and subsequently consumption of drinking milk. Consumers are least affected by the appearance of the packaging (2.27) and the propagation (2.11) associated with drinking milk (Figure 4). Bytyqi et al. (2008) concludes that consumer behavior in the purchase of milk and dairy products is not affected by factors connected with the packaging of milk and dairy products. The GfK survey (2017) has shown that for the Slovak 
consumers is still a very important price when deciding about purchasing chosen food, including milk and dairy products, but the emphasis on quality is clearly rising. 59\% of consumers say they closely monitor the prices of food in different stores and shop where the best deal is offered. As a result, consumers are focusing on quality, but at the same time they are looking for quality for the best price. The research results of Ahmadi et al. (2019) have shown that consumers notice the price and composition of milk in terms of fat content in the process of buying and consumption of milk. In relation to the assessment of the various factors influencing the choice of milk by consumers, we found differences in the assessment of these criteria among the respondents (Hypothesis No. 4). Based on the Friedman test, it is possible to identify differences in factor evaluation confirmed by the statistical calculation of the p-value $(<0.0001)$, which is lower than the alpha significance level (0.05). By using Nemeny's method and based on the data in the following Table 1, we conclude that quality is the most important criterion when choosing milk (Group A), another group of significant factors is created by price, durability and composition (Group B), followed by a set of criteria created by the nutrition data and country of origin (Group C), the other group of factors consisted from the country of origin, the manufacturer and the size of packaging (group D), and the last group of factors is the appearance of packaging and the promotion of the product (Group E). By dividing the factors determining consumer behavior when choosing milk into these groups, it is possible to point to the differences in the assessment of individual criteria (groups) by consumers. The country of origin criterion is placed in two groups (Group C and Group D), which can be explained by the fact that there is no statistically significant difference in their ratings among Group C and Group D factors. However, between groups C and D there is a difference in the assessment of factors by consumers.

\section{Figure 5: Factors determining the purchase and subsequent consumption of drinking milk}

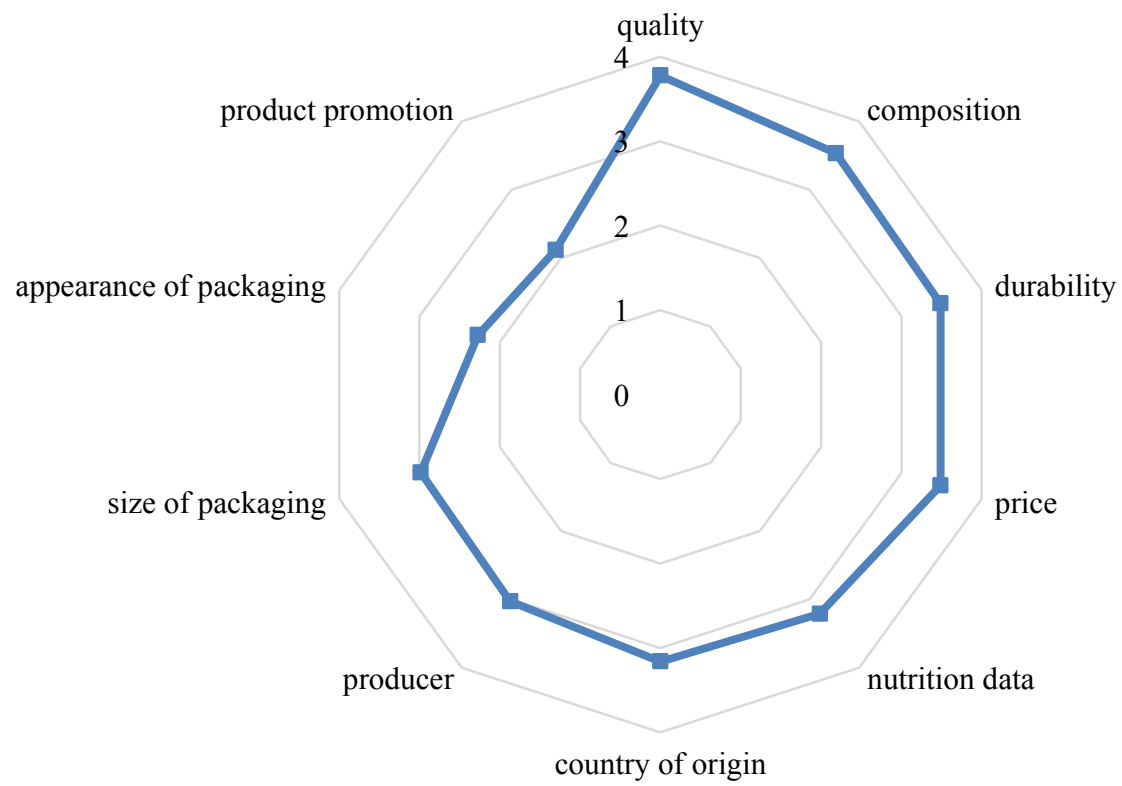

Source: questionnaire survey, 2018 
Table 1 Differences in factor evaluation when choosing milk by applying the Friedman Test and Nemeny's Method

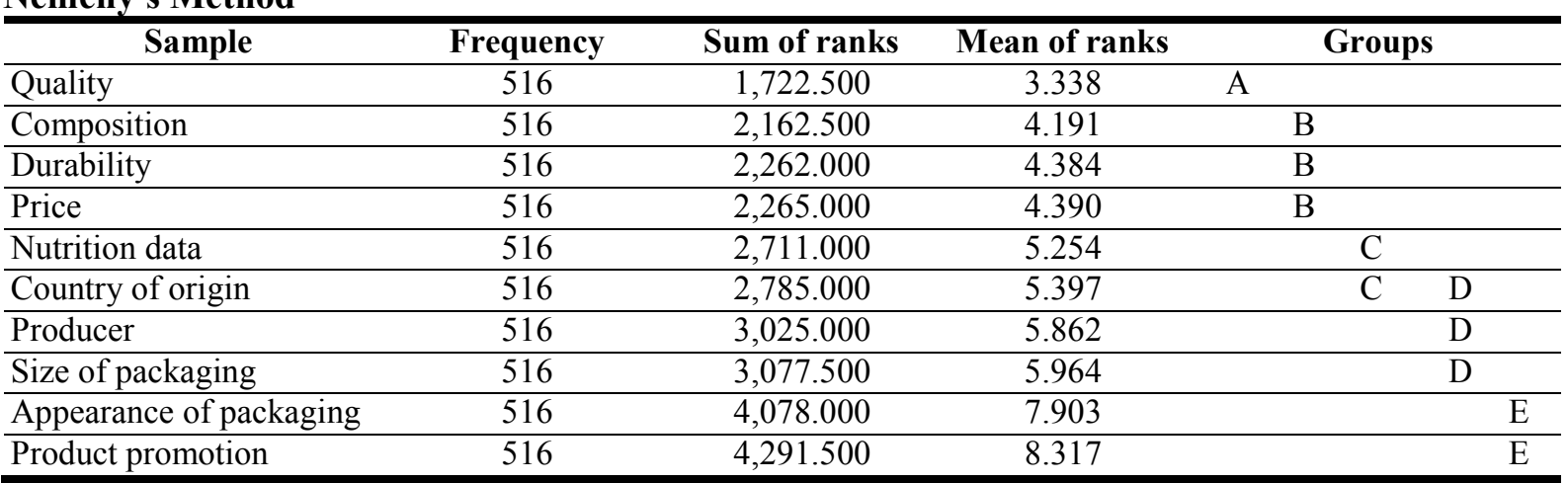

Source: questionnaire survey, 2018

\section{Conclusion}

The paper was focused on current issues concerning the consumption of drinking milk in the Slovak Republic. Based on the results, the current consumption of drinking milk is $45.3 \mathrm{~kg}$ per capita and year. The results of the questionnaire survey show that the average consumer involved in the research consumes 0.25 litres of drinking milk per day, which is approximately 27 grams of milk per day. Most Slovak consumers buy drinking milk daily or several times a week, suggesting that more than $50 \%$ of consumers prefer fresh milk. On the other hand, almost $35 \%$ buy milk once a week, indicating that they prefer durable milk. The other $13.3 \%$ of consumers buy milk at irregular intervals. In relation to the amount of consumption and the purchasing behaviour of consumers, we found out factors - quality, composition, durability and price of drinking milk as the main determinants affecting the purchase and subsequent consumption of drinking milk. It is necessary to deal with the given aspects as key determinants affecting the amount of consumption of drinking milk that has proven positive effects on the health of consumers.

\section{Acknowledgements}

This work was supported by the Slovak Research and Development Agency on the basis of Contract no. APVV-16-0244 "Qualitative factors affecting the production and consumption of milk and cheese".

\section{References}

[1] Ahmadi Kaliji, S., Mojaverian, S. M., Amirnejad, H., \& Canavari, M. (2019). Factors Affecting Consumers' Dairy Products Preferences. AGRIS on-line Papers in Economics and Informatics, 11 (2), 3-11. doi: 10.7160/aol.2019.110201

[2] Beck, K. L., \& Coad, J. (2017). Dairy Product (Calcium) Consumption and Iron Nutrition. In R. Watson (Ed.), Nutrients in Dairy and their Implications on Health and Disease (pp. 149-160). Cambridge, Massachusetts, USA: Academic Press. doi: 10.1016/B978-0-12-809762-5.00012-7

[3] Bousbia, A., Boudalia, S., Chelia, S., Oudaifia, K., Amari, H., Benidir, M., Belkheir, B., \& Hamzaoui, S. (2017). Analysis of factors affecting consumer behavior of dairy products in Algeria: A case study from the region of Guelma. Internastional Journal of Agriculture Research, 12 (2), 93-101. doi: 10.3923/ijar.2017.93.101 
[4] Bytyqi, H., Vegara, M., Gjonbalaj, M., Hajrip, M., Halim, G., Miftari, I., \& Bytyqi, N. (2008). Analysis of Consumer Behaviour in Regard to Dairy Products in Kosovo. Journal of Agricultural Research, 43 (3), 281 290. Retrieved from Research Gate. Retrieved from https://www.researchgate.net

[5] Čuboň, J., Haščík, P., \& Kačániová, M. (2012). Hodnotenie surovín a potravín živočíšneho pôvodu, Nitra: Slovenská pol'nohospodárska univerzita v Nitre.

[6] Dror, D. K., \& Allen, L. H. (2014). Dairy product intake in children and adolescents in developed countries: Trends, nutritional contribution, and a review of association with health outcomes. Nutrition Reviews, 72 (2), 68-81. doi:10.1111/nure.12078

[7] Geng, T., Qi, L., \& Huang, T. (2018). Effects of Dairy Products Consumption on Body Weight and Body Composition Among Adults: An Updated Meta- Analysis of 37 Randomized Control Trials. Molecular nutrition \& food research, 62 (1), 1700410. doi: 10.1002/mnfr.201700410

[8] GFK. (2017). Ako sa mení slovenský spotrebitel'. Retrieved from https://www.gfk.com/sk/insights/ tlacovespravy/ako-sa-meni-slovensky-spotrebitel/

[9] Herian, K. (2006). Milk is not a common food (Mlieko nie je bežná potravina). Mliekarstvo : Bulletin pre internú potrebu výrobcov a spracovatel'ov mlieka, 37 (2), 2-4.

[10] International Osteoporosis Foundation. (2015). Milk and other dairy foods are good for bone health. Retrieved from https://www.iofbonehealth.org/news/milk-and-other-dairy-foods-are-good-bone-health

[11] Keresteš, J. (2016). Milk in human nutrition (Mlieko vo výžive l’udí). Bratislava: Cad Press.

[12] Koca, T., Akcam, M., Serdaroglu, F., \& Dereci, S. (2017). Breakfast habits, dairy product consumption, physical activity, and their associations with body mass index in children aged 6-18. European Journal of Pediatrics, 176 (9), 1251-1257. doi: 10.1007/s00431-017-2976-y

[13] Košičiarová, I., Nagyová, L., \& Holienčinová, M. (2017). Consumer behaviour on Slovak yoghurt and fermented milk products market. Acta Universitatis Agriculturae et Silviculturae Mendelianae Brunensis, 65 (6), 1967-1978. doi: 10.11118/actaun201765061967

[14] Kubicová, L. (2008). Development of consumer demand for food (Vývoj spotrebitel'ského dopytu po potravinách). Nitra: Slovak University of Agiculture in Nitra.

[15] Kubicová, L', \& Dobák, D. (2012). Development and level of consumption of milk and dairy products in SR and modeling demand for food in selected household groups (Vývoj a úroveň spotreby mlieka a mliečnych výrobkov v SR a modelovanie dopytu po potravinách vo vybraných skupinách domácností). Nitra: Slovak University of Agiculture in Nitra.

[16] Kubicová, L', \& Habánová, M. (2012). Development of milk consumption and marketing analysis of its demand. Potravinárstvo Slovak Journal of Food Sciences, 6 (4), 66-72. doi: 10.5219/236

[17] Kubicová, L., Predanocyová, K., \& Kádeková, Z. (2019). The importance of milk and dairy products consumption as a part of rational nutrition. Potravinarstvo Slovak Journal of Food Sciences, 13(1), $234-243$. doi: $10.5219 / 1050$

[18] Matošková, D., \& Gálik, J. (2016). The market for milk and dairy products and its forecast for 2020 (Trh s mliekom a mliečnymi výrobkami a jeho prognóza do roku 2020). Ekonomika pol’nohospodárstva, 16 (2), 44 62.

[19] Nicklas, T. A., O'Neil, C. E., \& Fulgoni, V. L. (2009). The role of dairy in meeting the recommendations for shortfall nutrients in the American diet. The Journal of the American College of Nutrition, 28 (1), 73-81. doi: 10.1080/07315724.2009.10719807

[20] Nouzovská, Z. (2007). The importance of milk in human nutrition (Význam mlieka vo výžive človeka). Mliekarstvo: Bulletin pre internú potrebu výrobcov a spracovatel'ov mlieka, 38 (3), 20-22.

[21] Prentice, A. M. (2014). Dairy products in global public health. American Journal of Clinical Nutrition, 99 (5), 1212S-1216S. doi: 10.3945/ajcn.113.073437

[22] Skořepa, L. (2009). Regional Food Market (Regionální trh potravin). České Budejovice: Jih pro Jednotu, spotřební družstvo. 
[23] Statistical Office of the Slovak Republic. (2019). Consumption of selected kinds of foodstuffs per capita [statistics]. Available from DATAcube.

[24] Ware, M. (2016). Milk: Health Benefits and Nutritional Information. Retrieved from Medical News Today Web site: http://www.medicalnewstoday.com/articles/273451. php.

[25] Zeleňáková, L., \& Golian, J. (2008). Application of ELISA tests for the detection of falsification of milk and cheese (Aplikácia ELISA testov na detekciu falšovania mlieka a syrov). Nitra : Slovak University of Agriculture in Nitra. 


\title{
Factors Affecting Purchasing and Consumption Behaviour: A Case Study of Slovak Milk Market
}

\author{
L’udmila Nagyová ${ }^{1}$, Peter Šedík ${ }^{2}$, Jakub Berčík ${ }^{3}$, Marek Petril’ák ${ }^{4}$, Csaba Bálint Illés ${ }^{5}$ \\ Slovak University of Agriculture in Nitra ${ }^{1,2,3,4}$ \\ Faculty of Economics and Management, Department of Marketing and Trade \\ Address: Tr. Andreja Hlinku 2, \\ 94976 Nitra, Slovakia
}

Szent Istvan University in Gödöllö 5

Faculty of Economics and Social Sciences, Institute of Business Economics, Leadership and Management,

Address: Páter K. u. 1.

2100 Gödöllö, Hungary

e-mail: nagyoval26@gmail.com ${ }^{1}$, sedik.peter@gmail.com², jakub.bercik@uniag.sk³ m.petrilak93@gmail.com4, Illes.Balint.Csaba@szie.hu ${ }^{5}$

doi: 10.18515/dBEM.ISD.P01.2020.p016

\begin{abstract}
The aim of the paper was to study consumption and purchasing behaviour of milk consumer in Slovakia. The primary research was based on the questionnaire survey distributed online and with research sample $n=516$. Chi-square test, Fisher's Exact Test, Friedman test and Nemenyi test were applied for statistical testing. The results showed that respondents mostly consume both milk and dairy products. The majority of respondents prefer to consume durable milk with $1.5 \%$ or $3 \%$ fat both directly and as an ingredient in meals and beverages. Food stores, supermarkets and hypermarkets were indicated the most frequent places of purchase. Purchasing milk at the farmer's markets, fairs or stalls was more common in urban areas, whereas in rural areas it were farms. The country of origin and expiration date were evaluated as the most important factors during purchase, and the packaging material, brand and resealable packaging were evaluated as the least important factors.
\end{abstract}

Keywords: milk consumption, consumer research, purchasing factors

JEL Classification: M31, M37, Q13

\section{Introduction}

Milk is being considered as the first and main staple product in many countries in long human history. It provides a rich source of proteins for tissue growth, calcium for strong bones, vitamins such as vitamin $\mathrm{D}$ for calcium absorption or vitamin A for vision, carbohydrates for energy and many other beneficial substances for human health (Rahnama \& Rajabpour, 2017; Lonnerdal 2003). According to Yildiz Tiryaki \& Akbay (2008), milk consumption and preferences for dairy products vary across countries even though there exist certain recommendations of sufficient intake amounts. Based on Kajaba et al. (2012), the recommended annual intake of milk and dairy products is as follows: $220 \mathrm{~kg}$ of milk and dairy products of which $10.1 \mathrm{~kg}$ is cheese and curd. Moreover, $90.1 \mathrm{~kg}$ should be obtained by drinking milk and $14 \mathrm{~kg}$ from sour-milk products. In addition, each person is recommended to consume 602 grams of milk and dairy products on a daily basis, where at least 249 grams should be obtained from drinking milk. In order to increase consumption and popularity of milk it is 
necessary to socio-demographic and qualitative factors affecting production and consumption (Horská, 2018). In Slovakia, the average consumption of milk per capita has been slightly decreasing since 2010 . However, in terms of milk and dairy products the average consumption per capita has an increasing tendency (see Fig. 1). In 2018 the average Slovak resident consumed $172.1 \mathrm{~kg}$ of milk and dairy products of which around $46 \mathrm{~kg}$ was milk (Statistical Office of the SR 2019). Petril'ák et al (2017) stated that if retailers sell more dairy products produced in Slovakia, farmers may produce more value-added milk products. Moreover, farmers may sell fresh diary products of high quality, however if consumers are not aware of them and have very little information about them, they will not buy them (Petril'ák, Martovič \& Horská, 2019). The most important motives of milk consumption were identified by Kurajdová, Táborecká-Petrovičová \& Kaščáková (2015) who listed 4 motives: tradition, nutritional composition, health aspect and milk itself. Regarding the health aspects, milk consumption reduces risk of death (Bongard et al., 2012), prevents osteoporosis, maintains physical activity and reduces depression. Moreover, it supports good vision, body temperature regulation, development of brain and nerve tissues, resistance to various infections (Herian, 2006; International Osteoporosis Foundation, 2015).

Figure 1: Average consumption of milk and dairy products per capita in Slovakia

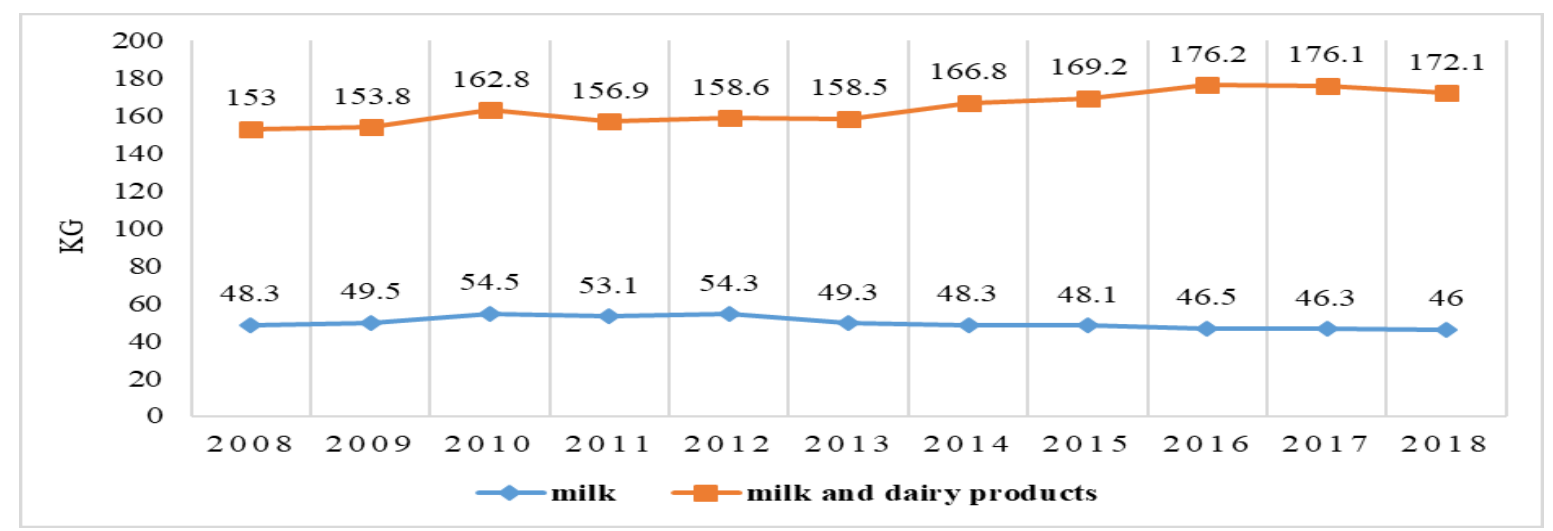

Source: Statistical Office of the SR 2019

\section{Data and Methods}

The aim of the paper was to study consumption and purchasing behaviour of Slovak consumer in the milk market. The research was based on primary data obtained via an online questionnaire survey conducted within the period of April and May in 2018. In total, 755 respondents attended the survey. However, after inclusion criteria (active milk consumption), only 516 respondents remained in the research sample. Demographic profile of respondents is shown in Table 1. The data were processed and analysed in statistical program IBM SPSS Statistics 25 and Xlstat.

Table 1: Demographic profile of respondents

\begin{tabular}{ll}
\hline Gender & \\
\hline male & $44.19 \%$ \\
\hline female & $55.81 \%$ \\
\hline Age structure & \\
\hline $18-24$ years & $31.20 \%$ \\
\hline $25-49$ years & $33.72 \%$ \\
\hline
\end{tabular}




\begin{tabular}{ll}
\hline$\geq 50$ years & $35.08 \%$ \\
\hline Place of residence & \\
\hline urban areas & $48.84 \%$ \\
\hline rural areas & $51.16 \%$ \\
\hline Economic activity & $25.97 \%$ \\
\hline student & $49.81 \%$ \\
\hline employed & $4.26 \%$ \\
\hline unemployed & $19.96 \%$ \\
\hline pensioner &
\end{tabular}

Source: own elaboration

For the purpose of a deeper analysis, the following hypotheses were formulated:

H1: There exists dependence between consumption of milk and dairy products and respondent's place of residence.

H2: There exists dependence between place of purchase and respondent's place of residence.

H3: There are differences in evaluation of purchasing factors towards milk in age segment $\geq 50$ years.

H4: There are differences in evaluation of purchasing factors towards milk in age segment 25 -49 years.

H5: There are differences in evaluation of purchasing factors towards milk in age segment 18 -24 years.

Formulation of hypotheses was based on similar consumer survey conducted among U.S. residents (Bir et al., 2019) and hypotheses confirmation was done by applying the following statistical tests:

- Fisher's Exact Test

- Chi-square test,

- Friedman test,

- Nemenyi test.

\section{Results and Discussion}

Results based on questionnaire survey showed that $72.3 \%$ of respondents consume milk both directly by drinking milk and indirectly as an ingredient in meals and beverages, $15.1 \%$ consume milk as an ingredient, and only $12.6 \%$ just drink it. In general, respondents prefer to drink either milk with $1.5 \%$ fat $(43.8 \%)$ or milk with $3 \%$ fat $(26.9 \%)$. Considering the expiration date of milk, only $35 \%$ prefer to consume fresh milk. Moreover, the survey examined whether respondents consume dairy products as well. The results showed that $83.3 \%$ of respondents consume both milk and various dairy products. The first hypothesis assuming the differences between urban and rural areas was formulated based on the above mentioned question. By applying Fisher's Exact Test, these differences were confirmed ( $p$-value $=0.003$ ). Higher percentage of consuming just milk is in urban areas (see Fig. 2). Regarding dairy products, cheese, butter, sour milk products, curd or cream is consumed the most. In addition, the Slovak 
study conducted by authors Kubicová, Predanocyová \& Kádeková (2019) showed that milk, cheese and butter is consumed on a weekly basis.

Figure 2: Consumption of milk and dairy products according to place of residence

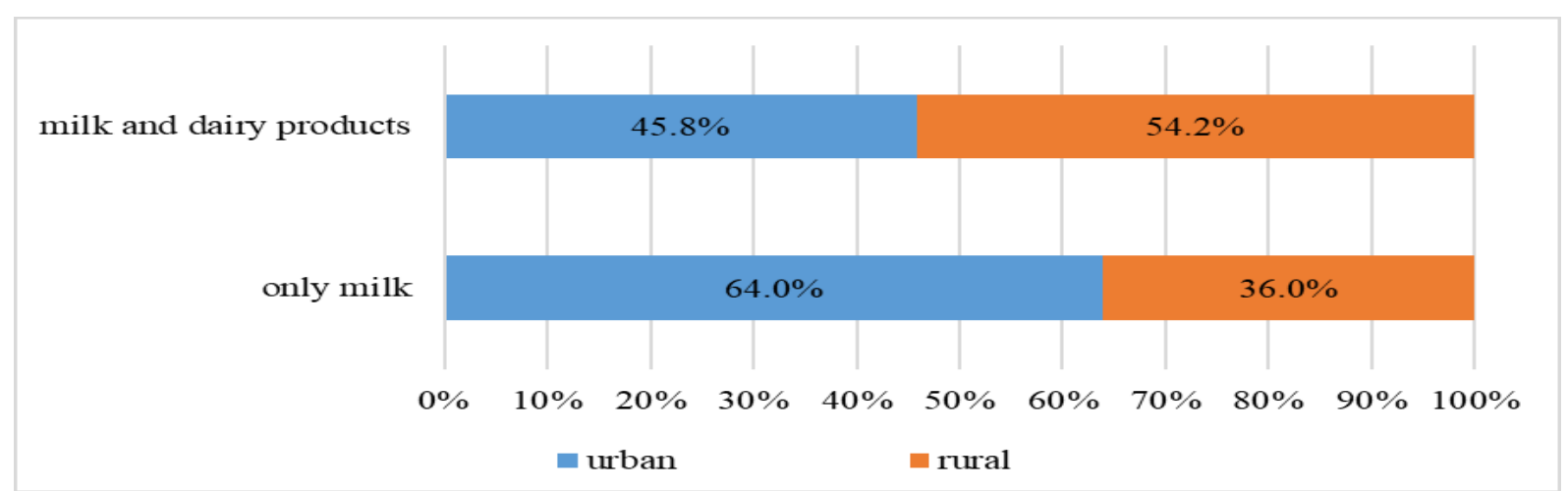

Source: own processing

Furthermore, the survey examined where respondents purchase milk most often. The majority purchase milk in food stores, supermarkets or hypermarkets. For deeper analysis, a hypothesis assuming differences between rural and urban areas regarding the place of purchase was formulated. This hypothesis was confirmed based on Chi-square test ( $\mathrm{p}$-value $=0.000$ ). In rural areas respondents purchase milk more from farms while milk purchased at the farmer's markets, fairs or stalls is more frequent in urban areas (see Fig. 3).

Figure 3: Place of purchase according to place of residence

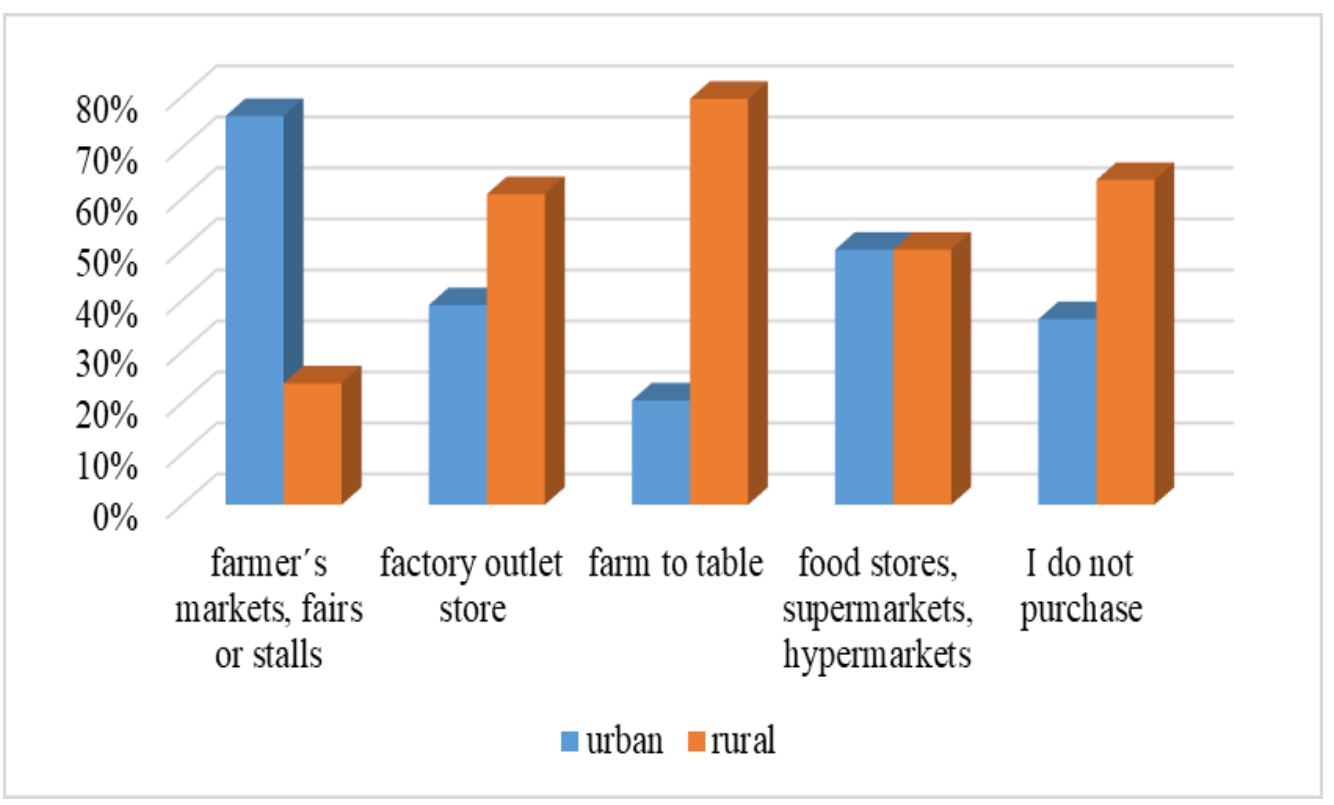

Source: own processing

Regarding the purchasing factors, the respondents were asked to evaluate the following factors: packaging material, resealable packaging, expiration date, country of origin, $\%$ fat and brand. The evaluation was based on a 6-point scale, where 6 represented the most important factor and 1 represented the least important factor (points could be repeated). For a deeper analysis, 
respondents were split into three segments (18 -24 years; $25-49$ years; $\geq 50$ years) and examined separately (see Fig. 4). Furthermore, the hypothesis assuming differences in evaluation of purchasing factors was formulated for each age segment. The hypothesis was confirmed in all segments applying Friedman test. For a precise identification of these differences Nemenyi test (see Tab. 2) was applied. The first age segment (18- 24 years) evaluated expiration date of milk as the most important factor, followed by the country of origin and the least important factors were packaging material and brand. Both $24-49$ years segment and $\geq 50$ years segment obtained the same differences between the factors. The most important factor in the purchase of milk was the country of origin followed by the expiration date and $\%$ fat. The least important factors were packaging material, brand and resealable packaging. The similar results were obtained in consumer research conducted in Slovakia, where young consumers evaluated advertising as the least important factor when purchasing dairy products (Kubeláková \& Šugrová, 2017). According to authors Hoque, Xie \& Nazneen, (2018) brands and search attributes such as shape and colour are less important for consumers when selecting fresh milk.

Figure 4: Evaluation of factors during purchase of milk

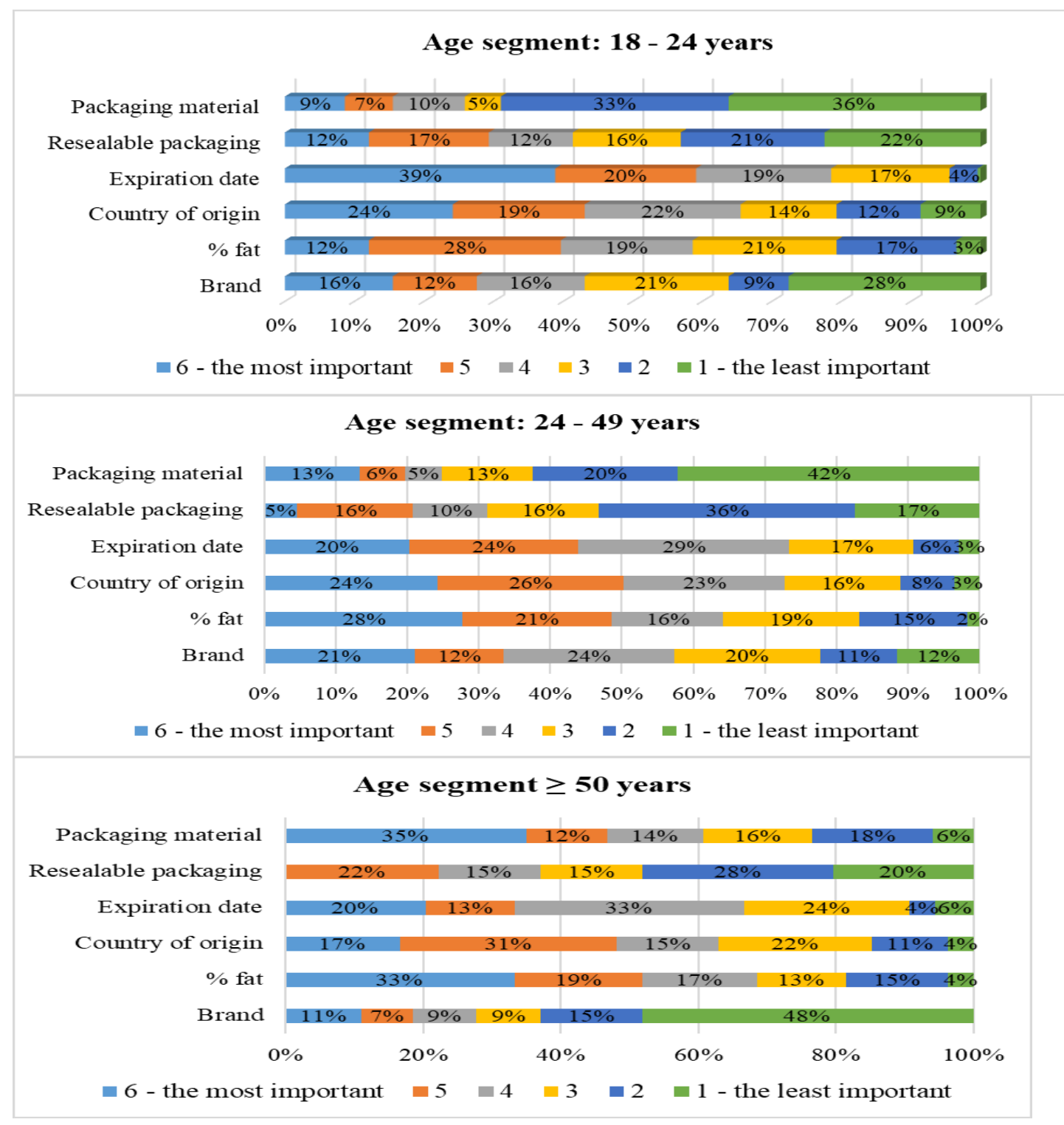


Source: own elaboration

Table 2: Multiple pairwise comparisons using Nemenyi's procedure

\begin{tabular}{|c|c|c|c|}
\hline Age segment: $18-24$ years & $\begin{array}{c}\text { Mean of } \\
\text { ranks }\end{array}$ & & Grou \\
\hline Packaging material & 2.738 & $\mathrm{~A}$ & \\
\hline Brand & 3.019 & A & \\
\hline Resealable packaging & 3.263 & A & $\mathrm{B}$ \\
\hline$\%$ fat & 3.663 & & $\mathrm{~B}$ \\
\hline Country of origin & 4.013 & & \\
\hline Expiration date & 4.306 & & \\
\hline Age segment: $25-49$ years & $\begin{array}{c}\text { Mean of } \\
\text { ranks }\end{array}$ & \multicolumn{2}{|c|}{ Groups } \\
\hline Packaging material & 2.532 & A & \\
\hline Brand & 2.803 & \multirow{4}{*}{$\begin{array}{l}\mathrm{A} \\
\mathrm{A} \\
\mathrm{A}\end{array}$} & \\
\hline Resealable packaging & 2.861 & & \\
\hline$\%$ fat & 4.220 & & $\mathrm{~B}$ \\
\hline Expiration date & 4.254 & & $\mathrm{~B}$ \\
\hline Country of origin & 4.329 & & $\mathrm{~B}$ \\
\hline Age segment: $\geq 50$ years & $\begin{array}{c}\text { Mean of } \\
\text { ranks }\end{array}$ & \multicolumn{2}{|c|}{ Groups } \\
\hline Packaging material & 2.478 & \multirow{6}{*}{$\begin{array}{l}\mathrm{A} \\
\mathrm{A} \\
\mathrm{A}\end{array}$} & \\
\hline Brand & 2.778 & & \\
\hline Resealable packaging & 2.889 & & \\
\hline$\%$ fat & 4.194 & & $\mathrm{~B}$ \\
\hline Expiration date & 4.322 & & $\mathrm{~B}$ \\
\hline Country of origin & 4.339 & & $\mathrm{~B}$ \\
\hline
\end{tabular}

Source: own elaboration

\section{Conclusion}

In conclusion, most respondents consume both milk and dairy products such as cheese, butter, sour milk products, curd or cream. Milk is mostly consumed both directly and as an ingredient in meals or beverages. The most preferred is durable milk with $1.5 \%$ or $3 \%$ fat. In general, milk is mostly purchased in food stores, supermarkets or hypermarkets. Purchasing milk from farms is more common in rural areas, while purchasing at farmer's markets, fairs or stalls is more frequent in urban areas. The most important factors during the purchase of milk were country of origin and expiration date, while the least important were packaging material, brand and resealable packaging.

\section{Acknowledgements}

This paper was supported by the Slovak Research and Development Agency on the basis of Contract no. APVV-16-0244 "Qualitative factors affecting the production and consumption of milk and cheese. 


\section{References}

[1] Bir, C., Widmar, N. O., Wolf, C., \& Delgado, M. S. (2019). Traditional attributes moo-ve over for some consumer segments: Relative ranking of fluid milk attributes. Appetite, 134, 162-171. doi:10.1016/j.appet.2018.12.007

[2] Bongard, V. et al. (2012). Consumption of milk is associated with a reduced risk of mortality in middle-aged men. Archives of Cardiovascular Di-seases Supplements, 4(1), 100. doi: 10.1016/S1878-6480(12)70708-5

[3] Herian, K. 2006. Milk is not a common food (Mlieko nie je bežná potravina). Mliekarstvo: Bulletin pre internú potrebuvýrobcov aspracovatelov mlieka, 37(2), 2-4.

[4] Hoque, M. Z., Xie, J., \& Nazneen, S. (2018). Effect of labelled information and sensory attributes on consumers' intention to purchase milk. South Asian Journal of Business Studies, 7(3), 265-286. doi:10.1108/sajbs-02-2018-0021

[5] Horská, E. (2018). Qualitative factors affecting the production and consumption of milk and cheese, Journal of Pharmaceutical Sciences \& Emerging Drugs. vol. 6, p. 22.

[6] International Osteoporosis Foundation. 2015. Milk and other dairy foods are good for bone health. Available at: https://www.iofbonehealth.org/news/milk-and-other-dairy-foods-are-good-bone-health

[7] Kajaba, I., Šimončič, R., Frecerová, K., Salkayová, I. 2012. Possibilities of Using Milk and Milk Products to Prevent Some Cancer -Current Views (Možnosti využitia mlieka amliečnych výrobkov vprevencii niektorých karcinómov -súčasné názory). Mliekarstvo: Bulletin pre internú potrebu výrobcov aspracovatel'ov mlieka, 41(2), 17-22.

[8] Kubeláková, A. \& Šugrová, M. (2017). Habit or choice? The decision - making process of young generation in purchasing dairy products in the Slovak Republic. International day of science 2017 economics, management, innovation proceedings of the international scientific conference. Moravian University College Olomouc, Czech Republicp. ISBN 978-80-7455-060-7.

[9] Kubicová, L., Predanocyová, K., \& Kádeková, Z. (2019). The importance of milk and dairy products consumption as a part of rational nutrition. Slovak Journal of Food Sciences, 13(1), 234-243. doi: $10.5219 / 1050$

[10] Kurajdová, K., Táborecká-Petrovičová, J., Kaščáková, A. (2015). Factors Influencing Milk Consumption and Purchase Behavior - Evi-dence from Slovakia. Procedia Economics and Finance, 34, 573-580. doi: $10.1016 / \mathrm{S} 2212-5671(15) 01670-6$

[11] Lonnerdal, B. (2003). Nutritional and physiologic significance of human milk proteins. American Journal of Clinical Nutrition, 77(6), 1537-1543.

[12] Petril'ák, M., Horská, E., Šumichrast, J., \& Palkovič, J. (2017). Comparison of Slovak dairy products with and without added value sold by commercial chains. Rural Development 2017. Kaunas: Aleksandras Stulginskis University. doi:10.15544/RD.2017.132

[13] Petrilák, M., Martovič, M., \& Horská, E. (2019). Efektívnost' využívania vybraných sociálnych sietí malými farmármi, ktorí ponúkajú lokálne mliečne výrobky na území Slovenska, Quo vadis massmedia \& marketing. Trnava : Univerzita sv. Cyrila a Metoda. 161-168.

[14] Rahnama, H, Rajabpour, S. (2017). Factors for consumer choice of dairy products in Iran. Appetite, 111, 4655. doi: 10.1016/j.appet.2016.12.004

[15] Statistical Office of the SR. (2019). Consumption statistics [statistics]. Available from DATAcube database

[16] Yildiz Tiryaki, G., \& Akbay, C. (2008). Consumers' fluid milk consumption behaviors in Turkey: an application of multinomial logit model. Quality \& Quantity, 44(1), 87-98. doi:10.1007/s11135-008-9182-y 


\title{
Placing of Smell in Restaurant and Aromatization' Impact on Customers and Profit
}

\author{
Johana Paluchová ${ }^{\text {, Jakub Berčík }}{ }^{2}$, Katarína Neomániová ${ }^{3}$, Patrícia Janičová ${ }^{4}$ \\ Slovak University of Agriculture in Nitra \\ Faculty of Economics and Management, Department of Marketing and Trade $1,2,3,4$ \\ Address: Tr. A. Hlinku 2, \\ 94976 Nitra, Slovak Republic \\ e-mail: johana.paluchova@gmail.com¹,jakub.bercik@uniag.sk², katarina.neomaniova@uniag.sk³ \\ patricia.janicova@uniag.sk ${ }^{4}$
}

doi: 10.18515/dBEM.ISD.P01.2020.p017

\begin{abstract}
Every day man is influenced by many factors and influences from the external or internal environment, which he/she perceives through the five sense organs, which are touch, sight, hearing, taste and last but not least a smell. Planning of restaurant marketing is very important and it is the key for booming business. Successful owners and restaurant managers create a marketing plan in advance for the whole year and in line with it forming its annual budget. There are several trends in doing restaurant marketing, one of them is an aroma marketing what is an unconscious tool thanks to it, restaurant owners are able to stimulate guests to order/ buy more, spend more time or to motivate them to pay for other extra food or beverages. Of course this leads the employees to the higher activity and pleasant conditions of environment. Information that is perceived by smell and directly affects decisions. It is much more than just releasing the aroma, a pleasant odor in space. It is a tool with a very wide range of uses such as inducing a feeling of relaxation, balance, awakening memories, inspiration, feelings or peace. An important goal of aroma marketing is to increase profits and turnover. The main aim of this paper is to investigate a restaurant marketing in a selected restaurant FAINA located in Michalovce City (Eastern Slovakia). We tested the selected "Herbs" fragrance placed in chosen restaurant during the selected period and we monitored the aroma impact on customers and as well as on service revenues, and last but not least we conducted a brief survey of the smell perception in selected space.
\end{abstract}

Keywords: aroma marketing, consumer perception, impact of smell, profit, restaurant

JEL Classification: M31, O30, L83

\section{Introduction}

\subsection{Foundation of Restaurant Marketing}

The restaurant needs can be divided into two groups, first one are the basics of need physiological and the second group specifies the needs associated with the use of leisure. Activities such as food safety and storage, technological processes for preparing beverages and meals and, of course, ensuring all of this are defined in the restaurant (Sládek, 2003). Marketing for restaurants is entirely different from marketing other products or services as well as doing the marketing strategies (Kubicová-Kádeková, 2017). An effective restaurant communications strategy should be go-to plan, influencing every decision to make and action to take (HorskáGálová-Mravcová, 2018). The content in restaurant comma strategy supplies the data to: formulate social media strategy, and to develop restaurant crisis communications plan and structure your loyalty program. Restaurants provide a unique combination of tangible and intangible aspects, both of which have to be marketed simultaneously (Khan, 2015). The 
restaurant industry has benefited from gains in consumer disposable income and consumer spending as well as increased use of technology that has helped to enhance customer service and efficiency of operations (Heroux, 2010). Restaurant marketers compile it into a customer database and use it for strengthening customer relationships (e.g., providing incentives to frequent diners, dissemination of points for purchases, mailing birthday cards, special offers, free gifts, promotions, events, and complaint handling) (Kasavana-Knutson 2000). Restaurant owners and managers understand that loyal customers are worth a great deal more than casual ones, so many restaurants adapt various types of customeroriented marketing strategies and loyalty programs (Mattila 2001; Jang-Mattila, 2005). The core product of a restaurant in undoubtedly food and beverages that appeal to people's sense of taste and smell. The effect of dining atmospherics (interior design, ambience, spatial layout, human element has an impact of emotional responses and influence on behavioral intention (Hung-Gu, 2012).

\subsection{Overview of Aromatization and Aroma Marketing}

Business used an aromatization will be control over: perception, sensitivity, radius of action (smell spreads over long distances, acts in the dark and continues to function even when the sender of the signal has already disappeared), long memory, speed reaction, and unique impact. Basically, aromatization is done by using of special equipment or devices which arrange the aroma spread in a space (Berčík-Paluchová et al., 2018). Aromatized equipment gives the possibility to obtain a well-being and comfort in any enclosed or spacious area. Due to the advanced technology, the fragrance is presented discreetly and gracefully. Aromagic (2019) presents, that aromatization for business creates soft and pleasant emotions, that go perfectly together with a brand, product or service. It allows the business to stand out among rivals and forms a positive impression about business. According to Berčík-Paluchová et al. (2016) scent marketing is a new direction of art of sales, which is based on the impact of fragrances on human behavior. The sense of smell acts on the nervous system many times faster than hearing. Aroma marketing is one of the modern forms of marketing that helps to improve the image of the store and brings new shopping experiences to customers (Sikela, 2014). It can be used in terms of: the surrounding scents fill the gaps in space or the concept of own brand odor-specific aroma for brand recognition in the market (StoreMedia, 2019; Kimmel, 2012). Müller-Alt et al. (2011) divided aroma marketing between three forms depending on the use of fragrance in the room: 1) marketer scent; 2) product scent and 3) environment scent. Aroma marketing is a series of cases where it is possible, with the influence of fragrances, to stimulate customers to buy goods and services and workers to be more active in the workplace. The aroma marketing uses different diffusers or odor techniques, while the fragments are tailored to the target audience profile (Jurášková et al., 2012). Aroma marketing importance is based on several factors: a) good air quality, can consciously help to change or improve the current mood of not only customers but also employees; b) has a positive impact on customers, often times they are much more generous in areas where aroma is discharged than in areas where it is not; c) its placement allows for increased sales and d) products and services are offered in a particularly favorable way. Kardes et al. (2014) said that fragrance marketing is a special sector of sensory marketing that studies and exploits the enormous potential of perfumes as a means of communication, emotion and memory. Aroma in the human brain immediately create a change in mood, and thus change the behavior of individual consumers. Aroma marketing as "marketing without dollars". Ambient fragrances have the potential to create a positive mood that translates into a more favorable assessment of trade and products and possibly higher sales revenues (Krishna, 2010; Levy-Weitz-Grewal, 2012; Spangenberg-Sprott et al.,2006). According to Pabian (2011); Cartwright (2014) aroma marketing is a part of: a) impact on customer behavior at point of sale 
using individually selected flavor mixtures; b) the art of using fragrances in a marketing campaign and accessing customer emotions; c) an important element supporting modern marketing strategies and part of the marketing mix; d) extremely effective trading tools; e) tool in the fight for customers, because one cannot resist the magic of fragrances, can close eyes and block ears, but we cannot stop breathing and f) scents can stimulate a person's appetite. The Table 1 illustrates the summarization of ambient odors especially recommended for restaurant spaces.

Table 1: Ambient and Recommended Aromas in Restaurant Industry regarding to Menu

\begin{tabular}{|l|l|}
\hline Type of Restaurant & \multicolumn{1}{|c|}{ Ambient/ Recommended Aromas } \\
\hline Steak house & wood, herbs, fresh bakery, baked meat, barbecue, chicken soup \\
\hline Italian & napoli, herbs, mozzarella, pasta, wine, crunchy bread, pastry \\
\hline Chinese & curcuma, ginger, soya soyce, chicken soup \\
\hline Mexican & guacamole, lime, nachos, tacos \\
\hline Sushi bar & sea food, seaweed, wasabi, spearmint \\
\hline Veggie & fresh salad, soya sauce, fresh bakery, olive oil, pastry, spearmint \\
\hline Chalet & bacon, sheep chesse, wood, popcorn \\
\hline Pizza tratoria & basil, garlic, pizza salami, mozzarela, napoli, crunchy bread, pastry \\
\hline Patisserie & $\begin{array}{l}\text { vanille, chocolate, fruit, coffee, cinnamon, chessecake, raisins, } \\
\text { candy, sugared almond, strawberry cream }\end{array}$ \\
\hline Organized event & flower, fresh, rose \\
\hline Christmas time & $\begin{array}{l}\text { apple, orange, cinnamon, chocolate orange peel, vanilla, clove, } \\
\text { gingerbread }\end{array}$ \\
\hline Coffeeshop & amaretto, cappuccino, chai, coffee, coke, tea (green/ white) \\
\hline
\end{tabular}

Source: own Table

If buying restaurant scents sounds outrageous, it's worth noting that the right smells can increase food sales. According to a study by the University of Paderborn, scents increased impulse buying by $6 \%$, buying intention by $14.8 \%$, and the length of a customer's stay by 15.9 $\%$. An open kitchen design is another solution. Because there are no walls that separate the kitchen from the dining area, the smells from the cooking food will waft freely over to the diners (Fohlio, 2019), e.g. the scent of fresh bread or freshly baked muffins in a restaurant can make guests feel the hunger since the freshly baked goods are right there, people decide to order some. The same thing goes when people smell an aromatic coffee scent released near the doorway of a cafe. The scent can invite people who were initially just passing by and at the same time, encourage diners to stay longer and again to buy more.

\section{Data and Methods}

The main aim of this paper is to investigate a restaurant marketing in a selected restaurant FAINA located in Michalovce City (Eastern Slovakia). We tested the selected "Herbs" fragrance placed in chosen restaurant during the selected period and we monitored the aroma impact on customers and as well as on service revenues, and last but not least we conducted a brief survey of the smell perception in selected space.

The main objects of observation are FAINA Restaurant: established in 2014 in Michalovce City, convenient location, good parking, catering, terrace, an area of $80 \mathrm{~m}^{2}, 5$ tables, 2 staff, 
offering breakfast, lunch, dinner, coffee and drinks (mainly Italian style of dining). The second object is Herbs aroma: chosen regarding to consultation with the owners Mr. Kudláč and Mr. Lebik, $150 \mathrm{ml}$ refill provided by Aroma Marketing Ltd. company. This aroma was dispread by Aroma Streamer 650 device (see Figure 1) with this description: a) room-size: approx. $150 \mathrm{~m}^{2}$ or $450 \mathrm{~m}^{3}$ (3 $\mathrm{m}$ ceiling height); b) digital display and time switch clock; c) easy adjustment of fragrance intensity; d) quick and easy scent change and e) wall mounting possible. Streamer devices are an absolute novelty on the Slovak market, compared to the competition, they excel in their timeless design, simple operation and absolute silence.

Figure 1: AromaStreamer 650 and Aroma Refill by REIMA AirConcept
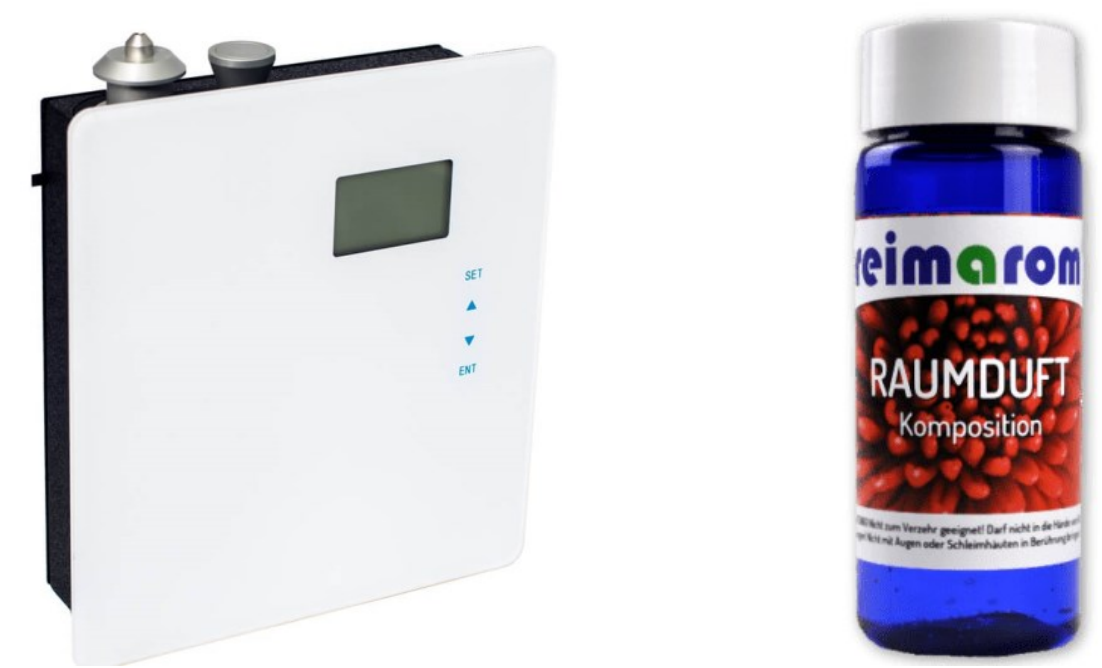

Source: https://www.duftmarketing.de/en/\#.

The last one, third object of our research were 52 respondents (see Table 2): segment of FAINA restaurants guests, who were personally addressed directly in selected service place. Data from questionnaire were obtained during one month. The customers were classified by age, gender, education and their actual feeling. These respondents were a part of research, when selected aroma - Herbs was placed in FAINA restaurant, during the aromatization' period.

Table 2: Structure of respondents

\begin{tabular}{|c|c|c|c|c|c|c|c|}
\hline $\begin{array}{l}\text { How you feel } \\
\text { right now? }\end{array}$ & & Age & & Gender & & Education & \\
\hline very good & $71.15 \%$ & $18-24$ & $19.23 \%$ & male & $55.77 \%$ & secondary & $55.77 \%$ \\
\hline good & $25 \%$ & $25-29$ & $25 \%$ & female & $44.23 \%$ & university Bc.degree & $9.62 \%$ \\
\hline neutral & $3.85 \%$ & $30-39$ & $26.92 \%$ & & & university master degree & $34.61 \%$ \\
\hline & & $40-49$ & $11.54 \%$ & & & & \\
\hline & & $50-59$ & $9.62 \%$ & & & & \\
\hline & & 60 and more & $7.69 \%$ & & & & \\
\hline
\end{tabular}

Source: own research

The following data were used: a) primary, such as: consultation with owners and selection of aroma, questionnaire with customers and profit of restaurant in chosen periods with aromatization and without it and b) secondary, such as: scientific papers, books in topic of 
market research, restaurant marketing, aroma marketing, sensory marketing, web pages of companies which make business with producing and selling of smells for business areas.

For the statistical relevance and deeper research were used methods of paper such as questionnaire, consultations with owner and Chi-squared test. Questionnaire: filled personally in FAINA restaurant with $100 \%$ return in time of food preparing. Finally, it has seven questions. The main benefit of questionnaire was to find out, how aroma influence the customers and how they perceive it in visited restaurant. The second one Consultations with both owners: in order to obtain their experiences and knowledge about aroma marketing and to select a smell for placing it in restaurant. The part of consultation was a training, how to use an AromaStreamer 650 diffuser. Chi-squared test $\left(\chi^{2}\right.$ test): statistic is commonly used for testing relationships between categorical variables, is any statistical hypothesis test where the sampling distribution of the test statistic is a chi-squared distribution when the null hypothesis is true (Obtulovič, 2010).

Our hypothesis: Is there a significant relationship between gender and aroma impact on higher appetite of food/ drinks?

H0: There is no significant relationship between the gender of the respondents and aroma impact on higher appetite of food/ drinks.

H1: There is significant relationship between the gender of the respondents and aroma impact on higher appetite of food/ drinks.

\section{Results and Discussion}

Placing of aroma in the restaurant, comparison of research time periods and impact of scent on customers and profit

In our restaurant FAINA was placed one aromatic unit - AromaStreamer 650 device by Aroma Marketing Ltd. company for one month. The selected aroma - Herbs was chosen after the consultation with both owners of service provider (see Figure 2). This scent best suited the conditions and structure of this restaurant (in menu list are the food such as salads, pizza, pasta, crunchy pastry, snacks etc.). The reasons, why we placed Herbs aroma was a fact, that owners preferred to use a scent of food more than drink (we rejected the aroma of coffee, tea, chocolate etc.) due to see, how this aroma influence the customers to eat more and order extra food. Area of the restaurant is approx. $80 \mathrm{~m}^{2}$, which qualifies the conditions for use the AromaStreamer 650 device. When the equipment was loaded, it was set to the first intensity level. After one week, the device rebuilt two degrees, the most satisfactory intensity up to the end of monitored month. It was a pleasant smell and not a very sharp one, which would make customers unpleasant moments spent in a restaurant. The device can be pre-set according to the opening hours or preference of the owners. In FAINA, the device was connected from Monday to Friday from $10 \mathrm{am}$ to $7 \mathrm{pm}$ (at the weekend, the restaurant is closed). The restaurant is open until $8 \mathrm{pm}$, but since the aroma remains in the space for about an additional hour, the appliance has shut down earlier, even from a gentle point of view. 
Figure 2: Placing and Setting the AromaStreamer 650 Equipment in FAINA Restaurant

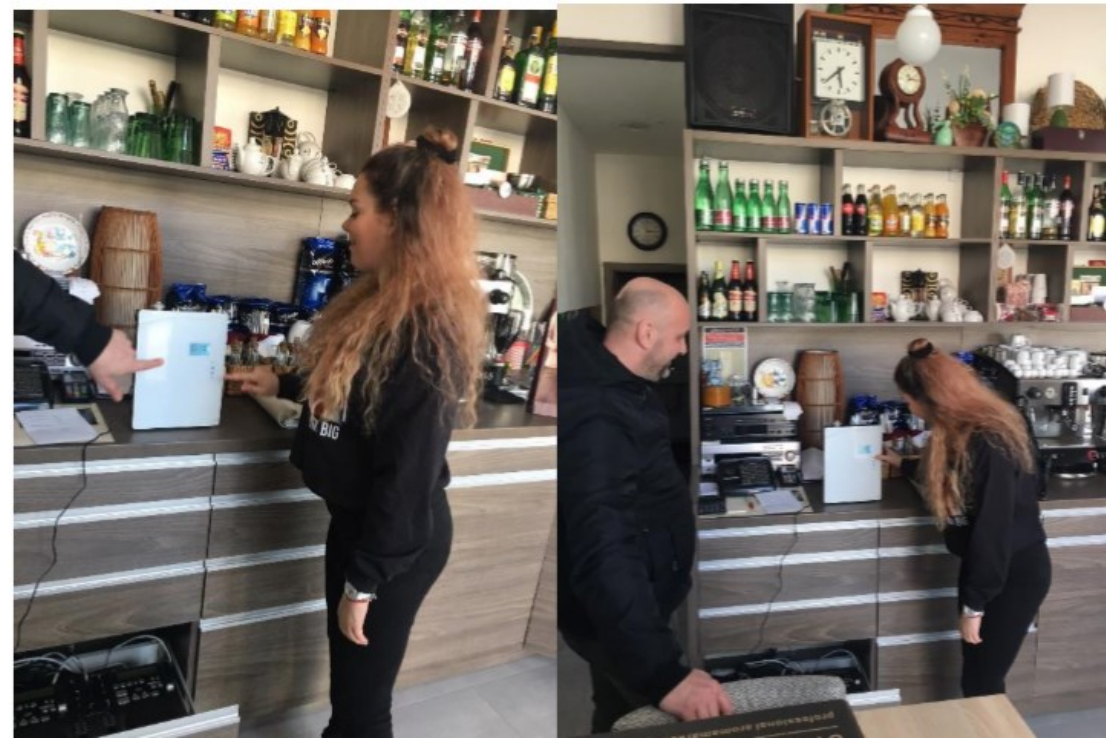

Source: own Figure

In the Table 3, we can see the profit achieved in the months before the space aromatization (March 2017 and February 2018). If we compare March 2017 and March 2018, we can see that in March 2018 the restaurant is pleased by $766 €$. In comparison of February 2018 and March 2018 we illustrate that in March 2018 the restaurant earned more in $178 €$. We assume that thanks to the aroma used in the restaurant, profits increased by nearly $200 € /$ per one month.

Table 3: Profit Comparison in Monitored Period and Sales Development

\begin{tabular}{|c|c|c|}
\hline March 2017 & February 2018 & March 2018 \\
\hline $2984 €$ & $3572 €$ & $3750 €$ \\
\hline Comparis ed period & & \\
\hline Index March 2017/ March 2018 & 1.25 & 25 \\
\hline Index February 2018/ March 2018 & 01.5 & 5 \\
\hline
\end{tabular}

Source: own Table

In the restaurant FAINA, sales in March 2018 increased by $25 \%$ compared to March 2017. On March 2018 we observed the same situation because the sales increased by $5 \%$ compared to February 2018. This increase can also be attributed to the aroma "Herbs", which was dispersed on March 2018. There was an increase in the sale of certain foods, namely tomato soup with cheese and basil and spaghetti with chicken breasts and herbs. As with the name, herbs are added to prepare these dishes. The aroma that has been released has given consumers a taste for meals containing herbs. As well as, we calculated the estimated costs and profit for one-year using aromatization for FAINA:

- equipment AromaStreamer 650: $400 €$

- $\quad$ aroma refill $150 \mathrm{ml}: 65 €$

- increase in profits when introducing aroma compared to last month. $150 €$

One refill is enough for about two months but since the FAINA is closed on weekends, we assume that it keeps two and a half months. This means that five aroma refills will be consumed 
per year. We have calculated this: 5 aromas x $65 €=325 €$ per year/ for scents. Since the increase of aroma dispersing compared to the previous month was $150 €$, we expect that the amount of profit will be approximately the same in the coming months. For the whole year which is 12 months, the total profit value will be $1800 €$. We expressed it by calculation: 150 $€ \times 12$ months $=1800 € /$ per year. When counting all costs, such as device price of $400 €$ and price of aroma refills for year $325 €$ we found that the total annual cost is $725 €$. Since the annual profit is $1800 €$ and after deducting the costs of $725 €$, the resulting value of the annual profit with the aromatization is $1075 €$.

Figure 3 illustrates that $40.38 \%$ of respondents said that they feel a pleasant aroma in restaurants. The smell of food and drinks was felt by $30.73 \%$ and $28.85 \%$ of customers did not feel anything.

\section{Figure 3: Do you feel any smell when entering} the restaurant?

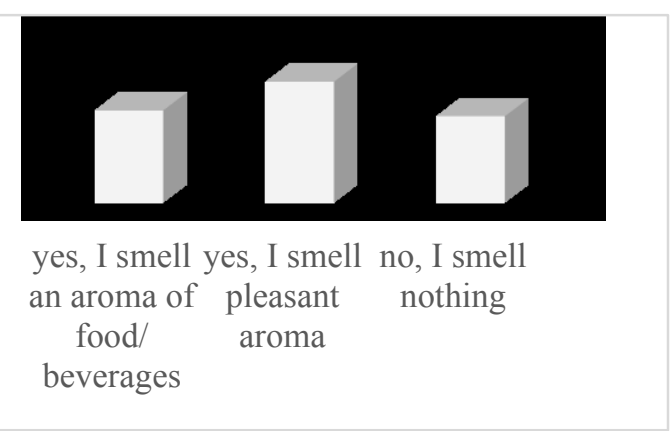

\section{Figure 4: How do we perceive the aroma} intensity?
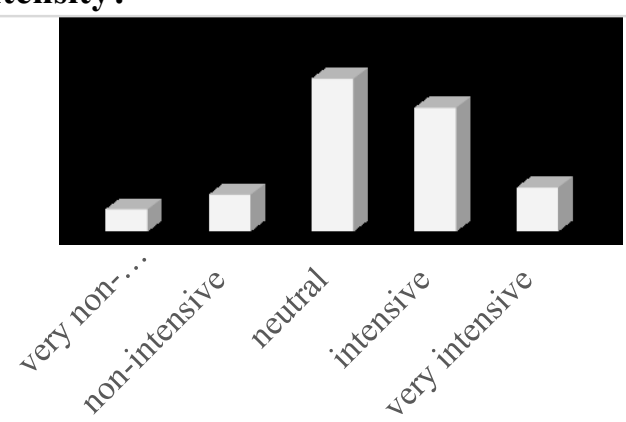

Source: own research

Most respondents $40.38 \%$ perceive the intensity of aroma in the restaurant neutral (see Figure 4). $32.69 \%$ perceive intense aroma in the restaurant. Other responses were: very intense 11.54 $\%$, non-intensive $9.62 \%$ and very non-intensive only $5.77 \%$. Most asked customers marked the fragrance association in restaurant as (Figure 5): herbs $51.92 \%$. This possibility was also our goal, because in the restaurant FAINA was just used aroma of "Herbs". Likewise, 17.30 $\%$ had the smell of coffee and other fragrances, which customers labeled as the smells of oil, pasta or fragrances they could not identify. Least customers surveyed felt the smell of chocolate and conifer, which represented only $1.92 \%$ in both cases.

Figure 5: What do you associate with a scent dispersed in restaurant?
Figure 6: Did you get a taste to consume food or beverage after scenting of aroma?

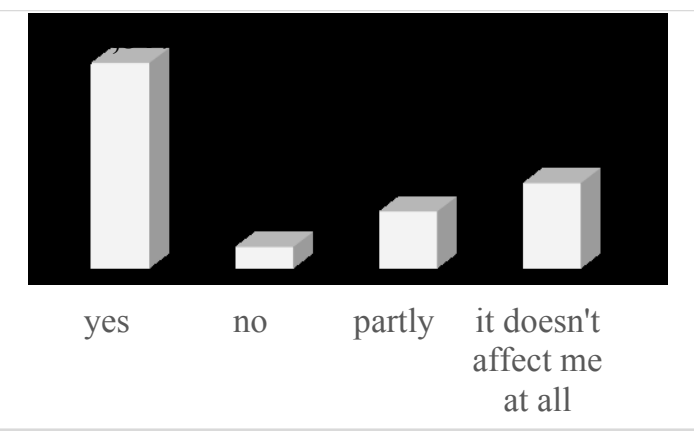

Source: own research

The fragrance provokes appetite/ beverage as $55.77 \%$ of respondents chose yes (see Figure 6). The answer at all does not affect me chose $23.08 \%$. $15.38 \%$ of the respondents were only partially affected by this fragrance. At least a percentage of $5.77 \%$ of respondents said that the 
flavor they released did not provoke appetite and beverages. The calculation and verification of our hypothesis we found out following:

- the calculated value (Test criterion) of the chi square test is: 9.5964,

- the critical value of the chi square test is: 7.8147 .

Test criteria $>$ critical value, i.e. we rejected the hypothesis $\mathrm{H} 0$ and accept the hypothesis $\mathrm{H} 1$. There is a correlation between the gender of the respondents and the effect of the dispersed odor on the appetite/ beverage of customers. We have statistical evidence that the smell affects customers. From our research, we can determine that this fragrance affects more male guests than female. Certain food and drinks can slow human digestion and causes gas. This leads to a bloated stomach and can reduce an appetite. Carminative herbs and spices help reduce stomach bloating and flatulence. In addition, any dishes cooked with herbs and spices obviously have delicious flavor and aroma. They will trigger an appetite to eat more. Herbs which stimulate the human appetite are for example: fennel, cinnamon, coriander, pepper, nutmeg, and lime.

\section{Conclusion}

The hospitality business is all about experiences, and scent marketing in hospitality is a perfect fit. Using a scent system, entrepreneurs easily and cost-efficiently improve the atmosphere in their establishments. The guests will feel better and company image will get a boost. At the same time, it can easily neutralize and eliminate unwanted smells. The summarization of aromatization and its impact on doing marketing of sense is based on these benefits:

- scent experience upgrades restaurant (much like a great logo or a beautiful lighting design, exclusive scents in HORECA radiate luxury and recognition),

- scent experience triggers guests (scent experiences can relax people, or wake them up depending on preference, a warm scent creates a cozy atmosphere in hotel lobbies and restaurants, inviting guests just stay a little longer. A fresh scent will wake them up and activate them, which is perfect for business events or meetings),

- scents evoke emotions (a recognizable scent will always remind people),

- scent experience neutralizes bad smells (most hospitality entrepreneurs constantly battle bad smells, for example those caused by a grease tank or cigarette smoke, an odorneutralizing system can replace those smells with a wonderful aroma).

In restaurant FAINA, which was our research object we finally summarize these results:

- dispersing aroma in restaurant has got an importance for this provider,

- the smell was intensive for $32.68 \%$ of the respondents and only $5.8 \%$ of customers considered it to be non-intensive, which suggests that the intensity of the smell was chosen correctly,

- "Herbs" scent was chosen correctly because $40.38 \%$ of customers felt a pleasant smell when entering the restaurant and associated it predominantly with the aroma of herbs, namely $51.92 \%$,

- based on the results of a questionnaire survey, we can conclude that $55.77 \%$ of the respondents are appetite-flavored; if the FAINA restaurant decided to use the aromatization unit in the future, it would encourage the sale of meals containing the variety of food which are associated with "herbs" odor.

Based on the information gathered from questionnaire research and consultations with restaurant 'owners, we would like to evaluate that the FAINA restaurant has a great perspective 
in terms of the aroma marketing. From the results of the comparison of the examined periods we can say that the scent was an effective tool for increasing the profits. It increased by nearly $200 €$, which is a noticeable amount after annual clearing and after deducting the cost of using the aromatization. After the first year of using the selected scent, the FAINA restaurant would increase by approximately $1075 €$. After the second year, it would practically be even more since the cost of purchasing the device in the second year we are running out. In this research, we selected the choice of used aroma only on based of consultation with both restaurant 'owners.

From this point of view, we would like to suggest:

- Very important factor in the correct use of aroma marketing is good air quality and ventilation, which in FAINA has a potential to improve it, since the space between the kitchen and the restaurant is divided only by a corridor without doors. One of the solution of this obstacle is to purchase a smart device that can keep the air in space at the optimum level, subsequently it reacts to the outside environment or weather, it regulates the temperature, dry air, humid air can set time when it turns on and off.

- It would be necessary to use also a neutralizing component, which has the ability to remove and neutralize unwanted odors from the kitchen, which after mixing with the aroma could have an unpleasant effect and the opposite effect to be needed in the long term of aroma marketing practice

- In the long term, it would be appropriate to replace the aroma, FAINA also offers sweets, that are long time at the bottom of sold products. Their sale could be supported by a sweet aroma such as chocolate, cake, cinnamon-apple or vanilla.

\section{Acknowledgements}

Research has been supported by the research grand APVV-17-0564 "The Use of Consumer Neuroscience and Innovative Research Solutions in Aromachology and its Application in Production, Business and Services ,, and VEGA 1/0570/18 „Using of Consumer Neuroscience by implementing of aromachology in selected business economies ,conducted at the Department of Marketing and Trade at the Slovak University of Agriculture in Nitra. The main goal of APPV and VEGA is to complexly reveal how are aromatic compounds sensed based on an interaction between explicit (sensory) and implicit analysis through consumer's neuroscience in real conditions of manufacturing plants, shops and in the sphere of services.

\section{References}

[1] Aromagic. 2019. Aromatization of Air-What is it? Retrieved from http://aromagic.eu/?lang=en.

[2] Berčík, J., Paluchová, J. et al. (2016). Placing of aroma compounds by food sales promotion in chosen services business. Potravinárstvo. 10(1), 672-679. DOI: https://doi.org/10.5219/666 .

[3] Berčík, J., Paluchová, J. et al. (2018). Aroma Marketing - a Modern Marketing Phenomenon. International scientific days 2018: Towards productive, sustainable and resilient global agriculture and food systems. Prague: Wolters Kluwer. 586-598 p. ISBN 978-80-7598-180-6.

[4] Cartwright, S. (2014). How and why businesses make use of scent marketing to boost sales. Retrieved from http://tinyurl.com/kbzwc8a.

[5] Fohlio. (2019). The Psychology of Restaurant Interior Design, Part 2: Scent. Retrieved from https://www.fohlio.com/blog/the-psychology-of-restaurant-interior-design-part-2-scent/. 
[6] Heroux, L. (2010). Restaurant Marketing Strategies in the United States and Canada. Journal of Foodservice Business Research. 5(4), 95-110, DOI: 10.1300/J369v05n04_07.

[7] Horská, E., Gálová, J., Mravcová, A. (2018). Výskum verejnej mienky a komunikačné stratégie. 1 ed. Nitra: SUA in Nitra. 52 p. ISBN 978-80-552-1822-9.

[8] Hung, V.C.S., Gu, T. (2012). Influence or Resturant Atmospherics on Patron Satisfaction and Behavioral Intentions. International Journal of Hospitality Management, 31(4), 1167-1177. https://doi.org/10.1016/j.ijhm.2012.02.004.

[9] Jang, D., Mattila, A. S. (2005). An examination of restaurant loyalty programs: What kinds of rewards do customers prefer? International Journal of Contemporary Hospitality Management 17 (5), 402-8. DOI: 10.1108/09596110510604823.

[10] Jurášková, O., Horňák, P. (2012). Velký slovník marketingových komunikácii. Praha: Grada. 272 p. ISBN 978-80-247-4354-7.

[11] Kardes, F.R., Cronley, M.L., Cline, T. W. (2014). Consumer Behaviour. 2 ed. Cincinnati, OH, USA: SouthWestern College Publishing. 576 p. ISBN 978-11-335-8767-5.

[12] Kasavana, M. L., Knutson, B. J. (2000). Investing in customer equity: Using technology to build your frequent diner programs. Journal of Hospitality and Leisure Marketing. 7 (1), 63-74. https://doi.org/10.1300/J150v07n01_05.

[13] Khan, M. A. (2015). Restaurant Franchising: Concepts, Regulations, and Practices. 3 ed. Oakvilee: Apple Academic Press, Inc., 618 p. ISBN: 978-1926-89 569-7.

[14] Kimmel, A. (2012). Psychological Foundations of Marketing. New York, NY, USA: Routledge. 304 p. ISBN 978-04-1562-001-7.

[15] Krishna, A. (2010). Sensory Marketing: Research on the Sensuality of Products. Abingdon, UK: Taylor and Francis Group. 428 p. ISBN 978-1841698892.

[16] Kubicová, L., Kádeková, Z. (2017). Strategic marketing. 1 ed. Nitra: SUA in Nitra. 143 p. ISBN 978-80-5521622-5.

[17] Levy, M., Weitz, A. B., Grewal, D. (2012). Retailing Management. New York, NY, USA: McGraw-Hill. 608 p. ISBN 978-0078028991.

[18] Mattila, A. S. (2001). Emotional bonding: Restaurant loyalty. In Cornell Hotel and Restaurant Administration Quarterly. 42 (6), 73-79. https://doi.org/10.1016/S0010-8804(01)81012-0.

[19] Müller, J., Alt, F. et al. (2011). Pervasive Advertising. USA: Springer. 366 p. ISBN 978-08-572-9351-0.

[20] Obtulovič, P. (2010). Bioštatistika. 4 ed. Nitra: SUA. 132 p. ISBN 978-80-552-0397-3.

[21] Pabian, A. (2017). Sensory marketing. Retrieved from http://www.rynekturystyczny.pl/artykul/2105/marketing-sensoryczny-w-dzialalnosci-biurpodrozy.html.

[22] Sikela, H. (2014). Čuch je významný zmysel. Retrieved from https://view.joomag.com/slovensky-vyberfebruar2014/0222656001396511613? page $=29$.

[23] Sládek, G. (2003). Podnikanie v pohostinstve a hotelierstve. 1 ed. Bratislava: Epos. 558 p. ISBN 80-8057523-1.

[24] Spangenberg, E.R., Sprott, D. E. et al. (2006). Gendercongruent ambient scent influences on approach and avoidance behaviors in a retail store. Retrieved from https://www.sciencedirect.com/science/article/pii/S0148296306001299 44.

[25] StoreMedia. 2019. Aroma marketing. Retrieved from https://www.storemedia.eu/aroma-marketing. 


\title{
Consumer Preferences on the Wine Market
}

\author{
Tomáš Rebič ${ }^{\text {, Elena Horská }}{ }^{2}$, Anna Dunay ${ }^{3}$ \\ Slovak University of Agriculture in Nitra ${ }^{1,2}$ \\ Faculty of Economics and Management, Department of Marketing and Trade ${ }^{1,2}$ \\ Address: Tr. A. Hlinku 2, \\ 94976 Nitra, Slovakia
}

Szent Istvan University in Gödöllö ${ }^{3}$

Faculty of Economics and Social Sciences, Institute of Business Economics, Leadership and

Management,

Address: Páter K. u. 1.

2100 Gödöllő, Hungary

e-mail: rebictomas@gmail.com¹, elena.horska@gmail.com², Dunay.Anna@szie.hu³

doi: 10.18515/dBEM.ISD.P01.2020.p018

\begin{abstract}
The aim of this paper is to characterize the situation on the wine market in the world and in the Slovak republic. In Slovakia, winemaking has a rich tradition that dates back to the distant past. Slovakia is characterized by a typical combination of soil composition and climatic conditions, thanks to which our grapes acquire a unique character. We are trying to compare wine production in the Slovak republic and in the world. We focus on the worldwide development of wine production and consumption, which also results in current trends. The article concentrates mainly on consumer and shopping habits, consumer preferences, perception of sensory properties of wine with the emphasis on increasing sales and supporting the consumption of Slovak wine. The database contained 407 respondents from the Nitra region aged from 19 to 70 years and the data were obtained through a questionnaire.
\end{abstract}

Keywords: consumer behaviour, wine market, wine production, consumer preferences

JEL Classification: L11, M31, M39

\section{Introduction}

Wine is the oldest drink of humanity, whose history dates back to the period of 5000 years BC. It has accompanied the most important developmental stages of humanity and the culture of farmers from the beginning. It has become a symbol of refinement and worship. The cult of wine was highlighted in literary or artistic monuments, as well as during antique celebrations. Many archaeological findings prove that growing of grape and wine production have been present in the Slovak republic for more than 2500 years since the time of the Celts and Romans. The vineyard has permanently taken its roots not only in the soil, but also in the economic and cultural life of our ancestors (Hronský, 2001).

\subsection{World}

European union (EU) is currently the world's largest producer, consumer, exporter and importer of wine. The EU wine industry is the most regulated area within the common market organization. However, wine production in the traditional countries of southern Europe has been declining in recent years. This is due to the grubbing-up of vineyards, which is a part of the EU's Common Agricultural Policy. Nevertheless, a third of the world's vineyards is still located in Spain, France and Italy. Countries of the European union belong to the largest 
producers and consumers of wine in the world, their production accounts for up to $60 \%$ of world production and consumption is around 60\% too. Wine production is growing increasingly in countries where grapes have not been grown in the past. The largest increase in vineyards is recorded in China, where in 2010-2015 up to 36\% of areas were added, slight increases are recorded in Argentina and Chile (Meravá, 2017).

Figure 1 shows the share of individual countries in the area of vineyards in the world in 2018. Spain has the largest share, up to $13 \%$, followed by France $(10.6 \%)$ and Italy $(9.5 \%)$. After European countries, China has the largest share in the area of vineyards with less than $12 \%$, followed by Turkey with $6.1 \%$ and the USA with $5.9 \%$. The rest of the world has a share of $43.2 \%$ of the vineyard area.

Figure 1: Share of individual countries in the area of vineyards in the world in 2018

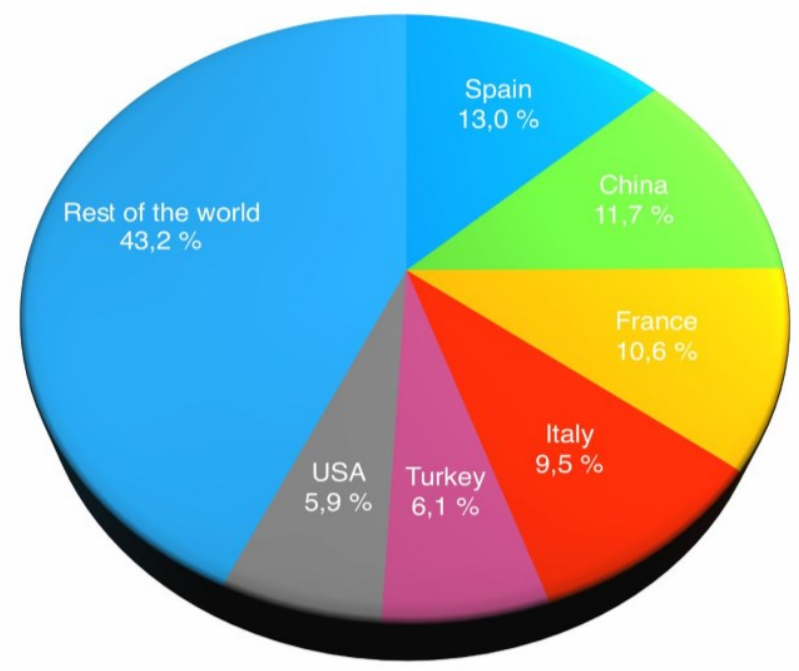

Source: VÚEPP, 2019, own processing. Retrieved from <http://www.vuepp.sk/dokumenty/komodity/2019/ Vino_19_v3.pdf >.

In terms of wine consumption, the USA is in the first place, in 2018. More than 13 percent of world wine production is consumed there. They even surpassed France and became the largest wine consumer in the world with an annual consumption of 33 million hectoliters. France was second, given the fact, that the population is only a quarter of that of the United States. In France, wine consumption is about 11 percent of total world wine production. The ranking of the 5 largest countries in terms of wine consumption is as follows:

1. USA (13.4\%),

2. France $(10.9 \%)$,

3. Italy $(9.1 \%)$,

4. Germany $(8.1 \%)$,

5. China $(7.2 \%)$.

The following Table 1 shows us the development of world wine consumption in the period from 2012 to 2018. In the USA, wine consumption had a growing tendency in the monitored period. It gradually increased from 30 to $33 \mathrm{mil}$. hl. On the other hand, in France, wine consumption gradually decreased over the same period. In 2012, 28 mil. hl was consumed 
there and by 2018 wine consumption fell to 26.8 mil. hl. Global wine consumption remained at the same level of 246 mil. hl., in the last two monitored years, 2017 and 2018.

Table 1: World wine consumption in mil. (hl)

\begin{tabular}{|l|l|l|l|l|l|l|l|}
\hline State & $\mathbf{2 0 1 2}$ & $\mathbf{2 0 1 3}$ & $\mathbf{2 0 1 4}$ & $\mathbf{2 0 1 5}$ & $\mathbf{2 0 1 6}$ & $\mathbf{2 0 1 7}$ & $\mathbf{2 0 1 8}$ \\
\hline USA & 30 & 30.2 & 30.6 & 30.9 & 31.7 & 32.6 & 33 \\
\hline France & 28 & 27.8 & 27.5 & 27.3 & 27.1 & 27 & 26.8 \\
\hline Italy & 21.6 & 20.8 & 19.5 & 21.4 & 22.4 & 22.6 & 22.4 \\
\hline Germany & 20.3 & 20.4 & 20.3 & 20.5 & 20.2 & 19.7 & 20 \\
\hline China & 17.1 & 16.5 & 17.4 & 18.1 & 19.2 & 19.3 & 17.6 \\
\hline Great Britain & 12.8 & 12.7 & 12.6 & 12.7 & 12.9 & 12.7 & 12.4 \\
\hline Russia & 11.3 & 10.4 & 11.1 & 10.8 & 10.5 & 11.1 & 11.9 \\
\hline Spain & 9.9 & 9.8 & 9.8 & 9.8 & 9.9 & 10.5 & 10.5 \\
\hline Argentina & 10.1 & 10.4 & 9.9 & 10.3 & 9.4 & 8.9 & 8.4 \\
\hline Australia & 5.4 & 5.4 & 5.4 & 5.5 & 5.4 & 5.9 & 6 \\
\hline Portugal & 5 & 4.2 & 4.3 & 4.8 & 4.7 & 5.2 & 5.5 \\
\hline Canada & 4.9 & 4.9 & 4.6 & 4.8 & 5 & 5 & 4.9 \\
\hline Romania & 4.3 & 4.6 & 4.7 & 4 & 3.8 & 4.1 & 4.5 \\
\hline South Africa & 3.6 & 3.7 & 4 & 4.3 & 4.4 & 4.5 & 4.3 \\
\hline Netherlands & 3.5 & 3.5 & 3.4 & 3.5 & 3.4 & 3.5 & 3.5 \\
\hline World total & $\mathbf{2 4 4}$ & $\mathbf{2 4 2}$ & $\mathbf{2 4 1}$ & $\mathbf{2 4 3}$ & $\mathbf{2 4 4}$ & $\mathbf{2 4 6}$ & $\mathbf{2 4 6}$ \\
\hline
\end{tabular}

Source: International organisation of vine and wine, 2017, 2019, own processing. Retrieved from $<$ http:// www.oiv.int/public/medias/6782/oiv-2019-statistical-report-on-world-vitiviniculture.pdf $>,<$ http://www.oiv.int/ public/medias/5479/oiv-en-bilan-2017.pdf>.

\subsection{Slovakia}

Winemaking in Slovakia has recently made a significant progress not only in quality, but also in emphasizing the uniqueness, specificity and tradition of Slovak wines. Wine-growing villages in Slovakia fall into six wine-growing areas: Južnoslovenská, Východoslovenská, Stredoslovenská, Nitrianska, Tokaj and Malokarpatská. According to Taliga (2000), each area is characterized by natural conditions that significantly affect the production of grapes and the quality of the wine itself. A negative factor that affects Slovak winemaking and viticulture is the decline of areas of vineyards, which causes adverse economic results. Today, wine production in our territory is very widespread, popular and at a high quality level. Each wine 
production region in the Slovak republic has its own specifics and focuses on the production of wine of the highest quality. It has its traditional taste, brand and origin.

As of 31st July 2019, 605 active winemakers and 220 traders in wine products, were registered in the register. Figure 2 shows the representation of wine producers within the areas, as follows: in the largest, Južnoslovenská wine-growing area, $18 \%$ of producers produce wine. The second largest wine-growing area in Slovakia is Malokarpatská, where $50 \%$ of wine producers are represented. It is followed by Nitrianska area with $15 \%$ of active winemakers, then Tokaj, the smallest wine-growing area with $6 \%$ of winemakers. Stredoslovenská and Východoslovenská areas have the same, 5\% representation of wine producers within the area and finally $1 \%$ are winemakers outside all of wine-growing areas.

\section{Figure 2: Representation of wine producers within areas (\%)}

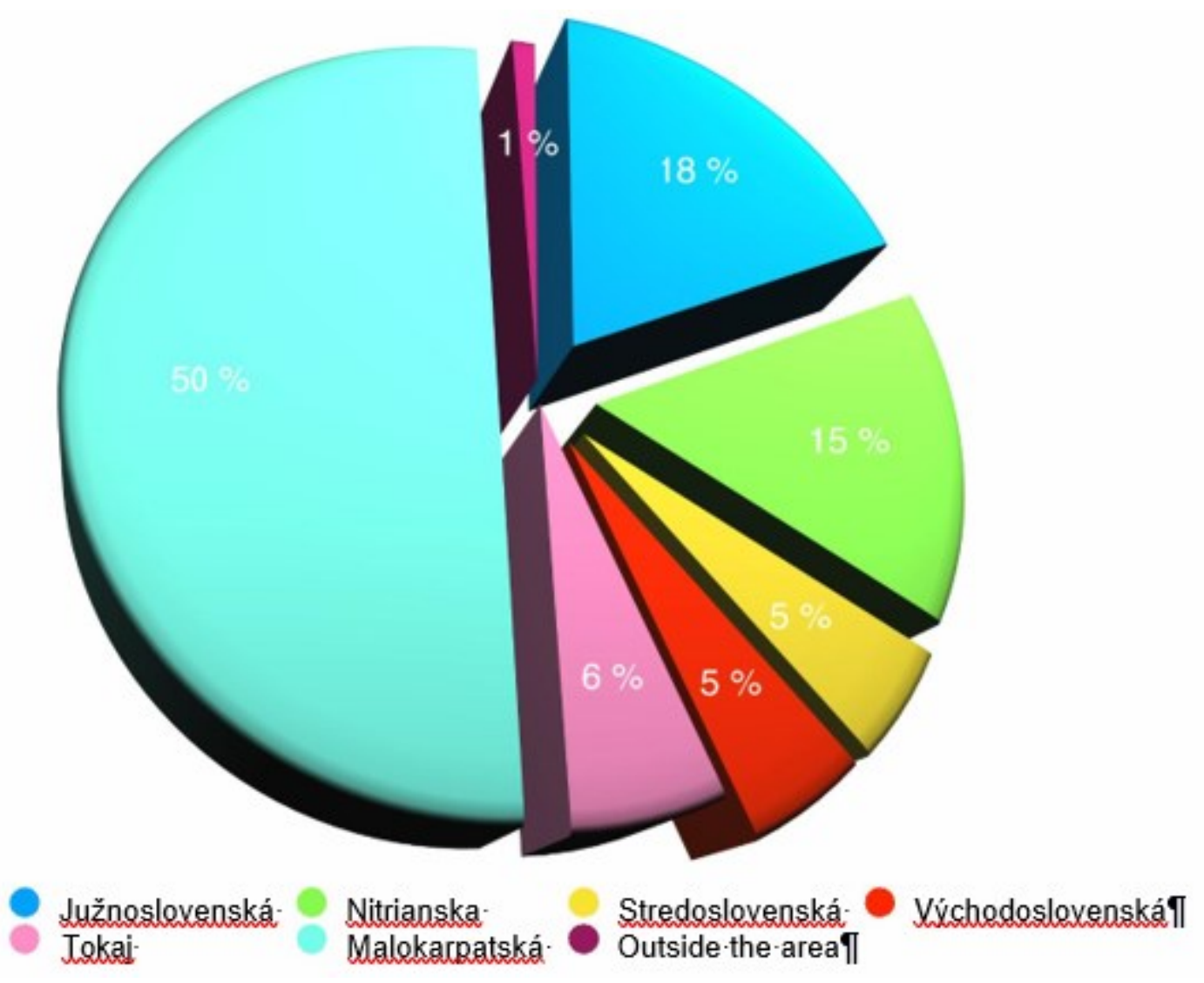

Source: VÚEPP, 2019, own processing. Retrieved from <http://www.vuepp.sk/dokumenty/komodity/2019/ Vino_19_v3.pdf $>$.

The accession of the Slovak republic to the European union in 2004 meant a process of breaking down trade barriers, thanks to which, cheap but not very high-quality foreign wines began to penetrate to the Slovak market. Domestic producers were not able to compete by price, so they focused on more expensive and higher quality products. At present, it is possible to watch innovative tendencies of Slovak winemaking, to which new technologies, as well as measures and regulations of the European union contribute. Our winemakers focus mainly on the production of quality wines, which underline the typical features and specifics of the given wine-growing area. 


\subsection{Consumer}

When examining consumer preferences on the market with different products, not just on the wine market, we must consider that this whole process is influenced by various factors. It is very important to focus on the marketing of the product that the consumer chooses, it is also necessary to determine the specifics of the product and analyze in more detail the market in which the product is offered. Definition of the term "consumer", whether it is an individual or a legal entity, like an organization or a village is also important.

Kulčáková and Richterová (1997) state that the term consumer is used to refer to two different types of consumer units, namely:

1. individual consumer,

2. organizations as consumers.

Both categories are important, the main difference is that the individual consumer buys products and services for his own consumption or for the use in the family. This includes the purchase of goods as a gift to another person. Goods are purchased for final consumption for individuals. The second group consists of organizations as consumers. This includes various companies, state institutions, which buy products mainly for the development of their activities, regardless of their nature, whether they are profitable or non-profitable.

All definitions of consumer collect basic consumer data, analyze and identify mostly his behaviour and the causes of it. It does not only concern current consumers, but also potential (future) consumers of the given products. Because if a producer wants to compete on the market, he must match his options with the needs of consumers or other customers in his production process. If he fails to do so, he will not be successful in his business and may stop production. Without synchronization with the needs of consumers, his business is doomed to extinction or competition.

\section{Data and Methods}

The aim of our experiment was to find out the preferences of consumers on the wine market with an emphasis on increasing sales and promoting the consumption of Slovak wine. We were finding out how consumers make their choices, either only on the basis of internal attributes (sensory properties), such as taste, color and smell, or only on the basis of external attributes (shape of the bottle, label design, brand, producer, country of origin), or a combination thereof. In order to achieve this aim, a marketing survey was conducted in the form of a questionnaire. The database contained 407 respondents from the Nitra region aged 19 to 70 years.

The questionnaire survey focused on consumer behaviour and on the identification of external (shape of the bottle, label, price) and internal attributes of wine (taste, color, smell), namely two samples of red dry wine, "Cabernet Sauvignon", from two local producers from Nitra region. We also observed their influence on consumer decisions when choosing a better quality wine.

The experiment was carried out online in a Google form and distributed, using emails and social networks. A questionnaire in paper form was used for older generation. To objectively examine the obtained data, we used several methods of scientific research - analysis, synthesis, induction, deduction, comparison, graphical and statistical methods - IBM SPSS version 25 and XLSTAT. 


\section{Results and Discussion}

The results of the consumer behaviour survey showed that respondents most often consume wine occasionally $(45 \%)$ or once a month/week. Approximately $20 \%$ of respondents stated that they consume wine on a regular basis $(12.4 \%$ every day and $7.8 \%$ several times a week). For a deeper analysis of the issue, the scientific assumption No. 1 was determined, which argues that the frequency of wine consumption is influenced by selected socio-demographic variables, such as gender, age, education, income or place of residence.

In terms of preferences, the survey of consumer behaviour focused on selected aspects, such as color, type of wine, its variety, origin, sugar content and others. Most respondents from the Nitra region prefer wine of Slovak origin $(57.7 \%)$, while almost one third does not care about the origin of the wine. Foreign wine, as preferred, was indicated by $13.3 \%$ of respondents, of which more than 58\% were men. From foreign wines, French wines were dominated $(44.3 \%)$, than Italian wines $(32 \%)$ and Spanish wines (16.7\%). More than $72.8 \%$ prefer still wine, $13.6 \%$ sparkling wine and the rest of the respondents have no preference. Another question was to find out what type of wine, according to color, respondents prefer. Most respondents indicated a preference for consuming red wine $(41 \%)$, followed by white wine $(37.2 \%)$ and finally rose wine $(17.7 \%)$. About $4 \%$ of people said, they did not prefer wine based on its color. Scientific assumption No. 2 was determined, which argues that the gender and age of respondents affect their preferences.

\subsection{Consumer behaviour when buying wine}

From the results of the survey, we can say that wine is not a product that people buy on a regular weekly basis. In a deeper analysis, we found that age segments from 19 to 25 years and from 41 to 50 years most often buy wine several times a month. The other three segments shop occasionally. In the case of purchase several times a week, from all segments, respondents from 26 to 30 years old buy wine most often, but it is only $24.5 \%$. Women buy wine mostly occasionally (64.8\%), while men buy several times a month (43.7\%). In another question of the survey within the framework of shopping behaviour, we were finding out where respondents buy wine the most frequently. There was a possibility of several answers. Most respondents buy wine in shops and retail chains (73\%), in a wine shop - specialized shops $(35.6 \%)$ or in a wine cellar $(18.3 \%)$. Around $10.4 \%$ of respondents buy wine at wine events and tastings. $6.6 \%$ buy directly from the winemaker and just over $3 \%$ use online shopping from e-shops. The achieved results are in accordance with the results of a questionnaire survey conducted by the authors Waldnerová, Nagyová and Kleinová (2013) in the Nitra region.

Part of the survey of shopping behaviour was also the identification of the influence of selected factors when buying wine. Respondents rated 19 factors that may influence the consumer's decision-making process using a 7-point scale, with 1 representing the least impact and 7 the largest impact (Figure 3). A scientific assumption has also been made, which states that there are statistically significant differences in the assessment of the importance of the criteria when buying wine. Statistically significant differences $(p=0.000)$ were confirmed by applying the Friedman test. Furthermore, the Nemenyi method was applied, which specifically identified, among which factors there are statistically significant differences in the assessment of their impact on the consumer when buying wine.

Based on the above-mentioned results, we can state that the taste, quality, smell, price, color, brand, discount and recommendation of acquaintances have the greatest influence when 
buying wine. We can say that the sensory attributes of wine, significantly influence the consumer's decision when buying it. On the contrary, the shape of the bottle, the harvest period, the label design or the wine-growing area have the least influence. Similar results were achieved in a Czech consumer study focused on the young generation (Generation Y), where the least important factor in wine selection was the shape of the bottle, the color of the wine and advertising (Němcová-Stanková, 2019). An interesting finding is the fact that factors, such as the country of origin and the producer also do not belong to the first half of the factors with a significant impact.

The online questionnaire survey also included a visual evaluation of two selected wines: sample A - PD Mojmírovce and sample B - PD Ivánka near Nitra, while the label of the first sample is more elaborated in design. Respondents had to choose which wine packaging (bottle + label) they would choose for regular consumption as well as for donation purposes. Both samples represent red wine 'Cabernet Sauvignon'. The results showed that 58\% would choose a bottle from PD Ivánka near Nitra for normal consumption (sample B). Mostly they were, either respondents under 30 or over 50 . The shape of the bottle when choosing wine is not important for $48 \%$ of men, on the contrary, $44.7 \%$ of women prefer wines with a nice label. According to Horská, Berčík, Krasnodebski, Matysik-Pejas \& Bakayová (2016), women react more emotionally than men when choosing wine, which can also influence the final choice of wine, and thus the preferences themselves.

Figure 3: Evaluation of the importance of factors when buying wine

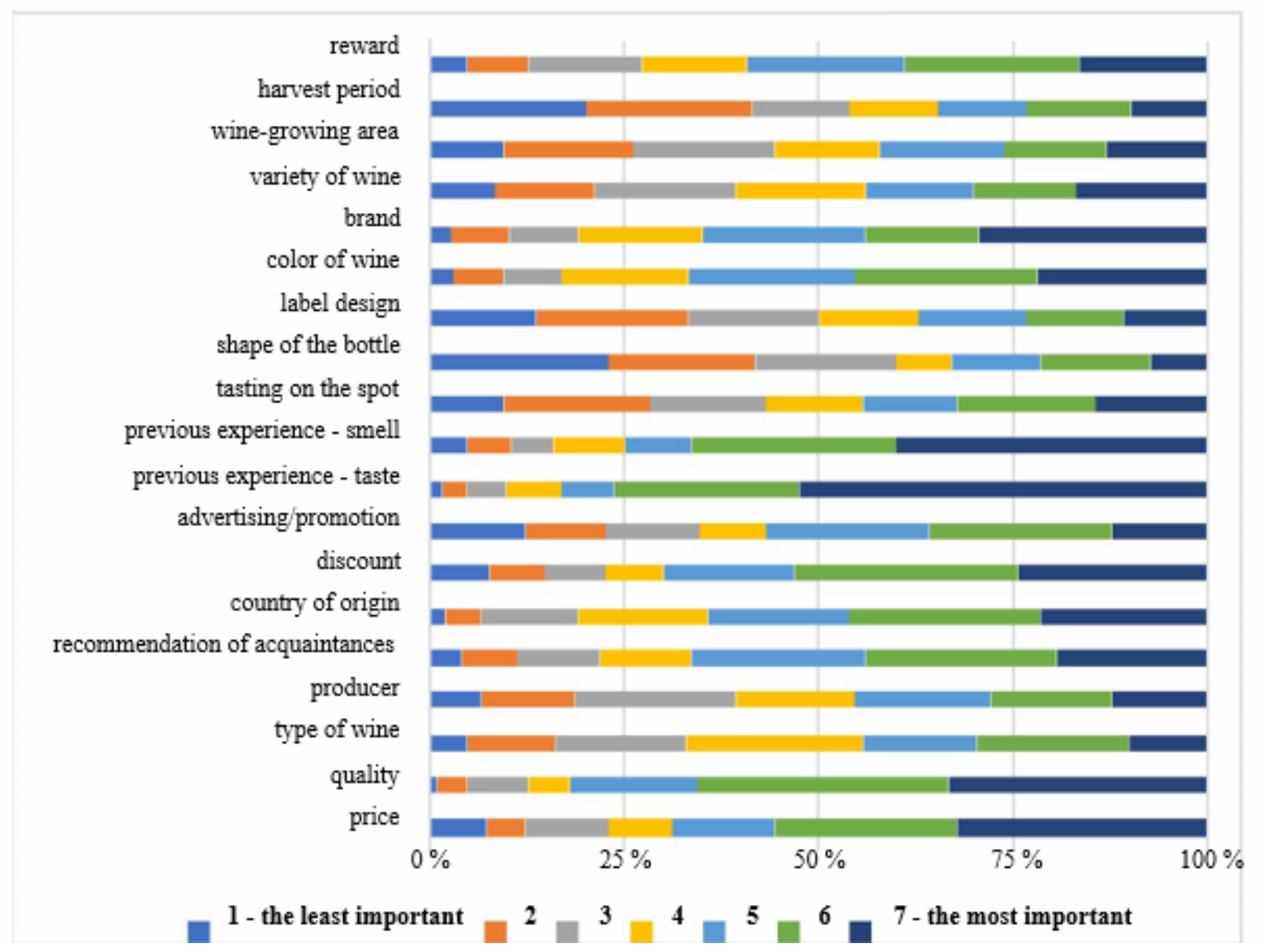

Source: Questionnaire survey, 2020 
Consumers tested two samples of red dry wine "Cabernet Sauvignon", 2019, from two different producers. The first sample was purchased from the producer PD Ivánka near Nitra, at a price of $2.25 € /$ piece. The second sample was made by PD Mojmírovce, at a price of $14.85 € /$ piece. Sensory properties (taste, smell and color) and overall acceptability, they expressed on a 7-point scale (where 1 - the best rating and 7 - the worst rating). The results showed that, sample No. 1 (PD Ivánka near Nitra - cheaper variant of wine) achieved, on average, a better evaluation in terms of taste and color. On the contrary, in the case of overall acceptability, sample No. 2 (PD Mojmírovce - more expensive variant of wine) had better evaluation. When evaluating the smell, both samples achieved the same score.

After evaluating both samples, the respondents further stated which sample of wine they considered to be of better quality and which sample they would buy. The results indicate that all respondents would purchase the sample they reported as of better quality. The majority of women (69\%) perceived (preferred) sample No. 1 as better, while the majority of men $(63.6 \%)$ indicated sample No. 2 , on the contrary.

\section{Conclusion}

In the paper, we followed the development and tendencies on the wine market in the world and in Slovakia. The EU is currently the world's largest producer, consumer, exporter and importer of wine. However, as a result of the EU's Common Agricultural Policy, wine production in southern European countries has been declining in recent years. Nevertheless, a third of the world's vineyards are in Spain, France and Italy.

This article brought a view of consumer research on the wine market, its consumer preferences, shopping behavior and perception of the internal and external attributes of wine, with the emphasis on increasing sales and supporting the consumption of Slovak wine. When obtaining primary information about wine consumers, the traditional method of data collection was used - a questionnaire survey conducted in written as well as in electronic form (Google form). In our shopping behaviour, we have identified the taste, quality, smell, price, color, brand, discount and recommendations of acquaintances as the most important factors that have the greatest influence when buying wine. When examining the influence of individual attributes of wine and their importance in evaluating the quality or choice of wine at the time of purchase, it was important to compare the decision of the consumer himself with different availability of information. The research also highlighted the role of sensory aspects in consumer purchasing decisions.

\section{References}

[1] Grunert, K. G., Larsen, H. H. \& Baadsgaard, A. (1996). Market Orientation in Food and Agriculture. Boston: Kluwer Academic Publishers.

[2] Horská, E., Berčík, J., Krasnodebski, A., Matysik - Pejas, R. \& Bakayová, H. (2016). Innovative approaches to examining consumer preferences when choosing wines. Agric.Econ-Czech, 62 (3), 124-133. Retrieved from https://www.agriculturejournals.cz/publicFiles/290_2015-AGRICECON.pdf.

[3] Hronský, V. (2001). Slovenské vína. Bratislava: Belimex.

[4] International organisation of vine and wine. (2019). Statistical report on world vitiviniculture. Paris, France: OIV Statistical report on vitiviniculture. Retrieved from <http://www.oiv.int/public/medias/6782/oiv-2019statistical-report-on-world-vitiviniculture.pdf $>$. 
[5] International organisation of vine and wine. (2017). World vitiviniculture situation. Paris, France: OIV Statistical report on vitiviniculture. Retrieved from $<$ http://www.oiv.int/public/medias/5479/oiven- bilan-2017.pdf $>$.

[6] Kulčáková, M. \& Richterová, K. (1997). Spotrebitel’ na trhu. Bratislava: Sprint Vfra.

[7] Meravá, E. (2017). Situačné a výhl'adové správy pre vinič hroznorodý a hroznové víno. Bratislava: MPRV SR- NPPC-VÚEPP. Retrieved from $<$ http://www.vuepp.sk/04 komodity.htm>.

[8] Němcová, J. \& Stanková, P. (2019). Factors influencing consumer behaviour of generation Y on the Czech wine market. $E \&$ \& $M$ EKONOMIE A MANAGEMENT, 22 (4), 145-161. Retrieved from $<$ https://10.15240/tul/001/2019-4-010>.

[9] Richterová, M., Klepochová, D., Kopaničová, J. \& Žák, Š. (2015). Spotrebitel’ské správanie. Bratislava: Sprint 2.

[10] Taliga, F. (2000). K otázkam legislatívy, marketingu a manažmentu v pol’nohospodárstve. Nitra: Slovenská pol'nohospodárska univerzita $\mathrm{v}$ Nitre.

[11] Výskumný ústav ekonoomiky pol'nohospodárstva a potravinárstva (VÚEPP). (2019). Vinič hroznorodý, hroznové víno. Bratislava: Meravá, E. Retrieved from $<\mathrm{http}: / /$ www.vuepp.sk/dokumenty/komodity/2019/Vino_19_v3.pdf $>$.

[12] Waldnerová, P., Nagyová, L. \& Kleinová, K. (2013). Consumer behaviour on the wine market in Nitra region. Polityki Europejskie, Finanse $i$ Marketing, 10, 729-736. Retrieved from $<$ http://agro.icm.edu.pl/agro/element/bwmeta1.element.agro-1e7cf33d-58ff-4a5b-8da8-1aa0 c97f43f1;jsessionid=A774C109B52D6873B883564D3FDD8CAC $>$. 


\title{
Consumer Behaviour towards Traditional Slovak Cheese "Parenica"
}

\author{
Peter Šedík ${ }^{1}$, Jakub Berčík ${ }^{2}$, L’udmila Nagyová ${ }^{3}$, Elena Horská ${ }^{4}$, Emese Tatar ${ }^{5}$ \\ Slovak University of Agriculture in Nitra ${ }^{1,2,3,4}$ \\ Faculty of Economics and Management, Department of Marketing and Trade 1,2,3,4 \\ Address: Tr. Andreja Hlinku 2, \\ 949476 Nitra, Slovakia \\ Szent Istvan University in Gödöllö 5 \\ Faculty of Economics and Social Sciences, Department of Managerial Economics \\ Address: Páter K. u. 1. \\ 2100 Gödöllő, Hungary \\ e-mail: sedik.peter@gmail.com¹, bercik.jakubxx@gmail.com², nagyoval26@gmail.com³, \\ elena.horska@gmail.com ${ }^{4}$, tatar.emese@szie.hu ${ }^{5}$
}

doi: 10.18515/dBEM.ISD.P01.2020.p019

\begin{abstract}
The purpose of the paper was to identify consumer and purchasing behaviour of Slovak consumers towards traditional Slovak cheese "Parenica". The research was based on primary data obtained via online questionnaire survey with 755 respondents in total. Following statistical tests were applied in hypothesis testing: Fisher's Exact Test, Chi-square test, Friedman test and Nemenyi test. Results showed that more than $55 \%$ of respondents consume this traditional Slovak cheese. Furthermore, cheese "Parenica" more consumed by respondents living in rural areas and younger than 50 years. The majority of respondents answered that tastier and in higher quality "Parenica" cheeses are produced on farms. However, nearly 50\% of respondents mostly purchase them at food stores, supermarkets or hypermarkets. Farm to table purchase is executed by $23.2 \%$ and is more frequent in case of respondents living in rural areas. In addition, the most important factors during purchase of "Parenica" cheese are fat, followed by expiration date, producer, type of milk, aroma and intensity of salty taste. The least important factor is resealable packaging.
\end{abstract}

Keywords: cheese consumption, consumer research, purchasing behaviour

JEL Classification: M31, M37, Q13

\section{Introduction}

Milk and dairy products are considered as the most important products of livestock. Many countries have recommendations on daily intake dairy products. For example, 1 cup of milk, 1 yogurt and 1 other dairy product. According to Weaver (2014) dairy products play essential role in dietary recommendations due to its rich content of essential nutrients such as highquality protein, minerals like calcium, magnesium, potassium, zinc, selenium, vitamins like thiamine, vitamin B-12, vitamin A, vitamin D and riboflavin. Furthermore, dairy products are frequently transformed into functional products involving low fat, probiotic, skim dairy products or fortified products with minerals, omega-3 fatty acids, vitamins or avoiding certain enzymes (lactose free dairy products). Demand for milk products is influenced by consumption patterns, demographic patterns, urbanization, lifestyle and income level because if consumer's wealth increases, the attention is focused more on product taste and individual preference (Bhanu et al. 2017). Among the first functional products were fermented dairy products and 
yogurts with probiotics (Bazhan et al. 2018). The intake of functional foods is growing because more and more consumers understand impact of food on their health (Cerjak \& Tomić, 2015). Consumption of dairy products are increasing in developing countries due to urbanization (Tolosa, et al. 2016). Moreover, development of new products, innovations and increased demand in emerging economies have caused increase in cheese consumption (Garanti \& Berberoglu, 2018). In general, European consumers like cheese. Around 10 million tons of cheese are consumed in the EU. In 2017 each resident consumed 14,2 kg of cheese in average. Predictions expect increasing tendency in overall consumption of cheese. (Statista Research Department, 2019).

According to Statistical Office of the Slovak Republic, cheese market has increasing tendency in overall consumption. On average a resident of Slovakia consumed $10.7 \mathrm{~kg}$ of cheese in 2017 and the overall consumption of cheese reached nearly 60000 tons.

\section{Figure 1: Development of cheese consumption in Slovakia}

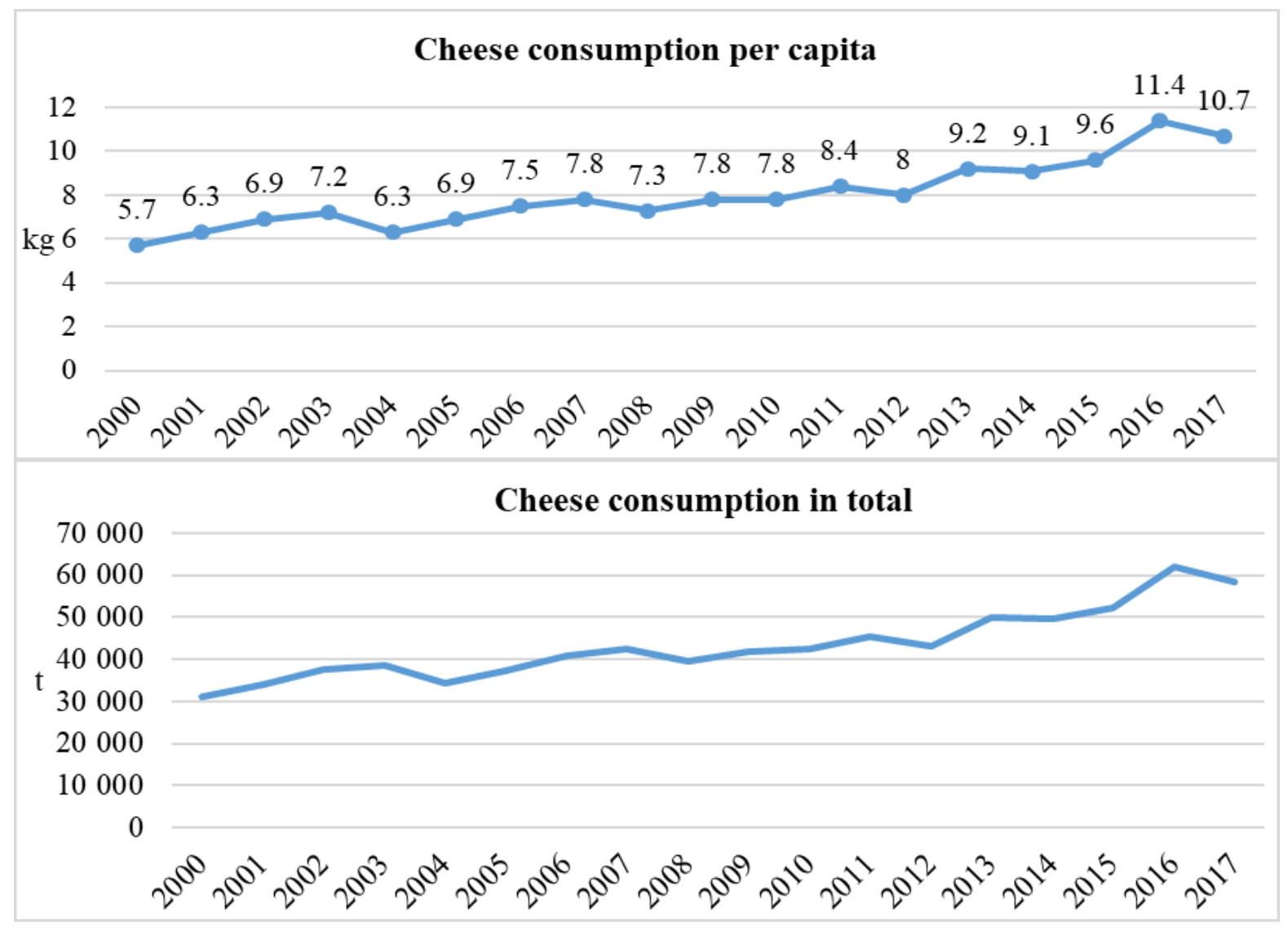

Source: Statistical Office of the SR 2019

\section{Data and Methods}

Purpose of the paper was to identify consumer and purchasing behaviour of Slovak consumers towards traditional Slovak cheese "Parenica". Primary research was based on the questionnaire survey conducted online during April - May in 2018. A total of 755 respondents fulfilled the questionnaire while only 422 respondents consume traditional Slovak cheese "Parenica". According to demographic profile of "Parenica" cheese consumers the research sample contains $58.29 \%$ females and $41.71 \%$ males, living in rural area $(52.84 \%)$ and urban area $(47.16 \%)$ and 
with following age structure: $18-24$ years $(33.89 \%), 25-49$ years $(36.49 \%)$ and $\geq 50$ years $(29.62 \%)$. Data were processed and analysed using the statistical programme IBM SPSS Statistics 25 .

For the purpose of a deeper analysis were formulated several hypotheses:

H1: There exists dependence between consumption of cheese "Parenica" and respondent's age

H2: There exists dependence between consumption of cheese "Parenica" and respondent's place of residence.

H3: There exists dependence between place of purchase and respondent's age.

H4: There exists dependence between place of purchase and respondent's place of residence.

H5: There are differences in evaluation of purchasing factors towards "Parenica" cheese.

Formulated hypotheses were tested by applying the following statistical tests:

- Fisher's Exact Test,

- Chi-square test,

- Friedman test,

- Nemenyi test.

\section{Results and Discussion}

Results showed that more than $55 \%$ of respondents consume traditional Slovak cheese "Parenica". The rest of respondents do not consume this type of cheese due to either its taste or health problems connected with digestion problems and excessive mucus production in organism. For the purpose of a deeper analysis, two hypotheses were formulated in order to examine whether age and place of respondence could have impacts on respondents 'consumption of "Parenica". Based on Fisher's Exact Test $(p$-value $=0.016)$ and Chi-square test $(p$-value $=0.003)$ both hypotheses were confirmed, and it could be stated that age and place of residence have the influence on consumption. Cheese "Parenica" is more consumed by respondents living in rural areas and younger than 50 years (Fig. 2).

Figure 2: Consumption of cheese "Parenica" according to selected demographic variables

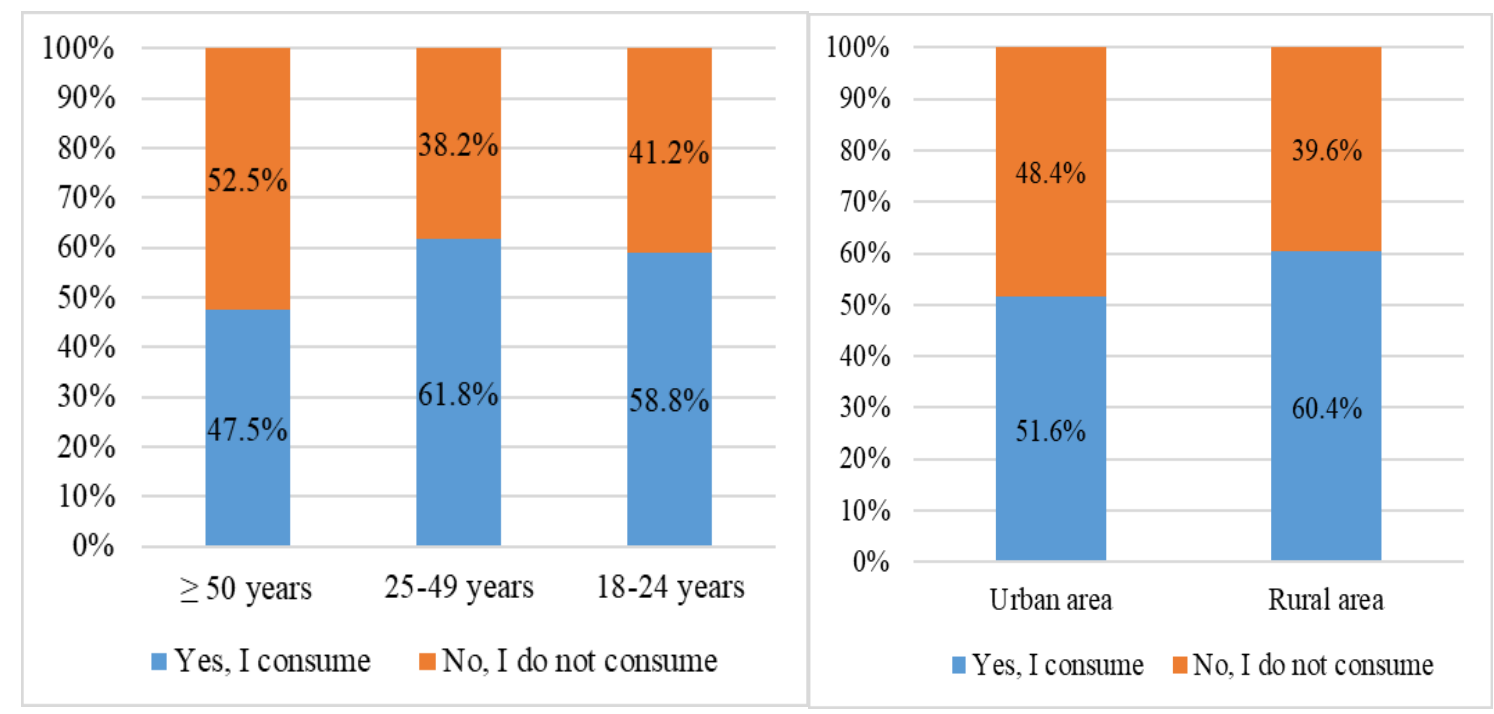

Source: own processing 
Regarding the consumption frequency of cheese "Parenica", out of 422 respondents only $24 \%$ consume it regularly $(6.6 \%$ on daily basis and $17.5 \%$ few times a week). The majority of respondents consume "Parenica" either occasionally $(37.2 \%)$ or few times a month $(38.6 \%)$. Interesting results were obtained when respondents answered whether they prefer smoked or unsmoked variant of cheese "Parenica". The precise half of them prefer smoked and the other half unsmoked variant. Although most respondents answered that tastier and higher quality "Parenica" cheeses are produced on farms, nearly a half of respondents most often purchase them in food stores, supermarkets or hypermarkets. Only $23.2 \%$ purchase it directly from the farm. Furthermore, there were formulated hypotheses regarding the dependence between place of purchase and respondent's age and place of residence. Based on Chi-square test, both hypothesis $3(p$-value $=0.036)$ and hypothesis $4(p$-value $=0.023)$ were confirmed. According to Figure 3, respondents between $18-24$ years mostly purchase "Parenica" cheese at food stores, supermarkets or hypermarkets while farm to table purchase is mainly executed by respondents older than 49 years. In addition, farm to table (selling directly to consumer) is more frequent in case of respondents living in rural areas (Fig. 3).

Figure 3: Place of purchase according to selected demographic variables

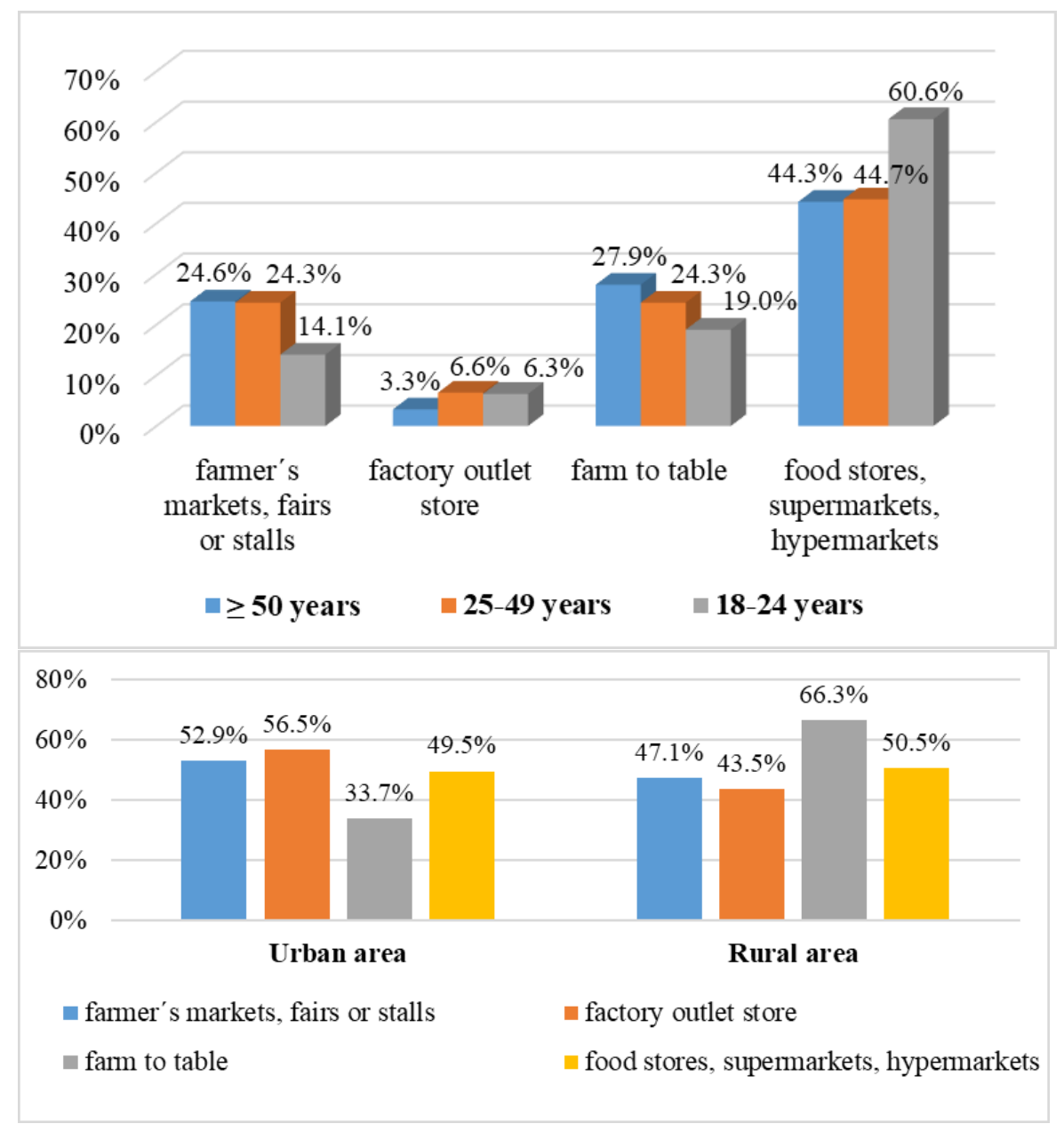

Source: own processing

The last hypothesis was formulated in terms of differences in evaluation of purchasing factors regarding "Parenica" cheese. Respondents had to evaluate 12 factors (see Fig. 4) on the 6-points scale, where 1 represented the least important and 6 the most important factor. By applying Friedman test, the least hypothesis was confirmed, and it could be stated that there exist 
differences in evaluation among at the last pair of factors. For deeper identification were applied post host test - Nemenyi test which identified between which factors exist statistically significant differences in evaluation (see Tab. 1). Based on the results, it could be concluded that the most important factor during purchase of "Parenica" cheese is fat, followed by expiration date, producer, type of milk, aroma and intensity of salty taste. The least important factor is resealable packaging followed by elasticity, brand, separability of fibres and colour intensity. The similar results were obtained in Spanish consumer research, where consumers indicated price, fat and salt content as the most important factor considered during purchase of cheese (Cruz Maceín, Iriondo DeHond \& Miguel, 2019). Aspect of packaging were examined in Slovak study focused on milk and dairy consumption where results showed that appearance of packaging, size of packaging or product promotion are the least determining factors of milk and dairy consumption (Kubicová et al., 2019). This fact is supported also by authors Bytyqi et al. (2008) who stated that consumer behaviours is not affected by packaging when purchasing milk and dairy products. Another study dealing with consumer behaviour on the market with dairy products identified packaging among least factors which lead to the purchase of dairy products (Košičiarová, Nagyová \& Holienčinová, 2017). However, authors Rybanská et al., (2019) stated that right visual features on dairy products can be influential in purchasing process. Moreover, acceptability of cheese may be affected by extrinsic attributes (Speight et al., 2019). According to Van Loo, Grebitus, and Roosen (2019) the importance of origin information on packaging is influenced by both consumer attention and ethnocentrism.

Figure 4: Evaluation of factors considered during purchase of cheese "Parenica"

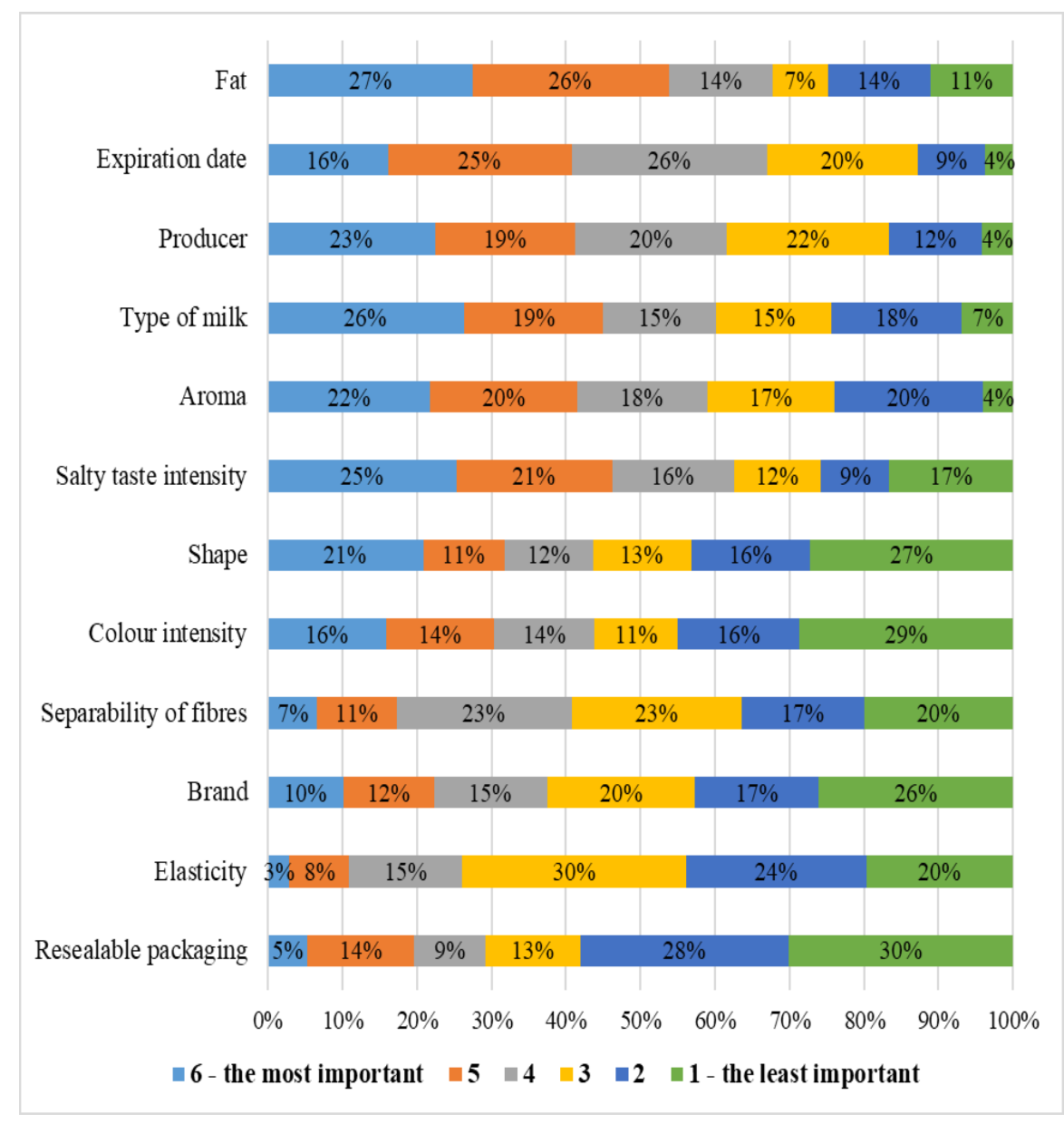

Source: own processing 
Table 1: Multiple pairwise comparisons using Nemenyi's procedure

\begin{tabular}{cc|cccc}
\hline Sample & $\begin{array}{c}\text { Mean of } \\
\text { ranks }\end{array}$ & \multicolumn{5}{|l}{ Groups } \\
\hline Resealable packaging & 4.8045 & A & & & \\
Elasticity & 5.0166 & A & B & & \\
Brand & 5.5154 & A & B & C & \\
Separability of fibres & 5.6564 & & B & C & \\
Colour intensity & 5.8199 & & B & C & \\
Shape & 6.0118 & & & C & \\
Salty taste intensity & 7.3211 & & & & D \\
Aroma & 7.3815 & & & & D \\
Type of milk & 7.5012 & & & & D \\
Producer & 7.5699 & & & & D \\
Expiration date & 7.6469 & & & & D \\
Fat & 7.7547 & & & & D \\
\hline
\end{tabular}

Source: own processing

\section{Conclusion}

In conclusion, 422 out of 755 respondents consume traditional Slovak cheese "Parenica". The main reasons for non-consumption was taste and health issues. Results showed that cheese "Parenica" is mostly consumed by respondents younger than 50 years living in rural areas. This type of cheese is mostly consumed occasionally or few times per month. The majority of respondents purchase it in food stores, supermarkets, hypermarkets in spite of the fact that they consider cheese "Parenica" produced on the farm tastier and of higher quality. Farm to table purchase is more common for respondents situated in rural areas. The most important factors were fat, expiration date, producer, type of milk, aroma and intensity of salty taste. The least important factor was resealable packaging.

\section{Acknowledgements}

This paper was supported by the Slovak Research and Development Agency on the basis of Contract no. APVV-16-0244 "Qualitative factors affecting the production and consumption of milk and cheese.

\section{References}

[1] Bazhan, M., Kalantari, N., Keshavarz-Mohammadi, N., Hosseini, H., Eini-Zinab, H., \& Alavi-Majd, H. (2018). Applying social marketing mix to identify consumers' preferences towards functional dairy products in Iran. Nutrition \& Food Science, 48(1), 45-60. doi:10.1108/nfs-04-2017-0067

[2] Bhanu, B., Serma Saravana Pandian, P. V., Vinothini, P. \& Mathanghi, S. K. (2017). Analysing the Consumer Preference for Dairy Products in Trivandrum City, India, International Journal of Science, Environment and Technology, 6(1), 650-654. E-ISSN 2278-3687, ISSN 2277-663X.

[3] Bytyqi, H., Vegara, M., Gjonbalaj, M., Hajrip, M., Halim, G., Miftari, I., \& Bytyqi, N. 2008. Analysis of Consumer Behaviour in Regard to Dairy Products in Kosovo. Journal of Agricultural Research, 43(3), 281290.

[4] Cerjak, M., \& Tomić, M. (2015). Buying Motives and Trust of Young Consumers for Functional Fermented Dairy Products: Evidence from Croatian Students. Journal of International Food \& Agribusiness Marketing, 27(3), 177-187. doi:10.1080/08974438.2014.918919 
[5] Cruz Maceín, J., Iriondo DeHond, M. \& Miguel, E. (2019). Cheese consumption culture in Central Spain (Madrid Region): drivers and consumer profile. British Food Journal, 122(2), 561-573. doi:10.1108/BFJ-082019-0578

[6] Garanti, Z., \& Berberoglu, A. (2018). Cultural Perspective of Traditional Cheese Consumption Practices and Its Sustainability among Post-Millennial Consumers. Sustainability, 10(9), 3183. doi:10.3390/su10093183

[7] Košičiarová, I., Nagyová, L. \& Holienčinová, M. 2017. Consumer Behaviour on Slovak Yoghurt and Fermented Milk Products Market. Acta Universitatis Agriculturae et Silviculturae Mendelianae Brunensis, 65(6), 1967-1978. doi:10.11118/actaun201765061967

[8] Kubicová, L., Predanocyová, K., \& Kádeková, Z. (2019). The importance of milk and dairy products consumption as a part of rational nutrition. Slovak Journal of Food Sciences, 13(1), 234-243. doi:10.5219/1050

[9] Rybanská, J., Nagyová, L., \& Tkáč, F. (2019). Selected Psychological Factors as Predictors of Consumer Choice in the Milk Product Market. Olsztyn Economic Journal, 14(3), 287-298. https://doi.org/10.31648/oej.4376

[10] Speight, K. C., Schiano, A. N., Harwood, W. S., \& Drake, M. A. (2019). Consumer insights on prepackaged Cheddar cheese shreds using focus groups, conjoint analysis, and qualitative multivariate analysis. Journal of Dairy Science, 102(8), 6971-6986. doi:10.3168/jds.2018-16209

[11] Statista Research Department. (2019). Cheese market in Europe - Statistics and Facts. Retrieved November 10, 2019, from https://www.statista.com/topics/3726/cheese-market-in-europe/

[12] Statistical Office of the SR. (2019). Consumption statistics [statistics]. Available from DATAcube database

[13] Tolosa, T., Verbeke, J., Piepers, S., Tefera, M., Getachew, Y., Supré, K., \& DeVliegher, S. (2016). Milk production, quality, and consumption in Jimma (Ethiopia): Facts and producers', retailers', and consumers' perspectives. Preventive Veterinary Medicine, 124, 9-14. doi:10.1016/j.prevetmed.2015.12.016

[14] Van Loo, E. J., Grebitus, C., \& Roosen, J. (2019). Explaining attention and choice for origin labeled cheese by means of consumer ethnocentrism. Food Quality and Preference, 78, doi:10.1016/j.foodqual.2019.05.016

[15] Weaver, C. M. (2014). How sound is the science behind the dietary recommendations for dairy? The American Journal of Clinical Nutrition, 99(5), 1217S-1222S. doi:10.3945/ajcn.113.073007 


\title{
The Current Situation and Needs of Milk Producers in the Slovak Republic
}

\author{
Petronela Švikruhová1, Zuzana Kapsdorferová ${ }^{2}$, Radka Kataniková ${ }^{3}$ \\ Slovak University of Agriculture in Nitra \\ Faculty of Economics and Management, Department of Management $t^{1,2,3}$ \\ Address: Tr. Andreja Hlinku 2, \\ 94976 Nitra, Slovakia \\ e-mail: petronela.svikruhova@uniag.sk¹, zuzana.kapsdorferova@uniag.sk², xkatanikova@uniag.sk ${ }^{3}$
}

doi: 10.18515/dBEM.ISD.P01.2020.p020

\begin{abstract}
Over the past 10 years, Slovakian dairy sector has experienced three dairy crises and one butter crisis. All these crises caused up to $37 \%$ of milk producers cease their production. The milk sector is weakened due to large market fluctuations. In long-term is this sector investment-undersized and is very labour intensive. Based on this, people are not interested in working in this sector. In the interests of food security and maintaining employment it should be in the interest of the new government to do everything possible to stabilize this sector. The year 2019 was one of the better years for primary milk producers. After some time, the situation has improved, mainly thanks to the recovery of milk purchase prices, but also thanks to support. However, there were not many reasons for great joy. The biggest joy is that this year was not for primary milk producers a crisis. Milk purchase prices have recovered slightly and averaged 32.6 cents per kilogram over the year. On the other hand, costs have risen again, either because of rising energy prices or because of rising labour costs caused by the government measures. Therefore, the primary objective of this paper is to point out on the current situation and needs of milk producers in Slovakia in relation to the strategic objective - Ensuring viable farm income.
\end{abstract}

Keywords: milk, milk producers, identification of needs of Slovak milk producers, common agricultural policy

JEL Classification: $Q 10, Q 13, Q 18$,

\section{Introduction}

Billions of people around the world consume milk and dairy products every day. Milk and dairy products are vital source of nutrition for people, they also present livelihoods opportunities for farmers, processors, shopkeepers, and other stakeholders in the dairy value chain. The importance of milk and dairy products to human nutrition has been repeatedly confirmed by nutritionists around the world.

Since ancient times is milk the most complex food and plays its important role in human society. Hippocrates alone 400 years BC considered milk as a medicine and recommended it as the basis of a healthy and nutritious diet. Similarly, there are as well many references to milk in the Bible, for example, "The Promised Land" is described as a land filled with milk and honey. The same opinion is shared by the authors Vanga and Raghavan (2018), who stated that cow's milk has been widely consumed around the world for hundreds of centuries and acts as an important source of protein. Its composition makes milk irreplaceable for a healthy diet. Its main ingredients include: proteins, fat, milk sugar, minerals (calcium, phosphorus, potassium, magnesium) as well as essential nutritional substances, vitamins and other important substances, thus forming a comprehensive balanced food for all age and health categories of people. 
Cow's milk proteins and related bioactive peptides may have significant effects on human health across the life span (Poppitt, 2020). When consumed according to appropriate national guidelines, milk and its derivatives contribute essential micro- and macronutrients to the diet, especially in infancy and childhood where bone mass growth is in a critical phase. Furthermore, preliminary evidence suggests potentially protective effects of milk against overweight, obesity, diabetes, and cardiovascular disease, while no clear data suggest a significant association between milk intake and cancer (Marangoni et. al., 2019, Thorning et.al. 2016).

\subsection{Development of milk production and milk yield in Slovakia}

The milk production is important for the society as a whole, both in terms of economy of state and the employment of rural population. It is a traditional economic sector, that due to its very favourable conditions promises a very viable future (Gurčík, et al. 2016).

Milk processing has strict rules in terms of both EU and national legislation. The production of milk and dairy products takes place in several stages and usually begins with the production of animal feed followed by the production of raw milk on the farm and further processing in the dairy company or on the farm itself. Milk production in Slovakia is under constant veterinary supervision from its production at the farm, during the entire processing process to the actual sale on the store shelves. In Table 1 below you can see the development of milk production and milk yield over the period $2012-2018$.

Table 1 Development of milk production and milk yield over the period 2012-2018

\begin{tabular}{cccccccc}
\cline { 2 - 7 } & \multicolumn{7}{c}{ Year } \\
\cline { 2 - 7 } & $\mathbf{2 0 1 2}$ & $\mathbf{2 0 1 3}$ & $\mathbf{2 0 1 4}$ & $\mathbf{2 0 1 5}$ & $\mathbf{2 0 1 6}$ & $\mathbf{2 0 1 7}$ & $\mathbf{2 0 1 8}$ \\
\hline $\begin{array}{c}\text { Milk production } \\
\text { (thousands of liters) }\end{array}$ & 931474 & 906686 & 921078 & 929536 & 906115 & 910683 & 905429 \\
\hline $\begin{array}{c}\text { Average annual } \\
\text { yield per cow (liters) }\end{array}$ & 6112 & 6334 & 6315 & 6537 & 6668 & 6937 & 7056 \\
\hline
\end{tabular}

Source: Own processing based on data from the Statistical Office of the Slovak Republic - Public database DATAcube

The intensification of the dairy sector as the prevailing trend that is expected in the upcoming 10 years, is caused by the abolition of milk quotas and a growing global population. Milk quotas were first introduced in 1984 in order to limit milk production in Europe but on $1^{\text {st }}$ April 2015, the milk quota was abolished, allowing farmers to expand their production, provided the phosphate production within limits (Jongeneel - Van Berkum, 2015).

In Table 1 above, we can observe a positive development in milk yield, which is growing every year. In 2018 there was a year-on-year increase in milk yield by up to $1191(2.7 \%)$ to 70561 milk per dairy cow per year, which represents the highest milk yield in the monitoring period so far.

As regards the dairy sector, the Europe Commission expects milk production to increase by $0.7 \%$ in 2019 to reach EUR 167.3 million. ton. This increase should be ensured by continuous global demand.

\subsection{Development of milk consumption in Slovakia}

As milk and milk production have their irreplaceable role in securing the state self - sufficiency in basic food, it is necessary to pay attention to not only to production, but also to consumption of these products. (Gurčík, et al. 2016). 
Based on their nutritional values, milk and dairy products have an irreplaceable role in daily consumption. Despite this, the consumption of milk and dairy products in Slovakia lags far behind the surrounding Central European countries. Since milk and dairy products are the main source of calcium and protein, its low consumption is unfavorable from a nutritional point of view.

Consumption of cow's milk and dairy products made from cow's milk represents approximately $98 \%$ of total milk and dairy products consumption in the Slovak Republic (Ministry of Agriculture and Rural Development of the Slovak Republic, 2019).

Table 2 Development of the Consumption of Milk and Dairy Products in kg per capita in the SR (2008-2018)

\begin{tabular}{|c|c|c|c|c|c|c|c|c|c|c|c|}
\hline & \multicolumn{11}{|c|}{ Year } \\
\hline & 2008 & 2009 & 2010 & 2011 & 2012 & 2013 & 2014 & 2015 & 2016 & 2017 & 2018 \\
\hline $\begin{array}{c}\text { Milk and dairy } \\
\text { products (kg) }\end{array}$ & 153,0 & 153,8 & 162,8 & 156,9 & 158,6 & 158,5 & 166,8 & 169,2 & 176,2 & 174,6 & 171,1 \\
\hline Milk (kg) & 48,3 & 49,5 & 54,5 & 53,1 & 54,3 & 49,3 & 48,3 & 48,1 & 46,5 & 46,4 & 46,0 \\
\hline
\end{tabular}

Source: Own processing based on data from the Statistical Office of the Slovak Republic - Food consumption in the SR in years $2008-2018$

In 2018 compared to 2017 there was a reduction in the milk and dairy products consumption $(2.0 \%)$. The consumption of milk and dairy products (in terms of milk without butter) was 171.1 $\mathrm{kg}$ i.e. by $3.5 \mathrm{~kg}$ lower $(2.0 \%)$ than in 2017.

In the view of the fact that milk and dairy products are important sources of calcium and valuable proteins, this low consumption is unfavorable from the nutritive point of view. Consumption of milk and dairy products significantly lagged compared to countries of Central Europe. In 2017 by available data from countries of central Europe for example the high consumption of milk and milk products in equivalent milk without butter had Czech Republic (239.3 1) and Poland (218 1). SR recorded consumption only 169.5 1. In 2017 the comparable amount in consumption as in SR recorded Hungary 160.71 (Statistical Office of the SR - Food consumption in the SR in 2018).

\section{Data and Methods}

The aim of the questionnaire research was to describe the current situation and identify the needs of milk producers. For this purpose, was used a questionnaire which consisted of two basic parts:

1. The current state of the milk producers in Slovakia.

2. Identification of the needs of the company in the new programming period CAP 20212027 in relation to the strategic objective - Ensuring viable farm income of the prepared Strategic Plan

In order to fulfil the goal that was set, we chose a questionnaire survey as the main method. We chose this method mainly because the questionnaire generally represents a series of questions of various types submitted in writing or digital form. The respondent answers questions with the content, number and type of questions determined by the purpose of the survey and the target group for which the questionnaire is intended. The questionnaire is suitable for obtaining data from many people, and the thematic scope may vary in size. Due to the consistency of the 
formulations, the data can be easily processed in bulk and the responses of different groups can be compared. In general, the advantage of questionnaire is in its wide scope. (in terms of content and number of respondents). The questionnaire is therefore a much more "economical" tool.

This questionnaire was used as the basic survey technique. The survey was carried out in the months of September - November 2019 by sending a link to an electronic questionnaire by email, but mainly by mail. The survey was carried out in Slovakia.

The criterion for establishing the survey sample were all the primary milk producers in Slovakia. Out of a total of 401 primary milk producers that process milk in Slovakia, we managed to reach 104 primary milk producers, which represents $27 \%$ of the total number of respondents surveyed.

Figure 1 The legal form and the regional representation of the respondents surveyed

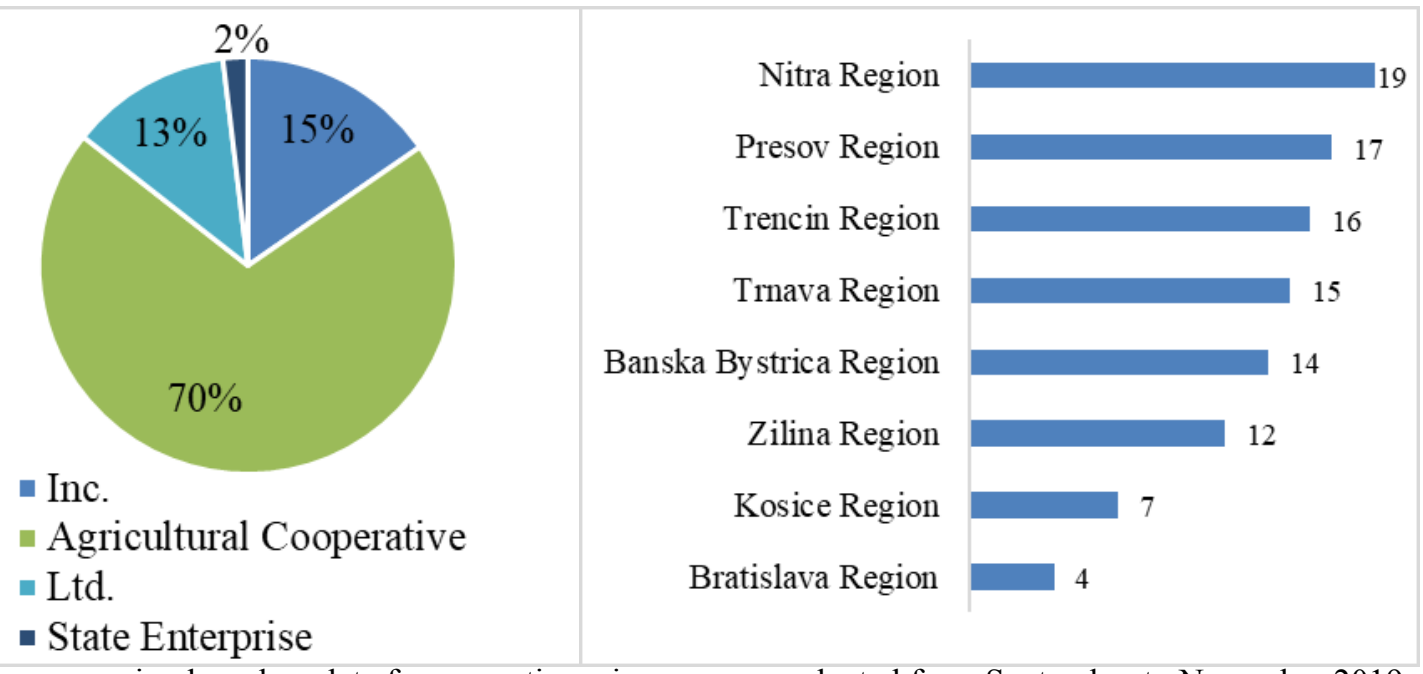

Source: Own processing based on data from questionnaire survey conducted from September to November 2019

In the Figure 1 above it can be seen that the largest share of respondents was from Nitra region and the largest share of respondents was agricultural cooperatives $(70 \%)$.

The questionnaire survey also included an analysis of the current state of dairy farms. From the analyzed data, we have decided to present data according to the number and age of stalls. As you can see in the In the upcoming period we need a government that will take the development of the dairy sector in its priorities and support this sector.

Figure 2 below up to $77 \%$ of all analyzed milk producers keep dairy cattle in stables built between $1950-1990$. Just $10 \%$ of the stables were built between the year $2011-2019$. Our analyzed sample have a total of 756 stables, in which 82303 all categories of dairy cattle are kept. According to our research the oldest stables in which dairy cattle are kept have an average age of 50 years. This finding is very serious. In the upcoming period we need a government that will take the development of the dairy sector in its priorities and support this sector. 
Figure 2 Share of stables according to the year of construction (\%)

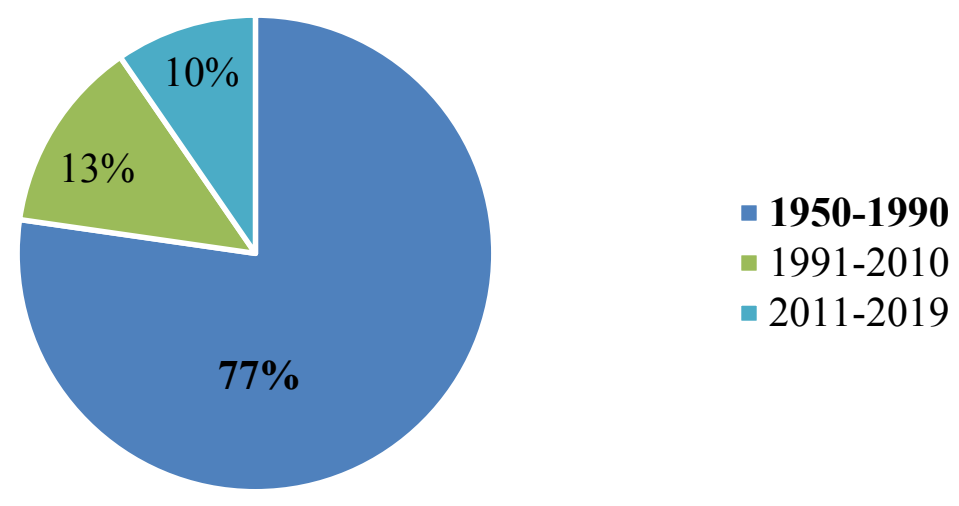

Source: Own processing based on data from questionnaire survey conducted from September to November 2019

\section{Results and Discussion}

The CAP has gone through a series of reforms since 1992, leading to better market integration and coherence. The introduction of decoupled direct payments has resolved various challenges but created new inconsistencies within the CAP. Nevertheless, the role of CAP subsides is still important in supporting farm income. Current trends and CAP's performance indicate that sustainability, along the axes of social, ecological and environment dimensions, has not been achieved and is unlikely to be achieved under current conditions. High criticism is also directed towards inefficiency and inequity of direct payments distribution, which do not reflect farmers' needs (Pe'er, Guy, et al., 2019).

As part of the preparation of the EU budget for 2021-2027, the European Commission put forward a new set of regulations to shape the future EU Common Agricultural Policy (CAP) on 1 June 2018. The aim of the new proposal is to achieve more subsidiarity and simplification, with greater responsibility given to Member States, a shift from ensuring single transaction compliance to monitoring system performance in each Member State, and reduced 'red tape', among other things. In general, a new CAP delivery model that should lead to a more resultsbased policy and greater flexibility in its implementation, while preserving its common dimension (Rossi, 2018, Matthews, 2018).

From the nine key objectives of the future CAP Strategic Plans we focused in our research mainly on Ensuring viable farm income. The main reason for choosing this strategic goal was that in 2017, farmers earned on average just under half of what could be gained in other jobs, from a third a decade ago.

The Slovak dairy market has been in an unfavorable situation in recent years. Several majors' changes have been made to the dairy market through this situation. Long-term low prices of raw cow milk led to the liquidation of primary milk producers (Váryová, et. al. 2019).

Slovak farmers can apply for direct support every year. The conditions for providing direct support are regulated by EU and Slovak legislation. In Slovakia, the state administration authority in providing support and subsidies is the Agriculture Paying Agency (APA). APA is a budgetary organization involved in financial relations with the budget of the Ministry of Agriculture and Rural Development of the Slovak Republic (Malatinec et al., 2016).

In the questionnaire survey, we asked respondents about the required amount of direct payments for livestock unit (LU). The average amount of direct payments required is $€ 420$ / LU in all 
categories of dairy cattle. It is interesting to note that many of the dairy producers complain about the low level of direct payments, but when they are given the opportunity to express their need, up to $22 \%$ of respondents have not commented on the issue. We calculated as well estimated total amount of required direct payments as number of LUs in Slovakia (approx. $200000) \mathrm{X} 420 € / \mathrm{LU}=$ about $€ 80$ million. As you can see from our simple formula, estimated total amount of required direct payments is $€ 80$ million.

The agricultural sector is characterized by the fact that there is a high level of risk. It was always this case, but in the last years, there is a tendency of the increasing of the risk (Nadezda et al., 2017). Based on the mentioned above, in our research, we further focused on issues related to risk management in primary milk production. Respondents were asked, what types of risks they most often encounter in primary milk production.

The results of the survey point out the fact, that Slovak primary milk producers are most often faced with four types of risk:

1. diseases and various animal injuries,

2. damage of forage caused by drought or wildlife,

3. lack of skilled labor and

4. unpredictable volatility in the price.

The most significant risk is price volatility. Whereas price volatility in agricultural markets is a permanent feature but has recently increased dramatically. The high price volatility in recent years has prompted questions about the future CAP regarding the possible benefits of more risk management tools and a more global approach to the functioning of the whole food chain. Obviously, in connection with climate change, the damage of forage caused by drought cannot be neglected either.

At the same time, we were interested in what proportion of insurance costs should be covered by the support. Talking about insurable risks, respondents have different opinion according to the share of insurance costs paid through support. As you can see in the Figure 3 up to $66 \%$ of respondents require $50 \%$ or more of the risk insurance support and again $27 \%$ of respondents did not answer this question.

\section{Figure 3 The share of insurance costs paid through support (number of responders)}

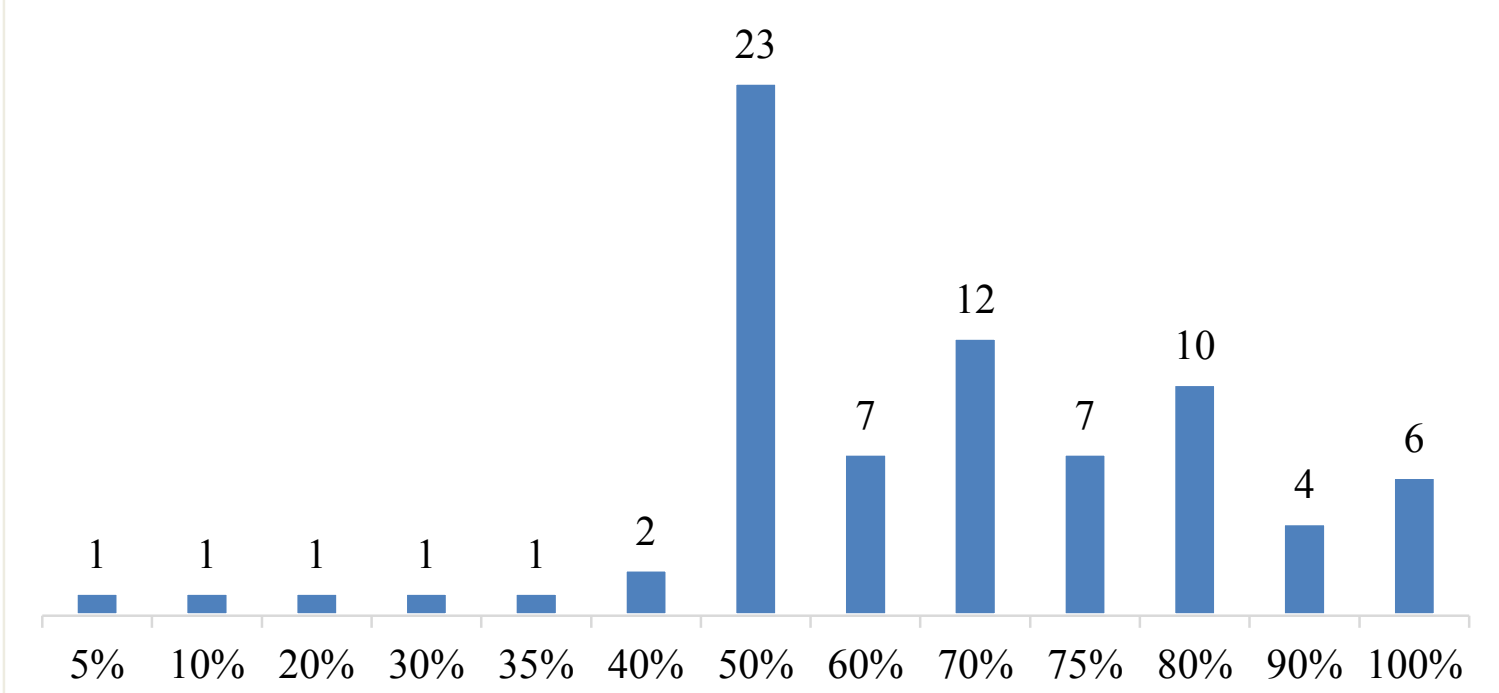

Source: Own processing based on data from questionnaire survey conducted from September to November 2019 
Dairy sector is sector with a regular volatility in income with sometimes big shocks (Agri, 2017). Because of this fact dairy sector must look for tools which compensate income losses. One of these tools can be risk fund. The creation of a risk fund should involve both the state and the farmers themselves, an alternative - the participation of commercial insurance companies.

Figure 4 Primary milk producers' interest in establishing a Risk Fund in the agriculture sector

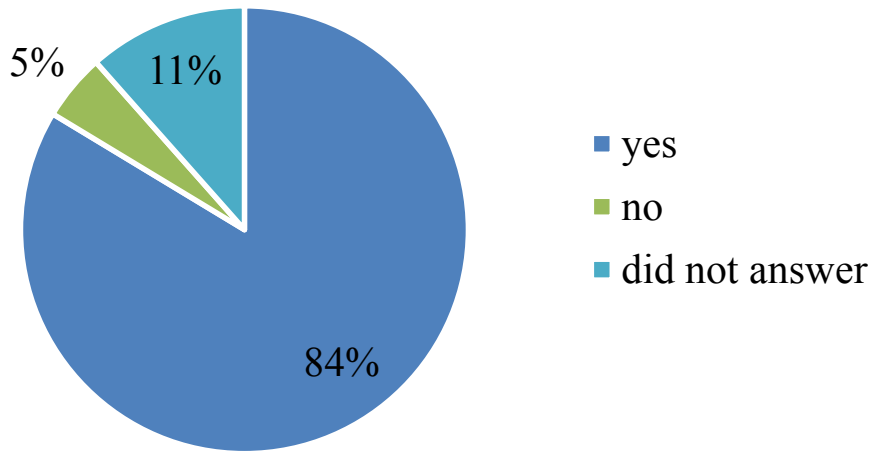

Source: Own processing based on data from questionnaire survey conducted from September to November 2019

This resource would cover the agricultural damage, which is also related to climate change and belongs to the uninsurable risks. As you can see in the Figure 4, up to $84 \%$ of respondents are interested in establishing risk fund in the agriculture sector that has been discussed in Slovakia for a long time.

According to our research up to $79 \%$ of primary milk producers would like to cover outages of revenues when the purchasing price of milk on the market falls from the risk fund. Because the volatility in price as the risk has an effect to more producers at the same time.

\section{Conclusion}

Milk production takes place all around the world. Global demand for dairy continues to increase in large part due to population growth, rising incomes, urbanization and westernization of diets in countries such as China and India.

In our research we pointed out the current situation and needs of milk producers in Slovakia in relation to the strategic objective - Ensuring viable farm income. We see that milk producers are not satisfied with the current amount of direct payments. Slovak primary milk producers are most often faced with four types of risk as diseases and various animal injuries, damage of forage caused by drought or wildlife, lack of skilled labor and unpredictable volatility in the price. The most significant risk is for them price volatility. Up to $79 \%$ of primary milk producers would like to cover outages of revenues when the purchasing price of milk on the market falls from the risk fund, of which creation is great interest (84\%).

In our research we identified the other forms of support as well on ensuring viable farm income, which are: promoting employment, reduce health and social contributions, fixing a minimum purchase price for milk, abolish the VAT on milk, stronger support of Green Diesel project.

The conditions, in which the milk is produced are insufficient. The oldest stables in which dairy cattle are kept have an average age of 50 years. It is certain that we need to make our primary 
milk producers more competitive. In the upcoming period we need a government that will take the development of the dairy sector in its priorities and support this sector.

\section{Acknowledgements}

This work was supported by the Slovak Research and Development Agency on the basis of Contract no. APVV-16-0244 "Qualitative factors affecting the production and consumption of milk and cheese ".

\section{References}

[1] Agri, D. G. (2017). Risk management schemes in EU agriculture; dealing with risk and volatility.

[2] Gurčík, L., Dobošová, L', Richter, M., Kubicová, L., \& Dobák, D. (2016). Controlling as a management system of milk production and consumption in Slovakia and the Czech Republic. The Agri-food Value Chain: Challenges for Natural Resources Management and Society: International Scientific Days 2016, 329-338.

[3] Jongeneel, R. A., \& van Berkum, S. (2015). What will happen after the EU milk quota system expires in 2015?: an assessment of the Dutch dairy sector (No. 2015-041). LEI Wageningen UR.

[4] Malatinec, T., Marišová, E., \& Grešová, L. (2016). EU vision of sustainable agriculture, land use, forestry and management of natural resources-level of the Slovak state administration convergence to the EU requirements. International Journal of Sustainable Development \& World Ecology, 23(3), 257-265.

[5] Marangoni, F., Pellegrino, L., Verduci, E., Ghiselli, A., Bernabei, R., Calvani, R., ... \& Giacco, R. (2019). Cow's milk consumption and health: a health professional's guide. Journal of the American College of Nutrition, 38(3), 197-208.

[6] Matthews, A. (2018). The CAP in the 2021-2027 MFF Negotiations. Intereconomics, 53(6), 306-311.

[7] Nadezda, J., Dusan, M., \& Stefania, M. (2017). Risk factors in the agriculture sector. Agricultural Economics, 63(6), 247-258.

[8] Pe'Er, G., Zinngrebe, Y., Moreira, F., Sirami, C., Schindler, S., Müller, R., ... \& Hansjürgens, B. (2019). A greener path for the EU Common Agricultural Policy. Science, 365(6452), 449-451.

[9] Poppitt, S. D. (2020). Milk proteins and human health. In Milk Proteins (pp. 651-669). Academic Press.

[10] Rossi, R. (2018). CAP horizontal regulation. Retrieved from https://pdfs.semanticscholar.org/ddf6/3a4flac671848ef47c013ef6adec450fbab8.pdf

[11] Statistical Office of the SR (2019) Food consumption in the SR in 2018 [statistics].

[12] Thorning, T. K., Raben, A., Tholstrup, T., Soedamah-Muthu, S. S., Givens, I., \& Astrup, A. (2016). Milk and dairy products: good or bad for human health? An assessment of the totality of scientific evidence. Food \& nutrition research, $60(1), 32527$.

[13] Vanga, S. K., \& Raghavan, V. (2018). How well do plant based alternatives fare nutritionally compared to cow's milk? Journal of food science and technology, 55(1), 10-20.

[14] Váryová, I., Poláková, Z., Košovská, I., Vaňová, A. F., \& Krajčírová, R. (2019). Analysis of development of raw cow milk prices in the conditions of the Slovak Republic. Potravinarstvo Slovak Journal of Food Sciences, 13(1), 906-914. 


\title{
Review of Aroma Marketing Application in Electronics Stores
}

\author{
Adam Vakoš ${ }^{1}$, Michaela Šugrová ${ }^{2}$, Johana Paluchováa ${ }^{3}, J^{\prime k u b}$ Berčík $^{4}$ \\ Slovak University of Agriculture in Nitra \\ Faculty of Economics and Management, Department of Marketing and Trade ${ }^{1,2,3,4}$ \\ Tr. A. Hlinku 2, \\ 94976 Nitra, Slovakia \\ e-mail: adam.vakos@gmail.com¹,michaela.sugrova@uniag.sk²,johana.paluchova@uniag.sk², \\ jakub.bercik@uniag.sk ${ }^{4}$
}

\section{doi: 10.18515/dBEM.ISD.P01.2020.p021}

\begin{abstract}
Aroma marketing as a modern phenomenon in the field of neuromarketing, which become to be more typical and irreplaceable element of global brands' sale strategies in the field of producers who produce the consumer electronics goods. A suitable scent choice allows a pleasant atmosphere of shopping environment, subconsciously influences on customer's senses, positively contributes to the time spent at the point of sale and participates in creating of emotional relations towards a particular sale, salespersons/ brands. The main goal of this paper is point out to the opportunities and usages of aroma marketing in retail environment sold the electronics goods and as well as its impact on the customer based on available theoretical literature sources. Today, in business practice there are global leaders on the electronics market, which successfully apply their own specifics aromas, f. e. Apple, Sony or Samsung. Paper is composed on processing of available theoretical knowledge and background and presents the methodological bases for planned future research oriented on the importance of the aromatization placing in electronics stores.
\end{abstract}

Keywords: Aroma marketing, Customers, Electronics stores, Emotions, Scents

JEL Classification: M31, O30, L83

\section{Introduction}

As we enter to the new environment, the brain without our knowledge, will evaluate what colors, materials, or fragrances are presented in it that can be manipulated to create positive associations, emotions and impulses for customers to ensure a long-term relationship with a particular place, product or brand (Patera, 2016). Already since 1990s, Spangenberg-CrowleyHenderson (1996) defines the effect of fragrances on time spending in shop through experiments in which the amount of time spent in an aromatized shop increased by $40 \%$, while people in a non-aromatized space reported that the time spent in the shop seemed longer than it was. The shop valuation as a whole, but also of shop environment was more positive just when it was scented. This implies that "delicate" fragrances positively influence the people time spent in the store and also the overall rating of concrete shop. Fragrances trigger certain parts of the brain that are responsible for creating the emotions and memories. Up to $75 \%$ of our emotions arise from what we feel. Of all the senses, smell is the only one with a direct connection to the brain (Randhin-Latasha-Tooraiven-Monishan, 2016). According to the Sense of Smell Institute, on average, a person is able to recognize about 10,000 different odors (Bradford-Desrochers, 2016). As far as research in this area (the ability of the aroma to influence human behavior) is concerned, it is still on the beginning. Despite the lack of evidence, the concept of aroma using to influence consumer behavior is becoming an increasingly attractive tool for traders. The following figure (Figure 1) we set out the framework for the use of aroma marketing in practice. 
Figure 1: Framework for Using of Aroma Marketing

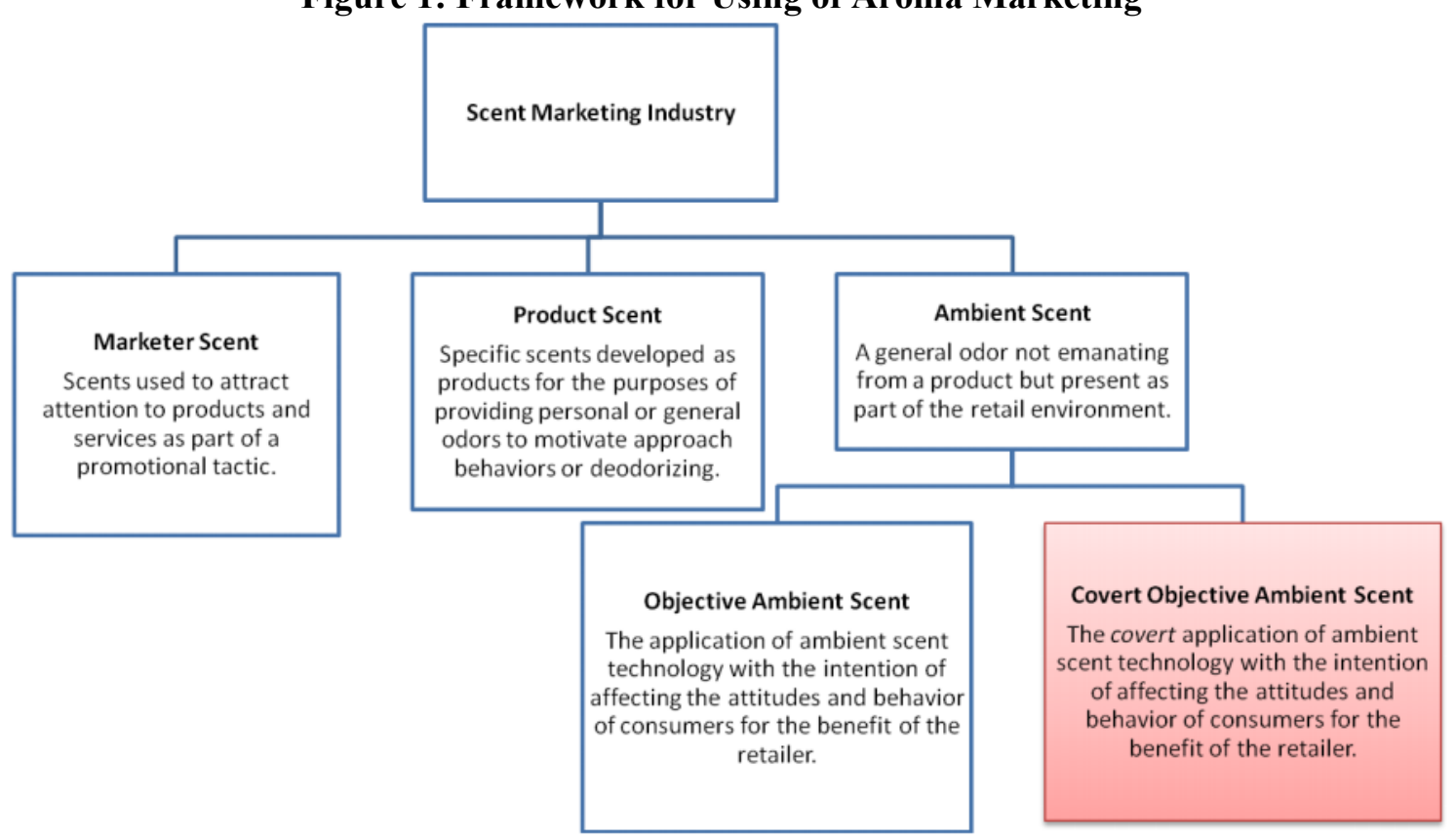

Source: Bradford-Desrochers, 2016

Customers rate a shop and products more favorably if there is an aroma related with product and focused on certain gender (Spangenberg-Sprott-Grohman-Tracy, 2006). On average, women detect odors more easily than men and responses to cerebral fragrances are stronger for women, these differences were occurred in all age categories and in all cultures tested up to this time (Doty-Applebaum-Zusho-Settle 1985; Yousem et al., 1999). Customers will remember more about the product, even its copy if it is fragranced. If a product is unexpectedly fragranced and competing products are not, people will remember not only the smell, but even their views on the aroma of the product (Dooley, 2012). In addition, scent can motivate buyers to purchase certain goods, but may also form certain associations (Borusiak-Pierański-Brohm-Domurath, 2017). Thanks to the aroma, the customer establishes a connection with a specific product, service or brand, leaving a permanent memory footprint in it (Nagyová-Horská-Berčík, 2017). Using of fragrance as part of a marketing campaign gives sellers an added benefit of branding more effectively in addition to achieve the customers.

Advantages of aroma using in marketing are among other things these following (Cartwright, 2014):

- scents can help increase sales: they can trigger immediate emotional reactions from customers and aroma marketing can be very effective in increasing sales;

- aromas make customers linger: subjects are more likely to look and overlook products in the rooms that have been flavored, and reported more positive opinions and a tendency to wait longer in the ranks of the store compared to the non-flavored same store;

- fragrances help to create a brand image: they are useful for people to remember or create associations in their minds, which is why it may be useful to create all the rounded brand image;

- odors create a perception of quality: customers tend to perceive an aromatized product or space as better and will be willing to pay more when shopping in an aromatized shop. 
Given the potential impact of fragrances on human thinking and action, it is surprising that the relationship between olfaction and action has so far received only limited theoretical analysis and empirical attention (Holland-Hendriks-Aarts, 2015). It is imperative that the customer feel satisfied in the shop, as the shopping atmosphere and its control can contribute to greater customer satisfaction (Paluchová-Berčík-Neomániová, 2016).

\section{Data and Methods}

The main aim of this paper is to point out the possibilities and ways of using aroma marketing in the environment of electronics stores and its impact on customers based on available sources of theoretical literature. All information necessary to achieve this goal was drawn from secondary sources within the scope of available scientific articles, professional publications and websites. The processed theoretical materials are focused on the importance, methods of technical implementation and practical use of aroma marketing in real conditions by world producers in the electronics market. Part of the article in the "results" section are examples of real applications of aroma marketing in the practice of electronics stores. All processed information points to the great potential of using aroma marketing as a modern phenomenon in sales-oriented marketing. In the last part of the article "conclusion", we summarized the findings based on the processed theoretical sources and submitted our own suggestions and recommendations.

As part of the planned research under real conditions (selected electronics stores), we plan to use the following methods to collect primary data:

- traditional marketing methods (questionnaire survey, focus group discussion, observation),

- neuromarketing methods (biometric and neuroimaging methods), innovative technologies such as digital solutions or own devices for controlling of air quality compared in aromatized vs. non-aromatized spaces.

In laboratory conditions, research needs to be focused on testing of existing aromatic compounds, designing/ choosing the new scents and application them to the chosen stores in business, production or services areas.

\section{Results and Discussion}

There are two basic methods for applying olfactory communication at the point of sale. The first method is the overall aromatization of the premises in order to create a connection of products or point of sale with positive emotions. The second concept is the so-called. zoning, the purpose of which is to attract attention to a particular place or product, or to neutralize unpleasant odors. This also includes the zone-wide spread of the fragrance with intervention of the entrance/ entry, referred to as the "welcome effect" (Sikela, 2014; Štibinger, 2012). It is necessary to distinguish correctly whether fragrance is the primary or secondary attribute of a product. The primary attribute is when the fragrance itself is the main reason consumers buy the product (deodorants, flowers, perfumes and others). Fragrances and odors are a secondary feature of a product when consumers buy the product for its other characteristics or purpose (electronics, cars, furniture, etc.) (Krishna-Rosino, 2012). We must also differentiate between the fragrances used to scented the product and the aroma used to fragranced the space, for example, all or part of the store, referred to as the smell of the surrounding environment. Its 
main characteristic is that it is not object-specific. There are several ways to vary such aromas at the site of action (Haugtvedt-Herr-Kardes, 2008):

- according to the quality of their emotional impact (i.e. how pleasant the aroma is perceived),

- according to their level of incentive,

- according to their specific intensity.

Sikela (2014) describes and divides the selection criteria for fragrance from the following perspectives, indicating what are the main aspects to consider when choosing the appropriate odor for use throughout the environment, the product range, or for a particular product or brand.

Purpose:

- aroma for brand supporting,

- aroma of implicit character, that refreshes the space, feels cool/ warm, illuminates or gives the impression of luxury and the like;

- aroma in accordance with the goods or services sold.

Category: a selection of scents used for a specific product or brand.

Chaarcters: selection by color, style, design and overall tuning of the space.

Although a suitable fragrance is selected to help differentiate the manufacturer's environment or brand, the obstacle often lies in its technical implementation. The first thing to consider in the in-store environment is the air flow. Indeed, by the movement of customers and the natural air flow, the aroma can also spread to the surroundings, which in turn adversely affects other product categories in close proximity or, at best, will influence buying behavior, for example in favor of local competitors (Jesenský, 2018).

In the past, perfume spraying technology (so-called aerosol technology) was used. However, it is now being abandoned and is moving towards a technique for releasing perfume molecules which, unlike spraying droplets, are lighter than air, retained for longer, and the resultant effect is much longer and more effective (Lišková, 2014). Another parameter to consider when choosing the right technology is the size of the space. On the one hand, an overly concentrated fragrance may have the opposite effect to the original intensity and discourage the customer, on the other hand, if a home appliance is installed in a large space, the investment is almost unnecessary because it will not last long in that space and insufficiently or not at all (Štibinger, 2010). With regard to the deployment of flavorings within zone applications to support the sale of selected brands or products, their distribution can be controlled and limited in a specific (or smaller) space by means of modern intelligent diffusers (Boček-Jesenský-Krofiánová, 2009). A fragranced atmosphere promoting sales through olfactory stimulation within the sales / business service presupposes the selection of an optimum aroma blend that is consistent with the product offered, while ensuring a certain level of air quality and, last but not least, rational application methods - intensity, dose, timing (Berčík-Paluchová- Vietoris-Horská, 2016).

Ensuring buyer comfort is becoming increasingly demanding, and retailers are constantly trying to take advantage of new technologies and provide customers with not only meeting their needs, but also preserving their shopping experience (Berčík-Paluchová-Gálová-NeomániováHladíková, 2016). Apple is known for focusing on detail and trying to engage as much sense in communication as possible. Thus, the fragrance has become one of the essential components of its marketing sales promotion strategy. The involvement of olfactory in communication can be demonstrated on the products themselves. 


\section{Case of Apple}

Many Apple customers can recall the scent of packaging materials, ink, paper, plastic, and especially aluminum components they met when they bought a new Apple product home. By unpacking the Apple product box and smelling the product smell, we create an emotional bond not only to the feeling of purchase, but especially to the product itself. This fragrance was even custom made by Apple and used in world exhibitions or product exhibitions (Cosic, 2012). The process of creating this original fragrance began with defining the desired effect of the fragrance and profiling a suitable concept for its integration into the company's communication strategy. The fragrance demanded by Apple was quite unusual and its production was closely involved in French perfume industry specialists. To reproduce the smell of the new product as faithfully as possible, the unpacked "Apple Macbook Pro" was shipped to a leading laboratory in France where professional perfume manufacturers took samples of the fragrances with the aroma of adhesive, plastic, rubber and paper that they had obtained when they unboxed the new computer. Aroma designers then used these samples as essential ingredients to create a suitable blend of original fragrances. The mixture, with its unique formula, was then tested in the Air Aroma laboratory until the optimum ratio of individual fragrances was selected. The final aroma is called "Apple Unboxing". Most Apple stores, however, did not take advantage of the aforementioned aroma, and the problem recently dealt with by store managers was the increasing number of complaints about unpleasant odor, especially in stores with high traffic frequency. The reason lies in the fact that crowds of people go through the shops every day, and there is a large number of computers, electronics and devices generating chemical odors that can be noticeable in a confined space. Designing a suitable ventilation system has become the first step in the solution (Zigterman, 2014). The result was the installation of technologically advanced odor sensors to activate the ventilation system. As soon as the molecules of chemicals and other gases reach the level at which ventilation is set, they start their activity and remove the smell. Subsequently, it is possible to apply the aroma through aromatizing units to ensure a fresh store environment (Zigterman, 2014). Fragrances are becoming an increasingly important element and an indispensable part of the global brands of consumer electronics manufacturers. Lindström (2010) cites the retail sector as a clear example of a place where flavorings are primarily used to manipulate consumer reactions and behavior. Fragrance is a relatively inexpensive and effective way to make the retail environment more attractive (Warren-Kriach, 2016).

\section{Case of Sony}

Sony has created its own fragrance for its Sony Style store network, containing a blend of vanilla, mandarin and cedar to make customers, especially women, feel comfortable and relaxed at the showroom (Vlahoš, 2007). An increasing number of retailers are using their brandspecific fragrances.

\section{Case of Samsung}

For example, Samsung's flagship stores have their own scent, consisting of a combination of pineapple and melon (Pelsmacker-Geuens- Bergh, 2013). The aim is to ensure uniqueness and fine differentiation from the competition. A Samsung study showed that customers spent $26 \%$ more time in this aroma shop and went through three times more sales departments (Sikela, 2014). Samsung and Sony present the fragrances as original odors for their commercial 
operations (Tischler, 2015). Given the increasing trend in the application of aromas in the retail environment, it is important to focus research on how aroma marketing can influence consumers in purchasing decisions or how to use and apply it effectively in non-food stores (Poon, 2013). One of the most important surveys of scent marketing for the future is the odor impact on business profits, time spending by shopping, association between brands and gender, age etc. (Paluchová-Berčík-Horská, 2017).

\section{Conclusion}

This article provides a theoretical overview of the importance, methods of technical implementation and practical use of aroma marketing in the real conditions of retail electronics stores. Increasing competition and liberalization of the global market increasingly force manufacturers to seek new approaches to promote the sale of their products. The basic tool in this area is marketing, which currently is not only intended to reach the target group of potential customers, but above all to convince them and to obtain them in the long term by means of unique factors accompanying the purchase time or the product itself. The aim is to create a customer relationship to the brand at the point of sale. This is where sensory marketing, including olfactory marketing, deals with the impact of fragrances on consumers' purchasing behavior. The main aim of this paper was to point out the possibilities and ways of using aroma marketing in the environment of electronics stores and its impact on customers based on available sources of theoretical literature.

In the "results" section we pointed out the methods for the application of olfactory communication at the point of sale - the overall aromatization of the premises with the aim of creating a connection of products or point of sale with positive emotions and so-called "zoning", the purpose of which is to attract attention to a particular place or product, or to neutralize unpleasant odors. We have found that a distinction needs to be made between the fragrances used to aromatized the product and the aroma used to fragrance the space itself. In addition, we pointed out the possibilities of variations in flavorings, the criteria for selecting the fragrance, as well as the importance of the technical implementation of the fragrance with regard to the air flow and the size of the shop space. Finally, we have given specific examples of aroma marketing applications in electronics stores - Apple, Sony and Samsung to promote sales.

In further research, we recommend the real application of aroma marketing to selected electronics stores and investigate the impact of flavorings on customers' purchasing and decision-making process, the amount of time spent by customers in the store, the number of stops in the store, visual and emotional attention, and the like. Air quality and multisensory perception should also be studied. Given that so far only a few authors have addressed the issue of aroma marketing and the impact of fragrances on customer behavior at scientific level, we recommend paying more attention to this issue, especially in electronics stores, since aroma marketing can be considered a modern phenomenon and a relatively affordable alternative to sales promotion.

\section{Acknowledgements}

Research has been supported by the research grand APVV-17-0564 "The Use of Consumer Neuroscience and Innovative Research Solutions in Aromachology and its Application in 
Production, Business and Services ,, and VEGA 1/0570/18 „Using of Consumer Neuroscience by implementing of aromachology in selected business economies „,conducted at the Department of Marketing and Trade at the Slovak University of Agriculture in Nitra. The main goal of APPV and VEGA is to complexly reveal how are aromatic compounds sensed based on an interaction between explicit (sensory) and implicit analysis through consumer's neuroscience in real conditions of manufacturing plants, shops and in the sphere of services.

\section{References}

[1] Berčík, J., Paluchová, J., Vietoris, V., Horská, E. (2016). Placing of aroma compounds by food sales promotion in chosen services business. Potravinárstvo. 10(1), 672-679. DOI: https://doi.org/10.5219/666

[2] Berčík, J., Paluchová, J. et al. (2018). Aroma Marketing - a Modern Marketing Phenomenon. International scientific days 2018: Towards productive, sustainable and resilient global agriculture and food systems. Prague: Wolters Kluwer. 586-598 p. ISBN 978-80-7598-180-6.

[3] Boček, M., Jesenský, D., Krofiánová, D. (2009). POP - In-store komunikace v praxi: trendy a nástroje marketingu v místě prodeje. Praha: Grada Publishing. 215 pp. ISBN 978-80-24728-407.

[4] Borusiak, B., Pierański, B., Brohm, D., Domurath, N. (2017). Application of neuromarketing in communication with the customer. Neuromarketing in food retailing. Wageningen: Wageningen Academic Publishers, pp. 103-117. ISBN 978-908686-8-438.

[5] Bradford, K. D., Desrochers, D.M. (2009). The Use of Scents to Influence Consumers: The Sense of Using Scents to Make Cents. Journal of Business Ethics. 90(0), 141-153. https://doi.org/10.1007/s10551010-0377-5.

[6] Cartwright, S. (2014). How and why businesses make use of Scent Marketing to boost sales. Retrieved from https://website-designs.com/online-marketing/scent-marketing/scent-marketing-to-boost-sales/.

[7] Cosic, A. (2012). The scent of an Apple product, sourcing the Macbook Pro fragrance, Air-aroma. Retrieved from www.air-aroma.com/blog/the-scent-of-a-apple-product-sourcingthe-macbook-profragrance.

[8] Dooley, R. (2012). Brainfluence: 100 Ways to Persuade and Convince Consumers with Neuromarketing. New Jersey: John Willey \& Sons, pp 286. ISBN 978-1-118-11336-3.

[9] Doty, R. L., Applebaum, S., Zusho, H., Settle, R.G. (1985). Sex differences in odor identification ability: a cross-cultural analysis. Neuropsychologia. 23(5), pp. 667-672. https://doi.org/10.1016/00283932(85)90067-3.

[10] Haugtvedt, C. P., Herr, P. M., Kardes, F. R. (2008). Handbook of Consumer Psychology. Oxford: Taylor \& Francis. pp 1296. ISBN 978-0805856033.

[11] Holland, R. W., Hendriks, M., Aarts, H. (2005). Smells Like Clean Spirit: Nonconscious Effects of Scent on Cognition and Behavior. Psychological Science. 16(9), pp. 689-693. DOI:10.1111/j.14679280.2005.01597.x.

[12] Jesenský, D. (2018). Marketingová komunikace v místě prodeje: POP, POS, in-store, shopper marketing. Praha: Grada Publishing. pp 237. ISBN 978-80-271-0252-5.

[13] Krishna, A., Rosino, L. (2012). An integrative review of sensory marketing: Engaging the senses to affect perception, judgment and behavior. Journal of Consumer Psychology. 22(3), pp. 332-351. https://doi.org/10.1016/j.jcps.2011.08.003.

[14] Lindström, M. (2010). Brand sense: sensory secrets behind the stuff we buy. London: Kogan Page. pp 272. ISBN 978-1-43917-201-8.

[15]Lišková, I. (2014). Možnosti využití více smyslové in-store marketingové komunikace v prodejnách firmy Apple: bachelor thesis, Praha: Univerzita Karlova, 67 p. Retrieved from [https://dspace.cuni.cz/handle/20.500.11956/62450. 
[16] Nagyová, L., Horská, E., Berčík, J. (2017). Application of neuromarketing in retailing and merchandising. Neuromarketing in food retailing. Wageningen: Wageningen Academic Publishers, pp. 119-142. ISBN 978-908686-8-438.

[17] Paluchová, J., Berčík, J., Neomániová, K. (2016). The atmosphere and its impact on consumer behavior in food stores. International Scientific Days. Nitra: Slovak University of Agriculture in Nitra, pp. 804811. Retrieved from http://www.slpk.sk/eldo/2016/dl/9788055215037/files/10/paluchova-et-al.html.

[18] Paluchová, J., Berčík, J., Horská, E. (2017). The sense of smell. Sensory and aroma marketing. Wageningen: Wageningen Academic Publishers, pp. 27-55. ISBN 978-90868-6-841-4.

[19] Patera, J. (2016). Vyvoněné obchody. Marketing Sales Media. 4(2), pp. 20-21. Retrieved from https://marketingsales.tyden.cz/rubriky/marketing/.

[20] Pelsmacker, P., Geuens, M., Bergh, J. (2013). Marketingová komunikace. Praha: Grada Publishing. pp 584. ISBN 8024702541.

[21] Poon, T. (2013). It Smells Crowded: An Experimental Investigation of Olfactory Influence on Spatial Perception: master thesis, Montréal: Concordia University, 58 p. Retrieved from https://spectrum.library.concordia.ca/976957/1/Poon_MSc_S2013.pdf.

[22] Randhir, R., Latasha, K., Tooraiven, P., Monishan, B. (2016). Analyzing the Impact of Sensory Marketing on Consumers: A Case Study of KFC. Journal of US-China Public Administration. 13(4), pp. 278-292. DOI: 10.17265/1548-6591/2016.04.007.

[23] Sikela, H. (2014). Zmyslový marketing. Retrieved from https://www.ta3.com/clanok/1041008/zmyslovymarketing.html.

[24] Spangenberg, E. R., Crowley, A. E., Henderson, P. W. (1996). Improving the store environment: Do olfactory cues affect evaluations and behaviors? Journal of Marketing. 60(2), pp. 67-80. DOI: $10.2307 / 1251931$.

[25] Spangenberg, E. R., Sprott, D.E., Grohmann, B., Tracy, D.L. (2006). Gender-congruent ambient scent influences on approach and avoidance behaviors in a retail store. Journal of Business Research. 59(12), pp. 1281-1287. https://doi.org/10.1016/j.jbusres.2006.08.006.

[26] Štibinger, A. (2010). Vůně jako nástroj smyslového marketing. Brand \& Stories. 4(1), pp. 23. Retrieved from http://www.b-s-c.cz/img/archiv/2010/04-2010-Stories.pdf.

[27] Štibinger, A. (2012). Vše, co jste chtěli vědět o aroma marketingu, ale nevěděli, kde se na to zeptat...Brand \& Stores. 9(1). Retrieved from http://www.popai.cz/novinky-old/vse-co-jste-chteli-vedet-o-aromamarketingu-ale-nevedeli-kde-se-na-to-zeptat.

[28] Tischler, L. (2015). Smells like Brand Spirit. Fast Company. Retrieved from http://www.fastcompany.com/magazine/97/brand-spirit.html.

[29] Vlahos, J. 2007. Scent and sensibility. The new york times. Retrieved from https://www.nytimes.com/2007/09/09/realestate/keymagazine/909SCENT-txt.html. 


\title{
Development of Raw Cow Milk Prices in the Conditions of the Slovak Republic and Hungary and its Comparison
}

\author{
Ivana Váryová ${ }^{1}$, Zuzana Poláková ${ }^{2}$, Peter Obtulovičํㅜ Iveta Košovská $^{4}$ \\ Slovak University of Agriculture in Nitra \\ Faculty of Economics and Management, Department of Accounting ${ }^{1,4}$ \\ Faculty of Economics and Management, Department of Statistics and Operational Research ${ }^{2,3}$ \\ Address: Tr. A. Hlinku 2, \\ 94976 Nitra, Slovakia \\ e-mail: ivana.varyova@uniag.sk¹, zuzana.polakova@uniag.sk², peter.obtulovic@uniag.sk³, \\ iveta.kosovska@uniag.sk ${ }^{4}$
}

doi: 10.18515/dBEM.ISD.P01.2020.p022

\begin{abstract}
The aim of the paper is to analyse and compare the development of average purchase prices of raw cow milk in the Slovak Republic and Hungary in a time period 2010 - 2019 and to forecast the trend of these prices by December 2020. The essential information sources were monthly data from the Market Report of Milk and Dairy Products issued by the Agricultural Information Department - ATIS and data from Eurostat database. Box-Jenkins methodology was used to analyse time series and to forecast their future development. It can be stated that the purchase prices of raw cow milk in the observed period show high volatility. As in the Slovak Republic, crisis periods have been also identified in Hungary, during which the milk price has fallen below 30 eurocents per kilogram. Within the whole observed period prices of raw cow milk in the Slovak Republic exceeded the milk prices in Hungary. In the next forecast period, a significant decrease in the purchase price of raw cow milk in the Slovak Republic is expected. By July 2020, a decrease in Hungary is expected, followed by an increase.
\end{abstract}

Keywords: analyse, crisis, milk, price, trend

JEL Classification: Q10, Q11, Q13

\section{Introduction}

Eating food is one of the most important needs of every person (Nagyová, Andocsová, Géci, Zajac, Palkovič, Košičiarová \& Golian, 2019). Milk and milk products are the essentials of human nutrition therefore the dairy industry is necessary for healthy development of Europe and belongs to the most important sectors (Pilvere, Nipers \& Krievina, 2016). According to Krivošíková, Nagyová, Kubelaková and Mokrý (2019) milk is sometimes called a "super-food" because it contains all the necessary ingredients like sugars, fats and proteins needed for the proper functioning of the human organism. The Slovak Republic and Hungary as a part of the Central Europe belong to region with long tradition and consumption of milk and milk products (Špička, 2015). Raw cow milk represents one of the most important commodities in the agricultural market. Raw cow milk is an essential source of the nutrition of calves and a raw material for the production of liquid milk and dairy products (Šimo, Mura \& Buleca, 2016).

Milk production and processing is influenced by the Common Agricultural Policy of the European Union. Milk farmers are not able to generate profits therefore they are supported through direct and indirect operational subsidies (Doubek, Švasta \& Ackermann Blažková, 2012; Foltínová \& Špička, 2014). The milk quota system, one of the most important instruments of the Common Agricultural Policy, was introduced in 1984 to the European Union dairy 
market. Its purpose was to control the structural surpluses of milk which arose because of imbalances between supply and demand for milk encouraged by subsidies to the sector (CostaFont \& Revoredo-Giha, 2018). The cow milk production volumes were not regulated in the European Union before the milk quota system had been introduced. Intervention purchases and guaranteed prices for milk producers were provided by previous system regardless of the milk production volume (Vöneki, Mándi-Nagy \& Stark, 2015). The milk quota system has been removed since the $1^{\text {st }}$ of April 2015. After abolition of milk quota system, the European milk producing countries started to be exposed to the milk prices of the world market (Buleca, Kovác $\&$ Šubová, 2019). The liberalization of the milk market conditions caused the milk price volatility. The milk producers have become more dependent on the milk prices of the world market (Schulte and Musshof, 2018; Schulte, Musshof \& Meuwissen, 2018; Parzonko 2018).

The dairy sector is one of the most important sectors of agriculture in the Slovak Republic and has a longstanding tradition. Milk and milk products represent a significant part of the food components of Slovak households (Lajdová, Kapusta \& Bielik, 2017; Jamrich \& Vargová, 2018). A survey conducted by Kubicová, Predanocyová and Kádeková (2019) showed that 80 $\%$ of Slovak consumers include consumption of milk and dairy products in their healthy lifestyle. Most popular kind of milk is cow milk in the Slovak Republic. Consumption of cow milk and dairy products made from cow milk represents approximately $98 \%$ of total milk and dairy products consumption in the Slovak Republic (Ministry of Agriculture and Rural Development of the Slovak Republic, 2019).

Váryová, Poláková, Košovská, Ferenczi Vaňová and Krajčírová (2019) identified three periods as critical for the Slovak dairy sector during the period from 2006 to 2018. During these periods, the price of milk has fallen below 30 eurocents per kilogram. Long-term low prices of raw cow milk led to the liquidation of primary milk producers in the Slovak Republic.

\section{Data and Methods}

The aim of the paper is to analyse and compare the development of average purchase prices of raw cow milk in the Slovak Republic and Hungary in a time period 2010 - 2019. At the time of submitting the data, data were available until December 2019. The paper is aimed at analysing the trend of average purchase prices of raw cow milk ex post and based on this ex post analysis to carry out an ex ante prognosis by December 2020.

In the process of writing this paper, information from the Dairy Market Reports issued by the Agricultural Information Department - ATIS was used. Monthly data from January 2010 to December 2019 on average monthly purchase prices of raw cow milk were used. The data about the average purchase prices of raw cow milk in Hungary were gained from Eurostat database. The statistical software SAS was used for the analysis.

Modeling the future development is a methodically demanding activity that can be realized by several methods. In this paper, the Box-Jenkins methodology (ARIMA and SARIMA models) as more advanced method and approach was used to analyse time series and to forecast their future development. This methodology can be also used to forecast the future development in other research areas. The ARIMA model and combined models were used by Groma, Nagyová, Obtulovič and Kádeková (2018) to analyse the development of advertising costs for selected media in the Slovak Republic.

By analysing the average purchase price of raw cow milk, the best model suitable for constructing future development forecasts is looked for. The Box-Jenkins methodology is 
designed for modeling of stationary and non-stationary time series and time series with seasonal component. It consists of three steps: identification, parameter estimation and model validation. Methodology has its advantages and disadvantages. Its advantage is flexibility and quick adaptation to changes in the character of the time series. The entire modeling process can be full automated using software applications, reducing the subjective human factor intervention. The statistical software SAS was used for the analysis in this paper. The intuition of the solver plays a decisive role in the forecasting process. The disadvantages include, for example, a need to have a sufficiently long time series (at least 50 observations, in our case we had 120 observations) available for the modeling, the practical application is time consuming and the possibility of simple interpretation of the resulting models' parameters is lost.

ARIMA models (AutoRegressive Integrated Moving Average models) are constructed from time series values, which are a linear combination of intrinsic historical values and historical values of residual deviations (so-called random shocks). A presumption of stationarity is the condition of using Arima models, i.e. the time series statistical properties do not change over time. It is a random variable that has a constant mean value over time, the variance is constant over time, and the linear relationship between the two time shifted random variables is zero (Obtulovič \& Sojková, 1999). The Winters' additive models chosen based on the most widely used relative measure of prediction accuracy mean absolute percentage error (MAPE) and determination index $\mathrm{I}^{2}$ value were used in the paper.

$$
\begin{aligned}
& M A P E=\frac{1}{n} \sum_{t=1}^{n} \frac{\left|y_{t}-y_{t}^{\prime}\right|}{y_{t}} \\
& I^{2}=\frac{C-N}{C}=1-\frac{N}{C}=1-\frac{\sum_{j=1}^{n}\left(y_{j}-y_{j}^{\prime}\right)^{2}}{\sum_{j=1}^{n}\left(y_{j}-\bar{y}\right)^{2}}
\end{aligned}
$$

\section{Results and Discussion}

The paper focuses on the development analysis of average purchase prices of raw cow milk in the conditions of the Slovak Republic and Hungary from January 2010 till December 2019. The development of average purchase prices of raw cow milk in the Slovak Republic and in Hungary is presented in the Figure 1. 
Figure 1: Development of the raw cow milk's average price in the Slovak Republic and Hungary

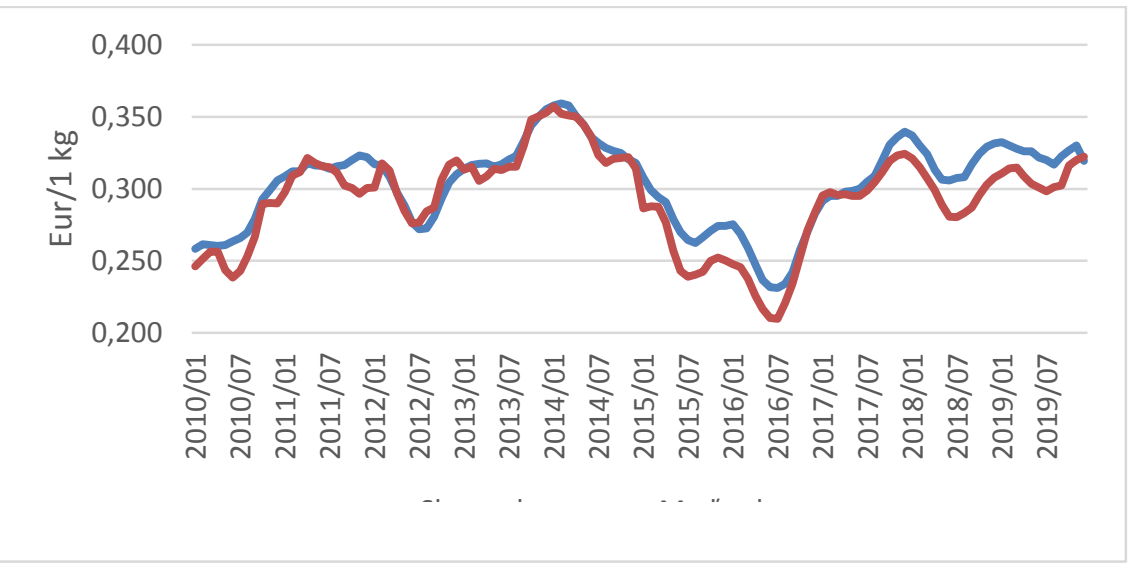

Source: Monthly reports on purchase of milk and cream and production of milk products (MARD SR) and Eurostat, own processir

Slovakia Hungary

The paper assesses un punu wimu tunuws su vaned "great dairy crisis" in 2008 - 2009. During the "great dairy crisis" there was a significant deterioration in the dairy market. The significant drop in the milk supplies from Oceania in the previous year 2007 led to the quick and substantial increase in prices. After the restoration of the world supply of milk, the prices returned to more usual levels, but the subsequent financial and economic crisis and its negative impact on milk producers in the European Union has contributed to the volatility of prices. While milk production in the European Union has been continuously stable, the reduction in global and European demand for milk and dairy products has led to a collapse in prices in the European Union. As a result, the prices of raw cow milk in the Slovak Republic have decreased significantly. According to Váryová \& Košovská (2018), the "great dairy crisis" culminated in May 2008, when the raw cow milk price fell below 18 eurocents per kilogram (17.67 Eur/100 $\mathrm{kg})$. In the next months of the year 2009, the price was gradually increasing.

The development of average purchase prices of raw cow milk in the observed period in both countries has a very similar trend. Since the beginning of the observed period until the year 2012 the prices were rising with several slight deviations mainly in Hungary. The increase in milk price after reaching the price bottom in 2009 during "great diary crisis" continued and in December 2010 the milk price exceeded 30 eurocents per kilogram at Slovak primary producers (30.57 Eur $/ 100 \mathrm{~kg}$ ). With the partial retreat of the economic recession, the price level of milk was rising until a temporary decline in early 2012. This decline in milk prices was the result of a previous significant increase in global milk production that exceeded demand. During the period from April to October 2012, the raw cow milk price temporarily fell below 30 eurocents per kilogram. Such low prices do not cover the costs of primary milk producers despite the support provided to primary milk producers. According to the Slovak Chamber of Agriculture and Food, production costs are between 40 and 42 eurocents per kilogram.

During this temporary crisis period, the lowest milk price dropped to the level 27.18 Eur/100 $\mathrm{kg}$ in July 2012. In the next months, the raw cow milk price was rising steadily and at the end of 2013 it reached the historic highs, exceeding 35 eurocents per kilogram. The price growth continued until February 2014, when the raw cow milk price climbed to $35.95 \mathrm{Eur} / 100 \mathrm{~kg}$. This price level is also the highest raw cow milk price in the Slovak Republic during the whole observed period of the years $2010-2019$. 
After reaching the historic price maximum, the raw cow milk prices began to decrease gradually. This price development in the Slovak Republic copied the development of the world prices of milk and dairy products and resulted into the next milk crisis in the years $2015-2016$. During this crisis period, average purchase prices of raw cow's milk were kept below 30 eurocents per kilogram long term (February 2015 - June 2017). Especially the year 2016 was challenging for the primary milk producers when the raw cow milk price oscillated approximately between 23 and 28 eurocents per kilogram during the whole year. The price dropped to a minimum in July 2016, when the milk processors were purchasing $100 \mathrm{~kg}$ of raw cow's milk for only 23.12 Eur. These were the lowest purchase raw cow milk prices since the "great dairy crisis". The absolute difference between the highest and lowest average raw cow milk price in the Slovak Republic during the observed period is $12.83 \mathrm{Eur} / 100 \mathrm{~kg}$.

Milk crisis in this period was caused by a global imbalance between supply and demand. Several events which occurred in this period caused the decrease in the worldwide demand for milk and milk products. One of the reasons was the decline in demand in response to the high milk prices from the turn of 2013 and 2014 when historical maximums of milk prices were also reached in the Slovak Republic. The decline in demand was also negatively affected by the ban on imports of agricultural products from the European Union into the Russian Federation. Embargo was introduced on 7 August 2014 until then the Russian Federation was the largest export market for milk and milk products from the European Union. Currently the validity of Russian embargo is prolonged till 31 December 2020. The unfavourable situation in the dairy sector was also exacerbated by China's weakening demand for dried cow milk from European producers during this period, with China being the world's largest dairy importer. In addition to falling demand, price developments in the dairy sector were also affected by the abolition of the European Union milk quota system, which ended on 1 April 2015. With the abolition of milk quotas, the dominant European dairy producers could increase their production. The larger quantities of produced milk, together with a decline in demand for the above-mentioned reasons, have led to milk surpluses on the European market, which in turn has led to a further decline in the purchase prices of raw cow milk.

The unfavourable situation on the milk market in Slovakia for more than 2 years began to stabilize in the second half of 2017, when the average purchase price of raw cow milk exceeded 30 eurocent per kilogram of milk. Since then, milk prices have been relatively stable, with the last known average price of raw cow milk at the time of article processing (December 2019) at $31.95 \mathrm{Eur} / 100 \mathrm{~kg}$. According to Štefániková from the Slovak Union of Primary Milk Producers (Kaliská, 2020), the year 2019 as the last year of the assessed period is considered a better year, as the purchase prices of milk have stabilized. At the same time, however, production costs increased due to rising energy prices and labour costs caused by the introduction of government measures. If there was no support in the dairy sector, a loss of approximately 8 eurocents would be generated on each kilogram of milk. In 2019, the aggregate aid for milk production reached an average of 5 eurocent per kilogram of milk, resulting in a loss of around 3 eurocent per kilogram of milk.

Winters Method - Additive was applied in the analysis of ex-post development and forecast of expected average purchase prices of raw cow milk in both countries. The rate of model forecast accuracy is determined by the MAPE besides others, its value in the Slovak Republic is 0.84 and as well as with the value of determination index $\mathrm{I}^{2}$, which value is 0.989 which can be considered as a very good model. The model was selected not only based on values of MAPE and $\mathrm{I}^{2}$ but also based on white noise and the presence of unit root. The prognosis of future development of average purchase prices of raw cow milk in the Slovak Republic was realized 
based on the selected model. The monthly development till September 2019 is in the Figure 2 presenting the chart of real and estimated values. Stretch connects the balanced values which present the alignment of time series by means of selected model. The forecast for the next year 2020 is displayed from a dashed vertical line by point as well as $90 \%$ confidence interval (Figure 2).

Figure 2: Forecast of the raw cow milk's average price in the Slovak Republic

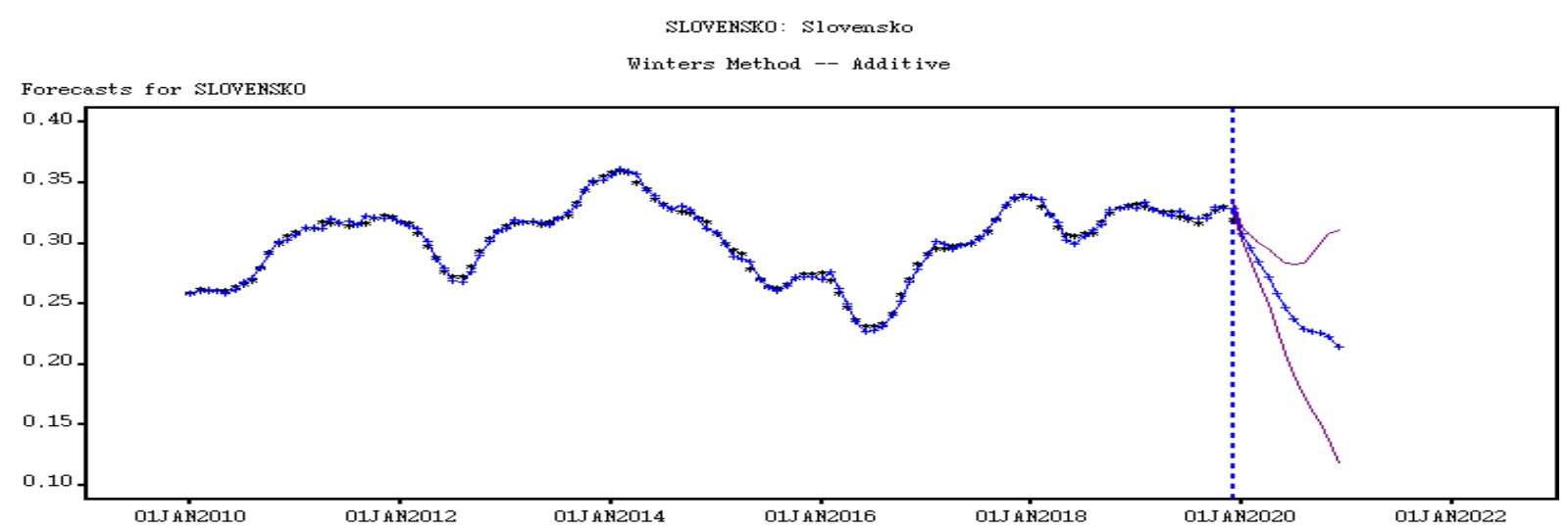

Source: Monthly reports on purchase of milk and cream and production of milk products (MARD SR), own calculations using SAS software

The results determine that in the next forecast period, in 2020, the decrease of average purchase price of raw cow milk in the Slovak Republic is expected. Figure 3 presents the forecast prices of milk by means of before mentioned model.

Figure 3: Point and interval forecasts of the raw cow milk's average price in the Slovak Republic

\begin{tabular}{|c|c|c|c|c|c|c|c|c|c|}
\hline \multicolumn{10}{|c|}{ Forecast Ilata Set } \\
\hline \multicolumn{10}{|c|}{$\begin{array}{l}\text { SLOVERSKO: Slovensko } \\
\text { Winters Method -- Additive }\end{array}$} \\
\hline IARTE & ACTUSLL & PREDICT & U90 & L90 & ERROR & HERROR & LEVYEL_. & TRERD_ & SSFACTOR \\
\hline 01FEB2020 & . & 0.2966 & 0,3067 & 0.2865 & . & ' & 0.2913 & $-0,008724$ & 0,005286 \\
\hline $01 \mathrm{WASR} 2020$ & . & 0,2849 & 0,3007 & 0.2690 & . & . & 0.2826 & $-0,008724$ & 0,002242 \\
\hline 01APR2020 & . & 0.2725 & 0.2949 & 0,2500 & . & . & 0.2739 & $-0,008724$ & $-0,001438$ \\
\hline $01 \mathrm{MH} Y 2020$ & . & 0,2590 & 0.2886 & 0.2294 & T. & . & 0.2652 & $-0,008724$ & $-0,006159$ \\
\hline 01JUN2020 & . & 0.2468 & 0.2843 & 0.2093 & 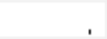 & . & 0.2564 & $-0,008724$ & $-0,009609$ \\
\hline 01JUL2020 & . & 0.2372 & 0.2831 & 0,1912 & . & & 0.2477 & $-0,008724$ & $-0,0105$ \\
\hline $01 \AA J U 62020$ & . & 0.2291 & 0,2840 & 0.1741 & 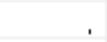 & & 0.2390 & $-0,008724$ & $-0,009921$ \\
\hline 01SEP2020 & . & 0.2268 & 0.2913 & 0.1624 & . & & 0.2303 & $-0,008724$ & $-0,003456$ \\
\hline 010СТ2020 & . & 0.2264 & 0,3009 & 0.1519 & . & . & 0,2216 & $-0,008724$ & 0,004850 \\
\hline $0110 \% 2020$ & . & 0.2229 & 0,3078 & 0.1379 & . & & 0.2128 & $-0,008724$ & 0,0100 \\
\hline $01 D E C 2020$ & . & 0,2148 & 0,3107 & 0,1189 & . & . & 0.2041 & $-0,008724$ & 0,0107 \\
\hline
\end{tabular}

Source: Monthly reports on purchase of milk and cream and production of milk products (MARD SR), own calculations using SAS software

The next part of paper deals with the development analysis of average purchase prices of raw cow milk in Hungary. Figure 4 presents the development of average purchase prices of raw cow milk from January 2010 till December 2019 together with the prognosis for the year 2020 .

The development of average purchase prices of raw cow milk has a similar course in Hungary as in the Slovak Republic in the period 2010 - 2019. Several fluctuations can be observed in the assessed period, based on the graph. In both the Slovak Republic and Hungary, several crisis periods can be identified, during which the price fell below 30 eurocents per kilogram. These 
periods correspond to crisis periods in the dairy sector of the Slovak Republic. After a period of "great dairy crisis", milk prices in Hungary gradually increased until April 2012, when they temporarily dropped again below 30 eurocent per kilogram of milk. This period is the same as the transitional crisis period in the Slovak Republic. A comparable price development can be observed also at the turn of 2013 - 2014, when milk prices reached maximum during the assessed period. In January 2014, the price of raw cow milk climbed to $35.73 \mathrm{Eur} / 100 \mathrm{~kg}$, which is the highest average purchase price of raw cow milk in Hungary for the period 2010-2019.

During the crisis period 2015-2016, the development of purchase prices for raw cow milk was comparable in both countries. In Hungary, too, the milk crisis caused the purchase price of raw cow milk to fall below 30 eurocents per kilogram for more than two years. In particular, the year 2016 was critical, as in the Slovak Republic and Hungary, the price fell to a minimum. The price in July 2016 was at the level of $20.96 \mathrm{Eur} / 100 \mathrm{~kg}$. It presents the lowest average purchase price of raw cow milk in Hungary for the observed period. This price is still 2.16 Eur $/ 100 \mathrm{~kg}$ lower compared to the achieved minimum in the Slovak Republic. During the milk crisis in 2015-2016, raw cow milk prices in Hungary fluctuated at a lower level than in the Slovak Republic. The absolute difference between the highest and lowest average raw cow milk price in Hungary during the observed period is 14.77 Eur $/ 100 \mathrm{~kg}$.

The long-term unfavourable situation gradually began to stabilize during 2017 and in August 2017 the price of milk exceeded 30 eurocents per kilogram. However, the average purchase price of raw cow milk remained above this level for only a few months, and in 2018 there was a temporary decrease and fall below 30 eurocents per kilogram. In the same period, raw cow milk prices in the Slovak Republic were also close to, but maintained above 30 eurocents per kilogram (June $2018=30.59 \mathrm{Eur} / 100 \mathrm{~kg}$ ). Since then, the average purchase prices of raw cow milk in Hungary have had relatively constant values, with a one-off fluctuation and a fall in price below 30 eurocents per kilogram in July 2019. The last known average price of raw cow milk was $32.22 \mathrm{Eur} / 100 \mathrm{~kg}$ at the time of processing (December 2019). The situation of the Hungarian dairy market is still unfavourable because the milk prices can not compensate for the high feed and fuel prices. Feeding costs account for the majority of production costs in milk production. Thus, it is difficult for the Hungarian dairy farmers to produce in a profitable way (Blaskó, 2012; Szücs \& Szőllösi, 2015).

The rate of model forecast accuracy used in model for the analysis of ex-post development and forecast is determined by the MAPE besides others, its value in Hungary is 1.65 and as well as with the value of determination index $\mathrm{I}^{2}$, which value is 0.965 . This model can be considered as a very good model based on these values. The model was selected not only based on values of MAPE and $\mathrm{I}^{2}$ but also based on white noise and the presence of unit root. The prognosis of future development of average purchase prices of raw cow milk in Hungary was realized based on the selected model. The monthly development till December 2019 is in the Figure 4 presenting the chart of real and estimated values. Stretch connects the balanced values which present the alignment of time series by means of selected model. The forecast for the next year 2020 is displayed from a dashed vertical line by point as well as $75 \%$ confidence interval (Figure 4). 
Figure 4: Forecast of the raw cow milk's average price in Hungary

MÁ_ARSKO: Madarsko

Winters Wethod -- Additive

Forecasts for $\mathrm{NAH} A$ RSKO

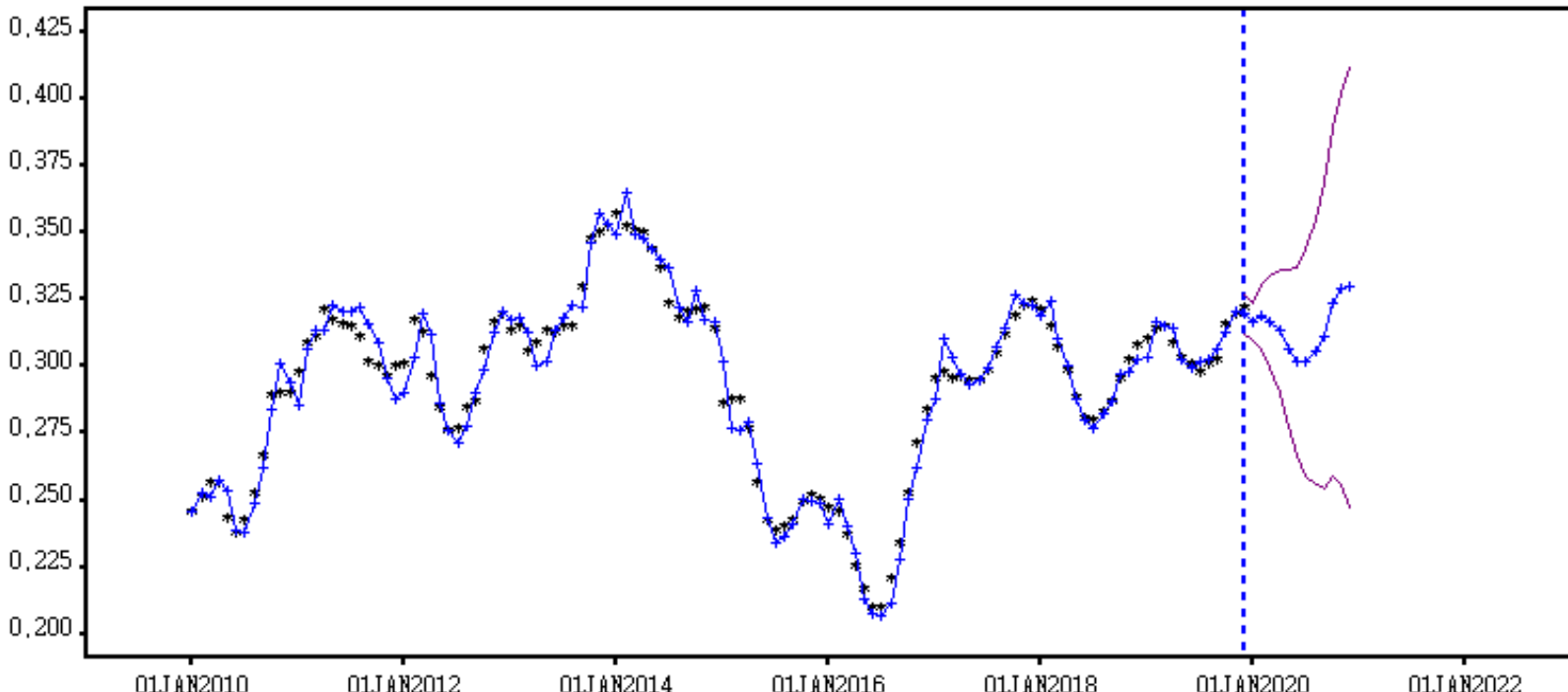

Source: Eurostat database, own calculations using SAS software

The results demonstrate that in the next forecast period, the year 2020, a slightly decreasing trend is expected, simultaneously the increasing trend of average purchase price of raw cow milk in Hungary. Figure 5 presents the forecast prices of milk by means of before mentioned model.

Figure 5: Point and interval forecasts of the raw cow milk's average price in Hungary

\begin{tabular}{|c|c|c|c|c|c|c|c|c|c|}
\hline & & & & $\begin{array}{r}\text { Fore } \\
\text { Wis_ } \\
\text { Winters }\end{array}$ & $\begin{array}{l}\text { st Data } \\
0 \text { : Madar } \\
\text { hod -- }\end{array}$ & tive & & & \\
\hline DATE & ACTUAL & PREDICT & U75 & L75 & ERROR & HERROR & _LEVEL_ & _TREHD_ & _SFACTOR \\
\hline $01 \mathrm{FEB} 2020$ & & 0.3188 & 0.3309 & 0.3067 & . & . & 0.3119 & 0,000626 & 0.006916 \\
\hline 01WÁR2020 & . & 0.3167 & 0.3340 & 0.2994 & & . & 0.3125 & 0.000626 & 0.004241 \\
\hline 01APR2020 & . & 0.3134 & 0.3364 & 0.2905 & & . & 0.3131 & 0.000626 & 0.000299 \\
\hline $01 \mathrm{HAY} 2020$ & . & 0.3069 & 0.3359 & 0.2779 & . & . & 0.3137 & 0,000626 & $-0,006882$ \\
\hline 01JUH2020 & . & 0,3019 & 0,3374 & 0.2664 & . & . & 0.3144 & 0.000626 & -0.0125 \\
\hline 01JUL2020 & . & 0,3016 & 0.3440 & 0.2593 & & 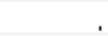 & 0.3150 & 0.000626 & $-0,0134$ \\
\hline 01भJUG2020 & . & 0.3058 & 0.3554 & 0.2561 & & & 0.3156 & 0.000626 & $-0,009873$ \\
\hline 01SEP2020 & . & 0.3115 & 0.3687 & 0.2543 & & & 0.3163 & 0.000626 & -0.004758 \\
\hline 010СТ2020 & . & 0.3239 & 0,3891 & 0.2588 & . & . & 0.3169 & 0.000626 & 0.007056 \\
\hline 01HOV2020 & & 0.3290 & 0.4024 & 0.2555 & & ' & 0.3175 & 0.000626 & 0.0115 \\
\hline 01DEC2020 & & 0.3297 & 0.4118 & 0.2476 & & & 0.3181 & 0,000626 & 0.0116 \\
\hline
\end{tabular}

Source: Eurostat database, own calculations using SAS software

\section{Conclusion}

The paper focused on the analysis of the trend of average purchase prices of raw cow milk in the Slovak Republic and Hungary in the period from 2010 to 2019. Based on the ex post analysis carried out, a forecast of milk price development by December 2020 has also been done. It can be stated that the average purchase prices of raw cow milk showed a fluctuation course in both countries. The maximum of average purchase prices of raw cow milk for the whole observed 
period was obtained in Hungary in January 2014 (35.73 Eur/100 kg) and in the Slovak Republic one month later in February $2014(35.95$ Eur $/ 100 \mathrm{~kg})$. The lowest price of milk during the reviewed period was found in both countries in July 2016, in the Slovak Republic 23.12/100 kg and in Hungary $20.96 / 100 \mathrm{~kg}$. Within the whole observed period the prices of raw cow milk in the Slovak Republic exceeded the milk prices in Hungary. It can be stated, that during the whole observed period the differences between the purchase prices of raw cow milk in both countries were at the level of approximately 1 Euro $/ 100 \mathrm{~kg}$ (average value $=1,02 \mathrm{Eur} / 100 \mathrm{~kg}$, median = 1,03 Eur/100 kg).

Based on the analysis of the development of average milk prices two periods were identified as critical for the dairy sector during the reviewed period in the Slovak Republic and in Hungary. During these periods, the price of milk has fallen below 30 eurocents per kilogram. One more crisis period with prices below 30 eurocents per kilogram was identified in year 2018 only in Hungary. At such low milk prices and high production costs, despite the support provided to primary milk producers, a loss occurs at many primary producers in the Slovak Republic and in Hungary as well. Many businesses closed their milk production during the Great Dairy Crisis. The next milk crisis in 2015 - 2016 again led to the liquidation of this area of animal husbandry. Before the Great Dairy Crisis, 777 primary producers of raw cow milk were registered in the Slovak Republic, currently there are only 396 (as from 31 December 2019), which represents a one-half decrease.

\section{Acknowledgements}

This work was supported by the Slovak Research and Development Agency on the basis of Contract no. APVV-16-0244 "Qualitative factors affecting the production and consumption of milk and cheese“.

\section{References}

[1] Blaskó, B. (2012). Analysis of the producer price of Hungarian raw milk in international comparison. Applied Studies in Agribusiness and Commerce - APSTRACT, 6(1), 29-35. doi: 10.19041/Apstract/2012/5/4

[2] Buleca, J., Kováč, V. \& Šubová, N. (2019). Milk production related to price of raw cow's milk in selected European countries. Potravinarstvo Slovak Journal of Food Sciences, 12(1), 798-805. doi: https://doi.org/10.5219/1002

[3] Costa-Font, M. \& Revoredo-Giha, C. (2018). An empirical analysis of UK milk contract prices 2004-2016. Agribusiness, 34(1), 112-141. doi: https://doi.org/10.1002/agr.21531

[4] Doubek, V., Švasta, J. \& Ackermann Blažková, L. (2012). Agricultural trade on the example of milk from the perspective of the multi-criteria analysis. Agricultural Economics, 58(7), 315-323. doi: https://doi.org/10.17221/168/2011-AGRICECON

[5] Foltínová, A. \& Špička, J. (2014). The use of controlling in agricultural enterprises and their competitiveness. Agricultural Economics, 60(7), 314-322. doi: https://doi.org/10.17221/19/2014-AGRICECON

[6] Groma, P., Nagyová, L., Obtulovič, P. \& Kádeková, Z. (2018). Development of advertising spending in Slovakia. In International Scientific Days 2018 (pp. 609-623). Praha, Czech Republic : Wolters Kluwer ČR.

[7] Jamrich, M. \& Vargová, L. (2018). Demand for dairy products in Slovak households: A Double-Hurdle approach. Acta Oeconomica Universitatis Selye, 7(2), 59-70.

[8] Kaliská, I. (2020). Margita Štefániková: Požiadali sme, aby sa prehodnotil hlavne normatív na dojnicu (Margita Štefániková: We have asked for a review of the dairy standards in particular). Retrieved from https://polnoinfo.sk/margita-stefanikova-poziadali-sme-aby-sa-prehodnotil-hlavne-normativ-na-dojnicu/ 
[9] Krivošíková, A., Nagyová, L., Kubelaková, A. \& Mokrý, S. (2019). Consumer preferences on milk market. Potravinarstvo Slovak Journal of Food Sciences, 13(1), 961-970. doi: https://doi.org/10.5219/1221

[10] Kubicová, L., Predanocyová, K. \& Kádeková, Z. (2019). The importance of milk and dairy products consumption as a part of rational nutrition. Potravinarstvo Slovak Journal of Food Sciences, 13(1), $234-243$. doi: https://doi.org/10.5219/1050

[11] Lajdová, Z., Kapusta, J. \& Bielik, P. (2017). Price analysis and competitiveness of the dairy supply chain. In Proceedings of the $7^{\text {th }}$ International Scientific Conference on Managerial Trends in the Development of Enterprises in Globalization Era (ICoM) (618-629). Nitra, Slovak Republic : Slovak University of Agricultura in Nitra.

[12] Ministry of Agriculture and Rural Development of the Slovak Republic. (2019). Mlieko: Situačná a výhl'adová správa k 30. 6. 2019 (Milk: Situation and outlook report as of 30. 06. 2019). Bratislava, Slovak Republic : Research Institute of Agricultural and Food Economics. Retrieved from http://www.vuepp.sk/dokumenty/komodity/2019/Mlieko10_19_v2.pdf

[13] Nagyová, L., Andocsová, A., Géci, A., Zajac, P., Palkovič, J., Košičiarová, I. \& Golian, J. (2019). Consumer's awareness of food safety. Potravinarstvo Slovak Journal of Food Sciences, 13(1), 8-17. doi: https://doi.org/10.5219/1003

[14] Obtulovič, P. \& Sojková, Z. (1999). Adaptívne prístupy k modelovaniu vývoja vybraných ukazovatel’ov (Adaptive approaches to modeling the development of selected indicators). In Agrarian Perspectives VIII. (pp. 673-676). Praha, Czech Republic : Czech University of Life Sciences in Prague.

[15] Parzonko, A. (2018). Milk production costs in Polish and other EU countries dairy farms - assessment in 2009-2015. In Proceedings of the 2018 International Scientific Conference "Economic Science for Rural Development” (pp. 154-161). Jelgava, Latvia : Latvia University of Life Sciences and Technologies.

[16] Pilvere, I., Nipers, A. \& Krievina, A. (2016). Analysis of the factors affecting cost efficiency in the dairy industry in Latvia. In Proceedings of the 2016 International Scientific Conference "Economic Science for Rural Development” (pp. 252-259). Jelgava, Latvia : Latvia University of Life Sciences and Technologies.

[17] Schulte, H. D., \& Musshoff, O. (2018). Insurance prospects after European dairy quota abolition. Agricultural Finance Review, 78(2), 223-232. doi: https://doi.org/10.1108/AFR-06-2017-0047

[18] Schulte, H. D., Musshoff, O. \& Meuwissen, M. P. M. (2018). Considering milk price volatility for investment decisions on the farm level after European milk quota abolition. Journal of Dairy Science, 101(8), 75317539. doi: https://doi.org/10.3168/jds.2017-14305

[19] Szücs, I. \& Szőllösi, L. (2015). Problems of the Hungarian dairy sector in connection with the abolition of the milk quota system. Roczniki Naukowe Stowarzyszenia Ekonomistów Rolnictwa i Agrobiznesu, 17(3), 379-385.

[20] Šimo, D., Mura, L, \& Buleca, J. (2016). Assessment of milk production competitiveness of the Slovak Republic within the EU-27 countries. Agricultural Economics, 62(10), 482-492. doi: http://doi.org/10.17221/270/2015-AGRICECON

[21] Špička, J. (2015). The efficiency improvement of Central European corporate milk processors in 2008-2013. Agris on-line Papers in Economics and Informatics, 7(4), 175-188.

[22] Váryová, I. \& Košovská, I. (2018). Development of purchase prices for cow's milk in the Slovak Republic and comparison with the Czech Republic. In Inproforum 2018 (pp. 239-246). České Budějovice, Czech Republic : University of South Bohemia in České Budějovice.

[23] Váryová, I., Poláková, Z., Košovská, I., Ferenczi Vaňová, A. \& Krajčírová, R. (2019). Analysis of development of raw cow milk prices in the conditions of the Slovak Republic. Potravinarstvo Slovak Journal of Food Sciences, 13(1), 906-914. doi: https://doi.org/10.5219/1196

[24] Vőneki, É., Mándi-Nagy, D. \& Stark, A. (2015). Prospects for the European Union and Hungarian dairy sectors after the abolition of the milk quotasystem. Studies in Agricultural Economics, 117(1), 1-9. doi: https://doi.org/10.7896/j.1424 


\section{SESSION 3}

THE AGRICULTURAL POLICY AND AGRI-FOOD VALUE CHAIN ANALYSIS: ECONOMICS, MANAGEMENT AND LOGISTICS 


\title{
Cultivation of Medicinal Plants in Slovakia and Czech Republic
}

\author{
Dávid Červený1, Jana Ladvenicová ${ }^{2}$, Zuzana Bajusová ${ }^{3}$, Jozef Palkovič ${ }^{4}$, Lubomír \\ Gurčík $^{5}$
}

\author{
Slovak University of Agriculture \\ Faculty of Economics and Management, Department of Economics $1,2,3,5$ \\ Faculty of Economics and Management, Department of Statistics ${ }^{4}$ \\ Address: Tr. A. Hlinku 2 \\ 94976 Nitra, Slovakia \\ e-mail: xcerveny@uniag.sk¹, jana.ladvenicova@uniag.sk², zuzana.bajusova@uniag.sk³, \\ jozef.palkovic@uniag.sk ${ }^{4}$, lubomir.gurcik@uniag.sk
}

doi: 10.18515/dBEM.ISD.P01.2020.p023

\begin{abstract}
Soil is a major component of the environment and is an important production factor. The total land area in Slovakia is practically unchanged. The land fund consists of both agricultural land and nonagricultural land. The area of agricultural land and its individual components has been decreasing in recent years from year to year. Medicinal plants have an irreplaceable role in crop rotation. The paper focuses on the analysis of crop yield, fertility, harvested areas in two countries - Slovakia and the Czech Republic during the period 2000 - 2018. By the Pearson correlation coefficient, we identify factors that influence the cultivation of medicinal plants and determine their rate of determination. Based on the research we have found that in Slovakia the harvest area of medicinal plants is growing, while the average harvest area is at the level of $1250 \mathrm{ha}$. The average harvested area of medicinal plants in the Czech Republic reached the level of $3287 \mathrm{ha}$. The average fertility rate in Slovakia was $1.77 \mathrm{t} / \mathrm{ha}$, while in the Czech Republic it reached a lower value of $0.82 \mathrm{t} / \mathrm{ha}$. We have found that there is a strong relationship between area and total yields. This relationship is stronger in the Czech Republic, which means that higher yields in Slovakia are due to increased efficiency rather than increasing the area.
\end{abstract}

Keywords: medicinal plants, fertility, yield, harvest area, Slovakia, Czech Republic

JEL Classification: Q12, Q24

\section{Introduction}

Agriculture and food production in Slovakia are one of the main pillars of the national economy. The sustainability of these industries is crucial for further economic development as well as for ensuring the country's food security and satisfying domestic demand (Kozáková \& Urbánová, 2018). Crop production is the dominant sector for the agricultural industry. The major part of arable land is devoted to the cultivation of crops especially cereals, feed crops and industry crops (Čeryová \& Svetlanská, 2017). All herbs are plants, but not all plants are herbs. An herb is a plant that is beneficial as a food, flavor, or as a therapeutic agent with therapeutic effect. An herb is a special type of plant that has the ability to induce a change in the body, e.g. as a medicament or after use in a meal (Harding, 2004). The use of plants to treat diseases is as old as mankind itself. The oldest references to herbs can be found in ancient Chinese medicine and on Egyptian papyrus thousands of years old. Herbs are a permanent part of our lives. Healthy life is closely related not only to medicinal plants, but also to healthy nutrition (Dugas, 2004). Herbal medicine is undoubtedly the oldest system of medical science in the world. Utilization of nature's wealth for health benefits and the cure, prevention and mitigation of diseases plays a big role in human civilization particularly in developing countries. Globalization of the local 
knowledge regarding the use of indigenous medicinal plants by traditional healers and localization of globally advanced technologies have boosted the growth of herbal industry and created immense global interest towards herbal medicine (Banerjee, Mitra, 2011). As per World Health Organization (WHO), more than seventy percent of the world population trust on Traditional Healers (mainly herbal source) for the health care system. In fact, plants are the oldest friends of humans. They did not only provide food and shelter, but also served humanity to cure different diseases. The traditional medicine, also sometime called herbal or natural medicine, exists in one way or the other in different cultures and civilizations, such as Arab, Babylonian, Chinese, Egyptians, Greco, Japanese (Aftab, 2018). Herbs are therefore plants whose leaves or stem and other parts are used medicinally or for their aroma and taste. Herbs come in a variety of sizes, shapes and scents. Nowadays, many experts are engaged in researching the properties of herbs and how people use them. These plants gain respect and will play an important role in a healthier approach to life (McVicar, 2002). Healthy plant material is therefore essential for maintaining product quality. However, cultivation of both medicinal and aromatic plants is facing problems, the major being lack of production technology and unregulated marketing (Gahukar, 2018). Šalomon (2015) defines medicinal plants as plants that can be applied directly or indirectly in human and veterinary medicine or are used as raw materials for the pharmaceutical industry or other industries. Technologically formulated into medicaments, they become medicaments and adapted for use as medicaments. In Europe, around 800 plant species are used for treatment. Approximately 600 species are used in human medicine, of which about 350 are used in homeopathy (Mochnacký, Benčat', Kočík, Benčat'ová, 2016). Nowadays, medicinal herbs play a more important role in human consciousness than ever before. This is evidenced by reports in the mass media and an increasing number of books on this issue. Medicinal plant science has a tradition in India and China. In the Czech Republic, MASP is obtained from cultivation in the wild nature and from imports. Compared to other crops, they have specific requirements for cultivation, harvesting and post-harvest treatment, which corresponds to their special use. The cultivation of this kind of plants is demanding for a higher proportion of manual work in cultivation technologies, has limited possibilities of using mechanized technology and plant protection products. Harvesting and post harvesting is difficult (the most common treatment is drying) (Růžičková et al., 2013). Medicinal plant harvesting is a global concern as plants are the source of the majority of medicines, either traditional or western in the world (van Wyk, Prinsloo, 2018).

\section{Data and Methods}

Data for the article for Slovakia were taken from the Statistical Office of the Slovak Republic. The data source for the Czech Republic was the Situation and Prospective Report issued by the Ministry of Agriculture of the Czech Republic. The period under review was the years 2000 2018. In the paper, we quantify the index as a proportion of the years 2018 and 2000, in order to determine the overall change in percentage for the whole analyzed period and the average value for the whole period for individual indicators. We compare in this article cultivation medicinal plants in Slovak republic and Czech Republic. We use available data which include harvested area, total yields, yield per hectare, arable land, agriculture land. Data for other factors that could affect the cultivation of medicinal plants are currently not available for these countries.

The aim of the article is to identify the factors that influence the cultivation of medicinal plants through Pearson correlation coefficient and determine the extent of their influence. The strength (intensity) of linear dependence can be assessed from the absolute value of the correlation coefficient. The closer the absolute value of the correlation coefficient is to 1 , the stronger is 
the dependence. If the correlation coefficient is equal to 1 or -1 , we are talking about complete correlation (direct or indirect) and the variables $\mathrm{X}$ and $\mathrm{Y}$ are in relation to the functional dependence.

The point estimate of the pair correlation coefficient $\mathrm{p}_{\mathrm{xy}}$ is the selection pair correlation coefficient $r_{x y}$. Its calculation is based on covariance:

$$
\operatorname{cov} x y=\frac{1}{n} \sum_{i=1}^{n}\left(x_{i}-\bar{x}\right)\left(y_{i}-\bar{y}\right)=\overline{x y}-\bar{x} \cdot \bar{y}
$$

which is a measure of the mixed variability of the $\mathrm{X}$ and $\mathrm{Y}$ variables (hence the sxy symbol). The covariance can take values from the interval $\langle-\infty ; \infty\rangle$ and expresses the direction of linear dependence between two variables.

The correlation coefficient requires not only information on whether or not there is a relationship between variables, but also information on the intent of this dependency. Therefore, covariance is divided by the standard deviations of the variables $\mathrm{X}$ and $\mathrm{Y}$, thus obtaining a correlation selection coefficient:

$$
\mathrm{r}_{\mathrm{xy}}=\frac{\operatorname{cov} x y}{S x * S y}
$$

Test of statistical significance of the pair correlation coefficient $p_{x y}$. This test is also called the linear independence test of the variables $\mathrm{X}$ and $\mathrm{Y}$. The null hypothesis

$\mathrm{H}_{0}=\mathrm{p}_{\mathrm{xy}}=0$ (the pair correlation coefficient is not statistically significant)

we test against an alternative hypothesis

$\mathrm{H}_{1}=\mathrm{p}_{\mathrm{xy}} \neq 0$ (the pair correlation coefficient is statistically significant)

Following statistics are used to test linear independence:

$$
t=\frac{r_{x y}}{\sqrt{1-r_{x y}^{2}}} \cdot \sqrt{n-2}
$$

which has the Student distribution with $(\mathrm{n}-2)$ degrees of freedom. We reject the null hypothesis about the linear independence of $\mathrm{X}, \mathrm{Y}$ variables if they are valid $|t|>t_{1-\frac{\alpha}{2}}(n-2)$. (Pacáková et. al., 2009).

Comparison of Slovak Republic and Czech republic was conducted by Mann-Whitney test. This method was chosen, because two independent samples for comparison did not followed normal distribution and included only small number of observations. Mann -Whitney test is non parametrical method for comparison of two independent samples, therefore is based on ranks of the data. Method is based on calculation of two statistics:

$$
\begin{aligned}
& U_{1}=n_{1} n_{2}+\frac{n_{1}\left(n_{1}+1\right)}{2}-R_{1} \\
& U_{2}=n_{1} n_{2}+\frac{n_{2}\left(n_{2}+1\right)}{2}-R_{2}
\end{aligned}
$$


Where $\mathrm{n} 1$ and $\mathrm{n} 2$ are sample sizes of compared groups, $\mathrm{R} 1$ is sum of ranks of group 1 ad $\mathrm{R} 2$ is sum of Ranks of group 2. Test statistic for the Mann Whitney test is the smaller of U1 and U2. Null hypothesis of the test suggests no difference between compared groups. Alternative hypothesis suggests significant differences between compared groups. Test was conducted using SAS software and test decision was conducted comparing $p$-value with significance level. In case, when p-value is smaller than significance level, should be accepted alternative hypothesis. When p-value is higher than significance level, then should be accepted null hypothesis.

\section{Results and Discussion}

At the beginning of this section we analyze development of harvested areas, yield and fertility in both countries compared.

Referring to Fig. 1 it is clear that the development of harvested areas in the Czech Republic and Slovakia has a different trend. In Slovakia, this trend is positive and growing faster than in Czech Republic, as the harvested areas are continuously growing throughout the period under review. When comparing the last and the first year of the monitored period, we record increase more than 4 times in the harvested areas of medicinal plants, the average harvested area of medicinal plants is at the level of 1250 ha. The largest harvested areas in the SR are in the Košice, Prešov and Žilina regions due to suitable climatic and soil conditions for cultivation of medicinal plants in comparison with other regions of the SR. In addition to the above mentioned factors, the increase in harvested areas of medicinal plants is also influenced by sales and allocated subsidies. There is a negative trend in the Czech Republic. While at the beginning of the period under review, the area of medicinal plants was 2201 ha and in 2004 the area increased to 559 ha and subsequently decreased to 2643 ha by 2016. In the whole monitored period, the area of medicinal plants harvested in the Czech Republic increased by $62 \%$, and its average harvested area was 3287 ha. In both countries have medical plants only small share on total size of arable land. But this share is increasing exponentially in Slovakia, in Czech Republic is stable with small increasing rate. Results would be similar also if we compared absolute values.

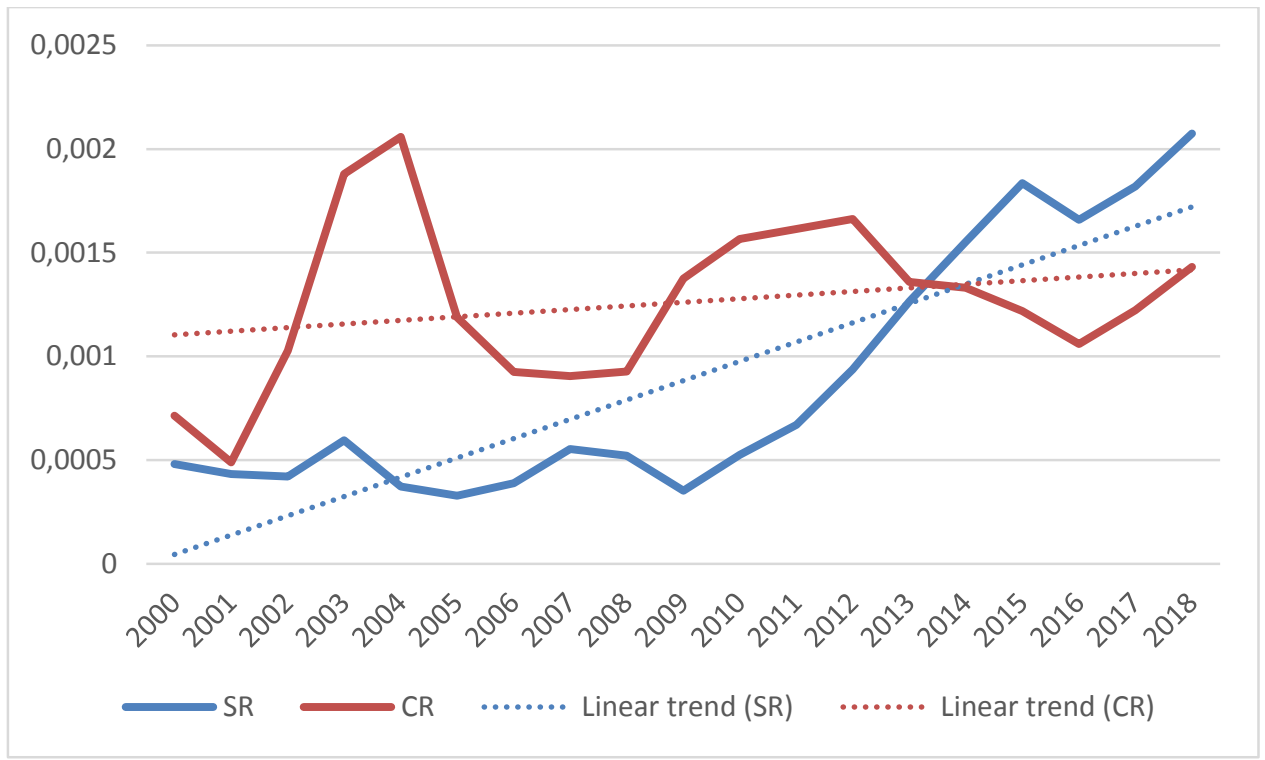

Fig. 1 Development of medicinal plants harvested areas in Slovakia and the Czech Republic as share of arable land $2000-2018(\%)$ 
Source: Statistical Office of the Slovak Republic and from the Situation and Prospective Report issued by the Ministry of Agriculture of the Czech Republic, authors own processing

The development of the medicinal plants yield (Fig. 2) in Slovakia has a growing and stepped nature. Between 2002 and 2009, the yield of medicinal plants increased almost 6.5 times, then we record a year-on-year decrease of the yield by almost half, so that in the period 2010-2014 this volume increased almost 10 times when it reached the maximum in the period under analysis ( 7 189, 7 ha). From that moment, the yield decreased until it reached $2198 \mathrm{t}$ at the end of the reference period. When comparing the last and the first year of the monitored period, we can see that the crop volume of medicinal plants increased almost 10-times. The average harvest was 2065 ha. In the Czech Republic, we have seen an increase in the yield of medicinal plants throughout almost the entire period, with the exception of 2015 and 2016, when the crop oscillated at 2000 ha. The biggest increase in yields is recorded between 2001 and 2004, when the yields increased more than 5 times. When comparing the last and the first year of the monitored period, we recorded an increase in medicinal plants yield almost around $102 \%$, the average yield of medicinal plants was $2764 \mathrm{t}$. Production trends are like trends in harvested areas. Total harvested amount in Slovakia is increasing faster than in Czech Republic. If this trend will continue in the future, production of medical plants in Slovakia will be probably higher than in Czech Republic.

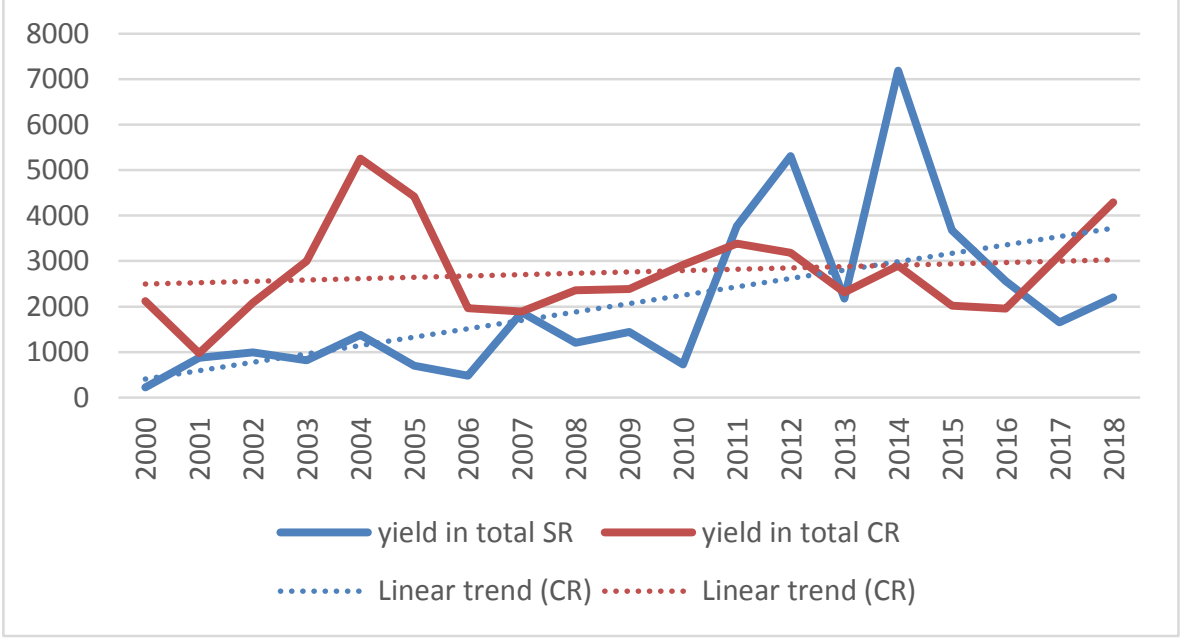

Fig. 2 Development of medicinal plant yield in Slovakia and Czech Republic in $2000-2018$ (in t) Source: Statistical Office of the Slovak Republic and from the Situation and Prospective Report issued by the Ministry of Agriculture of the Czech Republic, authors own processing

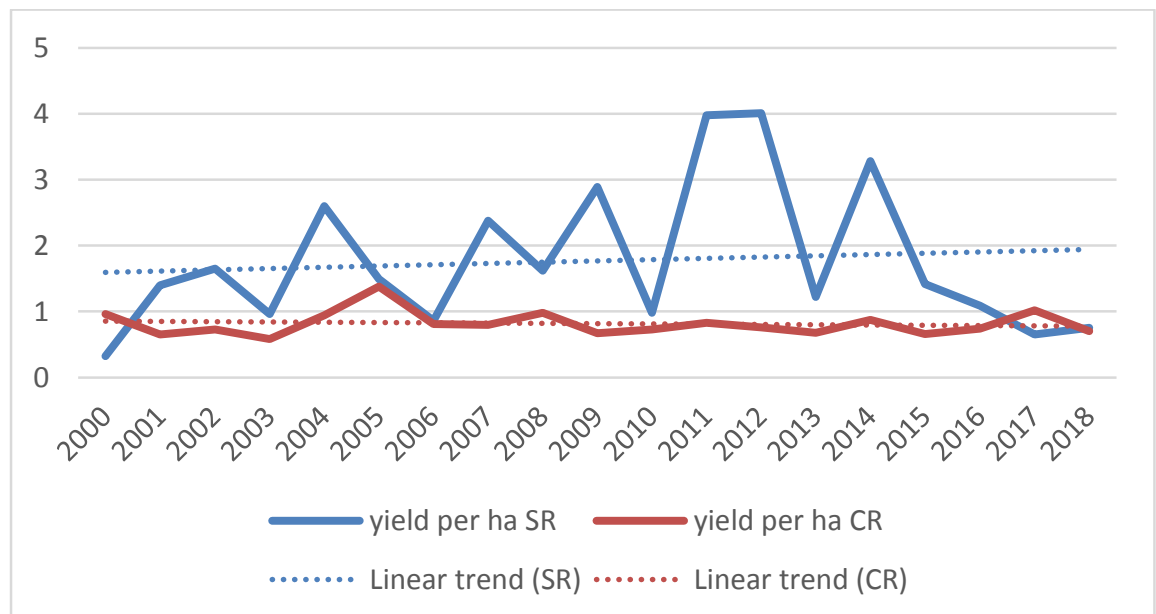

Fig. 3 Development of medicinal plants fertility in Slovakia and Czech Republic in 2000 - 2018 (in t per ha) 
Source: Statistical Office of the Slovak Republic and from the Situation and Prospective Report issued by the Ministry of Agriculture of the Czech Republic, authors own processing

Fig. 3 shows the development of fertility of medicinal plants in both countries. The average fertility rate of medicinal plants in the Czech Republic is $0.82 \mathrm{t} / \mathrm{ha}$, while it exceeded $1 \mathrm{t} / \mathrm{ha}$ only in 2005 and 2017. When comparing the last and the first year of the monitored period we can see that the fertility decreased by $27 \%$. On the other hand, when looking at fertility in Slovakia, it is evident that it shows higher values for almost the entire period, with the exception of the beginning and the end of the period under review. In 2011 and 2012, fertility in Slovakia was more than 4 times higher than in the Czech Republic. Average fertility in Slovakia reached $1.77 \mathrm{t} / \mathrm{ha}$. When comparing the last and the first year of the period under review, we see more than a 2-times increase. Yields per ha are stable, with slightly increasing trend in Slovakia. This means, that significant increasing trend in production of medical plants in Slovakia is caused not only by increasing size of area for medical plant cultivation, but also by increasing yields per ha.

Yields per ha for Czech and Slovak republic are compared also on fig. 4. Figure shows the distribution and box plots for both countries. It is obvious, that average yield per ha is higher in Slovak republic, but also variability is greater compared to Czech Republic. In Czech Republic can be seen small variability and small difference between maximum and minimum yield. In Slovak Republic is maximum value higher than in Czech Republic and minimum value even smaller than in Czech Republic. Therefore, can be concluded, that production in Czech Republic is smaller, but more stable, compared to Slovak Republic.

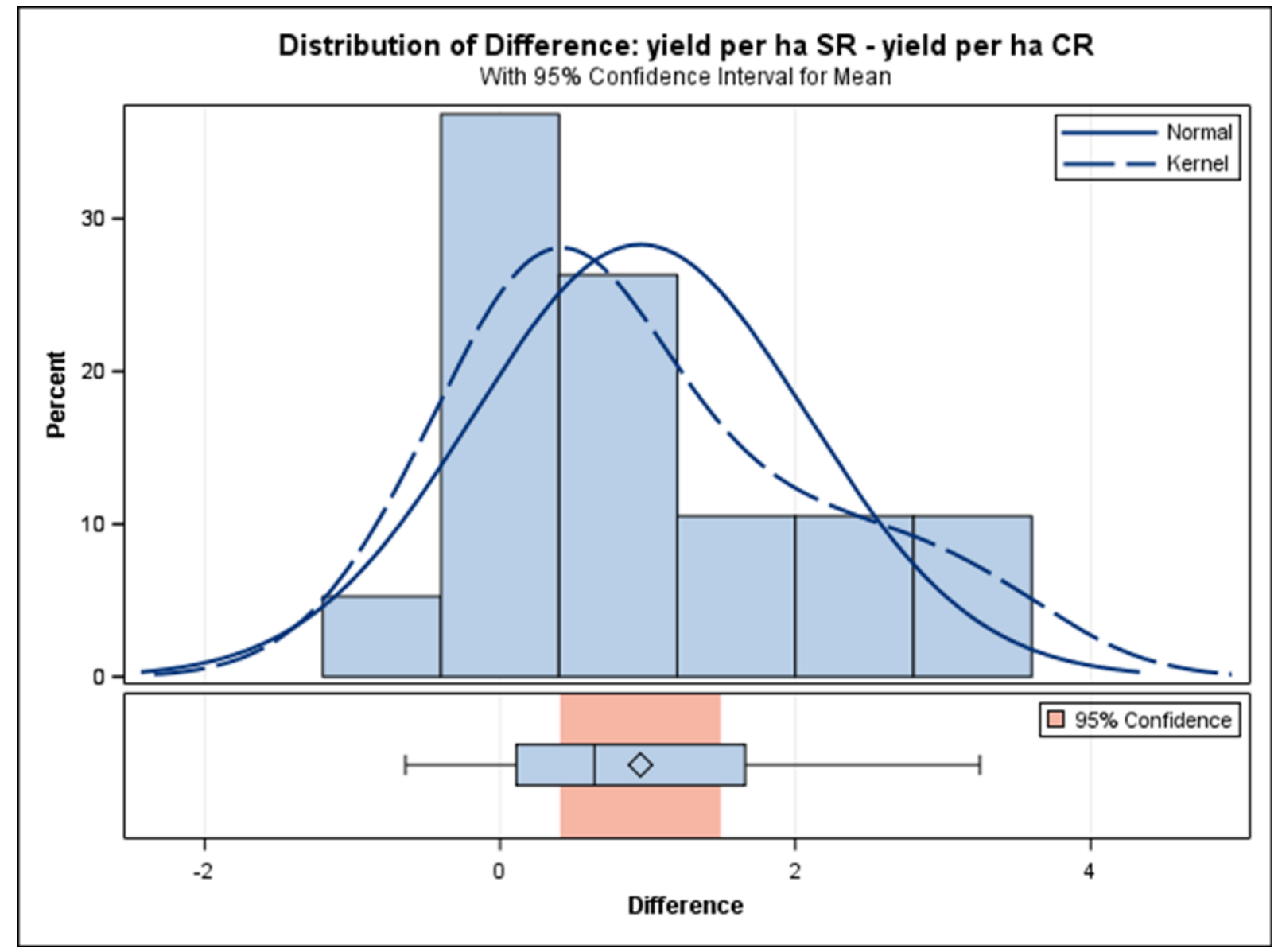

Fig. 4 Distribution of yields per ha - comparison of Czech Republic and Slovak Republic

Source: Author's processing based on the data from Statistical Office of the Slovak Republic and from the Situation and Prospective Report issued by the Ministry of Agriculture of the Czech Republic 
Both distributions of values are close to normal distribution, but according to normality test are significantly different from normal distribution. Thus, for statistical comparison should be used nonparametric Mann-Whitney test. According to test results, p-value equal to 0,0013 suggests rejection of null hypothesis. It can be concluded significant difference between yields in Slovak and Czech Republic. This is also the evidence, that yields in Slovakia are significantly higher than in Czech Republic. This difference can suggest two possible reasons. First, is the higher efficiency of medical plant cultivation in Slovakia, compared to Czech Republic. Second, difference in the type of cultivated plants, therefore in Slovakia are probably cultivated plants with higher yield per ha, than in Czech Republic. Identification of main reasons for this difference in yields, and in motivation of farmers to cultivate medical plants could be possible suggestions for further research.

Table 1 shows comparison of correlation coefficients, which measures relationship between yields and other factors, between Czech Republic and Slovak Republic. Significant correlations are those with $\mathrm{p}$-value smaller than 0,05 ). As was expected, there can be seen strong relationship between area and total yields. This relationship is stronger in Czech Republic, which means that higher total yields in Slovakia are caused by increased efficiency (increased yield per ha) rather than by increasing of area. There was not confirmed significant relationship between size of agriculture land, or arable land and yield per ha. Only in Slovak Republic was found significant negative relationship between agricultural land, arable land and total yield.

Table 1: Comparison of correlation coefficient between Slovak and Czech Republic

\begin{tabular}{|c|c|c|c|c|}
\hline Correlation coef. & \multicolumn{2}{|c|}{ Czech Republic } & \multicolumn{2}{c|}{ Slovak Republic } \\
\hline p-value & total yields & yield per ha & total yields & yield per ha \\
\hline & 0.74347 & -0.08545 & 0.52146 & -0.16024 \\
area & 0.0003 & 0.7280 & 0.0220 & 0.5123 \\
\hline & & 0.45845 & & 0.66937 \\
total yields & 1.00000 & 0.0484 & 1.00000 & 0.0017 \\
\hline & 0.45845 & & 0.66937 & \\
yield per ha & 0.0484 & 1.00000 & 0.0017 & 1.00000 \\
\hline & -0.36107 & 0.01201 & -0.55610 & -0.01235 \\
agriculture land & 0.1288 & 0.9611 & 0.0134 & 0.9600 \\
\hline & -0.26724 & 0.08272 & -0.57759 & -0.23075 \\
arable land & 0.2687 & 0.7364 & 0.0096 & 0.3419 \\
\hline
\end{tabular}

Source: Author's processing

\section{Conclusion}

Consumption of herbal medicines is widespread and increasing. Harvesting from the wild, the main source of raw material, is causing loss of genetic diversity and habitat destruction. Domestic cultivation is a viable alternative and offers the opportunity to overcome the problems that are inherent in herbal extracts (Canter, Thomas \& Ernst, 2005)

Based on the research we can conclude that the harvest areas of medicinal plants in the Czech Republic are larger than in Slovakia during the whole monitored period. On the other hand, the harvest areas of medicinal plants in Slovakia are continuously increasing. Since 2005 we have seen an increase in yields of medicinal plants in the Czech Republic. The development of the medicinal plants yield in Slovakia has a growing and step-like character. Although fertility in the Czech Republic is lower, it is more stable, while in Slovakia it is higher. Using correlation 
coefficients, we investigated the existence of relationships between yields and other factors affecting the cultivation of medicinal plants in both countries. Among factors that affect cultivation medicinal plants include for example redemption price, subsidies but information about this data are not currently available. We have found that there is a strong relationship between area and total yields. This relationship is stronger in the Czech Republic, which means that higher yields in Slovakia are due to increased efficiency (in $t /$ ha) rather than an increase in area. Presented paper offers only small insight into issue of medical plants cultivation, because it was significantly limited by the availability of data. But results offer suggestions of possible future research topics in this area. It would be necessary to collect more data about other possible factors influencing medical plants cultivation to get more results about other variables influencing this problem, which would allow to analyze other related issues mentioned in this paper. But medical plants cultivation is actual topic with increasing importance.

\section{References}

[1] Aftab, K. (2018). Natural products pharmacology. Acad. J. Med. Plants. 6 (12). 402-403. Doi: 10.15413/ajmp.2018.0180

[2] Banerjee, S., \& Mitra, A. (2011, November 23). Changing landscape of herbal medicine: Technology attributing renaissance. International Journal of Pharmacy and Pharmaceutical Sciences. 4 (1). 47-52.

[3] Canter, P.H., Thomas, H., \& Ernst, E. (2005) Bringing medicinal plants into cultivation: opportunities and challenges for biotechnology. Trends in Biotechnology. 23 (4). 180-185. Doi: 10.1016/j.tibtech.2005.02.002

[4] Čeryová, D., \& Svetlanská, T. (2017). Economic optimization of crop production and its environmental aspect in selected regions of Slovakia. Proceedings from international conference of PhD. Students "Scienta Iuventa 2017”. Banská Bystrica: Univerzita Mateja Bela. 9 - 18.

[5] Dugas, D. (2004). Zdravý život s babkinými bylinkami. Liečivé rastliny na prevenciu a liečbu poda l’udovej mediciny. Žilina: Knižné centrum.

[6] Gahukar, R.T. (2018). Management of pests and diseases of important tropical/subtropical medicinal and aromatic plants: A review. Journal of Applied Research on Medicinal and Aromatic Plants. 9. 1-18. Doi: 10.1016/j.jarmap.2018.03.002

[7] Harding, J. (2004). The herb bible: A complete Guide to Growing and Using Herbs. Bath: Parragon Plus.

[8] Kozáková, J., \& Urbánová, M. (2018). Is current system of direct payments suitable for farmers in Slovakia? Potravinarstvo. Slovak Journal of Food Sciences, 12 (1). 716 - 722. Doi:10.5219/941

[9] Liečivé rastliny. (2009). Praha: Ottovo nakladatel'stvo.

[10] McVicar, J. (2002). New Book of Herbs. London: Dorling Kindersley Limited.

[11] Mochnacký,S., Benčat', T., Kočík, K. \& Benčatová, B. (2016). Liečivé rastliny. Zvolen: Technická Univerzita.

[12] Pacáková, V. et. al. (2009). Štatistické metódy pre ekonómov. Bratislava: Wolters Kluwer. 411 s. ISBN 97880-8078-284-9.

[13] Růžičková, G. et al. (2013). Léčivé a kořeninové rostliny z čeledi miřikovité. Olomouc: Vydavatelství Ing. Petr Baštan.

[14] Situační a výhledová zpráva. Léčivé, aromatické a kořeninové rostliny. (2018). Praha: Ministerstvo zemědělství. 48 s. ISBN 978-80-7434-472-5.

[15] Štatistický úrad SR. (2010-2018). Definitívne údaje o úrode pol’nohospodárskych plodín a zeleniny v SR za roky 2010 - 2018. Bratislava: ŠÚ SR. Available online: www.slovak.statistics.sk.

[16] Šalomon, I. (2015). Praktikum a metódy využitia rastlín so sekundárnym metabolizmom. Prešov: Prešovká univerzita $v$ Prešove.

[17] Van Wyk, A.S., \& Prinsloo, G. (2018). Medicinal plant harvesting, sustainability and cultivation in South Africa. Biological Conversation. 227, 335-342. Doi: 10.1016/j.biocon.2018.09.018 


\title{
Strategic Imperatives for the Development of the Grain Market in Ukraine
}

\author{
Anatolii Dibrova ${ }^{1}$, Larysa Dibrova ${ }^{2}$, Maksym Dibrova ${ }^{3}$ \\ National University of Life and Environmental Sciences of Ukraine \\ Kyiv, Ukraine \\ e-mail: dibrova@nubip.edu.ua ${ }^{1}$,dibrova_larisa@ukr.net ${ }^{2}$,max_dibrova@ukr.net ${ }^{3}$
}

\section{doi: 10.18515/dBEM.ISD.P01.2020.p024}

\begin{abstract}
The article makes an economic assessment of the current state of development of the grain industry, identifies the main trends and factors that influence the formation of supply and demand in the grain market. The effectiveness of the mechanism of regulation of the grain market in Ukraine on the basis of indicators "Nominal Coefficient of Producer Protection" (NCPP) and "Market Price Support" (MPC) for grain producers used by the OECD is analyzed. The forecasts of gross harvests of basic grains, as well as their volumes of domestic consumption in Ukraine for the period up to 2030, were developed using the AGMEMOD partial equilibrium model (AGricultural MEmber states MODelling). Conditions of transport and logistics infrastructure of the grain market of Ukraine were evaluated. On the given research, strategic guidelines for the development of the grain market and the mechanism of its regulation have been proposed.
\end{abstract}

Keywords: agriculture policy, grain market, supply and demand, logistics, AGMEMOD model

JEL Classification: $Q 11, Q 13, Q 17, Q 18$

\section{Introduction}

In recent years, Ukraine has significantly increased grain production and entered to the cohort of its major producers and exporters. Despite the positive dynamics, a number of problems that have appeared and hinder its further development. In particular, infrastructure costs for grain exports remain at a rather high level, which reduces the competitiveness of domestic grain in the foreign market. The transport infrastructure does not quite meet the needs of the grain market due to the operation of the railway transport, the unpredicted increase in tariffs for the transportation of grain by rail, mainly the unsatisfactory state of highways, the lack of development of river transport. To date, the problem with logistics was less felt, since export volumes were significantly lower, and high grain prices with surplus blocked additional logistics costs. However, in the context of lower world prices observed during 2013-2017, the ineffectiveness of transport and logistics infrastructure on the grain market was significantly affected by the incomes of agricultural producers.

Positive tendencies of increasing the production volume and grain export, accompanied by prices instability and incomes of commodity producers, monopolization of the market and over concentration of production by large companies, it is not always possible to balance the interests of the main market participants (producers, consumers and the state).

Practice shows that due to insufficient quality, Ukraine exports mostly cheap feed grain, while it is forced to import meat and dairy products, and animal feed. From this point of view, the preservation of such trends shows that our state can remain an appendage of raw materials of developed countries, giving them added value and creating new jobs for them. In this case, without structural changes in the agriculture sector of the domestic economy, in our opinion, it will be quite difficult to solve the problems of poverty, unemployment in the countryside and the revival and development of rural areas. 
The above assertion has been widely corroborated by many studies by foreign and Ukrainian scientists. In particular, the issue of grain market development and its mechanism of regulation is at the forefront of scientific research and is widely represented in the specialized literature. A significant contribution to the development of theoretical, methodological and practical issues of these aspects was made by Zhemoyda (2014), Kvasha and Ilchuk (2013), Kovalova (2015), Kozak (2016), Mesel-Veselak (2018), Shpychak (2014). However, nowadays, there is no sufficient reason to say that all issues of the extremely important problem of grain development, in particular, have received a comprehensive scientific and methodological justification and practical solution. There is still a wide scope for research. In particular, the methodological basis of the mechanism of regulation of grain production needs to be improved in order to enhance its normative, predictive and stimulating function.

\section{Data and Methods}

During the research, the following methods were used: comparative analysis and expert assessments - for the analysis of quantitative and qualitative indicators of development of the domestic grain market in the conditions of globalization; statistical-economic - for the collection and processing of statistical data, studying the dynamics of exports and imports of grain; economics and mathematics - to predict the impact of demand factors (consumption on food and feed purposes, exports and stocks) and supply (yield, area, production, imports and stocks) on the grain market for the period up to 2030.

In order to evaluate the effectiveness of agricultural policy and the level of domestic support of agriculture there was used the methodology which is applied in the country-members of OECD. The methodology of the quantitative estimation of the state support is substantiated in the works of such famous scientists as Josling (1973), Tsakok (1990), Vanzetti (2002), Webb, Lopes, and Penn (1990).

The research has shown that price instability in the grain market indicates a lack of effective state regulation. In particular, the following manifestations of such imperfection include: instability of prices and incomes of commodity producers; not entirely predictable state policy; it is not always possible to balance the interests of the main market participants (producers, consumers and the state).

Therefore, in a market economy, for the development of a balanced agrarian policy, it is very important to correctly determine its effectiveness, directly for those who produce agricultural products (Josling, 1973).

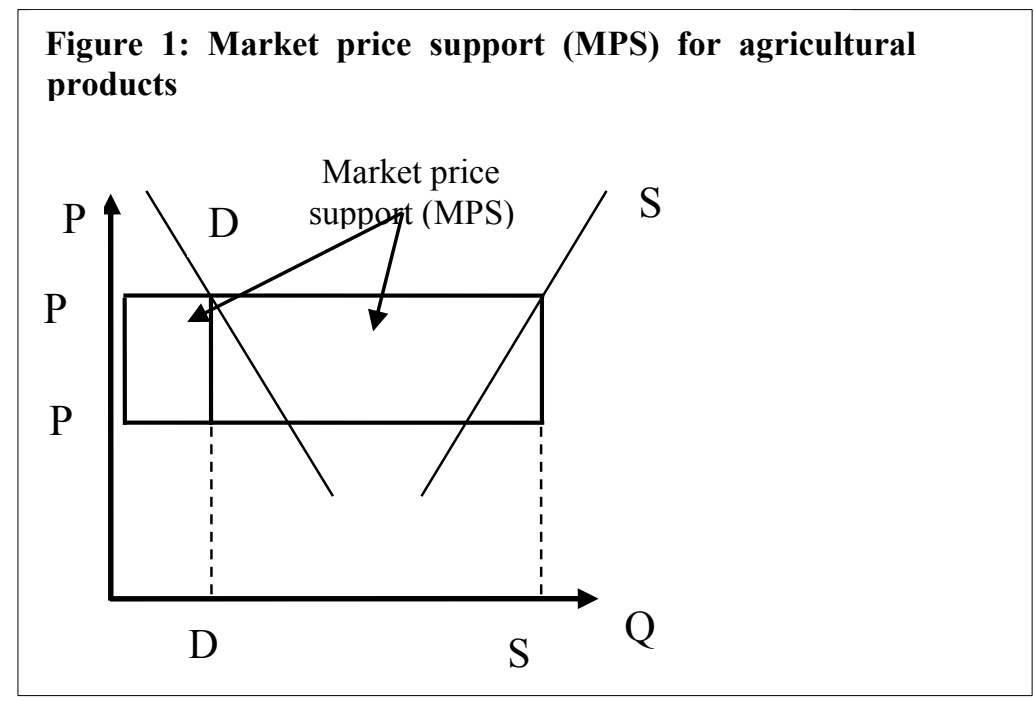


$\mathrm{D}_{1}$ - the demand of the domestic market; $\mathrm{S}_{1}-$ the offer of the domestic market

Source: (Methodology for the measurement of support and use in policy evaluation, 2003)

With the methodology of the Organization for Economic Cooperation and Development (OECD), the indicator «Market price support» (MPS) is calculated, which determines the monetary value of gross transfers to producers from consumers and taxpayers for the year that arose as a result of state policy measures that create a gap between prices for a certain kind of grain in the domestic and foreign markets («Methodology for the measurement of support and use in policy evaluation», 2003) (Figure 1).

Indicator of MPS is determined in producer prices and is calculated by the formula:

$$
M P S=\left(P_{p}-P_{w}\right) * S_{1}
$$

where: MPS - Market price support; $\mathrm{P}_{\mathrm{p}}$ - internal price per unit of output; $\mathrm{P}_{\mathrm{w}}$ - world price per unit of output; $\mathrm{S}_{1}$ - the offer of the domestic market.

Using the multiple linear regression in given research were defined factors, which have big impact on break-even level of production wheat $(y)$. Independent variables include the following parameters: harvested area, yield, stocks, import, domestic consumption, export, average cost of implementation, level of inflation. The theoretical regression equation is:

$$
\mathrm{y}=\alpha_{0}+\alpha_{1} \mathrm{x}_{1}+\alpha_{2} \mathrm{x}_{2}+\ldots+\alpha_{\mathrm{m}} \mathrm{x}_{\mathrm{m}}+\varepsilon,
$$

where: $\alpha$ - unknown variable; $\mathrm{x}$ - predictor of multiple regression; $\varepsilon$-random error

To predict the development of the grain market in Ukraine, an econometric, dynamic, multinational, multi-product AGMEMOD partial equilibrium model (AGricultural MEmber states MODelling) is used, which is used by the European Commission to analyze agricultural policy and development of the agro-food market. The AGMEMOD model allows considering the regional specificity of the relationship between the grain market of Ukraine and the world market and assessing the effects of changes in agricultural policy on agricultural development for the period up to 2030 .

\section{Results and Discussion}

Ukraine's grain market is one of the main segments of the agro-food market, the state of which determines the food security of the country, the results of economic activity of agricultural producers and, in general, the well-being of the Ukrainian people.

The formation of the mechanism of state regulation of the grain market in Ukraine took place in several stages: 2000-2008 increased regulatory influence; 2008-2010 liberalization due to Ukraine's accession to the WTO, high yields and activity of grain business players; 2010-2011 - introduction of an export quota mechanism. Since 2014, a new stage of grain market deregulation has come, which has led to the abolition of the quarantine certificate for inland transport of grain, 14 permits, 6 licenses have been revoked, and more than 50 other changes have been implemented. From January 1, 2017, all participants of the grain market are operating under conditions of complete abolition of the special VAT regime, and from April 1, 2017 - its automatic compensation for exporters has been introduced (Krylov, 2019).

According to the table 1, production of grains in Ukraine for 2016-2018 comparing to the 20012003 has doubled because of the yields from $24,2 \mathrm{c} /$ ha to $45,3 \mathrm{c} / \mathrm{ha}$.

Among the major grains, the largest increase in gross harvests was achieved by corn. Thus, in the research period, it has increased 6 times, breaking the 30 million mark in some years of 
harvest. This was facilitated by the expansion of the harvested area from an average of 1.4 million hectares in 2001-2003 to 4.4 million hectares in 2016-2018, with an increase of almost twice the average yield. Moreover, thanks to the development of breeding and introduction of new technologies, the corn spread covers almost all natural and climatic zones of Ukraine.

Gross wheat harvests in Ukraine also increased by an average of 1.7 times in 2016-2018 compared to 2001-2003 by increasing the average yield from $25,4 \mathrm{c} /$ ha to $40,2 \mathrm{c} /$ ha or 1,6 times. However, during the analyzed period there is no stability of gross barley collection, in particular its production in 2016-2018 decreased by more than 770 thousand tons or by $8.5 \%$ compared to 2001-2003, due to the reduction of the harvested area by almost $40 \%$. The yield of barley increased 1,5 times (Table 1).

Table 1: Production, harvested areas and yields of Ukraine's major grains averaged over the period 2001-2003 to 2016-2018

\begin{tabular}{|c|c|c|c|c|c|c|}
\hline & $\begin{array}{l}2001- \\
2003 \\
\end{array}$ & $\begin{array}{c}2004- \\
2006 \\
\end{array}$ & $\begin{array}{l}2007- \\
2009 \\
\end{array}$ & $\begin{array}{c}2010- \\
2012 \\
\end{array}$ & $\begin{array}{l}2013- \\
2015 \\
\end{array}$ & $\begin{array}{l}2016- \\
2018 \\
\end{array}$ \\
\hline \multicolumn{7}{|c|}{ Grains } \\
\hline Production, ths. ha & 32914,7 & 38027,7 & 42871,1 & 47411,3 & 62345,5 & 66020,4 \\
\hline Harvested area, ths. ha & 13336,7 & 14524,3 & 14759,4 & 14896,4 & 15024,2 & 14563,8 \\
\hline Yield, c/ha & 24,2 & 26,1 & 28,7 & 31,7 & 41,6 & 45,3 \\
\hline \multicolumn{7}{|c|}{ wheat } \\
\hline Production, ths. ha & 15167,8 & 16722,2 & 20236,5 & 18312,5 & 24308,5 & 25602,4 \\
\hline Harvested area, ths. ha & 5362,8 & 5871,9 & 6585,9 & 6190,4 & 6472,1 & 6384,7 \\
\hline Yield, c/ha & 25,4 & 28,5 & 30,3 & 29,4 & 37,6 & 40,2 \\
\hline \multicolumn{7}{|c|}{ corn } \\
\hline Production, ths. ha & 4898,7 & 7486,3 & 9784,7 & 18584,0 & 27591,3 & 29514,8 \\
\hline Harvested area, ths. ha & 1433,4 & 1893,1 & 2144,0 & 3521,1 & 4512,4 & 4432,4 \\
\hline Yield, c/ha & 34,1 & 39,7 & 45,4 & 52,5 & 60,9 & 66,5 \\
\hline \multicolumn{7}{|c|}{ barley } \\
\hline Production, ths. ha & 9127,6 & 10466,9 & 10141,8 & 8173,0 & 8298,7 & 8356,6 \\
\hline Harvested area, ths. ha & 4224,8 & 4700,4 & 4416,4 & 3764,7 & 3013,8 & 2615,0 \\
\hline Yield, c/ha & 21,9 & 22,3 & 22,9 & 21,8 & 27,7 & 31,9 \\
\hline
\end{tabular}

Source: Calculated according to the date (Crop Production of Ukraine, 2018).

In the structure of grain production in Ukraine during the analyzed period, agricultural enterprises produce about $80 \%$ of the total, including farms - $12-13 \%$, respectively $20 \%$ is accounted for by households that mainly grow a large part of oats, millet and rye and buckwheat. At the same time, large enterprises are mainly focused on exporting grains (corn, wheat), which are more profitable from the point of view of profit and therefore require greater investment of resources per hectare (Kozak \& Gryshhenko, 2016).

Analyzing the current grain market, it is necessary to pay attention to the uneven development and imbalance of supply and demand by individual cereals. In particular, if in the last 5 marketing years in Ukraine the supply of wheat and corn tends to increase, then the rye reduced by almost half, oats - by $25 \%$. The main directions of grain use within the state are the formation of consumption fund, feed and seed fund, food production and industrial grain processing (Table 2).

Feed and food consumption account for the largest share in the structure of grain consumption. The decrease in the number of livestock in Ukraine in recent years is offset by the increase in the number of poultry. In view of the above, feed is used in absolute values at the level of 11- 
15 million tons, but in relative terms we tend to decrease. In particular, in 2018 it was $16.7 \%$, compared to $2015-22.3 \%$. Food consumption of grain is a relatively stable value, although in recent years there has been a tendency to decrease it. The main reasons include: population decline; the departure of a significant number of our citizens for work abroad; more economical to baked goods; change in diet.

Table 2: Balance of cereals and legumes in Ukraine, thousand tones

\begin{tabular}{l|r|r|r|r|r|r|r|r|}
\hline & \multicolumn{1}{c}{2001} & \multicolumn{1}{c}{2005} & 2010 & 2014 & 2015 & 2016 & 2017 & 2018 \\
\hline Production & 33930 & 38016 & 39271 & 63859 & 60126 & 66088 & 61917 & 70057 \\
Carry out & -757 & -314 & -2054 & 2977 & -3204 & 2130 & -1465 & 5447 \\
Import & 200 & 226 & 175 & 263 & 190 & 240 & 255 & 280 \\
Total supply & 34887 & 38556 & 41500 & 61145 & 63520 & 64198 & 63637 & 64890 \\
Export & 814 & 12650 & 14239 & 33423 & 38338 & 41451 & 42499 & 42940 \\
Feed consumption & 18527 & 13817 & 14787 & 15678 & 14189 & 12278 & 11011 & 11698 \\
Sowing & 4600 & 3294 & 3222 & 2883 & 2597 & 2330 & 2120 & 2232 \\
Loss & 1220 & 375 & 794 & 1593 & 1400 & 1350 & 1106 & 1253 \\
Industrial use & 876 & 670 & 1650 & 1281 & 1089 & 1044 & 1246 & 1157 \\
Food consumption & 8850 & 7750 & 6808 & 6224 & 5897 & 5745 & 5655 & 5610 \\
\hline
\end{tabular}

Source: (Balances and consumption of basic food products by the population of Ukraine, 2018).

The analysis shows that an increase in grain production is accompanied by an increase in its export capacity. Over the past 3 years, Ukraine has exported record grain volumes of over 40 million tons. However, this is not always reflected in an increase in foreign exchange earnings. For example, in 2017, Ukraine exported a record amount of cereals - 41.5 million tons, which is almost $10 \%$ higher than 2015 exports. But as world commodity prices decline, export earnings remained almost at the level of 2015 - about $\$ 6.5$ billion. A significant problem in the export of cereals is also the quality of products. As of 2018, more than half of wheat sold outside the state is fodder. That is, the share of non-food grain increases, which is reflected in the price and, accordingly, of export earnings.

The value of the «Market price support» indicator for wheat growers in Ukraine for 2000-2017 indicates a significant amount of shortfall in gross transfers from consumers and taxpayers (Figure 2).

Figure 2: Indicators «Nominal producer protection coefficient» and «Market price support» of wheat producers in Ukraine per 1 ton of grain per average period, UAH

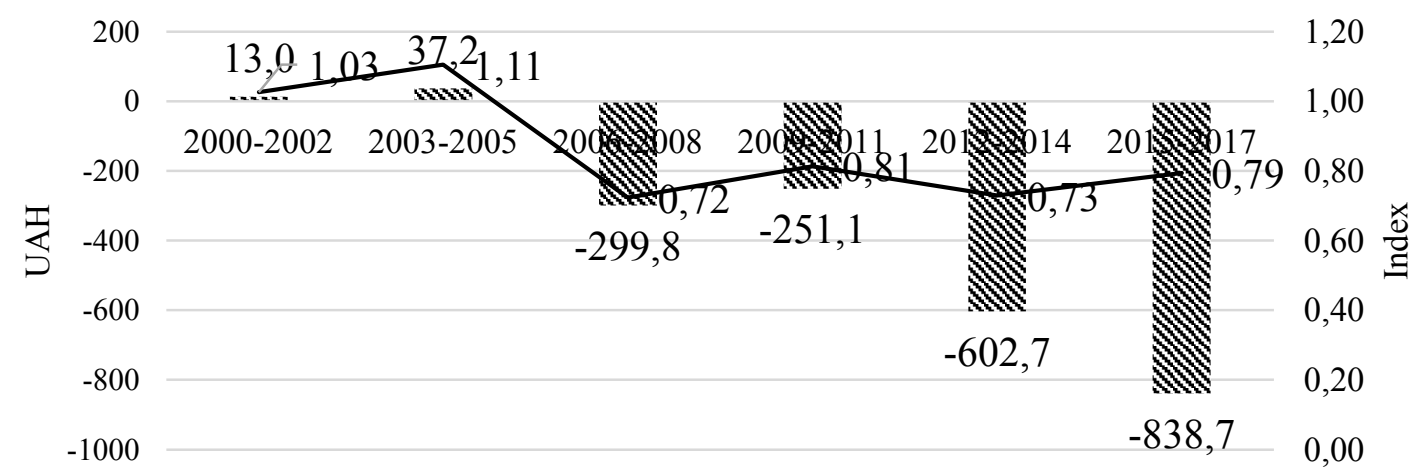

sw: Indicator MPS to wheat per 1 MT of grain, UAN

- Indicator NPC to wheat producers, index

Source: Calculated according to the date (OECD, 2018). 
The received values of NPC index for wheat producers (as a ratio of average prices farmers receive in the domestic market to world market prices expressed in producer prices) confirms price instability and lack of an efficient mechanism for regulating the grain market in Ukraine.

In particular, as the competitiveness of domestic grain on the world market is ensured by lower grain prices, wheat exporters (grain traders) compensate for their price losses due to lower grain quality and logistic costs due to low purchasing prices. According to the calculations, wheat purchasing prices at the enterprise level on average for 2015-2017 in Ukraine were 21\% lower than the world average. At the same time, agricultural commodity producers in turn compensate for price losses due to the low cost of land lease and wages of employees. Therefore, further increase in grain production in Ukraine needs a reduction in logistics costs due to the development of transport and logistics infrastructure of the grain market in the medium and long term.

The obtained values of the Indicator of the Producer Protection Ratio (defined as the ratio of domestic purchase price to the world price) for grain producers confirm the price instability and insufficient effectiveness of the mechanism of regulation of the grain market in Ukraine.

An econometric, dynamic, multinational, multi-product partial equilibrium model AGMEMOD (AGricultural MEmber states MODelling) was used to predict the development of the grain market in Ukraine. The forecast of gross harvests of basic cereals, as well as the consumption of grain for food and feed, is based on the balance of supply and supply of grain in Ukraine for the period from 2000 to 2015 (Figure 3).

Figure 3: Forecasting the gross harvest of main grains and consumption for food and feed purposes in Ukraine for the period up to 2030 using the AGMEMOD partial equilibrium model, million tones

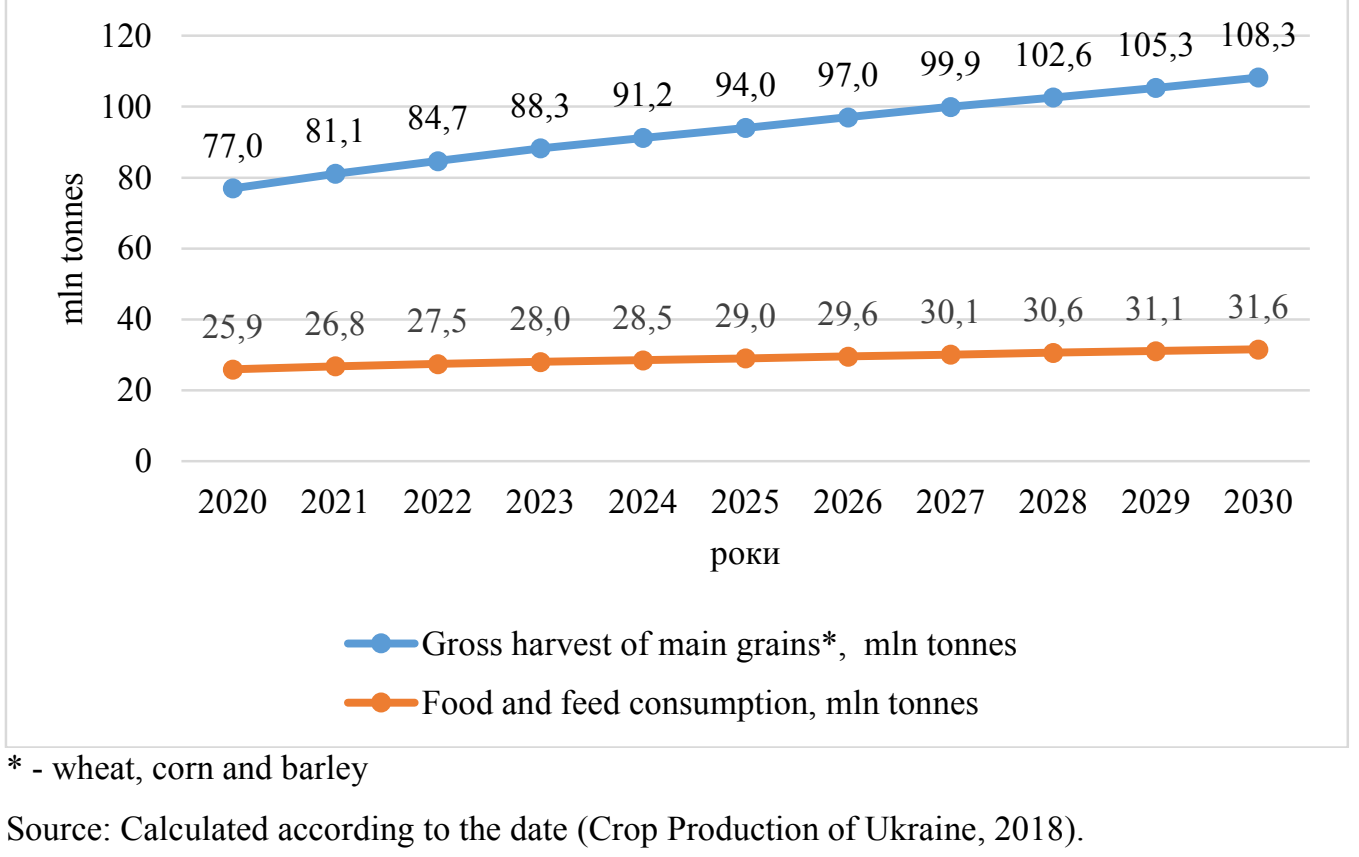

The results obtained indicate that the production potential of cereals by 2030 could reach more than 100 million tons. At the same time, without structural changes in the development of agriculture, they are aimed, first of all, at the revival of the livestock industry, since otherwise the volumes of domestic grain consumption will be reduced in favor of increasing its exports. As a result, it can lead to a deepening of both transport and logistical problems and other problems of the grain economy (increasing the deficit of moisture, etc.).

The calculations indicate that there is considerable potential for increasing grain production 
and, consequently, increasing exports. At the same time, farmers should ensure the production of quality grain. The developed forecasts made it possible to formulate the prerequisites for balancing the supply and demand of grain, determining the export potential of the industry, forming a system of state regulation aimed at preventing probable problems of the development of grain production.

The analysis showed that the central part in regulating the grain market is its price, which must balance the interests of producers and consumers, exporters and importers. The imbalance of these interests is especially evident in the conditions of crises that periodically arise in the development of the domestic and world economy. The basis of the proposed model is the interaction of demand (domestic consumption and exports), supply (gross fees through harvested areas and yields, imports, stocks), inflation and average annual price and their impact on the efficiency of wheat production. Multiple linear regression in the work determines the quantitative influence of the factors that most change the level of profitability of wheat production $(\hat{y})$. The multiple linear regression equation for the abovementioned wheat grain parameters for the 2000/01 - 2016/17 marketing years is as follows:

$$
\hat{\mathbf{y}}=-61,3-0,02 \times_{1}-2,27 x_{2}+0,016 x_{3}-0,014 x_{4}-0,01 x_{5}+0,014 x_{6}+0,002 \times_{7}+0,99 x_{8}
$$

where: $\hat{y}$ is the level of profitability, \%; $x_{1}$ - harvested area, thousand hectares; $x_{2}$ - yield, $k g$ / ha; $\mathrm{x}_{3}$ - average price of 1 ton, $\mathrm{UAH} ; \mathrm{x}_{4}$ - stocks, thousand tons; $\mathrm{x}_{5}$ - import, thousand tons; $\mathrm{x}_{6}$ - domestic consumption, thousand tons; $\mathrm{x}_{7}$ - export, thousand tons; $\mathrm{x}_{8}$ - inflation rate, $\%$.

The multiple correlation coefficient is 0.881 ( 0 to 1 ), which means that the correlation between the predicted level of wheat grain profitability and the linear combination of the above parameters is extremely tight. The statistical significance of the result is confirmed by a high coefficient of determination of $\mathrm{R} 2=0.777$, and implies that the regression accounts for $77.7 \%$ of the variance in the value of the average annual domestic grain price. The results obtained are fully consistent with the provisions of the Law of Supply and Supply

Table 3: Infrastructure costs for grain exports (FOB terms) as of June 2017

\begin{tabular}{|c|c|c|c|c|}
\hline № & Costs & $\begin{array}{c}\text { Standard (methodology) of } \\
\text { calculation }\end{array}$ & $\begin{array}{c}\text { Cost per } 1 \\
\text { ton of grain, } \\
\text { UAH }\end{array}$ & $\%$ \\
\hline 1. & Transportation costs * (by rail to the seaport) & $\begin{array}{l}489 \mathrm{~km} \text { at the tariff of } \\
\text { Ukrzaliznytsia with VAT }\end{array}$ & 256,80 & 42,7 \\
\hline 2. & Ship loading on port & 12 dollars US \$ $1 / \mathrm{t}$ & 322,56 & 53,6 \\
\hline \multirow[t]{6}{*}{3.} & Total cost of certificates, total, including: & & 17,06 & 2,8 \\
\hline & certificate of origin & $\begin{array}{l}\text { is included in the cost of } \\
\text { loading services }\end{array}$ & - & - \\
\hline & $\begin{array}{l}\text { quality certificate (including cost of analyzes } \\
\text { and work of survereur) }\end{array}$ & 0.3 dollars US / tonne & 1,43 & - \\
\hline & fumigation certificate & 0.5 dollars US / tonne & 0,63 & - \\
\hline & non-radioactive certificate & $\begin{array}{l}\text { is included in the cost of } \\
\text { loading services }\end{array}$ & 15,00 & - \\
\hline & phytosanitary certificate & $\begin{array}{l}\text { is included in the cost of } \\
\text { loading services }\end{array}$ & - & - \\
\hline \multirow[t]{2}{*}{4.} & Cargo customs declaration & 150 dollars USA & 5,58 & 0,9 \\
\hline & TOTAL COST & & 602,0 & 100,0 \\
\hline
\end{tabular}


Taking into account the increase of export volumes of grain in recent years and the export orientation of the Ukrainian grain market in general, port grain terminals have become the key subject of the transport and logistics system. The analysis shows that the transport infrastructure does not meet the needs of the domestic market due to the operation of the railway transport, the unsatisfactory condition of individual sections of the connecting roads of the regions with the Black Sea ports, undeveloped river transport. This can be accompanied by high tariffs for transportation, in particular, the level of costs for agrarian logistics in Ukraine far exceeds the relevant indicators in developed countries exporting grain. In particular, calculations of infrastructure costs for the export of grain from Ukraine amounted to about $600 \mathrm{UAH}$ per 1 tonne, or about $15 \%$ of all costs (Table 3 ).

In order to increase the efficiency of transport and logistics infrastructure, it is necessary to establish clear and transparent "rules of the game" in the market, which will stimulate competition and attract private investments to develop the objects of logistic infrastructure, development of river transport infrastructure. It is also necessary to establish clear rules and tariffs for the use of railway infrastructure, stimulate investment attraction for the renewal of grain storage and transshipment capacities, automation of transport and logistics processes, which will allow not only to improve the efficiency of the logistics system, but also to provide the necessary speed of transportation of significant volumes of grain.

\section{Conclusion}

Over the last few years, Ukraine has seen a tendency to increase the basic parameters of grain production, mainly due to increased yields. However, due to the uneven development and imbalance of supply for individual crops, in particular as wheat and corn production increased, the supply of barley, rye and oats decreased. These trends are primarily related to the market situation, which causes farmers to grow more profitable crops. The increase in gross grain collection is accompanied by an increase in its export capacity, since the domestic market is unable to meet the demand for actual volumes of its production. However, due to the decline in world commodity prices, the record volume of domestic grain exports does not deliver the expected revenue.

In the research, the average value of the Market Price Support indicator for wheat producers in Ukraine was calculated per 1 ton of grain. The values obtained indicate a significant amount of under-gross transfers to wheat producers from consumers. The value of the indicator «Nominal factor of protection of the producer» of wheat in Ukraine also confirms price instability and insufficient effectiveness of the mechanism of regulation of the grain market in Ukraine.

The quantitative influence of supply and demand factors on the efficiency of grain production in Ukraine has been determined using the developed econometric model. The results show that the inflation rate, the average annual price, the volume of domestic consumption and the volume of exports have a significant positive correlation with the level of profitability of production.

According to the results of a comprehensive analysis of the current state of the transport infrastructure, it was found that it does not meet the needs of the internal grain market due to the unsatisfactory condition of the roads, the railways and the underdeveloped river transport. Restraining factors for grain exports are domestic transportation and logistics infrastructure, which operates with low efficiency of grain processing and transportation. In particular, the cost of grain logistics from a producer in Ukraine to ports on the Black Sea is approximately $30 \%-40 \%$ higher than the cost of similar costs in France or Germany, and 30\% higher than in 
the US. Therefore, the contradiction between the pace of grain development and the transport and logistics infrastructure becomes an urgent problem and needs to be addressed at the state level by improving the mechanism of regulation of the grain market.

In a market economy, the regulation of grain production should be driven primarily by the balance of supply and demand. Based on the projections, gross yields of cereals and legumes by 2030 could potentially exceed 100 million tones. At the same time, without structural changes in the development of agriculture aimed at reviving the livestock industry, grain consumption will decrease in favor of its export. As a result, it can lead to a deepening of both transport and logistics and other problems of the grain economy related to environmental factors, including natural and climatic conditions.

\section{References}

[1] Agri-food projections for EU member states. (2008). Model AGMEMOD. Retrieved Oct. 25, 2019, from: http://www.agmemod.eu/index.php/information/about-agmemod.

[2] Dibrova A., Dibrova L., Krylov Ya., Dibrova M. (2019). Strategic guidelines for the development of the grain market and a mechanism for its regulation. Ekonomika APK. 6. 26-35. doi.org/10.32317/22211055.201906026

[3] Golomsha N. \& Dziadykevych O. (2016). Trends and prospects of world grain market. Ekonomika APK. 8. 49-52.

[4] Josling T. Agricultural Protection: Policy and International Trade. - Rome: FAO, 1973.

[5] Kovalova, O. (2015). Capacity assessment of grain subcomplex in the economy of Ukraine. Global and National Problems of Economy. 7. 155-159.

[6] Kozak, O. \& Hryshchenko, O. (2016). The current features of grain branch development in Ukraine. Ekonomika APK. 1.38-47.

[7] Krylov Ya. (2018). Major development trends in the grain market and mechanisms of its regulation in Ukraine. Ukrainian Journal of Applied Economics. Volume 3. 43-53.

[8] Kvasha S. \& Ilchuk M. (2013). Economic substantiation of program of wheat production in Ukraine. Ekonomika APK. 3. 16-24.

[9] Mesel-Veseliak V. (2018). Regional production of grain crops in agricultural enterprises of Ukraine. Ekonomika APK. 5. 5-14.

[10] Official website of the Administration of Sea Ports of Ukraine. Available at: http://www. http://www.uspa.gov.ua.

[11] Regulyuvannya agrarnogo sektoru ekonomiky` Ukrayiny` $v$ umovax yevrointegraciyi. [Regulation of the agrarian sector of Ukraine's economy in the conditions of European integration]. (2014). In Dibrovy', A. D. and Andriyevs 'kogo V. Ye. (ed.). Nacz. un-t bioresursiv i pry`rodokory`stuvannya Ukrayiny', In-t rozvy'tku agrar. ry'nkiv. Kiev. Ukraine.

[12] Shpychak, O. (2014). Potential of the grain market in Ukraine: problems and perspectives. Ekonomika APK. 7. 83-91.

[13] State Statistics Service of Ukraine. (2018). Balances and consumption of the main food products by the population of Ukraine 01/01/2000 to 01/01/2019 [statistics]. Available from SSSU Data database.

[14] State Statistics Service of Ukraine. (2018). Crop production of Ukraine. 01/01/2000 to 01/01/2019 [statistics]. Available from SSSU Data database.

[15] Staty`sty`chny`j byuleten` «Osnovni ekonomichni pokazny`ky` vy`robny`cztva produkciyi sil’s'kogo gospodarstva $\mathrm{v}$ sil's 'kogospodars 'ky'x pidpry'yemstvax». [Statistical bulletin "Basic economic indicators of agricultural production in agricultural enterprises"]. (for 2011, 2012, 2013, 2014, 2015 and 2016). State Statistics Service of Ukraine. Available at: www.ukrstat.gov.ua. 
[16] The Organisation for Economic Co-operation and Development. (2003). Methodology for the measurement of support and use in policy evaluation. Retrieved Oct. 25, 2019, from http://www.oecd.org/dataoecd /36/47/1937457.pdf

[17] The Organisation for Economic Co-operation and Development. (2018). Producer and Consumer Support Estimates database 01/01/2000 to 01/01/2018 [statistics]. Available from OECD Data database.

[18] Tsakok I. Agricultural Price Policy: A Practitioner's Guide to Partial -Equilibrium Analysis, 1990.

[19] Vanzetti D. Simulating the impact on developing countries of market access reform. Contributed paper at the 46th Annual Conference of the Australian Agricultural and Resource Economics Society, Canberra, 13-15 February 2002.

[20] Webb A.J., Lopes M., Penn R. Estimates of Producer and Consumer Subsidy Equivalents. Government Intervention in Agriculture, 1990.

[21] Zhemojda, O. V. (2014). Napryamy` formuvannya propozy`ciyi na ry`nku agroprodovol choyi produkciyi Ukrayiny`. [Directions of the proposal formation in the market of agro-food products of Ukraine]. NNCz "Int agrar. ekonomiky'". Kiev. Ukraine. 


\title{
Providing of Export Potential for Agricultural Organization
}

\author{
Olga Karpova ${ }^{1}$, Vladimir Savkin ${ }^{2}$ \\ Orel State Agrarian University \\ Ass. professor of Finances, investments and credit Chair \\ Professor of Economy and management in agro-industrial complex Chair \\ Address: Russia, General Rodin str. 69, \\ 302019 Orel, Russia. \\ e-mail: sviridova.o@list.ru'; v.i.savkin@mail.ru²
}

doi: 10.18515/dBEM.ISD.P01.2020.p025

\begin{abstract}
In conditions of non-stable demand on agricultural raw materials and food products agricultural companies is oriented on foreign markets. With the aim to decrease risks of failure, it is necessary to give complex estimation of export potential. Agricultural export-oriented organization functions in external environment and, at the same time, has its internal environment. External environment influences directly on a company by such national factors, like agricultural policy, mass communications, food security and marketing infrastructure. Essential significance has government strategy of export potential support in common and strategy of promotion on international markets in particular. International factors affect agrarians indirectly by dimensions of addressable markets, cultural and language particularities, interstate relations. Nowadays there are interstate relations, which play a major role in stability of production cross borders flow of agricultural sphere. Internal environment of agricultural organization consists of production, marketing, economic, innovating factors. Climate in the structure of production factors is most unpredictable and out of control resource. About quarter of total damage and loss in all sectors of the world economy comes on agriculture. Summing influence of all these factors, criterions for complex estimation of external and internal export potential are proposed and integral indicators are formed. According the complex estimation of export potential for agricultural organization it is possible to determine right strategic position of it.
\end{abstract}

Key words: export potential, agricultural export-oriented organization, internal environment, external environment, access to foreign markets.

JEL Classification: F510, F520

\section{Introduction}

Nowadays agricultural sector of economy faces with such a challenge, like not stable demand on agricultural raw materials and food products. Changing of consumer preferences, high level of market competition, reinforcement of requirements for quality level of production etc. inspire agricultural organization to search new marketing and management approaches, production technologies and, as a result, new market outlets.

In spite of restrictions on import in some countries, international market is much more broader, than national one. But forming of an access to foreign markets is very complicated and longterm process. It links with some expenditures, which could not be covered in case of failure. Thus, before making decision about going abroad agricultural companies must estimate its export potential in detail. 


\section{Data and Methods}

The research is based on general scientific methodology, including combination of systematic and process analysis, socio-economic approaches to tasks decision. In the process of research work empiric, analysis and synthesis methods and methods of quality and quantity analysis have been used.

Information base of research consists of data of Food and Agriculture Organization of the United Nations, World Trade Organization, Federal customs service of the Russian Federation and other official web-sites in the Internet. Some of data are formed according to practical experience of authors' work in research and development centers of Ministry of Agriculture of the Russian Federation.

\section{Results and Discussion}

Agricultural export-oriented organization functions in conditions of internal and external environment influence. External environment is represented as national, as well as international factors. International factors are dimensions of addressable markets, cultural and language particularities, interstate relations etc.

Dimensions of addressable markets are one of most important indicators, which determines potential success of agricultural organization, exported its production abroad. Proportion of demand and supply on certain international market of food products and agricultural raw materials forms probable future total revenue from activity on external market. Demand on agricultural products is sensitive not only to price and attractiveness of marketing communications, but especially to quality. Nutrition, health benefit, freshness, taste attractive new consumer and stimulate to return regularly steady one. Agricultural supply determine the market price, structure of marketing communications and mine quality characteristics of products according to level of competition. Knowledge of cultural and language particularities can expand export flow of an agricultural company. Moreover it may stimulate to organize production and export of new products. Interstate relations is very important factor in conditions of modern world economy. Embargo or other restrictions of international economic relations are main negative effects from external environment of a company. They can stop all production flows, as export, as well as import. Russian-European relations in the sphere of agricultural trade is remarkable example. See figure 1.

Figure 1 - Dynamics of international trade between the Russian Federation and the European Union, from 2013 till 2019.

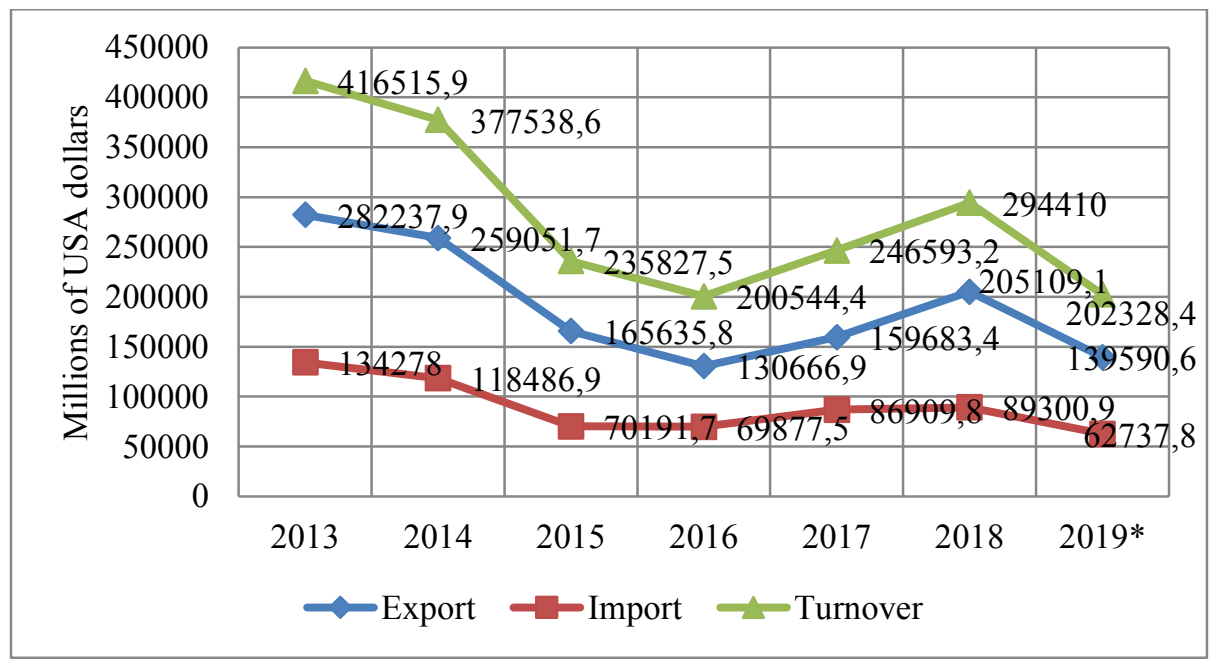


* Data for I, II, III quarters of the year.

Source: Federal customs service of the Russian Federation.

From 2014, when the European Union (EU) introduced restrictive measures for the Russian Federation (RF) after joining of Crimea to Russia, and the Russian Federation imposed retaliatory sanctions, international trade between these two parties start to reduce. In 2016 Russian export, import and turnover of the trade with the EU attained their lowest level. In comparing with 2013 recession was on $54 \%$, 48\%, 52\% correspondingly. From year to year Russian-Europe trade is growing. But, to this date, it does not reach digits of 2013 (time before sanctions). In 2018 the export was lower on $27 \%$, the import - on $34 \%$ and the turnover - on $29 \%$.

National factors of external environment for agricultural export-oriented organization are agricultural policy, mass communications, food security and marketing infrastructure. Agricultural policy of a government plays really important and, sometimes, decisive role in development of agriculture. Nowadays question of food security in context of common economic security is one of most important for all countries in the world. So, most of governments support agricultural sector of economy. Despite World Trade Organization (WTO) achievement: "At the 2015 Nairobi Ministerial Conference, WTO members agreed on a historic decision to eliminate agricultural export subsidies, the most important reform of international trade rules in agriculture since the WTO was established" (Agriculture: work in the WTO, 2020), the biggest part of world agricultural market is forming with governmental help.

Moreover, a lot of countries have government strategy of export potential support. In these conditions export-oriented company has next advantages: economizing on staff training expenses, marketing researches, promotion on foreign markets, brand forming and communicating etc. All of they are covered on national level by different efforts, leading according to state programs of export potential realization. On the other hand a country, supporting agricultural export, receive growing production of agricultural raw materials and food products, as a result, growing gross domestic product (GDP) with reducing unemployment level; quality improvement of corresponding goods; advancement of agricultural processes, as production, as well as management; widening of taxes flow as a result of financial results improving.

During active moving of economy abroad wrong public opinion could be developed. First of all because of luck of information. In this case mass communications become an instrument of problem decision. The main task of branch mass media in the agricultural sphere is informing people on regional, as well as on national level about food security achievement and only as a result about next level of agricultural development - forming access to foreign markets. Commercial marketing communications, integrating with governmental marketing communications, have to inform society about all possibilities, capacities, production volumes in agrarian sector of economy and about all advantages of export potential realization.

Marketing infrastructure as a part of external sphere of development for export-oriented agricultural organization includes export infrastructure, complex of marketing for international clients and complex of marketing communications. Export infrastructure reflects development level of transport infrastructure, logistic chains, customs affaires, mechanism of quality conformance certification, system of testing laboratories etc. Complex of marketing, crossing the same complex inside of a company, become complicated, orienting on foreign clients. As a rule Product receives stricter requirements for quality, Price become higher due to additional costs (for import, sometimes export, duties), Promotion, including complex of marketing 
communications, bases on national strategy of access to foreign markets forming. It consists of advertisement, public relations, packaging, marking, discount system etc.

Part of expenditures on promotion could be saved, if agricultural company acts according to common strategy of promotion on international markets. For example, participation in international exhibitions, like International Production \& Processing Expo (USA), World Food Istanbul (Turkey), Seafood Expo Global (Belgium), Fruit Attraction (Spain) etc., is too expensive for one, even medium agricultural business. But it is possible to present its production on such a significant level, participating in national delegation.

Resuming all information above, it is possible to propose next criterions for complex estimation of external export potential:

international:

$\checkmark \quad$ world market share of organization (WMS);

$\checkmark \quad$ fullness of consideration of national particularities ((NP), it is estimating according to interrogation);

national:

presence/ absence of international contracts (IC);

$\checkmark \quad$ dimension of governmental support (GS);

$\checkmark \quad$ presence of branch mass communications (BMC);

$\checkmark \quad$ providing of the food security (FS);

$\checkmark \quad$ presence/ absence of marketing infrastructure (MI).

Thus, integral indicator of the external export potential estimation could have next view:

IEExtEP $=\mathrm{WMS} \times(\mathrm{NP} \uparrow \downarrow) \times \mathrm{IC} \times \mathrm{GS} \times \mathrm{BMC} \times(\mathrm{FS} \pm) \times(\mathrm{MI} \pm)$

Assembly of external environment factors forms local export potential of agro-industrial complex on regional, national and international levels. But this proposition is not so categorical. Because local export potential, like an export potential of a country includes possibilities of business to work in conditions of international markets. It means, that internal environment factors of agricultural export-oriented organization participate in the process of local export potential forming.

Internal environment of organization are forming under affection of next factors: production, marketing, economic, innovating. Production factors consist of resources possibilities of a company. Labor, land, capital, entrepreneurship, information, climate are main factors of production.

Most of employees in the agricultural sphere live close to their working place, have their household. Very often their home acquirements can be applied at work and vice versa. It means, that agrarian employer has some advantages in the process of staff training. He can enforce necessary important skills instead of already well-developed. Agricultural export-oriented organization requires some personnel, who know foreign languages, international standards of quality, customs particularities etc. Their absence could become obstacle for access to foreign markets.

Land for agriculture is main resource. Quantity and quality of agricultural lands are competitive advantages not only for a company, but for a whole country. It is a base for food safety of a nation. 
Technologies of plants growing and animal breeding, premium variety of seed grains and animal breeds between different types of capital have the highest value for agricultural organizations. But plant, machinery and finances help agrarians to increase productivity.

Entrepreneurship as a production factor in the agricultural export-oriented organization is high valuable resource. Bringing the company to foreign markets, making correct management decisions, feeling future profitable projects in high-risked agricultural sphere provide a company with stable future development.

Well-circulating information flows inside of an agricultural organization conduce to overcome variety of losses, either non-conforming products, or extra processing, over production etc. Taking into account space of fields or quantity range of animals, speed of management reactions depends entirely on information.

For agricultural sphere climate is one of more unpredictable and out of control resources. That is why we must split it off the land. Significance of the climate for the agricultural sector of economy is rising up from year to year. For last twenty years quantity of natural disasters, caused extreme climatic event, was doubled. (The state of food security and nutrition in the world, 2018.)

According to FAO's (Food and Agriculture Organization of the United Nations) data agriculture suffers from different types of climate disasters on $23 \%$ of total damage and loss in all sectors of the world economy. (The impact of disasters and crises on agriculture and food security, 2017.) Moreover $83 \%$ of drought damage and loss occur in the agricultural sector of economy, see figure 2. On volcanic eruption, storm and flood come $30 \%, 23 \%$ and $17 \%$ of damage and loss in agriculture correspondingly.

Figure 2 - Disaster damage and loss in agriculture as share of total damage and loss across all sectors (2006-2016), by type of hazard

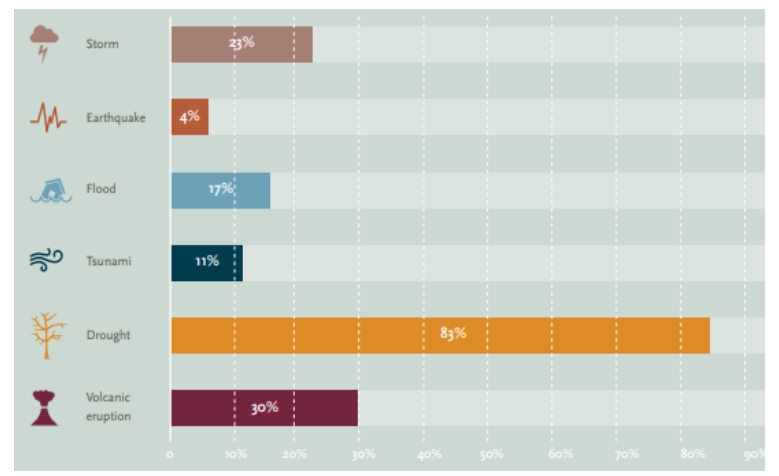

Source:The impact of disasters and crises on agriculture and food security, 2017. FAO.
Figure 3 - Disaster damage and loss in agriculture by agricultural sub-sector, percentage share of total (2006-2016)

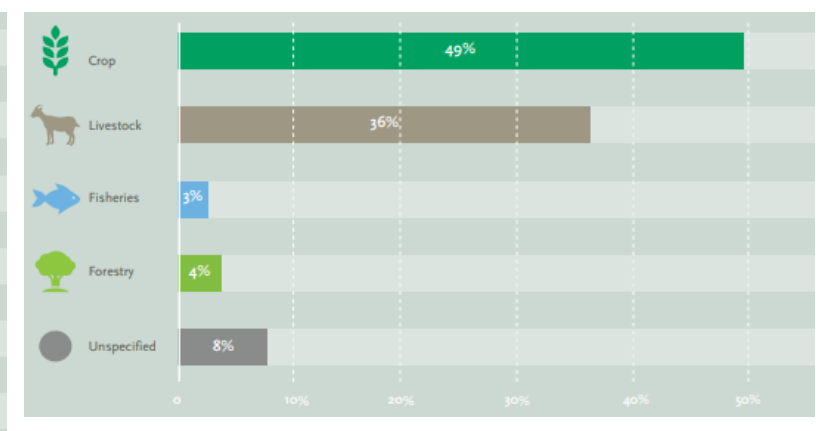

Source:The impact of disasters and crises on agriculture and food security, 2017. FAO.

Between series of agricultural raw materials and food products crop has the biggest part of losses $(49 \%)$ ) from climate impact, see figure 3 . There is livestock on the second place with $36 \%$ of total disaster damage and loss in agriculture. On the forestry and fisheries come $4 \%$ and $3 \%$ losses from climate correspondingly.

Economic and marketing factors are next two according to influence level inside of exportoriented agricultural companies. Main economic indicators of the company development, like volume of sales, variable and fixed costs, marginal revenue, profitability, determine whole strategy of activity. Dimensions of production, investment's flow, commencement of a new 
production depend of economic results of company. Agricultural sector of economy has one feature, which distinguish it from others. Very often agrarians receive really great support from governmental side. These subsidies could improve economic position of agricultural organization. Moreover they stimulate internal players become better in quality and assortment context and achieve international markets.

If we talk about internal environment of an organization marketing affect by standard 4P. Which Product we plan to supply on foreign market, for what Price, according to which Promotion strategy and at what Place. Categories of productions, main characteristics, quality level, trade mark etc. compose complex of different production elements, that influence on client, including external one, in the process of making purchasing decision. Price plays second role. The price determine place of a product on a market. Governmental financial support for agriculture allows producers sell their production for lower prices. At the beginning of international activity it can help companies to win some marketing space. Promotion strategy and place of sales finalize not internalization of a company, but preparing for it. Internal promotion experience will be some base for new stage of marketing development. At this question specialized governmental services can afford assistance.

Innovating factor consists of embodied ideas, giving strategic competitive advantages for a company. Every well-developing economic agent faces necessity to improve its business with the aim to win in competitive struggle. New equipment, technologies of production, management approaches are not full range of innovating decisions, which will be able to be a key to success not only on internal market, but on foreign one.

Summing all information above, we propose next criterions of complex estimation of internal export potential:

$\checkmark \quad$ Correlation of production program (PP) to production capacity of an organization (PC);

$\checkmark \quad$ Return on equity (ROE) and return on assets (ROA), in the process of estimation these two indicators can be used alternatively;

$\checkmark \quad$ Market share (MS) and consumer satisfaction ((CS), it is calculated according to interrogation), in the process of estimation these two indicators can be used alternatively;

$$
\begin{array}{ll}
\checkmark & \text { Net profit (NP); } \\
\checkmark & \text { Patents and know-how (P). }
\end{array}
$$

So integral indicator of the internal export potential estimation will have next view:

$$
\text { IEIntEP }=(\mathrm{PP} / \mathrm{PC}) \times \mathrm{ROE}(\mathrm{ROA}) \times \mathrm{MS}(\mathrm{CS} \uparrow \downarrow) \times \mathrm{NP} \times \mathrm{P}
$$

Following the results of complex estimation of internal and external export potential, it is possible to determine strategic position of an organization. It will be either export one, which can lead to limited or unlimited growth or refocusing on internal market. This type of analysis could help agricultural organizations to avoid unnecessary costs, linking with complicated process of forming access to foreign markets.

\section{Conclusion}

In conclusion it is possible to say, that providing of export potential for agricultural organization is complex mechanism, which include influence of external and internal environment of development. Internal environment of a company is particular base for export potential. 
External environment, forming inside the local export potential of whole agro-industrial complex, under government strategy of export potential support, represents sphere, where export potential is forming, growing and realizing. Common scheme of export potential providing for agricultural organization is presented in next figure.

Figure 4 - Scheme of export potential providing for agricultural organization.

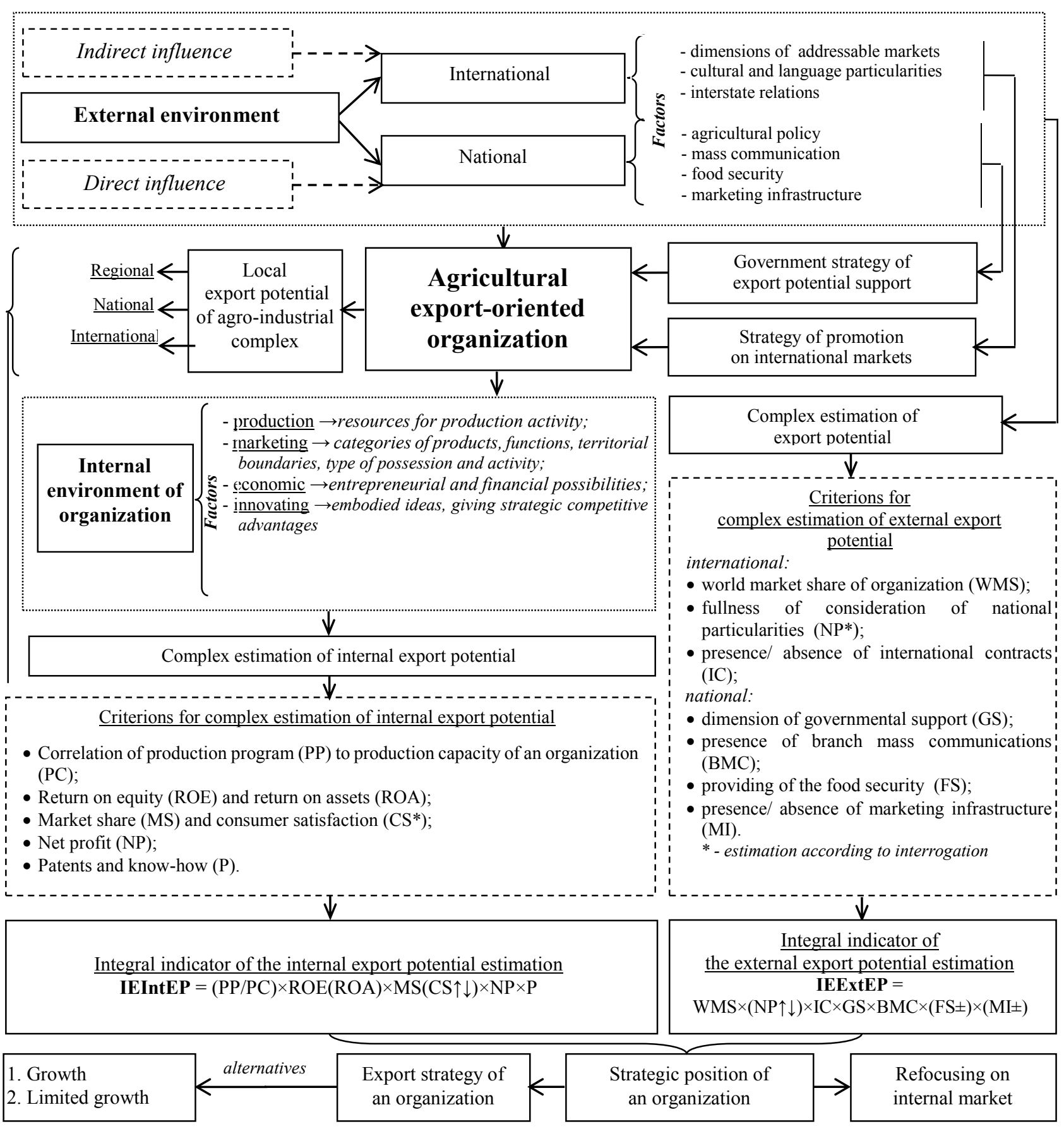

\section{References}

[1] Agriculture: work in the WTO. Official web-site of the World Trade Organization (WTO). Retrieved January 21, 2020, from: https://www.wto.org/english/tratop_e/agric_e/negoti_e.htm;

[2] Federal customs service of the Russian Federation. Web site: http://eng.customs.ru/;

[3] Kapsdorferová Z., Sviridova O. Impact of Sanctions on Agricultural Policy in European Union and Russia. International Scientific Days 2016. The Agri-Food Value Chain: Challenges for Natural Resources 
Management and Society. Retrieved January 21, 2020, from: https://spu.fem.uniag.sk/mvd2016/proceedings/en/articles/s3/kapsdorferova_sviridova2.pdf;

[4] The impact of disasters and crises on agriculture and food security, 2017. Food and Agriculture Organization of the United Nations. Retrieved January 21, 2020, from: http://www.fao.org/3/I8656EN/i8656en.pdf;

[5] The state of food security and nutrition in the world. Building climate resilience for food security and nutrition, 2018. Food and Agriculture Organization of the United Nations. Retrieved January 21, 2020, from: https://www.who.int/nutrition/publications/foodsecurity/state-food-security-nutrition-2018-en.pdf?ua=1;

[6] Top 100 Agriculture \& Forestry Events. Retrieved January 21, 2020, from: https://10times.com/top100/agriculture-forestry. 


\title{
Application of Forms and Types of Agricultural Advisory in Public and Private Consultancy
}

\author{
Barbara Kielbasa ${ }^{1}$ \\ University of Agriculture in Krakow \\ Faculty of Agriculture and Economics, Department of Management and Economics of Enterprises ${ }^{1}$ \\ Address: Al. Mickiewicza 21, \\ 31-120 Krakow, Poland City \\ e-mail: bkielbasa@ar.krakow.pl ${ }^{1}$
}

doi: 10.18515/dBEM.ISD.P01.2020.p026

\begin{abstract}
The article deals with selected aspects of managing an advisory organization in terms of tasks performed and an advisory methodology. A comparison was made between the advisory activities of public agricultural advisory units in Poland and private advisory companies accredited by the Ministry of Agriculture and Rural Development. Data was obtained using a survey method, with a set of standardized questions. The data obtained are presented in tabular and descriptive form. Based on the information obtained, it can be concluded that individual consulting, used to solve specific customer problems, is still a common form of consulting in both types of organizations. In terms of the types of advice provided, it is clearly seen that there is a great need for technological, as well as organizational and economic consulting. Based on the obtained data, it is possible to indicate the directions of activity of consulting organizations that should be developed and strengthened in order to meet the needs of its clients.
\end{abstract}

Keywords: agricultural advisory, consulting units, forms, methods of agricultural advisory

JEL Classification: $Q 16$

\section{Introduction}

Currently, a diverse farm advisory system operates in various European Union countries, but its common goal is, among others, to improve the professional qualifications of farmers and rural residents, improve the level of agricultural income, increase the competitiveness of farms and support sustainable rural development. The European Union countries, implementing the agricultural advisory system, based on various models (systems) (Kapsdorferová \& Kadlečíková, 2014).

In many EU countries there is a state (traditional) agricultural advisory system. In this case, it is fully financed from the state budget, without charging customers for services. A number of countries have been admitted to the public agricultural advisory system by commercial companies that, after obtaining accreditation, can operate within the scope of the EU agricultural advisory system and benefit from aid under the Common Agricultural Policy (Angileri, 2011). This system can be called mixed or public-private, and it works, among others in Poland. In some countries, this system is referred to as a "semi-state" due to the fact that consultancy is provided by state organizations, charging fees for certain services from their clients.

If the advice is organized or financed entirely by clients, private persons or private companies, we are talking about a private (commercial) agricultural advisory system (Dutka \& Mickiewicz 2015). Considering EU countries, such a system works e.g. in Austria, Denmark, Finland, France and the Netherlands. 
As already mentioned, there is a public-private agricultural advisory system in Poland, which consists of: public agricultural advisory units, chambers of agriculture, organizations within scientific units (research institutes), task groups in producer organizations and accredited private consulting companies. In addition to the agricultural advisory system, there are a number of companies and organizations that provide agricultural services with means of production or process agricultural raw materials, providing various advice and consultations (Sikorska-Wolak, Krzyżanowska \& Parzonko, 2014).

\section{Data and Methods}

The purpose of the article was a generic analysis of advisory services provided as part of the agricultural advisory system in Poland, in which there are public agricultural advisory units and private companies that can use public funds, if they are accredited by the Ministry of Agriculture and Rural Development.

The article develops one of the key problem areas of modern agricultural consulting, defined as the analysis of customer needs and the value of consulting by type. It is important to identify the most desirable forms and methods of consulting in the context of customer needs (i.e. farmers problems). The article presents statistics on the use of advisory services by clients (mainly agricultural producers) and an analysis of this data will be carried out, also in the light of the effectiveness of individual advisory forms. The article indicates the main directions of public and commercial consultancy. The study is completed with the presentation of own research on selected aspects of consultancy in the field of agribusiness, addressed to agricultural producers, pointing to its most important aspects in terms of consulting needs of this customer segment.

The research methods used are critical analysis of literature sources and surveys conducted among public advisory units (16 facilities) and accredited private consulting companies (146 facilities), which provide services to agricultural producers in Poland (www.doradca.cdr.gov.pl).

The research was conducted in the form of a web survey with a structured questionnaire (Callegaro, Manfreda \& Vehovar 2015). The questionnaire used closed, semi-open and open questions. The survey questionnaire contained 20 questions regarding, among others:

- Advisory forms and methods used in the process of solving customer problems,

- The effectiveness of individual forms and methods of consulting,

- Customer advisory needs by type,

- Providing advisory services in the context of the objectives and strategies of agricultural development in Poland.

The survey questionnaire was addressed to all sixteen regional agricultural advisory centers in Poland (public advisory) and private advisory companies that have been accredited by the Ministry of Agriculture and Rural Development and are on the current list of accredited entities. The result of the research was obtaining feedback from $13(81.2 \%$ of total) public agricultural advisory organizations and 52 (35.6\% of total) private, accredited consulting companies. All data and information collected during the study were analyzed in qualitative and quantitative terms. This made it possible to create statistics with a percentage distribution of answers to individual questions (Klepacki, 2009). This article focuses on the forms and types of consultancy used in the two groups of organizations studied (private consulting companies and public agricultural consulting units).

The obtained research results can be used by public agricultural advisory units and, as well as owners of private consulting companies to develop an effective advisory methodology. This 
will not only better use of the resources of the consulting company, but above all better meet the needs of their clients.

\section{Results and Discussion}

Organization management, including consultancy, means striving to create the desired future, taking into account the conditions of the present and past data (historical data). Management produces effects and phenomena that occur over time (in the future) (Werr \& Stjernberg, 2003). In organizations offering advice and consulting, all activities are focused on the client's interest, and thus on achieving the desired situation at a specific time in the future.

Several key stages (functions) can be distinguished in the management process, and the process itself is repetitive. Stages of the management process, i.e. planning, organizing, motivating and controlling the organization can be divided into smaller subsystems (Griffin, 1993).

As part of the planning process, it is possible to distinguish such subfunctions as collecting information, sorting and analyzing acquired data, forecasting and developing ways to solve customer problems, including planning the participation of an adviser in this process (Wiatrak, 2008). The functions of organizing in a consulting company consist primarily of the right selection of the consulting staff, grouping activities and employees for a given task (customer problem), as well as assigning and delegating tasks (Kostera, 2013). The motivating function mainly consists in effectively encouraging employees to carry out assigned tasks (Stoner \& Freedman, 1989). As part of this function, many tasks can distinguished, such as instructing employees, setting tasks and measures of their fulfillment, determining salaries, as well as assessing and developing staff. The human resources development process and employee knowledge management are one of the most important tasks of managers in this types of organization. The last of the management function is controlling, which includes many subfunctions, such as e.g. task identification and procedure setting, formal and substantive control of tasks, and development of post-audit recommendations (Griffin, 1993).

When analyzing the functions and levels of management of an advisory organization in the agribusiness sector, it is necessary to distinguish several significant differences that characterize this sector and distinguish it from other sectors of the national economy (Kiełbasa, 2009). The following aspects should be taken into account in the management processes of an advisory company, especially a public agricultural advisory units (Parzonko, 2016):

- Regulations under the Common Agricultural Policy, which task is to define overarching objectives and strategies for the development of agriculture in European Union countries,

- Methods and ways of implementing the strategy and achieving the main objectives recommended by the Ministry of Agriculture and Rural Development in Poland,

- Public agricultural advisory units and private consulting companies that deal with strategy implementation. The task of these organizations is to care for the development of people, processes and systems to enable the implementation of the defined strategy,

- Advisers and farmers who provide results through their contribution to the implementation of the strategy and the selection of appropriate forms and methods of consulting, tailored to a given group of clients and their specific problems.

In general, advice is primarily to help clients (farmers) solve their problems (BieńkowskaGołasa, Parzonko \& Sieczko, 2019). To this end, an advisory organization or consultancy company must have, and thus properly manage, knowledge and information resources treated as "goods" in such organizations. A consulting company must have the appropriate knowledge and preparation to solve specific problems of clients dealing with a given type of agricultural activity. By analyzing the subject scope of consultancy in the traditional approach, it is possible 
to distinguish a number of tasks (services) carried out by agricultural advisory entities, including (Prus \& Drzażdżyńska, 2017; Parzonko, 2011):

- Proper development, processing and transmission of information,

- Performing diagnostic and analytical activities,

- Implementation of tasks within agricultural andragogy (teaching adults - farmers),

- Analyzing the client's current situation and creating the desired vision,

- Development of alternative solutions using a proactive approach,

- Help in implementing solution proposals into practice.

Various problems of agricultural producers and other participants of the food chain make it necessary to use a combination of forms and methods of consulting (Kujawiński, 2009). Individual, group and mass counseling can be used as consultative forms. Most often a combination of two or three forms is used.

As part of individual advice, a conversation is used, i.e. an individual discussion with the client, during which a diagnosis of his problems is made, a solution strategy is established, and assistance is offered in its implementation. The group form offers many different methods and ways, which are helpful primarily in the process of teaching and transferring knowledge to agricultural producers (trainings, courses, lectures, workshops, study trips, etc.). The mass form is primarily used for informing and transmitting information remotely to a large, often anonymous group of recipients. It is mainly used to disseminate (spread on a large scale) information and innovation (Kiełbasa \& Kalinowski 2018).

In the process of designing effective forms and methods of consulting, the subject scope of consulting is taken into account. The subject scope of agricultural advisory refers to the advisory functions in agribusiness, which are implemented in public advisory units and in private consulting companies. In the European Union, several major types of agricultural advisory services can be identified. The most important of them are technological, organizational and marketing consulting as well as agri-environment-climate consulting (Toruński, 2011).

Technological consulting may refer to both plant production, animal production and agricultural technology. Consultancy in the field of animal husbandry covers issues related to animal production, animal husbandry systems, fattening, nutrition, disease prevention as well as animal treatment (Pawlewicz, 2006). Advice in this regard should be provided by specialists zootechnicians. In the field of plant production, important from the farmer's point of view are problems such as knowledge about types of cultivation, species and varieties of plants, types of fertilization, agrotechnic methods, recognition of diseases and pests, as well as methods of harvesting and storing agricultural produce (Trziszka, Nowak \& Chyłek, 2009). In the field of agricultural technology, technological consultancy covers issues related to the purchase and use of agricultural machinery and equipment. This advice should be provided by specialists mechanists who have knowledge of plant cultivation systems and the use of machines, as well as the proper functioning and equipment of livestock buildings and agricultural buildings (Orłowska, 2013).

Organizational and economic consultancy concerns comprehensive management of a farm or agricultural enterprise, constituting an element of building a competitive advantage. In the modern world, it plays an increasingly important role in all types of organizations (Kiełbasa, 2016). This type of advice provides on cost-benefit analysis, analysis of agricultural production efficiency and effectiveness indicators, as well as effective investment. Business plans are also drawn up. An important task of advisers in this area is to help clients complete applications for obtaining EU funds and other grants (Kalinowski \& Kiełbasa, 2010). 
Marketing consulting is also important from the point of view of agricultural producers. It answers the important question: How and where to sell produced agricultural products? Food producers are constantly looking for answers to these questions and looking for ways to increase the value of products sold, e.g. by sorting, processing, packaging, and others (Pudełkiewicz, 2011). Marketing is also about building a strategy that will allow you to compete on the wholesale and retail markets. This often requires producers` effort to create teams or producer groups, as well as developing effective marketing messages or creating new ways to reach the customer (e.g. direct marketing or Community Supported Agriculture, thanks to which a farmer can gain financial security) (www.nal.usda.gov).

There is also environmental consultancy in the European Union (known as agri-environmentclimate consultancy) provided by authorized (accredited) consultants. These advisers are specialized in, among others, the scope of the Code of Good Agricultural Practice, crosscompliance requirements, nature protection issues, ecological production, recognition of natural habitats and cultural heritage (Kania \& Kiełbasa, 2011).

In Poland, over 6,500 advisers work in total under the accreditation of the Ministry of Agriculture and Rural Development, including the largest group of advisers providing services for farmers and agricultural producers (Table 1). These numbers fall on 16 public agricultural advisory organizations financed from the state budget, and 146 accredited advisory companies, employing specialists from various fields.

Table 1: The number of accredited advisers providing services for agriculture and forestry as well as the number of advisory organizations in Poland (the state of 14.12.2019)

\begin{tabular}{lc}
\hline \multicolumn{1}{c}{ Specification } & Number in 2019 \\
\hline Agricultural advisers & 3262 \\
Agri-environmental advisers & 2220 \\
Nature experts & 679 \\
Forest advisers & 385 \\
Public agricultural advisory organizations & 16 \\
Private accredited consulting companies & 146 \\
\hline
\end{tabular}

Source: based on data of Agricultural Advisory Centre in Poland, www.doradca.cdr.gov.pl

Advisory services in both private companies and units financed from the state budget are carried out in three forms: individual, group and mass. The choice of form or forms and the methods available within them is dictated primarily by the specificity of the client's problem, reporting to a consulting company, and the possibilities of an advisory organization. Individual counseling is usually more cost and time consuming compared to group or mass counseling. Group form is often used, where through various trainings and workshops the knowledge on a given topic is transferred to farmers. Considering the surveyed entities, it can be concluded that individual consultancy plays a dominant role in terms of time devoted and resources for solving individual clients` problems (Figure 1). 
Figure 1: The share of advisory forms used in the units surveyed

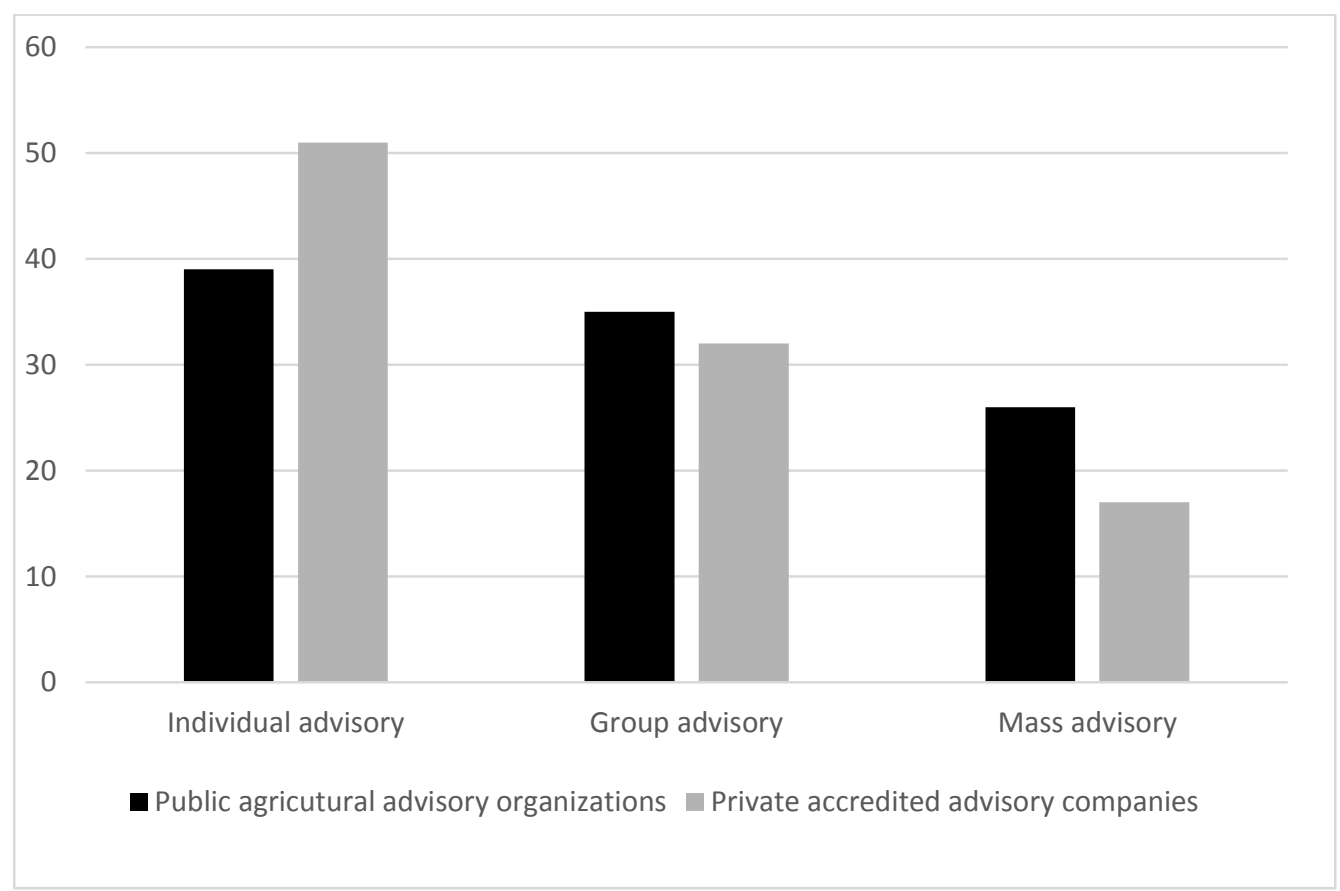

Source: based on own research

In organizations that answered the questions about the forms and methods of consultancy used, it is clear that the individual-direct form dominates, requiring the adviser to be proactive and have the ability to solve complex customer problems (Figure 1). Soft skills such as empathy, active listening and persuasion are also important. This form is particularly often used in private companies (Figure 1), which focus on a specific customer wanting to sell their service or product. It does not change the fact that many companies also conduct group counseling, inviting farmers and producers to various trainings or demonstrations, the purpose of which is to encourage the purchase of a given product or service. These trainings are usually free for its participants.

Mass consulting in private companies was understood as the formulation and transmission of marketing messages (commercial offers) to potential customers. In public units, mass consulting focuses on slightly different purposes, i.e. on providing current producers with agricultural information, e.g. market information, information on legal changes or important dates (e.g. deadlines for submitting applications, etc.). Comparing the responses obtained from private consulting companies and public consultancy units, it can be concluded that they are similar. However, the forms and methods of consulting were understood differently and implemented differently in these two types of organizations. It also results from the fact that management functions, i.e. planning, organizing, motivating and controlling, are implemented in a slightly different way in private companies and in public organizations.

Figure 2 shows the types of consultancy services provided, carried out in various forms (individual, group, mass) in the examined organizations. Representatives of the surveyed organizations were asked to indicate the participation of individual types of consultancy, divided into six main groups: consultancy in the field of plant production, in the field of animal husbandry, agricultural technology (machinery), organizational and economic consultancy, as well as marketing and environment protection consultancy. Respondents were asked to indicate the share (in \%) of implemented types of consultancy services in their unit, divided into 6 most important types (fig. 2). 
Figure 2: Frequency of application of selected types of advisory services offered by the surveyed entities $($ six types $=100 \%)$.

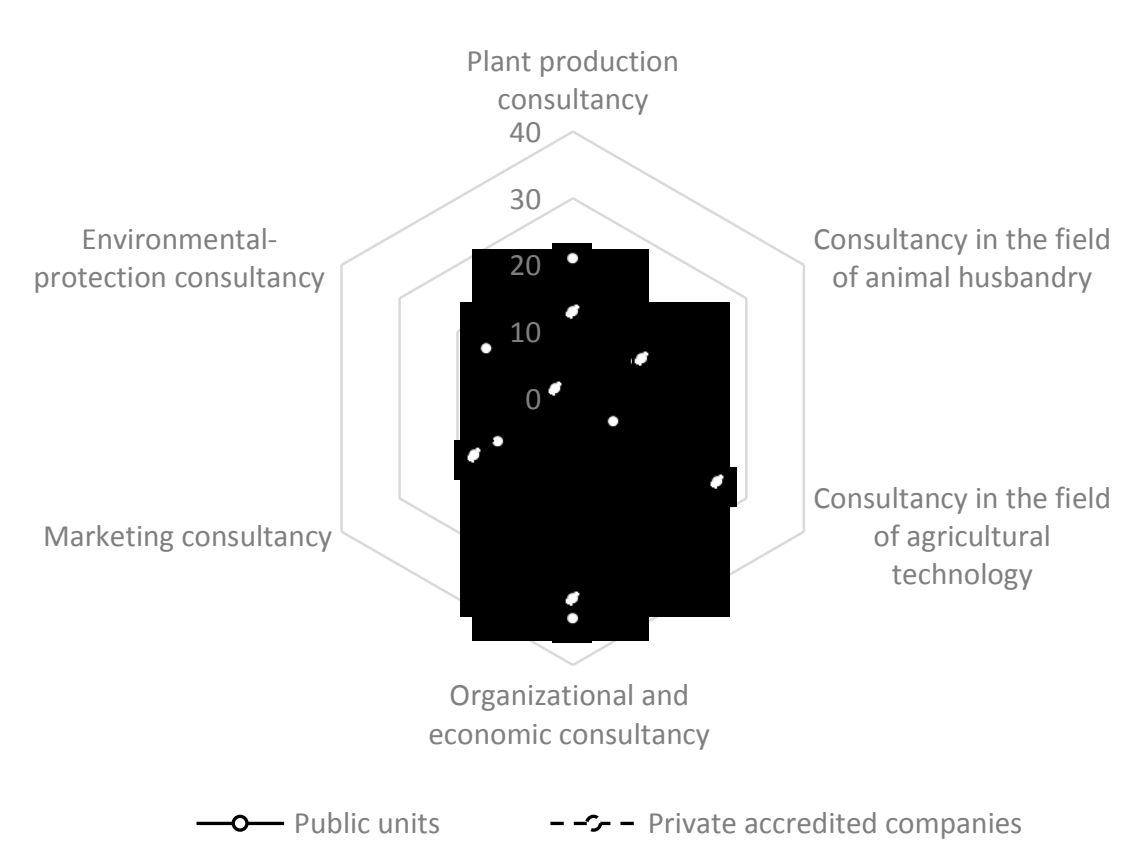

Source: based on own research

According to the obtained data, the largest needs of customers are reported in the field of organizational and economic consultancy, targeting both private companies and public consultancy units. This advice concerns the overall management of a farm or agricultural enterprise, obtaining external funds or developing business plans. Technology consultancy is important for private consulting companies, which they often provide when mediating in the sale or rental of agricultural equipment and machinery. In turn, public agricultural advisory units often give advice in the field of plant production technology and protection of the agricultural environment, using for this purpose the knowledge of agri-environmental advisers.

\section{Conclusions}

The results presented in the article are for review purposes only and do not apply to the full population of respondents. The study involved representatives of 11 out of 16 public regional agricultural advisory units and about $1 / 3$ of private advisory companies accredited by the Polish Ministry of Agriculture and Rural Development. It should be remembered that in the Polish agricultural advisory system there are many other entities that play important roles in the agricultural knowledge and information system. These units conduct scientific research in the field of agriculture and processing, provide specialist advice, provide support to farmers (e.g. chambers of agriculture), or operate in the field of product innovation.

The acquired data allowed a specific review of the consultancy forms used and types of consultancy provided by selected consulting companies. The undoubted advantage of using consulting services by farmers and food producers is the opportunity to look at the situation from the perspective of an external observer. As it turns out, regardless of the type of advice provided, the most effective method remains individual advice, used to solve specific problems of farmers. Clients, when reporting to a consulting company, usually ask questions about a specific problem they face personally, expecting help in solving it. Such expectations require 
advisers to be familiar with the internal and external conditions of the organization or farm 's operation, and thus the need to carry out a detailed analysis of the client's problem. In the process of individual counseling, soft competences of advisers are also necessary, which contribute to effective motivation and encouragement of clients to active participation in the process of problem solving and the implementation of developed solutions.

Based on the conducted research, it can be concluded that technological consulting remains the key consultancy, and for several years also organizational and economic consultancy plays an important role, which is necessary for proper management of the entire farm or agricultural enterprise. Agricultural producers see the need for knowledge not only about technology, but also about the efficient and effective use of their (usually limited) resources. The efficiency and effectiveness of managing these resources is a key issue when it comes to building a competitive advantage. Therefore, consulting companies should maintain and strengthen the consulting forms used and use them adequately to the type of consultancy being applied and the needs reported by clients.

\section{Acknowledgements}

The publication was financed from the subsidy of the Ministry of Science and Higher Education for the Agricultural University of Hugo Kołłątaj in Krakow for 2019, number SUB/20190113000000-D 119.

\section{References}

[1] Angileri, V. (2011). Farm Advisory System in the EU: proposals for improvement. Results of the FAS workshop. Report, Warsaw 8-9 February 2011, 1-18, https://publications.jrc.ec.europa.eu/ repository/bitstream/JRC64680/lbna24799enn.pdf

[2] Bieńkowska-Gołasa, W., Parzonko, A.J \& Sieczko, A. (2019). Agricultural advisory services in the process of shaping entrepreneurial attitudes. Proceedings of the 2019 International Conference "Economic Science For Rural Development” No 50, Jelgava, LLU ESAF, 9-10 May 2019, 29-36 doi: 10.22616/ESRD.2019.003.

[3] Callegaro, M., Manfreda, K.L \& Vehovar, V. (2015). Web Survey Methodology. SAGE Publications Ltd., London.

[4] Dutka, B. \& Mickiewicz, B. (2015). Farm Advisory Service in Poland in light of legal regulations. Nordic View To Sustainable Rural Development, Proceedings of the25th NJF Congress, Riga, Latvia, 16-18 June 2015, 504-507.

[5] Griffin, R.W. (1993). Management. Boston: Houghton Mifflin Company.

[6] Kania, J. \& Kiełbasa, B. (2011). The role of farm advisory system in implementation of cross-compliance requirements among Polish farmers. 20th ESEE European seminar of extension education private-public partnerships for advisory services in Europe. Proceedings of the 20th ESEE Finland. JTO School of Management, Kirkkonummi, 142-148, ISBN 978-951-9411-54-5.

[7] Kalinowski, S. \& Kiełbasa, B. (2010). Znaczenie usług doradczych w kreowaniu aktywności inwestycyjnej producentów rolnych. Acta Scientiarum Polonorum Oeconomia, 9 (2), 91-100.

[8] Kapsdorferová, Z. \& Kadlečíková, M. (2014). AKIS and advisory services in Slovakia. Report for the AKIS inventory (WP3) of the PRO AKIS project, April 2014, 1-36.

[9] Kiełbasa, B. (2009). Agrobiznes a gospodarka żywnościowa - podobieństwa i różnice. Wieś i Doradztwo, 2(54). Wydawnictwo Uniwersytetu Rolniczego w Krakowie, 16-21.

[10] Kiełbasa, B. (2016). Overcoming barriers to efficient farm management: The role of knowledge and information management in the rural advisory sector. International Scientific Days 2016. The Agri-Food Value Chain: Challenges for Natural Resources Management and Society. Conference proceedings, (Ed.) E. Horská, Z. Kapsdorferová, M. Hallová, 758-768, doi:10.15414/isd2016.s9.05

[11] Kiełbasa, B. \& Kalinowski, S. (2018). Knowledge and Information in the Processes of Managing the Organization Case Study. Proceedings of International Scientific Days 2018. "Towards Productive, 
Sustainable and Resilient Global Agriculture and Food Systems", Slovak University of Agriculture, Faculty of Economics and Management, Nitra, 815-829, doi: 10.15414/isd2018.s3.08

[12] Klepacki, B. (2009). Wybrane zagadnienia związane z metodologią badań naukowych. Roczniki Nauk Rolniczych, Seria G, 96 (2), 38-46.

[13] Kostera, M. (2013). Doradztwo organizacyjne: ujęcie systemowe. Warszawa: Wydawnictwo Poltext.

[14] Kujawiński, W. (2009). Metodyka doradztwa rolniczego. Wydawnictwo Centrum Doradztwa Rolniczego w Brwinowie, Oddział w Poznaniu.

[15] Orłowska, M.J. (2013). Działania doradcze podejmowane dla transferu innowacji technologicznych do gospodarstw rolniczych na przykładzie kujawsko-pomorskiego ośrodka doradztwa rolniczego. Zagadnienia Doradztwa Rolniczego, 4, 54-69.

[16] Parzonko, A.J. (2016). Selected aspects of agricultural extension services in Poland. Economic and Regional Studies, 9, 121-131.

[17] Parzonko, A.J. (2011). Recent Trends in Agricultural Advisory in Poland. Roczniki Naukowe Stowarzyszenia Ekonomistów Rolnictwa i Agrobiznesu, 6, 171-175.

[18] Pawlewicz, A. (2006). Rola doradztwa i innych źródeł wiedzy w modernizacji gospodarstw rozwojowych. Zeszyty Problemowe Postępów Nauk Rolniczych, 514, 305-315.

[19] Pudełkiewicz, E. (2011). Reflections around the concept of marketing in agribusiness. Scientific Journal Warsaw University Of Life Sciences - SGGW, European Policies, Finance And Marketing, 5(54), 115-130.

[20] Prus, P. \& Drzażdżyńska, K. (2017). Farmers' assessment of training services and the impact of agricultural advisory on selected developmental factors affecting farming. Proceedings of the 2017 International Conference "Economic Science For Rural Development", No 44, Jelgava, LLU ESAF, 27-28 April 2017, 338-344, ISBN 978-9984-48-260-6.

[21] Sikorska-Wolak, I., Krzyżanowska, K. \& Parzonko, A.J. (2014). Doradztwo w zmieniajacej się sytuacji społeczno-ekonomicznej obszarów wiejskich. Wydawnictwo SGGW, Warszawa, 24-37.

[22] Stoner, J.A.F \& Friedman, R.E. (1989). Management. Englewood Cliffs: Prentice Hall.

[23] Toruński, J. (2011). Quality management of consulting services on the example of the Agricultural Consulting Centre. Zeszyty Naukowe Uniwersytetu Przyrodniczo-Humanistycznego w Siedlcach. Seria: Administracja i Zarzadzanie, 16 (89), 9-24.

[24] Trziszka, T., Nowak, Cz. \& Chyłek, E.K. (2009). Bariery wprowadzenia do praktyki w sektorze rolnospożywczym nowoczesnych technik i technologii. Zagadnienia Doradztwa Rolniczego, 4, 33-54.

[25] Werr, A., \& Stjernberg T. (2003). Exploring Management Consulting Firms as Knowledge Systems. Organization Studies, 24(6), 881-908, doi.org/10.1177/0170840603024006004.

[26] Wiatrak, A.P. (2008). Advisory services in the system of public services. Their essence, scope and functions. Wspótczesne Zarządzanie, 2, 34-44. 


\title{
Comparative Analysis of the Milk Market in the V4 Member Countries
}

\author{
Veronika Mihálová ${ }^{1}$, Daniela Hupková ${ }^{2}$, Ludmila Dobošová ${ }^{3}$, Ondrej Beňuš ${ }^{4}$, \\ Yelyzaveta Synetska ${ }^{5}$, Erika Loučanová ${ }^{6}$ \\ Slovak University of Agriculture in Nitra \\ Faculty of Economics and Management, Department of Economics ${ }^{1,2,3,4,5}$ \\ Address: Tr. A. Hlinku 2, \\ 94976 Nitra, Slovakia \\ e-mail: mihalova.ve@gmail.com¹; daniela.hupkova@uniag.sk², DobosovaL@gmail.com³, \\ ondrej.benus@uniag.sk ${ }^{4}$, xsynetska@is.uniag.sk ${ }^{5}$, loucanova@tuzvo.sk ${ }^{6}$
}

\section{doi: 10.18515/dBEM.ISD.P01.2020.p027}

\begin{abstract}
Milk as a major commodity derived from animal production is source of a number of dairy products form a substantial part of the population's diet. Milk is produced in every Member State of the European Union. The Slovak milk market is part of the EU's open market and is affected by the situation on world markets. The main objective of the article is to describe the evolution of main indicators of milk market, to compare them between the The Visegrad Four (V4) countries. V4 is a group of four Central European countries: Slovakia, the Czech Republic, Hungary and Poland, which joined the European Union on 1 May 2004. Therefore, the article evaluates selected indicators in the period from the accession of V4 countries to the EU to the present day limited by the data obtained. The article also presents data on the use of milk produced in the EU in 2018 as well as the development of basic indicators of the milk market in Slovakia. The agriculture of the Slovak Republic has undergone many changes in recent decades. In particular, the transformation process with liberalization requirements has had an impact on reducing agricultural production by intensifying foreign competition and weakening domestic demand. We revealed, Slovakia has the lowest cow's milk production per capita among the V4 countries as well as the lowest milk consumption. Raw cow's milk prices in each V4 country were below the EU average throughout the period under review and changed so significantly that this demonstrates the volatility of the agrarian milk market.
\end{abstract}

Keywords: milk production, cow's milk, price, V4 countries

JEL Classification: E31, Q02, Q11

\section{Introduction}

Each EU Member State is involved in the production of milk in the European Union (EU). Despite the instruments of the Common Agricultural Policy (CAP), farmers in EU Member States do not have the same producer prices of raw cow's milk. There are significant differences, with V4 countries having their production prices below the EU average for a long time. The reason is different natural conditions of each country, different productivity and number of dairy cows. The CAP has regulated milk production in the EU through a milk quota system. After the abolition of milk quotas, farmers can better focus on market opportunities and track market needs. It also affected the prices of milk and dairy products. Countries that have significantly increased their production after the abolition of quotas are able to break through to foreign markets and compete with domestic producers at lower prices. Slovak farmers are unable to produce milk at as low costs as German, which in Slovakia means that domestic milk will be sold at a higher price than imported German milk. Milk producers in their home country can sell at a loss or should look for more efficient ways of lowering their costs and getting to the level of milk production price at the EU average level. Price volatility attends the agricultural 
markets still, but in extreme cases countries have access to tools such as storage regimes, public purchase of butter or milk powder.

Milk is produced in every Member State of the European Union without exception. Milk is even the most important product in the EU in terms of value, as it accounts for about $15 \%$ of agricultural production. The EU is an important member of the world market for milk and dairy products as a leading exporter of many dairy products, most of which are cheeses. The total current EU-28 milk production is estimated at around 166 million tons per year. The main producers are Germany, France, Great Britain, Poland, Netherlands and Italy, which account for almost $70 \%$ of the total EU production (Hörl \& Hess, 2017). The largest world producers are also the US, Australia and New Zealand.

After years of significant overproduction of milk and dairy products, in 1984 the Common Agricultural Policy introduced milk quotas in the EU. Earlier, European milk producers had guaranteed milk prices (significantly higher than on world markets) regardless of market demand. The system also had an impact on prices in the world market as the EU subsidized exports to these markets. Since 1984 each European state has had two types of quota: the first defined the maximum quantity of milk delivered to the dairy and the other determined the limit for direct sales at farm level. If the manufacturer exceeds a given limit and achieves overproduction, appropriate sanctions have been imposed. (Statistics Explained, 2015)

Progressive reforms of the EU Common Agricultural Policy (CAP) have focused more on the market providing more tools to help producers in sensitive areas such as mountain areas where production costs are higher, states European Commission (2017). In 2003 the European Commission decided to partially reform the dairy sector and abolish the quota system in 2015 .

The EU is the most important milk producer in the world and a major player which, with or without quotas, is connected with the dynamics world market. Quotas certainly do impede farmers to follow market signals and take advantage of market opportunities. Following the ending of milk quotas, production should be based on market needs. (NFU, 2015) However, raw cow's milk production in the EU is dependent on factors: gross domestic product at market prices, final consumption expenditure of households and population according to Bórawski et al. (2020).

The quota system - and the threat of levies - have helped limit the development of EU production. Since then, there have been other important changes to the CAP which have led to a much more market-oriented sector. Gradual CAP reforms have seen a reduction in guaranteed prices, with a number of policy instruments aimed at stabilizing farmers' incomes, in particular the direct payments system, separated from production. (NFU, 2015)

Changes in the product market lead to shifts in milk prices. Production of all products increases under the quota elimination scenario. The fall in prices will cause liquid milk consumption to increase by 3 to $4 \%$ compared to baseline values. Cheese production will rise by 7 to $10 \%$. (Westhoff \& Young, 1999)

Budzynska \& Chojnacki (2018) confirm that after the abolition of milk quotas, the competitiveness of the EU dairy sector has increased, which also shows a more than $4 \%$ increase in milk production and the expansion of dairy products to world markets. With an over $80 \%$ increase in butter exports, a $42 \%$ increase in skimmed milk powder exports and a $5 \%$ increase in cheese exports, the EU has become the largest exporter of these products. While the situation is pushing prices down, producers have guaranteed adequate revenues due to increased product sales. This should support further improving the competitiveness of the EU dairy industry on the world market due to the increasing demand for dairy products. 
Not only the quota system has affected milk production and prices. There are many differences between dairy sectors in each country. Cechura et al. (2014) show productivity and efficiency differences between Czech and Slovak milk producers. They confirmed with estimate of stochastic metafrontier multiple output distance function that both Czech and Slovak milk producers highly exploit their production possibilities. However, it turned out that productivity was different. Only the West Slovak regions can keep pace with competitors. Other regions of Slovakia were found to be lagging behind. The most productive regions are Central Bohemia and Moravian-Silesian regions. Regional differences are caused by the technical efficiency and management component.

According to Bouamra-Mechemache et al. (2008), demand is the main factor driving the market prices of dairy products in the EU. Demand for dairy products is relatively price inelastic but is more sensitive to changes in income (especially for butter and cheese). If the growth rate of demand for dairy products is $0.5 \%$ per year, ten years later, agricultural milk prices would be 5-7\% lower and the producer surplus would be reduced by EUR 2 billion.

Based on the relationship between the V4 countries, Vargová \& Rajčániová (2017) verified the validity of the law of one price between raw cow's milk prices in 2005-2017. The fastest correction after the price shock will occur on the Hungarian market. The Slovak market reacts faster to price shocks than the Polish market and it takes the Polish market the longest time to return to equilibrium. They also confirmed that Slovakia and the Czech Republic are more sensitive to the shocks of the Hungarian market than Poland.

\section{Data and Methods}

This article presents data from publicly available online sources, in particular the European institutions, which were the source of data on prices, milk production and utilisation of milk. Data on basic dairy market indicators were obtained from public sources such as VUEPP, Eurostat, Faostat and the European Commission. The investigated commodity in paper is milk, because milk is a major agricultural commodity and dairy products have a significant share of the food market of each EU country. Milk accounts for around 15\% of total EU agricultural production.

The paper uses a comparison method, which compares the values of variables (milk production, milk consumption, apparent milk yield, milk prices) at the horizontal level, i.e. for territorially separated units at the national level. For comparison in the paper are chosen EU countries - the Visegrad four.

The Visegrad Four (V4) was founded in 1991 by three countries, one of which was divided into the current two states and thus disappeared. V4 is a group of four Central European countries: Slovakia, Czech Republic, Hungary and Poland. The advantage is that the people of the countries have common religious traditions, cultural and intellectual values that they want to protect and develop. On 1 May 2004, they joined the European Union together in an effort to remove obstacles in cooperation with other countries located in Europe. The Visegrad Four has only one institution and it is the International Visegrad Fund, which has been working since 1999 and is based in Bratislava. 
Table 1: Area and population in V4 countries, 2015

\begin{tabular}{lcc} 
& Area $\left.\mathbf{( k m}^{\mathbf{2}}\right)$ & Population (mil.) \\
\hline Slovakia & 49000 & 5,4 \\
Czech Republic & 79000 & 10,5 \\
Poland & 313000 & 38 \\
Hungary & 93000 & 9,8 \\
\hline
\end{tabular}

Source: European Union (2019)

Indexes are used to reflect the annual change in indicators. They quantify by what percentage the observed indicator has declined or increased. Indexes are counted as follows:

$$
\text { Index }(\%)=\left(\left(\frac{\text { Indicator }_{t}}{\text { Indicator }_{t-1}}\right)-1\right) * 100 \%
$$

Because the apparent milk yield depends on the dairy cow's structure, this article calculates the apparent milk yield by the following formula:

$$
\text { Apparent milk yield }(\mathrm{kg} \text { per cow })=\frac{\text { Raw cow's milk produced }(1000 \text { tonnes })}{\text { Dairy cows }(1000 \text { heads })} * 1000
$$

\section{Results and Discussion}

In 2019 cow's milk collection has a downward trend in the EU, as in January 2019 it decreased by $1,5 \%$ (value of 196000 tonnes) compared to January 2018. Poland $(+3,2 \%)$, the United Kingdom $(+1,7 \%)$, Romania $(+6 \%)$ and Estonia $(+4,9 \%)$ recorded a positive year-on-year change in cow's milk collection. On the other hand, cow's milk collection decreased year-onyear in Bulgaria (-12,7\%), Austria (-7,6\%), Hungary (-6,6\%). Since milk collection is related to production, in 2019 a decrease in cow's milk collection resulted in a reduction in the production of dairy products, specifically whole milk powder, skimmed milk powder, drinking milk, cheese and butter. In January 2019, cheese exports increased by $8 \%$ compared to January last year. The largest customers were the USA, Japan and Switzerland. Export of milk powder began to rise more, while exports of butter, butter oil and whey fell. (European Union, 2019)

Table 2 shows differences in production of cow's milk and milk products between V4 countries. There are two ways of utilisation of milk production on a farm. Mainly, the raw milk is used to deliver to further processing by the dairy industry, what means cow's milk collection. The second part of the use of milk produced on the farm generally includes domestic consumption, direct sales and cattle feeding. More than $90 \%$ of raw cow's milk goes to the processing industry; almost 5\% of the milk is consumed by livestock in Slovakia. The largest milk producer in EU is Germany, which produces more than 30 mil. tons of cows' milk and obtained products. The second largest EU producer is France and the third is United Kingdom. Slovakia has the lowest cow's milk production among the V4 countries, but at the beginning of the analysed period, it was Hungary. Now, Hungary produces 1,5 times more milk than Slovakia, which was $33 \mathrm{~kg}$ more per capita in 2018. Overall, the Czech Republic achieves more than triple milk production than Slovakia and is $44 \%$ more per capita. Poland also exceeds the milk production of 13 times more compared to Slovakia and it is $207 \mathrm{~kg}$ more per capita. Of course, cow's milk production depends on factors such as cattle stocks in each country, as well as the level of agriculture and the associated climatic conditions. The level of production in V4 countries in 2018 is different from that in 2004 . Slovakia as the only V4 country showed an average yearon-year decrease in milk production per capita by $1,5 \%$. Other V4 countries increased their production over the period under review. Production in Poland increased the most and the least in Hungary. 
Table 2: Raw cow's milk from farm per capita (kg) and indexes of changes

\begin{tabular}{|c|c|c|c|c|c|c|c|c|}
\hline & \multicolumn{2}{|c|}{ Czechia } & \multicolumn{2}{|c|}{ Hungary } & \multicolumn{2}{|c|}{ Poland } & \multicolumn{2}{|c|}{ Slovakia } \\
\hline & $\begin{array}{l}\text { Raw } \\
\text { cow's } \\
\text { milk per } \\
\text { capita }\end{array}$ & $\begin{array}{l}\text { Index of } \\
\text { year-on- } \\
\text { year } \\
\text { change }\end{array}$ & $\begin{array}{c}\text { Raw } \\
\text { cow's } \\
\text { milk per } \\
\text { capita }\end{array}$ & $\begin{array}{c}\text { Index of } \\
\text { year-on- } \\
\text { year } \\
\text { change }\end{array}$ & $\begin{array}{c}\text { Raw } \\
\text { cow's } \\
\text { milk per } \\
\text { capita }\end{array}$ & $\begin{array}{c}\text { Index of } \\
\text { year-on- } \\
\text { year } \\
\text { change }\end{array}$ & $\begin{array}{c}\text { Raw } \\
\text { cow's } \\
\text { milk per } \\
\text { capita }\end{array}$ & $\begin{array}{c}\text { Index of } \\
\text { year-on- } \\
\text { year } \\
\text { change }\end{array}$ \\
\hline 2004 & 255,25 & - & 187,27 & - & 309,55 & - & 200,86 & - \\
\hline 2005 & 275,79 & $8,04 \%$ & 191,01 & $1,99 \%$ & 312,33 & $0,90 \%$ & 204,74 & $1,93 \%$ \\
\hline 2006 & 270,66 & $-1,86 \%$ & 183,01 & $-4,19 \%$ & 314,02 & $0,54 \%$ & 203,24 & $-0,73 \%$ \\
\hline 2007 & 268,75 & $-0,71 \%$ & 183,01 & $0,00 \%$ & 317,27 & $1,04 \%$ & 200,07 & $-1,56 \%$ \\
\hline 2008 & 270,80 & $0,76 \%$ & 183,22 & $0,11 \%$ & 325,98 & $2,75 \%$ & 196,61 & $-1,73 \%$ \\
\hline 2009 & 266,71 & $-1,51 \%$ & 175,28 & $-4,33 \%$ & 326,39 & $0,12 \%$ & 177,80 & $-9,57 \%$ \\
\hline 2010 & 256,45 & $-3,85 \%$ & 168,25 & $-4,01 \%$ & 322,94 & $-1,06 \%$ & 170,30 & $-4,22 \%$ \\
\hline 2011 & 260,86 & $1,72 \%$ & 171,49 & $1,93 \%$ & 326,15 & $0,99 \%$ & 172,15 & $1,08 \%$ \\
\hline 2012 & 267,93 & $2,71 \%$ & 182,53 & $6,43 \%$ & 332,81 & $2,04 \%$ & 172,59 & $0,25 \%$ \\
\hline 2013 & 270,96 & $1,13 \%$ & 178,91 & $-1,98 \%$ & 334,13 & $0,40 \%$ & 168,54 & $-2,34 \%$ \\
\hline 2014 & 279,05 & $2,99 \%$ & 189,90 & $6,14 \%$ & 341,58 & $2,23 \%$ & 171,85 & $1,96 \%$ \\
\hline 2015 & 287,13 & $2,90 \%$ & 196,98 & $3,73 \%$ & 348,26 & $1,96 \%$ & 171,72 & $-0,07 \%$ \\
\hline 2016 & 290,39 & $1,13 \%$ & 195,13 & $-0,94 \%$ & 348,83 & $0,16 \%$ & 166,83 & $-2,85 \%$ \\
\hline 2017 & 291,07 & $0,24 \%$ & 200,82 & $2,91 \%$ & 360,62 & $3,38 \%$ & 167,74 & $0,55 \%$ \\
\hline 2018 & 297,97 & $2,37 \%$ & 199,30 & $-0,75 \%$ & 373,15 & $3,47 \%$ & 166,20 & $-0,92 \%$ \\
\hline $\begin{array}{c}\text { Average } \\
2004- \\
2018\end{array}$ & & $1,15 \%$ & & $0,50 \%$ & & $1,35 \%$ & & $-1,30 \%$ \\
\hline
\end{tabular}

Source: Eurostat (2019)

Individual milk yields can be affected by many factors but the apparent milk yield depends on the structure of the dairy herd. The apparent milk yield in the EU reached $7208 \mathrm{~kg}$ per cow in 2018. Poland has the highest number of dairy cows as well as produced cow's milk, but at the same time, it shows the lowest apparent milk yield below the EU average. The Slovak Republic with several times lower production and the number of dairy cows than Poland is also below the EU average. Czechia and Hungary achieve above-average apparent milk yield. Among the EU countries, Denmark, Estonia and Finland have the highest values of apparent milk yield and Czechia is on the $7^{\text {th }}$ place.

Table 3: Milk production, dairy cows and apparent milk yield, 2018

\begin{tabular}{|c|c|c|c|}
\hline & $\begin{array}{c}\text { Raw cow's milk } \\
\text { produced (1000 } \\
\text { tonnes })\end{array}$ & $\begin{array}{c}\text { Dairy cows } \\
(1000 \text { heads })\end{array}$ & $\begin{array}{c}\text { Apparent milk } \\
\text { yield (kg per } \\
\text { cow) }\end{array}$ \\
\hline Czechia & 3162 & 359 & 8816 \\
\hline Hungary & 1949 & 239 & 8154 \\
\hline Poland & 14171 & 2214 & 6400 \\
\hline Slovakia & 905 & 128 & 7075 \\
\hline
\end{tabular}

Source: Eurostat (2020), own calculation 
Figure 1: Milk consumption kg/capita/year (excluding butter)

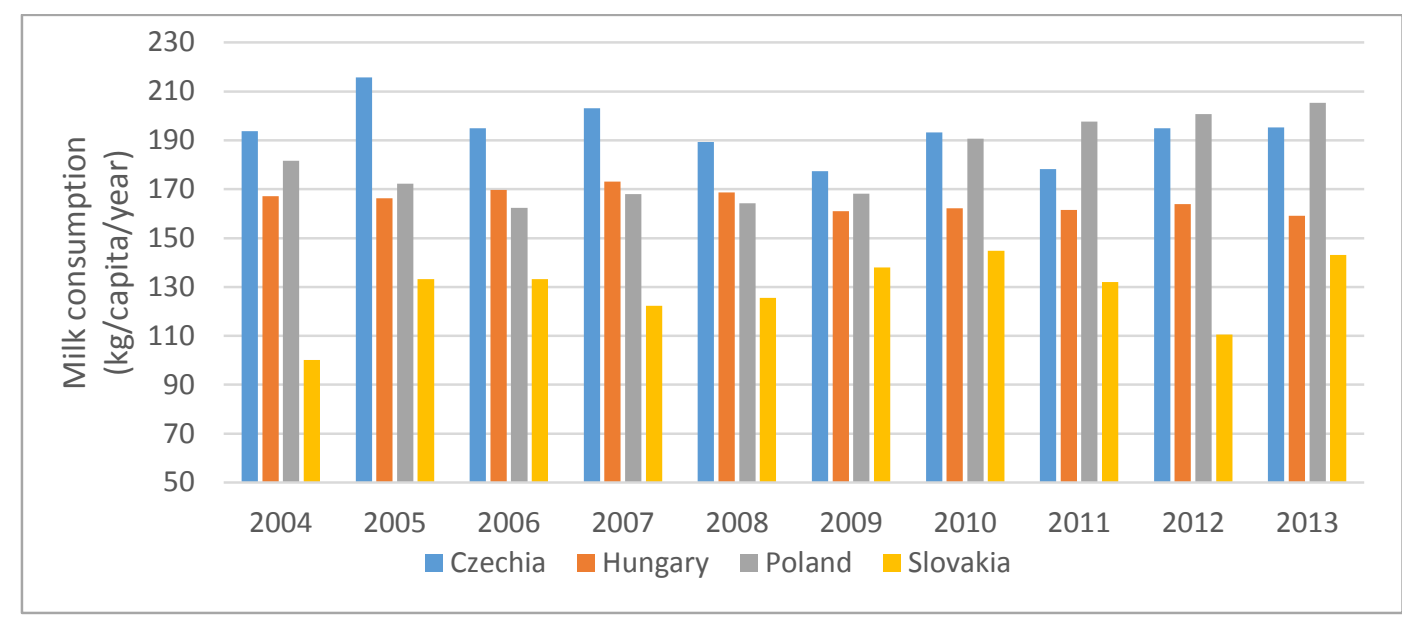

Source: Faostat (2020)

In the period under review, the Czech Republic had the highest milk consumption until 2011; since that year, it was Poland. Slovakia has the lowest milk consumption among the V4 countries and has a persistent problem that it is well below the OECD recommended dose in consumption of milk and dairy products. Hungary achieves higher milk consumption than Slovakia, which decreased by $5 \%$ over the period under review, while it increased by $43 \%$ in Slovakia. Milk consumption also showed an upward trend in Poland of $13 \%$. Generally, western EU countries have higher milk consumption and their average life expectancy is 4 years longer, which may be related to milk consumption.

However, both processors and milk producers in Slovakia are seeking to increase milk consumption to the recommended value through various support programs that are adapted to their characteristics by the target group. The "Adopt a Cow" program has been developed for children to familiarize themselves with the food vertical of milk, ie how milk gets from the producer to the consumer. The "School Milk" program, which promotes milk consumption in school canteens and is being implemented through subsidies to milk processors, is ongoing.

On the Table 4 is describing of milk utilisation in whole EU in 2018. Totally, there was 156,8 million tonnes of whole milk processed by production. From milk delivered to dairies are processed a lot of fresh and manufactured products. By production of butter and yellow products in 201843 million tons of skimmed milk was generated and 46,1 million tons of whole milk was needed. Big volume of all EU's milk delivered to dairies was used by cheese and butter production. In 2018, 30,1 million tons of drinking milk was produced and placed on the EU milk market, which is $1,95 \%$ less than last year. On the contrary, cheese was produced more than in 2017 (10,3 million tonnes). EU milk market offered in 2018 8,2 million tons of acidified milk, the same as last year.

Table 4: Utilisation of milk and dairy products obtained in 2018, EU (million tonnes)

\begin{tabular}{|l|r|r|r|}
\hline & \multicolumn{2}{|c|}{ Utilization of milk } & Products \\
& $\begin{array}{c}\text { Skimmed } \\
\text { milk }\end{array}$ & Whole milk & obtained \\
\hline Total & 2,0 & 156,8 & - \\
\hline Sub-total of processes generating skimmed milk & $-58,4$ & 64,8 & - \\
\hline Butter and yellow products & $-43,0$ & 46,1 & 2,4 \\
\hline Cream & $-15,4$ & 18,7 & 2,7 \\
\hline $\begin{array}{l}\text { Sub-total of processes consuming skimmed } \\
\text { milk }\end{array}$ & 60,4 & 92,0 & \\
\hline Drinking milk & & & \\
\hline
\end{tabular}




\begin{tabular}{|l|r|r|r|}
\hline Powder products & 21,3 & 4,6 & 3,0 \\
\hline Concentrated milk & 1,1 & 1,6 & 1,1 \\
\hline Acidified milk & 1,4 & 6,8 & 8,2 \\
\hline Buttermilk & 0,5 & 0,0 & 0,5 \\
\hline Cheese & 17,0 & 59,1 & 10,3 \\
\hline Milk based drinks & 1,0 & 0,6 & 1,8 \\
\hline Caseins & 5,9 & 0,0 & 0,2 \\
\hline Other fresh products & $-0,2$ & 1,9 & 2,4 \\
\hline
\end{tabular}

Source: Statistics Explained (2020)

Figure 2: Monthly prices of raw cow's milk Jan 2004 - Dec 2018 (eur/100 kg)

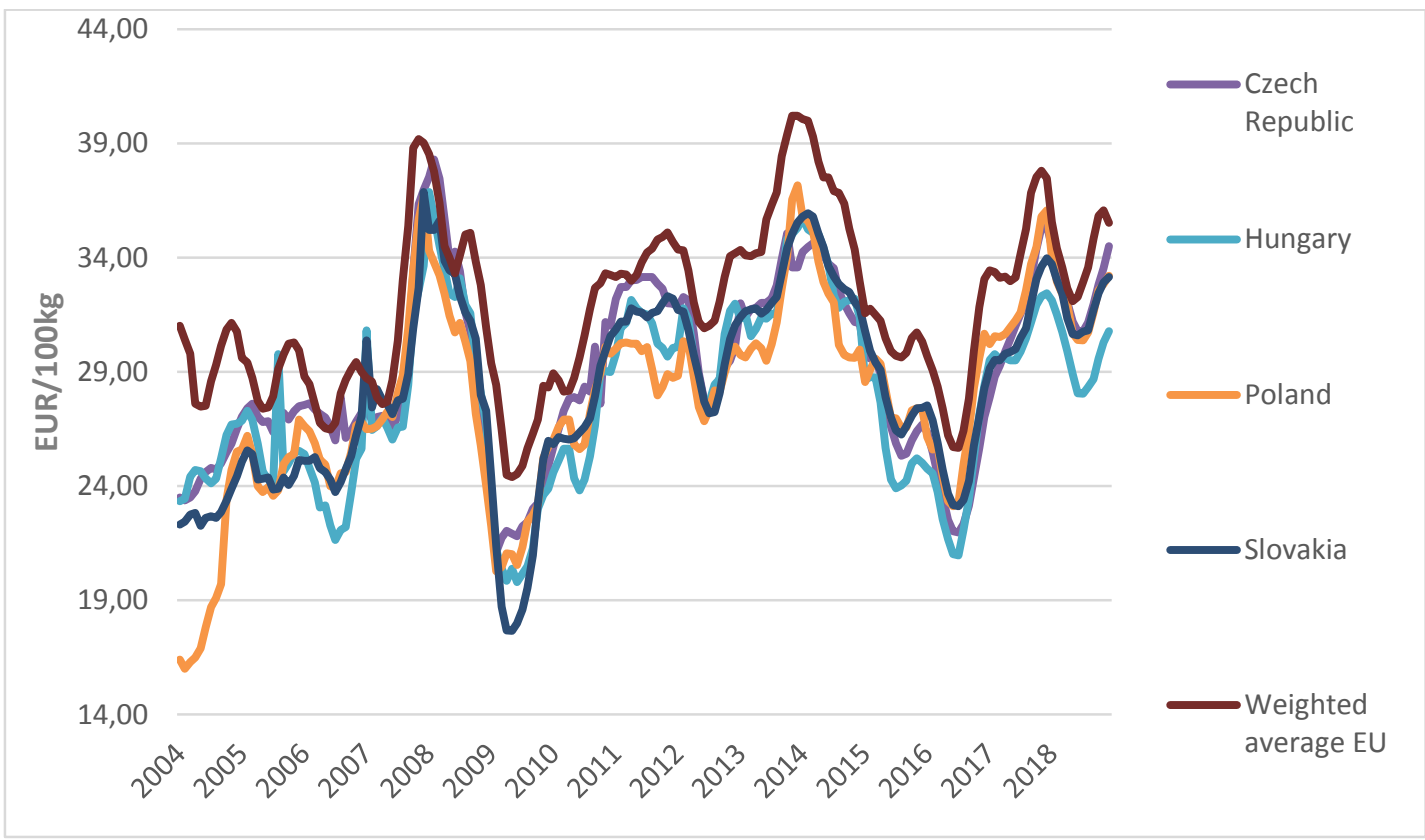

Source: European Commission (2019)

Since the accession to the European Union, there have been many differences in the monthly prices of raw cow's milk between the V4 countries (see Figure 2). In 2004, when the V4 countries joined the European Union together, their prices were well below the EU average with a variation of around 5 eur/100 kg for Hungary and the Czech Republic. For Poland, the deviation was the biggest, as in the first months it was almost 15 eur $/ 100 \mathrm{~kg}$. Raw cow's milk prices approached the EU average after a few months, but the problem is that they cannot match the EU average throughout the period. Prices in the V4 countries only followed developments over the period under review, but were still below the EU average. The fact, that milk production prices in Slovakia have been below the EU average for a long time and that processors buy milk from primary producers in Slovakia for a lower amount than the EU average is highlighted by Ryba, 2018. He also points to the values of aid paid to dairy farmers, primary producers, exceptional aid, compensatory payments or CAP 1st and 2nd pillar payments, the aim of which is to stabilize dairy cow numbers in the Slovak Republic, which fell by $18.57 \%$ in the $2004-2017$ reporting period. Figure 2 shows that the EU average of cow's milk prices was exceeded by Hungary and Slovakia in early 2007 and the Czech Republic in 2008 .

By comparing the prices of raw cow's milk on the European market according to Figure 2, we can characterize international dairy markets as markets with significant price volatility. The development of milk prices could be described as reflecting the fluctuation of the phases of higher and lower prices. The last months of 2007 brought a significant increase in prices carried over to 2008. Already in May 2007, most agricultural experts expected that milk prices will 
jump in coming months as producers pass along increased costs for livestock feed (higher corn prices because of ethanol) and a spike in overseas demand (CNNMoney, 2019). In 2009, milk prices fell by an average of $35 \%$ from their maximum, due to a reduction in milk demand, due to the economic recession and excess supply on international markets. The following years, when the economy recovered and demand rose again, average EU prices of raw cow's milk increased until 2013. Milk prices reached their maximum in November 2013, as a result of the impending crisis and the high input price. In 2015, we see another significant reduction in milk prices. The reasons were a decline in demand in response to high prices in 2013, an increase in dairy production in China and an embargo of the Russian Federation on dairy products from the main export countries. In 2016, milk prices were low as it was after the abolition of milk quotas and milk production increased. The reason why milk prices have risen again after 2016 can be found in demand and cattle. According to the development of dairy cows, it is clear that their numbers are decreasing and so fewer cows have to meet demand. Farmers are reducing their cows because feed prices have gone up last year.

The primary production and processing of milk is one of the most important sectors of the Ministry of Agriculture and Rural Development of the Slovak Republic. The Slovak milk market is part of the EU's open market and is also secondarily influenced by the situation on world markets. The primary production of milk is at the first stage of the vertical of the milk supply chain. It represents the structure of entities such as agricultural cooperatives, farms, dairy farms and subsequently the production of raw cow's milk. Primary producers are the weakest link of the whole vertical due to the high fragmentation and specificity of their production.

Table 5: Basic indicators about milk sector in Slovakia and their indexes

\begin{tabular}{|c|c|c|c|c|c|c|c|c|}
\hline Indicator & $\begin{array}{l}\text { Number of } \\
\text { dairy cows } \\
\text { (1000 head) }\end{array}$ & $\begin{array}{l}\text { Index of } \\
\text { change }\end{array}$ & $\begin{array}{l}\text { Milk yield } \\
(\mathrm{kg} / \mathrm{cow})\end{array}$ & $\begin{array}{l}\text { Index of } \\
\text { change }\end{array}$ & $\begin{array}{c}\text { Milk } \\
\text { production } \\
(1000 \mathrm{t})\end{array}$ & $\begin{array}{l}\text { Index of } \\
\text { change }\end{array}$ & $\begin{array}{c}\text { Costs (eur/1 } \\
\text { liter of } \\
\text { milk) }\end{array}$ & $\begin{array}{l}\text { Index of } \\
\text { change }\end{array}$ \\
\hline 2007 & 181 & - & 5946 & - & 1074,6 & - & 0,37 & - \\
\hline 2008 & 176 & $-2,76 \%$ & 6025 & $1,33 \%$ & 1057,2 & $-1,62 \%$ & 0,4 & $8,11 \%$ \\
\hline 2009 & 166 & $-5,68 \%$ & 5770 & $-4,23 \%$ & 957,3 & $-9,45 \%$ & 0,37 & $-7,50 \%$ \\
\hline 2010 & 161 & $-3,01 \%$ & 5692 & $-1,35 \%$ & 918 & $-4,11 \%$ & 0,39 & $5,41 \%$ \\
\hline 2011 & 156 & $-3,11 \%$ & 5946 & $4,46 \%$ & 928,3 & $1,12 \%$ & 0,43 & $10,26 \%$ \\
\hline 2012 & 152 & $-2,56 \%$ & 6296 & $5,89 \%$ & 959,4 & $3,35 \%$ & 0,4 & $-6,98 \%$ \\
\hline 2013 & 147 & $-3,29 \%$ & 6334 & $0,60 \%$ & 933,9 & $-2,66 \%$ & 0,42 & $5,00 \%$ \\
\hline 2014 & 146 & $-0,68 \%$ & 6505 & $2,70 \%$ & 948,7 & $1,58 \%$ & 0,42 & $0,00 \%$ \\
\hline 2015 & 142 & $-2,74 \%$ & 6733 & $3,50 \%$ & 957,4 & $0,92 \%$ & 0,38 & $-9,52 \%$ \\
\hline 2016* & 138 & $-2,82 \%$ & 6900 & $2,48 \%$ & 952,2 & $-0,54 \%$ & - & - \\
\hline $\begin{array}{c}\text { Average } \\
2007- \\
2016\end{array}$ & & $-2,96 \%$ & & $1,71 \%$ & & $-1,27 \%$ & & $0,60 \%$ \\
\hline
\end{tabular}

Source: VUEPP, * estimate, - not available

Number of dairy cows decreased by $24 \%$ in Slovakia in the period 2007-2016, with an average year-on-year decline of $2,96 \%$. The main reasons were rising input prices, low profitability of milk production, imports of milk and dairy products to Slovakia, agrarian market volatility mainly due to extreme weather fluctuations with impact on cereal and feed prices and the European milk crisis, which caused a dramatic fall in farm milk prices. On the other hand, milk yields increase by an average of $1,71 \%$ year on year. Aspects of increasing are improving animal husbandry conditions, advances in animal genetics, breeding practices and innovations in technology that make it possible to achieve above-average milk yields in some areas of 
Slovakia around $10000 \mathrm{~kg}$ per dairy cow. Only in 2009 and 2010, the milk yields fell due to the global crisis, when farmers were saving on feed rations and animal health care to reduce costs.

Milk production has a downward trend in Slovakia and the reason is the decline in dairy cows, which is stronger year-on-year than the increase in the milk yield per cow. On the other side, the situation in primary production as well as in the manufacturing industry is also strongly influenced by the policy of retail chains that import too many dairy products to Slovakia that compete with Slovak products in price. Based on the above facts, the total production of cow's milk in Slovakia decreased by $11,4 \%$ in the period under review. The primary milk production in Slovakia and consequently the dairy industry in Slovakia are significantly influenced by the situation on the international dairy markets due to the openness and production performance of the Slovak economy, especially within the EU. According to Eurostat data, we accounted for $0,57 \%$ of total EU milk production in 2017 .

\section{Conclusion}

The European Union is the most important milk producer in the world and is connected with the dynamics world market. Each EU Member State is involved in the production of milk in the European Union. EU milk production was regulated by the CAP through a milk quota system. After the abolition of milk quotas, farmers can better focus on market opportunities and competitiveness of the EU dairy sector has increased.

Totally, there was 156,8 million tonnes of whole milk processed in 2018 and Slovakia produced 904,62 thousand tonnes cow's milk in this year. More than $90 \%$ of all cow's milk produced on a farm in Slovakia was collected, delivered to dairies and used to produce dairy products in the processing industry. Slovakia has the lowest cow's milk production among the V4 countries and as the only V4 country showed an average year-on-year decrease in milk production per capita by $1,5 \%$. Hungary produces $33 \mathrm{~kg}$ more milk per capita than Slovakia, Czechia $32 \mathrm{~kg}$ more per capita and Poland $207 \mathrm{~kg}$. Poland is the country with the highest number of dairy cows and milk produced, but it has the lowest apparent milk among the V4 countries. On the other hand, Czechia and Hungary are above the EU average.

Slovakia and Hungary are lagging in milk consumption per capita, but Poland and the Czech Republic have a satisfactory consumption. On the positive side, milk consumption in Slovakia and Poland has increased, while unfortunately in Hungary. In consumption of milk and dairy products, Slovakia is below the recommended WHO doses of $220 \mathrm{~kg}$ per person, but milk producers and processors are developing programs to increase it.

In 2004, when the V4 countries joined the European Union, their milk prices were well below the EU average with a huge variation. They were still below the EU average over the period under review and just followed development of EU average price. These low milk prices in connection with the high costs of Slovak farmers affected, that they produce at a loss and without financial support, they would all shut down. Unfortunately, domestic dairy products are sold at a higher price than imported, which could displace domestic products.

The prices of raw cow's milk on the European market characterize international dairy markets as markets with significant price volatility. Milk prices reached their maximum in 2008 and then fell by an average of $35 \%$, due to a reduction in milk demand, due to the economic recession and excess supply on international markets. Following years, the economy recovered and demand rose again. In 2015, a significant reduction in milk prices was caused due to a decline in demand, an increase in milk production in China, and an embargo of the Russian 
Federation on dairy products. Last years, the milk prices have gone up because of higher feed prices.

The Slovak milk market is part of the EU's open market and is also secondarily influenced by the situation on world markets. Total production of cow's milk in Slovakia fell by $11,4 \%$ in the period 2007-2016 due to a decline in dairy cows. Number of dairy cows decreased because of rising input prices, low profitability of milk production, imports of milk and dairy products and market volatility. On the other hand, the milk yield of dairy cows increases from year to year.

\section{Acknowledgements}

This paper was supported by the Ministry of Education, Science, Research and Sport of the Slovak Republic under project VEGA 1/0913/17

\section{References}

[1] Bouamra-Mechemache, Z., Réquillart, V., Soregaroli, C., \& Trévisiol, A. (2008). Demand for dairy products in the EU. Food Policy, 33(6), 644-656. doi: 10.1016/j.foodpol.2008.05.001

[2] Bórawski, P., Pawlewicz, A., Parzonko, A., K. Harper, J., \& Holden, L. (2020). Factors Shaping Cow's Milk Production in the EU. Sustainability, 12(1), 420. doi: 10.3390/su12010420

[3] Budzynska, A., \& Chojnacki, P. (2018). Competitiveness of EU Dairy Industry in the Global Market after the Abolition of Milk Quotas. Vienna (Austria): 29th IBIMA Conference, 2778-2788. Retrieved from https://ibima.org/accepted-paper/competitiveness-of-eu-dairy-industry-in-the-global-market-after-theabolition-of-milk-quotas/

[4] Cechura, L., Hockmann, H., Mala, Z., \& Maly M. (2014). Productivity and efficiency differences between Czech and Slovak milk producers. Review of Agricultural and Applied Economics (RAAE), 17(2), 17-21. doi: 10.22004/ag.econ.196636

[5] CNNMoney. (2019). Got milk? Get ready to pay more. Retrieved September 25, 2019, from https://money.cnn.com/2007/05/02/news/economy/corn_milkprices/

[6] European Commission. (2019). Milk market observatory [statistics]. Available from https://ec.europa.eu/info/food-farming-fisheries/farming/facts-and-figures/markets/overviews/marketobservatories/milk-market-observatory_en

[7] European Union. (2019). European Union: 500 million people - 28 countries [PowerPoint slides]. Retrieved from https://europa.eu/european-union/sites/europaeu/files/docs/body/eu_in_slides_sk.pdf

[8] Eurostat. (2019). Production of cow's milk on farms by NUTS 2 regions [statistics]. Available from https://ec.europa.eu/eurostat/data/database?p_p_id=NavTreeportletprod_WAR_NavTreeportletprod_INST ANCE_nPqeVbPXRmWQ\&p_p_lifecycle $=0 \& p \_p \_s t a t e=$ normal\&p_p_mode $=$ view\&p_p_col_id $=$ column$2 \& \mathrm{p} \_\mathrm{p}$ _col_pos $=1 \& \mathrm{p} \_\mathrm{p} \_$col_count $=2$

[9] Eurostat. (2020). Milk and milk product statistics [statistics]. Available from https://ec.europa.eu/eurostat/statisticsexplained/index.php/Milk_and_milk_product_statistics\#Milk_production

[10] Faostat. (2020). Food Supply - Livestock and Fish Primary Equivalent [statistics]. Available from http://www.fao.org/faostat/en/\#data/CL

[11] Hörl, M., \& Hess, S. (2017). The Export Competitiveness of the EU Dairy Industry. XV EAAE Congress, "Towards Sustainable Agri-food Systems: Balancing Between Markets and Society" August 29th September 1st, 2017.2 Parma, Italy. Retrieved from http://ageconsearch.umn.edu/record/260893/files/The\%20Export\%20Competitiveness\%20Of\%20The\%20E U\%20Dairy\%20Industry.pdf

[12] NFU Online. (2015). The end of milk quotas: FAQs. Retrieved September 25, 2019 from https://www.nfuonline.com/sectors/dairy/dairy-news/the-end-of-milk-quotas-faqs/

[13] Polytechnika. (2013). Pripravme sa na zrušenie kvót mlieka. Retrieved September 30, 2019 from http://www.polytechnika.sk/admin/files/1407.pdf 
[14] Ryba, Š. (2018). Situácia na trhu mlieka a mliečnych výrobkov doma a v Európskej únii. Rol'nícke noviny: Dojnice, VII, 4-7. ISSN 0231-6617. Retrieved from https://www.rno.sk/dojnice-2017/

[15] Statistics Explained. (2015). Milk and milk products - 30 years of quotas. Retrieved September 30, 2019 from https://ec.europa.eu/eurostat/statistics-explained/index.php/Archive:Milk_and_milk_products__30_years_of_quotas

[16] Statistics Explained. (2020). Utilisation of milk and dairy products obtained, EU-28, 2017 (million tonnes) [statistics]. Available from https://ec.europa.eu/eurostat/statisticsexplained/index.php?title=File:Utilisation_of_milk_and_dairy_products_obtained,_EU-

28,_2018_(million_tonnes).png

[17] Vargová, L., \& Rajčániová, M. (2017). Spatial Price Transmission of Milk Prices Among the Visegrad Countries. Visegrad Journal on Bioeconomy and Sustainable Development, 6(2), 79-83. doi: 10.1515/vjbsd2017-0014

[18] VUEPP. (2019). Situačné a výhl'adové správy. Retrieved September 28, 2019 from http://www.vuepp.sk/04_komodity.htm

[19] Westhoff, P., \& Young, R. (1999). Elimination or Expansion of Milk Quotas -- Impacts on European Milk Supply, Demand and Prices. Dairy research symposium, October 1999, Kansas City, 93-103. Retrieved from https://www.researchgate.net/publication/265005177_Elimination_or_Expansion_of_Milk_Quotas_-_Impacts_on_European_Milk_Supply_Demand_and_Prices 


\title{
Investment Analysis of Apple Production in Isparta Province, Turkey
}

\author{
Kubilay Ucar ${ }^{1}$, Jozef Repisky ${ }^{2}$, Martina Zaujecová ${ }^{3}$ \\ Independent researcher $\mathrm{PhD}$ in agriculture economics ${ }^{1}$ \\ Slovak University of Agriculture in Nitra ${ }^{2,3}$ \\ Faculty of Economics and Management, Department of Statistics and Operation Research ${ }^{2,3}$ \\ Address: Tr. A. Hlinku 2, \\ 94976 Nitra, Slovakıa \\ e-mail: kubilay82ucar@hotmail.com¹,jozef.repisky@uniag.sk², martina.soporova@gmail.com³
}

\section{doi: 10.18515/dBEM.ISD.P01.2020.p028}

\begin{abstract}
This research is focused on analysing of profitability of apple investment in Isparta province of Turkey. For this purpose, analysed data were obtained from an apple orchid belonging to Egirdir Horticultural Crops Research Institute, Egirdir, Isparta, Turkey. Obtained data have been shown in the tables issued by using of percentage and index calculations. In this study, an apple investment life is 20 years. The criteria of Net Present Value (NPV), Benefit- Cost Ratio (BCR) and Internal Rate of Return (IRR) were used for investment analysis. $12 \%, 10 \%$ and $8 \%$ discount rates were selected to calculate NPV, BCR and IRR. The NPV were found to be positive 7469,02\$, 12708,85\$ and 19424,37\$, respectively. BCR was found bigger than 1, it was calculated 1,61, 1,78 and 1,88 respectively. IRR was found 16,05\%.
\end{abstract}

Keywords: Investment analysis, net present value, profitability, sensitivity analysis

JEL Classification: G11, Q10, Q14

\section{Introduction}

Apple (Malus Communis L.) is one of the most popular horticultural crops with total worldwide harvest area of 4.933.841 ha and production of 83.139.326 tons in 2017. Countries having the largest apple producing area are China (45.01\%), India (6.82\%), Poland (3.57\%), Russian Federation $(3.82 \%)$ and United States $(2.65 \%)$. Countries having the large producing apple are respectively China (49.79\%), United States (6,22\%), Turkey (3.65\%), Poland (2.93\%), Italy (2.31\%) (FAOSTAT 2019).

Turkey has a suitable geographic condition and climate for apple production. A lot of apple varieties are grown in Turkey such as; Amasya, Golden Delicious, Granny Smith, Starking Delicious and Starkrimson Delicious. Apples are consumed fresh and used in jam, ice cream, pies and juice. It is contributing countries economic condition. Turkey is one of leading apple producer country. Its apple production with total harvest area of 175.357 ha and production of 3.032.164 tons in 2017 (FAOSTAT, 2019). Apple is growing in almost all area of Turkey. The most important apple producing provinces are Amasya, Isparta, Karaman and Nigde provinces.

Although the technical aspects of apple production have been studied extensively. There is no available information of the economic aspects of apple production. In recent years, many studies have been made on the economic side of apple production (Akcay et al, 1999; Demircan et al,2005; Oguz and Karacayir, 2009; Bayramoglu et al, 2009; Topcu et al ,2010; Karamürsel, et al ,2012; Celık, \& Emre, 2014; Demircan et al,2016; Kanat et al,2017). One study was done to analyse efficiency and productivity of apple farming (Gül.M, 2005). Some studies have been done to analyse energy use and input-output costs (Akdemir et al, 2012; Ozkan et al, 2004; Yilmaz, H. 2004). A study has been made on apple investment (Uzunoz and Akcay, 2006). But there is still need for study, especially in local level. The main purpose of this study is to analyse the profitability of apple investment in Isparta province of Turkey. 


\section{Data and Methods}

This study was carried out in Isparta, Turkey (Longitude: $30^{\circ} 33^{\prime} \mathrm{E}$, Latitude: $37^{\circ} 45^{\prime} \mathrm{N}$ ). It is in the Mediterranean region which has Mediterranean climate conditions. Where coldest month is January and warmest month is July. The annual precipitation is about $564,00 \mathrm{~mm}$. Isparta province has important potential in terms of apple production. In 2018, 717,401 tons of apple were produced in 22,748.50 ha area in Isparta province (TurkStat, 2019). In the study, the data for investment analysis were obtained from the the Egirdir Horticultural Crops Research Institute, Isparta. Turkey for the year of 2018. Statistical data used in the study have been obtained from FAOSTAT and Turkish Statistical Institute (TurkStat). The economic period is taken as 20 years for apple. Establishment period for apple is first and second year and production period contains 3-20 years. Cash flows were calculated for 1-20 years as establishment period. Capital interest costs and management costs were estimated of $10 \%$ and $3 \%$ total variable costs respectively. M9 apple varieties were used for this investment. In the study different discount rates $(12 \%, 10 \%$ and $8 \%)$ were used. Net Present Value (NPV), Benefit Cost Ratio (BCR), and Internal Rate of Return (IRR) were computed.

\section{Net Present Value}

$$
N P V=\sum_{t-1}^{T} \frac{C_{t}}{(1+r)^{t}}-C_{0}
$$

Where;

$\mathrm{Ct}=$ net cash inflow during the period $\mathrm{t}$

$\mathrm{Co}=$ total initial investment costs

$\mathrm{r}=$ discount rate, and

$\mathrm{t}=$ number of time periods

\section{Internal Rate of Return (IRR)}

$$
I R R=r_{a}+\frac{N P V_{a}}{N P V_{a}-N P V_{b}}\left(r_{b}-r_{a}\right)
$$

$r_{\mathrm{a}}=$ lower discount rate chosen

$\mathrm{r}_{\mathrm{b}}=$ higer discount rate chosen

$\mathrm{N}_{\mathrm{a}}=\mathrm{NPV}$ at $\mathrm{r}_{\mathrm{a}}$

$\mathrm{N}_{\mathrm{b}}=\mathrm{NPV}$ at $\mathrm{r}_{\mathrm{b}}$

\section{Benefit / Cost Ratio}

$\mathrm{B} / \mathrm{C}$ indicator is calculated as the sum of positive cash flow divided by the sum of the negative cash flow. If the value of indicator is greater than one, it means that proposed project will be profitable and should be accepted. Project with the highest value of $\mathrm{B} / \mathrm{C}$ should be considered the best.

$$
\text { Benefit }- \text { Cost Ratio }=\frac{\sum_{t=1}^{t=1} \frac{B_{t}}{(1+t)^{t}}}{\sum_{t=1}^{t=1} \frac{C_{t}}{(1+t)^{t}}}
$$


$\mathrm{Bt}=$ benefit in each year

$\mathrm{Ct}=$ cost in each year

$\mathrm{t}=1,2, \ldots, \mathrm{n}$ (time)

$\mathrm{n}=$ number of years

$\mathrm{i}=$ discount rate

\section{Results and Discussion}

In 2007-2018 period apple production increased from 2,457,845 tonnes to 3,625,960 by rising in the rate of $47.53 \%$ in Turkey. In same period, Isparta apple production increased from $2,457,845$ tonnes to $3,625,960$ by rising in the rate of $47.53 \%$ (Table 1) (TurkStat, 2019). Establishment and production costs constitute investment cost. Soil preparing and planting, maintenance and harvesting-transporting are one of investment cost components. First and second years investment establish period before fruit bearing. Establishment costs calculated for two years were 24,062.92 $\$ \mathrm{ha}^{-1}$ and 5,783.38 $\$ \mathrm{ha}^{-1}$ respectively (Table 2). Production costs was calculated for 12,992.43 $\$ \mathrm{ha}^{-1}$ in production period between 3-20 years (Table 3). Variable costs were $78,29 \%$ of total costs. In addition, Labour cost, Fertilizers+Manure, Pesticide, Harvesting+Marketing were 17,67\%,17,19\%, 16,63\% and 15,30\% of the total variable costs. In a study done in Turkey, average cost of apple production was determined as 4,856.12 \$ha ${ }^{-1}$ (Demircan et al. 2005). Another research has been done in Turkey production cost was found $3010,75 \$ \mathrm{ha}^{-1}$ (Kanat et al, 2017). Average apple production is 40.00 tonnes per hectare, apple price is 470,00 \$ton ${ }^{-1}$ and income was calculated 18,800.00 \$ha ${ }^{-1}$ (Table 4).

Table 1.Turkey and Isparta Apple Production (ton) and Harvested area (ha), (TurkStat, 2019)

\begin{tabular}{|c|c|c|c|c|c|c|c|c|}
\hline \multirow[b]{2}{*}{ Year } & \multicolumn{4}{|c|}{ Turkey } & \multicolumn{4}{|c|}{ Isparta } \\
\hline & $\begin{array}{l}\text { Production } \\
\text { (ton) }\end{array}$ & $\begin{array}{c}\text { Index } \\
2007=100\end{array}$ & Area (ha) & & $\begin{array}{l}\text { Production } \\
\text { (ton) }\end{array}$ & $\begin{array}{c}\text { Index } \\
2007=100\end{array}$ & Area (ha) & $\begin{array}{c}\text { Index } \\
2007=100\end{array}$ \\
\hline 2007 & $2,457,845$ & 100 & $55,084.20$ & 100 & 496,596 & 100 & $18,105.60$ & 100 \\
\hline 2008 & $2,504,494$ & 101.90 & $55,576.60$ & 100.89 & 741,186 & 149.25 & $18,552.00$ & 102.47 \\
\hline 2009 & $2,782,365$ & 113.20 & $56,829.80$ & 103.17 & 610,838 & 123.01 & $20,568.00$ & 113.60 \\
\hline 2010 & $2,600,000$ & 105.78 & $57,564.80$ & 104.50 & 549,371 & 110.63 & $21,011.50$ & 116.05 \\
\hline 2011 & $2,680,075$ & 109.04 & $57,245.10$ & 103.92 & 609,929 & 122.82 & $20,672.20$ & 114.18 \\
\hline 2012 & $2,888,985$ & 117.54 & $60,353.30$ & 109.57 & 634,795 & 127.83 & $21,761.90$ & 120.19 \\
\hline 2013 & $3,128,450$ & 127.28 & $59,623.10$ & 108.24 & 634,862 & 127.84 & $21,677.80$ & 119.73 \\
\hline 2014 & $2,480,444$ & 100.92 & $59,072.80$ & 107.24 & 646,266 & 130.14 & $22,364.80$ & 123.52 \\
\hline 2015 & $2,569,759$ & 104.55 & $58,581.10$ & 106.35 & 435,938 & 87.79 & $22,612.20$ & 124.89 \\
\hline 2016 & $2,925,828$ & 119.04 & $58,036.70$ & 105.36 & 596,503 & 120.12 & $22,813.70$ & 126.00 \\
\hline 2017 & $3,032,164$ & 123.37 & $58,226.90$ & 105.71 & 617,375 & 124.32 & $23,150.80$ & 127.87 \\
\hline 2018 & $3,625,960$ & 147.53 & $56,419.20$ & 102.42 & 717,401 & 144.46 & $22,748.50$ & 125.64 \\
\hline
\end{tabular}


Table 2. Establishment of Production Cost $\left(\$ \mathrm{Sha}^{-1}\right)$

\begin{tabular}{|l|r|r|}
\hline \multirow{2}{*}{\multicolumn{1}{|c|}{ Cost Items }} & \multicolumn{2}{c|}{ Year } \\
\cline { 2 - 3 } & \multicolumn{1}{c|}{1. year } & \multicolumn{1}{c|}{$2 . y e a r$} \\
\hline Soil preparing and planting & $15,530.34$ & \\
\hline Labor Cost & $2,832.96$ & $1,725.09$ \\
\hline Fertilizers+Manure & 797.68 & 594.40 \\
\hline Amonyum Nitrat & 38.43 & 352.83 \\
\hline Potasyum Nitrat & 85.09 & 241.57 \\
\hline Manure & 674.16 & 0.00 \\
\hline Pesticide & 343.45 & 816.79 \\
\hline Insektisit & 343.45 & 443.45 \\
\hline Herbisit & & 373.34 \\
\hline Harvesting+Marketing & & 341.20 \\
\hline Irrigation & 374.53 & 464.53 \\
\hline Electricity & 89.89 & 197.38 \\
\hline Total Variable Cost (1) & $19,968.84$ & $3,798.20$ \\
\hline Capital Interest (\%10) & $1,996.88$ & 374.66 \\
\hline Management (\%3) & 599,07 & 112,40 \\
\hline Land Rent & $1,498,13$ & $1,498.13$ \\
\hline Total Fixed Cost (2) & $4,094.08$ & $1,985.18$ \\
\hline Total Production Cots (1+2) & $24,062.92$ & $5,783.38$ \\
\hline
\end{tabular}

Table 3. Production Costs $\left(\$ \mathrm{~S}^{-1}\right)$

\begin{tabular}{|l|r|r|}
\hline \multirow{2}{*}{ Cost Items } & \multicolumn{2}{c|}{ Year } \\
\cline { 2 - 3 } \multicolumn{1}{c|}{} & \multicolumn{1}{c|}{$(3-20)$} & \multicolumn{1}{c|}{$(\%)$} \\
\hline Labor cost & $2,296.25$ & 17.67 \\
\hline Fertilizers+Manure & $2,233.26$ & 17.19 \\
\hline Amonyum Nitrat & 464.04 & 3.57 \\
\hline Potasyum Nitrat & 628.05 & 4.83 \\
\hline Manure & $1,141.16$ & 8.78 \\
\hline Pesticide & $2,160.30$ & 16.63 \\
\hline Insektisit & $1,435.96$ & 11.05 \\
\hline Herbisit & 724.34 & 5.58 \\
\hline Harvesting+Marketing & $1,987.75$ & 15.30 \\
\hline Irrigation & 974,53 & 7.50 \\
\hline Electricity & 519,85 & 4.00 \\
\hline
\end{tabular}




\begin{tabular}{|l|r|r|} 
Total Variable Cost (1) & $10,171.95$ & 78.29 \\
\hline Fixed Cost & & \\
\hline Capital Interest (\%10) & $1,017.19$ & 7.83 \\
\hline Management (\%3) & 305,16 & 2.35 \\
\hline Land Rent & $1,498.13$ & 11.53 \\
\hline Total Fixed Cost (2) & $2,820.48$ & 21.71 \\
\hline Total Production Cost (1+2) & $12,992.43$ & 100.00 \\
\hline
\end{tabular}

Table 4. Annual Income of Apple Production

\begin{tabular}{lc}
\hline Income Particulars & Years (3-20) \\
\hline Production (tonne/ha) & 40.00 \\
\hline Apple Price $\left(\mathbf{S t o n}^{-1}\right)$ & 470.00 \\
\hline Total Income $\left(\mathbf{\$ h a}^{-1}\right)$ & $18,800.00$ \\
\hline
\end{tabular}

Cash flows were calculated for 1-20 years. First and second year is an establishment period, production period contains 3-20 years and economic life is 20 years. In period of investment life first and second year there is no any income, so the cash flow is negative -24,062.92 $\$$ and -5,783.38 \$, respectively. Net Present Value (NPV), Benefit Cost Ratio (BCR) and Internal Rate of Return (IRR) were used for investment analysis. $12 \%, 10 \%$ and $8 \%$ discount rates were selected to calculate NPV, BCR and IRR. The NPV were found to be positive 7,469.02\$, $12,708.85 \$$ and $19,424.37$ respectively. BCR was calculated $1,61,1,78$ and 1,88 respectively. IRR was found $16,05 \%$ (Table 5). This amount was found $22.12 \%$ in a research done in Turkey (Uzunoz and Akcay 2006). In Romania 20.20\% (Badui et al. 2015) and in Slovakia 29\% (Ucar et al ,2016).

Sensitivity analysis was carried out to see the change of investment profitability. $3 \%-5 \%$ increase of cost was analysed. In 3\% increase of cost condition, NPV chances between $4433,516 \$$ and $15,475.43 \$$, BCR changed between 1.46 and 1.81 and IRR was found 14.38. In $5 \%$ increase of cost condition NPV changed between 2,409.85\$ and 12,842.80 \$, BCR changed between 1.36 and 1.69, IRR was found 13.28\% (Table 6).

Table 5. Cash Flows of Apple Investment (\$ha-1)

\begin{tabular}{l|c|c|c|}
\hline \multirow{2}{*}{ Items } & \multicolumn{3}{c}{ Year } \\
\cline { 2 - 5 } \multicolumn{1}{c|}{ 1.year } & 2.year & $(3-20)$ years \\
\hline Product income & $24,062.92$ & $18,800.00$ \\
\hline Investment costs & $24,062.92$ & $5,783.38$ & $12,992.43$ \\
\hline Production costs & $-24,062.92$ & $-5,783.38$ & $5,807.57$ \\
\hline Total costs & \multicolumn{3}{c}{ Discount Rate } \\
\hline Cash Flows & $12 \%$ & $10 \%$ & $8 \%$ \\
\hline
\end{tabular}




\begin{tabular}{|l|c|c|c|}
\hline NPV & $7,469.02$ & $12,708,85$ & $19,424.37$ \\
\hline BCR & 1.61 & 1.78 & 1.88 \\
\hline IRR & \multicolumn{4}{|c}{$16.05 \%$} \\
\hline
\end{tabular}

Table 6. Sensitivity analysis of apple investment

\begin{tabular}{lccc}
\hline & Assuming 3\% increase of cost \\
\hline Discounted rate (\%) & $12 \%$ & $10 \%$ & $8 \%$ \\
NPV (\$) & $4,433.516$ & $9,267.31$ & $15,475.43$ \\
BCR & 1.46 & 1.61 & 1.81 \\
IRR (\%) & $14.38 \%$ & \\
& & & \\
\hline & & $10 \%$ & $8 \%$ \\
\hline Discounted rate (\%) & $12 \%$ & $12,842.80$ \\
NPV (\$) & $2,409.85$ & $6,972.95$ & 1.69 \\
BCR & 1.36 & 1.51 & \\
IRR (\%) & & $13.28 \%$ & \\
\hline
\end{tabular}

\section{Conclusions}

Turkey has geographic condition for fruit production. Apple is important fruit for increase of farmer profit. It is contributing farmer income during agriculture period. Establishment costs calculated for two years 24,062.92 $\$ \mathrm{ha}^{-1}$ and 5,783.38 $\$ \mathrm{ha}^{-1}$ respectively. Production costs were calculated for 12,992.43 $\$ \mathrm{ha}^{-1}$ in production period. The main cost of apple production is labour cost, pesticide, fertilizers + manure and harvesting + marketing respectively. Investment life of apple investment is 20 years. In this research, the criteria of Net Present Value (NPV), BenefitCost Ratio (BCR) and Internal Rate of Return (IRR) were used for investment analysis. In all discount rates $(12 \%, 10 \%, 8 \%)$ Net Present Value (NPV) found positive, IRR 15\% and Benefit Cost Ratio (BCR) higher than 1. In all conditions, apple investment was found profitable. Some suggestions for improving apple production in the Turkey as follow; Suitable planting spaces should be preferred, farmer should be informed about pest and fertilizer management, cooperatives should be improved, farmers should be informed about contract farming systems and crop insurance.

\section{References}

[1] Akcay, Y., Akay, M., \& Uzunoz, M. (1999). Research on the determination of the cost and profiblity of the peach, apple and sour cherry grown in central district of Tokat Province. Gazi Osmanpasa Universty Journal of Agricultural Faculty, 16(1):85-98.

[2] Akdemir, S., Akcaoz,H., \& Kizilay, H., (2012). An analysis of energy use and input costs for apple production in Turkey.Journal of Food, Agriculture \& Environment Vol.10 (2): 473-479. 
[3] Badiu, D., Arion, F,H., Muresan, IC, Lile, R., \& Mitre, V. (2015). Evaluation of Economic Efficiency of Apple Orchard Investments, Sustainability, (7):10521-10533.

[4] Bayramoglu, Z., Celik, Y., \& Oguz, C. (2009). Current situation and development opportunities of apple production in the province of Konya. Journal of Agricultural Sciences Research, 2(1):11-15.

[5] Celık, Y., \& Emre, M. (2014). The effect of economic size on profitability of apple farms. Bulg. J. Agric. Sci.,20: 46-50.

[6] Demircan, V., Yilmaz, H., \& Binici, T. (2005). Determination of cost and return of apple production in Isparta province, Turkish Journal of Agriculture, 11(2):71-80.

[7] Demircan,V., Atasay, A., Ekinci, K., İşçi, M., \& Altındal, M. (2016). Comparison of cost and profitability of organic and conventional apple nursery tree growing. Custos e @gronegócio on line v.12, n.3, p:180-192. www.custoseagronegocioonline.com.br

[8] Egirdir Horticultural Crops Research Institute, Annual Records, (2017) Isparta. Annual Records. Accessed December, 2018.

[9] FAOSTAT (2019). Crop production statistics, http://faostat.fao.org, Accessed: November 2019.

[10] Gül,M.(2005). Thecnical Efficiency and Productivity of Apple Farming in Antalya Province of Turkey. Pakistan Journal of Biological Science 8(11): 1533:1540.

[11] Kanat, Z., Çelik, Y., \& Çay,Ş. (2017). The Cost Analysis Of Semi-Dwarf And Dwarf Apple Production In Konya., Selcuk J Agr Food Sci, Vol, 31 (1), p:56-62.

[12] Karamürsel, D., Atasay, A., Öztürk, F.P., \& Öztürk, G.( 2012). An Economic Analysis of Organic and Conventional Apple Production. V. Storage and Marketing Symposium of Horticultural Crops, September 18-21, 2012, Izmir.

[13] Malik, Z, A. (2013). Assesment of apple production and marketing problems in Kashmir Valley. Journal of Economic \& Social Development,9(1):152-156.

[14] Oguz, C., \& Karacayir, H,F. (2009). Apple production, consumption, market structure and foreign trade in Turkey. Journal of Agricultural Sciences Research, 2(1):41-49.

[15] Ozkan, B., Akcaoz, H. and Fert, C. (2004). Energy input-output analysis in Turkish agriculture. Renewable Energy vol. 29 p:39-51.

[16] Piyush, M., Kumar, T,R., \& Sachin, C. (2013). Production and marketing of apple fruit crop- a study Premiseto Shimla District of Himachal Pradesh, India. International Journal of Bio-Resource and Stress Management, 4(4):610-613.

[17] Repiský, J. (2006). The evaluation of investment strategies under risk. In: Management Number 44, Year XI December 2006 - University of Beograde - Serbia, 2006. s. 36-45. ISSN 1820-0222.

[18] Sharif, M., Akmal, N., \& Taj, S. (2009). Financial viability for investing in citrus cultivation in punjab, Pakistan. J. Agric. Res., Vol 47 no:1 , p. 79-89.

[19] The Turkish Ministry of Agriculture and Forestry, Directorate of Isparta (MAF). (2017) Annual Records. Accessed December, 2018.

[20] TurkStat, Agricultural Statistics, http://www.tuik.gov.tr, Access:November 2019.

[21] Robinson, T., Hoying, S., Sazo, MM., DeMarree, A., \& Dominguez, L. (2013). A vision for apple orchard systems of the future. New York Fruit Quarterly, 21(3):11-16.

[22] Topcu, Y., Uzundumlu, A,S., Celep, S., \& Hun, S. (2010). Analysis of the factors affecting apple farming: The case of Isparta province, Turkey.Scientific Research and Essays, 5(14):1881-1889.

[23] Ucar, K.; Palkovic, J., \& Engindeniz, S. (2016). Apple Investment in Europe: A Case Study for Slovakia. Journal of Agricultural Faculty of Uludag University, Volume: 30, Number: Special Issue, 152-15.

[24] Uzunoz, M.,\& Akcay, Y. (2006). A profitability analysis of investment of peach and apple growing in Turkey. Journal of Agriculture and Rural Development in the Tropics and Subtropics, 107(1):11-18.

[25] Yilmaz, H. (2014). Analysis in terms of apple producers of government supported crop in surance policies as a risk management tool in Turkey. Acta Sci. Pol. Hortorum Cultus, 13(5): 3-12. 
[26] Yilmaz, I., Ozalp, A., \& Aydogmus, F. (2010). Determination of the energy efficiency in dwarf apple production in Antalya Province: a case study for Elmali. Akdeniz University Journal of Agricultural Faculty, 23(2):93-97.

[27] Zbanca, A., \& Negritu, G. (2013). Feasibility of investments for planting and maintenance of apple orchards by applying various technologies. Economic Engineering in Agriculture and Rural Development, 13(1):465469. 


\section{SESSION 4}

BIOECONOMY, RESOURCE MANAGEMENT AND SUSTAINABLE DEVELOPMENT 


\title{
Linear Programming for Land Allocation - Example of Selected Crops in Slovakia
}

\author{
Tatiana Bullová ${ }^{1}$, Peter Bielik ${ }^{2}$, Izabela Adamičková ${ }^{3}$, Mária Urbánová ${ }^{4}$, Dominika \\ Čeryová 5 \\ Slovak University of Agriculture in Nitra \\ Faculty of Economics and management, Department of Economics ${ }^{1,2,3,4,5}$ \\ Address: Tr. Andreja Hlinku 2, \\ 94976 Nitra, Slovakia \\ e-mail: tatiana.bullova@uniag.sk¹, peter.bielik@uniag.sk²,izabela.adamickova@uniag.sk³, \\ maria.urbanova1@uniag.sk4, dominika.ceryova@uniag.sk ${ }^{4}$
}

doi: 10.18515/dBEM.ISD.P01.2020.p029

\begin{abstract}
From mathematical tools, the most widely used technique in agriculture planning is linear programming $(L P)$. The LP models have a wide range of application in agriculture and enable to solve different types of maximizing vs. minimizing problems (profit, cost, resource allocation,...). Allocation of agricultural land is an important way to promote the intensive and economic use of land resources and achieve the goal of sustainable development. In presented article we introduce the example of LP model for agricultural land allocation among selected crops in production areas of Slovakia with the objective of profit maximization. The constraint in form of land endowment is applied and we adjusted the model by balance equations to prevent overspecialization. Generated LP model would be very well applicable for different scale of production, from farm level to regional level.
\end{abstract}

Key words: linear programming, land allocation, crops, land endowment

JEL classification: $C 61, Q 10, Q 15$

\section{Introduction}

The land on which the farmers perform their activities is perceived as the national wealth of any country. It is very important to utilize the land efficiently (mainly nowadays) when the competition in European Union (EU) increases (Urbánová et al, 2018). The key tasks of the agricultural land are to ensure food security, promote sustainable development, reduce the effects of climate change and eliminate poverty. The European model of multifunctional agriculture takes into account not only the primary production but also the social and cultural functions related to agricultural activity (Labuda and Murtinova, 2014). Moreover, one of the priorities of agriculture is optimal ways of using natural resources in field systems, input-output analysis and their ratios (Ministry of Agriculture and Rural Development of SR, 2010). For these reasons, actions which are aimed at the development and sustainable protection of soil resources, support for investments in land, should be developed (Ladvenicová et al., 2018). Land-use allocation is an important way to promote the intensive and economic use of land resources and achieve the goal of sustainable development (Liu et al., 2015).

Agriculture planning problems are important from both social and economic view points. The problems of land allocation for different crops, production maximization of crops and profit maximization are addressed in agricultural management system. Also, agriculture is a process that, at any moment of time is associated with the issue of risk and there is no certainty (Basumatary and Mitra, 2020).

Farmers use a wide range of production systems, which result in large variations in productivity among farms. The limited availability of mathematical models to assess agriculture planners 
affects the development of sustainable and effective agricultural production. From mathematical tools, the most widely used technique in agriculture planning is linear programming (LP). LP models can be used for maximization of production of crops, for allocating the land under cultivation and for minimizing cost (Sharma et al., 2007). According to Grubišić et al. (2019), there is much to be done on popularization of optimization of agricultural production if we aim at getting it widely used by small farmers. Also, according to Kaim et al. (2018), optimal land use allocation with the intention of ecosystem services provision and biodiversity conservation is one of the key challenges in agricultural management. Good examples of optimization for land use allocation problems can be found worldwide, as the example of LP use for optimal land use considering the water efficiency (Cui et al., 2018) or forest management using the multi-criteria decision analysis (Mendoza and Martins, 2006; Uhde et al., 2015).

The total area of the SR is maintained at 4903 thousand ha., where agricultural land is about $49.31 \%$ and the rest is a non-agricultural land fund. On average, more than $71 \%$ of the soil is cultivated in Slovakia (Ladvenicová et al.,2018). In Slovakia there is possible to identify 4 agricultural production areas, all with different soil conditions, altitude and structure of cultivated crops. Maize production area (West-south plain, East plain) has the most favourable condition for maize and wheat cultivation, rape production area (West part of Slovakia, Košice hollow-basin, South-Slovakian hollow-basin) with wheat cultivation and appropriate condition for sugar beet cultivation, potato-oat area (500-600 m.a.s.l. ) with potato, wheat and perennial forage cultivation and mountains production area (from 600 m.a.s.l. - less favoured areas) with perennial forage and less demanding cereals (Svetlanská \& Turčeková, 2016). The transition toward market economy after 1990 had led to change in the structure of agricultural sector causing the continuous decrease of livestock since 1993 (especially pigs). In the period between 2000 and 2011 there was a decline in the stocks of pigs by 61\% (Kročková, 2013). Therefore the crop production predominates in terms of value creation of the agriculture.

Optimization models can often provide prescriptive results to land allocation problems. Aim of this article is to identify suitable LP model for the optimal land allocation within each production area among selected crops - wheat, barley, sunflower, rapeseed, maize, perennial forage and sugar beet- which are the major crops cultivated in Slovakia.

\section{Data and methods}

We use a LP model for identification of optimal land allocation among the selected crops in order to demonstrate the LP as tool for assessing the economic solution for farmers, respecting the crop combination.

For this purpose we suppose the following conditions:

- each agricultural area has limited amount of arable land (land endowment) and the model takes into consideration only 7 selected crops,

- crops are characterized by inputs in forms of expenses for seed $(€ /$ ha), purchased fertilizers $(\mathrm{PF}, € / \mathrm{ha})$, chemical protection (CHP, $€ /$ ha), agrochemical services containing expenses for the services of external institution for pedological analysis,

- objective is to allocate the land among the crops in order to maximize profit.

The research objective is to build LP model for four production areas which will maximize the overall profit with respect to optimal land allocation among 7 selected crops.

Data source is the National Agricultural and Food Centre of Slovakia, Branch: Research Institute of Agriculture and Food. We selected the year 2013 for this LP model declaration due to the consistency of input data (for this year all necessary data were available). 
Table 1: Maize production area - land endowment 46951.48 ha

\begin{tabular}{|l|c|c|c|c|c|c|}
\hline Crop & Profit & Land & Seed & PF & CHP & ACHS \\
\hline wheat & 153.67 & 1 & 68.66 & 167.04 & 86.52 & 18.6 \\
\hline barley & 109.07 & 1 & 65.35 & 134.24 & 96.65 & 14.6 \\
\hline sunflower & 284.11 & 1 & 106.57 & 144.44 & 155.58 & 13.23 \\
\hline rapeseed & 411 & 1 & 69.56 & 210.94 & 214.23 & 32.57 \\
\hline maize & 133.8 & 1 & 174.02 & 122.7 & 98.23 & 22.79 \\
\hline sugar_beet & 1613.82 & 1 & 192.52 & 194.74 & 381.23 & 48.63 \\
\hline prennial_forage & -6.21 & 1 & 8.22 & 20.76 & 15.3 & 15.52 \\
\hline
\end{tabular}

Source: processed by authors according the database Research Institute of Agriculture and Food

Table 2: Rape production area - land endowment 30101.37 ha

\begin{tabular}{|l|c|c|c|c|c|c|}
\hline Crop & Profit & Land & Seed & PF & CHP & ACHS \\
\hline wheat & 107.42 & 1 & 56.44 & 147.66 & 93.52 & 29.34 \\
\hline barley & 107.22 & 1 & 87.06 & 103.35 & 85.9 & 23.69 \\
\hline sunflower & -92.81 & 1 & 102.69 & 86.21 & 167.78 & 28.19 \\
\hline rapeseed & 231.6 & 1 & 58.68 & 222.32 & 265.36 & 47.43 \\
\hline maize & 104.44 & 1 & 161.55 & 136.41 & 79.26 & 58.15 \\
\hline sugar_beet & 1297.37 & 1 & 201.23 & 104.43 & 405.62 & 84.51 \\
\hline prennial_forage & -62.58 & 1 & 24.15 & 30.88 & 10.85 & 6.79 \\
\hline
\end{tabular}

Source: processed by authors according the database Research Institute of Agriculture and Food

Table 3: Potato-oat production area - land endowment 19349.04 ha

\begin{tabular}{|l|c|c|c|c|c|c|}
\hline Crop & Profit & Land & Seed & PF & CHP & ACHS \\
\hline wheat & 224.63 & 1 & 61.78 & 153.58 & 105.9 & 38.98 \\
\hline barley & 122.29 & 1 & 61.94 & 117.38 & 84.08 & 25.01 \\
\hline sunflower & -55 & 1 & 93.91 & 120.28 & 178.14 & 33.94 \\
\hline rapeseed & 267.36 & 1 & 61.71 & 200.55 & 249.6 & 24.81 \\
\hline maize & 100.53 & 1 & 131.09 & 149.93 & 65.8 & 55.53 \\
\hline sugar_beet & 0 & 1 & 0 & 0 & 0 & 0 \\
\hline prennial_forage & -14.79 & 1 & 4.99 & 38.24 & 3.6 & 7.26 \\
\hline
\end{tabular}

Source: processed by authors according the database Research Institute of Agriculture and Food

Table 4: Mountains production area - land endowment 7812.2 ha

\begin{tabular}{|l|c|c|c|c|c|c|}
\hline Crop & Profit & Land & Seed & PF & CHP & ACHS \\
\hline wheat & -3.39 & 1 & 45.96 & 85.36 & 45.53 & 19.14 \\
\hline barley & -200.91 & 1 & 49.6 & 101.94 & 61.89 & 25.65 \\
\hline sunflower & 0 & 1 & 0 & 0 & 0 & 0 \\
\hline rapeseed & 200.18 & 1 & 61.94 & 180.33 & 224.81 & 20.38 \\
\hline
\end{tabular}




\begin{tabular}{|l|c|c|c|c|c|c|} 
maize & 0 & 1 & 0 & 0 & 0 & 0 \\
\hline sugar_beet & 0 & 1 & 0 & 0 & 0 & 0 \\
\hline prennial_forage & 43.41 & 1 & 11.15 & 17.42 & 4.01 & 0.82 \\
\hline
\end{tabular}

Source: processed by authors according the database Research Institute of Agriculture and Food

To prevent overspecialization, there were created convex combinations of crops for each production area in form of 3 crop mixes -M1, M2, M3. Mixes were created based on historical development of crops combination.

Table 5: Crop mixes /maize, potato-oat production area

\begin{tabular}{|l|c|c|c|c|}
\hline Production area & Crop & M1 & M2 & M3 \\
\hline Maize & wheat & 0.25 & 0.3 & 0.28 \\
\hline & barley & 0.14 & 0.14 & 0.13 \\
\hline & sunflower & 0.15 & 0.12 & 0.12 \\
\hline & rapeseed & 0.12 & 0.12 & 0.1 \\
\hline & maize & 0.2 & 0.22 & 0.25 \\
\hline Potato-oat & sugar_beet & 0.03 & 0.02 & 0.02 \\
\hline & prennial_forage & 0.11 & 0.08 & 0.1 \\
\hline & wheat & 0.34 & 0.4 & 0.32 \\
\hline & barley & 0.08 & 0.07 & 0.08 \\
\hline & sunflower & 0.1 & 0.12 & 0.13 \\
\hline & rapeseed & 0.15 & 0.12 & 0.17 \\
\hline & maize & 0.12 & 0.11 & 0.13 \\
\hline & sugar_beet & 0 & 0 & 0 \\
\hline & prennial_forage & 0.21 & 0.18 & 0.17 \\
\hline
\end{tabular}

Source: processed by authors

Table 6: Crop mixes /rape, mountains production area

\begin{tabular}{|l|c|c|c|c|}
\hline Production area & Crop & M1 & M2 & M3 \\
\hline Rape & wheat & 0.36 & 0.32 & 0.3 \\
\hline & barley & 0.13 & 0.12 & 0.11 \\
\hline & sunflower & 0.1 & 0.06 & 0.08 \\
\hline & rapeseed & 0.11 & 0.15 & 0.18 \\
\hline & maize & 0.17 & 0.18 & 0.2 \\
\hline Mountains & sugar_beet & 0.04 & 0.05 & 0.06 \\
\hline & prennial_forage & 0.09 & 0.12 & 0.07 \\
\hline & wheat & 0.1 & 0.15 & 0.17 \\
\hline & barley & 0.2 & 0.25 & 0.2 \\
\hline & sunflower & 0 & 0 & 0 \\
\hline & rapeseed & 0.2 & 0.2 & 0.25 \\
\hline & maize & 0 & 0 & 0 \\
\hline & sugar_beet & 0 & 0 & 0 \\
\hline & prennial_forage & 0.5 & 0.4 & 0.38 \\
\hline
\end{tabular}

Source: processed by authors 


\section{Methodology:}

Linear programming form:

Objective function:

$\operatorname{Max} \mathrm{Z}=\sum_{a, c} \pi_{a, c, p} * x_{a, c}$

s.t.

$\sum_{c} b_{a, c, L} * x_{a, c} \leq E_{a}$

If we want to prevent overspecialization it is necessary to include 2 balance equations:

$\sum_{m} M_{a, c, m} * \theta_{a, m} \leq \operatorname{Land}_{a, c}$

$\sum_{c} \operatorname{Land}_{a, c} \leq \sum_{m}\left(\theta_{a, m} \sum_{c} M_{a, c, m}\right)$

If we want to add environmental targets in form of reduction expenses (therefore the use) for purchased fertilizers and chemical protection by $3 \%$ :

$\sum_{a, c} b_{a, c, P F} * x_{a, c} \leq \sum_{a} P F E_{a} * 0.97$

$\sum_{a, c} b_{a, c, C H P} * x_{a, c} \leq \sum_{a} C H P E_{a} * 0.97$

Where:

a- area

c- crops

$\mathrm{P}$ - profit

E - land endowment

$\mathrm{b}$ - constant

$\mathrm{x}, \theta-$ decision variables

$\mathrm{m}-$ crop mixes

PFE - max purchased fertilizers expenses

CHPE - max chemical protection expenses

\section{Results and discussion}

The basic solution without taking balanced equations or environmental constrains into consideration gives us the objective function value of $121,560,849.18 €$. Under this solution all arable land in maze production area would be devoted to sugar beet cultivation. Sugar beet would be also the only crop on arable land in rape production area. In potato-oat production area and mountains production area, land endowment would be fully used on rapeseed cultivation. Adding the expenses reduction to the baserun model causes diversification of production only in case of potato-oat production area. Arable land is allocated between wheat $(11,225.92 \mathrm{ha})$ and rapeseed $(8,123.12 \mathrm{ha})$. Profit would drop to $121,081,165.79 €$.

Overspecialization was eliminated by adding balance equations involving crop mixes for each production area. Tab7 represents the resulting allocation of arable land among the crops based on the optimal land mixes. Optimal mix for maze production area (MPA) is crop mix one from Tab5, for rape production area (RPA) the optimal crop mix is M3 from Tab6, M2 from Tab5 is optimal for potato-oat production area (POPA) and M3 from Tab6 for mountains production area (MNPA). The value of objective function has changed after adding balance equations to $18,292,360.9 €$. The resulting values of variables for each production area are shown in Tab8. 
Shadow prices values tell us how much arable land should be added to certain production area in order to generate one more $€$ of profit.

Table 7: Optimal land allocation

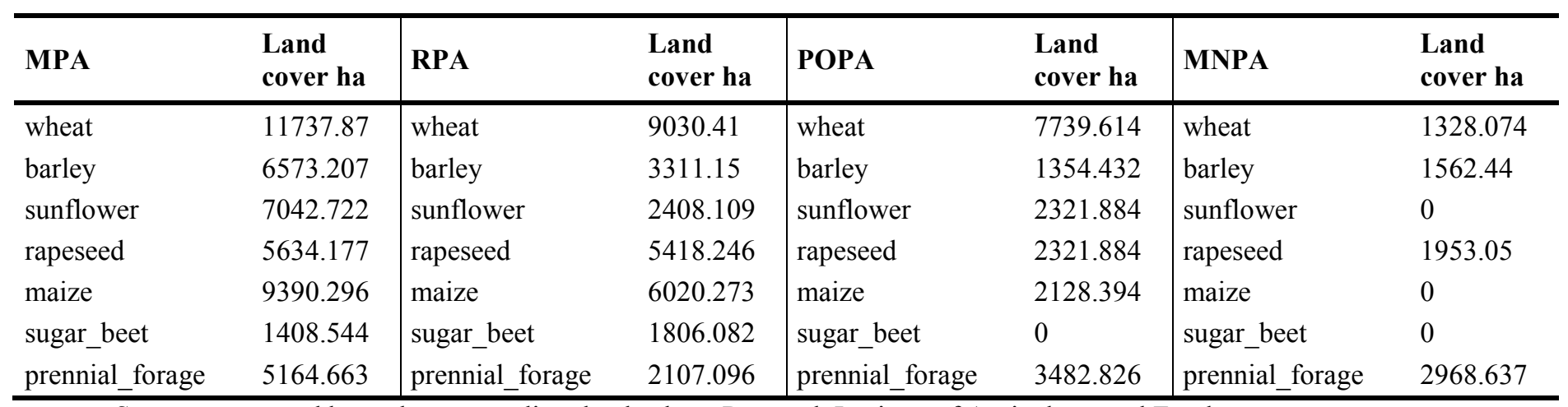

Source: processed by authors according the database Research Institute of Agriculture and Food

Tab8 also represents the cost related to the most profitable solution for each production area. This fact means, that the generated LP model would be very well applicable for different scale of production, from farm level to regional level.

Table 8: Resulting values of variables

\begin{tabular}{llllllll}
\hline Area & Profit & Land & Seed & PF & CHP & ACHS & ShadowP \\
\hline MPA & $10,334,738.7$ & $46,951.5$ & $4,325,663.2$ & $6,582,512.7$ & $5,491,984.8$ & $953,631.5$ & 220.1 \\
RPA & $5,196,489.2$ & $30,101.4$ & $2,750,075.9$ & $4,162,727$ & $4,203.381 .9$ & $1,185,284$ & 172.6 \\
POPA & $2,559,714.9$ & 19,349 & $1,219,769$ & $2,544,856.8$ & $2,079,255.1$ & $615,450.3$ & 132.3 \\
MNPA & $201,418.1$ & $7,812.2$ & $292,607.6$ & $676,546.8$ & $608,136.1$ & $107,733.4$ & 25.8 \\
\hline
\end{tabular}

Source: processed by authors according the database Research Institute of Agriculture and Food

After including additional constrains in form of purchased fertilizers and chemical protection expenses reduction, the optimal crop mix changed only in case of MNPA. Expenses reduced by $3 \%$ caused shift toward M1 crop mix in MNPA. Profit decreased to 18,169,533.43€.

Crop production in Slovakia is characterized by major share of cereals production, which is in compliance with results, where the major part of arable land in MPA, RPA and POPA is occupied by wheat. In mountains area perennial forage is the most widely cultivated from 7 selected crops.

\section{Conclusion}

The constructed LP model facilitated the optimal agricultural land allocation in 4 agricultural production areas of Slovakia among 7 selected crops. Model was constructed to serve the purpose of maximization of profit for selected cop mix. Including the balance equation enabled to prevent overspecialization in production areas. The results represented the way to distribute the land among different crop respecting the agronomical requirements of crop production and aiming the profit maximization at the same time. Without taking into consideration the environmental constraints and the prevention of overspecialization, all the production area would allocate land toward cultivation of most profitable crop. However, respecting the 
agronomical and environmental requirements of soil, it is crucial to incorporate the crop mixes and look for the most profitable mix respecting the technical requirements. According to our simplified model, it can be concluded that the crops which are most profitable for almost all production areas are wheat, maize and sunflower. As we limited our model only to 7 major crops, for the further research it would be vital to include more diversified crop mixes and also incorporation of water efficiency in the model.

We tried to prove that LP models are the suitable way to manage the systems in agricultural production. The model can be used for different scales (from farm level to national scale) and different production conditions. Furthermore, the LP enables to incorporate various limitation and scenarios in for of constraints. The resulting values proved the fact that the dominating crops in Slovakia are cereals.

\section{Reference}

[1] CUI, G., WANG, X., LI, CH., LI, Y., YAN, S., YANG, Z. (2018). Water use efficiency and TN/TP concentrations as indicators for watershed land-use management: A case study in Miyun District, north China. In: Ecological Indicators, 2018, Vol. 92, pp. 239-253, ISSN 1470-160X

[2] GRUBIŠIĆ, M., KOLAREC, B., MAMIĆ, M. (2019). A Linear Programming Approach to Land Allocation in Vegetable Production: a Case Study from Croatia. In. International Journal of Modeling and Optimization, 2019, Vol. 9, No. 3, pp.160-165. ISSN- 2010-3697

[3] KAIM, A., CORD, A.F., VOLK, M. 2018. A review of multi-criteria optimization techniques for agricultural land use allocation. In: Environmental Modelling \& Software. 2018. Vol. 105, pp.79-93, DOI: https://doi.org/10.1016/j.envsoft.2018.03.031

[4] KROČKOVÁ, B. Polnohospodárstvo a jeho vplyv na životné prostredie v Slovenskej republike k roku 2011. 2013. In: . Banská Bystrica: Slovak environmental agency, No. 4.

[5] LADVENICOVÁ, J., BAJUSOVÁ, Z., GURČÍK, L. (2018). The current situation within the soil market and the land price in V4 countries. In Inproforum 2018. České Budějovice: University of South Bohemia České Budějovice, 2018, p. 254--259. ISBN 978-80-7394-726-2

[6] LIU, Y., YUAN, M., HE, J., LIU, Yanfang (2015). Regional land-use allocation with a spatially explicit genetic algorithm. In Landscape and Ecological Engineering 2015, Volume 11, Issue 1, pp 209-219, https://doi.org/10.1007/s11355-014-0267-6

[7] MENDOZA, G.A., MARTINS, H., 2006. Multi-criteria decision analysis in natural resource management: a critical review of methods and new modelling paradigms. In: Ecological Management 2006, Vol. 230 Issue 1-3, pp. 1-22, https://doi.org/10.1016/j.foreco.2006.03.023

[8] Ministry of Agriculture and Rural Development, 2010. Národný strategický plán rozvoja vidieka SR. Available on: http://www.rrasi.sk/images/stories/kniznice/Narodny_strategický_plán_ rozvoja_vidieka_SR.pdf

[9] MURTINOVA, S., LABUDA, M. 2014. Environmentálne hodonotenie multifunkčnosti pol’nohospodárstva (Komparačná analýza). ACTA ENVIRONMENTALICA UNIVERSITATIS COMENIANAE ( BRATISLAVA ). 2014, 22(1), 25-36. ISSN 1335 - 0285.

[10] Research Institute of Agriculture and Food Economics. 2015. Sample survey of economic results in Slovak Farm Accountany Data Network [online]. Bratislava, 2015

[11] URBÁNOVÁ, M., DOBOŠOVÁ, L., KOZÁKOVÁ, J., ĎURIŠOVÁ, E., ČERYOVÁ, D. (2018). Physical and economic size of farms in the EU 28 - focus on Slovakia. In Agrarian perspectives XXVII. Praha: Czech University of Life Sciences, 2018, p. 408--415. ISBN 978-80-213-2890-7

[12] BASUMATARY, U. R, MITRA, D. K., (2020). A Study on Optimal Land Allocation through Fuzzy MultiObjective Linear Programming for Agriculture Production Planning in Kokrajhar District, BTAD, Assam, India, In International Journal of Applied Engineering Research. 2020, Volume 15, Number 1, pp. 94-100, ISSN 0973-4562 
[13] SHARMA, D. K., JANA, R.K., GAUR, A. (2007). Fuzzy goal programming for agricultural land allocation problems. In Yugoslav Journal of Operations Research 2007, Volume 17, Issue 1, p. 31-42, DOI: 10.2298/YUJOR0701031S

[14] SVETLANSKÁ, T., TURČEKOVÁ, N. (2016). Land use optimization with respect to alternative costs of crop production choices - case of Slovakia. In The agri-food value chain: challenges for natural resources management and society. Nitra : Slovak University of Agriculture. 2016, p. 1066--1073. ISBN 978-80-5521503-7. URL: http://dx.doi.org/10.15414/isd2016.s13.08.

[15] UHDE, B., HAHN, W.A., GRIESS, V.C., KNOKE, T., 2015. Hybrid MCDA methods to integrate multiple ecosystem services in forest management planning: a critical review. In: Environmental Management 2015, Vol. 56, Issue 2, pp. 373-388. DOI: https://doi.org/10.1007/s00267-015-0503-3 


\title{
Evaluation of Development of Selected Renewable Energy Indicators and their Interdependence in the V4 Countries
}

\author{
Dominika Čeryová ${ }^{1}$, Filip Valentíni ${ }^{2}$, Natália Turčeková ${ }^{3}$, Izabela Adamičková ${ }^{4}$, Tatiana \\ Bullová ${ }^{5}$ \\ Slovak University of Agriculture in Nitra \\ Department of Economics ${ }^{1,2,3,4,5}$ \\ Address: Tr. A. Hlinku 2, \\ 94976 Nitra, Slovakia \\ e-mail: dominika.ceryova@uniag.sk¹,xvalentini@is.uniag.sk² ${ }^{2}$,natalia.turcekova@uniag.sk³ \\ izabela.adamickova@uniag.sk ${ }^{4}$, tatiana.bullova@uniag.sk ${ }^{5}$
}

doi: 10.18515/dBEM.ISD.P01.2020.p030

\begin{abstract}
The share of renewable energy sources (RES) in all four Visegrad countries (V4 countries) - the Slovak Republic, the Czech Republic, Hungary and Poland) is one of the lowest in the European Union (EU$28)$ and well below the EU average. Some publication mention that V4 countries ignores climate threats, attempts to extend fossil fuel burning, violates air pollution limits and undermines the development of renewable energy. However, energy from wind, sun, water, geothermal springs and biomass is clean and inexhaustible and use of alternative sources is becoming part of all realistic scenarios for the support of sustainable development and energy safety in V4 countries. The main goal of the paper is to evaluate the development of selected indicators in the field of renewable energy sources in 2009-2016 and monitor their interdependence. The objects of the research are V4 countries. The selected indicators are: electricity generation from renewable energy sources, installed electricity capacity for renewable energy sources, investments made by public financial institutions, number of employees working in renewable energy sector and turnover from main economic activities related to renewable energy sector. We used statistical methods like Kruskal - Wallis test, Friedman analysis of variance and Spearman's rank correlation coefficient.
\end{abstract}

Keywords: renewable energy selected indicators, renewable energy sources, Visegrad countries

JEL Classification: $C 14, Q 20, Q 40$

\section{Introduction}

Renewable energy, in the light of the current policy implemented in the European Union is a priority for energy security and sustainable energy. This problem is particularly important in areas with relatively low energy self - sufficiency, or areas where the energy generation is predominantly based on fossil fuels (Piwowar, Olszańska \& Režný, 2017). Magda (2016) mentions, that the Visegrad Group countries are among those in the European Union, which are dependent on import of strategic energy sources (e.g. oil or gas), as their home production is far from being able to secure sufficient for the customers. Pach-Gurgul \& Ulbrych (2019) add that currently, Slovakia and Hungary are economies whose dependence on energy import is above average compared to the European Union. On the other hand, Poland and Czech Republic are relatively less dependent, and yet, their dependence is growing. According to Bajusová, Pavl'áková, Bajus \& Dobák (2015), fossil fuel shortage and environmental pollution are considered to be two basic energy problems of mankind. In our opinion, one of the solution of two mentioned basic energy problems are renewable energy sources. Bajusová, Ladvenicová, Bullová \& Gurčík (2019) agree and add that the increasing consumption of energy, as well as exhaustibility of fossil resources, initiates the necessity of finding renewable sources. Likewise, Anton \& Nucu (2020) state that the consumption of renewable energy contributes not only to 
a cleaner environment (through reduction of greenhouse gas emissions) but also to independence from fossil fuel markets and to energy security. The results of Bozsik \& Magda (2018) showed that the four countries are highly dependent on oil and natural gas and the renewables replaced mainly the coal.

Energy affects all aspects of modern life and clean energy available at prices people can afford is a key issue to improve the standard of living (Fridleifsson, 2001) and Ndebele (2020) adds that electricity generation from renewable energy sources has been promoted in many countries through various instruments. According to Chodkowska-Miszczuk, Kulla \& Novotný (2017) e.g. feed in tariffs were adopted in Czech Republic, Hungary and Slovakia. Another kind of support system, a quota system, was adopted in Poland, what includes tendering and certificate systems. Renewable energy sources supply $14 \%$ of the total world energy demand (energy supplies from renewables are according to Twidell \& Weir, 2015 essential components of every nation's energy strategy, not least because of concerns for the local and global environment, for energy security and for sustainability) and they include biomass, hydropower, geothermal, solar and wind energy (Panwar, Kaushik \& Kothari, 2011). The results of Beňuš \& Čeryová (2019) showed that the Czech Republic and Hungary have fulfilled targets (market share of renewable energy on total consumption) set by the Directive already in 2016. Slovakia is only $1 \%$ below the target set by the directive. Poland was the worst performer among V4 countries. This country has the highest target (15\%) set by the directive but the observed growth potential was the weakest. The largest share of renewable energy consumption in the Slovak Republic, the Czech Republic, Hungary and Poland represents energy produced from solid biomass. On the other hand, the lowest share of renewable energy consumption in the Slovak Republic and the Czech Republic represents wind energy, in Hungary solar energy and in Poland geothermal energy (Čeryová, Turčeková, Svetlanská, Kapustová \& Ďurišová, 2018).

The world's transition to a low - carbon economy necessitates a massive shift in the allocation of investments / capital (IRENA, 2020). According to Venugopal, Srivastava, Polycarp \& Taylor (2012) public finance institutions provide public capital to support public and private sector projects. A number of such institutions have been established and resourced with the aim of supporting renewable energy investments. The main types of public finance institutions are: i) International financial institutions (e.g. the European Investment Bank), ii) Development Finance Institutions (e.g. the German Development Bank), iii) Local financial institutions, iv) Export credit agencies, v) Climate finance institutions (e.g. Green Climate Fund) Wuester, Lee \& Lumijarvi (2016). Investors' confidence that the regulatory and financial basis of their investments will be honoured facilitates their readiness to finance renewable energy projects at more affordable conditions. Given the tendency of governments to renege on promises of support once investments have been made, external guarantees are needed to protect investors (Boute, 2020).

\section{Data and Methods}

The main aim of the paper is to evaluate the development of selected indicators in the field of renewable energy sources in 2009 - 2016 and to monitor their interdependence. The objects of the research are the Visegrad Group countries - Slovak Republic, Czech Republic, Hungary and Poland. Countries are examined from the perspective of the renewable energy situation in total for hydropower, wind, solar, biomass and geothermal energy. The data necessary to achieve this objective are obtained from the following sources:

1. Statistical Office of the European Communities - Eurostat:

a. population of the Visegrad countries,

2. International Renewable Energy Agency - IRENA: 
a. electricity generation from RES in MWh / inhabitant,

b. installed electricity capacity for RES in MW / inhabitant

c. investments made by public financial institutions to RES in \$ / inhabitant,

d. number of employees working in the RES sector (n) / inhabitant,

e. turnover from the main economic activity related to the production, distribution, installation, operation and maintenance of equipment in the RES sector in \$ / inhabitant.

Non-parametric statistical methods were used in the statistical processing of the data set - more selective series tests and dependence tests:

A. Kruskal - Wallis test

$$
H=\frac{12}{N(N+1)} \sum_{i=1}^{k} \frac{R_{i}^{2}}{n_{i}}-3(N+1)
$$

Where:

$\mathrm{k} \quad$ - number of random samples tested,

$\mathrm{n} \quad$ - random selection,

ni - nth random selection,

$\mathrm{Ri}$ - sum of sequential values of all members of each selection in the ith selection,

$\mathrm{N} \quad-\mathrm{n} 1+\mathrm{n} 2+\mathrm{n} 3+\ldots+\mathrm{nk}$.

We tested the null hypothesis based on the selected significance level $(\alpha=0.05)$, at which a statistically significant difference was identified.

B. Friedman analysis of variance

$$
\mathrm{F}=\frac{12}{\mathrm{nk}(\mathrm{k}+1)} \mathrm{R}-3 \mathrm{n}(\mathrm{k}+1)
$$

Where:

$\mathrm{k} \quad$ - number of selections tested,

$\mathrm{n} \quad$ - range of selection,

$\mathrm{R} \quad-$ resultant sums of columns in the order of squared squared.

The graphical representation of the identified trends in the data of the Visegrad countries over the period of the evaluated period (2009 - 2016) using curves was processed in the form of scatterplot matrices and the curve fitting with trend data (exponential curves).

C. Spearman's rank correlation coefficient

$$
\text { rho }=1-\frac{6 \sum_{i=1}^{n} d_{i}^{2}}{\mathrm{n}\left(\mathrm{n}^{2}-1\right)}
$$


Where:

$\sum_{i=1}^{n} d_{i}^{2} \quad$ - the sum of all differences squared.

The established range of Spearman's rank correlation coefficient (rho) values may indicate:

1. Poor correlation between $0.00-0.30$;

2. Slight correlation between 0.31 and 0.50 ;

3. Mean correlation between 0.51 and 0.70 ;

4. Strong correlation between 0.71 to 1.00 .

A statistically significant dependence is said if the significance indicator (p) is lower than the significance level $(\alpha=0.05)$.

\section{Results and Discussion}

\section{Slovak Republic}

Under the conditions of the Slovak Republic, the selected indicators in the field of renewable energy sources have fluctuating character throughout the monitored period. Most of the energy generation comes from the hydropower sector, where the most installed electricity capacity for RES are built in Slovakia (the correlation between production and output was characterized as statistically significant on the basis of $\mathrm{p}$ value). Investments made by public financial institutions had very low values per capita and were close to zero. In 2013, the European Investment Bank provided funds for renewable energy production, with a focus on overhauls and refurbishments and capacity expansion in the hydropower sector. The amount of investment per capita was \$ 13 (5410836 inhabitants of the Slovak Republic in 2013). In the biomass and solar energy sector, we record the largest turnover of economic activities in the field of production, installation, distribution, operation and maintenance of renewable energy equipment. The biomass sector in Slovakia provides the largest number of jobs (see Figure. 1).

Figure 1: Development of selected RES indicators and their interdependence - Slovakia

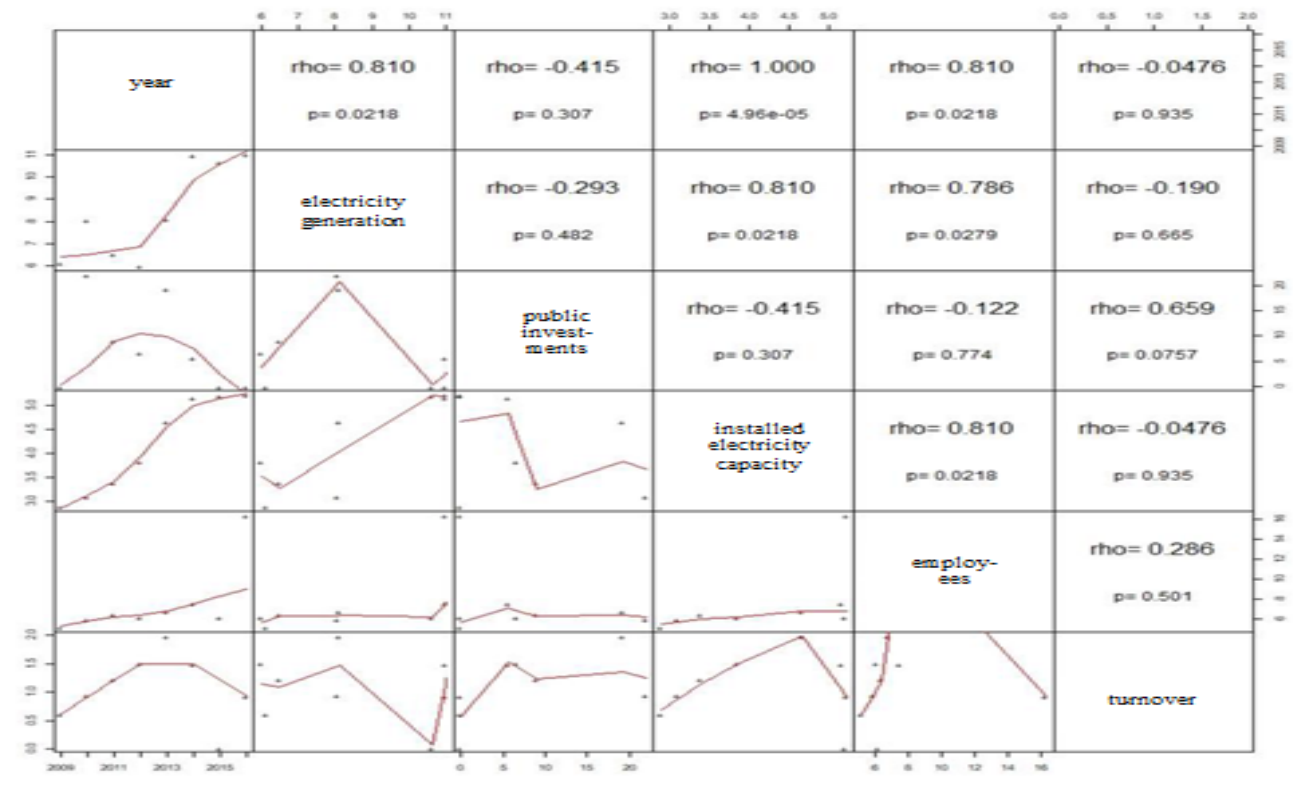

Source: author's calculations 


\section{Czech Republic}

In the Czech Republic, electricity generation (per capita) has been increasing in time over the years 2009-2016. Most contributed to this is the biomass energy sector, in which energy production has been growing throughout the period under review. Investments made by public financial institutions peaked in 2010 and 2011, when the European Investment Bank granted the Czech Republic \$246 per capita to support the solar energy sector. In recent years the values per capita of the Czech Republic have been very low, so we can say that investments from public financial institutions developed in a systematic way in time. Installed electricity capacities have been increasing over time (most of the installed electricity capacities are recorded in the sector of renewable hydropower and solar energy). The evolution of the indicators over time is statistically significant in the following cases: year - electricity generation $(\mathrm{p}=0.00114)$ and year - installed electricity capacity $(\mathrm{p}=0.000397)$ and this correlation is characterized as strong based on rho value (see Figure 2).

Figure 2: Development of selected RES indicators and their interdependence - Czech Republic

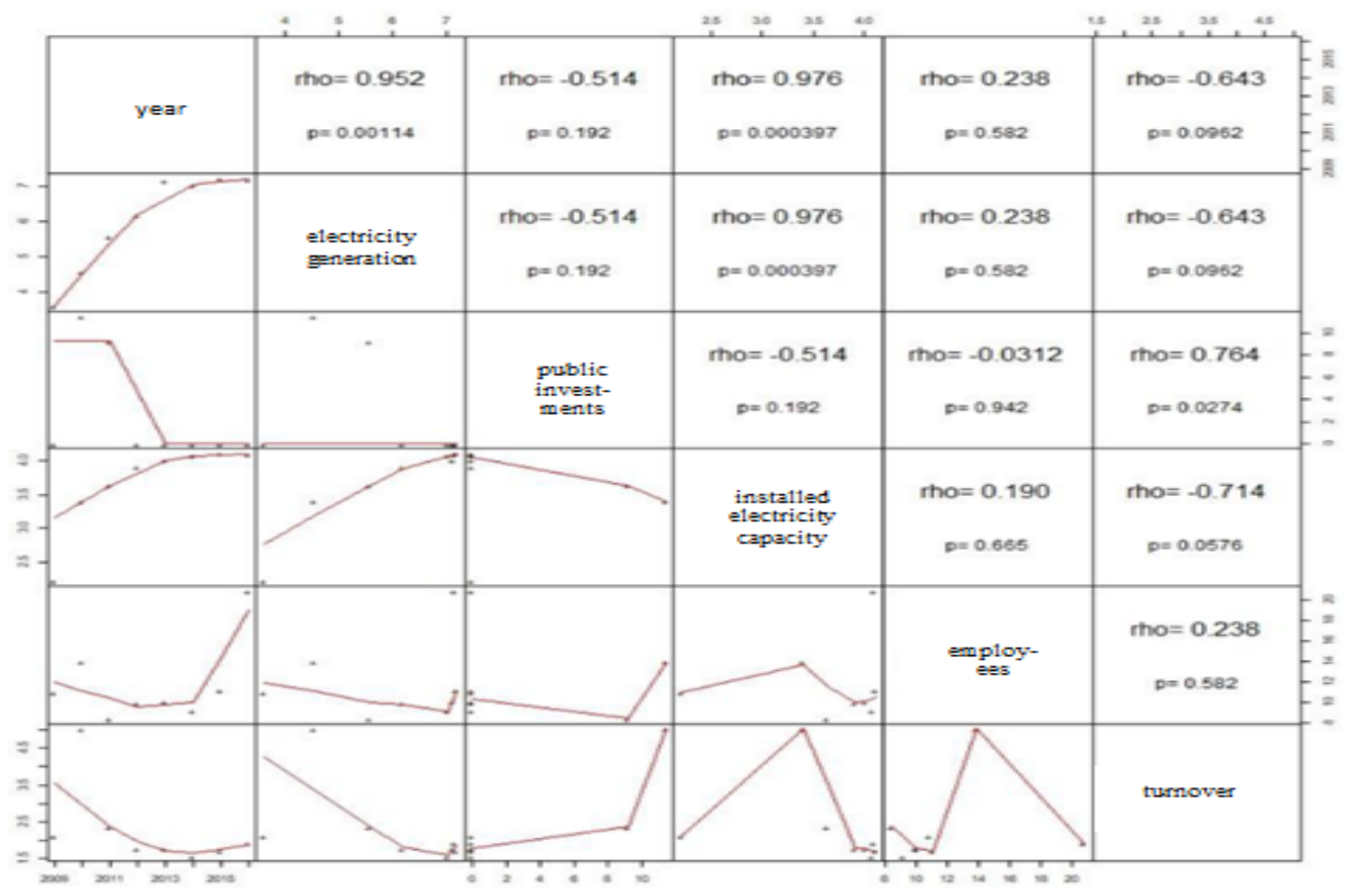

Source: author's calculations

\section{Hungary}

Looking at the picture that corresponds to the situation in Hungary, it can be stated that investments made by public financial institutions have developed evenly and public sector support has been so low that it was close to zero per capita. We see a fluctuation in the trend in 2010, when Hungary's equity investment from the European Bank for Support and Development (EBRD) of $\$ 13.22$ per capita was provided to support Hungary's wind farms. Turnover from economic activity has increased in the period between 2015 and 2016, when the value from the sale, installation, distribution, operation and maintenance of biomass energy equipment increased by $\$ 64$ per capita. Correlations (statistically significant) between indicators are seen in those cases where the p value is less than 0.05 (see Figure 3). 
Figure 3: Development of selected RES indicators and their interdependence - Hungary

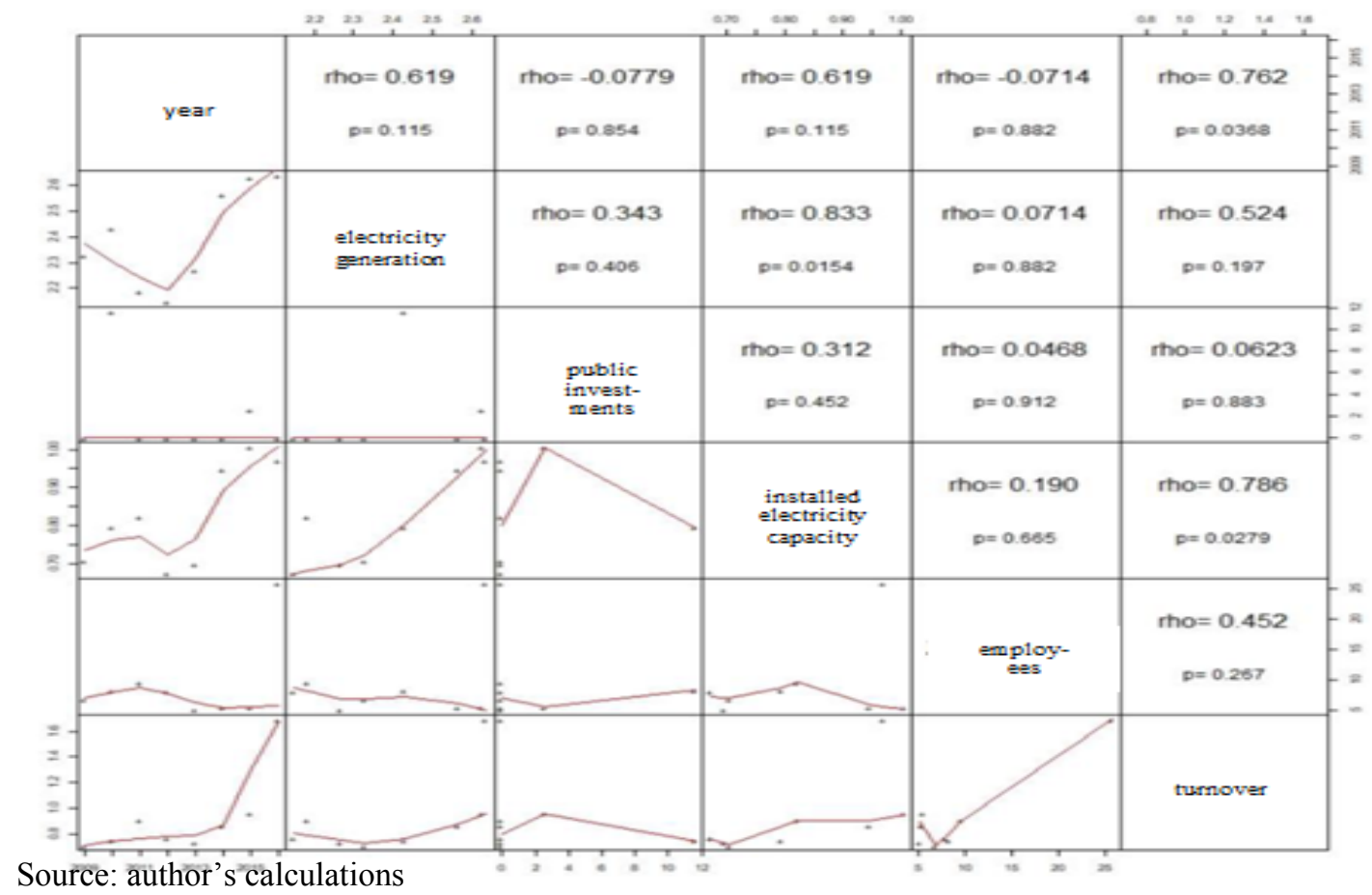

\section{Poland}

For indicators of electricity generation, installed electricity capacity and turnover we assume development, characterized as increasing. On the other hand, we see a decline in public investments. Almost every year, the value of investments expressed per capita decreased (rho $=-0,857$, i.e. indirect dependence). Employment in the renewable energy sector has been constantly developing with less fluctuations. In Poland, a correlation was found between: year and electricity generation $(p=4.96 \mathrm{e}-5)$; year and public investments $(\mathrm{p}=0.0107)$; year and installed electricity capacity $(p=4.96 \mathrm{e}-5)$; year and number of employees in the renewable energy sector $(p=0.0154)$. The situation can be seen in the next figure (see Figure 4$)$.

Figure 4: Development of selected RES indicators and their interdependence - Poland

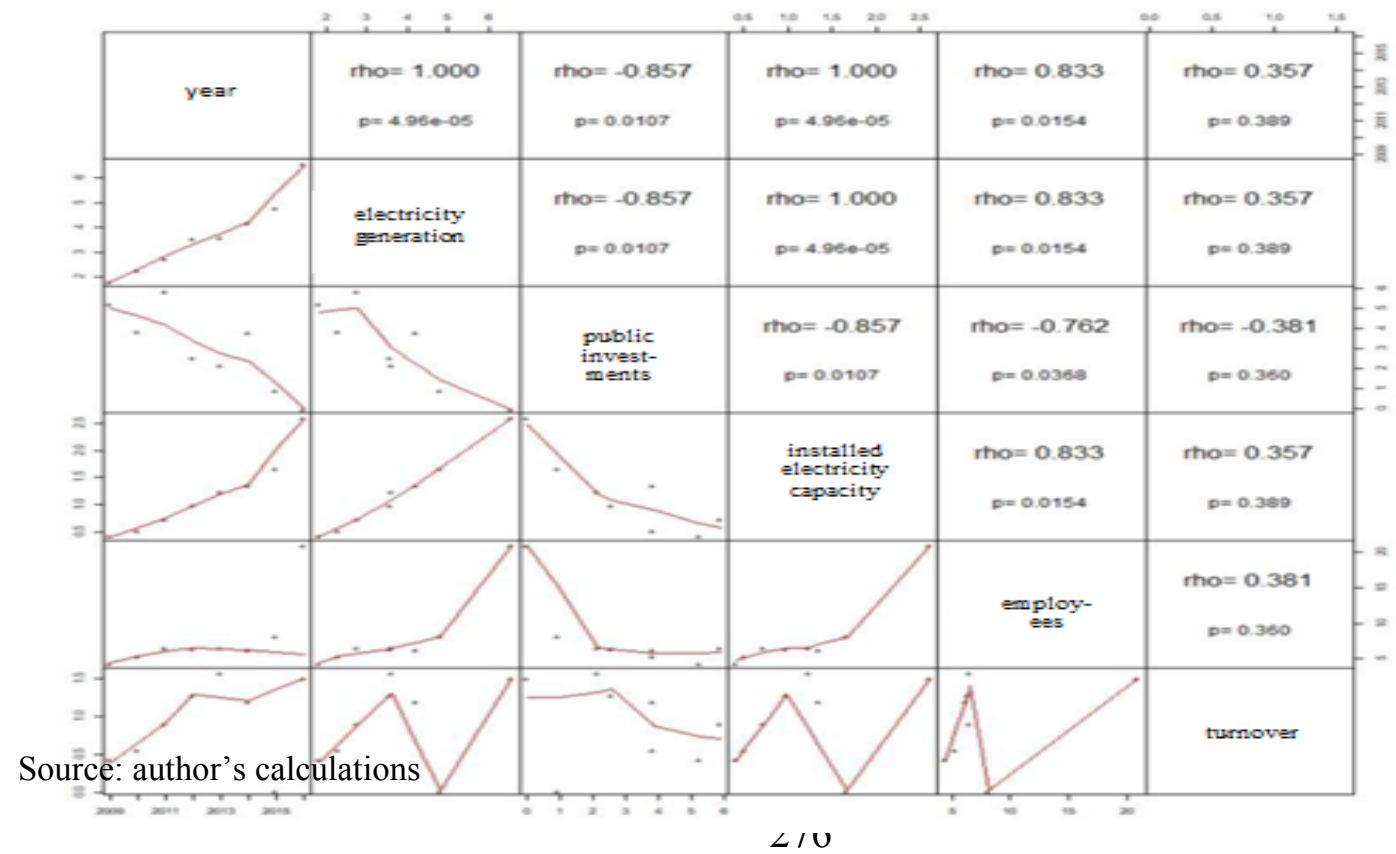




\section{Conclusion}

The main goal of this paper was evaluation of development of selected renewable energy indicators and monitored their interdependence in V4 countries. The selected indicators were: electricity generation from renewable energy sources, installed electricity capacity for renewable energy sources, investments made by public financial institutions, number of employees working in renewable energy sector and turnover from main economic activities related to renewable energy sector. We used the following statistical tests: Kruskal - Wallis test for variance analysis of dependent variables and Friedman test for variance analysis of independent variables. In the evaluation of selected indicator we focused on finding their correlation by Spearman's rank correlation test. Under the conditions of the Slovak Republic, the indicators are fluctuating throughout the period under review. Most of the electricity generation comes from the hydropower sector. Investments made by public financial institutions had very low values per capita and were close to zero. In the biomass and solar energy sector, we recorded the largest turnover from economic activities. The biomass sector in Slovakia provided the largest number of jobs. In the Czech Republic, electricity generation has been increasing in time. The biomass energy sector contributed most to this. Investments made by public financial institutions developed at an unsystematic time and were very low. Installed capacities of equipment had a growing tendency. In Hungary, it can be stated that investments from public financial institutions have developed evenly and public sector support has been so low that it is close to zero per capita. Turnover from economic activity has grown in character between 2015 and 2016. Under the conditions of Poland, the indicators of electricity generation, installed electricity capacity and turnover assume a rather growing development. On the other hand, we saw a decline in public investments. Employment developed constantly. Based on the achieved results, we conclude that most indicators showed fluctuating character. We can state that the exception was installed electricity capacity, which developed by the increased tempo over the year and the dependence was also statistically significant. Public investments showed a non-systematic character and in some years were characterized by extreme values (outliers).

\section{References}

[1] Anton, S.G. \& Nucu, A.E.A. (2020). The effect of financial development on renewable energy consumption. A panel data approach. In Renewable energy, 147 (1), pp. 330-338. DOI: 10.1016/j.renene.2019.09.005.

[2] Bajusová, Z. - Ladvenicová, J. - Bullová, T. \& Gurčík. L. (2019). Evaluation of economic impact of biodiesel production in Slovakia. In Visegrad journal of bioeconomy and sustainable development, 8(2), pp. 75 - 77. ISSN: $1338-8339$.

[3] Bajusová, Z. - Pavláková, S. - Bajus, P. \& Dobák, D. (2015). Impact of biofuels production on the structure of agricultural land in Visegrad countries. In Proceedings ICABR 2015: X. International conference on applied business research, pp. $91-100$.

[4] Beňuš, O. \& Čeryová, D. (2019). Current trends in Slovak legislation regulating renewable energy production. In Visegrad Journal on Bioeconomy and Sustainable Development, 8(1), pp. 13-17. DOI:10.2478/vjbsd-2019-0003.

[5] Boute, A. (2020). Regulatory stability and renewable energy investment: The case of Kazakhstan. In Renewable and sustainable energy reviews, 121. https://doi.org/10.1016/j.rser.2019.109673.

[6] Bozsik, N. \& Magda, R. (2018). Analysis of energy consumption of the Visegrad countries. In Visegrad Journal on Bioeconomy and Sustainable Development, 7 (2), pp. 36-41. DOI: 10.2478/vjbsd-2018-0007.

[7] Čeryová, D. - Turčeková, N. - Svetlanská, T. - Kapustová, Z. - Ďurišová, E. (2018). Renewable energy market in V4 countries. In International scientific days 2018. Praha: Wolters Kluwer. pp. 921 - 931. ISBN: 978-80-7598-180-6. DOI: https://doi.org./10.15414/isd2018.s4.03. 
[8] Chodkowska-Miszczuk, J. - Kulla, M. - Novotný, L. (2017). The role of energy policy in agricultural biogas energy production in Visegrad countries. In Bulletin of Geography-Socio-economic Series, 35 (35), pp. 1934. DOI: http://dx.doi.org/10.1515/bog-2017-0002

[9] Fridleifsson, I.B. (2001). Geothermal energy for the benefit of the people. In Renewable and sustainable energy reviews, 5, pp. $299-312$.

[10] IRENA. (2020). Renewable energy finance: Green Bonds. Abu Dhabi: International Renewable Energy Agency. ISBN 978-92-9260-187-4.

[11] Magda, R. (2016). Future possible uses of renewable energy in the V4 countries. In International scientific days 2016: The agri-food value chain: challenges for natural resources management and society, pp. 123128. ISBN: 978-80-552-503-7. DOI: 10.15414/isd2016.s2.03.

[12] Ndebele, T. (2020). Assessing the potential for consumer - driven renewable energy development in deregulated electricity market dominated by renewables. In Energy policy, 136. DOI: 10.1016/j.enpol.2019.111057.

[13] Pach-Gurgul, A. \& Ulbrych, M. (2019). Progress of the V4 countries towards the EU's energy and climate targets in the context of energy security improvement. In Entrepreneurial business and economics review, 7 (2), pp. 175-197. DOI: https://doi.org/10.15678/EBER.2019.070210.

[14] Panwar, N.L., Kaushik, S.C. \& Kothari, S. (2011). Role of renewable energy sources in environmental protection: A review. In Renewable \& Sustainable Energy Reviews, 15 (3), pp. 1513 - 1524. DOI: 10.1016/j.rser.2010.11.037

[15] Piwowar, A. - Olszańska, A. \& Režný, L. (2017). Development of renewable energy in the Visegrad countries - comparative analysis. In Hradec economic days, 7 (1), pp. 696-705.

[16] Twidell, J. \& Weir, T. (2015). Renewable energy resources. $3^{\text {rd }}$ edition. London: Routledge. 816 p. ISBN: 978-131-5766-41-6.

[17] Venugopal, S. - Srivastava, A. - Polycarp, C. \& Taylor, E. (2012). Public financing instrument to leverage private capital for climate - relevant investment focus on multilateral agences [online]. Available on: https://www.wri.org/publication/public-financing-instruments-leverage-private-capital-climate-relevantinvestment. 


\title{
Environmental Awareness of Young People and its Importance for the Green Jobs Development
}

\author{
Anna Mravcová ${ }^{1}$, Danka Moravčíková ${ }^{2}$ \\ Slovak University of Agriculture in Nitra \\ Faculty of economics and management, Department of Social Science ${ }^{1,2}$ \\ Address: Tr. A. Hlinku 2, \\ 949 76, Nitra, Slovakia \\ e-mail:mravcova.anna@uniag.sk ${ }^{1}$,danka.moravcikova@uniag.sk ${ }^{2}$
}

doi: 10.18515/dBEM.ISD.P01.2020.p031

\begin{abstract}
New challenges and demands are put mainly on young people to realize the needed change today. They will have to live, sooner or later, with the consequences of a devastated environment which was left to them by previous generations. However, young people are very innovative and creative to develop new forms activism and effective responses to environmental issues. Because of this it is necessary to support their informedness and raise their environmental awareness and responsibility which are important to ensure sustainable development. This has special importance also in their future life - mainly in the working sphere which can be oriented pro-environmentally from the very beginning. Youth understands, perhaps better than others, that mankind is not living in a zero-sum, environment-versus-economy world and they can play an important role in this context through their future jobs. The paper therefore examines and analyses the importance of environmental awareness of young people in ensuring the life on Earth. It analyses the received data about the level of this awareness globally and its possible impact on the development of green jobs as one of the green economy basis and youth unemployment solutions.
\end{abstract}

Keywords: environmental awareness, green economy, green jobs, sustainable development, young people

JEL Classification: F64, O44, Q56

\section{Introduction}

Current era of globalization and worsening environment lead mankind to the necessity of understanding many new connotations. Environmental issues belong among the most profound and complex challenges requiring still bigger attention today as well as in the upcoming future. An increase of environmental problems arises the importance of a term environmental awareness. The main goals of environmental awareness are to conserve the nature of our living places that we share with other living organisms. To support environmental awareness, individuals must be sensitive to global and local environment and fulfil their responsibilities.

The role of youth is very accurate here, as it is the rising generation in which the intensified environmental awareness can be achieved more easily. The appropriate attention must be paid to the reform and extension of environmental education, to ensure that the media play effective role in facilitating learning about environmental issues, challenges, needs and possibilities, etc. Environmental awareness becomes from individuals, through the smallest units of society like family to the whole community including educators, governments up to global society. It means - every individual is responsible to protect the environment.

Young people have good assumptions here to develop new forms of activism and bring new tendencies in heading these problems adequately also through their jobs. Therefore, new challenges and demands are put on them and their awareness raising as they have wide possibilities to face the reality of environmental crisis. They will have to face real consequences 
of the irresponsible action of last generations that devastated the world over the acceptable limits. Young generation is, on the other hand, very competent as receiving many new skills necessary for life in the harmed world and act effectively in every sphere where they operate.

The paper therefore examines and analyses the importance of environmental awareness of young people in ensuring the life on Earth for future. It analyses the data received from various surveys and researches about the youth environmental awareness worldwide and then it analyses the importance and possible impact of this awareness and activism on the development of green jobs ${ }^{3}$ which are one of the basis of the new green economy ${ }^{4}$ as well as one of the solutions for the global problem of youth unemployment. Our assumption is that young people understand the connected connotations more than other social groups and have generally high level of environmental awareness. This can contribute to the development of the green jobs as they are more interested in environmentally friendly working ambient which supports transformation to the green economy worldwide and achieving sustainable development.

\subsection{Environmental awareness and the potential of young people}

Still more people understand that we need to manage our planet - its resources, climate and ecosystems - in the sustainable manner. Deep support for environmental protection worldwide accompanied by increased environmental awareness have being seen also because of evident demonstration of the environmental crisis consequences. The best way we can protect our environment is by providing information and making sense of individual to its responsibility regarding environmental issues. Pro-environmental behaviour among general public is important in the whole world. People, and especially the youth, have many interconnections with the environment and the commitments toward it, so that they do not excessively harm it and provide themselves with an appropriate living environment, thereby linking their privileges with the corresponding responsibilities (more in Krogman \& Foote, 2011). Thus, tere is a need to spread environmental awareness, in the context of successful solving of environmental crisis.

Environmental awareness can be understood in several ways. For example, as "an attitude to life" that is aimed at protecting and improving the environment. It is a form of behaviour, thought and attitude of individual and community to maintain a balanced way of interaction with the environment. The basis of this awareness is to get benefit from environment without its harming (Eren \& Yaqub, 2015). There is a need to support its dissemination and raising as well as building responsibility which are crossing the national and any other borders today.

UNESCO and United Nations Environment Programme (UNEP) refer to the environmental awareness as to "the growth and development of awareness and understanding towards the biophysical environment and its problems, including human interactions and actions" (Taylor, 1983). Crucial to establish a comprehensive climate reform and achieve full environmental

\footnotetext{
${ }^{3}$ Green jobs are pivotal to sustainable development and respond to the global challenges of environmental protection, economic development and social inclusion. Green jobs are decent jobs that contribute to preserve or restore the environment. They help reduce consumption of energy and raw materials, limit greenhouse gas emissions, minimize waste and pollution, protect and restores ecosystems and support adaptation to climate change. They are the response to two major challenges of our time: how to deal with climate change and environmental degradation, and how to deliver development and decent work. Green jobs and green economy are key to sustainable future (ILO, n.d.).

${ }^{4}$ The green economy is an economic model that arises from an analysis where, in addition to the benefits of the profit from a certain production, consideration is also given to the environmental impact of the production itself. The objective is to calculate the potential damage to the environment caused by the entire transformation process of raw materials, from their extraction to transport and transformation into energy and products and finally the possible environmental damage that their definitive elimination or disposal produces (Morning Future, 2018).
} 
regulation for society is to act together which needs to involve everyone. Environmental awareness comes from individual, but its reach is wide. It is spread by receiving information from various sources - the most common and important is environmental education, but also observation, direct experience, etc. Based on this and many other factors, people are creating their preferences. In this sense we see that the power of media is raising. The importance of this awareness is underlined also because it supports developing and promoting new ways of positive action towards the environment among people, and especially young people who are usually more creative and emotionally interested in its protection in more effective ways. All in order to achieve sustainability of the world and ensure the survival of mankind and other living species on Earth for the future.

Building such awareness among youth is important in all aspects as it helps to look at the consequences of human actions globally. This can lead to the internal need to take environmental responsibility for the personal decisions and actions (more about environmental responsibility in St'ahel, 2015). The increase of participation of young citizens also means that legal frameworks would be more respected and economic mechanisms would be more accepted thus increase their effectiveness (see also Eclac, 2000). Environmental awareness, its dissemination, support and accepting responsibility for the actions, shall represent priority for every society today. People need to understand relationship between human and nature, the sense of participation, the legal awareness about the environment, the attitude towards the environment around and, that the environment is devastated by human. All this can lead to the participation in the positive change.

We want to underline that the concept of environmental awareness has not been clearly defined yet, but according to various studies, researches, and demonstrations also among young people, we can see that they are not content with the current state of the environment. Mostly they think that the stakeholders are not doing enough to protect the environment and solve its problems. But there is a question whether individuals are doing enough. Environmental awareness thus helps to recognize the fragility of the environment and the importance of its protection. Its promoting is a key part of environmental action to end the environmental crisis and achieve sustainability and responsibility towards respecting the rights of human, nature and life. Building this awareness requires socio-political interventions in form of various policies, strategies, goals and laws - the support of government and regional groupings, as important part of the environmental recovery. However, people and mainly the stakeholders must find the appropriate way how to spread it and how to move individuals and young people to participate in improving environment more than just participate in the demonstrations.

Environmental awareness is also connected with the appropriate level of environmental intelligence which should represent a part of the current education at all levels. Students perceive highly the environmental issues. In order to achieve higher environmental intelligence, it is important for all education institutions to extend the environmentally oriented courses. The realized studies showed the difference regarding environmental awareness of students who attended such training seminars in comparison to non-attenders of those seminars (Eren \& Yaqub, 2015). Awareness of students is significant, as after the graduation it can direct them to start their professional activities in environmentally friendly jobs from the very beginning.

\section{Data and Methods}

This research study arises from the qualitative research coming from the content analysis of the available scientific studies and articles about the concept of environmental awareness of young people and their potential contribution to the sustainable world development also through willingness in participation in the pro-environmentally oriented jobs. In this regard, the paper 
is arising also from the analysis of the obtained data of the current state and perspectives of environmental awareness of youth through the surveys made worldwide. By this, we want to justify the significance and relationship of these categories for green jobs development.

The paper examines and highlights the importance of the concept of environmental awareness and justifies it particularly in the mind of the young people as generation that can significantly influence the positive development of the world through their activism and possible direction in the working environment. We justify this fact also through data collected from selected researches, documents and surveys about the environmental awareness among youth. After this, we explore and analyse the received data according to our theoretical research and critically demonstrate them in the context of the sphere of green jobs development, as an important basis of transformation to the green economy, and as an important solution for the global problem of high youth unemployment.

In the end, we receive valuable information. We are able to summarize and evaluate the findings, and point out the importance and potential of our examined areas as well as the need for support of the environmental awareness especially among young people for their positive pro-environmental and pro-sustainable acting in their professional lives and careers. Received results enable us to see the real status in analysed area and make own outcomes to extend our scope, as we assume that young people have high level of the environmental awareness and this can contribute to the development of green jobs, as they are more interested in environmentally friendly working ambient which supports transformation to the green economy worldwide as well as achieving sustainable development.

\section{Results and Discussion}

\section{1 Level of young peoples' environmental awareness}

The negative impact of the current way of lives on the environment lead us to the necessity of paying more attention to the analysis of human environmental informedness and behaviour, and their social interactions.

The inclusion of the environment as a topic in the economic and social development schemes creates the need for monitoring the environmental quality and awareness of the population (see also Alcalá et al., 2006). There is a raising need to do researches focused on what people, and especially young people, know, think and feel about their environment. We agree with Soto et al. that surveys and interviews are efficient ways to obtain this information. The results are needed also to propose and design policies and address public behaviour that develop the active participation of citizens (Soto, et al., 2014). Although the perceptions of humanity have been addressed in many studies, they are only a little focused on young people. Youth represents an area of special interest with great dynamism and opportunities to access education and have a big perception of the processes of the ecological deterioration (Soto, et al., 2014) at the local as well as global level. The added value of young people is that they have positive impact on number of other people personally or through the social networks as rigid part of their lives.

Many organizations pay attention to the youth as the biggest possibilities for the real change can come from them. UN is one of the most active in this field. It realizes various activities to encourage young people to engage with environmental issues. For example, Youth 2030 is the United Nations Strategy on Youth which aim is to scale up global, regional and national actions to meet young people's needs, realize their rights and tap their possibilities as means of change. The importance is underlined also by several stats showing that they are informed and often very interested in these issues. For example, according to UN data: 
- nearly half a million of youth in the world have taken action on climate change through some small grant's programmes in their communities (UNDP Fast Facts, 2015);

- up to $84 \%$ of young people agree that they need more information to prevent climate change and about $73 \%$ say they already feel the effects of environmental crisis (UN Office of the Secretary-General's Envoy on Youth, 2015);

- according to $89 \%$, young people can make a difference on environmental problems. However, at the same time, they are sceptic that without any clear change the world will act quickly enough to address these problems;

- young people are the key actors in awareness raising, running educational programmes, promoting sustainable lifestyles, protecting nature, supporting renewable energy, adopting and implementing environmentally friendly practices and projects (UN Office of the Secretary-General's Envoy on Youth, 2015);

- the role of youth is even more important in the countries of global South where they constitute the majority of population and have increasing awareness, and so have the power to transform societies in the world towards sustainable future;

- young people understand more than other social groups that climate change and other environmental issues represent a major threat also to the socio-economic stability of their lives (United Nations Youth, 2010). This is visible mainly in the global South countries harmed by environmental issues more, where more than $3 / 4$ of all young people live.

Because of the importance of this topic we examined the data also of several surveys realized worldwide among young people and their awareness about the environment:

1. Masdar Gen Z Global Sustainability Survey. It involved around 5000 young people across the globe in order to understand the challenges they see in the future, touching also environment. The results show that:

- the surveyed youth feel that protecting the environment is more important than economic profit and they see education and social awareness as key to gain sustainable development;

- surveyed young people want sustainable future and believe that more investments in renewable resources from public and private sector are crucial to achieve this;

- the environment was ranked as third among the top five challenges faced by young people today, after poverty and the threat of terrorism. At the same time, it was identified as the top challenge to address in the next 10 years by $40 \%$ of respondents;

- the surveyed young adults are serious about taking responsibility for the environmental legacy they have inherited, believing that it is the biggest issue for their generation to solve. At the same time, they were sceptical of corporations' attempts to deal with climate change;

- about $46 \%$ chose possibility to spend money on products from companies that behave in a sustainable way. $31 \%$ do not want to support companies following unsustainable practices; - according to the results of this survey young people does not see the older generation capable of addressing environmental problems;

- they think (and we agree), that it is important for global environment that companies will take young people's opinions seriously;

- respondents think that young people are more choosing products which are environmentally friendly. This helps the reality that young people dispose with the consumer power which is an effective tool to make corporations reconsider their actions;

- the survey also showed the reality that young people's trust in government, media and big businesses to behave sustainably is low and, on the other hand, young people shall have more power to influence political decisions in such field. According to the demands of current societies, situation and needs for achieving sustainable future, governments and 
older generations should give young people wider space for their participation in these issues (Al Wasmi, 2016).

2. The Global Survey for Sustainable Lifestyles. It examined what young people think about their daily lives and activities, their aspirations for the future, and beliefs about the role they play in influencing a real change (UN Environment, $n$. d.) as the lifestyle has strong impact on the environment and on communities. The survey examines how do young adults from different cultures worldwide perceive, picture and shape sustainable lifestyle. This survey had 8000 respondents from 20 countries. It was conducted by the UNEP, as the youth wants to be a force for change and create their own visions of sustainable development. The results show that:

- respondents consider poverty and environmental degradation to be the world's two biggest challenges, but they want more information on how they can participate at the change;

- they need help to understand the combined environmental, economic and social pillars of sustainable development - how are they influencing each other;

- results highlighted the need to work together to better understand, educate and empower young people worldwide so they can create their own positive visions of sustainable lifestyles and become involved in the change with more power;

- respondents are mostly willing to participate and help improve the world in which they live;

- they want to have and know more options to include sustainable practices in their lives. There is a need to have initiatives that are involving but not disturbing, where they can interact and participate;

- there is a need to build trust and participation. This will allow them to support and develop effective sustainable solutions for environment. According to this, associations and nongovernmental organizations shall build partnerships with young people to inform and engage each other in sustainable lifestyle practices;

- there is the need to promote research and education for sustainable lifestyles including consumption patterns, to help shift towards sustainable lives (UN Environment, n. d.).

3. Survey called "Future of Humanity" shows the fact that young people feel that climate change is very important issue facing the world. The survey was made on behalf of Amnesty International, where more than 10000 people were questioned in age 18-25 years (also known as Generation Z). The survey was made in 2019, in 22 countries. The results show that:

- from the list of 23 major issues facing the world, $41 \%$ of respondents chose climate change as one of the most important. The second was pollution $-36 \%$ and third terrorism $-31 \%$. Fourth and fifth were loss of natural resources and racial inequality;

- they mostly pointed global warming as one of the most important environmental issues facing the world $-57 \%$. The second was ocean pollution $-42 \%$, third air pollution $-31 \%$, and deforestation $-31 \%$;

- for these young people, the environmental crisis is one of the defining challenges of their age. What can be also something like a wake-up call to world leaders to take more decisive actions in this climate emergency or risk betraying younger generations further;

- at a national level corruption was mostly cited as one of the most important issues (36\%), followed by economic instability (26\%), then pollution (26\%), climate change (22\%);

- alongside climate change, a clear majority of young people value human rights in general and want to see their governments take more responsibility to protect them, which is strongly connected with necessity of environmental protection; 
- the most cited option in the question who they believe should take the most responsibility for protecting the environment, is governments - 54\%, then individuals $28 \%$ and $14 \%$ businesses (Amnesty International, 2019).

4. The TUI Foundation's third annual "Young Europe" survey. 8220 young people in 11 EU countries (Germany, Denmark, Finland, France, Greece, the UK, Italy, Norway, Poland, Sweden and Spain) were questioned in 2019, to understand better the life environment, identity/ies and political attitudes of young Europeans. The results show that:

- young Europeans in most of surveyed countries pointed the environment together with migration and economy as the "key problems";

- $\quad 1 / 5$ of young Europeans took part in some demonstration within the last year $-22 \%$ and for $43 \%$ the key topic motivating them to take action is environmental protection;

- engagement of young people tends to take place online or online and offline. This means, for example, "liking" contributions in social media $-49 \%$, participation in online petitions $-42 \%$, sharing contributions in social media $-31 \%$, etc.;

- $55 \%$ of respondents marked the climate protection and environmental policy as an opportunity rather than a threat for their personal lives. And they also want to do something with these problems, not just talk about them;

- they clearly declared that they want European countries to cooperate more in these issues however, they do not believe this will happen (TUI Group, 2019).

5. Flash Barometer Survey 455 called "European Youth", realized within the EU countries, as young people are an important part of European society. The survey points to the fact that the Treaty on the Functioning of the European Union emphasizes the importance of encouraging young people to participate in the democratic life of Europe. The EU's Youth Strategy also outlines initiatives in the main areas (employment and entrepreneurship, social inclusion, participation, education and training, health and well-being, voluntary activities, youth and the world, and creativity and culture). Respondents were in age 15-30. The results show that:

- $\quad 31 \%$ of respondents say they have been involved in organized voluntary activities in the last 12 months. Their voluntary activities were mostly aimed at changing something in their local community $-69 \%$, for $29 \%$ it was in their country, $10 \%$ say in other European countries, and $11 \%$ another part of the world;

- $\quad 14 \%$ of respondents say they have participated in activities or projects aimed at fostering cooperation with youth from other countries;

- the highest priorities according to them shall be for the EU: education and skills $-53 \%$, and the second is protection of the environment and the fight against climate change $-50 \%$, then employment $-42 \%$;

- in one of the list of priorities in which the EU should take action - the $49 \%$ mention protection of the environment and nature, after the half of respondents $(50 \%)$ who chose the area of health and well-being;

- among three ideas for the future of Europe that young people most agree with - belong promoting behavior change through environmentally-friendly projects such as sustainable transport or recycling systems across Europe $-40 \%$, other selected options are - promotion of critical thinking and the ability to search for information in order to combat fake news and extremism; easy access to information for young people who want to move and work abroad in order to encourage their employment (both 49\%) (European Commission, 2018). 
6. Survey realized in Turkey, focused on determining environmental awareness and sensitivity level of university students - 500 university students from different levels were surveyed. The results show that:

- students there have high level of consciousness and awareness for sustainable environment, about the use of natural resources, energy saving, waste recycling and reusing and they often realize these practices in their real lives;

- they think current societies do not have adequate environmental awareness, but the results indicated that there is high level of awareness at least among the surveyed subjects;

- the respondents' answers (90\%) to the question about the action to be taken for the sustainable environment showed, that the level of environment related activities in their country is not sufficient;

- young people shall have proper level of environmental awareness (96\% agreed);

- $61 \%$ answered that they have already been participating in a project or seminary on the environment, course on environmental awareness which should be, according to $83 \%$, mandatory for all university students;

- the respondents are conscious in the energy consumption. The participants strongly recommended also the need for recycling, proper choosing of products that can be reused instead of disposable products, the prevention of usable water from contaminants, etc.;

- nearly $60 \%$ of the participants think that the printed and electronic media are important for spreading information about environment to raise the awareness;

- in the case of self-employment $71 \%$ of respondents preferred to protect environment over the raise of their profit. Only $11 \%$ of them preferred increasing their profits. $18 \%$ had no opinion in this question (Eren \& Yaqub, 2015).

7. Selcuk University survey in Turkey, with the purpose to determine students 'awareness of environmental issues and their behaviour towards the environment. 375 students from various disciplines were surveyed. The results show that:

- about $1 / 3$ of respondents $(27,74 \%)$ perceive global warming as the most important global environmental issue;

- nearly half of them $(47,47 \%)$ agreed that education is the most appropriate and imminent solution that can be taken against the environmental problems;

- printed and electronic media are regarded as the most intriguing equipment according to nearly $3 / 4$ of the respondents $(73,73 \%)$ that increases people's awareness;

- only $8 \%$ of the respondents are already members of some environmental organization (Serpil, 2006) what can influence their future environmental orientation also in finding jobs or in case of starting own business.

8. Important are also the results of Youth report from Germany. A study looking into political attitudes of German youth has found that the environment is on the top of their concerns. It shows that youth wants to take action and that they are actively interested in environmental problems. Their top interests are environmental protection and climate change. They actively participated at protests - Fridays for future generation. The statistics showed, for example, that in $2015,56 \%$ of young people were worried about global warming in Germany. In 2019 it was already $65 \%$. They also understand that each individual can do something, but this is not enough. According to them everyone has to take action (DW, 2020).

On the basis of all these data and information we can see that it is important to make the voices of young people heard in the process of environmental improvement and also in order to achieve green economy based on green growth and green jobs. 


\subsection{Young people and green jobs development for achieving sustainability}

Because of still more visible consequences of the environmental crisis and the unsustainability of current human development, urgent and major adjustments are required to promote sustainable forms of production and consumption, and to improve natural resource management. Young people are particularly vulnerable to the impacts of environmental crisis in the work environment. Many of them are not able to find job. On the other hand, many of them have experience with threatening environment in their work or with environmental problems what can even lead to the massive loose of jobs. Environmental crisis and youth employment are closely linked and therefore the transition to the environmentally friendly and sustainable economy which relates to different - better and greener - opportunities, is more than required. "Greening the economy involves investments in technology, energy, buildings and infrastructure in sustainable ways and will have significant impacts on the world of work, driving job creation and upgrading" (ILO, 2016). But most of all, it involves investments in education and environmental awareness rising of young people as the actors of change who are increasingly concerned about environmental issues and accept the key role they can play in greening economies.

Young people represent an important part of every nation. The adopting of current employment policies connected with the forming economic reality, to which global societies as well as individual organizations put still higher attention, mainly through promoting green jobs in green economy, is very important also in the case to solve other problems, for example, the problem of youth unemployment. Thus, we agree that environmental awareness raising, and educating young people in green initiatives, technologies and jobs, as important accelerators for achieving sustainable development and green economy, is one of its necessary basis.

Through this awareness young people gain needed skills and knowledge for green employment and responsible behavior as actors in the green economy. We agree with Kopnina, H. (2014), who shows that the development of sustainable business environment begins with informing young people about the alternative conceptions as well as instructing them about potential solutions to the sustainability challenges. Young people are the main target group as they are the most open to new ideas and adapt easily to the new requirements of the green economy.

In this economy, development of green jobs becomes the basis of sustainable economic development and react to the global challenges of all three sustainable development pillars environmental protection, economic development and social inclusion.

Considering the capability and willingness of young people to adapt and accept the changes, green employment policies need to be aimed especially at this social group. This is the way to support sustainable development and help to solve the problem with youth unemployment (Aceleanu - Serban \& Burghelea, 2015). Up to now, millions of green jobs have been created across all sectors and there are more work opportunities, according to the report of the ILO Green Jobs Initiative. The shift to greener economy that could generate up to 60 million additional jobs globally by 2030 and lift tens of millions of workers out of poverty, also offers big opportunities for young people (Decent Jobs for Youth, 2017).

Green growth and green jobs for youth were also the main purpose of an expert group meeting in Bangkok, already in the end of 2012 and of many others after this. Youth unemployment is a serious problem worldwide and belongs among top priorities of the world. UN highlighted, that the meeting in Bangkok, for example, emphasized that youth development in this sphere is an important accelerator for making progress in sustainable development, which underlined also the importance of green jobs and the role of youth as tool for change (United Nations, 2012). So, beside the climate change which is believed to be one of the most defining issues of our time and threatens our very existence on the Earth, there is another huge problem - millions 
of young unemployed people all around the world. Green jobs therefore provide the opportunity to tackle climate change as well as help young people to have sustainable future.

Young people in rural areas have even worse situation. There are not enough jobs to sufficiently integrate them after school into the work environment. The worldwide goal is therefore also to support young people in these areas who are unemployed and who have little if any education to make an improvement in their employment and income situation through green jobs. As we can see, for example, from the report in Marocco, there is a project aimed at young entrepreneurs in areas related to the environment such as fishing or processing wood and natural products. This already increased number of qualified jobs for young people. The project wants to create a decentralized advice and training network for green employment that can facilitate long-term development in these regions. The plan contains vision that at least 2000 young people (between 16 and 35 years) find new employment by the year 2022. Another goal is to support at least 1000 young people and ten company founders in increasing their incomes through their projects simultaneously be protecting natural resources and nature (GIZ, 2018).

As we can see also from many studies and good practices, still more businesses in industry and services are investing in green technologies, products and green employment. Green economy is beneficial also because the businesses that do this have a greater international presence. This phenomenon is even more apparent in the manufacturing sector. Good example is here Italy where $46 \%$ of exporting businesses are eco-investing against $27,7 \%$ of other sectors (Morning Future, 2018). Spread of the green economy can have an important impact on the development also of the agricultural sector and youth employment (again, for example, Italy is first in Europe with the number of farms running by young people under the age of 35 . They have also number of new professional positions which have arisen there within the transformation to the green economy, as: Horticultural Tutor; Agri-wellness; Agri-stylist; Digital livestock breeder; Agriculturalist; Agri-wedding planner; Agri-chef; Organic Farmer; Environmental Chemist, etc. (Morning Future, 2018)). Green jobs can be realized in own business, non-profit organizations, government, education - in other words - nearly every type of job can be transformed onto green and realized in environmentally friendly way, when there is a will, appropriate awareness and knowledge. These jobs can cover all sectors of society. Moreover, today, small businesses, self-employment and entrepreneurships are very much a part of the new green economy (GoodWork, 2019). Some of the green jobs require specific skills or education, but all of them require at least some level of the mentioned awareness. When people want to do any kind of environmentally friendly job or create ecological business, they have to practice this approach also in their real life.

Young people's interest in the environment lead to the fact that they are key drivers for green jobs and green practices in professional sphere. This generation of young people is the largest the world has ever known. Their opportunities for communicating, acting and influencing are unprecedented, so are the challenges they face. Also because of this, the appropriate level of the environmental awareness can be very helpful in creation of green jobs as well as environmentally friendly entrepreneurial environment, as young people are actively trying to protect the environment and participate at finding innovative solutions today. They are the social group which support and try to realize environmentally friendly practices the most at home and in their professional lives. However, as we see, they need the appropriate space and support for their acting. As we already mentioned, for this purpose and because the youth has big potential in these efforts, $\mathrm{UN}$ is actively working with young people through various programs. This vision was clearly declared also in the document - Youth Strategy for 2014 2017, that was aimed at supporting youth and at deepening youth focus across all areas of employment, entrepreneurship, etc. (more in UNDP, 2014). According to the UN documents, youth participation has brought moral, intergenerational and equity-based values as well as 
constructive technical and policy inputs to the visible advance and improvement in this issue. Beside other mentioned activities, they also engage actively in climate change projects within different national and international organizations (see also United Nations Youth, n. d.). The focusing on green jobs is being developed alongside existing initiatives incorporating education and campaigning on environmental issues mitigation.

\section{Conclusion}

According to our theoretical analysis and collected data from selected documents, studies and surveys, we can justify that young people's environmental awareness has significant importance in the transformation to the green economy and in achieving sustainability within all three areas of sustainable development. We can point out also the fact that young people, according to the surveyed respondents worldwide and international documents, have good background on the basic environmental and ecological concepts and are mostly aware of the seriousness of environmental problems, where they present also their dynamism, emotivity and active approaches in wide range of social areas. We can see potential of young people in the context of positive changes in individual societies as they have broad knowledge, information and skills needed for the life in this globalized world. However, they need also space to realize this potential more.

Young people can, according to our analysis, have therefore positive impact on greening economy and on solving the problem of youth unemployment in a significant extent. This can be manifested also through green jobs development, as just young people are more vulnerable and capable to participle in this type of jobs. They want to be active. However, there is a requirement for establishing the closer partnerships among governments, intergovernmental as well as non-governmental organizations and youth for joint environmental initiatives aimed at building the capacity of individuals and young people as future leaders in new strategies of sustainable development, in the forming green economy. More space needs to be provided for young people to present their ideas, activism, dynamism, and act for positive change and to fulfil advantages of green employment opportunities and for development of whole societies worldwide. All these can according to our opinion help to develop green jobs across whole spectrum of social spheres and to transform global economy to the greener and more sustainable.

\section{Acknowledgements}

The authors gratefully acknowledge the contribution of the Scientific Grant Agency of the Slovak Republic under the grant 1/0685/17.

\section{References}

[1] Aceleanu, M., I. - Serban, A. C. \& Burghelea, C. (2015). "Greening” the Youth Employment - A Chance for Sustainable Development. Sustainability, 7, 2623-2643. DOI:10.3390/su7032623.

[2] Alcalá, J. et al. (2006). Community diagnosis of the environmental problematic: an example from Chihuahua City, Mexico. Revista Latinoamericana de Recursos Naturales, 2, 81-88.

[3] Al Wasmi, N. (2016). Young people value environment over money, according to global survey. Retrieved from https://www.thenational.ae/uae/young-people-value-environment-over-money-according-to-globalsurvey-1.190473.

[4] Amnesty International. (2019). Climate change ranks highest as vital issue of our time - Generation Z survey. Retrieved from https://www.amnesty.org/en/latest/news/2019/12/climate-change-ranks-highest-as-vitalissue-of-our-time/. 
[5] Decent Jobs for Youth. (2017). Green Jobs for Youth. Retrieved from https://www.decentjobsforyouth.org/theme/green-jobs-for-youth\#WHY.

[6] DW. (2020). Environment tops the list of concerns of young people. Retrieved from https://www.dw.com/en/environment-tops-the-list-of-concerns-of-young-people/av-50843833.

[7] Eclac. (2000). Role of Environmental Awareness in Achieving Sustainable Development. Economic Commission for Latin America and the Caribbean, 23 November, 2000. Retrieved from https://repositorio.cepal.org/bitstream/handle/11362/31562/S00111003_en.pdf?sequence=1.

[8] Eren, B. \& Yaqub, M. (2015). Environmental Consciousness Survey of University Students. AKADEMIK Platform. Retrieved from http://www.isites.info/PastConferences/ISITES2015/ISITES2015/papers/C1ISITES2015ID54.pdf.

[9] European Commission. (2018). European Youth. Flash Eurobarometer 455 Report. Brussels: EU.

[10] GIZ. (2018). 'Green jobs' for young people in rural areas. Retrieved from https://www.giz.de/en/worldwide/80411.html.

[11] GoodWork. (2019). What is a green job? Retrieved from https://www.goodwork.ca/what-is-a-green-job.

[12] ILO. (2016). Create green jobs to realize the benefits of low emission development. Retrieved from https://www.ilo.org/wcmsp5/groups/public/---ed_emp/---gjp/documents/publication/wcms_517110.pdf.

[13] ILO. Promoting green jobs for youth. Retrieved from https://www.ilo.org/global/about-theilo/artworks/topics/green-jobs/lang--en/index.htm.

[14] Kopnina, H. (2014). Metaphors of Nature and Economic Development: Critical Education for Sustainable Business. Sustainability, 6, 7496-7513. DOI: 10.3390/su6117496.

[15] Krogman, N. \& Foote, L. (2011). Global Citizenship and the Environment: Embracing Life in All Its Forms. Shultz, L. et al. Global Citizenship Education in Post-Secondary Institutions. New York: Peter Lang, pp. 108-119.

[16] Morning Future. (2018). Young people go into action: the 10 trendiest green jobs. Retrieved from https://www.morningfuture.com/en/article/2018/06/20/young-work-green-jobs-agricolture-professioncoldiretti/347/.

[17] Serpil, O. (2006). A Survey of Awareness and Behaviour in Regard to Environmental Issues among Selcuk University Students in Konya, Turkey. Journal of Applied Sciences, 6, 347-352. DOI: $10.3923 /$ jas.2006.347.352.

[18] Soto, R. et al. (2014). Environmental Awarensess of the Young in a Rural Community in the Sierra Tarahumara, Chihuahua, Mexico. Journal of Education and Practice. 5(4). Retrieved from https://www.researchgate.net/publication/261511129_Environmental_Awareness_in_Youthpdf.

[19] St’ahel, R. (2015). Environmentálna zodpovednost' a environmentálna bezpečnost'. Filozofia, 70(1), 1-12.

[20] Taylor, J. L. (1983). UNESCO-UNEP International Environmental Education Programme. Guide on simulation and gaming for environmental education. Hungary: UNESCO.

[21] TUI Group. (2019). Youth Study "Young Europe 2019" of TUI Founfation. Retrieved from https://www.tuigroup.com/en-en/media/press-releases/2019/2019-05-03-tui-foundation-youth-study.

[22] UN Environment. Global Survey on Sustainable Lifestyles. Retrieved from https://www.unenvironment.org/explore-topics/resource-efficiency/what-we-do/one-planet-network/globalsurvey-sustainable.

[23] UN Office of the Secretary-General's Envoy on Youth. (2015). \#YouthStats: Environment and Climate Change. Retrieved from https://www.un.org/youthenvoy/environment-climate-change/.

[24] UNDP. (2014). UNDP Youth Strategy 2014-2017: Empowered Youth, Sustainable Future. New York: United Nations.

[25] UNDP Fast Facts. (2015). Youth and Climate Change. Bureau for Policy and Programme Support. Retrieved from http://goo.gl/Luyn3P.

[26] United Nations. (2012). Green growth and jobs for youth. Retrieved from https://www.un.org/development/desa/youth/green-growth-and-jobs-for-youth.html.

[27] United Nations Youth. (2010). Youth and Climate Change. Retrieved from http://bit.ly/1FBQsfy. 


\title{
Restructuring of Economy in a New Global Environment to a Sustainable - one of the Tasks for a Global Citizen
}

\author{
Eva Pechočiaková Svitačová ${ }^{1}$, Anna Mravcováa \\ Slovak University of Agriculture in Nitra \\ Faculty of economics and management, Department of Social Science ${ }^{1,2}$ \\ Address: Tr. A. Hlinku 2, \\ 94976 Nitra, Slovakia \\ e-mail: eva.svitacova@uniag.sk ${ }^{1}$, mravcova.anna@uniag.sk ${ }^{2}$
}

doi: 10.18515/dBEM.ISD.P01.2020.p032

\begin{abstract}
Together with emergence and development of the global economy, global problems, risks, and threats of the global nature have been accumulating in the current world as well as the global and transnational threats have been spreading, which undoubtedly includes the devastation of the nature and environmental pollution. The strategic purpose of the adaptation strategy of modern civilization and the „driving engine of the economy" is achieving welfare for human. However, at the cost of increasing productive and unproductive burden of the nature, which seriously endangers stability of the ecosystem. This is one of the reasons why it is necessary to restructure the economy in the new global environment to a sustainable. This means that it will not focus primarily on ensuring welfare for present man, but it will focus mainly on its sustainable existence. The task to restructure economy to sustainable one is current for a global citizen whose duty is to mitigate the socio-cultural burden of nature and to live sustainably.
\end{abstract}

Keywords: economy restructuring, nature, culture, global environment, global citizen

JEL Classification: F63, F64, Q56

\section{Introduction}

Globalization is affecting many inequalities, global problems, and risks that threaten the functioning of some areas and societies of the Earth today. The special category of global problems represents those that are related to the global threat of the environment. One of the causes of their emergence is economic globalization, which raises demands on natural resources and burdens the environment.

The emerging global economy is characterized by considerably higher economic efficiency in the use of productive factors and by higher qualitative level of economic growth in services and goods. However, several problems are associated with its functioning and development. One is linked to the development of consumption and its global level, which has been becoming an indispensable condition for economic prosperity and economic growth. The real needs of people in societies are getting into a background, and not only their needs, but also their lifestyles, are adapting to economic criteria and interests. Negative thing connected with the development of economic growth and growth of consumption is a major socio-cultural burden of nature, biosphere abuse, and disruption of the ecosystem's equilibrium. The emerging economy, which is one of the cultural subsystems, plays a dominant role in the globalized culture and it is considered to be the main offender of environmental pollution, consumption of non-renewable resources, and emergence of global environmental problems. That is why we mark it as an anti-natural. Besides some other reasons, this is also a serious reason for restructuring economy to sustainable one. At the same time, this reason becomes a challenge 
not only for economists or managers but also for politicians, and ultimately for every global citizen who should take responsibility for the lives of future generations.

\subsection{Anti-natural and anti-human orientation of the culture and economy as its subsystem - one of the reasons for economy restructuring in the new global environment}

The culture, created by human purposeful activity is referred today to a ,species selfish activity" with dangerous consequences for the Earth and human (Šmajs, Binka \& Rolný, 2012). It is also referred to a ,comprehensive product of the human offensive adaptation strategy, as an anti-natural system with own constitutive information and destiny dependent on human" (Šmajs, 2006). Regarding the fact that it was being formed in the host environment of the biosphere it has an imbued non-natural dimension, it is not in an equal relation to the nature, and we designate it as an anti-natural system. This system naturally expands in the broader natural environment of the Earth on which the human is dependent.

In the contemporary culture, economy represents the leading place. It creates conditions for satisfying the diverse needs of people and it is a promise of the better quality of their lives. After all, it has always been dictating the development of culture. However, especially for the current man, the economic criteria become more important than his other interests. Economy represents an intentional economic activity that removes the products, processes and energy from the nature, and which delivers them to the culture. Whether for the direct human consumption or for further processing. J. Šmajs states, that by its acting it is focused against the most organized ontic layer of the planet, against the biosphere, as well as against the naturally arranged non-living structures, which transforms into cultural forms (Šmajs, 2010). As he adds: „It is time for economic processes to be evaluated in term of good and evil not only for human and culture, but also for the superior natural system, the biosphere that includes human, economy, and culture" (Šmajs, 2010, p. 128).

Together with development of the global economy a globalized culture with developed abiotic technologies is being considered, which is at the same time exploited and pushed by two related and for the Earth devastating principles: first, the biological adjustment of man to an aggressive adaptive strategy in the sphere of entrepreneurship, and secondly, by hypertrophied consumption instinct in the way of people's lives“ (Šmajs, 2008, p. 57). The globalization of culture is associated with such attributes as „consumer global“, „mass“, or „pseudoculture“, „world culture“, etc. ${ }^{5}$ For example, Juvin and Lipovetsky denoted the world-culture as a period of capitalism expansion across the globe, when the market became a planetary one and all states embarked on the path of privatization and economic-financial deregulation. It is a cultural capitalism in which cultural and communication industry have become an instrument of economic growth, and the so-called „cultural economy“ in which the real world of

\footnotetext{
${ }^{5}$ The emergence of the so-called consuming global culture is being considered thanks to the modern technologies, technological innovations, and global information and communication facilities. It relies on cultural schemes, but also on goods and products that have begun to spread globally. H. Arendt was thinking about mass culture in her publication „Between Past and Future“ (1994). She explained that it is a term derived from the term mass society. Both terms represent mutually interconnected phenomena. Their common denominator is not mass, but society into which that mass was incorporated. Culture becomes mass when the mass society come at the cultural objects. Under the pressure of consumerism, the gradual transformation of culture into pseudoculture is considered. The emergence of world culture is related to revolution in the field of communication technologies, with the emergence of transnational media networks and with expansion of the cultural industry. Among other features of the world culture belong, for example, the short durability of cultural products, worship of the presence, suppression of the culture on hyper-fast and more immense, etc. World culture is also associated with the so-called global uniformity and diversity. Besides the fact that world culture leads to the same patterns of behavior on the Earth and to the unified lifestyle, to which the technical universality has contributed ,political and cultural diversity raises on the background of uniformity“ (Juvin \& Lipovetsky, 2012, p. 51).
} 
production represents itself as a world of culture and culture raises the economic demands (Juvin \& Lipovetsky, 2012) is being developed. The economy has changed into culture and the culture is closely associated with commerce. It is a result of combination of the main organizational principles - the market, consumer lifestyle, science and technology, individualism and the cultural-communication industry. It is characterized by similar consumption practices and goals, as well as by generally accepted thinking and action. It can be marked as some economic totalitarianism, because the symbolism, cultural meanings, myths and principles create such a market that enforces laws of adaptation, flexibility, modernization, etc. It is a supranational culture supported by the market in society where the new consumer economy aimed at changing production and increasing its diversity, was established.

The globalization of culture enhances the anti-naturality of culture and its development is accompanied by problems that have global dimension. Considering the increasing demands on natural resources as well as burden on the environment, we can agree that a specific and increasingly significant category of global problems are those related to the global threat of the environment - global environmental problems (Huba \& Ira, 2004). Their emergence is largely related to the fact that mankind unreasonably „operates“ with natural resources. Regarding the efforts to increase the quality of human life and in ambition to achieve prosperity, the mankind actively interferes to the environment, as well as the atmosphere, climate, soil, water, the cycle of substances, and living organisms are affected intensively, while the human civilization also affects itself. It turns out that man is not only a culture creator, but also a depredator. He has a share in the gradual degradation of the environment as well as in the destruction of living conditions on the planet. $\mathrm{He}$ is responsible for the worsening state and quality of life on the Earth, not only in light of man but also in light of other life-forms on the Earth (apart from human beings), that obviously points to the conflict among the culture and nature. The current economy has its share in this. Mainly by supporting the consumer's lifestyle and mass consumption it is resulting in great socio-cultural burden on nature. But also, that in addressing needs it leans upon the approaches and practices which do not pay sufficient attention to the rare and non-renewable natural resources.

The proof of conflict among the culture and nature are the global environmental problems that are affecting all components of the environment as well as human, and the environmental crisis, which is also understood as a state of lack in an economic sense, which refers to the exhaustion of raw materials, energies, etc., but also as a lack of nature itself (Kolářský \& Suša, 1998). It is stated that the environmental crisis is a cultural feeling. It is the „frustration of modern enlightenment faith in the conquest, overcoming of the nature, in the domain of man over the nature - as the legitimating myth of the socio-economic dynamics of expansion of modern civilization“"(Kolářský \& Suša, 1998, p. 68). It is the state of real being of the global ecosystem and its components, as well as the cultural situation, state of values and principles. It assumes the awareness of ecosystem's ultimateness and of resources usage limits. Also, the awareness of anti-naturality and anti-humanity of the global culture without the borders, as well as antinaturality of the consumption-oriented economy.

On the one hand, economic development can be the basic driving force for other development dimensions. For example, it is considered to be an „ordained treatment" for poverty in developing countries. On the other hand, it has its natural limits. These are, among other things, given by the quality of environment in which the economic activities are carried out by ecological services that the specific environment can provide, as well as by the long-term availability of natural resources. In general, we can call them environmental limits (Hokrová \& Táborská, 2008). 
In the context of the effort to achieve economic growth as well as the economy development, there is a need for control. This is despite the fact that the objective of these activities is human. Economic growth cannot, however, restrict other forms of growth (for example, social and cultural) and it cannot endanger nature neither. Already in the 70s of the 20th century there have been warnings whether the Earth is able to maintain the economic growth, population growth and resource consumption as well as the rapid destruction and devastation of the ecosphere through the pollution and farming methods (Meadows et al., 1972).

Growing production and consumption in the new global environment are unbearably burdening nature so that the nature gradually decreases or even loses its production capacity. The result of excessive economic activity is not only the dangerous reduction of the Earth natural order, decreasing (disintegration) the area of natural ecosystems, but also the abusing of man and nature through the unnatural technical metabolism. Long-term devastation of environment can significantly affect the life of inhabitants in specific area by disseising them of the natural resources essential to the life, living or housing. Because of this, people in the affected areas are forced to find solutions that lead to other inequalities and problems in the world. For example, they are leaving their homes and looking for food somewhere else, which is a prerequisite for environmental migration.

Considering the fact that economy in the new global environment is focused on consumption but also considering the means by which its development is being achieved, as well as due to its devastating effects and impacts on the ecosystem of the Earth and especially on its biosphere, we call it anti-natural, insufficiently compatible with the environment. It is launched against the most organized ontic layer of the planet, that represents a purposeful ecosystem on which everyone is dependent. Culture has anti-natural character, and anti-natural is also the economy, which helps to spread the world culture, through which it damages the cultural system, nature and ultimately also human. We agree with the statement that: „We must radically transform the anti-natural culture that the human being devastates" (Šmajs \& Krob, 1991, p. 86). As because economy represents its subsystem, we must transform also the economy and restructure it to sustainable one.

As it is stated, the costs associated with environmental damage are often not included in the market prices of products and services, so they are not beard by consumers, but by all people of the Earth, eventually also by next generations (Hokrová \& Táborská, 2008). Although, the negative impacts on environment associated with economy functioning are nonuniform, they affect the disruption of global ecosystem life functions, and this has disastrous consequences for all inhabitants of the Earth. And so, in addition to the fact that economy in the new global environment can be described as anti-natural, we also describe it as anti-human. What is antinatural is also anti-human; because what damages nature also harms human and his culture (Šmajs, 2006).

The anti-naturality and anti-humanity of economy in the global environment are serious reasons for restructuring of economy to be sustainable, and truly enable the development of human and culture. It is most necessary to prevent the situation that the world of culture will develop by dominant assistance of economy at the expense of nature, in the new global environment.

\section{Data and Methods}

This theoretical study stems from the qualitative research coming from the theoretical analysis of the situation in the world. Based on this, it was first justified that contemporary culture can 
be described as anti-natural and anti-human also thanks to the economy, which is one of the subsystems of culture. Although economic development may be a key driver of other dimensions of development, the study critically demonstrates the anti-naturality of the economy in the new global environment, which is due to the process of globalization of culture. So-called world culture is emerging, which damages the cultural system, nature and, ultimately, human. Regarding this background, the theoretical study points out that the economy in the new global environment has a significant share in deepening the conflict between culture and nature, and the values that are key to the concept of sustainable development are now apparently in conflict with the stereotypes of today's economic thinking. Thus, it is not possible to assign the attribute ,sustainable“ to the economy in the global environment. In this context, the study highlights one of the current and leading challenges for global citizen - to restructure the economy onto the sustainable. Relying on the principles of sustainable development, the study justifies why this challenge, and, at the same time, the role is addressed not only to economists, managers and other economic actors, but to every citizen - global citizen. Global citizenship education appears to be one of the ways to fulfill this most important task through which the environmental awareness of citizens in the global environment can be greatly shaped and strengthened, and responsibility for the state of the ecosystem and the global environment can be generated. Global citizenship education is presented as a way to shape responsible citizens of the global world who, among other things, should strive to develop the economy in such a way that they think of future generations, duly aware of the value of non-renewable resources and of the whole nature.

\section{Results and Discussion}

\subsection{Restructuring of economy to sustainable one - the current task for global citizen}

We can agree that the idea of sustainable development has become a general idea of integrating environmental care into all systems of social and economic life (Suša \& St'ahel, 2016). The basic principles of sustainable development discussed and adopted by the UN World Commission on Environment and Development in 1987 in Brundtland Report ${ }^{6}$, lately improved, detailed and adopted worldwide in 1992 at the United Nations Conference on Environment and Development in Rio de Janeiro, as well as the Millennium Development goals ${ }^{7}$ adopted at the Millennium Summit in 2000 by the UN and confirmed on the World Summit on Sustainable Development in Johannesburg in 2002, and the most current Sustainable Development Goals adopted in 2015 at the United Nations Development Summit ${ }^{8}$, must be clearly reflected in the everyday life of society, and therefore also in the economy.

Sustainable development ,is a process and a holistic approach to achieving an integration of social, economic, and environmental justice. It is governed by the "less is more" principle (in the context of ecological modernization). It is the key to new ecological businesses" (Klimková, 2016, p. 83).

\footnotetext{
${ }^{6}$ The Brundtland Report defined the term sustainable development first time as "development that meets the needs of the present without compromising the ability of future generations to meet their own needs" (World Commission on Environment and Development, 1987, p. 43).

${ }^{7}$ More about eight Millennium Development Goals in UNDP, 2000.

${ }^{8}$ Basic principles are currently settled in the 2030 Agenda for Sustainable Development (United Nations, 2015) which contains also 17 Sustainable Development Goals and their 169 targets. Those represent the most important contemporary global problems from the social, environmental and economic area. They are one of the highest priorities of the entire international community today on its way to form sustainable place from the Earth and to ensure the life on it also for next generations.
} 
Economic activities, objectives, plans or practices need to be realized in accordance with sustainable development and the economy needs to be directed towards sustainability through a set of sustainable development indicators. ${ }^{9}$ Given the above, in the new global environment we describe both culture and economy (as one of its important subsystems) as anti-natural as well as anti-human. However, we cannot agree that the current economy is directed towards sustainability. This state is one of the reasons for the need of its restructuring.

The economy restructuring requires, in particular, awareness of the fact that culture stands and falls with the maintenance of natural conditions that shaped human. Then, it assumes to bring the original, superior place to the natural system which created human, and which enabled him to satisfy the necessaries of life by its natural activity before the emergence of culture and economy. Nature is a system that allows existence of economy and culture. It is a superior host system to the culture. As it is stated, this system is „more powerful“" than the global culture and decides ultimately about its destiny as well as about the destiny of human (Šmajs, Binka \& Rolný, 2012).

Restructuring of economy is both challenge and task not only for economists, managers and other economic subjects, but ultimately for every citizen. Their task is to „think globally and act locally“. ${ }^{10}$ Also H. Jonas formulated new imperative, appropriate to the new type of subject: „Act in the way that the effects of your actions are compatible with the lasting of real humanistic life on the Earth.“ Or simply: „Do not threaten the conditions of unlimited lasting of mankind on the Earth" (Jonas, 1997, p. 35). Jonas is clearly aware that we do not have the right to vote for no-being of future generations because of the existence of the present ones or leastwise to risk this no-being. Also, that we can talk about the individual right to suicide, but not about the mankind right to suicide (Jonas, 1997).

The state of the environment, which is a basic condition for the existence of life, points to the irresponsibility of people as citizens in the global world. This is despite the fact that the right to an adequate environment belongs among the basic human rights. Global citizens are responsible not only for achieving higher standard of living and ensuring better quality of life on the Earth, but also for creating equal conditions for quality life of next generations. From sustainability point of view, they should aim at the preserving any natural assets or at least at protecting them from devaluation and depletion above the acceptable extent.

Given the above mentioned reasons for the need to restructure the economy in global environment, as well as the outlined responsibility of each global citizen, including every entity in the economy, there is a need to prevent the cultural world from developing in the new global environment with dominant economic assistance at the expense of the nature. This assumes reasonable ${ }^{11}$ considering of satisfying the diverse values of the population and aspiring to build

\footnotetext{
${ }^{9}$ The sustainable development and goals for its achievement must be followed-up and reviewed by using the set of global indicators. These must be complemented by indicators at the regional and national levels which must be developed by individual states (UN Knowledge Paltform, 2015). For example, in Slovakia there was adopted a set of indicators for sustainable development, for evaluation of fulfillment the National strategy for sustainable development in environmental pillar complemented with other areas connected with the environment: social pillar, economic pillar and institutional pillar (more in Enviroportál, 2018).

${ }^{10}$ This motto was used for the first time in the first half of the 20th century by Scottish social activist and town planner P. Geddes. In this case, there was an emphasis on action towards the whole ambient. The focus on environmental sphere, for which the password is so popular today, became around the second half of the 20th century.

${ }^{11} \mathrm{~J}$. Rawls distinguished between reasonable and rational. These are the so-called „two moral powers“" he considered to be a part of the basic nature of a citizen. To act reasonably means to design and respect the good conditions of cooperation that people are willing to follow, and they are confident that others will do the same.
} 
sustainable economy that will ensure balance between the social, economic and environmental dimension of development. We find it gratifying that some economic subjects are already involved in this direction and are involved in the so-called "green initiatives". These include, for example, Green Economics, Sustainable Economics, Sustainable Marketing and some others, whereby they are linked, for example, with the implementation of environmentally appropriate practices and technologies in production to ensure, as much as possible, the environmental protection and efficiency in the natural resources usage.

However, this is clearly not enough, and so the question remains, how to ensure that every citizen in the current interconnected world will be properly aware of the value of nature as universal basis of life and does not disvalue it in the effort to ensure conditions for quality life.

One of the promises how to prepare economists and managers responsibly, so that they can first participate in the restructuring of the economy onto sustainable and then in its development, is the education for global citizenship ${ }^{12}$. Within this education, the entities directly or indirectly engaged in the economy will learn, among other things, about the reasons leading to the need to restructure the economy. For example, by pointing to the global environmental problems or to the causes of the global environmental crisis, and in this regard also to point out the anti-naturality and anti-humanity of the economy that has a considerable concern in these ,ailments“. In this context, education for global citizenship points out that the cultural development cannot be ensured only by supporting economic growth and consumption. And also, that the social welfare, which is an economic goal, must be attained in such way that we remain the non-human world beyond the danger as far as possible, because we are just as dependent on it as this world is dependent on ourselves (Rich, 1994, p. 35).

The reciprocity from which everyone benefits is expected. Rational refers only to a single actor, with the ability to think in the searching just for his own goals and interests (see Rawls, 1995).

12 Global citizenship represents still forming phenomenon with non-unified definition. Therefore, it is still relatively controversial and necessarily linked to a high degree of abstraction. However, this phenomenon relates to global problems and with the need for ensuring sustainable development of human societies on the Earth. As globalization deeply interconnects our world and every person can easily act variously thorough the world the global citizenship phenomenon has started to be still more popular. However, contrary of national or transnational citizenship global citizenship is not a legal term. We can see it, for example, as some ethical assertion about universal values and transnational responsibility. Also, as an ethos or set of moral principles and codes of conduct. Or we can perceive it as a kind of human rights philosophy. Generally, global citizenship should show people the citizenship from global perspective and help to give them information, knowledge and skills necessary for life in the current world. It gives people some promise of transnationality to perceive everyone equally. It presents an idea of universal inclusiveness. It describes ,citizenship beyond the borders“. We can understand it as a planetary citizenship focused on the global responsibility of individuals to protect the planet (UNESCO, 2014). There are plenty of insights on this phenomenon which vary from the idea that everyone is a citizen of the world to the opinion that in a legal sense such thing as a global citizen cannot exist. Global citizenship relates to the term global responsibility in the sense that everyone is a citizen of the world and everyone should see his/her range of the responsibility. In such approach, global citizenship is perceived as a way of thinking and behaving. It means a specific insight on life and belief that everyone can make a change (Young \& Commins, 2002). Regarding the unifying power of the citizenship concept global citizenship has a potential to become an important unitary element in individual societies. In its essence it can contribute to a greater equity, sustainability, equality with respecting diversity. It is a project of global justice that wants to withstand the pressure of the present times of prosperity and to encourage individuals and societies to participate in the new knowledge economy. It tries to transform the foundations of societies into fairer, focusing on a socially, politically, culturally and economically strengthened public sphere (Mravcová, Šeben Zat'ková \& Pechočiaková Svitačová, 2017). However, people will be able to think and act globally only when they are informed and when they feel that they are a real part of the global entity. Therefore, an important aspect of the phenomenon of global citizenship is education for it. This education should be aimed at creating responsible, active and critically thinking citizens in the global scale and it should applies a multilateral approach, concepts, methods and theories from related fields, including education on human rights, peace education, education for sustainable development, and education for international understanding. It supports human curiosity, solidarity and shared responsibility (UNESCO, 2014). 
According to Rich, this means giving up an anthropologically narrowed interpretation of human responsibility in favor of holistic perspective that includes environmental dimension.

Explaining values on behalf of which the economy needs to be restructured including the value of nature, the correct interpretation of goals and objectives of economy ${ }^{13}$ should encourage them at the same time to look for effective ways in which they can be actively involved in this process. In addition to the fact that citizenship education can help citizens strengthen their responsibility for the state of our planet and earthly nature, its task is to direct citizens to choose such economic goals and practices that do not bring welfare just to them, but which mitigate the socio-cultural burden of nature and thus do not endanger present human, nature and future generations.

\section{Conclusion}

The value preceding of culture above the nature is not the only negative consequence of insufficient self-reflection of human or insufficient reflection of the current state of ecosystem and of the entire nature. Another negative consequence is understanding of the economy as the most important subsystem of culture. This understanding is supported by the current society focused on consumption and immediate benefit. Although, in today's society we cannot deny the importance to the economy, at the same time, we cannot do it to the nature neither, which at any given time, also in the globalization era, represents the host environment - the only home of human and culture. Nevertheless, the current economy and, ultimately, the entire culture, seem to be anti-natural and anti-human.

The task to restructure economy in the new global environment to sustainable one becomes maximally current for every global citizen. Through education for global citizenship it is possible to shape and strengthen considerably his environmental awareness, and wake responsibility for the state of the ecosystem and of entire global environment. Although, education for citizenship does not provide direct guidance or practices how to restructure the economy to sustainable one, it can significantly contribute to the formation of personalities who are engaged directly or indirectly in the economy today and in the future, and thus to codecide on the quality of life in the new global environment.

\section{Acknowledgements}

The authors gratefully acknowledge the contribution of the Scientific Grant Agency of the Slovak Republic under the grant 1/0685/17.

\section{References}

[1] Arendt, H. (1994). Krize kultury. Praha: Mladá Fronta.

[2] Enviroportál. (2018). Indikátory TUR. Retrieved from http://www1.enviroportal.sk/ indikatory/schema.php?schema $=33$.

[3] Hokrová, M. \& Táborská, S. (eds.). (2008). Globální problémy a rozvojová spolupráce. Témy, o které se lidé zajímají. Praha: Člověk v tísni.

[4] Huba, M. \& Ira, V. (2004). Globalization and Global Environmental Problems. Životné prostredie, 38(5), 233-236.

\footnotetext{
${ }^{13}$ Regarding the rising economy of life, he tried to interpret the meaning and basic purpose of economy together with other purposes of economy (see Rich, 1994).
} 
[5] Jonas, H. (1997). Princíp odpovédnosti. Pokus o etiku pro technickou civilizaci. Praha: Oikoymenh.

[6] Juvin, H. \& Lipovietsky, G. (2012). Globalizovaný Západ. Polemika o planetární kultúře. Praha: Prostor.

[7] Klimková, A. (2016). Ethical leadership and eco-ethical program as specific and direct way to sustainability community. Zeszyty naukowe politechniki Slaskiej, 195, 81-91.

[8] Kolářský, R. \& Suša, O. (1998). Filosofie a současná ekologická krize. Praha: FÚ AV.

[9] Meadows, D. et al. (1972). The limits to growth. A Report for the club of Rome's Project on the Predicament of Mankind. New York: Universe Books.

[10] Mravcová, A., Šeben Zat'ková, T. \& Pechočiaková Svitačová, E. (2017). Globálne občianstvo v terciárnom vzdelávaní. Nitra: SUA.

[11] Rawls, J. (1995). Teorie spravedlnosti. Praha: Victoria publishing.

[12] Rich, A. (1994). Etika hospodářství (Sv. 1, Theologická perspektiva). Praha: Oikoymenh,

[13] Suša, O. \& St’ahel R. (2016). Environmentální devastace a sociální destrukce. Praha: Filosofia.

[14] Šmajs, J. (2006). Ohrozená kultúra. Od evolučnej ontológie k ekologickej politike. Banská Bystrica: PRO.

[15] Šmajs, J. (2008). Potřebujeme filosofii přě̌ití? Brno: Doplněk.

[16] Šmajs, J. (2010). Ekonomika a př́roda - filosofická reflexe problému, Ekonomický časopis, 2, $126-143$.

[17] Šmajs, J., Binka, B. \& Rolný, I. (2012). Etika, ekonomika, př́roda. Praha: Grada Publishing a. s.

[18] Šmajs, J. \& Krob, J. (1991). Úvod do ontologie. Brno: Masarykova univerzita.

[19] UN Knowledge Paltform. (2015). Indicators_in the Transforming Our World - The 2030 Agenda for Sustainable Development. Retrieved from https://sustainabledevelopment.un.org/topics/indicators.

[20] UNDP. (2000). Millennium Development Goals. Retrieved from http://www.undp.org/content/undp/en/home/sdgoverview/mdg_goals.html.

[21] UNESCO. (2014). Global Citizenship Education. Preparing learners for the challenges of the $21^{\text {st }}$ century. Paris: UNESCO.

[22] United Nations. (2015). Transforming our world: the Agenda 2030 for sustainable development. New York: United Nations General Assembly.

[23] World Commission on Environment and Development. (1987). Our Common Future. Oxford: Oxford University press.

[24] Young, M. \& Commins, E. (2002). Global Citizenship: The Handbook for Primary Teaching. Cambridge: Oxfam. 


\title{
EU Member States Competitiveness and Competitive Potential
}

\author{
Eva Richterová ${ }^{1}$, Martin Richter $^{2}$, Eva Matejková $^{3}$, Zlata Sojková ${ }^{4}$ \\ Slovak University of Agriculture in Nitra \\ Department of Statistics and Operations Research ${ }^{1,3,4}$ \\ Department of Economics ${ }^{2}$ \\ Address: Tr. A. Hlinku 2, \\ 94976 Nitra, Slovak republic \\ e-mail: eva.richterova@uniag.sk¹, martin.richter@uniag.sk², eva.matejkova@uniag.sk², \\ zlata.sojkova@uniag.sk ${ }^{4}$
}

doi: 10.18515/dBEM.ISD.P01.2020.p033

\begin{abstract}
The competitiveness is one of the main criteria for economic performance evaluation and reflects the unit's success in a broader comparison. The aim of this paper is to assess the EU28 countries' competitiveness by creating a Competitiveness Index 2018 (CI 2018), analyze how countries utilize their competitive potential and verify the initial hypothesis: EU member states with the best positions according to competitiveness outcomes are those countries that fully utilize the competitive potential and have the best efficiency results. CI 2018 is created from four outputs 'competitiveness variables by applying Principal component analysis. Based on CI 2018 EU countries are divided into three groups: strong competitive countries, competitive countries, and weak competitive countries. The most competitive country is Luxembourg. Input competitiveness variables (driven forces) are used to create four indicators, represented by competitive potential: Labour market and human resources, Innovation potential, Quality of human potential and Business potential. Output oriented CCR model assuming constant returns to scale is applied to estimate countries 'transformation efficiency. Efficient EU countries, which can improve their competitive position only by increasing inputs, are Luxembourg, Denmark, Netherlands, Germany, The United Kingdom, Italy, Cyprus, and Greece. Other EU countries can improve their competitive position by increasing the utilization of competitive potential. According to results the initial hypothesis of the analysis is accepted.
\end{abstract}

Keywords: competitiveness, competitiveness index, driven forces, competitive potential, efficiency

JEL Classification: A10, C14, C38, C67

\section{Introduction}

In recent years, competitiveness is one of the main criteria for economic performance evaluation and reflects the unit's (country, region, firm) success in a broader comparison. Although national competitiveness is a yearly monitored characteristic, even if there is still no common definition of this concept. Porter (1998) claims that the only meaningful concept of national competitiveness is productivity. The World Economic Forum (2016) defines it as "the set of institutions, policies, and factors that determine the level of productivity of a country". According to Garelli (2002), national competitiveness includes the economic consequences of non-economic areas. Bienkowski (2008) defines competitiveness as a country`s ability to achieve economic growth faster than other countries and at the same time increases its prosperity in a way that its economic structure is changing and effectively adapts to the movement of international trade.

\subsection{Evaluation of competitiveness}

Since the year 2005, the World Economic Forum analyses national competitiveness by creating a Global competitiveness index (GCI). GCI is designed on the basis of 148 economies`soft and 
hard data. In the year 2018 Germany is in the first position, the Netherlands is in the second position and the United Kingdom is in the third position in GCI ranking (World Economic Forum, 2018).

World Competitiveness Yearbook (2018), published by the Institute for Management Development, ranking 63 countries ' competitiveness results using 258 indicators. In the year 2018, the US takes first place among the world's most competitive economies, followed by Hong Kong, Singapore, the Netherlands, and Switzerland.

Both indices do not distinguish between competitiveness drivers (factors) and competitiveness outcomes and they create a comprehensive index on the basis of both sides.

Staníčková (2015) evaluates the EU countries` competitiveness with respect to distinguish between inputs and outputs of competitiveness. Driven forces are divided into six factors: Economic growth and development, Level of infrastructure, Health phenomena in human life and cultivation, Inflation trends, transport, healthy lifestyle, the performance of educational institutions and public administration, Participation in education and Expenditure on education and civilization diseases. Outcomes of competitiveness are grouped into three factors: Economic performance and innovative potential, Knowledge-based economy, and Labour market. In the case of input factors, the most economically powerful countries with the best factor endowment are advanced old EU Member States such as Denmark, Sweden, the United Kingdom, Austria, France, Luxembourg, and Ireland. To very close intent, results of inputprofile indicate results of output-profile. In the case of output factors, countries with a high level of efficiency and performance trend are the Netherlands, the United Kingdom, Denmark, France, and Sweden. Germany is the country reflecting stable and good economic results. Melecký (2013) classifies EU countries into clusters according to the similarity of created input' and output factors. In the case of inputs, Denmark and Sweden have the greatest level of competitiveness indicators. In the case of outputs, Germany has the highest economic efficiency and performance.

When we distinguish between competitiveness inputs and outputs, it is possible to analyze the mutual relationship between them and find out the possible way of increasing the country's competitive position. According to Šegota, Tomljanović, and Hudek (2017), the traditional indicators of competitiveness are incomplete because they do not consider the macroeconomic efficiency of the country. A more realistic evaluation of macroeconomic competitiveness should be the combination of traditional competitiveness indicators and the results of the evaluation of macroeconomic efficiency. Therefore countries should focus not only on the competitiveness results but also on the efficiency of transformation - how they transform their competitiveness incomes on their competitiveness outcomes - how full they utilize the competitive potential.

Staníčková (2013) builts a Country Competitiveness Index (CCI), which consists of eleven pillars grouped according to the different dimensions (input versus output aspects) of national competitiveness. The methodology of CCI is suitable for measuring national efficiency by the DEA method and to study productivity growth. According to her results, the most advanced countries are Scandinavian countries and Luxembourg, which have recorded the best results in the level of efficiency and no trend in productivity change.

Melecký (2013) claims that the DEA method becomes a suitable tool for comparing the level of countries' competitive potential. By using DEA methods he evaluates how efficient the EU member states are to transform their inputs into outputs. EU member state is ranked as efficient if it utilizes its competitive advantages, which is otherwise limited by the number of its own disposable production factors. Only 3 efficient countries within the whole time period are found: Luxembourg, Malta, and Cyprus. 
The aim of this paper is to assess the EU28 countries' competitiveness by creating a Competitiveness Index 2018 (CI 2018). By using DEA methods analyze how efficient EU countries are and how they utilize their competitive potential. The last aim is to verify the research hypothesis - EU member states with the best positions according to competitiveness outcomes are those countries that fully utilize the competitive potential and have the best efficiency results.

\section{Data and Methods}

Working database consists of 4 output variables (Gross domestic product - GDP, Gross value added - GVA, Compensation of employees - CompEmp, Disposable income - Income) and 17 inputs variables (Gross fixed capital formation - GFCF, Export of goods and services - Export, Total fertility rate - TotFerRate, Life expectancy - LifeExp, Number of beds in hospitals BedsHosp, Students with tertiary education - TerEduc, Employment rate - EmpRate, Economic activity rate - ActRate, Number of establishments - NumEstab, Intramural R\&D expenditure - GERD, R\&D personnel and researchers - R\&DPer\&Resd, Human resources in science and technology - HRST, Patent applications - PatApp, Life satisfaction - LifeSatisf, Energy production - EnergyProd, Infant mortality rate - InfMorRate, Unemployment rate UnempRate), downloaded from Eurostat for year 2018.

Principal component analysis (PCA) is used to evaluate EU28 countries ' competitiveness by the creation of the Competitiveness Index 2018. PCA is an ordinal method that examines how variables are mutually correlated. If the variables are correlated, the amount of information they capture can be expressed by a smaller number of variables, thus reducing the dimension. In the PCA, the set of $p$ observed variables $X_{1}, X_{2}, \ldots, X_{p}$ is transformed into a set of new variables $Y_{1}, Y_{2}, \ldots, Y_{p}$ (principal components) such that they are a linear combination of original variables:

$$
\begin{gathered}
Y_{1}=a_{11} X_{1}+a_{12} X_{2}+\cdots+a_{1 p} X_{p} \\
Y_{2}=a_{21} X_{1}+a_{22} X_{2}+\cdots+a_{2 p} X_{p} \\
\ldots \ldots \ldots \ldots \cdots \cdots \cdots \\
Y_{p}=a_{p 1} X_{1}+a_{p 2} X_{2}+\cdots+a_{p p} X_{p}
\end{gathered}
$$

Coefficients $a_{i j}$ represent weights (saturations), estimated to not change overall variability. New variables (principal components) are not mutually correlated and the first principal component explains the main part of common variables 'variability and therefore is the most important. The optimal number of components is determined based on Kaiser's rule, which claims to use those principal components whose eigenvalues are higher than the average of all eigenvalues (Stankovičová and Vojtková, 2007).

Factor analysis (FA) is applied to create competitiveness factors, represent EU28 countries ` driving forces. FA assumes that the dependencies between analysed variables are due to the effect of some immeasurable variables standing in the background.

The method is based on a set of observable variables $X_{j j}=1,2, \ldots, p$ having a multidimensional distribution with a $p$-membered mean value vector $\mu_{X}$ and a covariance matrix $\sum p$ of rank $p$. The general FA model assumes that there exists $q$ in the background standing common factors $F_{1}, F_{2}, \ldots, F_{q}$, while $q<p$. These factors allow to expressed the $j$-th observable random variable $X_{j}$ by the following equation: 


$$
X_{j}=\mu x_{j}+a_{j 1} F_{1}+a_{j 2} F_{2}+\cdots+a_{j q} F_{q}+e_{j}
$$

where: $e_{j}, j=1,2, \ldots, p$ - random (error) components referred to as specific factors,

$a_{j k}$-factors` weights, explaining the impact of $k$-th common factor on variable $X_{j}$.

Significant common factors are those whose eigenvalue is greater than 1 . Based on the factor weights, the variable that has the highest factor weight is selected for each factor. For better interpretation, varimax orthogonal rotation is used (Stankovičová and Vojtková, 2007).

Data envelopment analysis (DEA) is used to calculate the efficiency of transformation competitiveness inputs into competitiveness outputs. DEA is a method based on linear programming. It measures the relative efficiency within a set of peer entities (decision-making units, DMUs), which operate under similar conditions, converting multiple inputs into multiple outputs. The basic DEA model measures the efficiency of a DMU relative to similar DMUs in order to estimate a "best practice" frontier. The initial DEA model is originally presented in Charnes, Cooper, and Rhodes and is built on the earlier work of Farrel (Cooper, Seiford, Zhu, 2004). Dual CCR output-oriented model (with multiple inputs and outputs), assuming constant returns to scale (CRS) is applied to estimate technical efficiency. For evaluation of territorial efficiency, DEA in the form of CRS model is often used (Melecký, Staníčková, Hančlová, 2019). Output oriented model attempts to maximize outputs while using no more than the observed amount of any input.

Suppose each $D M U_{j}(j=1,2, \ldots n)$ produces a vector of output $y_{j}=\left(y_{1 j}, \ldots, y_{r j}\right)$ by using a vector of inputs $x=\left(x_{1 j}, \ldots, x_{i j}\right)$. OO CCR CRS envelopment model is formulated as:

$$
\max f=\varphi
$$

Subject to

$$
\begin{aligned}
-\varphi y_{r o}+\sum_{j=1}^{n} y_{r j} \lambda_{j} \geq 0, & r=1,2, \ldots, s \\
\sum_{j=1}^{n} x_{i j} \lambda_{j} \leq x_{i o}, & i=1,2, \ldots, m \\
\lambda_{j} \geq 0, & j=1,2, \ldots, n
\end{aligned}
$$

where: $\quad \varphi$ - unrestricted variable, describes the output enlargement rate

$$
x_{i o}, y_{r o}-\text { are input and output vectors of } D M U_{0}
$$

The higher the value of $\varphi$, the less efficient the DMU, for efficient DMU $\varphi=1$ (Cooper, Steinford, Tone, 2006).

\section{Results and Discussion}

In the first part, the EU countries' competitiveness is assessed based on the Competitiveness Index 2018 - CI 2018. CI 2018 is formed from four chosen competitiveness output variables: Gross domestic product - GDP, Gross value added - GVA, Compensation of employees CompEmp and Disposable income - Income. To reduce significant correlations between selected variables and to catch information contained in all four output variables Principal 
component analysis is used. One principal component PRIN1 is created by an outputs` linear combination and it is explaining $95.20 \%$ of total outputs`variability.

Table 1: Eigenvectors

\begin{tabular}{|l|c|}
\hline \multicolumn{2}{|c|}{ Eigenvectors } \\
\hline & PRIN1 \\
\hline GDP & 0.506 \\
GVA & 0.505 \\
CompEmp & 0.504 \\
Income & 0.485 \\
\hline
\end{tabular}

Source: Own calculations, software SAS

The impact of output competitiveness variables on a created Competitiveness Index, represented by a principal component, is given by eigenvectors (Table 1). All output variables share approximately the same weight on the main component creation (from 0,485 to 0.506 ).

According to the reached value of Competitiveness Index 2018 countries are divided into three groups: strong competitive countries, competitive countries, and weak competitive countries. There are 9 countries in the group "Strong competitive countries": Luxembourg, Ireland, Denmark, Sweden, Netherlands, Austria, Finland, Germany, and Belgium. The most competitive is Luxembourg with the highest value of CI 2018. The group "competitive countries" consists of 6 countries: United Kingdom, France, Italy, Spain, Cyprus, and Slovenia. 13 European countries, namely Portugal, Estonia, Czechia, Malta, Lithuania, Greece, Slovakia, Latvia, Hungary, Poland, Croatia, Romania and in the tail with Bulgaria belong to the "weak competitive countries" group (Figure 1).

Figure 1. Competitiveness of EU28 countries

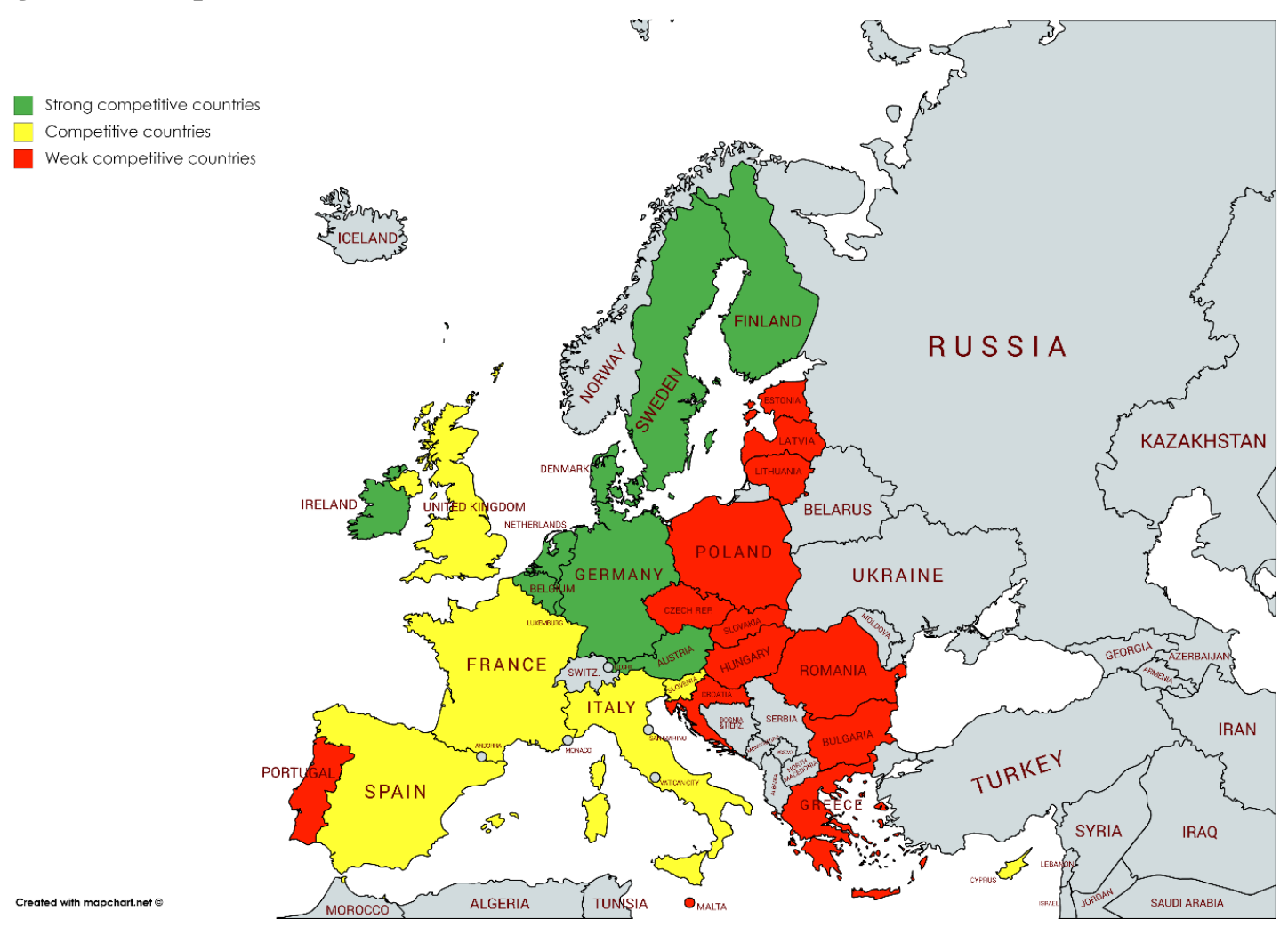

Source: Own calculations, mapchart.net 
If countries want to improve their competitive position, it is necessary to analyze the driven forces of competitiveness and the mutual relationship between competitiveness outputs and inputs. Even if each country has different competitive potential, its full utilization is important. Because of that, countries should focus on efficiency transformation - how they transform their competitiveness drivers on their competitiveness outcomes.

Based on the fact above, it is possible to determine the initial hypothesis of the analysis EU member states with the best positions according to competitiveness outcomes are those countries that fully utilize the competitive potential and have the best efficiency results.

The competitive potential is given by driven forces of competitiveness, represented by 17 input variables. Input variables are used to create four input indicators by applying Factor analysis. The Factor analysis 's role consists of 2 steps: the first step is removing multicollinearity and the second step is the creation of a smaller number of common factors reflecting countries comparative advantages - input indicators.

Varimax orthogonal rotation is used as a rotation method to obtain the best interpretable results (Table 2).

Table 2. Rotated factor pattern

\begin{tabular}{|l|r|r|r|r|}
\hline & Factor1 & Factor2 & Factor3 & Factor4 \\
\hline GFCF & 0.18280 & 0.11931 & 0.01776 & 0.94881 \\
\hline Export & 0.23781 & 0.19417 & -0.03783 & 0.90857 \\
\hline TotFerRate & 0.74492 & 0.10037 & -0.01245 & 0.14613 \\
\hline LifeExp & -0.19564 & 0.58249 & 0.60729 & 0.31163 \\
\hline BedsHosp & 0.06052 & -0.19842 & -0.82895 & 0.05158 \\
\hline TerEduc & 0.54558 & 0.10717 & 0.85407 & -0.09549 \\
\hline EmpRate & 0.87837 & 0.30799 & -0.09398 & 0.00632 \\
\hline ActRate & 0.81590 & 0.19685 & 0.30639 & -0.00137 \\
\hline NumEstab & -0.45356 & -0.01781 & 0.13943 & 0.70641 \\
\hline GERD & 0.43065 & 0.78642 & 0.23133 & 0.18905 \\
\hline R\&DPer\&Res & 0.35320 & 0.71664 & 0.37268 & 0.13748 \\
\hline HRST & 0.65302 & 0.61068 & 0.21032 & 0.07045 \\
\hline PatApp & 0.48405 & 0.70882 & 0.15734 & 0.28232 \\
\hline LifeSatisf & 0.18740 & 0.75614 & -0.11236 & -0.11564 \\
\hline EnergyProd & -0.04682 & 0.60246 & 0.40944 & 0.22712 \\
\hline InfMorRate & -0.29672 & -0.18630 & -0.64145 & -0.11542 \\
\hline UnempRate & -0.56810 & -0.31011 & 0.58096 & 0.00804 \\
\hline
\end{tabular}

Source: Own calculations, software SAS

The first competitiveness indicator - "Labour market and human resources", correlates mainly with Total fertility rate (0.745), Employment rate (0.878), Economic activity rate (0.816), Human resources in science and technology (0.653) and Unemployment rate (-0.568).

The second competitiveness indicator - "Innovation potential" is constructed mainly by variables as Intramural R\&D expenditure (0.786), R\&D personnel and researchers (0.717), Patent applications (0.709), Life satisfaction (0.756) and Energy production (0.602). The innovative potential has a crucial role in a modern competitiveness concept. Lacka (2015) analyses the Competitiveness of the New European Union States between 2006 and 2013 
through the level of innovativeness. According to her findings, none of these states does reach the comparable innovative potential level as leaders in innovation.

The third competitiveness indicator - "Quality of human potential" positively correlates mainly with Life expectancy (0.607), Tertiary education graduates $(0.654)$ and negatively correlates mainly with Number of beds in hospitals (-0.829) and Infant mortality rate (-0.641).

Fourth competitiveness indicator - "Business potential" is created mainly by Gross fixed capital formation (0.949), Export of goods and services (0.909) and Number of establishments (0.706).

For the purpose of input-output transformation effectivity assessment, only one input variable - the most relevant with the highest correlation is chosen from each input indicator (Table 2, red numbers). The efficiency of $28 \mathrm{EU}$ member states is calculated by dual CCR output-oriented model (with multiple inputs and outputs), assuming constant returns to scale (CRS). From the computed technical efficiency, it is obvious if a country uses its whole competitive potential (Table 3). Efficient countries with technical efficiency $=1$, have the ratio of outputs and inputs in an optimum and there is no requirement to change. TE value higher than 1 indicates that incurred inputs are greater than outputs achieved and the country could improve its competitiveness by more effective inputs utilization.

Table 3. EU member states`Technical efficiency and CI 2018

\begin{tabular}{|c|c|c|c|c|c|c|c|}
\hline Country & TE & $\begin{array}{c}\text { TE } \\
\text { rank }\end{array}$ & CI 2018 & Country & TE & $\begin{array}{c}\mathrm{TE} \\
\text { rank }\end{array}$ & CI 2018 \\
\hline Luxembourg & 1.000 & 1 & 1 & Slovenia & 1.142 & 14 & 15 \\
\hline Ireland & 1.348 & 24 & 2 & Portugal & 1.105 & 11 & 16 \\
\hline Denmark & 1.000 & 1 & 3 & Estonia & 1.459 & 26 & 17 \\
\hline Sweden & 1.185 & 17 & 4 & Czechia & 1.547 & 27 & 18 \\
\hline Netherlands & 1.000 & 1 & 5 & Malta & 1.171 & 16 & 19 \\
\hline Austria & \begin{tabular}{|l|}
1.079 \\
\end{tabular} & 9 & 6 & Lithuania & 1.212 & 18 & 20 \\
\hline Finland & 1.134 & 12 & 7 & Greece & 1.000 & 1 & 21 \\
\hline Germany & 1.000 & 1 & 8 & Slovakia & 1.277 & 21 & 22 \\
\hline Belgium & 1.140 & 13 & 9 & Latvia & 1.268 & 20 & 23 \\
\hline $\begin{array}{c}\text { United } \\
\text { Kingdom }\end{array}$ & 1.000 & 1 & 10 & Hungary & 1.624 & 28 & 24 \\
\hline France & 1.154 & 15 & 11 & Poland & 1.393 & 25 & 25 \\
\hline Italy & 1.000 & 1 & 12 & Croatia & 1.308 & 23 & 26 \\
\hline Spain & 1.091 & 10 & 13 & Romania & 1.223 & 19 & 27 \\
\hline Cyprus & 1.000 & 1 & 14 & Bulgaria & 1.285 & 22 & 28 \\
\hline
\end{tabular}

Source: Own calculations, MS Excel

The efficient countries are Luxemburg, Denmark, Netherlands, Germany, United Kingdom and Greece (Table 3, highlighted by red color).

Luxemburg is a country that achieved the first position in a CI 2018 ranking, and it is efficient, so this country can be considered as the most competitive country with full competitive 
potential utilization. Other efficient countries with full competitive potential utilization, could not get a higher position in the case of competitiveness outcomes without an increase in their inputs.

Denmark, Netherlands, and Germany belong to the group of "strong competitive countries" and fully utilize the competitive potential. On the other hand, three efficient countries (United Kingdom, Italy and Cyprus) belong to the group "competitive countries" and fully utilize their competitive potential. So the only way how these countries can increase competitiveness is by inputs increasing. Greece is from the group "weak competitive countries" and is efficient, so the only way how to increase its competitive position is through inputs increase.

Ireland is on the second position in a CI 2018 ranking, but its input-output transformation is inefficient (is on the 24. position in TE ranking). For the full competitive potential utilization, it should produce $34,8 \%$ more outputs with given inputs. If Ireland would fully utilize its competitive potential, it could be almost as competitive as Luxembourg (model countries benchmarks for Ireland are Luxembourg and Greece).

Sweden in on the fourth position in a CI 2018 ranking, but it transforms inputs into outputs inefficient. To fully utilize its competitive potential, Sweden should produce $18.5 \%$ more outputs using the same amount of inputs (benchmarks for Sweden are Denmark, Italy, Luxembourg, and The United Kingdom).

Austria, Finland, and Belgium also belong to the group "strong competitive countries". Focusing on the full utilization of its competitive potential with given inputs, Austria should produce $7,9 \%$ more outputs, Finland $13.4 \%$ more outputs, and Belgium $14 \%$ more outputs.

Countries that belong to the middle group marked as "competitive countries", achieve middle positions according to TE ranking. From "competitive countries" France, Spain, and Slovenia are inefficient. If these countries want to utilize their competitive potential fully to become efficient with given inputs, France should produce $15.4 \%$ more outputs, Spain $9.1 \%$ more outputs, and Slovenia $14.2 \%$ more outputs.

Countries that belong to the group "weak competitive countries" are all inefficient and on a similar position in both rankings with the only exception of Greece. Relatively good position 11. position according to TE ranking achieves Portugal, with the value of $\mathrm{TE}=1.105$. If Portugal wants to fully utilize its competitive potential, it should produce $10.5 \%$ more outputs with given inputs. Other inefficient "weak competitive countries" would increase outcomes between $21.2 \%-62.4 \%$ with the same inputs. The highest value of TE $=1.624$, the last position in TE ranking and the 24. position in IC 2018 ranking achieved Hungary. This country uses its competitive potential really weak what is the reason, why Hungary, even if it has good competitive potential, reaches a very low competitive outcome.

With some exceptions, such as Ireland, Sweden, Greece, etc., the initial hypothesis of the analysis is accepted - EU member states with the best positions according to competitiveness outcomes are those countries that fully utilize the competitive potential and have the best efficiency results.

\section{Conclusion}

From 28 EU member states, Luxembourg is the most competitive country with the highest value of created Competitiveness Index 2018 and belongs to the group "strong competitive countries" followed by Ireland, Denmark, Sweden, Netherlands, Austria, Finland, Germany, and Belgium. According to Staníčková (2015), Luxembourg together with Denmark, Sweden, the United Kingdom, Austria, France, and Ireland are the most economically powerful countries with the 
best factor endowment. The United Kingdom, France, Italy, Spain, Cyprus, and Slovenia belong to the group "competitive countries". The rest of the analyzed EU countries belong to the group "weak competitive countries", namely: Portugal, Estonia, Czechia, Malta, Lithuania, Greece, Slovakia, Latvia, Hungary, Poland, Croatia, Romania, and the least competitive country Bulgaria.

In comparison with the Global competitiveness index 2018 ranking, EU member states state in a different position due to their final competitiveness. The most competitive country in GCI 2018 ranking is Germany, the least competitive country is Croatia. Germany has the highest economic efficiency and performance (Melecký, 2013). GCI 2018 calculate the final competitiveness index based on both hard and soft data, with a higher number of variables and with different methodology (World Economic Forum, 2018).

Fura, Wojnar, Kasprzyk (2017) divided EU28 countries into 4 groups based on their level of Europe 2020 strategy achievements. One of the main goals of the Europe 2020 strategy is improving Europe's competitiveness to a level similar to other developed economies in the world. A high level of Europe 2020 strategy achievements is observed in Sweden, Denmark, Austria, Finland, Slovenia, France, and Czechia. The first four countries are considered as "strong competitive countries" in CI 2018 ranking. The most competitive Luxembourg is on the other hand situated in the group, where countries are less advanced in their implementation of the strategic goals. Italy together with "weak competitive countries" Croatia, Malta, Spain, Greece, Bulgaria, and Romania is situated in the last group with the lowest level of strategic goals achievement.

If countries want to improve their competitive position, it is necessary to analyze the driven forces of competitiveness, which represent the country`s competitive potential. The country fully utilizes its competitive potential and could get a better competitiveness outcome/position, only if it transforms its competitiveness inputs on outputs efficient.

The competitive potential is given by four competitiveness indicators: "Labour market and human resources", "Innovation potential", "Quality of human potential", and

"Business potential". For the purpose of input-output transformation effectivity assessment, only one input variable - the most relevant is chosen from each input indicator.

The most competitive country (on the first position in a CI 2018 ranking) with full competitive potential utilization is Luxembourg. According to Staníčková (2013), Luxembourg is one of four countries placed on the first position in the term of efficiency. Other efficient countries are Denmark, Netherlands, Germany, The United Kingdom, Italy, Cyprus, and Greece. The efficient "competitive countries" (The United Kingdom, Italy, and Cyprus) and efficient "weak competitive country" (Greece), could increase their competitive position only through inputs increase.

Ireland, Sweden, Austria, Finland, and Belgium also belong to the group "strong competitive countries". Focusing on the full utilization of its competitive potential with given inputs, Ireland should produce $34.8 \%$ more outputs, Sweden $18.5 \%$ more outputs, Austria $7,9 \%$ more outputs, Finland 13.4\% more outputs, and Belgium 14\% more outputs to become even more competitive.

Countries that belong to "competitive countries", achieve middle positions according to TE ranking. From "competitive countries" France, Spain, and Slovenia are inefficient. If these countries want to become efficient with given inputs, France should produce $15.4 \%$ more outputs, Spain $9.1 \%$ more outputs, and Slovenia 14.2\% more outputs. 
Countries that belong to the group "weak competitive countries" are all inefficient and on a similar position in both rankings with the only exception of Greece. The last position in TE ranking and the 24. position in IC 2018 ranking achieved Hungary. This country uses its competitive potential really weak what is the reason, why Hungary reaches a very low competitive outcome.

With some exceptions, the initial hypothesis of the analysis is accepted - EU member states with the best positions according to competitiveness outcomes are those countries that fully utilize the competitive potential and have the best efficiency results.

Šegota, Tomljanović, and Hudek (2017) prove a similar research hypothesis, that EU countries that are ranked high by the Global Competitiveness Index are those with the best efficiency result. According to their research, almost all best-rated countries in GCI ranking (in a top 20) are efficient. Melecký (2013) and Staníčková (2013) claim that the best results are traditionally achieved by economically powerful countries that are efficient.

\section{References}

[1] Bienkowski, W. (2008). How much are studies of competitiveness worth? Some critical theoretical reflections on the issue. 2 nd Economic Forum on 'New Europe', Lancut. doi:10.4324/9780203892527.ch8.

[2] Cooper, W. W., Seiford, L. M., \& Zhu, J. (Eds.). (2004). Handbook on Data development analysis. Boston, Kluwer Academic Publishers.

[3] Cooper, W. W., Seiford, L. M., \& Tone, K. (2th ed.). (2006). Data Envelopment Analysis. New York, Springer-Verlag New York Inc.

[4] Fura, B., Wojnar, J., \& Kasprzyk, B. (2017), Ranking and classifications of EU countries regarding their level of implementation of Europe 2020 strategy. Journal of Cleaner Production 165 (2017) 968-979. doi: 10.1016/j.jclepro.2017.07.088

[5] Garelli, S. (18th ed.). (2006). IMD World Competitiveness Yearbook. IMD - International Institute for Management Development

[6] Ku, G. (2008). Learning to de-escalate: The effects of regret in escalation of commitment. Organizational Behavior and Human Decision Processes, 105(2), 221-232. doi:10.1016/j.obhdp.2007.08.002

[7] Lacka, I. (2015). Innovativeness and Competitiveness of the New European Union States in Variable Economic Situation between 2006 and 2013. Procedia - Social and Behavioral Sciences 213 ( 2015 ) 185 191. doi: 10.1016/j.sbspro.2015.11.424

[8] Melecký, L. (2013). Assessment of EU Competitiveness Factors by Multivariate Methods. International Journal of Social, Behavioral, Educational, Economic, Business and Industrial Engineering Vol:7, No:6 (2013) 1709-1715. Retrieved from https://pdfs.semanticscholar.org/

[9] Melecký, L. (2013). Use of DEA Approach to Measuring Efficiency Trend in Old EU Member States. VŠBTechnical University of Ostrava (2013-08). Retrieved from https://dspace.tul.cz/

[10] Melecký, L., Stančíková, M., \& Hančlová, J. (2019). Nonparametric Approach to Evaluation of Economic and Social Development in the EU28 Member States by DEA Efficiency. J. Risk Financial Manag., 12(2), 72. doi: $10.3390 / \mathrm{jrfm} 12020072$

[11] Porter, M. (1998). The competitive advantage of nations. New York, SIMON \& SCHUSTER.

[12] Staníčková, M. (2013). DEA Method for Evaluation of EU Performance. International Journal of Social, Behavioral, Educational, Economic, Business and Industrial Engineering Vol:7, No:6 (2013) 1730-1736. Retrieved from https://pdfs.semanticscholar.org/

[13] Staníčková, M. (2015). Classifying The EU Competitiveness Factors using Multivariate Statistical Methods. Procedia Economics and Finance 23 ( 2015 ) 313 - 320. doi: 10.1016/S2212-5671(15)00508-0

[14] Stankovičová, I. Vojtková, M. (2007). Viacrozmerné štatistické metódy s aplikáciami. Bratislava, IURA Edition. 
[15] Šegota, A., Tomljanović, M., \& Hudek, I. (2017). Contemporary approaches to measuring competitiveness - the case of EU member states. Zbornik Radova Ekonomskog Fakultet au Rijeci 35(1) 123-150. doi: $10.18045 /$ zbefri.2017.1.123

[16] World Economic Forum. (2016). What is competitiveness? Retrieved October 17, 2019, from https://www.weforum.org/agenda/2016/09/what-is-competitiveness/

[17] World Economic Forum. (2018). The Global Competitiveness Report 2018. Retrieved October 17, 2019, from https://www.weforum.org/reports/the-global-competitveness-report-2018 


\section{SESSION 5}

INNOVATION SYSTEMS, ENTREPRENEURSHIP AND MODERN BUSINESS PROSPECTS 


\title{
Connection Between Ethics and Diversity - Theoretical Study
}

\author{
Jana Kozáková ${ }^{1}$ \\ Slovak University of Agriculture in Nitra \\ Faculty of Economics and Management, Department of Management ${ }^{1}$ \\ Address: Trieda A. Hlinku 2, \\ 94976 Nitra, Slovakia \\ e-mail: jana.kozakova@uniag.sk ${ }^{1}$
}

doi: 10.18515/dBEM.ISD.P01.2020.p034

\begin{abstract}
Corporate ethics as a topic is very good known not just for scientists, but in corporate practice too. Ethics separately is one of the first philosophical problems ever and it has been in the centre of interest for philosophers for centuries. In fact, since antics. Currently, it is still one of the most protracted topics in modern society and is connected to various subjects such as medical ethics, law ethics, teaching ethics, ect. and, last but not least corporate ethics or business ethics. Regarding internationalization and globalization, these topics are actual worldwide, mostly after millennium. One of the newest problems of corporate and business practice related with ethics is diversity and its management. Diversity management is known for decades, but its importance increase in last few years after migration crisis in EU and USA. Article explains and evaluates these terms and their interconnections and reflects on the current problems that have caused them to become one of the most recent topics in the world of economy and business.
\end{abstract}

Keywords: corporate ethics, business ethics, diversity, management

JEL Classification: L26, M14, K22, L53

\section{Introduction}

Corporate ethics and diversity management are two different concepts with separate theoretical framework. Indeed, they both are in the centre of interest of research and business too. Modern companies can not abandon ethical principles in their everyday occurrences as well as they have to preserve diversity principles.

Term "ethics" is originally derived from the Greek word 'ethos' which means a person's fundamental orientation toward life. It may be defined by the theory of morality which attempts to systematize moral judgments (Paswan, 2015). Actually, the term is widely used with the conection with business practice as a business ethics or corporate ethics. Business ethics has a long history through storytelling to illustrate and reinforce the sense of value, family, belief and justice (Fischer and Lovell, 2009).

Corporate ethics is currently the problem of key importance in the business practice. In past, it was conducted mainly in the most developed countries of western Europe and United states of America. Globalization and internationalization caused the massive penetration of multinational companies to markets of less developed countries what caused spreading of the topics into business practice of host economies. The trend relatively fast incorporated domestic subjects on these markets. At firs the entities with foreign capital and suppliers of multinational companies. Shortly after them also their domestic competitors and connected entities.

One of the oldest definitions of business ethics provides Velasquez (2002) who explain it as a form of applied ethics, which includes not only the analysis of moral norms and moral values, 
but also attempts to apply conclusions of this analysis to assortment of institutions, technologies, transactions, activities and pursuits that we call business.

Sroka and Lörinczy (2015) added, that if a company wishes to be perceived as a reliable partner in business, recommend that they should implement the elements of this concept, or indeed the concept of business ethics itself. Ethics in business became one of the key approaches in companies worldwide and it is not longer connect with the most developed countries and regions. Yong-Ki, et al. (2014) even states, that ethical management would seem to be a must in today's business climate.

According to Ferrell (2019) customers value business ethics as a critical behaviour in their perceptions of brand attitudes. Vadastreanu, et al., (2015) adds that the road to success for companies in today's economic environment is more demanding than ever and the capacity of adapting to the rapid changes is compensatory in order to resist on the market. The managers struggle, daily, with increasingly complex problems, caused by fierce competition in the market but also from the rising demands of customers. In this context, managers are tempted to pick an easy way, a shortcut, which will give them an advantage over the competitors. Usually this shortcut is in contradiction with the request of ethics. In other studies (Fassin, 2000; Strobel, et. al., 2010), related to the business ethic the authors consider that business ethics includes the ensuring that the highest legal and moral standards are respected in relationships with people from the business community. This includes the most important person in your business: client. On the other hand, short-term profit compared with the cost of losing a customer is deadly in the long term for business.

In connection with the ethic approaches in business, an increasing number of organizations are attempting to enhance inclusiveness of under represented individuals through proactive efforts to manage their diversity (Gilbert, et al., 1999). Diversity is a recognizable source of creativity and innovation that can provide a basis for competitive advantage. On the other hand, diversity is also a cause of misunderstanding, suspicion and conflict in the workplace that can result in absenteeism, poor quality, low morale and loss of competitiveness. Firms seeking competitive advantage therefore face a paradoxical situation. If they embrace diversity, they risk workplace conflict, and if they avoid diversity, they risk loss of competitiveness. The advantages and disadvantages associated with workforce diversity put organizations in a position of managing a paradoxical situation (Özbilgin, et al., 2015). In spite of the dialogic and inclusive claims made by the diversity movement, its basic framework and methods serve to limit and repress productive dialogue on race rather than produce effective organizational change. The diversity movement represents an important ideological strategy that seeks to re- assert the privacy of the corporate sphere and its employment decisions, making its emergence a significant element of the general social- political attempt to manage and contain racial conflict and social contradiction (Kersten, 2000).

\section{Data and Methods}

Article based on the theoretical framework of the problems of corporate ethics and business ethics with the connection to the problem of diversity and diversity management. It is theoretical study elaborated on the basis of an analysis of available literary sources, which deals with the issue. In addition, google n-gram application was used to evaluate the usage of selected terms in all available literature (written in English) published on the Internet. The time period 
from 1800 to the present has been chosen for our purposes. Last but not least the usage of mentioned topics in Slovak conditions was included.

\section{Results and Discussion}

The problem of "corporate ethics" has been included in the field of scientific research relatively recently. As can be seen on Google ngram, the usage of the topic in English is slowly increasing after 1980, with the slight skip after 2000. In comparison with the term "ethical code" it is with a long delay since this topic has been in English literature since the $19^{\text {th }}$ century. At the same time, the term "code of conduct" began to be used, but to a lesser extent. After the Second World War the term "ethical code" was used more or less to the same extent, but the publications on "the code of conduct" were rapidly expanded (Picture 1).

Picture 1 Usage of phrases „corporate ethics", "ethical code" and "code of conduct" in English publications (1970-2008)

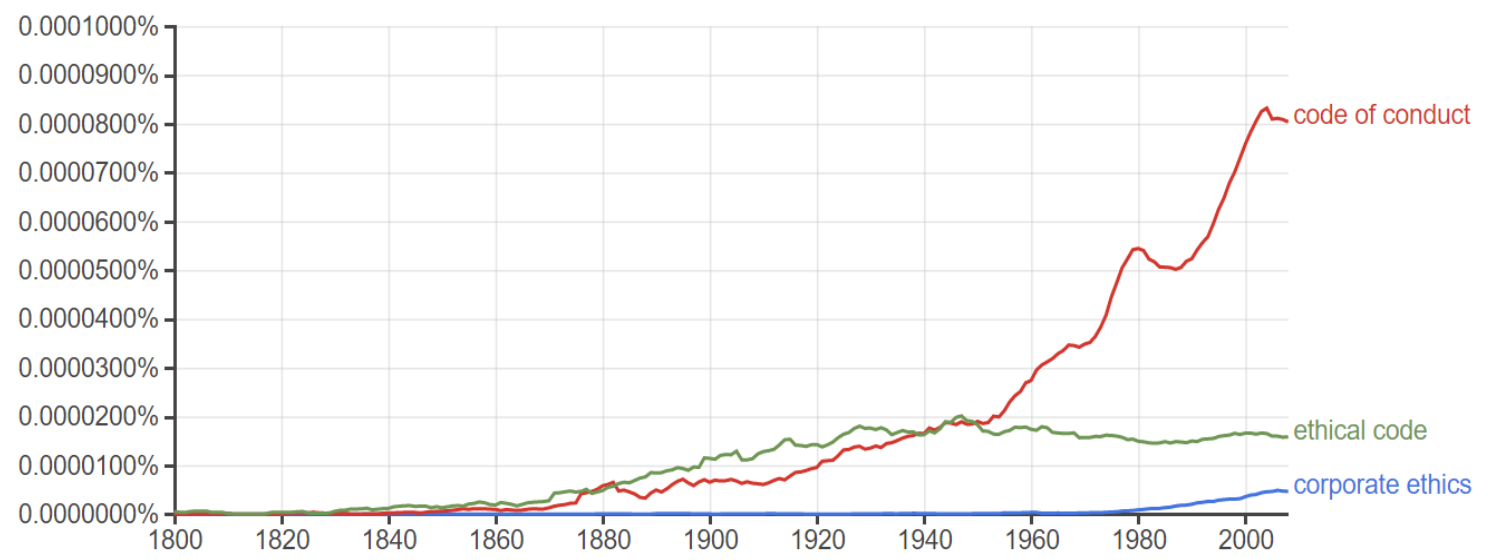

Source: Google ngram, 2019

Comparing the usage of phrases „corporate ethics “and „diversity management" we can find major differences (Picture 2). Term "corporate ethics" is known for more than two centuries, but "diversity management" started to be use between 1985 and 1990. In five years the topic overrun "corporate ethics" and its popularity is growing rapidly practically until now. This facts are interesting because, as Kesebir and Kesebir (2012) stated, the usage of almost all morality-related terms has been disappearing in books. An explanation can be related with the fact, that strategic management field, which is purely related to company performance, has taken these concepts into consideration and found any proof which shows us that these concepts have an impact on corporate performance and strategy (Tayşir and Pazarcık, 2013). In addition (as shows Picture 3), common application of business ethics and diversity management reduces agency costs of earnings management and creates values (Labelle, Gargouri and Francoeur, 2009) 
Picture 2 Usage of phrases „,corporate ethics "and „diversity management" in English (1970-2008)

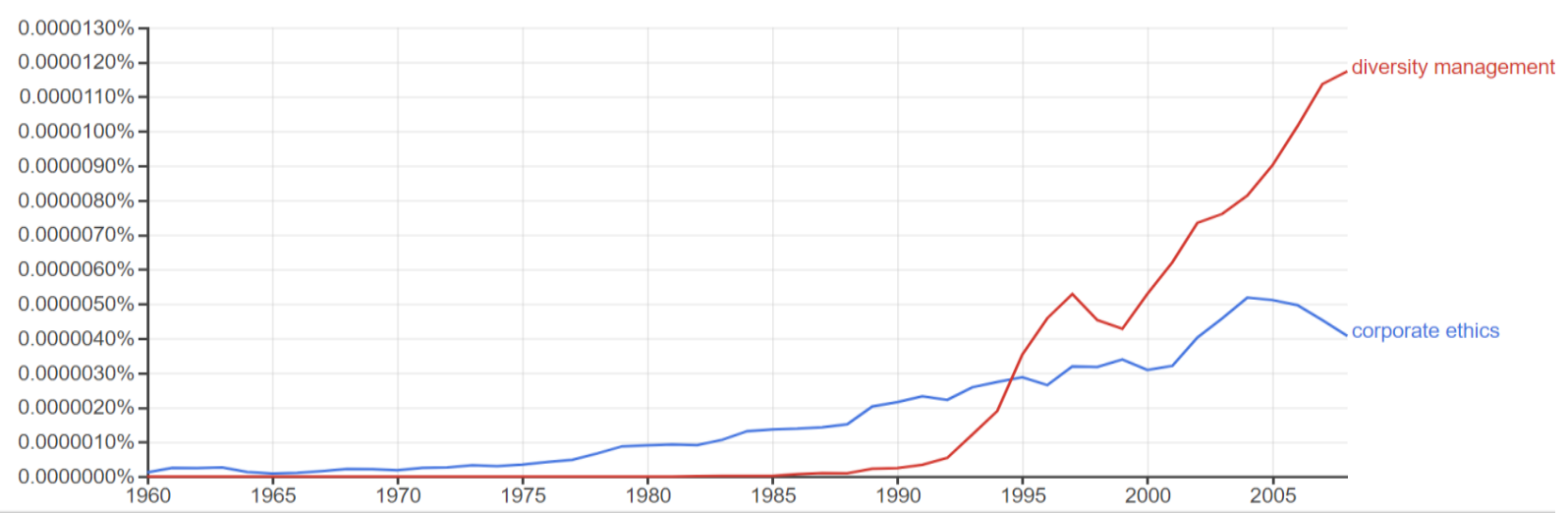

Source: Google ngram, 2019

In corporate practice, the problem of ethics is processed mainly by western Europe and USA companies. In transition economies it is relatively weaker rooted, since it is promoted mostly by foreign multinational companies. In Slovakia the topic is still considered a novelty and despite fact that majority of companies have some form of the ethical code, the public has a little knowledge about it. One of the rare researches from middle Europe area realized Sroka and Lörinczy (2015) on 200 companies (an alcohol industry - 40 companies, the tobacco industry - 30 companies and the pharmaceutical industry - 30 companies) from V4 countries (Slovakia, Czech republic, Hungary and Poland). They outcomes confirmed that business ethics is regarded as a significant factor which has an influence both on the success and profits of modern companies in V4, and its role is set to increase in the future. However, they outline apparent unwillingness of respondents to participate in the research.

\section{Picture 3 Ethics, diversity and financial reporting quality}

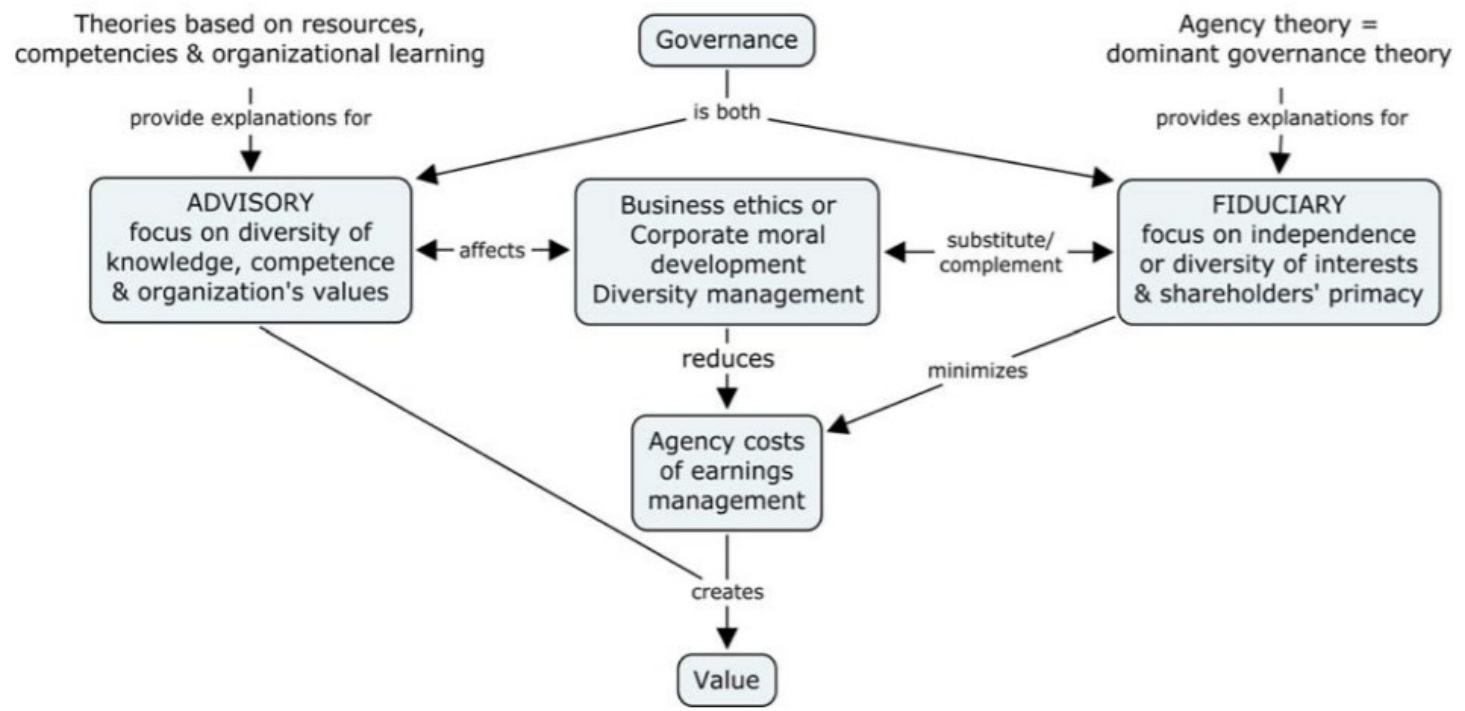

Source: Labelle, Gargouri and Francoeur (2009) 
Philosophers ask what diversity and disagreement can tell us about the nature of ethical argument and inquiry, and they consider the implications of diversity and disagreement for ethical practice and social life. (Moody-Adams, 2015). The intersection research of the topics "corporate ethics" and "diversity management" has not been addressed in literature until the last two years. However, researches are linking diversity management as a part of human resources management and the corporate ethics as a part of corporate social responsibility until 2014 (Stahl, et al., 2014; Lee, et al., 2014; Starostka-Patyk and Zwada, 2015). There is no evidence of similarly focused research (published in indexed scientific journals) in Slovak conditions. In addition, cross-cutting research into areas of ethics and diversity globally highlighting mainly the ethics of gender diversity, especially in terms of company management or board chairs (Dallas, 2002; Gul et al., 2007; Krishnan and Parsons, 2008; Francis et al., 2009) or the diversity of interests between directors and top management and its indirect effect on performance (Francoeur et al., 2008; Levi et al., 2008). However, as Carter et al. (2003) states back in 2003, one of the most significant governance challenges of the modern company face is establishing an optimal mix within the board of directors in terms of gender, race, and culture. Armstrong et al. (2008) adds that diversity and employment equality management policy is part of a High Performance Work System, which improves the quality of work and organizational productivity. And the employees' perceptions of their organization's values of ethics and equity motivate them to put forth additional efforts (Lambert, 2000).

On the other side, despite fact that organizational ethics is currently emphasized, little research examines the relationship between ethics codes and employees' responses to the work environment (Adams et al., 2001). In particular, the ability of codes to influence employees' attitudes about socially responsible conduct such as the acceptance of workplace diversity requires further elucidation. According to Gilbert et al. (1999), "research which specifically addressed diversity is necessary to provide understanding of diversity interventions, and to provide information to the practitioner on the impact of diversity management."

\section{Conclusion}

Article presents theoretical study of the problems of corporate ethics and business ethics with the connection to the problem of diversity and diversity management. The topic of corporate ethic has been included in the field of scientific research after 1980, but it starts to be use regularly after 2000. Surprisingly, connected subject of ethical code has been in English literature since the $19^{\text {th }}$ century. We can conclude that term "corporate ethics" is known for more than two centuries. On the other hand, the "diversity management" started to be use between 1985 and 1990. But, in five years the topic overrun "corporate ethics" and its popularity is growing rapidly until now, which can be explained with the fact, that strategic management, which is purely related to company performance, has taken these concepts into consideration and shows that these concepts have an impact on corporate performance and strategy. Still the intersection research of the topics "corporate ethics" and "diversity management" has not been addressed in literature until the last two years. No such research was conducted in Slovak conditions. In addition, cross-cutting research into areas of "ethics" and "diversity" globally highlighting mainly the ethics of gender diversity, especially in terms of company management or board chairs.

\section{Acknowledgement}

The paper is part of the project KEGA 005SPU-4/2019 "Theory and Practice of the International Management and Entrepreneurship in the Multicultural Environment" conducted at the at the Faculty of Economics and Management of the SUA in Nitra. 


\section{References}

[1] Adams, J. S., Tashchian, A., Shore T. 2001. Codes of Ethics as Signals for Ethical Behavior, Journal of Business Ethics 29, 199-211. Retrieved: 12/2019. Online: https://link.springer.com/content /pdf/10.1023\%2FA\%3A1026576421399.pdf

[2] Armstrong, C., Flood, P. C., Guthrie, J. P., Liu, W., Maccurtain S., Mkamwa T. 2008. New Models of High Performance Work Systems. The Business Case for Strategic HRM, Partnership and Diversity and Equality Systems (The Equality Authority and National Centre for Partnership and Performance). Retrieved: 12/2019. Online:

https://www.researchgate.net/publication/264417491_The Business_Case_for_Strategic_HRM_Partnershi p_and_Diversity_and_Equality_Systems_Equality_Research_Series_New_Models_of_High_Performance_ Work_Systems.

[3] Carter, D. A., D’Souza, F., Simkins, B. J., Simpson W. G. 2008. The Diversity of Corporate Board Committees and Financial Performance', Working paper, Retrieved: 12/2019. Online: http://ssrn.com/abstract=1106698

[4] Dallas, L. L. 2002. The New Managerialism and Diversity on Corporate Boards of Directors', Public Law and Legal Theory Working Paper 38(Spring) (University of San Diego School of Law), p. 30, Retrieved: 12/2019. Online: http://ssrn.com/abstract_id $=313425$

[5] European Commission (2003). Commission Recommendation 2003/361/EC of 6 May 2003, OJ L 124 of 20.05.2003.

[6] Fassin, Y., 2000. Innovation and ethics ethical considerations in the innovation business, Journal Of Business Ethics, Volume 27, Issue 1-2. doi:10.1023/A:1006427106307.

[7] Ferrell, O.C., Harrison, D. E., Ferrell L., Hair J. F. 2019. Business ethics, corporate social responsibility, and brand attitudes: An exploratory study. Journal of Business Research, vol. 95, Feb.2019, p. 491-501. https://doi.org/10.1016/j.jbusres.2018.07.039.

[8] Fischer, C. M.,Lovell, A. 2009. Business ethics and values: individual, corporate and international perspectives. Harlow: Pearson Education Limited

[9] Francis, B., Hasan, I., Park, J. C., Wu Q. 2009. Gender Differences in Financial Reporting Decision Making: Evidence from Accounting Conservatism',2009 FMA Annual Meeting Program, October 21-24, Reno, Nevada

[10] Francoeur, C., Labelle R., Sinclair-Desgagne B. 2008. Gender Diversity in Corporate Governance and Top Management', Journal of Business Ethics 81(1),83-95. doi: 10.1007/s10551-007-9482-5

[11] Gilbert, J. A., Stead, B. A., \& Ivancevich, J. M. (1999). Diversity management: A new organizational paradigm. Journal of business ethics, 21(1), 61-76. https://doi.org/10.1023/A:1005907602028.

[12] Gilbert, J.A., Stead, B.A. Ivancevich, J.M. 1999. Diversity Management: A New Organizational Paradigm. Journal of Business Ethics 21/1 (1999), 61-76. Retrieved: 12/2019. Online: https://www.jstor.org/stable/25074155

[13] Google $\quad 2019 . \quad$ ngram, $\quad$ Retrieved: $12 / 2019 . \quad$ Online: https://books.google.com/ngrams/graph?content=corporate+ethics\%2Cdiversity+management\&year_start= 1960 \&year_end $=2008 \&$ corpus $=15 \&$ smoothing $=1 \&$ share $=\&$ direct_url $=t 1 \% 3 \mathrm{~B} \% 2 \mathrm{C}$ corporate $\% 20$ ethics $\% 3$ B $\% 2 \mathrm{Cc0} \% 3 \mathrm{~B} . \mathrm{t} 1 \% 3 \mathrm{~B} \% 2 \mathrm{Cdiversity} \% 20$ management $\% 3 \mathrm{~B} \% 2 \mathrm{Cc} 0 \# \mathrm{t} 1 \% 3 \mathrm{~B} \% 2 \mathrm{Ccorporate} \% 20$ ethics $\% 3 \mathrm{~B} \% 2$ Cc0\%3B.t1\%3B\%2Cdiversity\%20management\%3B\%2Cc0 (retrieved 2019:24.10)

[14] Gul, F. A., Srinidhi, B., Tsui, J. 2007. Do female directors enhance corporate board monitoring? Some evidence from earnings quality', Working paper, The Hong Kong Polytechnic University

[15] Kersten, A. 2000. Diversity management: Dialogue, dialectics and diversion, Journal of Organizational Change Management, Vol. 13 No. 3, pp. 235-248. https://doi.org/10.1108/09534810010330887.

[16] Kesebir P, Kesebir S. The cultural salience of moral character and virtue declined in twentieth century America. Journal of Positive Psychology 2012; 7 (6), 1-10. doi: 10.1080/17439760.2012.715182

[17] Krishnan, G. V., Parsons, L. M. 2008. Getting to theBottom Line: An exploration of Gender and Earnings Quality', Journal of Business Ethics 78, 65-76. doi: 10.1007/s10551-006-9314-z 
[18] Labelle, R., Gargouri, R.M., Francoeur, C. 2009. Ethics, Diversity Management, and Financial Reporting Quality. Journal of Business Ethics (2010) 93:335-353. doi:10.1007/s10551-009-0225-7

[19] Lambert, S. J.: 2000. Added Benefits: The Link Between Work-Life Benefits and Organisational Citizenship Behaviour, Academy of Management Journal 43(5), 801-815.doi: 10.2307/1556411

[20] Lee, Y.K., Choi, J., Moon, B-Y., Babin, B.J. 2014. Codes of ethics, corporate philanthropy, and employee responses International Journal of Hospitality Management 39 (2014), 97-106. doi:10.1016/j.ijhm.2014.02.005

[21] Levi, M., Li K., Zhang F. 2008. Mergers and Acquisitions: The Role of Gender', Unpublished working paper, University of British Columbia.

[22] Moody-Adams, M.M. 2015. Diversity and Disagreement in Ethics: Philosophical Implications. International Encyclopedia of the Social \& Behavioral Sciences (Second Edition) 2015, p. 589-594. doi:10.1016/B978-008-097086-8.63019-2.

[23] Özbilgin, M., Jonsen, K., Tatli, A., Vassilopoulou, J., \& Surgevil, O. (2015). Global diversity management. London, United Kingdom: Palgrave Macmillan.

[24] Paswan, R.K. 2015. Role of ethics in modern business: an important key aspect of the concern, $\quad$ Retrieved $11 / 2019 . \quad$ Online: http://www.internationalseminar.org/XIII_AIS/TS\%201\%20(A)/17.\%20Mr.\%20Ranjit $\% 20$ Kumar\%20Paswan.pdf

[25] Sroka, W., \& Lörinczy, M. 2015. The perception of ethics in business: analysis of research results. Procedia Economics and Finance, 34 (2015), 156 - 163. doi: 10.1016/S2212-5671(15)01614-7.

[26] Sroka, W., Lörinczy, M. 2015. The perception of ethics in business: analysis of research results Procedia Economics and Finance 34 (2015) 156 - 163. doi: 10.1016/S2212-5671(15)01614-7

[27] Stahl, G.K., Brewster, Ch. J., Collings, D.J., Hajro, A. 2014. Enhancing the role of human resource management in corporate sustainability and social responsibility: A multi-stakeholder, multidimensional approach to HRM Human Resource Management Review. doi:10.1016/j.hrmr.2019.100708

[28] Starostka-Patyk, M., Tomski, P., Zawada, M. 2015. Diversity Management as a Part of Corporate Social Responsibility Policy. Procedia Computer Science 65 (2015) 1038-1045. doi:10.1016/j.procs.2015.09.055

[29] Strobel, M., Tumasjan, A., Welpe, I., 2010. Do Business Ethics Pay Off? The Influence of Ethical Leadership on Organizational Attractiveness, Zeitschrift Fur Psychologie-Journal Of Psychology, Volume 218, Issue 4

[30] Tayşir, E.A., Pazarcık, Y. 2013. Business ethics, social responsibility and corporate governance: Does the strategic management field really care about these concepts? Procedia - Social and Behavioral Sciences 99 (2013 ) 294 - 303. doi: 10.1016/j.sbspro.2013.10.497.

[31] Vadastreanu, A.M., Maier, D., Maier, A. 2015. Is the Success Possible in Compliance with Ethics and Deontology in Business? Procedia Economics and Finance, vol. 26/2015, p. 1068-107. https://doi.org/10.1016/S2212-5671(15)00931-4.

[32] Velasquez, M.G. 2002. Business Ethics Concepts \& Cases. Pearson Education, 2012. Retrieved: 12/2019. Online: https://www.academia.edu/36451144/Business_Ethics_Concepts_and_Cases.

[33] Yong-Ki, L., Joowon Ch., Bo-young, M., \& Babind, B.J. (2014). Codes of ethics, corporate philanthropy, and employee responses. International Journal of Hospitality Management, 9 (2014), 97-106. doi.org/10.1016/j.ijhm.2014.02.005 


\title{
New Approaches to the Education and Personal Development of Food Business Employees
}

\author{
Silvia Lenčéšová ${ }^{1}$, Mária Šajbidorová ${ }^{2}$, Zuzana Lušňáková ${ }^{3}$ \\ Slovak University of Agriculture \\ Faculty of Economics and Management, Department of Management ${ }^{1,2,3}$ \\ Address: Tr. A. Hlinku 2, \\ 94976 Nitra, Slovakia \\ e-mail: lencesova.silvia@gmail.com¹, maria.sajbidorova@uniag.sk², zuzana.lusnakova@uniag.sk
}

doi: 10.18515/dBEM.ISD.P01.2020.p035

\begin{abstract}
Education, personal development, special training and the creation of work skills represent the most important methods of human capital development in today's society. With current requirements, if employees want to become successful, they must constantly develop their knowledge and skills as well as their practical experience. The objective of the paper is to find out how food businesses working in Slovakia implement new approaches in education and development of employees. The research actively included 453 food businesses from all the Slovakia. We decided to research the given issue in practice of food businesses because especially these businesses are producers of domestic foodstuffs. Production of quality domestic food products is considered not only important as for people's nutrition and availability of quality domestic products but as well because of sustainability of employment in this field, development and application of quality, qualified and engaged employees. In addition, we consider it necessary to attract, develop and retain talented professionals in the management of businesses in Slovakia, while maintaining the sustainability of the food industry. The statistical relations and correlations between variables were performed by Spearman test and Kruskal-Walis test using programs EXCEL and SAS Enterprise Guide 7.1. We found out that food businesses in Slovakia have already started to implement innovative approaches to the personal management, but there are still significant reserves and shortcomings. The positive aspect is the food businesses managers realize the importance of employees' education and development because nowadays, the main task of businesses is to find, recruit, select and retain a quality potential and talented employees.
\end{abstract}

Keywords: education, employees' development, food businesses, new approaches

JEL Classification: M10, M12, M53

\section{Introduction}

\subsection{Education and Personal Development of Employees}

The term development refers to the long-term and developmental process. From the current state of knowledge and abilities it moves us to the future state. It is not oriented towards improving work performance in the current job, but is future-oriented. Its aim is to build potential in the organization. Development is about achieving the desired change through learning (Hroník, 2007).

Employee development is one of the goals of human resources management. If the company has recruited suitable employees who are highly motivated and perform well, the company is able to retain them, and then the goal of employee development resulting from dynamic changes in the company environment must be met. To make staff development effective, a lot of time and cost is spent on education and training employees and their managers (Blštáková, Gálik, Joniaková, \& Tarišková 2016). 
Strategic development aims to create a logical, coherent and comprehensive framework for people's development. A large part of the processes will be directed towards the development of human resources and create an environment that stimulates the education and development of employees. Although the strategic development of human resources is a business-oriented issue, its policy must take into account individual needs and aspirations. The primary concern of human resources development policy should be to take care of the employment of people inside and outside the organization (Měrtlová, 2015).

Employee education is characterized as a regular process, where work behaviour, the level of knowledge, skills and motivation of employees of the company, using different procedures is adjusted and changed. The intention is to reduce the gap between the current competencies of employees and the requirements imposed on them (Strenitzerová, 2015).

Education is a permanent process in which one not only acquires but also develops new knowledge and skills while adapting to changes in work behavior. Education can be characterized as: (Michalčová \& Gavurová, 2007)

1. emotional process - education is understood as upbringing and is a process of creating and developing physical, mental and character traits of a person,

2. cognitive process - education is understood as teaching and it is a process of learning different knowledge,

3. volitional process - education is understood as training and it is a process in which a person acquires the features and skills of training,

4. information-communication process - the information process is understood as listening, reading and writing, and the communication process is understood as a presentation that expresses the level of knowledge acquisition.

The goal of education is to increase the productivity and efficiency of independent employees and thus increase the performance of the company. It is a way to improve the attitude and commitment of subordinates to superiors ( $\mathrm{Li}, \mathrm{Li} \& \mathrm{Wu}, 2017)$.

The universities as educational institutions have to consider the contemporary trend in the knowledge management that knowledge becomes the important mean of production and educated employees are providing firms with competitive advantages (Országhová, 2019).

\subsection{New Trends in Education and Personal Development of Employees}

The demand for skills building drives the development of corporate education. Trends in this area include the growth of intelligent learning systems that can recommend learning at the right time and the arrival of systems that put learning directly into business processes. Today, corporate education is a multitude of different approaches. They are divided into four main areas $-4 \mathrm{E}$ : (Bershin, 2017)

- education (formal education),

- exposure (meeting and recognition the right people),

- experience (work experience, qualifications, projects),

- environment (tools, support, working equipment).

One should continually deepen and broaden his knowledge. Therefore, education and jobcreation are becoming a lifelong process in which the organization becomes increasingly essential. Methods of employee education include eg. couselling, which is one of the newest methods of education and is an interaction and communication, which overcomes the unidirectional relationship between the trainer and the trained person respectively superior and subordinate (Lušňáková, Lenčéšová \& Hrdá, 2019). 
Practical experience shows that the greatest attention is paid to training of specialists in companies within the framework of education and development. For administrative staff and workers, companies prefer to limit their training to compulsory training. In general, however, businesses prefer to self-educate employees, basically transferring the focus of responsibility for these activities to their shoulders. Of the "off the job" methods, the use of lecture forms is highly prevalent, which is not a very positive signal either. The proportion of e-learning and Internet forms of educational programs is relatively high (Lušňáková, Lenčéšová \& Hrdá, 2019).

Of the "on the job" methods, coaching and mentoring are the most used. Mentoring and coaching are often confused in practice, but the difference between them is evident. In the case of motivation, guidance and transfer of know-how in building a career or everyday activity, mentoring is mainly used as a professional skill. A close partnership is established between the mentor and the mentee due to the mutual trust on which mentoring is based. The mentoring is used throughout the organization, shifting valuable information and resources further on the basis of professional experience acquired in practice (Vančová, 2018).

Another method of development is coaching. It is a special kind of conversation that requires active listening, asking open questions, skill, using reflection and feedback. The employee must be self-confident and convinced of success; on the other hand, there must be space for mistakes. Unlike a mentor, the coach does not provide advice but support. The coach's role is to help the coachee achieve the goal through self-awareness through appropriate questions. Mentoring and coaching are both based on mutual trust, but anyone cannot become a coach, as the coaching skills of the International Coaching Federation need to be acquired (Kolodziejczak, 2015).

An extended form of education is also the use of project work as part of training activities and workplace rotation (Blštáková, Gálik, Joniaková, \& Tarišková, 2016). The blended leasing method combines classical educational methods with e-learning. Currently, many businesses use face-to-face training, but $80 \%$ of these businesses would like to use blended leasing in the future. This method makes it possible to make an ordinary training an experience during which the employee will work with the technology. For this method to work successfully, it is necessary to properly combine technology with education, which is quite demanding as each organization has specific requirements. Another important factor for the success and functionality of this method is the need to first evaluate the situation in teams and devise a strategy (Jindřichová, 2019).

Talent management that has been captured and integrated into the organization has become one of the most widespread topics in people management. One of the main challenges for today's organizations is building and sustaining talent through efficient human resource management. Talent management focuses on developing talents that are strategically important for the future of the organization (Dúbravská \& Solanková. 2015).

\section{Data and Methods}

The aim of the paper is to evaluate the implementation of new trends in education and development of employees in food businesses operating in Slovakia. A questionnaire called "New trends in human resource management in food businesses" was created based on elaborated theoretical results. The first part was identification questions such as a size of a company, legal form, capital share of the company and the region of Slovakia in which the company operates. The second part consisted of 6 questions, of which within 1 respondents could choose from the above options and in 5 they expressed their agreement or disagreement. 
Positive, rather positive, neutral, rather negative or negative attitude to question was expressed on a five-level Likert scale.

The questionnaire was, within pilot research in February 2019, tested on a sample of 20 companies in the Nitra region. After little modification, the final research was done from March to April 2019, the questionnaire was provided by a phone call arrangement or e-mail arrangement to 470 food businesses operating in Slovakia. The respondents, who answered the questions, were managers from human resource departments. In case that the organization did not have separated department for human resources, the questionnaire was filled in by the manager or the owner, responsible for this area. By the beginning of May 2019 we received electronic or a printed version of 453 filled questionnaires ready for use, elaboration and evaluation. The data obtained from the questionnaire survey were processed using the table processor MS EXCEL 2016. The data were then evaluated using the statistical software SAS Enterprise Guide 7.1.

In total, 453 enterprises were involved in the research, of which 70 were large enterprises, 125 were medium-sized enterprises, 148 small enterprises and 110 micro enterprises from all eight regions of the Slovak Republic. In terms of organizational and legal form of business, we focused exclusively on companies that are either joint-stock companies (160 companies) or limited liability companies (239 companies). In terms of equity participation, the survey involved 379 exclusively Slovak enterprises, 35 exclusively foreign enterprises and 39 companies with combined capital participation.

From the data obtained from the questionnaire, where respondents had a possibility to express the level of approval or disapproval with the statement on a five-level Likert scale, we found the characteristics of a position. According to Prokeinová (2010), through application of basic descriptive characteristics we gain values of modus and averages of individual respondents' preferences.

In the next part of the research we applied correlation analysis. Correlation analysis represents, according to Benda-Prokeinová (2014), statistical approach which describes a relationship between numeral variables. The more the absolute value of correlation coefficient reaches one, the stronger the dependence and vice versa, the more it reaches zero, the weaker the dependence. For testing statistical hypothesis resulting from research assumptions, mathematical-statistical methods - non parametrical test were applied: Kruskal-Wallis test and Spearman coefficient. We searched for differences in answers of the questionnaire based on specific identification symbols, dependence between two variables, as well as the power of this dependence (Markechová, Stehlíková and Tirpáková, 2011; Rimarčík, 2007).

\section{Results and Discussion}

As the theoretical background suggests, employee education and development is an expression of some kind of employer care for employees, which may ultimately benefit both parties (Kovacik, 2016). 
Figure 1: Characteristics of position evaluating education and development of employees

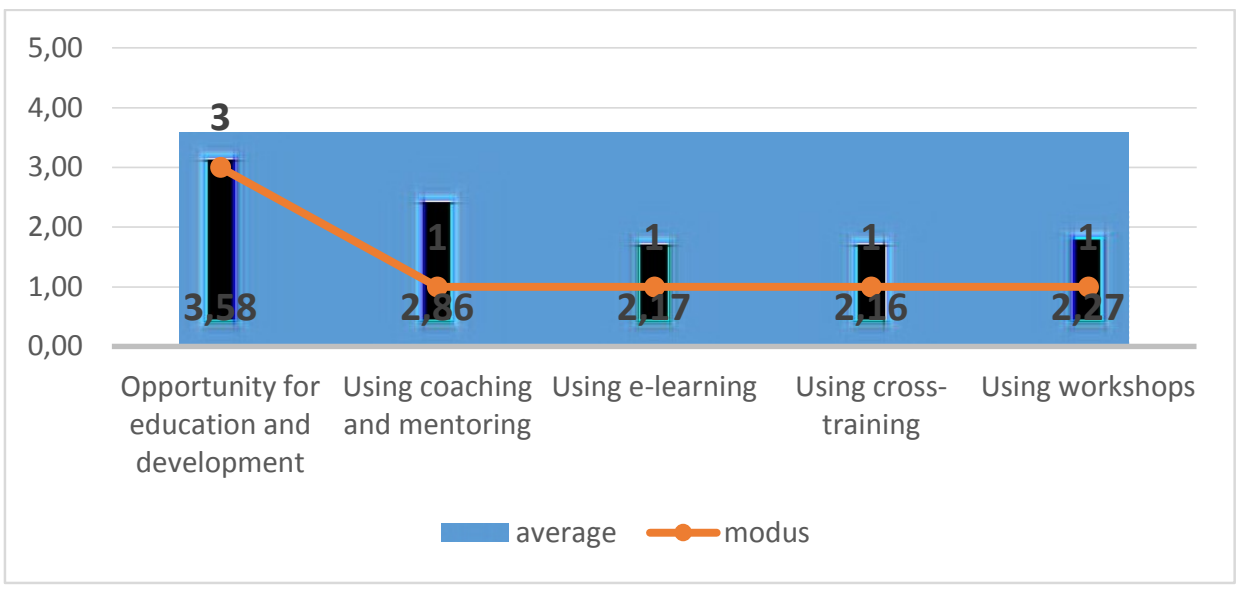

Source: own processing

Employee education forms part of the working life of both the employer and the employee. The formation of working abilities and skills is a lifelong process for each employee. It includes training and professional development to assist in their work. Professional development enables individuals to be prepared to handle future tasks and responsibilities and helps them expand their knowledge beyond the scope of their current work (Vetráková, 2017).

Position characteristics, namely average and most frequently answers to questions are shown in Figure 1. The bar graph represents the average answers of the respondents (data are displayed in the base of the graph) and the line graph shows the most frequent answers of the respondents (data are displayed above the graph).

The most frequently chosen value expressing a neutral attitude to the statement "We provide employees with opportunities for their development and education" was the value " 3 " (I agree rather than disagree). This answer was chosen by $29.36 \%$ of business managers. The average response was 3.58. It is between 3 and $4.27 .15 \%$ of business representatives totally agreed with the statement and $6.18 \%$ totally disagreed. In the statement "We use coaching and mentoring for employee education and development" the most frequently chosen answer $(24.06 \%)$ was the "absolutely disagree" answer. $17.44 \%$ of respondents partially disagreed. The average response rate reached 2.86, which is close to the neutral "I agree rather than disagree" answer, and this was also the second most common answer, which was specifically chosen by $23.4 \%$ of respondents. $35.1 \%$ of companies absolutely or partially agreed.

The average chosen value expressing the level of agreement with the statement "Employee education and development is also realized through e-learning" was 2.17 . It corresponds to the value 2 - "partially disagree". The most common answer was "absolutely disagree" and up to $51.88 \%$ of businesses responded. Only $12.36 \%$ of companies absolutely agreed.

Almost the same average response of 2.16 was given by the statement "We use cross-training for employee training and development" and the most common answer (49\%) was "absolutely disagree". Only $8.17 \%$ of business representatives agreed absolutely. Similarly, the statement "We use workshops to educate and develop our employees" received similar values. The average response was close to the "I disagree" (2.27) and the modus reached 1. Up to $44.37 \%$ of respondents absolutely disagreed with this statement, and only $11.03 \%$ of managers absolutely agreed.

$83.3 \%$ of the respondents to the question whether training and development in the company is carried out by means of internal or external methods, that external methods were chosen by 
means of internal and $43.9 \%$ of respondents. It is evident that some companies use both methods simultaneously.

Table 1: Kruskal-Wallis test for education and development of employees

\begin{tabular}{|l|c|c|c|c|}
\hline & \multicolumn{4}{|l|}{ Values of Kruskal-Wallis test according to } \\
\hline & $\begin{array}{l}\text { Company } \\
\text { size }\end{array}$ & Legal form & $\begin{array}{l}\text { Capital } \\
\text { participation }\end{array}$ & Region \\
\hline $\begin{array}{l}\text { Opportunity for education and } \\
\text { development }\end{array}$ & 0.0881 & 0.1441 & $0.0354^{*}$ & $0.0175^{*}$ \\
\hline Using coaching and mentoring & $0.0348^{*}$ & 0.0808 & $0.0043^{* *}$ & $0.0166^{*}$ \\
\hline Using e-learning & $<0.0001^{* *}$ & $0.0014^{* *}$ & $<0.0001^{* *}$ & $0.0009^{* *}$ \\
\hline Using cross-training & $<0.0001^{* *}$ & $0.0305^{*}$ & $<0.0001^{* *}$ & $0.0086^{* *}$ \\
\hline Using workshops & $<0.0001^{* *}$ & $0.0136^{*}$ & $<0.0001^{* *}$ & $0.0002^{* *}$ \\
\hline
\end{tabular}

Source: own processing

The existence of statistically significant differences between the responses according to the size of enterprises, legal form of business, capital participation or the region in which they operate was determined by the Kruskal-Wallis test, the results of which are shown in Table 1. Values marked "*" represent statistically significant differences at a significance level of $95 \%(\alpha=$ $0.05)$ and values marked $" * * *$ represent highly statistically significant differences at a confidence level of $99 \%(\alpha=0.01)$.

We have found that the capital participation of the enterprise and the region in which it operates has an impact on providing opportunities for development and education to employees. Both factors are less than $\alpha=0.05$ and therefore there are statistically significant differences in responses. Based on our findings, the size of the business and the legal form of business do not affect the provision of development and training opportunities to employees.

The size of the company, its capital participation and the region in which it operates affect the use of coaching and mentoring. Capital participation has a significant impact because the Kruskal-Wallis test results in a value of 0.0043 , which is less than $\alpha=0.01$, and thus represents the existence of highly statistically significant differences in respondents' responses. On the other hand, in the case of the legal form of business, we found that there are no statistically significant differences and therefore the legal form of business does not affect the use of coaching and mentoring.

The use of e-learning in the education and development of employees is significantly influenced by all identifying features of companies. For all four, the Kruskal-Wallis coefficient values are less than $\alpha=0.01$. This means that there are statistically significant differences in respondents' responses. Similarly, there is the possibility of using rotation (training), with the only difference that in the case of the legal form of business, the value of the Kruskal-Wallis coefficient is less than $\alpha=0.05$, which means that the legal form of business exists statistically significant differences in the significance level of $95 \%$.

The same results were observed in workshops where all the identifying features have an impact on their implementation and use in the training and development of employees in companies. In the case of the size of the enterprise, shareholding and region, these are highly statistically significant differences in responses to the significance level of $99 \%$ and in the legal form of business there are statistically significant differences in responses to the significance level of $95 \%$.

We determined the power of dependence between individual statements based on an analysis of the Spearman correlation coefficient. Values of the Spearman correlation coefficient are shown in the Table 2. 
Table 2: Values of the Spearman correlation coefficient

\begin{tabular}{|c|l|l|l|l|l|}
\hline & \multicolumn{1}{|c|}{ S1 } & \multicolumn{1}{|c|}{ S2 } & \multicolumn{1}{|c|}{ S3 } & \multicolumn{1}{|c|}{ S4 } & S5 \\
\hline S1 & 1.00000 & $0.38102^{* *}$ & $0.25710^{* *}$ & $0.23878^{* *}$ & $0.26702^{* *}$ \\
\hline S2 & $0.38102^{* *}$ & 1.00000 & $0.45810^{* *}$ & $0.46650 * *$ & $0.40627 * *$ \\
\hline S3 & $0.25710^{* *}$ & $0.45810^{* *}$ & 1.00000 & $0.53530 * *$ & $\mathbf{0 . 5 5 3 3 5 * *}$ \\
\hline S4 & $0.23878^{* *}$ & $0.46650^{* *}$ & $0.53530^{* *}$ & 1.00000 & $0.46377^{* *}$ \\
\hline S5 & $0.26702^{* *}$ & $0.40627 * *$ & $\mathbf{0 . 5 5 3 3 5 * *}$ & $0.46377 * *$ & 1.00000 \\
\hline
\end{tabular}

Source: own processing

$\mathrm{S} 1=$ We provide employees with opportunities for their development and education.

S2 $=$ We use coaching and mentoring to educate and develop our employees.

$\mathrm{S} 3$ = Employee education and development is also realized through e-learning.

$\mathrm{S} 4=\mathrm{We}$ use cross-training for employee training and development.

$\mathrm{S} 5=$ We use workshops to educate and develop employees.

The highest correlation value of 0.55335 is between questions S3 and S5 and is highly statistically significant. It represents a substantial to very strong dependence between the use of e-learning and the use of workshops in employee education and development. At the same time, this is the highest value of dependence found in our research. The second substantial to very strong dependence is 0.53530 , is between the questions S3 and S4, and is also highly statistically significant. It means a substantial to very strong dependence between 2 we find 5 medium to substantial dependencies, which are marked in grey. The other three correlations are low to moderate. All correlations are highly statistically significant.

\section{Conclusion}

Education, special training and the creation of work skills represent the most important methods of human capital development in today's society. With the current requirements, if an employee wants to become successful, they must constantly develop their knowledge, skills and practical experience (Trel'ová \& Olšavský, 2017). Nowadays, a larger number of organizations are investing in employee education and development with the aim of sustaining the growth of the organization and equipping employees with the necessary knowledge and skills to become increasingly productive and innovative (Govaerts, Kyndt, Vreye \& Dochy, 2017). As regards business managers, it is essential to support self-development in particular, as it is difficult to penetrate the work of creative individuals but is even more difficult to influence. It is important to emphasize internal motivation and self-development in business and managerial work (Šajbidorová, 2012).

From the results of our research we see significant reserves in providing education and development opportunities for food business employees in Slovakia, as the companies have taken a neutral position on this issue. Even three-quarters of businesses do not provide their employees with the opportunity to work in international teams at all, which would greatly help to develop their language as well as professional knowledge and skills.

It is also unflattering to note that food businesses in Slovakia rarely use coaching and mentoring and almost never use new methods such as e-learning, rotation or workshops to develop and educate their employees. The authors Armstrong and Taylor focused on the actual simultaneous use of new trends in the field of employee education and development in practice and their following findings are more positive than the situation within the food business in Slovakia:

- Internal development programs and training are the most popular development methods.

- Employee training through e-learning is more common in larger organizations.

- Coaching and mentoring are commonly used. 
- Many organizations offer training for students, volunteers, clients, etc.

The aim of education is to increase the productivity and efficiency of the employees themselves and thus to increase the performance of the company. It is also a way to improve the attitude and commitment of subordinates to superiors. Investing in employee training could intensify employees' decisions and concentrate on employees' commitment to their jobs.

Based on our research, we recommend businesses to provide employees with a variety of opportunities for personal development and education, support education within and outside the organization, with a clear goal of acquiring the necessary knowledge and skills.

Every employer should strive to develop the skills and qualities of its employees. This is one of the ways it can increase labour productivity. We can say that providing opportunities for employee education and development is towards this goal.

\section{Acknowledgements}

This paper was created within the project VEGA "Integrated talent management model and its impact on economic results of enterprises" from The Ministry of Education, Science, Research and Sport of the Slovak Republic. Project registration number VEGA 1/0543/17

\section{References}

[1] Armstrong, M. \& Taylor, S. (2015). Řizeni lidských zdrojů: Moderní pojetí a postupy. Praha: Grada Publishing

[2] Benda-Prokeinová, R. (2014). Štatistika v SAS-e, SAS v štatistike. Nitra: ASPA

[3] Bershin, J. (2017). Technologické trendy. Available at: www.simpletalent.sk/trendy/technologicke-trendy2017-v-hr-podla-josha-bersina

[4] Blštáková, J., Gálik, R., Joniaková, Z., \& Tarišková, N. (2015). Zmeny v riadení lưdských zdrojov, riadenie ludských zdrojov v zmenách. $1^{\text {st }}$ ed. Bratislava: EKONOM

[5] Dubravska, M. \& Solankova. E. (2015). Recent Trends in Human Resource Management in Selected Industry in Slovakia and the Czech Republic. Procedia Economics and Finance, 26: 1014-1019, doi: 10.1016/S22125671(15)00924-7

[6] Govaerts, N., Kyndt, E., Vreye, S. \& Dochy, F. (2017). A supervisor's perspective on their role in transfer of training. Human resource development quarterly. 28 (4): 515-552, doi: 10.1002/hrdq.21286

[7] Hroník, F. (2007). Rozvoj a vzdelávaní pracovnikú. Praha: Grada Publishing

[8] Jindřichová, M. (2019). Trendy ve firemním vzdelávaní. Available at: https://www.vimvic.cz/clanek/reportz-hr-vecera-7-trendy-ve-firemnim-vzdelavani

[9] Kolodziejczak, M. (2015). Coaching Across Organizational Culture. Procedia Economics and Finance, 23: 329-334, doi: 10.1016/S2212-5671(15)00491-8

[10] Kováčik, J. (2016). Vzdelávanie zamestnancov - prehlbovanie a zvyšovanie kvalifikácie. Available at: https://www.epravo.sk/top/clanky/vzdelavanie-zamestnancov-prehlbovanie-a-zvysovanie-kvalifikacie3307.html

[11] Li, Ch., Li, J. \& Wu, Z. (2017). Dark side of investment in employee education in privately-held companies. Finance research letters. 22: 190-196, doi: 10.1016/j.frl.2016.12.023

[12] Lušňáková, Z., Lenčéšová S. \& Hrdá, V. (2019). Nové trendy v teórii a praxi manažmentu l'udských zdrojov. Nitra: Slovenská pol’nohospodárska univerzita

[13] Měrtlová, L. (2014). Řizení lidských zdroju a lidského kapitálu firmy. Jihlava: Akademické nakladatelství CERM

[14] Mihalčová, B. \& Gavurová, B. (2007). Organizačná kultúra ako faktor úspešnosti organizácie. Manažment v teórii a praxi, 3(4): $64-72$ 
[15] Országhová, D. (2019). Future managers knowledge and competences in the context of university mathematics education. In Modern technologies in education. 1. ed. 495 p. Opole: Wyższa Szkoła Zarządzania i Administracji w Opolu, pp. 84-105. Retrieved December 10, 2019 from:

$<$ http://pedagogika.wszia.opole.pl/ebook/mono2019_2.pdf $>$

[16] Strenitzerová, M. (2015). Riadenie l’udských zdrojov. DOLIS s.r.o.

[17] Šajbidorová, M. (2012). Formovanie kompetentnosti manažérov pol’nohospodárskych podnikov. Aktuálne trendy manažmentu $v$ konkurenčnom prostredi Topol’čianky 21. - 22. septembra 2011- zborník z medzinárodnej konferencie. Nitra: Slovenská pol’nohospodárska univerzita

[18] Trel'ová, S. \& Olšavský, F. (2017). Investment in Education and Training of Employees of the Company. Conference: 29th International-Business-Information-Management-Association Conference. 3569-3579

[19] Vančová, A. (2018). Mentoring vs. Koučing. Available at: https://advanca.sk/mentoring-vs-koucing/

[20] Vetráková, M. (2017). Riadenie l’udských zdrojov v ubytovacích zariadeniach hotelového typu. Bratislava: Wolters Kluwer 


\title{
Air Quality and Other Factors Influencing Suitability of Food Businesses Work Environment
}

\author{
Zuzana Lušňáková ${ }^{1}$, Mária Šajbidorová ${ }^{2}$, Silvia Lenčéšová ${ }^{3}$, Boris Rumanko ${ }^{4}$ \\ Slovak University of Agriculture, \\ Faculty of Economics and Management, Department of Management ${ }^{1,2,3,4}$ \\ Address: Tr. A. Hlinku 2, \\ 94976 Nitra, Slovakia \\ e-mail: zuzana.lusnakova@uniag.sk ${ }^{1}$,maria.sajbidorova@uniag.sk ${ }^{2}$, lencesova.silvia@gmail.com³ \\ rumanko.boris@gmail.com ${ }^{4}$
}

\author{
doi: 10.18515/dBEM.ISD.P01.2020.p036
}

\begin{abstract}
There are many factors significantly influencing compliant work environment. Air quality at the workplace is one of the important factors influencing the absolute quality of work environment. The objective of the paper is to evaluate the attitude of managers towards air quality at the workplace and other factors influencing the suitability of work environment. The research actively included 438 food businesses from all the Slovakia. The statistical relations and correlations between variables were performed by Cronbach alpha, Spearman test, Kruskal-Walis test using programs EXCEL and SAS Enterprise Guide 7.1. Based on the responses of food business managers in Slovakia and based on analysis we can state that - depending on size and location - companies are trying to ensure air quality workplace for their employees, they also pay attention to colour arrangement and lighting of workplace as well as they apply work-life balance principles on workplace. On the other hand, there is only one medium to the essential positive dependence - between maintaining air quality at the workplace and paying attention to the colour arrangement and lighting of the work environment. We have identified the reserves in terms of the quality of the working environment. At a time when competition is steadily intensifying, employers are also gaining advantages over their competitors through the quality working environment and satisfied employees. A well-created working environment thus has a positive impact across the whole of society, bringing not only an improvement in the health of the population, but also an increase in the standard of living of workers.
\end{abstract}

Keywords: air quality, food business, work environment

JEL Classification: M12, M14

\section{Introduction}

The work environment suitably adapted to the capabilities and needs of employees is an extremely important factor for companies to build and maintain a good market position.

As a result of the continuous modernization and improvement of workflows, there is an increasing demand for the creation and modification of the working environment, consisting of a set of external material and intangible factors directly affecting the employee and his work. The employee not only co-creates, but also changes the working environment through his efforts, mental and physical work.

Work environment and working atmosphere are crucial factors of the employees' satisfaction. Creating a suitable work environment is a complex process, and the fact that a working person spends $1 / 3$ of a day in that environment also plays an important role.

Aspirations for workplace design have been identified as: environmentally sustainable; foster innovation and creativity; establish connections; improve communication and collaboration; 
provide efficient space for effective work; flexibility over time; welcoming and connected to the community; healthy; and, up to date technology (Chapman et al., 2015). Good interior design of office environment could stimulate a manager's creativity and could therefore contribute to an organization's innovation (Ceylan et al., 2008).

Creation of the interior should minimalize negative impacts, utilize ergonomics in the interior and create conditions for healthy and suggestive environment (Taha et al., 2016). Modern organizations expect creativity of their employees but motivation for creativity in unfavourable work conditions, bad work environment and high work pressure is very difficult (Shao, Nijstad, Tauber, 2019).

There is growing public awareness regarding the risk associated with poor indoor air quality in the home and workplace. Because Americans spend approximately 22 hours every day indoors, susceptible individuals are at much greater risk of adverse health effects from chronic low levels of exposure to indoor air pollutants over time (Bernstein et al., 2008).

Indoor air and other problems in the same workroom could be defined individually in quite different ways. Therefore, an individual approach has to be implemented for every workplace considering the anthropological and other features of the worker who will work in the certain workplace (Traumann et al., 2014). Indoor air quality in the workplace is critical for occupants' health and productivity. In general, sensory perception reflects immediately perceived air quality. Within a minute of a change in air quality, there will be an instant response such as sneezing or yawning if it is uncomfortable (Park et al., 2019).

Competitive advantage of companies could be sustainability of work force, decreased fluctuation of employees, necessary training with positive impact on the whole efficiency of the company. Top management must intentionally monitor and implement new trends in work with human resources in international corporations. This might help employees to be more quality and attractive human resources in the future (Lušňáková, 2018).

\section{Data and Methods}

The objective of the paper is to evaluate the attitude of managers towards air quality at the workplace, and other factors which are an important part of suitable working environment.

A tool for analysis was the questionnaire. Identification questions, such as a size of a company, legal form, capital share of the company and the region of Slovakia in which the company operates, were the first part. Positive, rather positive, neutral, rather negative or negative attitude to question was expressed on a five-level Likert scale.

The research was done from March to June 2019 by a phone call arrangement or e-mail arrangement to 493 (small, medium, big) food businesses operating in all eight parts of Slovakia. The respondents who answered the questions were business managers. By the end of June 2019 we received electronic or a printed version of 438 filled questionnaires ready for use, elaboration and evaluation.

The questionnaire's answers were elaborated and classified which enabled consequent verification of the given research assumptions by selected mathematical-statistical methods and formulation of suggestions and recommendation for the practice.

In order to evaluate the attitude of managers towards air quality at the workplace and other factors which are an important part of a suitable work environment, we formulated and, based on realized analysis verified, the following research assumption: 
A: We suppose that the companies ensuring air quality at the workplace pay also attention to other factors influencing compliant work environment.

Processing the data, obtained by the questionnaire, was done through table processor MS EXCEL 2016. The data was evaluated through statistical software SAS Enterprise Guide 7.1.

The consistency of a selection file was found by Cronbach alpha coefficient. Cronbach alpha coefficient belongs to widely used methods of scale reliability evaluation and represents level of the internal consistency. If Cronbach alpha coefficient reaches values of 0.7 and more, it represents sufficient internal scale consistency (Benda-Prokeinová, 2014).

From the data obtained from the questionnaire, where respondents had a possibility to express the level of approval or disapproval with the statement on a five-level Likert scale, we found the characteristics of a position. According to Prokeinová (2010), through application of basic descriptive characteristics we gain values of modus and averages of individual respondents' preferences.

In the next part of the research we applied correlation analysis. Correlation analysis represents, according to Benda-Prokeinová (2014), statistical approach which describes a relationship between numeral variables. The more the absolute value of correlation coefficient reaches one, the stronger the dependence and vice versa, the more it reaches zero, the weaker the dependence.

For testing statistical hypothesis resulting from research assumptions, mathematical-statistical methods - non parametrical test were applied: Kruskal-Wallis test and Spearman coefficient. We searched for differences in answers of the questionnaire based on specific identification symbols, dependence between two variables, as well as the power of this dependence (Markechová, Stehlíková, Tirpáková, 2011; Rimarčík, 2007).

\section{Results and Discussion}

Ergonomics should be one of the primary prerequisites within creation of administrative places to create environment where an employee will be able to focus on performance without being disrupted by noise, weak or overrating light or inappropriate chair. Similarly, this place must react to the company culture and identity. The result should be environment with pleasant, stimulating atmosphere which should motivate employees to higher performance.

As new technologies emerge, a professional life changes as well. New generations of employees come to work and they require change of work environment in which people will work. It manifests in benefits offered by companies and in a number of people working separately. Even work environment must adjust to changes. Especially in case that companies want executive and productive employees, who are happy to go to work. Companies must react to these changes if they want to keep and attract talents of new generation. If employees have pleasant work environment, they will be happy at work. Due to this fact they will communicate better, cooperate more effectively and moreover they will be able to live healthy life. And therefore their productivity will rise, which will manifest in the company's results.

Within selected issue, which we consider highly actual, we paid attention to analysis and evaluation of facts, gained by realization of the questionnaire in food businesses in Slovakia.

The questionnaire contained statements, approved or disapproved by the respondents (management members of selected companies) on a five-level Likert scale. Due to application of five-level Likert scale it was inevitable to test sufficiency of its internal consistency. The 
value of Cronbach Alfa reached the level of 0.833025 , which represents sufficient internal scale consistency. Based on the given fact we used the next analysis.

Table 1: Cronbach Alpha coefficient

\begin{tabular}{|c|c|}
\hline \multicolumn{2}{|c|}{ Cronbach Coefficient Alpha } \\
\hline Variables & Alpha \\
\hline Raw & 0.837452 \\
\hline Standardized & 0.833025 \\
\hline
\end{tabular}

Source: own elaboration

Work environment significantly influences work performance of employees as well as their creativity and commitment. Speaking of connection between employee and work environment, there are factors which directly or indirectly influence employee. Properly set up work environment, which significantly takes into account needs and imagination of employees can be, in the end, positive contribution in many areas of the company especially speaking of midterm and long-term horizon (Pindrochova, 2015).

The questionnaire contained questions intentionally focused on monitoring adjustment of work environment to employees - to feel needed, motivated, committed and to make them perform their best.

Managers of food businesses in Slovakia who were the respondents, expressed their level of approval or disapproval within six statements.

Average and the most common answers recorded, are shown in the Figure 1. The bar graph represents average answers of respondents (data is shown in the basis of the graph) and a line graph shows the most common answers of respondents (data are shown above the graph).

Figure 1: Characteristics of a position evaluating factors of work environment

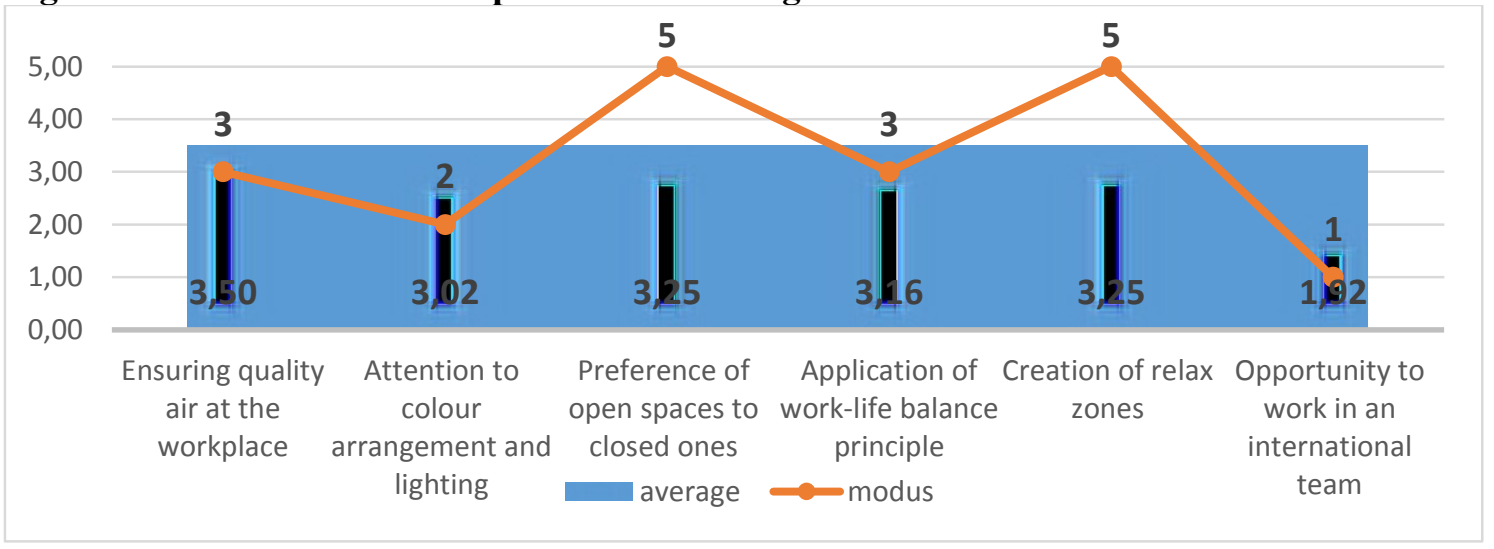

Source: own elaboration

The statement "In the company we ensure quality air at the workplace " has got an average answer of 3.5 and the most common answer with the value 3 „I rather agree than disagree“, which was expressed by $31.13 \%$ of companies' representatives. Absolute approval was expressed by $22.96 \%$ and absolute disapproval was expressed by $5.52 \%$ of companies. As a result of this finding we can state, there are significant reserves in terms of air quality assurance in food businesses in Slovakia.

The average answer to the statement " $A$ huge attention is paid to colour arrangement and lighting of workplace" was neutral, the most common answer reached the value 2 - partial 
disapproval- $26.71 \%$ of company representatives. Absolute approval was expressed by $17.44 \%$ and absolute disapproval was expressed by $12.14 \%$ of companies.

Big difference in average and most common answer can be seen in the answer to the statement "In the company we prefer working in an open environment to working in closed offices". The average answer was neutral and reached value of 3.25. The respondents often marked the answer absolutely agree (5). Up to $26.49 \%$ of respondents answered so and $15.45 \%$ of companies absolutely disagreed.

The average answer expressing level of approval with the statement "In the company we apply principle of work-life balance =balance between working time and free time activities" was evaluated as neutral (3.16). The most common answer was also neutral (3) - I rather agree than disagree and this was the answer of $40 \%$ of companies. Around $11.48 \%$ absolutely agreed and $15.89 \%$ of companies absolutely disagreed. The answers to clear statements were not so clear at all.

Another significant difference in average and the most common answer was within the statement "Employees are provided with relax zones in the company". Average answer was 3.25 and the most common was 5 - I absolutely agree. The value 5 as absolute agreement was expressed by $26.49 \%$ of respondents and the answer 1 was selected by $13.25 \%$.

The statement "Employees have opportunity to work in international teams" reached average answer of 1.92 and the most common value was 1 , expressing absolute disapproval $(60,71 \%$ of company representatives), $13.91 \%$ of respondents partially disagreed. From the mentioned above it is clear that up to $\mathrm{a} / 4$ of companies $(74.62 \%)$ do not provide employees with possibility to work in international teams at all.

The realized Kruskal-Wallis test proved, whether there are dependences between answers of respondents based on size of company, legal form of business, capital share of company and region where the company operates. The results of Kruskal-Wallis test for questions from the fifth section are given in the table 2 . Values marked , "* represent statistically significant differences on the significance level of $95 \%(\alpha=0.05)$ and values marked , "** represent highly statistically significant differences on the significance level of $99 \%(\alpha=0.01)$.

Table 2: Results of Kruskal-Wallis test - work environment for employees

\begin{tabular}{|c|c|c|c|c|}
\hline & \multicolumn{4}{|c|}{ Values of Kruskal-Wallis test according to } \\
\hline & $\begin{array}{l}\text { Size of } \\
\text { company }\end{array}$ & $\begin{array}{l}\text { Legal form of } \\
\text { business }\end{array}$ & $\begin{array}{l}\text { Company capital } \\
\text { share }\end{array}$ & Region \\
\hline Ensuring quality air at the workplace & $<0.0001 * *$ & 0.2178 & 0.2420 & $0.0017 * *$ \\
\hline $\begin{array}{l}\text { Attention to colour arrangement and } \\
\text { lighting }\end{array}$ & 0.1573 & 0.6828 & 0.3128 & $0.0051 * *$ \\
\hline $\begin{array}{l}\text { Preference of open spaces to closed } \\
\text { ones }\end{array}$ & $<0.0001^{* *}$ & $0.0452 *$ & 0.2047 & 0.1737 \\
\hline $\begin{array}{l}\text { Application of work-life balance } \\
\text { principle }\end{array}$ & $0.0006^{* *}$ & 0.5215 & 0.2516 & 0.1843 \\
\hline Creation of relax zones & $<0.0001 * *$ & 0.7945 & 0.6059 & 0.5050 \\
\hline $\begin{array}{l}\text { Opportunity to work in an international } \\
\text { team }\end{array}$ & $<0.0001 * *$ & $0.0034 * *$ & $<0.0001 * *$ & $<0.0001 * *$ \\
\hline
\end{tabular}

Source: own elaboration

Ensuring air quality at the workplace depends on the size of the company, there is existence of highly statistically significant differences on the significance level $\alpha=0.01$. Air quality at the workplace is also influenced by region where the company operates. As we can see from the Table III, the value of this factor is 0.0017 which represents existence of highly statistically significant differences among the answers of companies from different regions. Legal form of 
business and capital share of company do not influence ensuring air quality at the workplace in statistically significant way.

Same like with the previous question, paying attention to colour arrangement and lighting from the managerial point of view is influenced only by the region where the company operates. However, the value 0.0051 is lower than $\alpha=0.01$, thus they are highly statistically significant differences in the answers of the respondents. Size of company, legal form of business and capital share of company do not influence paying attention to colour arrangement and lighting of work environment.

In case of preference of open spaces to closed ones we can see lower value as for the size of company 0.0001 , meaning that there is existence of highly statistically significant differences on the significance level of $\alpha=0.01$. As for the legal form of business we can see the value of 0.0452 , representing existence of statistically significant differences on the significance level of $95 \%$. Thus, we can state that size of company and legal form of business influence preference of open space to closed ones and at the same time, capital share of company and region where the company operates does not influence the preference.

Size of company has influence only on work-life balance application. As for the size of company the value is 0.0006 , representing existence of highly statistically significant differences in answers. However, legal form of business, capital share of business and region where company operates do not influence application of principle work-life balance in a company.

Creating relax zones in companies is also influenced only by size of company, because value $<0.0001$ is lower than $\alpha=0.01$ and therefore it is highly statistically significant differences in answers of respondents. Legal form of business, capital share of business and region where company operates do not influence creating relax zones in companies.

In case of providing opportunities to work in international teams we can see in all the factors values of Kruskal-Wallis test which are lower than alpha $=0.01$ and therefore within all the factors there are highly statistically significant differences in answers of respondents. It means that size of company, legal form of business and capital share of company as well as region where the company operates have significant influence on providing opportunities to work in international teams.

Table 3: Results of Spearman test - work environment for employees

\begin{tabular}{|l|l|l|l|l|l|l|}
\hline & $\begin{array}{l}\text { Air } \\
\text { quality }\end{array}$ & $\begin{array}{l}\text { Color and } \\
\text { light }\end{array}$ & Workspace & $\begin{array}{l}\text { Work-life } \\
\text { balance }\end{array}$ & $\begin{array}{l}\text { Relax } \\
\text { zone }\end{array}$ & $\begin{array}{l}\text { International } \\
\text { teams }\end{array}$ \\
\hline Air quality & 1.00000 & $\mathbf{0 . 3 6 6 6 5 *}$ & $0.26181^{* *}$ & $0.30343^{* *}$ & $0.13450^{* *}$ & $0.16976^{* *}$ \\
\hline Color and light & $\mathbf{0 . 3 6 6 6 5 * *}$ & 1.00000 & $0.24741^{* *}$ & $0.25007^{* *}$ & 0.02874 & $0.15660^{* *}$ \\
\hline Workspace & $0.26181^{* *}$ & $0.24741^{* *}$ & 1.00000 & $0.30034^{* *}$ & 0.01150 & 0.00542 \\
\hline Work-life balance & $0.30343^{* *}$ & $0.25007^{* *}$ & $0.30034^{* *}$ & 1.00000 & $0.20002^{* *}$ & $0.23406^{* *}$ \\
\hline Relax zone & $0.13450^{* *}$ & 0.02874 & 0.01150 & $0.20002^{* *}$ & 1.00000 & $0.14433^{* *}$ \\
\hline International teams & $0.16976^{* *}$ & $0.15660^{* *}$ & 0.00542 & $0.23406^{* *}$ & $0.14433^{* *}$ & 1.00000 \\
\hline
\end{tabular}

Source: own elaboration

Using Spearman correlation coefficient (Table 1) we verified power of dependence among answers. Values marked ,*“ represent statistically significant differences on the significance level $\alpha=0.05$ and values marked , ${ }^{* * *}$ represent highly statistically significant differences on the significance level $\alpha=0.01$. 
The highest recorded correlation has a value of 0.36665 and it is highly statistically significant. It represents medium to essential positive dependence between ensuring air quality at the workplace and paying attention to colour arrangement and lighting of work environment. We found two other medium to essential dependences between ensuring air quality at the workplace and application of work-life balance principles as well as preferring open spaces to closed ones and application of work-life balance principles. Except this, we found nine highly statistically significant correlations which belong to the category of low to medium dependences and the remaining three of them are not statistically significant.

On the base of research made by Lušňáková et al (2017) employees work in their own offices or share „open space office“ with colleagues. The employees who possess their own office (even though shared with a colleague) answered positively the questions connected with thermal comfort, confidentiality and ease within work tasks. On the contrary, employees working in "open space offices“ perceived their work environment as problematic. Except noise, they negatively evaluated even thermal comfort, strong air-conditioning, missing personal space. There was also confirmed relationship which showed strong dependence between disposition of a workplace and air quality and thermal comfort.

The selected companies within our research expressed neutral attitude even to the question whether they pay attention to colour arrangement and lighting of workplace. The author Tzempelikos (2017) states that employer must pay a huge attention to workplace so it is not too noisy, dusty, it must have a lot of light, light walls, fresh air, temperature, chill, humidity, good air flow, microclimate.

Analysed companies expressed neutral attitude to application of work-life balance principles and free-time of employees. The need for a change of neutral attitude to highly interested confirms the research of authors Beauregard and Henry (2009), who say that application of work-life balance principle can significantly influence efficiency and productivity of organization and save costs. It also positively influences and empowers social sphere.

\section{Conclusion}

Within "Material and methods" we formulated research assumption:

A: We suppose that the companies ensuring air quality at the workplace pay also attention to other factors influencing compliant work environment.

Based on the given analysis, it was verified and the results are as follows: research assumption was partially accepted. Based on the given characteristics of position we can state that companies have neutral attitude to ensuring air quality at the workplace, work-life balance principle application as well as to work environment (they marked answer with value ,3“). On the base of our analysis we can state that - depending on size and location - companies are trying to ensure air quality workplace for their employees, they also pay attention to colour arrangement and lighting of workplace and apply work-life balance principles on workplace. On the other hand, there is only one medium to essential positive dependence - between ensuring air quality at the workplace and paying attention to colour arrangement and lighting of work environment.

Based on our analyses, our recommendations for improving the working environment for employees are based on:

- unequivocal compliance with laws, standards and regulations in order to maintain employees' health 
- ensuring a suitable work environment for all employees regardless of the place of work in the company,

- ensuring adequate and safe work environment for employees with regards to labour intensity and expected performance, or to communicate and arrange needs, expectations of both interested sides,

- ensuring balance between personal and professional life of employees, to communicate and elaborate a system which would meet the requirements of both, the employee and the employer,

- setting the rules of flexibility of working time and place of work for employee and to ensure control of fulfilled tasks,

- providing employees with possibility to work in teams, in the area of other organization, in another country, which may help to develop their personality, knowledge, skills and consequently loyalty.

\section{Acknowledgements}

The paper is part of the research projects APVV-17-0564 "The Use of Consumer Neuroscience and Innovative Research Solutions in Aromachology and Its Application in Production, Business and Services"

\section{References}

[1] Beauregard, T.A. \& Henry, L.C. (2009). Making the link between work-life balance practices and organizational performance. Human Resource Management Review, 19 (1): 9-22. doi: 10.1016/j.hrmr.2008.09.001

[2] Benda-Prokeinová, R. (2014). Statistics in SAS, SAS in statistics [Štatistika v SAS-e, SAS v štatistike]. Nitra: ASPA

[3] Bernstein, J.A., Alexis, N ., Bacchus, H., Bernstein, I.L., Fritz, P., Horner, E., Li, N., Mason, S., Nel, A. \& Oullette, J. (2008). The health effects of nonindustrial indoor air pollution. In Journal of allergy and clinical immunology. 121 (3): 585-591. doi: 10.1016/j.jaci.2007.10.045

[4] Ceylan, C., Dul, J. \& Aytac, S. (2008). Can the Office Environment Stimulate a Manager's Creativity? In Human Factors and Ergonomics in Manufacturing. 18 (6): 589-602. ISSN: 1090-8471

[5] Chapman, J., Jones, D.\& Gray, F. (2015). Perceptions of change in office space design: redesigning Barwon Water's office environment. In Living and learning: research for a better built environment. Conference: 49th International Conference of the Architectural-Science-Association Location. Pages: 203-214. ISBN 978-0-9923835-2-7

[6] Lušňáková, Z., Juríčková, Z., Šajbidorová, M. \& Lenčéšová, S. (2018). Trends in work with human resources in Slovak agricultural enterprises. International scientific days 2018. Praha: Wolters Kluwer ČR. 1253-1264. doi: $10.15414 /$ isd2018.s5.08

[7] Lušňáková, Z., Šajbidorová, M., Hrdá, V. (2017). Creativity supporting workplace from the employee's point of view. In Managerial trends in the development of enterprises in globalization ERA. Nitra: SPU. s. 401-407. ISBN 978-80-552-1739-0.

[8] Markechová, D., Stehlíková, B. \& Tirpáková, A. (2011). Statistical methods and their applications [Štatistické metódy a ich aplikácie]. Nitra: Univerzita Konštantína Filozofa

[9] Park J., Loftness, V., Aziz, A. \& Wang, T-H. (2019). Critical factors and thresholds for user satisfaction on air quality in office environments. In Building and Environment. Volume 164, 106310, doi: 10.1016/j.buildenv.2019.106310

[10] Prokeinová, R. (2010). Usage of SAS as a tool of quantitative analysis in a questionnaire [Využitie SASu ako nástroja kvantitatívnych analýz $\mathrm{v}$ dotazníkovom prieskume]. SAS Technology Forum 2010: 13. ročník konferencie.

[11] Rimarčík, M. (2007). Statistics for practice [Štatistika pre prax]. Košice: Marián Rimarčík 
[12] Shao, Y., Nijstad, A. B. \& Tauber, S. (2019). Creativity under workload pressure and integrative complexity: The double-edged sword of paradoxical leadership. Organizational Behavior and Human Decision Processes, 155: 7-19, doi: 10.1016/j.obhdp.2019.01.008

[13] Taha, A. V., Sirkova, M., \& Ferencova, M. (2016). The Impact of Organizational Culture on Creativity and Innovation. In Polish journal of management studies. 14 (1): 7-17. doi: 10.17512/pjms.2016.14.1.01

[14] Traumann, A., Kritsevskaja, M., Tint, P. \& Klauson, D. (2014). Air quality as an important indicator for ergonomic offices and school premises. In Agronomy Research. 12(3): 925-934.

[15] Tzempelikos, A. (2017). Advances on daylighting and visual comfort research. Building and environment. 113:1-4. doi:10.1016/j.buildenv.2016.12.002 


\title{
Agricultural University Students and their Attitudes Towards Entrepreneurship: Selected Aspects
}

\author{
Danka Moravčíková ${ }^{1}$, Martina Hanová ${ }^{2}$ \\ The Slovak University pf Agriculture in Nitra \\ Department of Social Sciences ${ }^{1}$ \\ Department of Statistics and Operational Research ${ }^{2}$ \\ Address: Tr. A. Hlinku 2 \\ 94976 Nitra, Slovakia \\ e-mail: danka.moravcikova@uniag.sk¹,martina.hanova@uniag.sk ${ }^{2}$
}

doi: 10.18515/dBEM.ISD.P01.2020.p037

\begin{abstract}
This article presents selected results and findings from the research project realized at the Slovak University of Agriculture in Nitra, under the grant 1/0685/17 of the Scientific Grant Agency of the Slovak Republic. It attempts to answer the question of how young people perceive their personal readiness for self-employment and entrepreneurship and whether they (as students of the agricultural university) consider their position specific in a comparison with the students of differently oriented study programmes. For primary data collection questionnaire survey on a sample of 414 respondents and qualitative methods (focus groups, brain-writing) were used. The authors briefly introduce the description analysis results and then they interpret attitudes and opinions of agricultural students on their entrepreneurial readiness in relation to gender aspect and available monthly budget, and their reflection of differences within the Slovak academic environment. Although the paper represents a case study of the only agricultural university in Slovakia, and therefore it is not possible to generalize the research findings, many of them confirm the findings of more extensive researches of this target group or complete the information from analytical and strategic documents at the EU and country level.
\end{abstract}

Keywords: youth entrepreneurship, agricultural students, entrepreneurial readiness

JEL Classification: Z10, Z13, Z19

\section{Introduction}

In contemporary Europe, it is very difficult for young people to find their place in the labour market. Promoting and increasing young people's labour market participation has therefore become a political priority, mainly because of their potential and the development of human capital. For example, already in 2012, the European Commission published The Entrepreneurship 2020 Action Plan. This document proposed measures to "unlock" Europe's business potential and to remove existing obstacles in doing business. (EC, 2012) The decision to become an entrepreneur or self-employed person is difficult and is determined by various factors at the micro-, mezo- and macro-level of the society. Despite the low proportion of young entrepreneurs and self-employers in general, young people in Europe are very interested in setting up their own business, as various studies and researches declare. Although the proportion of "interested persons" is significantly higher than the proportion of young entrepreneurs and self-employers in Europe, it is significantly lower in comparison with other parts of the world, e.g. Brazil, China, India, and the United States. It should be stressed that self-employment and entrepreneurship are not the only solution to tackling the youth unemployment crisis, and there is no doubt that Europe should make a greater effort to create a business-friendly environment and to support young people in transforming their creative ideas 
to successful business plans. At the same time, it should be clear that entrepreneurship or selfemployment is not a suitable life strategy for everyone, but only for those young people who dispose the right skills, attitudes and values, as well as the so-called "entrepreneurial spirit".

Within the European framework, the entrepreneurship and initiative are considered key competences for lifelong learning. However, entrepreneurial skills do not mean only the ability and knowledge to create and run a business. Business education consists of both technical, socalled hard skills, and so-called soft skills. Entrepreneurship is the ability to create and build something new, the ability to recognize new opportunities, the knowledge of own skills and abilities, the willingness to enter into risky situations, the ambition and desire to achieve goals, and the ability to acquire and use various resources to acquire the necessary competences. (Driessen, Zwart, 2002) Entrepreneurship is seen as a key cross-cutting competence applicable by individuals and groups, including existing organizations across all spheres of life. Special attention paid to young people and their entrepreneurial potential has resulted in the definition of three basic pillars: education and training; creation of business-friendly environment; and targeting specific groups that are not yet able to fully realize their business potential. The European Commission has also proposed the project Youth Entrepreneurship Strategies (YES) to increase the number of young entrepreneurs in Europe, and Erasmus for Young Entrepreneurs (EYE) - the exchange program that provides the opportunity for peer learning. Similar efforts and initiatives have also been implemented in member states. (Eurofound, 2015)

Self-employment is a solution how to increase employment in some areas of the economy, including agriculture. For example, it is stated that labour shortages are expected in some agricultural jobs in Slovakia, mainly due to the expected high number of entrepreneurs leaving the labour market by 2023 - in particular, farmers, milkers, but also fruit and vegetable processors, farm workers, fruit growers, etc. will be missing. There is an additional demand for approximately 10,000 people with agricultural education. (Trexima, 2018) However, the employment in the agro-sector is not attractive enough for young people. The low attractiveness is also supported by the fact that there is only a small number of young people working in this sector. The majority of the EU farmers is aged 55 years and over, and only $6 \%$ of all EU farms are youth-led (by farmers under 35 years). (Šebesta, 2019) The big challenge is therefore to persuade young people to start farming. Greater involvement of young people in agriculture has thus become one of the European Commission's main priorities in the forthcoming reform of the EU's Common Agricultural Policy. It is not only oriented on increasing the employment of young people in the agro-sector, but also on increasing the number of self-employers and business development.

The research, whose selected findings are presented in this article, was conducted at the Slovak University of Agriculture in Nitra (SUA in Nitra) within the research project Attitudes of young people towards self-employment. One of the main reasons for its realisation and respondents' selection was the fact that the SUA in Nitra is the only agricultural university in Slovakia, where we face a long-term acute shortage of educated young people in the agricultural sector. The study of attitudes and behaviour of students of the SUA in Nitra is therefore very important for further development of agricultural education and also for the sector itself.

\section{Data and Methods}

The methodology of the research project was based on the principle of triangulation - a combination of quantitative and qualitative methods. In addition to the questionnaire, brainwriting and focus group techniques were used. The questionnaire was based on the work 
of Juračak and Tica (2016) and the original version was prepared in English language. Our respondents were personally contacted with a request to complete the questionnaire in Slovak language. In parallel, a questionnaire was also carried out at partner universities among students of agricultural and life science universities in Croatia, Poland and Serbia in order to compare this situation in the context of the macroeconomic situation of individual countries. (Juračak, Majewski, Lukič, Markovič, and Moravčíková, 2019).

The questionnaire contained a total of six thematic sections. The first part concerned previous business experience. The second, third, fourth and fifth parts were devoted to evaluating the perceived suitability of self-employment, entrepreneurial self-sufficiency and business plans and assessment of the specific status of students of agricultural university. The sixth part identified the social, economic and spatial background of respondents. All questions of the compiled questionnaire, except one, were formulated as closed questions. The Likert range was chosen in a uniform manner and allowed respondents to express their level of consent or disagreement with statements offered on a five-point scale of 1 to 5. On all issues 1, it meant 'I totally disagree' and 5 'I totally agree'. Selected statistical methods using SAS and Statgraphics software were used to analyse empirical data of quantitative nature.

The case study included 414 students from all six faculties of the SUA in Nitra. Their selection was targeted, proportionally involving bachelor students (65\%) and master's students (35\%). The proportion of respondents from different faculties was based on the calculation of the sample size, which respected their share among all university students. The representativeness of the selection set according to faculties was verified using the Chi quadrat test of good conformity based on a comparison with current data on the structure of full-time students at individual faculties of the university. The test result confirmed the representativeness of the sample by faculties and degree of study, which was the basic precondition for carrying out further analyses.

This article presents selected results and findings from research conducted at the SUA in Nitra, which attempts to answer the question of how young people perceive their personal readiness for self-employment and entrepreneurship and whether they consider their position as students of agricultural university to be specific compared to students of other universities. Although this is a case study of the agricultural university and therefore it is not possible to generalize research findings, many of them confirm the findings of more extensive researches of this target group, or they confirm information from analytical or strategic documents at the EU level and national level as well.

\section{Results and Discussion}

In view of the research objectives, which included a comparison of the situation of students of economically oriented study programmes with those of other study programmes, the proportion of the two categories was $41 \%$ and $59 \%$. Other observed identifiers included the place of permanent residence, the approximate monthly budget which students have, preferences in the type of future employment according to sectors and subjective expectations or ideas about their situation within five years. $67 \%$ of the respondents came from the rural environment and $33 \%$ of our student respondents came from the urban environment. The highest proportion of students (42\%) had a monthly budget of $151-300 €$, followed by a monthly budget of up to 150 $€$, and only $10 \%$ of students had an average monthly budget of $301-450 €$ and $11 \%$ had more than $450 €$ per month. The preferred sectors of future employment are visualised in Fig. 1. Less than half of our respondents $(45 \%)$ did not expect a significant change in their situation in five 
years' time, a pessimistic view of their own future was presented by $35 \%$ of respondents compared to $20 \%$ of students who declared optimistic expectations, i.e. a better situation than the current one.

The results of the primary data analysis point to the fact that personal experience and positive examples can play a decisive role in young people's decision-making about their economic careers and can increase perceptions of the attractiveness of entrepreneurship and selfemployment. On the other hand, it should be stressed that in the next steps we analysed only the preferences and intentions of students, not their "true" socio-economic behaviour, and therefore it is not possible to generalise these findings.

Figure 1: Preferable place of future employment

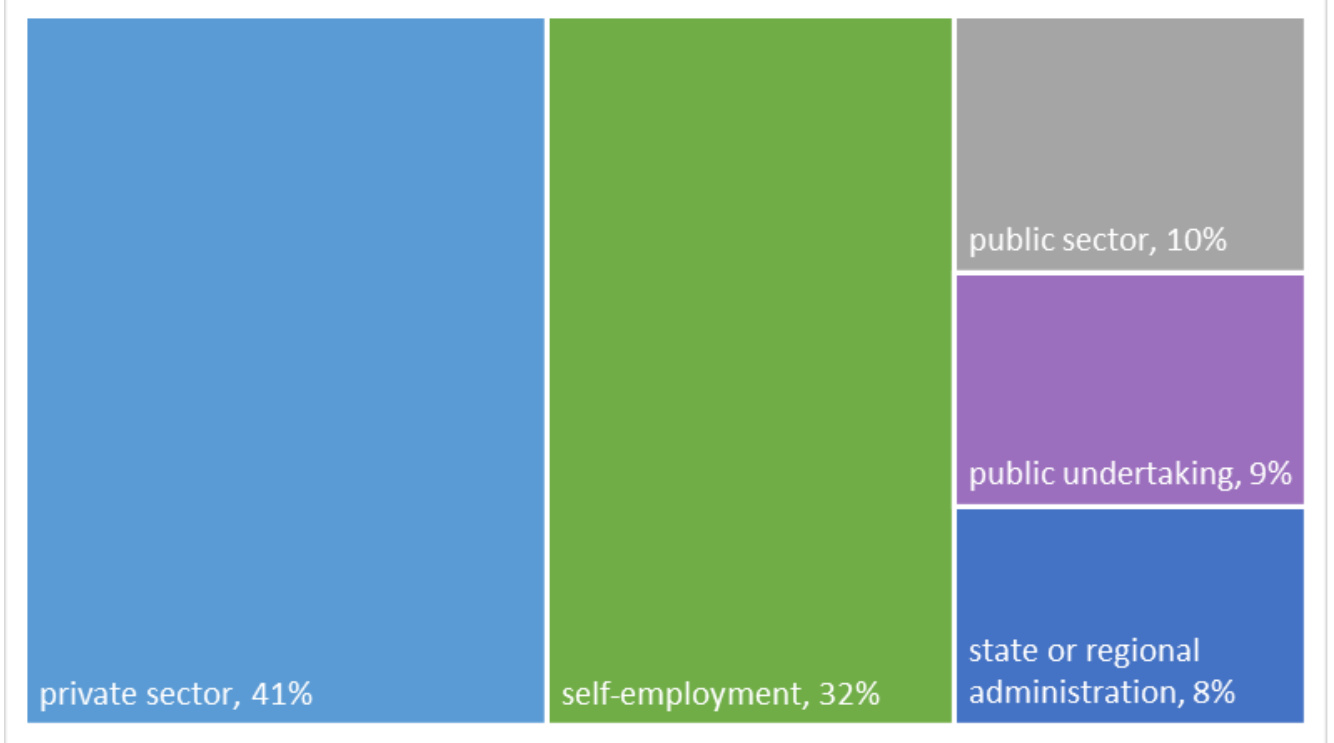

Source: Questionnaire survey, own processing.

Most of the students interviewed have a personal experience of paid employment, and most of them who have entrepreneurs' parents have been involved in work in a family business. As we assumed, only a small part of them (approximately one fifth) also worked on the farm. Most respondents (47\%) have experience working on smaller farms of up to 50 hectares, a further $35.3 \%$ said they worked on farms with an area of between 60 and 300 ha and less than a fifth worked on large farms of 1500 ha to 3600 ha. A very positive finding is that a large proportion of students with business parents $(80.0 \%)$ rate their personal experience positively, and there is also a statistically significant relationship between this category of respondents and their preferred future jobs by sector - they clearly favour private sectors or self-employment. The results of the questionnaire survey of students of various SPU faculties in Nitra showed dependency with high statistical significance among students of economic (FEM) and noneconomic study programmes (other faculties) and the intensity of perceived value of selfemployment and entrepreneurship, as well as the intention to do business or self-employment. (Moravčíková, Hanová, and Pechočiaková Svitačová, 2019) The highest dependency was found between the faculty/type of study program and the intention to run its own farm in the future. Within the whole sample of respondents, the proportion of those who want to establish their own farm in the future was relatively high $(27.0 \%$ of "economic" and $48.0 \%$ of "non-economic" students). The data indicate surprisingly the lower "business spirit" of the FEM students compared to other SPU faculties in Nitra. 
In their responses, students presented self-confident attitudes and views on personal readiness for business. The highest proportion of respondents said that if they will decide to run their own business, they would have done it. They most believe in their creativity and the ability to inspire and impress potential collaborators for their own business visions. (Figure 2) The average values for these responses were in the range of 3.93-3.80 on a five-stage scale.

Figure 2: Entrepreneurial self-efficacy perception: stronger aspects

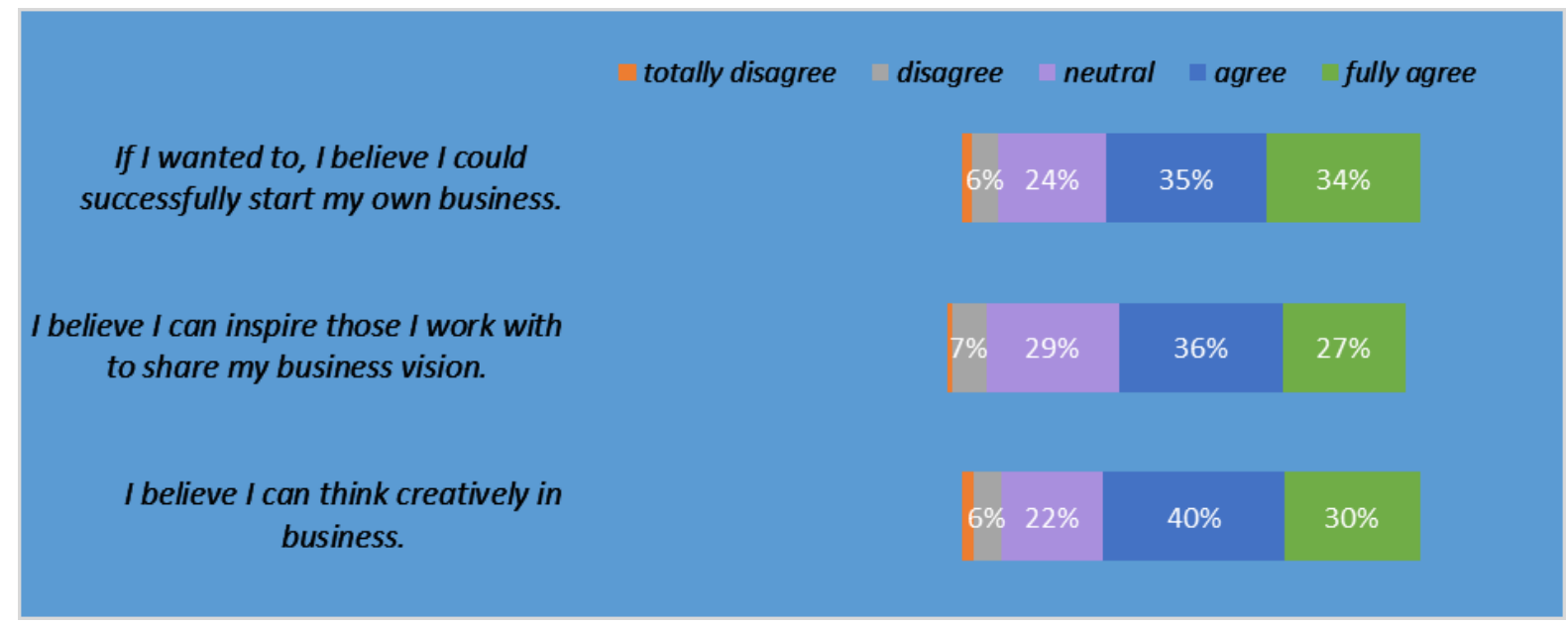

Source: Questionnaire survey, own processing.

On the contrary, when assessing more specific knowledge and skills, our respondents were a little more cautious, but this is related not only to the subjective assessment of their personal qualities, but also to the objective perception of the social/societal environment and its "entrepreneurship-friendly character" (...and especially how the young generation perceives it). This applies in particular to the search for start-up financing mechanisms and ability to realize market analysis. In this case, the mean response values were 3.14 and 3.25.

Figure 3: Entrepreneurial self-efficacy perception: weaker aspects

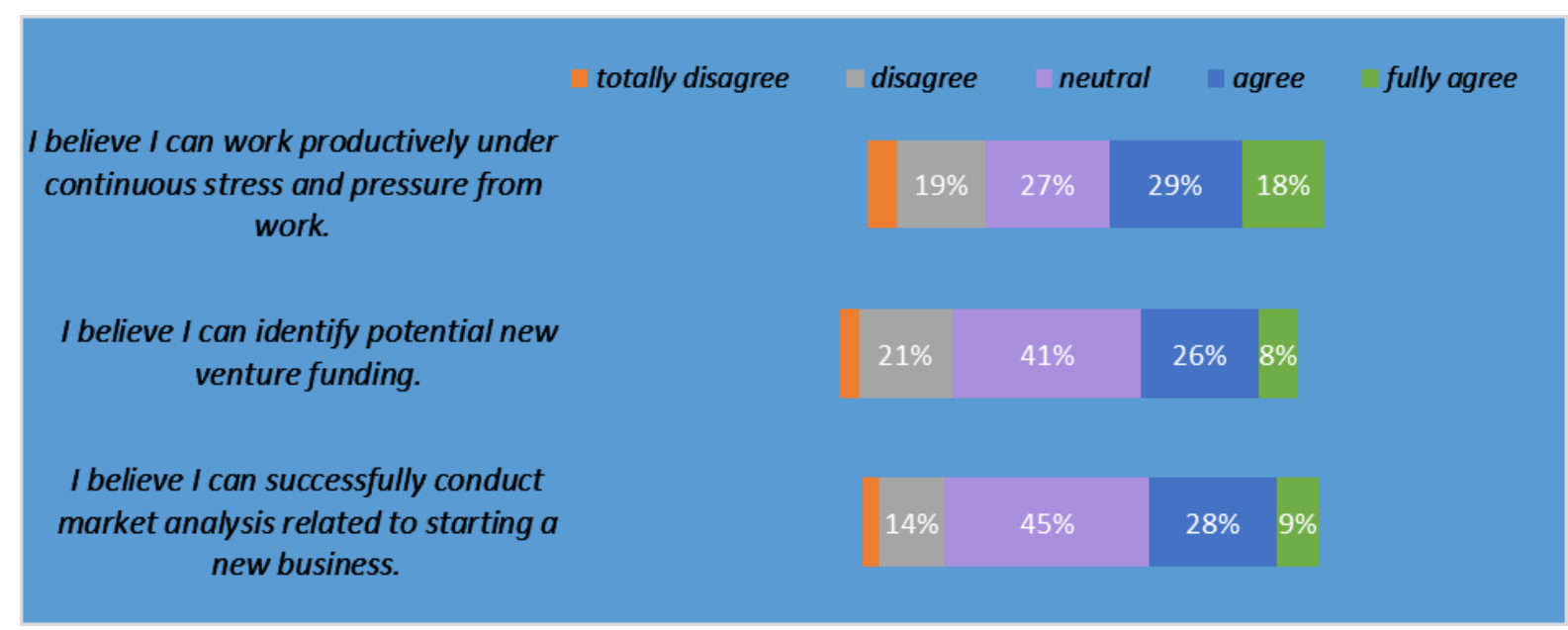

Source: Questionnaire survey, own processing. 
In relation to the opinions of respondents to compare their position within the type of university and faculty, the predominance of neutral positions is evident. It is a positive finding that the largest proportion of consent opinions (45\%) were expressed by our students that the study programme that they attend prepares them sufficiently for future careers. On the other hand, about the same proportion of respondents declared that there are differences between the universities in Slovakia in the preparation of students and graduates for self-employment.

Figure 4: Perception of differences between readiness for self-employment of agricultural students and students of other faculties/universities

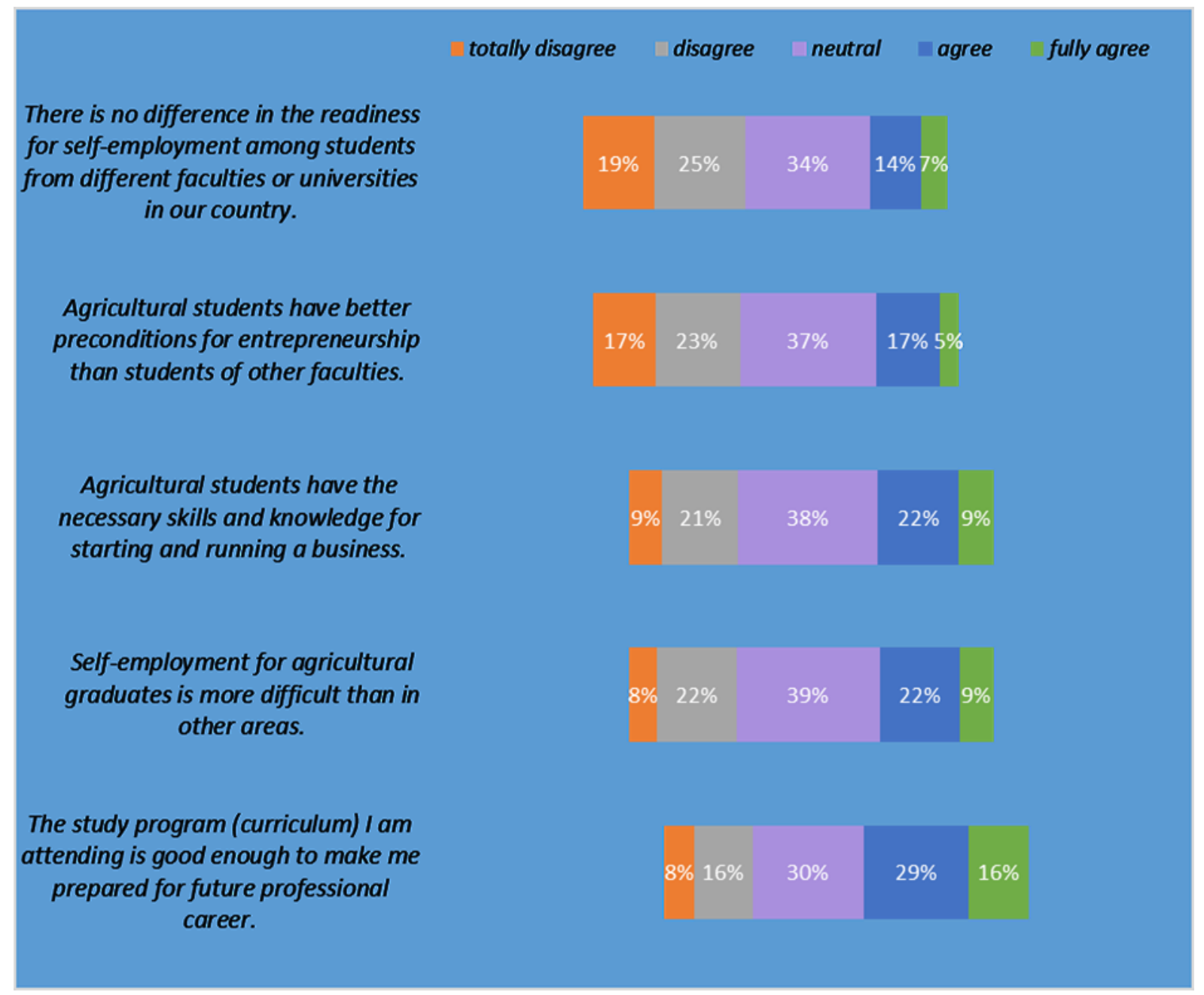

Source: Questionnaire survey, own processing.

Almost a third of the interviewed students consistently stated that as students of agricultural and life science universities they have the necessary knowledge and skills to start up business, but their business and self-employment is more complicated than in the case of students of other disciplines. 


\section{Conclusion}

The above interpreted quantitative findings suggest and confirm two lines. The first is sociopsychological, in which our research confirms the typical features of today's young generation of university students, their increased self-confidence and belief in themselves. The second line indirectly underlines the not very positive status of entrepreneurs in our society and also the lack of strategic mechanisms and financial instruments to support creativity, innovative ideas and ideas of young potential entrepreneurs and self-employed persons (e.g. start-up support, innovative vouchers, existence if business angels, accessible seed and proof-of-concept funds, business incubators and accelerators etc.). These problems are not systematically and long-term solved in Slovakia, usually they rely mostly on resources of one-off projects and the European initiatives and activities in this field.

\section{Acknowledgements}

The authors gratefully acknowledge the contribution of the Scientific Grant Agency of the Slovak Republic under the grant 1/0685/17.

\section{References}

[1] Driessen, M. P. \& Zwart, P. S. (2002). The role of the entrepreneur in small business success: the Entrepreneurship Scan. Retrieved from Semantic Scholar. Retrieved from https://www.semanticscholar.org/paper/The-role-of-the-entrepreneur-in-small-business-\%3A-DriessenZwart/480a0039bcd325f99bb204f70d1ef92b046f0c1b.

[2] Eurofound (2015). Youth entrepreneurship in Europe: Values, attitudes, policies. Luxembourg: Publications Office of the European Union. Retrieved https:/www.eurofound.europa.eu/publications/report/2015/labour-market/youth-entrepreneurship-ineurope-values-attitudes-policies.

[3] European Commission (2012). The Entrepreneurship 2020 Action Plan. Retrived from https://eurlex.europa.eu/legal-content/EN/TXT/?uri=CELEX:52012DC0795.

[4] Juračak, J., Majewski, E., Lukič, A., Markovič, T. \& Moravčíková, D. (2019). Comparative analysis of selfemployment intentions among university students in four Central and Eastern European countries. Journal of Central European Agriculture. 20 (4), 1302-1315. doi: /10.5513/JCEA01/20.4.2442

[5] Juračak, J. \& Tica, M. (2016). Graduate Students' Opinions about Entrepreneurship as an Employment Opportunity. Applied Studies in Agribusiness and Commerce - APSTRACT. Debrecen: Center-Print Publishing House. doi: 10.19041/APSTRACT/2016/1/4

[6] Moravčíková, D., Hanová, M. \& Pechočiaková Svitačová, E. (2019). Spoločenské súvislosti sebazamestnávania a agropodnikania mladých l’udí. Nitra: VES SPU.

[7] Šebesta, A. (2019). Európske pol’nohospodárstvo prejde technologickou revolúciou, hlavným heslom bude udržatel'nost'. Retrived from Euractiv.sk. Retrived from https://euractiv.sk/section/ekonomika-aeuro/opinion/europske-polnohospodarstvo-prejde-technologickou-revoluciou-hlavnym-heslom-budeudrzatelnost/.

[8] Trexima (2018). Prognózy vývoja na trhu práce $v \quad S R \quad I I$. Retrieved from https://www.upsvr.gov.sk/buxus/docs/statistic/NP_prognozy/Strednodobe_prognozy_vyvoja_na_trhu_prac e.pdf. 


\title{
CSR Awareness among Foodservice Companies (Study in Ukraine within the Environmental Pillar)
}

\author{
Oksana Sokil ${ }^{1}$, Drahoslav Lančarič ${ }^{2}$, Iveta Ubrežiová ${ }^{3}$ \\ Slovak University of Agriculture in Nitra ${ }^{1,2}$, Catholic University of Ružomberok ${ }^{3}$ \\ Department of Management ${ }^{1,2}$, Department of Management ${ }^{3}$ \\ Trieda A. Hlinku $2^{1,2,4}$, Nábr. Jána Pavla II. $15^{3}$ \\ Nitra $^{1,2}$, Poprad $^{3}$ Slovakia \\ e-mail: xsokil@uniag.sk ${ }^{1}$,drahoslav.lancaris@uniag.sk ${ }^{2}$, iveta.ubreziova@ku.sk $^{3}$
}

doi: 10.18515/dBEM.ISD.P01.2020.p038

\begin{abstract}
Economic science has proven and confirmed that the social responsibility of business organizations is no less important than sustainable economic infrastructure, political stability, or the implementation of innovative development projects to ensure sustainable development. However, it is worth noting that the high level of skepticism and the low level of awareness among society members about the CSR importance do not allow this phenomenon to develop in the appropriate way. The main aim of the paper is to determine the level of CSR awareness among Ukrainian foodservice business. Besides, the purpose of the work is to determine the main barriers and incentive which influence the enterprise CSR performance. The questionnaire survey was conducted during February-March 2019 among Ukrainian companies operating in foodservice market.
\end{abstract}

Keywords: Corporate Social Responsibility, foodservice, environmental pillar

JEL Classification: E02, Q13, Q56

\section{Introduction}

The entities surrounding the business organization expect from it not only economically responsible actions, but also to take part in solving social, environmental and other problems. The responsible attitude of companies to their own product or service, to consumers, staff, partners, their active social position is a necessary factor in shaping a modern corporate strategy. The development of the socio-economic level of society creates additional special requirements for corporations (Zhukovs'ka, 2009; Aßländer, 2011; Kharlamova, 2012).

Works of researchers and scientists are devoted to solving issues and problems related to the development and implementation of corporate social responsibility. However, to date, there is no single commonly accepted definition of CSR. CSR can be defined as the systematic responsibility of a company for the produced product to consumers, employees, partners, the community and the environment (Burlakova, 2009; Kolot, 2014).

It is possible to say that a lot of society members do not yet have an objective, impartial, modern understanding of the essential nature and role of CSR, the importance of this phenomenon for business organizations and society. Moreover, the environmental pillar of CSR has the biggest gap in its understanding of importance among society members (Kolk, 2010).

The main purpose of the study is to find out the level of CSR awareness. Moreover, the aim of the research is to find out the main problems which block the CSR implementation into the company's activity. The main factors which motivate a firm to perform CSR measures will be researched. Besides, the most common activities in environmental tiller direction are required 
to discover. The research will be conduct among Ukrainian companies which are operating within the foodservice industry.

The following questions will help to achieve the established purpose:

1. What are the main factors which motivate foodservice firms to perform CSR activities?

2. What are the main barriers that foodservice companies face during the CSR implementation?

3. What are the most common activities implemented by the foodservice business in the CSR environmental pillar direction?

Besides, the hypothesis was formed:

The level of CSR awareness is determined by the financial situation of the company.

\subsection{The CSR importance}

CSR is a multilevel, fuzzy concept which prone to change and improving (Liyanage et al., 2016). However, CSR introduces a comprehensive tool of reconciling society and business (Wamitu, 2014). We can argue that the CSR covers the positive aspects of the company's activities, such as the providing benefits to disabled customers, fair wages, fair relationships with competitors, energy-saving and other compliance with obligations undertaken by a company outside (Cadbury, 2006). The idea of Corporate Social Responsibility is to develop livelihoods to as many people as possible. The firm should concentrate not only on profit but also to takes into consideration the demands of its stakeholders which have an influence on the performance of the company. Stakeholders put pressure on the company in the context of economic, environmental and social spheres (Ubrežiová, 2016).

\section{2 Environmental pillar}

Increasing concern about natural resource scarcity and climate change has had a significant impact on the global development of environmental reporting. Therefore, the rationalization of the resources using, the search for alternative species, reducing the environmental burden, etc have become one of the major problems for society. Countries around the world are beginning to impose stringent requirements on the environmental component of companies through the technical standards implementation (Matviychuk, 2016). It should be emphasized that the absence of a long-term social strategy, information about the company's environmental protection programs, its voluntary contribution to solving social and environmental problems increases the risk of increasing distrust by stakeholders. To follow CSR requirements in case of environmental aspects, companies can measure their environmental impact and implementing environmental management (Uddin, 2008).

According to the previous studies, it can be concluded that external stakeholders generally prefer companies committed to environmental protection (Hall et al., 2010; Li and Zhang, 2010). Generally, protection of the environment is carried out according to the public interest and is considered an external component of private life. Government agencies are primarily responsible for environmental issues solving. Moreover, these institutions focused on providing a safe environment (Mazurkiewicz, 2005). Some authors argue that companies need to create strategic advertising for its CSR activities. Such kind of actions can have a positive effect on consumers' decisions due to the fact that advertising of certain products or services builds a sense of hope and trust of buyers to the company (Kim, 2012). 


\subsection{Ukraine and CSR}

The integration of Ukraine into the world community forces domestic companies to join the search for a mechanism which helps to overcome the contradictions between the government, business and society. This situation actualizes the issues of studying and adapting foreign experience in case of implementing CSR principles into domestic practice (Hrytsyna, 2016).CSR strategy developing is a conceptual task for many Ukrainian companies. This situation can be explained by the fact that it is not only a matter of spontaneous charity but of systemic activity embedded in all business processes (Kolosok, 2015).

Previous studies show that in Ukraine the representatives of international foreign enterprises have a broader focus on CSR activities than domestic companies. Such kind of business direct its activities to the education program development, a healthy lifestyle promotion or nature conservation practices. This activity is carried out in accordance with the internal policies and regulations of the headquarters. On the other hand, the activity of domestic enterprises in the field of CSR expresses episodic character and is represented by individual charity events (Koryahina, 2011; Komarova, 2016).

An analysis of the CSR development level in Ukraine shows that only high-income corporations have a well-developed strategy in this area. Representatives of the fuel and energy complex companies, spirits producers and telecommunication companies are leaders in the field of the CSR strategy development within the domestic market. However, it should be recognized that companies whose products and other activities are most closely related to personal consumption are also widely involved in various models of social responsibility development and dissemination (Kolot, 2014).

Besides, previous studies also show that the permanent and continuous implementation of CSR actions in a company's development strategy determines the number of benefits for its successful operation. In particular, companies' CSR programs sometimes find hidden levers of efficiency gains that were otherwise simply impossible to see. For example, reducing emissions is one of the main CSR measures. The ongoing purposeful search of ways to solve this problem induces enterprises to purchase new technologies. In the future, such kind of activities could become the key to the firm's efficiency improving. Besides, CSR measures help to increase motivation and productivity of employees, since all company workers are simultaneously citizens or consumers. Based on this, it can be said that caring for the community and society will be transformed into caring for the workers. Moreover, Ukrainian enterprises point out that psychological factors of motivation to work are very important for any organization. Widespread implementation of CSR contributes to the growth of intangible assets, in particular enhancing the company's business and public reputation, reducing the risks of possible market losses, improving access to new markets through improved reputation. Assuredly, speaking of Ukraine, there are many examples where companies can make significant profits or reduce risks by paying attention to social responsibility (Mazurenko, 2012).

\section{Data and Methods}

The use of the survey had helped to identify the main areas of activity within the environmental pillar among small and medium-sized enterprises in Ukraine operating in the field of the food services market. The main factors that motivate/do not motivate companies to perform CSR activities were also analyzed. The main barriers that hinder the activities of firms in this field were outlined. The plans for CSR implementation and development were analyzed. 
The questionary sample was created after researching and analyzing literature which is related to the investigated topic (Zinchenko and Saprykina, 2017). The survey was conducted among management services representatives of the enterprises, which occupy the foodservice sector of Ukraine. The study was carried out in Kyiv, Lviv, Odesa due to the fact that those cities are the most visited cities of the country (The State Statistics Service of Ukraine, 2018). The respondents were interviewed during February-March 2019. The questionnaires were completed by filling out electronic samples which were sent via email. Part of the respondents was interviewed during personal meetings or by telephone calls. The survey sample includes 10 questions which are grouped into 4 parts. The questionnaire includes closed and semi-closed questions:

- Part I include questions about general information of the enterprise such as ownership structure or financial situation;

- Part II contains questions which give the possibility to evaluate the level of management awareness about CSR. Moreover, this part of the survey helps to determine factors which motivate/ do not motivate firms to implement CSR activities. In addition, the section gives information about the factors which prevent the development of the company in this area;

- Part III represents the information about the enterprise's activities within the environmental pillar of CSR;

- Part IV allows evaluating the firm's plans for further CSR development activities.

Likert scale was used for the questionnaire. Such a method provides the possibility for the respondent to represent the extent of his/her agreement or disagreement with a certain statement. In this case, the five-level Likert item was used: 1 - "not dealing with" to 5 - "dealing a lot" or 1 - "strongly disagree" to 5 - "strongly agree".

To analyze the data, Excel and XLSTAT Statistical Software were used. In order to test the hypotheses, the Spearman correlation coefficient was used.

\section{Results and Discussion}

A total of 107 fulfilled samples from surveyed companies were received. From the sample, the companies' sizes were the following: 63 - the small-sized enterprises, 44 - medium-sized. The majority was formed by companies with existence duration of 5 to 10 years $(49(45.8 \%)), 1$ to 5 years -29 firms $(27.1 \%)$, more than 10 years -23 companies $(21.5 \%)$, less than 1 year 5 (5.6\%). 83 companies are formed by domestic owners, 22 firms - by the domestic owner with foreign investor, 1 company is formed by subsidary of MNC and 1 respondent has foreign owner. Moreover, the majority (43 companies) point out to have a very good financial situation, 24 firms- above average, 22 respondents - average and 18 companies have rated the financial condition as below average. Furthermore, this general information about respondents is represented in Table 1.

The second part of the questionnaire provides information about respondents' attitude toward CSR. The results have shown that the majority of surveyed companies $(66(61.7 \%))$ are familiar with CSR term.

Table 1 represents the information about respondents' answers toward factors which motivate/do not motivate the company to implement CSR. The results of the survey have shown that maintaining/increasing the company's reputation is the primary motivating factors for CSR implementation. Besides, the majority of the respondents have noted that ethical and moral 
reasons, improving the financial situation, an increase of workers motivation and the increasing/maintaining the level of customers' loyalty are also important factors which induce firms to develop CSR activities.

Table 1. Factors that motivate/do not motivate company to implement CSR

\begin{tabular}{|c|c|c|}
\hline \multirow[b]{2}{*}{ Factors } & \multicolumn{2}{|c|}{ Number of companies } \\
\hline & do not motivate & $\overline{\text { motivate }}$ \\
\hline Ethical and moral reasons & 4 & 103 \\
\hline Improving the financial situation & 5 & 102 \\
\hline Refine investor relations & 51 & 56 \\
\hline $\begin{array}{llll}\text { Improvement } & \text { relations with the } \\
\text { community }\end{array}$ & 29 & 78 \\
\hline $\begin{array}{l}\text { The maintaining/increasing the } \\
\text { company's reputation }\end{array}$ & 1 & 106 \\
\hline Increase of workers motivation & 4 & 103 \\
\hline The environment protection & 37 & 70 \\
\hline $\begin{array}{l}\text { Third party pressures (buyers, } \\
\text { competitors, suppliers, etc.) }\end{array}$ & 99 & 8 \\
\hline $\begin{array}{l}\text { The increasing/maintaining the level of } \\
\text { customers' loyalty }\end{array}$ & 7 & 100 \\
\hline
\end{tabular}

Table 2 shows that $84(78.5 \%)$ respondents report that the weak legislation toward CSR is a major barrier to improve or develop CSR activities among foodservice companies in Ukraine. The positive fact is that only $6(5.6 \%)$ companies have mentioned that CSR activities are not important for the firm.

Table 2. The main barriers to implement/improve the company's CSR activities

\begin{tabular}{|l|c|}
\hline Factor & Number of companies \\
\hline Lack of knowledge & $50(46.7 \%)$ \\
\hline Lack of resources & $42(39.3 \%)$ \\
\hline Weak legislation toward CSR & $84(78.5 \%)$ \\
\hline Weak workers' motivation & $6(5.6 \%)$ \\
\hline Shortage of human resources & $26(24.3 \%)$ \\
\hline Lack of time for implementation & $43(40.2 \%)$ \\
\hline It is not important for the company & $6(5.6 \%)$ \\
\hline
\end{tabular}

Table 3 represents a list of CSR environmental activities that have been proposed for enterprises to evaluate. The results of the survey have shown that reducing environmental impacts and waste separation are the most common activities undertaken by surveyed businesses. On the other hand, promoting mutual cooperation with other firms in the area of environment and exploring and developing the area of environmental protection are absolutely rare activities among companies. 
Table 3. The analysis of the environmental pillar

\begin{tabular}{|l|c|c|c|c|c|}
\hline Activity & $\begin{array}{c}\text { 1 - not } \\
\text { dealing with }\end{array}$ & $\mathbf{2}$ & $\mathbf{3}$ & $\begin{array}{c}\mathbf{5} \text { - } \\
\text { dealing } \\
\text { a lot }\end{array}$ \\
\hline Energy conservation friendly work & 0 & 23 & 54 & 29 & 1 \\
\hline $\begin{array}{l}\text { Eco-friendly } \\
\text { practices }\end{array}$ & 3 & 28 & 51 & 22 & 3 \\
\hline $\begin{array}{l}\text { Increase awareness of workers } \\
\text { about environmental protection }\end{array}$ & 0 & 0 & 5 & 43 & 59 \\
\hline Reducing environmental impacts & 30 & 38 & 36 & 3 & 0 \\
\hline $\begin{array}{l}\text { Promoting mutual cooperation } \\
\text { with other firms in the area of } \\
\text { environment }\end{array}$ & 0 & 2 & 40 & 49 & 3 \\
\hline $\begin{array}{l}\text { Purchase of environmentally } \\
\text { friendly machinery and equipment }\end{array}$ & 0 & 0 & 7 & 36 & 64 \\
\hline Waste separation energy-intensive & 0 & 8 & 43 & 53 & 3 \\
\hline $\begin{array}{l}\text { Decreasing } \\
\text { processes }\end{array}$ & & & & & 15 \\
\hline $\begin{array}{l}\text { Exploring and developing the area } \\
\text { of environmental protection }\end{array}$ & 64 & 32 & 10 & 0 & 1 \\
\hline Transport optimization & 0 & 7 & 27 & 60 & 13 \\
\hline Waste minimization & 0 & 1 & 19 & 50 & 37 \\
\hline Water conservation & 0 & 25 & 54 & 28 \\
\hline
\end{tabular}

The last part of the questionnaire presents information about the respondents' future plans to implement or develop CSR activities. The results of the survey have shown that the majority of the interviewed firms (67 companies $(62.6 \%)$ ) are planning to increase the number of activities related to the development of CSR. Moreover, 89 out of 107 firms have indicated that the company's development strategy includes CSR-related activities.

Spearman's correlation test was used for analyzing the correlation between CSR concept awareness and the financial situation of the company. The study has shown that there is a statistically significant correlation between investigated variables $(p=0.001, p<0.05)$. The result is interpreted in Table 4.

Table 4. Correlation matrix according to Spearman's correlation

\begin{tabular}{|l|l|l|}
\hline Variables & $\begin{array}{l}\text { Financial situation of the } \\
\text { company in last three years }\end{array}$ & $\begin{array}{l}\text { The level of CSR concept } \\
\text { awareness }\end{array}$ \\
\hline Financial situation of the company in last three years & 1 & $0.795^{*}$ \\
\hline The level of CSR concept awareness & $0.795^{*}$ & 1 \\
\hline
\end{tabular}

$*<0.0001$

Therefore, it can be concluded that the hypothesis is confirmed.

\section{Conclusion}

Nowadays, the world is experiencing unprecedented, interconnected environmental problems, including climate change, lack of water, energy, food, and reduction of biological diversity. These problems can only be solved by combining the efforts of business, government and citizens to develop a common concept of doing business, the central aim of which is an 
awareness of the uniqueness and comprehensiveness of natural wealth, understanding the complexity of the relationship between economic and non-economic resources. An important role in this belongs to the environmental component of CSR, the implementation of which allows taking an active part in the detection and timely prevention of environmental risks.

It should be noted that the environmental pillar of CSR is not being implemented sufficiently actively among Ukrainian food service companies. Activities in this area are not systematic and insufficient to counteract the negative impact on the environment.

The study has shown that the maintaining/increasing the company's reputation, ethical and moral reasons, an increase of workers motivation are the main factors which motivate investigated firms for implementing CSR activities (the answer for RQ1). On the other hand, investigated companies have noted that weak legislation toward CSR is the main barrier to implement/improve the company's CSR activities (answer for RQ2). In addition, we can conclude that waste separation, reducing environmental impacts and waste minimization are the most common activities among Ukrainian food service companies within CSR environmental pillar (answer for RQ3). The results of the study showed that the level of CSR awareness is determined by the financial situation of the company, therefore we can conclude that our hypothesis is confirmed.

It is worth mentioning that it can be costly to purchase environmentally friendly machinery or equipment with minimal impact on the environment for the food sector companies. Therefore, it is advisable for such kind of business to start focusing on low-cost activities which company can perform on a permanent basis. Such measures may be: increase employees' knowledge about environmental protection and water-saving.

\section{Acknowledgements}

The publication of this article is supported by the Slovak Agency KEGA - Project KEGA 005SPU-4/2019 "Theory and Practice of the International Management and Entrepreneurship in Multicultural Environment".

\section{References}

[1] Aßländer, M. S. (2011). Corporate Social Responsibility as subsidiary co-responsibility: a macroeconomic perspective. Journal of Business Ethics, 99(1), 115-128. doi: 10.1007/s10551-011-0744-X

[2] Burlakova, YU. (2009). Corporate social responsibility as a basis for harmonizing the well-being of society. Ekonomika: problemy teoriyi ta praktyky : zbirnyk naukovykh prats', 252, 881-891.

[3] Cadbury, A. (2006). Corporate social responsibility. Twenty-First Century Society. Journal of the Academy of Social Sciences, 1(1), 5-21. doi: 10.1080/17450140600679883

[4] Hall, J. K., Daneke, G. A. \& Lenox, M. J. (2010). Sustainable development and entrepreneurship: past contributions and future directions. Journal of Business Venturing, 25, 439-448. doi: 10.1016/j.jbusvent.2010.01.002

[5] Hrytsyna, L. A. (2016). Corporate social responsibility of enterprises: foreign and domestic experience. Naukovyy visnyk Uzhhorods'koho natsional'noho universytetu. Mizhnarodni ekonomichni vidnosyny ta svitove hospodarstvo, 10(1), 99-102. Retrieved from: http://elar.khnu.km.ua/jspui/handle/123456789/5256

[6] Kharlamova, A. O. (2012). Corporate social responsibility as necessary factor for forming corporate strategy. Efektyvna ekonomika, 9. Retrieved from: http://www.economy.nayka.com.ua/?op=1\&z=1410

[7] Kim, E. E. K., Kang, J. \& Mattila, A. (2012). The impact of prevention versus promotion hope on CSR activities. International journal of hospitality management - Elsevier, 31(1), 43-51. doi: 10.1016/j.ijhm.2011.05.004 
[8] Kolk, A., \& Van Tulder, R. (2010). International business, corporate social responsibility and sustainable development. International Business Review 19(2), 119-125. doi: 10.1016/j.ibusrev.2009.12.003

[9] Kolosok, A. (2015). Foreign experience of corporate social responsibility and prospects of its application in Ukraine. Ekonomichnyy chasopys Skhidnoyevropeys'koho natsional'noho universytetu im. Lesi Ukrayinky, 1, 15-19. Retrieved from: http://nbuv.gov.ua/UJRN/echcenu_2015_1_5.

[10] Kolot, A. M. (2014). Corporate social responsibility: modern philosophy, problems of development. Ekonomika Ukrayiny, 3, 70-82. Retrieved from: http://nbuv.gov.ua/UJRN/EkUk_2014_3_7

[11] Komarova, K. V. \& Kovalchuk, N. V. (2016). Social responsibility as an integral part of strategy for the development of business at Ukraine enterprises. Ekonomika ta innovatsiynyy rozvytok natsional'noho hospodarstva. Innovatsiyna ekonomika, 5-6(63), 25-30. Retrieved from: http://biblio.umsf.dp.ua/jspui/handle/123456789/2470.

[12] Koryahina, T. V. (2011). Trends in the development of corporate social responsibility in Ukraine. Zahal'ni pytannya ekonomiky. Investytsiyi: praktyka ta dosvid, 4, 30-32. Retrieved from: http://www.investplan.com.ua/pdf/4_2011/10.pdf.

[13] Li, W. \& Zhang, R. (2010). Corporate social responsibility, ownership structure, and political interference: evidence from China. Journal of Business Ethics, 96, 631-645. doi: 10.1007/s10551-010-0488-z

[14] Liyanage C., Ulutaş Duman D., Giritli H., McDermott P. (2016). Corporate social responsibility in construction industry: a comparative study between UK and Turkey. Built Environment Project and Asset Management, 6(2), pp. 218-231. doi: 10.1108/BEPAM-08-2014-0039

[15] Matviychuk, L. O. \& Tkach, K. I. (2016). Genesis of concepts of corporate social responsibility. Ekonomika i suspil'stvo, 6, 332-337. Retrieved from: http://www.economyandsociety.in.ua/journal/6_ukr/57.pdf.

[16] Mazurenko, V. P. \& Zasenko, O. YU. (2012). Modern concept of corporate social responsibility in international business. Efektyvna ekonomika, $6 . \quad$ Retrieved from: http://www.economy.nayka.com.ua/?op=1\&z=1199.

[17] Mazurkiewicz, P. (2005). Corporate Environmental Responsibility: Is a common CSR framework possible? DevComm-SDO World Bank. Retrieved from: http://siteresources.worldbank.org/EXTDEVCOMSUSDEVT/Resources/csrframework.pdf.

[18] Ubrežiová, I., Horská, E., Moravčíková, K., \& Kovácsová, B. (2016). Socio - responsible behavior of small and medium sized companies. Economic science for rural development: rural development and entrepreneurship bioeconomy home economics, 44, 156 - 163.

[19] Uddin, M. B., Hassan, M. R. \& Tarique, K. M. (2008). Three Dimensional Aspects of Corporate Social Responsibility. Daffodil International University Journal of Business and Economics, 3(1), 199-212. Retrieved

from: https://www.academia.edu/3021818/Three_Dimensional_Aspects_of_Corporate_Social_Responsibility

[20] UKRSTAT (2018), State Statistics Service of Ukraine, available at: https://ukrstat.org/en (accessed 15 March 2019).

[21] Wamitu, S. (2014) Corporate Social Responsibility: Intentions and Practice. Open Journal of Business and Management, 2, 116-126. doi: 10.4236/ojbm.2014.22015.

[22] Zhukovs'ka, V. M. (2009). Social responsibility as a direction of implementation of corporate development strategy. Finansy Ukrayiny, 14-21.

[23] Zinchenko, A., \& Saprykina, M. (2017). Corporate Social Responsibility 2005-2010: State and Prospects for Development. Kyiv: Vydavnytstvo „Yuston”. Retrieved from: http://csr-ua.info/csr-ukraine/wpcontent/uploads/2018/10/CSR_2017_reserch-1.pdf. 


\title{
Use of Management Information Systems in Corporate Management
}

\author{
Michaela Trnková ${ }^{1}$, Anna Látečková ${ }^{2}$ \\ Slovak University of Agriculture in Nitra \\ Faculty of Economics and Management, Department of Accounting ${ }^{1,2}$ \\ Address: Tr. Andreja Hlinku 2, \\ 94976 Nitra, Slovak Republic \\ e-mail: xtrnkova@uniag.sk ${ }^{1}$, anna.lateckova@uniag.sk ${ }^{2}$
}

doi: 10.18515/dBEM.ISD.P01.2020.p039

\begin{abstract}
It is very important that timely and correct information is available to managers. The availability of such information not only leads to decisions on individual activities in the enterprise, but can also contribute to increasing its competitiveness in the market. It is therefore necessary to have implementation of a quality management information system in the company that provides to managers of all levels of management required information. With the help of a good management information system, the company can more easily achieve its strategic goals, increase employee performance and productivity, and thus positively influence the economic result. Management information systems work with large amounts of data and assist in their collection, sorting, processing, storage and distribution. The article deals with the use of management information systems in practice and remedying shortcomings, which contribute greatly to the inefficiency of processes in the company.
\end{abstract}

Keywords: accounting, information, management, management information system

JEL Classification: M10, M15, M41

\section{Introduction}

Nowadays, special purpose automated technologies are needed to deal with work requirements and save time, which are needed to input and process manual data. These technologies, among other things, provide information in a visual form - graphically, thus contributing to making timely decisions as well as improving the control process itself (Zhan a kol., 2019).

Managers need quality information to make their decisions. These are obtained by analyzing digitally stored data, whether in enterprise information systems or by analyzing publicly available data from the Internet. One of the decisive factors of the right decision-making and the overall functioning of the organization is the quality of this data (Hamranová, Beláňová, 2017).

In most businesses, the level of information management is not fully controlled. Information systems create support for business processes in order to optimize them based on experience with similar business processes (Šilerová, Kučírková, 2008).

The Management Information System (MIS) is a powerful tool for quick and effective management decision making and nowadays is a necessity in the management of the company. It contains unique information based on the needs of people making strategic decisions in the business and provides them with accurate, consistent data that answer their questions about the real situation of enterprise (Taušová a kol., 2013).

MISs are the largest, most complex and demanding information systems implemented by enterprises, a significant departure from the individual and departmental information 
systems prevailing in the past. MISs and related integrated technologies are a transforming force in the accounting profession (Grabski, Leech, Schmidt, 2011).

High levels of competition in a globalized business environment force companies to innovate to remain competitive (Jimenez-Jimenez, Martinez-Costa, Sanchez Rodriguez, 2019).

The introduction of information systems can greatly help organizations to achieve greater efficiency and effectiveness. Information systems promise to increase rationalization, reduce duplication, streamline business processes and integrate various systems. They offer greater competitive advantage and innovation, and through redundancy eliminate unnecessary management tasks. Despite these claims, implementation continues to be characterized by poor performance and return on investment. Support for top management is a key factor in making information systems more successful. Top managers who support positive access to information systems can build a strong coalition and create a vision that is in line with the corporate strategy (Ringland, 2010).

MIS is a highly complex enterprise information system. The implementation of these systems requires high costs, time and resources of the company (Rajnoha, 2014).

Investing in information systems and new management tools alone does not guarantee better business results. Investments in new information systems should be made in accordance with strategic management. The tools should be aligned with the business strategy, which requires a high level of involvement of company managers. The profitability of an information system depends on its usefulness in managing and improving key strategic business areas. Positive impact on the financial results of the company is not only the quality of the information system itself, but also the strategy of implementation of the information system (Perez-Mendez, Machado-Cabezas, 2015).

It is very important that the implementation of the information system leaves satisfied users and fulfills (more or less) the strategic objectives of the organization or the objectives related to all levels of management and all areas through information systems and information technologies (Bolek, Kokles, Romanová, Zelina, 2018).

\section{Data and Methods}

Management information systems represent an important tool for achieving the competitiveness of the companies on the market in the current company management. The main objective of the present article is to assess the use of management information systems in corporate governance. We will specify the main objective in more detail into the subobjectives, which are:

1. assessment of the integration of management information systems in enterprises,

2. detection of errors on the basis of accounting information;

3. measuring the dependence between the integration of management information systems and the occurrence of errors.

The solution was based on the results of the research project VEGA 1/0489/15 "Increasing the efficiency of decision-making of managers with the support of information systems and accounting" at the Department of Accounting, of the Faculty of Economics and Management, of the Slovak University of Agriculture in Nitra. 
The following methods are used: questionnaire, structured interview, analysis, synthesis, comparison, mathematical-statistical and graphical methods.

Primary data are obtained by questionnaire method. The compiled questionnaire was available online. We also contacted businesses via e-mail and telephone. In total, we approached 70 enterprises. Within the set time (6 months) we received answers from 51 respondents. Managers in economic positions in the company answered the questionnaire questions.

Statistical methods of determining the relevance and dependence of the obtained data to confirm or disprove the statistical hypotheses between indicators are used to evaluate the data from the questionnaire survey. For this purpose, we will use the software MS Excel 2016. For statistical evaluation, we set up research hypotheses to confirm or refute our research assumptions regarding the use of management information systems in business management. Research hypotheses:

H0: There is no statistical dependence between software integration and the occurrence of errors.

H1: There is a statistical dependence between software integration and the occurrence of errors.

We verified the dependencies between the examined traits using the Chi-square test $-\chi^{2}$ square contingency test. The test consists in comparing empirical and theoretical frequencies, therefore what would be empirical frequencies if the features were independent.

Calculation of theoretical frequencies (Matejková, Pietriková, Poláková, 2018):

$$
E=\frac{\left(a_{i}\right) *\left(b_{j}\right)}{n}
$$

where:

$a_{i}$ - the number of statistical units with the $i$-th variant of character $A$

$b_{j}-$ the number of statistical units with the $j$-th variant of character $B$

$\mathrm{n}$ - sample size

Test criterion (Matejková, Pietriková, Poláková, 2018):

$$
\chi^{2}=\sum_{i=1}^{m} \sum_{j=1}^{r} \frac{(E-T)^{2}}{T}=\frac{\left(\left(a_{i}\right)-\left(a_{i} b_{j}\right)_{0}\right)^{2}}{\left(a_{i} b_{j}\right)_{0}}
$$

where:

$\mathrm{m}-$ number of rows

$\mathrm{r}$ - number of columns

$E\left(a_{i} b_{j}\right)$ - empirical frequencies

$\mathrm{T}\left(\mathrm{a}_{\mathrm{i}} \mathrm{b}_{\mathrm{j}}\right)_{0}$ - theoretical frequencies

After this, we compare the calculated test criterion with the critical value $\chi^{2}$ of the distribution, which we calculate using the CHISQ.INV.RT function. We enter the significance level 0.05 and degrees of freedom into the function, which are calculated as (number of rows - 1) * (number of columns - 1). If the value of the test criterion is greater than the critical value $\chi^{2}$ of the distribution, then the null hypothesis is rejected. We will verify whether there is a dependency between the qualitative features observed. If so, then it is necessary to determine the intensity of this dependence. For this calculation we use the Cramer V - coefficient. This coefficient represents the most appropriate measure of association between two qualitative 
variables. Acquires values from 0 (no relationship) to 1 (perfect relationship) (Matejková, Pietriková, Poláková, 2018).

$$
V=\sqrt{\frac{\chi^{2}}{n(\min ((m, r)-1)}}
$$

\section{Results and Discussion}

Based on the published questionnaire, we obtained answers from 51 respondents, which were mainly small and medium-sized enterprises. $13.70 \%$ of respondents reported less than 10 employees, $64.70 \%$ employ $11-50$ employees and $21.60 \%$ have $51-250$ employees. We have found that the following MISs are used in these companies:

1. Sidus - http://www.sidus.cz/info

2. Aurus - https://aurus.sk/

3. Wintes - https://intes.webnode.sk/

4. Softip - https://www.softip.sk/sk/

5. Mado - https://www.hour.sk/uctovny-softver-mado

6. Pohoda- https://www.pohoda.sk/

7. Olymp - https://www.kros.sk/olymp/

8. MRP - https://mrp.sk/

9. Codex - http://www.codex.sk/

10. Infodata- http://www.infodata-se.sk/

11. Asseco Spin - https://assecosolutions.sk/produkty/asseco-spin

There are currently MISs on the market that integrate business processes across different activities. The large number of systems offered with different characteristics can complicate the choice of the right solution for the company. When choosing a suitable MIS, it is very important that it covers as much as possible the basic business processes from warehousing, manufacturing, logistics to accounting, human resources, planning and the like.

However, the common mistake of many businesses is that they do not use one integrated MIS, but several separate software for each area. It is then much more difficult for an enterprise to maintain such a MIS and to provide a current flow of information to managers.

Based on the questionnaire data, we found that out of 51 enterprises, up to $29.40 \%$ use multiple softwares to address individual areas. The following chart shows the percentage comparison of the answers to the question of using one MIS in the company. 
Figure 1: Question evaluation - Do you use one management information system in your company?

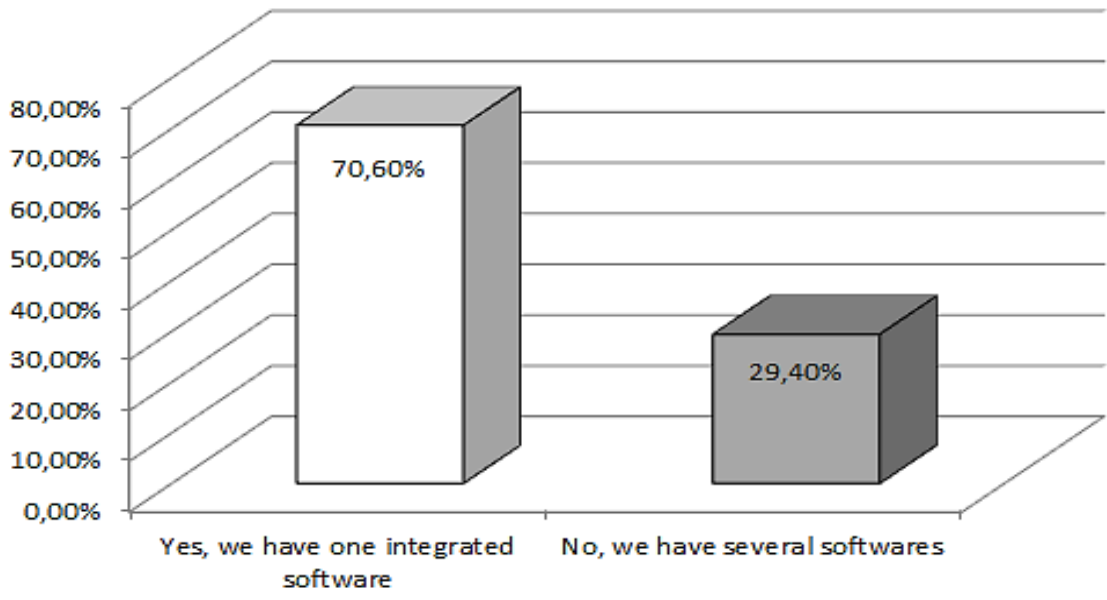

Source: author's calculations

Knowledge of managerial accounting in financial management is very important. The manager can thus avoid various mistakes that could lead to incorrect decisions. We asked if an error had occurred due to incorrect accounting information. Up to $80.40 \%$ of respondents answered positively to this question and only $19.60 \%$ answered in the negative. If the manager has basic accounting knowledge and is able to read financial statements, it greatly helps to run the business more efficiently and contributes to increasing its competitiveness.

The above is also confirmed by Bolek, Látečková, Bigasová (2017), who state that correct and reliable information is the basis for management and decision-making in which the pragmatic aspect of accounting information is applied. For accounting information to be of real benefit to managers, managers need to adopt basic accounting principles. However, knowledge of accounting software is also needed to automate accounting information to provide reliable, real-time information for decision making.

Figure 4: Question evaluation - Were you in situation where get an error based on incorrect accounting information?

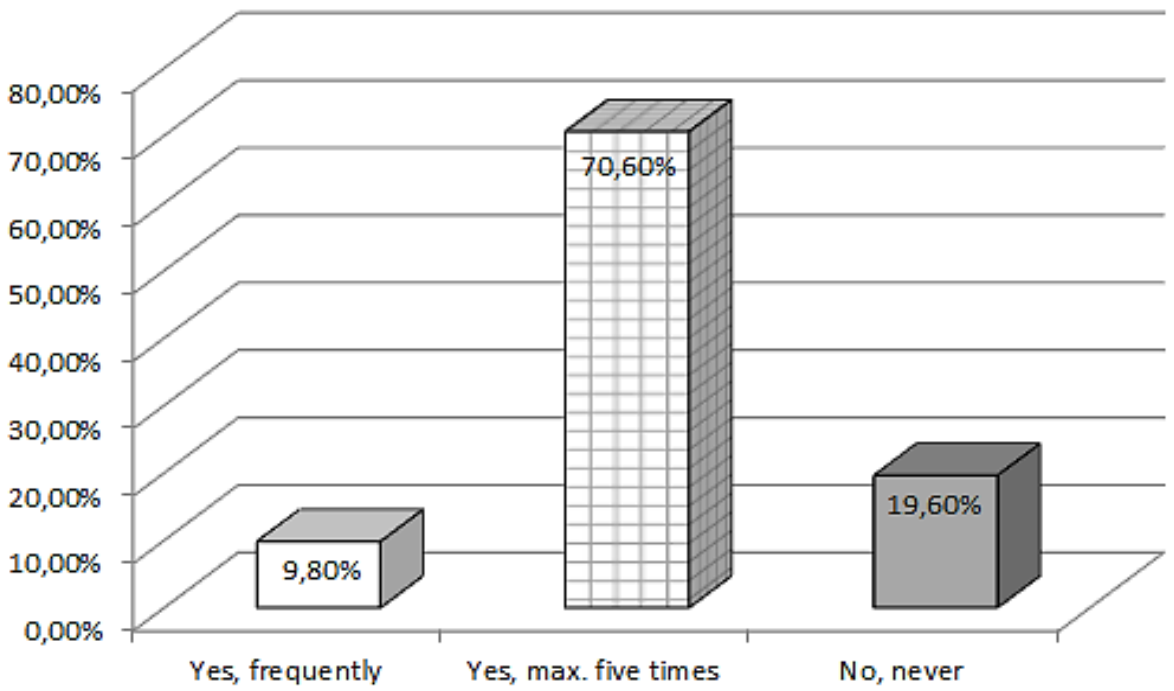

Source: author's calculations 
Subsequently, on the basis of established hypotheses, we measured the dependence between the determined qualitative features. We first calculated the empirical and theoretical frequencies and then we could quantify the test criterion and the critical value.

\section{Table 1: Empirical frequencies}

\begin{tabular}{lcccc} 
Count of Respondent & \multicolumn{2}{l}{ Occurrence of errors } & & \\
\hline Integrated software & Yes, often & Yes, max. 5-times & No, never & Grand Total \\
\hline Yes & 2 & 29 & 5 & 36 \\
No & 3 & 7 & 5 & 15 \\
\hline Grand Total & 5 & 36 & 10 & 51
\end{tabular}

Source: author's calculations

Table 2: Theoretical frequencies

\begin{tabular}{lcccc} 
Count of Respondent & \multicolumn{2}{l}{ Occurrence of errors } \\
\hline Integrated software & Yes, often & Yes, max. 5-times & No, never & Grand Total \\
\hline Yes & 3,53 & 25,41 & 7,06 & 36 \\
No & 1,47 & 10,59 & 2,94 & 15 \\
\hline Grand Total & 5,00 & 36,00 & 10,00 & 51
\end{tabular}

Source: author's calculations

Table 3: Calculation of test criterion

Count of Respondent Occurrence of errors

\begin{tabular}{lcccc}
\hline Integrated software & Yes, often & Yes, max. 5-times & No, never & Grand Total \\
\hline Yes & 0,66 & 0,51 & 0,60 & \\
No & 1,59 & 1,22 & 1,44 & \\
\hline Grand Total & & & & 6,02
\end{tabular}

Source: author's calculations

\section{Test criterion $\chi^{2} \quad \mathbf{6 , 0 2}$}

\section{Critical value $\quad \mathbf{5 , 9 9}$}

The value of the calculated test criterion is 6.02. Critical $\chi^{2}$ distribution at degrees of freedom $(\mathrm{m}-1) *(\mathrm{k}-1)$, thus $(2-1) *(3-1)$ is 5.99. A comparison of the two values shows that the value of the test criterion is greater than the critical value of the $\chi^{2}$ distribution $(6.02>5.99)$. That is, the null hypothesis is rejected, so there is a statistical dependence between software integration and the occurrence of errors. We accept the hypothesis H1, there is a statistical dependence between software integration and the occurrence of errors. If the company uses more than one software then there are frequent mistakes. Since there is a statistical dependence between the qualitative characteristics examined, it is necessary to determine the intensity of this dependence. We chose Cramer V - coefficient.

\section{Cramerov V - coefficient $\quad 0,3435$}

The Cramer V- coefficient value of 0.3435 confirms the weak statistical dependence between the mentioned statistical features.

In this context, we agree with Fárek (2018), which also points to the importance of one integrated MIS in the enterprise. Here it is important to realize that buying a quality system that 
integrates activities across the all enterprise will not be a cheap matter. The system will assist in planning, management, control in the company and its usefulness is for several years.

\section{Conclusion}

Nowadays, businesses are increasingly using different information and communication technologies. These modern technologies include MIS, which contains enormous amounts of data. They can collect, sort, process, store and transmit this data on the basis of manager's requirements. Managers thus obtain the necessary information from MIS, either in text or graphical form, for further decision-making and planning processes within the company. In practice, we often encounter problems related to the implementation and subsequent use of management information systems in companies. The main problems are imperfect interconnection of individual autonomous software in the company and the subsequent failure of the information flow. Based on the respondents' answers to the questionnaire, we argue that there are still a lot of businesses that do not use an integrated MIS, but a number of software to cover each business activity. This, in turn, leads to problems regarding the updating and maintenance of the entire MIS, resulting in additional costs and a waste of time. An integrated MIS can positively influence the company's competitiveness and market position. We also consider it important that managers have knowledge of accounting. Thus, the manager, by checking the financial statements, can prevent incorrect decisions. On the basis of statistical evaluation of established hypotheses, hypothesis $\mathrm{H} 0$ is rejected. We accept the hypothesis $\mathrm{H} 1$ and we can claim that using of multiple softwares in an enterprise instead of one integrated MIS leads to frequent errors. We have also confirmed the claims of other authors who point to the importance of one integrated MIS in the enterprise. This will help not only to make fewer errors but also to improve the quality of business processes, which ultimately contributes to increasing its competitiveness in the market.

\section{Acknowledgements}

This paper was created within the project VEGA Increasing the efficiency of decision-making of managers with the support of information systems and accounting. Project registration number $1 / 0489 / 15$.

\section{References}

[1] Bolek, V., Kokles, M., Romanová, A., \& Zelina, M. (2018). Information Literacy of Managers: Models and Factors. Journal of Business Economics and Management, 19 (5), 722-741. doi: 10.3846/jbem.2018.6906

[2] Bolek, V., Látečková, A., \& Bigasová Z. (2017). Software solutions for usage of accounting information. Proceedings of 9th annual international scientific conference COMPETITION. 103-115.

[3] FÁREK, R. (2018). Faktory výběru vhodného ERP systému. Časopis IT Systems, 2018 (2), 6-7. ISSN 1802002X.

[4] Grabski, S. V., Leech, S. A., \& Schmidt, P. J. (2011). A Review of ERP Research: A Future Agenda for Accounting Information Systems. Journal of Information Systems, 25 (1), 37-78. doi: 10.2308/jis.2011.25.1.37

[5] Hamranová, A., \& Beláňová B. (2017). The data and information management in slovak enterprises. . Proceedings of 9th annual international scientific conference COMPETITION. 221-233.

[6] Jimenez-Jimenez, D., Martinez-Costa, M., \& Sanchez Rodriguez, C. (2019). The mediating role of supply chain collaboration on the relationship between information technology and innovation. Journal of Knowledge Management, 23 (3), 548-567. doi: 10.1108/JKM-01-2018-0019

[7] Matejková, E., Pietriková, M. \& Poláková, Z. (2018). Praktikum zo štatistiky A. (4rd ed.). Nitra, Slovenská pol'nohospodárska univerzita 
[8] Pérez-Méndez, A. J., \& Machado-Cabezas, Á. (2015). Relationship between management information systems and corporate performanceRelación entre los sistemas de información de gestión y el resultado empresarial. Revista de Contabilidad, 18 (1), 32-43. doi: 10.1016/j.rcsar.2014.02.001

[9] Rajnoha, R., Kádárová, J., Sujová, A., \& Kádár, G. (2014). Business Information Systems: Research Study and Methodological Proposals for ERP Implementation Process Improvement. 2nd World Conference on Business, Economics and Management, 109, 165-170. doi: 10.1016/j.sbspro.2013.12.438

[10] Ringland G, (2010). The Role of Scenarios in Strategic Foresight. Technological Forecasting \& Social Change, 77 (9), 1493-1498. doi: 10.1016/j.techfore.2010.06.010

[11] Šilerová, E., \& Kučírková, L. (2008). Knowledge and information systems. Agricultural Economics, 54 (5), 217-223. doi: 10.17221/245-AGRICECON

[12] Taušová, M., Čulková, K.., \& Csikósová, A. (2013). Using of information and communication Technologies in SMEs at the development of Slovakia region. International Multidisciplinary Scientific GeoConference Surveying Geology and Mining Ecology Management, SGEM, 1(4), 287-294.

[13] Zhan, J., Ge, X. J., Huang, S. D., Zhao, L., Wong, J. K. W., \& He, S. X. (2019). Improvement of the inspection-repair process with building information modelling and image classification. Facilities, 37 (7-8). 395-414. doi: 10.1108/F-01-2018-0005 


\title{
The Code of Conduct in Slovak Companies
}

\author{
Mária Urbánová ${ }^{1}$, Jana Kozáková ${ }^{2}$, Iveta Ubrežiová ${ }^{3}$ \\ Slovak University of Agriculture in Nitra ${ }^{1,2}$, Catholic University of Ružomberok ${ }^{3}$ \\ Department of Economis ${ }^{1}$, Department of Management ${ }^{2}$, Department of Management ${ }^{3}$ \\ Trieda A. Hlinku $2^{1,2}$, Nábr. Jána Pavla II. $15^{3}$ \\ Nitra $^{1,2}$, Poprad $^{3}$, Slovakia \\ e-mail: maria.urbanova1@uniag.sk¹,jana.kozakova@uniag.sk², iveta.ubreziova@ku.sk³
}

doi: 10.18515/dBEM.ISD.P01.2020.p040

\begin{abstract}
In current globalized business environment, the issue of business ethics increasingly catches the interest of author and managers in business practice as well. Observance of ethical principles in business is retracted from the point of view of everyday activities in the company, but more and more often it is also formally processed into company documents. The main practise of formalization ethics in the company is to incorporate The code of Conduct or the Ethical Code into business standards. This is not a widespread practice in Slovakia, but the growing number of foreign companies that set up business in our market or buy shares in existing companies bring new managerial practices and formalization of ethics is one of them. Article deals with the formalization of the ethical principles in 178 Slovak companies of different size, ownership and business focus. According to the realized mathematical and statistical analysis, we identified that the year of entry into the Slovak market and ownership interest are the most important regarding business ethics and its formalization through the Code of Conduct.
\end{abstract}

Keywords: Corporate Ethics, Code of Conduct, Slovakia, factors

JEL Classification: L26, M14, K22, L53

\section{Introduction}

In a modern globalized world, ethics has recently become increasingly important not just in relation to the behaviour of individuals but companies as well. According to Goel and Ramanathan (2014) business ethics covers the areas of moral principles and decision making, governance issues and codes of conduct for a business. One of the oldest concepts of business ethics provides Velasquez (2002) who define it as a form of applied ethics, which includes not only the analysis of moral norms and moral values, but also attempts to apply conclusions of this analysis to assortment of institutions, technologies, transactions, activities and pursuits that we call business.

Ethics in business is of key importance in the existence of companies in numerous countries and regions. If a company wishes to be perceived as a reliable partner in business, Sroka and Lörinczy (2015) recommend that they should implement the elements of this concept, or indeed the concept of Business Ethics itself. Yong-Ki, et al. (2014) even states, that ethical management would seem to be a must in today's business climate. Therefore, companies pay increased attention to implementation of ethical principles into their everyday processes and formalization of their beliefs. Given the potentially deleterious consequences (Jose and Thibodeaux, 1999), many firms are attempting to institutionalize good ethics by establishing a formal code of ethics, credos, ethical values statement, and/or codes of conduct ( $\mathrm{Ki}$ et al., 
2012). According to Tayşir and Pazarcık (2013) it is clear that business ethics is related to moral norms and values, but as Velasquez (2002) adds, companies do have moral duties in a secondary sense and that is why they now implementing ethical codes or codes of conduct as a tools for regulation of employee's behaviour.

Lee et al., (2014) demonstrated that existence of the code of ethics in the company directly affects its philanthropy and organizational engagement. Corporate philanthropy, in turn, positively relates to employee engagement and turnover intention. In addition, results of Valentine and Fleischman (2002) indicated that employees in organizations that had an ethics code were more tolerant of societal diversity than the ones working in organizations that did not have an ethics code. Authors also showed the relation between traditional orientation toward gender roles and acceptance of diversity. Their findings imply that companies to some degree define societal norms, possibly through training programs that make employees aware of their differences. Schmidt, Mac Williams and Neal-Boylan (2017) also offers a code of conduct to address inclusion and diversity since it can be on the workplace easily encouraged by exclusionary behaviours (which may include incivility, bullying, and workplace violence), discrimination and isolation of individuals and groups who are different. Therefore, Gilbert and Ivancevich (1999) states that relations in the business should base on the ethical behaviour which takes knowledge and commitment in diversity management and which work beyond the law.

\section{Data and Methods}

The first step, which was used in the elaboration of the work, was to find information on a selected topic, the main part of which is ethic. The sources of information used include scientific literature, online books, magazine articles etc. After a thorough study and information about the issue, we proceeded to the next step - applying the acquired knowledge and creating a questionnaire.

The main research method is therefore a questionnaire conducted by trained interviewers who personally collected data in selected companies. In spite of the fact that the questionnaires were not anonymous, names and identifications of companies were not used. Raw data were adjusted (Munk, et al., 2013) and subsequently evaluated by selected mathematical-statistical methods. The basic sample was collected by interviewers during the year 2018. The sample of 178 enterprises was calculated as representative at $95 \%$ confidence level and $7 \%$ confidence interval. The sample involves only subjects registered in Slovakia despite their ownership structure or location of mother company. Subjects were of different regions, size and business focus.

The questionnaire consisted of several separate parts out of which sorting questions and specific questions connected with corporate ethics were chosen to be examined. These concrete 9 questions were chosen for further statistical evaluation:

B3 Number of employees

B4 Ownership interest

C3 Year of entry into the Slovak market

C4 Head office of the parent company - region

E1 Is there a formal document in the company dealing with business ethics? 
E2 What is the range of this document?

E4 What was the main reason for the adoption of the Code of Ethics (or equivalent document)?

E7 Since when has this document been adopted, changed or upgraded in any way?

E8 Has the company in the past been faced with a "scandal" related to Code of ethics?

After processing the data from the questionnaire, standard deviation was used to measure the differences of each observation from the mean. The smaller the standard deviation, the closer the values are about the mean. This means that the term was rated similarly by all respondents and the variance were smaller. Firstly, Shapiro-Wilk test of normality was used to determine if a data set is well-modelled by a normal distribution. The test compares the scores in the sample to a normally distributed set of scores with the same mean and standard deviation; the null hypothesis is that "sample distribution is normal." If the test is significant, the distribution is non-normal which case of the data examined was. Therefore, Kruskal-Wallis nonparametric method for testing whether samples originate from the same distribution was applied. It is used for comparing two or more independent samples of equal or different sample sizes. Hhypotheses were set, and then verified using selected mathematical-statistical methods: The significance level $\alpha$ was determined at 0.05 , i.e. a $5 \%$ test error is accepted. If the p-value is $\leq \alpha$, then $\mathrm{H} 0$ is rejected at the significance level $\alpha$ and we accept H1. If p-value $>\alpha$, then $\mathrm{H} 0$ is not rejected at the significance level $\alpha$. As a post hoc test to the Kruskal-Wallis test the Bonferroni correction test was applied. It compensates for that increase by testing each individual hypothesis at a significance level of alpha $/ \mathrm{m}$, where alpha is the desired overall alpha level and $\mathrm{m}$ is the number of hypotheses. (Miller, 1996). Bonferroni correction was calculated to counteract the problem of multiple comparisons between the examined questions.

\section{Results and Discussion}

The application of ethical principles into corporate practice of Slovak companies was examined on the sample of 178 subjects out of which the biggest percentage was among large companies $(65 \%)$ and medium-size companies of $23 \%$ (Picture 1). Micro and small companies was represented by just $12 \%$ altogether. Companies were divided into mentioned groups, according to the European Union recommendation 2003/361. The definition uses three quantitative measures, namely the number of employees, annual net turnover and assets.

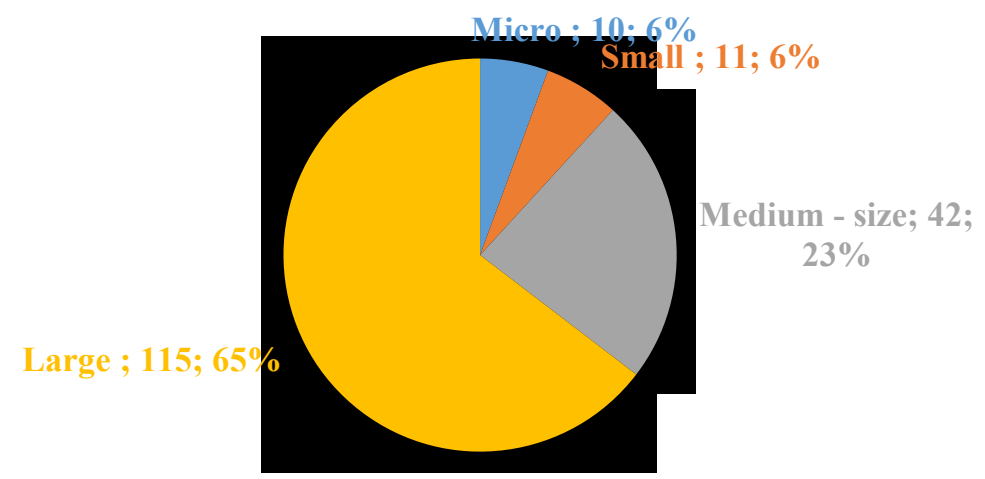

Picture 1 The size of selected companies (2018)

Source: Own calculations 
Examined companies were all registered as business entities in Slovakia, but it has to be mentioned, that their ownership was not strictly Slovakian. This discrepancy is quite common in Slovakia for a long term and is subject of examination of several authors (Mura and Mižičková, 2006; Diačiková a L'ach, 2019). In our research, the foreign ownership outweighs throughout the whole sample and mainly between large and medium sized companies (Picture 2).

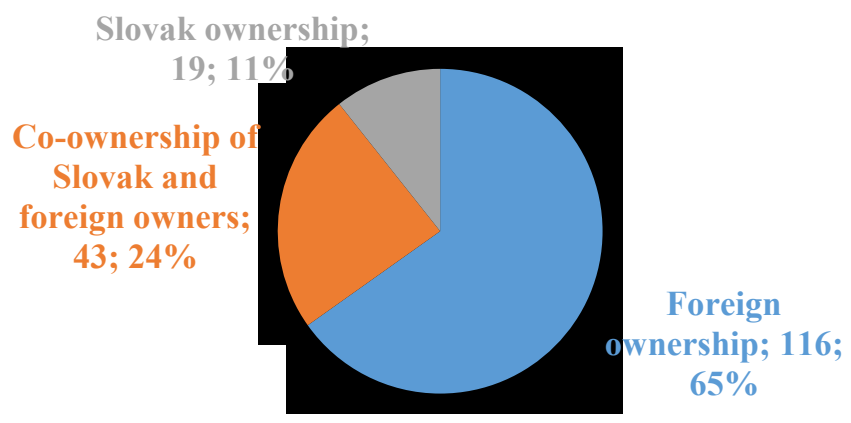

\title{
Picture 2 Ownership structure of selected companies (2018)
}

\author{
Source: Own calculations
}

The most of the examined companies head seats were located in the European Union $(82 \%)$, the same number of companies were originally from USA and Asia (7\%), South America just 1 subject and surprisingly only 7 subjects were from Europe outside of the EU (Picture 3).

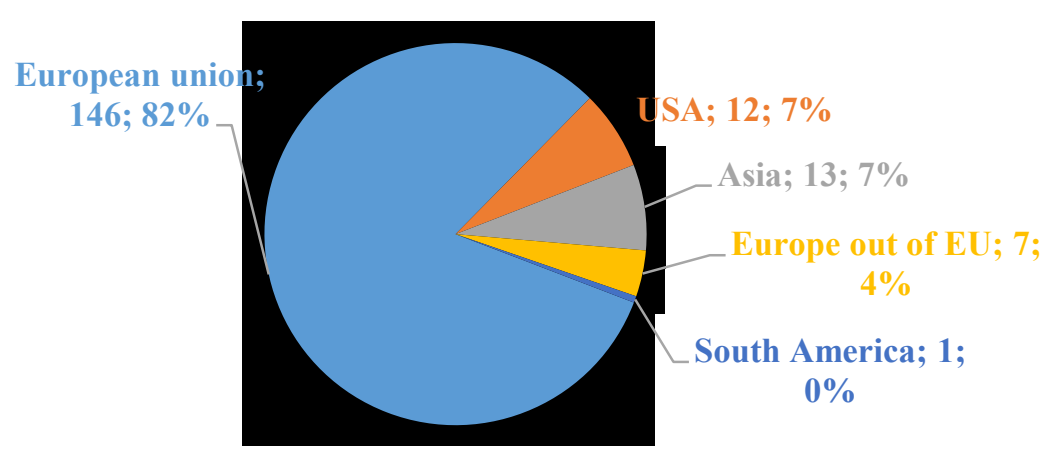

Picture 3 The region of headquarters (2018)

Source: Own calculations

$96 \%$ of the observed subjects has the ethics somehow incorporated into the official documents, however formally designed The Code of Conduct or Ethical Code has just 132 of them (Picture 4). Another $22 \%$ of them already implemented problem of ethics, but not as specific individual document just as a part of other guidelines, or they solve the ethics just on operative level as a part of the plans or strategies. 


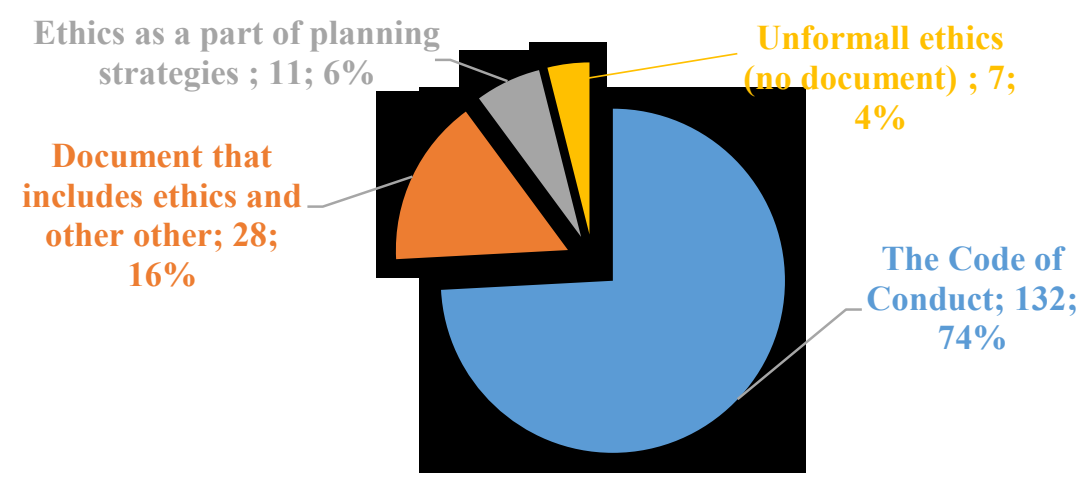

Picture 4 Formal incorporation of ethics into company documentation (2018)

Source: Own calculations

A half of examined companies has the Code of Conduct (or similar document) of relatively small range, less than 10 pages. In addition, $24 \%$ of them has the document of 10 to 50 pages. This indicates that companies officially incorporated ethical principles into their documentation, but they are solving ethical problems just generally. Only $10 \%$ of them has large ethical documents where they have a space for specific problems and their solving. Surprisingly, $16 \%$ of companies does not have public document and it is accessible just for specific employees (Picture 5).

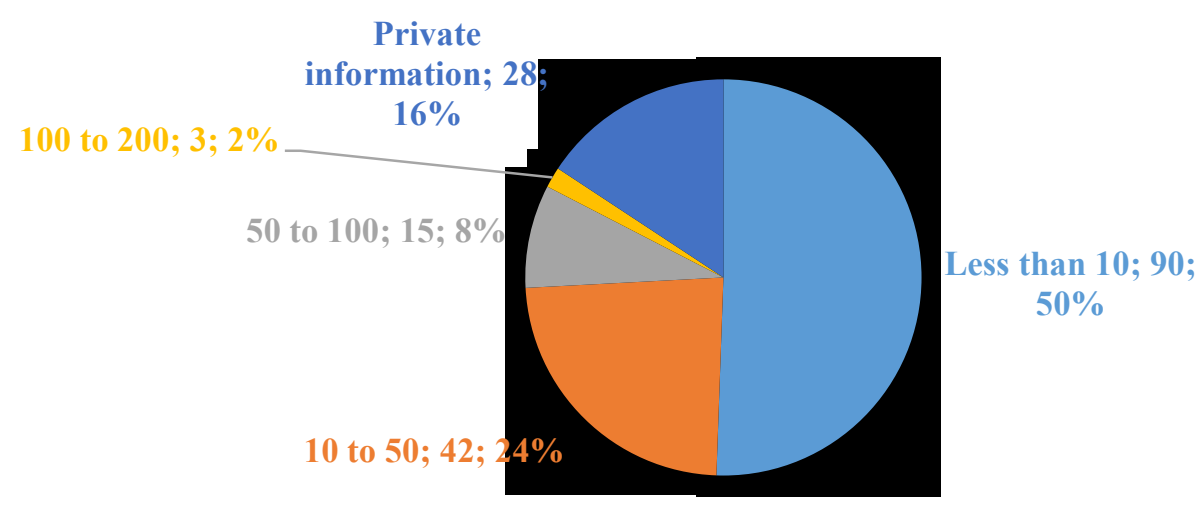

Picture 5 The length of the companies Code of Conduct (or similar document)

Source: Own calculations

In business practice, there can be a several reasons for adopting ethical principles officially. In multinational companies there is usually a pressure of mother company, to follow similar corporate culture in whole holding, but this reason outlined just $33 \%$ of examined companies. As the main reason of incorporating the Code of Conduct (or similar document) into documentation we identified the efforts to build companies goodwill. Therefore, more than a half of examined companies are using corporate ethics as a part of marketing. As well as another $4 \%$ which are following current trends and partly additional $3 \%$ which are using it in competition. On picture 6 , there are the several results in relation to the perception of main reasons, which are affecting the incorporation of the Code of Conduct. $53 \%$ of all companies 
agree with the theory, that it is necessary to invest the idea and costs for increasing of efforts to build the goodwill in company and $33 \%$ state about the necessity of adaptation the ethical principles of mother company

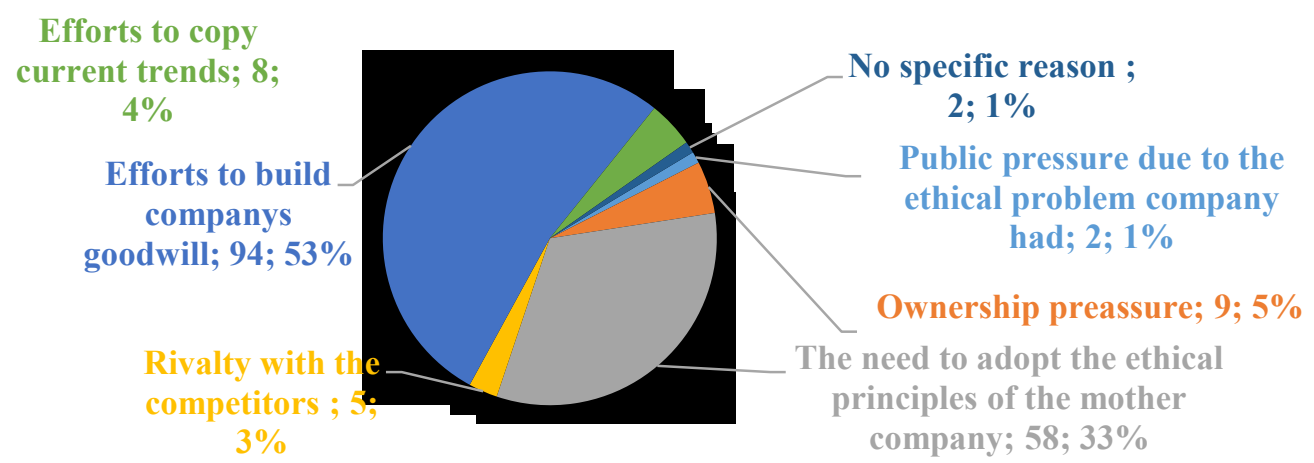

\section{Picture 6 The main reason of incorporating the Code of Conduct (or similar document)}

Source: Own calculations

On the other hand, $5 \%$ took into account the ownership pressure, $4 \%$ of evaluated companies the efforts to copy current trends, $3 \%$ the rivalty with the competitors and $1 \%$ of enterprises said about no specific area.

Only $1 \%$ of examined companies reported that they adopt the ethical principles officially due to the previous ethical problem company had. Nevertheless, $15 \%$ of them are introducing specific ethical problems in their Code of Conducts and provide step by step guideline for employees, how to proceed in specific situations (corruption, sexual and other harassment, etc...). On the other hand, the majority of examined companies $(82 \%)$ are rejecting the unethical practices just generally and they have not elaborated their documents in such detail and do not describe specific problems in them.

When we were talking about the importance of the Code of Conduct in the Slovak companies, we were separating the specific areas this document address. From the research is following, that $82 \%$ of companies refused the general rejection of unethical practices. Why are we dealing with this confirmation? It is a consequence that a lot of the Slovak companies operate in the international environment or the companies are like the daughter companies of companies, which have a headquarters in foreign countries as well as the ethical relationships with employees, business partners and stakeholders in the evaluated companies seem to be on the satisfactory level, based on the results of the questionnaire survey as it can be seen on Picture 7.

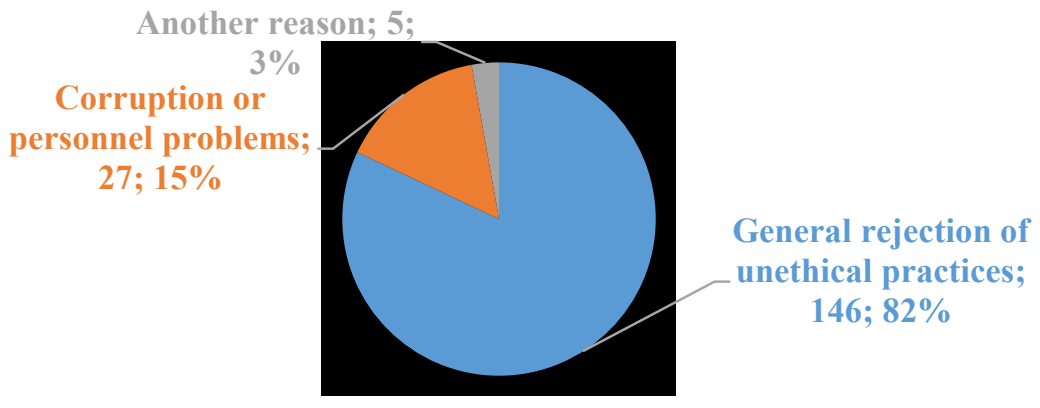

Picture 7 Specific areas this document address

Source: Own calculations 
$15 \%$ of companies differ a corruption or personnel problems. Moral standards, even if they are not recorded in the ethical code of the firm are often very important. Only $3 \%$ of companies specified ,another" reasons (Picture 7).

Incorporating the Code of Conduct (or similar document) into company's documentation usually means a milestone in shifting their corporate culture and managers tend to pay close attention to it. On the other hand, they do not so consistently pay attention to its innovation and adaptation to the current situation. Over the half of examined subjects are upgrading this document, but not regularly and 22\% has not change it since its incorporation (Picture 8).

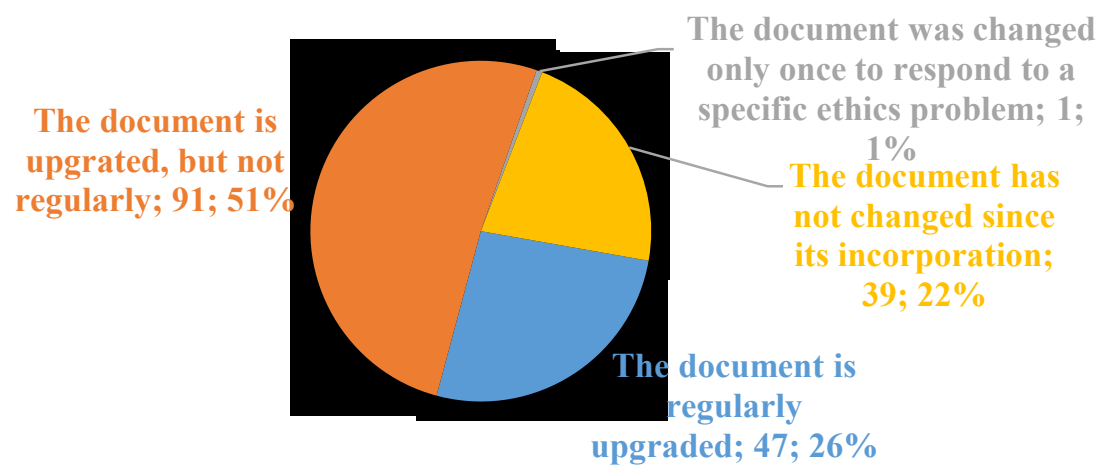

Picture 8 The main reason of incorporating the Code of Conduct (or similar document)

Source: Own calculations

The main attention was devoted also to the questions, if the Code of Conduct is changed or not (Picture 8 ). $51 \%$ of companies answered, that the Code of Conduct is upgraded, but not regularly, $26 \%$ of companies stated, that the document is regularly upgraded. Based on our opinion, it depends on ownership as well as strategies of the firms, because the firms must keep the principles of strategies from mother companies or they apply the "own strategy" if there are the companies with "a clear Slovak capital".

Just $13 \%$ of respondents self-proclaimed that in the past they had already faced an ethical problem (Picture 9), nevertheless, only 1\% of them (Picture 8 ) has changed their code of Conduct as a consequence.

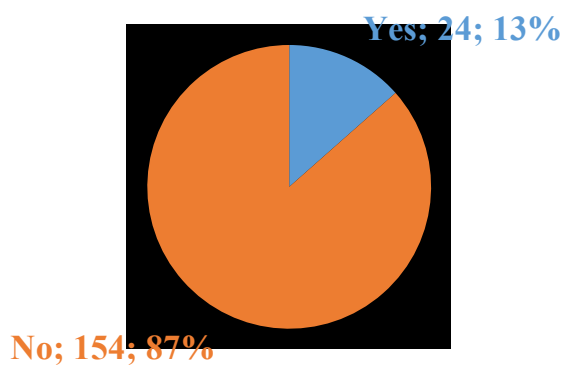

Picture 9 Has the company in the past already faced a "scandal" related to ethical violations?

Source: Own calculations

Last but not least attention was paid to who created the document in the company. In more than a $60 \%$ it was a representative of mother company. In $32 \%$ it was owner and /or top management of the company. Surprisingly, just $5 \%$ of respondents admitted that the document was prepared by specialised external company (consultant, PR or law) as a supply. 


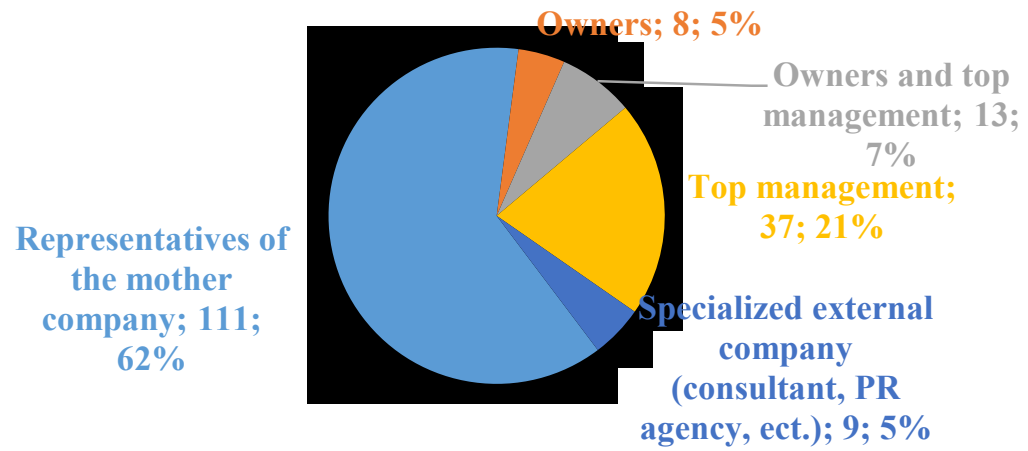

Picture 10 Authors of the Code of Conduct

Source: Own calculations

Based on the outcomes from the descriptive statistics we can conclude that most of the questions have low standard deviation, which indicates that the values tend to be close to the expected value what means that there is not too wide range of variance (Table 1).

Table 1: Summary statistics

\begin{tabular}{|c|c|c|c|c|c|c|c|}
\hline $\begin{array}{c}\text { Variabl } \\
\mathrm{e}\end{array}$ & $\begin{array}{c}\text { Observ } \\
.\end{array}$ & $\begin{array}{l}\text { Obs. with } \\
\text { missing } \\
\text { data }\end{array}$ & $\begin{array}{l}\text { Obs.without } \\
\text { missing } \\
\text { data }\end{array}$ & Min & Max & Mean & $\begin{array}{c}\text { Std. } \\
\text { deviatio } \\
\text { n }\end{array}$ \\
\hline B3 & 178 & 0 & 178 & 1.000 & 4.000 & 3.472 & 0.845 \\
\hline B4 & 178 & 0 & 178 & 1.000 & 3.000 & 2.545 & 0.681 \\
\hline C3 & 178 & 0 & 178 & 1.000 & 5.000 & 1.337 & 0.802 \\
\hline C4 & 178 & 0 & 178 & 1.000 & 4.000 & 1.399 & 0.776 \\
\hline E1 & 178 & 0 & 178 & 1.000 & 6.000 & 2.213 & 1.714 \\
\hline E2 & 178 & 0 & 178 & 1.000 & 7.000 & 4.191 & 1.187 \\
\hline E4 & 178 & 0 & 178 & 1.000 & 4.000 & 2.180 & 1.058 \\
\hline E7 & 178 & 0 & 178 & 1.000 & 2.000 & 1.865 & 0.343 \\
\hline \multirow[t]{2}{*}{ E8 } & & & & 1819.00 & 2017.00 & 1998.78 & \\
\hline & 178 & 0 & 178 & 0 & 0 & 1 & 16.405 \\
\hline
\end{tabular}

Source: Own calculations

The Shapiro-Wilk test of normality indicated that the variable from which the sample was extracted does not follow a normal distribution (Table 2). Therefore, the non-parametric test was chosen to test the samples.

Table 2: Shapiro-Wilk test

\begin{tabular}{lr}
\hline Variable\Test & \multicolumn{1}{c}{ Shapiro-Wilk } \\
\hline (B3 & $<\mathbf{0 . 0 0 0 1}$ \\
(B4 & $<\mathbf{0 . 0 0 0 1}$ \\
(C3 & $<\mathbf{0 . 0 0 0 1}$ \\
(C4 & $<\mathbf{0 . 0 0 0 1}$
\end{tabular}




\begin{tabular}{ll} 
(E1 & $<\mathbf{0 . 0 0 0 1}$ \\
(E2 & $<\mathbf{0 . 0 0 0 1}$ \\
E4 & $<\mathbf{0 . 0 0 0 1}$ \\
(E7 & $<\mathbf{0 . 0 0 0 1}$ \\
(E8 & $<\mathbf{0 . 0 0 0 1}$ \\
\hline
\end{tabular}

Source: Own calculations

From non-parametric tests, the Kruskal-Wallis test was used and hypotheses were set: H0: The samples come from the same population; H1: The samples do not come from the same population.

Computed $p$-value is lower than the significance level alpha $=0,05$, which means the null hypothesis $\mathrm{H} 0$ is rejected and the alternative hypothesis $\mathrm{H} 1$ is accepted (Table 3 ). The risk to reject the null hypothesis $\mathrm{H} 0$ while it is true is lower than $0,01 \%$.

Table 3: The Kruskal-Wallis test

\begin{tabular}{lr}
\hline K (Observed value) & 1030.930 \\
K (Critical value) & 15.507 \\
DF & 8 \\
p-value (Two-tailed) & $<0,0001$ \\
alpha & 0.05 \\
\hline
\end{tabular}

Source: Own calculations

Ties have been detected in the data and the appropriate corrections have been applied. According to the $\mathrm{p}$-values of the Bonferroni procedure we can conclude, that there is a high significance between most of the examined questions. Just between the pairs of E4:B3, E1:C4, E7:E2, E8:E2 and E8:E7 the significance was not proved.

Table 4: p-values of Bonferroni procedure (corrected significance level: 0.0014)

\begin{tabular}{|c|c|c|c|c|c|c|c|c|c|}
\hline & B3 & B4 & $\mathrm{C} 4$ & E1 & E2 & E4 & E7 & E8 & $\mathrm{C} 3$ \\
\hline B & & $<$ & $<$ & $<$ & $<$ & & $<$ & $<$ & $<$ \\
\hline 3 & 1 & 0.0001 & 0.0001 & 0.0001 & 0.0001 & 0.017 & 0.0001 & 0.0001 & 0.0001 \\
\hline B & $<$ & & $<$ & $<$ & $<$ & $<$ & & $<$ & $<$ \\
\hline 4 & 0.0001 & 1 & 0.0001 & 0.0001 & 0.0001 & 0.0001 & 0.001 & 0.0001 & 0.0001 \\
\hline $\mathrm{C}$ & $<$ & $<$ & & & $<$ & $<$ & $<$ & $<$ & $<$ \\
\hline 4 & 0.0001 & 0.0001 & 1 & 0.539 & 0.0001 & 0.0001 & 0.0001 & 0.0001 & 0.0001 \\
\hline E & $<$ & $<$ & & & $<$ & $<$ & $<$ & $<$ & $<$ \\
\hline 1 & 0.0001 & 0.0001 & 0.539 & 1 & 0.0001 & 0.0001 & 0.0001 & 0.0001 & 0.0001 \\
\hline E & $<$ & $<$ & $<$ & $<$ & & $<$ & & & $<$ \\
\hline 2 & 0.0001 & 0.0001 & 0.0001 & 0.0001 & 1 & 0.0001 & 0.133 & 0.869 & 0.0001 \\
\hline E & & $<$ & $<$ & $<$ & $<$ & & $<$ & $<$ & $<$ \\
\hline 4 & 0,017 & 0.0001 & 0.0001 & 0.0001 & 0.0001 & 1 & 0.0001 & 0.0001 & 0.0001 \\
\hline $\mathrm{E}$ & $<$ & & $<$ & $<$ & & $<$ & & & $<$ \\
\hline 7 & 0.0001 & 0.001 & 0.0001 & 0.0001 & 0.133 & 0.0001 & 1 & 0.181 & 0.0001 \\
\hline
\end{tabular}




\begin{tabular}{rrrrrrrrrr}
$\mathrm{E}$ & $<$ & $<$ & $<$ & $<$ & & $<$ & & $<$ \\
8 & 0.0001 & $\mathbf{0 . 0 0 0 1}$ & $\mathbf{0 . 0 0 0 1}$ & $\mathbf{0 . 0 0 0 1}$ & 0.869 & $\mathbf{0 . 0 0 0 1}$ & 0.181 & 1 & $\mathbf{0 . 0 0 0 1}$ \\
$\mathrm{C}$ & $<$ & $<$ & $<$ & $<$ & $<$ & $<$ & $<$ & $<$ & \\
3 & $\mathbf{0 . 0 0 0 1}$ & $\mathbf{0 . 0 0 0 1}$ & $\mathbf{0 . 0 0 0 1}$ & $\mathbf{0 . 0 0 0 1}$ & $\mathbf{0 . 0 0 0 1}$ & $\mathbf{0 . 0 0 0 1}$ & $\mathbf{0 . 0 0 0 1}$ & $\mathbf{0 . 0 0 0 1}$ & 1 \\
\hline
\end{tabular}

Source: Own calculations

\section{Conclusion}

Article examined the application of ethical principles into corporate practice of 178 Slovak companies (large - $65 \%$, medium-size - $23 \%$, small and micro - $12 \%$ ) mostly owned by foreign investors $(65 \%)$ and controlled by mother companies from European Union $(82 \%)$. Practically all of them (96\%) has the ethics somehow incorporated into the official documents, however formally designed The Code of Conduct or Ethical Code has just 132 of them. A half of them are of the relative small range ( $\leq 10$ pages), a quarter has only 10 to 50 pages only 10 $\%$ of them has large ethical documents where they has a space for specific problems. The main reason of incorporating the Code of Conduct into company's official documentation was effort to build goodwill and therefore they were solving ethics as a part of marketing strategy. This indicates also the fact that the majority of examined companies $(82 \%)$ are rejecting the unethical practices just generally and only $26 \%$ of them are upgrading it regularly despite fact, that $13 \%$ of respondents already faced an ethical problem in the past. One of the reasons can be fact, that in more than a $60 \%$ companies, the document created representatives of mother company, not directly owners or top managers.

Outcomes of the descriptive statistics confirmed low standard deviation of most of the questions and the Shapiro-Wilk test of normality indicated use of non-parametric test for further examination. Following Kruskal-Wallis test confirmed p-value lower than the significance level alpha $=0.05$, and therefore we accepted alternative hypothesis H1: The samples do not come from the same population. Results enhanced by Bonferroni procedure indicated high significance of two factors (the year of entry into the Slovak market and ownership interest) with all the other examined questions. Therefore, we can conclude, that the year of entry into the Slovak market and ownership interest are the most important regarding business ethics and its formalization through the Code of Conduct, or similar document.

\section{Acknowledgements}

The paper is part of the project KEGA 005SPU-4/2019 "Theory and Practice of the International Management and Entrepreneurship in the Multicultural Environment" conducted at the at the Faculty of Economics and Management of the SUA in Nitra.

\section{References}

[1] Diačiková, A., Lach, M. (2019). Manažment podnikania a podnikových procesov (Business Management and processes of enterprise). Svit: Chemosvit, 2019, 400 p.

[2] Gilbert, J. A., \& Ivancevich J. M. (2000). Valuing Diversity: A Tale of Two Organizations. Academy of Management Executive, 14, 93-105. doi: 10.5465/AME.2000.2909842

[3] Goel, M., \& Ramanathan, P.E. (2014). Business Ethics and Corporate Social Responsibility-Is there a dividing line? Procedia Economics and Finance, 11 (2014), 49 - 59. doi: 10.1016/S2212-5671(14)00175-0

[4] Jose, A., \& Thibodeaux, M.S. (1999). Institutionalization of ethics: the perspective of managers. Journal of Business Ethics, 22 (1999), 133-143. doi: 10.1023/A:1006027423495 
[5] Ki, E.J., Choi, H.L., \& Lee J. (2012). Does ethics statement of a public relations firm make a difference? Yes it does!! Journal of Business Ethics, 105 (2012) 267-276. doi: 10.1007/s10551-011-0971-1

[6] Lee, Y.K., Choi, J., Moon, B-Y., \& Babin, B.J. (2014). Codes of ethics, corporate philanthropy, and employee responses. International Journal of Hospitality Management, 39 (2014), 97-106. doi:10.1016/j.ijhm.2014.02.005

[7] Miller, R. G. 1966. Simultaneous Statistical Inference. McGraw- Hill Book Comp., New York 1966, 272 p. https://doi.org/10.1002/bimj.19700120508

[8] Munk, M., Drlik, M., Kapusta J., Munková, D. (2013). Methodology Design for Data Preparation in the Process of Discovering Patterns of Web Users Behaviour. Applied Mathematics \& Information Science, vol. 7, no. 1, p. 27-36. http://dx.doi.org/10.12785/amis/071L05

[9] Mura, L., Mižičková, L. (2006): The changes in the business background of Slovakia and their impact on small and medium enterprises, Competitiveness in the EU-Challenge for the V4 countries (2006), ed. Slovak University of Agriculture in Nitra, pp.901-906

[10] Schmidt,B.J., MacWilliams, B.R., \& Neal-Boylan, L. (2017). Becoming Inclusive: A Code of Conduct for Inclusion and Diversity. Journal of Professional Nursing, 33/2 (2017), 102-107. doi.org/10.1016/j.profnurs.2016.08.014

[11] Sroka, W., \& Lőrinczy, M. (2015). The perception of ethics in business: analysis of research results. Procedia Economics and Finance, 34 (2015), 156 - 163. doi: 10.1016/S2212-5671(15)01614-7

[12] Tayşir, E.A., \& Pazarcık, Y. (2013). Business Ethics, Social Responsibility and Corporate Governance:Does the Strategic Management Field Really Care About These Concepts? Procedia - Social and Behavioral Sciences, 99, 294-303. doi: 10.1016/j.sbspro.2013.10.497

[13] Valentine, S., \& Fleischman, G. (2002). Ethics Codes and Professionals' Tolerance of Societal Diversity. Journal of Business Ethics, 40 (2002). 301. doi.org/10.1023/A:1020827411937

[14] Velasquez, M.G. (2002). Business Ethics Concepts \& Cases. Pearson Education, 2012. Retrieved from: https://www.academia.edu/36451144/Business_Ethics_Concepts_and_Cases

[15] Yong-Ki, L., Joowon Ch., Bo-young, M., \& Babind, B.J. (2014). Codes of ethics, corporate philanthropy, and employee responses. International Journal of Hospitality Management, 9 (2014), 97-106. doi.org/10.1016/j.ijhm.2014.02.005

[16] EK, 2003. EU recommendation 2003/361. Commission Recommendation of 6 May 2003 concerning the definition of micro, small and medium-sized enterprises (Text with EEA relevance) (notified under document number C(2003) 1422). http://data.europa.eu/eli/reco/2003/361/oj. 


\section{SESSION 6}

TRADE, FOREIGN INVESTMENT AND INDUSTRIAL POLICIES IN THE EU 


\title{
The Role of Government in the Investment Activity of the Regions
}

\author{
Irina Belinskaia ${ }^{1}$, Natalia Frolova ${ }^{2}$ \\ The Leningrad State University after named A.S. Pushkin ${ }^{1,2}$ \\ Address: Peterburgskoe shosse, 10 \\ Saint-Petersburg-Pushkin, Russia \\ e-mail: belinska@yandex.ru', frolova.molla@gmail.com²
}

doi: 10.18515/dBEM.ISD.P01.2020.p041

\begin{abstract}
The macroeconomic growth indicators of the country is impossible without the efforts of the of investment role in the economy. The formation of conditions for increasing the investment activity of business entities is based on an effective system of managing regional systems. At the same time, one of the decisive factors in creating a successful state policy is the structure of government bodies. This article discusses the influence of the state government system (on the example of the regional level) on the parameters of investment activity. For research, methods of statistical analysis and expert evaluation are used. The objects of research are the regions of the Russian Federation. Detailing and revealing the level of influence was carried out in one of the most representative regions. As a result of the study, evidence was obtained of the need to implement measures to improve the efficiency of public administration in the development strategy of the country's investment activity.
\end{abstract}

Keywords: investment activity, regional system, public administration, management mechanism efficiency

JEL Classification: $R 58$

\section{Introduction}

Research on the concepts of "innovation "and" innovation policy " was conducted throughout the 20th century. This interest is due to the large impact of innovation parameters on the success of individual companies and countries as a whole. In 1920-1930 the theory of large cycles was developed by Kondratiev. In his book, he provides a justification for the theory of cyclical alternation of alternating phases in industrial production, justifies the" model of cycles": short (3-3. 5 years), commercial and industrial (7-11 years) and large cycles (48-55 years). (Kondratev N. (2002). In 1939, the Austrian and American economist J. Schumpeter publishes his work "business Cycles". In it, N. D. Kondratiev's thesis about the interaction of three wave movements with respect to three levels of equilibrium is confirmed. The scientist assumed the dynamics of the capitalist economy in the form of a synthesis of three waves. The superimposition of one wave on another explains the General state of the market at any given moment. He proposed a four-phase scheme in which recovery is followed by recession and recovery is followed by depression. (Schumpeter J., 2009). The basis of the innovation theory of Schumpeter are: innovative activity, distinction between product innovations and process innovations, the place of innovation in the cyclical dynamics of the economy, inevitability of overcoming the force of inertia, the resistance of the environment (Yakovets, Y., 2004).Problems of innovation management at the state level were investigated in the works of Brian Twiss. He considered innovation as a process in which an invention or scientific idea acquires an economic content and the creative character of innovation (Twiss, B. 1989). In G. Mensch's book "Technological path: innovations overcome depression", the rate of economic growth is associated with the cyclical appearance of basic innovations. According to the scientist, when basic innovations exhaust their potential, there is a situation of technological stalemate that characterizes stagnation in economic development. The process of moving from 
one technological path to another occurs through the transition from basic innovations to improving ones and then to pseudo-innovations (Mensch G., 1972) English economist K. Freeman believed that the depression suppresses innovation activity in the economy. A depression is a period in which organizational innovations are needed to prepare the economy for the emergence of technological innovations at the stage of recovery (Freeman C. and Soete, L., 1974). Freeman's theory complements Schumpeter-Kondratiev's theory of innovationcyclical economic growth by considering social aspects and employment problems. The scientist identified the relationship between innovation and social problems, and concluded that in the formation of large Kondratiev cycles that affect all areas of the economy, the key factor is not only innovation, but also employment (Freeman C., 1996). Russian economist E. Yasin considers that at the present stage prospects of Russia's development is ambiguous, since the absence of surplus labor, producing finished products to foreign markets in the conditions of slump in production and energy efficiency, increase the gross domestic product is only $2-3 \%$. According to the scientist, economic growth is possible due to innovations and increasing the level of human capital (Yasin E. et al, 2013). Issues of development of innovative infrastructure in the Russian Federation are discussed in the book (Koroleva L. and Yermoshina, T., 2014).

Improving the efficiency of the innovation infrastructure of the country and its individual regions stimulates the growth of key indicators of the macroeconomic system. The complex nature of the studied problem determines the presence of a large number of factors that affect the investment activity of economic entities. Now the logic and mechanism for restoring innovation activity have not been practically worked out. The governing regional bodies have not formulated a specific effective concept of structural changes in the innovation sphere, nor have they defined which economic entities should set the direction of these structural changes and initiate investment in innovation.All this makes it necessary to find ways out of the current crisis situation in the innovation sector, to initiate further comprehensive research of theoretical, methodological and organizational and economic problems of the country's investment complex, and develop recommendations for the activation of innovation processes. The scientific literature is actively developing in this direction. Solovieva A.B. to study the factors of increasing investment activity in the region of the investment process aimed at minimizing the constraining conditions for the development of investment attractiveness (Solovieva. A., 2017). The collection of scientific articles devoted to the study of the regional economy and territorial management problems, reveals the principles of municipal and regional state regulation development of the process of investment attractiveness (Risin. I, 2016). At the same time, raising the level of the investment infrastructure of the region is the main driver. Turekulova, Babasheva are exploring the mechanism of state regulation of investment activity, according to the author, is a system that consists of certain elements, unity and interaction, which determine its effectiveness and functionality. The process of increasing the efficiency of interaction between investors and companies through the implementation of investment activities of the mechanism of state regulation is carried out by a particular set of targeted application effective in a particular country, a particular region, means, directions, forms and methods of regulatory impact (Turekulova et al., 2016). Eichfelder S., Schneider K. pay most attention to assessing the effectiveness of investment regulation instruments in the country. Moreover, the authors attach great importance to the system of tax preferences (Eichfelder, S., Schneider, K., 2014).

Thus, at present, methodological approaches are not used to determine the factors of activation of investment activity using studies of the public administration system. Anywayone of the fundamental reasons that form an effective environment for organizing investment activity, in our opinion, is the state regulation of this process. In order to study the validity of this thesis, 
the presented scientific article analyzes the influence ofinvestment activity of individual regionslevel and the state of the public administration system parameters.

\section{Data and Methods}

As a base for the study, data on the regions of the Russian Federation presented in the rating of investment activity are used. This document has been developed by the Association of innovative regions of Russia in 2012 together with the Ministry of economic development of the Russian Federation. The Association of innovative regions of Russia has issued a nationwide "rating of innovative regions". In 2018, it is based on the indicators of 29 (previously there were 23) indicators from four thematic blocks: research and development; innovation; socio-economic conditions of innovation and innovation activity in the region.

To assess the effectiveness of managing the investment activity of the authorities in the studied region by methods of expert assessment and extrapolation, an analysis of the internal efficiency of the authorities was carried out. This process allows you to assess the level of potential of government for solving problems of increasing investment attractiveness.

\section{Results and Discussion}

For the analysis, we selected the Yaroslavl region, as it is in the group of "medium-strong" innovators in 2018, taking the overall 16th place in Russia, located between the Tula and Voronezh regions. Despite the relatively high position, the experts we interviewed noted that compared to last year, the region has passed, falling by two places at once. The leadership in the rating, as expected, belong to St. Petersburg, the Republic of Tatarstan and the capital of Russia, Moscow. Following them are the Tomsk, Moscow and Novosibirsk regions.

Table 1: Rating of innovative regions of Russia 2018 (13)

\begin{tabular}{|c|c|c|c|c|c|}
\hline Rank & Region & $\mathrm{I}=\Sigma \mathrm{i} / 29$ & $\begin{array}{l}\% \text { from the } \\
\text { average }\end{array}$ & Group & $\begin{array}{l}\text { Change of position in } \\
\text { the rating (compared } \\
\text { to } 2017-2.0+\text { ) }\end{array}$ \\
\hline 1 & St. Petersburg & 0.68 & $172,9 \%$ & \multirow{8}{*}{$\begin{array}{l}\text { strong } \\
\text { innovators }\end{array}$} & 0 \\
\hline 2 & Republic of Tatarstan & 0.67 & $169,6 \%$ & & 1 \\
\hline 3 & Moscow & 0.65 & $166,4 \%$ & & -1 \\
\hline 4 & Tomsk region & 0.63 & $161,2 \%$ & & 0 \\
\hline 5 & Moscow region & 0.60 & $152,2 \%$ & & 2 \\
\hline 6 & Novosibirsk region & 0.58 & $148,6 \%$ & & -1 \\
\hline 7 & Kaluga region & 0.57 & $145,0 \%$ & & -1 \\
\hline 8 & Nizhny Novgorod region & 0,55 & $140,8 \%$ & & 3 \\
\hline 9 & Ulyanovsk region & 0,54 & $138,2 \%$ & \multirow{11}{*}{$\begin{array}{l}\text { medium strong } \\
\text { innovators }\end{array}$} & -1 \\
\hline 10 & Samara region & 0,54 & $137,2 \%$ & & -1 \\
\hline 11 & $\begin{array}{l}\text { Tyumen region (without } \\
\text { JSC) }\end{array}$ & 0,53 & $133,9 \%$ & & 3 \\
\hline 12 & Republic of Bashkortostan & 0,52 & $132,9 \%$ & & 0 \\
\hline 13 & Republic of Mordovia & 0,52 & $132,1 \%$ & & 0 \\
\hline 14 & Sverdlovsk region & 0,52 & $131,5 \%$ & & 3 \\
\hline 15 & Tula region & 0,51 & $128,8 \%$ & & -5 \\
\hline 16 & Yaroslavl region & 0,50 & $127,5 \%$ & & -1 \\
\hline 17 & Voronezh region & 0,50 & $126,7 \%$ & & 2 \\
\hline 18 & Perm region & 0,49 & $125,8 \%$ & & 0 \\
\hline $19 \ldots$ & Chuvash Republic & 0,49 & $123,8 \%$ & & 1 \\
\hline 30 & Altai territory & 0,43 & $109,9 \%$ & & 4 \\
\hline
\end{tabular}




\begin{tabular}{|c|c|c|c|c|c|}
\hline 31 & Penza region & 0,43 & $109,7 \%$ & \multirow{3}{*}{$\begin{array}{l}\text { average } \\
\text { innovators }\end{array}$} & -6 \\
\hline 32 & Vladimir region & 0,43 & $108,7 \%$ & & -6 \\
\hline 33. & Stavropol region & 0,43 & $108,6 \%$ & & 14 \\
\hline 66 & Kamchatka region & 0,31 & $78,7 \%$ & \multirow{6}{*}{$\begin{array}{l}\text { medium-weak } \\
\text { innovators }\end{array}$} & -7 \\
\hline 67 & Sakhalin region & 0,29 & $73,2 \%$ & & 6 \\
\hline 68 & Kabardino-Balkar Republic & 0,28 & $70,4 \%$ & & 8 \\
\hline 69 & Magadan region & 0,28 & $70,1 \%$ & & -1 \\
\hline 70 & $\begin{array}{l}\text { Yamalo-Nenets } \\
\text { Autonomous district }\end{array}$ & 0,27 & $69,4 \%$ & & 5 \\
\hline 71 & $\begin{array}{l}\text { Republic Of North Ossetia- } \\
\text { Alania }\end{array}$ & 0,27 & $68,5 \%$ & & -4 \\
\hline
\end{tabular}

The figure shows the information we collected about the dynamics of attracting investment in the innovation sector of the economy of the Yaroslavl region for 2014-2018.

Figure 1: Dynamics of attracting investment in the innovation sector of the economy of the Yaroslavl region for 2014-2018

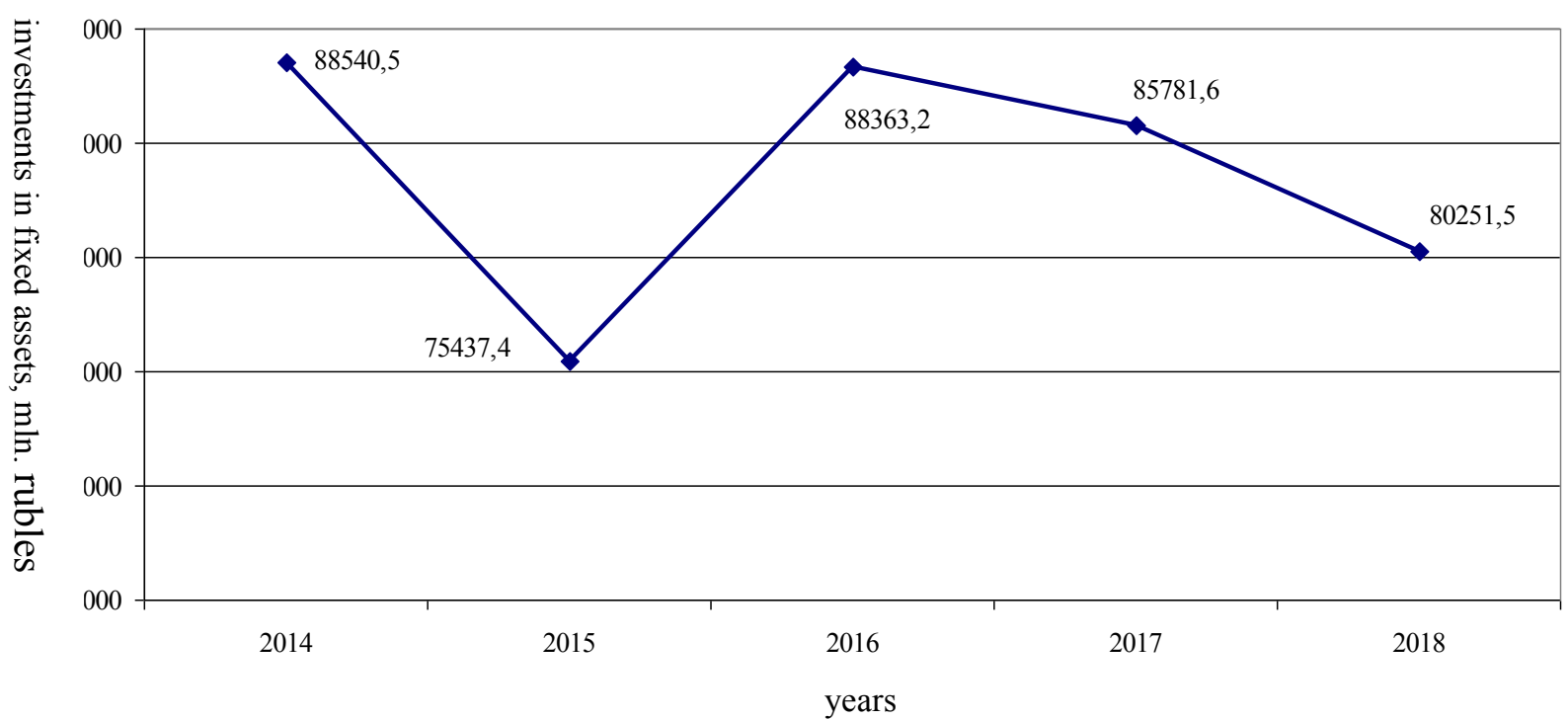

Source: authors

Shown in the picture, the data about volume of investments into the innovative sphere of the Yaroslavl region in 2014 was 88540,5 million rubles; in 2015 there was a decline of 13103,1 million RUB to 75437,4 million RUB; in 2016 relative to 2015, investment in innovation has increased for 12925,8 million RUB. and amounted to RUB 88363,2 million RUB; in 2017 relative to 2016 investment in innovation fell to 85781,6 million RUB; 20182017 relatively decreased investment in the innovative sphere on 5530,1 million RUB to 80251,5 million RUB.

To assess the effectiveness and current efficiency of regional management of investment activity and the interaction of regional authorities with local business, in our opinion, it is advisable to analyze the internal effectiveness of the authorities of the Yaroslavl region, i.e. to identify the extent of use of its internal capabilities. The main task at this stage is to assess the potential of the organizational structure of management for the implementation of management decisions at minimal and necessary costs, i.e. compliance with the actual use of internal capabilities of the block "management mechanism" formalized in the form of a generalizing indicator $\mathrm{K}_{\mathrm{my}}$. The scale of evaluation of this indicator with a 10-point scale is as follows:

- (8-10) - the organizational structure of the regional administration and the management mechanism work effectively; 
- (6-8) - the organizational structure of the Yaroslavl region has the potential to contribute to the productive functioning of innovation activity in the region, but at the same time, the management mechanism does not effectively ensure the implementation of targets and development of solutions to achieve the maximum results of innovation activity at the minimum and necessary costs;

- (3-6) - the organizational structure of regional management is extremely low in effectiveness, and the management mechanism does not provide interaction of elements of investment activity and their purposeful development;

- (0-3) - the organizational structure of regional management is not capable, it does not meet the goals and objectives of innovative development of the region.

To assess the effectiveness of the management mechanism of the Yaroslavl region, we use the method of expert assessments. The experts were asked to evaluate the work of the organizational structure of the authorities of the Yaroslavl region in the field of stimulating innovation activity on the following parameters: the duration of the management cycle, continuity management, cadence management, efficiency of decisions, efficiency of the control system, the level of diligence of the management, the level of quality of managerial decisions, the level of working time in the administration.

The experts were specialists of the authorities of the Yaroslavl region: head of the Department of investment and industry, head of the Department of agriculture and consumer market, Director of the Department of state order, head of the Department of regional development and foreign economic activity.

The expert assessment of indicators of the organization of administrative processes of authorities of the Yaroslavl region is presented in table 2.

Based on the obtained average estimates of indicators of management processes in the sphere of stimulation of innovative activity in the government of Yaroslavl region, calculate the coefficient of efficiency of the mechanism of management of innovative activity of the $K_{\mathrm{My}}$. The $K_{\mathrm{мy}}$ indicator is calculated using the formula: $K_{\mathrm{my}}=\sum \mathrm{Ri}$; where $\mathrm{Ri}$ is the value of specific index of efficiency of the mechanism of management of innovative activity; $\mathrm{Ri}=\mathrm{q} \times \mathrm{A}$; where $\mathrm{q}$ is the weighting coefficient of the indicator of the effectiveness of the control mechanism; A expert score.

Table 2: Expert assessment of indicators of management processes in the sphere of stimulating investment activity of the authorities of the Yaroslavl region

\begin{tabular}{|l|c|c|c|c|c|}
\hline \multirow{2}{*}{ Indicator } & \multicolumn{4}{|c|}{ Score in points (from 1 to 10) } \\
\cline { 2 - 6 } & $\begin{array}{l}\text { The head of the } \\
\text { Department of } \\
\text { investment and } \\
\text { industry }\end{array}$ & $\begin{array}{l}\text { Head of the } \\
\text { Department of } \\
\text { agriculture } \\
\text { and consumer } \\
\text { market }\end{array}$ & $\begin{array}{l}\text { Head of the } \\
\text { Department of } \\
\text { regional } \\
\text { development } \\
\text { and foreign } \\
\text { economic } \\
\text { activity }\end{array}$ & $\begin{array}{l}\text { Director of } \\
\text { the state } \\
\text { order } \\
\text { Department }\end{array}$ & $\begin{array}{l}\text { Average } \\
\text { expert } \\
\text { rating }\end{array}$ \\
\hline $\begin{array}{l}\text { Duration of the } \\
\text { management cycle }\end{array}$ & 9 & 8 & 7 & 7 & 7,75 \\
\hline $\begin{array}{l}\text { Management cycle } \\
\text { continuity }\end{array}$ & 8 & 8 & 9 & 6 & 7,75 \\
\hline Control rhythm & 8 & 9 & 8 & 6 & 7,75 \\
\hline $\begin{array}{l}\text { The timeliness of the } \\
\text { decisions }\end{array}$ & 6 & 6 & 7 & 7 & 6,5 \\
\hline $\begin{array}{l}\text { Cost-effectiveness of } \\
\text { the control system }\end{array}$ & 7 & 7 & 7 & 6,5 \\
\hline
\end{tabular}




\begin{tabular}{|l|c|c|c|c|c|}
\hline $\begin{array}{l}\text { The level of } \\
\text { performance of the } \\
\text { management apparatus }\end{array}$ & 8 & 7 & 9 & 5 & 7,25 \\
\hline $\begin{array}{l}\text { Level of quality of } \\
\text { preparation of } \\
\text { management decisions }\end{array}$ & 9 & 7 & 8 & 7 & 7,25 \\
\hline $\begin{array}{l}\text { The level of working } \\
\text { time usage }\end{array}$ & 7 & 7 & 7 & 7 & 7,0 \\
\hline
\end{tabular}

The calculation of the efficiency coefficient of the mechanism for managing innovation activity of the authorities of the Yaroslavl region is presented in table 3.

Table 3: Calculation of the coefficient of efficiency of the mechanism for managing innovative activity of authorities of the Yaroslavl region

\begin{tabular}{|l|c|c|c|}
\hline \multicolumn{1}{|c|}{ Indicator } & Weighting coefficient (q) & $\begin{array}{c}\text { Score in points } \\
\text { (A) }\end{array}$ & $\begin{array}{c}\text { Value of indicator } \\
\text { (R) }\end{array}$ \\
\hline $\begin{array}{l}\text { Duration of the } \\
\text { management cycle }\end{array}$ & 0,1 & 7,75 & 0,78 \\
\hline $\begin{array}{l}\text { Management cycle } \\
\text { continuity }\end{array}$ & 0,1 & 7,75 & 0,78 \\
\hline Control rhythm & 0,13 & 7,75 & 1,01 \\
\hline $\begin{array}{l}\text { The timeliness of the } \\
\text { decisions }\end{array}$ & 0,21 & 6,5 & 1,37 \\
\hline $\begin{array}{l}\text { Cost-effectiveness of the } \\
\text { control system }\end{array}$ & 0,13 & 6,5 & 0,85 \\
\hline $\begin{array}{l}\text { The level of performance } \\
\text { of the management } \\
\text { apparatus }\end{array}$ & 0,07 & 7,25 & 0,51 \\
\hline $\begin{array}{l}\text { Level of quality of } \\
\text { preparation of management } \\
\text { decisions }\end{array}$ & 0,16 & 7,5 & 1,20 \\
\hline $\begin{array}{l}\text { The level of working time } \\
\text { usage }\end{array}$ & 0,1 & 7,25 & 0,73 \\
\hline Total & 1 & - & 7,20 \\
\hline
\end{tabular}

\section{Conclusion}

Thus, the efficiency coefficient of the innovation activity management mechanism for the authorities of the Yaroslavl region is 7,20. The resulting value falls into the range (6-8). This means that the organizational structure has the potential to contribute to the productive functioning of the authorities, but the mechanism for managing innovation activity is not precisely configured. It does not fully ensure the implementation of targets and the development of solutions to achieve the planned results of the activation of the innovation process at the optimal cost.

As a result of the study, the main directions of interaction development between government bodies and business entities of the regions of the Russian Federation in the field of increasing investment activity are formulated.So, it is necessary to develop organizational schemes for interaction with entrepreneurial structures, to develop measures aimed at developing potential conducive to the productive functioning of innovative activity in the region, and to form an organizational structure for regional management that meets the goals and objectives of the region's innovative development. The findings of the study region are representative of all subjects of the Russian Federation. 


\section{References}

[1] Kondratev, N. (2002) Big cycles of conjuncture and the theory of foresight. Moscow: $767 \mathrm{p}$.

[2] Schumpeter, Joseph Alois (2009) Essays: On Entepreneurs, Innovations, Business Cycles, and the Evolution of Capitalism. NY. 341 p.

[3] Yakovets, Y. (2004) Epochal innovations of the XXI century. Moscow. .437 p.

[4] Twiss, B. (1989) Management of scientific and technical innovations. Moscow. $271 \mathrm{p}$.

[5] Mensch, G. (1972) Basisinnovationen und Verbesserungsinnovationen Zeitschrift für Betriebswirtschaft. Vol. 42, 291-297.

[6] Freeman, C., Soete, L. (1974) The Economics of Industrial Innovation. Harmondsworth. 322 p.

[7] Freeman, C. (1996) Wave in the World Economy. Aldershot, 132 p.

[8] Yasin, E. G., Akindinova, N. V., Yakobson L. I., Yakovlev, A. A. (2013) Choosing a path: scenarios for the development of Russia Investments in Russia. Vol. 6, 45-48.

[9] Koroleva, L. P., Yermoshina, T. V. (2014) Innovative infrastructure: composition and place in the innovation system of the economy. Innovations. Vol.12. 59-61.

[10] Solovieva, A. (2017). Basic objectives of the state governance of the region investment activity. In Problems of reforming accounting and taxation in the modern economy. strategic directions for the development of rural villages of the Tver region in the xxi century. Conference Proceedings. Tver SU Publisher, 19-123.

[11] Risin, I (2016) Methodological and information provision of strategic analysis of the region. Actual problems of the regional economy and territorial management, 84-86.

[12] Turekulova, A., Turekulova, D., Babasheva G., Satkanova, R., Ospanova, A., Nurgaliyeva, Z (2016) The mechanism of state regulation of the investment activity. International Economic Society, Vol 10, Issue 3, $136-139$

[13] Association of Innovative Regions of Russia. Official site. http://www.i-regions.org/reiting/rejtinginnovatsionnogo-razvitiy 


\title{
Competitiveness of the Meat Industry in Hungary and the Slovak Republic Fourteen Years after Joining the EU
}

\author{
Ondrej Beňuš ${ }^{1}$ L'udmila Dobošová $^{2}$, Daniela Hupková ${ }^{3}$, Veronika Mihálová ${ }^{4}$ \\ Slovak University of Agriculture in Nitra \\ Faculty of Economics and Management, Department of Economics 1, 2, 3,4 \\ Address: Tr. Andreja Hlinku 2 \\ 94976 Nitra, Slovakia \\ e-mail: ondrej.benus@uniag.sk¹,ludmila.dobosova@uniag.sk², daniela.hupkova@uniag.sk³ \\ veronika.mihalova@uniag.sk ${ }^{4}$
}

doi: 10.18515/dBEM.ISD.P01.2020.p042

\begin{abstract}
Hungary and the Slovak Republic joined the European Union in 2004. Participating in the Single market has caused increased research activity in various areas of economics in all Member States. Agri-food competitiveness has also been one of the key objects of investigation. Following the latest research, we investigated one of the most important branches of the agri-food industry, the meat industry. Research refers to relative export advantage, relative trade advantage and revealed comparative advantage of meat industry branches in Hungary and the Slovak Republic. Measured values show significant changes in competitiveness in both countries during observed years 2004-2018. There were five (Hungary) or four (Slovak Republic) competitive branches of the meat industry in the observed countries in 2004. After fourteen years, we identified only three branches still competitive on the Single Market in each of both countries.
\end{abstract}

Keywords: meat industry, revealed comparative advantage, relative export advantage, relative trade advantage keywords,

JEL Classification: $Q 10, Q 17, Q 19$

\section{Introduction}

Agri-food industry represents a traditional part of each country's economy. Although its role in the economy of developed countries has experienced a significant decline in the past decades, the agri-food sector will preserve its key role in each country. Today, food security and quality of food are one of the main topics that are taken very seriously by policymakers. One of the key elements responsible for the growth of the agri-food sector is its competitiveness on the global market.

Central European countries have joined the European union in 2014 and since then there is an eminent focus on the competitiveness of these countries on the Single Market.

It is necessary to determine if there is enough presence of these countries on inter-EU trade in the case of the agri-food industry. There is subsequent research (Bojnec, 2001) conducting more intra-trade orientation of the agri-food industry in developed countries. On the other hand, the same research (Bojnec, 2001) has found evidence that the New Member States (joining the European Union in 2004) have a prevailing inter-trade orientation of the agri-food industry.

Available research (Svatoš, Smutka, \& Miffek, 2010) has shown that the trade of agricultural and food commodities was equal between the group of Old Member States (12 countries) and New Member States (countries joining the EU in 2004). Some authors have also experienced results that were confirming the rising trade of agri-food commodities from Central European countries (Bojnec \& Ferto, 2008). A growing trend in the trade of agri-food commodities was determined also by Török and Jambor (2013) who investigated trade between the years 1999 
and 2010. These authors also made broader conclusion relating agri-food trade between the New Member States and the Old Member States. They admitted that the trade between the New Member States and the Old Member States grew. But despite the growth of trade, effects were less favourable for the New Member States. The new Member States experienced a negative balance in trade during the observed period of time, according to the mentioned authors. A second very important conclusion is that the dependence of New Member States on the Single Market had been growing during the whole observed time. The structure of agri-food trade prevailed also a very important fact. The new Member States dominated in the export of raw materials. On the other hand, Old Member States dominated in the export of processed agrifood commodities.

Latest research (Bojnec \& Ferto, 2018) supports the key role of New Member States on the Single market when supporting further specialization possibilities and increase of economies of scale. This fact also supports the international competitiveness of agri-food commodities produced in Member states of the EU. Some authors (Jambor \& Hubbard, 2013) pointed out that the structure of competitive products has a changing structure. The new Member States are competitive in raw materials but lack the same level of competitiveness in processed agri-food commodities.

To this date, the competitiveness of the agri-food sector within the New Member States has been put to the test by many authors. Current literature (French \& Vollrath, 1991; Yu R., Cai J., \& Leung, 2009) shows that the most broadly used method is Balassa's (1965) revealed comparative advantage.

Investigation of agri-food competitiveness, in general, does not provide information on key strengths or weaknesses of the agri-food industry in the selected country. Latest research has moved more toward the individual investigation of agri-food commodities. Authors tend to investigate specific sectors of the agri-food industry (for example Török \& Jambor, 2016; Bojnec \& Fertő, 2016; Leua, A., Famit, P., Singh, N., \& Parmar, 2017).

\section{Data and Methods}

The main aim of the research activity was to investigate the development of meat industry competitiveness in two Central European countries on the Single Market. Hungary and the Slovak Republic joined the EU in 2004 and from this moment they are an integral part of the Single Market of the EU. To deepen already existing research in this field (Jambor \& Hubbard, 2013) we decided to investigate the development of the competitiveness in separate meat industry branches in Hungary and the Slovak Republic.

For our calculations, we used the Combined Nomenclature based on the Council Regulation (EEC) No. 2658/87 of 23 July 1987 on the tariff and statistical nomenclature and on the Common Customs Tariff.

Our investigation is not intended to measure the competitiveness of the breeding industry (classified under Nomenclature "Live animals"). We decided to focus our research exclusively on processing industry (classified under Nomenclature "Meat and edible meat offal").

The territorial restriction was set to the Single Market. We focused on the competitiveness between the Member States of the European Union and excluded export and import related to non-EU countries. The main aim was to highlight the development of competitiveness in the Single Market. A single unit used in our research refers to trade value (gross value in euro).

The trade of the EU is limited only to intra-EU trade as defined by the Regulation (EC) No 638/2004 of the European Parliament and the Council of 31 March 2004 on Community 
statistics relating to the trading of goods between the Member States and repealing Council Regulation (EEC) No 3330/91. Based on this presumption, we investigated exports and imports of Hungarian and Slovak meat industry on the Single Market.

Data was obtained from EUROSTAT. We did not use national databases of both observed countries but we focused on one common database securing comparable data for our calculations.

Time period observed during our research was set to years from 2004 to 2018 . The year 2004 is representing the time when both countries joined the EU. This fact will help us to investigate the whole development of the meat industry competitiveness.

Table 1: Meat industry branches included in the investigation of the revealed comparative advantage of Hungary and the Slovak Republic

\begin{tabular}{c|l}
\hline \hline Nomenclature code & Definition \\
\hline \hline 201 & Meat of bovine animals (fresh and chilled) \\
\hline 202 & Meat of bovine animals (frozen) \\
\hline 203 & Meat of swine (fresh, chilled or frozen) \\
\hline 204 & Meat of sheep or goats (fresh, chilled or frozen) \\
\hline 205 & Meat of horses, asses, mules or hinnies (fresh, chilled or frozen) \\
\hline 206 & $\begin{array}{l}\text { Edible offal of bovine animals, swine, sheep, goats, horses, asses, mules or hinnies } \\
\text { fresh, chilled or frozen) }\end{array}$ \\
\hline 207 & $\begin{array}{l}\text { Meat and edible offal of the poultry of heading 0105 (fresh, chilled or frozen) } \\
\text { including edible offal }\end{array}$ \\
\hline 208 & $\begin{array}{l}\text { Other meat and edible meat offal (fresh, chilled or frozen) including meat and } \\
\text { edible offal }\end{array}$ \\
\hline 209 & $\begin{array}{l}\text { Pig fat, free of lean meat, and poultry fat, not rendered or otherwise extracted } \\
\text { fresh, chilled, frozen, salted, in brine, dried or smoked) }\end{array}$ \\
\hline $\begin{array}{l}\text { Meat and edible meat offal, salted, in brine, dried or smoked, edible flours and } \\
\text { meals of meat offal }\end{array}$ \\
\hline \hline
\end{tabular}

Source: own processing based on Council Regulation (EEC) No. 2658/87 of 23 July 1987 on the tariff and statistical nomenclature and on the Common Custom Tariff

Our research does not contain the following meat products:

- Products of the kinds described in heading 201, 202, 203, 204, 205, 206, 207, 208, 2010, unfit or unsuitable for human consumption

- Guts, bladders or stomachs of animals and animal blood

- Animal fat, other than products of heading 209

- Nomenclature 205.

We decided to exclude the nomenclature 205 (Meat of horses, asses, mules or hinnies) because the available data sets did not contain any information about export and import in selected countries for several years. This fact will not change the structure of competitiveness in the Hungarian and Slovak meat industry. It represents only $0.00037 \%$ (Hungary) or $0,0064 \%$ (Slovak Republic) of total meat export (EUROSTAT, 2020).

Our calculations are focused on the competitiveness of the meat industry in Hungary and the Slovak Republic. Balassa (1965) is a pioneer in this field. His approach of measuring comparative advantage is used by many authors to this date. Balassa (1965) measured 
comparative advantage by using only export data. We decided to add import data to the measurement. This approach follows the measurement of comparative advantage revealed by Vollrath (1991). We use three indicators:

- RXA - relative export advantage,

- RTA - relative trade advantage,

- RCA - revealed competitiveness.

$$
\begin{gathered}
R X A_{a}^{i}=\left(\frac{X_{a}^{i}}{X_{n}^{i}}\right) /\left(\frac{X_{a}^{r}}{X_{n}^{r}}\right) \\
R M A_{a}^{i}=\left(\frac{M_{a}^{i}}{M_{a}^{c}}\right) /\left(\frac{M_{m}^{i}}{M_{m}^{c}}\right) \\
R T A_{a}^{i}=R X A_{a}^{i}-R M A_{a}^{i} \\
R C A_{a}^{i}=\operatorname{Ln}\left(R X A_{a}^{i}\right)-\operatorname{Ln}\left(R M A_{a}^{i}\right)
\end{gathered}
$$

Letter " $\mathrm{X}$ " represents export and " $\mathrm{M}$ " import in our calculations. The subscript " $\mathrm{i}$ " refers to the selected country and subscript " $r$ " refers to all countries except the country described by the subscript " $i$ ". Subscript "a" refers to the selected product and the subscript " $n$ " refers to all products except the product described by the subscript "a".

In order to provide a better understanding of our calculations, we decided to divide observed branches of the meat industry into three separate groups. Each group is defined by different values referring to our revealed comparative advantage measured in the last observed year 2018 (see Table 2). There were no available data for nomenclatures 206 and 209. We decided to use the revealed comparative advantage measured in the year 2017 in these two cases.

Table 2: Three groups defined by different values of three measured indicators

\begin{tabular}{c|c}
\hline \hline Group & RCA \\
\hline \hline 1. & RCA $>0$ \\
\hline 2. & RCA $=<-1$ \\
\hline 3. & RCA $=<-2$ \\
\hline \hline
\end{tabular}

Source: own processing by the author

There were no available data for nomenclatures 206 and 209. We decided to use revealed comparative advantage measured in the year 2017 in these two cases

\section{Results and Discussion}

Investigated branches of the meat industry had different growth or decline pathway during the investigated timeframe. Selection of competitive branches would restrict our research only to a few nomenclatures. We decided to distinguish between three groups defined by the measured value of the revealed comparative advantage in the year 2018 (with the exemption of 206 and 209 nomenclatures). 


\subsection{Competitive branches of the Hungarian and Slovak meat industry}

Our research is focused on the most competitive branches of the Hungarian and Slovak meat industry. We identified 6 branches (three in Hungary and three in the Slovak Republic) with a positive revealed comparative advantage in the year 2018. This group of nomenclatures represents $60.4 \%$ (Hungary) or $64.8 \%$ (Slovak Republic) of total meat exports in the year 2018 (EUROSTAT, 2020).

Table 3: Branches of the Hungarian meat industry

\begin{tabular}{|c|c|c|c|c|c|c|c|c|c|}
\hline & \multicolumn{3}{|c|}{206} & \multicolumn{3}{|c|}{207} & \multicolumn{3}{|c|}{208} \\
\hline & RXA & RTA & RCA & RXA & RTA & RCA & RXA & RTA & RCA \\
\hline 2004 & 0.33 & -2.30 & -1.74 & 6.14 & 5.56 & 1.54 & 3.28 & 3.10 & 2.93 \\
\hline 2005 & 0.42 & -1.52 & -1.19 & 5.27 & 4.64 & 1.44 & 3.63 & 3.63 & 7.67 \\
\hline 2006 & 0.54 & -1.85 & -1.09 & 5.40 & 4.74 & 1.49 & 3.45 & 3.40 & 4.27 \\
\hline 2007 & 0.49 & -0.03 & 0.24 & 5.24 & 4.40 & 1.18 & 2.84 & 2.40 & 1.84 \\
\hline 2008 & 0.42 & -1.96 & -1.35 & 5.45 & 4.54 & 1.14 & 2.48 & 2.27 & 2.44 \\
\hline 2009 & 0.43 & -1.56 & -1.07 & 4.99 & 4.31 & 1.34 & 3.57 & 3.52 & 4.26 \\
\hline 2010 & 0.27 & -1.92 & -1.49 & 4.24 & 3.69 & 1.42 & 2.72 & 2.60 & 3.09 \\
\hline 2011 & 0.31 & -1.39 & -1.10 & 4.55 & 4.04 & 1.49 & 2.98 & 2.93 & 3.98 \\
\hline 2012 & 0.36 & -1.36 & -0.96 & 5.08 & 4.69 & 1.81 & 3.49 & 3.39 & 3.39 \\
\hline 2013 & 0.55 & -1.19 & -0.61 & 5.14 & 4.51 & 1.38 & 3.41 & 3.24 & 2.85 \\
\hline 2014 & 0.42 & -0.81 & -0.58 & 5.43 & 4.71 & 1.30 & 3.53 & 3.38 & 3.05 \\
\hline 2015 & 0.45 & -1.11 & -0.76 & 5.51 & 4.92 & 1.46 & 3.95 & 3.92 & 4.79 \\
\hline 2016 & 0.46 & -0.68 & -0.41 & 5.96 & 5.45 & 1.60 & 4.58 & 4.55 & 4.82 \\
\hline 2017 & 0.68 & -0.27 & 0.16 & 4.36 & 3.65 & 1.20 & 5.43 & 5.36 & 4.22 \\
\hline 2018 & 0.60 & -0.28 & 0.14 & 4.04 & 3.30 & 1.11 & 5.10 & 5.07 & 4.97 \\
\hline
\end{tabular}

Source: EUROSTAT, own processing by the author

Both countries experienced positive values in nomenclature 207 (Meat and edible offal of the poultry of heading including edible offal) and 208 (Other meat and edible meat offal including meat and edible offal). Both observed nomenclatures experienced also positive values in the area of relative export advantage and relative trade advantage with one exemption. We measured negative values when investigating the relative trade advantage of the nomenclature 208 in the Slovak Republic. This negative development was observed from the year 2008 until 2013. Using data gained by measuring relative export advantage and lative trade advantage we assume that the main cause had been caused by the rise of imports followed by the stagnation of exports.

The third positively rated branch was identified under nomenclature 206 (Edible offal of bovine animals, swine, sheep, goats, horses, asses, mules or hinnies) in Hungary. It is necessary to highlight that the revealed comparative advantage was identified only in two last measured years and in the year 2007. Negative relative trade advantage during the whole period of time underlines overall weak performance of this branch.

Table 4: Branches of the Slovak meat industry

\begin{tabular}{r|r|r|r|r|r|r|r|r|r}
\hline \hline & \multicolumn{3}{|c|}{204} & \multicolumn{3}{c|}{207} & \multicolumn{3}{c}{208} \\
\cline { 2 - 10 } & \multicolumn{1}{|c|}{ RXA } & \multicolumn{1}{c|}{ RTA } & \multicolumn{1}{c|}{ RCA } & \multicolumn{1}{c|}{ RXA } & \multicolumn{1}{c|}{ RTA } & \multicolumn{1}{c}{ RCA } & \multicolumn{1}{c}{ RXA } & \multicolumn{1}{c}{ RTA } & RCA \\
\hline \hline 2004 & 0.31 & 0.29 & 3.08 & 4.32 & 2.36 & 0.44 & 4.68 & 4.66 & 5.52 \\
\hline 2005 & 0.01 & 0.00 & -0.58 & 2.53 & 0.79 & 0.24 & 1.06 & 0.95 & 2.25 \\
\hline 2006 & 0.97 & 0.95 & 3.86 & 3.08 & 0.99 & 0.27 & 2.00 & 1.75 & 2.15 \\
\hline
\end{tabular}




\begin{tabular}{r|r|r|r|r|r|r|r|r|r}
2007 & 1.12 & 1.09 & 3.64 & 3.78 & 1.96 & 0.44 & 0.50 & 0.16 & 0.41 \\
\hline 2008 & 0.00 & -0.02 & $:$ & 3.79 & 2.06 & 0.48 & 0.16 & -0.08 & -0.36 \\
\hline 2009 & 0.56 & 0.56 & 4.40 & 4.97 & 3.27 & 0.62 & 0.01 & -0.34 & -3.54 \\
\hline 2010 & 0.28 & 0.26 & 2.89 & 4.40 & 2.66 & 0.53 & 0.87 & -0.20 & -0.19 \\
\hline 2011 & 0.62 & 0.59 & 2.98 & 6.07 & 4.14 & 0.59 & 0.21 & -2.07 & -2.42 \\
\hline 2012 & 0.54 & 0.49 & 2.38 & 5.15 & 3.37 & 0.59 & 0.17 & -0.58 & -1.52 \\
\hline 2013 & 0.54 & 0.50 & 2.58 & 5.91 & 4.24 & 0.70 & 0.30 & -0.01 & -0.08 \\
\hline 2014 & 0.89 & 0.84 & 2.86 & 7.15 & 5.21 & 0.68 & 2.07 & 1.39 & 1.11 \\
\hline 2015 & 0.81 & 0.74 & 2.52 & 7.15 & 5.72 & 0.86 & 2.49 & 1.96 & 1.54 \\
\hline 2016 & 0.69 & 0.63 & 2.56 & 6.34 & 5.29 & 1.06 & 0.95 & 0.39 & 0.48 \\
\hline 2017 & 0.98 & 0.94 & 3.21 & 3.72 & 2.84 & 0.96 & 1.50 & 0.92 & 0.86 \\
\hline 2018 & 6.41 & 6.38 & 3.08 & 4.43 & 3.19 & 0.77 & 5.60 & 4.91 & 1.95 \\
\hline \hline
\end{tabular}

Source: EUROSTAT, own processing by the author

: - data not available

The third branch with identified revealed comparative advantage was nomenclature 204 (Meat or sheep or goats) in the Slovak Republic. We measured the positive values of the revealed comparative advantage during the whole observed period of time with the exemption of the year 2004. This nomenclature does not show a significant advantage in relative export values during most years but our measurements show positive results in relative trade advantage.

It is positive that we identified revealed comparative advantage in the nomenclature 2007. Products belonging to this nomenclature represent 53.8\% (Hungary), respectively 56.8\% (Slovak Republic) of the total meat export in the year 2018 (EUROSTAT, 2020). This helps to improve the overall competitiveness of the whole meat industry export in both countries.

\subsection{Less competitive branches of the Hungarian and Slovak meat industry}

Less competitive branches are defined by the revealed comparative advantage lower than 0 but higher than -1 in the last observed year 2018. Respecting this restriction we identified four branches in Hungary and five branches in the Slovak Republic. They represent $32.9 \%$ (Hungary) or $34.5 \%$ (Slovak Republic) of the overall meat export. Products included in nomenclature 201, 203 and 210 were identified in both countries when the nomenclature 203 (Meat of swine) is the most important. It represents 27.2\% (Hungary), respectively $25.4 \%$ (Slovak Republic) of the total meat exports (EUROSTAT, 2020). Measured values of the relative trade advantage and revealed comparative advantage clearly identify the main reason for a weaker performance in selected countries. There was clear growth in export in import activity but in comparison, there was no clear improvement during observed years. In the case of the Slovak Republic, we identified even worse values of the relative trade advantage as usual in the year 2012, 2015 and 2016. If we compare total export and import values (in EUR) we see a loss of competitiveness in this area, too. The export grew by $1.9 \mathrm{x}$ and the import by $3 \mathrm{x}$ in Hungary between years 2004 and 2018. In comparison, the export grew by 4.2x and the import by $5.8 \mathrm{x}$ in the Slovak Republic in the same period of time.

Table 5: Branches of the Hungarian meat industry

\begin{tabular}{|c|c|c|c|c|c|c|c|c|c|c|c|c|}
\hline & \multicolumn{3}{|c|}{201} & \multicolumn{3}{|c|}{203} & \multicolumn{3}{|c|}{204} & \multicolumn{3}{|c|}{210} \\
\hline & RXA & RTA & RCA & RXA & RTA & RCA & RXA & RTA & RCA & RXA & RTA & RCA \\
\hline 2004 & 0.16 & 0.08 & 0.70 & 0.72 & -2.33 & -0.81 & 0.11 & 0.04 & 0.37 & 0.08 & 0.00 & 0.06 \\
\hline 2005 & 0.12 & 0.02 & 0.20 & 0.86 & -1.52 & -0.59 & 0.05 & -0.09 & -0.92 & 0.04 & -0.16 & -1.60 \\
\hline 2006 & 0.10 & -0.02 & -0.11 & 0.97 & -0.97 & -0.43 & 0.08 & -0.10 & -0.80 & 0.03 & -0.22 & -2.16 \\
\hline 2007 & 0.13 & -0.01 & -0.01 & 0.87 & -1.04 & -0.49 & 0.00 & -0.12 & -7.24 & 0.01 & -0.35 & -3.40 \\
\hline
\end{tabular}




\begin{tabular}{r|r|r|r|r|r|r|r|r|r|r|r|r}
2008 & 0.15 & 0.02 & 0.19 & 0.73 & -0.94 & -0.54 & 0.00 & -0.03 & $:$ & 0.03 & -0.35 & -2.42 \\
\hline 2009 & 0.17 & -0.02 & -0.01 & 0.89 & -1.16 & -0.47 & 0.00 & -0.05 & -3.88 & 0.04 & -0.34 & -2.20 \\
\hline 2010 & 0.17 & -0.05 & -0.24 & 1.06 & -1.74 & -0.50 & 0.02 & -0.05 & -1.16 & 0.06 & -0.19 & -1.35 \\
\hline 2011 & 0.13 & -0.08 & -0.43 & 0.86 & -1.68 & -0.61 & 0.01 & -0.09 & -2.12 & 0.17 & -0.22 & -0.71 \\
\hline 2012 & 0.15 & 0.05 & 0.43 & 0.78 & -2.61 & -0.80 & 0.01 & -0.06 & -2.19 & 0.06 & -0.19 & -1.33 \\
\hline 2013 & 0.16 & 0.05 & 0.38 & 0.74 & -1.78 & -0.71 & 0.02 & -0.06 & -1.58 & 0.08 & -0.20 & -1.14 \\
\hline 2014 & 0.10 & -0.02 & -0.11 & 0.73 & -1.65 & -0.72 & 0.01 & -0.07 & -2.17 & 0.08 & -0.24 & -1.27 \\
\hline 2015 & 0.11 & -0.05 & -0.31 & 0.70 & -2.45 & -0.89 & 0.01 & -0.10 & -2.14 & 0.12 & -0.32 & -1.12 \\
\hline 2016 & 0.11 & -0.05 & -0.28 & 0.62 & -2.65 & -1.01 & 0.05 & -0.05 & -0.60 & 0.12 & -0.33 & -1.19 \\
\hline 2017 & 0.13 & -0.03 & -0.11 & 0.81 & -1.74 & -0.67 & 0.04 & -0.04 & -0.57 & 0.13 & -0.26 & -0.94 \\
\hline 2018 & 0.12 & -0.04 & -0.17 & 0.89 & -1.52 & -0.62 & 0.65 & 0.57 & -0.12 & 0.15 & -0.25 & -0.80 \\
\hline
\end{tabular}

Source: EUROSTAT, own processing by the author

: - data not available

We identified also the nomenclature 204 as a "less competitive" branch of the Hungarian meat industry. This is in contradiction with the development of this nomenclature in the Slovak Republic where we measured positive values of the revealed comparative advantage. We can't evaluate this finding as a significant cause of lower overall competitiveness of the Hungarian meat industry because it represents only $0.25 \%$ of the total meat export in Hungary (in the Slovak Republic this nomenclature represents $2.35 \%$ ).

Table 6: Branches of the Slovak meat industry

\begin{tabular}{|c|c|c|c|c|c|c|c|c|c|}
\hline & \multicolumn{3}{|c|}{201} & \multicolumn{3}{|c|}{203} & \multicolumn{3}{|c|}{206} \\
\hline & RXA & RTA & RCA & RXA & RTA & RCA & RXA & RTA & RCA \\
\hline 2004 & 0.47 & 0.45 & 3.04 & 0.46 & -2.27 & -1.13 & 0.22 & -1.25 & -1.61 \\
\hline 2005 & 0.68 & 0.56 & 1.62 & 0.82 & -2.21 & -0.72 & 1.11 & 0.43 & 0.75 \\
\hline 2006 & 0.50 & 0.35 & 1.10 & 0.87 & -1.87 & -0.66 & 0.17 & -0.31 & -0.68 \\
\hline 2007 & 0.32 & 0.15 & 0.58 & 0.87 & -1.72 & -0.63 & 0.13 & -0.27 & -0.79 \\
\hline 2008 & 0.23 & 0.08 & 0.49 & 0.94 & -2.02 & -0.62 & 0.36 & -0.16 & -0.04 \\
\hline 2009 & 0.27 & 0.14 & 0.80 & 0.83 & -2.55 & -0.73 & 0.17 & -0.08 & 0.03 \\
\hline 2010 & 0.10 & -0.04 & -0.33 & 1.41 & -1.46 & -0.33 & 0.10 & -0.16 & -0.43 \\
\hline 2011 & 0.23 & 0.09 & 0.50 & 0.68 & -1.45 & -0.70 & 0.61 & 0.22 & 0.99 \\
\hline 2012 & 0.14 & -0.04 & -0.20 & 1.08 & -1.27 & -0.44 & 0.23 & -0.12 & 0.11 \\
\hline 2013 & 0.14 & -0.10 & -0.49 & 0.92 & -1.57 & -0.56 & 0.05 & -0.34 & -1.54 \\
\hline 2014 & 0.33 & 0.09 & 0.32 & 0.37 & -1.62 & -1.18 & 0.10 & -0.34 & -1.05 \\
\hline 2015 & 0.25 & -0.11 & -0.29 & 0.44 & -1.90 & -1.12 & 0.04 & -1.47 & -3.05 \\
\hline 2016 & 0.29 & -0.08 & -0.14 & 0.45 & -2.83 & -1.25 & 0.08 & -0.45 & -1.35 \\
\hline 2017 & 0.21 & -0.18 & -0.48 & 0.87 & -2.38 & -0.72 & 0.32 & -0.73 & -0.70 \\
\hline 2018 & 0.17 & -0.21 & -0.67 & 0.81 & -1.77 & -0.72 & 0.50 & 0.50 & \\
\hline
\end{tabular}

Source: EUROSTAT, own processing by the author

: - data not available

The second most important nomenclature influencing the overall export value of the meat industry are products included in nomenclature 201 (Meat of bovine animals). These products represent a share of $4.3 \%$ (Hungary) or $5.6 \%$ (Slovak Republic) on the total meat export (EUROSTAT, 2020). This nomenclature is an example of the growth of the competition after joining the EU. The meat of bovine animals was an important export product for both mentioned countries in the past. After investigation of the relative trade advantage and revealed comparative advantage we see a clear loss of the competitiveness during the observed period 
of time. Similar to the previously mentioned nomenclature there was a clear influence of the growth in imports. The worst situation was determined in the Slovak Republic where the value of imports rose by $108.7 \mathrm{x}$ between years 2004 and 2018 compared to the export growth of $1.31 \mathrm{x}$.

Table 7: Branches of the Slovak meat industry

\begin{tabular}{|c|c|c|c|c|c|c|}
\hline & \multicolumn{3}{|c|}{209} & \multicolumn{3}{|c|}{210} \\
\hline & RXA & RTA & RCA & RXA & RTA & $\mathrm{RCA}$ \\
\hline 2004 & 0.03 & -2.52 & -4.51 & 0.02 & -0.05 & -1.18 \\
\hline 2005 & 0.68 & -1.53 & -1.21 & 0.50 & 0.31 & 0.92 \\
\hline 2006 & 0.71 & -1.84 & -1.19 & 0.49 & 0.33 & 1.16 \\
\hline 2007 & 0.30 & -2.78 & -2.24 & 0.30 & 0.02 & 0.17 \\
\hline 2008 & 0.65 & -2.26 & -1.31 & 0.22 & -0.05 & -0.10 \\
\hline 2009 & 0.53 & -2.06 & -1.39 & 0.17 & -0.07 & -0.35 \\
\hline 2010 & 0.46 & -2.37 & -1.64 & 0.15 & -0.27 & -0.99 \\
\hline 2011 & 0.41 & -2.45 & -1.75 & 0.30 & -0.33 & -0.63 \\
\hline 2012 & 0.73 & -1.40 & -0.94 & 0.19 & -0.49 & -1.18 \\
\hline 2013 & 0.51 & -1.82 & -1.38 & 0.36 & -0.19 & -0.35 \\
\hline 2014 & 1.01 & -1.22 & -0.68 & 0.52 & -0.12 & -0.08 \\
\hline 2015 & 1.18 & -1.19 & -0.60 & 0.32 & -0.41 & -0.64 \\
\hline 2016 & 1.00 & -0.69 & -0.67 & 0.87 & 0.19 & 0.34 \\
\hline 2017 & 1.07 & -0.80 & -0.63 & 0.95 & 0.41 & 0.67 \\
\hline 2018 & 0.12 & 0.12 & : & 0.25 & -0.42 & -0.83 \\
\hline
\end{tabular}

Source: EUROSTAT, own processing by the author

: - data not available

Nomenclatures 210 (Meat and edible meat offal, salted, in brine, dried or smoked, edible flours and meals of meat offal), 206 (Edible offal of bovine animals, swine, sheep, goats, horses, asses, mules or hinnies) and 209 (Pig fat, free of lean meat, and poultry fat, not rendered or otherwise extracted) included in this second group have only marginal share on the total meat export.

\subsection{Least competitive branches of the Hungarian and Slovak meat industry}

The last group is represented by the least competitive products measured during the observed years (results measured of revealed comparative advantage in the year 2018). We identified nomenclature 202 (meat of bovine - frozen) in both countries. The negative development of this nomenclature corresponds with nomenclature 201 as they are basically connected. Both nomenclatures represent the meat of bovine. The nomenclature 202 related to frozen meat shows an even greater loss in competitiveness.

Table 8: Branches of the Hungarian meat industry

\begin{tabular}{r|r|r|r|r|r|r}
\hline & \multicolumn{3}{|c|}{202} & \multicolumn{1}{c}{209} & \multicolumn{1}{c}{ RTA } & \multicolumn{1}{c}{ RCA } \\
\cline { 2 - 7 } & \multicolumn{1}{|c|}{ RXA } & \multicolumn{1}{c|}{ RTA } & \multicolumn{1}{c|}{ RCA } & \multicolumn{1}{c}{ RXA } & \multicolumn{1}{c}{ RTA } \\
\hline \hline 2004 & 0.12 & -1.63 & -2.81 & 0.90 & -2.64 & -1.29 \\
\hline 2005 & 0.00 & -1.54 & $:$ & 1.39 & -3.19 & -1.19 \\
\hline 2006 & 0.00 & -2.05 & $:$ & 1.84 & -3.62 & -0.97 \\
\hline 2007 & 0.13 & -1.67 & -2.77 & 1.62 & -3.56 & -1.06 \\
\hline 2008 & 0.49 & -0.79 & -1.22 & 1.22 & -3.22 & -1.08 \\
\hline 2009 & 0.39 & -1.18 & -1.63 & 1.43 & -3.95 & -1.10 \\
\hline
\end{tabular}




\begin{tabular}{r|r|r|r|r|r|r}
2010 & 0.14 & -0.97 & -2.34 & 2.33 & -5.04 & -0.94 \\
\hline 2011 & 0.27 & -0.72 & -1.60 & 1.95 & -4.29 & -0.93 \\
\hline 2012 & 0.24 & -0.82 & -1.73 & 1.47 & -4.73 & -1.25 \\
\hline 2013 & 0.17 & -0.87 & -2.05 & 2.00 & -5.28 & -1.10 \\
\hline 2014 & 0.21 & -1.03 & -2.04 & 1.98 & -8.18 & -1.41 \\
\hline 2015 & 0.14 & -1.14 & -2.44 & 1.86 & -6.64 & -1.35 \\
\hline 2016 & 0.15 & -1.08 & -2.36 & 1.58 & -3.27 & -1.26 \\
\hline 2017 & 0.15 & -0.90 & -2.16 & 1.89 & -3.15 & -1.00 \\
\hline 2018 & 0.15 & -0.92 & -2.13 & 1.90 & -4.66 & -1.12 \\
\hline \hline
\end{tabular}

Source: EUROSTAT, own processing by the author

: - data not available

Comparing the development of competitiveness in the nomenclature we observed different trends in both countries. We measured values of the revealed competitive advantage over -2.00 in Hungary over most of all observed years (except the year 2009, 2011 and 2012). This is in contradiction with development observed in the Slovak Republic where the measured values exceeded 2.00 only in the three last investigated years. The import-export ratio did not change significantly in Hungary (5.7x in favour of import) if we compare the years 2004 and 2018 (EUROSTAT, 2020).

Table 9: Branches of the Slovak meat industry

\begin{tabular}{r|r|r|r}
\hline \multirow{2}{*}{} & \multicolumn{3}{|c}{202} \\
\cline { 2 - 4 } & \multicolumn{1}{c}{ RXA } & \multicolumn{1}{c}{ RTA } & \multicolumn{1}{c}{ RCA } \\
\hline 2004 & 0.28 & -0.41 & -1.10 \\
\hline 2005 & 0.10 & -0.24 & -1.40 \\
\hline 2006 & 0.13 & -0.36 & -1.52 \\
\hline 2007 & 0.29 & -0.01 & -0.27 \\
\hline 2009 & 0.27 & -0.02 & -0.39 \\
\hline 2010 & 0.38 & 0.21 & 0.47 \\
\hline 2011 & 0.50 & 0.21 & 0.21 \\
\hline 2012 & 0.70 & 0.06 & -0.25 \\
\hline 2013 & 0.31 & -0.11 & -0.61 \\
\hline 2014 & 0.21 & -0.13 & -0.78 \\
\hline 2015 & 0.22 & -0.63 & -1.64 \\
\hline 2016 & 0.28 & -0.18 & -0.80 \\
\hline 2017 & 0.07 & -0.35 & -2.06 \\
\hline 2018 & 0.05 & -0.26 & -2.03 \\
\hline \hline SOun & 0.03 & -0.20 & -2.16 \\
\hline
\end{tabular}

Source: EUROSTAT, own processing by the author

To the last group of meat industry branches, we also included the nomenclature 209 (Pig fat, free of lean meat, and poultry fat, not rendered or otherwise extracted). According to our measurements products included in this nomenclature experienced values of the revealed comparative advantage above -1.00 in Hungary for most of all observed years. The import and export ratio almost doubled during observed years (1.25x in 2004 vs. 2.08x in 2018) (EUROSTAT, 2020). This development leads to an even higher loss of competitiveness in this country after joining the EU. 
This last group of nomenclatures representing the least competitive branches of the meat industry has only a marginal impact on the total competitiveness of the whole meat industry. The share on export was only $1.63 \%$ (Hungary) or $0.14 \%$ (Slovak Republic) in 2018.

\section{Conclusion}

The main aim of the paper was to identify changes that occurred in individual branches of the meat industry in Hungary and the Slovak Republic after joining the EU in 2004. We focused our research on the Single Market of the EU and investigated exports from Hungary and the Slovak Republic to other EU countries (intra-EU trade).

Competitiveness of extra-EU trade has experienced different development in observed countries. Hungary preserves its extra-EU trade competitiveness after joining the EU but there was a clear decline according to the available research. In contradiction, there was marginal growth in competitiveness in the Slovak Republic but the overall revealed comparative advantage of the country sits below 1 (Bojnec \& Fertö, 2014).

Entering the Single Market boosted international trade with meat industry products. In most cases, the import value rose faster than the export value. This contributes to our findings that there was an overall loss in competitiveness in the majority of meat industry branches in Hungary and the Slovak Republic. This conclusion is in compliance with results and findings of already available literature (Jambor \& Hubbard, 2013; Törok \& Jambor, 2013).

Focus on individual branches within the meat industry in Hungary and the Slovak Republic added a new view on the competitiveness within the mentioned industry. We put to the test nine of ten product groups listed under individual nomenclatures in each investigated country separately. Based on our calculations we decided to divide all nine investigated nomenclatures into three separate groups in order to highlight their common characteristics.

The first group represents three competitive $(\mathrm{RCA}>0)$ nomenclatures in each of both countries. In contradiction, we observed five competitive nomenclatures $(201,204,207,208$ and 210) in Hungary and four competitive nomenclatures (201, 204, 207 and 208) in the year 2004. We observed a change in competitiveness in investigated nomenclatures in this group, too. The Slovak Republic lost competitiveness in the nomenclature 201 representing 5.6\% of the total meat export (EUROSTAT, 2020). There were even more evident changes in Hungary when considering the number of nomenclatures losing their competitiveness. Nomenclatures 201, 204 and 210 representing $5.73 \%$ of total meat export lost their competitiveness according to our measurements during the years 2004 and 2018. The only positive element was nomenclature 206 where Hungary (nomenclature 206 represents $1.8 \%$ of total meat export in Hungary) gained revealed comparative advantage during the investigated period of time.

The market share represents $60.4 \%$ (Hungary) or $64.8 \%$ (Slovak Republic) of the total intraEU meat export (EUROSTAT, 2020) in this first group. This is a positive conclusion for both countries when competitive branches of the Hungarian and Slovak meat industry represent more than half of total meat exports. The main reason for this result is the revealed comparative advantage identified in the nomenclature 207 representing 53.8\% (Hungary) or 56.8\% (Slovak Republic) of the overall intra-EU meat export. But we came to a different conclusion when comparing revealed comparative advantage of the mentioned nomenclature in years 2004 and 2018. There was a growth in the competitiveness in the Slovak Republic and the decline in Hungary.

The second group represents nomenclatures where the measured revealed comparative advantage was less than 0 but also not lower than -1 . The total share on the meat export was 
again very similar between two compared countries when it represented $32.8 \%$ (Hungary) or $34.5 \%$ (Slovak Republic) of the total meat export in the year 2018 (EUROSTAT, 2020). On the other hand, the movement of products within this category was the most significant of all three individual groups. There was negative development in the competitiveness of three nomenclatures in Hungary during the observed period of time. The nomenclature 201, 204 and 210 lost revealed comparative advantage in the year 2018 (compared to the year 2004). Only the nomenclature 203 showed stable position in competitiveness during years 2004 and 2018 . In the Slovak Republic, we experienced even higher activity of movement between established groups defining the different state of competitiveness. The only negative development was identified when investigating nomenclature 2012. In this case, we established a loss of revealed comparative advantage. The rest of the products listed under nomenclature 203, 206 and 209 experienced positive development. We could not identify revealed comparative advantage in any of the mentioned nomenclatures in the year 2018 but there was a positive development in terms of rules set for our three groups. All these products were in the third group in 2004 but fourteen years later we measured values that qualified their performance for the second group.

The third group is represented by two nomenclatures (202 and 209) in Hungary and one (202) in the Slovak Republic. These products had only a share of $1.6 \%$ (Hungary) or $0.14 \%$ (Slovak Republic) on the total meat export in the year 2018. There was no change in Hungary during the investigated period of time and we identified only the nomenclature 202 and 209 as the least competitive branches of the meat industry. However, there were changes in the Slovak Republic. Only one nomenclature (202) was classified in this group in the year 2018 (compared to four in the year 2004), according to our measurements.

We identified positive results when most of the meat export preserved their competitiveness in both countries during the observed period of time. On the other hand, we see a clear decline in number of competitive branches in both countries, according to our measurements of the revealed comparative advantage. Joining the EU and the Single Market has brought intensification of the trade. This was also eminent from our calculations. On the other hand, the intensification of trade has brought more rapid growth in import than in export values in the meat industry. The investigated industry represents elementary part of any economy. The Single Market is highly competitive area and all meat producers in New Member States need to adjust their strategic decision in order to preserve their competitiveness on this market.

\section{Acknowledgements}

This paper was created within the project Jean Monnet Eramus+ Economic and Legal Basics of Entrepreneurship in Agrifood Industry. Project registration number 600459-EPP-1-2018-1SK-EPPJMO-MODULE.

\section{References}

[1] Leua, A., Famit, P., Singh, N., \& Parmar, G. (2017): Export Opportunity of Agricultural Commodities of India: Revealed Comparative Approach. Indian Journal of Economics and Developmnet, 13(2A), 705-709. doi: 10.5958/2322-0430.2017.00156.1

[2] Balassa B. (1965). Trade Liberalization and Revealed Comparative Advantage. The Manchester School, 33(2), 99-123. doi.org/10.1111/j.1467-9957.1965.tb00050.x

[3] Bojnec, Š. (2001). Trade and revealed comparative advantage measures: regional and Central and East European agricultural trade. Eastern European Economics, 39(2), 72-98. doi: https://doi.org/10.1080/00128775.2001.11040990

[4] Bojnec, Š., \& Fertő, I. (2014). Meat export competitiveness of European Union countries on global markets. Agricultural and Food Science, 23(3), 194-206. 
[5] Bojnec, Š., Fertö, I. (2018). Drivers of the duration of comparative advantage in the European Union's agrifood exports. Agricultural Economics, 64(2), 51-60. doi: https://doi.org/10.1111/j.1744-7976.2008.00148.x

[6] Bojnec, Š., Fertő, I. (2008). European enlargement and agro-food trade. Canadian Journal of Agricultural Economics, 56(4), 563-579. Doi: https://doi.org/10.1111/j.1744-7976.2008.00148.x

[7] Bojnec S., \& Fertő I. (2016). Export competitiveness of the European Union in fruit and vegetable products in the global markets. Agricultural Economics, 62(7), 299-310. doi: 10.17221/156/2015-AGRICECON

[8] Council Regulation (EEC) No 2658/87 of 23 July 1987 on the tariff and statistical nomenclature and on the Common Custom Tariff

[9] EUROSTAT (2020). International trade in goods by HS2-HS4 from 2004 to 2018. [statistics]. Available from EUROSTAT Data database.

[10] Jambor, A., \& Hubbard, L. J. (2013). Changing product structure and comparative advantage: the case of Hungarian agri-food trade. Ekonomický časopis - Journal of Economics, 61(8), 846-860.

[11] Regulation (EC) No 638/2004 of the European Parliament and the Council of 31 March 2004 on Community statistics relating to the trading of goods between Member States and repealing Council Regulation (EEC) No 3330/91

[12] Svatoš, M. Smutka, L., \& Miffek, O. (2010). Competitiveness of agrarian trade of EU-15 countries in comparison with new EU member states. Agricultural Economics, 56(12), 569-582.

[13] Törok, A., \& Jambor A. (2013). Agri-food trade of the New Member States since EU accession. Agricultural Economics, 59(3), 101-112.

[14] Törok, A., \& Jambor A. (2016): Determinants of the revealed comparative advantages: The case of the European ham trade. Agricultural Economics, 62(10), 471-482.

[15] Vollrath T.L. (1991). A theoretical evaluation of alternative trade intensity measures of revealed comparative advantage. Weltwirtschaftliches Archiv, 127(2), 265-280.

[16] Yu R., Cai J., \& Leung P. (2009). The Normalized Revealed Comparative Advantage Index. The Annals of Regional Science, 43(1), 267-282. doi: 10.1007/s00168-008-0213-3 


\title{
Public Procurement as an Innovative Tool of EU Policies (Case Study)
}

\author{
Radomíra Hornyák Gregáňová ${ }^{1}$, Viera Papcunová ${ }^{2}$ \\ Slovak University of Agriculture in Nitra ${ }^{1}$, Constantine the Philosopher University in Nitra ${ }^{2}$ \\ Faculty of Economics and Management, Department of Mathematics ${ }^{1}$ \\ Faculty of Natural Sciences, Institute of Economics and Management ${ }^{2}$, \\ Tr. A. Hlinku $2^{1}$, Tr. A. Hlinku $1^{2}$ \\ 94976 Nitra, Slovakia \\ e-mail: radomira.greganova@uniag.sk ${ }^{1}$, vpapcunova@ukf.sk²
}

doi: 10.18515/dBEM.ISD.P01.2020.p043

\begin{abstract}
The electronic contracting system (ECS) is required to be used by all contracting public authorities (State, HTUs, municipalities), as well as persons who are not contracting public authorities but have been provided with at least $50 \%$ of the contract value by the contracting public authority. In The ECS system it is possible to procure in 16 areas. From 1st July 2014 to 31 January 2015, electronic marketplace was running in trial operation. Since 1 February 2015, all contracting public authorities are obliged to award contracts through this tool. The aim of the paper is to evaluate individual contracts as well as savings gained through electronic contracting system (ECS) for the period 2014 - 2019. We analyzed the number of contracts in individual groups, the volume of contracted funds as well as the savings in time series. The results of the analysis show that although the number of contracts is decreasing, the total contracted amount of contracts increases. This situation is due to legislative adjustments that have increased the minimum financial limits for public procurement, thus reducing the number of contracts. The analysis show that the introduction of the ECS system is bringing yearly costsavings in the ordering of goods and services, and also the process of the public procurement has become more transparent.
\end{abstract}

Keywords: public procurement, electronic contracting system, electronic marketplace, strategy Europe 2020

JEL Classification: $P 43, H 41, O 38, K 12$

\section{Introduction}

Public procurement is according to Khan (2018), Krajcirova et al. (2016) an important government system for spending public money on the purchase of goods, works and services needed for public programs and projects. Over the past two decades, public procurement has evolved from the simple purchase of goods, works and services to complex government activity, which aims to manage the entire procurement process under the supervision of qualified and competent experts. Nowicki (2018) notes that the literature points to the basic objective of public procurement, which should be the economic efficiency of purchases. Without the necessary regulation in this respect, it will be difficult for the contracting authority to state why it has adopted a specific relationship between the price (costs) and the value that the contracting authority intends to achieve for the purchase. The principle of economic efficiency is based on this relationship and should always be optimized in line with the values that the contracting authority plans to achieve in the public interest (Vavrek and Benkova, 2018)

MacGregor Pelikánová and Cvik (2019) note that, in 2017, the European Commission presented an Initiative to make procurement more efficient and sustainable in full with using digital technologies to simplify and accelerate procedures under the heading "Increasing the impact of public investment through efficient and professional procurement." The Initiative was a response to the Investment Plan for Europe and its efforts to promote economic development and strengthen the single internal market. The initiative defines six priority axes for the 
implementation of the investment plan for Europe and focuses in particular on the importance of public procurement in EU Member States. The importance of public procurement at EU level is also confirmed Sostar and Marukic (2017), Hudáková (2015) note, that public procurement at EU level is considered to be one of the key instruments of the Strategy Europe 2020 to deliver smart, sustainable and inclusive growth. The EU public procurement rules set out aim at making the use of public procurement more strategic in order to achieve common society objectives and ensure the most efficient use of public funds. All EU Member States were required to harmonize their procurement laws and regulations with Directive 2014/24/EC, Directive 2006/24/EC and Directive 2014/25/EU by April 2016. The importance of public procurement is also confirmed by Šumpíková and Duurčeková (2019) who note that, according to the European Commission, the public procurement market in the Czech Republic accounted for 14\% of GDP in 2016 (similar to the UK), which is approximately EUR 26.5 billion. EUR. Flynn (2018) states that in the countries of the Across Organization for Economic Cooperation and Development countries, on average, $12.8 \%$ of GDP and $29 \%$ of total government expenditures account for public procurement.

All countries in the world organize public procurement through ministries, agencies or other bodies, but differ in organizational aspects, the legal basis of the procurement process as well as in the scope and division of responsibility for the different stages of the process. Similarly, public procurement methods themselves vary from country to country, depending on the purchasing policies used in each country. In order to streamline government spending in the procurement process, it uses a centralized approach in most countries. However, there are also several developed countries that generally use a decentralized approach in public procurement (Aboelazm and Afandy, 2019). In Romania Preda (2019) states, that the public procurement system in is one of the most important systems in the country affecting the national economy. The procurement system in Romania is similar to the procurement systems in the other EU Member States and European public procurement legislation is transposed into national law. The number of procurement contracts concluded in Romania in 2018 was 35354 and their estimated value was 139718293 ths.lei, excluding VAT. In Kazakhstan, public procurement represents a large part of the country's public spending. Between 2016 and 2018, the share of public procurement in the Republic of Kazakhstan represented on average $32.3 \%$ of public expenditures (Issabayeva et al., 2019).

Given the purchasing power of the state, public procurement can become a strategic tool of public administration that can have a possible impact on the market, on a more sustainable way of production and also on consumption. However, it is important to remove or reduce barriers that reduce the effectiveness of the entire procurement process. Research conducted by Euflausino and Ribeiro de Mello (2019) in 2014 on a sample of 77 public servants in Brazil showed that the factors they considered to be middle barriers to public procurement included legislation, knowledge in the field, costs and specifications in the auction notice. Another problem with public procurement to identified Sergeeva (2018) in her research where she states, that despite the increasing importance of the public procurement market in world and domestic practice, there are barriers to developing a common methodology for monitoring the impact of public procurement on the economic, social, political and other aspects of modern society life. But Flynn (2018) notes that the European Commission proposed a methodology for measuring the performance of public procurement in 30 EEA countries. Existing evaluations suggest that there are significant performance gaps between EEA countries, even though they are subject to the same political and regulatory regime. 


\section{Data and Methods}

The electronic contracting system (ECS) is required to be used by all contracting public authorities (State, HTUs, municipalities), as well as persons who are not contracting public authorities but have been provided with at least $50 \%$ of the contract value by the contracting public authority. An electronic contracting system is a public administration information system that serves to ensure the supply and purchase of goods, works or services commonly available on the market, by means of an auction procedure, and to ensure related activities. Electronic market place as a tool for effective performance of public administration consist of: electronic market place for below-threshold contracts (since 07/2014) and Electronic Marketplace for above threshold contracts (since 12/2015). ${ }^{\mathbf{1 4}}$

ECS is administered by the Ministry of the Interior of the Slovak Republic. ECS was established on July 1, 2014 and contains three main functionalities:

- The Electronic Marketplace is a system of fully electronic system of awarding of contracts and presentation of tenders for goods and services commonly available on the market. This means that in accordance with the Act No. 343/2015 Coll. on public procurement, the Electronic Marketplace is a public administration information system which serving to ensure the supply and purchase of goods or services commonly available on the market as well as related activities. The Electronic Marketplace is administered by the the Ministry of the Interior of the Slovak Republic.

- A dynamic purchasing system is an electronic tool for the implementation of open supplier qualification systems.

- Electronic process support represents electronic support of public procurement processes in the areas of information, communication, explanation, electronic delivery.

From $1^{\text {st }}$ July 2014 to 31 January 2015, electronic marketplace was running in trial operation. Since 1 February 2015, all contracting public authorities are obliged to award contracts through this tool. From $1^{\text {st }}$ November 2017, the contracting public authority may decide whether to proceed with the placing of below-the-threshold contracts for the supply of goods and services normally available on the market using the electronic marketplace or without using the electronic marketplace. When public authority to decide not apply the electronic marketplace, they use a call for tenders published in the public procurement journal. The obligation to use the Electronic Marketplace for the public procurement process applies to all contracts for construction works, goods and services normally available above 5,000 € excluding VAT up to $134,000 €$, respectively $207,000 €$ excluding VAT (depending on the type of contracting authority). Until September 2015, the minimum threshold from which it was necessary to procure via Electronic Marketplace was $€ 1000$ without VAT.

The aim of the paper is to evaluate individual contracts as well as savings gained through electronic contracting system (ECS) for the period 2014 - 2019. We analyzed the number of contracts in individual groups, the volume of contracted funds as well as the savings in time series.

\section{Results and Discussion}

Electronic contracting system present a tool for fully automatic placement of tenders, which automatically generates contracts based on results of the competition without any human input which is performed anonymously, in an auction style manner, with unlimited public control, including automatic notification of relevant economic operators (picture 1). It is also a central

\footnotetext{
${ }^{14}$ www. eks.sk
} 
trading place which is obligatory for contracting authorities and voluntary for anybody who registers to the system, which is free of charge. In Slovak Republic public procurement is governed by the Act. 343/2015 Coll. about public procurement. Grega et al. (2019) notes that Slovak legislation in the field of public procurement was revised 35 times in the decade after 2006. A survey which carried out the authors showed that in $201768 \%$ of suppliers and $59 \%$ of suppliers identified excessive bureaucracy as one of the three main problems of the public procurement system and $56 \%$ of suppliers identified frequent legislative changes as a barrier.

The results of analysis of Svidroňová et al. (2016) have shown that the use of public eprocurement at the local level is evaluated very positively. It is implemented mostly in order to increase transparency and cost effectiveness. It is in the hands of individuals (procurement officers, managers, employees) how e-procurement will be implemented in the public sector, which is the determinant of the inner context. The research of Sičáková-Beblavá, et al. (2011) show that savings of public-sector organizations by using electronic auctions in Slovakia range between 6 and $12 \%$. Issabayeva et al. (2019) note that e-public procurement has great potential to improve procurement processes. It helps to increase competitiveness and also the use of digital technologies minimizes transaction costs for business, increases trust and transparency of public customers' decisions. Pavel (2010) analyzed public procurement of Czech road and railway infrastructure. He concluded that another tenderer on average lowered the price by $3.27 \%$ as initially awarded. On the other hand, the low number of tenderers caused the final price of the contract to increase by $11.56 \%$. In the case of Slovak Republic Šípoš and Klátik (2013) analyzed all levels of public procurement in 2012, focusing on the impact of competitiveness, electronic auctions and the method of tendering. Their research has shown that the price decreases with the increasing number of offers, up to a maximum of five. On average, electronic auctions reduce the price by $5 \%$ and the use of open tenders also helps lower the final price.

\section{Picture 1: Website of ECS}

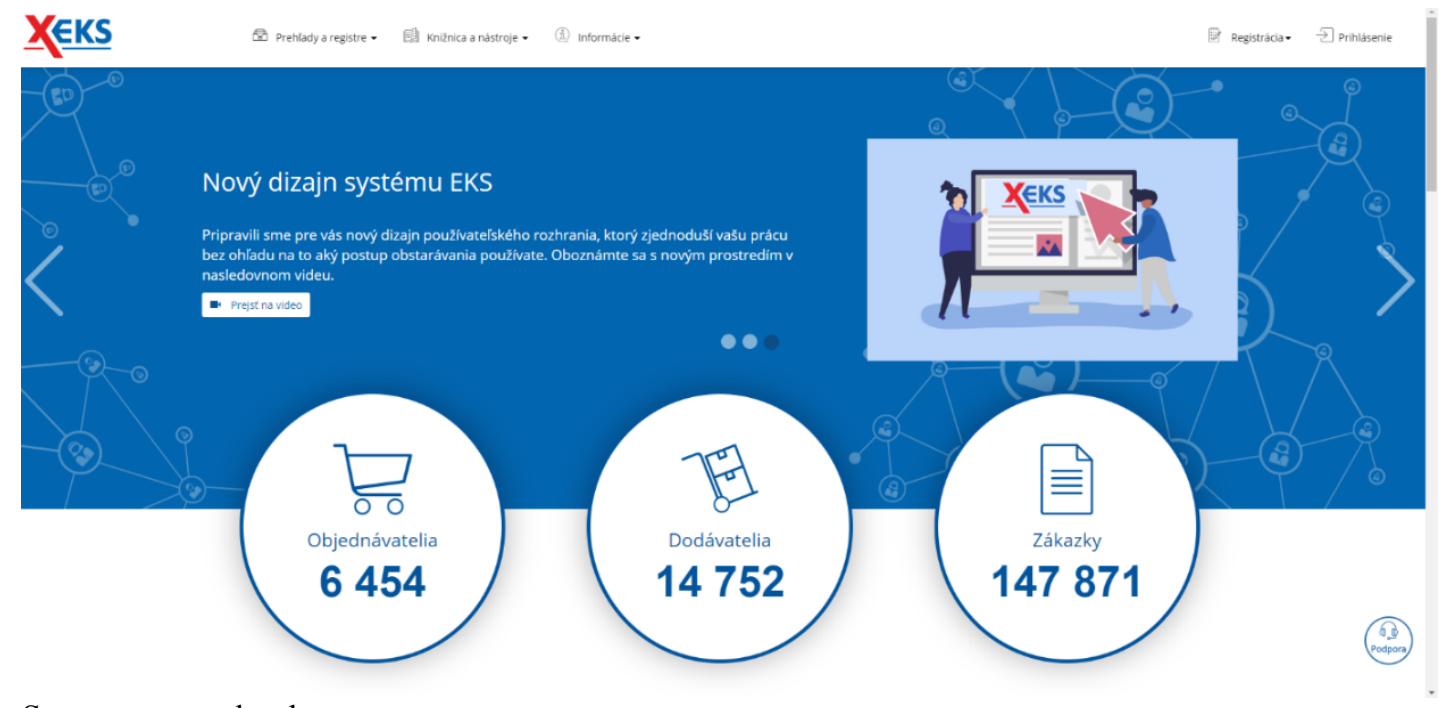

Source: www.eks.sk

The public procurement cycle begins with planning, which is an indispensable step towards successful procurement in an economic, efficient, transparent and fair way. When procuring advisory services, the procedure varies from country to country. Some countries use contract selection methods to select consultants because they relate to the procurement of goods and works. Others use standardized methods (laws, regulations, guidelines), which more and more countries incorporate into their legislation (Khan, 2018). The process of the individual steps 
from the contract announcement to closing of the contract which using in Slovak Republic is shown in picture 2 .

Picture 2 Process diagram of the individual steps of ECS in Slovak Republic

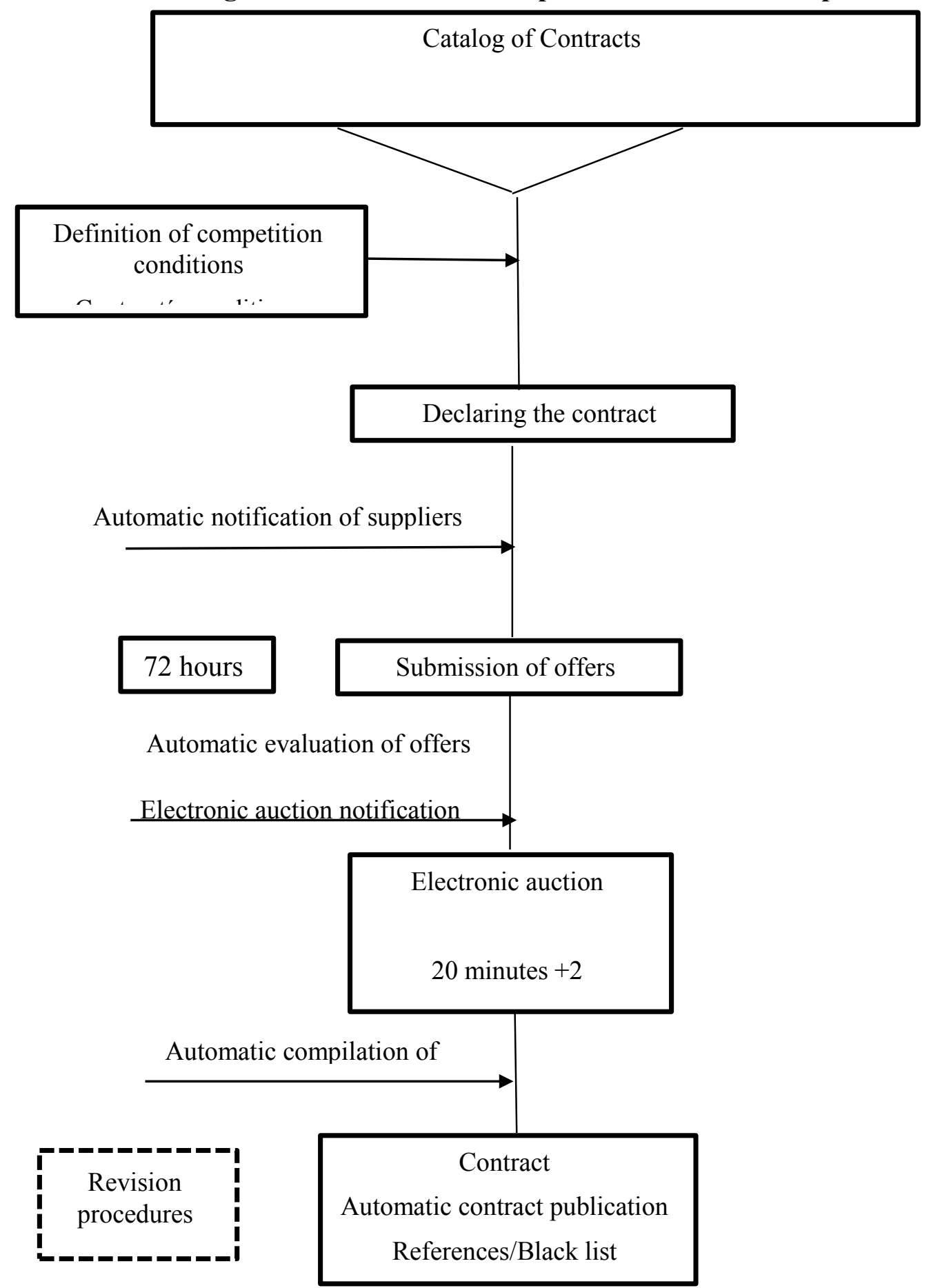

Source: www.eks.sk

In Sweden, public procurement is very similar to Slovak Republic. The municipality (contracting authority) chooses the auction format and the award mode (free or restricted). The call for tenders is followed by a two-stage auction: in the first stage (invited) suppliers decide on their participation. In the second phase, the participating suppliers submit their tenders. The last step is to select the winner according to the criteria for the evaluation of tenders Hyytinen et al. (2018). 
Figure 1: Development of the indicator of public procurement - decision speed in V4 countries in time period 2015-2018

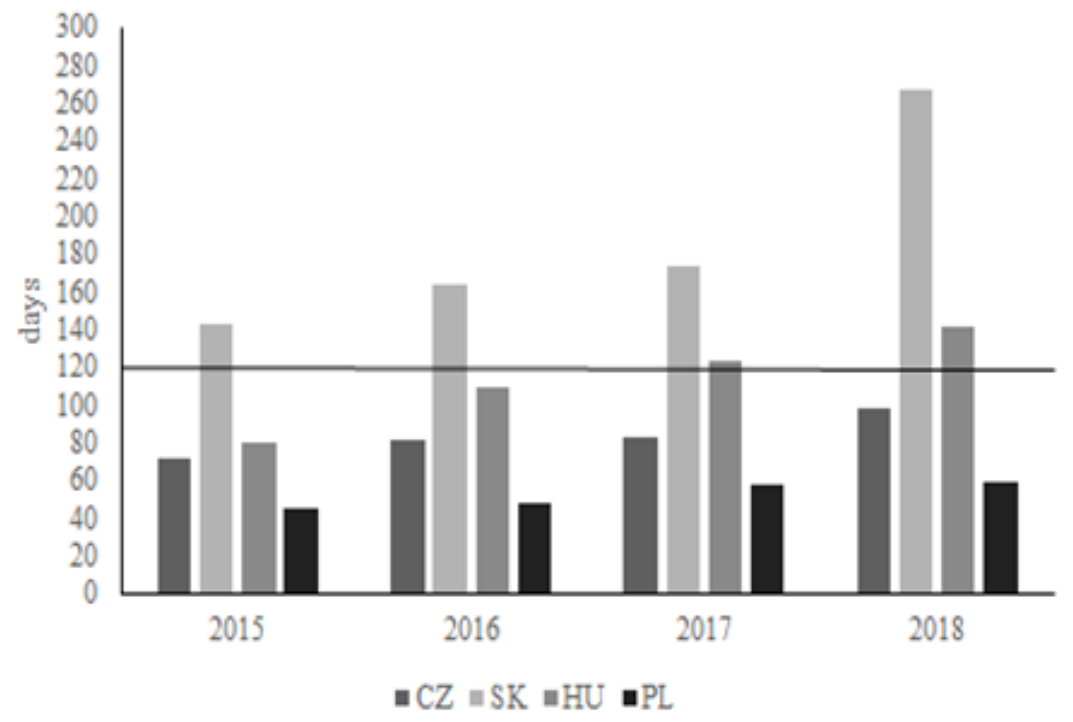

Source: European Commission, TED, our processing

An important aspect of the public procurement process is also the middle decision period, it means, the time between the deadline for receipt of tenders and the date of award of the contract. This indicator in Slovak Republic ranged in the time period 2015-2018 in the range of 142-267 days, which is far above the EU average of, which is 120 days (figure 1). The other V4 countries except Hungary achieved below the EU average each year. It follows that such lengthy procedures make individual contracts more expensive and at the same time create uncertainty for both public buyers and companies.

In The ECS in Slovak Republic is trade in following 16 areas: food, agricultural products and catering services $\square$ clothing, footwear and textile, protective and working clothing $\square$ health care $\square$ cleaning of equipment, means, hygiene and service cleaning $\square$ materials, chemicals and chemical products $\square$ building materials, buildings works, repair and maintenance and consulting of consulting services $\square$ machinery, mechanism and transport equipment and transportation services $\square$ technical, electrical equipment, hw/sw and related services $\square$ security devices, equipment, security and safety services, security systems including accompanying services $\square$ electrotechnical equipment, lighting and measurement technology $\square$ electric, gas, fuel and public services $\square$ office equipment $\square$ equipment and accessories of kitchen, school and office $\square$ educational services $\square$ communal goods and services $\square$ others. The most number of contracts were realized in 2016 (table 1). Comparison between 2015 and 2016, the number of contracts realized by ECS increased by 1029 . As of $1^{\text {st }}$ January 2019, the amendment to the Act on Public Procurement applies, where the act does not apply to contracts up to 5,000 €. It is one reason for the sharp drop of the number of contracts is this amendment. In practice mean that such contracts, which not exceed the established financial limit, can be ordered by direct award without public procurement. 
Table 1: Trading on the ECS in the period 2014-2019

\begin{tabular}{|l|c|c|c|c|c|c|}
\hline $\begin{array}{l}\text { Number of } \\
\text { contracts }\end{array}$ & $\mathbf{2 0 1 4}$ & $\mathbf{2 0 1 5}$ & $\mathbf{2 0 1 6}$ & $\mathbf{2 0 1 7}$ & $\mathbf{2 0 1 8}$ & $\mathbf{2 0 1 9}$ \\
\hline $\begin{array}{l}\text { Contract price } \\
\text { (ths.€) }\end{array}$ & 1306.6 & 471.6 & 17437.8 & 19839.2 & 16227.1 & 23983.1 \\
\hline Saving (ths. $€$ ) & 281.2 & 209.3 & 4617.4 & 3409.8 & 989.4 & 2579.8 \\
\hline
\end{tabular}

Source: www.eks.sk, our processing

Although the system has predefined 16 groups within which it is possible to trade, it is mostly traded in the category - office equipment. In 2014, these contracts accounted for $45 \%$ of all contracts. In the following year, these contracts slightly decreased, to $40 \%$ of the total number of contracts. We are seeing a decline of the numbers of these contracts also in the others years. Of the total number of contracts in 2016, contracts for office equipment only accounted for $19 \%$, and in the following years only $17 \%$ respectively $15 \%$ (Figure 2 ). Office equipment is a daily part of the performance of administrative staff in public administration. The need to use the EKS system when contracting goods up to $1,000 €$ without VAT has complicated the situation considerably, as the procurement process is relatively time consuming. Subsequent changes in the Act on Public Procurement, in particular an increase in the financial limit, accelerated the entire purchasing process and, on the other hand, reduced the volume of contracts goods within this category.

Figure 2: Development of the number of contracts in individual groups of goods and services in time period 2014-2019

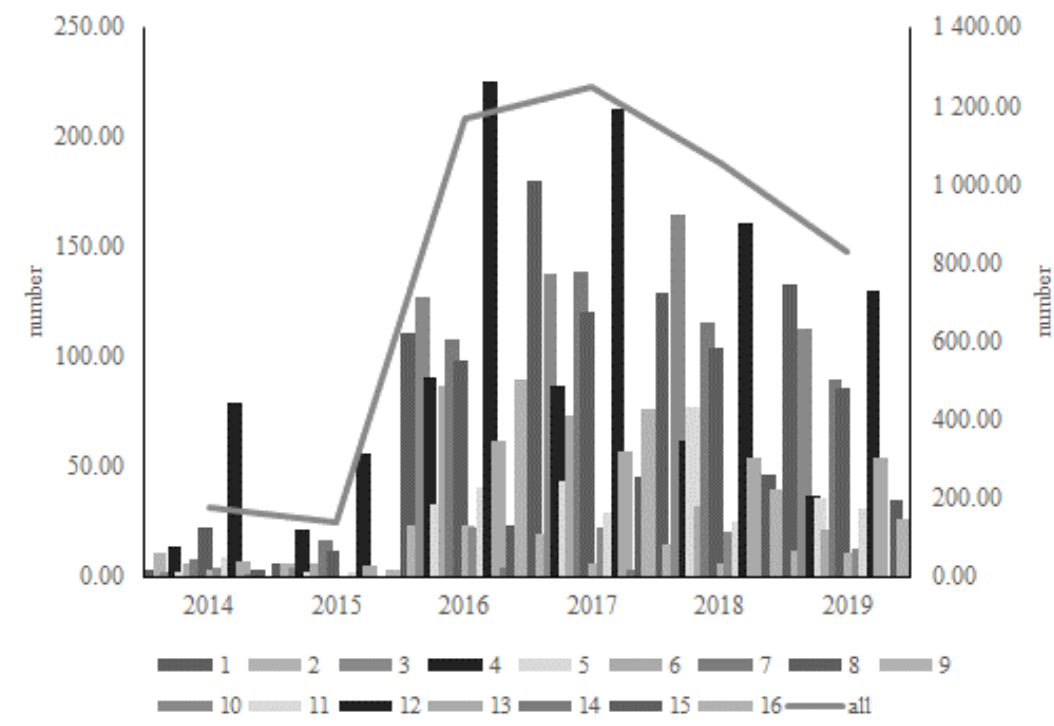

Legend: 1-food, agricultural products and catering services, 2-clothing, footwear and textile, protective and working clothing, 3-health care, 4cleaning of equipment, means, hygiene and service cleaning, 5-materials, chemicals and chemical products, 6- building materials, buildings works, repair and maintenance and consulting of consulting services, 7- machinery, mechanism and transport equipment and transportation services, 8- technical, electrical equipment, hw/sw and related services, 9- security devices, equipment, security and safety services, security systems including accompanying services, 10- electrotechnical equipment, lighting and measurement technology, 11- electric, gas, fuel and public services, 12- office equipment, 13- equipment and accessories of kitchen, school and office, 14- educational services, 15- communal goods and services, 16- others

Source: www.eks.sk, our processing

In the first year, contracts were placed in all groups except for other goods and services. However, there was a change in the following year. In 2015, no contracts were awarded for security systems and equipment, electrical equipment, educational services and communal services and goods. In 2017, the highest number of machines and transport equipment has been procured since started ECS system (139 contracts). The similar situation was also with contracts 
of food, agricultural products and catering services (figure 3). Within health care, the highest number of contracts was registered in 2018 (165 contracts).

Figure 3: Development of the contracts price in individual groups of goods and services in time period 2014-2019

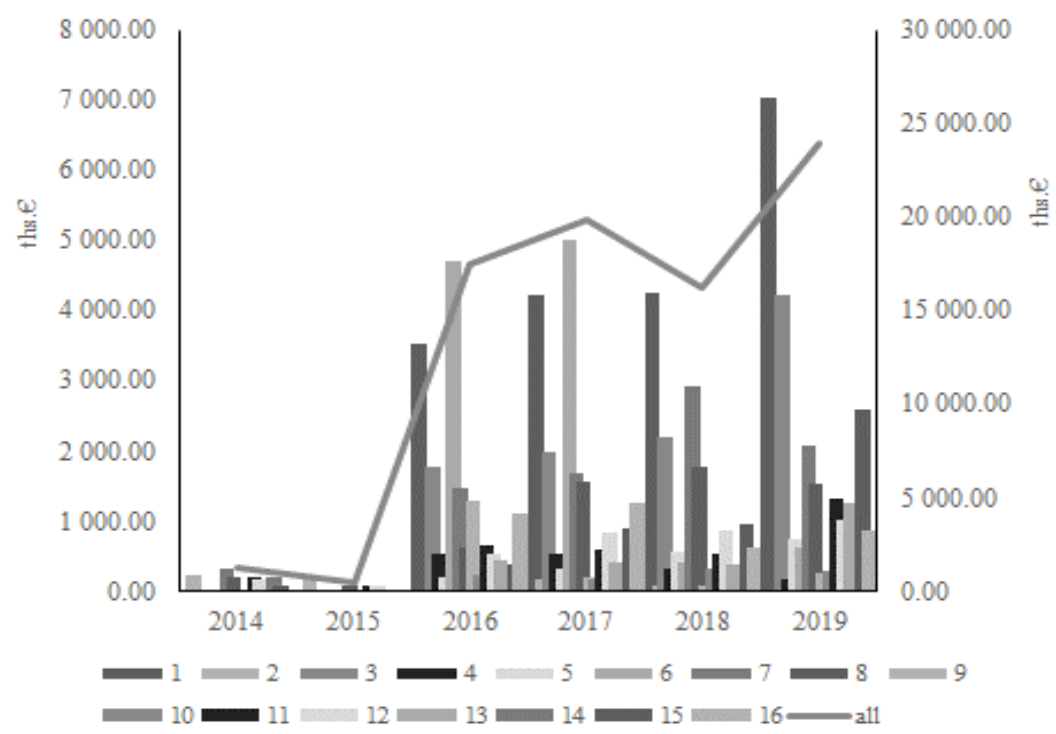

Legend: 1-food, agricultural products and catering services, 2-clothing, footwear and textile, protective and working clothing, 3-health care, 4cleaning of equipment, means, hygiene and service cleaning, 5-materials, chemicals and chemical products, 6- building materials, buildings works, repair and maintenance and consulting of consulting services, 7- machinery, mechanism and transport equipment and transportation services, 8- technical, electrical equipment, $\mathrm{hw} / \mathrm{sw}$ and related services, 9 - security devices, equipment, security and safety services, security systems including accompanying services, 10- electrotechnical equipment, lighting and measurement technology, 11- electric, gas, fuel and public services, 12- office equipment, 13- equipment and accessories of kitchen, school and office, 14- educational services, 15- communal goods and services, 16- others

Source: www.eks.sk, our processing

The highest total savings more than 4.6 mil. $€$ was in 2016. In individual groups, the highest savings in this year was achieved in group - building materials, buildings works, repair and maintenance and consulting of consulting services $(2,1$ mill. $€)$. In contrast, the lowest total savings was in 2018 amounted to 1.9 mil. $€$. (Figure 4).

Figure 4: Development of the savings in individual groups of goods and services in time period 2014-2019

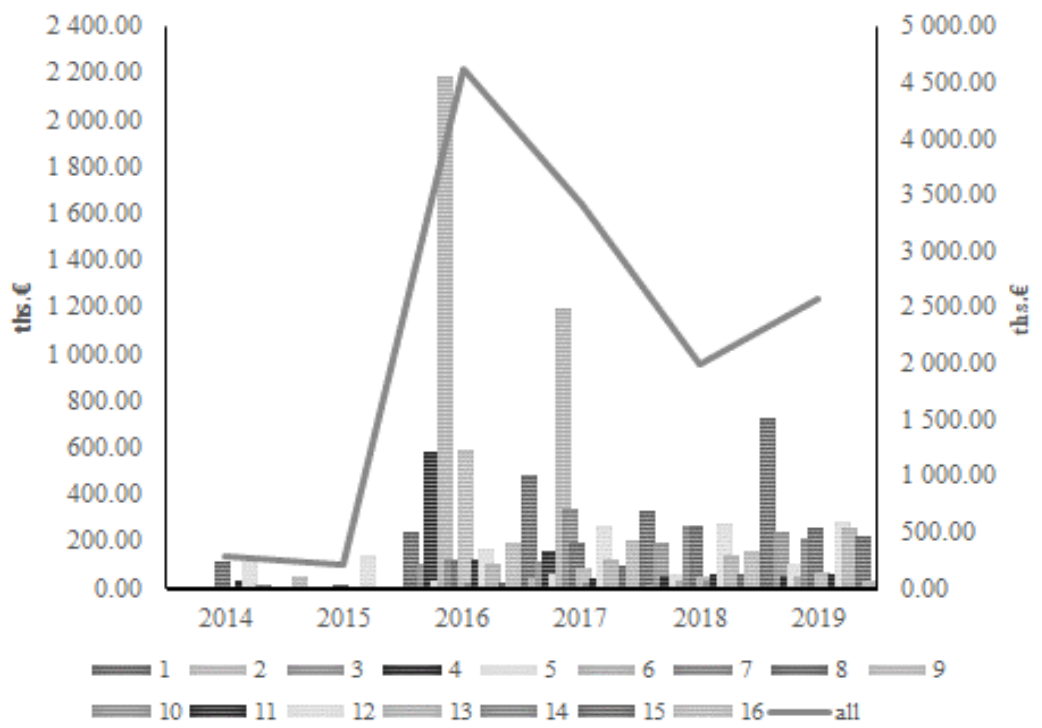

Legend: 1-food, agricultural products and catering services, 2-clothing, footwear and textile, protective and working clothing, 3-health care, 4cleaning of equipment, means, hygiene and service cleaning, 5-materials, chemicals and chemical products, 6- building materials, buildings 
works, repair and maintenance and consulting of consulting services, 7- machinery, mechanism and transport equipment and transportation services, 8- technical, electrical equipment, hw/sw and related services, 9- security devices, equipment, security and safety services, security systems including accompanying services, 10- electrotechnical equipment, lighting and measurement technology, 11- electric, gas, fuel and public services, 12- office equipment, 13- equipment and accessories of kitchen, school and office, 14- educational services, 15- communal goods and services, 16- others

Source: www.eks.sk, our processing

One reason was the decrease of the total numbers of contracts about 198 compared to the previous year. In 2019, savings in food, agricultural products and catering services grew significantly by more than 2 times compared to the previous year, although the numbers of contracts increased only slightly by $3 \%$ (it represent 4 contracts). Generally we can say that the creation of savings is related primarily to the nature of the ordered goods and services and especially their suppliers. There are some specific goods and services (eg. health care, food industry) in which a less number of suppliers are registered in the ECS system, or the ordered services and goods are very specific. As a result, there is not enough competition from suppliers, respectively there is a monopoly supplier of the goods or services in question. The result of this situation is less savings.

Figure 5: Development of the $\varnothing$ price and $\varnothing$ savings of 1 contract in ECS system in time period 2014-2019

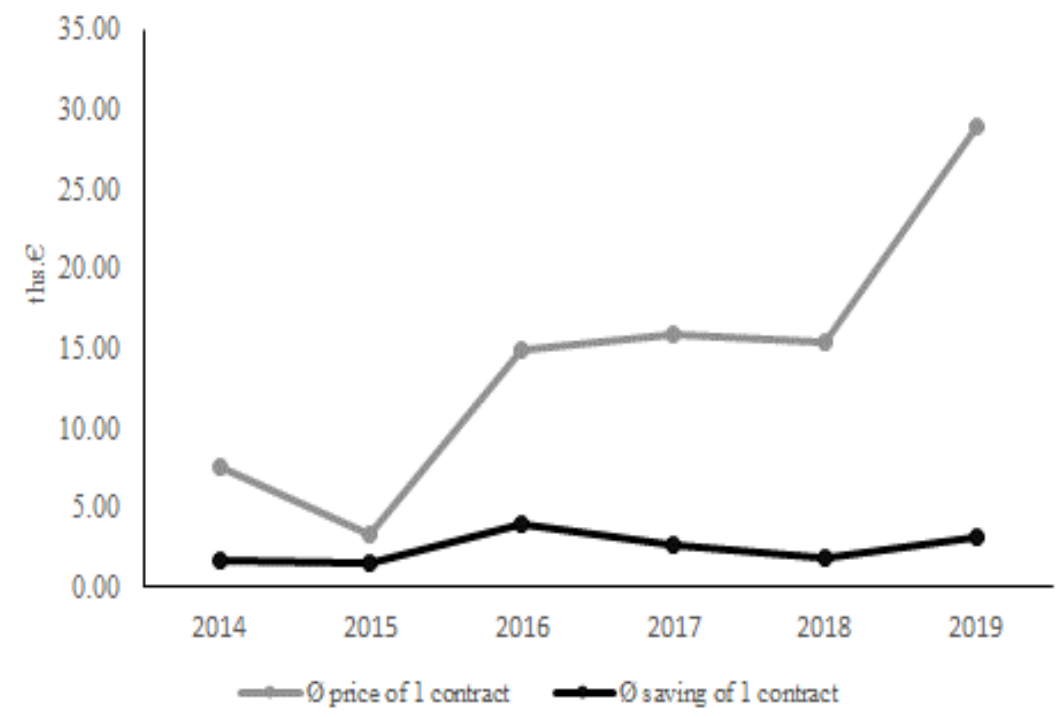

Source: www.eks.sk, our processing

In the analysed time period, the average price of one contract almost four times higher compared to 2014 and 2019. This is mainly related to the increase of the volume of contracted contracts. While in 2014, when the system was started, the average price per contract was 7.5 ths. $€$, already in 2019 it was 28.9 ths. $€$. Although in 2015 it is possible to observe a decrease in the average price of 1 contract, we can say that the ECS system has gradually become a common part of procurement of goods and services within the public administration. Despite the fact that the number of contracts and the total contracted price have changed quite dynamically, the average savings per contract are not so dynamic. Average savings per order in the analysed time period ranged from 1,505.98 €-3,953.21€ (Figure 5).

\section{Conclusion}

The results of the analysis show that although the number of contracts is decreasing, the total contracted amount of contracts increases. This situation is due to legislative adjustments that have increased the minimum financial limits for public procurement, thus reducing the number 
of contracts. On the other hand, the analysis shows that the total financial volume of individual contracts increases in each category. The aim of the implementation of the ECS system was to increase transparency and public control in the award of contracts, as well as more efficient and cost-effective purchase of goods and services. At the same time, it was expected that competition would increase and that there would be create area for including small and mediumsized enterprises get involved into the process of public procurement. The analysis show that the introduction of the ECS system is bringing yearly cost-savings in the ordering of goods and services, and also the process of the public procurement has become more transparent.

\section{References}

[1] Aboelazm, K. S., \& Afandy, A. (2019). Centralization and decentralization of public procurement Analysis for the role of General Authority for Governmental Services (GAGS) in Egypt. Journal of Advances in Management Research, 16(3), 262-276. https://doi.org/10.1108/JAMR-05-2018-0049

[2] Sičáková-Beblavá, Šatníková, S., \& Klátik, P. (2011). Elektronické aukcie vo verejnom obstarávaní: Teória a prax na Slovensku. Bratislava: International Transparency

[3] Euflausino, M. A., \& Ribeiro de Mello, G. (2019). Where the legitimation of sustainable public procurements finds conflict: an analysis of public procurement agents' perceptions on sustainable procurements. Revista de Administração Da UFSM, 12(4). https://doi.org/10.5902/1983465923676

[4] Flynn, A. (2018). Measuring procurement performance in Europe. Journal of Public Procurement, 18(1), 213. https://doi.org/10.1108/JOPP-03-2018-001

[5] Grega, M., Orviska, M., Nemec, J., \& Lawson, C. (2019). Factors Determining the Efficiency of Slovak Public Procurement. NISPAcee Journal of Public Administration and Policy, 12(1), 43-68. https://doi.org/10.2478/nispa-2019-0002

[6] Hudáková, J. (2015). Analysis of Foreign Trade Among Slovakia and the Country V4 after the Changeover. Chinese Business Review, 14(3), 119-125. https://doi.org/10.17265/1537-1506/2015.03.001

[7] Hyytinen, A., Lundberg, S., \& Toivanen, O. (2018). Design of public procurement auctions: evidence from cleaning contracts. RAND Journal of Economics, 49(2), 398-426. https://doi.org/10.1111/1756-2171.12232

[8] Issabayeva, S., Yesseniyazova, B., \& Grega, M. (2019). Electronic Public Procurement: Process and Cybersecurity Issues. NISPAcee Journal of Public Administration and Policy, 12(2), 61-79. https://doi.org/10.2478/nispa-2019-0014

[9] Khan, N. (2018). Public Procurement Fundamentals: Lessons from and for the Field. Emerald Group Publishing Ltd.

[10] Krajcirova, R., Vanova, A. F., \& Orszaghova, D. (2016). Profit Distribution and Payment of Dividends in Certain Commercial Companies and Cooperatives in Terms of Accounting and Tax Legislation of the Slovak Republic and the European Union. In Auzina, A. (Ed.) New Dimensions in the Development of Society Marketing and Sustainable Consumption Finance and Taxes (pp. 296-304). Latvia: Univ Agriculture.

[11] McGregor Pelikánová, R. \& Cvik, E. D. (2019). Awareness And Perception of Modernized Electronic Public Procurement - Czech Case Study. Ad Alta: Journal of Interdisciplinary Research, 9(1), 34-40. h

[12] Nowicki, H. (2018). Economic Policies, Objectives, and Principles of The System of Public Procurement Law. Polityka Gospodarcza a Cele i Zasady Systemu Prawa Zamówień Publicznych., 23, $203-219$. https://doi.org/http://dx.doi.org/10.12775/SIT.2018.035

[13] Pavel, J. (2010). Analýza vlivu míry konkurence na cenu rozsáhlých staveb dopravní infrastruktury. Politická ekonomie, 58(3), 343-356. DOI: 10.18267/j.polek.734

[14] Preda, I. (2019). Swot Analysis of the Public Procurement System in Romania. Knowledge HorizonsEconomics, 11(2), 66-76. www.orizonturi.ucdc.ro

[15] Sergeeva, S. A. (2018). Sustainable Socio-Economic Development of the Country Using the Results of Statistical Analysis of the Public Procurement Volume. Astra Salvensis, 147-158.

[16] Sostar, M., \& Marukic, A. (2017). Challenges of Public Procurement in EU Funded Projects. Management, 22(2), 99-113. http://hrcak.srce.hr/management?lang=en

[17] Svidroňová, M. M., Meričková, B. M., \& Gondášová, L. (2016). E-procurement in Contracting-out of Public 
Goods and Services: Evidence from Slovakia. Nispacee Journal of Public Administration and Policy, Vol. 9 , No.1, Pp. 57-71. ISSN 1337-9038, 9(1), 57-71. https://doi.org/https://doi.org/10.1515/nispa-2016-0003 Open access

[18] Š́́poš, G., \& Klátik, P. (2013). Kvalita verejného obstarávania na Slovensku v roku 2012. http://www.transparency.sk/wp-content/uploads/2013/01/TIS-Analyza-VO-2012-1.pdf

[19] Šumpíková, M., \& Ďurčeková, I. (2019). Transaction Costs, Outsourcing, and the Public Procurement Review Process in the Czech Republic and Slovakia. NISPAcee Journal of Public Administration and Policy, 12(2), 233-250. https://doi.org/10.2478/nispa-2019-0021

[20] Vavrek, R., \& Benkova, E. (2018). Performance of EU Countries over Time and Its Spatial Autocorrelation. In Stanickova, M and Melecky, L and Kovarova, E and Dvorokova, K (Ed.), Proceedings of the 4th International Conference On European Integration 2018 (ICEI 2018), PTS 1-3 (pp. 1563-1570). Vsb-Tech Univ Ostrava. 


\title{
Assessing of Businesses Environment's Essential Indicators in Indonesia
}

\author{
Renáta Krajčírová ${ }^{1}$, Martina Krajčírová2 ${ }^{2}$ Alexandra Ferenczi Vaňová ${ }^{3}$, Jozef \\ Bojňanský ${ }^{4}$ \\ Slovak University of Agriculture in Nitra, \\ Faculty of Economics and Management, Department of Accounting ${ }^{1,2,3,4}$, \\ Address: Tr. A. Hlinku 2, \\ 94976 Nitra, Slovakia \\ e-mail: renata.krajcirova@uniag.sk¹,xkrajcirova@is.uniag.sk², alexandra.ferenczi@uniag.sk², \\ jozef.bojnansky@uniag.sk ${ }^{4}$
}

doi: 10.18515/dBEM.ISD.P01.2020.p044

\begin{abstract}
Indonesia is the fourth most populous country of Southeast Asia and currently becomes to one of the mostly expanded country. The article assesses the selected business environment's indicators of political, economic, social and technological environment. The indicators such as the development of the corruption perception index, gross domestic product, unemployment rate and inflation rate as well as the assessment of selected issues tax system are presented and those are essential in the investment process and they represent the base for the elaborated analysis of strengths and weaknesses, opportunities and risks by means of which the future country development can be predicated.
\end{abstract}

Keywords: gross domestic product, unemployment rate, inflation rate, corruption

JEL Classification: E 60, E 69, F 00

\section{Introduction}

The Republic of Indonesia is the member of several international organizations and groups. It is the founding member of the Association of Southeast Asian Nations (ASEAN). The organization was founded in 1967 in order to stabilize security in the region and economic cooperation (Association of Southeast Asian Nations, 2019). Indonesia is the part of the World Trade Organization (WTO), the United Nations Organization (UNO), the group of biggest economics in the world G-20, the International Monetary Fund (IMF), the Asia-Pacific Economic Cooperation (APEC). It is also the member of the Organization of the Petroleum Exporting Countries (OPEC), the organization of developing states G-33 and the development association of the largest Muslim countries D-8. Indonesia is the part of Asian Development Bank, the Asian Infrastructure Investment Bank and the World Bank.

In 1992 the country signed the significant agreement on trade ASEAN Free Trade Area (AFTA). Since 2010 it directs to the common trade based on the ASEAN Trade in Goods Agreement (ATIGA). The essential step to this aim was the elimination of reciprocal duties after forming the ASEAN Economic Community (AEC) in 2016. As the part of ASEAN, it signed the FTA (Free trade agreement) with Chine and Australia, from 2010 with the New Zealand and later with Korea. Indonesia - Japan Economic Partnership Agreement was signed in 2008 (the Ministry of Foreign Affairs of the Slovak Republic, 2019).

Since 2016 Indonesia negotiates Comprehensive Economic Partnership Agreement (CEPA) with the European Union. The last negotiation took place in June 2019 and indicates the progress in negotiation, mainly from the point of view of conditions, market entrance, the enhancement of common trade and direct investments (European Union External Action, 2019).

Indonesia has navigated the transition from authoritarian to democratic rule quite successfully (Basri \& Hill, 2020). Jakarta the capital of Indonesia, is one of the rapidly growing coastal 
megacities in Asia (Dsikowitzky et al., 2020). The development of urban areas and settlements by the government and the private sector has an impact on the environment, for that they need to develop a city planning plan based on the concept of environmentally friendly sustainable development (Susila Adiyanta, 2020). Asia's infrastructure needs from 2016 to 2030 will exceed USD 26 trillion (Guild, 2020).

\section{Data and Methods}

The aim of the article is to assess the businesses environment in the Republic of Indonesia by means of the development of selected macroeconomic indicators in the period of years presented by the corruption perception index, gross domestic product, unemployment rate and inflation rate as well as the assessment of selected taxes in the country. These values are significant indicators representing qualitative and quantitative evolution of the economy.

Data are acquired mainly from the available database sources of the Ministry of Foreign Affairs, the European Central Bank, the Word Bank and the International Monetary Fund.

Inductive-deductive, analytical-synthetical and comparative scientific methods present the base for the article processing.

The article presents the assessment of political-legal, economic, social-cultural and technological environment as well as the factors which influence or will influence the business environment of the country in the period of 1996 to 2018. In case of corruption the development of corruption index is assessed in the period of 2012 to 2018. In addition, current tax system are described within the article processing.

The assessment of selected indicators resulted in the identification of strengths, weaknesses, opportunities and threats of business environment of the assessed country. SWOT are to be described as the tool of strategic analysis to make useful and identify the competitive advantage of the country.

\section{Results and Discussion}

The essential factor which needs to be treated from the point of country functioning and political environment is the level of corruption in the country. Corruption Perception Index (CPI) assesses the country in accordance with the perceived corruption in the public sector and in 2018 it obtained the value 38 in the Republic of Indonesia and within the total ladder of assessed countries Indonesia placed in the $89^{\text {th }}$ place. It can be stated that the level of corruption in the Republic of Indonesia is above the average. In 2017 the country place in the $96^{\text {th }}$ place from 180 (Transparency International, 2018). This placement presents the value of CPI 37. From the annual change it can be noted that the current country placement in the area of corruption improved, what in the worldwide ranking meant the improvement of position by 7 places. Figure 1 assesses the Corruption Perception Index in the years 2012 till 2018. Even though the Republic of Indonesia is progressing in the question of corruption, the crucial rate of corruption is still the part of business environment in the country (Department for International Trade, Foreign and Commonwealth Office, 2018). 
Figure 1: The development of Corruption Perception Index

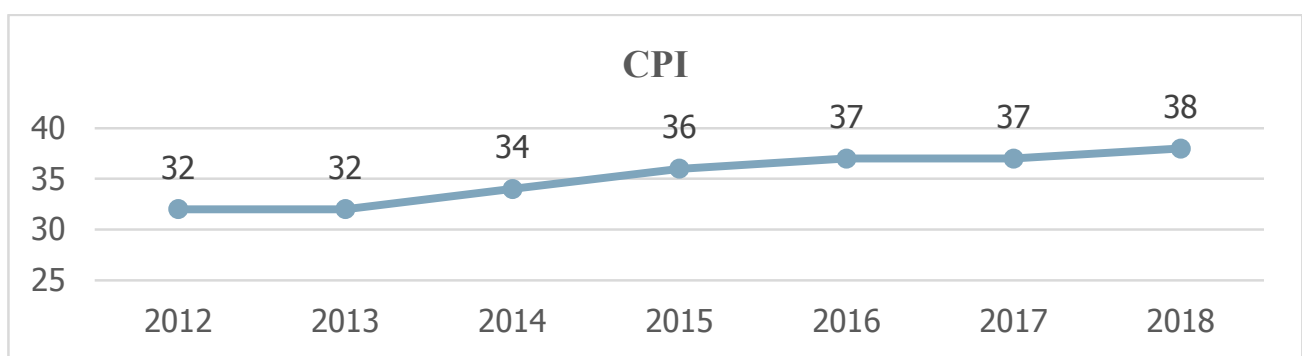

Source: Transparency International, https://www.transparency.org/

Indonesia is the largest economy in Southeast Asia and according to purchasing power parity is the $10^{\text {th }}$ largest economy of the world (The World Bank Group, 2019). The aim of the longterm development plan RPJMN (Rencana Pembangunan Jangka Menengah Nasional) is the creation of self-sufficient, equitable, democratic, peaceful and uniform country. The plan contains the institutional restructuring and its aim is to sustain the economy in a growing development. The concerned plan deals mainly with the improvement of infrastructure, social programme with the emphasis to the education and health care. The public expenditures in these areas were available thanks to the reform of long-term energetic subsidies. In the economy of Indonesia, the private sector prevails. This fact secured the bigger stability in comparison with the countries with lower dependency on the private sector within the global crisis in years 2008 and 2009. The currency of the Republic of Indonesia is the Indonesian rupiah (IDR). As at 1 November 2019 according to the European Central Bank the exchange rate (EUR) to Indonesian rupiah was set in the ratio EUR $1=$ IDR 15 640.93. For the year 2019, since 1 November 2018 the average of exchange rate of this currency against the euro was disclosed to the value of 15999.39 (European Central Bank, 2019).

In general, the Gross Domestic Product (GDP) is the most complex indicator and is determined by the domestic consumption, investments, governmental expenditures and foreign trade balance. The development of GDP change of the Republic of Indonesia in the years 1996 till 2018 in percentage presents Figure 2. The main factor which positively supports the growth of economy is the domestic consumption, approximately in the amount of $60 \%$, which is positively influenced by domestic and direct foreign investments in the amount of $33 \%$, the size of country population and the growth of middle-class population.

Figure 2: The development of gross domestic product

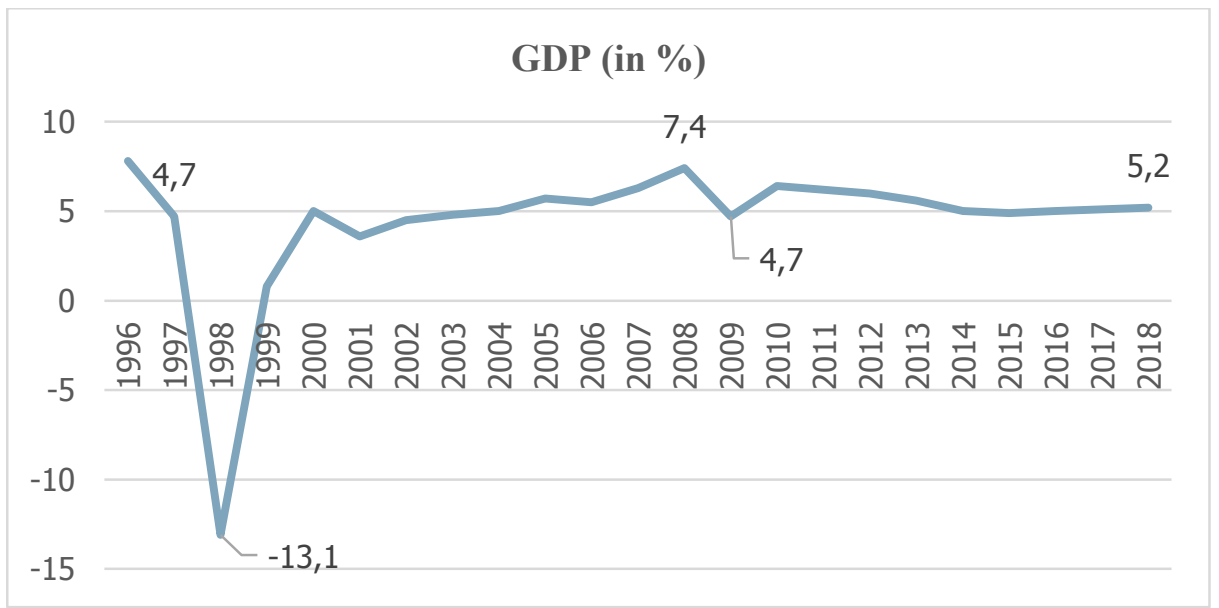

Source: International Monetary Fund, https://www.imf.org/

Figure 2 presents the significant change in the growing trend of GDP in the years 1996 till 1999, as well as in the years 2008 and 2009. The decline of GDP change achieved the negative value 
in the amount of $13.1 \%$ because of Asian crisis in the years 1997 and 1998 . Within this period the depreciation of Indonesian currency towards the American dollar can be observed up to $600 \%$. The process of recovery from the crisis was gradual because it included a comprehensive process of introducing new institutions and other administrative changes in the country. In the years 2000 till 2008 the growing trend of GDP from 5\% to $7.4 \%$ can be determined. In 2008 the economy of Indonesia was influenced by the world financial crisis. The result of its influence was the slow-down of annual growth of GDP from $7.4 \%$ to $4.7 \%$. The economy of the Republic of Indonesia is influenced mainly by the behaviour of domestic consumers, thanks to what the world crisis in the year 2018 did not affect Indonesia significantly. From 2010 till the present no further significant ups and downs were in the development of GDP. According to the data of International Monetary Fund, in 2018 GDP obtained the value of $5.2 \%$. In the absolute expression the value of GDP of the Republic of Indonesia presented the value 1.042B USD in 2018 (The World Bank Group, 2019). Based on the acquired data of GDP per capita presents the value 4.16K USD. In comparison with the developed countries of Indonesia it still obtains very low values. Nevertheless, in comparison with neighbour countries like Philippines (3.2K USD), Papua New Guinea (2.74K USD) and East Timor (2.26K USD), the value of GDP per capita was significantly higher in Indonesia. Despite of this, the value of GDP per capita in Indonesia is substantially behind in comparison with Australia (53.83K USD), Malaysia (11.14K USD) and Thailand (7.79K USD) (International Monetary Fund, 2019).

The percentage expression of employment in the country by sectors is partially differentiated from the ratio of GDP in individual sectors of Indonesia (Figures 3 and 4). The area of agriculture has the lowest ratio in the creation of GDP within the selected factors, but it employs the majority of economically active population.

Figure 3: GDP by sectors

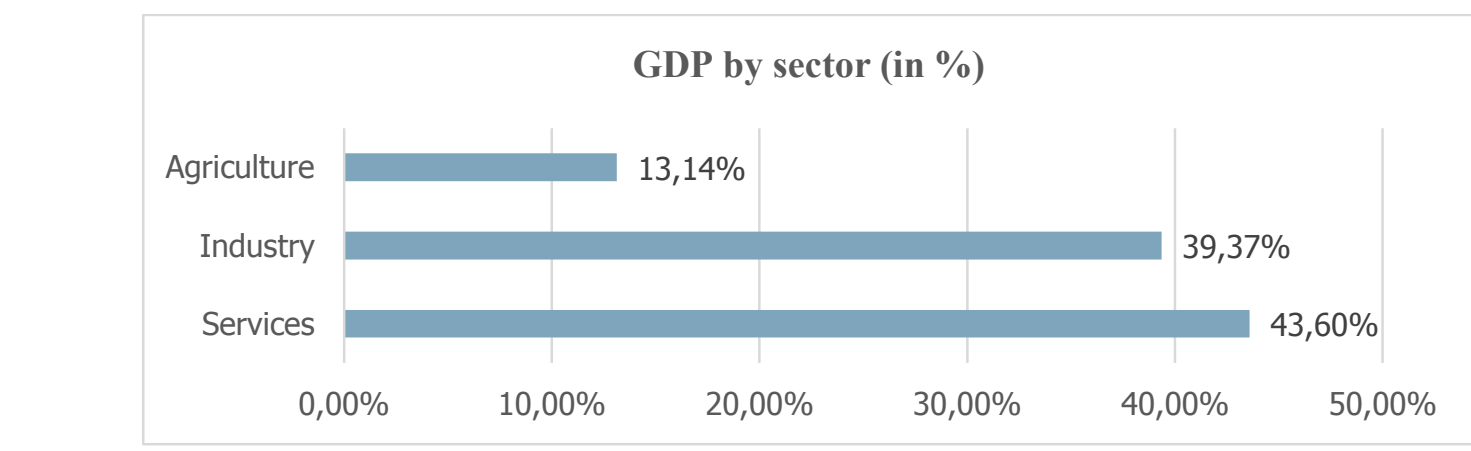

Source: Ministry of Foreign Affairs of the SR, https://mzv.sk/

In 2018 the unemployment rate in Indonesia was in the value of 5.3\% (The World Bank Group, 2019). As regards the size of population in Indonesia and the fact that annually the labour market is increased by almost $2 \mathrm{M}$ of economically active population, there is a challenge for the country to create enough jobs and hereby there is an opportunity for foreign investments. From the point of view of business environment this indicator is assessed from the provincial aspect. The data of unemployment rate in August 2018 report the lowest values in the province Bali, which obtained the unemployment rate in the amount of 1.37\% (Badan Pusat Statistik, 2019). In this context, please note that almost the half of the population is less than 30 years of age. 
Figure 4: Population employment by sectors

Population employment by sectors

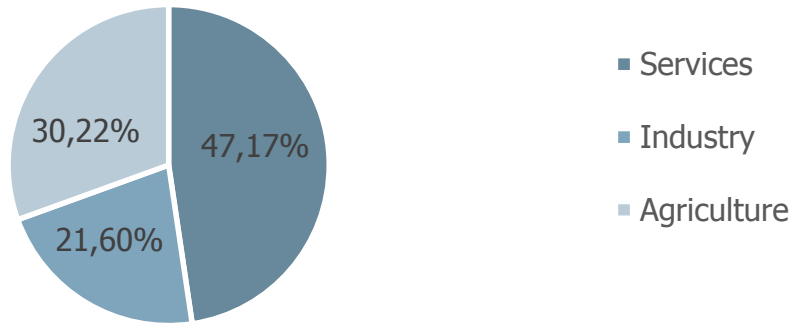

Source: Ministry of Foreign Affairs of the SR, https://mzv.sk/

Pursuant to the data of the World Bank the inflation rate presented the value $3.81 \%$ in 2017 . The crucial ups and downs were reported in the years 1998 and 1999 when the inflation rate achieved extreme values in the amount of $58.45 \%$ and $20.48 \%$. They were caused by Asian crisis (Chappelow, 2019). The development of inflation rate was stabilized after the crisis period and obtained approximately the value of $6.99 \%$ in the years 2000 till 2017. (Figure 5).

\section{Figure 5: Inflation rate development}

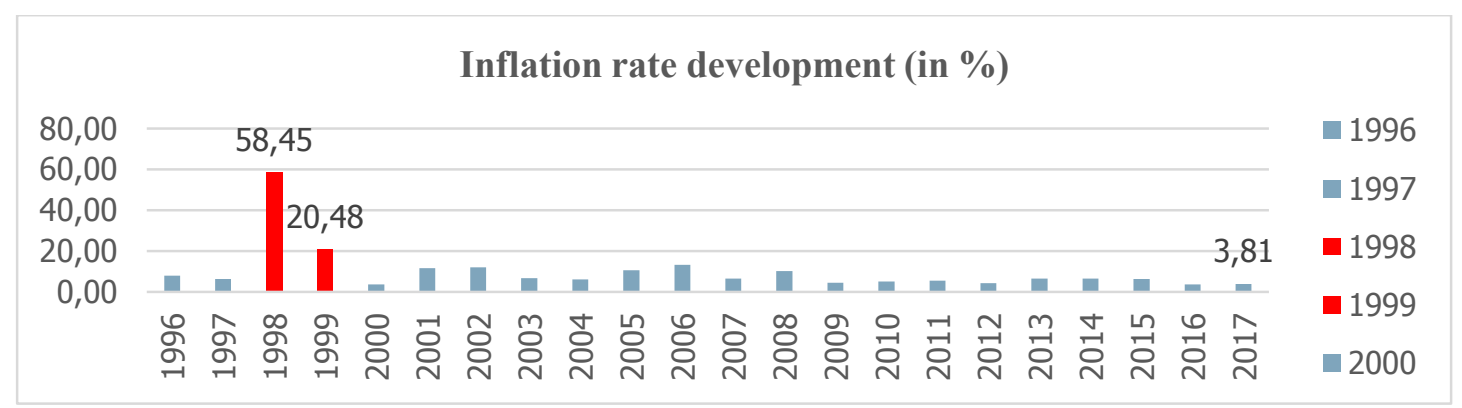

Source: World Bank, https://data.worldbank.org/

The crucial factor in the decision-making process of foreign investor entrance to business environment of this country is the assessment of tax policy.

It can be stated that the tax system of the Republic of Indonesia significantly differentiates from systems of other countries of Southeast Asia as well as the EU countries. In general, the tax system of Indonesia contains direct and indirect taxes. The country tax incomes present approximately 12 or $13 \%$ of GDP and are one of the tools for the improvement of business environment. The current income tax rate of legal persons is in the amount of $25 \%$. Legal entities / companies with gross sales till 50B IDR can deduct 50\% from the standard income tax rate of legal persons. The income tax of legal persons in the amount of $20 \%$ can be applied by a company which is listed on the Indonesian stock exchange (IDX) and at least $40 \%$ of its shares is listed on this stock exchange.

The natural person is treated as the tax resident if he has permanent residence in Indonesia, respectively he stays in the country more than 183 days for 12 months period or the natural person is located in the country during the fiscal year or he intends to become a resident of Indonesia (PWC, 2019). Table 1 presents the actual income tax rate of legal persons. 
Table 1: Income tax rate of natural persons

\begin{tabular}{|l|c|}
\hline Income in M IDR & Income tax rate in \% \\
\hline$<$ 50M IDR & 5 \\
\hline$>$ 50M IDR < 250M IDR & 15 \\
\hline > 250M IDR < 500M IDR & 25 \\
\hline$>$ 500M IDR & 30 \\
\hline
\end{tabular}

Source: Indonesian Pocket Tax Book 2019

Currently the basic rate of value added tax is in the amount of $10 \%$ which is applied to supply of goods or services in Indonesian customs area. In a particular case the tax rate can be increased up to $15 \%$ or decreased to the level of $5 \%$. The tax subject from luxury goods are selected goods where the rate of $75 \%$ is applied. The goods export from Indonesia is exempt from tax.

Tax allowances can be required in Indonesia. The regulation of tax allowances in the tax area means the decrease of tax rates of direct taxes, value added tax and import customs as well as the advantage of assets depreciation. These advantages are applied mainly in less developing areas of the Republic of Indonesia with insufficient infrastructure and higher unemployment rate.

In 2017 the expenditures on research and development presented $0.24 \%$ of GDP (The World Bank Group, Unesco Institute for Statistics, 2017). In comparison with the year 2019 the ratio of expenditures on research and development in relation to GDP presented only $0.08 \%$ (Robertson, 2019). Based on this fact the increase of expenditures on technological development can be observed.

Infrastructure is one of the governmental priorities in Indonesia. There are 673 airports, 8.159 $\mathrm{km}$ of railway lines and more than $496 \mathrm{~K}$ of roads in the country. Despite the high number of road kilometres, approximately $40 \%$ present the roads of unpaved character. Insufficient infrastructure together with high population present the problem in the form of traffic restrictions. The indicator of railway infrastructure is used for better quality assessment of railway infrastructure. It assesses countries in the range from 1 to 7 where the highest value means higher quality. It can be stated that in the period of last ten years there is a continual growth of its quality. In 2009 the indicator presented the value 2.77, while in 2019 it obtained the value 4.7. In the world ranking of this indicator Japan took the first place with the value 6.8. As regards the geographic arrangement of Indonesia, ship transport has a crucial position.

Internet connection as well as communications is an essential factor influencing business environment. Data on mobile network coverage from 2016 state $100 \%$ coverage. The number of internet users for the last ten years increased fivefold. Almost double increase of users can be observed in the period from 2016 till 2018. Despite the users increase the quality, speed and signal in some outfields of Indonesia are insufficient (The World Bank Group, 2019).

Logistic Performance Index (LPI) assesses the areas including the effectiveness of customs administration, simplicity of consignment handling, quality of logistic services and consignment monitoring. They are separately assessed in the range from 1 to 5 . Indonesia took the $46^{\text {th }}$ place from the number of assessed countries, it presents the value of index 3.15 in 2018 . In comparison the highest index LPI took SRN in the amount of 4.20 in 2018 (The World Bank Group, 2018).

\section{Conclusion}

Based on the assessment of selected indicators of business environment of the Republic of Indonesia we concluded strengths, weaknesses, opportunities and risks which shall be considered when an investor starts doing business in Indonesia. 
It could serve as a guide for investors preliminary planning efforts.

Table 2: The assessment of business environment of Indonesia

\begin{tabular}{|l|l|}
\hline Strengths & Weaknesses \\
\hline - Market size & $\bullet \quad$ Corruption \\
- Macroeconomic stability & $\bullet \quad$ Insufficient infrastructure \\
- Prediction of economic growth & $\bullet \quad$ Protectionist measure \\
\hline Opportunities & Risks \\
\hline $\begin{array}{l}\text { - Relatively young population } \\
\text { - Development of technological environment } \\
\text { - Enhancement of expenditures to research and } \\
\text { development }\end{array}$ & $\bullet \quad$ Natural disasters (frequent earthquakes) \\
\hline
\end{tabular}

Source: own processing

Strengths of business environment present competitive advantage of the country. On the other hand, weaknesses present market insufficiencies. Market size means the country population which presents $265 \mathrm{M}$ of inhabitants with prevailing young population of economically active population. The macroeconomic stability in the country is mainly demonstrated in strong domestic consumption. Economic growth in the observed period of years significantly contributes to market attractivity for foreign investments.

Liberalization as one of opportunities influences the decision-making on foreign investors entrance to the country. Young population together with digitalization and technologies present the market with millions of users on social networks and so the possibility of further development in this area.

Despite the decrease in the level of corruption in last years, Indonesia still discloses values above the average. Protectionist measures within foreign trade and foreign investments include closing of several sectors for foreign investors.

The size of Indonesia and its geographic location present several advantages in the form of mineral resources occurrence. On the other hand, the position on the clash of tectonic boards means the dangers of earthquakes and the incidence of volcanic activity.

According to the global index of competitiveness issued by the World economic forum, Indonesia took the $50^{\text {th }}$ place within 141 assessed country in 2019. Within the countries of ASEAN, Indonesia took the $4^{\text {th }}$ place after Singapore, Malaysia and Thailand (Schwab, 2019).

\section{References}

[1] Association of Southeast Asian Nations. (2019). About ASEAN. In: asean.org [online]. Retrieved 17.10.2019 from https://asean.org/asean/about-asean/

[2] Badan Pusat Statistik. (2019). Tingkat Pengangguran Terbuka (TPT) Menurut Provinsi, 1986-2018. In: bps.go.id [online]. Retrieved 23.10.2019 from https://www.bps.go.id/statictable/2014/09/15/981/tingkatpengangguran-terbuka-tpt-menurut-provinsi-1986---2018.html

[3] Basri, Ch. \& Hill, H. (2020). Making Economic Policy in a Democratic Indonesia: The First Two Decades. In: Asian Economic Policy Review, (2020) 9999, 1-21. doi: 10.1111/aepr.12299

[4] Department for International Trade, Foreign and Commonwealth Office. (2018). Guidance: Overseas Business Risk - Indonesia. In: gov.uk [online]. Retrieved 21.10.2019 from https://www.gov.uk/government/publications/overseas-business-risk-indonesia/overseas-business-riskindonesia

[5] Dsikowitzky, L. et al. (2020). Analysis and environmental risk assessment of priority and emerging organic pollutants in sediments from the tropical coastal megacity Jakarta. In: Regional Studies in Marine Science, 34, 101021. doi: https://doi.org/10.1016/j.rsma.2019.101021

[6] European Central Bank. (2019). Indonesian rupiah (IDR). In: ecb.europa.eu [online]. Retrieved 20.10.2019 from 
https://www.ecb.europa.eu/stats/policy_and_exchange_rates/euro_reference_exchange_rates/html/eurofxref -graph-idr.en.html

[7] European Union External Action. (2019). EU-Indonesia CEPA Negotiations. In: eeas.europa.eu [online]. Retrieved 20.10.2019 from https:/eeas.europa.eu/headquarters/headquarters-homepage/53277/euindonesia-cepa-negotiations_en

[8] Guild, J. (2020). The political and institutional constraints on green finance in Indonesia. In: Journal of sustainable finance \& investment. doi: https://doi.org/10.1080/20430795.2019.1706312

[9] Chappelow, J. (2019). Asian Financial Crisis. [online]. Investopedia. Retrieved 24.10.2019 from https://www.investopedia.com/terms/a/asian-financial-crisis.asp

[10] International Monetary Fund. (2019). GDP per capita, current prices, U.S. dollars per capita. In: imf.org [online]. $\quad$ Retrieved $20.10 .2019 \quad$ from https://www.imf.org/external/datamapper/NGDPDPC@WEO/OEMDC/ADVEC

[11] International Monetary Fund. (2019). Real GDP growth, [online]. Retrieved 13.3.2019 from https://www.imf.org/external/datamapper/NGDP_RPCH@WEO/IDvysoký nárast N?year=2019

[12] Ministerstvo zahraničných vecí Slovenskej republiky. (2019). Ekonomická informácia o teritóriu: Indonézska republika. In: mzv.sk [online]. Retrieved 20.10 .2019 from https://www.mzv.sk/documents/10182/620840/Indon\%C3\%A9zia++ekonomick $\% \mathrm{C} 3 \% \mathrm{~A} 9+$ inform $\% \mathrm{C} 3 \% \mathrm{~A} 1 \mathrm{cie}+\mathrm{o}+$ terit $\% \mathrm{C} 3 \% \mathrm{~B} 3 \mathrm{riu}+2019$

[13] PWC. (2019). Indonesian pocket tax book 2019. In: pwc.com [online]. Retrieved 21.10.2019 from https://www.pwc.com/id/en/pocket-tax-book/english/pocket-tax-book-2019.pdf

[14] Robertson, L. (2019). Indonesia needs to get serious about R\&D. [online]. Jakartapost. Retrieved 20.9.2019 from https://www.thejakartapost.com/life/2019/02/18/indonesia-needs-to-get-serious-about-rd.html

[15] Schwab, K., World Economic Forum. (2019). The Global Competitiveness Report 2019. [online]. In: weforum.org. $\quad$ Retrieved 16.11 .2019 from http://www3.weforum.org/docs/WEF_TheGlobalCompetitivenessReport2019.pdf

[16] Susila Adiyanta, F.C. (2020). Urban space governance and sustainable green development in Indonesia. In: International Journal of Energy Economics and Policy, 10(1), 1-6. doi: https://doi.org/10.32479/ijeep.8065

[17] The World Bank Group, Unesco Institute for Statistics. (2017). Research and development expenditure (\% of GDP). In: data.worldbank.org [online]. Retrieved 9.11 .2019 from https://data.worldbank.org/indicator/GB.XPD.RSDV.GD.ZS?end=2017\&locations=ID\&start=2017\&view= bar

[18] The World Bank Group. (2019). Country score card 2018. In: lpi.worldbank.com [online]. Retrieved 16.11.2019 from https://lpi.worldbank.org/international/scorecard/line/254/C/IDN/2018

[19] The World Bank Group. (2019). GDP (current US\$) - Indonesia. In: data.worldbank.com [online]. Retrieved 20.10.2019 from https://data.worldbank.org/indicator/NY.GDP.MKTP.CD?locations=ID\&view=chart

[20] The World Bank Group. (2019). Individuals using the Internet (\% of population) - Indonesia. In:

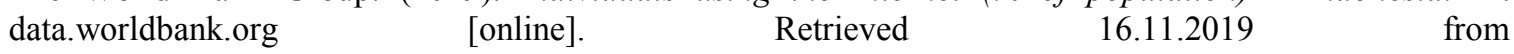
https://data.worldbank.org/indicator/IT.NET.USER.ZS?end=2018\&locations=ID\&start=2008

[21] The World Bank Group. (2019). Inflation, consumer prices (annual \%) - Indonesia. In: data.worldbank.org [online]. $\quad$ Retrieved 23.10 .2019 from https://data.worldbank.org/indicator/FP.CPI.TOTL.ZG?end=2017\&locations=ID\&start=1996

[22] The World Bank Group. (2019). The World Bank in Indonesia. In: worldbank.org [online]. Retrieved 20.10.2019 from http://www.worldbank.org/en/country/indonesia/overview

[23] The World Bank Group. (2019). Unemployment, total (\% of total labor force) (modeled ILO estimate) Indonesia. In: data.worldbank.org [online]. $\quad$ Retrieved 19.10 .2019 from https://data.worldbank.org/indicator/SL.UEM.TOTL.ZS?end=2018\&locations=ID\&start=1996

[24] Transparency International. (2019). Corruprion Perception Index 2018. In: transparency.org [online]. Retrieved 20.10.2019 from https://www.transparency.org/cpi2018\#detail 


\title{
Uzbek Agrarian Foreign Trade and its Competitiveness
}

\author{
Akhmadjon Ortikov ${ }^{1}$, Luboš Smutka ${ }^{2}$, Michal Steininger ${ }^{3}$ \\ CULS Prague \\ Faculty of Economics and Management, Department of Economics ${ }^{1,2,3}$ \\ Kamýcká 129 \\ Prague, Czech Republic \\ e-mail: smutka@pef.czu.cz²
}

doi: 10.18515/dBEM.ISD.P01.2020.p045

\begin{abstract}
The value of agrarian trade turnover increased from about 140 mill. USD up to 1.7 billion USD during the years 1992 - 2015. This paper examines Uzbek foreign trade in agricultural products from these approaches: Uzbekistan trade balance and international competitiveness. The goal of the paper is the determination of changes in agricultural trade character. The comparative advantages are analysed in according to different groups of countries (Asian countries, CIS countries, EU28, other European countries, developing countries). The agrarian trade competitiveness and territorial and commodity structure changes are analysed in 1992 - 2015. The commodity structure of agricultural trade is analysed on the basis of the standard Harmonized system classification. Uzbek agricultural exports are competitive, especially with regard to Asian and CIS countries.
\end{abstract}

Keywords: Agrarian foreign trade, Uzbekistan, Competitiveness, Trade Balance, Comparative Advantage.

JEL Classification: $Q 13, Q 17, Q 19$

\section{Introduction}

Uzbekistan is one of the main producers of fruits and vegetables in the CIS members countries. After the signed a protocol establishing the free trade zone between the Republic of Uzbekistan and Community of Independent States (CIS) in 2013, the trade turnover of agricultural products of Uzbekistan significantly increase. Uzbek agricultural and foodstuff export territorial structure in 2000 - 2015 was heavily focused in relation to CIS countries. The share of CIS members in agricultural exports and imports reached 83,3\% (respectively 33,6\% in 2000). The dominant positions are kept by Russia, Kazakhstan and Belarus. Kazakhstan has become an extremely important trade partner for Uzbek agrarian export within the last few years. (Ilyina, 2016). The Russian Federation share in the Uzbek agricultural export reached about $87.3 \%$ in 2000 (respectively $15.6 \%$ in 2015). The share of Kazakhstan in the Uzbek agricultural export reached about $1,06 \%$ in 2000 (respectively 78,85\% in 2015). This article analyses trends of major changes in the territorial and commodity structure of Uzbekistan in the agricultural sector in 1992 - 2015. In this analysed time period post-soviet countries and the Republic of Uzbekistan significantly changed their trade strategies and policies. A negative feature of the Uzbek agrarian trade is a much faster increase in the value of imports compared to an increase in the value of exports - therefore the negative trade balance of Uzbekistan continues to grow.

\section{Data and Methods}

The paper is analysing the export potential of Uzbekistan in the international market of agricultural products in 1992 - 2015. The article is focused on trade competitiveness in relation to individual groups trade partners of Uzbekistan. Agricultural products used in the article are classificated by a Harmonized system dividing agricultural trade into 24 aggregations. The article calculates all value figures at current prices in USD. 
The paper analyses the allocation of comparative advantages in relation to the Asian countries market, as well as in relation to the rest of the world (CIS members, other European countries (without EU28), the European Union (EU28), developing countries). The methods are used to achieve the above-mentioned results: Herfindahl-Hirschman index (HHI), Lafay index (LFI), Trade balance index (TBI), Product mapping method and some other statistical characteristics (geomean, chain index, basic index, import/export coverage ratio etc.). This approach is based on a combination of indicators above-mentioned. Similar approach was also applied by Maitah et al, 2016; Bielik et al., 2013; Svatoš \& Smutka, 2010, 2012). HHI is calculated by squaring the market share of each country competing in the market and then summing the results - it can range from 0 to 10,000 . A market with an $\mathrm{HHI}$ of less than 1,500 is considered a competitive market, an HHI of 1,500 to 2,500 is a moderately concentrated marketplace, and an HHI of 2,500 or more is a highly concentrated marketplace. Using the LFI index, we may observe the difference between the general normalized trade balance and each item's normalized trade balance. The LFI index, by taking into account imports, allows controlling for intra-industry trade and re-export streams. In this sense definition, it is superior to the traditional Revealed Comparative Advantages index (RCA) (Balassa, 1965). The LFI index is used to eliminate the influence of cyclical factors that may affect the amount of trade streams in the short term, and to focus on bilateral trade relations between regions and countries. Contrarily negative values indicate de-specialization (Zaghini, 2003; Smutka et al., 2015). While the LFI index is focused on the analysis of the development of competitiveness, the TBI index analyses the development of the trade balance. A country is defined as a "net importer" in a specific product group if the TBI value is negative, and a "net exporter" if the TBI value is positive. (Widodo, 2009).

The figure 1 represents the matrix for the allocation of the whole set of exported commodities into four groups in accordance with two selected indicators - LFI and TBI. The data sources for individual analysis are State Committee of the Republic of Uzbekistan on Statistics and UN COMTRADE. The Product mapping method determines the whole process of profiling the commodity structure of agrarian foreign trade of Uzbekistan:

Figure 1. Modified product mapping scheme

\begin{tabular}{|c|c|c|}
\hline & Group B: & Group A: \\
& Comparative & Comparative \\
& Advantage & Advantage \\
& Net-importer & Net-exporter \\
& $($ LFI $>0$ and TBI $<0)$ & $($ LFI $>0$ and TBI $>0)$ \\
\cline { 2 - 3 } & Group D: & Group C: \\
& Comparative & Comparative \\
& disadvantage & Net-exporter \\
& Net-importer & (LFI $<0$ and TBI $>0)$ \\
\hline Uzbek Agrarian Foreign Trade & (LFI $<0$ and TBI $<0)$ & \\
Commodity Structure & \multicolumn{2}{|c|}{ TBI } \\
\hline
\end{tabular}

Source: own modification and processing (2019)

The use of the HHI is calculated by squaring the market share of each country competing in the market and then summing up the results. Herfindahl-Hirschman index is formulated as follow:

$$
\mathrm{HHI}=S_{1}^{2}+S_{2}^{2}+S_{3}^{2}+\ldots S_{n}^{2}
$$

where: $S_{\mathrm{n}}^{\mathrm{m}}$ is the market share percentage of country $\mathrm{n}$ expressed as a whole number, not a decimal. 
Trade Balance Index (TBI) by Lafay (1992) is the indicator of export-import activities. The TBI mainly is used to analyse if a country has a specializing in import (as a net importer) or in export (as a net exporter) for a specific group of products TBI is simply formulated as follows:

$$
\mathrm{TBIij}=(\mathrm{xij}-\mathrm{mij}) /(\mathrm{xij}+\mathrm{mij})
$$

where TBIij denotes trade balance index of country $\mathrm{i}$ for product $\mathrm{j}$; $\mathrm{xij}$ and mij represent exports and imports of group of products $\mathrm{j}$ by country $\mathrm{i}$ (Lafay, 1992). Values of the index range from -1 to +1 . Extremely, the TBI equals -1 if a country only imports, in contrast, the TBI equals +1 if a country only exports. Indeed, the index is not defined when a country neither exports nor imports. A country is called a "net exporter" if the TBI reaches positive values and "net importer" in a specific product if the TBI value is a negative group (Widodo, 2009; Zaghini, 2003).

The Lafay index (LFI), by considering imports, allows controlling for intra-industry trade and re-export flows (Lafay, 1992). It surpasses the traditional index of Revealed Comparative Advantages (Balassa, 1965). Since comparative advantages are structural, by definition it is extremely important to exclude the influence of cyclical factors that may affect the amount of trade flows in the short term. The Lafay Index takes these effects into account, given the difference between the normalized trade balance of each position and the overall normalized trade balance. Finally, LFI weighs the contribution of each product according to its importance in trading. For a given country, $i$, and for any given product $j$, the Lafay index is defined as:

$$
L F I_{j}^{i}=100\left(\frac{x_{j}^{i}-m_{j}^{i}}{x_{j}^{i}+m_{j}^{i}}-\frac{\sum_{j=1}^{N}\left(x_{j}^{i}-m_{j}^{i}\right)}{\sum_{j=1}^{N} x_{j}^{i}+m_{j}^{i}}\right) \frac{x_{j}^{i}+m_{j}^{i}}{\sum_{l=1}^{N} x_{j}^{i}+m_{j}^{i}}
$$

where xij and mij are exports and imports of product $\mathrm{j}$ of country $\mathrm{i}$, towards and from the rest of the world, respectively, and $\mathrm{N}$ is the number of items. Positive values of the Lafay index indicate the existence of comparative advantages in a given item (the larger the value the higher the degree of specialization). (Zaghini, 2003).

The RSCA index is a common decreasing commons transformation of the Balassa index (Balassa, 1991) or Revealed Comparative Advantage (RCA). In practice, the Balassa index is a generally accepted method for analysing the transaction date (Bielik et al., 2013; Dalum et al., 1998; Maitah et al., 2016). RCA is based on export performance and observed trade patterns. This index was used to determine the most important areas and product groups for the region's export trade. It is used in the international economy to calculate the relative advantage or disadvantage of a particular country in a particular class of goods or services. RCA measures a country's exports of a commodity (or industry) relative to its total exports and to the corresponding exports of a set of countries.

$$
\mathrm{RCA}=(\mathrm{X} i j / \mathrm{X} i t) /(\mathrm{X} n j / \mathrm{X} n t)=(\mathrm{X} i j / \mathrm{X} n j) /(\mathrm{X} i t / \mathrm{X} n t)
$$

where $\mathrm{X}$ represents exports, $\mathrm{i}$ is a country, $\mathrm{j}$ is a commodity (or industry), $\mathrm{t}$ is a set of commodities (or industries) and $\mathrm{n}$ is a set of countries. The RSCA index is characterized as follows:

$$
\mathrm{RSCA}=(\mathrm{RCA} i t-1) /(\mathrm{RCA} i j+1)
$$

The values of RSCAij index ranges from minus one to one. The RSCAij greater than zero implies that country $i$ has a comparative advantage in a group of products $j$. The RSCAij less than zero imply that country $i$ has a comparative disadvantage in a group of products $j$. (Svatoš \& Smutka, 2012). 


\section{Results and Discussion}

The agrarian trade of Uzbekistan is concentrated on CIS members, central Asian and European countries. The most dominant role is represented by CIS members, Asian countries and EU members. The Asian share in the Uzbek agricultural export and import reached about 7,5\% (respectively 13,2\% in 2000). The share of EU28 in agricultural export and import reached about $7,1 \%$ (respectively $52,4 \%$ in 2000 ). The share of CIS members in agricultural exports and imports reached $83,3 \%$ (respectively $33,6 \%$ in 2000 ).

The most dominant role in CIS is represented by the Russian Federation, Belarus and Tajikistan. The Russian Federation share in the Uzbek agricultural export and import reached about 87,3 $\%$ (respectively $12,2 \%$ in 2000). The share of Belarus in agricultural export and import reached about 3,4\% (respectively $0,2 \%$ in 2000). The share of Tajikistan in agricultural exports and imports reached 2,4\% (respectively $0,09 \%$ in 2000 ).

The Russian Federation share in the Uzbek agricultural export and import reached about 15,7 $\%$ (respectively $33,3 \%$ in 2015). The share of Belarus in agricultural export and import reached about $1,2 \%$ (respectively $0,4 \%$ in 2015). The share of Kazakhstan in agricultural exports and imports reached $78,9 \%$ (respectively $60,50 \%$ in 2015 ).

In 2000 - 2015 the share of individual trade partners changed. The Asian share in agricultural export and import reached $24,9 \%$ (respectively about $11,3 \%$ in 2015). The share of EU28 in total exports and imports reached 5,9\% (respectively 14,5\%). The share of CIS countries in total agricultural exports and imports reached $67.1 \%$ (respectively $68.5 \%$ ).

The nominal value of exports increased from cc 250 mil. USD up to cc 562 mil. USD. The value of imports recorded the growth from $271 \mathrm{mil}$. USD up to 1,2 bil. USD. The total value of negative agri-food trade balance increased from cc 21 mil. USD up to cc 650 mil. USD. Negative trade indicators are increasing, the interannual export growth (2 times growth) is significantly higher than the inter-annual import growth rate (5 times growth). Despite of constantly increasing negative trade balance, the export/import coverage ration significantly increased from $14 \%$ to $46 \%$ and a highly concentrated marketplace emerged.

The current agricultural trade performance of Uzbekistan is heavily focused on CIS and Asian countries - those partners represents nearly $92 \%$ of export value and $80 \%$ of import value. During the analysed time period their shares in exports and imports increased by $22 \%$ (respectively 38\%). The key aspect of the Uzbek agrarian trade is its low-price competitiveness. Based on volume (tons) and value (total value, unit value) analysis, the bulk commodities (vegetables and fruits) could be considered as the main driver of agricultural export growth. Post-Soviet countries' markets represents the key territory for export-oriented activities of Uzbek agri-food trade. Mutual trade agreements (trade preferential agreements and free trade zone) could be considered as the key element supporting ambitions of national export.

Comparative advantages (in the world, with CIS members) were proved through the application of LFI and TBI indices taking into consideration only agricultural trade performance.

The modified analytical approach provides a more accurate overview of Uzbek agrarian exports comparative advantages distribution. The number of items located in groups $\mathrm{B}$ and $\mathrm{C}$ are significantly reduced and the whole commodity structure is divided into two groups A and D. The modified approach is able to specify in more detail, the current level of Uzbek agrarian trade competitiveness and competitiveness development. The Uzbek agrarian trade commodity structure has been significantly changing its character. The commodity structure is still looking for its optimal state. 
The process of Uzbek agrarian sector transformation still did not finish the restructuring process and its commodity profile is constantly changing. The significant share in total exports is still represented by low added value products. The value of Uzbek agrarian trade is typical especially because of its specific character in relation to individual partner territories. The Uzbek agrarian trade is focused on the CIS, Asia and Europe. A significant increase in the value of exports and imports can be observed in relation to all the main territories representing the main Uzbek trading partners in the agricultural sector: Asian countries - export value growth by more than $600 \%$, CIS countries - export value growth by $2400 \%$. The positive feature of Uzbek agrarian trade is a much higher relative increase in the value of exports compared to the import value. Export/import coverage ratio also improved in the case of analysed regions: Asia from $20 \%$ to $102 \%$, Africa from $10 \%$ to $700 \%$, EU28 from $8 \%$ to $19 \%$, Other Europeans from $0.2 \%$ to $42 \%$, CIS from $24 \%$ to $45 \%$, North America $121 \%$ to $208 \%$.

Trade can be also observed at the level of the commodity structure: HS04, HS06, HS07, HS08, HS09, HS11, HS13, HS17, HS18, HS19, HS22, HS24. The problem of Uzbekistan is rather limited export competitiveness heterogeneity (aggregations HS07 and HS08 represent the key pillar of agri-food export activities). The comparative advantages analysis based on the LFI index confirmed the existence of comparative advantages existing at the bilateral level, especially in relation to post-Soviet countries (Russian Federation, Kazakhstan, the CIS countries) only in the case of a limited number of trade items. The results presented by the product mapping approach provide a more accurate overview of the distribution of comparative advantages of Uzbekistan's agrarian exports. Most of the items representing the agrarian trade commodity structure are distributed between two groups A (with comparative advantages: HS05, HS07, HS08, HS13, HS14, HS20) and D (without comparative advantages: HS01, HS02, HS03, HS04, HS06, HS09, HS10, HS11, HS15, HS16, HS17, HS18, HS19, HS21, HS23). The commodity structure is still not in an optimal state. The Republic of Uzbekistan is not competitive at the general level, but it has only bilateral comparative advantages. Comparative advantages exist especially with regard to trading partners who apply restrictive trade policies in relation to the world market. The mutual trade is far from the real price competitiveness - it is rather the result of politics.

\subsection{Comparative advantages in relation to different groups of countries}

As a CIS member, Uzbekistan can operate within the CIS market without any restrictions. The agrarian trade of Uzbekistan is also influenced by multilateral agreements signed under the WTO rules, as well as signed at the bilateral level between individual members of the CIS and the EU. The significant dynamics of commodity structure development can be seen both in relation to the LFI and to the TBI index. The structure of agrarian trade has not been stabilized yet, and agricultural trade is still looking for the ideal state. Significant changes in the competitiveness of Uzbek agrarian trade in 2000 - 2015 can be observed especially in relation to the Asian countries, other European countries, CIS countries, Africa and EU28 countries.

The share of Group A products in the total volume of agricultural exports increased significantly in $2000-2015$ according to the product mapping matrix. The proportion of items located in group D was significantly reduced. Developing countries have not changed their role in Uzbek agrarian trade activities both in the case of exports and imports. TBI and LFI index did not proved any important changes. The Republic of Uzbekistan is largely focused on trade activities carried out in relation to developed and especially Asian countries and the CIS.

The agrarian trade of Uzbekistan changed its structure during the analysed time period. The share of agrarian exports realized under the group A increased from about $92 \%$ to $95.33 \%$. The share of A group in total imports changed from $2.58 \%$ to $3.04 \%$. Group B decreased its share in total agrarian export and imports from $3.16 \%$ to $0.93 \%$ (respectively from $2.22 \%$ to $1.88 \%$ ). 
The share of exports and imports realized under the group C decreased from $2.54 \%$ to $0.00 \%$ (respectively from $1.67 \%$ to $0.00 \%$ ). Exports and imports realized under the group D: The share of exports in total agrarian exports increased from $2.30 \%$ to $3.74 \%$ and the share of realized imports increased from $93.52 \%$ to $95.8 \%$. The conducted analysis also proved the dominant role of CIS countries as the main trade partners of the Republic of Uzbekistan. Their share in agrarian exports and imports is dominant $67.1 \%$ (respectively $72 \%$ ). The share is rapidly increasing - in 2000 the share of CIS in total imports was only $33 \%$.

The agrarian trade of Uzbekistan is concentrated on CIS members countries. The share of agrarian exports realized under the group A decreased from $98.7 \%$ to $94 \%$. The share of A group in total imports decreased from $9.8 \%$ to $6.4 \%$. Group B increased its share in total agrarian export and imports from $1.6 \%$ to $6 \%$ (respectively from $6.6 \%$ to $11.6 \%$ ). The share of exports and imports realized under the group $\mathrm{C}$ decreased from $0.10 \%$ to $0.00 \%$ (resp. from $0.00 \%$ to $0.9 \%$ ). Exports and imports realized under the group D: The share of exports in total agrarian exports increased from $0.1 \%$ to $0.2 \%$ and the share of realized imports decreased from $83.5 \%$ to $81.7 \%$.

\section{Conclusion}

In analysed time period the agrarian trade of Uzbekistan is continually increasing its value and changing both commodity and territorial structure character. The relative value of exports increased three times faster in comparability to the value of imports. The trade balance is still negative. The problem is very low added value of Uzbek exports, while added value of imports is much higher. Negative feature is also constantly decreasing food self-sufficiency. Uzbek agricultural trade is extremely vulnerable and dependent on limited number of partners especially CIS. The commodity structure development is opposite - diversification trend was proved. The commodity exports structure is based mainly on the variety of low added value items having comparative advantages (notably at the bilateral level). While Uzbek agrarian trade is fairly competitive (with respect to Asia and CIS countries), competitiveness towards other territories (European countries, especially developing countries, Latin and North America) is very limited. The combination of the TBI, LFI and product mapping approach analyses proved the comparative advantage of the following set of aggregates/trade items: alcohol, cereals, dairy products, drinks, fish, juices, live animals, meat products, plants, products shredding, sugar, vegetable juices, vegetable oils and weaving materials.

\section{Acknowledgements}

The paper is processed with financial support of IGA, FEM, CULS Prague. Grant number 20181018 - Economic specifics of the post-Soviet countries.

\section{References}

[1] Balassa, B. (1965). Trade liberalization and "revealed" comparative advantage. The Manchester School of Economics and Social Studies, 33(2), 99-123. ISSN 10490078

[2] Balassa, B. (1991). Comparative Advantage. Trade Policy and Economic Development. New York University Press. ISBN 0814711677

[3] Bielik, P., Smutka, L. \& Svatoš, M. (2013). Czech and Slovak agricultural foreign trade - two decades after the dissolution. Agricultural Economics, 59(10), 441-453. doi:10.17221/26/2013-AGRICECON

[4] Dalum, B., Laursen K. \& Villumsen G. (1998). Structural change in OECD export specialization patterns: de-specialization and 'stickiness'. International Review of Applied Economics, 12(3), 423-443. doi:10.1080/02692179800000017 
[5] Ilyina, D. (2016). Review of the agro-food trade policy in the post-Soviet countries 2014-15. FAO, 143-158. ISBN 978-92-5-409116-3

[6] Lafay, G. (1992). The measurement of revealed comparative advantages. In M. G. Dagenais \& P. A. Muet (Eds.), International Trade Modeling (pp. 209-234). London: Chapman \& Hill. ISBN 10: 0412450003/0412-45000-3

[7] Maitah, M., Řezbová, H. \& Smutka, L. (2016). European Sugar Production and its Control in the World Market. Sugar Tech, 18(3), 236-241. doi:10.1007/s12355-016-0439-9

[8] Smutka, L., Steininger, M. \& Maitah, M. (2015). The Czech agrarian foreign trade - ten years after the EU accession. Proceedings of the Agrarian perspectives XXIV, Prague, 385-392. ISBN 978-80-213-2581-4

[9] Svatoš, M. \& Smutka, L. (2010). Development of agricultural foreign trade in the countries of Central Europe. Agricultural Economics, 56(4), 163-175. doi:10.17221/22/2010-AGRICECON

[10] Svatoš, M. \& Smutka, L. (2012). Development of agricultural trade and competitiveness of the commodity structures of individual countries of the Visegrad Group. Agricultural Economics, 58(5), 222-238. doi:10.17221/51/2011-AGRICECON

[11] Widodo, T. (2009). Comparative Advantage: Theory, Empirical Measures and Case Studies. Review of Economic and Business Studies, 2, 57-82. ISSN 2068-7249

[12] Zaghini, A. (2003). Trade advantages and specialization dynamics in acceding countries. Frankfurt am Main, Germany: European central bank, 4-15. ISBN 1725-2806 


\section{SESSION 7}

INFORMATION AND COMMUNICATION TECHNOLOGIES NETWORK AND INFORMATION TECHNOLOGIES 


\title{
Modelling and Simulation of the Bulk Service Queueing Systems
}

\author{
Veronika Achimská1, Katarína Kramárová2 \\ University of Žilina ${ }^{1,2}$ \\ Faculty of Operation and Economics of Transport and Communications, Department of \\ Communication ${ }^{1}$, Department of Economics ${ }^{2}$ \\ Univerzitná 8215/1 \\ 01026 Žilina, Slovakia \\ e-mail: veronika.achimska@fpedas.uniza.sk ${ }^{1}$, katarina.kramarova@fpedas.uniza.sk²
}

doi: 10.18515/dBEM.ISD.P01.2020.p046

\begin{abstract}
The article deals with the use of simulation and modeling in the field of bulk service queueing systems. In this paper we describe the process of construction of a simulation model, the running of simulation itself and the possibility of creating output statistics suitable for solving problems in the area of managerial decision-making. We illustrate this issue on examples from the field of postal services that suitably represent systems with bulk service queueing. By combining general knowledge of simulation models and specific practical examples, we are able to present the potential of using simulation models in the field of ex-ante managerial decision-making.
\end{abstract}

Keywords: simulation, bulk service queueing systems, model construction, future decision-making

JEL Classification: C63, C61, C26, C36, C80

\section{Introduction}

The goal of sustainable agriculture is to meet society's food and textile needs in the present without compromising the ability of future generations to meet their own needs. Practitioners of sustainable agriculture seek to integrate three main objectives into their work: a healthy environment, economic profitability, and social and economic equity. Every person involved in the food system-growers, food processors, distributors, retailers, consumers, and waste managers - can play a role in ensuring a sustainable agricultural system. (Feenstra et al, 2020)

Simulation is a strong tool of knowledge about development possibilities of processes and phenomena that carries elements of randomness. In the business environment, there it is often necessary to make decisions that affect the future in order to gain a certain advantage. However, a decision-making is undoubtedly one of the difficult tasks of every manager. Simulation is one of the tools that can help us in the process of making decisions especially in situations where it is not possible to handle analytical expression appropriately. (Lampa et al, 2018)

In order to exploit the potential of simulation in a full range, it is needed to understand the basic principles of simulation model construction. Therefore, the aim of this article is to describe the construction of a simulation model of bulk service queueing systems on simple practical examples. Using the simulation, we can then present benefits of new progressive management systems or advantages of implementing modern technologies. (Keil et al, 2016)

Although bulk service queuing models are commonly used more in the field of tertiary sector to which we are specialized, we can find their use also in the primary sector, namely in agricultural systems. In conclusion, we will give some examples. 


\section{Definition of bulk service queueing systems}

According to Kvet (2015), the mass-service models are characterized by the fact that the system, in which the service lines (service channels) are located, receives a customer input stream to service their requests. Customer service takes some time during which the service line is blocked (it cannot provide service to another customer). After the termination of the service, customers release the line and create a customer outflow. The models of mass-service are used in a number of areas. At present, the trends of their use are obvious e.g., they are closely related to the IT sector, where, for example, they are widely applied to solve server traffic problems and their offtake capacities. (Schwarz \& Epp, 2016; Gupta et al, 2019)

Systems of this nature also include post offices, which represent the main contact points with postal operators for postal customers.

Queues are typically formed in front of service places (cashiers, ATMs, etc.). Every service place contains a number of resources that can simultaneously serve customers. If customers come to a service area with all resources taken, they have to wait in a queue. Shape of the queue can be predetermined by defined queuing line (used typically in supermarkets, at the airports, etc.); or the customer simply freely stands behind the last customer, so the queuing line is formed dynamically. (Pecho et al, 2017)

\subsection{Modelling of customer service at post offices}

Nowadays, postal market is in tough situation, while trying to adjust the postal services to fit the customers' needs. (Pechota et al, 2017) Postal operators operating on the postal market, like other sectors of services, create contact points for their customers where customers can meet their needs, e.g. send a letter, parcel, pay a postal order etc. These contact points (postal offices) are subjects of simulation model (thereinafter " $S M$ ") definition in the postal sector. The competitive strength in the postal market is obvious, therefore postal operators have responded among other things by providing a range of new e-services at the post offices. Except that while traditional letters have decreased in numbers, parcel delivery has increased significantly. It is logical that these developmental changes also affect the operation of postal services. (Trimble et al, 2015)

From the point of view of the SM, any postal office represents a closed system whose real behaviour we want to note in a simulation model. Thus the SM can be understood as the simplified model of real system. According to the timeline construction of a system in simulation models, we distinguish event, activity and process models. In this article we deal with the creation of the SM with the construction of the timeline "forward" (from left to right), i.e. the event based SM. The basic concept of such SM is an event that represents a change a state of the system at a point in time. Events have two basic attributes, namely:

- time at which the event occurs,

- type of event.

In the models we distinguished dependent and independent events. The postal operation system, which has more than one customer service point (counter), is characterized as an n-link service channel model. Such SM contains the following events:

- customer arrival,

- inclusion of a customer to the smallest queue,

- access to the service line,

- termination of service on the line (leaving the system).

For correct functioning of the simulation, it is necessary to carry out the field-measurements (primary research), or to collect a data from already implemented systems (secondary research) on those events that have a random character. In so defined model, the independent events are 
customer arrival and termination of service on the line. These events include the randomness occurring in everyday life. These independent events are simulated by using pseudo-random numbers, which are (after their generation) adjusted to the appropriate distribution values for the required type of event.

\section{Construction of simulation model}

Dependent events of the SM do not contain randomness, so we can express them by mathematical notation following independent events. For example, the access to the service line (counter) of that customer, who was the first waiting in the queue before the counter, occurs when the previous customer terminates its service on the line (independent event).

The construction of the event SM has its characteristic structure, which formally consists of the following steps:

- initialization,

- selection of the nearest event,

- time adjustment,

- realization of the selected event,

- checking the simulation time.

Characteristically, the first step is different from the others in that it is the only one requiring user intervention, the creator ,touch “ of the SM. In this step, the user sets the basic parameters of the SM before the start of the simulation. Next steps (2 to 5) no longer need the invention of the user they are realized by using a random number generator and represent the simulation cycle itself. In the next chapter, the functionality of these steps is described in more detail.

\subsection{Setting of simulation}

In the following section we will characterize individual components of the SM on examples from the area of postal operations (customer service at the counters) in order to better understand the construction of the SM. When creating the structure of the model, the first step is to initialize the input variables of the model. The event SM captures events over time, so setting up the duration of the simulation and creating a basic timeline is an essential part of initializing variables (simulation start time, simulation end time, service line, queue, input flow parameters, service time parameters on the line, customer arrival time, customer service end time).

Simulation start time is a time variable that is determined by the real numeric value considered in the units of measure appropriate for the system. In the postal sector, these units of measure are minutes. As a part of the initialization, we are talking about the beginning of the simulation and thus creating the beginning of the simulation timeline. So it is natural that during initialization (preparatory part - identification of simulation elements) we set it as follows:

$\circ$ designation as $\mathrm{T}=0$;

However, in the simulation cycle (steps 2 to 5), this variable will record the current simulation time, so generally for the $T$ values is true that $T \in R+$.

Simulation end time represents a time variable that determines how long we want to simulate the ongoing processes in the SM.

- designation as Te;

E.g. if we work in the model with time units in minutes, then 480 minutes represents 8 hours, i.e. simulation of one eight-hour working process - i.e. normal operating time e.g. in post offices, banks, etc., then $\mathrm{Te}=480$. 
Service line is the element of the SM, which has two states in a numerical form - takes the value 0 (when not working, free) or 1 (when working - customer service is in progress).

○ designation as L;

Depending on the number of these elements, we are talking about either the single-link SM (SM1), which internal structure is simpler, or n-link SM (thereinafter "SMN"). In the case of the SMN, it is necessary to distinguish the lines from each other (for example with a sequence index) in order to monitor their status individually, for each line separately.

Queue is an element that takes positive integer values, including zero, and represents the number of queuing customers. Theoretically, the value of the queue can grow to infinity.

○ designation as Q;

In case of the SMN, this can be a system with separate queues, where it is necessary to distinguish these queues from each other and assign them a link to the line before which they are formed (for example, a consecutive index with a link index) to monitor their status individually, each queue separately. For the multiple SM queues, it is important to identify queuing rules for the simulation process, e.g. FIFO, LIFO, etc.

Input flow (stream) parameters determine the nature of a random event (customer arrival) and allow to conveniently transform random generated numbers, which have a uniform distribution of probability, to values with another statistical distribution that most closely copy the occurrence of such event in the real system. The values of parameters are taken from the findings of primary or secondary researches realized in the real conditions. Therefore, it is also important to identify a given statistical distribution of the probability of a random variable (most often the input stream in post offices has an exponential distribution with the parameter $\mu$, or Poisson distribution with the parameter $\lambda$ ).

$\circ$ designation as $\operatorname{Ex}\left(\mu_{0}\right)$, Po $(\lambda)$;

Service time parameters on the line/s determine the nature of the random event (e.g. service time at counter/s in a post office). Likewise, their value determines the shape of the desired probability distribution for that type of the random event. The method of determining the specific value of the parameter/s is the same as in the previous case - primary or secondary research under the real system conditions, during which the identification of given statistical probability distribution is also performed (in the area of postal services, most often has an exponential distribution with the $\mu$ parameter or a normal distribution with the $\mu$ and $\sigma$ parameters). However, for the same parameter designations, it is necessary to index these or otherwise distinguish their unambiguous belonging to the random variable.

o designation as $\operatorname{Ex}\left(\mu_{1}\right), N\left(\mu_{2}, \sigma\right)$;

The last variables needed to initialize are the occurrence times of possible events in the modelled system. Event occurrence times have in them a random element defined by the previous two variables. It is therefore necessary to distinguish two types of events that may occur in the bulk service queuing system, namely customer arrival time, and customer service end line.

Customer arrival time is a moment, which we generate during the simulation through the appropriate distribution with the given parameter and after that, we add it to the current time of simulation $\mathrm{T}$. This process ensures a flow of the simulation process separately. By initialization we determine the value of this variable according to the best practice in the real modelled system. It is a time stamp and its value will therefore be from a set of real positive numbers.

○ designation as $\mathrm{ToE}_{0} ; \mathrm{TE}_{0} \in \mathrm{R}+$;

Where ToE represents the time of event, 0 -identify the type of the event (customer has arrived to the system). 
Customer service end time is the moment of occurrence of this event is the same like in the previous case. But when we initialize this event it has to be considered basic logic of the system. It means that the request to "terminate the customer service" cannot occur until the customer enters into the system. Therefore, we usually initialize this variable at a time (moment) that is outside the simulation time (usually like $\mathrm{Te}+1$ ).

$\circ$ designation as $\mathrm{ToE}_{1}$ (in the SM1) or $\mathrm{ToE}_{\mathrm{i}}, \mathrm{i}=1,2, \ldots \mathrm{N}$ (in the SMN);

The ToE index $\in \mathrm{R}+$ (must definite like greater value than $\mathrm{ToE}_{0}$ ), where ToE means the time of the event and index $(1,2,3, \ldots)$ identifies the type of the event (terminate the customer service) and also the line (postal counter) on which it was happen.

If all the variables needed to run the model are initialized, we can proceed to the beginning of the SM cycle, i.e. to the simulation process ("the created SM program already runs without user intervention").

\subsection{Simulation cycle}

The simulation proceeds in a cycle of repetitive steps so that new random events (moments) are successively modelled, thus passing the simulation time $T$ until the user decides to pause the simulation or until comes the end time of the simulation. The sequence of the simulation process steps (simulation cycle) is represented by the above-mentioned steps 2 to 5 of the event SM.

The second step in the structure of the event SM (the first simulation phase) is to select the nearest event. The closest event is the event that is modelled first in terms of its timeline position relative to the start of the simulation.

Selecting this event is followed by the third step, which is to reset the time T (current simulation time) on the timeline to the time (moment) at which the selected event occurred. In this way, the passage of time, which in the SM compared to real systems can run several times faster (what is big advantage of SM), is ensured.

The fourth most extensive step in the structure of the SM is the realization of the selected event. During this phase of the simulation, it is necessary to have the logic of all process operations in relation to the occurrence of random events set correctly in the SM. An important part is, for example, the system of queue creation in bulk queuing models (FIFO, LIFO, SIRO, PRI), or other preferences in the field of customer service (ordered customers or not ordered, etc.).

The last phase of the simulation has a control function. Here is the cycle of repeating steps completed by checking the current simulation time. If the current simulation time is less than the initialized simulation end time $(\mathrm{T}<\mathrm{Te})$, steps 2 to 5 are repeated, and the SM further simulates events at a time copying the real system. However, when the current simulation time $\mathrm{T}$ does not satisfy the condition $\mathrm{T}<\mathrm{Te}$ (i.e. exceeds the specified simulation end time), the simulation process ends and it is possible to produce the desired output, most often in the form of various statistics.

\subsection{Collection of statistics in simulation models}

After constructing the SM and fine-tuning the simulation process, the necessary statistics for the system decision-making process are collected. The advantage of the SM is the possibility of creating several scenarios of simulating the functioning of the real system and their mutual comparison, without the necessity of spending resources for their realization. According to the nature of the collected statistics we distinguish statistics:

- integrated over time (weighted, where weight is the duration of a given level of desired characteristic)

- not integrated over time (simple statistics) 
In postal conditions, it is interesting to observe, for example, integrated statistics such as average number of waiting customers (thereinafter " $A W C$ "), average occupancy of the line (thereinafter " $A O L$ "), or average number of people in the system - customers in the post office (thereinafter "ANS"). Since they are integrated statistics, their calculation is realized as a weighted average according to the following equations:

$$
A W C=\frac{\sum Q \cdot\left(T-T_{0}\right)}{\sum\left(T-T_{0}\right)}=\frac{\sum Q \cdot\left(T-T_{0}\right)}{T e}
$$

F - number of waiting,

(T-T0) - waiting time;

$$
A O L=\frac{\sum L \cdot\left(T-T_{0}\right)}{\sum\left(T-T_{0}\right)}=\frac{\sum L \cdot\left(T-T_{0}\right)}{T e}
$$

$\mathrm{L}$ - line occupancy,

(T- $\left.\mathrm{T}_{0}\right)$ - occupancy time;

$$
A N S=\frac{\sum P N .\left(T-T_{0}\right)}{\sum\left(T-T_{0}\right)}=\frac{\sum P N \cdot\left(T-T_{0}\right)}{T e}
$$

$\mathrm{PN}$ - number of people in the system (it is necessary to monitor this status in model additionally),

(T-T0) - status time.

Equally interesting, and from the point of view of the postal regulation and setting of standards also very important non-integrated statistics, is the average waiting time (thereinafter " $A W T$ "). It is calculated as a simple arithmetic mean, but it is necessary during the simulation to provide a wait time measurement for each unit whose SM logic determines the queuing obligation. In the result (after the simulation), we then determine it as follows:

$$
A W T=\frac{\sum W T}{N o W}
$$

WT - waiting time,

NoW - number of waiting.

\section{Management decisions}

After creating and fine-tuning the SM and preparing necessary statistics, the simulation can be used as a managerial decision-making tool. The primary model should simulate as closely as possible the state of the current real system. Subsequently, it is possible to make various adjustments in the model settings, either depending on the planned implementation of new technologies, or if an exceptional situation arises, thus simulating changes in the resulting statistics in response to changes in inputs. These statistical results in one or more experimental models allow the user to evaluate the ex-ante situation in the modelled system and make the final decision.

Such models will also find their application in sustainable agriculture. For example, growers can use these models to simulate crop processing at the time of maturation of individual crops (operator line $=$ manpower (pickers, mechanization). As well as food processors, they can simulate, for example, a food packaging system through bulk service queueing models. Simulation of the agricultural system can then help to decide about the optimal number of pickers to harvest during the ripening period, how to behave effectively in the case of unexpected low crops, how to use manpower or the available machinery efficiently. 


\section{Conclusion}

In this paper, we wanted to point out that simulation is a good decision support tool. It is a helpful tool when designing the system as well as in applying it in the already running service. Simulation enables analysis, optimization and prediction and creates a "forward look". The simulation model represents a replacement of a real system, where we can train and test various scenarios and monitor the functioning of the system under changed conditions without the real costs of these changes. In addition to changing the system structure, we can also simulate exceptional situations, risks, dangers, etc.

Simulation and simulation models are useful tools supporting a managerial decision, which should be used when managers have to make decisions about the future of an organization. For this reason, the construction of simulation models, their nature, principles and rules should be part of the education process in all programs of study with managerial focus.

\section{Acknowledgements}

This contribution was undertaken as part of the research project VEGA 1/0721/18 Research on the Economic Impact of Visual Smog in Transport Using Neuroscience Methods.

\section{References}

[1] Feenstra, G., Ingels, Ch., Campbell D. (2020). What is sustainable agriculture (Agricultural Sustainability Institute) Retrieved January 21, 2020, from https://asi.ucdavis.edu/programs/ucsarep/about/what-issustainable-agriculture

[2] Gupta, G. K., Banerjee, A., \& Gupta, U. C. (2019). On finite-buffer batch-size-dependent bulk service queue with queue-length dependent vacation. Quality Technology \& Quantitative Management. DOI: $/ 10.1080 / 16843703.2019 .1675568$

[3] Kvet, M. (2015). Úvod do teórie hromadnej obsluhy (THO), Lecture 5. Retrieved 25 October, 2018 from http://www.fsi.uniza.sk/ktvi/leitner/2_predmety/SMOA/05_THO

[4] Lampa, M., Samolejova, A. \& Sikorova, A. (2018). Possibilities of simulation of bulk service processes in metallurgical production. Conference on Metallurgy and Materials (METAL) Location: Brno, CZECH REPUBLIC, MAY 23-25, 2018, 1916-1921

[5] Keil, R., Hedrich, F., Kremenova, I. \& Madlenak, R. (2016). Modelling of technological reliability in traffic logistic networks in urban areas. In 2016 International Conference on Electronic, Information and Computer Engineering (Vol. 44).

[6] Pecho, M., Adamko, N., \& Varga, M. (2017). Modelling of Pedestrian Queuing Behavior Independent of Movement Model Utilizing BDI Reasoning in ABAsim Architecture. Conference on Information and Digital Technologies Location: University of Zilina, Fac Management Sci \& Informat, Zilina, SLOVAKIA, JUL 0507, 2017, 313-321

[7] Pechota, M., Matuskova, M., \& Madlenakova, L. (2017). The trend of cost of universal services provided by national postal operator and correlation between price of letter mail and amount of sent letter mails in Slovakia. 12th International Scientific Conference of Young Scientists on Sustainable, Modern and Safe Transport Location: High Tatras, SLOVAKIA, MAY 31-JUN 02, 2017, 574-579

[8] Schwarz, J. \& Epp, M. (2016). Performance evaluation of a transportation-type bulk queue with generally distributed inter-arrival times. International Journal of Production Research, 54 (20), 6251-6264, DOI: 10.1080/00207543.2015.1092613

[9] Trimble, J., Chilmani, K. R. \& Sibangiso, N. (2015). Strategies for community focused postal service development. African Journal of Science, Technology, Innovation and Development, 7 (5), 358-363. DOI: $10.1080 / 20421338.2015 .1085175$ 


\title{
Remote Laboratory Management System for Teaching and Experimentation
}

\author{
Pavel Beňo ${ }^{1,2}$, Sandra Šprinková ${ }^{2,3}$ \\ Trnava University in Trnava ${ }^{1}$ \\ Hornopotočná 23, 91843 Trnava, Slovakia \\ IdeaCreative s.r.o. ${ }^{2}$ \\ Horná Krupá 3, 91965 Horná Krupá, Slovakia \\ Faculty of Education ${ }^{3}$ \\ Trnava University in Trnava, Priemyselna 4, 91843 Trnava, Slovakia \\ e-mail: Pavel.Beno@truni.sk¹; Beno@ideacreative.eu²; Sandra.Sprinkova@tvu.sk²,3
}

doi: 10.18515/dBEM.ISD.P01.2020.p047

\begin{abstract}
As time goes by, the meaning of RL IS becoming more and more popular and our Team from the begging was one of the best in this technology. One of the news in remote laboratories is implementing the technology of thin client for the usage of $R L$ in learning process. On the one hand, we know how to use this technology on managing every laboratory and on the other hand, use him as imagine unit for learning. The main methods used in our system is virtualization and cloud system, which operate the technology of TC. Our designed system is fully developed to correspond to the requirements of remote laboratories. It is therefore ready for interoperability with other systems and is able to accommodate various RLs building technologies. The main goal of our work is to enable a wide range of scientific and education spheres to use our systems. Overall, we can imagine that the proposed system can serve a number of classrooms based on TC technology and teach science through RLs.
\end{abstract}

Keywords: thin client, cloud computing, virtualization, remote laboratories

JEL Classification: L86, D85, L63

\section{Introduction}

The whole world is getting used to informatization. Informatization interfere into every area of peoples happening. Also, informatization worked its way into education and research process. It is more and more wanted and our new, young generation requests more and more to be all the things online. Obviously, it is a taxation for development and as the technology grows. If young generation does not have anything online, it is not only willing to give it an attention. In some way or another, informatization affected the process of learning subjects as science (physics, electrotechnology or chemistry). For this are used Remote Laboratories (RL), which is even more on point name. RLs start up mainly for purposes, which are [1]:

- Increasing accessibility to laboratories by a factor of 4 within 3 years, since current lab utilization is less than $10 \%$,

- Decrease fixed and variable expenditure by $50 \%$, since faculty budget spends between $15-40 \%$ on lab infrastructure and personnel, around AUD 400 million per year,

- Improve learning objectives and outcomes to support better learning,

- Enhance sharing of knowledge, expertise and experience,

- Reduce start-up costs of laboratories.

In other words, we can see these purposes [2]: 
- Relax time constraints - adapting to pace of each student, if there was insufficient time in lab;

- Relax geographical constraints - disregarding the physical locality of the student;

- Economies of scale - as sharing labs allows sharing of large fixed costs of traditional buildings;

- Improve quality of experiment - as it can be repeated to clarify doubtful measurements in lab;

- Improve effectiveness - as student may improve effectiveness of time spent at lab by rehearsal;

- Improved safety and security - as no risk of catastrophic failure.

\section{Data and Methods}

\subsection{Internet School Experimental System}

We are trying to keep up with this in providing remote laboratories for science and educational process. Remote laboratories upraise from hands-on laboratories, which are connected to PC and moreover are capable of providing the information in digital form. Very briefly said, we are measuring data and provide them through Internet (Figure 1).

Figure 1: Block diagram of Remote Experiment

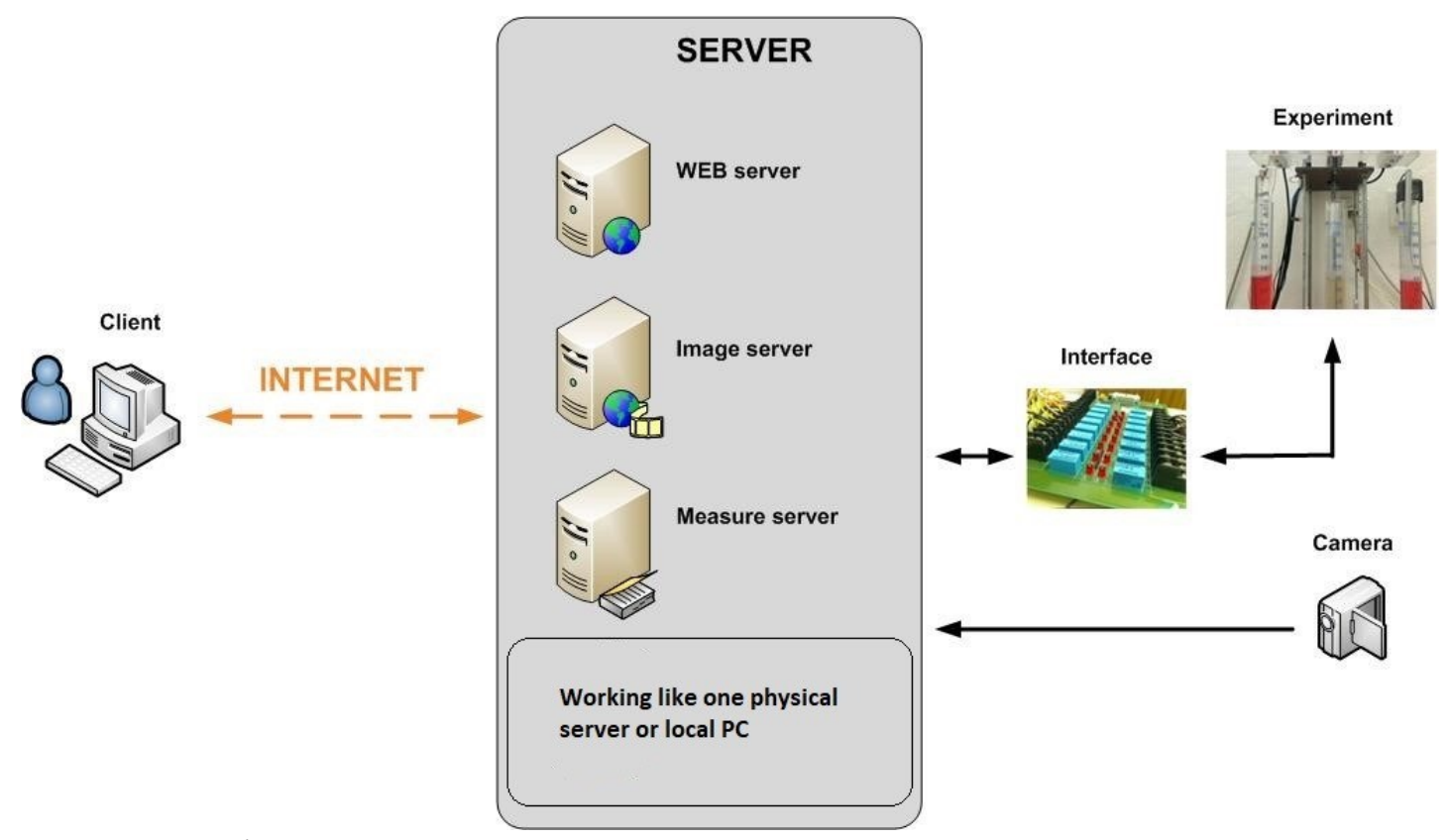

Source: Own processing

When we look at the picture carefully, it can be seen that in one side the client come through internet and on the other side, it is placed a classical physical experiment (RE). That one (RE) is connected to the PC through Internet School Experimental System (ISES) [3] and transducer card, analog-digital/digital-analog (ADDA). By this way, the data are being transferred to the PC, which are processed and measured by the Measure server (MS). MS provide them through WEB server straight to client, which can control given RE. On their screen, clients can see the course of the measurement alone, as it was situated right in the laboratory. Demonstration of this type of interface is on Figure 2, where there is experiment on Free fall. 
Figure 2: Example of Remote Laboratory - Free Fall

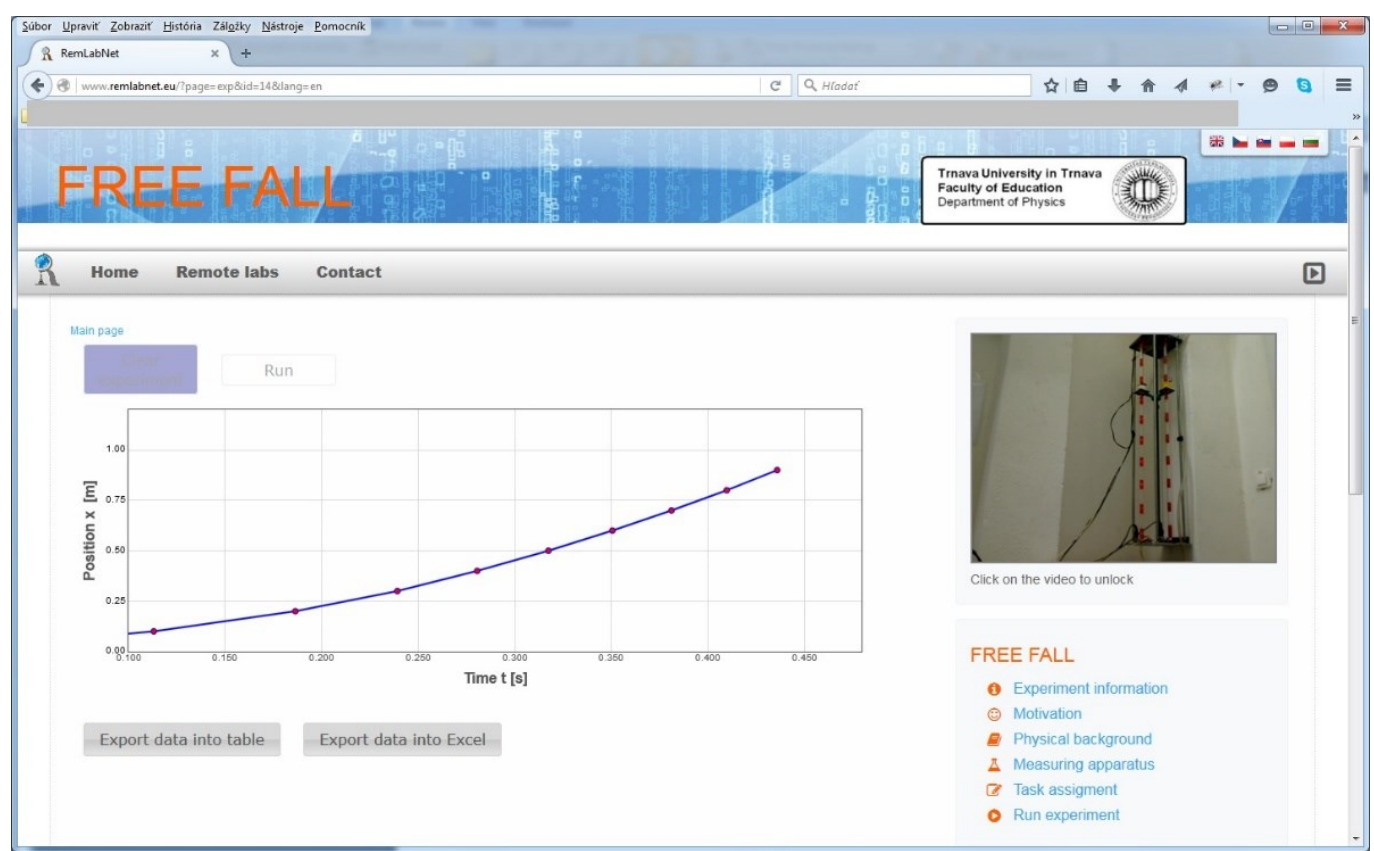

Source: Own processing from REMLABNET"

To picture what is happening in RL, camera and Image server are used. Camera shoot changing parts of RE. This can be moving parts (pendulum, engine, ball, etc.) or light or different signals (LED, measuring devices, etc.). In the case of Free Fall, it can be seen on the camera how the engine lifts the steel ball in glass barrel and after the launch of experiment how this one falls down through sensors situated on the glass barrel.

\subsection{Remote Laboratory Management System}

In consideration of the big amount of RLs, we accomplished the state, when it was necessary to move the management and administration of data into one point. For this we built Remote Laboratory Management System (RLMS) and we called it REMLABNET [4] [5] [6] [7]. In the biggest boom of building RLs, we had REMLABNET connected to more than 40 RLs and we were the part of the world's best [8]. All of the functionalities of REMLABNET are composed in virtual cloud (see Figure 3 ) with components needed to communication with usage of Cloud Computing (CC) technology. Every server, which is needed in RLMS works as virtual machine, with its specific operation system and specifically and safely setup communication. This setup system is simple on the run and significantly simples the management. 
Figure 3: REMLABNET - own design

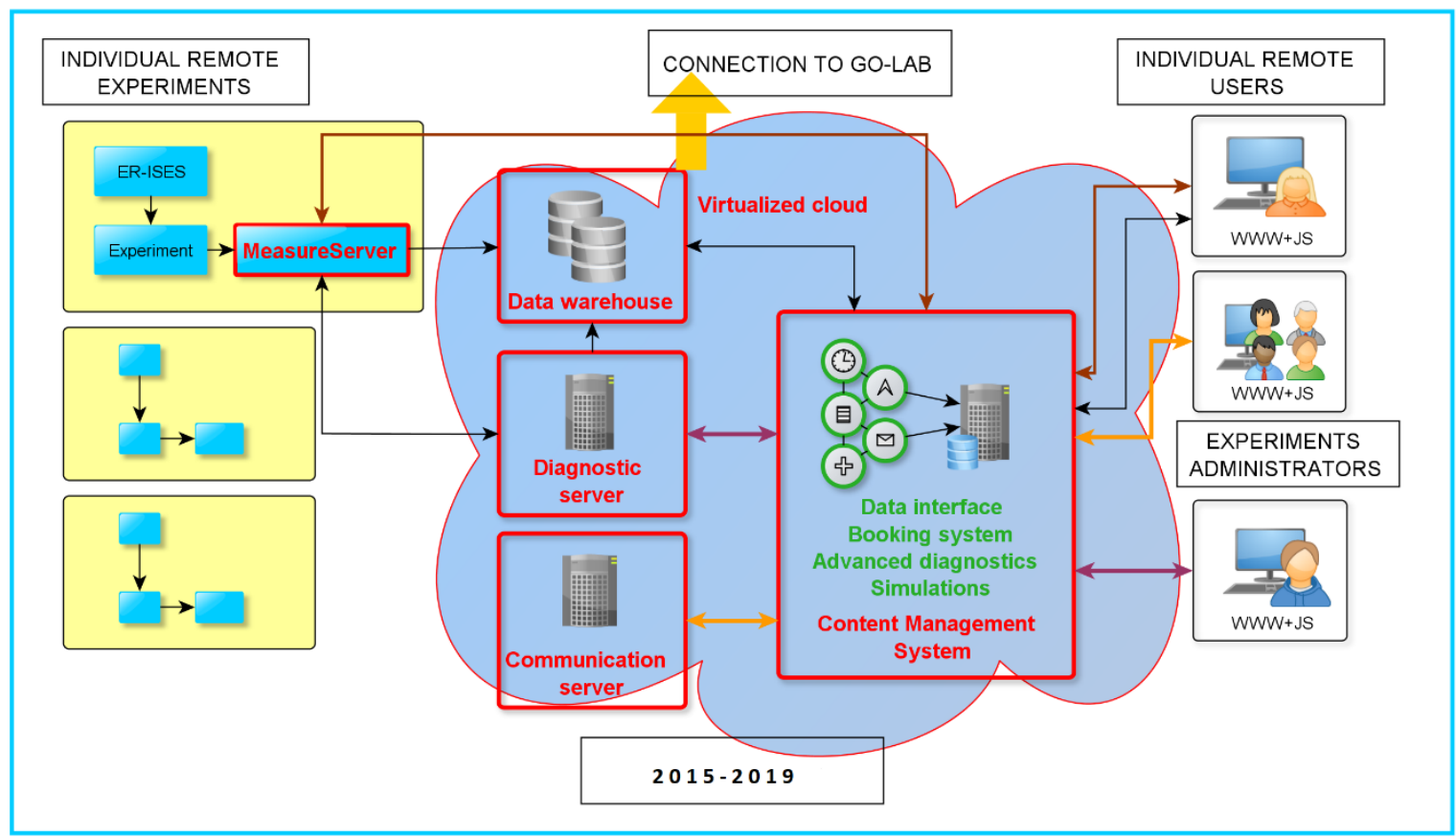

Source: Own processing

\subsection{Cloud Computing}

Our CC concept is depicted in the Figure 4. CC involves every needed part for communication, where every server and every part is using take advantage of virtualization and abide the security and security standards. In the frame of physical composition and placing single parts of complex REMLABNET, we can talk about big cloud, which is spread in present between multiple DTCs and it built in the way, that it can be spread on the huge part of the land of European union (EU) in the frame of federalization. Looking at picture 4, we see our cloud design with its main blocks, which contains the necessary components to make the cloud fully functional and reliable. First of all, we can divide the CC cells into three basic columns. The first two from the right called High Security and BigData were supposed to be an extension of the basic cloud solution. Nowadays, only High Security is in operation, which is also part of this dissertation. This block contains the most important security blocks that we had to secure during implementation. Process security is a part where we define our main processes that need to be protected. Our main processes are the communication interfaces of individual RLs, and we must protect them, as these are our largest assets. Network security is managed from a University environment, but REMLABNET also uses the network settings above the University's measures. Application data security ensures security at the REMLABNET data level, its storage and individual accesses. Infrastructure security is a block that we use to secure the complete REMLABNET infrastructure, including its physical security. Terminal security is a block that handles security on a thin client level. Security authentication is the last block to ensure correct and secure access of clients and administrators. 
Figure 4: REMLABNET - Cloud computing concept

I

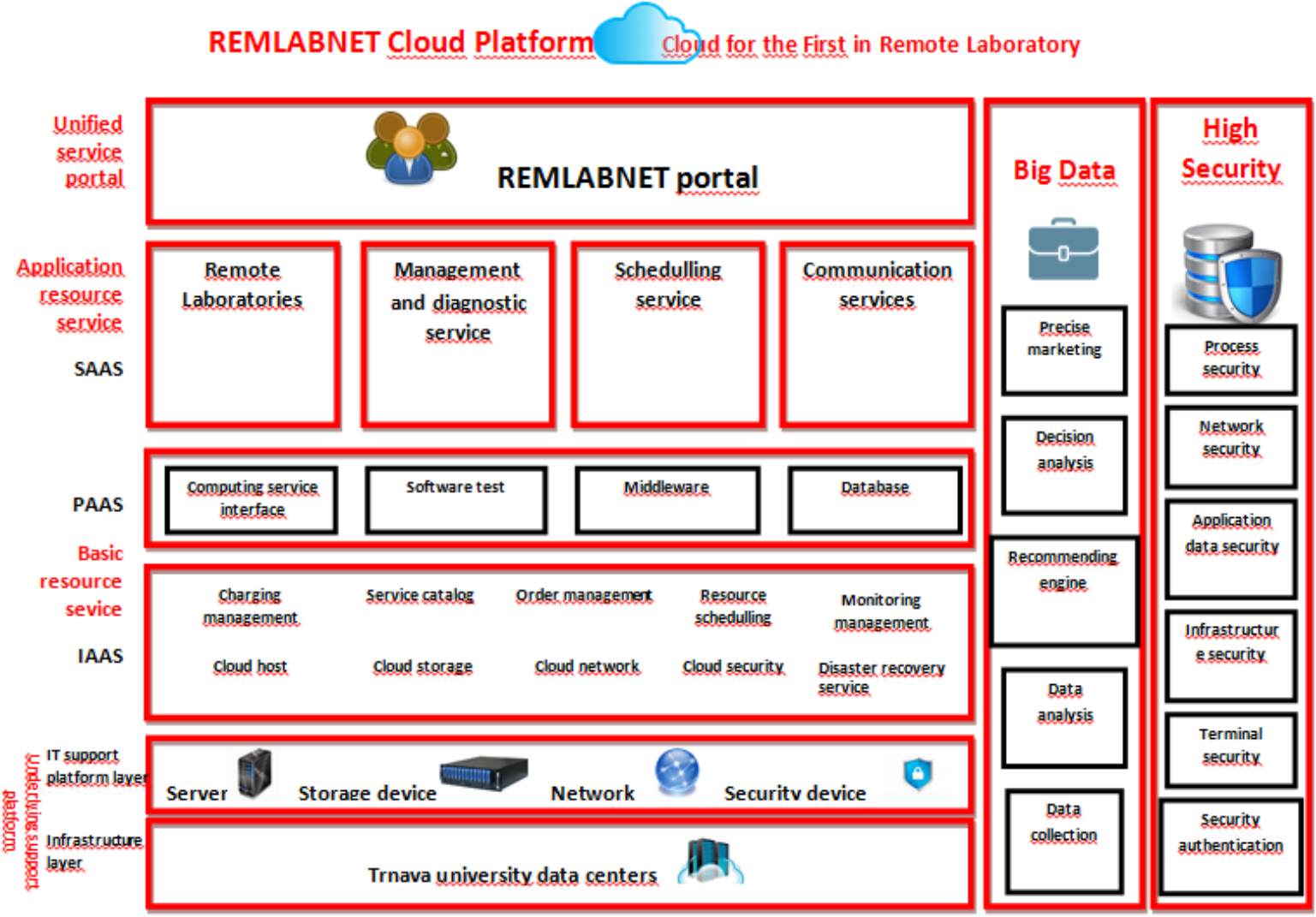

Source: Own processing

The second Big Data block was to be solved by my colleague, but after three years he gave up, and so we are still looking for a new doctoral student in this area. We consider it not as a boy, but certainly for the benefit of our cloud solutions. The last big block I designed is the cloud itself, which may work without the expansion blocks, but it would be more vulnerable than anyone else's call. If we look closely at this block, we can see its progress. So, let's go from bottom to top. First of all, we can talk into DTCs. In the case of REMLABNET, it is one of the DTCs used within Trnava University in Trnava. We have already written that these DTCs are geographically separated and hence security is increased by mirroring the main servers required for operation. If the requirements were met, these DTCs could be expanded further to increase the possibility of the entire cloud. Another block I mention is the HW itself, where it is unnecessary to pause, because the cloud can run on any HW platform. Both mentioned blocks are often a kind of Underlying support platform. We have already written that these DTCs are geographically separated and hence security is increased by mirroring the main servers required for operation. If the requirements were met, these DTCs could be expanded further to increase the possibility of the entire cloud. Another block I mention is the HW itself, where it is unnecessary to pause, because the cloud can run on any HW platform. Both mentioned blocks are often a kind of Underlying support platform.

The next two blocks are Basic resource service (BRS). BRS is basically the aggregate name we introduced for IaaS and PaaS. Since we do not and cannot provide these services as a public institution, they are merely a supporting component. IaaS contains mainly blocks such as Charging management for basic HW administration; Service catalog for established services is not used; Order management, which is currently not used, but we counted with it; Resource Scheduling for scheduling HW resources; Monitoring management for cloud oversight; The 
cloud host was to serve to ensure the use of individual hosts within the infrastructure; Cloud storage for creating storage space; cloud network is a service we do not currently use; Cloud security is the ability to provide security for our clients as a service, and Disaster Recovery Service is an internal service serving within the backup and recovery in the event of a crash. In the case of PaaS, the main blocks are the Computing service interface, which serves as an opportunity to use the computational performance of DTCs; Software test provides the possibility of a test interface for case tests within the scope of application development, interfaces for RLs and the like; Middleware is a block serving solely as an interface and Database provides the ability to use database as a service, which we basically do not use for clients, but only for our own needs REMLABNET. Another big part of our cloud is Application resource service, which is part of SaaS. This includes in particular Remote Laboratories, which we provide as a service through REMLABNET; Management and diagnostic service enabling the use of servers and RLs security services; Scheduling service currently unused module created by our former colleague to secure access to RLs when needed; Communication services is a module for creating virtual classes and communication between teacher and pupils, between pupils with each other or even between individual classes. At the highest level is the Unified service portal, through which the system is accessed. For clients and administrators, it is REMLABNET interface with their rights and accesses, which are set within the system.

\subsection{Thin Client}

A Thin client (TC) is a networked computer with few locally stored programs and a heavy dependence on network resources. It may have very limited resources of its own, perhaps operating without auxiliary drives, CD or DVD drives or even software applications.

Typically, a thin client is one of many network computers that share computation needs by using the resources of one server. A thin client often has low cost hardware with few moving parts and can usually function better in a hostile environment than a fat or rich client.

In global, we are talking about two categories (shown on Figure 5):

1. thick client, called sometimes fat client

2. thin client, where is difference in thin client or zero client (only HW configurations)

Figure 5 - Thin and Fat Client compared to a complete system

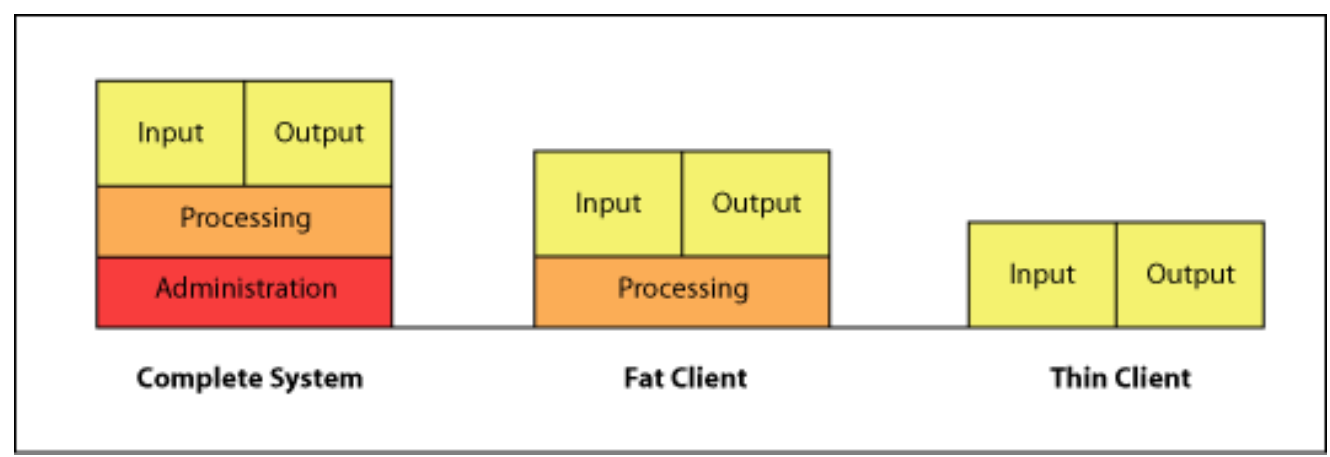

Source: online [10]

We are arriving at decision to move to thin clients from local PCs for administration of the laboratories. TCs are sometimes called 'dumb terminals' and can offer a number of advantages:

- Increased security

- $\quad$ Easier upgrades 
- Lower cost of ownership

- $\quad$ Reduced energy consumption

- Reliability

If we are looking at individual experiments, we can see these differences on Figure 6, where we show using new concept with TC.

\section{Figure 6 - New schema with using TC}

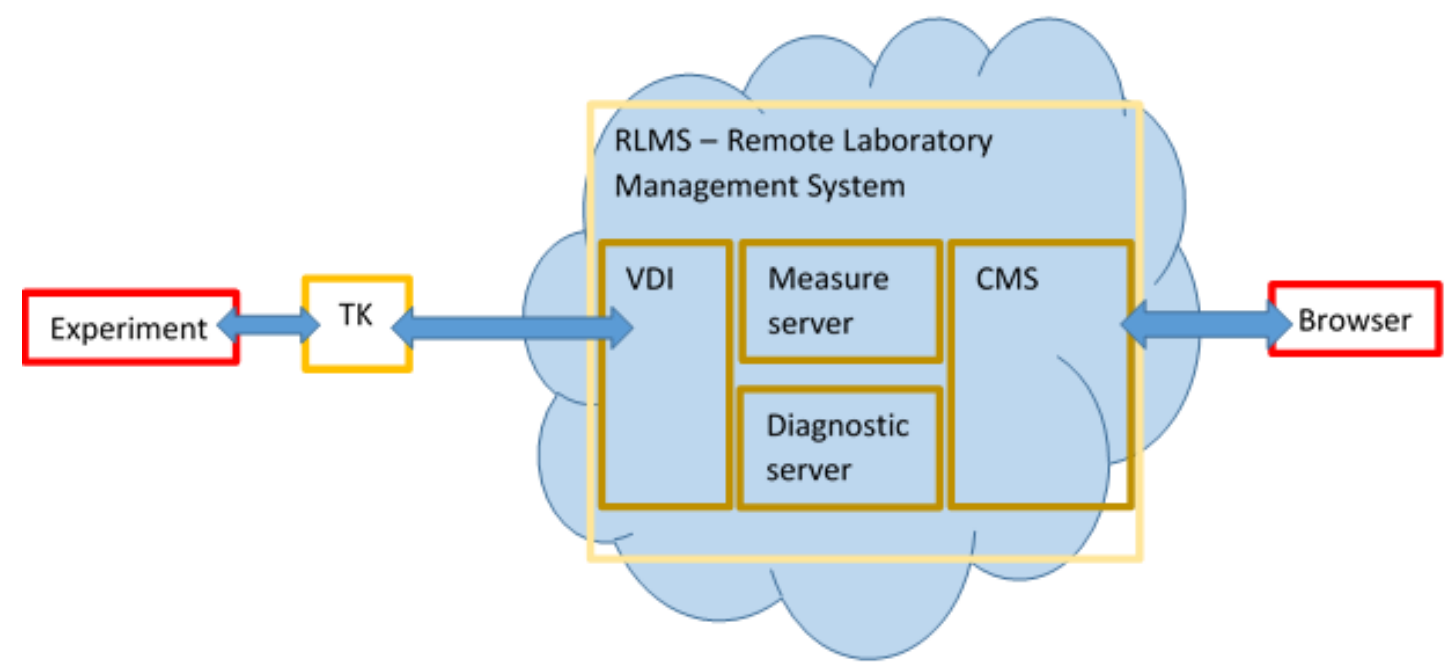

Source: own processing

We can see, that all SW parts of experiment are moved to Cloud. Every part can start from template and this is good way for easier administration and possibility to connect different $\mathrm{HW}$ configuration of RLs to RLMS REMLABNET. In REMLABNET, we are trying two different styles of thin client. First is old system from Oracle SunRay (old Sun Microsystem SunRay) and second is thin client from Huawei. These are shown on Figure 7.

Figure 7 - Thin clients used in REMLABNET
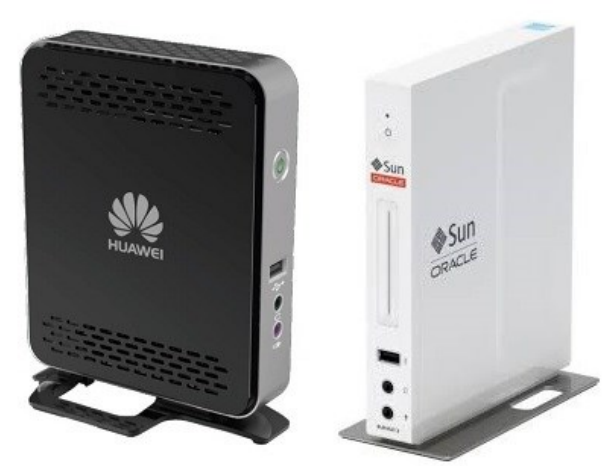

Source: own processing

\section{Federalization of Remote Laboratories}

Our system REMLABNET is connected to system SCOPES, as a part of the project of Swiss National Science Foundation (SNSF) and Swiss Agency for Development and Co-operation (SDC). Schematically this connection is depicted in Figure 3, where in the upper area it can be seen the arrow of connection onto Go-Lab. In this way, REMLABNET is connected or as in 
the frame of SCOPES, we say, federalized with Global Online Science Labs or Inquiry Learning at School (Go-Lab project EU FP7) through HTTP plug-in [10] for Smart Gateway. This HTTP plugin server works as web service. Remote experimentation through Go-Lab include a big number of laboratories accessible through Internet with the possibility of direct communication with sensors and actuating components.

\section{Conclusion}

In this paper we showed our idea of construct Cloud computing system with important parts like using thin client. Our work is oriented to save money in education and research, if everyone builds their own Remote laboratories. We have connected many laboratories from Zlin University, Trnava University, Charles University and other in the world. Our work is in simple terms „Bring Technology to Service!“”.

\section{Acknowledgements}

The paper was published thanks to the University of Trnava, where the virtualized cloud is running. Thanks also belongs to IdeaCreative, which helps to create cloud services and underlines research in the area of RLs. The biggest thanks belong to EUNIS Slovakia, which helped with financial part. We would also like to thank prof. Javier Garcia-Zubia, for his valuable advice and support for our solutions.

\section{References}

[1] Beňo, P. Cloud computing solutions and security of EU remote interactive laboratories network, Doctoral Thesis ed., Zlin: TBU Zlin, 2019.

[2] C. C. coordination, "Cartography for Swiss Higher education," 261 2012. [Online]. Available: http://www.ecartouche.ch/content_reg/cartouche/formats/en/html/Client_learningObject2.html. [Accessed Zurich].

[3] Go-Lab, “Go-Lab,” 210 2019. [Online]. Available: http://www.golabz.eu.

[4] LabShare, "LabShare Australia," LabShare, [Online]. Available: http://www.labshare.edu.au/project/. [Accessed 2610 2016].

[5] Lustig, F. et al., "Real Interactive Physics Experiments with Data Collection and Transfer acroes Internet," in FOI ITHEA, Wroclaw, Poland, 2007.

[6] Matarrita, C.A., Concari, S.B., "Remote laboratories used in physics teaching: a state of the art," in International Conference on Remote Engineering and Virtual Instrumentation (REV), Madrid, Spain, 2016.

[7] Schauer F. et al., "REMLABNET II - open remote laboratory management system for University and secondary schools research based teaching," in International conference on remote laboratory and virtual instrumentation, Bangkok, Thailand, 2015.

[8] Schauer F. et al., "REMLABNET III — federated remote laboratory management system for University and secondary schools," in International Conference on remote laboratory and virtual instrumentation, Madrid, Spain, 2016.

[9] Schauer F. et al., "REMLABNET IV — LTI federated laboratory management system with embedded multiparameter simulations," in International Conference on remote laboratory and virtual instrumentation, New York, USA, 2017.

[10] Schauer, F. et al., "REMALBNET - open remote laboratory management system for e-experiments," in International Conference on remote laboratory and virtual instrumentation, Porto, Portugal, 2014. 


\title{
Transformation of Indexes between Relational and No-relational Databases for Distributed Data
}

\author{
Roman Čerešňák ${ }^{1}$, Michal Kvet ${ }^{2}$, and Karol Matiaško ${ }^{3}$ \\ University of Zilina ${ }^{1,2,3}$ \\ Faculty of Management Science and Informatics, Department of Informatics \\ Address: Univerzitna 8215/1, \\ 01026 Žilina, Slovakia \\ e-mail: Roman.Ceresnak@fri.uniza.sk¹,Michal.Kvet@fri.uniza.sk², Karol.Matiasko@fri.uniza.sk ${ }^{3}$
}

doi: 10.18515/dBEM.ISD.P01.2020.p048

\begin{abstract}
In many discussion forums and magazines, discussions are held about which type of database is best suited to the specific situation. There is currently no best database for every situation. From these reasons, more and more databases are being created to get better manipulation and data access. Many companies experiment with different types of databases to get the best possible database for them. In such attempts, it is not only the data that is moved between the source and target databases, but it is necessary to ensure that the indexes are present in the database. For relational databases, solution indexes are very similar to each type. However, for non-relational types, the solution is diametrically different because of different types of non-relational databases and of course, a different approach. In this paper, we will propose two ways how to transform indexes from source database to target or relational database MySql to non-relational database MongoDB.
\end{abstract}

Keywords: transformation, databases, MySql, MongoDB

JEL Classification: O10, I23, D83, L86

\section{Introduction}

Transforming indexes between relational and non-relational databases is only part of the overall transformation of data from one database type to another. In this paper, we trade with the conversion of indexes from the relational database MySql to the non-relational database MongoDB. These types of databases do not differ diametrally from each other in the logic of data handling, but as far as indexes are concerned, there are no methods that exist in either database.

The data is stored in "jumbled copies", which are a collection of 8 kilobytes $(\mathrm{KB})$ data pages. Data rows are not stored in any particular order, and there is no specific sequence of data page sequences in a row. Data pages are not linked in any "catalog". If we insert new lines into the page and the page is already full, the data pages will be split. For illustration, please note the following image.

There are two critical points to consider before deciding to create an index over a table. The first is the nature of the data and second one is the queries related to that table. SQL Server uses indexes to determine the location of a row on a data access page instead of scanning the entire table and all data. Therefore, consider the following: indexes speed up queries using JOINs and sorting and grouping data, indexes apply row uniqueness when defined when creating an index, indexes are created and maintained in ascending order and last but not least realize that indexes need to be built on columns with a high degree of selectivity - so most of the data in the column should be unique (so it makes no sense to create an index above the Gender column, which contains only Male and Female). Although useful, they have several drawbacks. They take up disk space, require special maintenance (DBAs give me the truth) and also consume resources (memory, processor). Therefore, do not create indexes that are 
underused and indexes above columns with duplicate rows (M, W). [1][2]It is best to develop indexes above frequently asked rows such as primary keys, foreign keys - columns often used for joining tables, columns that are searched for returns of value ranges, and columns that are accessed how to sort the data.

MySql can access data without the use of indexes, by using clustered indexes, by using unclustered indexes, and by using unclustered indexes while the clustered indexes exist. First, perhaps to clarify the terms. A clustered index can only be defined for one table at a time. The index determines the physical order of the rows in the table. Each table should have a clustered index. The order of the leaf pages (which we will discuss in a moment) of the unclustered index is different from the physical order of the rows in the table. The unclustered index creates its index pages sorted into a tree structure and finds the desired value in them quickly, then only searches the record in the "kick" using the row identifier (if there is no clustered index for this table).

The indices use a standard B - tree. In English, we use the term balanced tree or something like a balanced tree. This tree gives quick access to information via scanning for keyword(index values) in the index. We come to the difference between the unclustered and unclustered index. A non-clipped index creates its B-tree at the index page level (not the physical records in the table). From these index pages, "lines" then lead to the individual values in the table using the row identifier. [3][4][5] If you query a column with an unclustered index, it will look up the value (or range of benefits). If there is a clustered index, it will send the record value, but already for the column with the clustered index, and it will default to the value or range. If the clustered index did not exist, the row identifier would have to point to data directly in the data pages (but not ordered). Therefore, the fastest query performed above the clustered index column will be executed. It has a whole range of values together because this column physically sorts the rows of the table, and we do not need to search for individual records.

Indexes encourage the efficient achievement of queries in MongoDB. Without indexes, MongoDB must achieve a collection scan, i.e. scan each document in a group, to select these documents that match the question announcement. If a suitable index exists for a query, MongoDB can utilise the index to limit the number of records it must inspect.

\section{Figure 1: Example of query command in MongoDB}

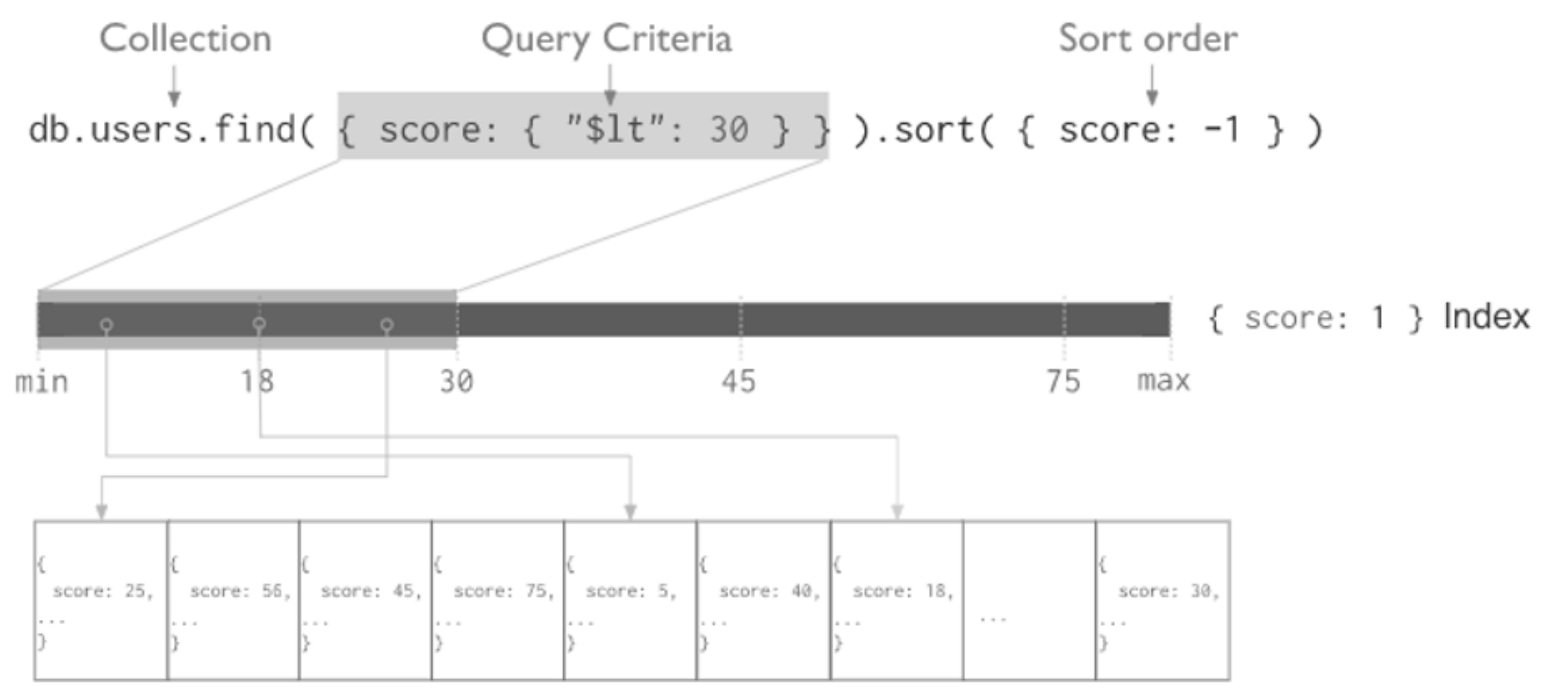

There are many hits in the relational database that are not in the non-relational database. They are:

- Indexes are unique data structures that store a small portion of the collection's data set in an easy to traverse form. The index repositories the value of a specific field or set of 
tracks, ordered by the amount of the area. The ordering of the index records supports efficient balance events and range-based query operations. Besides, MongoDB can return sorted results by using the order in the index.[6]

- Index unique scan is a strategy for looking into a solitary key worth using an individual file, and it generally restores a single value. It would help if you supplied AT LEAST the main segment of the list to get to information through the data (this may return $>1$ line as the uniqueness won't be ensured). [6][7]

- Index range scan is a technique for getting to a range estimation of a specific segment. At any rate, the main section of the list must be provided to get to information by means of the list. It very well may be utilized for extend activities (for example $><>=<=$ between) or where the information to be returned isn't exceptional. [6][7][15]

- Index Full Scan is feasible for the entire record to be checked instead of a range filter (for example where no compelling predicates have accommodated a table). Full file filters are picked when insights demonstrate that it will be more proficient than a Full table output and a sort. The file squares are checked individually, not utilizing multisquare I/O (like an FTS or Index FFS). For instance, we may do a Full file filter when we do an unbounded output of a list and need the information to be requested in the list request. The optimizer may decide that selecting all the information from the index and not sorting is more efficient than doing a FTS or a Fast Full Index Scan and then sorting. A Full Index sweep will perform single square I/o's thus it might end up being wasteful. In the accompanying model, Index BE_IX is a linked list on emp (empno,ename). [9][10]

- Index fast full scan skip check discovers regardless of whether the segment isn't the main segment of a linked file. It skirts the first column(s) during the pursuit. The main part (empno) is skipped. [16][17][14]

- File Fast Full Scan (Index FFS) An Index Fast Full Scan (Index FFS) filters all the squares in the list utilizing multiblock I/O. This implies the lines are not returned in an arranged request. Record FFS might be suggested using INDEX_FFS indicate and can be executed in equal. It can likewise be utilized to get to the second segment of linked lists because the entire file is being recovered when contrasted with a range filter which may not improve all the squares.[11][12]

As for the non-relational database MongoDB, it implements other types of indexes. The most important are:

- Single Field Index - MongoDB recommends the work of user-defined ascending/descending indexes on a separate field of a record. For a single-field index and sort controls, the sort order (i.e. ascending or descending) of the index key does not import because MongoDB can cross the index in either direction.[3][4]

- Multikey Index (which is shown in Figure 1)- MongoDB practices multikey indexes to index the content stored in arrays. If you index an area that operates an array value, MongoDB performs separate index records for every part of the collection. These multikey indexes support queries to select files that contain arrays by matching on element or parts of the displays. MongoDB automatically decides whether to build a multikey index if the indexed domain provides an array value.[1][2]

- Geospatial Index - To support dynamic queries of parallel geospatial data, MongoDB provides two individual indexes: $2 \mathrm{~d}$ indexes that use planar geometry when returning results and 2 dsphere indexes that use spherical geometry to yield results.

- Text Index - MongoDB implements a text index prototype that recommends searching for sequence content in a collection. [1][2] 


\section{Data and Methods}

Based on our model, which is shown in Figure 2, which offers the transformation of data from a relational database to a non-relational one, it was necessary to resolve the situation by looking at the indexes. Our process did not offer a transfer of created index from MySql relational database to MongoDB when changing data from the source data structure to target structure. Therefore, it is necessary to implement in our model a solution that also deals with the problem of missing transformation of index from one database type to another type.

\section{Figure 2: Transformation model}

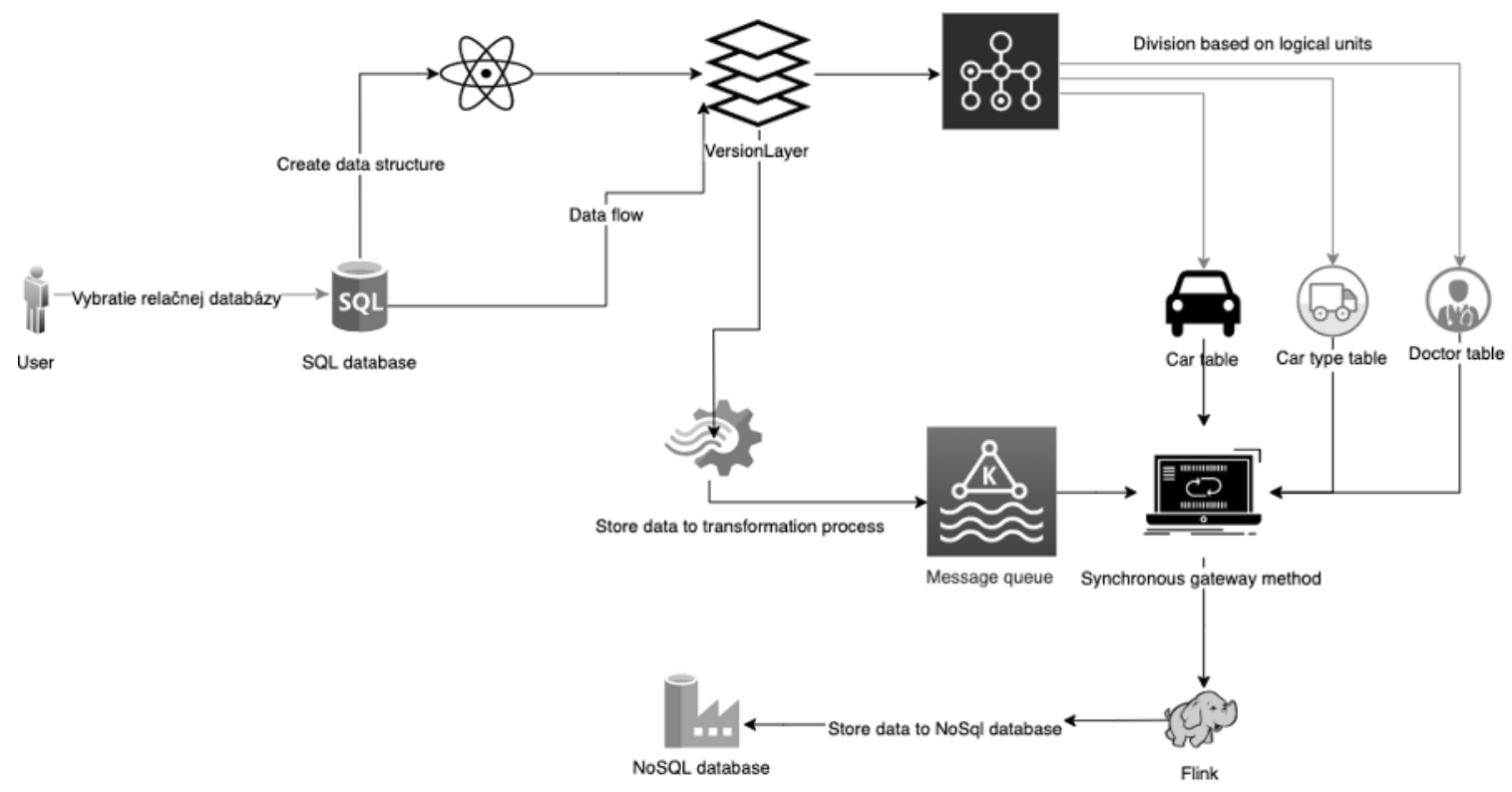

- Partial Index - Partial indexes only index the records in a collection that match a specified filter expression. By indexing a subset of the reports in an array, unfinished indexes have more moderate area requirements and reduced performance costs for index production and maintenance. Partial indexes offer a superset of the functionality of rare indexes and should be favoured over sparse indexes.

- Hashed Index - To support hash-based sharding, MongoDB implements a hashed index prototype, which indexes the hash of the value of a field. These indexes become a more random distribution of profits along with their area, but only promote.

- Unique index - The unique property for an index causes MongoDB to reject duplicate values for the indexed field. Other than the unique constraint, unique indexes are functionally interchangeable with other MongoDB indexes.

Based on these shortcomings, which our model or algorithm has not solved yet, we decided to create methods that we implement in this paper into our model. With this solution we try to improve or improve the transformation process.

\section{Results and Discussion}

We have created a method into the existing system that helps us to transform the index type in a 1: 1 ratio. If the database contains a range scan index, for example, during the transformation process, the source database creates as accurate copies of the index as possible in the no-relational database. The problem with this change is that the indexes found in the 
relational database do not fully match those in the no-relational database. Specifically, we mean the indexes in the MySql relational database and the no-relational MongoDB database.

For our purpose, we have chosen the database model shown in Figure 3. This model is always accessible to everyone using MySql Workbench. For our purposes, we have reduced the number of tables found in models by $50 \%$. The modified database model is a movie positioning model and is shown in Figure 3.

\section{Figure 3: Data model}

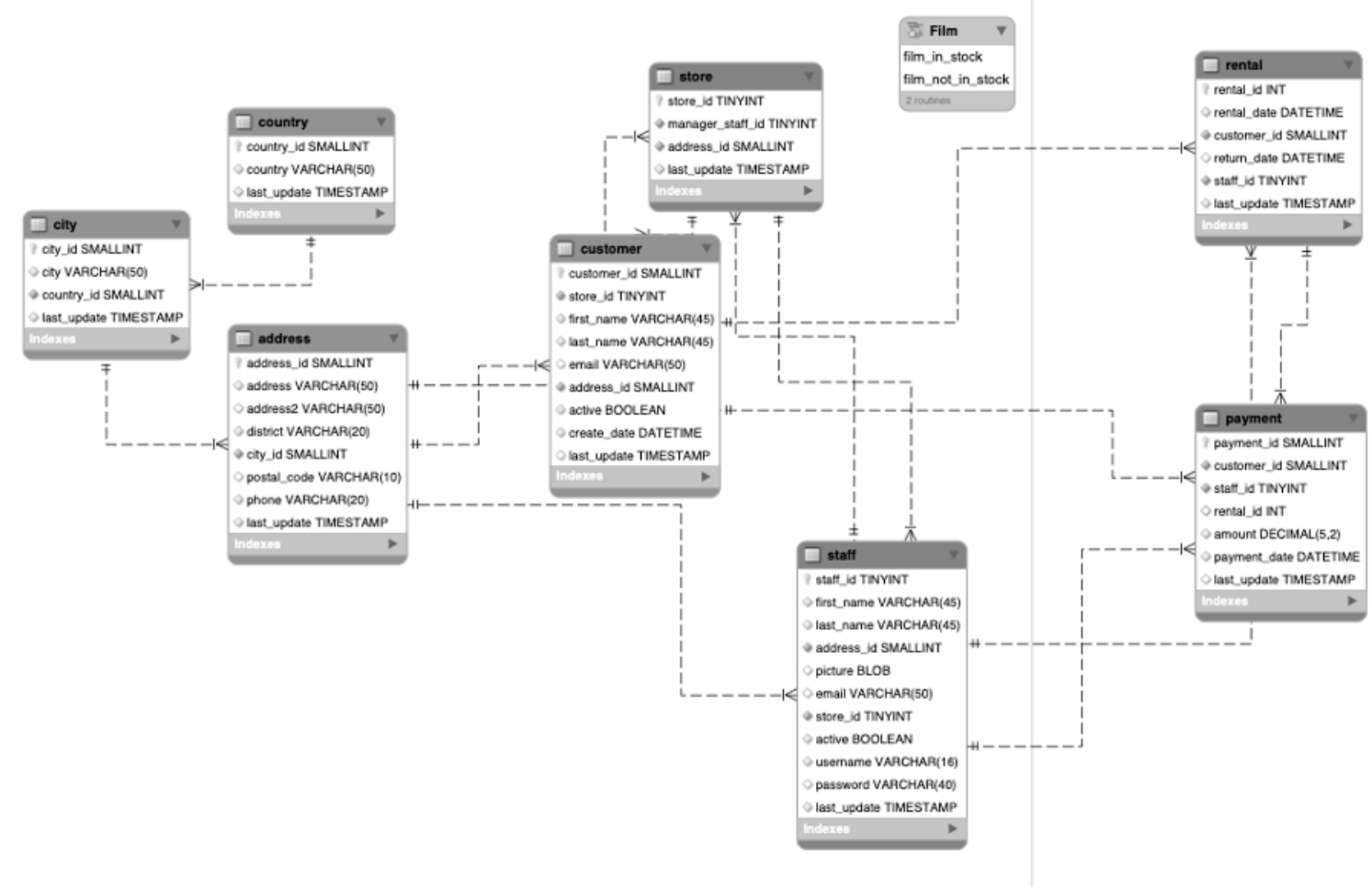

\subsection{Background Environments}

The machine used in the test has the following configuration:

- CPU: Intel(R) Core (TM) i5-6400 CPU @ 2,7GHz 2,71 GHz

- RAM: $16 \mathrm{~GB}$

- HD: 500 GB SSD

- Operating system: Windows 10

Flink system has the following configuration:

- RAM: 8 GB

- HD: 100 GB SSD

- CPU: Intel(R) Core (TM) i5-6400 CPU @ 2,7GHz 2,71 GHz

- 10 nodes

- 100 virtualized Cores

There are implicit secondary indexes above the primary tables above individual tables. This primary key must also be automatically created for the source database structure. Among the common indexes that occur in the relational database are indexes of the type range scan and unique scan. Therefore, these indexes are among our main priority in the transformation process. 
The tables we created based on the data model shown in Figure 3 do not contain any range scan and unique scan indexes, so we built them there. These indexes were not created above each table. The list of indexes that were created is as follows. For a single scan, these are:

- Customer

- Country

- City

- Address

The range scan was created over the following tables:

- Store

- Staff

- Payment

A condition for creating a unique index in a table is that the index must be created over a unique attribute. Therefore, we have modified the City, Country, Address, and Customer tables, and have declared the attributes city, address, country and email as unique attributes.

Example 1 to create a unique index above the Country table and create a range scan index above the Rental table.

CREATE UNIQUE INDEX country_ind

ON Country (country);

CREATE INDEX store ind

ON Rental (rental_date)

where rental_date $=$ sysdate;

Similarly, commands were created for the compiling tables that they mentioned in the list.

These indices are necessarily included in the transformation process during transformation. With our transformation algorithm, the best solution to start the process is to wait for all records to be created for a specific table above which the index should be created.

In our algorithm, we had to create an algorithm that detects specific types of indexes from the database and then, based on the rules, creates the best index even in the source address.

The following command was used to find out information about the indices contained in the database:

\section{SELECT}

TableName $=$ t.name,

IndexName $=$ ind.name,

IndexId = ind.index_id,

ColumnId $=$ ic.index_column_id,

ColumnName $=$ col.name,

ind.*

ic.*,

col.*

FROM

sys.indexes ind

INNER JOIN

sys.index_columns ic ON ind.object_id $=$ ic.object_id and ind.index_id $=$ ic.index_id INNER JOIN 
sys.columns col ON ic.object_id=col.object_id and ic.column_id = col.column_id INNER JOIN

sys.tables t ON ind.object_id $=$ t.object_id

WHERE

ind.is_primary_key $=0$

AND ind.is_unique $=0$

AND ind.is_unique_constraint $=0$

AND t.is_ms_shipped $=0$

ORDER BY

t.name, ind.name, ind.index_id, ic.index_column_id;

Based on this command, we get information about all indexes and also the columns above which the index is created. During the transformation it is necessary to implement this command in the following way:

- In the first step, all index types are detected

- The second step is to create a command for the non-relational database MongoDB, which is the equivalents of the relational indexes unique and range scan.

- These commands look like the following

db.TableName.createIndex ( ColumnName: 1$\},\{$ unique: true $\}$ )

db.TableName.createIndex(\{timestamp: 1, anonymous: 1$\}$ )

We called this transformation method IndexConverter and implemented it into our data transformation model.

\subsection{Experiments}

To verify how effectively our solution and how to time affect the total time needed to change data from the MySql relational database to MongoDB, we have put exactly 1000 records in each of the nine tables. These records were randomly generated and saved in tables.

We created an experiment that is so-called basic where there are no indexes in the database, and we measured the time needed for data transformation. The rates can be seen in Table 1 .

Table 3: Measure time of transformation

\begin{tabular}{cc}
$\begin{array}{c}\text { Source and } \\
\text { Destination }\end{array}$ & Time $[\mathrm{min}]$ \\
\hline MySql to MongoDB & 5 \\
\cline { 2 - 2 }
\end{tabular}

The time needed to change the data from the MySql relational database gave us about 5 minutes.

We have tested a similar process with the situation when the database contains indexes. The types of indexes and columns above which the created indexes are descriptively higher in the paper.

Table 4: Measure time for transformation and index transformation

Source and

Destination

MySql to MongoDB 5 minute and 6 second 
The time it took for the overall adjustment did not increase the amount that is of great benefit to us.

It is necessary to note that indexes are created at the end of the transformation process. The user who manipulates the application can work with the data at any time during the transformation process. However, only after it has finished, the database can perform data retrieval using indexes created.

To verify the results, it was also necessary to run an experiment for a more significant number of tables, even records and indexes created above the tables. In the models shown in Figure 3, there were nine tables. We created a copy of this model 10 times for our 1 experiment, which means that there are 90 tables, 9000 records and 80 indexes in the database. For the second experiment, we made the same copy of the model shown in Figure 3. We did not make ten copies, but 100 copies. We compared these experiments.

Table 5: Measure time for index transformation

\begin{tabular}{cc}
\hline Count of index & Time $[\mathrm{s}]$ \\
\hline 8 indexes & 6 \\
80 indexes & 24 \\
800 indexes & 52 \\
\cline { 2 - 2 }
\end{tabular}

The values we measured in the transformation process of exponential growth. These values are almost negligible compared to the time it takes to transform data from the MySql relational database to a non-relational MongoDB database.

\section{Conclusion}

Nowadays, there is a trend where many companies are experimenting and dealing with the advantages or disadvantages of switching between different types of databases. They are looking for a solution that would make it easier for them to manage, store, or move from one type of database to another type. Currently, there are many positives and negatives for which companies decide to stay or replace the data storage.

The solution we proposed in this paper simplifies the overall transformation of data from a relational database to a non-relational one, specifically the need to manually create a copy of the index when changing the data storage. The time to create an index when moving from one database type to another is not negligible, with the time needed to change the data overall.

We want to further improve this process. Indices are currently a great help in retrieving data from individual database systems, not only from non-relational databases, but also from relational types of database repositories. Future solutions will be directed to improve the IndexConverter method and improve it with the possibility of transforming other indexes.

\section{Acknowledgements}

This publication is the result of the project implementation:

Centre of excellence for systems and services of intelligent transport II., ITMS 26220120050 supported by the Research \& Development Operational Programme funded by the ERDF. This paper was created within the EUNIS-SK association.

\section{References}

[1] Ameri, P., Meyer, J., \& Streit, A. (2015). On a new approach to the index selection problem using mining algorithms. Proceedings - 2015 IEEE International Conference on Big Data, IEEE Big Data 2015. https://doi.org/10.1109/BigData.2015.7364084 
[2] Beaulieu, A. (2009). Learning SQL. Database.

[3] Bland, J. M., \& Altman, D. G. (2002). Validating scales and indexes. British Medical Journal. https://doi.org/10.1136/bmj.324.7337.606

[4] Čerešňák, R., \& Kvet, M. (2019). Comparison of query performance in relational a non-relation databases. Transportation Research Procedia. https://doi.org/10.1016/j.trpro.2019.07.027

[5] Chodorow, K. (2013). Mongo DB: The Definitive Guide. Mongo DB: The Definitive Guide.

[6] Fadoua, H., \& Amel, G. T. (2016). Heterogeneous NoSQL databases abstraction approach based on full text search indexes. Smart Innovation, Systems and Technologies. https://oi.org/10.1007/978-3-319-396279_37

[7] Goh, E. J. (2003). Secure Indexes. IACR Cryptol. EPrint Arch.

[8] Harrison, G. (2010). NoSQL and Document-Oriented Databases. Database Trends and Applications.

[9] Indexes. (2001). Chemical Processing. https://doi.org/10.7788/boehlau.9783412216825.ndx

[10] Kim, H.-J., Ko, E.-J., Jeon, Y.-H., \& Lee, K.-H. (2018). Techniques and guidelines for effective migration from RDBMS to NoSQL. The Journal of Supercomputing. https://doi.org/10.1007/s11227-018-2361-2

[11] Lahdenmäki, T., \& Leach, M. (2005). Relational Database Index Design and the Optimizers. Relational Database Index Design and the Optimizers. https://doi.org/10.1002/0471721379

[12] Larson, P. Å., Clinciu, C., Hanson, E. N., Oks, A., Price, S. L., Rangarajan, S., ... Zhou, Q. (2011). SQL server column store indexes. Proceedings of the ACM SIGMOD International Conference on Management of Data. https://doi.org/10.1145/1989323.1989448

[13] Navarro, G., \& Mäkinen, V. (2007). Compressed full-text indexes. ACM Computing Surveys. https://doi.org/10.1145/1216370.1216372

[14] O’Neil, P., \& Quass, D. (1997). Improved Query Performance with Variant Indexes. SIGMOD Record (ACM Special Interest Group on Management of Data). https://doi.org/10.1145/253262.253268

[15] Reis, D. G., Gasparoni, F. S., Holanda, M., Victorino, M., Ladeira, M., \& Ribeiro, E. O. (2018). An evaluation of data model for NoSQL document-based databases. Advances in Intelligent Systems and Computing. https://doi.org/10.1007/978-3-319-77703-0_61

[16] Tai, A., Wei, M., Freedman, M. J., Abraham, I., \& Malkhi, D. (2016). Replex: A scalable, highly available multi-index data store. Proceedings of the 2016 USENIX Annual Technical Conference, USENIX ATC 2016.

[17] Thomas, R. (1896). Indexes. Notes and Queries. https://doi.org/10.1093/nq/s8-X.247.234-e 


\title{
Precision Agriculture and its Tools in Environment of Slovak Farms
}

\author{
Marcela Hallová ${ }^{1}$, Martina Hanová ${ }^{2}$, Roderik Virágh ${ }^{3}$ \\ Slovak University of Agriculture in Nitra ${ }^{1,2,3}$ \\ Faculty of Economics and Management, Department of Informatics ${ }^{1,3}$, Department of Statistics and \\ Operations Research ${ }^{2}$ \\ Tr. Andreja Hlinku 2 \\ Nitra, Slovakia \\ e-mail ${ }^{1,2,3}$ : marcela.hallova@uniag.sk,martina.hanova@uniag.sk, roderik.viragh@uniag.sk
}

doi: 10.18515/dBEM.ISD.P01.2020.p049

\begin{abstract}
Technology is also increasingly spreading into agriculture. In order to boost productivity and profitability, farmer's need to carefully manage where they invest their time and resources. New technologies are making this possible at a scale never before possible. This creates an innovative way of farming called precision agriculture. A key component of this farm management approach is the use of information technology and a wide array of items such as GPS guidance, control systems, sensors, robotics, drones, autonomous vehicles, variable rate technology, GPS, automated hardware and software. Aim of this paper is to present the partial results of our research in the area of precision agriculture - using of the precision agriculture possibilities, its tools like GPS, GIS and VRT and advantages according the answers of respondents.
\end{abstract}

Keywords: Information and Communication Technologies, Precision Agriculture, GIS, GPS

JEL Classification: O13, O32

\section{Introduction}

Information technology is a daily part of private but mainly working life. They have a significant impact on the development of all areas of the economy, including agriculture. In such a landscape, technological innovations that can support organizations and entrepreneurs to face these problems become increasingly important (Trivelli et all, 2019). Knowledge is necessary for their processing, which is usually owned by a person who needs to use its current data and information - the owner of the company, employee, participant of a certain process (Šilerová et. al, 2019). A growing degree of technology take-up in agriculture has been the subject of many studies. The combination of technology and agriculture is often referred to as precision agriculture. Precision agriculture is an increasingly hot topic. The world population is in constant growth, which means that global food production needs to rise to keep pace with the projected demand (Palazzi et. al, 2019). Precision agriculture is based on use of information. In order to obtain, process and use the information adequate level of equipment, skills and knowledge have to be used. All the additional costs may be therefore expressed as costs of information" (Rataj, Galambošová, 2011). Precision agriculture (PA) gathers a range of application techniques aiming optimizing crop production and crop protection to obtain the best results with targeted practices, and within these targeted product applications (Alix, Capri, 2018). According the The International Society of Precision Agriculture (2019) the precision agriculture is a management strategy that gathers, processes and analyses temporal, spatial and individual data and combines it with other information to support management decisions according to estimated variability for improved resource use efficiency, productivity, quality, profitability and sustainability of agricultural production. Precision agriculture employs data from multiple sources to improve crop yields and increase the cost-effectiveness of crop management strategies including fertilizer inputs, irrigation management, and pesticide 
application (Friedl, 2018). Precision agriculture is a suitable solution to these challenges such as shortage of food, deterioration of soil properties and water scarcity. The developments of modern information technologies and wireless communication technologies are the foundations for the realization of precision agriculture (Feng et all, 2019).

A key component of this farm management approach is the use of information technology and a wide array of items such as GPS guidance, control systems, sensors, robotics, drones, autonomous vehicles, variable rate technology, GPS-based soil sampling, automated hardware, telematics, and software. Especially, the global positioning system (GPS) serves as the basis of precision farming development. It's mainly used for auto-steer systems and the production of geo-reference information. Driving in the field, GPS enables machinery to drive along repeatable tracks with accuracy, reducing possible errors made by the driver and allowing for on-time performance of farm operations (Folnovic, 2019). Now, GPS, autonomous vehicles, and software enable precision agriculture and agronomics which ensures less seed, fertilizer, and fuel are wasted. This lowers costs as well as saving time for the farmer (Guth, 2018).

Next technology, which is used very often is GIS (Geographic Information Systems). Geographic Information Systems (GIS) store, analyse and visualize data for geographic positions on Earth's surface. GIS is a computer-based tool that examines spatial relationships, patterns and trends. By connecting geography with data, GIS better understands data using a geographic context (gisgeography.com, 2020). GIS can be used to produce images, not just maps, but drawings, animations, and other cartographic products. From mobile GIS in the field to the scientific analysis of production data at the farm manager's office, GIS is playing an increasing rol in agriculture production throughout the world by helping farmers increase production, reduce costs, and manage their land more efficiently (Sood et all, 2015).

Another important technology is Variable Rate Technology (VRT). Variable rate technology allows the farmer to control the amount of input such as seeds, fertilizers, pesticides, and water. It provides optimization on planting density and improved application rate efficiency of pest protection products and nutrients, resulting in farm cost reduction and, most importantly, the reduction of negative environmental impact (Ivanov, 2018). In the following parts of the article we will discuss how precision agriculture and its methods are known in the conditions of Slovak agriculture.

Precision agriculture also has benefits like obtaining data in real time, saving time and costs, and providing better farm records essential for sale and succession (Folnovic, 2019).

\section{Data and Methods}

During 2018 and 2019 was conducted a survey at the Department of Informatics related on the impact of information and communication technologies on the economic growth of agriculture companies. One section was about the precision agriculture. The questions were constructed if the respondents are familiar with the term of PA. If the responses were positive, further questions were focused on the use of tools and methods of PA.

There are several methods used to calculate the sample size depending on the type of data or study design. The sample size in our survey was calculated by using the following formula:

$$
n=\frac{2\left(Z_{\alpha}+Z_{1-\beta}\right)^{2 \sigma 2}}{\Delta^{2}}
$$

where $n$ is the required sample size. For $Z \alpha, Z$ is a constant set by convention according to the accepted $\alpha$ error and whether it is a one-sided or two-sided effect. For $Z_{1-\beta}, Z$ is a constant set by convention according to power of the study. In the above-mentioned formula $\sigma$ is the 
standard deviation (estimated) and $\Delta$ the difference in effect of two interventions which is required (estimated effect size). Our research sample has 444 respondents and the questionnaire return was $36 \%$. Most of the research sample was small and medium farms with the plant and livestock production. We can state that the sample is representative.

The reliability of the items was analyzed using multidimensional survey techniques to judge the quality/reliability of the measurement procedure (e.g. the questionnaire scale) and to identify suspicious questionnaire items. One of the ways to directly estimate reliability is the Cronbach's Alpha Coefficient

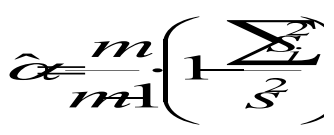

where $m$ is the number of items in the questionnaire, $\mathrm{s}^{2}$ is the questionnaire scale variance, and $\mathrm{sj}^{2}$ is the variance of the $j$ item in the questionnaire. Questions were also evaluated by other statistical methods like Mann-Whitney U Test (for Likert scale questions) and their results are presented in the following chapter.

\section{Results and Discussion}

One of the most important questions about precision farming was whether businesses were taking advantage of such farming. More than half of the companies (58\%) said they were using these opportunities as show Figure 1.

Figure 1 Companies using precision agriculture possibilities

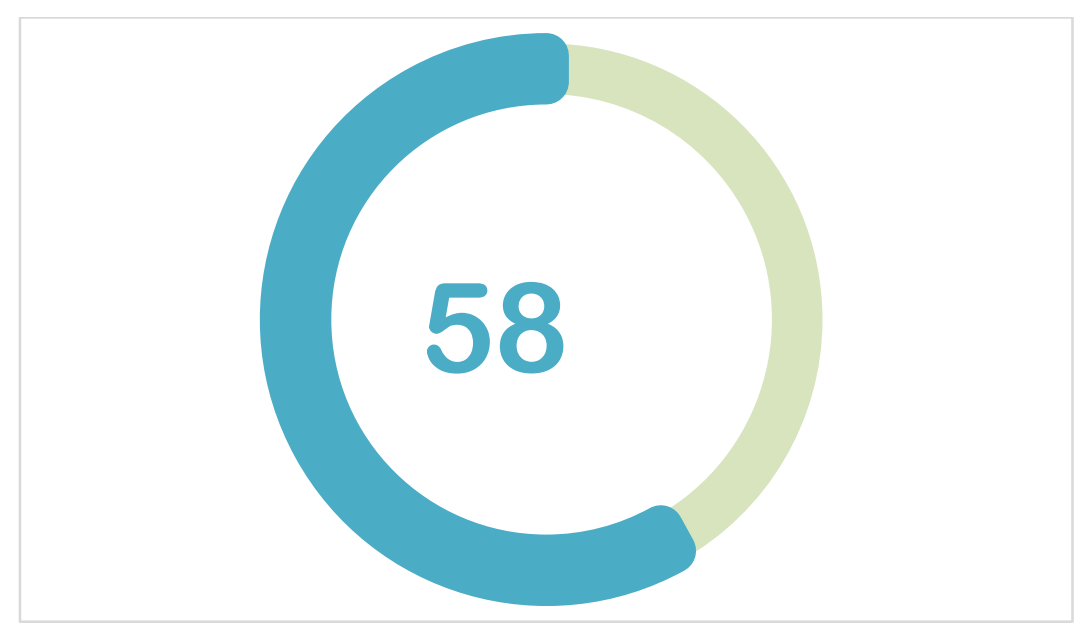

Source: own research, own processing

In the introduction part of this article the precision agriculture tools have been described. We described tools like GPS, GIS and VRT. These tools are not the only ones but the most used, that is the reason, why we aimed on it in our results. According our research, the most used tool in research sample was GIS (Geographic Information Systems). Second one was GPS (global positioning system). According of experiences of farmers, the best way is to use combination of GIS and GPS. The use of GPS and GIS together allows for real time data collection that acquires an accurate position. This means that farmers can use devices to map where exactly the resources of that farm will be used to increase the resource use as well as increase its efficiency. The results of our research shows that $23 \%$ of respondents use this combination. On the other side, combination of all three tools is used only in $2 \%$ of companies. Complete situation shows Figure 2. 
Figure 2 Using of GPS, GIS and VRT tools in precision agriculture

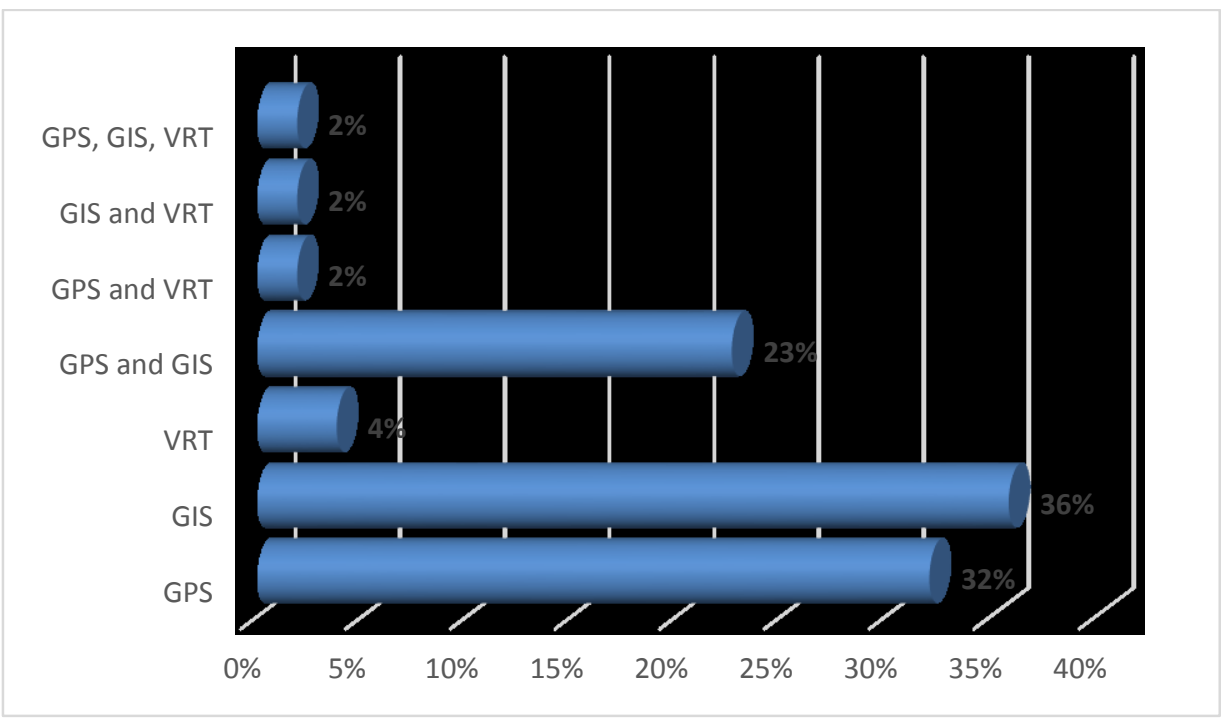

Source: own research, own processing

An important part of the survey was also the expression of approval or disagreement on the claims about precision agriculture. The results of various surveys have shown an increase in revenues, improved benefits for businesses in the future or reduced costs. In our survey we used Likert scale rating to measure opinions about precision agriculture. The claims about precision farming are as follows:

$>$ the costs of introducing precision farming tools are too high,

$>$ the net revenues from the introduction of technology are higher than from traditional agriculture,

$>$ precision farming will bring many benefits for the enterprise to the future,

$>$ precise agriculture can slow or stop the trend of people leaving rural areas,

$>$ precise agriculture will enable the company to adapt more quickly to climate change.

Results are shown in the Figure 3.

Figure 3 Statements about precision agriculture

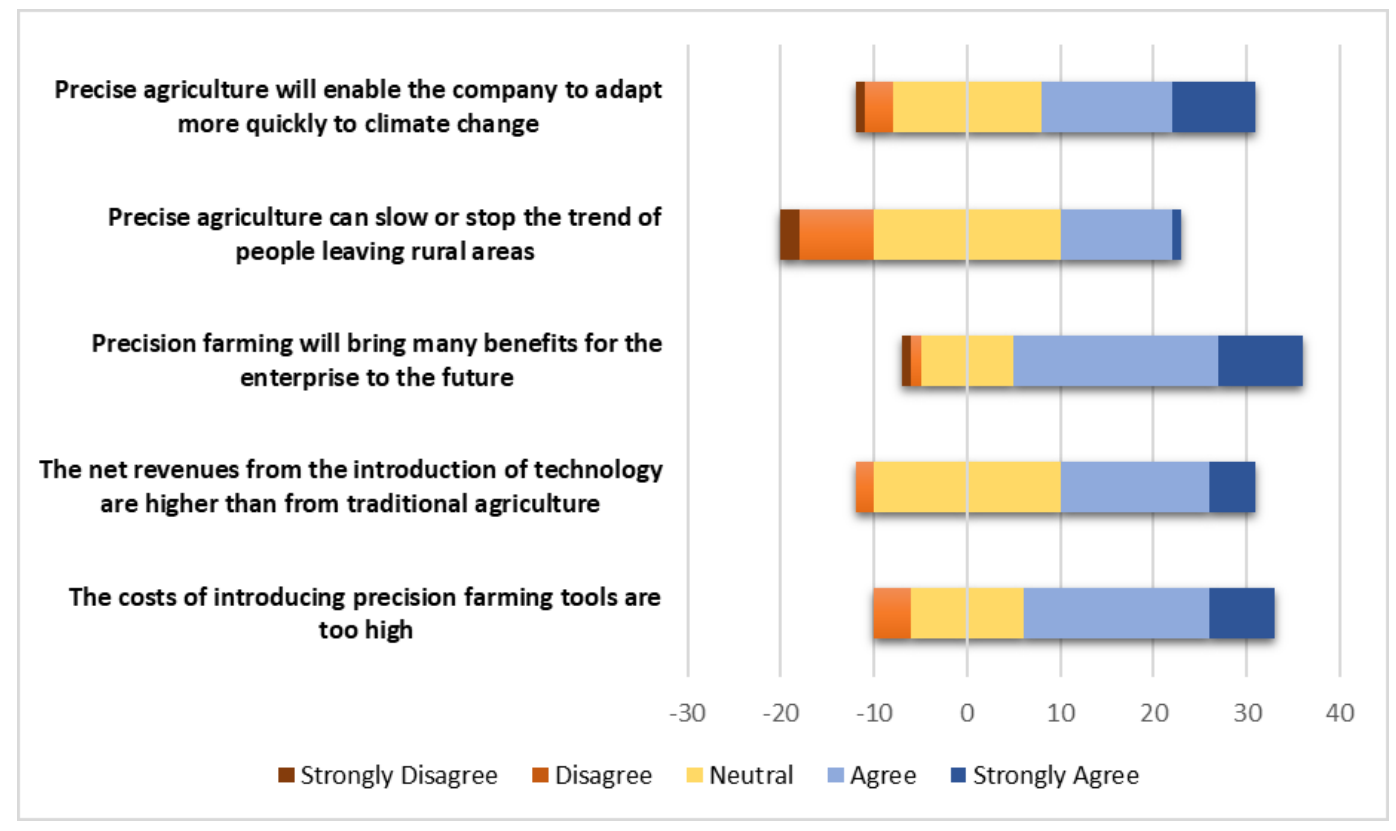

Source: own research, own processing 
As is shown in Figure 3, majority of respondents express their agreement or strong agreement with precision agriculture statements. The only argument to the detriment is that statement about costs. This means that for some respondents the cost of implementing precision farming tools is a problem. Disagree or strongly disagree is the highest in the statement that precise agriculture can slow or stop the trend of people leaving rural areas. In this claim, we can conclude that it is necessary to look for other ways to prevent young people leaving rural areas.

\section{Conclusion}

Information technology is constantly evolving and changing rapidly. Whether we like it or not, they affect all areas of the economy. They also extend to a traditional area such as agriculture. According to the survey results, more than half of the companies use the tools of precision farming. The most commonly used technologies are GPS and GIS. Reason can be that these technologies help to optimize farm operations, improve business practice and can be useful with the effective monitoring of agricultural activities. Most respondents agree respectively strongly agree with the statement that precision agriculture can bring benefits for the enterprise and enables rapid adaptation to climate change. Generally, can be summarized other benefits as GPS allows fields to be surveyed with ease, yield and soil characteristics can be mapped and minimises the risk to the environment particularly with respect to nitrate leaching and groundwater contamination via the optimisation of agrochemical products. But on the other side, there are some disadvantages too. Initial capital costs may be high and so it should be seen as a long-term investment and it may take several years before we have sufficient data to fully implement the system. And what will be in the future? Robots and autonomous vehicles will reduce labour costs, while increasing efficiency. GPS and contour mapping carried out by drones quickly provides farmers with highly detailed information on water levels and soil fertility - with data even being transferred via a cloud. Software gives operators a clear overview of operations and data analytics to help improve decision-making for the following year. Near future of the precision agriculture is to use RTK technology (Real Time Kinematic) with GPS technology. RTK signals talk with tractor, combine, application rig and help guide it accurately through the field (mywayrtk.com, 2020).

\section{References}

[1] Feng, X., Yan, F., Liu, X. 2019. Study of Wireless Communication Technologies on Internet of Things for Precision Agriculture. Wireless Personal Communications, Volume: 108 Issue: 3 Pages: 1785-1802. DOI: 10.1007/s11277-019-06496-7

[2] Folnovic, T. 2019. Benefits of Using Precision Farming: Producing More with Less. Retrieved from https://blog.agrivi.com/post/benefits-of-using-precision-farming-producing-more-with-less.

[3] Folnovic, T. 2019. Technology Essential for Precision Farming. Retrieved from https://blog.agrivi.com/post/technology-essential-for-precision-farming.

[4] Guth, D. 2018. The Future of Farming: IT in Agriculture. Retrieved from https://itelligencegroup.com/sk/global-blog/the-future-of-farming-it-in-agriculture/

[5] International Society of Precision Agriculture. 2019. Retrieved from https://www.ispag.org/.

[6] Ivanov, I. 2018. Variable Rate Application in Precision Agriculture. Retrieved from https://medium.com/remote-sensing-in-agriculture/variable-rate-application-in-precision-agriculture$70 \mathrm{a} 8 \mathrm{~b} 2 \mathrm{be} 871 \mathrm{~d}$.

[7] MyWay RTK, 2020. How It Works. Retrieved from http://www.mywayrtk.com/How_It_Works/.

[8] Rataj, V., Galambošová, J. 2011. Economical assessment of information in precision agriculture. recision Agriculture 2011 - Papers Presented at the 8th European Conference onPrecision Agriculture 2011, ECPA 2011 pp. 668-674. Retrieved from: https://www.researchgate.net/publication/289397914_Economical_ assessment_of_information_in_precision_agriculture 
[9] Sood, K., Singh, S., Rana, R., Rana, A., Kalia, V., Kaushal, A. 2015. Application of GIS in precision agriculture. National Seminar on "Precision Farming technologies for high Himalayas"At: Precision farming development centre and High Mountain Arid Agriculture Research Insitutue, Leh, Ladakh, Jammu and Kashmir, India. DOI: 10.13140/RG.2.1.2221.3368

[10] Šilerová, E., Hennyeyová, K., Rakovský, V., Jarolímek, J., Ulman, M. The influence of information technologies on competitiveness. In Agrarian perspectives XXVIII. Praha: Czech University of Life Sciences, 2019, s. 296--304. ISBN 978-80-213-2973-7 (brož.).

[11] Trivelli, L., Apicella, A., Chiarello, F., Rana, R., Fantoni, G., Tarabella, A. 2019. From precision agriculture to Industry 4.0 Unveiling technological connections in the agrifood sector. British Food Journal, Volume: 121 Issue: 8 Pages: 1730-1743. DOI: 10.1108/BFJ-11-2018-0747

[12] V. Palazzi, S. Bonafoni, F. Alimenti, P. Mezzanotte and L. Roselli, "Feeding the World With Microwaves: How Remote and Wireless Sensing Can Help Precision Agriculture," in IEEE Microwave Magazine, vol. 20, no. 12, pp. 72-86, Dec. 2019. doi: 10.1109/MMM.2019.2941618

[13] What is Geographic Information Systems (GIS)? 2020. Retrieved from https://gisgeography.com/what-gisgeographic-information-systems/ 


\title{
Virtual Reality Perspectives in Implementation into Serious Game Application
}

\author{
Marián Host'ovecký ${ }^{1}$ \\ University of Ss. Cyril and Methodius in Trnava \\ Address: Nám. J. Herdu 2, \\ Trnava, Slovakia \\ e-mail1: Marian.Hostovecky@ucm.sk
}

doi: 10.18515/dBEM.ISD.P01.2020.p050

\begin{abstract}
This paper analyses the perspective of the use and playing serious game with virtual reality. The serious game is designed for beginning teachers to solve specific and unspecific pedagogical situations during the lessons. A serious game was developed and programming in cross-platform game engine by Unity. Reasons why we chose this platform, it is a great tool for prototyping of video games and interactive visualizations. Another goal of this study is discussion which hardware equipment's of virtual reality could improves user experiences. Teachers could obtain more experiences with support of these equipment's walk, smell or haptic. It could be improving of solving problems and can improve the memory.
\end{abstract}

Keywords: serious game, design, development, application, virtual reality.

JEL Classification: O10, I23, C88, C91

\section{Introduction}

The dynamics of changes in the field of information technologies opens the doors to use of new methods in development for variety target groups of audience. Communication bandwidth (networks), computers, laptops, tablets and mobiles (hardware) and new generation of operating systems, program languages and game engines (software) offer possibilities of developing more attractive, funnier and more educating e-material or educational software.

The recent emergence of serious games as a branch of the computer gaming field has introduced the concept of games designed for a serious purpose other than pure entertainment, e.g. healthcare [1].

John Huizinga belongs to the authors who contributed to the development and promotion of the games in education. The game is characterized as "voluntary activity that is carried out within the fixed time and spatial boundaries, based on voluntarily accepted but absolutely binding rules which has its objective in itself and it is accompanied by feelings of tension and joy and knowledge of other than everyday life" [2].

Today's digital computer and videogames are characteristically long, challenging and complex. In order to 'beat' the game and successfully achieve the long-term objective of the game, players typically need to develop a variety strategies and skills. This has led some academics to recognize the videogame playing as "a demarcated learning project" [3]. Games, it would seem, provide powerful and meaningful contexts for learning. This view, while relatively new to the academic community, is one the game industry has already been aware of for some time. A major reason for this is the game business' equivalent of natural selection. Game studios are in the business of creating products where success is dependent on the ability of players to learn and overcome the various challenges and obstacles within the game [4]. 
Games are very good at using drama, storyline, humour and characters to create a compelling experience which, from a training point of view, develops memory hooks and means that learners not only remember what happened but also why it happened. If undertaken appropriately, GBL is the vehicle for embedding new knowledge and/or skills that can then be immediately applied in the workplace [5].

The presence of this new media, however, is insufficient to ensure its effective use; the mode of delivery of educational content is also an important consideration [6]. With respect to students, strong engagement has been associated with academic achievement [7]. Serious games can be applied to a broad spectrum of application areas, e.g. military, government, educational, corporate, healthcare. A key question, when discussing serious games, is what the concept itself actually means. Even a brief survey of the literature soon reveals that there seems to be as many definitions available as there are actors involved, but most agree on a core meaning that serious games are (digital) games used for purposes other than mere entertainment [8].

Educational games becoming increasingly popular. The use of educational video-games called as serious games can be effective only if elements such as goals, competition, challenges, and fantasy influence motivation and facilitate learning. Motivation refers to the initiation, the intensity and the persistence of behavior. Nevertheless, students are not always highly motivated. Previous research has claimed that a game's story can motivate students to use an educational game [9], [10].

Serious games have the potential of bridging the simulation and gaming worlds by harnessing the educational value of technology-enhanced simulation to teach specific technical or cognitive skills to learners (be they trainees or patients), alongside the motivational, interactive, and engaging aspects inherent in games. In addition to promoting learning via interaction, serious games are ideal for simulation as that they allow users to experience situations that may be otherwise difficult to experience in reality, due to factors concerning cost, time, safety, and ethic [11]. To make a successful serious game, one must first evaluate the needs of the envisioned learners, and decide what are the skills or knowledge than one want to teach. The learner's profile will be part of the constraints. Domain experts as well as educators will have to be part of the development and work in collaboration with the computer software or game developers. In addition to its domain-specific content, the game must be fun and challenging, with some type of story adapted to the trainee [6].

\section{Virtual reality in serious games}

Virtual reality (VR) has typically been portrayed as a medium, like telephone or television. This "new" medium is typically defined in terms of a particular collection of technological hardware, including computers, head-mounted displays, headphones, and motion-sensing gloves. The focus of virtual reality is thus technological, rather than experiential; the locus of virtual reality is a collection of machines [12].

The term has first been used back in the 60s, even if its roots date back to the 19th Century when the first 360-degree art through panoramic murals began to appear. Nearly one hundred years later, a mechanical device, the Sensorama1, engaged multiple senses to create an immersive VR. The system provided a multisensory experience of riding a motorcycle, including three-dimensional, full color film together with sounds, smells, and the feeling of motion, as well as the sensation of wind on the viewer's face. Since then, VR has evolved in several manners becoming more and more similar to the real world. ICT and VR have become 
strictly interconnected as computing power increases, and Human Computer interfaces become more and more complete and adaptive [13].

The terms virtual worlds, virtual cockpits, and virtual workstations were used to describe specific projects. In 1989, Jaron Lanier, CEO of WL, coined the term virtual reality (VR) to bring all of the virtual projects under a single rubric. The term therefor typically refers to threedimensional realities implemented with stereo viewing goggles and reality gloves [14]. The question also is: "What can we imagine under the term of VR and what it brings for society, education, corporations, medicine?" Virtual reality (VR) can be considered as technology that allows simulation of characters, objects, storyline, activity, space and time, etc. to create and guide the impression of reality. Its aim is to introduce and realize the possibilities of verification, application, implementation and testing that would be technically, technologically, financially, personally, geographically or otherwise difficult to realize in real environment and with real conditions. The question remains, however, how the virtual environment and the application are approaching the real environment and conditions. VR is not a new technology, but it's time to fully exploit and integrate into different sectors will and will gradually be integrated. This is a long-term issue. Only when the barriers that stand in the way will be gradually removed will the use of VR be considerably wider. With the possibility of gradually reducing the price of virtual devices, they will be available to ordinary households and individuals as other conventional devices are available today. Coates understand VR as electronic simulations of environments experienced via head-mounted eye goggle. and wired clothing enabling the end user to interact in realistic three-dimensional situations" [15].

\section{Game design and development}

In following lines, we will present the process of design, development and tools which were used for development of the serious game and devices of potential use of virtual reality.

\subsection{Game design}

When a game designer proposes a game, they analyse all aspects and elements of the game. The concept of the whole design must reflect the final form of the game. The idea at the beginning of the design is therefore the main driving engine. The basic element of the educational game was to design a simple story based on solving tasks (focusing on solving specific and unspecific situations) to meet the goal of the game.

At this stage, we have set the goal to choose the genre for the game and, at the same time, the way in which our story would be interpreted to the player (pupil/students). Among the fundamental objectives was also the robustness of the game. Therefore, it was important to choose the right genre of the game. Based on this, we chose an adventure. The genre offers the player movement and interaction. The player moves in an environment and communicates with the surroundings, collecting and touching objects. The main motive of the game is to solve the primary task that originates from the definition of the genre.

The splash screen was designed to show the situation (in the class) where a teacher is solving a specific situation with pupils/students (figure 1). Characters in serious games are composed of teachers and pupils. Under the term of sprite, we can understand a bitmap graphic designed to be part of a larger scene. It can either be a static image or an animated graph (figure 2). 
Figure 1: Splash screen of the serious games

Source: own production

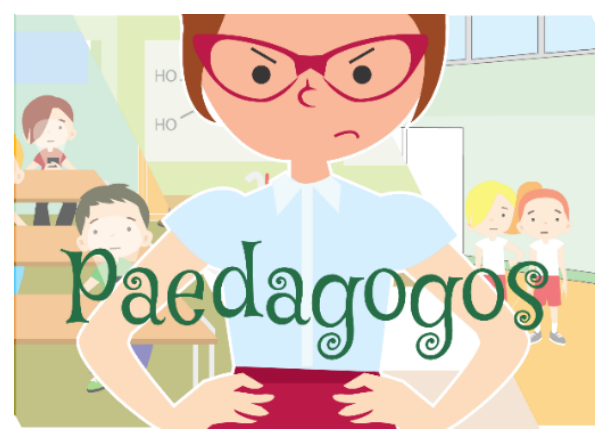

Figure 2: Sprites
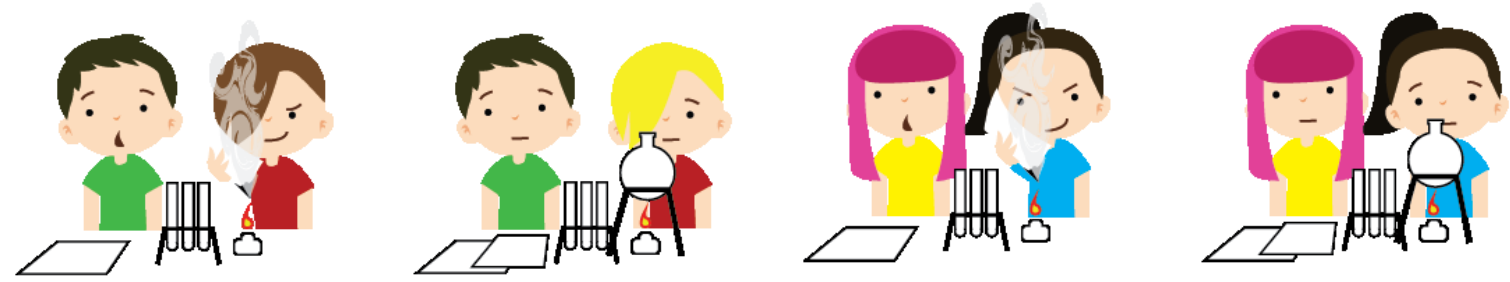

Source: own production

Our suggestion is developing a serious game in virtual reality which could be used for improve to solve specific or unspecific pedagogical situations. The demonstration of what it might look like see below (figure 3).

Figure 3: The demonstration of the serious game in VR resulting in more immersive gaming than traditional games using a computer or TV monitor
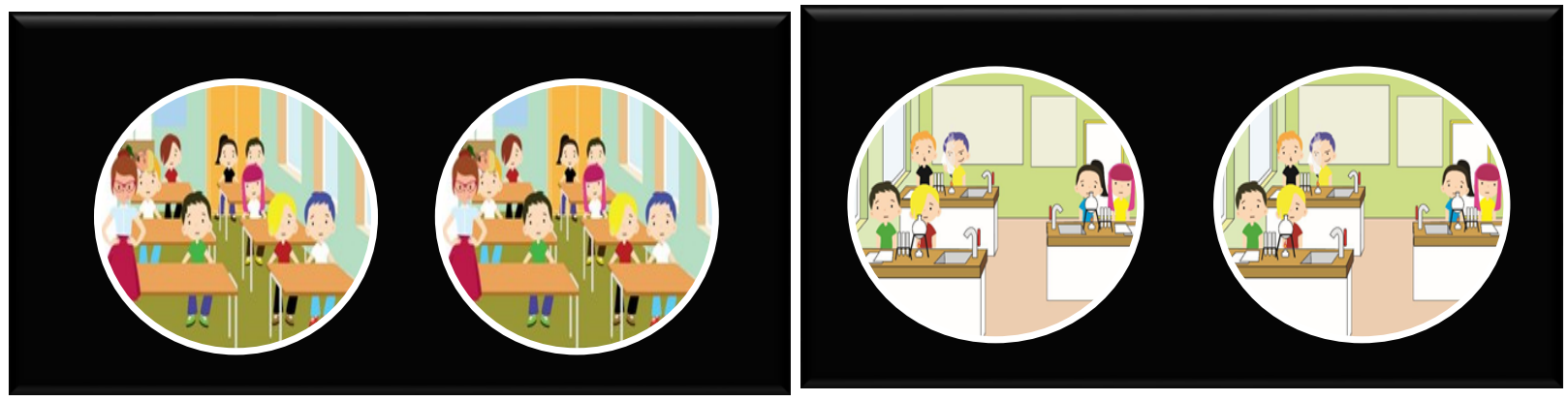

Source: own production

\subsection{VR devices recommended for the game}

The creation of a serious game involves different processes, technologies and specialists [16]. Between technologies which will be used in serious game with virtual reality are virtual reality headset, two controllers, two infrared laser emitter units-base stations (figure 4) and Feelreal's sensory mask (figure 5) and virtual reality device intended for walking.

Figure 4: Example of use of VR headset with headset, base stations and VR controllers

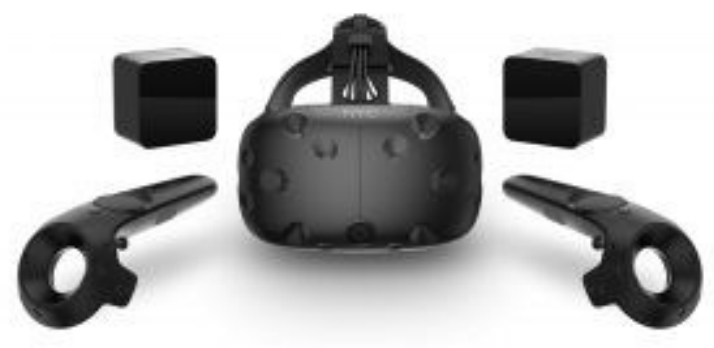

Source: https://www.droidshop.vn/ 
Virtual reality is a largely visual environment with sounds rounding out the experience. A number of devices bring haptic feedback into the picture, but smell remains absent. That may change in the future via Feelreal's sensory mask, a contraption that works with existing VR headsets to bring hundreds of smells to the user's virtual worlds. The Feelreal VR mask is something of an oddity, featuring a Darth Vader-like contraption that pairs with an existing VR headset so that it is positioned in front of the wearer's lower face. Aroma capsules contain various scents that are released to augmented the VR experience (figure 5) [17].

\section{Figure 5: Use of Feelreal Multisensory VR Mask}

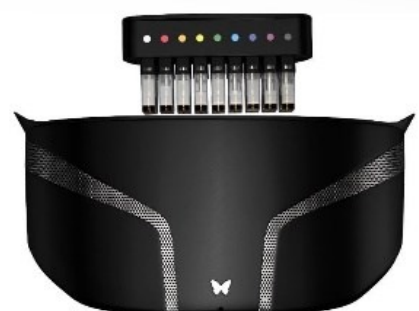

Source: https://www.slashgear.com

Another device is for walking in virtual reality. One of the most useful devices for our game is Kat Walk mini. This device is designed to move in virtual reality which allows you to walk, jump and run. This device could be used for walking in virtual reality from class to class, or in chemistry laboratory, or run and jump what can brings new user experiences (figure 6).

\section{Figure 6:}

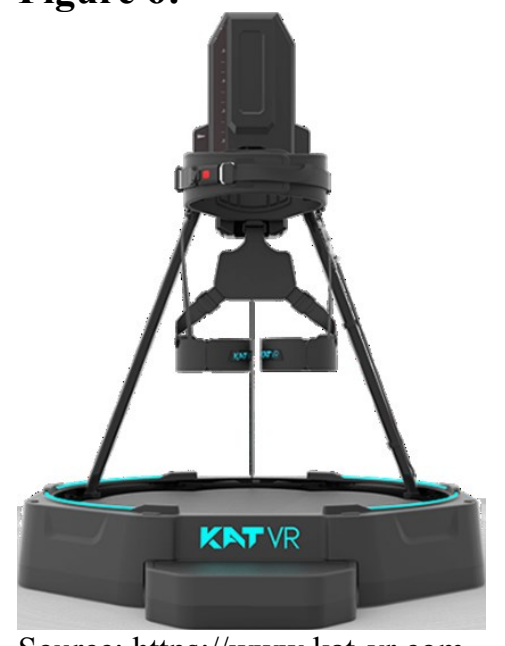

Source: https://www.kat-vr.com

\subsection{Development tools}

\section{Unity Game Engine}

Game engines are a new way to develop high-quality games easily and rapidly without needing intensive programming skills and computational resources. Today, there is growing interest in game engines due to the rapid development of hardware and system platforms. 3D game engines help game companies reduce their cost, time, and manpower, since game developers can use the available functionalities of the engine [18].

Unity comes with tools to support the workflow for 2D and 3D. It is a suitable, powerful and user-friendly game development tool. It is simple in operation and compatible with a wide variety of media format types such as graphics, audio, video and text. This game engine is a freeware. It offers several possibilities to create objects that are equivalent in practical use and 
their utilization depends on the user's habits. We used this game engine for develop of the game for 3D virtual reality development.

\section{Gimp}

It is an open-source raster image editor. It offers plenty advanced features including filters, Beziers curves, supported pre-installed plug-ins, layers and scripting. It is a multiplatform graphic software available for many operating systems.

\section{Blender Studio}

It is a professional application for 3D graphics used for modeling, animation and visualization of created models. The reason for using multiple programming software was the fact that the player rather enjoys good graphic design than other effects (music and sound). We wanted to achieve the best impression from the game and, therefore, we considered this when designing the game.

\section{GUI Development}

GUI design elements were created using external software for editing 2D graphics. We used mainly freely available programs, such as Gimp, in which we drew pictures to GUI representing key objects in the game. When creating the menu, we used a new system of Unity, which allows intuitive editing of individual windows and modifying their appearance and functionality by adding components. The screen contains the following buttons:

- Play Game - launches a new game.

- Help - a short guide to game controls and the goal of the game.

- Settings - settings (voice, sounds, music and graphic resolution).

- Credits - creators, acknowledgments.

- Exit- leaves the game.

\section{Testing}

Testing was realized by using of white box method based on the knowledge of the internal structure and source code of the tested system - the game. While testing this first phase, we encountered bugs that caused malfunction of one of the features. Errors were then removed. We are aware that we will encounter other iterations of testing, but we will reveal further shortcomings in the code.

\section{Conclusion}

"Digital age“ - a perfect name for this period we live in, in which technologies and internet have become a part of our everyday lives. They have an enormous impact on our lives and educate all generations $[19,20]$. Serious games can bring new perspectives of education. It can be described as a tool for improving specific skills or competences as a digital competences or math competences of students [21,22]. The game was designed and developed in association with methodologists, didactics and university teachers. Nowadays, the game is being developing in 3D for virtual reality. After the end of process development, we will to find out the effectiveness - it means motivation and understanding, contribution and attitude to the game. The results obtained from testing will be evaluated, published, and compared with other similar research works. Further research will be conducted to find out what kind of role teachers will have and how games can to give a hand to young teachers to solve specific and/or unspecific situations. After the end of development and testing the serious game will be available on a web portal for a wider sample of testing. 


\section{Acknowledgements}

This paper was supported by KEGA project no. 015UCM-4/2018 and association EUNIS-SK.

\section{References}

[1] Bopp, M. (2007). Storytelling as a motivational tool in digital learning games. In Hug, T. (Ed.), Didactics of Microlearning. pp. 250-266, Munster: Waxmann.

[2] Brečka, P. \& Valentová, M. (2017). Model of the Students' Key Competences Development through Interactive Whiteboard in the Subject of Technology. In: Informatics in education : A Journal of Eastern and Central Europe, 16(1), pp. 25-38. DOI 10.15388/infedu.2017.02.

[3] Chorianopoulos, K., Giannakos, M. \& Chrisochoides, N. (2014). Design Principles for Serious Games in Mathematics. In Proceedings of the 18th Panhellenic Conference on Informatics, Athens, Greece. doi: $10.1145 / 2645791.2645843$.

[4] Coates, G. (1992). Program from Invisible Site - a Virtual Show, aMultimedia Performance Work Presented by George Coates, "Performance Works, San Francisco, CA.

[5] Corti, K. (2006). Game-based Learning: A Serious Business Application. PIXELearning, Coventry.

[6] De Ribaupierre, S., Kapralos, B., Haji, F., Stroulia, E., Dubrowski, A., Eagleson, R. (2014). Healthcare Training Enhancement Through Virtual Reality and Serious Games. In Virtual, Augmented Reality and Serious Games for Healthcare, pp. 9-27. Springer Berlin Heidelberg doi: 10.1007/978-3-642-54816-1_2.

[7] Freina, L., \& Ott, M. (2015). A literature review on immersive virtual reality in education: state of the art and perspectives. In 2015 Proceedings of eLearning and Software for Education (eLSE), Bucharest.

[8] Huizinga, J. (2000). Homo ludens: o původu kultury ve hře. 2. vydanie. Praha: Dauphin, pp. 297, ISBN 807272-020-1

[9] Kanthan, R. \& Senger, J.L. (2011). The impact of specially designed digital games-based learning in undergraduate pathology and medical education. Archives of Pathology \& Laboratory Medicine, 135(1), pp.135-142. doi: 10.1043/2009-0698-OAR1.1.

[10] Krueger, M.W. (2001). Artificial reality (2nd ed.). Reading, MA: Addison-Wesley.

[11] Ma, M. \& Bechkoum, K. (2009). Serious games for movement therapy after stroke. In Systems, Man and Cybernetics, 2008. IEEE International Conference on Systems, Man and Cybernetics. pp. 1872-1877. doi: 10.1109/ICSMC.2008.4811562.

[12] Országhová, D., Hornyák Gregáňová, R., \& Tóthová, D. (2017). Mathematical tasks with applications and their presentation via information technology. In 16th Conference on Applied Mathematics, APLIMAT 2017 - Proceedings. pp. 1146-1152.

[13] Papert, S. (1998). Does Easy Do It? Children, Games, and Learning. Game Developer Magazine, 8889.

[14] Roston, B. A. (2018, December 28). Feelreal VR mask brings scents to virtual reality experiences. Retrieved February 10, 2020, from https://www.slashgear.com/feelreal-vr-mask-brings-scents-to-virtual-realityexperiences-27559423/

[15] Shute, V.J., Ventura, M., Bauer, M. \& Zapata-Rivera, D. (2009). Melding the Power of Serious Games and Embedded Assessment to Monitor and Foster Learning: Flow and Grow. In Ritterfeld, U., Cody, M., Vorderer, P. (eds.) Serious Games Mechanisms and Effects. Routedle Publishers, New York

[16] Stapleton, A. (2004). Serious games: Serious opportunities. In Proceedings of the 2004 Australian Game Developers Conference, pp: 1-6, Melbourne, Australia.

[17] Steuer, J. (1992). Defining Virtual Reality: Dimensions Determining Telepresence. Journal of Communication, 42(4), 73-93. doi: 10.1111/j.1460-2466.1992.tb00812.x

[18] Susi, T., Johanesson, M. \& Backlund, P. (2007). Serious Games - An Overview. Skövde, Sweden: University of Skövde.

[19] Tothová, D. \& Fabuš, J. (2015). Portal of Slovak universities. In ICABR International conference on applied business research, Sep 14-18, 2015. Brno: Mendel University. pp.1062-1068. ISBN 978-80-7509-379-0. 
[20] Valentová, M., Brečka, P. \& Tureková, I. (2017). The creation of gamification activities for primary pupils. In: INTED 2017: Proceedings from 11th annual International Technology, Education and Development Conference, Valencia, 6-8th of March, IATED Academy. pp. 409-417.

[21] Wattanasoontorn, V., Hernández, R. J. G., \& Sbert, M. (2013). Serious Games for e-Health Care. In: Gaming Media and Social Effects Simulations, Serious Games and Their Applications. Gaming Media and Social Effects, pp.127-146. Springer. doi: 10.1007/978-981-4560-32-0_9

[22] Zarrad, A. (2018). Game Engine Solutions. In INTECH 2018. pp. 75-87, doi: 10.5772/intechopen.71429 


\title{
The Digital Age and Its Pros and Cons for Society
}

\author{
Eva Oláhová ${ }^{1}$ \\ Slovak University of Agriculture in Nitra \\ Faculty of Economics and Management, Centre of Information Technologies \\ Address: Trieda A. Hlinku 2 \\ Nitra, Slovak Republic \\ e-mail1:Eva.Olahova@uniag.sk
}

doi: 10.18515/dBEM.ISD.P01.2020.p051

\begin{abstract}
The article deals with the digital age and life of individuals and society in the virtual world of the Internet and mobile networks. It analyzes the influence of two basic phenomena (and concepts) of the digital era: digital literacy and digital dementia and their impact on the individual and society. The author states how the permanently changing world of digital technologies is reflected in a change in the content of the concept of digital literacy. It also discusses the second aspect of the use of internet technologies, which may have a negative impact on the individual's intellectual abilities and are related to the concept of digital dementia. A real manifestation of excessive use of digital technologies are nonsubstance addictions, as confirmed by current research. These addiction disorders are becoming a societal (worldwide) problem especially in certain age groups of the population. Enlightenment in the field of mental health and at the same time, digital education can make a significant contribution to eliminating these undesirable manifestations of excessive use of digital technologies.
\end{abstract}

Keywords: digital dementia, digital literacy, digital technologies, non-substance addiction, learning

JEL Classification: J24, L86, O34

\section{Introduction}

The information and knowledge society is characterized by widespread implementation of digital technologies and services in various areas of social life. Specific features of the present time are the intersection of the life (activities) of the individual, business and society in the physical space of the real world and the virtual space of information and communication technologies. It is evident that a large part of the activities and information of different nature and content has figuratively "moved" into the digital space of the Internet. According to IBM's 2017 report on the Internet, there will be 2.5 trillion data generated a day on the Internet, with $90 \%$ of the world's data was generated in the previous 2 years. By 2020,40 -fold growth in data volume is expected (Marr, 2018). It should be emphasized that $80 \%$ of the data generated on the Internet are unstructured data, which includes many different kinds of documents - news feeds, blogs, audio and video streams, posts on social media, IoT and geo data (Linden, 2018). A similar situation exists in the services provided - ubiquitous connectivity allows users to access various services and applications continuously via mobile and Internet networks.

For facts given results, that being a user of digital technologies and navigating the digital world of services and available data is not easy, and requires some knowledge and skills. The positive aspects and benefits of the digital age for society are also linked to the negative aspects of increasing cybercrime and the potential threat to the end-user itself. Therefore, the article focuses on the end-user and addresses two different concepts - digital literacy and digital dementia. Digital literacy is the starting point for controlling digital technologies and represents its digital skills. Digital dementia is generally associated with a decline in the individual's 
intellectual abilities and is viewed by various experts as a controversial theory of the impact of digital technologies on humans.

\subsection{Digital literacy}

The digital skills of users of Information and Communication Technologies (ICT) are called digital literacy (DL). The general definition describes it as the ability to understand and use information in different formats from different sources presented through modern ICT.

The definition of digital literacy (and its characteristics) has changed significantly over time, (from its initial definition) which can be related not only to the permanent development of digital technologies, but also to their penetration into civic life. Heitin (2016) states that at present the term is so broad that some experts even stay away from it and preferring to speak more specific particular skills at the intersection of technology and literacy.

According Anderson \& Rainie (2012) internet literacy will be most-desired skills of 2020 (as the ability to search effectively for information online and to be able to discern the quality and veracity of the information).

The American Library Association (American Library Association, 2013) specifies in detail the digital literacy as the ability to effectively use information and communication technologies, the ability to find, understand, evaluate, create and communicate digital information, an ability that requires both cognitive and technical skills. The digitally literate user is able to use these skills and technologies to communicate and participate actively in civic society. The prerequisite for the development of these skills is not only ownership and availability of technologies, but also lifelong learning in ICT.

Similarly, is defined by Mnyanda \& Mbelani (2018), digital literacy includes a large number of complex cognitive, motor, sociological and emotional skills that users need to function in a digital environment.

According Payton \& Hague (2010) digital literacy made up of a number of inter-related components (functional skills, creativity, critical thinking and evaluation, cultural and social understanding, collaboration, the ability to find and select information, effective communication, e-safety) and is an important right of young people in an increasingly digital culture.

Leu et al. (2014) use the term deictic to refer to the changing nature of literacy, which is prompted by the constantly changing technologies within our society. Being literate tomorrow will be defined by even newer technologies and social practices that we will create to meet the expected needs. (Leu et al., 2011)

Kollár et al. (2015) argue that this is a complex phenomenon consisting in the technical mastery of digital technologies and their safe use, communication skills and the ability to work with digitized content.

Anderson \& Sofkova-Hashemi (2016) write that digital literacy are participatory, because users not only read content but interact with it, actively create their own content - they become its active producers.

According Nicholson (2017) digital literacy also includes the ability understanding of issues associated with digital technologies like data privacy. As more and more functions are transported to the internet, digital literacy skills are seen as essential for the successful use of the online environment and they become critical. 
Company JISC (2014) in defining the term uses plural - digital literacies. These are not only functional IT skills, but also richer a set of digital behaviors, practices and identities supported by different and changing technologies. Digital literacies are comprehensively defined in model with seven elements (as a range of other capabilities): media literacy, information literacy, digital scholarship, ICT literacy, communication and collaboration, learning skills, career and identity management.

\subsection{Digital dementia}

The term digital dementia is related to overuse of digital technologies and their negative impact on human intellectual abilities. The term was defined by a German psychiatrist and neuroscientist Manfred Spitzer, who is the author of two books devoted to this issues (Digitale Demenz, 2012 and Cyberkrank!, 2015). According Spitzer (2018) the result of overuse the digital technologies is the breakdown, respectively degradation of cognitive abilities (e.g. attention, memory, speech, thinking speed, ability of information comprehension, self control, etc.) Spitzer claims children and adolescents who often use digital media an early age, did not reach the intelligence quotient that could (in principle) be reached by them. Frequent use of digital media in adults could be lead to an accelerated deterioration in mental and social skills. Worsening, respectively the loss of cognitive abilities is the result of brain changes. The ability of the brain to 'learn' (receive and process information) is associated with the term neuroplasticity, whereby permanent connections between the brain's nerve cells are established - synapses. The brain changes and adapts its plasticity changes. The use of digital technologies changes the depth of information processing - information is processed more superficially, less synapses are activated, respectively do not create, and this state of Spitzer refers to digital dementia. The consequences of excessive use of digital technologies are as follows:)

- Disorders of memory, attention, reading, learning, concentration, self-control.

- Pathological non-substance addictions (from PC, Internet, social networks, smartphones).

- Limitation of physical activity, obesity, insomnia.

- Social isolation, loneliness, loss of empathy.

- Cyberphobias (technophobia, nomophobia, FoMO syndrome).

This is supported by the results of many studies carried out in the period 1980-2015, whose content and focus vary (in terms of research objectives, sample size, type of respondents and their age, geographical location, etc.)

The attitudes of the professional public to theory of digital dementia are critical. The attitude of the professional community to theory of digital literacy is critical. The digital dementia is a vague and controversial concept, because, as critics say, there is no reliable scientific evidence about it existence (Yamamoto et al., 2018; Appel \& Schreiner, 2014; Sommer, 2015; Špajdel, 2017).

\section{Data and Methods}

Digital technologies and the Internet affect many areas of our lives. Similarly, the question of examining their impact on the life of the individual (and society) is widespread. It can be said that it has an interdisciplinary character - it affects the fields of sociology, psychology, medicine, education, communication sciences. Because the author is professionally involved in the field of information and communication technologies, for the purposes of this article and an objective evaluation of both concepts were used freely available scientific studies and surveys. For the study of the term digital dementia were used (as the main literary source) 
Manfred Spitzer's books - Digitale Demenz (Spitzer, 2018) and Cyberkrank! (Spitzer \& Kratochvílová, 2016). To clarify the issue of digital literacy, the following standards have been analyzed:

- Framework DQ elaborated by Coalition for Digital Intelligence.

- Framework DigComp 2.0 and index DESI used in European Union.

- The framework used by the Institute for Public Affairs (IVO Slovakia) within the project Digital Literacy of Slovakia.

\section{Results and Discussion}

Digital literacy is represented by the digital skills of an individual who acts as an end user of digital technologies and services. Today, their availability is so widespread that they are used at an early age, when their use is more or less intuitive and digital skills contain only a "basic set" of skills. The Millennials and Z Generations refer to people who grew up in the digital age and who make extensive use of digital technology, electronics, the internet and the online social community. Digital literacy is a prerequisite for their successful use, but according to current research its level is inadequate (Martinéz, 2019; Williams, 2018). Different standards are used worldwide to assess the level of digital literacy based on the assessment of the level of different digital skills indicators.

\section{DQ Global Standards}

In March 2019 (DQ Institute, 2019) the Coalition for Digital Intelligence published document The DQ Global Standards Report 2019 which establishes for the first time a set of global standards for digital literacy, skills and readiness, known as the DQ framework. The goal of institutionalizing framework is the development of a common understanding, structure, and taxonomy for digital literacy for national governments, educators, technology companies, and service providers. The reason for elaboration was fact that various organizations and entities were using their own frameworks or were leveraging other frameworks (in 2017 the IEEE Digital Literacy Industry Connections Group conducted a literature review of over 100 different literacy and skill-building resources). DQ (or Digital Intelligence Quotient) is a comprehensive set of technical, cognitive, meta-cognitive, and socio-emotional competencies that enable individuals to face the challenges and harness the opportunities of digital life.

The DQ framework is structured as a matrix of two categories - digital life areas and maturity levels. Areas of digital life are: Digital Identity, Digital Use, Digital Safety, Digital Security, Digital Emotional Intelligence, Digital Communication, Digital Literacy, and Digital Rights. The competencies in these areas are differentiated by three levels of user maturity: Digital Citizenship, Digital Creativity, and Digital Competitiveness. (see Figure 1) 
Figure 1: The structure of DQ framework - competences

Areas of Digital Life

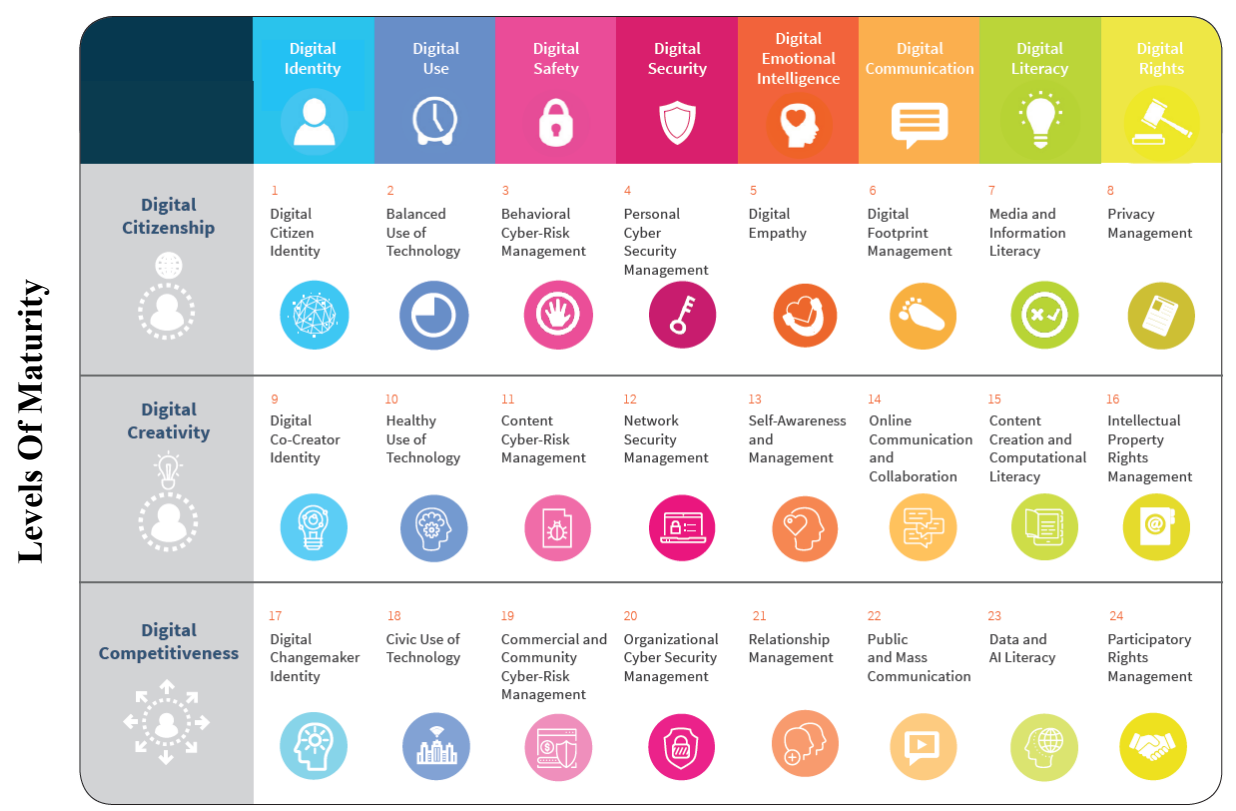

Source: DQ Global Standards Report 2019, DQ Institute, https://www.dqinstitute.org/

\section{DigComp a DESI}

Within the European Union, the DigComp 2.0 framework (Vuorikari et. al, 2016) and the index DESI (European Commission, 2019) are using to assess digital literacy. While DigComp is a reference framework for assessing digital competencies and skills of individuals, the index DESI is a more comprehensive indicator of the evaluation of the digital economy and the transformation of society, where digital competences are represented by Human Capital.

The DigComp 2.0 (Digital Competence Framework for Citizens) was adopted in 2015 and is a tool for measuring and assessment digital competences. Digital competences are defined as a combination of knowledge, skills and attitudes for the self-confident and critical use of information technology. DC is a composite indicator - defines five areas of competencies: Information and Data literacy, Communication and Collaboration, Digital Content Creation, Security, Problem solving. In these areas a set of 22 competences is elaborated. The level of user's proficiency is defined in three degrees: Basic user, Intermediate user and Advanced user. The implementation of DigComp 2.0 in practice may vary, for example Eurostat (European Union) uses four areas (information skills, communication skills, problem solving, software skills) and 22 competences. The IVO defines 28 competences in these areas and the overall digital literacy is expresses by the index DLI (Digital Literacy Index).

DESI (Digital Economy and Society Index) embraces the main areas of digital society: Connectivity (25\%), Human capital (25\%), Internet use (15\%), Digital technology integration (20\%), and Public digital services (15\%). Users' digital skills are represented by item Human Capital, as a composite indicator defines four areas of competencies (Information skills, Communication skills, Problem solving skills, Software skills for content manipulation) and a set of 22 digital skills. The level of user's proficiency is defined in four degrees: above basic, basic, low, no skills.

Based on the available data can be stated its gradual increase (monitoring from 2005, respectively 2011). The assessment of recent years (2016 -2018) suggests that its growth rate 
is slowing down, and is stagnating. The results indicate that EU Member States must take action in the future to tackle deficiencies and digital inequalities (Velšic, 2015; Velšic, 2018). While reports confirm the growing importance of digital technologies and services in life of individuals and society, they also indicate problematic areas of perception:

- Growing the feeling of "satiety" with digital technologies in everyday life.

- Refusing to use them for various reasons (does not feel their need, mutual alienation and loss of personal contacts, loss of "self-thinking", loss of privacy, cybercrime, harmful content on the Internet).

- Growth in mobile and Internet addictions, especially among young people (14-34 years) and the associated manifestations (lack of physical activity, inability to distinguish between virtual reality and real life, weakening the ability to communicate with others).

\section{Digital dementia and its consequences on digital life and end-user personality}

Digital literacy is the ability of an individual to navigate in digital space and use it according to your needs. The multitude of services and applications and their widespread availability thanks to smartphones, the Internet and networks, leads to the user being hyperconnected (always on, continuously linked through tech devices to other humans). According to surveys (Yamamoto et al., 2018; Velšic,2015; Host'ovecký \& Ivanová, 2016) he spends a lot of time in this environment, on average 7.5 hours a day. But setting a reasonable time limit is up to each individual to decide. The possibility is a digital activity known as OMline, i.e. a balanced work where the individual is at peace with himself and his applications (Horxx, 2018).

The current interdependence of technologies and services is reflected in the end-user working in mode of multitasking (multi-tasking and attention-switching) and multiskills. Partial knowledge may be inadequate and potentially endangering the end user. According to Spitzer (2016) medial multitasking results in distraction and disorders of attention and concentration. However, because of multitasking, people are learning more, they are more adept at finding answers to deep questions, because they can search effectively via the internet (Anderson \& Rainie, 2012). New technological solutions give them the right to supplement their knowledge and adapt (Oláhová, 2016). A practical example requiring user multiskills is the Office 365 for Education cloud solution (with 27 applications of a different nature in one place). The opposite of Spitzer's claims may be results of a survey the use of Office365 in the educational process. Students confirmed that they learned to work in a new way - to acquire new skills (Oláhová, 2018).

The Internet and smartphones have fundamentally changed the way we store and process information, both becoming a memorizing tool; our external memory. Research of the company Kaspersky (Kochetkova, 2015) showed that 91\% of Americans and $79.5 \%$ of Europeans confirmed using the Internet and devices as a tool for remembering (or reference book) and as an extension of their brain. According to Spitzer, this leads to lazing of the brain and superficial processing of information. Digital amnesia (or Google effect) is a tendency do not to remember information, respectively quickly to forget information and its content. Some experts contend the digital amnesia is a side effect of knowing that information is readily available. Nevertheless, the current generation favors working with e-information. In the survey of the preferences of the teaching materials used, $52.5 \%$ of students used electronic course and files in file repository; $35.9 \%$ of students used textbooks (Tóthová, 2018). The paradox is that an individual must have the skills to operate a smartphone and the Internet (it is digitally literate) and also he must remember the type of information and the storage location. 
The existence of digital addictions (in various forms) is a real manifestation of the use of digital technologies and their impact on the individual's mental health. They are referred to as modern non-substance dependencies, their exact definition is missing. According to Benkovič (2007) in the system of International Classification of Diseases (MCHK-10) the closest characteristic is: as other kinds of persistently repeated maladaptive behavior and in which a person seems to be unable to resist impulses for this mode of behavior. Spitzer's claims are true in this respect, and recent research confirms their increasing tendency (Anderson \& Rainie, 2012; Host'ovecký \& Ivanová, 2016; Yamamoto,2018). This is alarming from a societal point of view, as it is particularly apparent in the lower age categories (age 10-35). Non-substance dependencies include:

- Smartphone addiction (nomophobia) - is defined as a fear of being without your mobile phone or unable to use it. According statistic the average time spent on smartphones a day is 2 hours and 51 minutes and users average checks device 47 times a day.

- Internet Addiction Disorder (IAD) - in generally means the dependence on the network which drives a person to excessive and compulsive use of the internet. According various researches: worldwide the average daily time using the internet is about 6 hours per person (Proulx, 2020) and another fact $68 \%$ of students (secondary schools) often stay online for a longer than originally intended period of time (Host'ovecký \& Ivanová, 2016).

- Facebook Addiction Disorder (FAD) and Social media addiction (SMA) - means uncontrolled use of social media and spending excessive amounts of time, what it ultimately impairs other areas of life. The statistic uncovers that an average of 3 hours are spent per day per person on social networks and messaging.

- FoMO (Fear of Missing Out) - syndrome FoMO is characterized by the individual's fear and need to remain engaged with others' activities to ensure he won't miss anything.

- Other addictions: Internet Gaming Disorder (IGD), online shopping, watching TV, video.

How to determine a reasonable level of use of these devices and services? The answer is the concept known as digital detox. Digital detox refers to a period in which a person (by conscious decision) refrains from using electronic devices connected to the Internet. According research of Ofcom (Cape \& Rees, 2018) 33\% of participants reported feeling an increase in productivity, $27 \%$ felt a sense of liberation, and $25 \%$ enjoyed life more. Digital detox helps to reduce stress and to maintain a healthy balance between real life activities and the digital world.

\section{Conclusion}

Status online leads to insomnia and social isolation. Multitasking causes distraction. The Google effect switches our own memory to mobile/internet and reduces our cognitive abilities. Addiction disorders and cyberphobias lead to mental discomfort and endanger health. Digital media changes the depth of information processing by the brain. These are all the conclusions and statements of Spitzer in his two books. The indisputable fact is that digital technologies are now an essential part of the life of the individual and of society. Technologies integrate so smoothly into our lives that the boundary between "ourselves" and technology is disappearing. According Anderson \& Rainie (2012) we will think with, think inside and think through our intelligent tools, but their presence and impact on our lives will be less visible.

The basis is a sensible, sensitive and safe way of using them, which cannot be done without lifelong learning in this area. Being digitally literate is a challenge for individuals to master digital technologies and at the same time personal responsibility for their digital life and mental health. The article is a personal view of the author (as an IT professional and teacher) on the 
issue. Based on the results of surveys and work experience, the theory of digital dementia cannot be accepted. The existence of non-substance addictions (as well as digital dementia) falls within the field of psychological sciences and must be subject to further monitoring and research.

\section{References}

[1] Anderson, J., \& Rainie, L. (2012). Millennials will benefit and suffer due to their hyperconnected lives. Washington, Pew Research Center, Retrieved December 2019, from https://www.pewresearch.org/internet/2012/02/29/millennials-will-benefit-and-suffer-due-to-theirhyperconnected-lives/

[2] Anderson, P. \& Sofkova-Hashemi, S. (2016). Screen-based literacy practices in Swedish primary schools. Nordic Journal of Digital Literacy 11(2), 83-100. https://doi. org/10.18261/issn.1891-943x2016-02-01

[3] American Library Association (ALA) Digital Literacy Task Force (2013). ALA Task Force releases digital literacy recommendations. Retrieved December 27, 2019 from http://www.ala.org/news/pressreleases/2013/06/ala-task-force-releases-digital-literacy-recommendations

[4] Appel, M., \& Schreiner, C. (2014). Digitale Demenz? Mythen und wissenschaftliche Befundlage zur Auswirkung von Internetnutzung. Psychologische Rundschau, 65(1), 1-10. doi: 10.1026/00333042/a000186

[5] Benkovič, J., (2007). Novodobé nelátkové závislosti. In: Psychiatrie pro praxi, roč. 7, č. 6, s. 250-253.

[6] Cape, S., \& Rees, J. (2018, August). Communications market report 2016. Retrieved January 2020, from https://www.ofcom.org.uk/_data/assets/pdf_file/0024/26826/cmr_uk_2016.pdf

[7] DQ Institute. (2019, March). DQ Global Standards Report 2019. Retrieved January 10, 2020, from https://www.dqinstitute.org/wp-content/uploads/2019/11/DQGlobalStandardsReport2019.pdf

[8] European Commission. (2019, September 27). Human Capital and Digital Skills - reports and analysis on ICT skills. Retrieved from https://ec.europa.eu/digital-single-market/en/human-capital/

[9] Heitin, L. (2016). What Is Digital Literacy? Retrieved December $27 \quad 2019$ from https://www.edweek.org/ew/articles/2016/11/09/what-is-digital-literacy.html.

[10] Host'ovecký, M., \& Ivanová, M. (2016). Internet addiction of Slovak’s secondary school students. 2016 International Conference on Emerging eLearning Technologies and Applications (ICETA). https://doi.org/10.1109/iceta.2016.7802065

[11] Horxx, M. (2018, May 10). My Trend Words. Retrieved January 15 2020, from https://www.horx.com/en/futurism-today/my-trend-words/

[12] JISC. (2014, March 6). Developing digital literacies. Retrieved December 272019 from https://www.jisc.ac.uk/guides/developing-digital-literacies.

[13] Marr, B. (2018, May 21). How Much Data Do We Create Every Day? The Mind-Blowing Stats Everyone Should Read. Retrieved $\quad$ December 2019 from https://www.forbes.com/sites/bernardmarr/2018/05/21/how-much-data-do-we-create-every-day-the-mindblowing-stats-everyone-should-read/\#793f465a60ba

[14] Martínez, M. (2019, October 18). Digital natives, technological illiterates? Message posted to https://www.smartcitylab.com/blog/digital-transformation/digital-natives-technological-illiterates/

[15] Mnyanda, L. \& Mbelani, M., (2018). Are we teaching critical digital literacy? Grade 9 learners' practices of digital communication. Reading \& Writing. 9(1), a188. https:// doi.org/10.4102/rw.v9i1.188

[16] Nicholson, K. (2017). Innovation in public libraries: Learning from international library practice. Cambridge (Mass.): Chandos Publishing.

[17] Kochetkova, K. (2015, July). Message posted to https://www.kaspersky.com/blog/digital-amnesiasurvival/9194/

[18] Kollár, V., Polakovič, P., \& Gasperová, J. (2015). Digitálna gramotnost’ občana ako fenomén súčasnej informačnej doby: Digital lieracy citizens as a phenomenon of modern information era. Sustainability Environment - Safety 2015: Zborník príspevkov z Medzinárodnej vedeckej konferencie, 137-140. 
[19] Leu, D.J., McVerry, J. G., O’Byrne, W. I., Killi, C., Zawilinski, L., Everett-Cacopardo, H., Kennedy, C., \& Forzani, E., (2011). The New Literacies of Online Reading Comprehension: Expanding the Literacy and Learning Curriculum. Journal of Adolescent \& Adult Literacy. 55 (1), 5-14. doi: 10.1598/JAAL.55.1.1.

[20] Leu, D. J., Forzani, E., Rhoads, C., Maykel, C., Kennedy, C., \& Timbrell, N. (2014). The New Literacies of Online Research and Comprehension: Rethinking the Reading Achievement Gap. Reading Research Quarterly, 50(1), 37-59. doi: 10.1002/rrq.85

[21] Linden, P. (2018, August 28). Organizations need to give unstructured data its rightful place if they want to get value out of data. Message posted to https:/www.capgemini.com/

[22] Oláhová, E. (2016, June 24). Management of IT environment end users and the impact of new technological solutions. International Scientific Days 2016. The Agri-Food Value Chain: Challenges for Natural Resources Management and Society: Proceedings. https://doi.org/10.15414/isd2016.s9.03

[23] Oláhová, E. (2018, December). Using the Office 365 Cloud Solution in the Education Process. International Scientific Days 2018. Towards Productive, Sustainable and Resilient Global Agriculture and Food Systems: Proceedings. https://doi.org/10.15414/isd2018.s10.09

[24] Payton, S., \& Hague, C. (2010, January 1). Digital literacy across the curriculum: A Futurelab handbook. The National Foundation for Educational Research. Retrieved December 27, 2019 from https://www.nfer.ac.uk/publications/FUTL06/FUTL06.pdf.

[25] Proulx, A. (2020, January 17). Internet Addiction Statistics. Retrieved from https://www.therecoveryvillage.com/process-addiction/internet-addiction/related/internet-addictionstatistics/\#gref

[26] Spitzer, M., \& Kratochvílová, I. (2016). Kybernemoc!: jak nám digitalizovaný život ničí zdraví. Brno: Host vydavatelství, s.r.o.

[27] Spitzer, M. (2018). Digitálna demencia: ako pripravujeme seba a naše deti o rozum. Bratislava: Citadella.

[28] Sommer, M. (2015, September 28). What exactly is "digital dementia"? Elm Magazine. Retrieved from https://elmmagazine.eu/adult-education-and-social-media/what-exactly-is-digital-dementia/

[29] Špajdel, M. (2017). Digitálna demencia (?). In M. Spajdel (Ed.), Acta Psychologica Tyrnaviensia 21 (pp. 302-303). Kraków: Towarzystwo Słowaków w Polsce: Filozofická fakulta Trnavskej univerzity v Trnave, ISBN 978-83-8111-026-6.

[30] Tóthová, D. (2018). E-learning at Slovak University of Agriculture in Nitra. In Turčáni, M.-Balogh, Z. -Munk, M. DIVAI 2018. Praha: Wolters Kluwer ČR, 2018, s. 195-204. ISBN 978-80-7598-059-5

[31] Velšic, M. (2015). Digitálna gramotnost’ na Slovensku 2015, Inštitút pre verejné otázky. Bratislava 2015,17 p., ISBN 978-80-89345-51-9.

[32] Velšic, M. (2018, June). Digitálna gramotnost’ na slovensku 2018 zaostrené na robotiku. Inštitút pre verejné otázky. Bratislava 2018, 30 p., ISBN 978-80-89345-69-4.

[33] Vuorikari, R., Punie, Y., Carretero Gomez S., \&Van den Brande, G. (2016). DigComp 2.0: The Digital Competence Framework for Citizens. Luxembourg Publication Office of the European Union. doi:10.2791/11517. Retrieved from https://ec.europa.eu/jrc/en/publication/eur-scientific-and-technicalresearch-reports/

[34] Williams, T. (2019, September 6). Many College Students Are Not Digitally Literate. Retrieved January, 2020, from https://www.goodcall.com/news/many-college-students-not-digitally-literate-011701/

[35] Yamamoto, H., Ito, K., Honda, C., \& Aramaki, E. (2018, March). Does Digital Dementia Exist?. In 2018 AAAI Spring Symposium Series 


\title{
Analysis of Very Large Database Indexing
}

\author{
Veronika Šalgován ${ }^{1}$ Karol Matiaško \\ University of Žilina \\ Faculty of Management Science and Informatics ${ }^{1,2}$ \\ Department of Informatics 1,2 \\ Address: Univerzitná 8215/1, \\ 01026 Žilina, Slovakia \\ e-mail: Veronika.Salgova@fri.uniza.sk¹, Karol.Matiasko@fri.uniza.sk²
}

doi: 10.18515/dBEM.ISD.P01.2020.p052

\begin{abstract}
Storing and managing collections of data is a significant part of information technologies. The modern era of computerization brings explosion of information which need to be stored and processed. A large amount of data requires a lot of storage space, so very large databases are coming to the foreground. Data is organized in the process of database normalization reducing redundancy and dependency of information. This data is subsequently used for query execution and gaining the desired outputs. Various index techniques are used to increase query performance which is really important. This paper deals with analysis of index types and techniques in very large databases and data warehouses and also with different strategies for performing table join in indexes.
\end{abstract}

Keywords: index, query performance, table join, very large database

JEL Classification: O10, I23, D83, L86

\section{Introduction}

The growth of data, their collection, and processing have become a big challenge. They require very large databases to have a space to be stored in. For such large data, it is necessary to process them as optimally as possible and thus reduce the costs of different forms. A suitable solution for powerful optimization of query execution is building indexes on data sets. An indexing strategy is the design of an access method to a searched item [1]. The aim of this paper is to present various index types and techniques which can be used in very large databases.

\section{Index}

An important and powerful part of the optimization of query processing is an index structure that can significantly improve the performance of the database. Scanning through very large tables consisting of millions or billions of rows is a big waste of time when only a few of them need to be returned. An index is a database object which can be created optionally and is used primarily to increase query performance. Its purpose is similar to a book index that associates each topic with the page numbers on which the topic is located. Thanks to this information it is easy to navigate directly to a page containing a specific topic. The number of pages to read is minimal if the topic appears only on a few pages. The more the topic appears in the book, the less useful the index is.

The database index is used for direct access to the column value of a row inside the database with a row identifier called ROWID. The ROWID consists of these layers: identification of the data file, in which the row resists, the pointer to the block and position inside it. It uses also the specific object identifier. Thus, based on the definition, the ROWID value is unique for the standalone database [3]. With ROWID, table data can be easily retrieved with a minimum number of reads executed. However, if there exists no suitable index, every single row needs to 
be read to find the desired information in the table. This method is known as Full Table Scan and is one of the most expensive operations.

Although indexes bring a significant improvement in database performance, it is not appropriate to create them on every column or combination of columns of all the tables. Indexes consume disk space and system resources. When data in tables are updated, corresponding indexes need to be changed as well. It means they use storage, I/O, CPU, and memory resources [2].The unnecessarily large use of indexes can markedly decrease the performance of the database. The creation and deletion of an index absolutely do not affect the data in a table, it affects only the query performance.

In the database systems, there exist various index structures and approaches.

\subsection{B-tree Index}

The default and most often used type of index is B-tree, respectively B+ tree. This structure consists of a tree in which each path from the root to the leaf has the same length [3]. It means the tree is balanced. It is optimized for systems that write and read a lot of data. Model of the B-tree structure is in figure 1. Locators of the rows in the physical database, ROWID values, are stored in the leaf layer.

\section{Figure 1: B-tree structure}

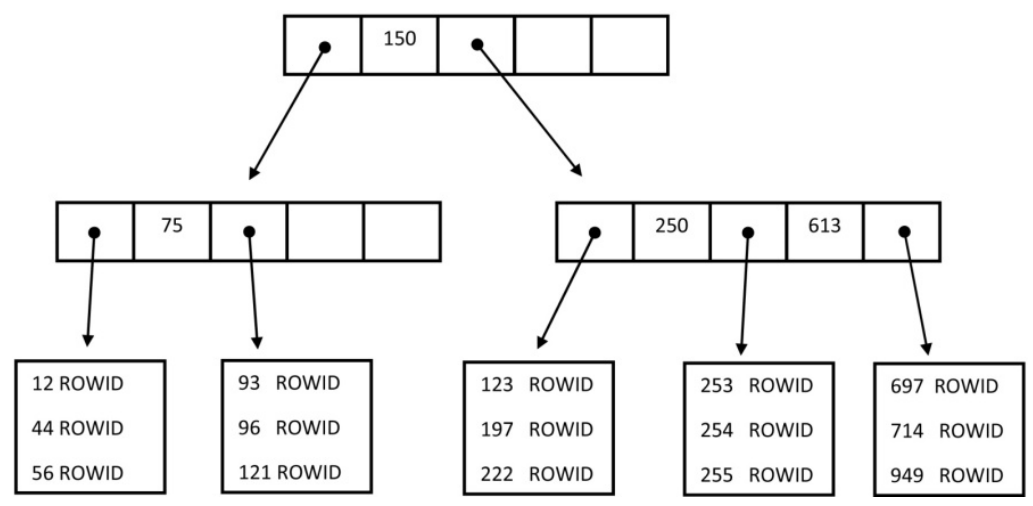

Source: [6]

$\mathrm{B}+$ tree index structure varies in the leaf layer, in which individual nodes are chained together and they form a linked list [6]. This layer contains sorted data based on the attributes which are indexed there.

An index of B-tree structure is created using create index statement as follow:

$$
\begin{aligned}
& \text { create index ind_student } \\
& \text { on student(surname); }
\end{aligned}
$$

B-tree indexes have several subtypes: index-organized table, unique index, reverse key index, key compressed index, and descending index.

\subsubsection{Index-Organized Table}

Data in the index-organized table (IOT) are stored in a B-tree index structure sorted according to the primary key. This is different from an ordinary table in which data is stored in an unordered way. Thus, the IOT structure is suitable when most of the column values of the index 
are included in the primary key. Creation of the IOT is provided by adding organization index statement to the end of the table creation statement as follows:

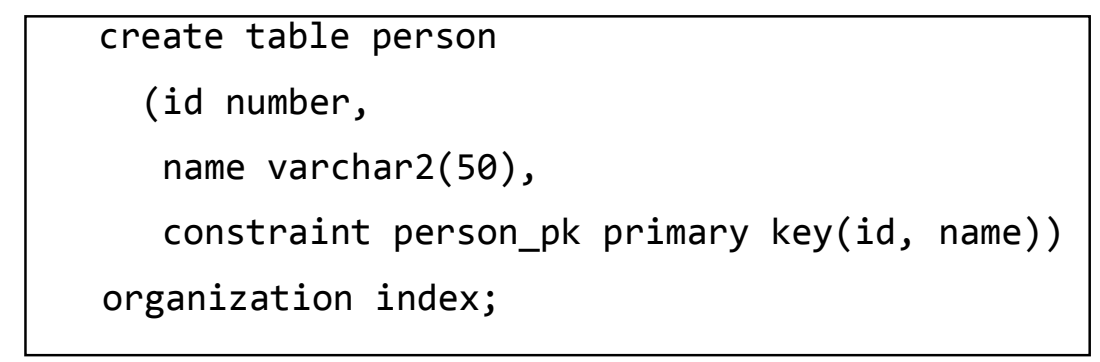

\subsubsection{Unique Index}

The complementary feature of a B-tree index is his ability to be unique. There is a guarantee that any inserted values into the corresponding table will not be the same, so this index can be used to enforce the uniqueness of the data. To define an index to be unique, the following statement is used:

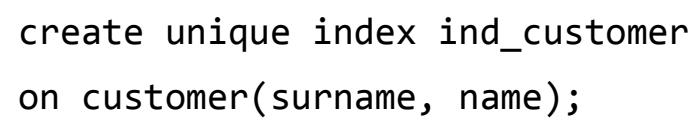

\subsubsection{Reverse Key Index}

This type of index reverses the bytes of the key-value to solve the problem of block contention on leaves in the right side of the b-tree index structure which can be caused when primary keys are generated by a sequence. It means, it is useful for balancing I/O in an index with many sequential inserts which would have many similar values clustered together. For example, when two primary keys are 1234 and 1235, a reverse key index changes them into 4321 and 5321 and after that adds them into an index. These new primary keys are not stored next to each other but are spread in different blocks of the structure. A reverse key index is created by including reverse clause as follow:

$$
\begin{aligned}
& \text { create index ind_subject } \\
& \text { on subject(id) reverse; }
\end{aligned}
$$

It is not possible to create a bitmap index or an index-organized table as reverse. The big disadvantage of a reverse key index is that an index range scan method cannot be used. Data are not sorted as it would be needed for this method because they are distributed over all the leaf nodes of the tree structure.

\subsubsection{Key Compressed Index}

For reducing the storage and $\mathrm{I} / \mathrm{O}$ requirements of concatenated indexes where the leading column is often repeated, it is useful to use key-compressed indexes. To create this type of index the following statement is used:

$$
\begin{aligned}
& \text { create index ind_customer2 } \\
& \text { on customer(surname, name) compress 2; }
\end{aligned}
$$

It is not possible to create a key-compressed index on a bitmap index. 


\subsubsection{Descending Index}

Indexes are stored in ascending order by default. That is, the numbers are arranged from the smallest to the largest values and the characters and strings as well. If there are some queries sorting some columns in ascending order and other columns in descending order, it is useful to define an index to be descending by using a keyword desc as follow:

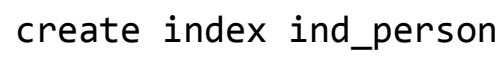

A descending index is not used on bitmap index and reverse-key index.

\subsection{Bitmap Index}

Bitmap indexes are recommended for columns with a low cardinality, which means a small level of uniqueness of column values. Figure 2 shows a table with a column of genders, in which there are only 2 unique values for males and females. Bitmap indexes store information in bit arrays known as bitmaps.

\section{Figure 2: A table with a suitable column for bitmap index}

\begin{tabular}{|c|c|c|}
\hline Id & Name & Gender \\
\hline 1 & John & $\mathrm{M}$ \\
\hline 2 & Alice & $\mathrm{F}$ \\
\hline 3 & Mike & $\mathrm{M}$ \\
\hline 4 & Amy & $\mathrm{F}$ \\
\hline 5 & Kate & $\mathrm{F}$ \\
\hline 6 & Smith & $\mathrm{M}$ \\
\hline 7 & Peter & $\mathrm{M}$ \\
\hline
\end{tabular}

Source: own processing

Bitmap indexes are suitable for SQL statements with many AND and OR operators in the WHERE clause. This index cannot be unique. It is used in systems for reporting and data analysis, known as data warehouse environments. These systems pull data from various sources together. It is not recommended to use a bitmap index in Online Transactional Processing Databases which typically involve many operations of insert, update, and delete.

\subsection{Function-Based Index}

This type of index is used for columns having the function applied to them, which need to be deterministic, for example:

$$
\begin{aligned}
& \text { create index_employee } \\
& \text { on employee(lower(name)); }
\end{aligned}
$$

The definition of function in the index must be exactly the same as in the WHERE clause. If it differs, the index is not used [5]. Function-based index can be bit-map, B-tree or unique. 


\subsection{Virtual Index}

It is possible to create an index which has no physical segment by using nosegment clause as follow:

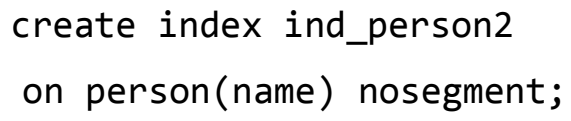

These nosegment indexes are used according to the value of the parameter _use_nosegment_indexes, which can be set as follow:

$$
\text { alter session set "_use_nosegment_indexes"=true; }
$$

When working with a large index without wanting to allocate space and to consume resources, with an intention to only determine if the index would be used by the optimizer, it is useful to use a virtual index. When creating an index with the nosegment keyword, it is possible to test the scenario. After determining that the index would be useful, it is possible to drop the index and replace it without using the nosegment clause [2].

\subsection{Invisible Index}

Marking indexes as invisible make them be ignored by the optimizer. However, they are maintained like any other indexes. They are useful in situations when testing how dropping an index would affect the performance. Indexes are becoming invisible using a keyword invisible as follow:

$$
\begin{aligned}
& \text { create index ind_employee2 } \\
& \text { on employee(name) invisible; }
\end{aligned}
$$

Indexes can be altered to change the visibility as follow:

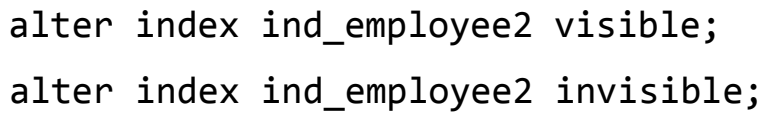

\subsection{Hash Index}

A hash index stores collections of buckets organized in an array. It uses a hash function mapping the values of index keys to corresponding buckets stored in the hash index [4]. Figure 3 shows different index keys that are mapped to different buckets in the hash index. $F(x)$ is the name of the hash function. 


\section{Figure 3: Mapping of a hash function}

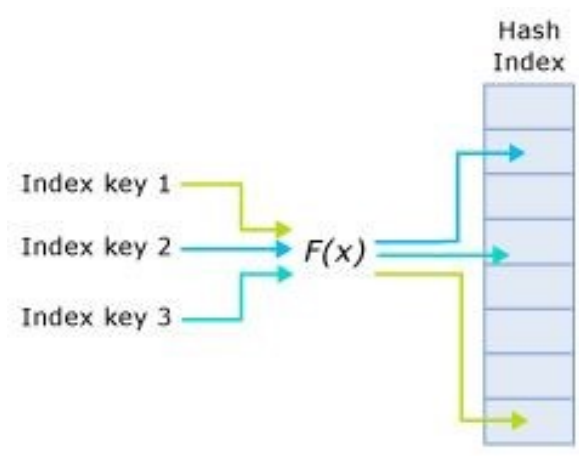

Source: https://docs.microsoft.com/en-us/sql/database-engine/hash-indexes?view=sql-server-2014

\section{Automatic Indexing}

Oracle provides a new feature that automatically creates, rebuilds, and drops indexes. The execution of these operations is based on the application workload. It analysis the current workload and identifies candidates for indexes. Indexes are created as invisible and it is tested whether they improve the performance. If so, then they can be altered to be visible and used in the application. However, if the performance is not improved, indexes are marked as unusable and subsequently are dropped.

\section{Join Strategies}

Join operations are important for database management. When executing queries involving multiple tables, the query optimizer can choose from three strategies for performing join operation: merge join, nested-loop join, and hash join. In terms of indexes, it is required to firstly process join conditions and conditions in WHERE clause, before processing attributes from the SELECT statement.

The merge join strategy is working with an index created on foreign key and is considered to be the best strategy. The nested-loop join uses two nested loops. It means, it reads the rows from the first table in a loop and passes each row to a nested loop processing the second table in the join operation. During hash join, the optimizer uses the smaller of the joined tables and creates a hash table on the join key. It uses a hash function to specify the location in the hash table.

\section{Partitioning}

The performance, manageability, and availability of applications are enhanced by partitioning. It reduces the total costs for storing a large amount of data in very large databases. Using partitioning, tables, indexes, and index-organized tables can be subdivided into smaller parts, as it is shown in figure 4 . 


\section{Figure 4: Partitioning of a table}
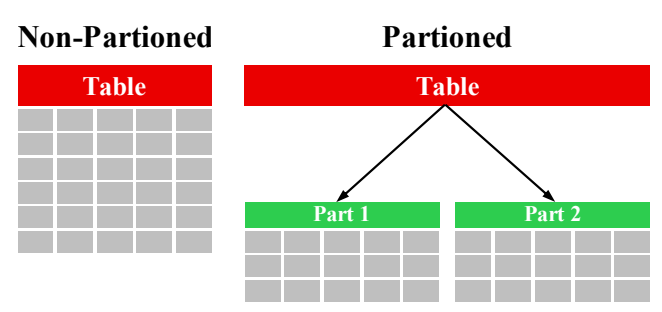

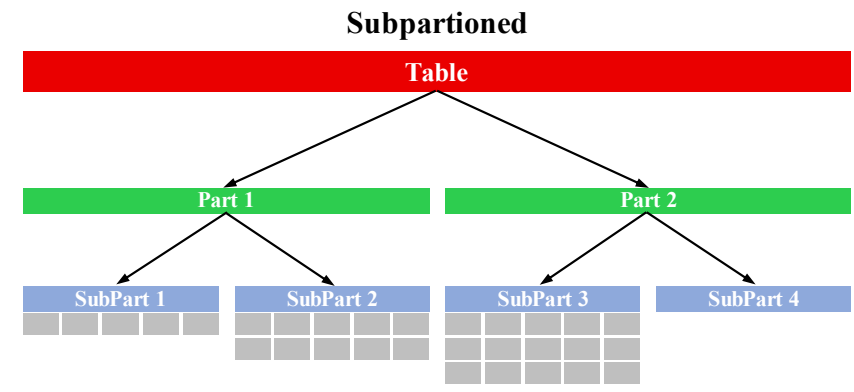

Source: [7]

Backup and recovery operations can be performed on individual partitions while other partitions are still available. This brings also great parallelism with more partitions. Unlike the situation in figure 4 , in real situations, it is likely that partitions are assigned to different tablespaces to reduce device contention [7].

\section{Conclusion}

Indexing structure is a very important part of optimizing database performance. Nowadays, the amount of data that we deal with when working with the database is constantly growing. This significantly increases the need for appropriate indexes to be used. In this paper, we have described various types of indexes and strategies for working with data. Reducing the total costs for storing a big amount of data is managed also by partitioning which assigns created partitions to different tablespaces. A significant element in executing partitioning is their balancing, which we would like to focus on in the near future.

\section{Acknowledgements}

This contribution/publication is the result of the project implementation: Centre of excellence for systems and services of intelligent transport II., ITMS 26220120050 supported by the Research \& Development Operational Programme funded by the ERDF.
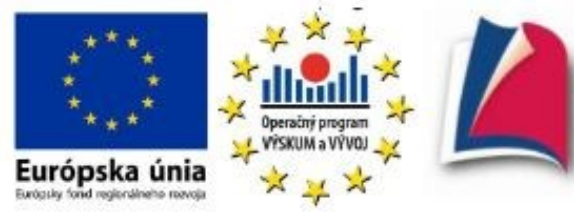

Agentúra

Ministerstva školstva, vedy, výskumu a športu SR

pre štrukturálne fondy EÚ

"Podporujeme výskumné aktivity na Slovensku/Projekt je spolufinancovaný zo zdrojov EÚ" The biggest thanks belong to EUNIS Slovakia, which helped with financial part.

\section{References}

[1] Adamu, F. B., Habbal, A., Hassan, S., Cottrell, R. L., White, B., \& Abdullahi, I. (2016). A Survey On Big Data Indexing Strategies. The 4th International Conference on Internet Applications, Protocols and Services.

[2] Clarion Technologies. How indexing helps in improving performance of databases. Retrieved February 4, 2020, from https://www.clariontech.com/blog/how-indexing-helps-in-improving-performance-of-databases

[3] Hash Indexes (2017). Retrieved February 4, 2020, from https://docs.microsoft.com/en-us/sql/databaseengine/hash-indexes?view $=$ sql-server-2014 
[4] Kuhn, D., Alapati, S., Padfield, B. (2011). Expert Indexing in Oracle Database 11g. Apress.

[5] Kuhn, D., Alapati, S., Padfield, B. (2016). Expert Oracle Indexing Access Paths. Apress.

[6] Kvet, M., Šalgová, V., Kvet, M., \& Matiaško, K. (2019). Master Index as a Data Tuple and Block Locator. Retrieved from Proceeding of the 25th Conference of FRUCT Association. Retrieved from https://fruct.org/publications/fruct25/files/Kve.pdf

[7] Oracle-Base. Partitioned Tables And Indexes. Retrieved Feruary 5, 2020, from https://oraclebase.com/articles/8i/partitioned-tables-and-indexes 


\title{
Optimization of Web Enviroment by Analyzing Website Traffic
}

\author{
Darina Tóthová ${ }^{1}$, Jakub Lacina $^{2}$, Marcela Foltánová ${ }^{3}$ \\ Slovak University of Agriculture in Nitra1, Center of Information Technology ${ }^{1,2}$ \\ Address: Tr. A. Hlinku 2, \\ 94976 Nitra, Slovakia \\ Escola de Sant Miquel dels Sants Primària Ronda Camprodon ${ }^{3}$ \\ 208500 Vic, Spain \\ e-mail: Darina.Tothova@uniag.sk ${ }^{1}, x L a c i n a @ u n i a g . s k^{2}$, M.Foltano@gmail.com³
}

doi: 10.18515/dBEM.ISD.P01.2020.p053

\begin{abstract}
The business website has a specific purpose that traces the prosperity of the business, implying the need to track and analyze their website traffic. The results of the website traffic analysis are therefore particularly important in the strategic decision making of managers.

According to web "trendy.builtwith.com" (Web Technology Usage Trends) and its ranking of web sites using analytics software, Slovakia holds 34th place with 109904 websites using certain analytics software, which represents $0.16 \%$ of all placed sites from around the world. Analytically software Google Analytics, which is used by 67,29\% of websites, predominates in Slovakia. 10176 websites have the phrase "google analytics" on their homepage.

Google Analytics is a free analysis program, which provides various output metrics gained by measuring web traffic on monitored (tracked) webpages. Google Analytics is a mega technology, as it is used by at least 29134826 websites on the Internet.
\end{abstract}

Keywords: website, web analytics, analytics tool, SEO, Portal of Universities

JEL Classification: O10, I23, D83, L86

\section{Introduction}

Nowadays, websites are of huge importance. They are used as an information and educational tool, for promotion, for e-commerce, for communication, for branding.

They are useful in making surveys; the questionnaires are made available to the visitors to websites (Hallova, Polakovic and Slovakova, 2017).

Implementation of new technological solutions in the field of information and communication technologies in all activities of the organization is now necessary and undeniable phenomenon that affects the quality of all internal/external processes of the organization (Olahova, 2016). The term Web analytics is understood as collection, measurement, analysis, reporting and interpretation of data gained from web with the purpose of further use. Data web traffic had been monitored and evaluated long ago, but its use and interpretation has been optimized just since new methods and tools were developed. They enable data processing and sophisticated data evaluation.

A very frequent term has become optimization, which is not meant to be only SEO (Search Engine Optimization), but above all a deeper understanding of the visitor, understanding their behavior on the web and discovering the most important barriers to achieving the desired results (Trejbal, 2012). 


\section{Data and Methods}

\subsection{Websites success}

A few years ago, clickstream visitors were considered as the basis for website success. Clickstream analysis uses two important concepts: metrics and Key Performance Indicators (KPIs). Metrics is a statistical variable that expresses the number of certain events or trends on a website (KAUSHIK, 2011).

Key Performance Indicators (KPIs) are metrics that testify to the success and effectiveness of the web to which they relate. We talk about concrete measurable value. Properly set KPIs are the basis for a successful web analytics application (Boháčková, Němec, 2009). Each organization usually has provided more indicators. Basic metrics include:

- Visitors

- Visits

- Time on Page

- Time on Site

- Bounce Rate

- Exit Rate

- Engagement

- Conversion Rate

Every good metric should have the following properties (KAUSHIK, 2011):

- Simplicity - the metric must be understandable to all involved.

- Relevance - must have a meaningful ability, so-called it must be usable to measure success in achieving objectives.

- Timeliness - it is related to the data collection and time period necessary for quality data evaluation, so that the resulting material for decision making are provided in time.

- Immediate usefulness - the metric must be understandable so that its results can be used immediately for quality decision making and lead to new knowledge.

Clickstream is a record that contains data about a user clicking a website on a computer screen through a mouse or touchpad.

Success on the web depends on Immediate usefulness - the metric must be understandable so that its results can be used immediately for quality decision-making and lead to new knowledge, 
evaluation of traffic analysis. However, this is not possible without a good analytical system. The Top 10 Web Analytics Tools rankings are as follows:

1. Google Analytics

2. Clicky

3. Mint

4. Church Analytics

5. KISSmetrics

6. Open Web Analytics

\section{CrazyEgg}

8. Piwik

9. CloudFlare

Google Analytics uses the method of coding websites. A tracking code programmed in JavaScript that provides data from a visitor's browser is inserted on each page.

Every time a page is loaded, this code connects into Google Analytics server that collects the data. This method also uses 'cookies'. Google Analytics works by running the inserted JavaScript code on the website you're tracking.

JavaScript is an object-oriented programming language and is sent to the server along with a web browser page. The programme and its function is executed on the server. The tracking script is stored in a separate file. Google Analytics uses and interprets the following data sources:

- An HTTP request from a visitor, i.e. visitor localization.

- Information about used browser and operating system.

- Cookies.

\subsection{SEO (Search Engine Optimalization)}

SEO is acronym from the English designation Search Engine Optimization, freely translated optimization for search engines. This optimization applies to the procedures, methods and strategies that move the web pages higher in search results when one performs a keyword search. It takes a lot of time to optimize web site, so it should consider whether or not should pay more attention to the information presented on social networks, or to mobile apps or personalized marketing.

The decision depends on answers to several questions, in particular:

- How much traffic does the site currently have, does it tend to increase the number of visits?

- Are these keywords, that the website contains and the area that the business unit is focused, are they generally searched?

- Is a tendency to increase the prosperity of an organizational unit by increasing traffic?

\subsection{Methodology}

The Degree of Google Analytics data usage is very complicated to determine. Analysis of web visit rate statistics in order to optimize the web environment, we implemented: 
- Questionnaire survey at Slovak universities.

- Detailed analysis of traffic statistics of the selected website.

- Analysis of attendance at the Portal of Slovak Universities (www.portalvs.sk).

\section{Results and Discussion}

Domestic and foreign universities conduct marketing activities on the Internet. Fabus, Juraj, Kremenova and Fabus Jozef (2014) followed marketing communication on the Internet. The Internet has long been a medium that allows sharing of information in text or graphic form or medium providing "chat" and e-mail based on a text (Host'ovecký-Zat'ková, 2011).

The results of analyzes from the Slovak universities' web sites confirm the fact that even the Slovak academic environment is aware of the crucial role of the web in making the results of its activities available and in the visibility in the virtual information and communication space (Jedličková, 2010). Measurable indicators are also written in Tools and Methods, 2006; Travis, 2014; Optimizesmart, 2018; Sauro, 2011; Šilerová, 2017; Tothova, 2017; Tools and Methods, 2006; Web Technology, 2017; Základní techniky, 2013.

\subsection{Questionnaire survey results}

In the research carried out in 2018 (Tothova, Galovičová, 2018) we also addressed the issue of using Google Analytics results. In the reviewed period, 28 responses were received from Slovak universities. Table 1 shows the results of the answers to the question when using Google Analytics data. Up to $64.3 \%$ of Slovak schools (who participated in the research) use the data and $35,7 \%$ do not use it.

Table 1: Usability of Google Analytics data

\begin{tabular}{|l|l|}
\hline & Slovakia \\
\hline Use & $64,30 \%$ \\
\hline Do not use & $35,70 \%$ \\
\hline
\end{tabular}

Source: Tothova, Galovicova, 2018

In complementary research, 23 secondary schools were addressed in the Zilina Region. In the period under review, we received 189 responses. Results were cleared -12 respondents were school staff and wrong students' answers. Subsequently, 177 responses were worked on.

In remote user testing, we asked students to choose one of the universities in Slovakia, visit their website and try to find the offered study programs. $88 \%$ of pupils have found study programs, and nearly $12 \%$ have not found (Table 2, Figure 2).

Table 2: Success of students when searching the study programs

\begin{tabular}{|l|c|}
\hline & Students \\
\hline Found study program & $88,10 \%(156)$ \\
\hline Did not find study program & $11,90 \%(21)$ \\
\hline
\end{tabular}

Source: Tothova, Galovičová, 2018 
The students who found the study program further evaluated how easy it was to find it, on a scale of 1 to 5, from very easy to very difficult. The results are shown in Figure 1.

Fig. 1: Graphic evaluation for searching the study programs.

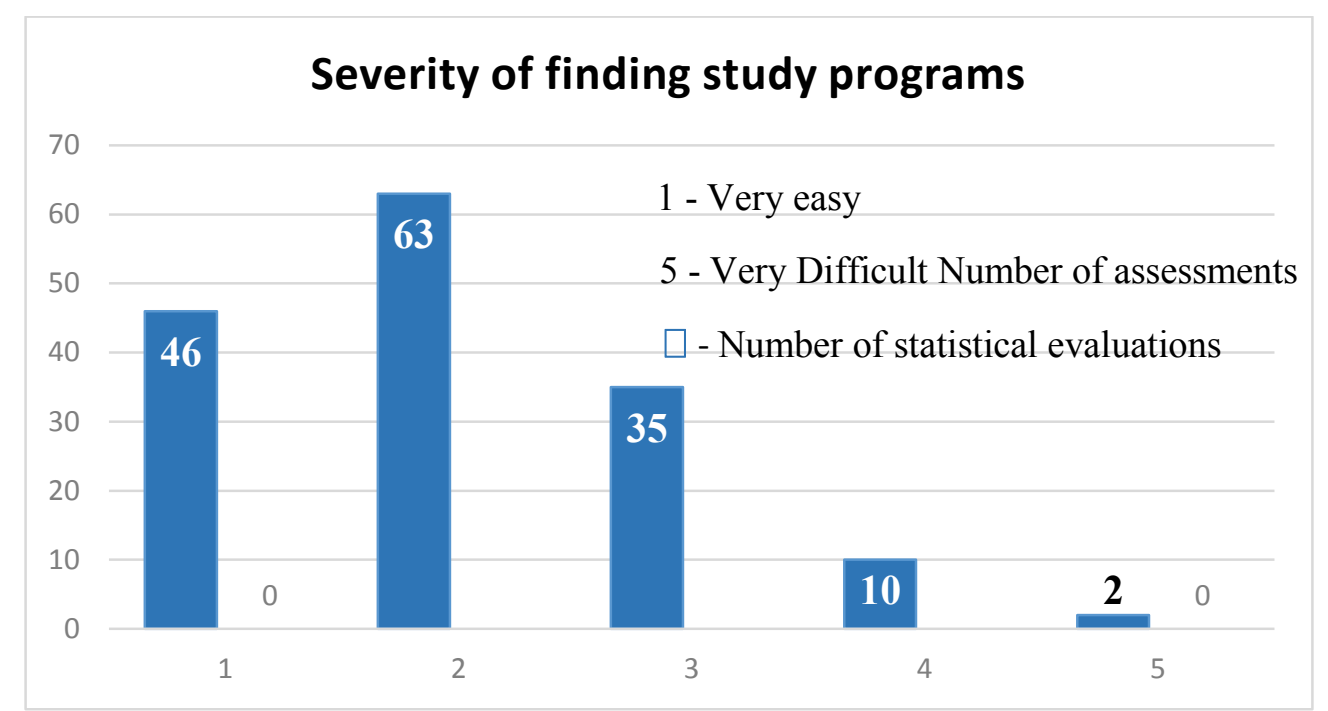

Source: Tothova, Galovičová, 2018

\subsection{Analysis of web traffic statistics for a selected website}

When analyzing traffic, it is also important where visitors come from, whether they arrive from a PPC ad (Pay per click) or non-targeted ad. PPC advertising is usually provided by a company that regularly evaluates PPC campaigns and, on the basis of their results, adds keywords, thus increases the targeted visit of customers, respectively of clients. For the needs of our research (Lacina, 2019) a company dealing with electrical installation work was chosen. The main goal of their website is to present the range of services provided. In the main menu are published certificates, services offer, gallery of realizations, company information, contact, links to social media. The page has a hidden JavaScript code provided by Google Analytics. It also uses JavaScript from Google Tag Manager to apply various extensions to Google Analytics.

In FIG. no. 2 is a detailed analysis of Google Analytics traffic

\section{Obr. 2 Web traffic statistics for the selected date range.}

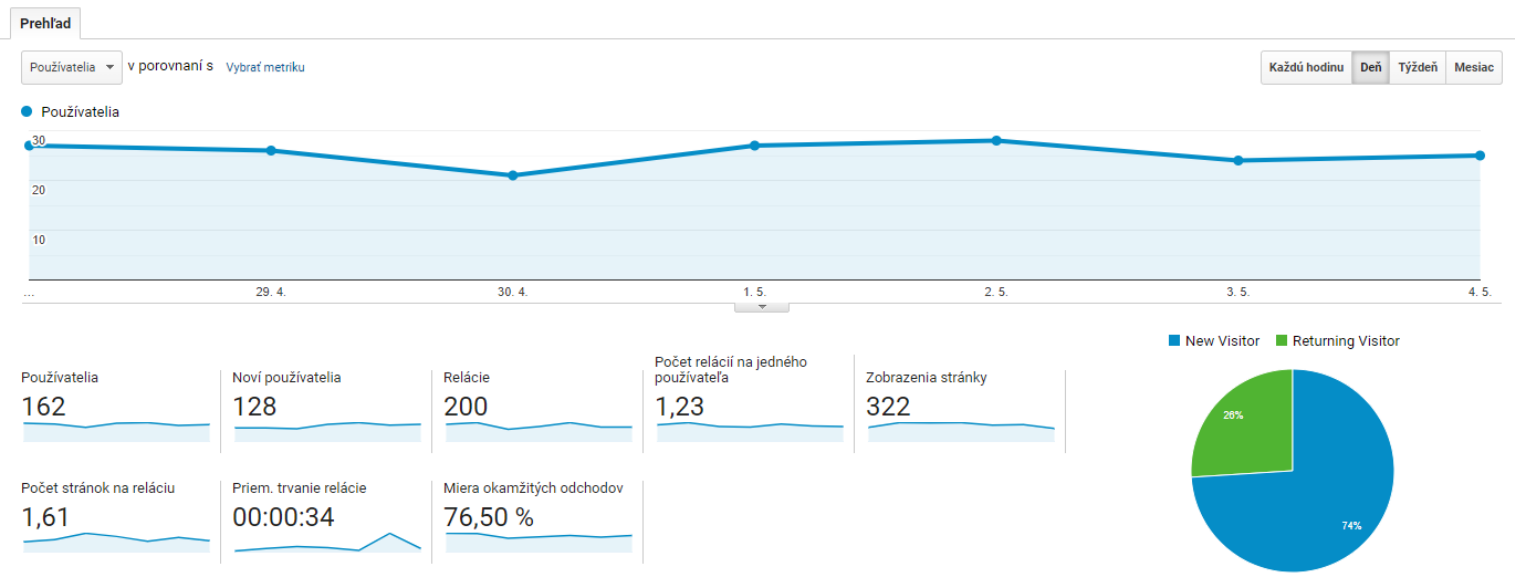

Source: Own elaboration. 
From the above statistics, we found that the website has a high bounce rate - over $75 \%$. A lot of keywords listed in the source code can be a problem. The page has up to 15 keywords in the source code header. While a large number of keywords can increases traffic to site, it also increases the chances of a visitor visiting website a multi-meaning keyword, such as an electrician, but looking for an electrician with a service that the business is not providing.

According to statistics, over the last 7 days of monitoring the number of visitors using amobile device navigating to a website was more than double to the number of visitors using a personal computer.

Departure rates can be negatively influenced by long scrolling, where the desired target of the visitor's interest is located at the very bottom of the long page (which is true in the case of the monitored company). Creating a separate page for this category would have a positive impact on visit rate statistics.

In the traffic sources statistic, we found that more than three-quarters of the visits are from PPC ads provided by Google Adwords. More than $15 \%$ of visits come from Display, which are ads shown to users looking for a particular service on their favorite sites, in Youtube videos, when viewing mails, or in applications on smart devices. This found that if the site didn't use paid ads, it would have nearly zero traffic. Direct visit is a powerful indicator of business branding and advertising campaigns via email or SMS. It represents visitors who accessed the site by directly entering a URL or clicking a link. A natural visit occurs when a visitor clicks on a search link in search engines like Google, Bing, Yahoo! However, these tools must evaluate the content of the page as reliable in order to rank higher in search. Referral visits indicate users who clicked a link on a Referral-like site such as azet.sk or seznam.cz.

Fig. 3 Traffic Sources

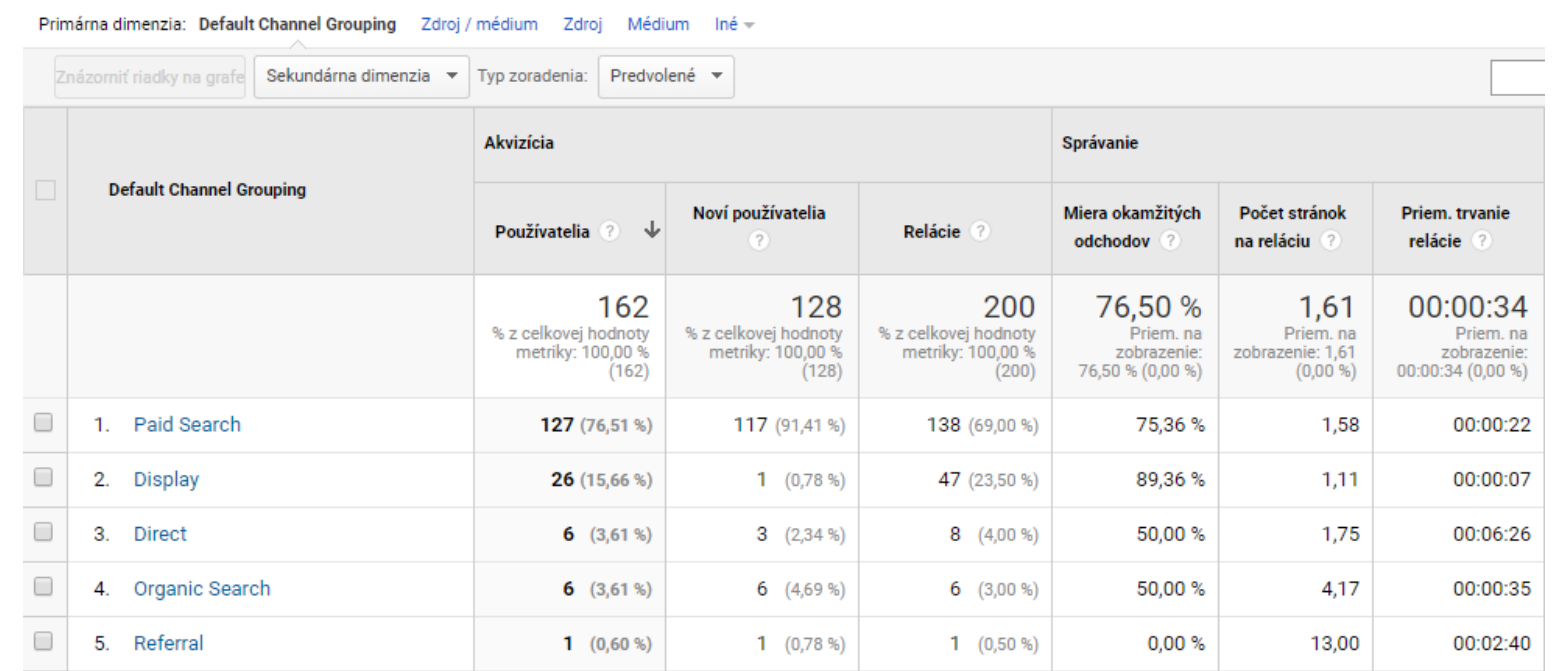

Source: Own elaboration.

\subsection{Evaluation of University Portal attendance}

University Portal (Portal of Slovak Universities - www.portalvs.sk) is the portal of all Slovak universities. It publishes professionally guaranteed information about universities, fields of study, programs, conferences, seminars and events at universities. The highest percentage of visitors belong to university applicants and their relatives.

At the beginning of its operation, the "Portal VŠ" used paid advertising for its promotion, currently it is promoted as follows: 
- Sending promotional e-mail to educational advisors at secondary schools.

- Sending leaflets for graduates to secondary schools in the required number.

- Sending newsletters to subscribed users.

- Publishing the logo of the University Portal with a link to the websites of secondary schools, preceded by request.

- Requirement to publish the logo of the University Portal with a link on the secondary school websites.

\section{Conclusion}

Based on the behavior of visitors on individual pages, various analyses can be performed to help make managerial decisions about increasing the efficiency and traffic to the site. The results will greatly help e.g. also to monitor the effectiveness of paid ads provided by Google AdWords, to track time spent on the site and on individual pages, which may result in the necessary change of layout of information on pages, adding elements to engage visitors.

Surveys and observations have shown that PPC advertising provided by a specialist company has significantly increased website traffic and profitability. Website traffic increased 3-5 times. The success of the Portal of Universities is carried out by measurable indicators and by increasing the rate of the Portal.

The success of the Portal of Universities is proved by the measurable indicators and by the increasing visit rate of the Portal.

Fig. 4 University Portal visit rate statistics for January 2020

\section{Portall $\zeta_{s k}$}

Statistics on page visits

Select a date range

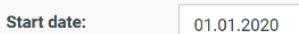

End date: $\quad 31.01 .2020$

Portálvš eKega

Visits

Pageviews:

119810

Bounce:

$41,20 \%$

Pageviews on visit:

New visits:

60487

5,84

Timeline

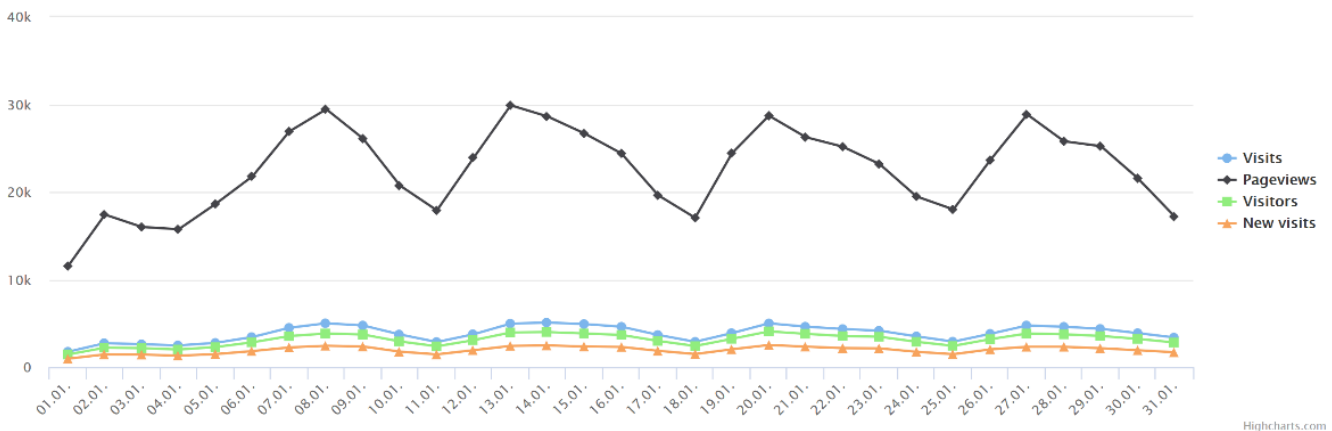




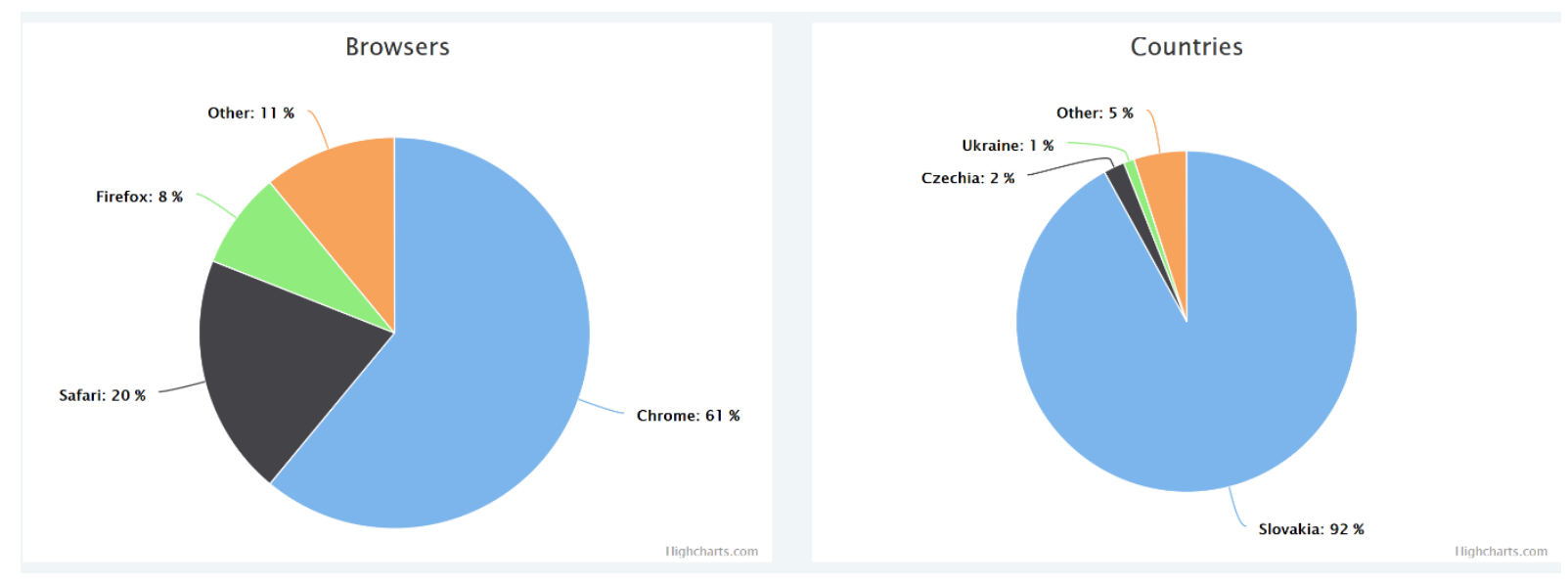

Source: www.portalvs.sk

\section{Acknowledgements}

This document has been produced with the support of association EUNIS-SK.

\section{References}

[1] Boháčková, Klára, Robert Němec (2009). Klíčové ukazatele výkonnosti (KPI) - jak sledovat to nejdůležitější. In RobertNemec.com [online]. 22.10.2009 [Cited 2013-11-11]. Retrieved from: http://webovaanalytika.robertnemec.com/klicove-ukazatele-vykonnosti-kpi/

[2] Clickstream. (2019) In Technopedia. [online] [Cited 2020.02.27]. Retrieved from: $<$ https://www.techopedia.com/definition/15403/clickstream>

[3] Čech, M. (2010) Nástroje webové analytiky. In Inflow. [online] [Cited 2020.02.27]. Retrieved from: $<$ http://www.inflow.cz/nastroje-webove-analytiky $>$

[4] Fabus, J., Kremenova, I. and Fabus, Jozef (2014). Internet Marketing in an Environment of University Institutions. In Edulearn14: 6th International Conference on Education and New Learning Technologies. Book Series: EDULEARN Proceedings Pages: 3459-3465

[5] Galovičová, T. (2017). Návrh metodiky pre vyhodnotenie použitelnosti webového rozhrania poskytovaných elektronických služieb [dizertačná práca]. Žilinská univerzita v Žiline. Fakulta prevádzky a ekonomiky dopravy a spojov; Katedra spojov. Vedúci dizertačnej práce: Kremeňová, Iveta, doc. Ing. PhD.; Stupeň odbornej kvalifikácie: doktor (PhD). Žilina: FPEDAS, ŽU, 2017. 146 s.

[6] Hallová, M., Polakovič, P. and Slováková, I. (2017) "Current Trends in Training of Managers in the Field of Information and Communication Technologies and Identifying the Barriers to Education of Managers", AGRIS on-line Papers in Economics and Informatics, Vol. 9, No. 4, pp. 45-52. ISSN 1804-1930. DOI 10.7160/aol.2017.090405.

[7] Host'ovecký, M., Zat'ková, T. (2011). In ICETA 2011: 9th IEEE International Conference on Emerging eLearning Technologies and Applications, October 27.-28.2011, Stará Lesná, The High Tatras, Slovakia : Proceedings / [CD Proceedings Editor: Anikó Szakál]. - [1. vyd.]. - Budapest, Hungary : Óbuda University, 2011. - ISBN 978-1-4577-0050-7. - S. 75-78.

[8] Jedličková, L. (2010). Webometria ako nástroj hodnotenia akademického webu: slovenské univerzity $\mathrm{v}$ prostredí $\mathrm{WWW}=$ Webometric analysis as a tool for evaluating the academic web sites: Slovak universities and World Wide Web. In Sietové a informačné technológie 2010. Zborník príspevkov z celoškolského seminára s medzinárodnou účast’ou, 20. máj 2010. Nitra: Slovenská pol’nohospodárska univerzita v Nitre, 2010. ISBN 978-80-552-0460-4. URL: http://www.slpk.sk/eldo/2011/zborniky/01-11/jedlickova.pdf.

[9] Kaushik, Avinash. (2011) Webová analytika 2.0: kompletní průvodce analýzami návštěvnosti. Vyd. 1. Brno: Computer Press, 2011. ISBN 978-80-251-2964-7.

[10] Lacina, J. (2019). Analýza štatistík návštevnosti za účelom optimalizácie webového prostredia: bakalárska práca, Nitra: SPU 
[11] Oláhová (2016). Management of IT environment end users and the impact of new technological solutions. In International Scientific Days 2016. 1st ed. online (1108 pp.). ISBN 978-80-552-1503-7. Nitra: SUA, 2016, pp.746-751, online. Retrieved from: <https://spu.fem.uniag.sk/mvd2016/proceedings/ en/articles/s9/olahova.pdf $>$.

[12] Optimizesmart (2018). Calculating True Conversion Rate in Google Analytics. [online] [Cited 2020.02.27]. Retrieved from: https://www.optimizesmart.com/fundamentally-wrong-conversion-rate/

[13] Sauro, J. (2011). Measuring Usabilty With The System Usability Scale (SUS). [online] [Cited 2017.02.06] Retrieved from: http://www.measuringu.com/sus.php

[14] Šilerová, Edita, Hennyeyová, Klára, Michálek, Robert, Kánská, Eva, Jarolímek, Jan Influence of the correct management of the IT department on the quality of data and information processing. (2017) In AGRIS on-line Papers in Economics and Informatics. Prague : Czech University of Life Sciences Prague. 9, $4 \quad$ (2017), $\quad$ s. 91--98. ISSN $1804-1930$. URL: http://dx.doi.org/10.7160/aol.2017.090409.

[15] Tóthová, D., Országhová, D. and Hornyák-Gregáňová, R. (2017). Web content management systems and their use in practice. In 20th international conference on information technology for practice 2017. Ostrava: Vysoká škola báňská - Technická univerzita, 2017, s. 103--112. ISBN 978-80-248-4089-5 (brož.).

[16] Tóthová, Darina, Galovičová, Terézia: Websites of Slovak Universities (2018). In International Scientific Days 2018. [electronic document]: "Towards Productive, Sustainable and Resilient Global Agriculture and Food Systems." Conference Proceedings, Nitra May 16-17, 2018 - 1. vyd. - Praha (Česko): Wolters Kluwer ČR, 2018. DOI 10.15414/isd2018.s10.13. ISBN 978-80-7598-180-6, s. 2231-2244 [online]

[17] Tools and Methods (2006). In Usabilitynet [online] [Cited 2020.02.27] Retrieved from:: http://www.usabilitynet.org/tools/list.htm

[18] Travis, D. (2014). 247 web usability guidelines. [online] [Cited 2020.02.27] Retrieved from: http://www.userfocus.co.uk/resources/guidelines.html

[19] Trejbal, Pavel (2012). Webová analytika v praxi I: Př́nosy webové analytiky. In Itbiz. [online] [Cit. 4.5.2019]. Retrieved from: <https://www.itbiz.cz/clanky/webova-analytika-v-praxi-1-prinosy-weboveanalytiky>

[20] Web Technology Usage Trends (2017). In BuiltWith. [online] [Citované 2020.02.27] Retrieved from:: http://www.usabilitynet.org/tools/list.htm

[21] Základní metriky. In Webová analytika (2013). [online] [Cited 2020.02.27]. Retrieved from:: <http://webanalytics.wikidot.com/zakladni-metriky> 


\section{SESSION 8}

AGRICULTURAL UNIVERSITY EDUCATION, QUALITY ASSURANCE AND HUMANITY STUDIES 


\title{
Foreign Languages - a Relevant Condition of Employers for Graduates of the Slovak Universities in the Central European Region
}

\author{
Lubomíra Moravcová ${ }^{1}$, L'udmila Mad'arová ${ }^{2}, S_{\text {Serhiy } \text { Moroz }^{3} \text {, Ivan Imrich }}^{4}$ \\ Slovak University of Agriculture in Nitra ${ }^{1,2,3,4}$ \\ Faculty of Economics and Management ${ }^{1,2,3}$, Faculty of Agrobiology and Food Resources ${ }^{4}$ \\ Department of Languages ${ }^{1,2}$, Department of Marketing and Trade ${ }^{2}$, Department of Veterinary \\ Disciplines ${ }^{4}$ \\ Address: Tr. A. Hlinku 2, \\ 94976 Nitra, Slovak Republic
}

doi: 10.18515/dBEM.ISD.P01.2020.p054

\begin{abstract}
Our article is focused on the importance of mastering foreign languages by the Slovak university graduates at today's workplace market on the one hand as well as on the needs of companies searching for graduates that have a good command of foreign language skills. We have also pointed to the need of mastering more foreign languages on the side of graduates. Slovakia is the country situated in the center of Europe where the labor market has to be understood in a broader context within this multicultural and multilingual world. Using the data that are based on the traditional survey of the company Profesia, we were able to more highlight the priorities of the companies awaiting the arrival of new graduates on the labor market. Our research has shown the increasing interest of the companies in the graduates mastering one or more foreign languages. It is evident from our research that it is not enough to be able to use only English as a major communication language. We have to accept that plurilingualism is more valued nowadays, especially because of the vision of new lucrative job opportunities, which are considered a great motivation for the fresh university graduates. Bilingualism and multilingualism offer a competitive advantage to both companies operating in the domestic and international business markets as well as to university graduates who pursue their career in them.
\end{abstract}

Key Words: university graduates, multilingual world, self-assessment, labor / workplace market, employers, plurilingualism

JEL Classification: I00, I23, F15

\section{Introduction}

In Slovakia, the situation regarding the workplace language needs has changed a lot in the last few years. More and more companies would clearly define their requirements on foreign language knowledge of the recent university graduates, as from their future potential employees. It is important to mention that in terms of mastering foreign language skills there hasn't been paid enough attention by the companies, even a few years ago, in comparison to as it is the case now, at present.

On the other hand, not even university departments of languages or university language centers have paid enough attention to particular language needs of the companies recently, in terms of their specific language requirements they have had on their future potential employees in certain communities. Therefore, it is still important to bridge the gap between the language teaching and language needs within the Slovak labor market.

As it is stated by law, the Slovak language is an official language in the country of Slovakia. Nevertheless, there are further minority languages spoken in the country: Hungarian, German, Polish, Ukrainian, Roman, etc. The second most spoken language is English followed by 
German, Spanish, French and Russian. There is an increasing need for English in the public, but especially in the private sector. But the need of other foreign languages, first of all of German, is also evident.

Our study is based on the results of the performed survey of students of the Slovak University of Agriculture in Nitra. Its purpose was to determine the level of students' self-assessment of their knowledge of foreign languages and using this knowledge for the future employment. Altogether, 342 questionnaires were filled, but only 332 questionnaires could be statistically processed. The survey was conducted during the months of September - November, 2018.

We have also monitored the interest of employers in university graduates according to their specific fields of study requirements, as well as according to mastering their foreign language skills.

The data based on the traditional survey of the company Profesia have been used for our research. We were able to more highlight the priorities of the companies awaiting the arrival of new graduates on the labor market. Our research has shown the increasing interest of the companies in the graduates mastering one or more foreign languages. It is evident from our research that it is not sufficient enough if students are only able to use English, that plurilingualism is more valued nowadays, especially because of the vision of new lucrative job opportunities, which are considered a great motivation for the fresh university graduates.

\section{The role of foreign languages in the professional world}

The influx of foreign investors into the Slovak market and the vision of lucrative job opportunities is a good motivation for the future job seekers. As far as job offers are concerned, job agencies monitor a great demand for graduates with a good command of different foreign language combinations. The best opportunity to find appropriate jobs have the ones who start looking for the first employment on the labor market right after school and have an active knowledge of one or more foreign languages. As stated by Gazzola and Mazzacani (2019), very good skills in foreign languages are associated with higher possibilities to find appropriate job positions.

Fabo, Beblavý and Lenaerts (2017) investigate the role of foreign languages in the labor markets of the Visegrad Four countries. Based on the countries' data from key online vacancy boards and from an online wage survey, the researchers argue that the knowledge of English and German languages is very important to have good employment possibilities in the Visegrad region.

As Veronika Ožvoldová (Tlačové správy 2014) (from the Manpower Personnel Agency) said to the News Agency of the Slovak Republic (TASR), the requirements for combinations of English and German, French, Russian, or English, Spanish and Italian languages are increasing. Performing the training in a company requiring knowledge of foreign languages could be a great start for university graduates, for the following building of their work habits, as well as gaining the experience for the further career growth. Experts have recommended that graduates should start looking for suitable job opportunities already during holidays, as the selection process may take up to two months. This, in particular, leads the young generation to an increased interest in studying foreign languages. Čiefová and Seresová (2017) also pay attention to the importance for students to study not only English, but also German, taking into account labor market requirements in Slovakia.

If we want to master a foreign language, we must have a particular motivation for it. We usually start with a kind of enthusiasm, with a vision of easy and fast communication. We will soon 
find out that it will not be the case from one day to the next, but it will be a journey full of hardto-understand grammatical structures with countless amounts of demanding and hard-tomemorize lexical and phraseological units. The initial enthusiasm combined with the increasing curriculum demands for learning gradually weakens, we keep trying less and less, we look for excuses, justify ourselves, and one day we completely stop learning.

Holan̆ (2015) states: if we want to learn a foreign language just for the purpose to pass the exams, to advance in a career or to show off before someone, we will never make it. What makes a man/a woman a multilingual personality is his/her passion for the language, fascination over the culture, literature, films, and a strong desire to understand the written text and to communicate in the particular foreign language. In order to learn a new language, the learning process should be mainly perceived as entertainment by a learner, definitely not as a drill or inevitable evil.

Andrulla Vasiliová (Hlavné správy 2018), the European Commissioner for Education, Culture, Multilingualism and Youth points to a Euro barometer survey, according to which multilingualism and language learning are important and we should be delighted about that. But we have to do much more for it in order to improve teaching and learning foreign languages. The ability to speak foreign languages extends one's horizons and opens the door; it increases the employment opportunities and can also bring more opportunities to businesses in the single market'. The survey has showed that more than half of Europeans (53 percent) use foreign languages at work and 45 percent think that thanks to the knowledge of foreign languages they have gained better jobs in their country.

A big boom has occurred at the Slovak schools in teaching English in the last few years. English has become a compulsory subject since the 3rd year of the elementary school. The Portal on Education and Self-Development states that Slovakia occupies the last place in the knowledge of English among the V4 countries. The amendment to the Education Act introduces English as a compulsory foreign language since 1st September, 2011. Today, English is not only considered a business language. We can say it has penetrated into all areas of human lives. HR professionals confirm that employees with a low level of competence in the English language are rarely promoted and earn less than their colleagues who have mastered English perfectly. Increasingly, a pure command of English is considered a barrier to get new and better jobs (Eduworld.sk 2018).

On the contrary, the study regarding the ability of the British to speak foreign languages has revealed that inhabitants of the United Kingdom have great deficiencies in their knowledge. According to the results of the survey released by the Daily Mail Portal, nearly two-thirds of the respondents have admitted they are not able to say a single word in other but the English language. One third of the respondents admitted they had tried to speak a foreign language, but only during a holiday abroad.

According to the survey, the young generation has the worst knowledge of foreign languages. Nearly 50 percent of people aged from 16 to 24 confirmed they had never spoken the foreign language studied at school. Although foreign language teaching is compulsory in Britain, only one out of ten declared some knowledge of the foreign language studied at school. The reason for this situation is laziness of the British, the fear of making mistakes and, in particular, the expectation that everyone in the world is able to speak English, writes the Daily Mail (2018). Stephan Meyer/Valérie Blondel/Beatrice Mall-Grob (2017) also focus on the issue: 'Why is the development of conversational competence important within higher education? And how might this goal be pursued?

Department of Languages of the Faculty of Economics and Management of the Slovak Agricultural University in Nitra has been member of the UNIcert ${ }^{\circledR}$ network since 2005 . The 
staff of the Department of Languages are members of CASAJC. Department has got accreditation for the language courses and examinations of the UNIcer ${ }^{\circledR}$ II (B2) for the English, German and Russian languages for students of agricultural and economic fields of study, as well as accreditation for the Language Programme of C1 language competence level (English and German languages for economists), UNIcert ${ }^{\circledR}$ III. The department staff are also members who represent the CASAJC Board.

\section{Methodology and aim of the study}

Our study is based on the results of the performed survey of students of the Slovak University of Agriculture in Nitra. Its purpose was to determine the level of students' knowledge selfassessment of foreign languages and using this knowledge for the future employment. Altogether, 342 questionnaires were processed for the figures, statistically just 332 of them. The survey was conducted during the months of September - November, 2018. The aim of this paper is to evaluate the achieved results of monitoring the University students regarding the foreign language competencies and their application in practice.

We have evaluated our research results in the tables and charts in the MS Office Excel Programme. The detailed mathematical-statistical data processing was performed in the statistical program SAS, version 9.1. We have used the Pearson Chi - Square test with comparing the differences in columns (for a given row) using the $\mathrm{z}$ - test (Bonferroni method) to find statistically significant dependencies in the frequencies of individual records.

\section{Results}

The monitored students were asked to respond to several questions about the study and use of foreign languages. The first question was: How long have you been studying the chosen foreign language? It was found out, on the basis of the processed data, that a large majority of students $(69.3 \%)$ have been studying a particular foreign language for more than 7 years. This was followed by students who have been studying it until 4 years $(20.5 \%)$ and $5-7$ years $(7.3 \%)$ (Figure 1).

Figure 1. Distribution of answers to the question 'How long have you been studying the chosen foreign language? $(\%)$

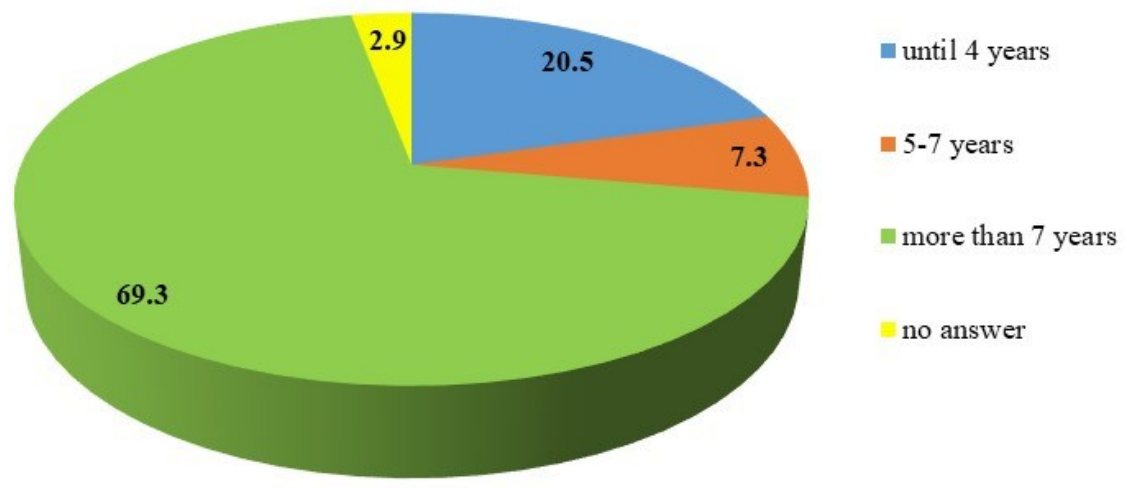

Source: authors' calculations based on the survey results 
The question 'How long have you been studying the chosen foreign language? ' was responded by 332 respondents (Table 1). The statistical analysis of the responses has shown that most students have been learning a foreign language for more than 7 years $(71.39 \%)$. This was followed by students studying the foreign language until 4 years $(21.08 \%)$, and finally from $5-7$ years $(7.53 \%)$. The differences in frequencies were statistically highly significant ( $\mathrm{p}$ $<0.001$ ). We have only taken completely completed questionnaires for the statistical processing, which was the total of 332 .

Table 1 Distribution of answers to the question: 'How long have you been studying the chosen foreign language?

\begin{tabular}{llll}
\hline Study duration & $\mathrm{n}$ & $\%$ & Significance \\
\hline Until 4 years & 70 & $21.1 \%$ & \\
5-7 years & 25 & $7.5 \%$ & $\mathrm{p}<0.001$ \\
More than 7 years & 237 & $71.4 \%$ & \\
\hline Total & 332 & $100.0 \%$ & \\
\hline
\end{tabular}

Source: authors' calculations based on the survey results

The next question was: 'How do you evaluate your level of the chosen foreign language knowledge'? Distribution of the survey responses for all study periods regarding this question was as follows (Figure 2):

Figure 2. Distribution of responses to the question 'How do you evaluate your level of knowledge of the chosen foreign language? $(\%)$

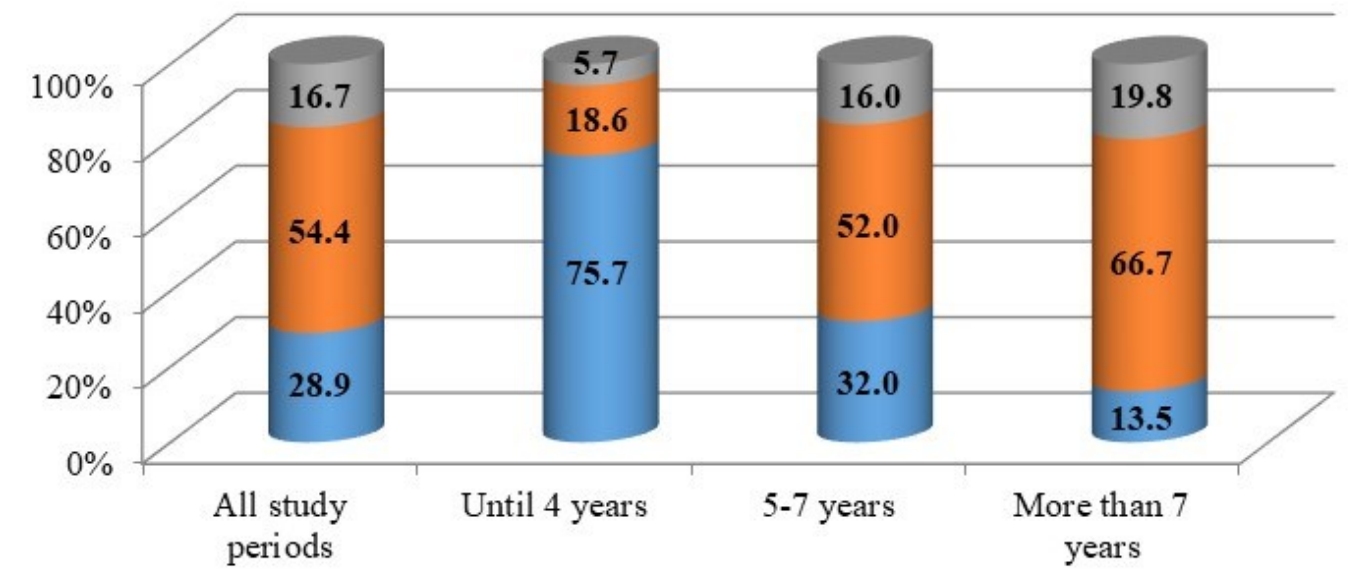

Active level, speaking and writing; My foreign language competence corresponds to my native language

- Intermediate level

Elementary level

Source: authors' calculations based on the survey results

$28.9 \%$ of students have mastered a foreign language at the elementary level; $54.4 \%$ of students have considered their knowledge at the intermediate level; $16.7 \%$ of the surveyed students evaluated their skills regarding their foreign language knowledge at the active level, speaking and writing, or their foreign language competence corresponded to their native language.

The situation looked somewhat different taken by study period. The increase of this period led to the noticeable reduction of the proportion of students with the elementary level of foreign language knowledge: from $75.7 \%$ (until 4 years) to $13.5 \%$ (more than 7 years). At the same time, there was the growth of the shares of students with the intermediate level of the language 
proficiency (from $18.6 \%$ to $66.7 \%$ ) and with the active level, speaking and writing, or their foreign language competence corresponded to their native language (from 5.7\% to $19.8 \%$ ).

It can be seen from the analysis of the level of foreign language control considered a function of the length of study (Table 2), that there is a statistically high correlation between the achieved level of foreign language proficiency and the length of study $(p<0.001)$. During the study period up to 4 years, majority of the respondents achieved only the elementary degree of foreign language skills, which was significantly more compared to the intermediate and active level ( $p$ $<0.05)$. There were no differences in the level of achievement among the students with a study duration from 5 to 7 years ( $>0.05)$. The best results were achieved by students who have been studying the language for more than 7 years. A substantial part of them has mastered the language on the middle, respectively active level, which is significantly more than at the elementary level $(\mathrm{p}<0.05)$.

Table 2 Dependence of the education level on the length of study

\begin{tabular}{lllll}
\hline$(\%)$ & \multicolumn{4}{l}{ Knowledge evaluation } \\
\hline Study duration & Elementary level & Intermediate level & Native and active level & Total \\
\hline Until 4 years & $57.0^{\mathrm{a}}$ & $7.1^{\mathrm{b}}$ & $7.3^{\mathrm{b}}$ & 21.1 \\
$5-7$ years & $8.6^{\mathrm{a}}$ & $7.1^{\mathrm{a}}$ & $7.3^{\mathrm{a}}$ & 7.5 \\
More than 7 years & $34.4^{\mathrm{a}}$ & $85.9^{\mathrm{b}}$ & $85.5^{\mathrm{b}}$ & 71.4 \\
Total & 100.0 & $100.0^{\mathrm{a}}$ & 100.0 & 100.00 \\
\hline Pearson Chi-Square & $\mathrm{p}<0.001$ & & & \\
\hline
\end{tabular}

Source: authors' calculations based on the survey results

Each subscript letter denotes a subset of knowledge evaluation categories, whose column proportions do not differ significantly from each other at the 0.05 level.

Regarding the next question 'How do you understand the necessity of foreign language skills for your future job?', most of the respondents (65.5\%) answered that knowledge of foreign languages would be very important for their future employment (Figure 3). 28.1\% of the respondents replied that this knowledge would be partly important. $6.4 \%$ of students had an opinion that it would not be important at all or did not know whether such knowledge would be important in this respect. Concerning the other presented study periods, majority of students also responded that it would be very important or partially important for their future jobs.

Figure 3. Distribution of answers to the question 'How do you understand the necessity of foreign language skills for your future job? (\%)

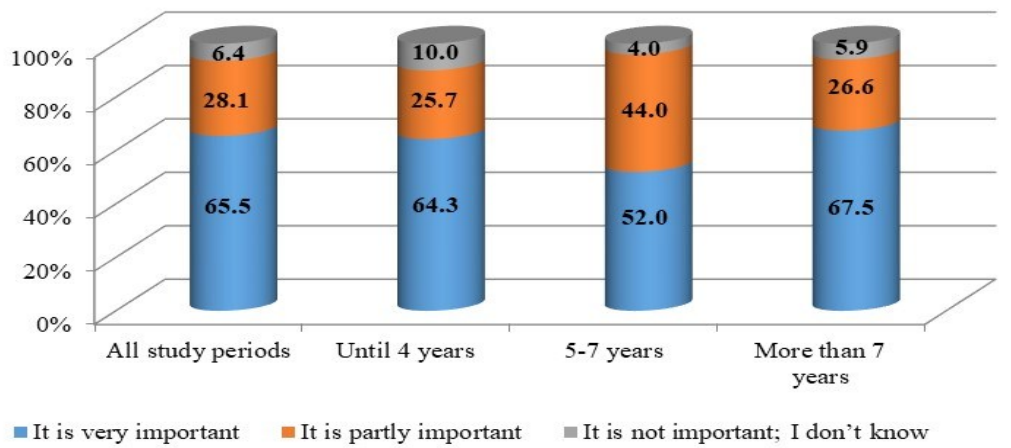

Source: authors' calculations based on the survey results 
Table 3 shows that respondents who had been studying a particular foreign language for more than 7 years had the greatest need for knowledge of foreign languages. Students with less than 4 years of study had the least need for foreign language learning. As to the study period of 5-7 years, they considered the need for studying a foreign language partially important. However, the analysis of the results did not confirm the relationship between the length of study and the need master a foreign language ( $\mathrm{p}>0.05)$.

Table 3 Dependence of foreign language needs on the length of study

\begin{tabular}{lllll}
\hline$(\%)$ & Language necessity & & \\
\hline Study duration & Not important, don't know & Partly important & Very important & Total \\
\hline Until 4 years & 31.8 & 19.6 & 20.6 & 21.1 \\
5-7 years & 4.5 & 12.0 & 6.0 & 7.5 \\
More than 7 years & 63.6 & 68.5 & 73.4 & 71.4 \\
Total & 100.0 & 100.0 & 100.0 & 100.00 \\
\hline
\end{tabular}

Pearson Chi-Square $\mathrm{p}>0.05$

Source: authors' calculations based on the survey results

The next question was 'Where would you like to work after graduation?'. The survey results showed that $34.8 \%$ of students would like to work in a Slovak company/institution, and $27.5 \%$ of respondents had plans to work in a foreign company/institution in Slovakia (Figure 4).

Figure 4. Distribution of answers to the question 'Where would you like to work after graduation (\%)

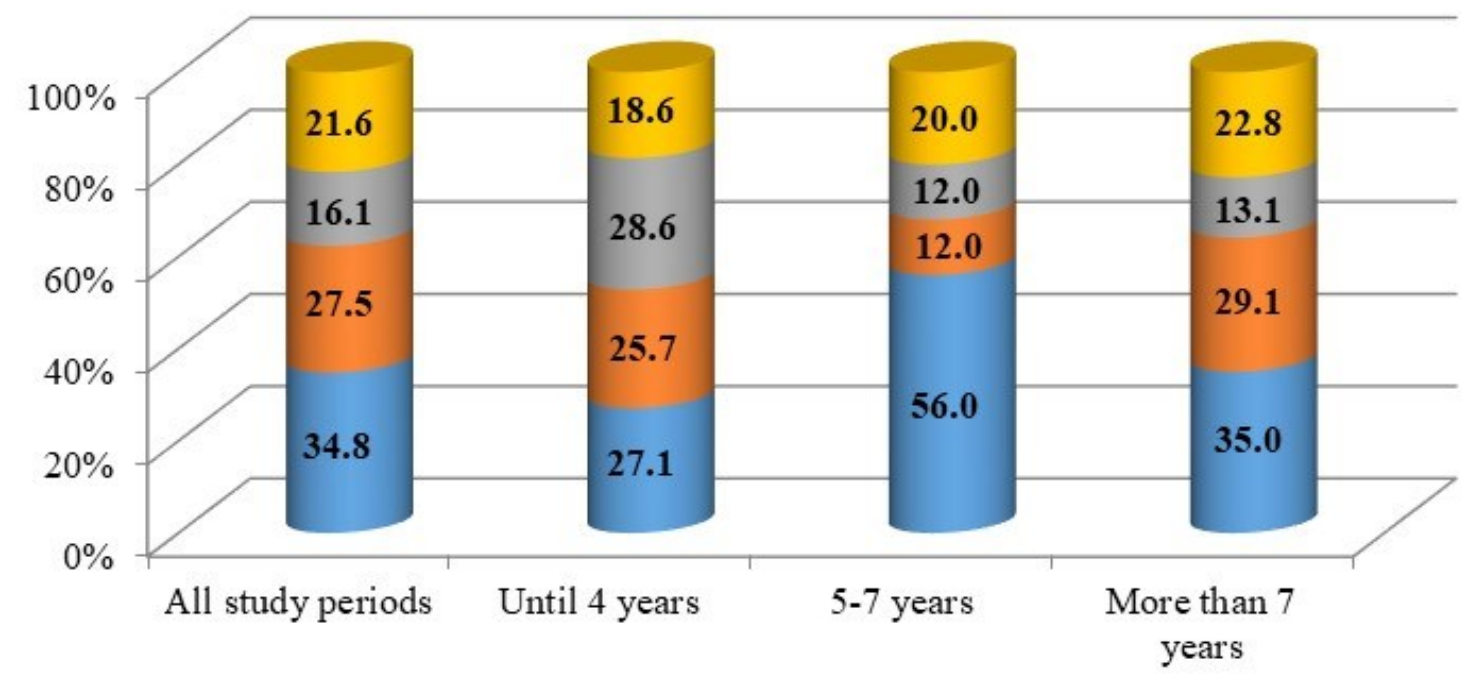

I don't know yet

= In Slovakia, in a foreign company/institution
I want to work abroad

- In Slovakia, in a Slovak company/institution

Source: authors' calculations based on the survey results

$16.1 \%$ of respondents would like to have an opportunity to work abroad, and $21.6 \%$ of respondents had not decided yet. Concerning the study period until 4 years, there was the increase of the proportion of the respondents who would like to work abroad (28.6\%) and the decline of the share of students intended to work in a Slovak company/institution $(27.1 \%)$. However, for the study period of 5-7 years, the opposite tendency was seen: the sharp increase 
of percentage of respondents who planned to work in a Slovak company/institution (56.0\%) with the simultaneous reduction of the students who wanted to find jobs in a foreign company/institution in Slovakia (12.0\%) and abroad (12.0\%). For the last presented study period (more than 7 years), the share of students intended to find job positions in a foreign company/institution in Slovakia grew to $29.1 \%$, while the percentage rate of students who wanted to be employed by a Slovak company/institution, declined to $35.0 \%$. The share of students who had not decided yet, regarding their future job positions, was equal to $22.8 \%$.

Table 4 shows the relationship between the expected employment and the length of study of the foreign language. The analysis shows that as far as the length of study - up to 4 years - is concerned, statistically most respondents would like to get employed abroad and least of them in Slovakia in a Slovak company $(\mathrm{p}<0.05)$. At students - with over 5 years of foreign language study, there was no significant difference in the answer 'where they wanted to work' ( $p>0.05)$.

Table 4 Dependence between the expected employment and the length of foreign language Study

\begin{tabular}{llllll}
\hline$(\%)$ & Work & & & & \\
\hline Study duration & $\begin{array}{l}\text { Slovakia in a } \\
\text { Slovak company }\end{array}$ & $\begin{array}{l}\text { Slovakia in a foreign } \\
\text { company }\end{array}$ & $\begin{array}{l}\text { Work } \\
\text { abroad }\end{array}$ & $\begin{array}{l}\text { Don't } \\
\text { know }\end{array}$ & Total \\
\hline Until 4 years & $16.4^{\mathrm{a}}$ & $20.0^{\mathrm{a}, \mathrm{b}}$ & $37.0^{\mathrm{b}}$ & $18.1^{\mathrm{a}, \mathrm{b}}$ & 21.1 \\
$5-7$ years & $12.1^{\mathrm{a}}$ & $3.3^{\mathrm{a}}$ & $5.6^{\mathrm{a}}$ & $6.9^{\mathrm{a}}$ & 7.5 \\
More than 7 years & $71.6^{\mathrm{a}}$ & $76.7^{\mathrm{a}}$ & $57.4^{\mathrm{a}}$ & $75.0^{\mathrm{a}}$ & 71.4 \\
Total & 100.0 & 100.0 & 100.0 & 100.0 & 100.0 \\
\hline
\end{tabular}

Pearson Chi-Square $\mathrm{p}<0.05$

Source: authors' calculations based on the survey results

Each subscript letter denotes a subset of knowledge evaluation categories, whose column proportions do not differ significantly from each other at the 0.05 level.

Earlier, we have conducted another research about the level of foreign language skills required by companies, banks, important for applicants' job positions in the Nitra region (see Moravcová, Mad'arová, and Moroz, 2018). The peculiarity of the available job offers was that a high level of foreign language skills was required for their significant part, namely: $\mathrm{C} 1$ and $\mathrm{C} 2$ (Figure 5). For both economic and non-economic job positions, this requirement was primarily related to other (non-English) foreign languages. It can be seen that the respective shares of these job requirements were $36.4 \%$ and $50.0 \%$.

According to calculations the carried out, with respect to all the study periods, only $16.7 \%$ of students had the foreign language competence at the advanced and proficient levels (Figure 6). Even for students who studied foreign languages for more than 7 years, the corresponding number was $19.8 \%$ only. In addition, it is necessary to take the fact into account that the actual level of students' knowledge of foreign languages was lower than their self-assessment results in this study.

Based on the above analyzed research results, special attention should be given to the following points. It is important to realize that majority of students understand the importance of learning foreign languages for their future careers. The share of these students grows with an increase of the foreign language study period. The number of students able to speak foreign languages at the advanced and proficient levels, which is nowadays required for the labor market of the Nitra region, is at a significantly lower level than required. 
Figure 5. The required level of knowledge of foreign languages in companies, banks for their job positions in the Nitra region (\%)
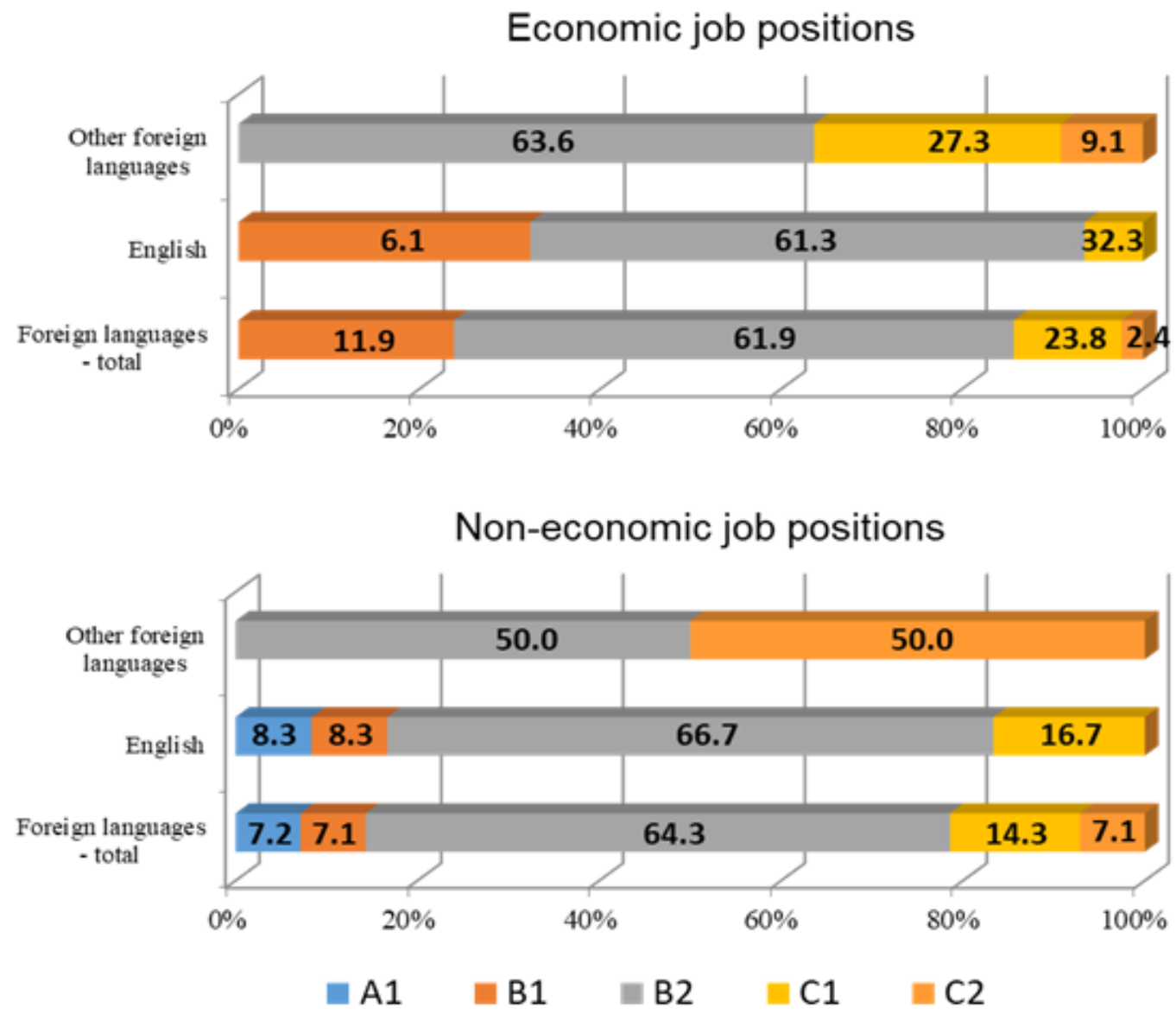

Source: Moravcová, Mad’arová, and Moroz (2018)

Figure 6. Knowledge of foreign languages at the advanced and proficient levels* (\%)

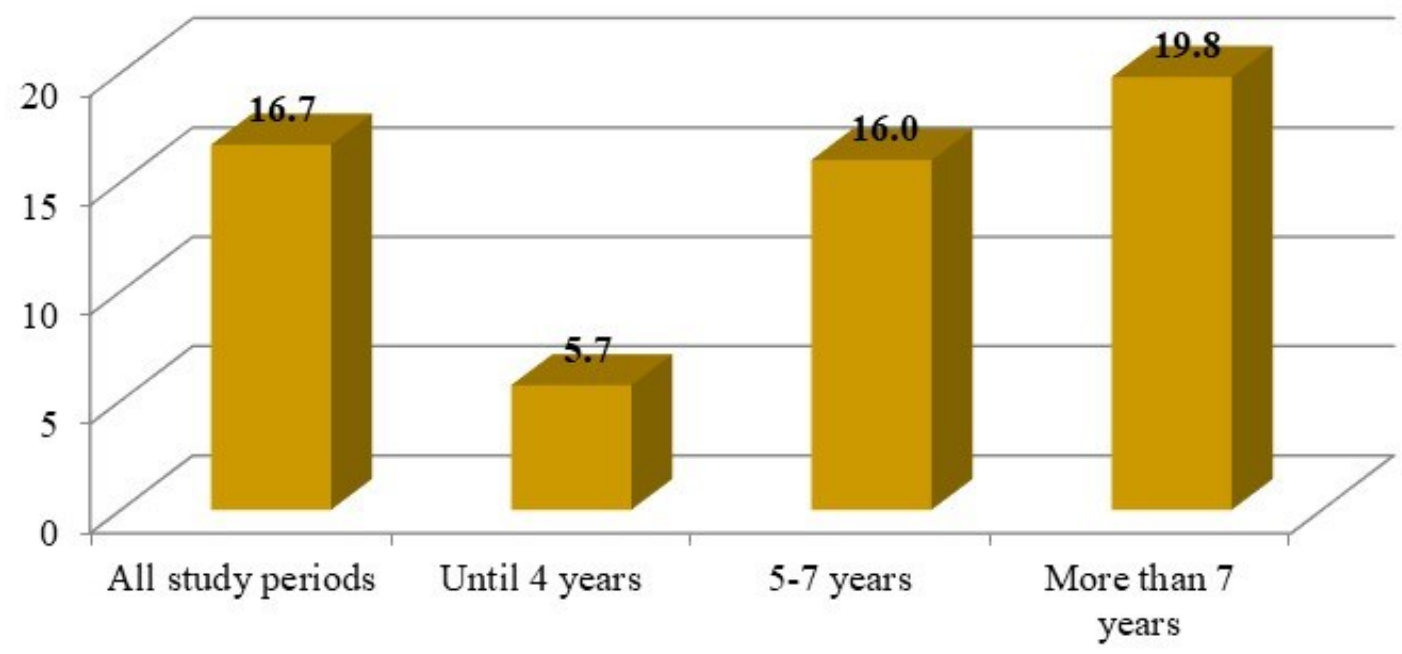

* Active level, speaking and writing + My foreign language competence corresponds to my native language Source: authors' calculations based on the survey results 


\section{Discussion}

As a traditional survey of the company Profesia ${ }^{15}$ has recently shown, employers are now eagerly awaiting the arrival of new graduates on the labor market. Compared to the last year, the interest in the recently graduated job seekers is increasing. The most desirable job candidates are absolutely considered graduates of the fields of informatics and engineering. Hlaváčová (2017) writes that the situation on the labor market is favorable for university graduates. Up to $90 \%$ of employers would also demand university education for junior job positions. However, candidates without the knowledge of at least one world language have a problem to find employment on the labor market. The interest in the graduates with a special focus on international relations and economics has particularly risen. The knowledge of foreign languages, which is especially appreciated by the foreign companies operating in Slovakia, is particularly considered an important strength of the freshly graduated economists.

Employers assume that students have the possibility to study foreign languages as well as to take part in the short- or long-term study stays abroad (Erasmus mobility, Erasmus +, CEEPUS), they have the choice of various study programs in English or German languages, new degree programs are being introduced, respectively extended, in cooperation with foreign universities (double degree). Job seekers who speak at least two world's languages have better conditions to find employment on the labor market.

The company Profesia compiles a ranking of individual universities and colleges according to the criterion - how many employers have viewed the CVs of graduates published on the Profesia.sk portal. Although the employers' interest in graduates is increasing, we have recorded a negative demographic trend, which is reflected in a decreasing number of students. Many Slovak students go to study abroad. They mostly choose the neighboring countries and their core interest is to study in the Czech universities. According to the Executive Director of Profesia Ivana Molnárová (Tlačové správy 2017) “...the problem is that most of students decide to stay where they have studied. This is also proved by statistical figures saying that more than 300,000 people have left Slovakia in the recent years. Out of these, up to half are under 30 years of age. Just this group of people is enormously missing out on our labor market."

In order to ordinary communicate in a particular foreign language, it is necessary to control, to some extent, all the speech skills: writing, reading, speaking and listening comprehensions. "This should be gained by a student through general language education (General English / Allgemeine Sprache Deutsch).

A general language, at least at a moderately advanced level, should form the basis for learning a specific purpose language (ESP - English for Specific Purposes/Sondersprache Deutsch), which can be divided into: the professional language needed to perform a particular job / profession (Vocational English / Berufssprache Deutsch) - for example in lower positions, or also for manual workers, and the professional foreign language required to pursue the profession, most often after graduating from a university (Professional English / Fachsprache Deutsch (Hronová - Petr 2017).”

It is very difficult to avoid foreign languages in the professional world today. English is taken for granted and knowledge of every other foreign language is considered an advantage. Companies that employ polyglot workers are more competitive. This knowledge opens up completely new opportunities for both employers and employees - both within and outside the company. There are only few jobs that wouldn't be touched by globalization. Reliable

\footnotetext{
${ }^{15}$ Profesia.sk is considered the most important Internet Work Portal operated by the Company Profesia spol. s.r.o. The 100 percent owner of the Company Profesia is a Finish Medial Group Alma Media.
} 
mastering of at least one foreign language is now considered a basic supposition for getting a job in the field of marketing, science or law. It is also expected in the professions with a medium level of qualification.

"We also have university graduates in working positions." Although they do not receive an extra pay for the language, these workers are favored in the new projects, in which they become instructors, trainers (also with performance evaluation)," said Vladimír Polák (Aktuality.sk 2009), Director of the Slovak Eissmann ${ }^{16}$ in Holíc for motornews.sk ${ }^{17}$ portal. According to Polak, it is very good for a worker to know German or English languages, just for the case. "They can then handle any claims or minor repairs of the parts," he added. The reason why college students are in the production processes is seen by the director in the fact that they are no able to find other job positions. According to Monika Martinková from Trenkwalder ${ }^{18}$, the knowledge of foreign languages will not affect the salary of an employee, but it will affect whether or not he/she gets a job. "If a company requests a foreign language and the candidate does not know it, he/she is automatically deprived of a chance to get an employment. It is no longer an exception that there are foreigners, even at lower levels of management, and therefore, at least the basic knowledge of one foreign language, most often English, is already required for the working positions. It is directly related to the robotization of the production processes, as control programs are also written mainly in English", Martinková says. According to her, the automobile industry has its own language specificity as far as the language is concerned. It is also possible to follow different approaches to languages. In addition to English, West Slovakia car producing companies require German, eventually French. English is sufficient for the KIA company" (ibd.).

According to the results of A. Hall (2008), demand for the English language is generally increased with the level of work requirements. Negotiation skills $(21 \%)$, as well as verbal and written skills (31\%), are expected at negotiations, especially in jobs where academic education is required. These skills are less often required at secondary or vocational education levels. In the simple jobs that are accessible without the completed vocational training, English is usually not required (84\%). The author points out that older people do not dispose of such foreign language competences as the younger generation. There is almost a two times higher chance to get a job for the 15 - 30-year-olds than for the over the 50-year-old ones.

It is quite normal that an employer working in the field of management, marketing, in the field of IT or media, must speak English. However, only "school" English is not enough here. Specific terms relevant to the professions concerned are considered a duty. But not only English is important, which is rather a basic requirement. Other foreign languages are equally important, depending on the profession, and may be also attractive for an employer. It is not just the issue that a potential employee is able to communicate with international customers or foreign copartners. Because who masters foreign languages, he/she shows cosmopolitanism and tolerance. People interested in foreign languages are also interested in foreign countries, foreigners and their cultures. They know how to deal with others and can be a win for firms and companies (Lingua jet 2018). It should be emphasized that all language skills make sense. Everyone must answer a question for himself / herself - which foreign language he / she will learn. A choice should be focused on the industry and partners of the future company. It is important to concentrate on the industry and partners of the future company at a choice.

\footnotetext{
${ }^{16}$ The company Eissmann Automotive Slovensko, with the seat in Holič, is engaged in the production of leather and synthetic leather interiers in cars.

${ }^{17}$ News portal aimed at the na automobile industry.

${ }^{18}$ Recruitment Agency Trenkwalde, a.s. Job and employee mediation, the online search for job offers.
} 
Nowadays, attractive opportunities are being revealed in the Chinese, Japanese and Arabic markets.

And how is it with the financial advantage of the employees disposing with foreign language competences? Everything is in the hands of employers. According to the Platy.sk ${ }^{19}$ portal, the salary of such a staff, mastering foreign language, is on average by $31 \%$ higher than the salary of the people who are not in the intensive contact with foreign languages. German is only used at work by one out of 10 employees, while older workers speak German much more often. Only $1 \%$ of the people use French and Russian at work. German, Russian and other language courses are increasingly attended. According to Miroslav Dravecký (HN online, 2018), the product manager of the Portal Platy.sk, this may be related to the finding that salary level of the people using German or French in their work is roughly comparable with the salary level of the people using English. There was no significant pay gap found out in the performed research among the three languages.

Another opinion is shared by Peter Tomasch (Habláková 2009), a personal manager of the Baumit ${ }^{20}$ Company, whose former employees mastering foreign-languages used to be financially awarded, a few years ago. The foreign language was an advantage for performing a faster career at that time. "Whoever had a command of the foreign language, he / she was able to establish a better contact with foreign management and therefore had a better chance of gaining a higher position. And that logically brought a higher financial rating. Today, speaking a foreign language is considered an essential requirement for employers, so it is not directly reflected in the valuation."

Multilingualism is one of the fundamental principles of the European Union (EU 2019). Multilingualism policy aims at:

Communicating with citizens in their own language,

Preserving Europe's rich linguistic diversity,

Promoting language learning in Europe.

The main objective of the EU citizens is ambitious: in addition to the mother tongue, all EU citizens should be able to communicate in two foreign languages. It is assumed that this can be best achieved by introducing teaching of two foreign languages to children from an early age. Further steps are being taken to encourage the EU countries to introduce learning programs taught in a particular foreign language so that school leavers could get better language skills.

The EU supports language learning for the following reasons:

To enable people to study and work abroad,

To enable people from different cultures to understand each other,

To successfully trade across Europe,

To support the linguistic industry (translation and interpretation, language learning, language technologies, etc.).

The Bologna Process places a great emphasis on improving the employability (The Bologna Declaration, 1999, London Communiqué, 2007). Moreover, LSP/ESP skills are expected of the recent graduates in their first employment. Preparing them for the task is often difficult because

\footnotetext{
${ }^{19}$ Platy.sk is the internet website where it is possible to gain comparison of salaries of more than six hundred work positions. The list of work positions reveals the work place market in the Slovak Republik and is being constantly updated.

${ }^{20}$ The company dealing with building materials.
} 
of many variables involved, such as the unpredictable nature of graduates' future work and languages, i.e. not only the language used at work (Lehtonen - Karjalainen, 2008).

\section{Conclusion}

The study is focused on the importance of mastering foreign languages by the Slovak university graduates at today's workplace market on the one hand as well as on the needs of companies searching for graduates that have a good command of foreign language skills. Current demands for foreign language competence are considered an important tool on the workplace market in Slovakia.

The aim of this study is to point to the importance of foreign language skills of the university graduates from their own point of view as well as from the point of view of the Slovak employers at the current labor market. Its purpose also was to determine the level of students' self-assessment of the knowledge of foreign languages and using this knowledge for the future employment. We have also used the company Profesia's data in order to be able to clarify particular language-related needs in the current Slovak companies.

The received results show that majority of students understand the importance of learning foreign languages for their future careers. The share of these students grows with an increase of the foreign language study period. However, the number of students able to speak foreign languages at the advanced and proficient levels, which is nowadays required for the labor market of the Nitra region, is at a significantly lower level than required. We have pointed to the need of mastering more foreign languages on the side of graduates, as Slovakia is the country situated in the center of Europe and the labor market has to be understood in a broader context within this multicultural and multilingual world.

\section{References}

[1] Aktuality.sk, 2009: Jazyky už nehýbu platom, treba ich na získanie zamestnania. https://www.aktuality.sk/clanok/143447/jazyky-uz-nehybu-platom-treba-ich-na-ziskanie-zamestnania/, (accessed 10 June 2019).

[2] Čiefová, M., \& Seresová, K., 2017: Teaching foreign languages at the University of Economics in Bratislava in connection to the needs of the labour market. Advanced Education, 8, 28-34. doi: 10.20535/24108286.94528

[3] Daily Mail, 2018: Dve tretiny Britov neovládajú žiadne cudzie jazyky https://www.topky.sk/cl/11/1291720/Dve-tretiny-Britov-neovladaju-ziadne-cudzie-jazyky, (accessed 7 June 2019).

[4] Eduworld.sk., 2018: Slovensko je na chvoste v znalostiach angličtiny spomedzi krajín V4, ukazujú výsledky prieskumu. Portál o vzdelávani a sebarozvoji. $\quad$ Vol. $36 \quad$ (3), pp. $492-$ 503, https://eduworld.sk/cd/ts/5342/slovensko-je-na-chvoste-v-znalostiach-anglictiny-spomedzi-krajin-v4ukazuju-vysledky-celosvetoveho-prieskumu, (accessed 3 June 2019).

[5] Europäische Union, 2019: EU Sprachen. https://europa.eu/european-union/about-eu/eu-languages_de, (accessed 7 June 2019).

[6] Fabo, B., Beblavý, M., \& Lenaerts, K. 2017: The importance of foreign language skills in the labour markets of Central and Eastern Europe: assessment based on data from online job portals. Empirica, 44(3), 487-508. doi: 10.1007/s10663-017-9374-6

[7] Habláková, M., 2009: Cudzí jazyk - výhoda či nutnost? Magazín Pravdy. https://zena.pravda.sk/ludia/clanok/270504-cudzi-jazyk-vyhoda-ci-nutnost/ (accessed 3 June 2019).

[8] Hall, A., 2008: Fremdsprachen im Beruf - Wer benötigt Fremdsprachenkenntnisse und auf welchem Niveau? In Fremdsprachen für die Wirtschaft. Institut für Bildungsforschung der Wirtschaft, Wien, pp. 223- 224. 
[9] Hlaváčová, Z., 2017: Vysokoškoláci zarábajú najviac, žiadaní sú na všetky pozície. Pravda XXVII/233. Vzdelávanie a kariéra, pp.15 - 17.

[10] Hlavné správy, 2018: Občania EÚ oceňujú znalost' cudzich jazykov, ale učit' sa im vel'mi nechce. Konzervatívny denník. https://www.hlavnespravy.sk/obcania-eu-ocenuju-znalost-cudzich-jazykov-ale-ucitsa-im-velmi-nechce/6625, (accessed 5 June 2018).

[11] HNonline, 2018: Chcete zarobit' viac? Učte sa cudzie jazyky. https://hnonline.sk/expert/1862127-chcetezarobit-viac-ucte-sa-cudzie-jazyky, (accessed 5 June 2019).

[12] Holaň, M., 2015: 5 dôvodov, prečo sa odmietame učit’ cudzie jazyky. https://www.letenkyzababku.sk/5dovodov-preco-sa-odmietame-ucit-cudzie-jazyky/, (accessed 17. November 2015).

[13] Hronová, Š. - Petr, J., O., 2017: Požadovaný profil absolventa na trhu práce imperativem pro kvalitní jazykové vzdělávaní na univerzitách. CASALC Review, 2017, Vol. 7(1), p. 65, ISSN 1804-9435.

[14] Lehtonen, T. - Karjalainen, S., 2008: University graduates' workplace language needs as perceived by employers. System 2008, Vol. 36 (3), pp. 492-503. https://doi.org/10.1016/j.system. 2008.01.003 (accessed 7 June 2019).

[15] Lingua jet, 2018: Welche Sprachen im Beruf wichtig sind und warum sie attraktiv machen. https://www.linguajet.de/blogs/news/sprachen-im-beruf, (accessed 11 June 2019).

[16] Gazzola, M., \& Mazzacani, D. 2019: Foreign language skills and employment status of European natives: evidence from Germany, Italy and Spain. Empirica, 46(4), 713-740. doi: 10.1007/s10663-019-09460-7

[17] Meyer, S., - Blondel, V., - Mall-Grob, B., 2017: Conversational interaction and the development of conversational competence in additional languages in higher education: Considerations for students, language centres, and language policy developers. Journal of the European Confederation of Language Centres in Higher Education (CercleS), Vol. 7(2), (accessed 7 June 2019).

[18] Moravcová, L., - Mad’arová, L', - Moroz, S., 2018: The Role of Foreign Languages for Career Growth Perspective of University Graduates in the Nitra Region. Proceedings of the International Scientific Days 2018 "Towards Productive, Sustainable and Resilient Global Agriculture and Food Systems", May 16-17 2018, Slovak University of Agriculture in Nitra, pp. 1978-1985.

[19] Tlačové správy, 2014: Znalost' viacerých cudzích jazykov je výhodou pri hl'adaní práce. http://www.teraz.sk/ekonomika/cudzie-jazyky-praca-absolventi/95725-clanok.html (accessed 25 August 2019).

[20] Tlačové správy, 2017: Kto boduje na trhu práce najviac? Toto je rebriček najžiadanejšich absolventov vysokých škôl, https://firma.profesia.sk/kto-boduje-na-trhu-prace-najviac-toto-je-rebricek-najziadanejsichabsolventov-vysokych-skol/, (accessed 10 June 2019). 


\title{
Evaluation of University Students' Mathematics Knowledge in Linear Algebra
}

\author{
Dana Országhová ${ }^{1}$, Mária Farkašová ${ }^{2}$, Norbert Kecskés ${ }^{3}$, Radomíra \\ Hornyák Gregáňová ${ }^{4}$ \\ Slovak University of Agriculture in Nitra \\ Faculty of Economics and Management, Department of Mathematics ${ }^{1,2,3,4}$ \\ Address: Tr. A. Hlinku 2 \\ Nitra, Slovakia \\ e-mail: dana.orszaghova@uniag.sk¹,maria.farkasova@uniag.sk², norbert.kecskes@uniag.sk², \\ radomira.greganova@uniag.sk ${ }^{4}$
}

doi: 10.18515/dBEM.ISD.P01.2020.p055

\begin{abstract}
Every knowledge based society needs a modern and effective system of higher education. Mathematical subjects in economic and technical study programs include linear algebra which provides tools for solving theoretical and practical problems. The main aim of the paper is to analyse the students' success rate in solving problems from linear algebra at the Faculty of Economics and Management, Slovak University of Agriculture in Nitra. We compared the results of examinations in compulsory mathematical subjects in the winter and summer semester in the first year of study at the above mentioned faculty. We used mathematical statistics to analyse the significance in differences in scores obtained by solving selected types of problems. The results of testing the hypotheses using the MannWhitney $U$ test showed that students are able to solve selected types of tasks from linear algebra at different level. The correctness of solution is based on the accuracy of numerical operations, so we also found the percentage success based on numerical errors made by students. In problems concerning linear combination of vectors, linear dependence and independence of vectors we found a numerical error rate of up to $62 \%$. Thus, if students master the problem solution method, it often happens that their success rate is reduced due to the lack of skills in computation with numbers.
\end{abstract}

Keywords: mathematical knowledge, linear algebra, knowledge evaluation, descriptive statistics, hypotheses testing

JEL Classification: I21, I23

\section{Introduction}

Modern and efficient system of higher education plays an important role in an open, creative, developing and knowledge-based society. Higher education is a process currently characterized by a knowledge triangle. It links higher education, research and business environment together in order to achieve excellence, faster regional development and its sustainability. Surveys show that Slovakia has an unfavourable situation in the structure of university students for research and development, since more than $50 \%$ of all students attend social and humanitarian studies. Students of natural and technical fields account for approximately $30 \%$ of all students. The total share of the population with completed university education makes $26.3 \%$ of the total population aged between 30 and 34 (Operational Program, 2014). For the needs of research and innovation in higher education, increasing emphasis should be placed on interconnection between quality education and excellent research, which is a prerequisite for technological innovation. That is why it is necessary to increase the number of creative people who will develop new technologies and products based on new ideas (Vokoun, 2015).

Evaluation of the quality of education is an important prerequisite for its further development and improvement. The quality of education is influenced by the input determinants of 
educational processes (i.e. characteristics of teachers and students, workplace profile, educational institution technical equipment, working atmosphere, etc.) as well as by the process of education itself, for which it is important to set goals, contents, forms and methods of educational activities (Turek, 2010; Průcha, 2009).

An important trend for changes in education is the information explosion through information technologies towards each member of the information society. It is necessary to process the provided information in a relevant way. Modern trends in education include the use of electronic learning materials and courses. Zábojníková (2013) presents the results of a survey carried out among the students of technical study programs on the benefits of a course in linear algebra related to the acquisition of new knowledge. Trigueros et al. (2013) report the results of teaching of linear algebra by means of applications of economic models. Many researches aim to analyse the conceptual and procedural access options to the content of mathematical subjects in engineering education (Engelbrecht, 2012) and various options for applying appropriate students' educational style (Pietriková et al., 2016). Mathematical methods and procedures in applied forms constitute a base for interconnection and development of professional knowledge in the areas of economic policy, state economics, business management, accounting, regional development etc. (Ferenczi Vaňová et al., 2015; Farkašová, 2016; Papcunová et al., 2017).

Linear algebra as a scientific discipline provides tools to express relationships between vectors and study vector spaces and linear mappings. Methods of linear algebra have applications in many areas of modern mathematics, which have theoretical and scientific character (Zlatoš, 2011) and are studied mainly at mathematical faculties. Vectors, matrices, determinants and systems of linear equations as basic parts of linear algebra are included in compulsory subjects of economic and technical study programs.

Table 1 shows an overview of topics in linear algebra taught at the Slovak University of Agriculture (SUA) in Nitra.

Table 1: Overview of topics in linear algebra in mathematics subjects

\begin{tabular}{|l|l|l|}
\hline Topic & Subject & Faculty \\
\hline $\begin{array}{l}\text { Linear dependence and } \\
\text { independence of vectors, } \\
\text { linear combination of vectors }\end{array}$ & Mathematics IB & $\begin{array}{l}\text { Faculty of Economics } \\
\text { and Management (FEM) }\end{array}$ \\
\hline \multirow{3}{*}{$\begin{array}{l}\text { Matrices, rank of a matrix, } \\
\text { inverse matrix }\end{array}$} & Mathematics IB & FEM \\
\cline { 2 - 3 } & Mathematics & $\begin{array}{l}\text { Faculty of European Studies } \\
\text { and regional development (FESRD) }\end{array}$ \\
\cline { 2 - 3 } & Mathematics & $\begin{array}{l}\text { Faculty of Biotechnology } \\
\text { and Food Sciences (FBFS) }\end{array}$ \\
\hline Determinant of a matrix & Mathematics IB & FEM \\
\hline \multirow{2}{*}{$\begin{array}{l}\text { Systems of linear equations } \\
\text { and methods of their solution }\end{array}$} & Mathematics IB & FEM \\
\cline { 2 - 3 } & Mathematics & FESRD \\
\cline { 2 - 3 } & Mathematics & FBFS \\
\hline
\end{tabular}

Source: authors

Software products with linear algebra computational capabilities facilitate the process of solution, but it is necessary to explain the meaning of computed values and their interpretation. The Department of Mathematics of the Faculty of Economics and Management (FEM) SUA in 
Nitra focuses on topics in linear algebra. Topics and tasks can also be found in the LMS Moodle electronic courses (Moodle SPU): "Linear Algebra" and "Practical Mathematics". These courses present the theoretical part of linear algebra, followed by illustrative examples with detailed solution and problems to solve. Tests with results were created for self-testing and verification of knowledge and through these courses students can also get the seminar work, which is a part of evaluation of acquired knowledge during the semester (Drábeková et al., 2019; Országhová et al., 2019).

\section{Data and Methods}

The aim of the paper is to analyse the test results in linear algebra in case of students of economy and management who are attending FEM SUA in Nitra. We focused on selected problems because mathematical apparatus and the methods of linear algebra are used in specialized subjects. Various optimization problems in economics are solved using linear equations, inequalities, systems of linear equations and inequalities.

The source material for the paper was the compulsory subject Mathematics IB, which is taught in the summer semester of the 1st year at the Faculty of Economics and Management of the Slovak University of Agriculture in Nitra. By means of descriptive statistics and statistical hypotheses testing we evaluated the success rate of students in solving selected problems from linear algebra. The research set for empirical research consisted of 80 students' test assignments in the Mathematics IB exam in the summer semester 2018/2019. In this dataset we evaluated the percentage of numerical errors in solution of the analysed problems by means of descriptive statistics.

Data set, created from scoring for individual mathematics tasks, do not meet the assumption of normal probability distribution. Therefore, we had to use a non-parametric test: the MannWhitney U test (Markechová a kol., 2011; Jurečková a kol., 2005). Using this test, we verify the validity of the hypothesis that the quantity $X$ corresponding to the scoring of the task "A" and the quantity $Y$ corresponding to the scoring of the task "B" have the same probability distribution.

Another set of data contained the final grades from the exams in both compulsory courses Mathematics IA (303) and Mathematics IB (289) in the academic year 2018/2019, which was graphically compared. We used MS Excel tools to process graphically the outputs.

\section{Results and Discussion}

This section presents the results obtained by data analysis of students' written tests and final grades in compulsory mathematics subjects.

\subsection{Evaluation of mathematics subjects exams in winter and summer semester}

Mathematical competences acquired during the study are important for economic and technical fields as well as for everyday life in today's society, which is characterized by the attribute "digital". Verbal communication and word problems formulation is during the solution process transformed into digital form by means of numbers and characters. It is therefore necessary to pay attention to the numeracy of students in mathematics teaching.

Linear algebra is included in the compulsory subject Mathematics IB at the Faculty of Economics and Management in the summer semester of the first year. In the academic year 2018/2019, 289 students took the exam in this subject. Grades were: A (1) 36 students, B (1.5), 32 students, C (2) 33 students, D (2.5) 60 students, E (3) 128 students, in total 289 (Fig. 1). The 
study average was: 2.37 . There were 363 students enrolled in the course, i.e. 74 students failed or did not participate in the exam.

Figure 1: Distribution of exam grades in the subject Mathematics IB 2018/2019

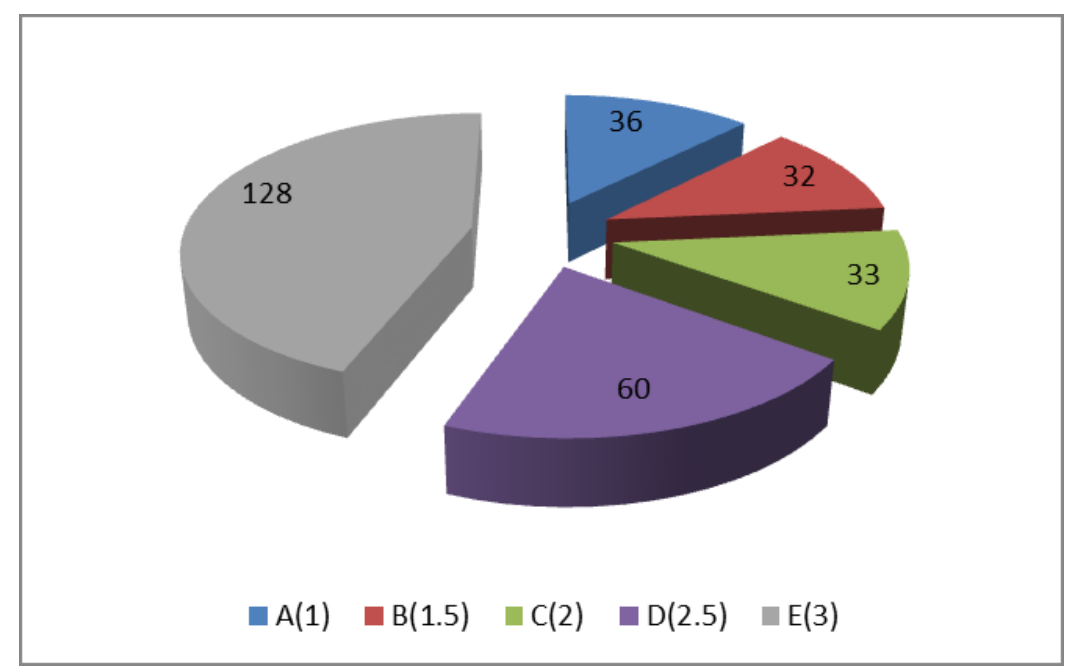

Source: authors

If we compare the results of the winter semester exam in compulsory subject Mathematics IA, in the academic year 2018/2019 303 students passed the exam: A (1) 36 students, B (1.5) 31 students, C (2) 55 students, D (2.5) 58 students, E (3) 123 students (Fig. 2). There were 347 active students enrolled in the course, i.e. 43 students failed or did not participate in the exam. The study average in the subject was 2.33 .

Figure 2: Distribution of exam grades in the subject Mathematics IA 2018/2019

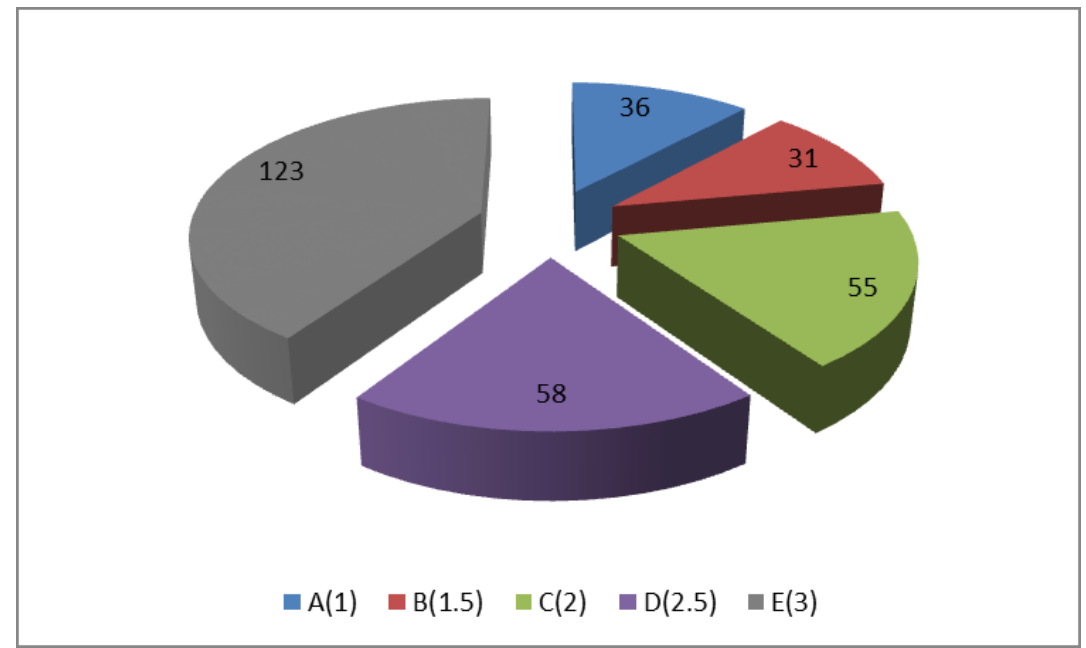

Source: authors

The trend of the study average in all subjects in the first year of the bachelor's degree study programs at the Faculty of Economics and Management of SUA is shown in Fig. 3. Within the period of 2009/2010 to 2017/2018 the achieved average grade gradually worsened. In the last year $2018 / 2019$ there was a small improvement in this study average by 0.01 . If we compare the average rating in both mathematics subjects in the first year of study (2.35), we see that it is better than the average rating in all subjects of the first year (2.69). The quality of study results in the first year of higher education is associated with the process of transition from secondary school to university and is also related to the level of knowledge of secondary school students. 
Figure 3: Achieved average grade at the faculty FEM in the $1^{\text {st }}$ year of study

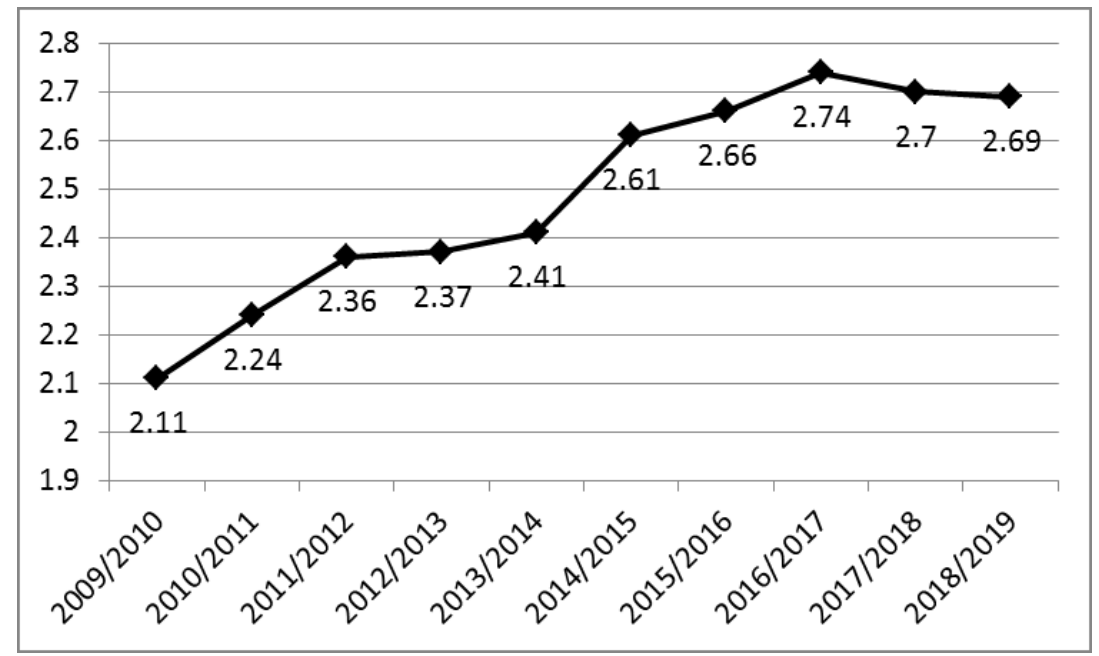

Source: Report (2019), authors' processing

\subsection{Examples of analysed problems from linear algebra}

The main topics taught in linear algebra are vectors, matrices, determinants and methods of solution of systems of linear equations. Solving problems from linear algebra lead to arithmetic operations with real numbers (elementary row operations, evaluation of determinants, equivalent operations applied to a system of linear equations). In addition to computational problems, the exam test also contains theoretical questions on this topic.

The following are examples of type problems in evaluated tests in the course Mathematics IB:

Task 1: Express vector $d=(-3,-1,3)$ as the linear combination of vectors $a=(-2,-1,2)$, $b=(6,3,-5), c=(11,5,-9)$. Solve the system of equations by the method of substitution.

Task 2: Find the inverse of the given matrix $C$ and verify the result, $C=\left(\begin{array}{ccc}2 & 3 & -2 \\ 1 & 2 & -1 \\ 3 & 8 & -4\end{array}\right)$

Task 3: Use the complete Gaussian elimination method to solve the homogeneous system of equations, justify the number of solutions by means of the Frobenius theorem and express the set of solutions:

$$
\begin{array}{r}
x_{1}+x_{2}-3 x_{3}-2 x_{4}=0 \\
x_{1}-x_{2}+5 x_{3}+4 x_{4}=0 \\
3 x_{1}+2 x_{2}-5 x_{3}-3 x_{4}=0 \\
4 x_{1}+3 x_{2}-8 x_{3}-5 x_{4}=0
\end{array}
$$

Task 4: Solve the system of linear equations by means of determinants

$$
\begin{aligned}
& 2 x_{1}+x_{2}-2 x_{3}=0 \\
& 4 x_{1}+3 x_{2}-5 x_{3}=4 \\
& 6 x_{1}+3 x_{2}-7 x_{3}=-4
\end{aligned}
$$


Theoretical questions: definition of a linear combination of vectors, linear dependence and linear independence of vectors, elementary row operations, matrix operations, inverse matrix definition, properties of determinants, systems of linear equations, Frobenius theorem and its consequence, Cramer's rule.

\subsection{Evaluation of students' success rate in solving problems from linear algebra}

The research set consisted of 80 students' tests in the subject Mathematics IB in the academic year 2018/2019. The correct solution of each task was evaluated by the maximum number of 5 points. We divided the problems into 4 groups as follows: the "linear combination" group contained problems in which it was necessary to find a linear combination of vectors or to evaluate linear dependence and independence of given vectors ( 80 evaluated tasks). The "inverse matrix" group consisted of problems of inverse matrix computation (30 evaluated tasks). The "elimination method" group covered problems of solving a system of linear equations by an elimination method, where the system could be either homogeneous or nonhomogeneous (number of evaluated tasks 80 ). The group "determinants" included solution of systems of linear equations by means of determinants ( 50 evaluated tasks).

The solution of the problem depends on the correctness of numerical computation; therefore, we were also interested in evaluating the solutions of the problems from this point of view. Fig. 4 shows the percentage evaluation of numerical errors in each type of problem. We see that the "linear combination" type of problem has the highest percentage of numerical errors $(62 \%)$.

Figure 4: Percentage evaluation of numerical errors in each type of problem

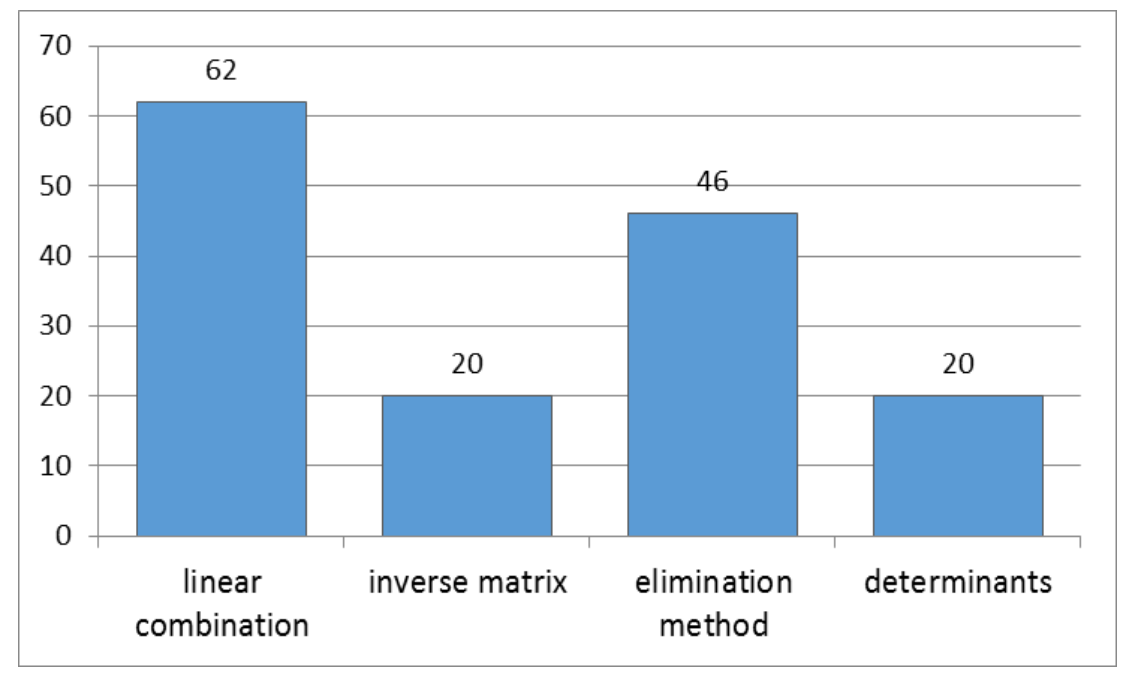

Source: authors

Within the same set of problems we found out that the assumption of normal probability distribution was not met. Therefore, we applied the Mann-Whitney $U$ test to verify the number of times a score from one sample (denoted "A") is ranked higher than a score from another sample (denoted "B"). Obtained test results at the preselected significance level alpha $=0.05$ are shown in Tab. 2. 
Table 2: Results of Mann-Whitney U test $(\alpha=0.05)$

\begin{tabular}{c|c|c|c}
\hline Sample "A" & Sample "B" & $p$-value & Result \\
\hline linear combination & elimination method & 0.00014 & $\mathrm{H}_{0}$ rejected \\
\hline linear combination & inverse matrix & 0.00010 & $\mathrm{H}_{0}$ rejected \\
\hline linear combination & determinants & 0.00000 & $\mathrm{H}_{0}$ rejected \\
\hline elimination method & inverse matrix & 0.05664 & $\mathrm{H}_{0}$ accepted \\
\hline elimination method & determinants & 0.00439 & $\mathrm{H}_{0}$ rejected \\
\hline inverse matrix & determinants & 0.88680 & $\mathrm{H}_{0}$ accepted \\
\hline
\end{tabular}

Source: authors

Based on the results of the Mann-Whitney U test, we can conclude that the analysed sample of students shows differences in the scoring obtained for the procedure and correctness of solving individual tasks from linear algebra (in four cases out of six). We have positive results in two cases, $\alpha=0.05$. First result: the randomly selected value from the sample "inverse matrix" is considered to be equal to the randomly selected value from the sample "determinants". Second one: the randomly selected value from the sample "inverse matrix" is considered to be equal to the randomly selected value from the sample "elimination method".

If we rank the analysed tasks according to the average score, we find that students solved best the problem of "determinants", followed by the tasks "inverse matrix" and "elimination method", and they worst solved the problem of "linear combination". Thus, individual problems are not equally demanding for students, although the method of solution is based on numerical operations with real numbers.

\subsection{Discussion}

Linear algebra is an important topic at economical and technical faculties. The aim of pedagogical experiments and research studies is to determine the level of knowledge of students in relation to methods and forms of study. Zábojníková (2013) claims that the knowledge of linear algebra is often reduced to mechanically learned methods and procedures that are sufficient for students to earn the required number of points in a credit or exam test. From the teaching process we know that students are able to understand and learn the methods and procedures of linear algebra, but solutions to problems are often numerically wrong. This originates from insufficient mathematical skills of primary, secondary and university students with real numbers, especially fractions and number sets, as confirmed by Hricišáková and Tomanová (2008). Results of the research showed (Drábeková et al., 2018) that there is a correlation between the number of earned points for solving a mathematical problem and the type of attended secondary school.

The presented analysis of study results confirmed that many students get an $E(3)$ rating for the exam and the average grade in the first year of study at the faculty FEM also approaches the same value. It is logical that the effort to improve teaching of mathematics subjects at the university depends on the quality of knowledge of students from previous studies and their motivation to acquire new knowledge.

\section{Conclusion}

In the paper we analysed the level of university students' knowledge and skills in solving problems from linear algebra. The results of Mann-Whitney U test showed that in terms of earned points students mastered solving the above-mentioned types of tasks from linear algebra at different levels. In linear algebra understanding of mathematical method does not guarantee 
the correctness of a solution which is based on numerical operations with real numbers. These facts originate from reducing the number of mathematics lessons in elementary and secondary schools, where pupils/students do not have enough lessons to acquire skills for consistency and precision in mathematical computations.

Despite the need for mathematical knowledge in technological development and innovation, teaching of mathematics subjects in the education system is being gradually reduced. This is subsequently reflected in the lack of skills and knowledge of students who do not have a good inclination to studying and solving mathematical problems. Students' results in mathematics examinations belong to indicators of the quality of higher education. In order to create permanent knowledge of students, it is necessary to pay attention to appropriate choice of problems and allow sufficient time to practice and memorize this knowledge. Research results show that students' achievements (knowledge, skills, and exams) are at a lower level than in the past. Improvement of this situation is not easy due to the current volume of mathematics teaching.

\section{Acknowledgements}

The paper was financially supported by the project grant KEGA 029SPU-4/2018: Digital educational applications in mathematics.

\section{References}

[1] Drábeková, J., \& Országhová, D. (2019). The role of Moodle quiz in math education. In ICERI 2019, 12th annual International Conference of Education, Research and Innovation. Seville, Spain: IATED, pp. $3743-$ 3748.

[2] Drábeková, J., Pechočiak, T., \& Matušek, V. (2018). Mathematical competencies of students entering university studies. Case study of Slovakia. Mathematics in Education, Research and Applications, 4(1), pp. 23-30. Doi: https://doi.org/10.15414/meraa.2018.04.01.23-30.

[3] Engelbrecht, J., Bergsten, C., \& Kågesten, O. (2012). Conceptual and procedural approaches to mathematics in the engineering curriculum: Student conceptions and performance. Journal of Engineering Education, 101(1), 138-162.

[4] Farkašová, M. (2016). Metódy štatistického riadenia kvality. In Quo Vadis matematické vzdelávanie? Nitra: Katedra matematiky FEM SPU, pp. 9. Retrieved December 10, 2019, from http://www.fem.uniag.sk/tl_files/fem/documents/Fakulta/Pracoviska/Katedra\%20matematiky\%20\%20dokumenty/SuborAbstraktov_final_KM.pdf.

[5] Ferenczi Vaňová, A., Krajčírová, R., Váryová, I., \& Košovská, I. (2015). Depreciation influence of fixed assets on accounting result and corporate income tax base pursuant accounting and tax legislation in the Slovak Republic. In Finance and Performance of Firms in Science, Education and Practice: The 7th International Scientific Conference. Proceedings. Tomas Bata University in Zlín, pp. 287-296.

[6] Hricišáková, D., \& Tomanová, M. (2008). Matematická gramotnost’ a jej význam pri výučbe na technických fakultách. In Sborník př́spěvku z 30. konference o matematice na VŠTEZ, pp. 71-76. Jednota českých matematiků a fyziků Praha.

[7] Jurečková, M., \& Molnárová, I. (2005). Štatistika s Excelom. AOS, Liptovský Mikuláš. 234 s.

[8] Markechová, D., Stehlíková, B., \& Tirpáková, A. (2011). Štatistické metódy a ich aplikácie. Nitra: Univerzita Konštantína Filozofa. 534 s.

[9] Moodle SPU. Fakulta ekonomiky a manažmentu SPU v Nitre. Retrieved December 10, 2019, from https://moodle.uniag.sk/course/index.php?categoryid=36.

[10] Operational Program Research and Innovation, 2014 - 2020 (Operačný program Výskum a inovácie, 2014 - 2020). Retrieved December 10, 2019, from http://hsr.rokovania.sk/data/att/144294_subor.doc

[11] Országhová, D., Farkašová, M., Hornyák Gregáňová, R., Pechočiak, T., Matušek, V., Kecskés, N., \& Drábeková, J. (2019). Matematika s aplikáciami. 1. vyd. Nitra: Slovenská pol'nohospodárska univerzita. 209 s. 
[12] Papcunová, V., \& Balážová, E. (2017). Rating of the property of the contributory organizations within the competence of municipalities in the Slovak Republic. 20th international colloquium on regional sciences. Proceedings Paper, pp. 862-868. DOI: 10.5817/CZ.MUNI.P210-8587-2017-113.

[13] Pietriková, M., Hornyák Gregán̆ová, R., \& Orlíková, M. (2016). Preferences in students' educational styles. Mathematics in Education, Research and Applications, 2(2), 54-60. Doi: http://dx.doi.org/10.15414/meraa.2016.02.02.54-60.

[14] Průcha, J. (2009). Modern Educational Science. 4th ed. Prague, Czech Republic: Portál, 488 p. (in Czech).

[15] Report on the results of educational activities in the academic year 2018/2019 (Správa o výsledkoch výchovno-vzdelávacej činnosti v akademickom roku 2018/2019). (2019). Fakulta ekonomiky a manažmentu SPU v Nitre (in Slovak).

[16] Trigueros, M., \& Possani, E. (2013). Using an economics model for teaching linear algebra. Linear Algebra and Its Applications, 438(4), 1779-1792. doi:10.1016/j.laa.2011.04.009.

[17] Turek, I. (2010). Didactics. Bratislava: Iura Edition, 598 p. (in Slovak).

[18] Vokoun, J. (2015). The development of the knowledge society potential. Finančná stabilita a udržatel'ný rast v Európskej únii: súčasný stav a perspektívy: zborník príspevkov z medzinárodnej vedeckej konferencie. Banská Bystrica. $\quad$ Retrieved December $10, \quad 2019$, from http://www.ef.umb.sk/konferencie/kfu_2015/prispevky\%20a\%20prezentacie/Sekcie/Vokoun.pdf.

[19] Zábojníková, E. (2013). E-learningový kurz lineárnej algebry pre inžinierske štúdium matematiky. Bratislava, FMFI (Doctoral dissertation) (in Slovak).

[20] Zlatoš, P. (2011). Lineárna algebra a geometria. Martinus, Bratislava, 744 s. (in Slovak). 


\title{
Trends of Number Newly Admitted University Students in the Slovak Republic
}

\author{
Tomáš Pechočiak ${ }^{1}$, Janka Drábeková ${ }^{2}$ \\ Slovak University of Agriculture in Nitra \\ Faculty of Economics and Management, Department of Mathematics ${ }^{1,2}$ \\ Address: Tr. A. Hlinku 2, \\ 949476 Nitra, Slovak republic \\ e-mail: tomas.pechociak@uniag.sk ${ }^{1}$, janka.drabekova@uniag.sk ${ }^{2}$
}

doi: 10.18515/dBEM.ISD.P01.2020.p056

\begin{abstract}
Education is identified as an important determinant of economic growth because higher levels of educational attainment lead to a more skilled and productive workforce, producing more efficiently a higher standard of goods and services, which in turn forms the basis for faster economic growth and rising living standards. In the present time, we have 35 universities with 116 faculties and approximately 137,000 students in tertiary education in Slovak Republic. In our paper we decided to examine trends of number of newly admitted students to these universities from 2009 to 2018. For research we used data from the Slovak Center of Scientific and Technical Information, the Statistical Office of the Slovak Republic and the Statistical Office of the European Union. We calculated basic characteristics of time series and analyzed the trend in researched time series using suitable regression function. The results of our work show, despite the slight growth of the population of Slovakia in the period from 2009 to 2018, the number of abiturients and thus also the number of enrolled university students has decreased trend. Nevertheless, that the numbers of newly admitted students to universities were decreasing during 2009-2018, graduates in tertiary education as percentage of the economically active population (aged 15-64) in Slovakia had increasing trend.
\end{abstract}

Keywords: students, tertiary education, population

JEL Classification: C20, I23, J10

\section{Introduction}

Investments in human capital, including education, skills upgrading, the development of education and science, are nowadays a significant prerequisite for the further development of society and its economic growth (Országhová et al., 2018). Education is one of the most important factor of reaching prosperous socio-economic environment of country.

According to research results published by Kozáková (2018) the successful entrepreneurs recommends teaching with the focus on the practice and giving advices. Universities should provide not only theoretical framework for future career our students but also some practical experiences and students should realize, that they will really need information and knowledge they receive at university and get rid of own illusions. The Tertiary Education System should reflect requirements employers that graduates with acquired knowledge, skills and attitudes have been beneficial in the current labour market (Országhová et al., 2018). There is great overlap between the jobs, skills and rewards of the graduate and non-graduate labour market. Skills development enhances both people's capacities to work and their opportunities at work, offering more scope for creativity and satisfaction at work. Policymakers has argued as well as assumed that the share of degree holders within the workforce is a direct measure of national competitiveness and economic strength within the global era (Tholen, 2014). However, if the structure of graduates does not meet the expectations and needs of the labour market the growth of the number of university graduates won't produce the desired effect. 
Available evidence firmly establishes that a combination of good education with training that is of good quality and is relevant to the labour market (ILO publication, 2011), because:

- empowers people to develop their full capacities and to seize employment and social opportunities,

- raises productivity, both of workers and of enterprises,

- contributes to boosting future innovation and development,

- encourages both domestic and foreign investment, and thus job growth, lowering unemployment and underemployment,

- leads to higher wages,

- when broadly accessible, expands labour market opportunities and reduces social inequalities.

According International Labour Organization (2011) the world population is marked by declining fertility and rising life expectancy. The primary consequence of both trends is population ageing. These trends have three major implications for education, skills and training (ILO publication, 2011):

1) First, economic growth will depend even more heavily than today on the productivity of the workforce, complemented by rising labour force participation rates, especially among women and older workers. The challenge of lifelong learning, particularly among ageing but economically active persons, will increase in salience correspondingly.

2) Second, in several regions the growing size of the youth cohort will continue to challenge both education and training capacities and job creation rates as more young people enter the world of work. Everywhere, young people with low skill levels are finding it hard to secure jobs.

3) Third, international flows of migrant workers will continue to grow, raising challenges concerning fair access to training and how to fill skill gaps in some countries without creating them in others.

Education at a Glance 2019, which is part of the Organisation's "I am the Future of Work" campaign, finds that $44 \%$ of $25-34$ year-olds held a tertiary degree in 2018 , compared to $35 \%$ in 2008 , on average across OECD countries. The employment rate of tertiary-educated adults is 9 percentage points higher than for those with upper secondary education and they earn $57 \%$ more (OECD, 2019). Demand for tertiary education continues to rise, but its further expansion will only be sustainable if it matches the supply of graduates with labour market and social needs and gives them the skills required to navigate the future (OECD, 2019).

\section{Data and Methods}

The presented data were obtained from the website of the Statistical Office of the Slovak Republic (www.statistics.sk), the Slovak Centre of Scientific and Technical Information (www.cvtisr.sk) and the Statistical Office of the European Union (ec.europa.eu/eurostat). We followed the time series of the numbers of study applicants of Slovak Universities, the numbers of admitted students and enrolled students in tertiary education in Slovakia, the numbers of admitted students planned Slovak Universities, 19 years old population and population of abiturients of Slovakia from 2009 to 2018 (Table 1, Table 3). We calculated basic characteristics of time series (first differences - absolute decline, relative rate of growth coefficient of growth, coefficient of increase, growth rate, increase rate). We analyzed the trend in researched time series using suitable regression function. We used index of determination as a criterion in deciding about the shape of the regression function. Software SAS and Excel were used to achieve results. 
Table 1: The number of students and applicants for university education in Slovakia

\begin{tabular}{|c|c|c|c|c|c|}
\hline Year & Study form & Universities Plan & Study Applicants & $\begin{array}{l}\text { Admitted } \\
\text { Students }\end{array}$ & $\begin{array}{l}\text { Enrolled } \\
\text { Students }\end{array}$ \\
\hline \multirow{3}{*}{2009} & Full-time & 47111 & 54027 & 42038 & 37734 \\
\hline & Part-time & 18306 & 24701 & 19635 & 15833 \\
\hline & Total & 65417 & 78728 & 61673 & 53567 \\
\hline \multirow{3}{*}{2010} & Full-time & 41293 & 52691 & 37864 & 33954 \\
\hline & Part-time & 18226 & 23468 & 19013 & 15328 \\
\hline & Total & 59519 & 76159 & 56877 & 49282 \\
\hline \multirow{3}{*}{2011} & Full-time & 43617 & 51771 & 39330 & 35581 \\
\hline & Part-time & 16727 & 18132 & 16256 & 13057 \\
\hline & Total & 60344 & 69903 & 55586 & 48638 \\
\hline \multirow{3}{*}{2012} & Full-time & 44936 & 48080 & 38790 & 34819 \\
\hline & Part-time & 15948 & 13892 & 12406 & 9739 \\
\hline & Total & 60884 & 61972 & 51196 & 44558 \\
\hline \multirow{3}{*}{2013} & Full-time & 46114 & 44955 & 37055 & 33523 \\
\hline & Part-time & 15945 & 10907 & 10321 & 8159 \\
\hline & Total & 62059 & 55862 & 47376 & 41682 \\
\hline \multirow{3}{*}{2014} & Full-time & 44196 & 40148 & 34091 & 30730 \\
\hline & Part-time & 14443 & 9808 & 9022 & 7265 \\
\hline & Total & 58639 & 49956 & 43113 & 37995 \\
\hline \multirow{3}{*}{2015} & Full-time & 42123 & 37349 & 32129 & 28703 \\
\hline & Part-time & 12743 & 9093 & 8258 & 6715 \\
\hline & Total & 54866 & 46442 & 40387 & 35418 \\
\hline \multirow{3}{*}{2016} & Full-time & 40242 & 34563 & 29982 & 26694 \\
\hline & Part-time & 12954 & 7691 & 7088 & 5638 \\
\hline & Total & 53196 & 42254 & 37070 & 32332 \\
\hline \multirow{3}{*}{2017} & Full-time & 39278 & 31798 & 28086 & 25307 \\
\hline & Part-time & 10952 & 6385 & 5923 & 4602 \\
\hline & Total & 50230 & 38183 & 34009 & 29909 \\
\hline \multirow{3}{*}{2018} & Full-time & 40503 & 33474 & 29743 & 26540 \\
\hline & Part-time & 11160 & 6053 & 5730 & 4482 \\
\hline & Total & 51663 & 39527 & 35473 & 31022 \\
\hline
\end{tabular}

Source: SCSTI

\section{Results and Discussion}

At the present time approximately $2.5 \%$ of the total population Slovak Republic (SR) study at Universities. In the academic year 2018/2019, there were 35 universities in Slovakia with 4380 study programs. We decided to examine the development trends of the number of newly admitted university students in Slovakia over the "last" decade, from 2009 to 2018. We were inspired by the papers of Antalíková (2019) and Kollár (2019).

Table 1 shows the planned number of newly admitted students, number of enrolled students, admitted students and study applicants for the years 2009 to 2018 in SR. Trend of number enrolled student in both type of study is evident in data of table 1 and illustrated in figure 1 . We can see that since 2009 there has been a steady decrease in the number of all enrolled students, only in the last observed year, 2018 was identified a slight increase.

According calculated basic characteristics of time series we can say that in 2010 compared to 2009 decreased number of enrolled university full-time students by 10\%. In 2011 the number of this students increased, but then in the next seven years we can see once again decline (see Table 1, Figure 1). For external students (Table 2), there is a year-on-year decline in the number of students throughout the period under review. The greatest decrease was recorded in 2012, when was introduced fee for part-time study in Slovakia. Another significant decrease occurred 
in 2016 and 2017, when the length of this form of study was extended from 3 years to 4 years at Bachelor's level and from 2 years to 3 years at Master's level. The opposite trend was detected in UK. Although part-time student numbers were decline overall over the period 2013/14 - 2017/18, but first year enrolments onto part-time first degree courses have increased between 2016/17 and 2017/18 (SB252, 2019). In the UK was also recorded a high proportion of foreign students. In 2017, a total of 436000 students from abroad ( $25.5 \%$ of the total number of students from abroad in the EU-28) were studying in the United Kingdom, far more than the number in any other EU Member State (Eurostat, 2019b).

Figure 1: The number of enrolled students in full-time and part-time form study

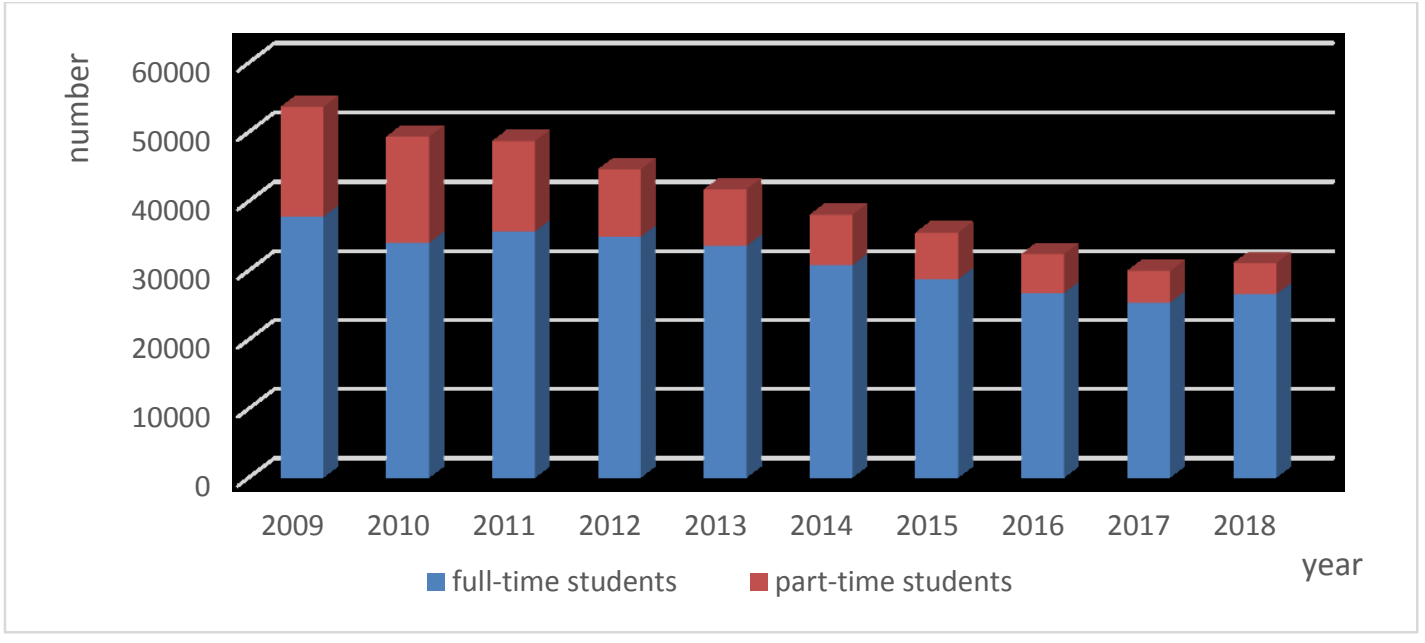

Source: SCSTI, own

Table 2: Some basic characteristics of time series enrolled part-time students

\begin{tabular}{|c|c|c|c|c|}
\hline Year & Enrolled Students & Absolute Decline & Growth Rate & Decline Rate \\
\hline 2009 & 15833 & & & \\
\hline 2010 & 15328 & -505 & 96.81 & -3.19 \\
\hline 2011 & 13057 & -2271 & 85.18 & -14.82 \\
\hline 2012 & 9739 & -3318 & 74.59 & -25.41 \\
\hline 2013 & 8159 & -1580 & 83.78 & -16.22 \\
\hline 2014 & 7265 & -894 & 89.04 & -10.96 \\
\hline 2015 & 6715 & -550 & 92.43 & -7.57 \\
\hline 2016 & 5638 & -1077 & 83.96 & -16.04 \\
\hline 2017 & 4602 & -1036 & 81.62 & -18.38 \\
\hline 2018 & 4482 & -120 & 97.39 & -2.61 \\
\hline
\end{tabular}

Source: SCSTI, own

The number of tertiary education students has been decreasing in recent years also in Slovenia. According to a Slovenia Statistical Office report, there were 75991 students enrolled in tertiary education in 2018/19 in Slovenia and it was 0.7\% less than the year before and the ninth consecutive year in a row that saw a decline in number of students enrolled in higher education. Currently $34.2 \%$ fewer students are enrolled in higher education than ten years ago, when there were 115445 university students studying in Slovenia (Sever, 2019).

The opposite upward trend in student numbers was observed for example in Morocco. In 2017, about 1.01 million students were enrolled in tertiary education in Morocco. This is a significant increase from 2000, when only 295634 students were enrolled in tertiary education programs in Morocco (Duffin, 2020).

Graphic interpretation of total number enrolled students and study applicants together with universities plan in the Slovak Republic for 2009 to 2018 is shown on figure 2. Negative 
regression coefficient indicates a downward trend in the observed time series. Figure 2 shows, that suggested number of admitted students which Slovak Universities planned, is greater than number of study applicants since 2013. The number of actually enrolled students is much lower than the universities plan throughout all the reporting period. Slovak Universities are planning a much larger number of admitted students as it is reasonably possible (see Figure 3, Table 3). Probably they do not follow demographic processes and continuous decline of arbiturients.

Figure 2: Total number of enrolled students, study applicants and projected number of students of Slovak Universities for 2009 to 2018

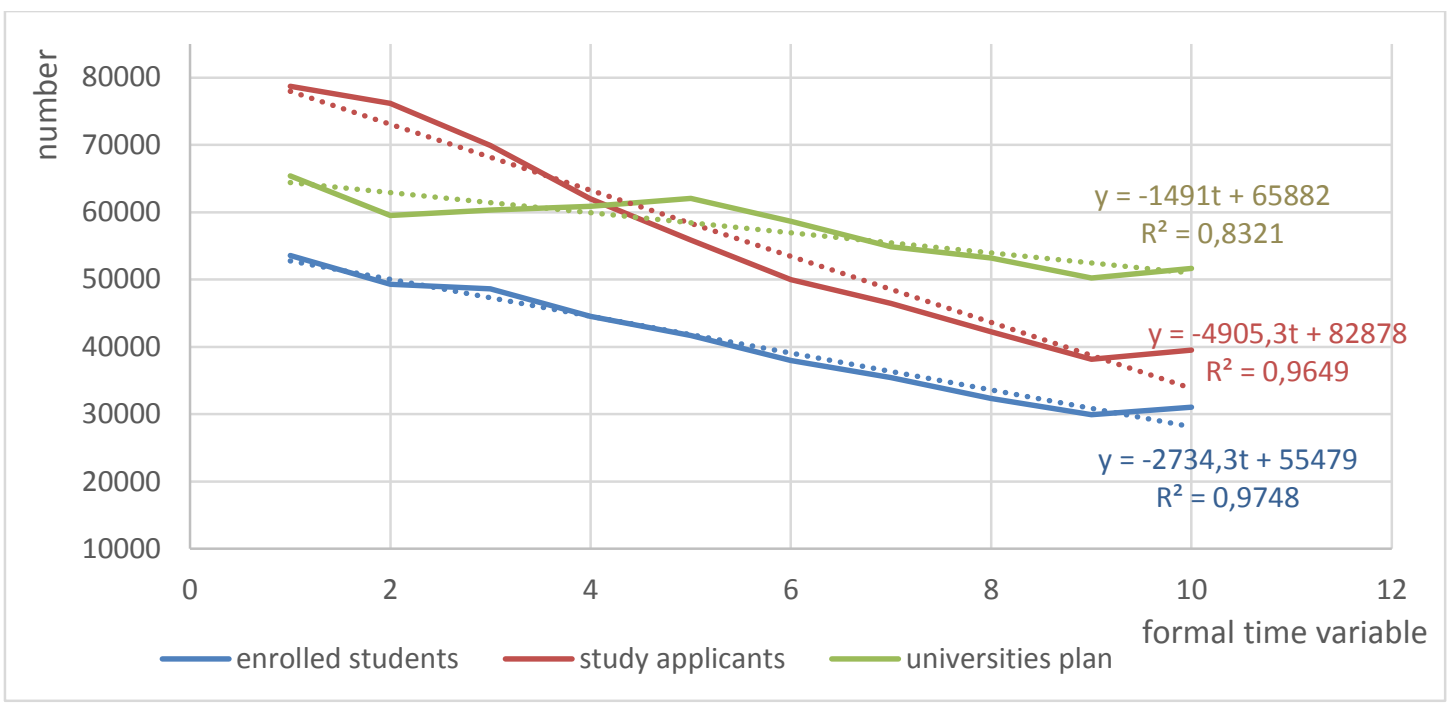

Source: SCSTI, own

Figure 3: The number of enrolled students in full-time form study, population of 19-year-olds and abituriants in the Slovak Republic in 2009 - 2018

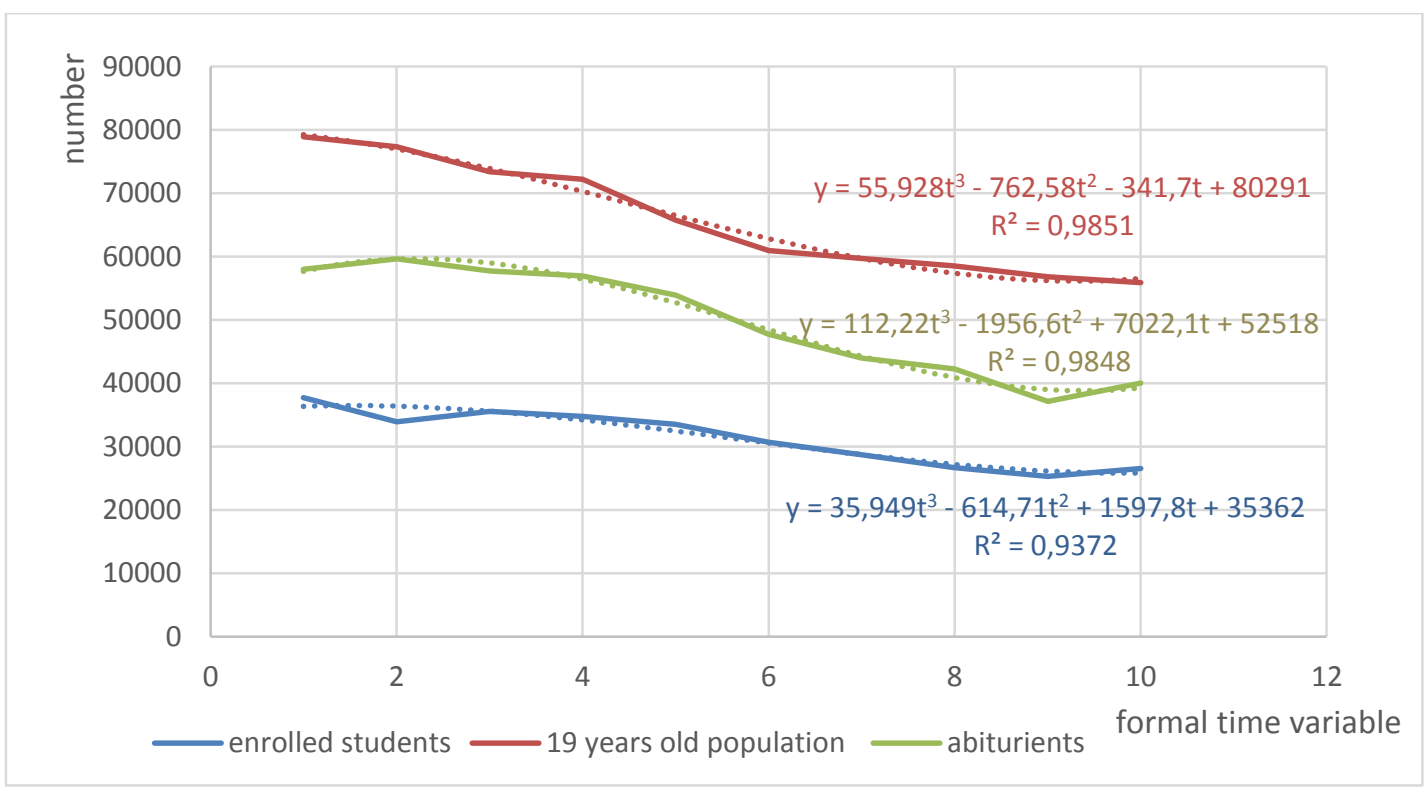

Source: SCSTI, SOSR, own

Table 3 shows selected demographic data of Slovakia and calculated relative rates. Based on data we can say that relative measures P1 and P2 are constantly decreasing. It means that 19year-olds and abiturients generate regularly lower percentage of the total population of the Slovak Republic during the reporting period. Approximately $75 \%$ of the 19 -year-olds 
population are the abiturients. In $2013,82 \%$ of 19 -year-olds population was formed abiturients, but in 2017 only $65 \%$. The enrolled students in the first year of the university is roughly twothirds of Slovak abiturients.

Table 3: Selected demographic data of the inhabitants SR

\begin{tabular}{|c|c|c|c|c|c|c|c|}
\hline Year & Population (total) & $\begin{array}{c}\text { 19 years old } \\
\text { population }\end{array}$ & Abiturients & P1 & P2 & P3 & P4 \\
\hline 2009 & 5418374 & 78911 & 57997 & 1.46 & 1.07 & 73.50 & 65.06 \\
\hline 2010 & 5431024 & 77385 & 59644 & 1.42 & 1.10 & 77.07 & 56.93 \\
\hline 2011 & 5398384 & 73411 & 57735 & 1.36 & 1.07 & 78.65 & 61.63 \\
\hline 2012 & 5407579 & 72240 & 56977 & 1.34 & 1.05 & 78.87 & 61.11 \\
\hline 2013 & 5413392 & 65797 & 53908 & 1.22 & 1.00 & 81.93 & 62.19 \\
\hline 2014 & 5418649 & 60991 & 47780 & 1.13 & 0.88 & 78.34 & 64.32 \\
\hline 2015 & 5423800 & 59712 & 43991 & 1.10 & 0.81 & 73.67 & 65.25 \\
\hline 2016 & 5430797 & 58544 & 42291 & 1.08 & 0.78 & 72.24 & 63.12 \\
\hline 2017 & 5439231 & 56814 & 37172 & 1.04 & 0.68 & 65.43 & 68.08 \\
\hline 2018 & 5446770 & 55900 & 40055 & 1.03 & 0.74 & 71.65 & 66.26 \\
\hline
\end{tabular}

P1 - 19-year-olds as \% of the total population of the Slovak Republic, P2 - abiturients as \% of the total population of the Slovak Republic, P3 - abiturients as \% of the 19-year-olds population, P4 - enrolled students as \% of abiturients, Source: SCSTI, SOSR, own

Despite the decreasing number of newly admitted students to universities, $\%$ of the population aged 15-64 years with tertiary level of education in Slovakia is increasing. While in 2009 only $13.4 \%$ of the economically active population had a university degree, in 2018 it was up to $22 \%$ (SOSR, 2020).

Figure 4: Tertiary educational attainment, by country (\% of the population aged 30-34)

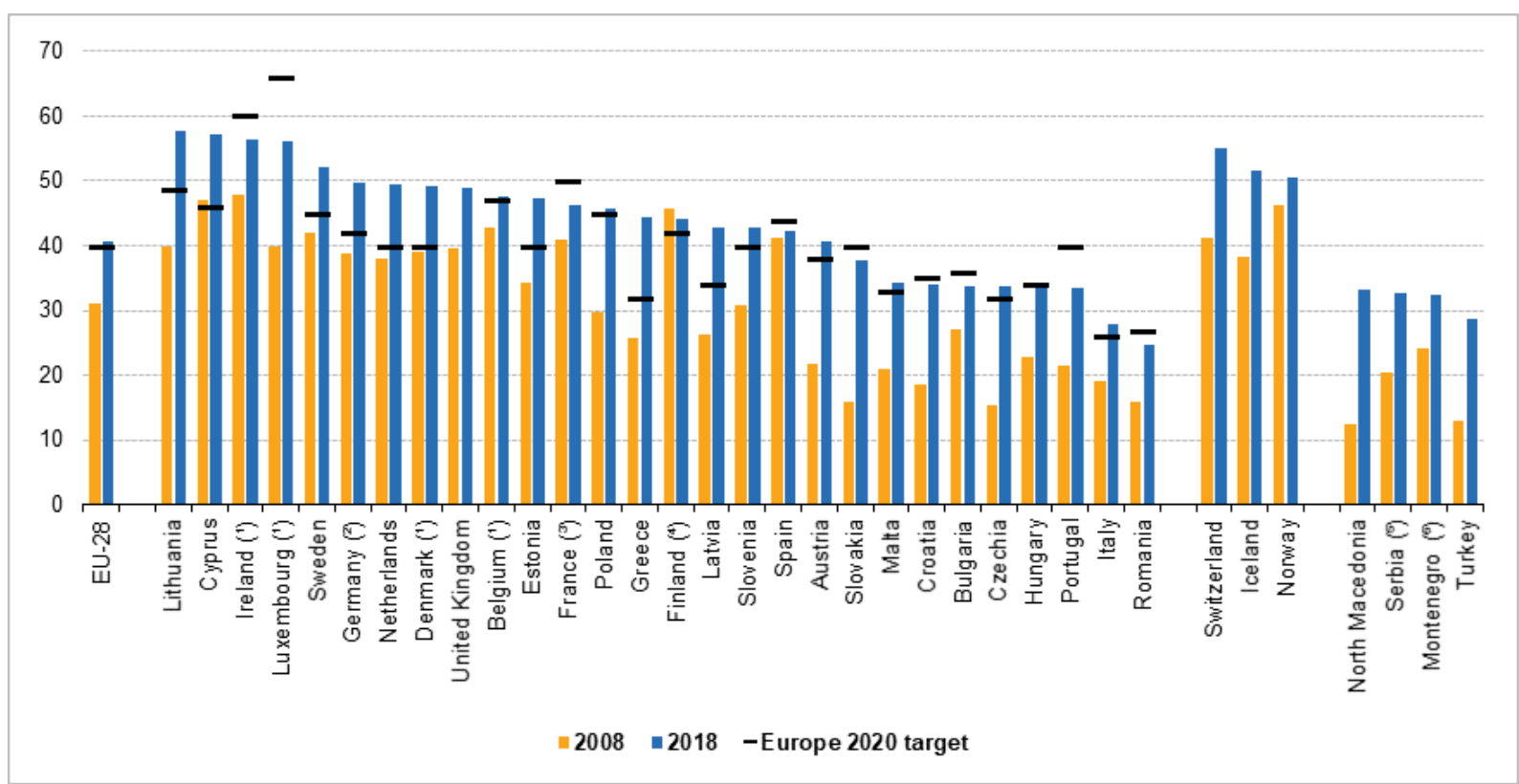

Source: Eurostat (2019a)

Tertiary education provided by universities and other higher education institutions, such as colleges and institutes of technology - plays a key role in knowledge-based societies therefore Europe 2020 target has been set by policymakers, namely, that by 2020 at least $40 \%$ of the population aged 30-34 years should have a tertiary level of education (Eurostat, 2019a). This target was transposed into national targets to reflect the specific situations of each EU Member State. In five EU Member States, at least half of those aged 30-34 had a tertiary level of education, with the highest shares in Lithuania (58\%), Cyprus (56\%) and Ireland (55\%). In contrast, the lowest proportions of those having a completed tertiary education were recorded 
in Romania (26\%), Italy (27\%) and Croatia (29\%) (see Figure 4). Compared with 2008, the share of people aged 30-34 years in the EU-28 with a tertiary level of educational attainment was 8.0 points higher in 2016. Spain was the only EU Member State to record a fall in its share, while the biggest increases - within the range of 15.0-19.0 points - were seen in Lithuania, Austria, the Czech Republic, Greece, Latvia and Slovakia (Eurostat, 2019a).

\section{Conclusion}

The results of our work show, that since 2009 there has been a steady decrease in the number of all enrolled students, only in the last observed year, 2018 was identified a slight increase. Negative regression coefficient indicates a downward trend in the observed time series. According calculated basic characteristics of time series we can say that the greatest decrease was recorded in 2012, when was introduced fee for part-time study in Slovakia. Another significant decrease occurred in 2016 and 2017, when the length of this form of study was extended. The number of actually enrolled students is much lower than the universities plan throughout all the reporting period. Slovak Universities are planning a much larger number of admitted students as it is reasonably possible. Despite the decreasing number of newly admitted students to universities, \% of the population aged 15-64 years with tertiary level of education in Slovakia is increasing. Slovakia belong to developing economies which have indeed expanded their tertiary educated workforce but, equally importantly, have created infrastructure and adopted policies and initiatives that make the expansion part of their national economic development. Because the expansion of graduates in the labour market does not necessarily lead to increased productivity, innovation or increased incomes.

\section{References}

[1] Antalíková, Š. (2019). Admission Procedure for Slovak Universities. Release of 2018 data over a 10-year period. ACADEMIA 3/2019, 4-17. Retrieved from https://www.cvtisr.sk/buxus/docs//ACADEMIA/ 2019/3_2019_academia.pdf

[2] Duffin, E. (2020). Number of students enrolled in tertiary education in Marocco 2000-2017. Statista publication. Retrieved from https://www.statista.com/statistics/645158/number-students-enrolled-tertiaryeducation-morocco/

[3] Eurostat (2019a). Europe 2020 indicators - education. Statistical article, ISSN 2443-8219. Retrieved from https://ec.europa.eu/eurostat/statisticsexplained/index.php/Europe_2020 indicators_education\#Increasing attainment_at_tertiary_level

[4] Eurostat (2019b). Learning mobility statistics. Statistical article, ISSN 2443-8219. Retrieved from https://ec.europa.eu/eurostat/statisticsexplained/index.php/Learning_mobility_statistics\#Number_and_share _of_students_from_abroad

[5] ILO Publication (2011). A Skilled Workforce for Strong, Sustainable and Balanced Growth: A G20 Training Strategy. International Labour Office - Geneva. ISBN 978-92-2-124278-9

[6] Kollár, R. (2019). The Development of Higher Education Students with Special Focus on Students of Natural and Technical Sciences in Slovakia. ACADEMIA 3/2019, 18-28. Retrieved from https://www.cvtisr.sk/buxus/docs//ACADEMIA/2019/3__2019_academia.pdf

[7] Kozáková, J. (2018). What is lacking in the entrepreneurship education in Slovakia? In: International scientific days 2018 "Towards Productive, Sustainable and Resilient Global Agriculture and Food Systems." Conference Proceedings. Praha: Wolters Kluwer ČR, 1943-1953. ISBN 978-80-7598-180-6

[8] OECD (2019). Education at a Glance 2019: OECD Indicators, OECD Publishing, Paris, https://doi.org/10.1787/f8d7880d-en

[9] Országhová, D., Flak, P., Papuncová, V. (2018). Tertiary education system in Slovakia. In: International scientific days "Towards Productive, Sustainable and Resilient Global Agriculture and Food Systems." Conference Proceedings. Praha: Wolters Kluwer ČR, 1995-2009. ISBN 978-80-7598-180-6 
[10] Sever, M. (2019). Student Enrolment in Tertiary Education, Slovenia, Academic Year 2018/2019. Statistical Office of the Republic of Slovenia. Retrieved from http://www.stat.si/StatWeb/en/show-news?id=8148

[11] Slovak Centre of Scientific and Technical Information [SCSTI] (2019). Štatistika prijímacieho konania na vysoké školy SR. Retrieved from https://www.cvtisr.sk/cvti-sr-vedecka-kniznica/informacie-o$\underline{\text { skolstve/statistiky/statistika-prijimacieho-konania-na-vysoke-skoly-sr.html?page_id=9723 }}$

[12] Statistical Bulletin SB252 (2019). Higher Education Student statistics: UK, 2017/2018. HESA, Cheltenham. Retrieved from https://www.hesa.ac.uk/news/17-01-2019/sb252-higher-education-student-statistics

[13] Statistical Office of the Slovak Republic [SOSR] (2020). Education attainment level. Tertiary education (levels 5-8) [statistics]. Available from DATAcube. Retrieved from http://datacube.statistics.sk /\#!/view/en/VBD SK WIN/kz1030rs/v kz1030rs $0000 \quad 00$ en

[14] Tholen, G. (2014). The Changing Nature of the Graduate Labour Market: Media, Policy and Political Discourses in the UK. Palgrave Macmillan, UK. ISBN 978-1-137-47906-8 


\title{
Preventing Food Waste and the Psychological Phenomenon of the "Best- Before Date"
}

\author{
Jana Rybanská ${ }^{1}$ \\ Slovak University of Agriculture in Nitra \\ Faculty of Economics and Management, Centre of Education and Psychological Counselling \\ Tr. A. Hlinku 2 \\ Nitra, Slovak Republic \\ e-mail: jana.rybanska@uniag.sk
}

doi: 10.18515/dBEM.ISD.P01.2020.p057

\begin{abstract}
Food waste prevention is currently a very important topic, because it is linked to the climate change and other global problems. Consumers in developed countries live in the consumerist societies, they waste limited resources and harm the environment. That is why there are efforts to reveal causes of such behaviour. Many factors have yet been discovered that support tendencies of consumers to waste food resources. One of them is that they do not understand labelling of food packaging. The main aim of the current paper is to analyse the situation on the Slovak food market and find out if Slovak consumers understand the individual date labels and how that affects their tendencies to waste food. A simple webbased survey instrument was designed to analyse a sample of 163 Slovak adults. It was found out that many Slovak consumers do not understand or do not notice the difference between "best before date" and "use by date" labelling on food packaging. That is why a lot of food is unnecessarily discard every day. "Best before date" labelling also create psychological effect, so even though consumers know that the food product is not risky for their health, they rather do not eat it.
\end{abstract}

Keywords: food waste, consumer behaviour, 2030 Agenda, sustainable development, best before date, expiration date

JEL Classification: $M 0, M 3, I 1, Q 0, Q 5$

\section{Introduction}

Food and water are the essential resources people need to survive. Nowadays, when there is still enough food in developed European countries and relatively small problems with drinking water supplies, consumers are often unaware of their consumerist behaviour and the associated waste of food. Wasting food resources is a long-term problem, food waste occurs throughout the whole food chain, from the primary agricultural production to the final consumption of individuals.

The main causes of wasting food resources at the level of households and individuals are still a lack of consumer awareness of the situation in the food chain, a consumerist way of life that is largely influenced and supported by modern marketing communication tools, and a lack of education in the field of responsible access to limited resources. That is why it is essential to constantly raise consumer awareness of this problem. Another important reason why consumers waste food is that they often do not understand the date labels on the food packaging.

Consumer psychology studies show that the consumer bases his purchasing decisions on feelings and emotions, not on the logic. Only afterwards he rationalizes or tries to justify his decisions rationally. The better we can reach potential customers at the emotional level, the higher is the chance they buy the product we offer. This is because strong, positive or negative emotions are remembered more quickly and for a longer time period. The consumer has the knowledge and experiences (supported by media) that food after expiration date can be 
dangerous for his health. Date labels automatically create a "mental block" and, even if the food is still good and eatable, the consumer feels uncomfortable about eating it. The current legislation does not help the situation, because consumer often do not understand the difference between the expiration date and the best before date.

The main aim of the current paper is to analyse the situation on the Slovak food market and find out if Slovak consumers understand the individual date labels and how that affects their tendencies to waste food resources.

\subsection{Food Waste Prevention and the 2030 Agenda for Sustainable Development}

Food waste prevention is a very important topic on the policy agenda. According to many authors and research studies, e.g. Stancu, Haugaard and Lähteenmäki (2016), Diaz-Ruiz, CostaFont and Gil (2018), Revilla and Salet (2018), Schanes, Dobering and Gözet (2018), Hebrok and Heidenstrøm (2019) and others, urgent measures need to be undertaken to reduce food waste significantly. However, it is important to carefully understand consumers' food-related behaviour to define measures that will lead to a long-lasting change in the situation (Diaz-Ruiz et al., 2018).

Creating different amount of food waste can be considered an individual food-related behaviour. Consumers have many different reasons for creating food waste, and thus it is very difficult to uncover the main factors and reasons that lead to this behaviour. Many research studies analyse the main causes of food waste generation and most frequently identified causes can be grouped in five categories: food purchase, food storage, food preparation, food consumption and lifestyle related to food (Diaz-Ruiz et al., 2018). Consumers' attitudes, values, knowledge and behaviour towards food are also important factors (Parfitt, Barthel and Macnaughton, 2010; Kosseva, 2013; Principato, Secondi and Pratesi, 2015). Diaz-Ruiz et al. (2018) have identified another three factors related to food habits: purchasing discipline, price importance and the importance of diet as representatives of food importance towards food waste generation.

Insufficient household management and poor planning of food shopping and subsequent emotional excessive buying can also cause the generation of food waste. Many (psychological) studies have shown that consumers who buy groceries when they are hungry buy more unnecessary goods (e.g. Singh, 2006; Parfitt et al., 2010; Göbel et al., 2012; Parizeau, Massow and Martin, 2015; Mallinson, Russell and Barker, 2016; Stancu et al., 2016 and others). Food shopping is also largely influenced by marketing communication tools, that can engage consumers on the emotional base and alter their purchasing discipline. Lack of education in the field of responsible access to limited resources worsens the situation on the food market and creates opportunities to acquire "bad" shopping habits.

Because over the last decade the problem of food waste has come to the fore also in connection with the climate change and sustainable development, attempts have been made to change the situation. As food waste generation is a global and society-wide problem, international organizations try to help. The issue of the food waste generation is closely linked to United Nations 2030 Agenda for sustainable development.

The UN 2030 Agenda is the most comprehensive set of global goals to achieve sustainable development. The key principles of the 2030 Agenda set out in a document approved by the UN General Assembly in September 2015 "Transforming our world: 2030 Agenda for Sustainable Development" are transformation, integration and universality. 2030 Agenda follows the UN Millennium Declaration from 2000. The millennium development goals (MDGs) were the first ever common vision and the first widely accepted framework for the 
global development and the formation of development policy (Office of the Deputy Prime Minister SR, 2015).

The transformational power of the 2030 Agenda is represented by 17 sustainable development goals (SDGs), elaborated into 169 related partial goals, to guide the structural, political, economic and social transformation of individual countries in response to the threats that is humanity currently facing. 2030 Agenda is not legally binding. It expresses the intention of countries to lead their development towards sustainability and to set their national policies, strategies and planning to contribute to the achievement of global goals (Office of the Deputy Prime Minister SR, 2018).

\section{SDGs are:}

1. No poverty,

2. Zero hunger,

3. Good health and well-being,

4. Quality education,

5. Gender equality,

6. Clean water and sanitation,

7. Affordable and clean energy,

8. Decent work and economic growth,

9. Industry, innovation and infrastructure,

10. Reduced inequalities,

11. Sustainable cities and communities,

12. Responsible consumption and production,

13. Climate action,

14. Life below water,

15. Life on land,

16. Peace, Justice and Strong Institutions,

17. Partnerships.

The issue of food wasting is elaborated further in Goal no. 12 - responsible consumption and production. Goal no. 12 "Sustainable consumption and production" is divided into 11 sub-units with measurable outputs. Partial goal no. 12.3 is to halve per capita global food waste at the retail and consumer levels and reduce food losses along production and supply chains, including post-harvest losses by 2030 (UN, 2015).

\subsection{Expiration Date vs. Best Before Date}

One third of all food produced globally is lost or wasted (Gustavsson, Cederberg and Sonesson, 2011). In response to this evidence UN Sustainable Development Goal 12.3 aims to halve global food waste at the retail and consumer level and reduce food losses throughout the whole food chain by 2030 (UN, 2015). In higher income countries, such as EU member states, it is household food waste that has received the greatest attention. This is mostly because households and individuals have been found to generate the greatest volume of food waste relatively to other stages of the food supply chain globally (Gustavsson et al., 2011; Thompson, Toma, Barnes and Revoredo-Giha, 2020).

In this paper we want to aim the attention to food date labels. Food labels provide a wide range of information about food products. They show nutritional information, ingredients and a range of different dates. Use by and best before dates (as well as sell by and display by dates) are often confusing for consumers. In Slovak Republic, the labelling of food is regulated by the 
Regulation no. 243/2015 of Ministry of Agriculture and Rural Development of the Slovak Republic, which is based and follows the European legislation.

The labelling of a food with an expiration date or the date of minimum durability is one of the mandatory information that must be on the food packaging. The date of minimum durability of a food (best before date) is the date until which the food retains its specific qualities when properly stored. The expiration date (use by date) refers to a food that is microbiologically perishable and can therefore present an immediate danger to human health in the short term. In other words, we should not consume food after the use by date. Food after the best before date can be consumed if it has been properly stored and not opened (Böhm-Klein, 2015).

Neff, Spiker, Rice, Schklair, Greenberg and Broad Leib (2019) found out that consumers frequently misunderstand food date labels. Viewing date labels as safety messages was also linked with food discards.

\section{Data and Methods}

A simple web-based survey instrument was designed to analyse the situation on the Slovak food market and finding out if Slovak consumers understand the individual date labels and how that affects their tendencies to waste food resources.

The investigated sample consists of 163 adults (61 men and 102 women), aged 23 - 57. All respondents have completed a minimum of secondary education, they are employed, and they live in Slovak Republic. Further characteristics of participants are stated in following table (Table 1).

Table 1: Participants according to gender and residence

\begin{tabular}{|l|l|l|l|l|}
\hline \multirow{2}{*}{} & \multicolumn{2}{|c|}{ Residence } & \multirow{2}{*}{ Total } \\
\cline { 3 - 5 } & Town & Village & 61 \\
\hline \multirow{2}{*}{ Gender } & Male & 40 & 21 & 102 \\
\cline { 2 - 4 } & Female & 64 & 38 & 163 \\
\hline Total & 104 & 59 & \\
\hline
\end{tabular}

Source: author's elaboration

An online questionnaire with both open and closed answers was constructed to achieve the research objectives. First, respondents were asked if they are familiar with terms "use by date" and "best before date". Then they were asked if they know the difference between these two terms. Respondents were also asked to write down reasons why they consume/do not consume food after the date stated on the food packaging and to express the degree of importance of the date labels on food products on the 7-degree scale ( 1 - not important at all; 7 - very important). Respondents also answered questions related to the food waste issues and food shopping behaviour.

Consumers were presented 6 essential food products (raw meat, fresh milk, fresh eggs, fresh bread, honey and tinned food) and they were asked to organize them according to the length of time they were still willing to consume these products after the date stated on the food packaging.

Following exploratory analyses and descriptive analyses, the correlation analysis was conducted. The identifying differences between groups was based on chi-square test. 


\section{Results and Discussion}

It was found out that more than $45 \%$ of respondents (74) do not distinguish between date labels "best before date" and "use by date". They consider them equivalent. More than $75 \%$ of respondents (56) who do not distinguish between date labels also stated that they do not consume food after the date stated on the food packaging, no matter if it is "best before date" label or "use by date" label, and that they most often discard these products. For comparison, Neff et al. (2019) in their research found out that $37 \%$ of U.S. consumers reported that they always or usually discard food when it is near the package date, and $84 \%$ said they did so at least occasionally. Although U.S. legislation concerning food labelling is different from the legislation in Slovakia and European Union, consumers seem to behave similarly, they are anxious about the quality (Predanocyová, et al., 2019) and potential harmfulness of food products. Golian et. al (2018) also found out that consumers have concerns about the health harming effects of food. The most hazardous foods are considered poultry meat, eggs and mayonnaise.

All respondents (163) from our survey stated that the safety of food products is very important for them. That confirms above mentioned findings. The average importance of the date labels on the food packaging on the 7-degree scale is 6,46 (Figure 1). We can conclude that consumers care about their food very much, they are careful about the quality of food products and if they are not sure about the qualities or date, they tend to discard them.

Figure 1: The average importance of the date labels on the food products

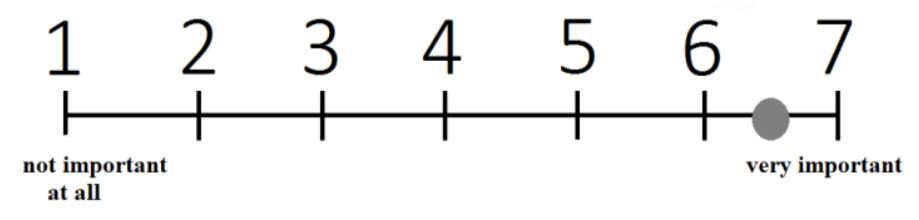

Source: author's elaboration

We did not find out statistically significant differences among respondents in distinguishing between date labels on food packaging depending on the settlement, age or gender.

The results of the correlation analysis show that respondents who stated that they distinguish between date labels also stated that they try to live healthy $\left(\mathrm{r}=0,68^{* *}\right)$. These respondents also stated that they waste food only occasionally $(\mathrm{r}=0,72 * *)$.

Respondents who distinguish between date labels "best before" and "use by" often described a "bad feeling" they have when their food is over the best before date, although they know it is not harmful. We assume that even though they distinguish between date labels, and even though they are aware that the food is not harmful for their health, there are other factors that cause their "fear" or "bad feeling" of consuming these products. "Best before date" label possibly create a psychological effect. Most important factors that stands behind this effect, according to answers of respondents on the question why they consume/do not consume food after the date stated on the food packaging, could be ambiguous information from media and social media, an increasing number of lifestyle diseases, an increasing number of food scandals (in Slovakia) and changes in legislation related to food products.

Consumers were presented 6 essential food products (raw meat, fresh milk, fresh eggs, fresh bread, honey and tinned food) and they were asked to organize them according to the length of time they were still willing to consume these products after the date stated on the food packaging. We intentionally did not specified the date labels, because we anticipated that there would be consumers who would not distinguish between different date labels. We are aware that this step could distort the results significantly. Our aim was to show the approximate 
willingness to consume food products over the expiration period. We also intentionally left out fresh fruits and fresh vegetables, because Slovak legislation (Regulation no. 243/2015) does not enact an obligation to state the date labels on these products. Results, showing the average number of days consumers are willing to consume food products after the stated date on the packaging, are presented in the Table 2 and Figure 2.

Table 2: Average number of days consumers are willing to consume food products after the stated date on the packaging

\begin{tabular}{|c|c|c|c|c|c|c|c|c|c|c|}
\hline \multirow{2}{*}{$\begin{array}{l}\text { Product } \\
\text { Raw Meat }\end{array}$} & \multicolumn{9}{|c|}{ Average number of days } & \multirow[t]{2}{*}{ Total } \\
\hline & 0 & 1 & 2 & 3 & 4 & 5 & 6 & 7 & More & \\
\hline & 72 & 51 & 23 & 8 & 4 & 3 & 1 & 1 & 0 & 163 \\
\hline \multirow[t]{2}{*}{ Fresh Bread } & 0 & 1 & 2 & 3 & 4 & 5 & 6 & 7 & More & \\
\hline & 20 & 49 & 51 & 21 & 7 & 4 & 3 & 5 & 3 & 163 \\
\hline \multirow[t]{2}{*}{ Fresh Eggs } & 0 & 1 & 2 & 3 & 4 & 5 & 6 & 7 & More & \\
\hline & 17 & 19 & 38 & 37 & 15 & 15 & 7 & 6 & 9 & 163 \\
\hline \multirow[t]{2}{*}{ Fresh Milk } & 0 & 1 & 2 & 3 & 4 & 5 & 6 & 7 & More & \\
\hline & 69 & 42 & 31 & 13 & 2 & 3 & 2 & 1 & 0 & 163 \\
\hline \multirow[t]{2}{*}{ Honey } & 0 & 1 & 2 & 3 & 4 & 5 & 6 & 7 & More & \\
\hline & 3 & 5 & 4 & 7 & 9 & 11 & 10 & 15 & 99 & 163 \\
\hline \multirow[t]{2}{*}{ Tinned food } & 0 & 1 & 2 & 3 & 4 & 5 & 6 & 7 & More & \\
\hline & 13 & 24 & 17 & 16 & 12 & 15 & 3 & 20 & 43 & 163 \\
\hline
\end{tabular}

Source: author's elaboration

Figure 2: The order of willingness of consuming food products according the time over the expiration date
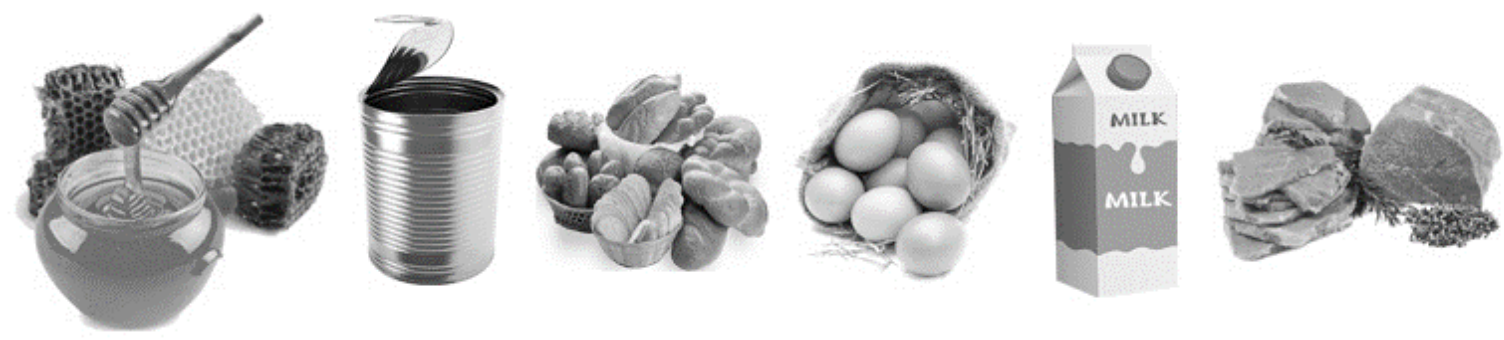

Source: author's elaboration

Honey is the food product that consumers are willing to consume long after its expiration date. It is mostly because most consumers do not trust honey sold in supermarkets, so they buy it from local beekeepers who are trustworthy. They know (or they believe to) healing effects of bee products, they trust the seller and they consider honey to be a superfood. These are the main reasons stated by respondents in the survey. Respondents expressed the least willingness to 
consume the food product after the expiration date for fresh meat. The main reasons are microbiological qualities of meat, fear of food poisoning and the doubts about the quality of meat.

\section{Conclusion}

The main aim of the presented paper was to analyse the situation on the Slovak food market and find out if Slovak consumers understand the individual date labels and how that affects their tendencies to waste food resources. It was found out that many Slovak consumers do not understand or do not notice the difference between "best before date" and "use by date" labelling on food packaging. That is why a lot of food is unnecessarily discard every day. "Best before date" labelling also create psychological effect, so even though consumers know that the food product is not risky for their health, they rather do not eat it.

"Use by" and "best before" dates (as well as sell by and display by dates - instructions for retailers, not customers) are often confused, but the differences between them are easy to remember when the right explanation is used. We agree with Neff et al. (2019) that the further education of consumers is needed to support the roll-out of label standards. Many Slovak nonprofit organizations, associations and universities prepare projects, campaigns and activities that help consumers with orientation on the food market. Social marketing activities with emotional content are also very helpful, because they can reach the consumer easily. The more emotional the content is, the faster consumer remembers it.

Faculty of Economics and Management of Slovak University of Agriculture in Nitra is currently working on two food-oriented projects that aim to help consumers develop the social consciousness on the sustainable consumption of food (SUSCOF project, strategic partnership Nr. 2018-1-TR-01-KA-204-058739 "Assessing and Changing Adults' Behaviour on Sustainable Consumption of Food" and research project VEGA 1/0368/19 "Life-satisfaction and other psychological dispositions as predictors of behavioural tendencies associated with food wasting"). Results of the projects will provide adults with the useful information and guidelines on true nutrition habits and consumption patterns, help them orient on the food market, distinguish information on food packaging and improve the household food management.

\section{Acknowledgements}

The paper is the outcome of the research project VEGA 1/0368/19 "Life-satisfaction and other psychological dispositions as predictors of behavioural tendencies associated with food wasting", solved in the Centre of Education and Psychological Counselling, Faculty of Economics and Management, Slovak University of Agriculture in Nitra.

\section{References}

[1] Böhm-Klein, K. (2015). Dátum spotreby a minimálna trvanlivost' - Aký je medzi nimi rozdiel? Retrieved 25 Januray, 2020, from: http://www.uspesne-podnikanie.sk/datum-spotreby-a-minimalna-trvanlivost-aky-jemedzi-nimi-rozdiel

[2] Diaz-Ruiz, R., Costa-Font, M., \& Gil, J. M. (2018). Moving Ahead from Food-Related Behaviours: An Alternative Approach to Understand Household Food Waste Generation. Journal of Cleaner Production, 172, 1140-1151. https://doi.org/10.1016/j.jclepro.2017.10.148

[3] Golian, J., Nagyová, L., Andocsová, A., Zajác, P., \& Palkovič, J. (2018). Food Safety from Consumer Perspective: Health Safety. Potravinárstvo, 12(1),313-322. https://doi.org/10.5219/917 
[4] Göbel, Ch. et al. (2012). Reducing Food Waste - Identification of Causes and Courses of Action in North Rhine-Westphalia. Münster. Retrieved from: https://www.fhmuenster.de/isun/downloads/120613_iSuN_Reducing_food_waste_-_Abridged_Version.pdf

[5] Gustavsson, J., Cederberg, C., \& Sonesson, U. (2011). Global Food Losses and Food Waste. Extent, Causes and Prevention. Study Conducted for the International Congress Save Food! at Interpack 2011, [16 - 17 May]. Food and Agriculture Organization of the United Nations, Düsseldorf, Germany. Rome (2011). Available online: www.fao.org/home/en/

[6] Hebrok, M., \& Heidenstrøm, N. (2019). Contextualising Food Waste Prevention - Decisive Moments Within Everyday Practices. Journal of Cleaner Production, 210, 1435-1448. https://doi.org/10.1016/j.jclepro.2018.11.141

[7] Kosseva, M. R. (2013). Introduction: Causes and Challenges of Food Wastage. In Kosseva, M. R., \& Webb, C. (Eds.), Food Industry Wastes: Assessment and Recuperation of Commodities. (pp. xv-xxiv). Elsevier. https://doi.org/10.1016/B978-0-12-391921-2.00019-6

[8] Mallinson, L. J., Russell, J. M., \& Barker, M. E. (2016). Attitudes and Behaviour Towards Convenience Food and Food Waste in the United Kingdom. Appetite, 103, 17-28. https://doi.org/10.1016/j.appet.2016.03.017

[9] Neff, R. A., Spiker, M., Rice, Ch., Schklair, A., Greenberg, S., \& Broad Leib, E. (2019). Misunderstood Food Date Labels and Reported Food Discards: A Survey of U.S. Consumer Attitudes and Behaviors. Waste Management, 86, 123-132. https://doi.org/10.1016/j.wasman.2019.01.023

[10] Office of the Deputy Prime Minister of the Slovak Republic for Investments and Informatization. (2015). Agenda 2030. Retrieved January 20, 2020, from: https://www.vicepremier.gov.sk/sekcie/investicie/agenda2030/index.html

[11] Office of the Deputy Prime Minister of the Slovak Republic for Investments and Informatization. (2018). Voluntary National Review of the Slovak Republic on the Implementation of the 2030 Agenda for Sustainable Development. $\quad$ Retrieved from: https://sustainabledevelopment.un.org/content/documents/20131Agenda2030_VNR_Slovakia.pdf

[12] Parfitt, J., Barthel, M., \& Macnaughton, S. (2010). Food Waste Within Food Supply Chains: Quantification and Potential for Change to 2050. Philosophical Transactions of the Royal Society B: Biological Sciences, 365, 3065-3081. https://doi.org/10.1098/rstb.2010.0126

[13] Parizeau, K., Massow, M., Martin, R. (2015). Household-Level Dynamics of Food Waste Production and Related Beliefs, Attitudes, and Behaviours in Guelph, Ontario. Waste Management, 35, 207-217. https://doi.org/10.1016/j.wasman.2014.09.019

[14] Predanocyová, K., Kubicová, L., Kádeková, Z., \& Košičiarová, I. (2019). Key factors affecting consumption of meat and meat products from perspective of Slovak consumers. Potravinárstvo, 13(1), 1001-1012. https://doi.org/10.5219/1198

[15] Principato, L., Secondi, L., \& Pratesi, C.A. (2015). Reducing Food Waste: An Investigation on the Behaviour of Italian Youths. British Food Journal, 117(2), 731-748. https://doi.org/10.1108/BFJ-10-2013-0314

[16] Regulation no. 243/2015 of Ministry of Agriculture and Rural Development of the Slovak Republic.

[17] Revilla, B. P., \& Salet, W. (2018). The Social Meaning and Function of Household Food Rituals in Preventing Food Waste. Journal of Cleaner Production, 198, 320-332. https://doi.org/10.1016/j.jclepro.2018.06.038

[18] Schanes, K., Dobering, K., \& Gözet, B. (2018). Food Waste Matters - A Systematic Review of Household Food Waste Practices and Their Policy Implications. Journal of Cleaner Production, 182, 978-991. https://doi.org/10.1016/j.jclepro.2018.02.030

[19] Singh, S. (2006). Impact of Color on Marketing. Management Decision, 44(6), 783-789. http://dx.doi.org/10.1108/00251740610673332

[20] Stancu, V., Haugaard, P., \& Lähteenmäki, L. (2016). Determinants of Consumer Food Waste Behaviour: Two Routes to Food Waste. Appetite, 96, 7-17. https://doi.org/10.1016/j.appet.2015.08.025

[21] Thompson, B., Toma, L., Barnes, A. P., \& Revoredo-Giha, C. (2020). Date-label Use and the Waste of Dairy Products by Consumers. Journal of Cleaner Production, 247, 1191174. https://doi.org/10.1016/j.jclepro.2019.119174 
[22] United Nations. (2015). Sustainable Development Goals: Responsible Consumption and Production. Retrieved January 25, 2020, from: https:/www.un.org/sustainabledevelopment/sustainable-consumptionproduction/

\title{
The Modern Ukrainian Model of Quality Assurance in the Agricultural University Education
}

\author{
Olena Vasylenko \\ Bila Tserkva National Agrarian University \\ Economics faculty \\ Address: sq. Soborna 8/1 \\ Bila Tserkva, Ukraine \\ e-mail: vasylenko521@gmail.com
}

doi: 10.18515/dBEM.ISD.P01.2020.p058

\begin{abstract}
The modern Ukrainian model of quality assurance in the agricultural university education are undergoing the development stage and need studying to improvethe economic efficiency of the institutions. In 2019 started a new wave of dynamic changes in Ukrainian agricultural higher education institutions management was launched aimed to ensure the education quality. The wave was predetermined by National Quality Assurance Agency for Higher Education work start. The paper deals with the analysis of the regulatory framework of the Ukrainian national system of educational as well as the existing models of agricultural institutions of higher education management and impact factors of the employers choice of the agrarian market of Ukraine. It determines the factors forming the modern model of higher education institutions management competitiveness at different management levels and an algorithm for the implementation of the system of agricultural university quality management.
\end{abstract}

Keywords: quality assurance, higher education institutions, competition, competitiveness, educational services market, stakeholders.

JEL Classification: A22, C52, I20, I21, Q11

\section{Introduction}

The modern agricultural market of educational services creates challenges for higher education institutions. These challengesrequire studying the institutions characteristics in order to improve their economic efficiency.

The issue of competition and competitiveness was not studied in Ukraine until the 90-ies of XX century since there was no need in it while modern conditions of hard competition between institutions of higher education make these economic categories highly relevant [1].

Currently, higher education has been undergoing reformation and it aims to conform to European educational trends. However, the steps taken to implement European standards should be consistent with the national peculiarities including economic aspects of higher education. To meet European standards means to be competitive, i.e. be in demand toeducational activities stakeholders.

The modern Ukrainian models of quality assurance in the agricultural university education are under development and should be studied with a view to the formation of algorithm for the implementation of the system of agricultural university quality management. 
New dynamic changes in agricultural higher educational institutions management started in Ukraine in 2019. They aim at ensuring management quality and are related to the fact that the National Quality Assurance Agency for Higher Education officially started its activities in Ukraine in February 2019. Currently, the Agency gains the ability to implement the state policy in the sphere of higher education and becomes a change catalyst aimed to buildits quality culture [2].

The strategic objectives of the National Agency up to 2022 include [2]:

- implementation of effective procedures for educational programsaccreditation;

- facilitating the internal education quality assurance systems functioning in institutions of higher education through information-aladvisoryactivities and benchmarking;

- standardsharmonization and development of criteria for quality assurance in higher education on the basis of the best international and national practices.

It should be noted that criteria for quality assurance in higher education have been already developed by the beginning of 2020 and the first wave of accreditations of educational programmes has already passed. Special attention is paid to the transparency of the process, the principle of confidence and good will to all participants of the accreditation process.

The reformation of the agrarian institutions of higher education in Ukraine provides for changes in their management, which is based not only on the basis of administrative management, but on the knowledge of market economy, the labour market and the needs of employers as well as. The ultimate goal of management should be strengthening the higher education institutions mission through ensuring a high level of teaching, training and research [3-4]. The university administration need to identify competitive advantages and reorganize the management structure so as not only to stay in the educational services market but to be successful as well.

\section{Data and Methods}

In 2019 , the share of agrarian higher education institutions students in Ukraine was $10,2 \%$ $(153,500)$ of the total number $(1,501,000$ studentsof which 387,917 studying for the Junior bachelor degree). Modern network of agricultural education institutions includes 128 institutions, of which 22 higher education institutions and 106 technical schools and colleges. They train specialists in 51 specialties of Bachelor degree and in 46 specialties of Master. $60,8 \%$ of full time bachelor students study for agricultural professions, $17,9 \%$ - for economic, 2,5\% for construction, 3,8\% - for food processing industry, 2,6 \% - for computer technologies, 12,4 $\%$ - for other specialties [5].

According to the source [6], the main impact factors of the employers choice of university graduates are: quality of education $(51 \%)$, reputation of the institution (12\%), university affiliate programs (7\%), scientific and technical base (4\%). The impact factors on the employers of agrarian sphere of Ukraine in the selection of university graduates according to the members of the association "Ukrainian Club of Agrarian Business" in 2019 survey in the context of specialties are presented in table 1 .

In this study, we used a combination empirical and comparison methods. Internal models of quality assurance for various agricultural institutionsare analyzed. An in-house model of quality management was developed in Bila Tserkva NAU [7]. The national legislative base on ensuring the quality of higher education and educational activitieswas studied.

\section{Results and Discussion}


We believe that the main factors forming the model are to be considered to defined the generalized modern models of management in higher education institutions (Fig. 1). These factors are inter related and provide a cyclical process. Consider the following factors through the analysis of the Ukrainian market of educational services and the characteristics of their relationship.

Table 1: Impact factors on employers of agrarian sphere at selection of graduates of higher educational institutions in Ukraine (2019)

\begin{tabular}{|c|c|c|c|c|c|c|}
\hline \multirow[b]{2}{*}{ Specialty } & \multicolumn{6}{|c|}{ Impact factors, \% } \\
\hline & 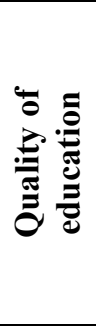 & 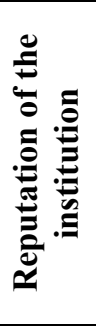 & 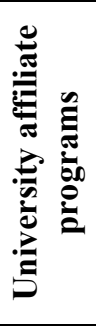 & 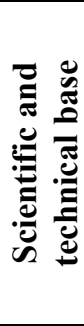 & 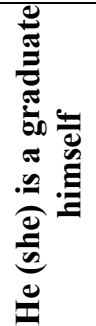 & $\frac{0}{0}$ \\
\hline Agroengineering & 48 & - & 9 & 13 & - & 30 \\
\hline Agronomy & 58 & 8 & 4 & 8 & - & 21 \\
\hline $\begin{array}{l}\text { Veterinary } \\
\text { medicine }\end{array}$ & 46 & 8 & 31 & - & - & 15 \\
\hline Economy & 60 & 12 & 4 & - & 4 & 20 \\
\hline Marketing & 47 & 27 & 7 & - & - & 20 \\
\hline $\begin{array}{l}\text { FEA } \\
\text { Management }\end{array}$ & 65 & 24 & - & 6 & 6 & - \\
\hline $\begin{array}{l}\text { Accounting and } \\
\text { Auditing }\end{array}$ & 55 & 20 & 5 & - & - & 20 \\
\hline
\end{tabular}

Source: formed by the author according to sources [7]

Figure 1. The competitiveness factors of the modern management model of higher education institution

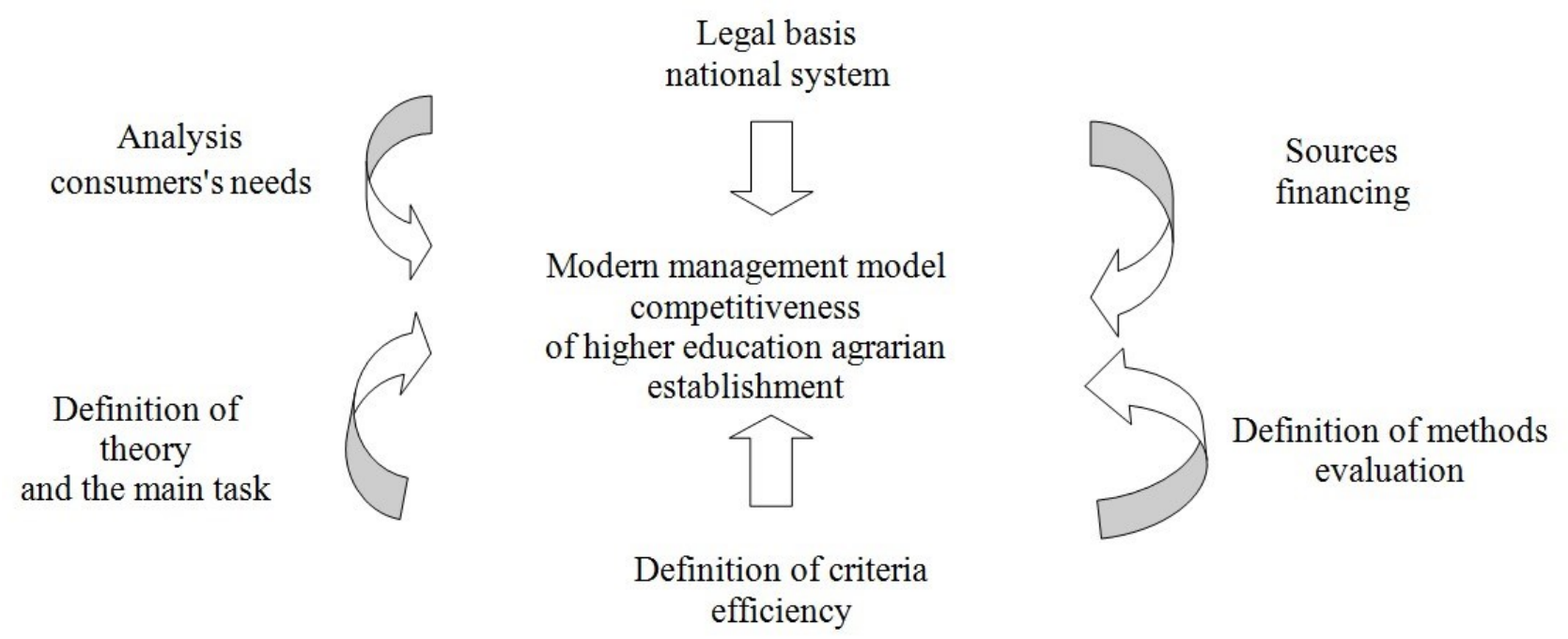


Let us analyze the legal framework of the Ukrainian national system. To date, it is based on the following basic documents:

- Law of Ukraine "On Education" of September 5, 2017 (Article 41 "Quality Assurance System for Education");

- Law of Ukraine "On Higher Education" of 1 July 2014 (Article 5 "Levels and Degrees of Higher Education", Article 6 "Certification of Higher Education Applicants", Article 10 "Standards of Higher Education", Article 16 "Quality Assurance System for Higher Education"

- Agreement on Association of Ukraine with the European Union, ratified by the Verkhovna Rada of Ukraine on September 16, 2014 (Chapter 23 "Education, Training and Youth");

- National Qualifications Framework of 2011;

- The list of branches of knowledge and specialties, which are subject to preparation of higher education institutions of April 29, 2015;

- Guidelines for the development of higher education standards in 2017;

- Higher education standards.

Based on the above normative legal documents, higher education institutions independently, on the rights to autonomy, develop their own internal quality assurance system. As this is a new experience for Ukrainian higher education institutions, it is recommended to take the principles outlined in the "Standards and Guidelines for Quality Assurance in the European Higher Education Area" (ESG - 2015) as a basis, which in particular determines the relationship between the Bologna Process and the education quality.

The Law of Ukraine "On Higher Education" [7] considers the two concepts:

- quality of higher education (set of qualities gained by a person with a degree, which reflects his professional competence, value orientation, social orientation and determines the ability to satisfy both personal spiritual and material needs, as well as the needs of society);

- quality of educational activity (the set of characteristics of the higher education system and its components, which determines its ability to meet the identified and anticipated needs of an individual or society).

The quality assurance system of higher education in Ukraine consists of:

- systems of internal quality assurance of educational activity;

- systems of external quality assurance of educational activity;

- quality assurance systems for the activities of the National Agency for Quality Assurance in Higher Education (NAQAHE) and independent institutions for the evaluation and quality assurance in higher education [8].

When developing an internal quality assurance system for universities, it should be borne in mind that the quality of higher education is ensured at the level of educational programs, and the quality of educational activity at the level of structural units [9].

As Ukraine seeks and confidently takes the first steps towards the implementation of a European quality assurance system, we will considera comparative analysis of the Ukrainian and European systems characteristic of most HEAs [10-11]. This analysis shows that, for European higher education institutions, the main consumer of educational services is the student and the 
employer. The development of the institution takes place in market conditions and aims at improving the quality of education.

In accordance with the standards and guidelines for quality assurance in the European Higher Education Area (2015) [12], the strategies, policies and procedures of higher education institutions should have an official status and be accessible to the general public, that is, management activities should be carried out in accordance with changed or replaced by newly developed internal regulations. Higher education institutions choose their policies independently and define management decision-making procedures aimed at enhancing the competitiveness of higher education institutions in the educational services market and aimed to join the European educational space. Higher education institutions face challenges sometimes problems at each stage of the managerial decision-making due to lack of experience and adaptation of national education to European standards.

Having analyzed the modern models of competitiveness management of higher education institutions in the market of educational services, we can note that the following factors will influence the development of the administrative model of competitiveness of higher educational institutions in the agricultural sector:

1) quality of educational services as the main factor of competitiveness formation;

2) research of the market of educational services in agricultural and definition of methods of market tendencies forecasting;

3) determining the methodology for competitiveness assessing;

4) identification of competitive advantages, factors of competitivenessincrease and key success factors;

5) financial and resource capacity of the university ensuring the competitiveness factors;

6) international activities.

Of particular importance in today's agrarianhigher education institutions of Ukraine is international activities: cooperation with foreign higher education institutions in the field of joint research and scientific publications; academic mobility of students and teachers; experience exchange including the matters of the institution management and higher education quality assurance. International activities require funding, therefore, Ukrainian higher education institutions have to consider additional funding instruments (table 2) based on the experience of leading European institutions. Scholarships and grants are the most popular ones in Ukraine.

Table 2: Supplementary Financing Instruments

\begin{tabular}{|l|l|l|}
\hline Instrument & Characteristics & States \\
\hline $\begin{array}{l}\text { Scholarships and } \\
\text { grants }\end{array}$ & $\begin{array}{l}\text { States and higher education institutionsoffer financial } \\
\text { aid with no refund }\end{array}$ & most countries \\
\hline Student loans & $\begin{array}{l}\text { Higher education institutionsprovide different forms of } \\
\text { loans }\end{array}$ & more than 60 countries \\
\hline $\begin{array}{l}\text { Labor capital } \\
\text { contracts }\end{array}$ & $\begin{array}{l}\text { Private enterprises offer contracts provided a student is } \\
\text { to refund a part of his/her income to investors who } \\
\text { receive a share of student's capital. }\end{array}$ & $\begin{array}{l}\text { Chile, Columbia, } \\
\text { Germany, the USA }\end{array}$ \\
\hline
\end{tabular}




\begin{tabular}{|l|l|l|}
\hline $\begin{array}{l}\text { Saving accounts for } \\
\text { study }\end{array}$ & $\begin{array}{l}\text { State encourages families to set saving accounts for } \\
\text { their children through providing tax benefits }\end{array}$ & $\begin{array}{l}\text { Belgium, Netherlands, } \\
\text { Spain, Sweden }\end{array}$ \\
\hline Vouchers & $\begin{array}{l}\text { Students have the right to study at ahigher education } \\
\text { institutionsof their choice }\end{array}$ & Bulgaria, Hungary \\
\hline
\end{tabular}

Source: formed by the author according to sources [13]

Having analyzed some process models of foreign agrarian institutions of higher education quality management [14-15], it can be noted that the quality assurance system is a mandatory component of a modern agrarian university management, in which the policy of the institution must be clearly defined; the legal documentation are to provide definition of processes, mechanisms and participants in educational activities.

It is necessary to ensure the quality of educational services at the expense of the reorientation from the functional activity of educational institutions to the process management and the construction of a management system based on close cooperation with entrants, students, employers as the main customers of higher education institutions activity.

Monitoring the consumers satisfaction with educational services: students, graduates, employers as well as monitoring the expectations of stakeholders (entrants and their parents) are prerequisites for quality assurance in higher education institutions. Monitoring is an important management function aimed to improve the quality of education through research into the educational process, expectations, needs and customer satisfaction with educational services.

Information is usually collected through questionnaires, it aims to identify the quality criteria for educational services that are the criteria of highest competitiveness and need improving at the university. The processed results are formulated in the form of a report and they are openly published on the universities websites. Assessment and analysis of the results of the study allow us to develop recommendations for managing the development of the organization, the work of its structural units in improving the education quality.

The results of the scientific study of the theoretical and methodological principles of the current agrarian higher education institutions management on the diferent levels make it possible to conclude that the development and implementation of a system of internal quality assurance of educational activities is to be the first step in improving the competitiveness of the organization (table 3). Taking into account the presented experience and analysis of modern models of agrarian higher education institutions competitiveness management, we propose an algorithm of the quality management system implementation at agrarian university (Fig. 2).

Table 3: Factors of competitiveness of agricultural higher education institutions at different levels of management

\begin{tabular}{|l|l|l|}
\hline Competitiveness factor & level of institution & Level of educational program \\
\hline Quality of education & $\begin{array}{l}\text { quality assurance of educational } \\
\text { process organization }\end{array}$ & $\begin{array}{l}\text { qualification of scientific and } \\
\text { pedagogical staff }\end{array}$ \\
\hline Reputation of the institution & $\begin{array}{l}\text { marketing policy } \\
\text { of higher education institution }\end{array}$ & $\begin{array}{l}\text { employment of graduates in the } \\
\text { specialty }\end{array}$ \\
\hline $\begin{array}{l}\text { University affiliate } \\
\text { programs }\end{array}$ & $\begin{array}{l}\text { international activities of higher } \\
\text { education institution }\end{array}$ & cooperation with foreign colleagues \\
\hline $\begin{array}{l}\text { Scientific and technical base } \\
\text { Infrastructure of higher education } \\
\text { institution }\end{array}$ & $\begin{array}{l}\text { specialized scientific and technical } \\
\text { base }\end{array}$ \\
\hline
\end{tabular}




\begin{tabular}{|l|l|l|}
\hline $\begin{array}{l}\text { He (she) is a graduate } \\
\text { himself }\end{array}$ & $\begin{array}{l}\text { cooperation with employers and } \\
\text { graduate }\end{array}$ & $\begin{array}{l}\text { involvement of graduates and } \\
\text { employers in the revision of the } \\
\text { educational program }\end{array}$ \\
\hline
\end{tabular}

Source: created by the author

\section{Conclusion}

It is found out that the main factors shaping the current model of higher education institution competitiveness management include the following: regulatory framework of the national system; analysis of consumer needs, policy and main objectives; sources of funding, determination of performance criteria and definition of assessment methods.

The quality assurance system is an indispensable component of modern agrarian university the management.The system components such as the policy of the institution, the main tasks, the approved legislative documentation with the defined processes, mechanisms and participants of educational activity must be clearly defined.

International activitiesis an important part of modern higher education institution, it involves using additional funding tools such as grants and scholarships.

The factors of competitiveness of agrarian higher education institutions at different management levels are determined.

The algorithm of introduction of agrarian university quality management system is offered.

Educational services quality can be ensured through close cooperation with entrants, students, employers as the main customers of agricultural higher education institutions activity

Figure 2: Algorithm for quality management system implementation at agrarian university 


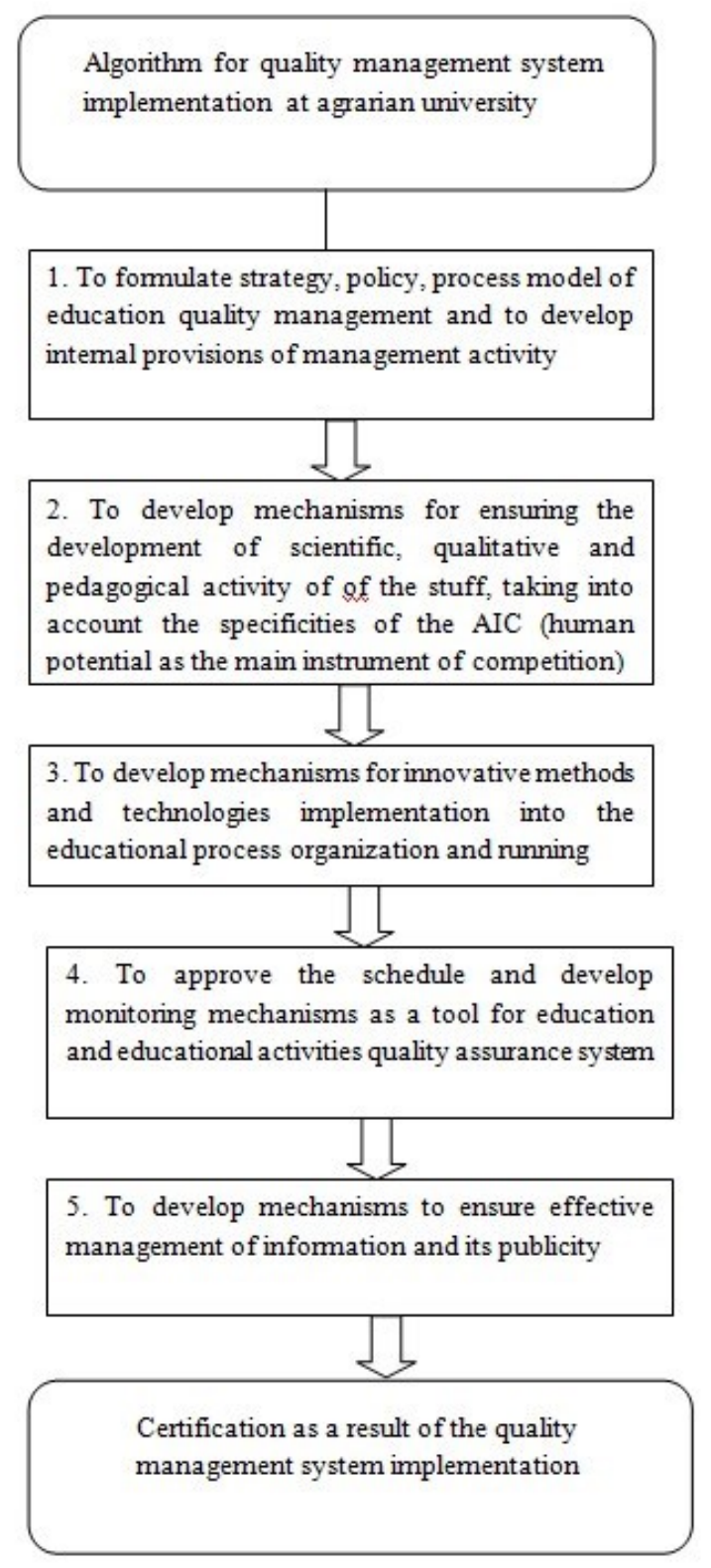

Source: created by the author

\section{References}

[1] Alex Lissits. (2019, July 25) TOP-10 universities in Ukraine. Where to go in agrarian establishments of Ukraine? AgroPortal. Retrieved from: https:/agroportal.ua/ua/views/blogs/top10-vuzov-ukrainy-kudadvigatsya-agrarnym-zavedeniyam-obrazovaniya/

[2] Bristol Veterynary School. Self-Evaluation Report 2 (2014). Examinations reports for the BVSc Programme: University Veterynary School. Retrieved from: https://www.bristol.ac.uk/medialibrary/sites/vetscience/documents/rcvsser2.pdf

[3] Finikova T.V., Sharova O.I. (2014) Monitoring of the Integration of the Ukrainian Higher Education System into the European Higher Education and Research Area: monitoring research:analytic report. International charity org. International Educational Policy Research Foundation. Kyiv, Ukraine: Taxon, 144 p.

[4] Higher Education Quality Assurance Concept of Ukraine. Towards Trust in Quality Assurance System, 516935-TEMPUS-1-2011-1-FITEMPUS-SMGR, 15.10.2011-14.10.2014. Retrieved from: http://dovira.eu/QA_concept.pdf 
[5] Hozhyk A. (2018) Educationqualityassurance internal system in Ukrainian higher education institutions. Typical Model. Training for coaches training experts on quality assurance in higher education. Retrieved from: https://projects.lnu.edu.ua/quaere/wp-content/uploads/sites/6/2018/10/Model-1.pdf

[6] Law of Ukraine "On Higher Education" (2014, October 15) Retrieved from: https://zakon2.rada.gov.ua/laws/show/1556-18

[7] Mospan N.V. Tendencies inhigher education financing mechanisms in the European Union / Public Retrieved from: https://www.narodnaosvita.kiev.ua/?page_id=2644

[8] Quality Policy of the Bila Tserkva National Agrarian University (2018). Bila Tserkva, Ukraine: BNAU. Retrieved from https://btsau.edu.ua/sites/default/files/Faculties/osvita/quality/polityka_bnau.pdf

[9] Self-Evaluation Report 2017 for the European Association of Establishments for University Education (EAEVE) (2018, January 15-19). University of Veterinary Medicine Hannover, Foundation. Standart Operating Procedure (SOP).

[10] Shpak O. (2010). Management features in the modern higher education system. Youth and the Market, 12(71), 10-13. doi: $10.31558 / 2307-2318.2019 .3 .10$

[11] Standards and Guidelines for Quality Assurance in the European Higher Education Area (ESG). (2015, May 14-15). Approved by Ministrial Conference in Yerevan. Retrieved from: https://enqa.eu/index.php/home/esg/

[12] Statistical and analytical studies of the activities of agricultural educational institutions for 2018. (2019) Kyiv, Ukraine: "Agroosvita".

[13] Strategy of the National Agency for Quality Assurance in Higher Education by 2022. Retrieved from https://naqa.gov.ua/mission-and-strategy-agencies/

[14] Vasylenko V.A. (2002). Theory and Practice of Management Decision Making: Manual. Kyiv, Ukraine: TsUL.

[15] Yelets O.P., Bohdan E.V. (2014) The essence of enterprise competition and competitiveness. Ways and factors of reducing the industrial enterprise productioncost. 82-91. doi: 10.30838/P.ES.224.100119.76.347

\title{
Creation of Partial Individual Study Plans by Students as a Possibility to Increase the Attractiveness of Higher Education at FEM SUA in Nitra
}

\author{
Roderik Virágh ${ }^{1}$, Marcela Hallová ${ }^{2}$, Peter Stuchlý ${ }^{3}$, Erik Janšto ${ }^{4}$, Silvia Virághová ${ }^{5}$ \\ Slovak University of Agriculture in Nitra \\ Faculty of Economics and Management, Department of Informatics ${ }^{1,2,3,4}$ \\ Faculty of Economics and Management, Centre of Education and Psychological Counseling 5 \\ Address: Tr. A. Hlinku 2 \\ Nitra, Slovak Republic \\ e-mail: roderik.viragh@uniag.sk¹,marcela.hallova@uniag.sk², peter.stuchly@uniag.sk², \\ xjansto@is.uniag.sk ${ }^{4}$, sebenova@is.uniag.sk ${ }^{5}$
}

doi: 10.18515/dBEM.ISD.P01.2020.p059 


\begin{abstract}
Current study plans at universities and colleges in the Slovak Republic are formed so that a substantial part of subjects is compulsory and there are only few which are elective. Students have a low variability in subjects which they can choose from in higher years of study and they might be more interesting for them. They cannot create their own study plans consisting only from subjects there are interested in. In our analytical study we design a study plan that will allow a university student to choose a substantial part of subjects during university studies. This study plan is created as an example for study program Business Economics at the bachelor and master grade for full-time students of study at the Faculty of Economics and Management on the Slovak University of Agriculture in Nitra. Compulsory subjects which are added to the curriculum are necessary for further study in the chosen field. Selective subjects give students more space to choose from subjects which there are interested in and which profile them in the current field of study.
\end{abstract}

Keywords: credit system, field of study, higher education, study program, study subject

JEL Classification: I20, I21, I23,

\title{
1. Introduction
}

Tertiary education is and should be about volunteering to study and acquire knowledge and education in a field of interest and fulfillment. We choose the field we want to study on a voluntary basis and strive to be admitted to study, either on the basis of the excellent high school results achieved or by meeting the admission requirements. After entering the university, we must complete all prescribed subjects and we have very little variability in which subjects we can include in the curriculum. Therefore, there is not much space for us to choose a substantial part of the subjects that we want to complete in our study profile and which we may be more interested in as subjects that are prescribed as compulsory. The need to complete certain subjects is justified in terms of obtaining the necessary perspective for further study and profiling. It was the problem of fixation of subjects that led us to write this study, where we propose such a study plan in which the student could choose subjects according to their specialization and interest within the faculty. We assume that this would make university studies more attractive and improve the quality of subjects, which would also contribute to a decrease in students' departure abroad for study purposes.

The following selected legislative documents are important for support our analytical study.

Act No. 131/2002 Coll. about universities

Academic Freedoms and Academic Rights $\S 4$ include the right to learn while retaining the freedom of choice in accredited degree programs.

Field of study $\S 50$ is an area of knowledge that can be subject to higher education at one of its three levels. The field of study is defined by the content, which is characterized in particular by the areas and extent of knowledge and skills that profile the graduate.

Study program $\$ 51$ can be carried out in the field of study, which is part of the system of study fields. A study program is a set of courses consisting of educational activities such as a lecture, seminar, exercise, final work, project work, laboratory work, internship, excursion, professional experience, state examination and combinations thereof and a set of rules designed so that successful completion of these educational activities, while respecting the above rules, enables to gain higher education. The student's study plan determines the time and content sequence of subjects and forms of evaluation of study results. In addition to the form of evaluation of study results, the study plan is established by the student himself or in cooperation with the study advisor within the framework of the set rules and in accordance with the study rules of the university or faculty. 
Student Rights $\S 70$ are to create a study plan according to the rules of the study program; enroll in another part of the study program if he / she has fulfilled the obligations stipulated in the study program or study regulations; respecting the time and capacity constraints of the study order and study program, choose the pace of study, the order of completion of subjects while maintaining their prescribed continuity, and choose a teacher in a subject taught by several teachers.

Decree 614/2002 Coll. on the study credit system $\$ 5$

By enrollment, the student determines what part of the duties prescribed by the study program he wants to complete in the following period of study to which the enrollment applies (trimester, semester or academic year). Students enroll in subjects so that the number of credits they can earn by successfully completing them in a given period is sufficient to meet the condition for continuing their studies.

\section{Data and Methods}

In this analytical study we used synthetic-analytical and inductive-deductive method and we analysed documents and legislation. A set of documents was formed of Act no. 131/2002 Coll. about universities; Decree 614/2002 Coll. on the study credit system; ECTS user guide; Longterm Plan for Educational, Research, Development and Other Creative Activities for Universities 2016 - 2021; study plans of the Faculty of Economics and Management SUA in Nitra; study plans of the Economic University in Bratislava; study plans of the Mendel University in Brno, study plans of the Szent István University in Gödöllő. The aim was also to apply a heuristic approach to the creation of conclusions and solution proposals. All study plans at other universities were about the same or similar to the study plan of Business Economics at FEM SUA in Nitra.

We also formed some research questions which allow us to analyze the current situation, problem fields and in the end help us to form conclusions and suggesting possible solutions:

1) How does study field profiling determine the inclusion of compulsory or compulsory optional subjects in the curriculum?

2) What is the representation of subjects in the field of study in terms of graduate profiling? (every compulsory, compulsory optional, selective or are there any subjects which the student does not need in his shaping in the study field?)

3) If students from the second year can choose their study subjects by own what impact would it have for some subjects in the field? (would they disappear?)

4) Can this design strengthen the quality of university study in the Slovak Republic and would it help to reduce the outflow of students abroad?

\section{Results and Discussion}

In our study we divide study subjects which a student must pass to compulsory and selective. We therefore suggest changing the name of the nomenclature from "compulsory optional" to "selective". In this case it will be only two types of subjects - compulsory and selective. Selective subjects would be possible to choose only from offer of the faculty where the students study their studying program. 
Compulsory subjects are prescribed by the student's curriculum and cannot be changed during their studies. The student chooses selective subjects himself / herself, but their number and sum of credits must fulfill the condition for successful completion of the study.

A methodical proposal for the allocation of compulsory and selective subjects during university studies is given in Tables 1 and 2.

Table 1: Methodical proposal for the allocation of compulsory and selective subjects during the first grade (bachelor) of university study

\begin{tabular}{|c|c|c|}
\hline \multicolumn{3}{|c|}{$1^{\text {st }}$ grade of university study (Bachelor) } \\
\hline $\begin{array}{c}1^{\text {st }} \text { year } \\
\left(1^{\text {st }} \text { and } 2^{\text {nd }} \text { semester }\right)\end{array}$ & $\begin{array}{c}2^{\text {nd }} \text { year } \\
\left(3^{\text {rd }} \text { and } 4^{\text {th }} \text { semester }\right)\end{array}$ & $\begin{array}{c}3^{\text {rd }} \text { year } \\
\left(5^{\text {th }} \text { and } 6^{\text {th }} \text { semester }\right)\end{array}$ \\
\hline \multirow{2}{*}{ All subjects are compulsory } & $50 \%$ compulsory subjects & \multirow{2}{*}{ All subjects are selective } \\
\hline & $50 \%$ selective subjects & \\
\hline
\end{tabular}

Source: Own processing

The Bachelor's degree program as a first degree program focuses on obtaining theoretical knowledge and practical knowledge based on the current state of science or art. Professionally oriented Bachelor's degree programs focus on mastering the use of this knowledge in the exercise of the profession. The number of credits required to complete the course is at least 180 credits for a bachelor's program with a standard length of study ( 3 and up to 4 academic years). The final work in the bachelor study program is the bachelor thesis. (Act No. 131/2002 Coll. about Universities, §52, p. 45)

Table 2: Methodical proposal for the allocation of compulsory and selective subjects during the second grade (Master) of university study

\begin{tabular}{|c|c|}
\hline \multicolumn{2}{|c|}{$2^{\text {nd }}$ grade of university study (Master) } \\
\hline $\begin{array}{c}1^{\text {st }} \text { year } \\
\left(1^{\text {st }} \text { and } 2^{\text {nd }} \text { semester }\right)\end{array}$ & $\begin{array}{c}2^{\text {nd }} \text { year } \\
\left(3^{\text {rd }} \text { and } 4^{\text {th }} \text { semester }\right)\end{array}$ \\
\hline $50 \%$ compulsory subjects & A1 ali \\
\hline $50 \%$ selective subjects & All subjects a \\
\hline
\end{tabular}

Source: Own processing

The second degree program aims to acquire theoretical and practical knowledge based on the current state of science, technology or art and to develop the ability of their creative application in the pursuit of their occupation or in continuing their university studies according to the doctoral study program. (Act No. 131/2002 Coll. about Universities, §53, p. 46)

In our proposed study plan it is necessary to determine the number of subjects and the number of credits for completion these subjects. We are based from the law that a student needs 180 credits in the first grade of study and 120 credits in the second grade of study to successfully complete bachelor or master program. Together 300 credits. Therefore, we propose that a student has to pass five (5) subjects during each semester. Upon successful completion of the subject he/she will receive 6 credits for each subjects. This is more clearly shown in Table 3 .

Table 3: Schedule of compulsory and selective subjects with credit assessment during university studies in full-time form

\begin{tabular}{|c|c|c|c|c|c|c|c|c|c|}
\hline \multicolumn{6}{|c|}{$1^{\text {st }}$ grade of university study (Bachelor) } & \multicolumn{4}{|c|}{$2^{\text {nd }}$ grade of university study (Master) } \\
\hline \multicolumn{2}{|c|}{$1^{\text {st }}$ year } & \multicolumn{2}{|c|}{$2^{\text {nd }}$ year } & \multicolumn{2}{|c|}{$3^{\text {rd }}$ year } & \multicolumn{2}{|c|}{$4^{\text {th }}$ year } & \multicolumn{2}{|c|}{$5^{\text {th }}$ year } \\
\hline \multirow{5}{*}{$1^{\text {st }}$ sem. } & $6(\mathrm{C})$ & \multirow{5}{*}{$3^{\text {rd }}$ sem. } & $6(\mathrm{C})$ & \multirow{5}{*}{$5^{\text {th }}$ sem. } & $6(S)$ & \multirow{5}{*}{$1^{\text {st }}$ sem. } & $6(\mathrm{C})$ & \multirow{5}{*}{$3^{\text {rd }}$ sem. } & $6(\mathrm{~S})$ \\
\hline & $6(\mathrm{C})$ & & $6(\mathrm{C})$ & & $6(S)$ & & $6(\mathrm{C})$ & & $6(\mathrm{~S})$ \\
\hline & $6(C)$ & & $6(\mathrm{C})$ & & $6(\mathrm{~S})$ & & $6(\mathrm{C})$ & & $6(\mathrm{~S})$ \\
\hline & $6(\mathrm{C})$ & & $6(\mathrm{C})$ & & $6(S)$ & & $6(\mathrm{C})$ & & $6(\mathrm{~S})$ \\
\hline & $6(C)$ & & $6(\mathrm{C})$ & & $6(S)$ & & $6(C)$ & & $6(S)$ \\
\hline \multirow{3}{*}{$2^{\text {nd }}$ sem. } & $6(\mathrm{C})$ & \multirow{3}{*}{$4^{\text {th }}$ sem. } & $6(\mathrm{~S})$ & \multirow{3}{*}{$6^{\text {th }}$ sem. } & $6(S)$ & \multirow{3}{*}{$2^{\text {nd }}$ sem. } & $6(\mathrm{~S})$ & \multirow{3}{*}{$4^{\text {th }}$ sem. } & $6(\mathrm{~S})$ \\
\hline & $6(C)$ & & $6(\mathrm{~S})$ & & $6(S)$ & & $6(\mathrm{~S})$ & & $6(\mathrm{~S})$ \\
\hline & $6(C)$ & & $6(\mathrm{~S})$ & & $6(\mathrm{~S})$ & & $6(\mathrm{~S})$ & & $6(\mathrm{~S})$ \\
\hline
\end{tabular}




\begin{tabular}{|c|c|c|c|c|c|}
\hline & $6(\mathrm{C})$ & $6(\mathrm{~S})$ & $6(\mathrm{~S})$ & $6(\mathrm{~S})$ & \multirow[t]{2}{*}{12 (DT) } \\
\hline & $6(\mathrm{C})$ & $6(\mathrm{~S})$ & 6 (BT) & $6(\mathrm{~S})$ & \\
\hline OVERALL & 60 & 120 & 180 & 60 & 120 \\
\hline
\end{tabular}

Source: Own processing

Explanatory notes:

C - compulsory subject, S - selective subject, BT - bachelor thesis, DT - diploma thesis, sem. - semester

In our proposal, number of hours spent to earn credits for accomplishing a subject is not exceeded neither for the semester nor for the academic year according to ECTS (1800 hours of workload $\div 60$ credits per academic year $=30$ hours of student workload to earn one credit. The subject is based on $6 \times 30=180$ hours of workload for the student.) Since all the subjects we propose are rated by six (6) credits, their intensity is objectively very similar.

ECTS is a learner-centered system for credit accumulation and transfer, based on the principle of transparency of the learning, teaching and assessment processes. Its objective is to facilitate the planning, delivery and evaluation of study programs and student mobility by recognizing learning achievements and qualifications and periods of learning. Workload is an estimation of the time the individual typically needs to complete all learning activities such as lectures, seminars, projects, practical work, work placements and individual study required to achieve the defined learning outcomes in formal learning environments. The correspondence of the fulltime workload of an academic year to 60 credits is often formalized by national legal provisions. In most cases, workload ranges from 1,500 to 1,800 hours for an academic year, which means that one credit corresponds to 25 to 30 hours of work. It should be recognized that this represents the typical workload and that for individual students the actual time to achieve the learning outcomes will vary. (ECTS Users' Guide, 2015, p. 10)

It is also in accordance with the law (Act No. 131/2002 Coll. about universities $\S 62$ p. 56) where it is written that the organization of all degrees and forms of higher education is based on a credit system. The credit system of the study uses the collection and transfer of credits. It enables the student to evaluate the student's workload in accordance with the rules contained in the study program. Credits are numerical values assigned to subjects, expressing the amount of work required to achieve prescribed learning outcomes. The standard workload of a student for the whole academic year in full-time form of study is expressed by 60 credits, 30 credits per semester and 20 credits per trimester.

We have also reviewed the study plans of similar study fields at other faculties in Slovakia and abroad. Most of the related fields have the same credit rating of subjects as we suggest, which is positive in terms of the mobility of students in foreign internships in related study programs.

However, the skill of the student may play a role in the completion of the subjects and his/her earlier or otherwise acquired knowledge in the subject may facilitate the completion of the subject. We can also include to it motivation, personal interest in the subject, respectively other subjective factors influencing student's studies. The stated values of the student load for individual subjects are therefore only approximate. These values must be stated in the information sheets of the subjects, which must be available to the students, especially if they already choose the subjects in the second, third, fourth and fifth year.

In the fourth year of study we left $50 \%$ of the subjects' compulsory. It is while in the second grade, it may happen that a student entering the second grade may be a graduate of another university or other field and therefore may not be familiar with the subjects, that are being taught.

Creating schedules 
In order to ensure that students can choose one of the selective subjects and be included in the schedule, they need to select selective subjects up to and including the 6th week of the $3^{\text {rd }}$ semester (inclusive) through the university information system in the second year. After this deadline schedules for $4^{\text {th }}$ semester will be created. For the third year, the student selects the subjects for the $5^{\text {th }}$ semester until $30^{\text {th }}$ June of the $4^{\text {th }}$ semester of the second year. In the $3 \mathrm{rd}$ year student chooses the subjects in the same way as in the 2 nd year, i.e. in the $5^{\text {th }}$ semester up to the 6 th week (inclusive). In the 4 th and 5 th year the same principle of selection subjects applies as during the 2 nd and 3 rd year.

The choice of subjects through the university information system would be open in the system from the 1st day of the 2 nd week of the winter semester, which represents a minimum of 5 weeks, during which students have the opportunity to obtain sufficient information about subjects, whether or not to include the subject in the curriculum. During the summer semester, the possibility of subject selection through the information system would be open from the 6th week of the summer semester to the mentioned 30th June.

Selective subjects can only be selected from the faculty subjects and not from other faculties. At FEM SUA in Nitra there are 129 selective subjects, which profile the student within his / her field of study at the faculty. However, a student may include a subject (s) from another faculty in his study plan, but the subject (or subjects) may not overlap with the subject in the schedule he has at his faculty where he is studying his study program. Also, these subjects from other faculties do not count towards the total number of credits after successful completion, necessary to successfully complete the study at the faculty. We offer this choice of subjects from other faculties to enable students to have a wider range of interest in subjects.

Subjects may not be repeated in the course of the study in the sense that in the 2 nd year in $4^{\text {th }}$ semester the student chooses the subject Accounting for Entrepreneurs and in the third year he would also like to choose this subject e.g. in the $5^{\text {th }}$ semester. Such a combination is not possible. The student must transfer the subject to the next year if he / she did not complete it in the previous academic year.

As there are more selective subjects and to avoid the preference of one subject, we propose to limit the number of students per subject. The minimum number of students per subject will be 5 and the maximum number of students will be 50. If we count with approximately 400 students per year, the minimum number of selective subjects in the second year of the summer semester and the other semesters of the upper years would be 8 .

With this method of choice of subjects, some subjects may become unattractive to students and may disappear. The possibility of solving this situation is that the teacher who teaches the subject teaches the subject at such a level, to make it attractive to students and therefore to choose it as a selective subject, resp. students from other faculties could also choose it. However, the subject information sheets must be drawn up in such a way that the student can see the distribution of the subject matter per semester during the weeks and the content of the subject matter. The student must have enough information to decide, whether it needs the subject in his study profile and whether it chooses the subject in its curriculum. It is also possible to consult subjects with teachers in order to find out more details about the subject.

We describe an example of the compulsory and selective subjects for the Business Economics study program at the first and second grade of study. Compulsory subjects would vary according to degree programs. However, selection subjects would be the same for all programs. We do not mention the code numbers of subjects because they are different when applying our study and some subjects may merge into one, e.g. Statistics A and Statistics B to the subject Statistics. 
Table 4: A sample example of compulsory and selective subjects for the Business Economics study program at the bachelor's degree

\begin{tabular}{|c|c|c|c|c|c|}
\hline \multicolumn{6}{|c|}{$1^{\text {st }}$ grade of university study (Bachelor) } \\
\hline \multicolumn{2}{|c|}{$1^{\text {st }}$ year } & \multicolumn{2}{|c|}{$2^{\text {nd }}$ year } & \multicolumn{2}{|c|}{$3^{\text {rd }}$ year } \\
\hline $1^{\text {st }}$ sem. & $2^{\text {nd }} \operatorname{sem}$. & $3^{\text {rd }}$ sem. & $4^{\text {th }}$ sem. & $5^{\text {th }}$ sem. & $6^{\text {th }}$ sem. \\
\hline World Language & Statistics & Microeconomics & $\mathrm{S}$ & $\mathrm{S}$ & $\mathrm{S}$ \\
\hline $\begin{array}{l}\text { Introduction to } \\
\text { Economics }\end{array}$ & $\begin{array}{l}\text { Basics of } \\
\text { Accounting }\end{array}$ & $\begin{array}{l}\text { Operations research - } \\
\text { Optimum } \\
\text { programming }\end{array}$ & $\mathrm{S}$ & $\mathrm{S}$ & $\mathrm{S}$ \\
\hline $\begin{array}{l}\text { Basics of } \\
\text { Management }\end{array}$ & $\begin{array}{l}\text { Business } \\
\text { Economy }\end{array}$ & Financial Analysis & $\mathrm{S}$ & $\mathrm{S}$ & $\mathrm{S}$ \\
\hline Mathematics & Law & Corporate Planning & $\mathrm{S}$ & $\mathrm{S}$ & $\mathrm{S}$ \\
\hline Informatics & Marketing & Macroeconomics & $\mathrm{S}$ & $\mathrm{S}$ & $\mathrm{S}$ \\
\hline
\end{tabular}

Source: Own processing

Table 5: A sample example of compulsory and selective subjects for the Business Economics study program at the master's degree

\begin{tabular}{|l|c|c|c|}
\hline \multicolumn{4}{|c|}{$\mathbf{2}^{\text {nd }}$ grade of university study (Master) } \\
\hline \multicolumn{1}{|c|}{ year } & \multicolumn{2}{c|}{$\mathbf{2}^{\text {nd }}$ year } \\
\hline $1^{\text {st }}$ semester & $2^{\text {nd }}$ semester & $3^{\text {rd }}$ semester & $4^{\text {th }}$ semester \\
\hline Taxation of Business Entities & $\mathrm{S}$ & $\mathrm{S}$ & $\mathrm{S}$ \\
\hline International Management and Business & $\mathrm{S}$ & $\mathrm{S}$ & $\mathrm{S}$ \\
\hline Data Mining & $\mathrm{S}$ & $\mathrm{S}$ & $\mathrm{S}$ \\
\hline Price and Pricing Policy & $\mathrm{S}$ & $\mathrm{S}$ & $\mathrm{S}$ \\
\hline Financial Management and Business Risk & $\mathrm{S}$ & $\mathrm{S}$ & $\mathrm{S}$ \\
\hline
\end{tabular}

Source: Own processing

Compulsory subjects have been chosen as basic subjects for the profiling of a student in a given field and should provide him with an insight into the needs of further study as well as the necessary knowledge for successful completion of the study as well as the creation of the final thesis.

Selective subjects are not limited by the grade of study. Therefore, a 2nd year student can select a subject which was before integrated in the, e.g. 4th year of study. The only condition for selective subjects is that the student can complete the extension of the subject, e.g. for Econometrics II must first complete Econometrics I, i.e. to integrate Econometrics I into the study plan first. These are so called subjects according to continuity - subjects conditioned by successful completion of other subjects (Decree 614/2002 Coll. on the Credit System of Study $\S 3$, p. 1).

In the first year of study, the World Language chosen by the student prior to commencement of study is a compulsory subject. In the following years, the student can choose another world language he wants to study. However, if he wants from a given language, e.g. English, to pass the UniCert II (B2) exam, he needs to complete the English language during four (4) semesters, i.e. World Language B, C, and D.

We also included Professional Practice in the selection of selective subjects. Students often carry out temporary work during their studies and therefore we propose that temporary work related to the field of study will be recognized as Professional Practice. There is a need of a practice coordinator for Professional Practice who decides if the temporary work is relevant to the field of study and can be recognized as this subject or not.

According to Decree No. 614/2002 Coll. on the Credit System of Study $\S 3$ 1.p, the final thesis - bachelor and diploma thesis - is considered as a subject. The final thesis is chosen by the student in university information system which must be completed, because their defense is a condition for successful completion of study at the given faculty. Final thesis is categorized as 
a selective subject, because the student chooses the supervisor of his / her final thesis. As soon as he / she chooses a supervisor or enrolls on a topic through the university information system, the student automatically assigns the final thesis as a selective subject to the relevant year and semester. From a technical point of view, this is a selective subject, but in practice the student chooses the topic of the final thesis announced by the supervisor, as its elaboration and defense are a prerequisite for successful completion of the study (compulsory subject).

A similar study model has been implemented in India at Rajarambapu Institute of Technology (RIT) as Choice Based Credit System (CBCS) for Engineering students in four years of study and for MBA students. They observed that inclusion of CBCS in academics has improved the placement, number of students admitted for higher studies and entrepreneurs. This model is more oriented on practical skills, but the way of forming a student's curriculum is very similar. The CBCS has many benefits: it offers a "cafeteria" approach in which the students can choose courses/subjects of their own choice; they can learn at their own pace because one size is not fit all; students need to be satisfied as per aspirations; the CBCS allows a student to study what he prefers in his own sequence as per his interests; students can also opt for an interdisciplinary approach to learning; the system improves the job opportunities of students; the system will help in enabling potential employers assess the performance of students on a scientific scale. (Kulkarni, Patil, 2019, 1.p)

\section{Conclusion}

For the implementation of our proposal, it is necessary for the applicants to meet certain prerequisites, which should be a matter of course when entering the university. These prerequisites include ambition, awareness, independence and purposefulness. The advantage would be if students already enrolled in the study had an idea of their future career orientation, which directly affect the choice of subjects in higher years of study. Unfortunately, we are now abandoning student demands because our education system is focused on quantity and not on student quality. Of course, this is related to the financing of education. On the other hand, the number of students at universities is decreasing due to the demographic curve and the related outflow of students abroad, whether for study or for work. We assume that our proposal would increase the motivation of students to study at universities mainly in Slovakia and at the same time would increase the attractiveness of offered study programs.

Our proposal is also supported by Long-term Plan for Educational, Research, Development, Artistic and Other Creative Activities for Universities 2016 - 2021 and that Ministry of Education, Science, Research and Sport of the Slovak Republic is interested in removing obstacles to higher education. At the level of students, it is about making full use of the possibilities of the credit system, such as student mobility within a university, but also between universities, both vertically and horizontally.

\section{References}

[1] Act no. 131/2002 Coll. on Universities. (2016) (Zákon č. 131/2002 Z. z. o vysokých školách a o zmene a doplnení niektorých zákonov $\mathrm{v}$ znení neskorších predpisov.) $123 \mathrm{p}$. Retrieved from https://www.portalvs.sk/sk/dokumenty-na-stiahnutie/2

[2] European union. (2015). ECTS Users' Guide 2015. Luxembourg: Publications Office of the European Union, (ISBN 978-92-79-43559-1) Retrieved from https://ec.europa.eu/education/resources-and-tools/documentlibrary/ects-users-guide_en

[3] Kulkarni, S., \& Patil, S. (2019). Choice Based Credit System (CBCS) - An Experimental Learning Approach at RIT, 2018 World Engineering Education Forum - Global Engineering Deans Council, WEEF-GEDC 2018, 29 January 2019, 4 p. Doi: 10.1109/WEEF-GEDC.2018.8629671 
[4] Decree of the Ministry of Education of the SR 614/2002 Coll. on Credit System of Study. (2002) (Vyhláška MŠ SR 614/2002 Z. Z. $\quad$ z. o kreditovom systéme štúdia.) 15 p. Retrieved from https://www.portalvs.sk/sk/dokumenty-na-stiahnutie/4

[5] Mendel University in Brno. (25-11-2019) Business Economics and Management-bachelor. Recommended plan. Retrieved from https://www.pef.mendelu.cz/b-emaj-meaj

[6] Mendel University in Brno. (25-11-2019) Business Economics and Management - master. Recommended plan. Retrieved from https://www.pef.mendelu.cz/meaj

[7] Ministry of Education, Science, Research and Sport of the Slovak Republic. (2016). Long-term Plan for Educational, Research, Development, Artistic and Other Creative Activities for Universities 2016 - 2021 (approved by the Government of the Slovak Republic 09.11.2016) Retrieved from https://www.minedu.sk/dlhodoby-zamer-vo-vzdelavacej-vyskumnej-vyvojovej-umeleckej-a-dalsejtvorivej-cinnosti-pre-oblast-vysokych-skol-na-roky-2016-2021-schvaleny-vladou-sr-09112016/

[8] Slovak University of Agriculture in Nitra. (25-11-2019) Faculty Economics and Management. Study programs for 1 st degree - bachelor. Business Economics study plan. Retrieved from https://fem.uniag.sk/tl_files/fem/documents/blok\%20STUDIUM/Bakalarske\%20studium/studijne\%20plany /2016/Studijny\%20program\%20EP.pdf

[9] Slovak University of Agriculture in Nitra. (25-11-2019) Faculty Economics and Management. Study programs for 2nd degree - master. Business Economics study plan. Retrieved from https://fem.uniag.sk/tl_files/fem/documents/blok\%20STUDIUM/Inzinierske\%20studium/studijne\%20plany /2016/Studijny\%20program\%20EP.pdf

[10] Szent István University. (25-11-2019) Faculty of Economics and Social Sciences. Business Administration and Management (bachelor) and Management and Leadership (master) student guide. Retrieved from http://gtk.sziu.hu/sites/default/files/upload/flipbook/student-guide_2018-2019.pdf

[11] University of Economics in Bratislava. (25-11-2019) Jednotky študijného programu pre bakalárske štúdium - I. stupeň. Faculty of Business Management. Ekonomika a manažment podniku - $1^{\text {st }}$ grade. Retrieved from http://betafpm.euba.sk/www_write/files/studium/1-2stupen/dobiehajuca-akreditacia/UP1st_EMP.pdf

[12] University of Economics in Bratislava. (25-11-2019) Jednotky študijného programu pre bakalárske štúdium - II. stupeň. Faculty of Business Management. Ekonomika a manažment podniku - $2^{\text {nd }}$ grade. Retrieved from http://betafpm.euba.sk/www_write/files/studium/1-2stupen/dobiehajuca-akreditacia/UP2st_EMP_EP.pdf

[13] Virágh, R., Jedličková, L., Virághová, S., \& Stuchlý, P. (2019). Credit system of study and possibilities of student mobility in the context of student profile and graduate profile of FEM SUA in Nitra: Analytical study. Vybrané otázky terciárnej edukácie, Edícia Universitas Moderna. 14 p.

\title{
Education for Sustainable Development and the Possibilities for Its' Implementation into the Teachers Preparation
}

\author{
Tímea Šeben Zat'ková ${ }^{1}$ \\ Slovak University of Agriculture in Nitra \\ Faculty of economics and management, Centre of Education and psychological counselling, \\ Tr. A. Hlinku 2, 94976 \\ Nitra, Slovakia \\ e-mail: timea.zatkova@uniag.sk ${ }^{1}$
}

doi: 10.18515/dBEM.ISD.P01.2020.p060 


\begin{abstract}
Education for Sustainable Development currently belongs to the modern trends in education and it is therefore necessary that teachers working in pedagogical practice are also trained in this field. The study presents brief theoretical analysis of the ESD and proposals for its implementation in the preparation of teachers on the basis of an analysis of the study plan of the Supplementary pedagogical study at the Slovak University of Agriculture in Nitra. According to the analysis, we can state that out of all 15 analyzed courses of the actually accredited program of Supplementary pedagogical studies, all courses have the potential of ESD themes implementation. However, this issue is not explicitly stated in the syllabuses of the current courses and also the prescribed themes by the Slovak ministry of Education do not include it, we plan to implement ESD into the curriculum for the next period of accreditation process, which starts in 2020.
\end{abstract}

Keywords: education to sustainable development, sustainable development, teacher preparation

JEL Classification: I21, I23, Q56

\title{
1. Introduction
}

Education for Sustainable Development (ESD) is currently a developing and very actual issue in the educational process due to the current changing social and natural conditions. ESD can be understood in various ways. Sometimes it can be explained in literature as: new trend in education, sometimes it is understood as a conception or dimension, approach, principle, educational content, topic, etc. Despite the many possible views at ESD, it should be remembered that this is indeed a phenomenon of the present time, which is addressed worldwide not only in educational theory and practice, but also in the economic, social or political spheres.

ESD is a new need, a need to respond to the growing number of people living in one place (and in our planet at all), and therefore it is a matter of importance and even dare to say that it is very vital. It is a response to current living conditions in the era of globalization, it is a reaction to deepening global problems, to the ecological crisis, and it includes the expert discussions on the carrying capacity of the environment, etc.

The aim of contemporary education of the 21 st century is to educate and teach people to live in changed and changing conditions differently, to adapt to the global reality of the world. This topic is brought to education programs by people who are aware of the existence of global problems and at the same time believe that something can still be changed. Concerns about our future are not the only reason for the need to implement ESD, but also the effort to maintain the mental and physical health of man.

The concepts of sustainability and sustainable development began to be used in the early 1970s, especially in the context of knowing that uncontrolled growth of any (population, production, consumption, pollution, etc.) is unsustainable in an environment of limited resources (Národná stratégia trvalo udržatel'ného rozvoja SR, 2001).

ESD is usually understood as education that promotes changes in knowledge, skills, values and attitudes in order to create a more sustainable and fair society for all. The aim of ESD is to strengthen and equip current and future generations to meet their needs using a balanced and integrated approach to the economic, social and environmental dimensions of sustainable development.

In short, sustainable development is to be integrated into education and education into sustainable development. ESD supports holistic and transformative education. This type of education deals with the content and learning outcomes, innovative pedagogy and 'learning in 
practical situations' and uses a school-wide approach to engage communities in achieving sustainable change. ESD supports teaching and learning in an interactive, student-centered way that enables research, action and transformation learning. Students have the opportunity to think critically and systematically to develop values and attitudes towards a sustainable future (Leicht, Heiss, Byun, 2018).

\subsection{Education and training for sustainable development in schools in Slovakia and its resources}

Sustainable development (SD) as a global development program for the 21st century was declared at the United Nations Conference on Environment and Development in Rio De Janeiro (1992). The basic document of the SD is the Declaration on the Environment and Development, which defines 27 principles (Toma, 2001). Guidance on how to translate these principles into life is represented by AGENDA 21, which is considered to be the first global document on the application of SD in different spheres at different hierarchical levels (In Kolšovská, 2009).

Membership in various international and European institutions gave the Slovak Republic the task of adopting several international policy documents and legal bases. In the context of a wide-range agenda at national and international level, there are also requirements for the preparation of teachers and their further education for the implementation and management of ESD. This need for teacher education is grounded in several documents.

Since the publication of Agenda 21 in 1992, the development of ESD has been observed worldwide. The idea of sustainability, despite its economic and social context, is usually primarily associated with ecology in a broad sense. Further coherence of the two educational approaches can be seen in the spreaders of ESD, which are often the same people who originally (and often continue to do) environmental education (EE). On the other hand, there are still ambiguous relationships between ESD and EE. In general, there are three types of EE and ESD relationships that occur in different countries:

a) Identical importance of EE and ESD - it is a perception of both concepts as synonyms, but this may make it difficult to communicate and implement in practice. This relationship therefore proves impractical.

b) ESD covers / builds on EE - as one of the pillars of education for sustainable development is the environmental perspective, some authors believe that education for sustainable development is linked to and extends environmental education. The UNESCO report (2009) points out that this may be a 'common sense', where the same activities as in the original EE continue to be carried out and, due to long tradition, are almost identical to the scope of ESD. Given the new (especially financial) opportunities for ESD support, these activities are merely "renamed." The US example is an example where $\mathrm{EE}$ is already a firmly built and functioning educational strategy and confrontation with ESD may be perceived as negative by the public.

c) EE and ESD as two partially overlapping conceptions - at present, particular educational and research institutions devote themselves to one or the other branch separately. EE is then understood in a narrower sense as education and enlightenment on the environment and ecology (Beyersdorf et al., 1998), while ESD is significantly multidimensional (Stoltenberg, 2008; De Haan, 1998) and refers to three, or several pillars of sustainability: ecological, economic, social, or cultural. The environmental component remains common to both concepts, as well as part of educational methods and forms ( In Kindlmannová and Vošahlíková, 2010). 
Kindlmannová and Vošahlíková (2010) state that both concepts overlap in a methodical and thematic way in many ways, but a fundamental difference can be seen in their theoretical starting points and their overall impact on education. EE can be more understood as a whole of themes, methods and forms of education created over the years, which is confirmed, among other things, by the existence of the cross-cutting theme of environmental education in educational programs in Slovakia. ESD is more of a perspective from which very different contents can be seen and realized. ESD then represents a kind of "added value" that enriches formal, non-formal and informal learning.

Education, in addition to being one of the fundamental human rights, is a prerequisite for achieving sustainable development and an important tool for effective governance, reasoned decision-making and the development of democracy. ESD develops and strengthens the ability of individuals, groups, communities, organizations and countries to make their own choices and choices in favor of sustainable development. It can lead to a change in people's views and thus enable them to make this world safer, healthier and more prosperous, thereby increasing the quality of life. ESD can provide critical thinking and awareness-raising as well as expanding opportunities, thus enabling the development of new concepts and the development of new methods and tools (Stratégie európskej hospodárskej komisie OSN pre výchovu k trvalo udržatel'nému rozvoju, 2007).

\subsubsection{Resources for ESD in Slovakia}

The gradually and intensively developing efforts to implement ESD into practice at the international and national levels led to the elaboration of the National Sustainable Development Strategy of the Slovak Republic (Národná stratégia trvalo udržatelného rozvoja SR, approved by the Government Resolution No. 978/2001 and the National Council Resolution No. 1989/2002) followed by the Action plan.

The Action Plan for 2005-2010 (Akčný plán trvalo udržatelného rozvoja v SR na roky 20052010, 2005) defined as one of its objectives the implementation of the basic principles of sustainable development in the curriculum at all levels of schools in the Slovak Republic and in the system of lifelong learning. In this respect, the integration of the Strategy for Sustainable Development into the education process and the development and approval of a new Concept of environmental education and training were envisaged (Koločány, 2006). The Action Plan already sets out particular objectives and needs for the Slovak Republic. The actual preparation of the action plan was carried out under the responsibility of the Office of the Government of the Slovak Republic, which can be considered as an important fact confirming the cross-sectoral character of the issue of SD (Hilbert, 2007).

The innovated Conception of Environmental Education and Training at all stages of schools in the Slovak Republic and in the Lifelong Learning System was approved by the Minister of Education of the Slovak Republic and the Minister of the Environment in July 2006. Huba drew attention to the unfavorable trend in this area after the end of the implementation period (20052010) of that Action Plan and after the interruption of the Commission for ESD activity (2013, In Ružičková, Nevřelová, Lehotská, 2015).

The conception considers ESD as a key factor in environmental education. The new concept of EE sets four basic priorities: (1) Adoption of philosophy, objectives and strategies to implement education for sustainable development, (2) Improving the quality of education in environmental education, (3) Innovation of EE and (4) extension of Concept of Environmental Education from 1997 on the aspect of ESD (Hilbert, 2007b).

Subsequently, the Action Plan on Education for Sustainable Development was developed. It also strives to translate ESD into a curricular transformation. The following environmental 
themes were proposed: Natural sciences around us; Energy and its transformations; Process, change, movement; Earth and space; Composition of substances; Communication. The topics are defined in a very general way, they are elaborated in detail within the particular study plans and curricula. As stated by Izakovičová (2010), the application of new tools for effective education and training - life orientation, application of new progressive didactic methods, increased competences for schools, etc. can be considered as a positive curriculum transformation. On the other hand, that freedom may cause environmental education to be marginalized in the particular school. This will largely depend on the environmental maturity of the teachers (Izakovičová, 2010).

Taking the following look at the practical implementation of ESD in our schools and its evaluation, we can say that it is a process that is in development and is almost at the beginning:

For example, Hilbert (2007) focused on the evaluation of the implementation of measures and the level of environmental knowledge of secondary school pupils, which was developed in 2000/2001 by the State School Inspectorate, thus implies the following:

The measures of the Concept are fulfilled at an average level. The incorporation of the curriculum of environmental minimum into the thematic plans at grammar schools is at a good level, at secondary vocational schools and secondary technical schools is only at an average level. Further education of teachers in the environmental field and the use of new materials and teaching aids is below the average level, the extracurricular activities of pupils in environmental area are on average level. The project - Schools Promoting Health is used in schools differently with regional differences. The measures resulting from national conferences are implemented at an average level. The average elaboration of the Concept of environmental education at schools prevails, the function of the coordinator is little widespread, which causes that integration and cooperation in the field of ecology and environmental science education reached only an average level. The level of environmental knowledge can be considered good to average.

Three years later, the Concept of Education for Sustainable Development in Slovakia was critically evaluated by conservationists: Ros (2004) states that ESD is all about seeking interconnection and education for responsibility. The definition and nature of SD understand only about $10 \%$ of teachers, which is low. He states that the notion of sustainable development is nowadays the motto that can be used to slap everything.

Whether sustainable development is the right way in education comments Hipš (2005) as follows: „As we develop more and more economically, we will inevitably need more resources and material from our planet, produce more waste, emissions ... I do not believe that humanity can align its material development while protecting the environment. Because I know that the planet has its limits, and human civilization cannot develop further in the current direction. Or it can, but not so that life on Earth can be sustainable."

In 2009, based on both theoretical and empirical experience, the following conclusions and recommendations were formulated as a result of the 5th National Conference on Education and Sustainable Development (5 národná konferencia, 2009):

- to clarify the coexistence of the terms 'environmental education' and 'sustainable development education',

- from the perspective of institutional instruments of ESD to strengthen the role of schools by possibilities of drawing on funds earmarked for ESD in the Ministry of Education, 
- to implement sustainable development across all teaching subjects and newly take in account the inclusion of cross-cutting themes ensuring a comprehensive concept of ESD;

- the tool of implementation is primarily the lifelong learning of teachers of particular subjects,

- to strengthen the key role of school directors and coordinators of ESD;

- lifelong learning is a tool for educating and managing schools in the field of sustainable development,

- to pay more attention to the founders of schools and hold meetings of their representatives and exchange of experience at national level with the presentation of good experience from abroad..

Similarly, Klimková (2017) evaluates ESD critically. According to her, the issue of ESD is still a marginal in Slovak conditions, it is reflected little, dialogue is sporadic; Despite the relatively long tradition of environmentally oriented fields of study in the countries of Central and Eastern Europe, it appears that the concept of ESD rather did not catch in the Slovak context. As some experts and theorists have pointed out, the reason why this is so will seem to be hidden in the fact that it is a fundamentally new type of education, transdisciplinary, open.

On the issue of transdisciplinarity and interdisciplinarity in ESD, Vladyková (2015, p. 109) states the following: „Complex societal challenges require hybrid solutions', this is implying continuous discourses and collaboration across the natural sciences, social sciences and humanities and the practical sphere of civil society (organizational practice, environmental practice, environmental movement). It is an educational concept (interdisciplinary in nature), which is relatively difficult to transform into specific educational and study programs and places high demands on the diverse competences of teachers related to the creativity and development of non-cognitive abilities much more than theoretical expertise. At the same time, this represents a challenge and a requirement to implement the concepts of sustainability and sustainable development, without distinction of major, in all undergraduate training programs. We fully agree with the above, but we note according to our experience, that in our undergraduate teacher training, only science teachers are really trained in sustainability concepts and teachers of other subjects lack that preparation. Environmental education can now be acquired at several faculties of Slovak universities in the form of master's or engineering studies, but what should be emphasized is that the environmental pillar is only one part of the concept of sustainable development. Other pillars are economic, social or human principles. The Johannesburg Declaration (2002) formulated the thesis of "collective responsibility for improving and strengthening the independent and mutually supportive pillars of sustainable development" (Kates et al., 2005).

Recent research show (UNESCO, 2012; Tilbury -Mulá, 2009, UE4SD, 2015, In Klimková, 2017):

- higher education does not take into account strategic documents of ESD and the EU vision of sustainability;

- ESD is rather a marginal issue in Slovakia or part of the curriculum and professional preparation of only several environmental programs;

- the UNESCO Final Report (2012) says that the ESD has not reached its full potential and that there are obvious problems in overcoming disciplinary boundaries (UNESCO, 2012, In Klimková 2017). 
As indicated above, in the Slovak educational practice ESD is implemented within environmental education. Formal EE in Slovakia is concentrated in schools. It is covered by the State Education Program, from pre-primary education up to secondary vocational education. At all levels of education, it is defined as a cross-cutting theme falling within the relevant educational areas. Cross-cutting themes defined in the curricula should be implemented by all teachers across all subjects. However, it is questionable to what extent are the cross-cutting themes implemented in real practice and whether it is not only at the level of formal documents.

In general, schools at all levels fulfill the content of environmental education by implementing diverse activities and projects. A more comprehensive approach to EE prove schools, that present the environmental focus and objectives in their school curricula and have been involved in long-term projects. These conclusions in the category of pre-primary education were reached also by the State School Inspectorate, presented in Report on environmental education in kindergartens in the school year 2012/2013 in Slovakia. Formal EE is coordinated by the Ministry of Education of the Slovak Republic (MŠVVaŠ SR). Recommendations for closer cooperation between the Ministry of the Environment and the Ministry of Education of the Slovak Republic in developing the curriculum are therefore justified. For this reason, it is important to define the necessary areas of education in the area of environmental care by the Ministry of the Environment. Equally important is mutual cooperation in the creation of publications and in activities focused on formal environmental education. In the case of recategorization of environmental education from a cross-cutting theme to the educational area, together with the development of curricula and publications, better results could be achieved in practice in the future (Rezortná koncepcia environmentálnej výchovy, 2015).

\section{Data and Methods}

The study is based on a theoretical review of relevant text sources defining the issues of ESD. The second part of the study is aimed at the content analysis of the curriculum of the Supplementary pedagogical study that is guaranteed by the Center of Education and Psychological Counseling of the Faculty of Economics and Management at the Slovak University of Agriculture in Nitra (SUA). Particularly analysis of study plan and syllabi of Supplementary pedagogical studies at SUA in Nitra was carried out with the aim to identify the opportunities for ESD implementation. A verbal interpretation of the results was used with the suggestion of possibilities for implementation of topics containing the issues of ESD in the framework of the preparation and training of future teachers of professional vocational subjects.

\section{Results and Discussion}

Teacher training is traditionally offered by universities. Vocational education teaching (VET) teachers, who are university graduates from other than teacher programs look for receiving full teacher qualification by completing Supplementary pedagogical studies aimed at acquiring of pedagogical competence. SUA prepares in addition to the future experts in the accredited study programs in various fields of study, also future teachers of vocational subjects (economic/ technical/ agricultural/ food science subjects) through Supplementary pedagogical study (SPS) in full-time and part-time study programs. In the preparation of these future pedagogical staff, their study plan includes courses that actually contain, or have the potential in the future to include the issues of ESD. Programs are actually accredited according the rules of Slovak 
Ministry of Education since the year 2014, but the year 2020 is the year in which their reaccreditation process starts.

The study is currently divided into modules: pedagogical-psychological; field-didactics; pedagogical practice, and subject-field module. Study plan of the SPS at SUA is shown in the table 1 .

Table 1: Study plan of Supplementary pedagogical study

\begin{tabular}{ccc}
\hline Course & Lessons & Credits \\
\hline 1st semester & & \\
\hline 1. Technology of education & 13 & 2 \\
2. General didactics & 26 & 4 \\
3. Pedagogical propedeutics & 13 & 2 \\
4. General and developmental psychology & 26 & 5
\end{tabular}

\begin{tabular}{lll}
\hline 2nd semester & & \\
\hline 5. Pedagogical communication & 13 & 3 \\
6. Theory of education & 26 & 4 \\
7. Didactics of vocational subjects & 39 & 6 \\
8. Pedagogical and social psychology & 39 & 6 \\
\hline 3rd semester & 13 & 2 \\
\hline 9. Classroom observation practice in & & 3 \\
$\quad$ vocational training & 26 & 3 \\
10. Methodology of vocational subjects & 26 & 3 \\
11. Methodology of research and educational \\
$\quad$ diagnostics
\end{tabular}

Source: SUA, 2017

For the new accreditation process, that starts in the year 2020 are prescribed by the Ministry of education the following themes and the minimal number of lessons, that have to be implemented into the curriculum of Supplementary pedagogical studies (Zákon o pedagogických a odborných zamestnancoch, 2019, § 44 ods. 3 a 5) :

1. Pedagogical and psychological basis (min. 90 lessons):

1.1. School system, state educational programs, 1.2. Theoretical models of learning and education, 1.3. The education of pupils with special educational needs, with an emphasis on the principle of equal access to education and taking into account the educational needs of the individual and their responsibility for their education; the principle of prohibiting all forms of 
discrimination and especially segregation, 1.4. Diagnostics and assessment of pupils, 1.5. Psychological aspects of pupil development, 1.6. Psychological aspects of creating social relationships at school, 1.7. Prevention of problematic behavior of pupils, 1.8. Pedagogical communication,

2. Social-science base (min. 20 lessons),

3. Field-didactic thematic unit or Subject-didactic thematic unit (min. 50 lessons) and Teaching practice (min. 40 lessons):

3.1. Design and implementation of teaching subjects, 3.2. Developing key competences of pupils in teaching subjects, 3.3. School educational program, 3.4. Self-reflection and selfevaluation of the teacher, 3.5. Creation of teaching materials and use of computer technology and presentation techniques in teaching, 3.6. Teaching practice.

Through the content analysis of the current curriculum and the syllabi of courses taught at SUA were identified (according to SUA, 2017) the following courses and topics in which ESD can be applied:

Pedagogical propedeutics - is the first pedagogical discipline students meet during their study. Students are acquainted with the basic pedagogical terminology and topics aimed at the types of the educational environment and the determinants of education, its aims, forms, means, and content of education. Global Education as well as multicultural and intercultural education, environmental education and ESD are considered as relatively new components of the educational content and they are briefly described in the course. In this course students learn also about the brief history of pedagogy. As part of the historical overview of different pedagogical conceptions and approaches, they are also in short informed about the origins and existence of global education and ESD.

In the course - General didactics, the following topics have potential to inform students about innovative educational methodologies and especially methodology of ESD: Pedagogical documents specifying the content of education, Goals and specific aims of education, Key competences in education. These topics have potential to include ESD issues by highlighting the theme of global education, environmental education and ESD as part of the pedagogical documentation and one of the target areas of competences development and education at each level of education. As the course includes also the theme on educational conceptions and the teaching methods as well, there is also an opportunity to familiarize students with the concept of ESD as one of the modern conceptions of education. It is also suitable to familiarize students with the methods and methodologies of ESD in the topic Teaching Methods.

Similarly, the themes of ESD can be implemented in the course - Didactics of vocational subjects (economic/technical/agricultural/food science), especially within the topics: Goals and objectives in vocational education; Society wide objectives in vocational subjects; Analysis of the general and specific objectives in vocational education; Content of education in VET; Didactic analysis of the content in a professional subject; Interdisciplinary and inner relationships in professional subjects. Under these themes, ESD can be analyzed in terms of its objectives, content and with regard to cross-curricular relationships to content of vocational subjects. Also the theme of key competences and their development in VET is analyzed in this course, so there is a space to underline the need for competences for sustainable development.

In the course Methodology of vocational subjects is possible to emphasize global sustainable dimensions in the following topics: Didactic principles in the teaching of vocational subjects; Forms of education in VET and possibilities of their use; Overview of educational methods and their use in the teaching of vocational subjects. Within these themes, it is possible to analyze specific methods, methodological procedures and organizational forms of education with 
application in vocational education and training. There is also a potential and enough space to specify the possibilities of ESD implementation into the specific vocational subjects.

The greatest scope for the development of skills, competencies and values of ESD in the training of VET teachers provides the course - Theory of education. Content of the course deals with specific content components of education, pedagogical approaches and their process. For example the course includes topics like: Multicultural Education - its' essence, process and realization aspects; Environmental and ecological education - its aims, content, forms, methods, means; Family and sexual education - their aims, content and methods; Moral education; Prosocial education- its aims, content, forms, methods, means; Current educational problems (social pathology, child aggression and criminality, work with Roma ethnicity,...); Family and social education - its aims, content, forms, methods, tools. These themes according to our opinion really contribute to education about human rights, education about sustainability, peace education and conflict prevention and intercultural education, which are a global dimension of education for civil rights and responsibilities. Finally, above mentioned themes are the basis for developing views and attitudes towards ESD and create the platform for emphasizing its' value dimension. This course is mainly focused on highlighting the goals, tasks, content, forms, tools and methods of specific content components of education (not only those previously mentioned), but with the main focus on personality development, value education, humanistic approaches implementation and positive education that are the component parts of ESD.

Great scope for highlighting the issues of development of competences for ESD and soft skills development provide psychological disciplines, mainly the courses: General psychology; Pedagogical and Social psychology. The most suitable topics included in psychologic disciplines and finally leading to implementation of ESD in teacher preparation are: Social attitudes; Social Communication; Social groups; Assertiveness and Empathy; Stress and conflict situations in the decision-making process; Change of attitudes and value orientation; Social motivation; Forms of social behavior (assertiveness, non-aggression, aggression); Social groups; Social motivation; Dynamics of small social groups; The leadership in small groups. The topics discussed in psychology are connected with several areas of human personality. They are related not only to the cognitive but also the affective aspects of the personality, and we can say that influencing the affective area is the most important for the education for SD.

ESD issues can be implemented also within the course Pedagogical communication in vocational education. Selected topics can be applied to human rights education and to their protection. Some of the specific topics in this course are: Basic knowledge of pedagogical communication; Principles and forms of interpersonal communication and Rules of discussion. There is also place for practicing the real communication skills that are necessary for development of competences for SD.

Within the subject-field module in accordance with the student's specific field of study, either in economic, agricultural, food or technical fields, there is also scope for inclusion of topics of sustainability and SD. Of course, these topics and specific courses are already within the competence of particular faculties of SUA providing study in accredited study programs along with the supplementary pedagogical studies. The course Inovations in the field (agriculture/food/economics/engineering) is provided by the relevant departments of the faculties (Faculty of Economics and Management/ Faculty of Engineering/ Faculty of Agrobiology and Food Resources/ Faculty of Biotechnology and Food Sciences) of the SUA. Certainly, there is a wide scope within the specific departments to include current themes based on the requirements of a modern society to achieve its' sustainable development, but the extent to which they are implemented at these workplaces has not been analyzed in our work. We can 
just presuppose that courses provided by the Faculty of Economics and Management are more focusing at economic aspect of SD, while the courses provided by other faculties underline the environmental aspects. But what is crucial for ESD is the fact that economical, ecological and social pillars of SD are equally important.

Practical preparation for ESD in vocational teaching for the future teachers are courses Clasroom observation and Teaching practice in vocational training. As part of these courses, students develop their professional teacher competences and are often confronted with a multicultural school environments where their current theoretical knowledge needs to be applied. Students have the opportunity to demonstrate their skills of a teacher in practice. Within pedagogical practice, they can meet heterogeneous groups of pupils from diverse ethnicities, nationalities, cultures and different countries. Student teachers can meet pupils coming from various social and cultural environments and their task is to adequately demonstrate their pedagogical competences. Teaching practice also has scope to apply ESD in the teaching of particular vocational subjects. Transdisciplinary character of ESD makes possible to implement it into all school subjects, whether economic, agricultural, food or technical.

Last but not least, it should be pointed out that the Final theses in SPS should also be offered by lecturers in a larger number on the given issue, as this is a new area, but at the same time highly up-to-date. Unfortunately, so far only 3 final theses on the topics of ESD or global education have been defended at the Center of Education and Psychological Counseling of FEM SUA; On the other hand, each academic year are defended 1- 2 final theses focused on environmental education.

Actually we did not found explicitly listed themes on ESD in the Courses: Methodology of research and educational diagnostics; School Organization and management; and Technology of education, but it is not impossible to implement there the SD dimension. At least it is possible to point out for example possibilities of the responsible sustainable management of the school or sustainable use of teaching aids, technology and materials in education.

We can state that out of all 15 analyzed courses of the actually accredited program of SPS at SUA, all courses have the potential of ESD implementation. Naturally some of them have higher potential than others, some courses already contain themes that can be considered as part of ESD. However, ESD is not explicitly stated in the syllabuses of the current courses and also the prescribed themes by the Slovak ministry of Education do not include it, we plan to implement ESD into the curriculum for the next period of accreditation process, which starts in 2020 .

Despite the widely accepted view that we need cultural and educational strategies that will lead to a sustainable society and sustainable communities, in teacher education programs and undergraduate teacher training in Slovakia, we will not find the concept of sustainability. The basic persistent problem in the Slovak Republic and abroad is how to adapt the content, forms and methods of education so that the necessary competences are really acquired by learners. The development of competences for SD is possible through many various contents, in many courses and subjects or educational areas. Competences are learned, developed and applied through practical activities.

The space for ESD implementation is also in some other courses not only within the framework of the above mentioned. Implementation of the ESD is possible not only through the content of the particular subjects, but throughout the whole educational process. ESD can take place in higher education in a number of ways. Besides implementing them into the syllabi of selected courses, it is also suitable to use e.g. student mobility, foreign internships and other irregular forms of education, or by creating a special courses, summer schools and the like. The process 
of education for SD in teacher training includes different teaching techniques and a rich and varied selection of teaching methods. In addition to traditional transmissive teaching methods (transfer of complete knowledge to students), there are more suitable cooperative and experiential methods and exercises, role playing, sensing and visualization methods, discussion... so called active methods. Interactive, cooperative, problem-based teaching and discussion are approaches that ensure that students' activity in the educational process is applied. Anything interactive in the educational process is welcome such as simulation activities and games, role playing, brainstorming, problem solving exercises, various types of discussion like group discussions, panel discussion or round table discussion, pair and group exercises, exchange of experiences, research and presentations, study visits, participative art, case studies, stories and fairy-tale exercises or visual aids (photographs, movies, collages, etc.), mind maps, moral dilemmas, situation methods and role plays. Effective tool in vocational education and also in the training of teachers of vocational subjects are case studies. "The case study is a method that is used in education, especially for its activating and motivational character, and from the pedagogical point of view it fully meets the requirement of linking the theory with the practice" (Šeben Zat'ková et al., 2014, p. 56). While implementing the ESD it is needed to create democratic, fair and human environment, including the active involvement of students. Active methods are mostly useful during seminars in the preparation of VET teachers.

\section{Conclusion}

Current education for SD does not aim to acquire a comprehensive knowledge of poverty, water problems, environmental hazards, etc. This knowledge is only a system by which one thinks about the world today. The initial focus of education is deeper. If it remained only in providing knowledge, it would quickly grow old. It is important to cultivate the ability of pupils and students to evaluate the global problem manifesting in one place so that we can apply this ability in another place. Not knowledge is an essential outcome of education, but the development of the non-cognitive personality traits, the formation of desirable values and value orientation of the contemporary youth, which will be reflected in their thinking, attitudes and especially in their responsible actions in everyday personal and working life.

According to the theoretical part and the analysis of SPS study plan and syllabi at SUA can be suggested some recommendations that should be reflected in the educational process with the respect to current societal requirements:

- A teacher at any level of education must first of all understand the global problems and their consequences, understand the importance of development aid and value the basic humanistic values that underlie ESD. Only in this way can teacher stimulate a sense of responsibility or even global responsible behavior of their pupils, students and future graduates. - The primary task of schools and therefore of teachers is to prepare professionals, professionals with a global awareness and global responsibility, so that these professionals perceive their field in a global context and perceive the implications of their field for sustainable development.

Based on the theoretical study of the issue and on our findings, we recommend: - to increase the motivation of teachers to implement environmental education and ESD in various forms (eg. to introduce a systemic approach to the inclusion of compensation for coordinators in the Act on Educational Staff),

- to innovate the curriculum in teacher preparation (not only at SUA) with emphasis on ESD;

- to develop skills and competences for sustainability among teacher students: a teacher at any level of education must first of all understand the global problems and their consequences, 
understand the importance of development aid and value the basic humanistic values that underlie

ESD.

- to implement ESD in further education of pedagogical staff, not only to prepare the future teachers for ESD, but to continually change minds of the experienced teachers that already work in educational

practice,

The education for sustainable development, is a concept designed to influence a person in particular in terms of non-cognitive development, in order to form attitudes, values, opinions and influence on susceptibility to economic and political process in the world, to develop critical thinking and to shape global civic attitudes, the value system. In summary ESD can be perceived as education for the 21 st century and for the future.

\section{Acknowledgements}

This paper was created within the project KEGA 033SPU-4/2019 Innovative concept of curriculum and methodological "e-support" for VET teachers preparation in the field of agriculture and food sciences.

\section{References}

[1] 5. národná konferencia s medzinárodnou účast'ou Výchova a vzdelávanie $\mathrm{k}$ trvalo udržatel’nému rozvoju. (2009). [online]. Banská Bystrica: UMB. [cit. 2017-09-09]. Retrieved from: <http://www.spirala.sk/wpcontent/uploads/100201-zavery-konferencie-tur.pdf $>$.

[2] Akčný plán trvalo udržatel'ného rozvoja v SR na roky 2005-2010. (2005). Schválený uznesením vlády SR č. 574 z 13.7.2005 [číslo materiálu 12744/2005]

[3] Beyersdorf, M.- Michelsen, G. - Siebert, H. (1998). Umweltbildung - Theoretische Konzepte - empirische Erkenntnisse - praktische Erfahrungen. Neuwied, Kristel: Lucherhand Verlag GmbH, 1998. ISBN 3-47203150-6.

[4] Hilbert, H. (2007a). Súčasný stav perspektívy vzdelania v oblasti TUR na Slovensku [online]. In Ekológia a Environmentalistika. Zvolen: TUZVO, p. 36 - 48. [cit. 4.10.2016]. Retrieved from: $<$ https://www.tuzvo.sk/files/FEE/dekanat_fee/5_hilbert_AFE.pdf $>$.

[5] Hilbert, H. (2007b). Implementácia výchovy a vzdelávania k trvalo udržatel’nému rozvoju na národnej úrovni [online]. In Enviromagazín 12, special issue, 2007. p. 4-5. [cit. 4.10.2016]. Retrieved from: $<$ http://www.enviromagazin.sk/enviro2007/enviromc2/03.pdf>.

[6] Hipš, J. (2005). Neučme o gulatých štvorcoch. In Ďalekohlad, vol. 2, no. 4, 2005, ISSN 1336-4642.

[7] Izakovičová, Z. (2010). Nové netradičné formy environmentálnej výchovy [online]. [cit. 2016 - 10- 4]. In Geographia Cassoviensis, vol. IV, no. 2, 2010, Retrieved from: $<$ http://geografia.science.upjs.sk/images/geographia_cassoviensis/articles/GC-201042/04Izakovicova.pdf $>$.

[8] Kates, R. W.- Parris, T. M.- Leiserowitz, A. A. (2005). What Is Sustainable Develop-ment? Goals, Indicators, Values, and Practice. Environment: Science and Policy for Sustainable Development, 47(3), pp. 8-21 [online]. [cit. 2014-12-15]. Retrieved from: <http://www.heldref.org/env.php>.

[9] Kindlmannová, J. - Vošahlíková, T. (2010). Podpora vzdělávání k udržitelnému rozvoji. Udržitelný rozvoj a jeho vztah k EVVO, definice kompetencí $\mathrm{k}$ udržitelnému jednání a analýza klíčových kompetencí v rámcových vzdělávacích programech $\mathrm{z}$ hlediska VUR (Studie) [online]. VÚP Praha, 2010. Podpora vzdělávání k udržitelnému rozvoji. [cit 2019-04-04]. Retrieved from: $<$ http://www.nuv.cz/uploads/Publikace/vup/Studie_podpora_VUR_final.pdf $>$.

[10] Klimková, A. (2017). Kompetencie pre udržatel'nost' ako cesta k spravodlivej, starostlivej a udržatel'nej spoločnosti [online]. In Edukácia, vol. 2, no. 1, ISSN 1339-8725. [cit. 2016 - 10- 4]. Retrieved from: $<$ https://www.upjs.sk/public/media/15903/Edukacia_1_17.pdf>.

[11] Koločány, F. (2006). Akčný plán trvalo udržatel’ného rozvoja 2005 - 2010 [online]. [cit. 2016 - 10- 4]. In Enviromagazín, vol. 2. 2006, pp. 4 - 5. Retrieved from: $<$ http://www.enviromagazin.sk/enviro2006/enviro2/03.pdf>. 
[12] Kolšovská, J. (2009). Možnosti využitia foriem a metód práce v záujmovom útvare s environmentálnym zameraním na I. stupni ZS. Bratislava: Metodicko-pedagogické centrum, Regionálne pracovisko Prešov, 63 pp.

[13] Leicht, A. - Heiss, J. - Byun, W. J. (2018). Issues and trends in education for sustainable development [online]. [cit 2019-04-04]. Paris: UNESCO, ISBN 978-92-3-100244-1. Retrieved from: $<$ https://www.schooleducationgateway.eu/sk/pub/resources/publications/edu-sustainabledevelopment.htm>.

[14] Národná stratégia trvalo udržatel’ného rozvoja SR schválená uznesením vlády SR č. 978/2001. (2001). [online]. [cit. 2016- 10-3]. Retrieved from: http://www.minzp.sk/dokumenty/strategicke-dokumenty/>.

[15] Rezortná koncepcia environmentálnej výchovy, vzdelávania a osvety do roku 2025. (2015). [online]. [cit. 2017 - 10- 27]. Retrieved from: <http://www.sazp.sk/app/cmsFile.php?disposition=i\&ID=59>.

[16] Ros, J. (2004). Výchova k udržatel'nému rozvoju je predovšetkým výchova k zodpovednosti. In Ďalekohl'ad, vol, 1, no. 3, 2004, 12 pp. ISSN 1336-4642.

[17] Ružičková, J.- Nevřelová, M.- Lehotská, B. (2015). Environmentálne vzdelávanie pre udržatel’ný rozvoj a ochranu biodiverzity $\mathrm{v}$ rámci vybraných študijných programov na Prírodovedeckej fakulte Univerzity Komenského v Bratislave [online]. In Envigogika: Charles University E-journal for Environmental Education, ISSN 1802-3061. [cit 2019-04-04]. Retrieved from: $<$ https://www.researchgate.net/profile/Blanka Lehotska2/publication/283805520 Environmental educatio n_for_sustainable_development_and_biodiversity_conservation_in_selected_study_programmes_at_the_Fa culty_of_Natural_Sciences_of_Comenius_University_in_Bratislava_SSlovak_Version/links/566d $\overline{4} 22608 \overline{\mathrm{a}} \mathrm{e} 4$ 30ab4ff771 c/Environmental-education-for-sustainable-development-and-biodiversity-conservation-inselected-study-programmes-at-the-Faculty-of-Natural-Sciences-of-Comenius-University-in-BratislavaSlovak-Version.pdf>.

[18] Šeben Zat'ková, T. a kol. (2014). Globálne rozvojové vzdelávanie na ekonomických fakultách. Nitra : Slovenská pol'nohospodárska univerzita, 107 s., ISBN 978-80- 552- 1266- 1.

[19] Stoltenberg, U. (2008). Bildungspläne im Elementarbereich. Ein Beitrag zur Bildung für nachhaltige Entwicklung? Deutsche UNESCO-Komision e. V., ISBN 978-3-940785-04-6.

[20] Stratégie európskej hospodárskej komisie OSN pre výchovu k trvalo udržatel’nému rozvoju [online]. (2007). [cit. 2016 - 10- 4]. In Príloha Enviromagazínu. Vol. 2. 2007. 1- 5 pp.

[21] SUA. (2017). Študijné programy [online]. [cit. 2017-06-06]. Retrieved from: https://is.uniag.sk/auth/katalog/brozura_programy.pl?fakulta=10;uobdobi=145;program=200;zvolit_progra $\mathrm{m}=$ Zvolit;zakladni_info $=1$; senat $=0 ;$ harmonogram $=1$;prehled_programu $=0$; charakteristiky $=1 ;$ prog_komise $=$ $0 ;$ predmety_sz=1;szr $=0$.

[22] Toma, P. (2001). Problematika trvalo udržatel’ného rozvoja a Slovenská republika [online]. [cit. 2016 - 10 6]. Bratislava: MŽP SR, 2001. Retrieved from: $<$ http://www.tur.sk/index.stm?apc=0 --

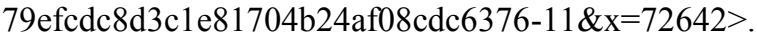

[23] Vladyková, L'. (2015). Úvod do filozofie ekológie. Košice: UPJŠ v Košiciach, Filozofická fakulta, 2015. pp. 131. ISBN 978-808152-276-5

[24] Zákon o pedagogických a odborných zamestnancoch a o zmene a doplnení niektorých zákonov. (2019). [online]. [cit. 2017-06-06]. Retrieved from: https://www.zakonypreludi.sk/zz/2019-138 


\section{SESSION 9}

AGRICULTURAL MARKETS AND INSTITUTIONS ORGANISED SESSION BY THE ASSOCIATION OF AGRICULTURAL ECONOMISTS IN SLOVAKIA - AAES 


\title{
Determinants of ECOWAS Cocoa Export. The Gravity Model Approach.
}

\author{
Emmanuel Bangmarigu1, Eva Bieleková ${ }^{2}$, Artan Qineti $^{3}$ \\ Slovak University of Agriculture in Nitra \\ Faculty of Economics and Management \\ Department of Economic Policy ${ }^{1,2,3}$ \\ Trieda Andreja Hlinku 2, \\ 94976 Nitra, Slovak Republic \\ e-mail: banmariguemma@yahoo.com,eva.bielekova@uniag.sk², artan.qineti@uniag.sk³
}

\section{doi: 10.18515/dBEM.ISD.P01.2020.p061}

\begin{abstract}
This study seeks to identify the main determinants influencing ECOWAS's cocoa export in light of current Global Economic Tendencies within the framework of the gravity model. Using STATA software, conventional gravity variables such as GDP, Production, exports, Free trade area, Population, Geographical distance, Foreign trade policy index, Trump and Brexit were applied and models estimated utilizing panel data covering six (6) major cocoa producing countries from the ECOWAS Sub region with two (2) major trading partners, the European Union and United states from 1994 to 2018. The empirical results reveal that cocoa beans export is positively influenced by the GDP of the exporter countries. $1 \%$ increase in exporter GDP causes export to grow by $2.9 \%$. We found that higher trade openness of exporter countries leads to higher export of cocoa beans; $1 \%$ increase in exporter FTPI increases the cocoa beans trade by ca. $0.8 \%$. The effect of free trade agreements is positive in case of PPML 3 model and countries that signed FTA tend to trade $21 \%$ more than otherwise. The negative and statistically significant coefficient of distance variable indicates that cocoa beans export falls with greater distance between exporter and importer countries. A $10 \%$ increase in distance lowers the cocoa beans export by $10.4 \%$. The influence of Brexit preparation and Trump policy decisions could not be estimated in the good-specified models PPML 2 and 3 because of multicollinearity with the fixed effects.
\end{abstract}

Keywords: ECOWAS, Export, Gravity model, Panel data, Cocoa

JEL: F10, F13, F14, Q17

\section{Introduction}

The global economy has become so interconnected that important trends and events in one region can have substantial effects on the opposite side of the globe for better or for worse. Global Economic Tendencies by definition refers to current issues of the global economy that shapes the future economy. We can liken Global Economic Tendencies to Brexit and Donald Trump policy directions. In Africa, key concerns were already framed around the way Brexit and Trump could impact on the local economic environment. The African Economy generally depends mainly on agriculture with a significant proportion exported. Africa is far more dependent on overseas trade than other economic regions, and major global players are the EU and North America that handle $63 \%$ and $40 \%$ respectively of their trade flow, Kohnert (2018). Africa's exports to the UK represent about $5 \%$ of Africa's total exports, Seedwell \& Jeremy (2016). U.S. goods imports from Sub-Saharan African countries in 2018 were $\$ 25.1$ billion, up $0.9 \%$ (\$218 million) from 2017, but down $70.9 \%$ from 2008. U.S. imports from the SubSaharan African countries account for $1.0 \%$ of overall U.S. imports in 2018. Growth in Africa was remarkable at the beginning of the Millennium and consequently leading to an increasing share of Africa in global GDP, from $4.4 \% 2000$ to $5.1 \%$ in 2015. 
Due to Africa's relatively low share in global trade, some have thought of RTAs in Africa as a vehicle for the promotion of trade, regional economies of scale, and market access for sustained growth and development Ogunkola (1998). Huff (2000) posited that developing countries are capable of gaining more from free trade. Trade and market integration are at the heart of ECOWAS. The Economic Trade Liberalisation Scheme (ETLS) is the main tool of ECOWAS and aimed at liberalising trade within the ECOWAS region. The common external tariff (CET) structure was established to further facilitate trade (de Roquefeuil et al., 2013). Until now 10 of the 15 ECOWAS countries have signed to ECOWAS CET. Bossuyt (2016) stated that weaker and more protected economies fear in signing the treaty because they are afraid of the economic power of the more solid economies. Some authors have argued that RTAs in Africa may not produce the desired effects due to substantial barriers to intra-African trade Lapegna (2016) and significant incentives for corruption (Saana, 2016a, p. 10). Studies of Carrere (2004) found evidence that the RTAs of SADC, COMESA, and ECOWAS have been trade-creating. Following this, Musila (2005) investigated the intensity of trade creation and diversion within ECOWAS, ECCAS, and COMESA. He found evidence of the ECOWAS having the highest level of trade creation followed by the COMESA and ECCAS.

Cocoa is not only important sources of export revenue, but also important sources of agricultural income, including income for smallholder farmers in those countries (World Bank, 2012). The largest regional cocoa bean trade is between Africa and the EU. Europe constitutes more than half of all net cocoa imports (ICCO, 2016), whiles the United States constitute $21 \%$ of the world cocoa imports. At present, while demand is stagnating in American countries $(25 \%$ of international demand) and in Europe (50\%), the world's primary consumption region, it is increasing slightly in Asian and Oceanian countries (13\%). This narrative took a dent in 2016, when Brexit and Trump took a centre stage in world politics, commodity prices tumbled and growth of largest economies in Africa stagnated Andrew (2018). Seedwell \& Jeremy (2016) asserted that Brexit could weaken trade between both the UK and EU on Africa as well as the Economic Community of West African States (ECOWAS). Brexit may also affect Africa's trade with the EU, in the area of Economic Partnership Agreement (EPA), which allows free trade. Lagarde (2018) emphasized that Brexit would not be enough to destabilise global markets. Other factors, such as fears of a global trade war of the US, currently weigh more heavily on market sentiment.

The main objective of this paper is to examine the main determinants of Cocoa export in the ECOWAS sub-region in light of current Global Economic Tendencies

This paper attempt to employ the gravity model to determine key aspects of Cocoa export in the case of ECOWAS in light of current global Economic tendencies. The study uses conventional gravity variables and a wide range of other factors such as foreign trade policy index, free trade area, Trump and Brexit to identify the key determinants of cocoa export in the ECOWAS sub-region.

\subsection{Review of Empirical Literature on the Gravity model}

The gravity model has been extensively used in analysing the pattern and the determinants of trade flows of countries particularly in Europe, Latin America, and Asia, the objective of this section is to review some of these studies as a guide to the choice of appropriate model and variables to be used in this study. Bulk of empirical studies rank the gravity model among the most accurate tools in explaining and predicting bilateral trade. Conventional theory of gravity model in international trade emerged in the early 1960s with the pioneering studies of Jan Tinbergen (1962) and Pöyhönen (1963). Later on, empirical works utilizing gravity model were initiated by Linnemann (1966) and Bergstrand (1985). Since then, evolution of the gravity model and diversity of its application has been remarkable. 
In separate investigations Eita (2008) and Gani (2008) have all employed the traditional gravity model, using panel data covering different periods and geographical locations and conversional gravity variables with dummies. Model results have been varied with Eita (2008) concluding that an increase in importer's GDP and Namibian GDP is associated with an increase in Namibian exports. Importer's GDP per capita was found to have a negative impact on export, while real exchange rate and Namibia's GDP per capita do not have significant impact on exports. As per the theoretical expectations, distance was found to be associated with a decrease in exports. Membership of SADC, EU and sharing a border with Namibia were found to positively and significantly promote Namibia's in exports. The study showed that Namibia has unexploited export potential with, Australia, Belgium, Kenya, Mauritius, Netherlands, Portugal, South Africa, Switzerland and the United Kingdom, among others.

In a recent study Braha et al. (2017) analyse key determinants of its agricultural export in Albania. They employ baseline gravity model considering conventional gravity variables for Albanian export flows for the period 1996-2013. The Poisson Pseudo-Maximum Likelihood (PPML) regression was used for stepwise estimations of the augmented gravity model including effects of Albanian Diaspora, exchange rate and price stability, trade liberalization and institutional distance. Main findings suggest that agricultural export flow increases with increasing economic size. On the other hand, growth in domestic demand, resulting from increase in population, leads to reduction of agricultural export. Moreover, agricultural export flows are determined by low transportation costs (distance), adjacency proximity (sharing common border) and linguistic similarities. Results of this study reveal that exchange rate variability has a positive impact, while bilateral institutional distance has diminishing effects on Albanian agricultural exports.

\section{Data and Methods}

\subsection{Theoretical background of the gravity model}

Gravity model is used for modelling the allocation of traded goods transmitted from the export country $(i)$ to the destination (importing) country $(j)$. In terms of international trade assessment, the model origins with Tinbergen (1962). Tinbergen proposed that bilateral trade flows can be approximated by employing the Newton's gravity equation:

$$
T_{i j}=a_{0} Y_{i}^{a_{1}} Y_{j}^{a_{2}} D_{i j}^{a_{3}} \varepsilon_{i j}
$$

where $T_{i j}$ is trade flow from country $i$ to country $j$ directly proportional to the gross domestic product (GDP) of $i$ and $j$ and inversely proportional to the distance between $i$ and $j, a_{0}, a_{1}, a_{2}$ and $a_{3}$ represent the estimated parameters and $\varepsilon_{i j}$ is the error term. We extend this equation by including variables with relevance to the international cocoa beans export to estimate their impact. The estimation is carried out using two methods. Firstly, we take the natural logarithms of continuous variables and estimate the log-linear model (2) by Ordinary least squares (OLS) technique:

$$
\begin{gathered}
\ln E X_{i j t}=\ln a_{0}+a_{1} \ln \text { prod }_{i t}+a_{2} \ln G D P_{i t}+a_{3} \ln G D P_{j t}+a_{4} \ln p o p_{j t}+a_{5} \ln \text { dist }_{i j}+ \\
a_{6} \text { FTA }_{i j t}+a_{7} \ln F T P I_{i t}+a_{8} \ln F T P I_{j t}+a_{9} \text { Trump }_{t}+a_{10} \text { Brexit }_{t}+\ln \varepsilon_{i j t}+\mu_{i j t}
\end{gathered}
$$

where:

$E X_{i j t}$ - value of cocoa beans export from export country $i$ to import country $j$ in year $t$ in mil. USD

$a_{0}-$ constant

$a_{1}-a_{10}$ - elasticities of variables

$\mu_{i j t}-$ country-specific and time-specific factors estimated as fixed effects capturing unobserved variability

$\varepsilon_{i j t}-$ error term

$\operatorname{prod}_{i t}-$ cocoa beans production of $i$ in thousand tones 
pop $_{j t}$ - population of $j$ in millions of people

$g d p_{i t}, g d p_{j t}-$ gross domestic product of $i$ and $j$ in bil. USD

dist $_{i j}$ - average distance of $i$ and $j$ in $\mathrm{km}$

$F T A_{i j t}$ - dummy equal unity when $i$ and $j$ have a signed free trade agreement

Trump $_{t}$ - dummy equal unity in years, when Trump won Elections in 2016.

Brexit $_{t}$ - dummy equal unity in years, when Brits voted to leave EU in 2016

Secondly, we employ the Poisson pseudo maximum likelihood (PPML) estimator proposed by Silva and Tenreyro (2006). In this case, the estimated model takes the following form:

$E X_{i j t}=\exp \left(\ln a_{0}+a_{1} \ln \operatorname{prod}_{i t}+a_{2} \ln G D P_{i t}+a_{3} \ln G D P_{j t}+a_{4} \ln p o p_{j t}+a_{5} \ln\right.$ dist $_{i j}+$

$a_{6}$ FTA $_{i j t}+a_{7} \ln$ FTPI $_{i t}+a_{8} \ln$ FTPI $_{j t}+a_{9}$ Trump $_{t}+a_{10}$ Brexit $\left._{t}+\mu_{i j t}\right) \varepsilon_{i j t}$

In OLS and PPML models, a set of time-specific dummy variables is included to capture export variation over time and a set of country-specific dummy variables for all exporter-importer pairs is included to account also for unobservable multilateral resistance, Mili \& Rayhan (2011); Gujarati (2004); Martin and Pham (2008). The adequacy of estimated models we will test by the Ramsey's regression equation specification error test (RESET) (Ramsey, 1969). When the RESET p-value is greater than 0.05 , we can conclude that the model is well-specified.

The models are estimated using STATA software. We employ the robust option in STATA to estimate standard errors robust to arbitrary patterns of heteroscedasticity, as was suggested by Shepherd (2013). Our assumption is that the error term is uncorrelated across clusters (i.e. pair of trading countries) but correlated within a cluster, and so we use the distance variable specific to each country-pair for clustering in data (Moulton, 1990).

\subsection{Description of variables}

To estimate the effects of factors influencing the international cocoa beans export, a balanced panel data set is created; the zero observation of the dependent variable are included. The dependent variable is the annual value of export of Côte d'Ivoire, Ghana, Guinea, Nigeria, Sierra Leone and Togo to EU and USA in the period of 1994 - 2018. Export data comes from UN Comtrade Database (HS code 180100 Cocoa beans; whole or broken, raw or roasted).

Data on gross domestic product (GDP) of exporting countries $i$ and GDP of importing countries $j$ is expressed in billion USD (current prices) and retrieved from the World bank database. Exporter's GDP can be considered as a proxy for productive capacity of the exporter. The population of importing country represents potential consumers of cocoa beans. A positive sign of the variable's coefficient would mean that bigger countries can absorb more of goods traded; a negative sign otherwise according to Giorgio (2004) Data on population size of importing countries is retrieved from the World bank database. Production variable is used as a proxy for output capacity (supply) of exporter. Production data was drawn from Faostats. Data on average distance between the trading countries comes from an online distance calculator website. Distance variable is used as a proxy for transport costs of trade. Foreign trade policy index (FTPI) is proxied by trade freedom index, which is a composite measure of the absence of tariff and non-tariff barriers that affect imports and exports of goods and services. It is incorporated to capture the degree of openness of trade. The index ranges from 0 to 100 . A trade freedom score of 100 indicates that the country imposes zero tariffs and nontariff barriers and thus signifies an environment that is most conducive to trade. We estimate the effect of free trade agreements (FTA) signed between exporters and importers, which are considered to decrease or eliminate tariffs and trade barriers. Data on FTA was retrieved from the Regional trade agreements information system (RTA-IS) of WTO. The last two variables are capturing the effect of Trump and Brexit on ECOWAS cocoa trade to the US, UK and USA.

To analyse the determinants of ECOWAS's bilateral trade flows within the framework of the gravity model, this study employs a panel dataset of annual observations on a cross-section of 
six (6) selected ECOWAS cocoa producing countries namely Cote d'Ivoire, Ghana, Guinea, Nigeria, Sierra Leone, and Togo and 2 major trading partners (European Union and the United states) over a period of 25 years from 1994 to 2018 collated from different secondary sources. The choice of the sample period and countries in the cross-section in this study is influenced by the availability of data on all the variables used in the study and the countries that are major producers and trade in cocoa over the sample period. Data on cocoa export flows were obtained from Comtrade, Data on Gross Domestic Product (GDP), population were acquired from UNCTAD. Data on cocoa production was obtained from faostats. Data on Foreign trade policy index was taken from the database of the World Heritage Foundation and data on distance was sourced from an online distance calculator website. Data on common RTAs with trading partners were utilized from the WTO (World Trade Organization). Data processing and empirical estimations were conducted on Stata 12.

\section{Results and Discussion}

Several West African countries generate significant export revenue from cocoa exports and are major players in world market for this commodity. The four largest West African cocoa exporters accounted for about 70 percent of cocoa exports in 2005 (FAOSTAT, 2012). Cocoa trade is closely related to production since only a small amount of production is consumed domestically by any major cocoa exporter. Since 1960, world cocoa production has increased more than threefold, from 1.2 to over 4 million tonnes, representing an average yearly growth rate of more than $2.60 \%$. This growth was punctuated by several jolts caused by structural adjustment policies, crop infestations, diseases and market speculation, all of which have affected production. Three countries dominate world production with their share of global net exports of Côte d'Ivoire (37\%), Ghana (22\%) and Indonesia (14\%) respectively (ICCO, 2016). West Africa, the world leader, produces over $99 \%$ of African cocoa. West African production is dominated by Côte d'Ivoire (2,034,000 tonnes in 2017) and Ghana $(883,652$ tonnes), which produce almost $60 \%$ of the world's cocoa. ECOWAS-SWAC/OECD (2007) from 1960 to 2006, world demand rose in step with production, reaching 3.5 million tonnes. Africa is by far the leading cocoa exporter.

In this current study, the standard gravity model was augmented and we have sort to include variables, such as GDP, production, population, geographical distance, foreign trade policy index and dummies for Free trade area, Trump policies and Brexit, to capture their impact on ECOWAS external trade.

The estimated results of the models are reported in Table 1. We shall interpret models, which passed the RESET test, PPML 2 and 3. Models and the explanatory variables explain $91 \%$ of the variability in cocoa beans export. The results show that cocoa beans export is positively influenced by the GDP of the exporter countries. $1 \%$ increase in exporter GDP causes exports to grow by $2.9 \%$.

We found that higher trade openness of exporter countries leads to higher export of cocoa beans; $1 \%$ increase in exporter FTPI increases the cocoa beans trade by ca. $0.8 \%$. On the other hand, the lesser the importer FTPI (i.e. when trade with EU and USA is characterized by greater trade barriers), the lesser export is carried out to EU and USA.

The effect of free trade agreements is positive in case of PPML 3 model, specifically, countries with signed FTA tend to trade $21 \%(\exp (0.19)-1=0.21)$ more than otherwise. The result is in line with the study of Yeboah et al. (2011), which finds the FTA effect being positive in case of cocoa beans export of WTO countries to USA. However, the result is not consistent in case of the second PPML 2 model, where the variable is statistically insignificant. 
Table 1. Estimation results

\begin{tabular}{|c|c|c|c|c|c|c|c|c|c|c|c|}
\hline & \multicolumn{2}{|c|}{$\begin{array}{l}\text { OLS 1 } \\
\text { FE i,j }\end{array}$} & \multicolumn{2}{|c|}{$\begin{array}{c}\text { OLS } 2 \\
\text { FE i, j, t }\end{array}$} & \multicolumn{2}{|c|}{$\begin{array}{l}\text { OLS } 3 \\
\text { FE ij, t }\end{array}$} & \multicolumn{2}{|c|}{$\begin{array}{c}\text { PPML 1 } \\
\text { FE i,j }\end{array}$} & \multicolumn{2}{|c|}{$\begin{array}{l}\text { PPML } 2 \\
\text { FE i, j, t }\end{array}$} & $\begin{array}{c}\text { PPML } 3 \\
\text { FE ij, } t\end{array}$ \\
\hline & Coef. & & Coef. & & Coef. & & Coef. & & Coef. & & Coef. \\
\hline $\ln$ prod & $\begin{array}{r}0.115 \\
(0.100)\end{array}$ & & $\begin{array}{r}0.280 \\
(0.132)\end{array}$ & $*$ & $\begin{array}{r}0.317 \\
(0.161)\end{array}$ & * & & & & & \\
\hline ln gdp exp & $\begin{array}{r}1.658 \\
(0.345)\end{array}$ & $* * *$ & $\begin{array}{r}1.853 \\
(0.326)\end{array}$ & $* * *$ & $\begin{array}{r}1.867 \\
(0.331)\end{array}$ & $* * *$ & $\begin{array}{r}1.851 \\
(0.373)\end{array}$ & $* * *$ & $\begin{array}{r}2.952 \\
(0.483)\end{array}$ & $* * *$ & $\begin{aligned} 2.937 & : * * * \\
(0.459) & \end{aligned}$ \\
\hline ln gdp imp & $\begin{array}{r}0.826 \\
(1.175)\end{array}$ & & $\begin{array}{r}1.829 \\
(1.826)\end{array}$ & & & & $\begin{array}{r}-0.477 \\
(0.700)\end{array}$ & & & & \\
\hline $\ln$ pop & $\begin{array}{r}-9.088 \\
(5.452)\end{array}$ & & $\begin{array}{r}-9.593 \\
(5.395)\end{array}$ & & $\begin{array}{r}-9.937 \\
(4.334)\end{array}$ & $* *$ & & & & & \\
\hline In dist & $\begin{array}{r}-6.951 \\
(1.279)\end{array}$ & $* * *$ & $\begin{array}{r}-6.954 \\
(1.321)\end{array}$ & $* * *$ & n.e. & & $\begin{array}{r}-10.372 \\
(4.452)\end{array}$ & $* *$ & $\begin{array}{r}-10.353 \\
(4.601)\end{array}$ & $* *$ & n.e. \\
\hline FTA & $\begin{array}{r}0.859 \\
(0.728)\end{array}$ & & $\begin{array}{r}0.935 \\
(0.740)\end{array}$ & & & & $\begin{array}{r}0.161 \\
(0.195)\end{array}$ & & & & $\begin{array}{l}0.190: * * * \\
(0.162)\end{array}$ \\
\hline ln FTPI exp & $\begin{array}{r}1.107 \\
(0.343)\end{array}$ & $* * *$ & $\begin{array}{r}1.019 \\
(0.376)\end{array}$ & $* *$ & $\begin{array}{r}1.035 \\
(0.385)\end{array}$ & $* *$ & $\begin{array}{r}0.299 \\
(0.082)\end{array}$ & $* * *$ & $\begin{array}{r}0.837 \\
(0.337)\end{array}$ & $* *$ & $\begin{array}{l}0.787 \text { :** } \\
(0.315)\end{array}$ \\
\hline ln FTPI imp & $\begin{array}{r}-7.906 \\
(3.395)\end{array}$ & $* *$ & $\begin{array}{r}-9.800 \\
(4.095)\end{array}$ & $* *$ & $\begin{array}{r}-10.875 \\
(3.743)\end{array}$ & $* *$ & $\begin{array}{r}-5.490 \\
(2.470)\end{array}$ & $* *$ & $\begin{array}{r}-6.374 \\
(1.398)\end{array}$ & $* * *$ & $\begin{array}{l}-7.629: * * * \\
(2.183)\end{array}$ \\
\hline Trump & $\begin{array}{r}-0.516 \\
(0.194)\end{array}$ & $* *$ & n.e. & & n.e. & & $\begin{array}{r}-0.307 \\
(0.096)\end{array}$ & $* * *$ & n.e. & & n.e. \\
\hline Brexit & $\begin{array}{r}0.165 \\
(0.382)\end{array}$ & & n.e. & & n.e. & & $\begin{array}{r}-0.229 \\
(0.173)\end{array}$ & & n.e. & & n.e. \\
\hline Constant & $\begin{array}{r}116.092 \\
(28.422) \\
\end{array}$ & $* * *$ & $\begin{array}{l}121.511 \\
(35.868) \\
\end{array}$ & $* * *$ & $\begin{array}{r}84.028 \\
(35.932) \\
\end{array}$ & $* *$ & $\begin{array}{l}103.758 \\
(38.263) \\
\end{array}$ & $* * *$ & $\begin{array}{r}90.380 \\
(41.694) \\
\end{array}$ & $* *$ & $\begin{array}{r}3.823 \\
(13.164) \\
\end{array}$ \\
\hline Observations & & 300 & & & & & & & & & \\
\hline $\begin{array}{l}\text { R-squared } \\
\text { RESET p-value }\end{array}$ & $\begin{array}{l}0.7 \\
0.0\end{array}$ & & $\begin{array}{l}0.79 \\
0.01\end{array}$ & & $\begin{array}{l}0.79 \\
0.00\end{array}$ & & $\begin{array}{l}0.861 \\
0.000\end{array}$ & & $\begin{array}{l}0.910 \\
0.073\end{array}$ & & $\begin{array}{l}0.9115 \\
0.0953\end{array}$ \\
\hline
\end{tabular}

Significant at: $* * * p<0.01, * * p<0.05, * p<0.1$

Note: Clustered standard errors are displayed in parentheses, clustered by distance between exporter and importer; the fixed effects are omitted for brevity; n.e. denotes variables, which were dropped to avoid perfect collinearity with fixed effects; FE i, j - exporter and importer fixed effects; FE i, j, t - exporter, importer and time fixed effects; FE t, ij - time and exporter-importer pair fixed effects

Source: own estimations

The negative and statistically significant coefficient of distance variable indicates that cocoa beans export falls with greater distance between exporter and importer countries. A $10 \%$ increase in distance lowers the cocoa beans export by $10.4 \%$. This result is in line with other studies analysing agricultural export determinants (e.g. Eita, 2008 in case of Namibian exports). We did not find a statistically significant influence of amount of cocoa beans production in exporter countries, so the changes in cocoa beans production in selected African countries did not affected its export in the selected time period. In case of Ghana, the study of Boansi (2013) shows a different result; greater cocoa beans production in Ghana lead to greater exports. During this period, neither the size of importer countries regarding number of its population and nor the importer's GDP had a statistically significant impact, which can mean that cocoa beans export to USA and EU and consumer preferences were relatively stable. The influence of Brexit preparation and Trump policy decisions could have not been estimated in the goodspecified models PPML 2 and 3 because of multicollinearity with the fixed effects, therefore, we cannot comment on their trade effect. 


\section{Conclusion}

The paper employs the gravity model approach to analyse main determinants of Cocoa export in ECOWAS. The study utilizes econometric approach using Poisson Pseudo-Maximum Likelihood (PPML) estimation for ECOWAS export flows with major trading partners for the period 1994-2018. Main results of the findings suggest that model explains $91 \%$ of the variability in cocoa beans export. The results show that cocoa beans export is positively influenced by the GDP of the exporter countries. We found that higher trade openness of ECOWAS member countries leads to higher export of cocoa beans; $1 \%$ increase in exporter FTPI increases the cocoa beans trade by ca. $0.8 \%$. On the other hand, the lesser the importer FTPI when trade with EU and USA is characterized by greater trade barriers, the lesser export is carried out to EU and USA. The effect of free trade agreements was positive in cases of countries with signed FTA which tend to increase trade by $21 \%$ more than otherwise. The negative and statistically significant coefficient of distance variable indicates that cocoa beans export falls with greater distance between exporter and importer countries. We did not find a statistically significant influence of amount of cocoa beans production in exporter countries, so the changes in cocoa beans production in selected ECOWAS countries did not affected its export in the selected time period. During this period, neither the size of importer countries regarding number of its population and nor the importer's GDP had a statistically significant impact, which can mean that cocoa beans export to USA and EU and consumer preferences were relatively stable. Lastly, the influence of Brexit preparation and Trump policy decisions could have not been estimated in the good-specified models because of multicollinearity with the fixed effects.

\section{Acknowledgements}

This work was supported by the Slovak Research and Development Agency under the contract No. APVV-16-0321.

\section{References}

[1] Andrew M. (2018). The consequences of Brexit for Africa: The case of the East African Community, Journal of African Trade 5 (2018), pp. 1-17.

[2] Baltagi, B.H. (2008). Econometric Analysis of Panel Data (Fourth Edition). John Wiley \& Sons, Chichester.

[3] Bergstrand, H.J. (1985). The Gravity Equation in International Trade: Some Microeconomics Foundations and Empirical Evidence. Review of Economics and Statistics, Vol. 67, No. 3, pp. 474-81.

[4] Boansi, D. (2013). "Competitiveness and determinants of cocoa exports from Ghana", International Journal of Agricultural Policy and Research, Vol. 1, No. 9, pp. 236-254. ISSN 2350-1561.

[5] Bossuyt, J. (2016). Political economy of regional integration in Africa: The Economic Community of West African States (ECOWAS) Report. ECDPM. Maastricht: ECDPM.

[6] Braha, K., Qineti, A., Cupák, A. and Lazorčáková, E. (2017). "Determinants of Albanian Agricultural Export: The Gravity Model Approach", AGRIS on-line Papers in Economics and Informatics, Vol. 9, No. 2, pp. 3 21. ISSN 1804-1930. DOI 10.7160/aol.2017.090201.

[7] Carrère, C. (2004). "African Regional Agreements: Impact on Trade with or without Currency Unions." Journal of African Economies 13, No. 2, pp. 199-239.

[8] de Roquefeuil, Q., Plunkett, D. and Ofei, F. (2014). The Impact of Closer Regional Economic Integration on Food Security in West Africa: Focus on the ECOWAS Common External Tariff. ECDPM Discussion Paper No. 154, January 2014, Maastricht: European Centre for Development Policy Management.

[9] ECOWAS-SWAC/OECD. (2007). Atlas on regional integration in West Africa.

[10] Eita, J.H. (2008). Determinants of Namibian Exports: A Gravity Model Approach, University of Namibia, Namibia. 
[11] FAO et al. (2015). Agricultural Growth in West Africa Market and policy drivers FAO. ISBN 978-92-5108700-8.

[12] FAO. (2012). Rome, Food and Agriculture Organization of the U.N.

[13] Gani, A. (2008). Factors Influencing Trade Betwen Fiji And Its Asian Partners. Pacific Economic Bulletin Volume 23 Number 2, The Australian National University

[14] Giorgio, R. (2004). "Empirical evidence on the north-south trade flows: An augmented gravity model". MPRA paper No. 1326. [Online]. Available: https://mpra.ub.unimuenchen.de/1326/1/MPRA_paper_1326.pdf [Accessed: 30 December 2019]

[15] Gujarati, D.N. (2004). Basic Econometrics. Fourth. The McGraw-Hill Companies.

[16] Huff, K. (2000). "Developing Country Concerns and Multilateral Trade Negotiations." CATRN Paper 2, Canadian Agricultural Network - Food Trade Research.

[17] ICCO, International Cocoa Organisation. (2016). Outlook for global supply and demand. Presentation on World Cocoa Conference, May 2012.

[18] Kohnert, D. (2018). More Equitable Britain-Africa Relations Post-Brexit: Doomed to Fail?, in: Africa Spectrum, Vol. 53, No. 2, pp. 119-130.

[19] Lagarde, C. (2018). "Fix the roof while the window of opportunity is open: three priorities for the global economy", Speech by the Managing Director of the IMF at University of Hong Kong, April 11th. http://www.imf.org/en/News/Articles/2018/04/09/spring-meetings-curtain-raiser-speech.

[20] Lapegna, A. (2016). Regional terrorism in West Africa and the Sahel connections. Global Issues $28 / 10 / 2016$

[21] Linnemann, H. (1966). An Econometric Study of International Trade Flows. Amsterdam: North Holland.

[22] MARTIN, W. and C. S. PHAM. (2008). Estimating the gravity model when zero trade flows are frequent. Economics Series; MPRA Paper No. 9453.

[23] Moulton, B. (1990). "An illustration of the pitfall in estimating the effects of aggregate variables on micro units", Review of economics and statistics, Vol. 72, No. 2, pp. 334-338. DOI 10.2307/2109724.

[24] Musila, J. W. (2005). The Intensity of Trade Creation and Trade Diversion in COMESA, ECCAS and ECOWAS: A Comparative Analysis.” Journal of African Economies 14, No. 1 (2005), pp. 117-141.

[25] NANTS. (2013). The current status, challenges and benefits of implementing the ECOWAS Trade Liberalisation Scheme.

[26] OECD/FAO. (2016). "Agriculture in Sub-Saharan Africa: Prospects and challenges for the next decade", in OECD-FAO Agricultural Outlook 2016-2025, OECD Publishing, Paris. http://ec.europa.eu/trade/policy/countries-and-regions/regions/west-africa/

[27] Ogunkola, E. Olawale. (1998). "An Empirical Evaluation of Trade Potential in The Economic Community of West African States." AERC Research Paper No. 84 (1998).

[28] Pöyhönen, P. (1963). A Tentative Model for the Volume of Trade between Countries. Weltwirtschaftliches Archiv, Vol. 90, pp. 93-99.

[29] Rahman, M. M. (2009). Australia's Global Trade Potential: Evidence from the Gravity Model Analysis Oxford Business and Economics Conference. St. Hugh's College, Oxford University, Oxford, UK, ISBN: 978-0-9742114-1-9.

[30] Ramsey, J.B. (1969). "Tests for specification errors in classical linear least squares regression analysis", Journal of royal statistical society, Vol. 31, No. 2, pp. 350-371. DOI 10.1080/14631377.2013.787737.

[31] Saana. (2015b). ATWA Stage 1 Report: Part 1 - Introduction and Context. November 2015.

[32] Seedwell, H. and Jeremy, W. (2016). Potential implications of Brexit for African Economies.

[33] Shepherd, B. (2013). "The gravity model of international trade: A user guide", Bangkok, United Nations publications, p. 76. ISBN-13 978-974-680-346-5.

[34] Silva, J.M.S. and Tenreyro, S. (2006). "The log of gravity", The review of economics and statistics, Vol. 88, No. 4, pp. 641-658. DOI 10.1162/rest.88.4.641. 
[35] Silva, J.M.S. and Tenreyro, S. (2011a). Further simulation evidence on the performance of the Poisson pseudo-maximum likelihood estimator. Economics Letters, 112, 220-222. https://doi.org/10.1016/j.econlet.2011.05.008 [L Links]

[36] Silva, J.M.S. and Tenreyro, S. (2011b). Poisson: Some convergence issues. The Stata Journal, Vol. 11, No. 2, pp. 207-212 [Links]

[37] Tinbergen, J. (1962). "Shaping the world economy; Suggestions for an international economic policy", New York, USA, Twentieth Century Fund, p. 330.

[38] World Bank. (2017). Global Economic Prospects, January 2017: Weak Investment in Uncertain Times. World Bank, Washington

[39] Yeboah, O.-A., Shaik, S., Wozniak, S.J. and Allen, A.J. (2011). "Does the WTO Increase Trade? The Case of U.S. Cocoa Imports from WTO-Member Producing Countries", Journal of Food Distribution Research, Vol. 42, No. 2, pp. 77-88. DOI 10.22004/ag.econ.139423. 


\title{
Who Participated in the Block Farm Scheme in Ghana?
}

\author{
Emmanuel Bangmarigu' ${ }^{1}$, Ema Lazorčáková2 ${ }^{2}$ Artan Qineti ${ }^{3}$ \\ Slovak University of Agriculture in Nitra \\ Faculty of Economics and Management \\ Department of Economic Policy ${ }^{1,2,3}$ \\ Trieda Andreja Hlinku 2, \\ 94976 Nitra, Slovak Republic \\ e-mail: banmariguemma@yahoo.com¹,ema.lazorcakova@uniag.sk²,artan.qineti@uniag.sk
}

\section{doi: 10.18515/dBEM.ISD.P01.2020.p062}

\begin{abstract}
This paper seeks to investigate how different individual and farm characteristics influence the decision of farmers in Yamah, the West Mamprusi District, Ghana, to participate in the Block Farming Scheme Programme. The study is based on data obtained by the use of a structured questionnaire from 62 respondents. The Logit model revealed that farmers with higher education and bigger family are more likely to participate in the block farming programme. On the other hand, farmers with larger farms are less likely to participate in the programme. Nevertheless, higher variety of cultivated crops and higher revenue from agricultural activities increase the probability of participating in the programme.
\end{abstract}

Keywords: Block Farming Scheme, Ghana, determinants of participation in BFS

JEL Classification: $Q 1, Q 12, Q 13, Q 18$

\section{Introduction}

Misguided economic policies, unfavourable weather vagaries, high dependency on rain fed agriculture, and failure to bring the necessary economic transformation have all contributed negatively to Ghana's agricultural performance in past decades (Gebremedhin, 2006). Declining soil fertility, land degradation, and shrinking landholding due to population pressure have contributed to the deterioration of food production (Al-Hassan, 2015). Moreover, food production in Ghana is highly vulnerable to the influence of adverse weather conditions as the agricultural sector is totally dependent on rainfall. Previous studies reported that a $10 \%$ decline in the amount of rainfall below the long-term average leads to a $4.4 \%$ reduction in agricultural food productivity (Webb et al., 1992). Furthermore, drought has increasingly occurred over recent decades, as has the proportion of the population negatively affected by it. These and other factors like low income of farmers, high household size, poor crop harvest, high cost of production inputs are responsible for the country's struggle to ensure food security, e.g. food availability, food access and food utilization (Al-Hassan, 2015). Hence, food security is an issue of great concern and one of the utmost national priorities that forms the cornerstone of sustainable development, economic growth and poverty reduction strategy in Ghana.

To support agricultural production and food security, the Ghana government embarked aggressive agricultural policy reform programmes in 2009. Policies that tackle food insecurity at the household level are seen as the most effective way to deal with the issue. The Block Farm Scheme (BFS) programme is among the programmes introduced for this purpose. The programme aims to increase food security, increase productivity and support higher yields, generate employment among the rural poor, especially the youth, improve incomes of farmers and improve farming as a business through the provision of subsidized mechanization services and inputs (fertilizers, improved seed, and pesticides) in the form of credit and recovery made 
in kind after harvest. The BFS was piloted in several locations in six regions of Ghana and later extended to cover the entire country.

The objective of this paper is (i) to identify determinants that influence farmers' participation in the Block Farm Scheme programme and (ii) to investigate how these determinants influence the probability that a farm joins the programme.

\subsection{The Concept of Block Farming}

Block farming is a scheme that was developed based on the cluster concept by Porter (1998). A cluster is defined as "a geographical proximate group or geographic concentration of interconnected companies, or firms in related industries in particular fields that compete but also cooperate and are closely linked by commonalities and externalities". The Block Farm Scheme in Ghana was modelled out of this concept.

The government of Ghana represented by the Ministry of Food and Agriculture (MoFA) launched the Block Farm Scheme in 2009 as a pilot project in several locations out of six regions, later it spread into the whole country. The programme run for 2009 and 2010. The notion was intended to bring several farmers on a large track of a single piece of land (in blocks) for the production of selected commodities in which the locations (regions, districts and communities) have comparative advantage. Due to the existing land tenure arrangement in Ghana, it was almost impossible for government to procure large tracts of farmland in all the regions for the Block Farm Scheme. Therefore, mostly farmers' land, own or borrowed, was ploughed and shared among them in blocks. The main crops cultivated under the scheme were maize, rice, sorghum, soybean, and vegetables (MoFA, 2011a).

The BFS was designed to focus on ensuring food security by an increase in farm productivity and improving incomes among farmers as well as generating employment among the rural poor especially the youth. Farmers who participated in the scheme had an advantage of exploiting economies of scale and benefiting from subsidised credit in the form of mechanization services, certified improved seed, subsidised fertilizer, agro-chemicals as well as extension services. By bundling the delivery of credit inputs and services, it was envisaged that they are delivered timely and at a lower unit cost. Agricultural extension agents (AEA) were supposed to work closely with farmers by monitoring and advising so that they follow recommended practices to meet expected yields. Following harvest, AEAs recover in kind or cash, the cost of the services and inputs provided by the government to the block farmers (MoFA, 2012).

The block farm concept is not a new phenomenon, a study conducted by Eliasu (2015) using treatment effect model examined the effect of the MoFA Block Farm Credit Programme (BFCP) participation on crop output in the Northern Region of Ghana and found out that farm size, quantity of seed used, quantity of fertilizer used and BFCP participation positively influenced crop output. Mushi and Ngaruko (2015) assessed the impact of farming systems on determinants of smallholder sugarcane farmers' financial sustainability between block farming and traditional farming systems. Their findings show that yield, price and costs have significant effects on financial sustainability, whereas the effect of land size and sucrose were not significant. Block farming has been found to be more effective than traditional farming system in ensuring profitability of farmers. IFPRI (2011) findings are in line with Tizoriba (2014) who revealed that block farms programme increased participating farmers' productivity, production, and income due to the input support scheme. However, the recovery rates were very low. The results showed that maize yields were slightly higher on farms of participating farmers compared to maize yields on the farms of non-participating farmers. 


\subsection{Organisational Management and Strategy of the Block Farm Scheme}

According to Eliasu (2015), potential beneficiaries of the Block Farm Scheme during the pilot phase in 2009 were initially identified, following a campaign on awareness of the scheme and registration of interested participants. The strategy for the devolution of the scheme applied a top down approach where information was relayed from the regions to the districts through the regional directors of MoFA. The programme was organized and implemented by executing the following steps:

Table 1. Programme Implementation Plan

\begin{tabular}{c|l}
\hline 1. & Formation of regional block farm management committees \\
\hline 2. & Formation of district block farm management teams \\
\hline 3. & Identification of block farm locations and selection of crops \\
\hline 4. & Identification and registration of beneficiaries \\
\hline 5. & Sensitization and organization of farmers into groups \\
\hline 6. & Development of implementation plans and schedules of operations \\
\hline 7. & Determination of inputs and services requirements (crop budget) \\
\hline
\end{tabular}

Source: MoFA

The two main factors that were considered under the scheme for the selection of crops to be cultivated in any of the four agro-ecological zones of Ghana were suitability of the crop and comparative advantage that the district/region has on the chosen crop. For the pilot phase in 2009, the six regions that were considered are Ashanti, Brong Ahafo, Central, Northern, Upper East, and Upper West. By 2010, all the 10 regions of Ghana were participating in the scheme (MoFA, 2012).

\section{Materials and Methods}

\subsection{Study Area}

The study was conducted in the North-East Region, specifically in the West Mamprusi District of Ghana, located in the Guinea Savannah agro-ecological zone. The district lies within longitudes $0^{\circ} 35^{\prime} \mathrm{W}$ and $1^{\circ} 45^{\prime} \mathrm{W}$ and latitude $9^{\circ} 55^{\prime} \mathrm{N}$ and $10^{\circ} 35^{\prime} \mathrm{N}$ with a total area of 2610.44 sq $\mathrm{km}$. The district is characterized by two distinct seasons, the dry season which starts from November to April and the rainy season, which starts in late April with little rainfall, rising to its peak in July-August and declining sharply and coming to a complete halt in OctoberNovember. Annual rainfall ranges between $950 \mathrm{~mm}-1,200 \mathrm{~mm}$. Maximum day temperatures are recorded between March-April of about $45^{\circ} \mathrm{C}$ while minimum night temperatures of about $12^{\circ} \mathrm{C}$ are recorded in December-January. Humidity levels between April and October can be as high as $95 \%$ at night falling to $70 \%$ in the day. Night humidity for the rest of the year ranges between $80 \%$ and $25 \%$. The natural vegetation of the district is composed of short trees of varying sizes and density, growing over a dispersed cover of perennial grasses and shrubs. The West Mamprusi District has a population of 121,117 from which 76,503 are residents of rural areas (GSS, PHC, 2010).

There are 86 villages and towns including some fishing and farm camps in the district. Out of them, Yamah was selected for this study (see Figure 1). Yamah was chosen for this study due to its long and enduring cyclical period of drought and floods in the crop production season coupled with escalating food prices exposing the community to serious food insecure 
challenges. Yamah is situated about 27 kilometres west of Walewale, the capital of the West Mamprusi District. The total population of Yama is 3,189 (PHC, 2010). Agriculture is the main source of livelihood, 85.5 percent of the inhabitants are engaged in it (PHC, 2010). Other livelihood activities of the people include fishing, small scale livestock rearing, Shea-butter extraction, petty trading, hunting, commercial charcoal burning, and small-scale mason work during the dry season. Small scale commercial Dawadawa production, tailoring, dressmaking, hairdressing, along with carpentry, carving and food vending.

Figure 1. Map of the study area - Yamah, Ghana
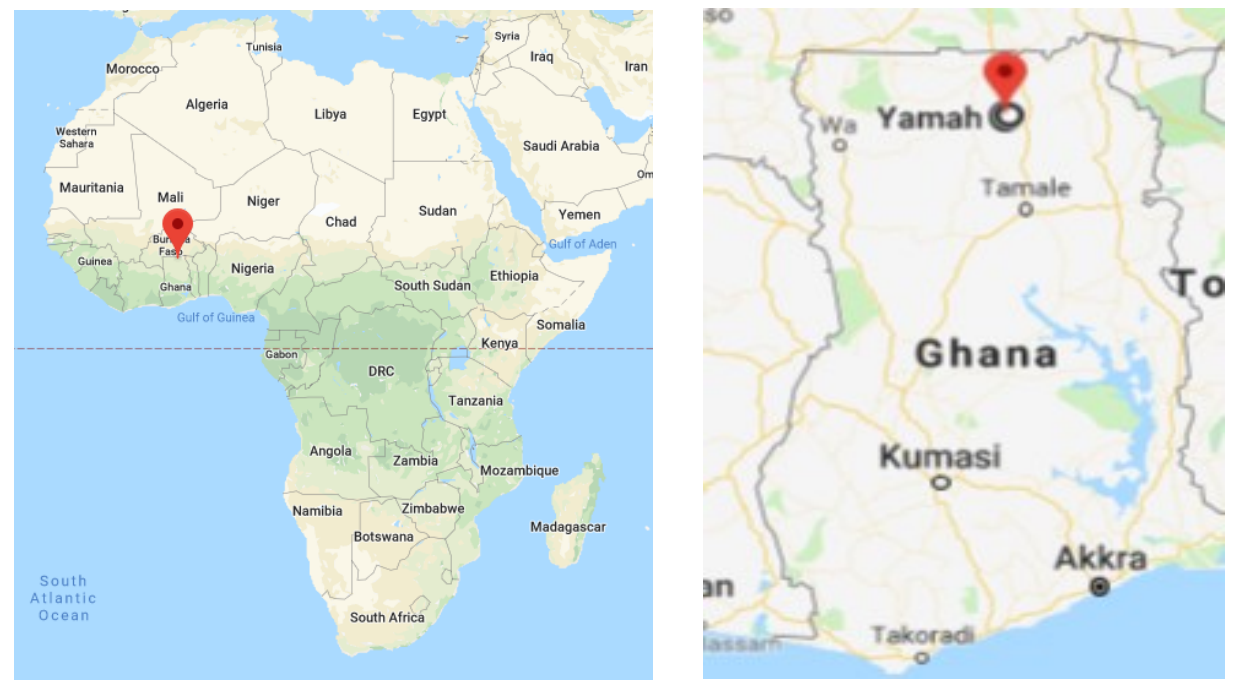

Yamah

coordinates:

$10^{\circ} 20^{\prime} 0^{\prime \prime}$ North, $1^{\circ} 1^{\prime} 0 "$ "West

Source: Google maps

\subsection{Data and Sampling Procedure}

This study assesses farmers' participation in the Block Farm Scheme in Yamah, the West Mamprusi District in the North East Region of Ghana. Data for the study were obtained by the use of structured questionnaire and collected in July 2018. A multistage sampling technique was employed to select the respondents. In the first stage, a purposive sampling was used to select one village area that had the highest participating farmers out of the four villages in the West Mamprusi District that participated in the Programme. The second stage involved the use of proportionate random sampling technique to select three groups from the list of the participating farmers' groups obtained from the District office of the Ministry of Food and Agriculture. This gave a total of sixty-two (62) respondents. Twenty-six (26) participating farmers and thirty-six (36) non-participating farmers were selected from Yamah communities.

\subsection{Methodology}

The decision whether or not to participate in the BFS programme is a qualitative binary variable. Hence, a logit model was employed and the probability that the response of a farmer is participation (1) or not participation (0) was modelled under the generalized utility framework and (Norris and Batie, 1987; Pryanishnikov and Katarina, 2003; Asfaw et al., 2012; Becerril and Abdulai, 2010; Fischer and Qaim, 2012).

A cumulative logistic probability function is specified as:

$p\left(y_{i}=1 \mid \boldsymbol{x}_{\boldsymbol{i}}\right)=e^{\boldsymbol{x}_{\boldsymbol{i}}^{\prime} \boldsymbol{\beta}} /\left(1+e^{\boldsymbol{x}_{\boldsymbol{i}}^{\prime} \boldsymbol{\beta}}\right)$

where $p\left(y_{i}=1 \mid \boldsymbol{x}_{\boldsymbol{i}}\right)$ is probability of participating in the programme, $\boldsymbol{x}_{\boldsymbol{i}}$ is vector of explanatory variables for $i$-th farmer, $\boldsymbol{\beta}$ is vector of coefficients to be estimated. 
Explanatory variables may include farmer's sex, age, marital status, education, farmer's family, farm size, agricultural revenue, number of crops cultivated by the farm, yield of individual crops, or area for individual crops, all related to 2008 (before the BFS programme was launched). The selection of characteristics to be analysed was guided by previous empirical literature (e.g. Nxumalo and Oladele, 2013; Nnadi and Akwiwu, 2008; Oladejo et al., 2011). Different model specifications have been tested because some of the characteristics may be statistically insignificant (do not influence the decision to participate in the BFS programme). The final model has been chosen according to its goodness of fit evaluated based on correctly specified cases. However, other measures like pseudo- $\mathrm{R}^{2}$, Akaike's information criterion (AIC) and Bayesian information criterion (BIC) also qualify the same model specification. Results of the final model are presented in the Results chapter.

\section{Results}

Based on data collected in the survey, we strive to determine which factors drive participation of farmers in Yamah, Ghana, in the BFS programme. Out of the 62 respondents, 26 participated in the scheme (44\% of the respondents), 36 not. Farmers differ in their personal and socioeconomic characteristics as well as in characteristics of their farm. According to our results, farmer's education, his/her family size, size of the farm, agricultural revenue and the numbers of crops cultivated on the farm influence participation in the Block Farming Programme.

As characteristics of the interviewed sample of farmers show, $48 \%$ of respondents did not have any education, $52 \%$ had at least primary education. Mean family size of the sample respondents was 6.97. The size of land owned by participating farmers in this study was on average of 5.16 ha. Mean agricultural revenue was 1293.55 Ghana cedis per year. Our findings also revealed that an average variety of 2.81 crops were cultivated. The structure of agricultural production includes mainly rice, maize, soya bean, cowpea, okra, one farmer also reported Bambara beans and one farmer groundnut.

Table 2. Descriptive characteristics of variables for the sample of farmers

Number of observations: 62

\begin{tabular}{c|c|c|c|c|}
\hline Variable & Mean & Std. Dev. & Min & Max \\
\hline Education & 0.6612903 & 0.7670157 & 0 & 3 \\
\hline Family size (nr. of people) & 6.967742 & 3.416295 & 1 & 17 \\
\hline Farm size (ha) & 5.158065 & 2.351738 & 1.6 & 14 \\
\hline Agricultural revenue (Ghana cedis) & 1293.548 & 1153.451 & 200 & 6500 \\
\hline Number of crops (nr.) & 2.806452 & 0.7859151 & 1 & 5 \\
\hline
\end{tabular}

Education coded as 0 for none, 1 for primary, 2 for secondary, 3 for university, 4 for higher. Other variables numerical.

We expected that farmers with education are capable of receiving information, process it and understand the information that comes out regarding any new technology or programme. Therefore, farmers who have some form of education are more likely to participate in the BFS programme than those who do not have education. Farinde et al. (2005) had identified literacy among other factors as a variable that positively influenced farmer participation in agricultural programmes. Thus, the education of the farmer is expected to have a positive impact on the decision to participate in the BFS. A farmer with a large household can easily participate in an 
agricultural project while delegating other important activities to other household members and vice versa. Also, each adult household member could be a source of information or beneficiary of an agricultural project hence as the household size increases, the higher the likelihood of coming into contact with an agricultural project. Farm size is an important factor to consider when participating in an agricultural project. Farm size is found to have a positive effect on farmer participation in agricultural project. (Abebaw and Haile 2013, Moje et al 2015). Contrary to this, Verhofstadt and Maertens (2014) indicated that owning more farm size decreases the likelihood of participating in an agricultural project. Crops such as rice, maize, soya beans and cowpea were planted by participants in the programme, their area in hectares and yields in kilogrammes per hectare were measured. However, the variety of cultivated crops is found to be a significant variable for programme participation. It may indicate a more experienced farmer who is interested in supplementary agricultural programmes. Agricultural revenue is expected to have a negative relation with the Block Farm Scheme participation because rich farmers may not be constrained financially and hence might not participate in the Block Farm Programme.

Table 3. Logit results

Table 3a. Logistic regression

\begin{tabular}{c|c|c|c|c|c|c|}
\hline & \multicolumn{3}{c}{ LR chi 2 (5)=38.62 } & \multicolumn{3}{c}{ Pumber of observations: 62 } \\
\hline & \multicolumn{3}{c}{ Log likelihood =-22.855861 } & \multicolumn{2}{c}{ Pseudo R2 $=0.4579$} \\
\hline $\begin{array}{c}\text { BFP } \\
\text { participation }\end{array}$ & Coef. & Std. Err. & $\mathbf{z}$ & p>|z| & [95\% conf. interval] \\
\hline Education & 1.475861 & 0.6480131 & 2.28 & 0.023 & 0.205779 & 2.745944 \\
\hline Family size & 0.506839 & 0.1737507 & 2.92 & 0.004 & 0.166294 & 0.847384 \\
\hline Farm size & -1.086205 & 0.3408345 & -3.19 & 0.001 & -1.754228 & -0.418182 \\
\hline Agri. revenue & 0.000898 & 0.0004012 & 2.24 & 0.025 & 0.000112 & 0.001685 \\
\hline Nr. of crops & 2.632594 & 0.8727196 & 3.02 & 0.003 & 0.922095 & 4.343093 \\
\hline constant & -8.057633 & 2.943616 & -2.74 & 0.006 & -13.82702 & -2.288251 \\
\hline
\end{tabular}

Table 3b. Marginal effects after Logit

\begin{tabular}{c|c|c|c|c|c|c|}
\hline $\begin{array}{c}\text { BFP } \\
\text { participation }\end{array}$ & $\mathbf{d y} / \mathbf{d x}$ & Std. Err. & $\mathbf{z}$ & $\mathbf{p}>|\mathbf{z}|$ & \multicolumn{2}{|c|}{$[\mathbf{9 5 \%}$ conf. interval] } \\
\hline Education & 0.337373 & 0.14796 & 2.28 & 0.023 & 0.047384 & 0.627361 \\
\hline Family size & 0.115860 & 0.03999 & 2.90 & 0.004 & 0.037474 & 0.194247 \\
\hline Farm size & -0.248300 & 0.07893 & -3.15 & 0.002 & -0.402997 & -0.093603 \\
\hline Agri. revenue & 0.000205 & 0.00009 & 2.25 & 0.024 & 0.000026 & 0.000384 \\
\hline Nr. of crops & 0.601795 & 0.19335 & 3.11 & 0.002 & 0.222845 & 0.980744 \\
\hline
\end{tabular}

Evaluated at sample mean. 
Table 3c. Goodness of fit

\begin{tabular}{c|c|c|c|}
\hline classified & True D & True -D & Total \\
\hline+ & 21 & 5 & 26 \\
\hline- & 5 & 31 & 36 \\
\hline Total & 26 & 36 & 62 \\
\hline Correctly specified & & & $83.87 \%$ \\
\hline
\end{tabular}

The results show that factors such as education, family size, farm size, agricultural revenue and number of cultivated crops are significant variables that influenced farmers' decision to participate in the BFS programme. While education, family size, agricultural revenue and number of crops, were found to be positively related to the participation in the BFS programme, farm size was found to be negatively related to participation in the programme.

The expected difference in probability of participating in the BFS programme associated with higher education of the farmer is 34 percent points, ceteris paribus. Farms with more family members were by 12 percent points more likely participating in the programme, ceteris paribus. The probability of participation increases by 2 percent points for farms with agricultural revenues higher by 100 Ghana cedis, ceteris paribus. And if the farm cultivates more crops, it is by 60 percent points more likely that it will participate in the BFS programme, ceteris paribus. On the other hand, the expected difference in probability of participating in the programme associated with one more hectare of farm land is -25 percent points. All marginal effects are calculated at the sample means. Out of 62 farmers who were interviewed during our survey, 26 farmers participated in the BFS programme and the model correctly classifies 21 cases. 36 farmers did not participate in the programme and the model predicts this result for 31 of them. In total, the model correctly classifies $83.87 \%$ of cases.

\section{Conclusion and Recommendations}

The objective of this paper was to identify determinants that influence farmers' participation in the Block Farm Scheme programme and to investigate how these determinants influence the probability that a farm joins the programme.

Findings has shown that an average of $52 \%$ participating farmers had education in any form (primary, secondary, or university). Farmers with higher education were more likely to participate in the Block farm programme in respect to farmers who does not receive Education. Our results confirm that farmers with education are capable of receiving information, process it and understand the information that comes out regarding any new technology or programme.

Farmers with large family size were more likely to participate in the Block Farm programme in respect to farmers with small family size. These results also confirm the expectation that farmers with a large household can easily participate in agricultural projects because of labour division, better knowledge and information spreading. Farm size is also an important factor of participation in the BFS programme. Our results do not confirm a correlation between more land and participation in the programme, they rather show that owning a bigger farm decreases the likelihood of participating in an agricultural project. On the other hand, higher variety of cultivated crops as well as higher agricultural revenue of the farmer are associated with higher likelihood of participation in the BFS programme. 
These results give some indications for policymakers that to make BFS more attractive, the scheme should include extension service in combination with elements of education, tailored with specific attributes for big families and smaller farms without discriminating for income groups. This is important as such programs contribute to reduction of food insecurity in Less Developed Countries where many different strategies by the respective government have been employed to increase food production, and block farming has been implemented in many of those countries.

\section{Acknowledgement}

This work was supported by the Slovak Research and Development Agency under the contract No. APVV-18-0512. The authors also acknowledge support of the project VEGA 1/0422/19.

\section{References}

[1] Abebaw, D., Haile, M. G. (2013). The impact of cooperatives on agricultural technology adoption: Empirical evidence from Ethiopia. Food Policy 38, 82-91.

[2] Al-Hassan, S. (2015). Food security in the upper East Region: A situation Analysis. UDS International Journal of development (UDSIJD) Volume 2 No.1 August, 2015. http://www.udsijd.org.

[3] Asfaw, S., Shiferaw, B., Simtowe, F., Lipper, L. (2012). Impact of Modern Agricultural Technologies on Smallholder Welfare: Evidence from Tanzania and Ethiopia. Food Policy 37 (3): 283-295. doi:10.1016/j.foodpol.2012.02.013.

[4] Becerril, J., Abdulai, A. (2010). The Impact of Improved Maize Varieties on Poverty in Mexico: A Propensity Score-Matching Approach. World Development 38 (7): 1024-1035. doi:10.1016/j. worlddev.2009.11.017.

[5] Eliasu, A. (2015). Effects of block farm credit programme participation on crop output in the northern region of Ghana. http://udsspace.uds.edu.gh/handle/123456789/1199.

[6] FAO, IFAD, UNICEF, WFP and WHO. (2018). The State of Food Security and Nutrition in the World.

[7] FAO. (1997). Category to Land and Water Information. Nigerian National Report on Water Resource Development. Food and Agriculture Organisation of the United Nations, Rome, Italy, pp. 190-201.

[8] FAO. (2005). Food and Agriculture Organization of the United Nations: AQUASTAT Database. http:/www.fao.org/waicent/faointo/agricult/aglw/aquastat/site visited 21/01/2014.

[9] FAO. (2014). FAO Statistical Yearbook 2014 on Africa Food and Agriculture. Food and Agriculture Organization of the United Nations, Regional Office for Africa, Accra, 2014.

[10] Fischer, E., Qaim, M. (2012). Linking Smallholders to Markets: Determinants and Impacts of Farmer Collective Action in Kenya. World Development 40 (6): 1255-1268. doi:10.1016/j. worlddev.2011.11.018.

[11] Gebremedhin, T.S. (2006). The analysis of urban poverty in Ethiopia. University of Sydney, Australia.

[12] Ghana Statistical Service, GSS (2008). Ghana Living Standards Survey Report of the Fifth Round (GLSS 5), Accra, Ghana.

[13] Ghana Statistical Service, GSS. (2010). Population and Housing Census.

[14] Hoken, H. (2016). Participation in farmer's cooperatives and its effects on agricultural incomes: evidence from vegetable-producing areas in China. IDE Discussion Papers 578, Institute of Developing Economies, Japan External Trade Organization.

[15] IFPRI. (2011). Institutional Alternatives to Implement Block Farming - Ghana. gssp.ifpri.info/institutionalalternatives-to-implement-block-farming/.

[16] MoFA. (2010). Agriculture in Ghana, Facts and Figures. Statistics, research and information directorate (SRID), Ghana: Accra. P. 2011.

[17] MoFA. (2011a). Youth in Agriculture Programme: Policy, Strategy and Sustainability. Accra: MoFA.

[18] MoFA. (2012). Evaluation of Four Special Initiatives of the Ministry of Food and Agriculture, Government of Ghana, 2012, 79,3-7. 
[19] MoFA. (2015). Ministry of Food and Agriculture of Ghana: Northern Region Agricultural Development Unit, July 2015.

[20] Mojo D., Fischer C., Degefa T. (2015). Social and environmental impacts of agricultural cooperatives: evidence from Ethiopia. Int J Sustain Dev World Ecol 22(5):388-400, http://dx.doi.org/10.1080/13504509.2015.1052860.

[21] Mushi A.S., Ngaruko D. D. (2015). Determinants of Financial Sustainability of Small Holder Sugarcane Farming Systems in Tanzania. African Journal of Economic Review, Volume III, Issue 2, July 2015.

[22] Nnadi F.N., Akwiwu C.D. (2008). Determinants of Youths' participation in Rural Agriculture in Imo State Nigeria. Journal of Applied Science, 8(2), 328-333.

[23] Norris, E., Batie, S. (1987). Virginia Farmers' Soil Conservation Decisions: An Application of Tobit Analysis. Southern Journal of Agricultural Economics, 19 (1): 89-97.

[24] Nxumalo, K. S., Oladele J.M. (2013): Factors Affecting Farmers participation in Agricultural programme in Zululand District, Kwazulu Natal, South Africa. Journal of Social Science, 34(1), 83-88.

[25] Oladejo, J. A., Olawuyi, S. O., Anjorin, T. D. (2011). Analysis of Women Participation in Agricultural Production in Egbedore Local Government Area of Osun State, Nigeria. International Journal of Agricultural Economics and Rural Development 4(1): 1-11.

[26] Porter, M. (1998). On farm cluster concept.

[27] Pryanishnikov, I., Katarina, Z. (2003). Multinomial Logit Model for Australian Labour Market. Australian Journal of Statistics, 4, 267-282.

[28] Tizoriba, R. M. (2014). The Effect of the Block Farms Programme on Improving Maize Farmers' Food Availability in the Wa Municipality of Ghana.

[29] Vorhofstadt, E., Maertens, M. (2014). Smallholder cooperatives and Agricultural performance in Rwanda: do organizational differences matter? Agricultural Economics, 45(S1), 39-52.

[30] Webb P., von Braun J., Yohannes Y. (1992). Famine in Ethiopia: Policy implications of coping failure at national and household levels. International Food Policy Research Institute, Washington, DC.

[31] WFP (2009): Comprehensive food security and vulnerability analysis. Accra, Ghana. http://www.wfp.org/food-security. Assessed 12 May 2016.

[32] WFP (2012): Comprehensive food security and vulnerability analysis. Accra, Ghana. http://www.wfp.org/food-security. Assessed 18 Jan. 2016. 


\title{
Horizontal price Transmission in Ghana. An Asymmetric Error Correction Model (AECM)
}

\author{
Emmanuel Bangmarigu ${ }^{1}$, Miroslava Rajčániová ${ }^{2}$, Artan Qineti $^{3}$ \\ Slovak University of Agriculture in Nitra \\ Faculty of Economics and Management, Department of Economic policy ${ }^{1,2,3}$ \\ Trieda Andreja Hlinku 2, \\ 94976 Nitra, Slovak Republic \\ e-mail: banmariguemma@yahoo.com ${ }^{1,}$ miroslava.rajcaniova@gmail.com ${ }^{2}$,artan.qineti@uniag.sk ${ }^{3}$
}

doi: 10.18515/dBEM.ISD.P01.2020.p063

\begin{abstract}
The objective of this paper is to (i) Examine the statistical relationship between world food prices and domestic food prices in Ghana. (ii) Investigate how price transmission changes before and during the Planting for Food and Jobs programme. To ensure self-sufficiency in food production and to reduce the vulnerability of Agricultural commodity price volatilities, the government of Ghana introduced the flagship programme the Planting for Food and Jobs (PFJ) programme in 2017, to revamp the declining growth of the agricultural sector in Ghana. Using Asymmetric Error Correction Model (AECM), we employed monthly time series data of World and local retail market prices of Maize and Rice (local and import) from the World bank source and the Statistics, Research and Information Directorate (SRID) of the Ministry of Food and Agriculture in Ghana for the period 01st January, 2009 to 31st, December 2019. Our empirical findings revealed a heterogeneous long run causality with respect to positive and negative shocks. We experienced a long run relationship among local and world rice prices in the period before the PFJ, while the times series in the period during PFJ are much more interconnected and we find three cointegration relationships. Maize prices were not cointegrated in the period before PFJ, but in the period during PFJ we observed one long run relationship between local and world maize prices. Ghana as a price taker in the global trade has limited policy instruments to respond to the global food price volatilities. The main policy advice is to increase budgetary support to PFJ in order to improve the programme and increase productivity of agriculture in Ghana.
\end{abstract}

Key words: Agro-commodities, Price Transmission, World prices, Local prices, times series and cointegration.

JEL classification: C32, Q02, Q10, Q11, Q17, Q18

\section{Introduction}

The interest of policy makers to associate prices changes and transmission process from world to domestic Agricultural markets has recently provoked large body of research globally Braha et al (2015): Minot (2010): Amikuzunu et al (2013), Abdulai. (2000). In Sub Saharan Africa the dramatic rise in agricultural price volatilities have forced many Agro-commodity exporting countries governments to responded to rising food prices by adopting or strengthening specific policy measures Tangermann, (2011), such as the Block farm concept and Planting for food and Jobs programme Rantšo \& Seboka (2019) and Tanko et al (2019) in order to keep prices low within domestic food markets. Food commodities have a dominant position on the structure of imports in Ghana since independence in 1957. Ghana still imports about $70 \%$ and $15 \%$ respectively of rice and maize consumed Darfour et al (2016). To ensure self-sufficiency in food production and keep prices of Agricultural commodities low the government of Ghana in 2017 implemented the Planting for Food and Jobs (PFJ), a flagship policy in the agricultural sector with the main goal of addressing the declining growth of agriculture in Ghana by modernising the agriculture sector to lead structural transformation of the national economy through food security, employment opportunities and reduced poverty Esoko 2015-2019 report. 
According to Tanko et al (2019) the policy is focused on increasing food production and ensuring food security in the country as well as reducing the food import bills to the barest minimum. The project consists of five significant pillars; supply of improved seeds to farmers at subsidised prices ( $50 \%$ subsidy), supply of fertiliser at subsidised prices (50\% price cut out), free extension services to farmers, marketing opportunities for produce after harvest, and EAgriculture-a technological platform to monitor and track activities and progress of farmers through a database system (PFJ, 2017). The five main crops selected are Maize, Rice, Soybeans, Sorghum and Vegetables including tomato, onion and Chili pepper in line with priority crops as proposed in Food and Agriculture Sector Development Policy II (FASDEP II) and its investment programme, the Medium-Term Agricultural Sector Investment Plan (METASIP) (PFJ, 2017).

PFJ seeks to motivate and encourage farmers to adopt certified seeds and fertilisers through a private sector-led marketing framework, by raising the incentives and complimentary service provisions on the usage of inputs, good agronomic practices, and marketing of outputs over an E-Agriculture platform (PFJ, 2017). The PFJ programme empower the beneficiaries with knowledge and skills on maximising the benefits of the usage of subsidised inputs like fertiliser through proximity extension services (MOFA, 2017). The outcome of the PFJ programme is measurable in terms of increased productivity, Agricultural income, and the trickle-down effect on consumption expenditure, among other variables. The development of the agriculture sector is a priority to the government of Ghana (FAO, 2015). In rising up to this challenge, the government of Ghana proposed an average annual budget of GHф 765 million (or US\$ 160 million) to support the Planting for Food and Jobs (PFJ) policy. These interventions, however, raise serious concerns about their actual direct effects in terms of lowering Agricultural commodity prices across agricultural markets. Therefore, the objective of this paper is to (i) Examine the statistical relationship between world food prices and domestic food prices in Ghana. (ii) Investigate how price transmission changes before and during the Planting for Food and Jobs programme.

The paper is organized as follows: Section 1 provides a descriptive background into the studied topic, Materials and Methods are presented in section 2, Section 3 presents the empirical results and discussion, Concluding remarks are presented in Section 4 of the paper.

\section{Previous studies on Price Transmission}

Horizontal price transmission means the linkage occurring among different markets at the same position in the supply chain. The notion of horizontal price transmission usually refers to price linkages across market places ie. spatial price transmission, however, it can also concern the transmission across different agricultural commodities Markets. Listorti (2012)

In recent times research on price transmission has been motivated largely due to the belief that co-movement of prices in different markets can be interpreted as a sign of efficient and competitive markets, while absence of co-movement is an indication of market failures. There is a relatively large number of studies that have sought to examine the degree of price transmission between markets within a country (see Rashid, 2004; Meyers, 2008; Negassa and Meyers, 2007and Moser et al, 2009).

Early studies of price transmission used simple correlation coefficients of contemporaneous prices. Mundlak and Larson (1992) estimate the transmission of world food prices to domestic prices in 58 countries using annual price data from the FAO. Their findings revealed a very high rates of price transmission: the median elasticity of transmission was 0.95 , implying that $95 \%$ of any change in world markets was transmitted to domestic markets. 
Around the 1980s, researchers became aware of the problem of non-stationarity. Standard regression analysis assumes that the mean and variance of the variables are constant over time. This signifies that the variable seeks to return toward its mean value, so the best estimate of the future value of a variable is its mean value. However, in the analysis of time-series data, prices including many other variables are often non-stationary, denoting that they move randomly instead of attempting to return to a mean value. One implication of this random walk behavior is that, the best estimate of the future price is the current price. When standard regression analysis is performed with non-stationary variables, the estimated coefficients are unbiased but the distribution of the error is non-normal, so the usual tests of statistical significance are invalid. As a matter of fact, with samples large enough, any pair of non-stationary variables would appear to have a statistically significant relationship, even if they are actually not related to each other (Granger and Newbold, 1974; Phillips, 1987).

Conforti (2004) explored price transmission in 16 countries, including three in sub-Saharan Africa, using the error correction model. found in Ethiopia statistically significant long-run relationships between international and local prices in four out of the seven cases, including retail prices of maize, sorghum and wheat. In Ghana, there was a long-run relationship between world and local wheat prices, but no such relationship for maize and sorghum. And in Senegal, he found a long-run relationship in the case of rice, but not maize. Generally, the degree of price transmission in the sub-Saharan African countries was less than in the Latin American and Asian countries. This current study attempt to use the error correction model to analyse the rate of price transmission before and after the planting for food and jobs policy intervention initiated by the Government of Ghana.

\section{Materials and Methods}

\subsection{Methodology}

We apply time-series modeling techniques to evaluate horizontal price transmission from world market to local markets in Ghana and vice versa. As the first step, we test the stationarity of time series the augmented Dickey-Fuller (ADF) unit root test. The number of lags of a dependent variable is determined by the Akaike Information Criterion (AIC). If both time series are not stationary, they are suitable to test for cointegration relationship between them. We employ the Johansen approach to test for cointegration.

The Johansen approach starts with a vector autoregressive model and reformulates it into a vector error correction model:

$$
\begin{aligned}
& Z_{t}=A_{1} Z_{t-1}+\ldots+A_{k} Z_{t-k}+\varepsilon_{t} \\
& \Delta Z_{t}=\sum_{i=1}^{k-1} \Gamma_{i} \Delta Z_{t-i}+\Pi Z_{t-k}+\varepsilon_{t}
\end{aligned}
$$

where $Z_{t}$ is a vector of non-stationary variables (retail prices), A different matrices of parameters, $t$ is time subscript, $k$ is the number of lags and $\varepsilon_{t}$ is the error term assumed to follow i.i.d. process with a zero mean and normally distributed $\mathrm{N}(0, \sigma 2)$ error structure. The estimates of $\Gamma_{i}$ measure the short-run adjustment to changes in the endogenous variables, while $\Pi$ contains information on the long-run cointegrating relationships between variables in the model. We test the adequacy of our VEC model by a series of tests: The Lagrange multiplier test for autocorrelation in the residuals, the Jarque-Berra test for normality of the residuals, and the stability test of the VEC model estimates. 
The above cointegration tests assume symmetric price transmission. In order to capture asymmetric movements in the residuals, Enders and Granger (1998) and Enders and Siklos (2001) propose to use threshold cointegration approach. Assuming the long run relationship between two nonstationary variables $X$ and $Y$

$$
\mathrm{Y}_{\mathrm{t}}=\lambda_{0}+\lambda_{1} X_{t}+\mu_{t}
$$

Where $\mu$ is the error term. Engle and Granger (1987) show, that cointegration exists if the null hypothesis $\rho=0$ is rejected in:

$$
\Delta \mu_{t}=\rho \mu_{t-1}+\xi_{t}
$$

Where $\xi$ is the error term for the residuals. Adjustment of the series of residuals expressed in $\rho \mu_{t-1}$ would be symmetric. To capture the assymetry in adjustment process, a two-regime threshold cointegration approach should be used:

$$
\Delta \mu_{t}=l_{t} \rho_{1} \mu_{t-1}+\left(1-I_{t}\right) \rho_{2} \mu_{t-1}+\xi_{t}
$$

Where $I t$ is the Heaviside indicator $I t=1$ if $\mu t-1 \geq \tau$ or $I t=0$ if $\mu t-1<\tau$. If $\mu t-1$ is bigger than the threshold $\tau$, then adjustment is at the rate $\rho 1$. If $\mu t-1$ is smaller than the threshold $\tau$, adjustment is shown in $\rho 2$. When $\rho 1=\rho 2$, then the adjustment process is symmetric. If the null hypothesis $\rho 1=\rho 2=0$ is rejected, then $X$ and $Y$ are cointegrated and the following TAR model is estimated:

$$
\Delta Y_{t}=\theta_{y}+\Sigma_{y}^{+} E_{t-1}^{+}+\Sigma_{y}^{-} E_{t-1}^{-}+\Sigma_{j=1}^{j} \alpha_{y j}^{+} \Delta Y_{t-j}^{+}+\sum_{j=1}^{j} \alpha_{y j}^{-} \Delta Y_{t-j}^{-}+\Sigma_{j=1}^{j} \beta_{y j}^{+} \Delta X_{t-j}^{+}+\sum_{j=1}^{j} \beta_{y j}^{-} \Delta X_{t-j}^{-}+\mathrm{U}_{y t}
$$

Where $\Delta Y t$ and $\Delta X t$ are dependent and independent variables in their first differences, $E$ is the error correction term, $\delta$ represents the speed of adjustment coefficients of $\Delta Y t$ if $Y t-1$ is above and below its long-run equilibrium, $\theta, \delta, \alpha$ and $\beta$ are coefficients and $v$ is the error term, $t$ is time subscript and $j$ is the number of lags. Two error correction terms are defined as:

$$
\begin{aligned}
& E_{t-1}^{+}=I_{t} \mu_{t-1} \\
& E_{t-1}^{-}=\left(1-I_{t}\right) \mu_{t-1}
\end{aligned}
$$

Enders and Granger (1998) and Enders and Siklos (2001) proposed also a model for cointegration, known as momentum threshold autoregressive model. The term "momentum" describes the rate of acceleration of prices and takes into account steep variations in the residuals; it is especially valuable when the adjustment is believed to exhibit more momentum in one direction than the other. Heaviside Indicator in this case is $I t=1$ if $\Delta \mu t-1 \geq \tau$ or $I t=0$ if $\Delta \mu t-1<\tau$.

Threshold error correction models were used for example by Goodwin and Holt (1999); Goodwin and Harper (2000); Goodwin and Piggott (2001); Serra and Goodwin (2003); Gonzales et al. (2003); Vavra and Goodwin (2005); Liao and Sun (2011) or Ning and Sun (2012). Abdulai (2000) used both TAR and M-TAR models and found out, that the M-TAR models fit data better than the others.

To summarize, four asymmetric models are considered in our study. They are threshold autoregression model with threshold value equal to zero; threshold autoregression model with threshold value estimated (consistent threshold autoregression model); momentum threshold autoregression model with threshold value equal to zero; and consistent momentum threshold autoregression model with threshold value estimated. A model with the lowest AIC and BIC will be used.

\subsection{Data}


Data used in this analysis is based on monthly observations of retail prices of Maize, Local rice and Imported rice in Agbogbloshie Market (Accra), Kumasi Central Market (Kumasi), Techiman central Market (Techiman), Tamale Aboabo market (Tamale) and Wa central market (Wa) respectively and obtained from the Statistics, Research and Information Directorate (SRID) of the Ministry of Food and Agriculture in Accra, Ghana. The data cover the period from $01^{\text {st }}$ January, 2009 to $31^{\text {st }}$, December 2019. World market monthly price data of Maize and Rice (Vietnams rice 5\%) for the period spanning from January 2009 to December 2019 was obtained from the World bank source and all prices, expressed in Cedis per kilogram.

\section{Results and Discussion}

\section{1 Testing the stationarity of time series:}

Table 1. Results of ADF Unit Root Tests on the Monthly Price Series

\begin{tabular}{|c|c|c|c|c|}
\hline & & & & \\
\hline & $\mathrm{ADF}_{\mathrm{c}}$ & $\mathrm{ADF}_{\mathrm{t}}$ & $\mathrm{ADF}_{\mathrm{c}}$ & $\mathrm{ADF}_{\mathrm{t}}$ \\
\hline lnmaize_local_accra & -1.398 & -2.634 & $-8.776 * * *$ & $-8.767 * * *$ \\
\hline lnmaize_local_kumasi & -1.579 & -2.919 & $-8.780 * * *$ & $-8.753 * * *$ \\
\hline lnmaize_local_techiman & -2.120 & -2.854 & $-9.204 * * *$ & $-9.321 * * *$ \\
\hline lnmaize_local_tamale & -1.843 & -2.092 & $-8.466 * * *$ & $-8.542 * * *$ \\
\hline lnmaize_local_wa & -1.619 & -0.564 & $-4.937 * * *$ & $-5.080 * * *$ \\
\hline lnrice_import_accra & -1.331 & $-3.219 *$ & $-8.390 * * *$ & $-8.352 * * *$ \\
\hline lnrice_local_accra & -1.082 & -2.027 & $-9.196 * * *$ & $-9.192 * * *$ \\
\hline lnrice_import_techiman & -1.236 & -1.306 & $-7.933 * * *$ & $-7.970 * * *$ \\
\hline Inrice_local_techiman & -1.893 & -2.105 & $-5.404 * * *$ & $-5.488 * * *$ \\
\hline rice_import_tamale & -2.009 & $-3.336 *$ & $-8.532 * * *$ & $-8.498 * * *$ \\
\hline rice_local_tamale & -2.092 & -1.813 & $-8.754 * * *$ & $-8.880 * * *$ \\
\hline rice_import_wa & -1.720 & 0.537 & $-4.084 * * *$ & $-4.392 * * *$ \\
\hline rice_import_kumasi & -1.943 & -2.997 & $-9.071 * * *$ & $-9.060 * * *$ \\
\hline rice_local_kumasi & -1.072 & -2.559 & $-8.584 * * *$ & $-8.557 * * *$ \\
\hline rice_local_wa & -1.707 & 0.075 & $-5.151 * * *$ & $-5.392 * * *$ \\
\hline maize_world & -1.559 & -2.329 & $-8.115 * * *$ & $-8.116^{* * *}$ \\
\hline rice_world & 0.028 & $-3.296^{*}$ & $-7.598 * * *$ & $-7.615 * * *$ \\
\hline
\end{tabular}

Source: Author's estimation result: Note: $\mathrm{ADF}_{\mathrm{c}}$ is the ADF with an intercept and $\mathrm{ADF}_{\mathrm{t}}$ with an intercept and a deterministic trend. $* * *, * * *$ denote significance at the $1 \%, 5 \%$ and $10 \%$ significance levels

The initial step of our empirical approach involves test on stationary of time series using the Augmented Dickey-Fuller (ADF) unit root tests: The results of the unit root tests are presented in Table 1. The results of the Augmented Dickey-Fuller unit root test confirm that all our time series are non-stationary; we stationarized them by taking first differences. The tests indicated that all variables were stationary in first differences. The lags of the dependent variable in the tests were determined by Akaike Information Criterion (AIC). The implication of this finding is that all the price series were generated by similar stochastic processes and can exhibit the tendency toward long-run equilibrium. This result is well supported by earlier findings that food commodity price series are mostly stationary after first-differencing in Ghana and elsewhere (Alexander \& Wyeth, 1994; Ogundare, 1999) perhaps owing to the possession by such series 
of trends arising from price inflation and cyclical variations from season leading to mean nonstationarity.

\subsection{Cointegration Test Results}

In the second step we tested for the existence of long-run relationship between variables. First we performed the multivariate Johansen cointegration test for two periods, before and after the 30. October 2017. From the results in Table 2, it follows that, there is one long run relationship among local and world rice prices in the first period, while the times series in the second period in Table 3, are much more interconnected and we find three cointegration relationships. The findings imply that similar stochastic processes, possibly induced by efficient information flow, drive the dynamics of prices in the system of markets (Motamed et al. 2008). In this way, world and local prices do not drift apart in the long run.

Table 2. Cointegration Results for rice prices in the period before 30. October 2017.

\section{Johansen tests for cointegration}

\section{Trend: constant}

3. Sample: 3-104
Numbers of obs $=102$

Lags $=2$

\begin{tabular}{|c|c|c|c|c|c|c|c|c|c|c|c|c|c|}
\hline $\begin{array}{l}\text { 4. } \\
5 \mathrm{~m}\end{array}$ & $\begin{array}{l}\operatorname{maxi} \\
\text { mank }\end{array}$ & $\begin{array}{l}6 . \\
\text { arms }\end{array}$ & $\mathrm{p}$ & 7. & LL & $\begin{array}{l}8 . \\
\text { value }\end{array}$ & eigen & $\begin{array}{l}9 . \\
\text { statistics }\end{array}$ & Trace & \multicolumn{2}{|c|}{$\begin{array}{l}10 . \quad 5 \\
\% \text { critical } \\
\text { value }\end{array}$} & \multicolumn{2}{|l|}{$\begin{array}{l}11 . \\
\% \text { critical } \\
\text { value }\end{array}$} \\
\hline 12. & $\mathbf{0}$ & $\begin{array}{l}13 . \\
10\end{array}$ & 1 & $\begin{array}{l}14 . \\
49695\end{array}$ & 852. & 15. & & $\begin{array}{l}16 . \\
7\end{array}$ & 264.606 & $\begin{array}{l}17 . \\
3.13\end{array}$ & 23 & $\begin{array}{l}18 . \\
7.18\end{array}$ & 24 \\
\hline 19. & 1 & $\begin{array}{l}20 . \\
29\end{array}$ & 1 & $\begin{array}{l}21 . \\
67449\end{array}$ & 889. & $\begin{array}{l}22 . \\
60\end{array}$ & 0.517 & $\begin{array}{l}23 \\
6 * 1 * 5\end{array}$ & 190.251 & $\begin{array}{l}24 . \\
2.89\end{array}$ & 19 & $\begin{array}{l}25 . \\
4.95\end{array}$ & 20 \\
\hline 26. & 2 & $\begin{array}{l}27 . \\
46\end{array}$ & 1 & $\begin{array}{l}28 . \\
4319\end{array}$ & 911. & $\begin{array}{l}29 . \\
29\end{array}$ & 0.347 & $\begin{array}{l}30 . \\
8\end{array}$ & 146.736 & $\begin{array}{l}31 . \\
6.00\end{array}$ & 15 & $\begin{array}{l}32 . \\
8.36\end{array}$ & 16 \\
\hline 33. & 3 & $\begin{array}{l}34 . \\
61\end{array}$ & 1 & $\begin{array}{l}35 . \\
0479\end{array}$ & 931. & $\begin{array}{l}36 . \\
30\end{array}$ & 0.319 & $\begin{array}{l}37 . \\
8\end{array}$ & 107.504 & $\begin{array}{l}38 . \\
4.24\end{array}$ & 12 & $\begin{array}{l}39 . \\
3.57\end{array}$ & 13 \\
\hline 40. & 4 & $\begin{array}{l}41 . \\
74\end{array}$ & 1 & $\begin{array}{l}42 . \\
77343\end{array}$ & 947. & $\begin{array}{l}43 . \\
60\end{array}$ & 0.279 & 44. & 74.0538 & $\begin{array}{l}45 . \\
.15\end{array}$ & 94 & $\begin{array}{l}46 . \\
3.18\end{array}$ & 10 \\
\hline 47. & 5 & $\begin{array}{l}48 . \\
85\end{array}$ & 1 & $\begin{array}{l}49 . \\
26024\end{array}$ & 960. & $\begin{array}{l}50 . \\
17\end{array}$ & 0.217 & 51. & 49.0801 & $\begin{array}{r}52 . \\
.52\end{array}$ & 68 & $\begin{array}{l}53 . \\
.07\end{array}$ & 76 \\
\hline 54. & 6 & $\begin{array}{l}55 . \\
94\end{array}$ & 1 & $\begin{array}{l}56 . \\
32579\end{array}$ & 969. & $\begin{array}{l}57 . \\
85\end{array}$ & 0.162 & 58. & 30.9491 & $\begin{array}{l}59 . \\
.21\end{array}$ & 47 & $\begin{array}{l}60 . \\
.46\end{array}$ & 54 \\
\hline 61. & 7 & $\begin{array}{l}62 . \\
01\end{array}$ & 2 & $\begin{array}{l}63 . \\
03626\end{array}$ & 977. & $\begin{array}{l}64 . \\
31\end{array}$ & 0.140 & 65. & 15.5281 & $\begin{array}{l}66 . \\
.68\end{array}$ & 29 & $\begin{array}{l}67 . \\
.65\end{array}$ & 35 \\
\hline 68. & 8 & $\begin{array}{l}69 . \\
06\end{array}$ & 2 & $\begin{array}{l}70 . \\
70457\end{array}$ & 982. & $\begin{array}{l}71 . \\
19\end{array}$ & 0.105 & 72. & 4.1915 & $\begin{array}{l}73 . \\
.14\end{array}$ & 15 & $\begin{array}{l}74 . \\
.04\end{array}$ & 20 \\
\hline 75. & 9 & $\begin{array}{l}76 . \\
09\end{array}$ & 2 & $\begin{array}{l}77 . \\
36494\end{array}$ & 984. & $\begin{array}{l}78 . \\
03\end{array}$ & 0.032 & 79. & 0.8707 & $\begin{array}{l}80 . \\
76\end{array}$ & 3. & $\begin{array}{l}81 . \\
65\end{array}$ & 6. \\
\hline 82. & 10 & $\begin{array}{l}83 . \\
10\end{array}$ & 2 & $\begin{array}{l}84 . \\
80032\end{array}$ & 984. & $\begin{array}{l}85 . \\
50\end{array}$ & 0.008 & 86. & & 87. & & 88. & \\
\hline 89. & & 90. & & 91. & & 92. & & 93. & & 94. & & 95. & \\
\hline $\begin{array}{l}96 . \\
\text { mt } \\
97 .\end{array}$ & $\begin{array}{l}\operatorname{maxi} \\
\text { mank }\end{array}$ & $\begin{array}{l}98 . \\
\text { arms }\end{array}$ & $\mathrm{p}$ & 99. & LL & $\begin{array}{l}100 . \\
\text { value }\end{array}$ & eigen & $\begin{array}{l}101 . \\
102 . \\
\mathrm{s}\end{array}$ & $\begin{array}{l}\text { Max } \\
\text { statistic }\end{array}$ & $\begin{array}{l}103 . \\
\% \text { critica } \\
\text { value }\end{array}$ & & $\begin{array}{l}104 . \\
\% \text { critical } \\
\text { value }\end{array}$ & \\
\hline
\end{tabular}




\begin{tabular}{|c|c|c|c|c|c|c|c|c|c|c|c|c|c|}
\hline 105. & 0 & $\begin{array}{l}106 . \\
10\end{array}$ & 1 & $\begin{array}{l}107 . \\
49695\end{array}$ & 852. & 108. & & 109. & 74.3551 & $\begin{array}{l}110 . \\
.81\end{array}$ & 62 & $\begin{array}{c}111 . \\
.09\end{array}$ & 69 \\
\hline 112. & 1 & $\begin{array}{l}113 . \\
29\end{array}$ & 1 & $\begin{array}{l}114 . \\
67449\end{array}$ & 889. & $\begin{array}{l}115 . \\
60\end{array}$ & 0.517 & 116. & 43.5148 & $\begin{array}{l}117 . \\
.12\end{array}$ & 57 & $\begin{array}{l}118 . \\
.80\end{array}$ & 62 \\
\hline 119. & 2 & $\begin{array}{l}120 . \\
46\end{array}$ & 1 & $\begin{array}{l}121 . \\
4319\end{array}$ & 911. & $\begin{array}{l}122 . \\
29\end{array}$ & 0.347 & 123. & 39.2320 & $\begin{array}{l}124 . \\
.42\end{array}$ & 51 & $\begin{array}{l}125 \\
.69\end{array}$ & 57 \\
\hline 126. & 3 & $\begin{array}{l}127 . \\
61\end{array}$ & 1 & $\begin{array}{l}128 . \\
0479\end{array}$ & 931. & $\begin{array}{l}129 . \\
30\end{array}$ & 0.319 & 130. & 33.4511 & $\begin{array}{l}131 \\
.28\end{array}$ & 45 & $\begin{array}{c}132 . \\
.57\end{array}$ & 51 \\
\hline 133. & 4 & $\begin{array}{l}134 . \\
74\end{array}$ & 1 & $\begin{array}{l}135 . \\
77343\end{array}$ & 947. & $\begin{array}{l}136 . \\
60\end{array}$ & 0.279 & 137. & 24.9736 & $\begin{array}{l}138 . \\
.37\end{array}$ & 39 & $\begin{array}{c}139 . \\
.10\end{array}$ & 45 \\
\hline 140. & 5 & $\begin{array}{l}141 . \\
85\end{array}$ & 1 & $\begin{array}{l}142 . \\
26024\end{array}$ & 960. & $\begin{array}{l}143 . \\
17\end{array}$ & 0.217 & 144. & 18.1311 & $\begin{array}{l}145 . \\
.46\end{array}$ & 33 & $\begin{array}{l}146 . \\
.77\end{array}$ & 38 \\
\hline 147. & 6 & $\begin{array}{l}148 . \\
94\end{array}$ & 1 & $\begin{array}{l}149 . \\
32579\end{array}$ & 969. & $\begin{array}{l}150 . \\
85\end{array}$ & 0.162 & 151. & 15.4209 & $\begin{array}{l}152 . \\
.07\end{array}$ & 27 & $\begin{array}{c}153 \\
.24\end{array}$ & 32 \\
\hline 154. & 7 & $\begin{array}{l}155 . \\
01\end{array}$ & 2 & $\begin{array}{l}156 . \\
03626\end{array}$ & 977. & $\begin{array}{l}157 . \\
31\end{array}$ & 0.140 & 158. & 11.3366 & $\begin{array}{l}159 . \\
.97\end{array}$ & 20 & $\begin{array}{c}160 . \\
.52\end{array}$ & 25 \\
\hline 161. & 8 & $\begin{array}{l}162 . \\
06\end{array}$ & 2 & $\begin{array}{l}163 . \\
70457\end{array}$ & 982. & $\begin{array}{l}164 . \\
19\end{array}$ & 0.105 & 165. & 3.3207 & $\begin{array}{l}166 . \\
.07\end{array}$ & 14 & $\begin{array}{l}167 . \\
.63\end{array}$ & 18 \\
\hline 168. & 9 & $\begin{array}{l}169 . \\
09\end{array}$ & 2 & $\begin{array}{l}170 . \\
36494\end{array}$ & 984. & $\begin{array}{l}171 . \\
03\end{array}$ & 0.032 & 172. & 0.8707 & $\begin{array}{l}173 . \\
76\end{array}$ & 3. & $\begin{array}{l}174 . \\
65\end{array}$ & 6. \\
\hline 175. & 10 & $\begin{array}{l}176 . \\
10\end{array}$ & 2 & $\begin{array}{l}177 . \\
80032\end{array}$ & 984. & $\begin{array}{l}178 . \\
50\end{array}$ & 0.008 & 179. & & 180. & & 181. & \\
\hline
\end{tabular}

Source: Author's estimation results.

Table3: Cointegration Results for rice prices in the period after 30. October 2017

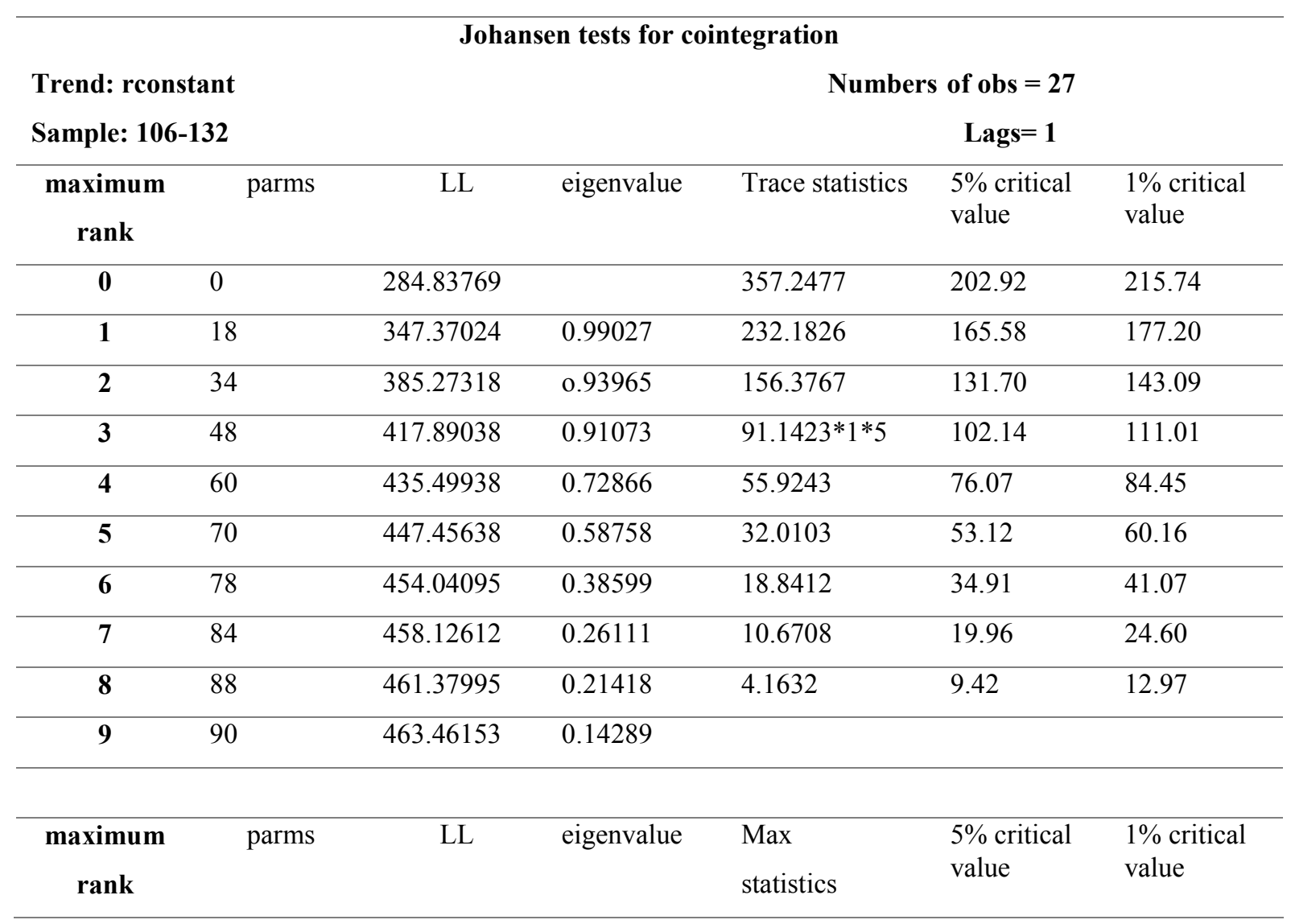




\begin{tabular}{lllllll}
\hline $\mathbf{0}$ & 0 & 284.83769 & & 125.0651 & 57.42 & 63.71 \\
\hline $\mathbf{1}$ & 18 & 347.37024 & 0.99027 & 75.8059 & 52.00 & 57.95 \\
\hline $\mathbf{2}$ & 34 & 385.27318 & 0.93965 & 65.2344 & 46.45 & 51.91 \\
\hline $\mathbf{3}$ & 48 & 417.89038 & 0.91073 & 35.2180 & 40.30 & 46.82 \\
\hline $\mathbf{4}$ & 60 & 435.49938 & 0.72866 & 23.9140 & 34.40 & 39.79 \\
\hline $\mathbf{5}$ & 70 & 447.45638 & 0.58758 & 13.1691 & 28.18 & 33.24 \\
\hline $\mathbf{6}$ & 78 & 454.04095 & 0.38599 & 8.1703 & 22.00 & 26.81 \\
\hline $\mathbf{7}$ & 84 & 458.12612 & 0.26111 & 6.5077 & 15.67 & 20.20 \\
\hline $\mathbf{8}$ & 88 & 461.37995 & 0.21418 & 4.1632 & 9.24 & 12.97 \\
\hline $\mathbf{9}$ & 90 & 463.46153 & 0.14289 & & &
\end{tabular}

Source: Authors estimation results.

The results of the cointegration test for Maize prices in the period before 30. October 2017 show that maize prices were not cointegrated in the first period, in the second period (see Table 4) which is the period after 30 . October 2017 , we can observe one long run relationship between local and world maize prices. However, the cointegration analysis cannot predict the direction of causality between the price series.

Table 4: Cointegration Results for maize prices in the period before 30. October 2017

\section{Johansen tests for cointegration}

Trend: rtrend

Sample: 2-104

\begin{tabular}{ccccccc}
$\begin{array}{c}\text { maximum } \\
\text { rank }\end{array}$ & parms & LL & eigenvalue & $\begin{array}{l}\text { Trace } \\
\text { statistics }\end{array}$ & $\begin{array}{l}5 \% \text { critical } \\
\text { value }\end{array}$ & $\begin{array}{l}1 \% \text { critical } \\
\text { value }\end{array}$ \\
\hline $\mathbf{0}$ & 6 & 602.61939 & & $113.0539 * 1 * 5$ & 114.90 & 124.75 \\
\hline $\mathbf{1}$ & 18 & 624.22187 & 0.34260 & 69.8489 & 87.31 & 96.58 \\
\hline $\mathbf{2}$ & 28 & 641.18513 & 0.28063 & 35.9224 & 62.99 & 70.05 \\
\hline $\mathbf{3}$ & 36 & 648.77306 & 0.13700 & 20.7466 & 42.44 & 48.45 \\
\hline $\mathbf{4}$ & 42 & 653.81745 & 0.09331 & 10.6578 & 25.32 & 30.45 \\
\hline $\mathbf{5}$ & 46 & 656.69841 & 0.05441 & 4.8959 & 12.25 & 16.26 \\
\hline $\mathbf{6}$ & 48 & 659.14634 & 0.04642 & & &
\end{tabular}

Numbers of obs $=103$

\section{Lags $=1$}




\begin{tabular}{lllllll}
\hline $\mathbf{5}$ & 46 & 656.69841 & 0.05441 & 4.8959 & 12.52 & 16.26 \\
\hline $\mathbf{6}$ & 48 & 659.14634 & 0.04642 & & &
\end{tabular}

Source: Author's estimation results

Table 5: Cointegration Results for Maize prices in the period after 30. October 2017

Johansen tests for cointegration

Trend: rtrend

Sample: 2-104

\begin{tabular}{|c|c|c|c|c|c|c|}
\hline $\begin{array}{l}\text { maximum } \\
\text { rank }\end{array}$ & parms & LL & eigenvalue & Trace statistics & $\begin{array}{l}5 \% \text { critical } \\
\text { value }\end{array}$ & $\begin{array}{l}1 \% \text { critical } \\
\text { value }\end{array}$ \\
\hline $\mathbf{0}$ & 6 & 602.61939 & & $113.0539 * 1 * 5$ & 114.90 & 124.75 \\
\hline 1 & 18 & 624.22187 & 0.34260 & 69.8489 & 87.31 & 96.58 \\
\hline 2 & 28 & 641.18513 & 0.28063 & 35.9224 & 62.99 & 70.05 \\
\hline 3 & 36 & 648.77306 & 0.13700 & 20.7466 & 42.44 & 48.45 \\
\hline 4 & 42 & 653.81745 & 0.09331 & 10.6578 & 25.32 & 30.45 \\
\hline 5 & 46 & 656.69841 & 0.05441 & 4.8959 & 12.25 & 16.26 \\
\hline 6 & 48 & 659.14634 & 0.04642 & & & \\
\hline $\begin{array}{l}\text { maximum } \\
\text { rank }\end{array}$ & parms & LL & eigenvalue & $\begin{array}{l}\text { Max } \\
\text { statistics }\end{array}$ & $\begin{array}{l}5 \% \text { critical } \\
\text { value }\end{array}$ & $\begin{array}{l}1 \% \text { critical } \\
\text { value }\end{array}$ \\
\hline 0 & 6 & 602.61939 & & 43.2050 & 43.97 & 49.51 \\
\hline 1 & 18 & 624.22187 & 0.34260 & 33.9265 & 37.52 & 42.36 \\
\hline 2 & 28 & 641.18513 & 0.28063 & 15.1759 & 31.46 & 36.65 \\
\hline 3 & 36 & 648.77306 & 0.13700 & 10.0888 & 25.54 & 30.34 \\
\hline 4 & 42 & 653.81745 & 0.09331 & 5.7619 & 18.96 & 23.65 \\
\hline 5 & 46 & 656.69841 & 0.05441 & 4.8959 & 12.52 & 16.26 \\
\hline 6 & 48 & 659.14634 & 0.04642 & & & \\
\hline
\end{tabular}

Numbers of obs $=103$

Lags $=1$ 
Table 6: Cointegrating equations for rice prices in the first period

\begin{tabular}{|c|c|c|c|c|c|c|c|}
\hline \multirow{2}{*}{$\begin{array}{l}\text { Equation } \\
\text { _cel }\end{array}$} & \multirow{2}{*}{$\begin{array}{ll}\text { Parms } \\
9\end{array}$} & chi2 & \multicolumn{5}{|l|}{ p>chi2 } \\
\hline & & 95.19607 & \multicolumn{2}{|l|}{0.0000} & & & \\
\hline \multicolumn{8}{|c|}{ Identification: beta is exactly identified } \\
\hline \multicolumn{8}{|c|}{ Johansen normalization restriction imposed } \\
\hline \multicolumn{2}{|l|}{ beta } & Coef. & Std. Err & z & $p>|z|$ & $\begin{array}{l}\text { [95\% conf } \\
\text { interval] }\end{array}$ & \\
\hline \multicolumn{8}{|l|}{ _cel } \\
\hline \multicolumn{2}{|c|}{ Inrice_import_accra } & 1 & & & & & \\
\hline \multicolumn{2}{|c|}{ Inrice_local_accra } & 15.27504 & 2.941322 & 5.19 & 0 & 9.510157 & 21.03993 \\
\hline \multicolumn{2}{|c|}{ Inrice_import_techiman } & -56.7855 & 6.088769 & -9.33 & 0 & -68.7193 & -44.8518 \\
\hline \multicolumn{2}{|c|}{ Inrice_local_techiman } & 2.437368 & 3.033186 & 0.8 & 0.422 & -3.50757 & 8.382302 \\
\hline \multicolumn{2}{|c|}{ Inrice_import_tamale } & -0.28597 & 1.630382 & -0.18 & 0.861 & -3.48146 & 2.909519 \\
\hline \multicolumn{2}{|c|}{ Inrice_local_tamale } & -0.92101 & 2.06876 & -0.45 & 0.656 & -4.9757 & 3.133686 \\
\hline \multicolumn{2}{|c|}{ Inrice_import_wa } & 33.02395 & 6.931046 & 4.76 & 0 & 19.43935 & 46.60855 \\
\hline \multicolumn{2}{|c|}{ Inrice_import_kumasi } & 7.590334 & 2.504165 & 3.03 & 0.002 & 2.682261 & 12.49841 \\
\hline \multicolumn{2}{|c|}{ Inrice_local_kumasi } & 18.89978 & 5.197091 & 3.64 & 0 & 8.713672 & 29.0859 \\
\hline \multicolumn{2}{|c|}{ Inrice_local_wa } & -3.04514 & 5.928465 & -0.51 & 0.607 & -14.6647 & 8.574434 \\
\hline \multicolumn{2}{|l|}{ _cons } & -0.7125 & & & & & \\
\hline
\end{tabular}

Source: Author's estimation results

The results of the econometric estimation of the VECM for rice price transmission in the second period in selected markets in Ghana revealed that in the period during PFJ local rice prices in Techiman, import rice prices in Wa, import rice prices in Tamale, import rice prices in Kumasi, local rice prices in Kumasi and local rice price in WA experienced a long run impact see table 7.Agro-commodity prices in Ghana react with different speed to positive and negative deviations, while world prices do not react to shocks in Ghanaian prices.

Table 7 Cointegrating equations model for rice prices in the second period

\begin{tabular}{lrlrrrr}
\hline Inrice_import_techiman & 1 & \multicolumn{1}{l}{. } & & \\
Inrice_local_techiman & 0 & (omitted) & & & & \\
\hline Inrice_import_tamale & -3.7973 & 2.053149 & -1.85 & 0.064 & -7.8214 & 0.226793 \\
\hline Inrice_local_tamale & -0.96485 & 0.565917 & -1.7 & 0.088 & -2.07403 & 0.144326 \\
\hline Inrice_import_wa & 8.478861 & 0.846832 & 10.01 & 0 & 6.819102 & 10.13862 \\
\hline Inrice_import_kumasi & -4.03367 & 0.363192 & - & 0 & -4.74551 & -3.32183 \\
& & & 11.11 & & & \\
\hline Inrice_local_kumasi & -2.22913 & 0.640001 & -3.48 & 0 & -3.48351 & -0.97475 \\
\hline Inrice_local_wa & -10.3707 & 1.016712 & -10.2 & 0 & -12.3634 & -8.37793 \\
\hline cons & 17.59119 &. & $\cdot$ &. &. &. \\
\hline
\end{tabular}




\begin{tabular}{lrlrrrr}
\hline _ce3 & & & & & & \\
\hline Inrice_import_accra & 0 & (omitted) & & & & \\
\hline Inrice_import_techiman & 0 & (omitted) & & & & \\
\hline Inrice_local_techiman & 1 & $\cdot$ & $\cdot$ & $\cdot$ & $\cdot$ & $\cdot$ \\
\hline Inrice_import_tamale & 1.330873 & 0.952287 & 1.4 & 0.162 & -0.53557 & 3.19732 \\
\hline Inrice_local_tamale & 0.455287 & 0.262482 & 1.73 & 0.083 & -0.05917 & 0.969743 \\
\hline Inrice_import_wa & -2.86053 & 0.392776 & -7.28 & 0 & -3.63036 & -2.09071 \\
\hline Inrice_import_kumasi & 1.666277 & 0.168455 & 9.89 & 0 & 1.336112 & 1.996443 \\
\hline Inrice_local_kumasi & 1.418946 & 0.296844 & 4.78 & 0 & 0.837143 & 2.000749 \\
\hline Inrice_local_wa & 2.331096 & 0.471569 & 4.94 & 0 & 1.406838 & 3.255354 \\
\hline _cons & -7.7342 &. & $\cdot$ &. & $\cdot$ &. \\
\hline
\end{tabular}

As presented in Table 8 the results of the econometric estimation of the VECM for maize price transmission in the second period in selected markets revealed that in the period during PFJ maize prices in Kumasi and Tamale experienced a long run impact.

Table 8 Cointegrating equations for maize prices in the second period.

\begin{tabular}{|c|c|c|c|c|c|c|c|}
\hline \multicolumn{8}{|c|}{ Cointegrating equations } \\
\hline Equation & Parms & chi2 & \multicolumn{2}{|c|}{ p>chi2 } & & & \\
\hline _ce1 & 5 & 93.62528 & \multicolumn{2}{|c|}{0.0000} & & & \\
\hline \multicolumn{8}{|c|}{ Identification: beta is exactly identified } \\
\hline \multicolumn{8}{|c|}{ Johansen normalization restriction imposed } \\
\hline beta & & Coef. & Std. Err & $\mathrm{z}$ & $p>|z|$ & {$[95 \%$ conf. } & interval] \\
\hline \multicolumn{8}{|l|}{ _ce1 } \\
\hline \multicolumn{2}{|c|}{ Inmaize_local_accra } & 1 & . & . & . & & . \\
\hline \multicolumn{2}{|c|}{ Inmaize_local_kumasi } & 1.48551 & 0.242052 & 6.14 & 0 & 1.011096 & 1.959924 \\
\hline \multicolumn{2}{|c|}{ Inmaize_local_techiman } & -1.38244 & 0.389262 & -3.55 & 0 & -2.14537 & -0.6195 \\
\hline \multicolumn{2}{|c|}{ Inmaize_local_tamale } & 2.671206 & 0.541286 & 4.93 & 0 & 1.610306 & 3.732106 \\
\hline \multicolumn{2}{|c|}{ Inmaize_local_wa } & -0.5308 & 0.184513 & -2.88 & 0.004 & -0.89244 & -0.16916 \\
\hline \multicolumn{2}{|c|}{ maize_world } & -2.85802 & 0.472212 & -6.05 & 0 & -3.78353 & -1.9325 \\
\hline \multicolumn{2}{|l|}{ _cons } & 0.51485 & 0.351353 & 1.47 & 0.143 & -0.17379 & 1.203488 \\
\hline
\end{tabular}

Source: Author's estimation results.

\subsection{Granger causality test between price series}

We tested the causality between price series using Granger causality test. It is important to note that there was no cointegration equation for maize in the first period, because there was no evidence of cointegration relationship detected in the price series. Secondly, some of the variables had to be excluded from the model for rice prices in the second period due to collinearity problems. That is why there are more variables in the first period than in the second 
period. Granger causality test revealed that the prices series do not have very volatile development which is also depicted in the results.

\section{Conclusion}

The objective of this paper was to first examine the statistical relationship between world food prices and domestic food prices in Ghana and secondly to investigate how price transmission changes before and during the Planting for Food and Jobs programme. For this purpose, we chose five local regional markets: Accra market, Kumasi market, Techiman Market, Tamale market and Wa market, and three Agricultural commodities namely Maize, Imported rice and Local rice. Selection of commodities reflected their importance connected on local food diet.

Analysis consisted of unit root test, cointegration tests, Granger causality tests, estimation of error correction models and test of price transmission asymmetry.

The main findings show that there was one long run relationship among local and world rice prices in the first period, whilst in the second period the times series were very much more interconnected and we find three cointegration relationships. This implies that world and local prices do not drift apart in the long run.

Maize prices were not cointegrated in the first period but in the second period we observed one long run relationship between local and world maize prices. However, the cointegration analysis could not predict the direction of causality between the price series.

Based on the error correction model our Investigations revealed that the speed or magnitudes of price transmission show varying degrees of price relationships. The coefficient of the prices in the first period are significant and show the expected signs of negative and positive relations respectively. We discovered one cointegrating relationship interconnecting several variables. We noticed a long run impact of local rice prices in Accra, import rice prices in Techiman, import rice prices in WA, import rice prices in Kumasi and local rice prices in Kumasi on the import rice prices in Accra in the first period but in the second period local rice prices in Techiman, import rice prices in $\mathrm{Wa}$, import rice prices in Tamale, import rice prices in Kumasi, local rice prices in Kumasi and local rice price in WA experienced a long run impact. Maize price transmission show a long run impact only in Kumasi and Tamale markets in the second period but in the first period the prices in the various markets were not cointegrated. It can be concluded that generally price series do not have very volatile development which is also depicted in main results. The main policy advice is to increase budgetary support to PFJs in order to improve the programme and increase productivity of agriculture in Ghana.

\section{Acknowledgements}

The authors gratefully acknowledge financial support received from the Slovak Research and Development Agency under the contract No. APVV-18-0512 and VEGA 1/0422/19.

\section{References}

[1] Abdulai, A. 2000. "Spatial price transmission and asymmetry in the Ghanaian maize market." Journal of Development Economics 63: 327-349.

[2] Amikuzuno, J., Issahaku, G., and Daadi B., (2013) 'Price Transmission between Imported and Local Rice Markets in a Liberalised Economy: Are Ghana's Rice Wars Just Much I Do About Nothing?', Journal of Economics and Sustainable Development, Vol.4, No.20, ISSN 2222-1700 (Paper) ISSN 2222-2855 (Online)

[3] Braha, K., Qineti, A., Cupák, A. and Lazorčáková, E. (2017). "Determinants of Albanian Agricultural Export: The Gravity Model Approach", AGRIS on-line Papers in Economics and Informatics, Vol. 9, No. 2 , pp. 3 21. ISSN 1804-1930. DOI 10.7160/aol.2017.090201. 
[4] Conforti, P. 2004. Price Transmission in Selected Agricultural Markets. FAO Commodity and Trade Policy Research Working Paper No. 7, Basic Foodstuffs Service, Commodities, and Trade Division, Food and Agriculture Organization, Rome.

[5] Darfour B and Rosentrater K (2016) “Agriculture and Food Security in Ghana 'Paper Number: 162460507, DOI: 10.13031/aim.20162460507

[6] FAO. Food and agriculture organisation of the united nations. Country fact sheet on food and agriculture policy trends- march, (2015). Ghana.

[7] Gonzales, F., Guillotreau, P., LeGrel, L., and Simonini, M. (2003) Asymmetry of price transmission within the French value chain of seafood products. INRA Working Paper http://netec.mcc.ac.uk/WoPEc/data/Papers/reainrawp49.html

[8] Goodwin, B.K. and Harper, D.C. (2000). Price transmission, threshold behavior, and Asymmetric Adjustment in the US pork sector. Journal of Agricultural and Applied Economics, 32: 543-553

[9] Goodwin, B. K. and Piggott, N. (2001). Spatial Market Integration in the Presence of Threshold Effects. American Journal of Agricultural Economics, 83: 302-17

[10] Granger, C. W. J. and Newbold, P. (1974). Spurious Regressions in Econometrics, Journal of Econometrics 2:111-120

[11] Enders, W. and Granger, C.W.J. (1998). Unit-root tests and asymmetric adjustment with an example using the term structure of interest rates. Journal of Business and Economic Statistics, 16: 304-311.

[12] Enders, W. and Siklos P.L. (2001). Cointegration and threshold adjustment. Journal of Business and Economic Statistics, 19 (2): 166-177

[13] GLSS6. (2014). Ghana living standard survey round 6 -main report, Ghana statistical service august, 2014. Undp

[14] Liao, X. C. and Sun, C. (2011). Asymmetric price transmission in the wood products sector in the Southern United States. In Proceedings of the 2010 Southern Forest Economics Workers Annual Meeting, pp. 14-31.

[15] Listorti, G., \& Esposti, R. (2012). Horizontal price transmission in agricultural markets: fundamental concepts and open empirical issues. Bio-based and Applied Economics, 1(1), 81-108

[16] Meyers, R. 2008. "Evaluating the efficiency of inter-regional trade and storage in Malawi maize markets." Report for the World Bank. Michigan State University, East Lansing, MI.

[17] MOFA. Ministry of food and agriculture, Ghana. Agricultural sector progress report (2017). Retrieved from http://mofa.gov.gh/site/wp-pontent /uploads/2018/09/MoFA\%202017\% 20AGRICULTURAL\%20PROGRESS\%20REPORT_Final. PPMED.MoFA.pdf

[18] Moser, C., C. Barrett, and B. Minten. 2009. "Spatial integration at multiple scales: Rice markets in Madagascar." Agricultural Economics 40: 281-294.

[19] Minot, N. (2010). "Transmission of World Food Price Changes to African Markets and Its Effect on Household Welfare', Food Security Collaborative Working Paper No. 58563, Department of Agricultural Food and Resource Economics, Michigan State University.

[20] Mundlak, Y., and D. F. Larson. 1992. "On the Transmission of World Agricultural Prices.” The World Bank Economic Review 6:399-422.

[21] Negassa, A., and R. Myers. 2007. Estimating policy effects on spatial market efficiency: An extension to the parity bounds model. American Journal of Agricultural Economics 89:338-352.

[22] Ning, Z. and Sun, C. (2012). Vertial price linkage between timber and forest products pri ces in the South. In S.R. Mehmood, editor, Proceedings of the 2011 Southern Forest Economics Workers (SOFEW) Annual Meeting, Little Rock, AR. 15 pp.

[23] PFJ. (2017). Planting for food and jobs strategic plan for implementation (2017-2020) ministry of food and agriculture. Ghana: Republic of Ghana.

[24] Phillips, P. C. B. 1987. Time series regression with a unit root. Econometrica 55:277-301.

[25] Rantšo \& Seboka, (2019)"'Agriculture and food security in Lesotho: Government sponsored block farming programme in the Berea, Leribe and Maseru Districts"'Vol 5: 1657300 doi.org/10.1080/23311932.2019.1657300 
[26] Rashid, S. (2004). Spatial Integration of Maize Markets in Post-Liberalised Uganda Markets, Trade and Institutions Division (MTID). Accra: IFPRI discussion Paper No. 7L.

[27] Serra, T. and Goodwin, B.K., (2003). Price transmission and asymmetric adjustment in the Spanish dairy sector. Applied Economics, 35: 1889-1899.

[28] Tanko et al., (2019)' 'planting for Food and Jobs (PFJ): A panacea for productivity and welfare of rice farmers in Northern Ghana Cogent Economics \& Finance, Vol 7: 1693121 doi.org/10.1080/23322039.2019.1693121.

[29] Tangermann, S. (2011). Policy Solutions to Agricultural Market Volatility: a Synthesis. International Center for Trade and Sustainable Development, Issue Paper No. 33.

[30] Vavra, P. and Goodwin, B.K. (2005). Analysis of Price Transmission Along the Food Chain. OECD Food, Agriculture and Fisheries Working Papers, No. 3, OECD Publishing. http://dx.doi.org/10.1787/752335872456 


\title{
Unfair Trading Practices in the Slovak Fruit Sector
}

\author{
Katarína Baráthová1, Ján Pokrivčák ${ }^{2}$, Miroslava Rajčániová ${ }^{3}$, Artan Qineti $^{4}$ \\ Slovak University of Agriculture in Nitra ${ }^{1,2,3,4}$ \\ Faculty of Economics and Management, Department of Economic Policy \\ Address: Tr. A. Hlinku 2 \\ 94976 Nitra, Slovak Republic \\ e-mail: xbarathovak@uniag.sk¹,jan.pokrivcak@uniag.sk²,miroslava.rajcaniova@uniag.sk², \\ artan.qineti@uniag.sk ${ }^{4}$
}

\section{doi: 10.18515/dBEM.ISD.P01.2020.p064}

\begin{abstract}
The topic of unfair trading practices (UTPS) in the food sector has become a huge concern within the EU leading to a need for an efficient regulation which eventually resulted in the approval of a Directive 2019/633. Studies show that UTPs are a serious issue in various sectors. The objective of this paper was to investigate the occurrence and impact of UTPs at three levels of Slovak fruit value chain - at the farmer, middleman and supermarket level. We conducted a series of three questionnaires. At the farm level, 64\% of respondents experienced at least 1 UTP in a relationship with their main buyer. Results confirmed statistically significant difference between members and non-members of POs in overall number of UTPS. The most serious UTPs include late payments (32\% of farmers), payments not related to a specific transaction (32\% of farmers), and unilateral contract and orders changes. Perception of UTPs by middlemen is even higher than perception of farmers. The most serious UTPs are late payments, expenses not related to the sales of their products, retaliation and cancelling orders on short notice. Respondents from supermarkets admitted possible occurrence of a few practices-late payments (16.7\%), short notice orders cancellation (16.7\%), unilateral changes in contracts (16.7\%), payments for losses and waste are common (16.7\%). These results confirm that UTPs are transmitted along the whole food supply chain.
\end{abstract}

Keywords: unfair trading practices, fruit, value chain, survey

JEL Classification: $Q 12, Q 13, Q 18$

\section{Introduction}

According to a definition of the European Commission (2013) unfair trading practices are practices that grossly differ from good commercial conduct, are contrary to good faith and fair dealing and are imposed by one trading partner on another. Although the topic was first brought to the attention of European policy makers in 2009 when the European Commission published a first communication on the issue, the discussion among food chain actors and policy-makers has considerably intensified only in the recent years.

The need for better protection of farmers in the food chains has been a result of structural changes and market conditions in EU agriculture. After 2006, global agricultural and food markets faced major volatility - world food prices increased dramatically and then were followed by strong declines in 2009 as a consequence of the global financial crisis. In 20102011 prices rose again. The price fluctuations were more problematic for farmers than for processing and retail industry (Swinnen et al., 2014). Moreover, this situation was accompanied by increasing concentration in the processing and retail industry (FoodDrinkEurope, 2011), which has made the suppliers more dependent of the small number of buyers (Ménard, 2017). As a consequence, food processors and especially retailers dispose of a far stronger bargaining power than suppliers (Vaqué, 2014). The imbalance in bargaining power between actors in agrifood chain is often cited as the main cause of UTPs (European Commission, 2013). Bargaining 
power is the power to acquire a concession from a business partner by threatening to impose costs, or withdraw a benefit, if the partner does not give the concession (Kirkwood, 2005). This might lead to incidence of various UTPs like unequal contract terms, supply constraints required from farmers by the processor, or unilateral retroactive changes in contracts (Di Marcantonio et al., 2018).

UTPs might occur at all stages of the supply chain and their effects can be transmitted on the other parts of the chain. Generally, farmers (especially small farmers) are considered to be the most vulnerable to UTPs (AMTF, 2016). It is a consequence of higher switching costs, fewer trading relationships and the fact that small players are less willing to use formal enforcement mechanisms and also have less countervailing power against powerful trading partners (European Commission, 2013). Fałkowski (2017) claims that UTPs may negatively affect different aspects of farmer decision-making process. Di Marcantonio et al. (2018) explain that the way how the contract terms between farmers and buyers are agreed and then respected is further reflected in revenues earned and costs incurred, which in turn influences farm profitability. Thus, UTPs also limit investments, innovations and improvements in productivity.

\subsection{Empirical research of UTP}

Increasing severity of UTPs has led to number of studies in recent years, but the empirical literature is still insufficient, especially in the agri-food sector. A large number of studies focused generally on the relationships in the food supply chain and provides rather indirect evidence of UTPs and their impacts (Fałkowski, 2017). The research of price transmission along the agri-food chain analyses the magnitude, direction and speed with which price movements are transmitted from farm to processing and retail levels or in the opposite direction (Perekhozhuk et al., 2017). It contributes to identification of potential market malfunctioning, but because there are several other factors which may influence the price transmission, it is not clear to what extent the observed asymmetries can be attributed to the imbalances in bargaining power (Bakucs et al., 2014). Thus, the research should not focus only on single transactions but on a supply chain as a whole (Fałkowski, 2017).

The first important survey dealing directly with UTPs was commissioned by the European Brands Association (AIM). The survey among 686 food processors from 15 EU member states showed that $96.4 \%$ of the respondents had been subject to at least one UTP in 2009 (CIAAAIM, 2011). Another survey carried out by Dedicated Research (2013) but in behalf of COPACOGECA showed that $94 \%$ of farmers and $95 \%$ of agri-food cooperatives had experienced at least one UTP. Study by BASIC (2015) which focused on banana producers from Costa Rica supplying to EU market confirmed the occurrence of several UTPs in banana supply chain, such as one-sided clauses in contracts stating that 'the buyer can withdraw from the contract at any point in time if his margin is insufficient', increased occurrence of last-minute cancellations of orders as well as rejections and quality claims during low-price seasons. Recent study by Di Marcantonio et al. (2018) investigated the incidence of UTPs in the dairy farm sector in selected regions of four EU countries (France, Germany, Poland and Spain). The survey identified in total 29 types of UTPs across different phases of contract development. Results revealed that $93 \%$ of surveyed farmers experienced at least one UTP, and $46 \%$ of surveyed farmers experienced at least three UTPs.

Meanwhile, discussions and analyses about UTP at the EU level continued In April 2018, European Commission introduced a proposal for a Directive on UTP in business-to-business relationships in the food supply chain with aim to serve as a common standard of protection across the EU (European Commission, 2018). The Directive was finally adopted in March 2019 and outlawed a list of 16 specific UTPs divided into 'black' and 'grey' practices. While the black 
practices are prohibited under any circumstances, grey practices are allowed if they are clearly and unambiguously agreed between the supplier and the buyer (European Parliament, 2019).

\section{Data and Methods}

The objective of this paper is to investigate the occurrence and impact of UTPs from Directive 2019/633 in the fruit sector in Slovakia. Compared to majority of studies where the focus is only on farmers, this paper aims to investigate UTPs at all stages of the fruit value chain. Therefore, we conducted a series of 3 surveys - at the farmer, middleman and supermarket level. The data collection was carried out between July and September 2019.

Farm survey: The farmer questionnaire was designed to cover the following aspects: (1) general information about the farm, (2) information about the trade relationship with main buyer, (3) information about UTPs based on Directive 2019/633, and (4) overall evaluation of the trade relationship with main buyer.

The Register of orchards in Slovakia provided by The Central Control and Testing Institute in Agriculture was used as a sampling frame. The sample selection was based on an orchard size in order to include fruit growers of all sizes. However, growers owning orchard of a size less than 1 ha were excluded since these grow fruit only for personal consumption and thus they do not encounter UTPs. Data were collected mainly through face-to-face interviews (68\%) but also through electronic form of the questionnaire (32\%). Face to face interviews lasted on average between 45 minutes to 1 hour. Fear factor as one of the most serious impediments of UTP research was significantly present. The final sample consists of 66 farmers. The representativeness was checked by a chi-square test $\left(\chi^{2}\right.$ test $)$. Because $\chi^{2}<$ critical value $(7.806$ $<7.815$ ) at level of significance $\alpha=0.05$, we failed to reject the null hypothesis, which means that the distribution in the sample does not significantly differ from distribution at national level and the sample size is representative in terms of farm size.

Table 1 Sample size of B-SEA survey

\begin{tabular}{|c|c|c|c|c|}
\hline \multirow{2}{*}{$\begin{array}{c}\text { Size of Fruit } \\
\text { Orchard (ha) }\end{array}$} & \multicolumn{2}{|c|}{ N. of farms } & \multicolumn{2}{c|}{ Sample } \\
\cline { 2 - 5 } & N. of fruit growers & $\mathbf{\%}$ & N. of fruit growers & \% \\
\hline $\mathbf{1}-\mathbf{1 0}$ ha & 201 & $57 \%$ & 30 & $45 \%$ \\
\hline $\mathbf{1 0}-\mathbf{5 0}$ ha & 123 & $35 \%$ & 6 & $9 \%$ \\
\hline $\mathbf{5 0}-\mathbf{1 0 0}$ & 19 & $5 \%$ & 3 & $5 \%$ \\
\hline$>\mathbf{1 0 0}$ ha & 9 & $3 \%$ & $\mathbf{6 6}$ & $\mathbf{1 0 0 \%}$ \\
\hline Total & $\mathbf{3 5 2}$ & $\mathbf{1 0 0} \%$ & & \\
\hline
\end{tabular}

Source: own processing

Middleman survey: The questionnaire was divided into three sections: (1) general information about the firm, (2) perception of UTP in the industry. The final sample size consists of 15 middlemen.

Supermarket survey: The questionnaire includes: (1) information about the firm, (2) the firm's perception about a general overview of the industry and occurrence of UTPs, and (3) information about the procurement channel. All big supermarket chains (11) in Slovakia were contacted. The final sample includes 6 supermarket chains (both domestic and foreign).

\section{Statistical tests}

At the farm level differences in variables - different UTPs according to categories of buyers were tested under the null hypothesis that the distribution of a variable was the same across categories. We applied non-parametric Kruskall-Wallis test for testing the differences. 
In order to test whether there is a significant difference in UTPs occurrence between farmers who are members of producer organizations (POs) and those who are not, independent samples $\mathrm{t}$-test was applied. The tested hypothesis was based on the assumption that when a farmer is the member of the PO, on average the fewer UTPs occur on the farm. Testing of this hypothesis is based on the research conducted by Di Marcantonio et al. (2018) who found that among other factors, membership to a cooperative in case of dairy farmers decreases the number of UTPs farmers are exposed to.

\section{Results and Discussion}

\subsection{Farmer survey}

Since apples represent the most grown fruit species in Slovakia, the survey mainly focused on apple producers ( $82 \%$ of surveyed farmers). Interviews were conducted in majority of cases with farm managers (94\% of cases). While average size of the farm was 730 ha, the average size of apple orchard was 28.3 ha and 9 ha in case of other type of fruits.

Table 2 Selected characteristics of farms in the fruit sector

\begin{tabular}{|l|c|}
\hline Type of the farm: & \% of farmers \\
\hline family farm & $19.7 \%$ \\
\hline incorporated & $62.1 \%$ \\
\hline cooperative & $18.2 \%$ \\
\hline
\end{tabular}

Source: own processing

\begin{tabular}{|l|c|}
\hline \multicolumn{1}{|c|}{ Farm's turnover (in mil. EUR) } & \% of farmers \\
\hline $0-2$ mil. EUR & $66.7 \%$ \\
\hline 2 - 10 mil. EUR & $31.8 \%$ \\
\hline $10-50$ mil. EUR & $1.5 \%$ \\
\hline
\end{tabular}

The investigation of UTPs occurrence focused on the trade relationship between the farmer and the main buyer (the one who buys the largest share of production). For $27 \%$ of farmers, private traders are the main buyers. Only $10.6 \%$ of farmers stated that they supply majority of production to supermarkets and $17 \%$ stated that they supply majority of production to other buyers (baby food producers, juice producers, distilleries...). Interestingly, $19.7 \%$ of farmers in our survey reported that they sell production only to consumers and thus they actually do not encounter UTPs. $26 \%$ of farmers reported that they are members of producer organization (PO) and since fruit POs in Slovakia have a condition that their members must deliver them at least $80 \%$ of their production, POs are the main buyers for all of their members.

\section{Organization of the trade relationship}

Regarding the length of the trade relationship, $38 \%$ of the surveyed farmers declared their trade relationship with the main buyer lasts longer than 10 years. $14 \%$ of farmers declared the trade relationship between 5 and 10 years, $48 \%$ less than 5 years, and $21 \%$ stated that they traded with their main buyer only one time. The formal contract is important in order to take legal action towards trading partner in case of a breach of contract terms. Farmers in our survey have either a formal contract with their main buyer $(38 \%)$ or a contract based on membership in a PO (28\%). 9\% use informal contracts and 26\% reported that there is no agreement with the buyer. These farmers sell fruit directly to consumers or trade with private traders.

Results show a certain level of uncertainty for farmers, because majority of them have a reliable estimate of the selling price after harvest (35\%) or after the products have been delivered to the buyer $(36 \%)$. Only $9 \%$ of farmers have the estimate before harvest, the remaining did not answer. In case of the quantity, only $11 \%$ of farmers have long-term agreement that specifies quantity and $29 \%$ of farmers have a reliable estimate before the harvest. This is mainly true in case of POs and other buyers. $26 \%$ have the estimate after the harvest. $15 \%$ of farmers receive unpredictable orders through the year (especially when the main buyer is a retailer). 


\section{UTPs occurrence at the farm level}

The main objective of the questionnaire was to investigate the occurrence of practices banned in the EU Directive. For each practice, farmers were asked ' how often a certain practice occurs and also to evaluate the fairness/unfairness of the practice. Given 10 black practices included in the Directive we decided to test the occurrence of 9 relevant UTPs in the Slovak fruit industry. In case of unilateral contract changes we wanted to differentiate between before and after transaction UTPs, therefore we asked farmers about unilateral changes in orders separately. Aggregated results are summarized in Table 3, which reports percentage of farmers who had experienced mentioned UTPs at least sometimes (or often or very often) and the percentage of farmers who perceive the practices as unfair or totally unfair.

Table 3 Occurrence of black UTPs

\begin{tabular}{|c|c|c|}
\hline Black UTPs & $\%$ of farmers & Perceived unfairness \\
\hline Late payments (later than 30 days for perishable agri-food products) & $31.8 \%$ & $92.6 \%$ \\
\hline Short-notice cancellations of orders & $22.7 \%$ & $85.7 \%$ \\
\hline Unilateral contract changes by the buyer & $24.5 \%$ & $25.7 \%$ \\
\hline Unilateral single order changes by the buyer & $30.2 \%$ & $60.5 \%$ \\
\hline Payments not related to a specific transaction & $31.8 \%$ & $28.0 \%$ \\
\hline Payments for wasted products/losses & $13.6 \%$ & $32.3 \%$ \\
\hline Refusal of a written confirmation of a supply agreement by the buyer & $4.5 \%$ & $100.0 \%$ \\
\hline Misuse of trade secrets by the buyer & $0.0 \%$ & $0.0 \%$ \\
\hline Commercial retaliation by the buyer & $9.1 \%$ & $75.0 \%$ \\
\hline Payments for costs of examining customer complaints & $13.6 \%$ & $46.2 \%$ \\
\hline
\end{tabular}

Source: own processing

Results show that the late payments are the most serious UTP. $32 \%$ of farmers reported that their main buyer is at least sometimes late with payments. There are however differences according to the type of the buyer. 76\% of farmers who are members of POs reported POs are never late. The issue is associated particularly with retailers and other buyers, $85 \%$ of farmers trading with retailers and 55\% trading with other buyers reported that buyer is at least sometimes late. Differences were confirmed as statistically significant by Kruskal-Wallis test.

Cancellation of orders in such a short time that does not allow producers to find an alternative for marketing of their production poses a significant problem for farmers, since perishable nature of their products decreases time to find an alternative. According to UTP Directive a notice of less than 30 days is considered as the short notice. Short-notice orders cancellations which happen at least sometimes were reported by $23 \%$ of farmers. Again, results statistically significantly differ with the type of the buyer (tested with Kruskal-Wallis test). The UTP occurs mainly in the relationship with retailers and private traders. $71 \%$ of farmers trading with retailers and $45 \%$ of those trading with private traders reported it happens at least sometimes.

Changes in the contract do not have to be necessarily considered as bad or unfair. It depends on how these changes are made. However, when changes are imposed, these might be considered as an unfair practice. Concerning the imposed changes in the contract, $25 \%$ of farmers reported that they experienced this practice. The most problematic are the imposed changes in prices and quality, reported by $20 \%$ and $23 \%$ of farmers, respectively. Changes in quality are problematic mainly in the relationship with supermarkets and changes in prices with other buyers. Unilateral changes in single orders were reported by $30 \%$ of farmers. Similarly as in case of contract changes, changes in prices and quality are the most serious.

Experience with payments not related to a specific transaction was reported by $32 \%$ of farmers. This practice occurs not only in the relationship with retailers as might be expected but also with POs. Interestingly, only $28 \%$ of these farmers consider this practice as unfair. Statistically significant differences were confirmed by Kruskal-Wallis test. Perceived fairness of the practice 
shows very important aspect - unfair practices depend on the context. This practice is perceived fairly mainly by the members of POs. POs provide their members with many services and also they store the production of their members. This is especially important for many members and therefore perceived as fair to pay for it, since one of the biggest problems of Slovak fruit sector are insufficient storage facilities.

Payments required by the buyer for wasted products and losses (after goods were already delivered to the buyer) and payments for examination of customer complaints represent the situation when the buyer transfer the costs on the supplier and this is considered to be unfair. These practices were reported by less than $14 \%$ of farmers.

When farmers meet with unfairness, they often choose to do nothing, because they might be threatened by buyers with acts of retaliation. $9 \%$ of farmers reported that their main buyer threatened them with termination of trade relationship explicitly or implicitly.

Table 4 Occurrence of grey UTPs in the contracts/agreements

\begin{tabular}{|l|c|c|c|c|c|}
\hline \multicolumn{1}{|c|}{ Grey UTPs } & \multirow{2}{*}{ N.A. } & \multirow{2}{*}{ Not in place } & \multicolumn{3}{c|}{ In place } \\
\cline { 5 - 6 } & & & Tacit & $\begin{array}{c}\text { Ambiguous } \\
\text { or unclear }\end{array}$ & $\begin{array}{c}\text { Clear and } \\
\text { Unambiguous }\end{array}$ \\
\hline Return/buyback of unsold products & 19.70 & 18.18 & 4.55 & 25.76 & 31.82 \\
\hline $\begin{array}{l}\text { Payments for displaying, listing or } \\
\text { stocking products }\end{array}$ & 19.70 & 59.09 & 1.52 & 4.55 & 15.15 \\
\hline Payments for promotions of products & 19.70 & 63.64 & 0.00 & 0.00 & 16.67 \\
\hline Payments for the advertising & 19.70 & 60.61 & 0.00 & 1.52 & 18.18 \\
\hline Payments for the marketing & 19.70 & 46.97 & 0.00 & 1.52 & 31.82 \\
\hline $\begin{array}{l}\text { Payments for staff of the buyer for } \\
\text { fitting-out premises used for the sale } \\
\text { of the supplier's products }\end{array}$ & 19.70 & 78.79 & 0.00 & 0.00 & 1.52 \\
\hline
\end{tabular}

Source: own processing

Generally, except for return/buyback of unsold products, grey practices (from the Directive) are not a serious issue in the fruit industry. In majority of cases, practices are either not in place, or are agreed clearly or unambiguously. The return/buyback of unsold products was reported by $26 \%$ of farmers as the ambiguous or unclear practice included in their contract. The occurrence was reported mainly by farmers trading with private traders, retailers and other buyers.

Many farmers consider the majority of above mentioned grey UTPs as well as some of black (e.g. misuse of trade secrets) irrelevant for fruit growing. These findings are important for future policy, because although UTP Directive provides some minimum protection for farmers by defining unfair practices, the list is not exhaustive. This means, that while some practices might be a serious threat for one sector, it does not need to hold for another sector.

At the end, farmers were asked to provide overall evaluation of the trade relationship with their main buyer. Results show a remarkable difference between the members of POs and farmers trading with other types of buyers. While $94 \%$ of PO-members consider their relationship with POs fair, results in case of other farmers are more heterogeneous. While $56 \%$ of farmers trading mainly with private traders reported that their relationship is unfair in some respect, $71 \%$ of farmers trading with retailers perceive their relationship unfair as well. Perception of total unfairness occurred only in case of farmers trading with other buyers $(27 \%)$. Overall, $5 \%$ of farmers consider the relationship with the main buyer unfair and $24 \%$ unfair in some respects.

\section{Overall occurrence of unfair trading practices}

Table 5 summarizes the occurrence of UTPs in the Slovak fruit sector by presenting the shares of fruit farmers reporting a certain number of UTPs (from Directive). Overall, $64 \%$ of surveyed 
farmers reported that they experienced at least 1 UTP in a relationship with their main buyer. Based on the results of farmers' overall satisfaction with main buyers, we decided to investigate whether a membership in POs really means a fairer relationship. $88 \%$ of farmers who are members of POs reported that they encountered at least 1 UTP in a relationship with the PO. On the other hand, $75 \%$ of farmers trading with other buyers (private traders, supermarkets, others) reported at least 1 UTP. However, when comparing number of farmers who experienced higher number of UTPs (at least 2 or more) the results are very different. The difference between number of UTPs experienced by members and non-members of PO are statistically significant. As confirmed by one-tailed t-test: p-value $<$ alfa $(0.005<0.01)$ non-members of POs experienced on average higher number of UTPs.

Table 5 Overall UTPs occurrence and difference between members and non-members of POs

\begin{tabular}{|l|c|c|c|}
\hline & $\begin{array}{c}\text { \% of all } \\
\text { farmers }\end{array}$ & $\begin{array}{c}\text { \% of members of } \\
\text { POs }\end{array}$ & $\begin{array}{c}\text { \% of non-members } \\
\text { of POs }\end{array}$ \\
\hline no UTP & $17 \%$ & $12 \%$ & $25 \%$ \\
\hline at least 1 UTP & $64 \%$ & $88 \%$ & $75 \%$ \\
\hline at least 2 UTPs & $39 \%$ & $24 \%$ & $61 \%$ \\
\hline at least 3 UTPs & $32 \%$ & $6 \%$ & $56 \%$ \\
\hline at least 4 UTPs & $21 \%$ & $6 \%$ & $36 \%$ \\
\hline at least 5 UTPs & $17 \%$ & $0 \%$ & $31 \%$ \\
\hline at least 6 UTPs or more & $6 \%$ & $0 \%$ & $11 \%$ \\
\hline
\end{tabular}

Source: own processing

\subsection{Middleman survey}

Middleman survey was based on a sample of 15 middleman firms - majority of them have the form of incorporated business (73\%), 20\% were POs and the rest were personal business firms $(0.07 \%)$. Participated firms were mostly specialized in the fruit trading $(67 \%)$ and apple trading (20\%). Due to reluctance of middlemen to talk about their own business, we decided to collect their opinions about UTP occurrence generally in the industry. The perception of UTPs in the industry was investigated with a 5-point Likert scale (1. I am not aware of the problem, 2. It is unusual, 3. It may happen sometimes, 4. It happens often, 5. It is customary) measuring the likelihood of UTPs in the relationship between middlemen and suppliers and between middlemen and their buyers. Table 6 summarizes the results - shows the share of respondents who think that a certain practice occurs in the fruit sector at least sometimes.

Table 6 Perception of UTPs in the fruit sector

\begin{tabular}{|c|c|c|}
\hline & $\begin{array}{c}\text { In the relationship: } \\
\text { Middlemen - } \\
\text { Suppliers }\end{array}$ & $\begin{array}{l}\text { In the relationship: } \\
\text { Middlemen - Buyers }\end{array}$ \\
\hline Payments are delayed, late and/or unpredictable & $100 \%$ & $100 \%$ \\
\hline Orders are cancelled on short notice & $73 \%$ & $80 \%$ \\
\hline Buyers impose unilateral changes to existing contracts & $60 \%$ & $53 \%$ \\
\hline $\begin{array}{l}\text { Suppliers must pay for expenses not related to the sales of their } \\
\text { products }\end{array}$ & $87 \%$ & $53 \%$ \\
\hline $\begin{array}{l}\text { Suppliers must pay (or are denied payments) for loss or waste } \\
\text { of products already delivered to the buyer }\end{array}$ & $100 \%$ & $87 \%$ \\
\hline Buyers refuse to write down contracts or orders & $27 \%$ & $53 \%$ \\
\hline Buyers take advantage of confidential information & $33 \%$ & $20 \%$ \\
\hline $\begin{array}{l}\text { Buyers cut orders if the suppliers try to exercise their } \\
\text { contractual rights }\end{array}$ & $87 \%$ & $67 \%$ \\
\hline Suppliers must pay for the costs of examining complaints & $33 \%$ & $27 \%$ \\
\hline Firms must comply with unnecessary quality standards & $60 \%$ & $87 \%$ \\
\hline
\end{tabular}

Source: own processing

Results show that the perception of UTPs by middlemen is even higher than the perception of farmers. The small sample size of middlemen plays a role here, but nevertheless results are the 
proof of UTPs existence in the sector. The most serious UTPs are late payments, payments for waste and losses, expenses not related to the sales of their products, possible retaliation and cancelling orders on short notice. These results are in line with results from farmers' survey. Apart from unfair practices included in the Directive, middlemen were also asked about higher and not justified quality requirements. Results confirmed the occurrence of this practice. Given the list of grey UTPs, the highest number of middlemen reported that returns of unsold products occur at least sometimes upstream as well downstream ( $83 \%$ and $73 \%$, respectively).

\subsection{Supermarket survey}

Respondents from supermarkets were asked to state how much they agree with a set of statements concerning the situation in the industry and with their suppliers using a 5-point Likert scale. With respect to the small sample size (6 supermarkets), we need to be cautious in interpretation and in generalization of the results but the survey still brings us a useful insight into the organization of fruit sales. Demand for apples strongly impacts the amount supermarkets are buying from their suppliers (confirmed by $33 \%$ of respondents). Majority of retailers agreed that consumer demand for apples is influenced by price promotions $(83 \%)$ and by changes in prices of other fruits $(33 \%)$. Given the relationships with suppliers, answers provide us a picture about the way the supply chain works. All respondents agreed that they have a few selected and trusted suppliers. $17 \%$ have also a group of suppliers they call in case of unexpected demand peak. Given the replaceability of trading partners, results show that for supermarkets it is not very difficult to replace the farmers. Results are in line with the farm survey $-40 \%$ of farmers perceive themselves as easily replaceable by their buyer. However, $41 \%$ of farmers reported that due to several reasons, they cannot replace their main buyer. This confirms a weaker position of farmers.

Similarly as in case of middlemen, respondents were asked to evaluate the perception of UTPs in the industry. They used a 5-point Likert scale measuring the likelihood of a set of UTPs from Directive 2019/633 (scale: 1. I am not aware of the problem, 2. It is unusual, 3. It may happen sometimes, 4. It happens often, 5. It is customary). The following table shows the percentage of respondents who confirmed that the certain UTP occurs in the industry at least sometimes.

Table 7 Occurrence of UTPs in the fruit industry perceived by supermarkets

\begin{tabular}{|l|c|}
\hline \multicolumn{1}{|c|}{ UTPs } & \% of respondents \\
\hline Payments are delayed, late and/or unpredictable & 16.67 \\
\hline Orders are cancelled on short notice & 16.67 \\
\hline Buyers impose unilateral changes to contracts/agreements & 16.67 \\
\hline $\begin{array}{l}\text { Suppliers must pay (or are denied payments) for loss or waste of products that were } \\
\text { already delivered to the buyer }\end{array}$ & 16.67 \\
\hline Orders are unpredictable and totally discretionary & 33.33 \\
\hline
\end{tabular}

Source: own processing

Note: the rest of the UTPs are not included in the table since they were chosen by no respondents

Respondents from supermarkets admitted possible occurrence of only a few practices - late payments $(16.7 \%)$, short notice orders cancellation (16.7\%), unilateral changes in contracts (16.7\%). 16.7\% reported that payments for losses and waste are common. Concerning the list of grey practices, all respondents reported that they are not aware of occurrence of these practices in the fruit industry. Interestingly, $33.33 \%$ of respondents think that orders are at least sometimes unpredictable.

Regarding the organization of procurement in the supermarkets, respondents were asked about commitment to buy and farmers' delivery obligation. While majority of respondents $(83 \%)$ do 
not have a commitment to buy a minimum quantity from their suppliers, the same number admitted that their suppliers have a delivery obligation, in most cases it is a contractual obligation. This was confirmed also in the farmer questionnaire $-14 \%$ of farmers trading with supermarkets reported they have a delivery obligation for a minimum quantity, but their buyers - supermarkets do not have a commitment to buy. It implies a certain level of imbalance in the trade relationship between supermarkets and farmers. However, the contractual obligation of farmers to deliver might be explained as an attempt of supermarkets to ensure stable supply, since $83 \%$ of respondents from supermarkets reported that it happens often that suppliers refuse orders or cancel delivery. But on the other hand, when the demand for apples is weak, supermarkets can still decline the delivery from their suppliers. And in case of high demand, they contact other farmers whom they use during demand peak. Similarly, 95\% of farmers trading with private traders and $73 \%$ trading with other buyers reported that their trade partners do not have a commitment to buy.

\section{Conclusion}

The paper confirmed the existence of UTPs in the Slovak fruit sector and uncovered several important issues. At farm level, $64 \%$ of respondents reported that they experienced at least 1 UTP in the relationship with their main buyer. The results confirmed statistically significant difference between members and non-members of POs. Farmers who are members of POs experienced on average lower number of UTPs. These results are in line with research of Di Marcantonio et al. (2018) who investigated occurrence of UTPs in the dairy sector of four EU countries. They found that among other factors membership to a cooperative/producer organization decreases number of UTPs the dairy farm is exposed to. This is also an important point for the future research, since many authors suggest that POs may play an important role in addressing UTP issue. Our research also showed that UTPs strongly depend on the context. Example of payments not directly related to sales of the product shows that many farmers consider these payments fair. These results show that it is important to take into account the specificities of the sector since the ban of some practices may bring unintended consequences to the functioning of the fruit value chain. On the other hand different sectors might face different problems. While grey UTPs listed in Directive proved to be a problem in dairy sector UTP research by Di Marcantonio et al. (2018), they did not prove to be a serious issue in the fruit sector. Therefore while EU Directive serves as a minimum level of protection, member states should be allowed to expand the list when needed but with careful analysis in order to avoid decline in the efficiency of supply chain. The main difference of the paper compared to previous studies lies in its complexity - UTPs occurrence was investigated not only at the farm level, but also at other stages of the fruit value chain. With respect to the small sample size (15 middlemen and 6 supermarkets), we need to be cautious in interpretation but these results still bring us a useful insight into the fruit value chain. Perception of UTPs by middlemen is even higher than at the farm level. As expected results from supermarket survey show much smaller UTPs occurrence. Overall, the most serious UTPs in the Slovak fruit sector are late payments, short notice orders cancellation, unilateral changes in contracts, and payments for losses and waste. These results also confirm that UTPs are transmitted along the whole food supply chain.

\section{Acknowledgements}

This paper was supported by the Slovak Research and Development Agency under the Grant No. APVV-18-0512 and was developed within the Tender of EC JRC: Pass-through of Unfair Trading Practices in EU food supply chains: Methodology and Empirical Application. 


\section{References}

[1] AMTF. (2016). Improving Market Outcomes: Enhancing the Position of Farmers in the Supply Chain. Retrieved from: https://ec.europa.eu/info/sites/info/files/food-farmingfisheries/farming/documents/amtf-report-improving-markets-outcomes_en.pdf

[2] Bakucs, Z., Fałkowski, J. and Fertő, I. (2014). Does Market Structure Influence Price Transmission in the Agro-food Sector? A Meta-analysis Perspective. Journal of Agricultural Economics 65(1): 1-25.

[3] Basic - Bureau for Appraisal of Social Impact for Citizen Information (2015). Banana value chains in Europe and the consequences of Unfair Trading Practices. Make Fruit Fair. October 2015.

[4] CIAA-AIM (2011). Unfair commercial practices in Europe. Dedicated study commissioned by CIAA and AIM.

[5] Copa Cogeca. (2007). COPA and COGECA Action Plan: Rebalancing the Power in the Food Chain. Brussels.

[6] Dedicated Research (2013). On behalf of COPA COGECA (European association of farmers and agricooperatives). Impact of Unfair Trading Practices in the European agri-food sector, April 2013.

[7] Di Marcantonio, F., Ciaian, P., Castellanos, V. (2018). Unfair trading practices in the dairy farm sector: Evidence from selected EU regions. Publications Office of the European Union.

[8] European Commission (2018). Proposal for a Directive of the European Parliament and of the Council on unfair trading practices in business-to-business relationships in the food supply chain. Brussels. Retrieved from: https://ec.europa.eu/info/law/betterregulation/initiative/223383/attachment/090166e5b9e75a66_en

[9] European Commission. (2013a). Green Paper on Unfair Trading Practices in the Business-to-business Food and Non-food Supply Chain in Europe. Retrieved from: https://eur-lex.europa.eu/legalcontent/EN/TXT/PDF/?uri=CELEX:52013DC0037\&from=EN

[10]European Parliament. (2019). European Parliament Legislative Resolution of 12 March 2019 on the Proposal for a Directive of the European Parliament and of the Council on Unfair Trading Practices in Business-to-Business Relationships in the Food Supply Chain (COM(2018)0173 - C8- 0139/.

[11]Fałkowski, J. (2017). The economic aspects of unfair trading practices: measurement and indicators. Unfair trading practices in the food supply chain: A literature review on methodologies, impacts and regulatory aspects (No. JRC108394). Joint Research Centre (Seville site).

[12]FoodDrinkEurope. (2011). Data \& Trends of the European Food and Drink Industry 2011. Retrieved from: https://www.fooddrinkeurope.eu/uploads/publications_documents/Final_DT_2012_04.06.pdf

[13] Kirkwood, J. B. (2005). Buyer Power and Exclusionary Conduct: Should Brooke Group Set the Standards for Buyer-Induced Price Discrimination and Predatory Bidding? Antitrust Law Journal 72: 625.

[14] Ménard, C. (2017). Summary and conclusions: the many challenges of unfair trading practices in food supply chain systems. Unfair trading practices in the food supply chain: A literature review on methodologies, impacts and regulatory aspects (No. JRC108394). Joint Research Centre (Seville site).

[15] Perekhozhuk, O., Glauben, T., Grings, M., Teuber, R. (2017). Approaches and methods for the econometric analysis of market power: A survey and empirical comparison. Journal of Economic Surveys 31(1): 303-325.

[16] Renda, A., Cafaggi, F., Pelkmans, J., Iamicelli, P. Correia de Brito, A., Mustilli, F. and Bebber, L. (2014). Study on the Legal Framework Covering Business-to-Business Unfair Trading Practices in the Retail Supply Chain. Retrieved from: https://doi.org/10.2780/91447.

[17] Sexton, R. J. (2017). Unfair trade practices in the food supply chain: defining the problem and the policy issues. Unfair trading practices in the food supply chain: A literature review on methodologies, impacts and regulatory aspects (No. JRC108394). Joint Research Centre (Seville site).

[18] Swinnen, J., Knops, L. and Van Herck, K. (2014). Food Price Volatility and EU Policies. Food Price Policy in an Era of Market Instability: A Political Economy Analysis: 457-78.

[19] Vaqué, L. G. (2014). Unfair Practices in the Food Supply Chain. A cause for concern in the European Union's internal market which requires an effective harmonizing solution. European Food and Feed Law Review, 9 (5): 293-301. 


\title{
Economic Loss of Small-Middle Enterprises from Unfair Dealing in the European Food Distribution System
}

\author{
Yevhen Kononets ${ }^{1}$, Artan Qineti ${ }^{2}$ \\ Slovak University of Agriculture in Nitra \\ Faculty of Economics and Management, Department of Economic Policy \\ Tr. Andreja Hlinku 2 \\ 94976 Nitra, Slovak Republic \\ e-mail: yevhen.kononets@ukr.net ${ }^{1}$, artan.qineti@uniag.sk ${ }^{2}$
}

doi: 10.18515/dBEM.ISD.P01.2020.p065

\begin{abstract}
A vast majority of actors in a food supply chain are small-middle enterprises (SME) which have annual turnover fewer than $50 \mathrm{mln}$. euro and employed people are fewer than 50. These companies comprise from $60 \%$ to $95 \%$ in food supply chains across the Europe.

Unfair dealing gains weight and relevance over the past few years dramatically. The main idea of the problematic states that weaker actor bears additional risks and unnecessary expenses induced by unequal bargaining power between the market participants. Food chain is especially vulnerable for impacts of unfair dealing due to the explicit disbalance in bargaining power in food supply system.

The main object of the article is to define degree of loss at SME's level precisely from actions of unfair commercial conduct.

The relevant statistical analysis is applied in order to find and prove the exact rate of annual losses with the high enough level of accuracy.
\end{abstract}

Keywords: Unfair trading practice, food supply chain, economic impact

JEL Classification: L81, C0, E6, Q17

\section{Introduction}

Food supply chain is a system of people and activities involved in moving food products from a primary producer to a consumer. Food supply chain consists of a number of vertically linked industries where the vast majority of actors are small and middle enterprises (SMEs) with annual turnover fewer than 50 mil. Euro, and employed less than 50 people (EC, 2003). These companies comprise from $60 \%$ to $95 \%$ of food supply chains across Europe (Eurostat, 2016). They possess low or no bargaining power and are the most vulnerable to unfair trading practices from the other stages of the chain.

Unfair Trading Practices (UTPs) are business-to-business practices that deviate from a good commercial conduct and are contrary to good faith and fair dealing (EC, 2018). Weight and relevance of these practices became the problem over the past few years. The result of unfair trading practices is that the weaker actor bears additional risks or unnecessary expenses induced by unequal bargaining power between the market participants.

We use the data derived from the survey conducted in 2017 by European Commission (EC, 2018) concerning the issue of unfair trading practices in the EU. European Commission is pursuing a purpose to assess the level of losses from unfair commercial practice making several attempts to conduct a public surveys between undertakings in the food supply chain. This survey on the initiative to improve the food supply chain involved $\mathbf{1 4 7 3}$ appropriate respondents across the Europe to answer the questionnaire. There were three targeted groups: individuals, undertakings in the food supply chain, consumer organizations. The questionnaire for undertakings consisted from several basic questions about SME such as place in a food supply 
chain, quantity of employees involved, country of residence and etc. The other call of questions was regarding manifestations of unfair trading practices in respondent's activity. They were asked to describe these practices with some explanations about circumstances and the consequences they occurred with. One of the question proposed to estimate in monetary value the costs incurred by the UTP. The main question of our interest was specifically, if producers can estimate the commercial significance of these costs in \% range to year turnover (EC, 2018). This question is particularly interesting, because it allows us to identify the rate of annual losses in revenues of dependable entities. Our main objective is to define the degree of loss of small and medium enterprises (SMEs) from experiencing unfair commercial conduct. With the help of linear difference equation as a type of recurrence relation in mathematical analysis we find and prove the rate of annual losses of weaker firms stemming out from unfair trading actions.

\section{Material and Methods}

The food supply chain in the EU comprises all actors and activities from primary agricultural production to food processing, distribution, retailing and consumption. It ensures that food products, including beverages, are delivered to the general public for personal, household consumption via retail sales or food services (catering, etc.). It also includes recycling and disposal stages where appropriate.

The food sector in many Member States displays some imbalances of bargaining power between firms at different levels of the supply chain. Such imbalances could be the source of potential problems whereby a trading partner considers that it has been treated unfairly by its counterpart with stronger bargaining power, be it either the supplier or the buyer. Competition policy can help to mitigate (some of) these problems only in few cases. Farmers and SME operators, who generally possess a low bargaining power, are thus particularly prone to be affected by UTPs (EC, 2018).

Average farm income per working unit is significantly below average wages obtained in other economic sectors in the majority of Member States. Direct payments narrow this gap and contribute to achieving one of the Treaty's CAP objectives as defined in the Treaty on the Functioning of the European Union: to ensure a fair standard of living for the agricultural community. Farm households can also gain non-agricultural on-farm and off-farm income, just as any other household (e.g. through tourism services, energy production or part-time work out of the farm in other activities).

The open public consultation is a measure of the European Commission to deliver a high quality and credible proposals by allowing interested parties to provide feedback by means of surveys and interviews ensuring also transparency and accountability. In such open public consultation in $2017,94 \%$ of respondents agreed or partially agreed that unfair trading practices occurred in relation to farmers. $83 \%$ agreed they occur in relation to processors, $38 \%$ in relation to retail organizations, $35 \%$ in relation to retailers, $39 \%$ in relation to traders and $60 \%$ in relation to consumers. Overall, respondents identified farmers, agricultural and in some countries food manufacturers as being most exposed to negative effects from UTPs in the food supply chain although such effects can occur at all levels of the chain (EC, 2018). These vulnerable categories are more often being operated as micro, small and middle-sized business entities.

The food distribution chain is also highly concentrated. Food products are distributed primarily through supermarkets, hypermarkets and discounters, which account on average for $71 \%$ of total packaged food sales in the EU Member States (EC DG AGRI, 2016). According to these data (not covering on-line and other non-store sales), the CR5 in the grocery retail sector was 
above $60 \%$ in the half of Member States (above $80 \%$ in Sweden and Finland) and below 40\% only in Italy, Bulgaria and Greece.

\subsection{Tackling measures within the EU}

The Supply Chain Initiative (SCI) was developed within the framework of the Commission's High Level Forum on the Better Functioning of the Food Supply Chain. It includes an agreement among associations of operators of the food supply chain to promote fair business practices in the food supply chain as a basis for commercial dealings (EC, 2015). As a result, the principles of good commercial practice appeared as the official document and significant memorandum of the association and their participants (The supply chain initiative, 2019).

One of the problems in the food Supply Chain Initiative (FSCI) is the absence of farmers' associations, which decided to pull out right after its creation. A 2014 report on Fair Relations in the Food Supply Chain (BIICL, 2014) found that "any procedural rules concerning investigations must provide for rules to protect confidentiality and anonymity". The results of the European Commission's public consultation in 2013 showed that about $67 \%$ of the respondents confirmed that fear of negative consequences in case of a complaint about UTPs is an important consideration. Only about $9 \%$ of the respondents disagreed (EC, 2013). In a 2011 study, $64 \%$ of respondents stated that the reason why they did not take further steps than discussing the issue with their buyers was that they were afraid of "commercial sanctions". 11\% stated that they were threatened with retaliation in case of taking action (DR CIAA and AIM, 2011).

Existing judicial and administrative redress possibilities in some Member States lack in effectiveness in tackling the fear factor. The sentiment of a lack of protection due to the absence of an EU approach that would provide for minimum protection is confirmed in recent surveys (EC, 2018).

The open public consultation on the initiative to improve the food supply chain of July 2017 showed $95 \%$ of respondents to agree that action should be taken to address UTPs in the food supply chain. $87 \%$ of respondents believed the European Union should act on UTPs. In this survey, performed among more than 400 professionals in the agri-food sector, $64 \%$ of the respondents stated that UTPs created uncertainty regarding costs, 59\% that they were leading to a reduction of investments for modernization of production facilities and $50 \%$ that UTPs had a negative impact on investment in new technologies (Renda, Cafaggi, 2014). According to this consultation, $62 \%$ of individuals and $58 \%$ of companies agreed or partially agreed that UTPs in the food supply chain have appreciable negative effects on consumers. For companies this ranged from $29 \%$ for retail to $90 \%$ for civil society organizations ( $48 \%$ for agriculture; $71 \%$ for agri-food sector). Payment delays are reported to have a negative impact on investments undertaken at the farm level, particularly in the context of countries in transition (Dedicated Research CIAA and AIM, 2011).

The category of micro, small and medium-sized enterprises (SMEs) is made up of all enterprises which employ fewer than 250 persons and which have an annual turnover not exceeding EUR 50 million, and/or an annual balance sheet total not exceeding EUR 43 million. Within the SME category, a small enterprise is defined as an enterprise which employs fewer than 50 persons and whose annual turnover and/or annual balance sheet total does not exceed EUR 10 million. Within the SME category, a microenterprise is defined as an enterprise which employs fewer than 10 persons and whose annual turnover and/or annual balance sheet total does not exceed EUR 2 million (EC, 2003) (Table 1). 
Table 1. Definition of SME in figures

\begin{tabular}{lccc}
\hline $\begin{array}{l}\text { Enterprise } \\
\text { category }\end{array}$ & Persons employed & Turnover & Balance sheet total \\
\hline Micro & $<10$ & $\leq € 2 \mathrm{mln}$. & $\leq € 2 \mathrm{mln}$. \\
Small & $<50$ & $\leq € 10 \mathrm{mln}$. & $\leq € 10 \mathrm{mln}$. \\
Medium & $<250$ & $\leq € 50 \mathrm{mln}$. & $\leq € 43 \mathrm{mln}$. \\
\hline
\end{tabular}

\section{Results and Discussion}

In the frame of mentioned public consultation in 2017, the third questionnaire was targeted to entrepreneurs, farmers and other SME entities and a total of 122 responses were received. 35\% of respondents were involved in agriculture, $48 \%$ in processing, $10 \%$ in retail, $4 \%$ in wholesale (remaining answers not classified). In terms of size, $70 \%$ of respondents were SMEs. $7 \%$ of the respondents classified themselves as buyers, $49 \%$ suppliers, $40 \%$ as acting as both supplier and buyer. A high share of replies is from Belgium, France, Italy, Spain and the United Kingdom (18 Member States have 3 or less replies).

$54 \%$ of the enterprises acting as buyers and $89 \%$ of suppliers state that late payments occur in business transactions. $14 \%$ to $30 \%$ of those acting as buyers stated that they have imposed other UTPs in a business transaction. For enterprises acting as suppliers $44 \%$ to $82 \%$ stated that they have been subject to an UTP as defined above. $30 \%$ of the enterprises acting as suppliers have been refused a contract in writing upon request. Suppliers were asked to estimate if they have been a victim to a UTP when buyers were established in other Member State. $24 \%$ of the respondents stated that they were "often or in a significant number of cases" in such situations. $19 \%$ of suppliers stated that dealing with a foreign buyer had a negative effect on their ability to challenge UTPs. $60 \%$ of the suppliers stated that UTP costs are more than $0.5 \%$ of the annual turnover of their business operation. Under certain assumptions in terms of weight for each category of answer, the weighted commercial significance of costs related to UTP can be estimated at $1.8 \%$ (taking into account the 100 answers of suppliers) to $1.5 \%$ (trimming out the extreme answers - no costs, cost over 5\%) of their turnover (EC, 2018). The last figures of weighted commercial significance of costs related to UTP are considered for closer discovering. As this number is the core point for estimation of the harmful effect on small business entities from the unfair trading practice phenomenon. Moreover, the effect more or less evenly spread out across the Europe and is extremely actual under the terms of fair income distribution and sustainable development of territories.

\subsection{Estimation of the loss level from UTP}

Survey data on the monetized costs of UTPs (potential benefits of legislation) in the food supply chain does exist, typically expressed as a share of turnover. Assuming similar figures across the EU and that for those companies that experience such practices related UTPs costs are between $1 \%$ and $2 \%$ of turnover, and knowing that agriculture SME turnover in the EU is about EUR 325 billion and food industry SME turnover in the EU is about EUR 470 billion a range for the magnitude of possible costs of UTPs occurring in the food supply chain can be calculated (UK Competition Commission, 2008). The approach would put these costs at EUR 1 billion to EUR 3.3 billion for agricultural SMEs and EUR 1.5 billion to EUR 4.7 billion for food SMEs (or EUR 2.5 billion to EUR 8 billion in total for both agriculture and food processing SMEs). The damage imposed by the six UTPs identified as occurring most frequently, which broadly align with the SCI principles of good practice, would be a further fraction of these figures. 
OPC was conducted with questionnaires. Regarding the issue the results were following: $60 \%$ of the suppliers stated that UTP costs are more than $0.5 \%$ of the annual turnover of their business operation. Under certain assumptions in terms of weight for each category of answer, Reference points set: 'over 5\%' (14 answers) $=5 \%$; ' 2 to $5 \%$ ' (18 answers $)=3.5 \%$; ' 0.5 to $2 \%$ ' $(22$ answers $)=1.25 \%$; ' $>0.5 \%$ ' ( 24 answers $)=0.25 \%$; 'nil or insignificant' $(16$ answers $)=0 \%$ (Table 7, Replies).

Participants were asked 'Can you estimate the commercial significance of these costs? In range $\%$, to your year turnover (the ranges are given)' (Table 2).

Table 2. All available responses on the question 14 with the only one choice option

\begin{tabular}{cl}
\hline$\circ$ & Nil or insignificant \\
\hline$\circ$ & $<0,5 \%$ of your year turnover \\
\hline$\circ$ & 0,5 to $2 \%$ of your year turnover \\
\hline$\circ$ & 2 to $5 \%$ of your year turnover \\
\hline$\circ$ & $>5 \%$ of your year turnover
\end{tabular}

Source: https://ec.europa.eu/info/consultations/initiative-improve-food-supply-chain_en

Writing down (Table 3 ) each possible choice in the sequential order combined with proper valid range in a correct mathematical form:

Table 3. Each choice with proper valid range in \%

\begin{tabular}{cccccc}
\hline Choice & 1 & 2 & 3 & 4 & 5 \\
\hline Valid ranges, $\%$ & 0 & $0-0,5$ & $0,5-2$ & $2-5$ & $>5$ \\
\hline
\end{tabular}

Source: developed by the authors

The line "Choice" - this is the consecutive numbering of every possible answer in order to operate with only choice number in following calculations. For example here, the answer ' $<0,5 \%$ of your yearly turnover' this is the sequential answer number two (Choice 2 ). In turn, The line "Valid ranges, \%", is numeric response value, actual range in numbers of each reply. For example, the answer ' 2 to $5 \%$ of your yearly turnover' implies \% range between $2-5$. So we just convert the possible answers into the mathematical view.

In order to find the average value from this survey for following application in calculations and statistics we have to find the average number of each allowable value range. However, in case of the last range there is no obvious reply as the maximum threshold is not identified. For solving this issue we apply statistical analysis for seeking the most likelihood meaning. Firstly, we count out the difference of each valid range:

Table 4. Each choice with proper value range, in \%

\begin{tabular}{cccccc}
\hline Choice & 1 & 2 & 3 & 4 & 5 \\
\hline Range & 0 & 0,5 & 1,5 & 3 & $?$ \\
\hline
\end{tabular}

Source: developed by the authors

Where, as mentioned, there is impossible to calculate on the last stage. So, now we calculate the change of difference in each following range:

Table 5. Each choice with proper range change, in \%

\begin{tabular}{cccccc}
\hline Choice & 1 & 2 & 3 & 4 & 5 \\
\hline Range change & 0 & 0,5 & 1 & 1,5 & $?$ \\
\hline
\end{tabular}

Source: developed by the authors 
Here again, the line 'Choice' - the consecutive number of answers and the line 'Range change'. The last is a difference of $\%$ range of each next Choice compared to the previous Choice. For example, the possible answer ' 0,5 to $2 \%$ of your yearly turnover' has range of $1,5 \%$ (Table 4 ), but previous Choice ' $<0,5 \%$ of your yearly turnover' has range $0,5 \%$ then it means that the answer ' 0,5 to $2 \%$ of your yearly turnover' has different possible range compared to the previous Choice and equals: $1,5 \%-0,5 \%=1 \%$. That is why, the Choice 3 (' 0,5 to $2 \%$ of your yearly turnover') has Change in range $=1$, as showed at this table. The same methodology is with the other Choices. And according to the 'Range change' each following Choice makes difference in $+0,5 \%$ with the previous one what might be described with function and equation. These descriptions are proposed in following pages where we are finding the lack data for calculation of the average loss in $\%$ of turnover.

As it is logically following from the existing range, that it is added by $0,5 \%$ in each range change from the first choice of respondents by creating the line function which is the best expressed as:

$$
f(x)=f(x)_{x-1}+0,5
$$

Where

$f(x)$ - range change function

$x$ - a choice number

There is valid to assume about strict line function in the range. Now, using mathematical analysis we are able to convert the function in mathematical equation:

$$
f(x)=(x-1)-\frac{(x-1)}{2}
$$

According to this, we find that the last change in range is going to be 2 , adding 0,5 to the last known value 1,5 or by putting choice $(x)=5$ into the formula.

Now it means, getting back to calculations of the ranges, the last range should be 5 , as 3 plus 2 . Getting this range, we obtain the last the only one reasonable range of choice 5 as $5-10 \%$. Summarizing above we get following (Table 6):

Table 6. Each choice with estimated values

\begin{tabular}{cccccc}
\hline Available responses & $\begin{array}{c}\text { Nil or } \\
\text { insignificant }\end{array}$ & $\begin{array}{c}<0,5 \% \text { of } \\
\text { your } \\
\text { yearly } \\
\text { turnover }\end{array}$ & $\begin{array}{c}0,5 \text { to } 2 \% \text { of } \\
\text { your yearly } \\
\text { turnover }\end{array}$ & $\begin{array}{c}2 \text { to } 5 \% \\
\text { of your } \\
\text { yearly } \\
\text { turnover }\end{array}$ & $\begin{array}{c}>5 \% \text { of } \\
\text { your } \\
\text { yearly } \\
\text { turnover }\end{array}$ \\
\hline Valid range, $\%$ & 0 & $0-0,5$ & $0,5-2$ & $2-5$ & $>5$ \\
\hline Choice & 1 & 2 & 3 & 4 & 5 \\
\hline Range & 0 & 0,5 & 1,5 & 1,5 & $\mathbf{2}$ \\
\hline Allowable values & 0 & $0,0,5$ & $0,5-2$ & $2-5$ & $\mathbf{5 - 1 0}$ \\
\hline
\end{tabular}

Source: calculated by the authors

Based on the data in the table above, now there is possibly to compose for visualizing the row of available data. There is notable accurate interdependency along red curve reflecting the difference in each available range in the Figure 1. 


\section{Figure 1. Interdependency of determinants}

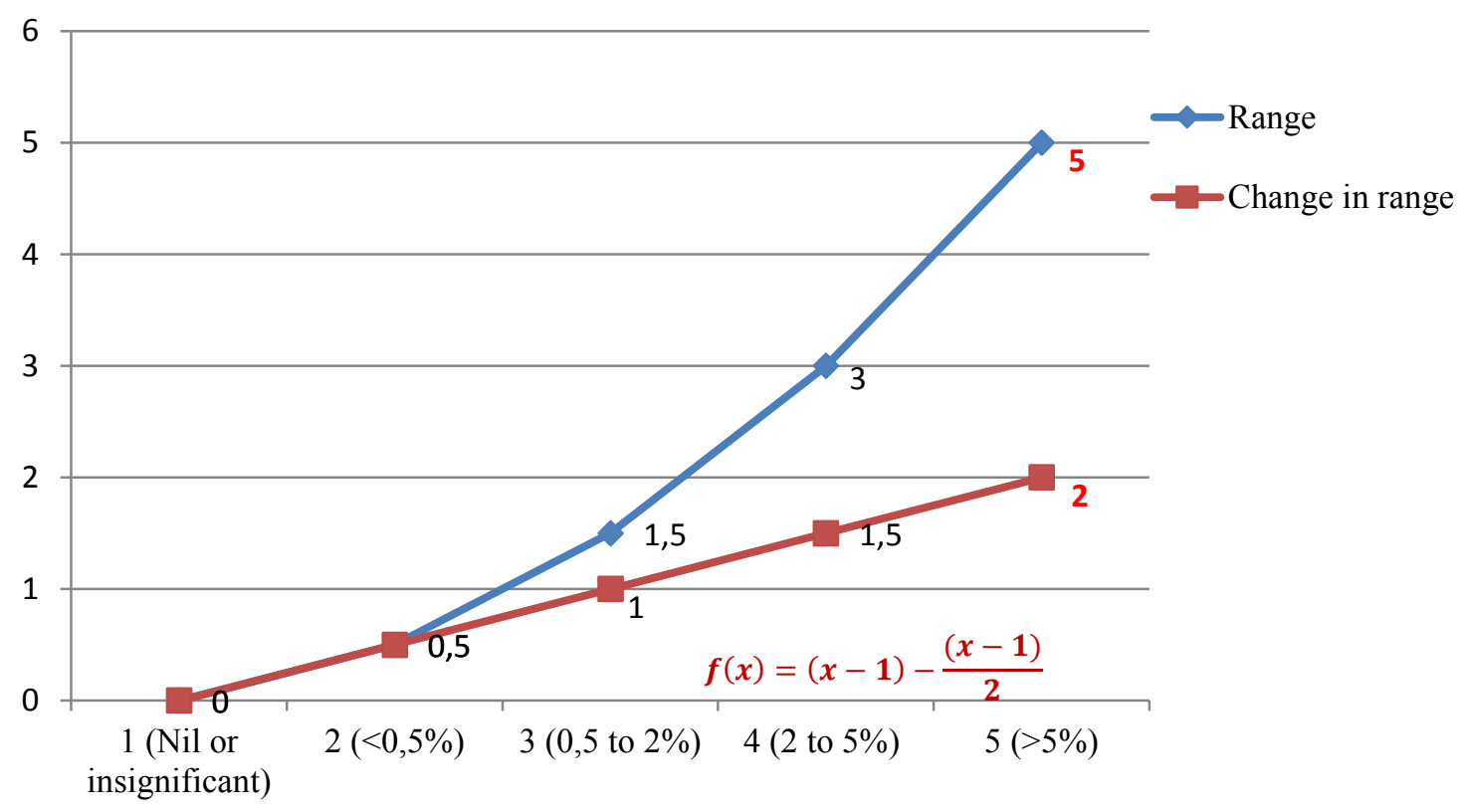

Source: Developed by the authors

The next stage is to find a simple statistical average of each range putting the appropriate number of replies together with the relevant choice (Table 7):

Table 7. Compared valid and statistical average in each range.

\begin{tabular}{ccccccc}
\hline Average in range & 0 & 0,25 & 1,25 & 3,5 & 7,5 & Total \\
\hline Valid responses & 16 & 24 & 22 & 23 & 15 & $\mathbf{1 0 0}$ \\
\hline Statistical average & 20 & 20 & 20 & 20 & 20 & $\mathbf{1 0 0}$
\end{tabular}

Source: Based on the data (Valid responses) at https://ec.europa.eu/info/consultations/initiative-improve-foodsupply-chain_en and own calculations.

In case the results would be evenly distributed the replies for each range would equal: $100 / 5=$ 20. However, it varies over the ranges based on real replies from the target auditory (Figure 2). As a result, the average shifts toward the higher values which belong to the concrete choices what is definitely worth to take in count in final calculation.

Figure 2. Distribution of responses by average values of the ranges

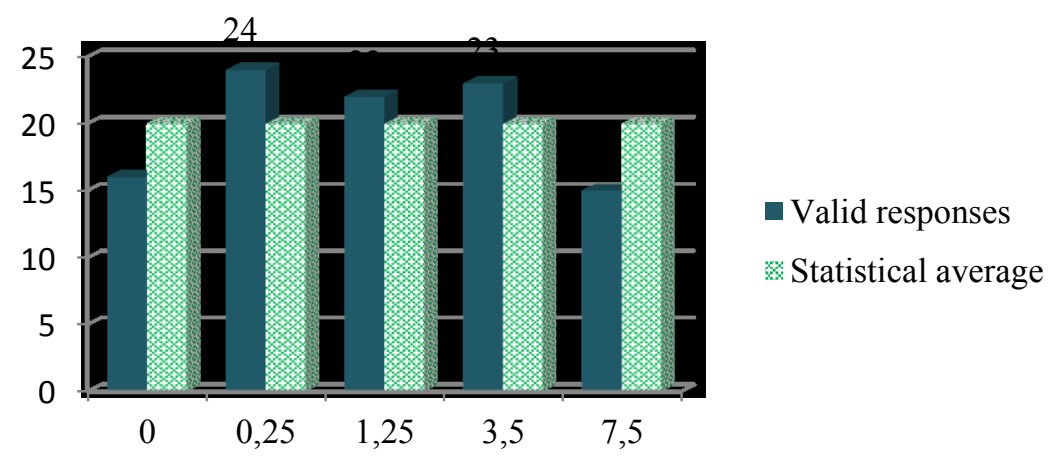

Source: Developed by the authors

Hence, we count the statistical weighted average $(s w A)$ of the whole range in the question to find the average economic loss for SME annually from UTP. 


$$
S w A=\frac{\sum_{\overline{V r n}}^{\mathrm{Arn}}}{R}
$$

Where,

$\mathrm{Ar}-$ Average in range

$\mathrm{Vr}-$ Valid responses

$\mathrm{n}-$ Choice $1-5$

$R$ - Quantity of all responses

$$
S W A=\frac{0 \times 16+\left(\frac{0,5+0}{2}\right) \times 24+\left(\frac{0,5+2}{2}\right) \times 22+\left(\frac{2+5}{2}\right) \times 23+\left(\frac{5+10}{2}\right) \times 15}{100}=\mathbf{2 , 2 6 5 \%}
$$

In conclusion, we can estimate the percentage loss to annual turnover from impacts of unfair trading practices out of 100 responses among undertakings in the open public consultation in 2017. According to our assessment these losses equal to $2.265 \%$ from company's revenue but not that $1.8 \%$ as was announced in accompanied documents of this survey. In further, we might apply new finding for any future relevant research.

\section{Conclusions}

Harmonized Indices of Consumer Prices (HICPs) (Table 8) are designed for international comparisons of consumer price inflation. HICP is used for example by the European Central Bank for monitoring of inflation in the Economic and Monetary Union and for the assessment of inflation convergence.

Table 8. HICP - inflation rate. Annual average rate of change (\%)

\begin{tabular}{cccccccc}
\hline geo $\backslash$ time & $\mathbf{2 0 1 2}$ & $\mathbf{2 0 1 3}$ & $\mathbf{2 0 1 4}$ & $\mathbf{2 0 1 5}$ & $\mathbf{2 0 1 6}$ & $\mathbf{2 0 1 7}$ & $\mathbf{2 0 1 8}$ \\
\hline EU (28 countries) & 2,6 & 1,5 & 0,6 & 0,1 & 0,2 & 1,7 & 1,9
\end{tabular}

Source: https://ec.europa.eu/eurostat/tgm/table.do?tab=table\&plugin=1\&language=en\&pcode=tec0 0118

The table illustrates annual inflation rate of change in European Union countries. Degree of decreased value of currency over the past six years is much fewer than $\mathbf{2 . 2 6 5 \%}$. Thus, there is possible to make an assumption that the monetary losses of revenue much larger from the UTP effect rather than from macroeconomic challenges in the Euro zone.

Also, there have been determined some differences between the loss rate from UTP and such macroeconomic effect as the inflation rate:

- Larger \% loss in monetary value (2013-2018) (Table 8)

- Quantitate loss of money but not qualitative as inflation impact. Loss rate from UTP implies the percentage of under-received currency income, in turn, the inflation rate qualitatively depreciates it what makes difference.

- it carries not such a mass character, thus the discussed effect is hidden and identified hardly enough.

The paper reveals the precise number-rate of lost or non-received incomes within SMEs what better describes its level according to the best knowledge of conducted EU consultations and provided survey data. The found value of $2.265 \%$ causes great interest inasmuch as it is larger than considered $1.8 \%$ and even much larger than the most known inflation rates during the past six years in the EU which on average is $1.74 \%$. However, the UTP issue is definitely not as 
much wide-known as it. Therefore, this is an inference to pay more attention on such hidden issues which takes place in the economies beyond the public attention.

\section{References}

[1] British Institute of International and Comparative Law (2014), Justine Stefanelli, Philip Marsden, Fair Relations in the Food Supply Chain - Establishing Effective European Enforcement Structures, p. 12.

[2] Dedicated Research (2019). Available at www.dedicated.be

[3] Dedicated Research CIAA and AIM, Unfair commercial practices in Europe. Presentation, March 2011, slide, p. 15.

[4] DG Agriculture and Rural development from Euromonitor, (2016). EU average MS concentration ratios (CR5) per food sector.

[5] European Commission (2003). Official Journal of the European Union (2003), Commission Recommendation 2003/361/EC of 6 May 2003 concerning the definition of micro, small and medium- sized enterprises (OJ L 124, 20.5.2003, p. 36.)

[6] European Commission (2013). DG GROW. Summary of responses to the European Commission Green.

[7] European Commission (2015). The High Level Forum on the Better Functioning of the Food Supply Chain comprises Member State national authorities responsible for the food sector at ministerial level and representatives of the private sector. Commission Decision 2015/C 179/03 of 1 June 2015.

[8] European Commission (2017). Agriculture and rural development Department, European Commission. (Consultation period 16.8.17-17.11.17). Questionnaires available at https://ec.europa.eu/info/consultations/ initiative-improve-food-supply-chain_en

[9] European Commission (2018). Fact Sheet, Tackling unfair trading practices in the food supply chain. MEMO/18/2703. Available at http://europa.eu/rapid/press-release_MEMO-18-2703_en.htm

[10] European Commission (2018). Impact Assessment. Initiative to improve the food supply chain (unfair trading practices). Accompanying the document Proposal for a directive of the European parliament and of the council on unfair trading practices in business-to-business relationships in the food supply chain. Brussels, 12.4.2018. SWD (2018) 92 final. Available at https://eur-lex.europa.eu/legal-content/HU/TXT/?uri= CELEX\%3A52018SC0092

[11] Eurostat (2019). Available at https://ec.europa.eu/eurostat/web/products-datasets/

[12] Renda\&Cafaggi (2014), Study on the legal framework covering business-to-business unfair trading practices in the retail supply chain, final report. Prepared for the European Commission, DG Internal Market DG MARKT/2012/049/E, ISBN: 978-92-79-29921-6, DOI: 10.2780/91447p. 116.

[13] The supply chain initiative (2011). Vertical relationships in the Food Supply Chain: Principles of Good Practice. Available at https://www.supplychaininitiative.eu/ regionalnational-supporting-initiatives, 29 November 2011

[14] UK Competition Commission (2008), Groceries market investigation - final report (UK), p. 168. 


\title{
Conditions for Improving the Position of Small-Scale Food Producers in Food Supply System
}

\author{
Yevhen Kononets ${ }^{1}$, Miroslava Rajčániová ${ }^{2}$ \\ Slovak University of Agriculture in Nitra \\ Faculty of Economics and Management, Department of Economic Policy \\ Tr. Andreja Hlinku 2 \\ 94976 Nitra, Slovak Republic \\ e-mail: yevhen.kononets@ukr.net ${ }^{1}$, miroslava.rajcaniova@uniag.sk²
}

doi: 10.18515/dBEM.ISD.P01.2020.p066

\begin{abstract}
There is an obvious necessity of well-functioning small food producers. They play an important role of agricultural sector. The efficiency of small farms fluctuates significantly and depends on plenty of factors. One of the most important aspects determining the efficiency of their production activity is the price of their production. Due to a strong imbalance in market power and bargaining power along food supply chain, small farms can be particularly affected. They can be a victim of unfairly low price for their production, late payments, imposing additional fees or deductions and other unfair trade practices. The recent research on unfair trade practices opens a question of possible benefits in using blockchain technology and other digital solutions in the food supply chain. This may help to eliminate such practices and protect weaker party of the contractual relationship to bring promising result in particularly more sustainable position on the market. It can also lead to a better functioning of food producers and the whole food supply chain. So far the topic is very pioneering and rare in the scientific literature. The aim of this paper is to determine the ways of possible elimination of given actual issue as well as to improve efficiency of family and small-scale producers in the food supply chain relying on the practical information of some farms obtained during the research .
\end{abstract}

Keywords: agricultural policy, food producers, food supply chain, small-middle enterprises, unfair trading practices

JEL Classification: F14, Q13, Q18

\section{Introduction}

There are serious concerns about the increasing concentration and consolidation of agricultural producers, retailers, and a significant drop in the number of processors and potential trading partners. This in many cases causes imbalances in bargaining power, unilateral changes to existing contracts, late payments, refusal to act, in particular to the detriment of weaker market players, and creates a "suitable environment" to implement so called unfair trade practices. Deepening problem of unequal market power among individual actors in food supply chain makes it necessary to improve market position of small farmers and food producers vulnerable to unfair trade practices. In fact, added value of the product is in contrary with unevenly distributed margins along the food supply chain. Hence, they do not have many sources for developing and live in the vast majority on the verge of survival. From that point, their mission is sooner defined to be as controlled appendage for retail and distribution activities rather than self-sufficient business entities.

As stated by Ciliberti and Frascarelli (2013) the issue of trade relationships along the food supply chain has assumed a great importance in the scientific and political debate, due to the recent exacerbation of two phenomena with strong social and economic impacts: the wide fluctuations of agricultural commodity prices during the period $2007-2008$, no doubt related to the gradual liberalization of the European agricultural market occurred in the last three decades 
(European Commission, 2008; Rosa and Vasciaveo, 2010), and the asymmetric prices transmission along the agro-food supply chain, which has exacerbated the decrease of the agricultural value added (Ismea, 2012).

Using blockchain technology may help to eliminate unfair trade practices and protect weaker party of the contractual relationship brings promising results. It can also lead to a better functioning of food producers and the whole food supply chain. So far the topic is very pioneering and rare in the scientific literature. One of the aim of the article is to determine possible, available and perspective technologies in contractual relationships between parties in the food industry in order to improve overall supply efficiency with restriction effect for unfair dealing.

\section{Unfair Trading Practices in the Food Supply Chain}

The European Commission defines unfair trade practices as practices that "deviate significantly from good business practice, conflict with good faith and fair trade, and are unilaterally imposed by one trading partner" (European Commission, 2010). However, the definition and detailed characteristics of each type of UTP are not sufficient to understand the whole concept. According to Falkowski et al. (2017) there are problems of thorough definition of unfair trade practice in directives and acts, as well as their slow implementation in practice. When identifying them, other important factors affecting the UTP rate shall be taken into account. Lee (2017) stressed both the imbalance in bargaining power and the so-called fear factor as important factors.

Bargaining power is the ability to obtain a better price or better conditions in a competitive market (Fletcher et al., 1961). Smaller actors in food supply chain, including farmers, often have little bargaining power and are therefore often victims of UTPs.

The other key factor in the development of unfair competition is the so-called fear factor. In general, weaker parties find it more difficult to take legal action against such practices, mainly because of concerns about the termination of trade relations. As reported by the Center for Research on Multinational Corporations (2013), this factor is widespread, particularly among suppliers. That is why one of the problems is that there is very little public information, which makes it difficult to investigate business practices and to investigate the extent to which UTPs lead to infringements.

For now, very few empirical researches have been carried out on unfair trade practices, especially in agriculture and food supply chains. The study of Basic (2015) shows how the growing market power and unfair trade practices of EU supermarkets affect small banana producers, with the risk being passed on from buyers to producers and the 'fear factor' apparently being present. Abad et al. (2012) conducted a survey to determine the scope and awareness of UTPs in the Philippines. The main conclusions show that their prevalence is widespread and that these practices have an adverse effect on commercial transactions and consumer welfare. In 2011, a survey of 684 suppliers was conducted in 15 EU countries (CIAAAIM, 2011). The results show that more than $96 \%$ of the organizations surveyed were exposed to UTPs. In $84 \%$ of the cases, this was a factor of non-compliance with the terms and conditions of customers, of which approximately $65 \%$ of companies did not take any measures against UTPs, which have a negative impact on the costs, revenues and innovations of companies. Copa-Cogeca (2013) also investigated the economic impacts of UTPs to quantify the consequences of these practices. Recent empirical evidence is provided by Di Marcantoni et al. (2018), who conducted extensive research on UTPs in the dairy sector in 4 selected European regions in France, Germany, Poland, Spain. 29 types of unfair practices in contract content, 
contract negotiation and contract implementation have been identified. A total of $93 \%$ of the dairy producers surveyed reported the presence of at least one of them, $54 \%$ at least two, and $30 \%$ confirmed the occurrence of at least 3 unfair trade practices with the main dairy purchaser.

\section{Data and Methods}

\subsection{Data collection strategy}

In order to determine the possible conditions for improving the position of small-scale food producers in the food supply system we decided to ask farmers for their actual opinion in the context of market functioning and in particularly focusing on price injustice and unfair dealing they face in their daily work. For that, we requested them basic parameters of the farm and qualitative information in form of their comments and explanations.

This research considers empirical analysis of data gained during separate face to face interviews with actual farmers, what was the primary source of information. Though, the choice of 3 smallscale producers ( 1 for each from the 3 production sectors and countries) is not sufficient for generalization of findings, however it creates a base for next research data sets in definite location and sector. For example, realizing the difference in fair trade experience among Austrian Bio certified farmers there is a need for future research to focus on Austrian small scale organic food producers and their daily interactions with unfair dealing.

The farmers chosen for discussion operate in different countries, in particular, Slovakia, Ukraine and Austria. Our selection of specific informants was based on their involvement in decision making around the food production activity rather than their direct functional area. They were expected to provide insights regarding their organizations' internal motives in decision making as well as local insights. Relying on data collection strategy, there is a reason to diversify considered respondents by main product specialization. It could enhance the strategy what will give us an opportunity to acquire as objective information as possible. The farmers are specializing on production of honey, cereals and livestock production which have own and different specifics of markets. There are obvious differences in both a scheme of growing, sorting, storing and transportation of these products that leads to different approaches for market strategy and interactions with buyers.

\subsection{Interview}

The semi-structured interviews typically lasted 1,5h. The process of interviewing was conducted with preliminary prepared questionnaire. There are two parts of information obtained: basic information about a farmer and questions about their activities. Open ended questions are prevailing that allows interviewees to mention other interesting aspects that might be relevant and important for the research. All entered information by respondents was approved with concession to share for scientific purposes. Despite some language barriers in communication, potential misunderstandings were nevertheless mitigated by regularly repeating and summarizing the exchanged information during discussions.

Obtained information we processed into three different case studies.

\section{Results}

\section{Case study 1: Honey Production in Ukraine}

The honey producer in Ukraine interviewed in our research was operating in Dnipropetrovsk region for 5 years. He is employing 2 people and producing 300 litres of honey a year farming 
at a land of about $80 \mathrm{~m} 2$. Beside the production of honey this producer has his own storing and packing facilities and does all the serving activities (accounting, marketing...) by himself.

One of the problems small food producers face in Ukraine is a huge administrative burden and high transaction costs. As stated by the producer, the reason he doesn't sell his production in big stores is, that he would need to collect huge number of documents that the cost of collecting all these papers would not be paid off for even 3 seasons. The second reason is the small size of the producer. Big retailers like ATB (Lidl) or Billa cooperate with bigger honey producers with about 150 beehives. Nowadays the honey producer is considered to be officially a beekeeper in Ukraine if he has at least 50 beehives. Small beekeepers with less than 50 beehives thus have to sell their production in retail themselves for example via internet market desks. This force him many times to sell his production for a price lower than recommended fair price (https://price.www.fairtrade.net/index.php). His actual average price of honey is 0.93 USD if he sells his production to wholesaler and 2.16 USD selling in retail. The actual fair price considered across the world and in particularly in this region is 2.3-2.55 USD. The price is perceived to be artificially low, set by wholesalers. Also, according to the opinion of the farmer the prices do not react to external factors as oil prices, USD exchange rate or other costs. Small producers have limited or no impact on prices of their products. Many small producers do not cooperate with wholesalers because of low prices and no negotiation power of small producers. Only big beekeepers with more than $1000 \mathrm{~kg}$ of production can bargain with wholesalers. The advantage to work with wholesalers if a producer has $500+\mathrm{kg}$ of honey production is that they come and carry away the production themselves. In addition, they provide exchangeable containers for honey storing. A disadvantage is the low price and too long periods for the quality tests to be done. Furthermore, those tests can be misleading and can get the producer waiting and losing other sales opportunities to hand over the honey at all.

Because honey doesn't belong to basic main products (such as potatoes or meet), households usually buy a maximum 31 of liquid honey per family, based on the farmer's experience. There is a demand for unordinary products like cream honey or honey candies, however small producers cannot afford to invest into extra equipment needed for such production. These producers do not get and EU support, neither any help nor assistance from associations of producers.

Later on we were interested in whether the producer could register his production in digital platform by himself every time just after harvesting. He replied positively and admitted that he would appreciate to ship out his production once it is harvested with no taking care of sorting, storing, packing etc. Most of all he would like to share sorting and storing activities (costs) with the buyer. The positives of his current situation are fast product sales, he can wait up to 10 days for payment after selling.

In this case the farmer experienced following practices recognized as unfair trading dealing:

- Retail stores impose too heavy technical and documentary requirements

- Delayed results of laboratory test or even distortion of results by dependent laboratory. 
Figure 1: Case Study of a Honey Producer in Ukraine
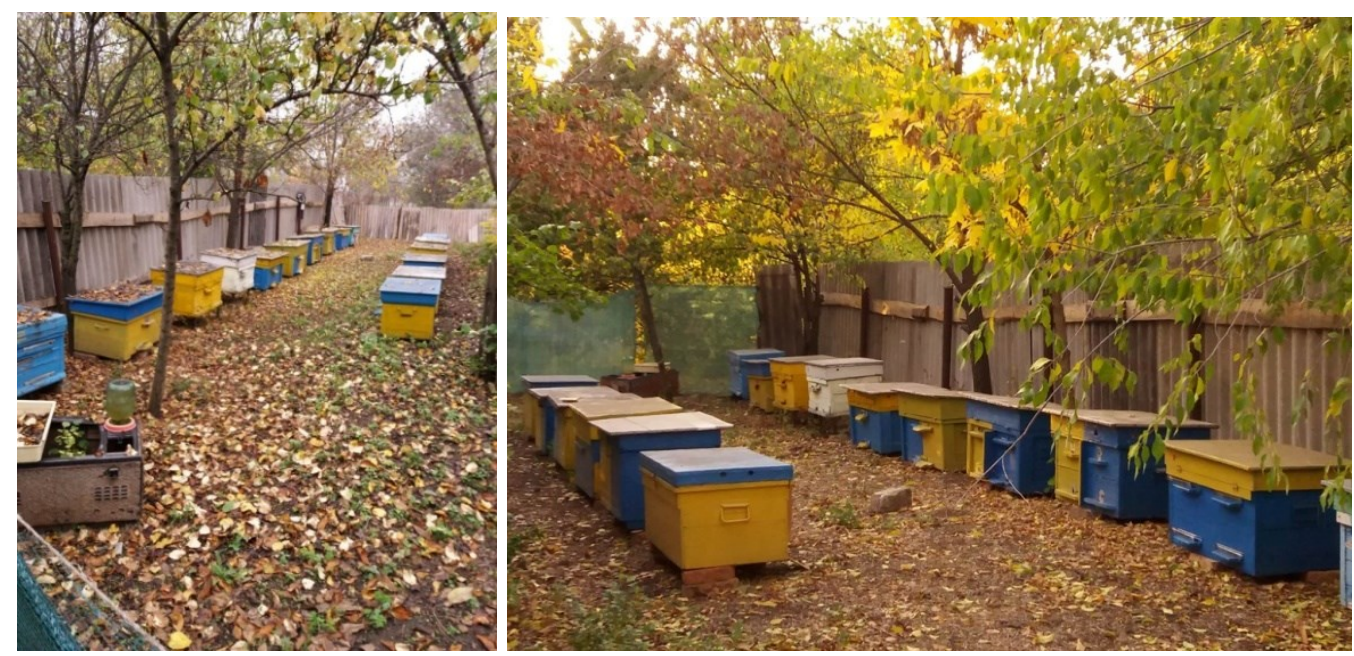

Source: Made by the authors

\section{Case study 2: Livestock production in Slovakia}

In Slovakia we obtained information from a producer of livestock, farming in the south-east of Slovakia in Roznava region. The producer has 20 years of farming experience with livestock production. Currently he produces 250 lambs, 50 cows, 60 bullies, 300 tons of wheat, 25 tons of oats, 30 tons of barley and 4000 hay rolls a year. He is employing 12 people and farming at about 900 hectares of agricultural land.

This producer is carries out also other processes such as storing, packing and delivery of his production and also other serving processes as administration, accounting and so on. Because he is not a holder of the license for slaughtering he cannot trade with retailers and he sells his production to wholesalers. He trades with known wholesalers from Slovakia and from Hungary because he has past experience with them. He also perceives his price for production to be lower than the fair price. Currently he sells lambs for 1.6 EUR/kg.a.w. (kilos for alive weight), beef cattle for 2 EUR/kg.a.w. and steer $=3 \mathrm{EUR} / \mathrm{kg}$.a.w. According to his experience there is no negotiation on price and the price is set solely by the wholesaler. Also, buyers claim to pay off wasted material from cutting animals in a rate of $3 \%$ of total price. The advantage of his current contract is agreed price in advance prior raising livestock and reliable with payments. The disadvantage is no price control and risk not get paid.

Regarding the use of digital platform as one way to improve his position, he states it would be possible to register his production in digital platform by himself every time just after harvesting and he would like to ship out his production once it is harvested with no taking care of sorting, storing, packing etc. He doesn't need any other processes to be shared with the buyer and theoretically he could wait 1 month after selling for the payment.

Currently the producer receives EU support payments of about $80 \%$ of his annual incomes, but he doesn't get any help or assistance from associations of producers (neither in issues of price forming).

In this case the farmer faced following practices recognized as unfair trading dealing:

- Payment periods longer than 30 days for perishable products

- Requiring the weaker party to pay claims for wasted products. 
Figure 2: Case Study of a Livestock Producer in Slovakia
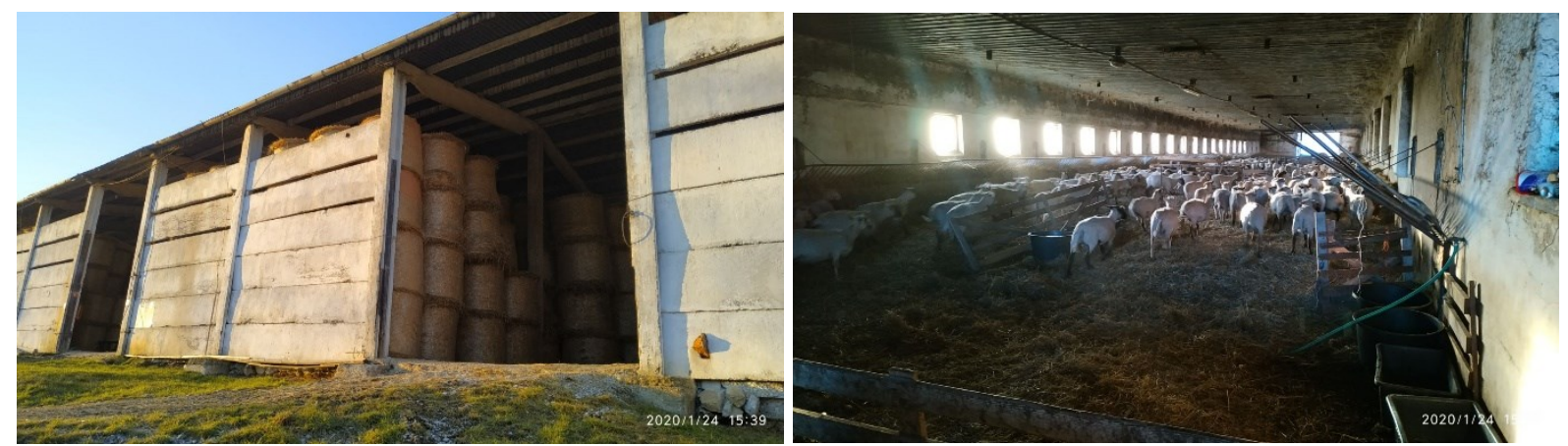

Source: Made by the authors

\section{Case study 3: Bio Cereal production in Austria}

Cereal producer interviewed was farming in Niederösterreich region of Austria. He is specializing at the production of Bio cereals such as soy, corn and wheat production with 27 years of experience in bio farming. His average number of employees is 1.5 (30 hours per week, one is part-time worker) and the volume of production fluctuates depending on crop strategy being grown, humidity and weather, in average it represents wheat it's 1,5 - 4 tons per hectare of wheat a year. He is operating at an area of 150 hectares of agricultural land.

This producer manages also storing and cleaning of his production and provides also other nonproduction activities such as accounting or advertising. He sells his production solely to three wholesalers from Austria. He perceives price of his production to be fair as the prices are dictated by the market and the trading partners do negotiate only minor changes. He also states these negotiations are sometimes tough enough. The actual average prices for his bio cereals are $670 \mathrm{EUR} /$ ton of soy, $270 \mathrm{EUR} /$ ton of wheat and $240 \mathrm{EUR} /$ ton of corn.

He states it is optional to record his production results in digital platform by himself every time just after harvesting, but it is not possible to ship out the production once it is harvested with no taking care of sorting, storing, etc. It is technologically necessary to harvest it then store and clean, however he already share some other activities with his trading partners like packing, delivery or quality control. The payment periods depend on the contract and usually there are pre advanced payments on $70 \%$ of the volume and the rest $30 \%$ are paid after picking a production.

The EU support payments consist of EU direct payments $270 \mathrm{EUR} / \mathrm{ha}$ and additional national support $330 \mathrm{EUR} / \mathrm{ha}$. The subsidies and direct payments take about $50 \%$ in total annual incomes of the farm, the rest is a revenue from selling crops produced. There is also some help and assistance provided by the association of organic producers such as Bio Austria.

In this case the farmer experienced following practice recognized as unfair trading dealing:

- Sometimes, it takes place for hard negotiating of final price after pre-agreed terms prior the cultivation season. 
Figure 3: Case Study of a Bio Cereal Producer in Austria
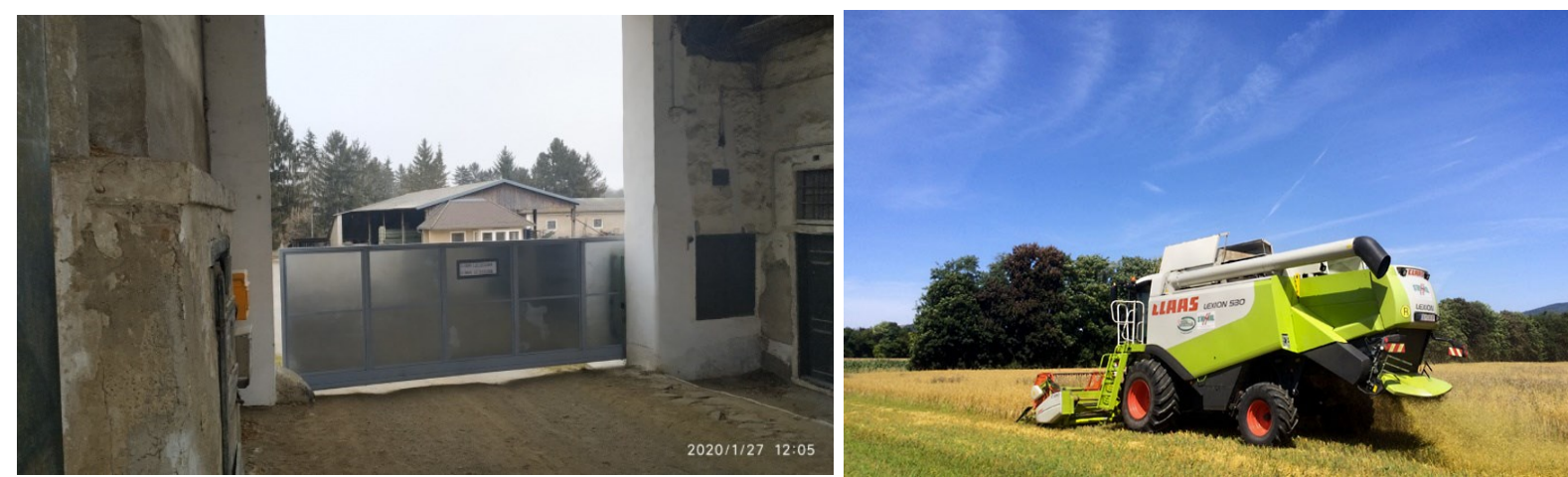

Source: Own processing and official web page of the farm.

\section{Conclusions}

First of all, the existence of unfair trade practices is being observed and evidenced in given cases no matter what state territory farmers do operate at.

There are some reasons we can emphasize based on the gained information:

- Not using of written contracts

- The farmers are not inclined to communicate through digital forms such as messengers or other internet opportunities. For such reasons as far away territory of operation, technology undeveloped infrastructure of local areas or simply unwillingness of farmers to communicate through internet protocol itself. It makes a room for limited information comes in and out, in particular mainly for potential buyers and interests beyond their habitual contact circles. There is relying on individual approach in relations in most cases.

- Ordinary farmers are usually anxious to provide information about their contracts. There is also a so called fear factor playing role and the atmosphere of mistrust reigns in interrelations between farmers and their buyers. It is much appreciated to have long stable and reliable contract, especially in terms of payments. So it is a challenge for a small producer to have new more profitable contracts.

- It turns out that farmers incline to prefer criteria such as security, guarantees, stability, sustainability and others. Hence, most of the times they do not make many attempts to improve their quality of production and/or activities to get better price and earn more. They need external incentives for working harder or with higher efficiency. Perhaps, it might be also because of dependency on subsidies rather than on sales from commercial activity.

The topic of unfair trade practices is crucial and needs to be studied and understood in further details. For better functioning of small food producers, eliminating their vulnerability to injustice and increasing overall efficiency in food dissemination we try to bring some preliminary conditions such as:

I. Certification (production). Making farm information available and accessible for public would increase interest from the side of potential customers as well as investors. Nowadays, all the information about farms is closed enough for public or provided in a compressed form and mostly about tax outcomes or subsidies. The practice of similar certification associations like those that operate in Austria, for example Bio Austria, or 
in the worldwide scale such as Fairtrade International, show positive impact on farming activity that would be a good reason to extend that experience on all European or national levels among all farms in act. The approach has to be elaborated in details during the next research.

II. Parameterization (product). The best window of real food production to digital world of operation might lie through number parameterization of food products that are being produced. This is possible to fulfill by laboratory testing or some mobile devices which are able to measure quality of production, simple physical dimensions and transmit them into digital open source immediately.

III. Smart-contracts (operation). The third pillar of a better functioning food industry is clear and reliable interactions between producer and buyer, that idea is practically achievable with implementing a system of blockchain based smart contracts for agricultural exploitation. It could partially guarantee the contract compliance, especially in terms of payments and other risks in frames of unfair trading practices.

Such metering points can be installed either directly at the producer's side or with the nearest partner in the food supply chain, for example, at the stage of storage or wholesaler. It mostly depends on area specialization, type of producer and even food sector. More detailed information will be tested and improved during the following complex research.

\section{Acknowledgements}

We gratefully acknowledge financial support received from the Slovak Research and Development Agency under the contract No. APVV-18-0512, GAČR project 19-18080S (Czechia), and VEGA 1/0422/19 (Slovak Republic).

\section{References}

[1] Abad, A. R., Gonzales, K., Rosellon, M., Yap, T. (2012). Unfair trade practices in the Philippines. Philippine Institute for Development Studies.

[2] Basic (2015). Banana value chains in Europe and the consequences of Unfair Trading Practices. Make Fruit Fair. October 2015

[3] Centre for Research on Multinational Corporations (2013). Response by SOMO to the Green paper on unfair trading practices in the business-to-business food and non-food supply chain in Europe.

[4] CIAA-AIM (2011). "Unfair commercial practices in Europe." Dedicated study commissioned by CIAA and AIM

[5] Ciliberti S., Frascarelli A. (2013). Mandatory Rules in Contracts of Sale of Food and Agricultural Products in Italy: An Assessment of Article 62 of law 27/2012. Selected Paper prepared for presentation at the 140th EAAE Seminar, "Theories and Empirical Applications on Policy and Governance of Agri-food Value Chains, " Perugia, Italy, December 13-15, 2013

[6] Di Marcantonio, F., Ciaian, P., Castellanos, V. (2018). Unfair trading practices in the dairy farm sector: Evidence from selected EU regions. Publications Office of the European Union.

[7] European Commission. (2008). Food prices in Europe, COM(2008), 821 final, Bruxelles.

[8] European Commission. (2010). Retail market monitoring report "Towards more efficient and fairer retail services in the internal market for 2020". Communication from the Commission to the European Parliament, the Council, the European Economic and Social Committee and the Committee of the Regions. Brussels.

[9] Falkowski, J., Menard, C., Sexton, R. J., Swinnen, J., Vandevelde, S. (2017). Unfair trading practices in the food supply chain: A literature review on methodologies, impacts and regulatory aspects (No. JRC108394). Joint Research Centre (Seville).

[10] Fletcher, L. B., Paulsen, A., Kaldor, D. R., Stucky, W. G. (1961). Bargaining power in agriculture. Center for Agricultural and Economic Adjustment, Iowa State University. CARD Reports. 14. 
[11] Ismea. (2012). La competitività dell'agroalimentare italiano. Check-up 2012. Roma.

[12] Lee, S. (2017). The Possibility of the Introduction of Business-to-Business Unfair Trading Practices Regulation in EU Law.

[13] Rosa F., Vasciaveo M. (2010). Dinamiche dei prezzi agricoli: volatilità, causalità ed efficienza dei mercati agricoli. XLVII Convegno SIDEA “L'agricoltura oltre la crisi”, 22-25 settembre, 2010, Campobasso. 


\section{SESSION 10}

FINANCE AND CURRENT ISSUES 


\title{
DEA in Performance Measurement of Dynamic Processes: Comparative Overview of the Literature. An Illustration of Dynamic Network DEA in Agricultural Enterprises
}

\author{
Tatiana Bencová ${ }^{1}$, Ivan Holúbek ${ }^{2}$, Marián Tóth ${ }^{3}$, Andrea Boháčiková ${ }^{4}$ \\ Slovak University of Agriculture in Nitra \\ Faculty of Economics and Management, Department of Finance $e^{1,2,3,4}$ \\ Address: Tr. Andreja Hlinku 2, \\ 94901 Nitra, Slovakia \\ e-mail: tatiana.bencova@uniag.sk',ivan.holubek@uniag.sk²,marian.toth@uniag.sk², \\ andrea.bohacikova@uniag.sk ${ }^{4}$
}

doi: 10.18515/dBEM.ISD.P01.2020.p067

\begin{abstract}
Standard non-parametric Data Envelopment Analysis (DEA) introduced by Charnes, Cooper, Rhodes (1978) does not provide adequate detail to identify the specific sources of inefficiency embedded in the activities on the level of production sub-processes of an enterprise, without considering the internal structure of the business. Färe, Grosskopf (1996) provided the theoretical groundwork for network DEA models. The idea behind Network DEA (NDEA) is that a decision making unit (DMU) is a complex structure comprised of heterogeneous internal sub-units each with its own set of inputs and outputs. The Dynamic Network DEA (DNDEA) extends NDEA by computing efficiency scores for each sub-unit and the DMU over all time periods based on intermediate products, which are links from a time period to the other. In the recent years there has been an exponential growth in the number of publications related to theory and applications of efficiency measurement for dynamic network systems.

The aim of this paper is twofold. The first task is to survey and classify the dynamic DEA models and to present the applications of these models across the literature. The second aim is to point out the application options of DNDEA for agricultural enterprises with internal structures. Taking into account the time period ( $t$ ) in DNDEA is appropriate by measure the performance of agricultural enterprises and can optimize and prompt the operational management decisions.

The objective of this work is to provide the methodological conclusions for further research about measuring agricultural enterprises performance using DNDEA approach.
\end{abstract}

Keywords: Data Envelopment Analysis, Efficiency, Intermediate product, Internal structures, Dynamic DEA, Agricultural enterprises

JEL Classification: C61, Q12, Q19

\section{Introduction}

Based on the fundamental contributions introduced by Debreu (1951), Shephard (1953) and Farell (1957), Charnes, Cooper and Rhodes (1978) proposed the well-known performance evaluation method called Data Envelopment Analysis (DEA) to measure the relative efficiency of Decision Making Units (DMUs). DEA is an effective non-parametric evaluation method for measuring the relative efficiency of a set of DMUs each of which uses multiple inputs to produce multiple outputs. In the traditional or standard DEA approaches, most noted CCR model (Charnes et al., 1978) and BCC model (Banker et al., 1984) and their later reformulations, DMUs are treated as black boxes whose internal structure is often ignored. This limits the possibilities to improving the specific sources of inefficiencies on the level of production sub-processes that can be gained to improve the system efficiency. Opening the black box of efficiency analysis offers managers to monitor and measure efficiency of their 
production sub-processes. The management is able to rapidly eliminating the specific inefficient activity in the framework of the operational management.

Inspired by the research about multi-stage production process Färe, Whittaker (1995), Färe, Grosskopf $(1996,2000)$ developed a model with intermediate inputs and outputs called network DEA (NDEA). This approach applies to the DMUs that consist of a network of SubDMUs (subprocesses), some of which consume resources produced by others and some of which produce resources consumed by others (Lewis, Sexton, 2004).

In recent years, NDEA approaches has gained considerable development both in the methodology and application, and become an important managerial tool for evaluating the performance of the system. Emrouznejad, Yang (2018) reported the top 5 most popular research keywords appeared in the DEA related articles published in the last years with the second place for research keywords Network DEA, two-stage DEA and efficiency decomposition. They also detect agriculture is the top application field of DEA methodology with the greatest numbers of journal articles.

The main types of NDEA models are discussed in the research papers from Färe, Grosskopf (2000), Färe et al. (2007), Castelli et al. (2010) and Halkos et al. (2014). Cook et al. (2010) reported from survey of Two-stage network models that the most often applied model is the static Two-Stage DEA model, where individual sub-processes are linked by intermediate product over one period. Such models have been studied by Wang el al. (1997), Kao, Hwang (2008), Chen, van Dalen (2010), Fukuyama, Weber (2010), Avkiran (2009) and Liang et al. (2008). Lewis, Sexton (2004) extended the Two-stage DEA method to a multi-stage network structure. Kao (2009) built a relational DEA model and accounted for the interrelations between various sub-processes: series, parallel and mixes structures. Tone, Tsutsui (2009) developed a slacks-based network DEA that evaluated divisional efficiencies as well as overall system efficiency.

Analysis the internal structure of DMUs makes NDEA approach a real evaluation method which is able to open the black box of DMU, even from a dynamic perspective. A dynamic model has the property that a decision in one time periods impacts on later time periods. Intermediate products are held over between time periods, in literature called also timeintermediate products or carry-overs (see Tone, Tsutsui, 2014). This means that some of the outputs in the first period are used as inputs in the second. Dynamic DEA was further developed by several authors, see for example Nemoto, Goto (1999, 2003), Sueyoshi, Sekitani (2005), Kao (2008), Bogetoft et al. (2009), Chen (2009) and Chang et al. (2009). Tone, Tsutsui (2010) extend this model within the slacks-based measure framework proposed by Tone (2001). The dynamic SBM (DSBM) can deal with inputs/outputs and carry-overs independently and categorized carry-over activities into: good, bad, free and fixed. This model was adapted the research papers Yu et al. (2013), Lu et al. (2014), Chang et al. (2016), Zha et al. (2016) and Ozcan, Khushalani (2017),

Applications of DNDEA abound, in fields such as electric utilities (Nemoto, Goto, 2003), agriculture production (Jaenicke, 2000, Kahi et al. 2017), airlines (Oltaf et al., 2016, Omrani, Soltanzadeh, 2016), retail department stores (De Mateo et al., 2006), life-insurance firms (Lu et al., 2014), hospitals (Ozcan, Khushalani 2017) and banking sector (Yu et al. 2013, Fukuyama, Weber, 2015, Zha et al., 2016).

To the best of our knowledge, this listing of DNDEA related publications and papers is the most complete source of references of this topic. Authors hope that this new updated bibliography sources will be helpful to researches and practitioners in this field and also encourage a potential data collection for an agriculture application.

The remainder of this paper is organized as follows. Following the introduction, the literature review and the classification DNDEA research papers are provided in Section 2. Section 3 offers the possible application of DNDEA models and the options for inputs, outputs and 
intermediates in agricultural enterprises over the time period. Section 4 outlines conclusions and provides comments for the future possible extensions of the current study.

\section{Literature review and classification of dynamic DEA approaches}

DEA considers the production system as a black box, which ignores internal relations of processes inside the system. In the real world, the structure of DMU contain of several connected sub-processes. One of the most important approaches for evaluating the system with several sub-processes is NDEA model, which takes into account internal structure via intermediate products in measuring the efficiency of DMU. Färe, Grosskopf $(1996,2000)$ introduces the NDEA model with multiple production stages. Over the last decade, a couple of radial NDEA models have been presented during the research papers (see Lewis, Sexton, 2004, Färe et al., 2007, Kao, Hwang, 2010, Cook et al., 2010).

However, NDEA model can only be used to compute efficiency for a single time period and assesses the processes of the system in a specific moment and ignores the dynamic effects within the production processes. In dynamic DEA presented by Tone, Tsutsui (2010), the DMUs efficiencies are assessed during several periods, but they do not deal with the internal structures. In their last study Tone, Tsutsui (2014) proposed the DNDEA model in which the DMUs were assessed in different periods with network structures. DNDEA model extends the NDEA model by computing efficiency scores for each sub-process and the entire organization over all time periods based on a long-term optimization using carry-over variables (intermediate variables), which are essentially links from a time period to the other. DNDEA models were first introduced by pioneering study by Färe, Grosskopf (1996) and have been extended in recent studies by Chen (2009), Tone, Tsutsui (2009, 2010, 2014), Kao (2013) and Wang et al. (2014). DNDEA studies developed different approaches and applications to measure the dynamic efficiency of DMUs. Kao (2014) proposed a literature overview of NDEA models and observed that one or two DNDEA studies were published annually until 2008. In the recent years, there has been a large growth in the number of research studies on DNDEA models. The first overview of DNDEA models was conducted by Fallah Fini et al. (2014) and discussed the similarities and differences between dynamic nonparametric approaches that focus on measuring the performance of companies. Mariz et al. (2017) performed a literature review on DNDEA models from 1996 to 2016.

This study is a literature review of DNDEA models and proposed a classification and references of the DNDEA studies presented in Table 1. The analysis consists of 44 research papers published from 1996 to 2017. The sample of studies were selected by the number of citations from Web of Science. The second column shows the applied approach in the research paper. Färe, Grosskopf (1996) introduced dynamic aspect of production and provided several theoretical contributions. Their study became the base for further studies on dynamic DEA (see Jaenicke, 2000, Bogetoft et al., 2009, Althin et al., 2010). Most commonly used model is the dynamic SBM with network structure (DSBM) developed by Tone, Tsutsui (2009, 2010, 2014). Kao (2013) extended relational approach for a network system to a dynamic network system. This relational DNDEA model became the basis for many other researchers (see Kou et al., 2016, Omrani, Soltanzadeh, 2016). The third column shows the application fields of DNDEA methodology including Farms, Airlines, Banking sector, Hospitals, Manufacturing companies and others. The fourth column shows the type of study: Theoretical (T), Theoretical and Practical (T/P) and Practical (P). 


\begin{tabular}{|c|c|c|c|}
\hline Author (s) & Applied techniques & Application field & Type \\
\hline Amirteimoori (2006) & DNDEA model with dynamic revenue efficiency & Gas companies & T/P model developed by Nemoto, Goto, 1999) \\
\hline Althin et al. (2010) & DNDEA model & Employment offices & P (model developed by Färe, Grosskopf, 1996) \\
\hline Avkiran (2015) & DSBM model & Banking sector & P (model developed by Tone, Tsutsui, 2014) \\
\hline Avkiran, McCrystal (2014) & Dynamic Network Range Adjusted Model & Residential aged care networks & P (model developed by Tone, Tsutsui, 2014) \\
\hline Bogetoft et al. (2009) & DNDEA model & Manufacturing industry & P (model developed by Färe, Grosskopf, 1996) \\
\hline Chang et al. (2016) & DSBM model & Airlines & T/P (model developed by Tone, Tsutsui, 2009, 2010, 2014) \\
\hline Chao et al. (2015) & DSBM model & Banking sector & P (model developed by Tone, Tsutsui, 2014) \\
\hline Chen (2009) & $\begin{array}{l}\text { DNDEA model with the formulation of } \\
\text { relationship between RTS }\end{array}$ & $\begin{array}{l}\text { Motivational example of three } \\
\text { supply chains }\end{array}$ & (2) \\
\hline De Mateo et al. (2006) & $\begin{array}{c}\text { DNDEA model with information on costs of } \\
\text { Adjustment }\end{array}$ & Retail department stores & T/P (model developed by Charnes et al., 1978, Färe et al. 1985) \\
\hline $\begin{array}{c}\text { Emrouznejad, } \\
\text { Thanassoulis (2005) }\end{array}$ & $\begin{array}{c}\text { Comparison between DNDEA and static DEA } \\
\text { model }\end{array}$ & Universities & T/P (model developed by Emrouznejad, Thanassoulis, 2003) \\
\hline Färe, Grosskopf (1996) & DNDEA model & Farms & T/P (model developed by Färe, 1988) \\
\hline Fukuyama, Weber (2015) & DNDEA model & Banking sector & $\begin{array}{l}\text { T/P (model developed by Färe et al., 2004, Fukuyama, Weber, } \\
\text { 2013) }\end{array}$ \\
\hline Jaenicke (2000) & DNDEA model & Farms & P (model developed by Färe, Grosskopf, 1996) \\
\hline Kahi et al. (2017) & An additive network DEA model & Food supply chain & T/P (model developed by Tone, Tsutsui, 2014) \\
\hline Kao (2013) & A relational DNDEA model & Forests & T/P (model developed by Kao, 2009) \\
\hline Ozcan, Khushalani (2017) & DSBM model & Hospitals & P (model developed by Tone, Tsutsui, 2014) \\
\hline Kou et al. (2016) & Relational Dynamic network model & $\begin{array}{c}\text { Innovation efficiency of OECD } \\
\text { countries }\end{array}$ & T/P (model developed by Kao, 2013) \\
\hline Kweh et al. (2015) & DSBM model & Semiconductor companies & P (model developed by Tone, Tsutsui, 2010) \\
\hline Li et al. (2016) & Virtual Frontier Dynamic Range Adjusted Model & Airlines & T/P (model developed by Färe, Grosskopf, 1996) \\
\hline Lin, Yang (2014) & DSBM model & Power industry & P (model developed by Tone, Tsutsui, 2010) \\
\hline Lu et al. (2014) & DSBM model & Life insurance industry & P (model developed by Tone, Tsutsui, 2010) \\
\hline Moreno et al. (2013) & DSBM model & $\begin{array}{c}\text { Wireline telecommunication } \\
\text { companies }\end{array}$ & P (model developed by Tone, Tsutsui, 2010) \\
\hline
\end{tabular}




\begin{tabular}{|c|c|c|c|}
\hline Nemoto, Goto (1999) & DNDEA model & N/A & $\mathrm{T}$ \\
\hline Nemoto, Goto (2003) & DNDEA model in production & Electric Utilities & $\begin{array}{l}\text { T/P (model developed by Färe, Grosskopf, 1996, Nemoto, } \\
\text { Goto, 1999) }\end{array}$ \\
\hline Oltaf et al. (2016) & DSBM model & Airlines & T/P (model developed by Tone, Tsutsui, 2014) \\
\hline $\begin{array}{l}\text { Omrani, Soltanzadeh } \\
\text { (2016) }\end{array}$ & A relational DNDEA model & Airlines & T/P (model developed by Kao, Hwang, 2010, Kao, 2013) \\
\hline Oulette, Yan (2008) & $\begin{array}{c}\text { DNDEA model with the theory of capital } \\
\text { investment }\end{array}$ & N/A & T (model developed by Nemoto, Goto, 1999,2003 ) \\
\hline Reshadi (2012) & DNDEA model & N/A & $\begin{array}{l}\text { T (model developed by Färe, Grosskopf, 1996, Nemoto, Goto, } \\
\text { 1999) }\end{array}$ \\
\hline Shafiee et al. (2013) & DSBM model & Banking sector & P (model developed by Tone, Tsutsui, 2010) \\
\hline Silva, Stefanou (2007) & Hyperbolic distance function for DNDEA models. & Dairy operators & T/P (model developed by Silva, Stefanou, 2003) \\
\hline Sinha (2015) & DSBM model & Life insurance companies & P (model developed by Tone, Tsutsui, 2010) \\
\hline Skevas et al. (2012) & DNDEA model with undesirable outputs & Arable farms & T/P (model developed by Chung et al. 1997, Färe et al., 2007) \\
\hline Sueyoshi, Sekitani (2005) & $\begin{array}{l}\text { The concept of returns to scale is incorporated } \\
\text { into the DNDEA }\end{array}$ & N/A & T (model developed by Banker et al, 1984, Nemoto, Goto, \\
\hline Tone, Tsutsui (2014) & DSBM model & $\begin{array}{c}\text { Motivational example of } \\
\text { electric utilities }\end{array}$ & $\mathrm{T}$ (model developed by Tone, Tsutsui, 2009, 2010) \\
\hline Tu et al. (2016) & $\begin{array}{c}\text { Weight-restricted Dynamic DEA (WrD-DEA) } \\
\text { model }\end{array}$ & Energy efficiency & T/P (model developed by Kao, 2013 and Wang et al. 2014) \\
\hline Von Guymueller (2009) & DNDEA model & Electricity regulation & T/P (model developed by Nemoto, Goto, 1999) \\
\hline Wang et al. (2015) & DSBM model & Electronics industry & P (model developed by Tone, Tsutsui, 2010) \\
\hline Wanke et al. (2015) & DSBM model & Banking sector & P (model developed by Tone, Tsutsui, 2010) \\
\hline Wanke, Barros (2016) & Virtual Frontier Dynamic Range Adjusted Model & Airlines & P (model developed by Li et al., 2016) \\
\hline Wu et al. (2013) & DSBM model & Hotel industry & P (model developed by Tone, Tsutsui, 2010) \\
\hline Yeh et al. (2016) & DSBM model & Environmental Policy & P (model developed by Tone, Tsutsui, 2010) \\
\hline You, Jie (2016) & DSBM model & Power-supply companies & T/P (model developed by Tone, Tsutsui, 2009) \\
\hline Yu et al. (2013) & DSBM model & Banking sector & P (model developed by Tone, Tsutsui, 2009, 2010, 2012) \\
\hline Zha et al. (2016) & DSBM model & Banking sector & T/P (model developed by Tone, Tsutsui, 2010, 2014) \\
\hline
\end{tabular}




\section{How to evaluate the efficiency of agricultural enterprises using dynamic NDEA?}

Production process of agricultural enterprise is characterized by multiple inputs and multiple outputs. An output from one process is used as an input to another. This output is called intermediate product (or carry-over). Agricultural enterprises are units with internal structures with both crops and livestock production. The first sector, where NDEA found its application was agriculture. Agriculture is the most application field of standard DEA methodology in the recent years (Emrouznejad, Yang 2018). Although this fact, we can find only a few research papers with measure the efficiency of agricultural enterprises using DNDEA approach.

Färe, Whittaker (1995) as the pioneer authors analyze the production efficiency of agricultural enterprises and have explicitly included intermediate products. They used NDEA model with static and dynamic sub-processes. The dynamic element in NDEA model is the herd of cattle from previous time period $t-1$, where was the final output. Agricultural enterprise has also the crop production, where some of the production products (hay, barley, wheat) are offered to the market and the other part of crop production is the intermediate product in livestock production (cattle feed). In livestock production some of the calves are selling on the market and the second part is incorporating into the herd of cattle. For evaluating the performance of agricultural enterprise with intermediate products during specified multiple periods, authors proposed NDEA model which can measure the efficiencies of the whole production and its internal subprocesses over time, simultaneously.

However, only a few authors followed their work in the field of agriculture. Jaenicke (2000) developed a DNDEA model of crop production that accounts for the rotation effect. In agricultural production, a stylized fact known as the rotation effect says crop rotations generate higher yields or productivity than identical crops grown in isolated monocultures. The soil capital (represents by terminal soil organic matter) in rotational crop production was the final product in the year $t$ and an input in the next year $t+1$. The soil capital is treated as an intermediate output that links each annual process. Results suggest that soil capitals inclusion makes both statistical and qualitative difference in productivity measurement.

Kahi et al. (2017) developed a DNDEA additive model for evaluating sustainability of supply chains with series structure. This study assists managers to identify inefficient supply chains and take proper remedial actions for performance optimization, while managers can plan their supply chains more properly and more accurately. This study improved and extended Tone, Tsutsui (2014) DNDEA model, because authors connect each network (as a whole) to other networks. They provided numerical illustrations to calculate the performance of supply chains produces tomato paste and sauce in several periods. Inputs and outputs of supply chains are given three stages including farms, canning factories and chain stores. These supply chains are assessed over three years with intermediate product Green research and Development.

Silva, Stefanou (2007) developed a hyperbolic distance function for dynamic measures of efficiency, which takes into account cost minimizing behavior. Authors illustrated their model for dairy farms. Skevas et al. (2012) analyze the dynamic effects of pesticides in the study of arable farms. Pesticides have a current production impact through reducing crop damage in the current period and a future impact through impacting the farm biodiversity which alters the future production environment. This study presents the difference in inefficiency arising from models that ignore the dynamic effects of pesticides in production decisions and the impact of production uncertainty. Authors find that efficiency increased dramatically when a production technology representation that considers both pesticides' dynamic impacts, and production uncertainty is adopted.

The agricultural studies described about are proof that DNDEA approach can be a new source of information about (in)efficient sub-processes in the agricultural enterprises and provided an in-depth analysis. Taking into account the time period in DNDEA is appropriate by measure 
the efficiency of agricultural enterprises and can optimize and prompt the operational management decisions.

The authors see the limitation of this work in collecting the data set with DMUs with internal structures. This study should be an incentive to collect this type of data and extend and improve the DNDEA research in agriculture field.

\subsection{DNDEA method}

The most commonly used NDEA model in agricultural field is DNDEA model. The formulation of DNDEA model is to create a network of sub-processes over time. In DNDEA model shown in Figure 1 are two time periods $t, t+1$. In each time period the agricultural enterprise produce a production $P^{\tau}$, where $\tau=t, t+1$. The decision of the enterprise in time period $t$ will affect the production in time $t+1$. Figure 1 shows illustrative example of DNDEA model in agricultural enterprise with two crop production sub-processes. Output from crop production in time $t$ consists of final output ${ }^{f} y^{t}$ and intermediate product (for example seed), which is used as input in time $t+1$. Exogenous inputs $x^{t}$ and $x^{t+1}$ enter into the production process in both time periods.

Figure 1: Dynamic NDEA model in agricultural enterprise with crop production

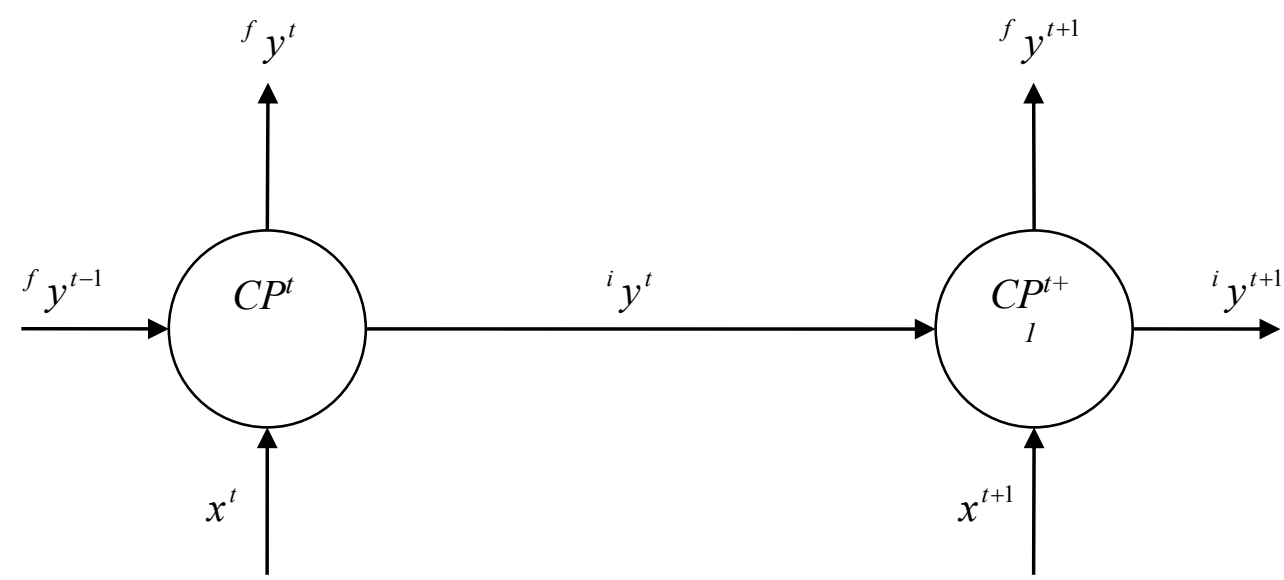

Source: Own resourcing

The network of sub-processes in DNDEA model consists of a finite number of static models. DNDEA model with output orientation in Figure 1 can be formulate using the following notation (see Färe, Grosskopf, 2000):

$\operatorname{Max} \varphi$

$$
\begin{aligned}
& \mathfrak{J}\left(x^{t}, x^{t+1}, y^{t-1}\right)=\left\{\left({ }^{f} y^{t},\left({ }^{f} y^{t+1}+{ }^{i} y^{t+1}\right)\right):\right. \\
& \varphi\left({ }^{f} y_{m}^{t}+{ }^{i} y_{m}^{t}\right) \leq \sum_{k=1}^{K} z_{k}^{t}\left({ }^{f} y_{k m}^{t}+{ }^{i} y_{m}^{t}\right), \quad m=1, \ldots, M, \\
& \sum_{k=1}^{K} z_{k}^{t} x_{k n}^{t} \leq x_{n}^{t}, \quad n=1, \ldots, N,
\end{aligned}
$$




$$
\begin{aligned}
& \sum_{k=1}^{K} z_{k}^{t i} y_{k m}^{t-1} \leq^{i} y_{m}^{t-1}, \quad m=1, \ldots, M, \\
& z_{k}^{t} \geq 0, \quad k=1, \ldots, K, \\
& \varphi\left({ }^{f} y_{m}^{t+1}+^{i} y_{m}^{t+1}\right) \leq \sum_{k=1}^{K} z_{k}^{t+1}\left({ }^{f} y_{k m}^{t+1}+{ }^{i} y_{m}^{t+1}\right), \quad m=1, \ldots, M, \\
& \sum_{k=1}^{K} z_{k}^{t+1} x_{k n}^{t+1} \leq x_{n}^{t+1}, \quad n=1, \ldots, N, \\
& \sum_{k=1}^{K} z_{k}^{t+1 i} y_{k m}^{t} \leq^{i} y_{m}^{t}, \quad m=1, \ldots, M, \\
& \left.z_{k}^{t+1} \geq 0, \quad k=1, \ldots, K\right\},
\end{aligned}
$$

where ${ }^{f} y_{k m}{ }^{t},{ }^{i} y_{k m}{ }^{t-1},{ }^{f} y_{k m}{ }^{t+1},{ }^{i} y_{k m}{ }^{t}, x_{k n}{ }^{t}, x_{k n}{ }^{t+1}$ represents inputs and outputs for $D M U_{k}$, when the number of DMUs can be expressed as follows $k=1, \ldots, K$. Each $D M U_{k}$ uses inputs and

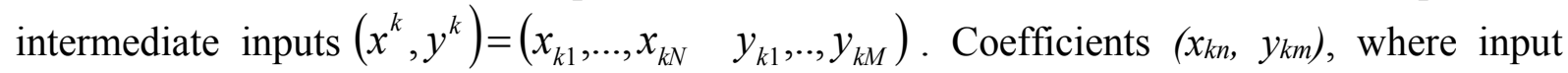
resource is $n, n=1, \ldots, N$, and output product is $m, m=1, . ., M$ for $D M U_{k}$, where $k=1, \ldots, K$. Every sub-process has assigned its own intensity vector $z_{k}^{\tau}$, when $\tau=t, t+1$ for every observation, or sub-process $k$.

\subsection{Variables options in DNDEA models}

Table 2 presents variable options (exogenous inputs, intermediate products, final outputs) for DNDEA model in agricultural enterprises. The period $t+1$ may not be the next calendar year, but it can also be a period of the next marketing year in the enterprise. In the (1) example the intermediate product is the potato production. The farm produce the amount of potato ${ }^{i} y^{t}$ in time period $t$, when one part represents the production for sale on the market in time $t$ and the other part became an intermediate product and in the year $t+1$ these potatoes were planted and became an input in the year $t+1$. The (2) example is for the livestock sector, namely the dairy cattle farms. In the year $t$ are the final outputs the dairy cows (or cows for meat) and the calves ${ }^{i} y^{t}$, when one part is for sale on the market in time $t$. The other part is the intermediate product and in the next year $t+1$ these calves are included in the herd of cattle (see Färe, Whittaker, 1996). The (3) example is for the crop production, namely the cereal sector. The agricultural enterprise combines its own seeds production with purchased seed. The final output is the production of grain for sale (or the livestock feed) and the straw (which can serve as bedding or fertilizer). The intermediate product represents the cereal seed, which is the output in year $t$ and input in the following year. The next example (4) is based on the rotation effect of crops (see Jaenicke, 2000). Appropriate selection of the pre-crops can increase the yield of the next crop. A suitable crop is for example the sugar beet, which by its biological effects has a positive effect on the soil structure for the following crops (e.g. spring barley). This crop rotation is based on root-cereal rotation. The final output is the sugar beet production and the intermediate product in the form of organically enriched soil, which is an input for the next crop. This rotational effect can be demonstrated for many other examples, e.g. biennial forage cropscereals (5). In the year $t$ the final outputs are the production of biennial forage crops, which is a valuable source of livestock feed. The biennial forage crops are a rich source of carbonaceous 
matter and leave a large amount of organic matter in the soil. This organically enriched soil represents an intermediate product and the input for the next crop (e.g. cereals). Such rotational effects could be also reported for the rotation of other crops: cereals-roots, cereals-biennial forage crops. The next illustrative example (6) is the production of silage. Suitable silage crops are e.g. corn silage, green oats, sugar beet tops, red clover, burgundy trefoil and others. For the example (6) was selected corn silage. The intermediate product is the silage stocks, what is the product of preservation process. The silage stocks is the input for the livestock production, e.g. herd of cattle in the next year $t+1$. The next example (7) is the intermediate product in the form of straw. The final outputs are the grain for sale, or the cereal seed. In addition to these final outputs threshed cereal stalks can be dried to obtain straw in year $t$. This straw is the input in year $t+1$ for the livestock sector, which is used for animal bedding. In the case of crop production farm, the straw is used to fertilize the soil. The last example (8) involves the undesirable output from crop production (see Skevas, et al., 2012). The final output is the crop production. However, the soil is losing important organic substances due to the use of nitrogen fertilizers and pesticides in the year $t$. For this reason, undesirable output is the undesirable impact of fertilizers and pesticides in the soil in the next year $t+1$.

Table 2: Options for inputs, outputs and intermediate products in DNDEA models

\begin{tabular}{|c|c|c|}
\hline $\begin{array}{l}\text { Exogenous inputs } \\
\quad \ldots, x^{t}, x^{t+1}, \ldots\end{array}$ & $\begin{array}{l}\text { Intermediate products } \\
\qquad,{ }^{f} y^{t-1},{ }^{i} y^{t},{ }^{i} y^{t+1}, \ldots\end{array}$ & $\begin{array}{l}\text { Final outputs } \\
{ }^{f} y^{t},{ }^{f} y^{t+1}, \ldots\end{array}$ \\
\hline $\begin{array}{c}\text { (1) Land Area, Labor Costs, Assets, } \\
\text { Material, Energy,... }\end{array}$ & Potato Production & $\begin{array}{l}\text { Potato Production for Sale, } \\
\text { for own Consumption }\end{array}$ \\
\hline $\begin{array}{l}\text { (2) Herd of Cattle, Assets, Labor costs, } \\
\text { Material, Energy,... }\end{array}$ & Calves & $\begin{array}{l}\text { Dairy cows, } \\
\text { (for meat) }\end{array}$ \\
\hline $\begin{array}{l}\text { (3) Land Area, Purchased Seeds, Labor } \\
\text { Costs, Assets, Material, Energy,... }\end{array}$ & Cereal Seed & $\begin{array}{c}\text { Grain (for sale, Feed) } \\
\text { Straw (Bedding, Fertilizer) }\end{array}$ \\
\hline $\begin{array}{l}\text { (4) Sugar Beet Seeds, Land Area, Labor } \\
\text { Costs, Assets, Material, Energy,... }\end{array}$ & $\begin{array}{c}\text { Organically enriched Soil } \\
\text { Rotation Effect }\end{array}$ & $\begin{array}{l}\text { Sugar Beet Production } \\
\text { for Sale } \\
\text { Livestock Feed }\end{array}$ \\
\hline $\begin{array}{c}\text { (5) Biennial Forage Crops Seed, Land } \\
\text { Area, Labor Costs, Assets, Material, } \\
\text { Energy,... }\end{array}$ & $\begin{array}{l}\text { Organically enriched Soil } \\
\text { Rotation Effect }\end{array}$ & $\begin{array}{l}\text { Production of Biennial Forage } \\
\text { Crops for Sale } \\
\text { for own Consumption }\end{array}$ \\
\hline $\begin{array}{l}\text { (6) Corn Silage Seeds, Land area, Labor } \\
\text { costs, Assets, Material, Energy,... }\end{array}$ & Silage Stocks & Production of Silage \\
\hline $\begin{array}{l}\text { (7) Seeds of Grains, Land Area, Labor } \\
\text { Costs, Assets, Material, Energy,... }\end{array}$ & Straw (Bedding, Fertilizer) & $\begin{array}{c}\text { Grain (for Sale) } \\
\text { Cereal Seed }\end{array}$ \\
\hline $\begin{array}{l}\text { (8) Fertilizers, Pesticides, Land Area, } \\
\text { Labor Costs, Assets, Material, Energy,... }\end{array}$ & $\begin{array}{l}\text { Impact of Fertilizers and } \\
\text { Pesticides on Soil }\end{array}$ & Crop Production \\
\hline
\end{tabular}

\section{Source: Own resourcing}

It is important to note, that these examples are illustrative and the choice of suitable variables in agricultural enterprises with complex internal structures is relatively large. The illustrative examples in this chapter are an incentive for further research in this area. 


\section{Conclusion and future research directions}

The starting research papers with DNDEA models were frameworks Färe, Grosskopf (1996, 2000) and Nemoto, Goto (1999). In the recent years was an increase in the number of DNDEA studies with potential to further deepen and develop the previous studies. The evolution of DNDEA models was presented in this study by analyzing 44 research articles. This study provides a literature overview of DNDEA studies, the dynamic models proposed, the application field and the type of DNDEA models. This review is expected to prompt researchers to perform new theoretical studies and stimulate DNDEA models in agricultural application.

The key question is as follows: How to evaluate the efficiency of agricultural enterprises using DNDEA model over time? By targeting this question, paper discuss existing DNDEA studies with agriculture application field and pointed out the limitation of the data set necessary for this type of analysis. This paper proposed the methodology of DNDEA models and the variables options in the agricultural application field.

Further research should also investigate in the literature review of this paper. The future research will focus on applying DNDEA model to agricultural enterprises. We will show how to apply DNDEA model to study agricultural production over time. We believe that the assessment of dynamic performance is an open research venue.

\section{Acknowledgements}

This paper was supported by the project VEGA no. 1/0338/18 with the title Impact of the Common Agricultural Policy on the mitigation of income risk in Slovak agriculture and factors determining the level of risk of agricultural companies.

\section{References}

[1] Althin, R., Behrenz, L., Färe, R., Grosskopf, S., \& Mellander, E. (2010). Swedish employment offices: a new model for evaluating effectiveness. European Journal of Operational Research, 207 (3), 1535-1544. https://doi.org/10.1016/j.ejor.2010.07.006

[2] Amirteimoori, A. (2006). Data envelopment analysis in dynamic framework. Applied Mathematics and Computation, 181 (1), 21-28, https://doi.org/10.1016/j.amc.2006.01.003

[3] Avkiran, N.K. (2015). An illustration of dynamic network DEA in commercial banking including robustness tests. Omega, 55, 141-150. https://doi.org/10.1016/j.omega.2014.07.002

[4] Avkiran, N.K., \& McCrystal, A. (2014). Intertemporal analysis of organizational productivity in residential aged care networks: scenario analyses for setting policy targets, Health Care Management Science, 17 (2), 113-125. https://doi.org/10.1007/s10729-013-9259-6

[5] Banker, R.D., Charnes, A., \& Cooper, W.W. 1984. Some models for estimating technical and scale inefficiencies in Data Envelopment Analysis, Management Science, 30 (9), 1078-1092. https://doi.org/10.1287/mnsc.30.9.1078

[6] Bogetoft, P., Färe, R., Grosskopf, S. Hayes, K., \& Taylor, L. (2009). Dynamic network DEA: an illustration, Journal of the Operations research Society of Japan, 52 (2), 147-162. https://doi.org/10.15807/jorsj.52.147

[7] Castelli, L., Pesenti, R., \& Ukovich, W. (2010). A classification of DEA models when the internal structure of the decision making units is considered. Annals of Operations Research, 173 (1), 207-235. https://doi.org/10.1007/s10479-008-0414-2

[8] Chang, H.L. Choy, Cooper, W.W., \& Ruefli, T.W., Using Malmquist indexes to measure changes in the productivity and efficiency of US accounting firms before and after the Sarbanes, Omega, 37 (5), 951-960. http://doi.org/10.1016/j.omega.2008.08.004

[9] Chang, Y.T., Park, H.K., Zou, B., \& Kafle, N. (2016). Passenger facility charge vs. airport improvement program funds: a dynamic network DEA analysis for U.S. airport financing. Transportation Research Part E: Logistics and Transportation Review, 88 (2), 76-93. https://doi.org/10.1016/j.tre.2016.02.001 
[10] Chang, Y.T., Park, H.K., Zou, B., \& Kafle, N. (2016). Passenger facility charge vs. airport improvement program funds: A dynamic network DEA analysis for U.S. airport financing. Transportation Research Part E: Logistics and Transportation Review, 88, 76-93. https://doi.org/10.1016/j.tre.2016.02.001

[11] Chao, C.M., Yu, M.M., \& Wu, H.N. (2015). An application of the dynamic network DEA model: the case of banks in Taiwan. Emerging Markets Finance and Trade, 51, 133-151. https://doi.org/10.1080/1540496X.2014.998887

[12] Charnes, A., \& Cooper, W.W., Rhodes, E. (1978). Measuring the efficiency of decision making units. European Journal of Operational Research, 2 (6), 429-444. https://doi.org/10.1016/0377-2217(78)90138-8

[13] Chen, C.M. (2009). A network-DEA model with new efficiency measures to incorporate the dynamic effect in production networks. European Journal of Operational Research, 194(3), 687-699. https://doi.org/10.1016/j.ejor.2007.12.025

[14] Chen, C.M., \& van Dalen, J. (2010). Measuring dynamic efficiency: theories and an integrated methodology. European Journal of Operational Research, 203 (3), 749-760. https://doi.org/10.1016/j.ejor.2009.09.001

[15] Chung, Y.H., Färe, R., \& Grosskopf, S. (1997). Productivity and undesirable outputs: a directional distance function approach. Journal of Environmental Management, $51 \quad$ (3), 229-240. https://doi.org/10.1006/jema.1997.0146

[16] Cook, W.D., Liang, L., \& Zhu, J. (2010). Measuring performance of two-stage network structures by DEA: A review and future perspectives. Omega, 38 (6), 423-430. https://doi.org/10.1016/j.omega.2009.12.001

[17] De Mateo, F., Coelli, T., \& O'Donell, C. (2006). Optimal paths and costs of adjustment in dynamic DEA models: with application to Chilean department stores. Annals of Operations Research, 145 (1), 211-227. https://doi.org/10.1007/s10479-006-0034-7

[18] Debreu, G. (1951). The Coefficient of Resource Utilization. Econometrica, 19 (3), 273-292. https://doi.org/10.2307/1906814

[19] Emrouznejad, A., \& Thanassoulis, E. (2005). A mathematical model for dynamic efficiency using data envelopment analysis. Applied Mathematics and Computation, 160 (2), 363-378. https://doi.org/10.1016/j.amc.2003.09.026

[20] Emrouznejad, A., \& Yang, G. (2018). A survey and analysis of the first 40 years of scholarly literature in DEA: 1978-2016, Socio-economic Sciences, 61, 4-8. https://doi.org/10.1016/j.seps.2017.01.008

[21] Fallah-Fini, S., Triantis, K., \& Johnson, A. (2014). Reviewing the literature on non-parametric dynamic efficiency measurement: state of the art. Journal of Productivity Analysis, 41 (1). https://doi.org/10.1007/s11123-013-0349-8

[22] Färe, R. 1988. Fundamentals of Production Theory. Springer-Verlaf, Berlin. https://doi.org/10.1007/978-3$642-51722-8$

[23] Färe, R., \& Grosskopf, S. (1996). Intertemporal production frontiers: with dynamic DEA. Boston: Kluwer Academic Publishers, 1996. ISBN 978-94-009-1816-0, p. 202. https://doi.org/10.1007/978-94-009-18160

[24] Färe, R., \& Grosskopf, S. (2000). Network DEA. Socio-Economic Planning Sciences, 34 (1), ISSN 00380121, 35-49. https://doi.org/10.1016/S0038-0121(99)00012-9

[25] Färe, R., \& Grosskopf, S., Lee, W.F. (2004). Property rights and profitability, In: Färe, R. Grosskopf, S. (Eds.), New Directions: Efficiency and Productivity, Kluwer Academic Publishers, Boston, 2004, 56-77.

[26] Färe, R., Grosskopf, S. \& Whittaker, G. (2007). Network DEA, in Zhu, J. and Cook, W.D. (Eds), Modeling Data Structures Irregularities and Structural Complexities in Data Envelopment Analysis, Chapter 12, Springer, New York, NY, pp. 209-240.

[27] Färe, R., Grosskopf, S. \& Whittaker, G. (2007). Network DEA. Modelling Data Irregularities and Structural Complexities in Data Envelopment Analysis, Springer US, 2007, 209-240. https://doi.org/10.1007/978-0387-71607-7

[28] Färe, R., Whittaker, G. (1995). An intermediate input model of dairy production using complex survey data. Journal of Agricultural Economics, 46 (2), 201-213. https://doi.org/10.1111/j.1477-9552.1995.tb00766.X

[29] Färe, R.. Grosskopf, S., \& Lovell, C.A. 1985. Measurement of Efficiency of production. Kluwer-Nijhoff Publishing Co., Boston, https://doi.org/10.1007/978-94-015-7721-2 
[30] Farell, M.J. (1957). The Measurement of Productive Efficiency. Journal of Royal Statistical Society, Series A (General), 120 (3), 253-290. https://doi.org/10.2307/2343100

[31] Fukuyama, H., \& Weber, W.L. (2010). A slacks-based inefficiency measure for a two-stage system with bad outputs. Omega, 38 (5), 398-409. https://doi.org/10.1016/j.omega.2009.10.006

[32] Fukuyama, H., \& Weber, W.L. (2015). Measuring Japanese bank performance: a dynamic network DEA approach. Journal of Productivity Analysis, 44 (3), 249-264. https://doi.org/10.1007/s11123-014-0403-1

[33] Halkos, G.E., Tzemeres, N.G., \& Kourtzidis, S.A. (2014). A unified classification of two-stage DEA models. Surveys in Operations Research and Management Science, $19 \quad$ (1), 1-16. https://doi.org/10.1016/j.sorms.2013.10.001

[34] Jaenicke, E.C. (2000). Testing for Intermediate Outputs in Dynamic DEA models: Accounting for Soil Capital in Rotational Crop Production and Productivity Measures, Journal of Productivity Analysis, 14, 247 266. https://doi.org/10.1023/A:1026503104672

[35] Kahi, V.S., Yousefi, S., Shabanpour, H., \& Saen, R.F. (2017). How to evaluate sustainability of supply chains? A dynamic network DEA approach. Industrial Management and Data Systems, 117 (9), 1866-1889. https://doi.org/10.1108/IMDS-09-2016-0389

[36] Kao, C. (2009). Efficiency decomposition in network data envelopment analysis: A relational model, European Journal of Operational Research, 192 (3), 949-962. https://doi.org/10.1016/j.ejor.2007.10.008

[37] Kao, C. (2013). Dynamic data envelopment analysis: a relational analysis. European Journal of Operational Research, 227(2), 325-330. https://doi.org/10.1016/j.ejor.2012.12.012

[38] Kao, C. (2014). Network data envelopment analysis: A review, European Journal of Operational Research, 239 (1), 1-16. https://doi.org/10.1016/j.ejor.2014.02.039

[39] Kao, C., Hwang, S.N. (2010). Efficiency measurement for network systems: IT impact on firm performance, Decision Support Systems, 48 (3), 437-446. https://doi.org/10.1016/j.dss.2009.06.002

[40] Kao, Ch., \& Hwang, S.N. (2008). Efficiency decomposition in two-stage data envelopment analysis: An application to non-life insurance companies in Taiwan. European Journal of Operational Research, 418-429. https://doi.org/10.1016/j.ejor.2006.11.041

[41] Kou, M., Chen, K., Wang, S., \& Shao, Y. (2016). Measuring efficiencies of multi-period and multi-division systems associated with DEA: an application to OECD countries' national innovation systems. Expert Systems with Applications, 46, 494-510. https://doi.org/10.1016/j.eswa.2015.10.032

[42] Kweh, Q.L., Kuo, K.C., Wang, W.K., \& Liu, H.M. (2015). Board independence, family control, and performance in Taiwanese listed semiconductor companies. Hitotsubashi Journal of Economics, 56 (1), 93 115. https://doi.org/10.15057/27192

[43] Lewis, H.F., \& Sexton, T.R. (2004). Network DEA: Efficiency Analysis of organizations with complex internal structure. Computers and Operations Research, 31 (9), 1365-1410. https://doi.org/10.1016/S03050548(03)00095-9

[44] Li, Y., Wang, Y., \& Cui, Q. (2016). Energy efficiency measures for airlines: an application of virtual frontier dynamic range adjusted measure. Journal of Renewable and Sustainable Energy, 8 (1), 15901. https://doi.org/10.1063/1.4938221

[45] Liang, L., Cook, W.D., \& Zhu, J. (2008). DEA models for two-stage processes: game approach and efficiency decomposition. Naval Research Logistics, 55, 643-653. https://doi.org/10.1002/nav.20308

[46] Lin, B., \& Yang, L. (2014). Efficiency effect of changing investment structure on Chinas power industry. Renewable and Sustainable Energy Reviews, 39, 403-411. https://doi.org/10.1016/j.rser.2014.07.018

[47] Lu, W., Wang, \& W., Long, Q. (2014). Intellectual capital and performance in the Chinese life insurance industry. Omega, 42 (1), 65-74. https://doi.org/10.1016/j.omega.2013.03.002

[48] Lu, W., Wang, W., \& Long, Q. (2014). Intellectual capital and performance in the Chinese life insurance industry. Omega, 42 (1), 65-74. https://doi.org/10.1016/j.omega.2013.03.002

[49] Mariz, F.B.A.R., Almeida, M.R., \& Aloise, D. (2017). A review of Dynamic Data Envelopment Analysis: state of the art and applications, International Transactions in Operational research, 25, https://doi.org/10.1111/itor.12468 
[50] Moreno, P., Lozano, S., \& Gutiérrez, E. (2013). Dynamic performance analysis of U.S. wireline telecommunication companies. Telecommunications Policy, 37 (6-7), 469-482. https://doi.org/10.1016/j.telpol.2012.12.001

[51] Nemoto, J., \& Goto, M. (1999). Dynamic data envelopment analysis: modeling intertemporal behavior of a firm in the presence of productive inefficiencies. Economic Letters, 64 (1), 51-56. https://doi.org/10.1016/S0165-1765(99)00070-1

[52] Nemoto, J., \& Goto, M. (2003). Measurement of dynamic efficiency in production: an application of data envelopment analysis to Japanese electric utilities. Journal of Productivity Analysis, 19 (2-3), 191-210. https://doi.org/10.1023/A:1022805500570

[53] Oltaf, L., Amiri, M., Bamdad Soufi, J., \& Pishdar, M. (2016). A dynamic network efficiency measurement of airports performance considering sustainable development concept: a fuzzy dynamic network-DEA approach. Journal of Air Transport Management, 272-290. https://doi.org/10.1016/j.jairtraman.2016.08.007

[54] Omrani, H., \& Soltanzadeh, E. (2016). Dynamic DEA models with network structure: an application for Iranian airlines, Journal of Air Transport Management, 57, 52-61. https://doi.org/10.1016/j.jairtraman.2016.07.014

[55] Oulette, P., \& Yan, L. (2008). Investment and dynamic DEA. Journal of Productivity Analysis, 29 (3), https://doi.org/10.1007/s11123-007-0079-x

[56] Ozcan, Y.A., \& Khushalani, J. (2017). Assessing efficiency of public health and medical care provision in OECD countries after a decade of reform. Central European Journal of Operational Research, 25, 325-343, https://doi.org/10.1007/s10100-016-0440-0

[57] Reshadi, M., \& Espahi, A.B. (2012). Dynamic DEA: relative efficiency measure of units. Applied Mathematical Sciences, 6 (55), 2719-2725.

[58] Shafiee, M., Sangi, M., \& Ghaderi, M. (2013). Bank performance evaluation using dynamic DEA: a slacksbased measure approach. Data Envelopment Analysis and Decision Science, 2013, 1-12. doi:10.5899/2013/dea-00026

[59] Shephard, R.W. (1953). The Theory of Cost and Production Functions. Princeton: Princeton University Press, 1953.

[60] Silva, E., \& Stefanou, S.E. (2003). Nonparametric dynamic production analysis and the theory of cost. Journal of Productivity Analysis, 19 (1), 5-32. https://doi.org/10.1023/A:1021865018717

[61] Silva, E., \& Stefanou, S.E. (2007). Dynamic efficiency measurement: theory and application. American Journal of Agricultural Economics, 89 (2), 398-419. https://doi.org/10.1111/j.1467-8276.2007.00999.x

[62] Sinha, R.P. (2015). A dynamic DEA model for Indian life insurance companies. Global Business Review, 16 (2), 258-269. https://doi.org/10.1177/0972150914564418

[63] Skevas, T., Oude Lansink, A., \& Stefanou, S.E. (2012). Measuring technical efficiency in the presence of pesticide spillovers and production uncertainty: the case of Dutch arable farms. European Journal of Operational Research, 223 (2), 550-559. https://doi.org/10.1016/j.ejor.2012.06.034

[64] Sueyoshi, T. \& Sekitani, K. (2005). Returns to scale in dynamic DEA. European Journal of Operational Research, 161 (2), 536-544. https://doi.org/10.1016/j.ejor.2003.08.055

[65] Tone, K., \& Tsutsui, M. (2009). Network DEA: A slacks-based measure approach. European Journal of Operational Research, 197 (1), 243-252. https://doi.org/10.1016/j.ejor.2008.05.027

[66] Tone, K., \& Tsutsui, M. (2010). Dynamic DEA: A slacks-based measure approach, Omega, Elsevier, 38 (34), 145-156. https://doi.org/10.1016/j.omega.2013.04.002

[67] Tone, K., \& Tsutsui, M. (2014). Dynamic DEA with network structure: A slacks-based approach, Omega, Elsevier, 42 (1), 124-131. https://doi.org/10.1016/j.omega.2013.04.002

[68] Tu, C.J., Chang, M.C., \& Chen, C.P., (2016). Progressive time-weighted dynamic energy efficiency, energy decoupling rate, and decarbonization: an empirical study on G7 and BRICS. Sustainability (Switzerland), 8 (9), 928. doi:10.3390/su8090928 
[69] Von Geymueller, P. (2009). Static versus dynamic DEA in electricity regulation: the case of US transmission system operators, Central European Journal of Operations Research, 17 (4), 397-413. https://doi.org/10.1007/s10100-009-0099-x

[70] Wang, C.H., Gopal, R.D., \& Zionts, S. (1997). Use of data envelopment analysis in assessing information technology impact on firm performance. Annals of Operations Research, 73 (1), 191-213. https://doi.org/10.1023/A:1018977111455

[71] Wang, W.K., Chan, Y.C., Lu, W.M., \& Chang, H. (2015). The impacts of asset impairments on performance in the Taiwan listed electronics industry, International Journal of Production Research, 53 (8), 2410-2426. https://doi.org/0.1080/00207543.2014.972526

[72] Wang, Z., Feng, C., \& Zhang, B. (2014). An empirical analysis of China's energy efficiency from both static and dynamic perspectives, Energy, 74, 322-330. https://doi.org/10.1016/j.energy.2014.06.082

[73] Wanke, P., \& Barros, C.P. (2016). Efficiency in Latin American airlines: a two-stage approach combining Virtual Frontier Dynamic DEA and Simplex Regression, Journal of Air Transport Management, 54, 93-103. https://doi.org/10.1016/j.jairtraman.2016.04.001

[74] Wanke, P., Barros, C.P., \& Faria, J.R. (2015). Financial distress drivers in Brazilian banks: a dynamic slacks approach, European Journal of Operational Research, $240 \quad$ (1), 258-268. https://doi.org/10.1016/j.ejor.2014.06.044

[75] Wu, W.W., Lan, L.W., \& Lee, Y.T. (2013). Benchmarking hotel industry in a multi-period context with DEA approaches: a case study, Benchmarking: An International Journal, 20 (2), 152-168. https://doi.org/10.1108/14635771311307650

[76] Yeh, L.T., Chang, D.S., \& Liu, W. (2016). The effect of organizational learning on the dynamic recycling performance of Taiwan's municipal solid waste (MSW) system. Clean Technologies and Environmental Policy, 18 (5), 1535-1550. https://doi.org/10.1007/s10098-016-1135-x

[77] You, Y.Q., \& Jie, T. (2016). A study of the operation efficiency and cost performance indices of powersupply companies in China based on a dynamic network slacks-based measure model, Omega, 60, 85-97. https://doi.org/10.1016/j.omega.2014.11.011

[78] Yu, M.M., Chen, L.H., Chen, K. CH., \& Tone, K. (2013). Operational efficiency in Taiwan banks with consideration of nonperforming loans: A dynamic network DEA. Workshop on DNDEA 2013, from http://www.grips.ac.jp/cms/wp-content/uploads/2013/03/DEA_Chapter9.pdf

[79] Zha, Y., Liang, N., Wu, M., \& Bian, Y. (2016). Efficiency evaluation of banks in China: a dynamic twostage slacks-based measure approach. Omega, 60, 60-72. https://doi.org/10.1016/j.omega.2014.12.008 


\title{
Risk Assessment of Agricultural Companies Using Accounting Beta
}

\author{
Andrea Boháčiková ${ }^{1}$, Tatiana Bencová ${ }^{2}$, Zuzana Kapustová ${ }^{3}$, Ivan Holúbek ${ }^{4}$ \\ Slovak University of Agriculture in Nitra ${ }^{1,2,3,4}$ \\ Department of Finance ${ }^{1,2,4}$, Department of Economics ${ }^{3}$ \\ Address: Tr. A. Hlinku 2, \\ 94976 Nitra, Slovak republic \\ e-mail: andrea.bohacik@gmail.com¹, tatiana.bencova@uniag.sk², zuzana.kapustova@uniag.sk³ \\ ivan.holubek@uniag.sk ${ }^{4}$
}

\section{doi: 10.18515/dBEM.ISD.P01.2020.p068}

\begin{abstract}
Risk in agriculture is a difficult concept to recognize, while it is affected by number of various factors interconnected to each other, causing volatility of farm income and prices. Moreover, in the attempt to assess the income risk of farms, we face the problem of unlisted character of majority of agricultural companies. The use of traditional risk measurement techniques for small unlisted businesses proves difficulties due to lack of market information. In the paper, we examine the volatility of return ROE of Slovak agricultural companies, using the accounting beta measure. Beta coefficient refers to the volatility of each farm in comparison to the market, and based on the result each farm can be classified to group of risky farms (with higher volatility), non-risky (with lower volatility), or negatively correlated farms (with negative beta). The agricultural companies are examined separately according to their legal form and production orientation.
\end{abstract}

Keywords: accounting beta, agriculture, income risk, return on equity, volatility.

JEL Classification: Q10, Q13, Q14

\section{Introduction}

Income from farming is volatile due to various random factors that affect production and prices. The increased volatility is mostly caused by the input and output price changes, which are more likely to attempt in farming due to the reliance of production on natural conditions and weather influences, disease outbreaks and adverse weather events, such as floods and droughts, as well as climate change. These events can negatively impact producers' incomes, markets, trade and consumers (Kahan, 2008). Risks in agriculture are interconnected, sometimes compounding and sometimes offsetting each other (Meuwissen et al., 2008). Therefore, the risk management in agriculture plays a key role nowadays, as an essential tool for farmers to anticipate, avoid and react to shocks, potential losses and increasing volatility of incomes (OECD, 2011). Agricultural risk can be a difficult concept to recognize, because there has not been a universal agreement on how to define and measure risk (Tangermann, 2011). Generally, risk refers to deviation of the evaluated variable (income, price, production etc.), and its level depends on the volatility over a certain period. The smaller the deviation, the tighter the distribution and the lower the risk (Hardaker et al., 2004). In the risk assessment, some of the authors focus on the stand-alone agricultural risk of individual farms, others took into account the whole market level (El Benni \& Finger, 2013; Tóth et al., 2016).

Agricultural companies in Slovakia belong to unlisted companies, it means their stocks are not publically traded on the exchange. The beta coefficient, in the Capital Asset Prising Model, that measures the risk is usually estimated using historical stock prices. The absence of historical price information for private firm equity, and the failure on the part of many private firm owners to diversify, can create serious problems with estimating and using betas for these firms (StPierre \& Bahri, 2006). While price information is not available for private firms, accounting 
earnings information may replace the data set (Vos, 1992). Different authors selected various accounting variables in the risk estimation for unlisted companies. Ball and Brown (1969) first showed that an accounting beta could be constructed from financial accounting statements according to yearly change in earnings. Hill and Stone (1980) refined the earlier work mentioned by considering the effects of financial and operating leverage in determining accounting betas. Vos (1992) derived the analysis using the Return on Equity ratio of the companies. Fama and French (1996) found that factors such as size, earnings/price, cash flow/price, book-to-market ratio, past sales growth, long-term and short-term past returns disappear in a three-factor model of asset pricing. Their three-factor model includes beta, the size effect and the book-to-market ratio. From the more recent research Bowman and Brush (2007) used the comparable company analysis (CCA) of a non-traded firms or division in estimating beta to a sample of 480 U.S. companies of similar size. St-Pierre and Bahri (2006) derived the model based on return on equity assesment to estimate the accounting beta, as an overall risk indicator for unlisted Canadian private small and medium size companies. Franc-Dąbrowska, J., Mądra-Sawicka, M., \& Bereżnicka, J. (2018) used the accounting approach to propose a methodology for calculating the cost of equity for unlisted agricultural companies in Poland.

In the paper, we use the empirical study of Vos (1992) to identify the risky and non-risky agricultural companies based on the beta assessment. The volatility of return on equity (ROE) of individual farms is compared to the overall market volatility, using the concept "riskcomposed equity beta".

\section{Data and Methods}

The data used for the analysis are obtained from the Ministry of Agriculture and Rural Development of Slovak republic. The data set consists of financial statements of 623 individual farms in the years $2004-2013$. The time period is chosen with the intention to focus on 10years period after Slovakia joined the European Union, and has become a part of Common Agricultural Policy (CAP) EU. Farms are divided and examined separately according to their legal form and production orientation. Only legal entities with a legal form of cooperative, limited liability company, or joint stock company have been selected. Based on the production orientation, the companies are divided into crop and animal farms. The classification criterion is more than $50 \%$ share of revenues from crop production or livestock production to the total sales of own products and services.

For identifying the risky companies, it is more beneficial to use the values of the beta coefficient than to rely on the specific value of the standard deviation. The standard deviation indicates whether the yield of the i-th asset (farm) is volatile, while the beta measures the volatility of the yield of a particular asset (farm) against the whole market.

The beta $(\beta)$ coefficient is an integral part of the Capital Asset Pricing Model. To calculate the beta of a security, the covariance between the return of the security and the return of the market must be known, as well as the variance of the market returns.

$$
\beta_{i}=\frac{\sigma_{i M}}{\sigma_{M}^{2}}
$$

$\beta_{i}$ - beta coefficient, volatility of $i$-th asset to the change of market portfolio 
$\sigma_{i M}$ - covariance of $i$-th asset with market portfolio

$\sigma_{M}^{2}$ - variance of market portfolio

For a publicly listed company with sufficient data, the most common way to estimate beta is to regress a company's returns against the returns to the market. The slope of this regression refers to the beta coefficient that can be used to find the high- and low-risky companies. For all other cases, an alternative approach is needed to estimate beta. The approach for estimating the beta of unlisted companies, such as agricultural companies is to use "risk-composed equity beta" defined as (Hill and Stone, 1980):

$$
\beta_{i}^{r}=d\left(R O E_{i} / d\left(R O E_{m}\right)\right.
$$

$\beta_{i}^{r}$ - accountig beta

$d$ - is the first moment change with respect to time

$R O E_{i}$ - return on equity of individual $i$ farm

$R O E_{m}$ - return on equity of $m$ farms on the market.

Based on the beta coefficient each individual agricultural company can be compared to the overall market risk and selected to group of risky companies (more volatile than the market), or non-risky companies (less volatile than market). The possible results are:

- $\beta=1$ exactly as volatile as the market

- $\beta>1$ more volatile than the market

- $\beta<1>0$ less volatile than the market

- $\beta=0$ uncorrelated to the market

- $\beta<0$ negatively correlated to the market

There are two significant limitations of this approach. The first is that farms usually measure earnings and return only once a year, leading to calculation with few observations and limited statistical power. The second is that earnings are often smoothed out, leading to mismeasurement of accounting betas.

\section{Results and Discussion}

The income risk of agricultural companies refers to the volatility of return within the selected period of time, and can be standardly measured by the standard deviation. The standard deviation measures the dispersion of data relative to its mean, regardless the positive or negative change of annual return. For identification of risky and non-risky agricultural companies it is more useful to use the beta coefficient, as a measure of the volatility of individual farms' returns relatively to the entire market.

The market has a beta of 1,0 and individual farms are ranked according to how much they deviate from the market. Therefore, we assume that the "risky" agricultural company is the one having the beta coefficient above 1,0., it means with the higher volatility than the market over the time. Farm with the beta coefficient less than 1,0 is considered as "non-risky" farm, it means with lower volatility of return than the market. Even if we named the group of farms with low 
betas "non-risky" it does not mean that there is zero risk. High-beta farms are supposed to be riskier but provide a potential for higher returns; while low-beta farms should have less risk but also lower returns.

Table 1: Characteristic of farms according beta coefficient

\begin{tabular}{l|ccccc}
\hline & All farms & Cooperatives & $\begin{array}{c}\text { Business } \\
\text { companies } \\
(\text { Ltd., } \boldsymbol{S S c} \text { ) }\end{array}$ & $\begin{array}{c}\text { Crop } \\
\text { production }\end{array}$ & $\begin{array}{c}\text { Animal } \\
\text { production }\end{array}$ \\
\hline Number of farms & 600 & 344 & 256 & 340 & 260 \\
No. farms beta $<\mathbf{0}$ & 82 & 45 & 37 & 26 & 56 \\
No. farms beta (0-1) & 212 & 137 & 75 & 95 & 117 \\
No. farms beta $>\mathbf{1}$ & 306 & 162 & 144 & 219 & 87 \\
$\begin{array}{l}\text { \% negatively } \\
\text { correlated }\end{array}$ & $13,67 \%$ & $54,88 \%$ & $45,12 \%$ & $31,71 \%$ & $68,29 \%$ \\
\% non-risky farms & $35,33 \%$ & $64,62 \%$ & $35,38 \%$ & $44,81 \%$ & $55,19 \%$ \\
\% risky farms & $51,00 \%$ & $52,94 \%$ & $47,06 \%$ & $71,57 \%$ & $28,43 \%$ \\
Max & 23,046 & 17,192 & 23,046 & 23,046 & 22,322 \\
Min & $-8,222959$ & $-8,222959$ & $-3,501576$ & $-8,222959$ & $-8,219936$ \\
Median value & 1,044028 & 0,84213 & 1,301872 & 1,648812 & 0,478659 \\
Average value & 1,845863 & 1,8 & 2,282657 & 2,478622 & 0,939304 \\
\hline S & & & &
\end{tabular}

Source: own processing

From the dataset consisting of 623 agricultural companies, the farms with insufficient information (missing data within years) are excluded. After removing the outliers, 600 farms could be used for calculation. The results, presented in Table 1, show that from the total number of farms (600), $51 \%$ are companies with higher volatility than the market and can be classified as risky (306 farms). From the point of legal form create the group of risky farms 162 cooperatives and 144 business companies. While the division is similar, when considering the production orientation of farms, the difference is more obvious. The majority of risky agricultural companies $71,6 \%$ are crop farms (with more than $50 \%$ of revenues from crop production), and only $28,4 \%$ are animal farms. It seems that the production orientation may be the factor having impact on the risk of agricultural companies.

Companies with a beta value lower than 1 are classified as non-risky farms, with lower volatility than market. The group consists of 212 farms, which account for $35 \%$ from the total number of farms in the sample. Almost $65 \%$ of non-risky farms are cooperatives, and farms with the orientation on animal production $(55,2 \%)$. The minority of farms has the legal form of limited liability company or join-stock company $(35,38 \%)$, and belongs to the crop farms $(44,8 \%)$. In the case of non-risky farms, the division according to the legal form shows more differences than to production orientation.

Negative value of beta means the negative correlation between individual farm and the market. Results show that 82 companies move the opposite direction than the market changes. The minimum and maximum of beta coefficient refer to extreme values of volatility, whether 
negatively or positively correlated farms. Those extremes should be rather excluded from the dataset in further analysis and determined as outliers.

The median value of beta 1,044 shows that half of the farms in the dataset is riskier than the market and the second half belongs to non-risky farms with volatility (0-1) or negatively correlated farms $(13,7 \%)$. The median value of beta within groups may confirm the assumption, that crop oriented farms (median 1,65), and business companies (median 1,3) rather belong to risky group, than cooperatives $(0,84)$, and animal farms $(0,48)$. For better understanding the distribution of frequencies, the histogram (Figure 1) is constructed.

Figure 1: Frequency distribution of farms' volatility (beta)
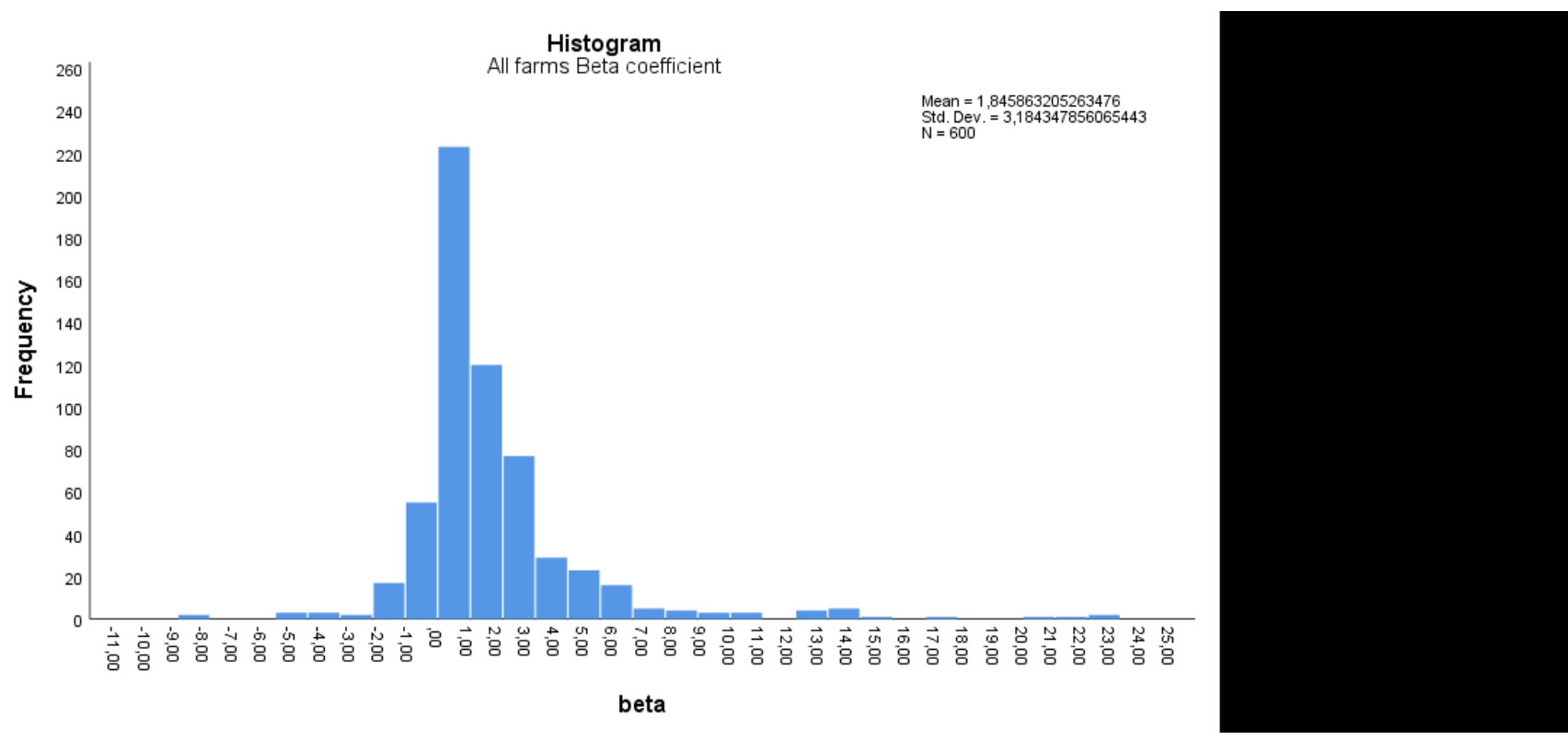

Source: own processing

A frequency distribution shows how often each different value in a set of data occurs. The peak value with the highest count of farms is the interval between (0-1). If the beta is more than 5 , only small number of farms remains in the settled intervals. As expected, there are outliers as the isolated bars on the both sides of the histogram. We assume that for the further analysis, it is not essential to examine the beta more than 5 or less than -1 .

When considering the frequencies of groups of farms, divided according to the legal form and production orientation, the histogram shape looks similar (Figure 2). However, in the case of crop farms, there is a high number of farms in the interval $(1,2)$, in comparison to animal farms with low frequency for this value. The identified difference does not occur in the division of legal forms. It is interesting, that the animal farms and cooperatives have almost twice as high frequency in the interval $(-1,0)$, representing the negatively correlated farms, that change the opposite way than the market.

Table 2 presents the volatility of farms, when separating the farms with extreme values of beta more than 5 or less than -1 . After that 251 farms are selected as the risky farms and 212 as nonrisky. The average return on equity ROE in the group of non-risky farms is $1,48 \%$ with an average standard deviation of $5,01 \%$. The ratio of the standard deviation to the average return, shows that for each 1 unit of average return there is 3,38 portion of risk it generates. The median value of beta coefficient of the group of non-risk farms is 0,438 ; with a minimum value of 0,0025 and a maximum of 0,973 . 
Figure 2: Frequency distribution according to legal form and production orientation
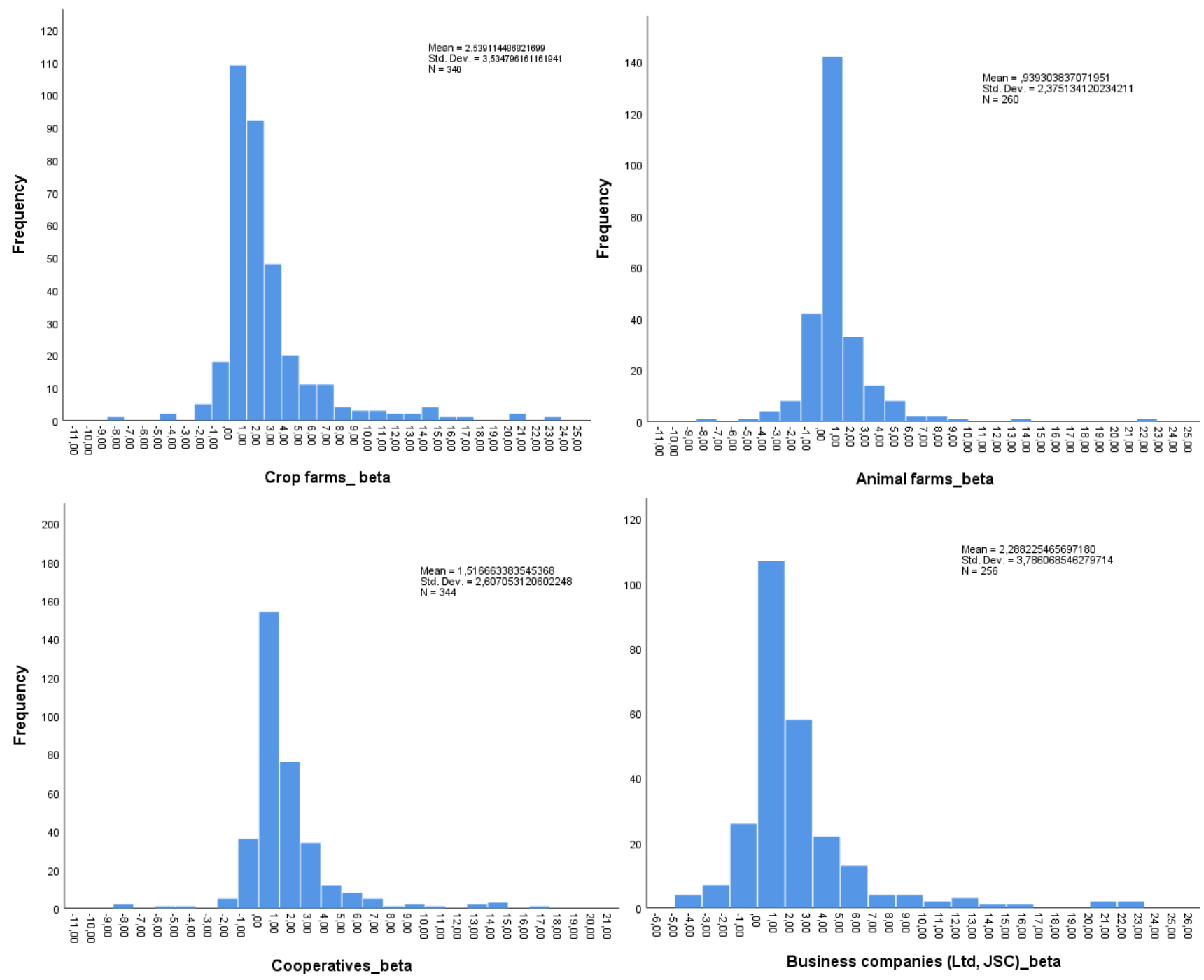

Source: own processing

Table 2: Group of farms according to the volatility (beta)

\begin{tabular}{lcccc}
\hline & Beta (-1-0) & Beta (0-1) & Beta (1-5) & Beta > 5 \\
\hline Number of farms & 55 & 212 & 251 & 55 \\
Beta Minimum & $-0,0026$ & 0,0025 & 1,0045 & 5,0478 \\
Beta Maximum & $-0,9235$ & 0,9728 & 4,998 & 23,0460 \\
Beta Median & $-0,2442$ & 0,4384 & 2,1639 & 7,3398 \\
ROE average & $2,01 \%$ & $1,48 \%$ & $3,64 \%$ & $-0,49 \%$ \\
Standard deviation average & $10,20 \%$ & $5,01 \%$ & $13,66 \%$ & $42,85 \%$ \\
Cooperatives & $65,45 \%$ & $64,62 \%$ & $55,38 \%$ & $41,82 \%$ \\
Business companies & $34,55 \%$ & $35,38 \%$ & $44,62 \%$ & $58,18 \%$ \\
Animal production & $70,91 \%$ & $55,19 \%$ & $30,68 \%$ & $18,18 \%$ \\
Crop production & $29,09 \%$ & $44,81 \%$ & $69,32 \%$ & $81,82 \%$ \\
\hline
\end{tabular}

Source: own processing 
The average return on equity ROE in the group of risky farms is $3,64 \%$ with the average standard deviation of $13,66 \%$. Both risk and return are approximately 2,5-times higher in comparison to non-risky group. It reflects the theoretical assumptions, that the higher risk is associated with higher probability of greater return. The ratio of the standard deviation to the average return reached similar result as in previous group, 3,75. It means there is a 3,37 portion of risk for the 1 unit of average return. It seems like the risk and return of farms grow linearly. The median value around 2 indicates that half of the farms in the risky group have 2-times higher volatility than market or lower. The rest of the farms reached volatility in the interval from (2,16-5). The minimum value of beta coefficient for risky group is 1,004 and a maximum 4,998 . The average risk and return measured by standard deviation and return on equity for each farm in the dataset for the selected period of time is presented in figure 3.

Figure 3: Average risk and return of farms

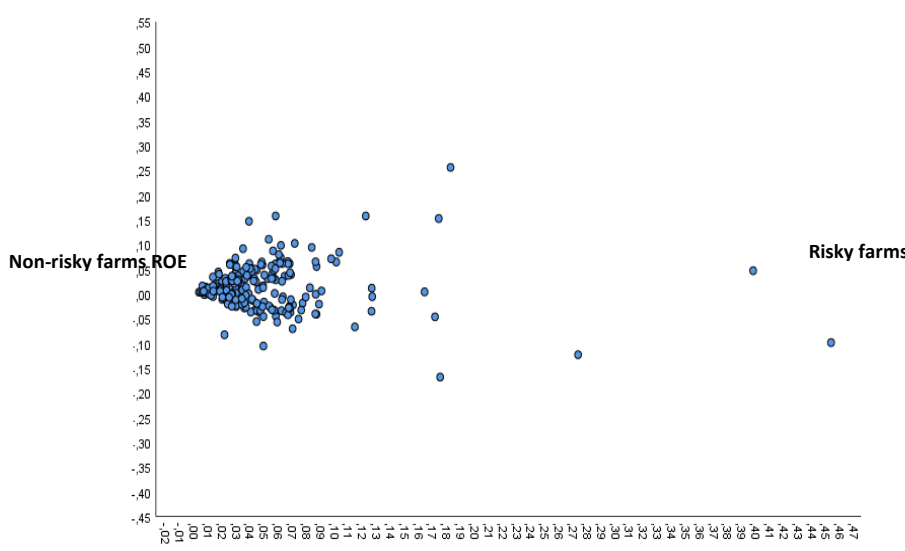

Non-risky farms standard deviation

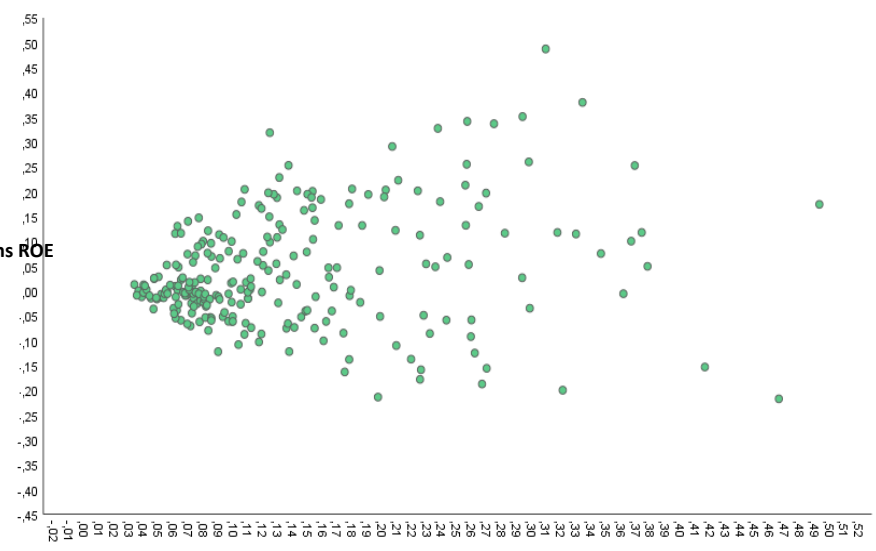

Risky farms standard deviation

Source: own processing

The group of negatively correlated farms that move the opposite way than the market, consists of 55 farms. The average return on equity ROE is $2,01 \%$ with an average standard deviation of $10,2 \%$. The ratio of the standard deviation to the average return, shows that for each 1 unit of average return there is 5,08 portion of risk it generates. The median value of beta coefficient of farms is $-0,2442$; with a minimum value $-0,0026$ and maximum $-0,9235$. The high percentage share is presented by animal farms $(70,91 \%)$, with more than $50 \%$ revenues from animal production, and cooperatives $(65,45 \%)$.

\section{Conclusion}

The Common Agricultural Policy 2014-2020 has been mainly aimed at compensating farmers for the negative effects of price volatility and tackling income volatility. Member States have the possibility to support three risk management tools (insurance schemes, mutual funds and an Income Stabilisation Tool) through their rural development programs. As the CAP offers the tools to mitigate the agricultural risk connected with income volatility, it should be import for each country to open the question of risk in agriculture in the scientific research. Basically, the first step is the identification of risky companies, that can be done by different approaches and measures.

In the paper, the volatility of yearly return (ROE) of Slovak agricultural companies during the period 2004 - 2013 is examined. We used the approach of "risk-composed equity beta" to identify the volatility of each individual farm in comparison to the market. It leads to the classification of companies to the group of "risky", "non-risky", or "negatively correlated". The agricultural companies are deeper analysed based on their production orientation and legal 
form. We have found out that there is higher percentage share of crop farms and farms with legal form of business companies (Ltd., JSC.) in the group of risky farms. The average return on equity ROE in the group of risky farms is $3,64 \%$ with the average standard deviation of $13,66 \%$. The majority of animal farms and cooperatives rather create the non-risky group. It should be noted that the non-risky group refers to the lower volatility than market, however it does not mean that farms included are without risk. The average return on equity ROE in the group of non-risky farms is $1,48 \%$ with an average standard deviation of $5,01 \%$. The great percentage of animal farms are also negatively correlated to the market, changing the different way than market changes.

The results show that production orientation is a factor having impact on the risk of Slovak farms, while the legal form does not play such an important role. These characteristic, as well as other factors, should be an issue for the further analysis.

\section{Acknowledgements}

This paper was supported by the project VEGA: Impact of the Common Agricultural Policy on the mitigation of income risk in Slovak agriculture and factors determining the level of risk of agricultural companies. Project registration number 1/0338/18.

\section{References}

[1] Ball, R., \& Brown, P. (1969). Portfolio theory and accounting. Journal of Accounting Research, 300-323.

[2] Bowman, R. G., \& Bush, S. R. (2007). Using comparable companies to estimate the betas of private companies. Journal of Applied Finance, Forthcoming.

[3] El Benni, N., \& Finger, R. (2013). The effect of agricultural policy reforms on income inequality in Swiss agriculture-An analysis for valley, hill and mountain regions. Journal of Policy Modeling, 35(4), 638-651.

[4] Fama, E. F., \& French, K. R. (1996). Multifactor explanations of asset pricing anomalies. The journal of finance, 51(1), 55-84. Franc-Dąbrowska, J., Mądra-Sawicka, M., \& Bereżnicka, J. (2018). Cost of Agricultural Business Equity Capital—A Theoretical and Empirical Study for Poland. Economies, 6(3), 37

[5] Hardaker, J. B. (Ed.). (2004). Coping with risk in agriculture. Cabi. 332 p. ISBN 0851998313

[6] Harwood, J. L., Heifner, R. G., Coble, K. H., Perry, J. E., \& Somwaru, A. (1999). Managing risk in farming: concepts, research, and analysis (No. 1473-2016-120714).

[7] Hill, N. C., \& Stone, B. K. (1980). Accounting betas, systematic operating risk, and financial leverage: A risk-composition approach to the determinants of systematic risk. Journal of Financial and Quantitative Analysis, 15(3), 595-637.

[8] Kahan, D. (2008). Managing risk in farming. Food and Agriculture Organization of the United Nations. ISBN 978-92-5-107543-2.

[9] Meuwissen, M. P., Asseldonk, M. A. P. M., \& Huirne, R. B. (Eds.). (2008). Income stabilisation in European agriculture: design and economic impact of risk management tools. Wageningen Academic Pub.

[10] OECD (2011). Managing Risk in Agriculture: Policy Assessment and Design. OECD Publishing. Paris. https://doi.org/10.1787/9789264116146-en.

[11] St-Pierre, J., \& Bahri, M. (2006). The use of the accounting beta as an overall risk indicator for unlisted companies. Journal of Small Business and Enterprise Development, 13(4), 546-561.

[12] Tangermann, S. (2011). Risk management in agriculture and the future of the EU's Common Agricultural Policy. Issue Paper, 34.

[13] Tóth, M., Rábek, T., Boháčiková, A., \& Holúbek, I. (2016). Risk and profitability of animal and crop production in Slovak farms. Trendy v podnikání, 12-20. ISSN 1805-0603.

[14] Vos, E. A. (1992). Differences in risk measurement for small unlisted businesses. The Journal of Entrepreneurial Finance, 1(3), 255-267. 


\title{
Influence of Direct Payments on the Economy of Chosen Agricultural Commodities in the Slovak Republic
}

\section{Patrik Rovný ${ }^{1}$, Dušan Dobák ${ }^{2}, Z_{\text {Zuzana Strápeková }}{ }^{3}$, Lenka Števonková Lavríková ${ }^{4}$}

Slovak University of Agriculture in Nitra,

Faculty of Economic and Management, Department of Trade and Trade ${ }^{1,2}$, Department of Finance ${ }^{3,4}$

Address: Tr. A. Hlinku 2,

94976 Nitra, Slovak republic

e-mail: patrik.rovny@uniag.sk ${ }^{1}$,dusan.dobak@uniag.sk ${ }^{2}$,zuzana.strapekova@uniag.sk³

lenkastevonka@gmail.com ${ }^{4}$

doi: 10.18515/dBEM.ISD.P01.2020.p069

\begin{abstract}
Direct payments represent a certain income for farmers, which will retain them in the event of adverse market developments or adverse weather conditions. We can state that subsidies are necessary to maintain the development of agriculture.

Prior to accession to the EU, Slovak agriculture had its own subsidy policy, which took into account the cost, fertility, profitability / loss of individual agricultural commodities. This means that in terms of selfsufficiency of production and supply of the population of the Slovak Republic, the state controlled production in terms of self-sufficiency by its regulations. After joining the EU, the customs barriers of the Slovak Republic fell, by which it protected its farmers from the import of surplus commodities to Western Europe. This was followed by the opening of the market for agricultural commodities within the EU. The Slovak Republic, as an accession state, has adopted EU regulations, which it has adopted in the accession negotiations.

The main objective of the paper is to evaluate the influence of direct payments in agriculture after the accession of the Slovak Republic to the EU on foreign agri-food trade of the Slovak Republic for the period 2005 - 2017.

The following methods were used:

- synthesis method - summary of the data obtained from different sources,

- method of analysis of obtained data - analysis of development of direct payments and foreign agrotrade of Slovakia,

- comparison method - comparison of data for individual years,

- graphical methods - data arranged in tables and subsequent processing into graphs,

- method of statistical indicators - use of change indices,

- calculation method - quantification of costs and relation to subsidies.

From the granted national package of subsidies, the Slovak Republic really received only a certain part of the EU financial budget, which rose by 5 and almost 10 percent each year. On the beginning in 2004 it was only 25 percent.
\end{abstract}

Keywords: direct payments, economy, commodities, , revenues, own costs, economical results

JEL Classification: $Q 12$

\section{Introduction}

Entrepreneurship on the agricultural land belongs among the oldest economic sectors of every country. Slovakia and its countryside was for many centuries a typical agrarian country. Despite the areal industrialization after 1950 agriculture remained its characteristic feature. Evidential sector organization of agricultural production was created as a result of manufacturing expansion. It was caused by industrialization process. It caused largely one-side orientation of rural regions towards the agricultural activities. In the current era of globalization, especially 
after the accession to the EU, the position of agriculture is changing especially in the trend of EU CAP reforms ( Horská, Nagyová \& Felixová, 2010; Kleinová \& Neománi, 2010).

Faced to sustainability problems, European agriculture is looking after better solutions to maintain jobs and economic activities while respecting the natural resources (Cvik \& MacGregor Pelikánová, 2015).

The changing position of agriculture and the differentiated rural areas is also reflected in the theoretical approaches trying to explain this transformation with agriculture seen as one of the sectors and industries in the rural areas which can ensure the sustainability of rural households and the quality of life in rural areas through combination of agriculture and other activities (tourism or other services) in the frame of multifunctionality concept. (Konecny, 2015)

According to the Common Agricultural Policy of the EU, agriculture needs to attain higher levels of production of safe and quality food, while preserving the natural resources that agricultural productivity depend upon. This can only be achieved by a competitive and viable agricultural sector operating within a properly functioning supply chain which contributes to the maintenance of a thriving rural economy (European Commission, 2013). Consumer demands and governmental legislations are becoming stricter and agricultural entrepreneurs need to commit increasing resources to animal welfare, environmental measures and landscape maintenance. Furthermore, farmers have to face challenges of: increased competition due to the gradual opening of markets, the need for integration within the agricultural chain, the diminishing attractiveness of the sector as an employer and the increasing flexibility of working hours and contracts (De Lauwere, 2005; Fuller-Love, 2006).

Utilised agricultural area of farm in EU 28 varies from less than 3 hectares in Malta to more than 100 in Estonia, United Kingdom and Czech Republic. However, physical size of farm in Slovakia is more than twice bigger than mentioned. Slovakia has the absolutely biggest farms in EU 28 with the UAA value of 556.15 ha.farm-1. This fact is considered by historical size of farm. Implemented CAP system is based on the support per hectare, which can be profitable for the countries with big UAA values as Slovakia. Therefore the implementation of the (CAP) system is bringing annually large amount of subsidies to Slovak agricultural sector, which greatly affects it and even deforms to some extent.

Slovakia has been the leader in the volume of average farm subsidies received over the two (yet finished) program periods and has surpassed all EU 28 countries. Surprisingly, Slovak records show much larger total farm input than farm output, with a difference of 155,076.33 EUR.farm1, which is the biggest difference among EU 28 countries. This discrepancy is visible also on the efficiency of Slovak farms which is second lowest in EU 28 with the value of 0.76 calculated as the ratio of total output and total input on the farm level. The inverse relationship between farm productivity and farm size was proven in the results of correlation between utilized agricultural area and total output, but for Slovakia with the trivial value of $(-0.083)$. They indicate decreasing returns to scale, where each hectare of land leads to the decrease of production.

Slovakia's coefficient of the correlation between total output and total subsidies indicates moderate positive relationship with the number of 0.37 , which means that when total subsidy increases, the value of total output increases proportionally. The strong negative correlation of total subsidies and utilised agricultural area (-0.57) showed inverse relationship what can be interpreted as the more subsidies farmers get, the less acreage will they utilize. Therefore, chosen model of CAP support seems to be not suitable for Slovak conditions and these facts indicate that the currently set subsidy system of CAP in Slovakia does not work entirely efficiently and should therefore be reformed in the forthcoming programming periods. The need to reform CAP system of farmers support in EU is strengthened by the existence of significant regional disparities in EU. Regarding to the generous production potential of individual areas, 
it is very difficult to select a suitable support system at Member State level. (Kozáková, Urbanová, 2018)

The main objective of the paper is to evaluate the influence of direct payments in agriculture after the accession of the Slovak Republic to the EU on foreign agri-food trade of the Slovak Republic for the period 2005 - 2017.

\section{Data and Methods}

The following methods were used:

- synthesis method - summary of the data obtained from different sources,

- method of analysis of obtained data - analysis of development of direct payments and foreign agro-trade of Slovakia,

- comparison method - comparison of data for individual years,

- graphical methods - data arranged in tables and subsequent processing into graphs,

- method of statistical indicators - use of change indices,

- calculation method - quantification of costs and relation to subsidies.

We put large datasets with sums in Excel spreadsheets and charts for clarity. However, some data was unavailable. The information, which was given in Slovak crowns before the accession of the Slovak Republic to the EU, we calculated for comparison and comparison with the valid conversion rate of $30.126 \mathrm{SKK} / \mathrm{EUR}$.

For the period 2005 - 2017 the analysis of own work is concentrated. Attention will be paid to the evaluation of achieved results as well as to the evaluation of the impact of the EU on the development of agriculture in Slovakia.

\section{Results and Discussion}

A major issue that affected the provision of direct payments was Slovakia's accession to the EU. The aid was granted on the basis of the Decree of the Ministry of Agriculture of the Slovak

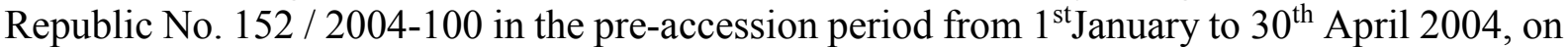
the basis of which crops on arable land, hops, tobacco and certain livestock farms (sheep, goats and lactating cows) were supported. Representatives of the state administration argued with the European Commission before joining the EU regarding the negotiation of conditions for Slovak farmers. A national package of eligible EU resources has been created completely from all production quotas and applicable support schemes. Subsequently, it was redistributed to hectare of agricultural land under the single area payment scheme (SAPS). Apart from the Slovak Republic, most new member states (with the exception of Slovenia and Malta) have accepted this method of payment of support for a transitional period, and this was due to the Slovak Republic failing to implement the Integrated Administration and Control System (IACS) by the date of accession for controlling and managing spent money.

From the granted national package of subsidies, the Slovak Republic really received only a certain part of the EU financial budget, which rose by 5 and almost 10 percent each year. On the beginning in 2004 it was only 25 percent. In addition, the European Commission allowed to add to the EU support national supplements from the state budget of the given state up to a maximum of 30 percent. In Slovakia, such a full national supplement was achieved thanks to government policy only in 2007, 2008 and 2009. The structure of direct payments changed quite often. SAPS - the single area payment belongs to the basic "untied" payments, which is made during the whole monitored period.

The mechanism of direct payments in the Slovak Republic changed from the planned end date in 2007 to the end of the Rural Development Program in 2014. Another transitional period was approved until the end of 2020, so the SAPS continues to apply. 
Through the Rural Development Program for the years 2007 to 2013, resp. From 2014 to 2020, animal welfare measures were supported directly in animal production. In some periods, the protection of habitats of permanent grasslands was also supported.

Payments have a growing trend, which is reflected especially in crop production, which is still subsidized to a greater extent than animal production. For example, in 2018 the amount of the basic payment is set at EUR $140.37 . \mathrm{ha}^{-1}$ and together with the payment for agricultural practices beneficial for the climate and the environment, which is in the amount of EUR 72.53.ha ${ }^{-1}$, it is a total of EUR $212.90 \mathrm{ha}^{-1}$ which is an increase compared to 2005, where the basic area payment was 69.70 EUR. ha ${ }^{-1}$ and together with the payment for arable crops in the amount of 90.20 Eur.ha ${ }^{-1}$ it was a total of 159.90 Eur.ha $^{-1}$ which represents an increase of $32 \%$ increase in payments.

Table 1 Economic information on subsidies before and after $\mathbf{E U}$ accession (in Eur)

\begin{tabular}{|c|c|c|c|c|c|}
\hline Commodity & Wheat & Potatoes & Sunflower & $\begin{array}{c}\text { Wine } \\
\text { grapes }\end{array}$ & $\begin{array}{l}\text { Dairy } \\
\text { cows } \\
\end{array}$ \\
\hline \multicolumn{6}{|l|}{ Year 2001} \\
\hline Subsidies per 1 ha (per 100 breeding days) & 50,95 & 813,58 & 53,48 & 227,35 & 84,94 \\
\hline Own costs per 1 ha (per 100 breeding days) & 573,72 & 3391,56 & 543,12 & 2098,75 & 463,06 \\
\hline Commodity price per 1 tonne (per 1 litter) & 141,87 & 145,72 & 269,3 & 134 & 0,29 \\
\hline $\begin{array}{l}\text { Yields per } 1 \text { ha (Milk utility per } 100 \text { breeding } \\
\text { days) }\end{array}$ & 4,45 & 18 & 2,2 & 5,16 & 1364 \\
\hline \multicolumn{6}{|l|}{ Year 2005} \\
\hline Subsidies per 1 ha (per 100 breeding days) & 159,90 & 159,90 & 159,90 & 159,90 & 5,58 \\
\hline Own costs per 1 ha (per 100 breeding days) & 661,72 & 4317,63 & 685,92 & 2736,01 & 593,74 \\
\hline Commodity price per 1 tonne (per 1 litter) & 122,42 & 220,47 & 238,70 & 335,49 & 0,33 \\
\hline $\begin{array}{l}\text { Yields per } 1 \text { ha (Milk utility per } 100 \text { breeding } \\
\text { days) }\end{array}$ & 4,38 & 17,52 & 2,22 & 3,84 & 1582,00 \\
\hline \multicolumn{6}{|l|}{ Year 2017} \\
\hline Subsidies per 1 ha (per 100 breeding days) & 206,62 & 206,62 & 206,62 & 255,00 & 76,33 \\
\hline Own costs per 1 ha (per 100 breeding days) & 890,00 & 4572,00 & 922,59 & 2797,70 & 784,00 \\
\hline Commodity price per 1 tonne (per 1 litter) & 151,66 & 258,03 & 346,00 & 505,08 & 0,29 \\
\hline $\begin{array}{l}\text { Yields per } 1 \text { ha (Milk utility per } 100 \text { breeding } \\
\text { days) }\end{array}$ & 6,02 & 16,56 & 2,38 & 4,87 & 1931,00 \\
\hline
\end{tabular}

Source: National Agricultural and Food Centre Branch: Research Institute of Agriculture and Food Economics, own calculation

Years $2001-2005$ converted at the exchange rate $1 \mathrm{EUR}=30,126 \mathrm{SKK}$

Table 1 shows the input values of selected commodities that were grown in the economic and production conditions of the Slovak Republic in 2001. As we can see, subsidies were oriented to individual commodities. After joining the EU and in the last year where we evaluate the amount of subsidies according to the new EU rules, we see uniform subsidies per 1 ha. In the next part of the work we will evaluate the impact of subsidies on the economy of production and cultivated commodities. 
Table 2 Economical indicators of subsidies before and after the accession of the Slovak Republic to the EU (in Eur.ha ${ }^{-1}$ )

\begin{tabular}{|c|c|c|c|c|c|}
\hline Commodity & Wheat & Potatoes & Sunflower & $\begin{array}{c}\text { Wine } \\
\text { grapes }\end{array}$ & $\begin{array}{l}\text { Dairy } \\
\text { cows }\end{array}$ \\
\hline \multicolumn{6}{|l|}{ Indicator } \\
\hline$\%$ coverage of costs by subsidies year 2001 & $8.88 \%$ & $23.99 \%$ & $9.85 \%$ & $10.83 \%$ & $18.34 \%$ \\
\hline \% coverage of costs by subsidies year 2005 & $24.16 \%$ & $3.70 \%$ & $23.31 \%$ & $5.84 \%$ & $0.94 \%$ \\
\hline \% coverage of costs by subsidies year 2017 & $23.22 \%$ & $4.52 \%$ & $22.40 \%$ & $9.11 \%$ & $9.74 \%$ \\
\hline Revenues - own costs year 2001 & 57.60 & -768.60 & 49.34 & -1407.31 & -67.50 \\
\hline Revenues - own costs year 2005 & -125.52 & -454.93 & -156.01 & -1447.72 & -72.81 \\
\hline Revenues - own costs year 2017 & 22.99 & -299.02 & -99.11 & -337.96 & -224.01 \\
\hline Revenues + subsidies - own costs year 2001 & 108.55 & 44.98 & 102.82 & -1179.96 & 17.44 \\
\hline Revenues + subsidies - own costs year 2005 & 34.38 & -295.03 & 3.89 & -1287.82 & -67.24 \\
\hline Revenues + subsidies - own costs year 2017 & 229.61 & -92.40 & 107.51 & -82.96 & -147.68 \\
\hline
\end{tabular}

Source: National Agricultural and Food Centre Branch: Research Institute of Agriculture and Food Economics, own calculation

Years $2001-2005$ converted at the exchange rate $1 \mathrm{EUR}=30,126$ SKK

Table 2 shows the calculations of the economic impacts of the subsidy support of the chosen agricultural commodities. The provision of subsidies in EU agriculture and in the Slovak Republic has a fundamental impact on the economic sustainability of agriculture. The redistribution of subsidies in the Slovak Republic after accession to the EU is based on support of single hectare, which favors crop production from an economic point of view, especially cereals and oilseeds, and disadvantaged special crop production (fruit, vegetables, viticulture). The principle of this situation is in terms of economic risk of these commodities in their cost per 1 ha of agricultural land. This means that, for example, densely sown cereals had an average cost per 1 ha of agricultural land of 573.72 EUR and potatoes had a cost of 3391.56 EUR.ha $^{-1}$. If we compare the amount of subsidies before accession to the EU, the potatoes had a support of 813 Eur.ha $^{-1}$, which represents $28 \%$ of the year 2017. After EU accession the single area payment for a specific commodity was reduced to $5 \%$. If we transform the given values into the economic results of the chosen crops, we will find that the wheat shows us high and potatoes achieved red numbers (minus values), into a negative economic result. It follows that, in terms of profitability of their production, farmers are gradually abandoning economically unfavourable commodities (potatoes, etc.) and replacing their growing areas with cereals and oilseeds - with commodities that have significantly lower input costs per 1 ha of agricultural land.

In livestock production, which did not receive support after EU accession, there was economic instability of production and profitability changed from positive to negative, as shown in Table 2. Livestock production is one of the key sectors of agricultural production in terms of maintaining and developing agricultural and rural employment. Plant production in Slovakia has been declining for a long time, which is related to economic conditions, especially its higher cost. The decline in production is closely linked to the decline in the number of livestock, but also the import of finished products. In terms of support for risky commodities of plant and animal production (from the state budget), the state should take more intensive care for support, as is the case in the surrounding states. Or re-evaluate subsidies for the farm and not for a single area. However, due to the long-term unfavorable price development, which in several segments usually lags behind 5 to 20 percent behind the level of production costs and insufficient support 
from public sources, it represents an economic burden for businesses, which they eliminate from profitable crop production. One of the causes of the decline in animal production in the Slovak Republic is mainly lower support compared to other EU Member States in the past, and the situation continues today. This is subsequently reflected in the technical backwardness of Slovak companies. The worst is cattle, pigs and poultry, and it is these groups that need special help, as they have the potential to create many jobs.

Livestock production (cattle and pig farming) with the current support is economically risky, which means that it is loss-making in most farms. Farmers are trying to eliminate this loss by buying new technologies and using EU support. If livestock production is still economically loss-making even after the use of new purchased technologies, the companies suppress the given production and leave the production after the termination of the contractual agreements and they no longer use the technologies.

The agricultural and food sector, like the entire Slovak economy, is characterized by a high degree of openness.

\section{Conclusion}

Support in agriculture is necessary to ensure food production and rural competitiveness, especially after the accession of the Slovak Republic to the European Union. State support plays a primary role, as it clearly affects production in agricultural holdings. The analysis of the impact of support on the development of the agricultural sector was the aim of this thesis. The implementation of subsidies in agriculture is also important from the point of view that it is determined by certain uncontrollable conditions, which to a large extent affect the final results. Agricultural business is directly linked to climatic conditions, which are risky due to the nature of its variability, and the land fund is limited. Without subsidies to agriculture, Slovakia would not be able to compete with the surrounding countries and there would be a reduction in the already low self-sufficiency.

Direct payments account for a significant proportion of EU spending. They are paid from the budget of the relevant EU Member State and subsequently reimbursed from the European Union budget. A certain package is set aside for the payment of direct payments, which will be paid to applicants after the specified conditions have been met. Payments are eligible, so anyone who applies for support and meets the published conditions will receive support.

Direct payments represent a certain income for farmers, which will retain them in the event of adverse market developments or adverse weather conditions. We can state that subsidies are necessary to maintain the development of agriculture. We think that Slovakia should contribute more from the state budget to this sector and negotiate better conditions in the EU than was the case in the pre-accession negotiations with the EU.

Prior to accession to the EU, Slovak agriculture had its own subsidy policy, which took into account the cost, fertility, profitability / loss of individual agricultural commodities. This means that in terms of self-sufficiency of production and supply of the population of the Slovak Republic, the state controlled production in terms of self-sufficiency by its regulations. After joining the EU, the customs barriers of the Slovak Republic fell, by which it protected its farmers from the import of surplus commodities to Western Europe. This was followed by the opening of the market for agricultural commodities within the EU. The Slovak Republic, as an accession state, has adopted EU regulations, which it has adopted in the accession negotiations. By joining the EU, our commodity prices have adapted to commodity prices to the open EU market and we have taken over new subsidy subsidies to the area, which have significantly affected the economy of our traditional commodities. The same area support without subsidies for livestock production has a major impact on the structure of agricultural production. Our calculations show that the single area payment favors low-cost crops (cereals, oilseeds) and 
disadvantages high-cost commodities (orchards, vineyards, vegetables, etc.), which had significantly higher subsidies before accession to the EU. From an economic point of view, it is more advantageous to produce low-cost crops than risky high-cost crops. For these reasons, the structure of agricultural production linked to the self-sufficiency of commodity production is changing significantly in favor of low-cost commodities, which are being replaced by highcost commodities in cropping practices. It follows from the above that Slovakia, which before accession to the EU was self-sufficient in the production of wine, vegetables, fruits, pork, etc. becomes dependent on imports of these commodities from other countries, which has a significant impact on the decline of the processing industry and thus on the trade balance of the Slovak Republic with agricultural commodities. This fact is constantly deepening from year to year.

The state must make greater support for high-cost commodities of plant and animal production from its own budgetary resources and thus prevent the decline of their production. If this assessed situation is not supported, then the decline in the deficit will deepen. The state from its own resources should give more support to the food industry, whose production capacity is constantly decreasing, which has an impact on the development of foreign trade balances in the agri-food sector.

The state must legally determine the placement of agri-food products in retail chains at a reasonable trade margin.

\section{References}

[1] Balassa, Bela (1965): Trade Liberalization and Revealed Comparative Advantage, Manches-ter School of Economic and Social Studies, 33, 99-123

[2] Bielik P. et al. (2010): Economics, Social Policy and citizen-ship in the EU evidence of V4 countries and perspec-tives for Ukraine. SPU, Nitra; ISBN 978-80-552-0448-2.

[3] Cvik, E. D. and MacGregor Pelikánová, R. (2015) 'Agricultural policy and law as reflected by Websites of Czech organic farmers', Proceedings of the Agrarian perspectives XXIII, Prague, pp. 82 - 89, ISBN 978$80-213-2581-4$

[4] Fuller-Love, N. (2006). Management development in smaller firms. International Journal of Management Reviews 8 (3), p.395-404. ISSN 1468-2370

[5] Horská, E., Nagyová, L., Felixová, I. (2010). CAGE distance framework among Visegrad countries, Ukraine and Russia and lessons for international business. Economics, Social Policy and Citizenship in the European Union : Evidence of V4 Countries and Perspectives for Ukraine. Nitra : SUA, 2010. pp. 54-98. ISBN 978-80-552-0448-2.

[6] Kleinová, K., Neománi, J. (2010): Perception of food origin by the Slovak consumer. Acta Universitatis Agriculturae et Silviculturae Mendelianae Brunensis., (2010), LVIII, No. 6, p.227-234. ISSN 2464-8310

[7] Kozáková, J. - Urbanová, M. (2018), "Is current system of direct payments suitable for farmers in Slovakia?" In: Potravinárstvo online: 29 October 2018 at www.potravinarstvo.com 2018 Potravinarstvo Slovak Journal of Food Sciences, License: CC BY 3.0, vol. 12, No. 1/2018 p. 716-722. ISSN 1337-0960 (online)

[8] Konecny, O. (2014) 'Rural Development, Multifunctionality and Agriculture: The Perspective of Czech Farmers', Proceedings of the Agrarian perspectives XXIII, Prague, pp. 304-311, ISSN 2464-4781

[9] Lauwere, C.C. de, (2005). The role of agricultural entrepreneurship in Dutch agriculture of today. Agricultural Economics 33, 2005, p.229-238. ISSN: 1574-0862

[10] Proudman, J., Redding, S. Evolving Patterns of International Trade. Review of International Economics. 2000, 8, No. 3, pp. 373-396. ISSN: 1467-9396 


\title{
Profitability of Enterprises in the Agricultural Sector in Terms of the Legal Form of Business
}

\author{
Ivana Kravčáková Vozárová1, Rastislav Kotulič², Peter Adamišin ${ }^{3}$ \\ University of Presov in Presov \\ Faculty of Management, Department of Economic Sciences and Economy ${ }^{1,2}$, \\ Department of Environmental Management ${ }^{3}$ \\ Address: Konštantínova 16, \\ 08001 Prešov, Slovak Republic \\ e-mail: ivana.kravcakova.vozarova@unipo.sk¹,rastislav.kotulic@unipo.sk², peter.adamisin@unipo.sk ${ }^{3}$
}

doi: 10.18515/dBEM.ISD.P01.2020.p070

\begin{abstract}
As a result of pressure on the formation of agribusiness, the volatile changes occur over the terms of the structure of business and its sustainability in the agricultural sector. Such economic situation in agriculture should support the using financial-economic analysis, that regularly monitors and reflects the level of financial health of enterprises. The profitability of the agricultural sector is influenced by number of specifics, namely natural conditions, seasonality of production, technological changes, intensity of land use, volume of subsidies, credit policy, but also the legal form of business. The aim of this paper is to evaluate the development of selected indicators of profitability of the agricultural enterprises in Slovakia in terms of legal form.
\end{abstract}

Keywords: financial analysis; profitability; return on assets; return on sales; legal form; Slovak Republic

JEL Classification: 013, Q12, R12

\section{Introduction}

The quality and objectivity of the financial relationships between creators and participants of the business environment have a decisive role in the current stage of development of the society where the considerations about the current status are at the forefront. These conditions are also valid for businesses operating in rural areas and therefore should be based on institutionalization and innovation, that act on their sustainable development, liquidity, solvency and sensitivity to financial risks (Serenčéš et al., 2014).

Strážovská and Strážovská (2006) consider the financial situation as a determinant of success of the company, which gives an indication about performance. A company needs to constantly monitor its financial situation, to be able nowadays to keep on the market. For these purposes, the financial analysis is necessary. The analysis using ratio indicators is the core of methodology of financial analysis and this is currently the most common method (Mrkvička \& Koláŕ, 2006).

Sometimes, the profitability indicators referred to as indicators of return are constructed as the ratio of the final effect of making business activities (output) to some base (input), which can be both on the asset side and also on the liability side. These indicators illustrate a positive or negative effect of the asset management, venture financing and liquidity to profitability (Kislingerová et al., 2007). These are synthetic indicators, which reflect the level of liquidity, activity and indebtedness. In theory, as well as in business practice, are in the context of company's profitability measurement used a lot of different profitability indicators due to various modifications of profit. 
According to Šiman and Petera (2010), just indicator of return on total assets (ROA) is supreme representative of business efficiency and an appropriate indicator for measuring business performance. It informs about the amount of effect that is created by a business asset and that is subsequently divided into net profit, interest payment and income tax. Using this indicator is assessed the performance of the company regardless of the tax rate and capital structure.

A further indicator of profitability is an indicator of return on sales (ROS). Return on sales or profit margin is the core of the business efficiency. This indicator indicates how many euros of net profit falls on one euro of revenues. According Rosochatecká et al. (2012), this indicator expresses the company's ability to transform products into cash. It characterizes the company success on the market. It depends on the prices of sold products and, on the profit, reflected in these prices also as on the efficiency when the costs are incurred. In the time series, this indicator should show an upward trend, on average $10 \%$.

The use of financial-economic indicators is typical not only in business practice but also in scientific work, that is confirmed by a variety of scientific studies (Seňová \& Antošová, 2015; Bod'a \& Úradníček, 2015; Kadlečíková et al., 2015; Svatošová, 2015; Jenčová et al., 2015; Dubravská, 2015; Širá, 2015; Huttmanová \& Chovancová, 2015; Lososová \& Zdeněk, 2014; Faltus, 2014; Čulková \& Taušová, 2013; Hakelová et al., 2013; Belás \& Cipová, 2013; Mura \& Buleca, 2012; Sedliačiková, 2011; Adamišin, 2008).

\section{Data and Methods}

The aim of this paper is to evaluate the development of selected indicators of profitability of the agricultural enterprises in Slovakia in terms of legal form.

The basis for the empirical part were secondary financial and additional data of agrarian enterprises provided by the Ministry of Agriculture and Rural Development of the Slovak Republic in the form of Information sheets from the company Radela Ltd. In terms of time series analysis, the paper is focused on the period from 2005 to 2014.

The following Table 1 shows the representation of the agricultural enterprises in the research sample by the legal form. In Slovakia, a higher share had business companies mainly limited liability companies and joint-stock companies than agricultural cooperatives.

Table 1: Research sample of agricultural companies by legal form, 2005-2014

\begin{tabular}{rrrrrrrrrrr}
\hline & $\mathbf{2 0 0 5}$ & $\mathbf{2 0 0 6}$ & $\mathbf{2 0 0 7}$ & $\mathbf{2 0 0 8}$ & $\mathbf{2 0 0 9}$ & $\mathbf{2 0 1 0}$ & $\mathbf{2 0 1 1}$ & $\mathbf{2 0 1 2}$ & $\mathbf{2 0 1 3}$ & $\mathbf{2 0 1 4}$ \\
\hline AC & 578 & 566 & 545 & 538 & 544 & 507 & 526 & 517 & 503 & 487 \\
\hline BC & 832 & 798 & 819 & 779 & 839 & 798 & 886 & 963 & 980 & 1000 \\
\hline SR & 1410 & 1364 & 1364 & 1317 & 1383 & 1305 & 1412 & 1480 & 1483 & 1487 \\
\hline
\end{tabular}

Note: AC - agricultural cooperatives; BC - business companies

From the ratio indicators of financial analysis were selected for the group of profitability the following indicators: return on total assets and return on sales. Just these parameters are the most important representatives of the group according to several authors (Šiman \& Petera, 2010; Rosochatecká et al., 2012). The calculation of given parameters is as follows:

$$
R O A=\frac{\text { EBIT }(\text { Earnings before Interest and Taxes })}{\text { Assets }}(\%)
$$




$$
R O S=\frac{E B I T \text { (Earnings before Interest and Taxes })}{\text { Sales of own products and services }}(\%)
$$

\section{Results and Discussion}

In this section, we analyzed the economic results of the agricultural enterprises in terms of organizational and legal form. We have analyzed the economic development of the company of two types of legal forms. The first were agricultural cooperatives (AC), historically a very important group of agricultural enterprises in Slovakia. The second group consisted of business companies (BC) that were represented mainly by limited liability companies and to a lesser extent by joint stock companies.

The ROA indicator was first parameter in the analysis of economic development by legal status. The results shown that the higher values of this ratio indicator were reached by business companies during the whole period (Figure 1). Very similar trend can also be seen in the case of agricultural cooperatives whose return on assets was fluctuated by a few percent lower.

In 2007, the enterprises of both legal forms reached the highest level of ROA. The business companies achieved ROA at $9.57 \%$, in the case of the agricultural cooperatives it was the most $3.52 \%$. In 2010, the enterprises of both legal forms achieved the largest decline in ROA, which was caused by the fact that the entire agricultural sector reached in a given year a negative economic result. A closer look at the overall development of the indicator is shown in following Figure 1.

Figure 1: Development of ROA by legal form (in \%), 2005-2014

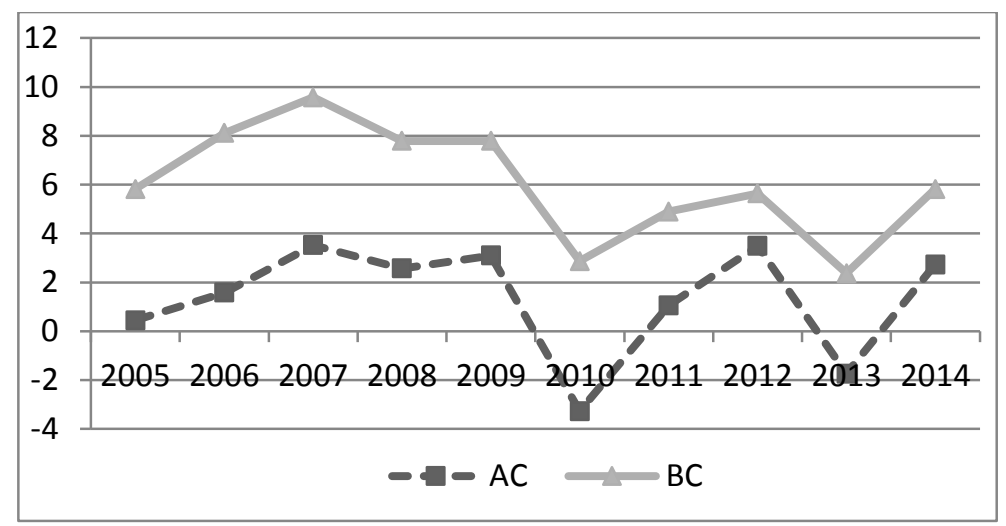

Note: AC - agricultural cooperatives; BC - business companies

When looking at the development of ROS, there was again recorded the better position of the business companies. As part of their overall development, there was not such large annual changes than in the agricultural cooperatives. In the case of the agricultural cooperatives, the development of ROS had very dynamic trend. This was due to the significant drop in profitability of sales in 2010 and 2013, when the agricultural sector in Slovakia achieved a significant loss in management. The highest levels of ROS $(14.58 \%)$ were reached by the business companies in 2009. On the other hand, in the case of the agricultural cooperatives, the highest level of ROS was recorded in 2007 (9.40\%). A closer look at the overall development of the indicator is shown in following Figure 2. 
Figure 2: Development of ROS by legal form (in \%), 2005-2014

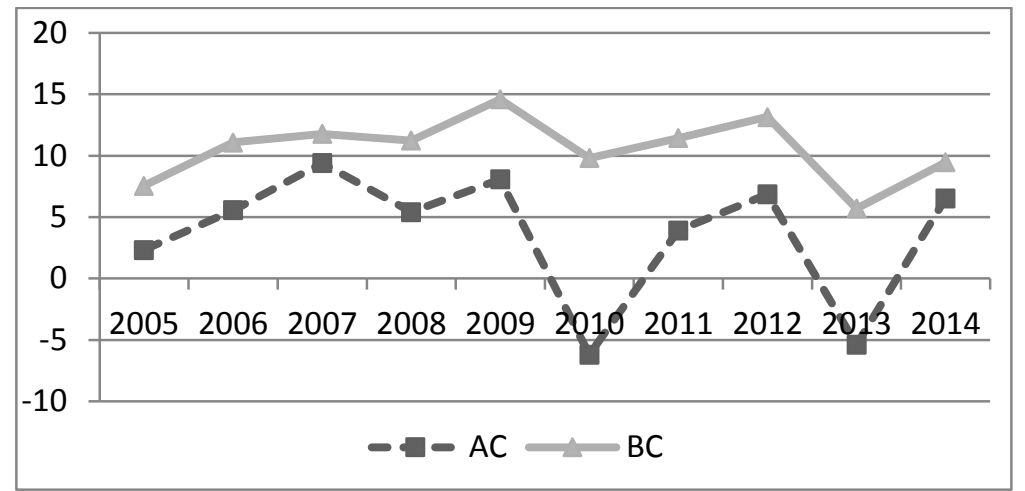

Note: AC - agricultural cooperatives; $\mathrm{BC}$ - business companies

A graphical comparison of return on assets of both forms (Figure 3) indicates the difference between these two groups. Shapiro-Wilk test confirmed the normal distribution $\left(\mathrm{W}_{\mathrm{AC}}=0,870\right.$; $\left.\mathrm{p}=0,096 ; \mathrm{W}_{\mathrm{BC}}=0,948 ; \mathrm{p}=0,637\right)$ and Levene test $(\mathrm{LE}=0,0007 ; \mathrm{p}=0,978)$ their homoscedasticity.

Figure 3: Comparation of legal forms by parameter ROA, 2005 - 2014

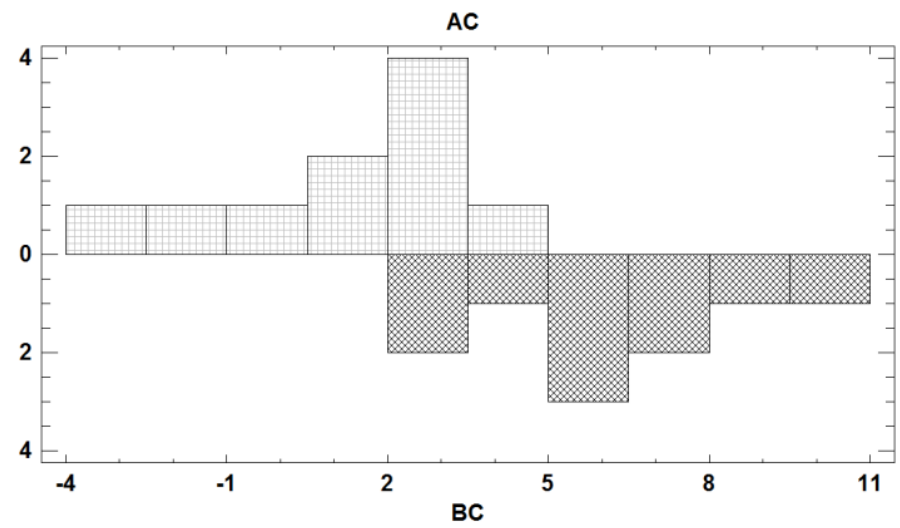

Note: AC - agricultural cooperatives; $\mathrm{BC}$ - business companies

When comparing the legal forms according to return on sales (Figure 4), we can observe more significantly overlap of results. Higher left-hand skewing of the achieved results of the agricultural cooperatives caused the rejection of the null hypothesis of Shapiro-Wilk test (W= $0.834, \mathrm{p}=0.037)$.

Figure 4: Comparation of legal forms by parameter ROS, 2005 - 2014

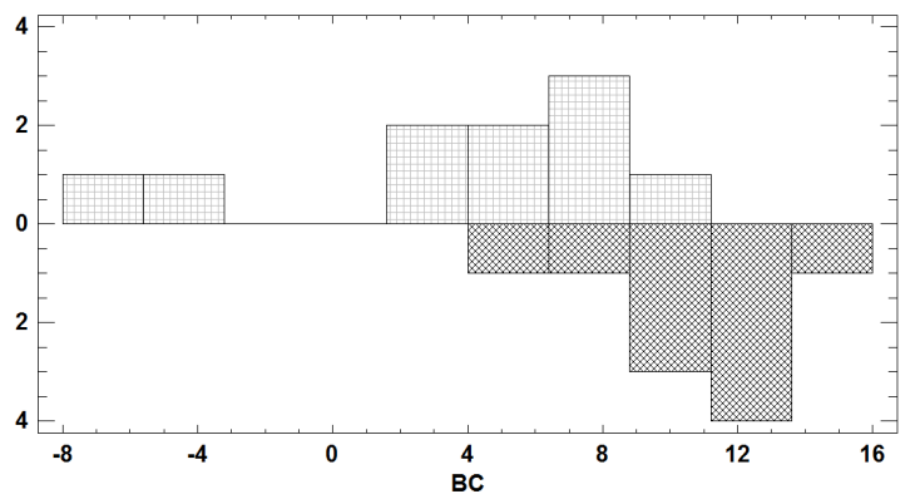

Note: AC - agricultural cooperatives; $\mathrm{BC}$ - business companies 


\section{Conclusion}

A company needs to constantly monitor its financial situation, to be able nowadays to keep on the market. For these purposes, the financial analysis is necessary. The financial analysis, using the ratio analysis is a useful management tool that will improve understanding of financial results and trends over time and provide key indicators of organizational performance. Profitability ratios are the most popular metrics used in the financial analysis.

Attractiveness and profitability of a company significantly influences the chances of success in the market environment. A better overall assessment of the indicators of profitability achieved the business companies in the all monitored period. According to study of MPRV SR 2018, persistent differences in the efficiency of the management of different legal forms can be a consequence of the structure of production with a preference of crop production before livestock and increased efficiency in cost factors, especially labor costs in business companies. Making a profit is one of the main objectives of the business, therefore the analysis of the determinants that affect it, has still great importance for the enterprise. The achievement of profitability to the extent possible is an important issue due to the need for ongoing adaptation of the Slovak agricultural enterprises to the European agricultural area.

\section{Acknowledgements}

This research was supported by the Scientific Grant Agency of the Ministry of Education, Science, Research, and Sport of the Slovak Republic and the Slovak Academy of Sciences, grant numbers VEGA 1/0578/18 and VEGA 1/0082/19; and by the Cultural and Educational Grant Agency of the Ministry of Education, Science, Research and Sport of the Slovak Republic, grant numbers KEGA 011PU-4/2019 and KEGA 024PU-4/2020.

\section{References}

[1] Adamišin, P. (2008). Macroeconomic Coherences of Regional Development in the Slovak Republic. In: Sbornik vybraných príspěvků z vědecký konference Hradecké ekonomické dny 2008: „Aktuální problémy rozvoje regionü“. Hradec Králové : Gaudeamus, 7-12.

[2] Bod'a, M., \& Úradníček, V. (2015). On usability of Altman's bankruptcy formula in the Slovak economic conditions. In: Culik, M (ed.). $10^{\text {th }}$ International Scientific Conference on Financial Management of Firms and Financial Institutions. Ostrava, VSB-TECH UNIV OSTRAVA, 64-71.

[3] Belás, J., \& Cipová, E. (2013). The quality and accuracy of bank internal rating model. A case study from Czech Republic. International Journal of Mathematics and Computers in Simulation, 7(2), 206-214.

[4] Čulková, K., \& Taušová, M. (2013). Decreasing of the Company Indebtedness Through Financial Investment. Journal of Investment and Management, 2(2), 23-27. doi:10.11648/j.jim.20130202.11

[5] Dubravská, M. (2015). Selected Approaches to Evaluation of the Best Non-life Insurance Company in the Polish Insurance Market. Polish Journal of Management Studies, 11(1), 47-55.

[6] Faltus, S. (2014). Firm Default Prediction Model for Slovak Companies. In: Deev, O; Kajurova, V; Krajicek, J (eds.). 11th International Scientific Conference on European Financial Systems 2014. Brno, Masarykova Univerzita, 173-177.

[7] Hakelová, M., Csikosová, A., \& Antošová, M. (2013). The model of manpower management influence on mining business effectiveness. Acta Montanistica Slovaca, 18(2), 85-90.

[8] Huttmanová, E., \& Chovancová, J. (2015). Evaluation of sustainable development in the regions of Slovakia using selected indicators. In: 5th Central European conference in regional science. Košice, Technical university of Košice, 300-306.

[9] Jenčová, S., Litavcová, E., \& Litavec, T. (2015). Quantification of funding and analysis of the financial position of engineering companies in the Slovak Republic. Polish Journal of Management Studies, 12(2), 7990 . 
[10] Sedliačiková, M. (2011). Forecasting of financial situation in a wood-working company. Acta Facultatis Xylologiae, 53(2), 93-101.

[11] Seňová, A., \& Antošová, M. (2015). Business performance assessment and the EFQM excellence model 2010 (Case study). Management (Croatia), 20(1), 183-190.

[12] Kadlečíková, M., Filo, M., Kapsdorferová, Z., \& Malejčíková, A. (2015). The impact of strategic management on selected financial and economic results of agricultural enterprises operating in the Slovak Republic. Acta Universitatis Agriculturae et Silviculturae Mendelianae Brunensis, 63(5), 1679-1686. doi:10.11118/actaun201563051679

[13] Kislingerová, E. a kol., (2007). Manažérske finance. 2. Vyd. Praha, C.H.Beck.

[14] Lososová, J., \& Zdeněk, R. (2014). Key factors affecting the profitability of farms in the Czech Republic. Agris On-line Papers in Economics and Informatics, 6(1), 21-36.

[15] MPRV SR. (2018). Správa o pol’nohospodárstve a potravinárstve v SR za rok 2018. Retrieved January 16, 2020, from file://C:/Users/Ivka/Downloads/sprava_o_polnohospodarstve_a_potravinarstve_sr_za_rok_2018.pdf

[16] Mrkvička, J., \& Koláŕ, P. (2006). Finanční analýza. Praha: Aspi, 2006.

[17] Mura, L., \& Buleca, J. 2012. Evaluation of Financing Possibilities of Small and Medium Industrial Enterprises. Procedia Economics and Finance, 3, 217-222. doi:10.1016/S2212-5671(12)00143-8

[18] Rosochatecká, E., Bervidová, L, Žídková, D., \& Tomšík, K. (2012). Ekonomika podniků. 10 vyd. Praha, Česká zemědělská univerzita v Prahe.

[19] Serenčéš, P., Tóth, M., Čierna, Z., Rábek, T., \& Prevužňáková, J. (2014). Benchmarking v Slovenskom pol'nohospodárstve. Ekonomika pol'nohospodárstva, 14(2), 1-19.

[20] Šiman, J., \& Petera, P. (2010). Financování podnikatelských subjektů. Teorie pro praxi. 1. vyd. Praha, C.H.Beck.

[21] Svatošová, V. (2015). Evaluation of Financial Strategy in Agricultural Companies. In: Kajurova, V., Krajicek, J. (eds.). 12th International Scientific Conference on European Financial Systems 2015. Brno, Masarykova univerzita, 568-578.

[22] Šrá, E. (2015). Slovak Food Processing Industry in the Context of Globalisation and Integration Tendencies. Polish Journal of Management Studies, 11(1), 158-167.

[23] Strážovská, E., \& Strážovská, L. (2006). Ekonomické analýzy. 1. vyd. Bratislava, Vysoká škola ekonómie a manažmentu verejnej správy v Bratislave. 